
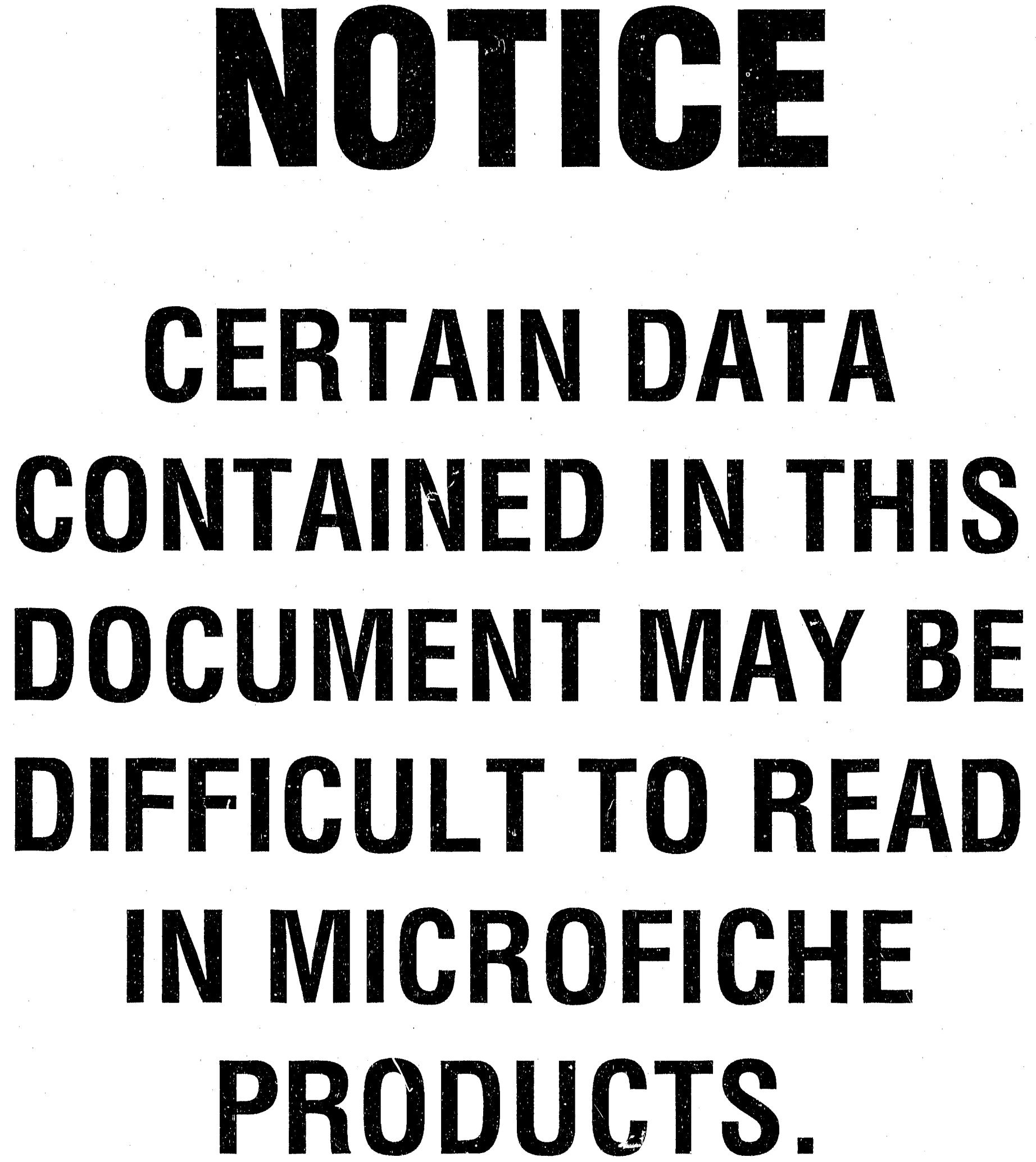


\section{TRENDS 990 A Compendium of Data on Global Change}

ORNL/CDIAC --36

DE91 000587
Thomas A. Boden Paul Kanciruk Michael P. Farrell

Technical Editors Robert J. Sepanski

Frederick W. Stoss

Carbon Dioxide Information Analysis Center Environmental Sciences Division Oak Ridge National Laboratory Oak Ridge, Tennessee, U.S.A.

37831-6335

August 1990

Sponsored by the U.S. Department of Energy Atmospheric and Climate Research Division

Carbon Dioxide Research Program

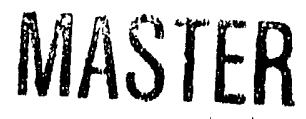




\section{Contributors}

Y.S. Korotkevich

Arctic and Antarctic

Research Institute

Leningrad, U.S.S.R.

Kaz. Higuchi

Neil B.A. Trivett

Victoria Hudec

Atmospheric Environment

Service

Downsvicw, Ontario,

Canada

Alberto Linés. Escardó
Beatriz Navascués
Carmen Rus
Ciudad Universitaria
Madrid, Spain
David J. Beardsmorc
Paul J. Frascr
Gracme I. Pearman
L. Paul Stecle
Commonwealth Scientific and
Industrial Research
Organization
Mordialloc, Victoria,
Australia

Rainer Schmitt

Consultant (meteorology')

Offenbach, F.R.G.
H.J. Kanter

K. Munzert

Reinhold Reiter

Rudolf Sladkovic

Fraunhofer-Institute for Atmospheric Research

Garmisch-Partenkirchen, F.R.G.

\section{Luigi Ciattaglia}

Italian Meteorological Service

Rome, Italy

J.M. Barnola

J. Chappcllaz,

C. Lorius

D. Raynaud

Laboratoire de Glaciologie et de Géophysique de

l'Environnement

Saint Martin d'Hères, France

\section{C.S. Wong}

Marine Carbon Research Centre

Sidney, British Columbia, Canada

\author{
James Hansen \\ Sergej Lebodeff \\ National Aeronautic and \\ Space Administration, \\ Goddard Space Flight \\ Center \\ New York, New York, U.S.A.
}


Jim K. Angell

National Oceanographic and

Atmospheric Administration,

Air Resources Laboratory

Silver Spring, Maryland, U.S.A.

Thomas J. Conway

Dale A. Gillette

Thomas B. Harris

Walter D. Komhyr

Patricia Lang

Russell C. Martin

Kenneth A. Masaric

Donald W. Nelson

James T. Peterson

Pieter Tans

Kirk W. Thoning

Lee S. Waterman

National Oceanographic and

Atmospheric Administration,

Environmental Research

Laboratories

Boulder, Colorado, U.S.A.

Ronald G. Baldwin

Michacl G. Burgin

Thomas R. Karl

National Oceanographic and Atmospheric Administration, National Climatic Data Center Asheville, North Carolina, U.S.A.

Gregg Marland

Oak Ridge National Laboratory

Oak Ridge, Tennessee, U.S.A.
M.A.K. Khalil

R.A. Rasmussen

Oregon Graduate Institute of

Science and Technology

Beaverton, Oregon, U.S.A.

Charles D. Kceling

Timothy P. Whorf

Scripps Institution of Oceanography

La Jolla, California, U.S.A.

G. Fischer

H. Fricdli

E. Lochbronner

H. Lötscher

A. Neftel

E. Moor

H. Oaschger

J. Schwander

U. Siegenthaler

B. Stauffer

University of Bern

Bern, Switzerland

P.D. Jones

T.M.L. Wiglcy

P.B. Wright

University of East Anglia

Norwich, U.K.

Manfred Forstreuter

Dieter Overdieck

Universitüt Osnabrück

Osnabrück, F.R.G. 


\section{Contents}

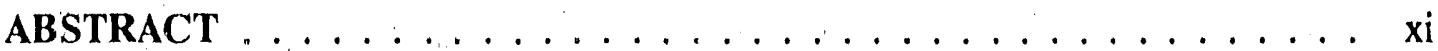

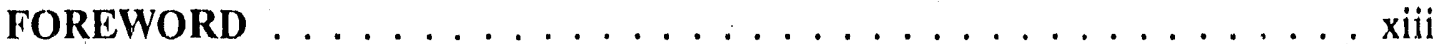

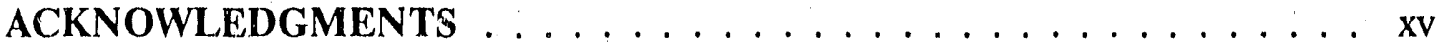

\section{ATMOSPHERIC CARBON DIOXIDE CONCENTRATIONS}

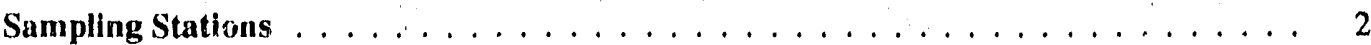

Introduction $\ldots \ldots \ldots \ldots \ldots \ldots \ldots \ldots \ldots \ldots \ldots \ldots \ldots \ldots \ldots \ldots$

Historical Record-Atmospheric $\mathrm{CO}_{2}$ from Ice Cores

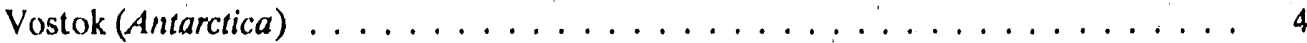

Siple Station $($ Antarctica $) \ldots \ldots \ldots \ldots \ldots \ldots \ldots$

Modern Record

U.S. Monitoring Programs and Stations

Scr:pps Institution of Oceanography

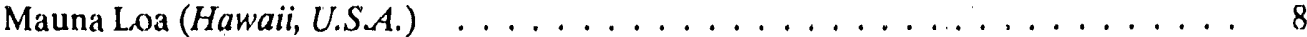

American Samoa (U.S. Territory) $\ldots \ldots \ldots \ldots \ldots \ldots \ldots \ldots \ldots$

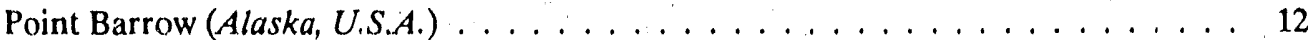

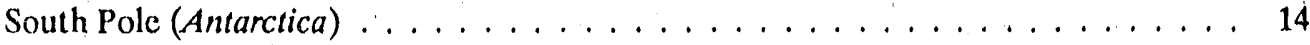

National Oceanic and Atmospheric Administration,

Climate Monitoring and Diagnostics Laborato:y

Continuous Monitoring Program

Amundsen Scott (South Pole, Antarctica) $\ldots \ldots \ldots \ldots$

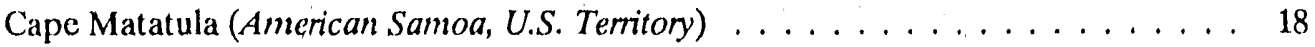

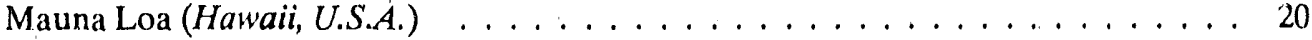

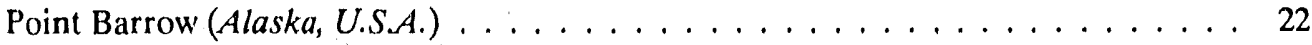

National Oceanic and Atmospheric Administration,

Climate Monitoring and Diagnostics Laboratory

wlask Sampling Program

Amsterdam Island (French Territory) $\ldots \ldots \ldots \ldots \ldots$

Amundsen Scott (South Pole, Antartica) $\ldots \ldots \ldots \ldots \ldots \ldots \ldots$

Ascension Island $(U . K.) \quad \ldots \ldots \ldots \ldots \ldots \ldots \ldots \ldots$

Cape Grim (Tasmania, Australia) $\ldots \ldots \ldots \ldots \ldots$

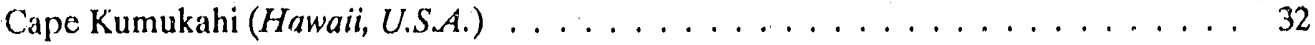

Cape Matatula (American Samoa, U.S. Territory) _ . . . . . . . . . . . . . . 34 
Cape Meares (Oregon, U.S.A.) $\ldots \ldots \ldots \ldots \ldots \ldots$

Christmas Island (Kiribati) $\ldots \ldots \ldots \ldots \ldots \ldots$

Cold Bay (Alaska, U.S.A.) . . . . . . . . . . . . . . . . . . . 40 40

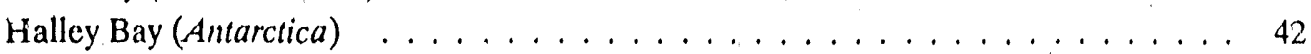

Kaitorete Spit (New Zealand $) \ldots \ldots \ldots \ldots 4$

Key Biscayne $($ Florida, U.S.A. $) \ldots \ldots \ldots \ldots \ldots \ldots \ldots \ldots$

Mahe Island (Seychelles) $\ldots \ldots \ldots \ldots$. . . . . . . . . . . . . . . 48

Mariana Island (Gtam, U.S. Territory) $\ldots \ldots \ldots \ldots \ldots \ldots \ldots$

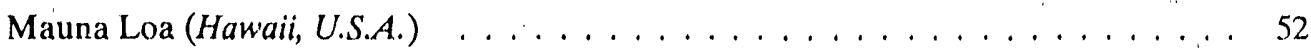

Mould Bay (Norhwest Territories, Canada) . . . . . . . . . . . . . . 54

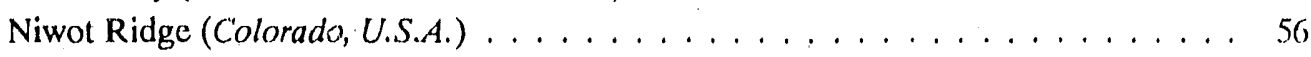

Ocean Station "M" (North Allantic Ocean) $\ldots \ldots \ldots \ldots \ldots \ldots$

Palmer Station (Anver Island, Antarctica) $\ldots \ldots \ldots \ldots$

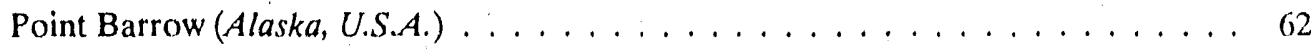

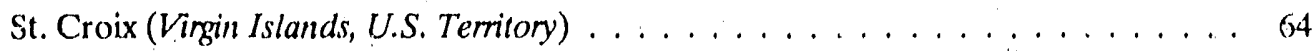

Terceira Island (Azores, Portuguese Territory) $\ldots \ldots \ldots \ldots 6$

\section{Spanish Monitoring Station}

Izaña Baseline Observatory (Canary Islands, Spain) $\ldots \ldots \ldots \ldots$

Italian Monitoring Station

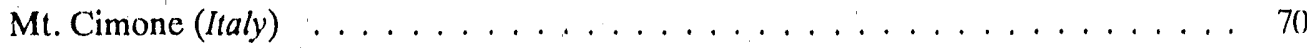

\section{Australian Monitoring Station}

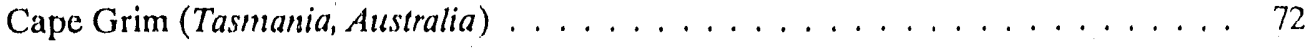

\section{Canadir n Monitoring Stations}

Alert (Nonhwest Territories, Canada) . . . . . . . . . . . . . . . . . 74

Cape St. James (British Columbia, Canada) . . . . . . . . . . . . . . 76

\section{Federal Republic of Germany Monitoring Stations}

Garmisch-Partenkirchen $(F . R . G.) \quad \ldots \ldots \ldots \ldots \ldots \ldots$

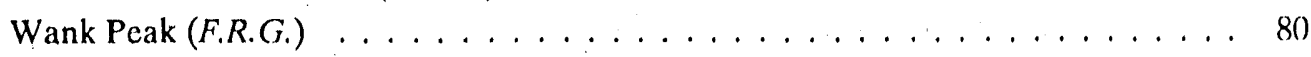

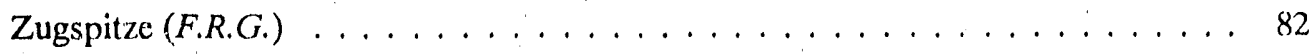

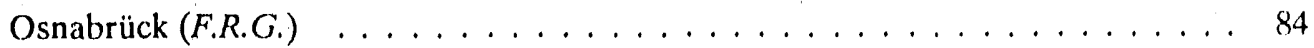




\section{Contents (cont'd)}

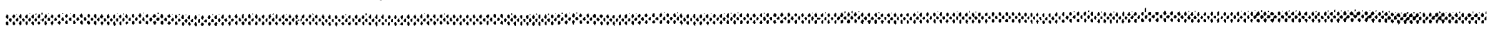

\section{GLOBAL AND NATIONAL CO2 EMISSIONS FROM FOSSIL FUEL BURNING, CEMENT PRODUCTION, AND GAS FLARING}

Introduction . . . . . . . . . . . . . . . . . . . . . . . . . . . . . . 89

Historical Record

Global . . . . . . . . . . . . . . . . . . . .90

Modern Record

Global . . . . . . . . . . . . . . . . . . . . . . 92

United States . . . . . . . . . . . . . . . . . . . . . . . . . . 94

Union of Soviet Socialist Republics $\ldots \ldots \ldots \ldots \ldots \ldots$

People's Republic of China . . . . . . . . . . . . . . . . . . . 98

Japan . . . . . . . . . . . . . . . . . . . . . . 100

Federal Republic of Germany $\ldots \ldots \ldots 102$

India . . . . . . . . . . . . . . . . . . . . . . . . . . 104

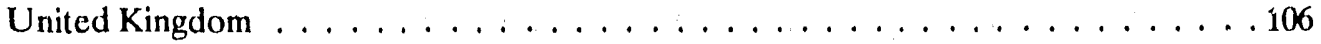

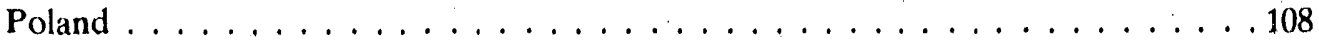

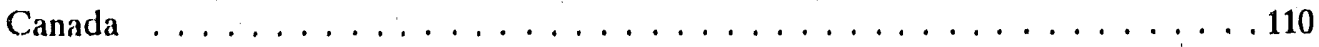

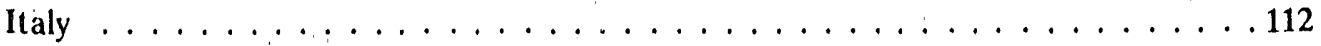

German Democratic Republic . . . . . . . . . . . . . . . . . . . . . 114

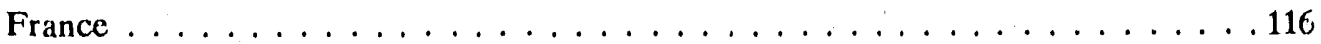

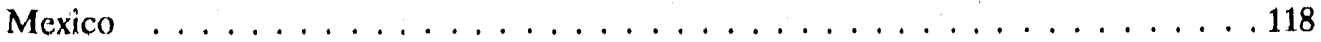

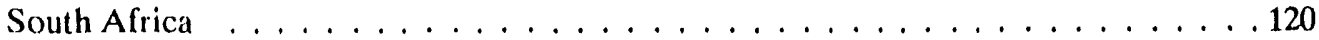

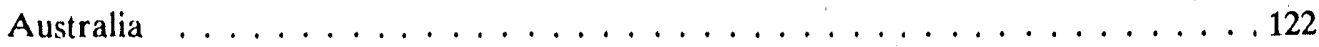

Czechoslovakia . . . . . . . . . . . . . . . . . . . . . . . . . . 124

Romania . . . . . . . . . . . . . . . . . . . . . . . . . . 126

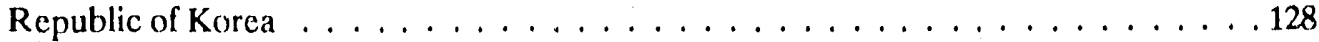

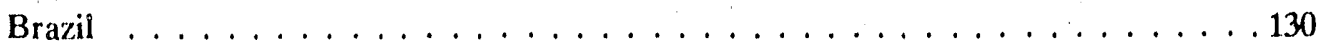

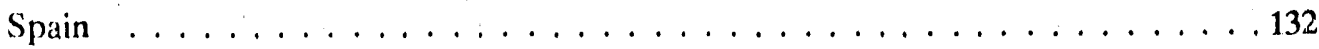

\section{ATMOSPHERIC METHANE CONCENTRATIONS}

Sampling Stations $\ldots \ldots \ldots \ldots \ldots$

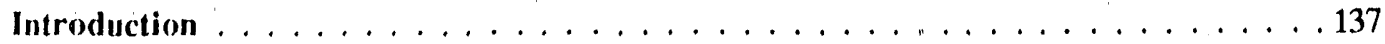




\section{ATMOSPHERIC METHANE CONCENTRATIONS (cont'd)}

Historical Record - Atmospheric $\mathrm{CH}_{4}$ from Ice Cores

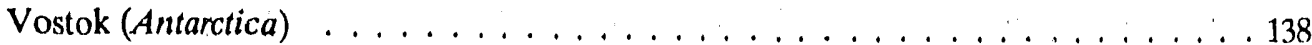

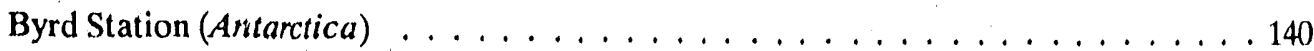

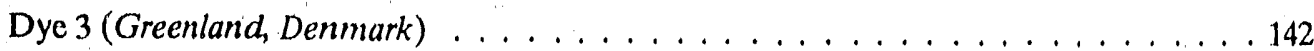

Siple Station (Antartica) $\ldots \ldots \ldots \ldots$. . . . . . . . . . . . . . 144

\section{Modern Record}

Oregon Graduate Institute of Science and Technology

Global . . . . . . . . . . . . . . . . . . . . . . . . . . . . . . 146

National Oceanic and Atmospheric Administration,

Climate Monitoring and Diagnostics Laboratory

Flask Sampling Program

Amsterdam Island (French Territory) $\ldots \ldots \ldots \ldots \ldots$. . . . . . . . . . . . 148

Amundsen Scott (South Pole, Antarctica) _. . . . . . . . . . . . . . . . 150

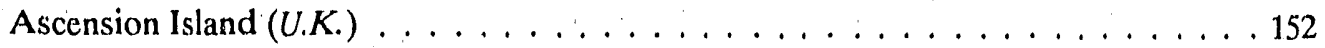

Cape Grim (Tasmania, Australia) $\ldots \ldots$. . . . . . . . . . . . . . . . . 154

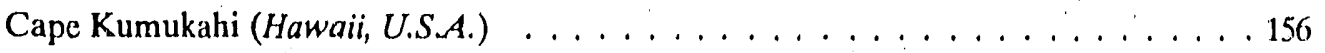

Cape Meares (Oregon, U.S.A.) _ . . . . . . . . . . . . . . . . . . 158

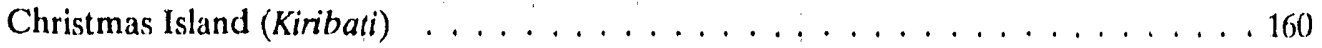

Cold Bay (Alaska, U.S.A.) . . . . . . . . . . . . . . . . . . . . . . 162

Halley Bay (Antanctica) _. . . . . . . . . . . . . . . . . . . . . . . 164

Key Biscayne (Florida, U.S.A.) $\ldots \ldots \ldots \ldots \ldots \ldots$

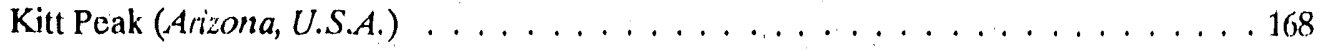

Mahé Island (Seychelles) ． . . . . . . . . . . . . . . . . . . . . . . . . 170

Mariana Island (Guam, U.S. Territory) $\ldots \ldots \ldots \ldots$. . . . . . . . . . . 172

Matatula Point (American Samoa, U.S. Territory) _ . . . . . . . . . . . . . . 174

Mauna Loa (Hawaii, U.S.A.) . . . . . . . . . . . . . . . . . . . . . . . 176

Mould Bay (Northwest Territories, Canada) _ . . . . . . . . . . . . . . . . . 178

Niwot Ridge (Colorado, U.S.A.) … . . . . . . . . . . . . . . . . . 180

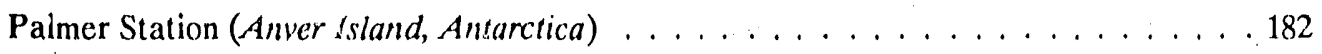

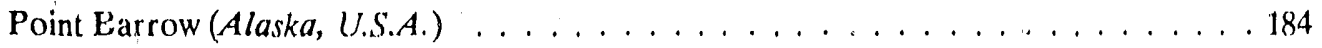

St. Croix (Virgin Islands, U.S. Territory) $\ldots \ldots \ldots \ldots$

Terceira Island (Azores, Portuguese Territory) $\ldots \ldots \ldots \ldots$ 


\section{Contents (cont'd)}

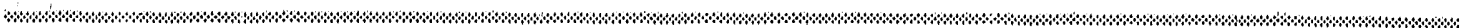

\section{TEMPERATURE RECORDS}

Introduction $\ldots \ldots \ldots \ldots \ldots \ldots$

Temperature Anomalies

Global and Hemispheric (Jones, Wigley, and Wright) . . . . . . . . . . . . . 194

Global and Hemispheric (Hansen and Lebedeff) . . . . . . . . . . . . . . 196

Global, Zonal, and Hemispheric

Global $\left(90^{\circ} \mathrm{S}-90^{\circ} \mathrm{N}\right) \ldots \ldots . . \ldots \ldots$

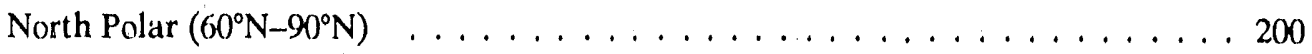

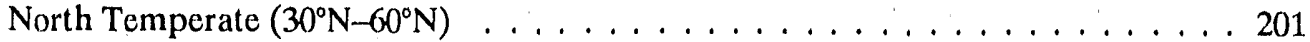

North Subtropics $\left(10^{\circ} \mathrm{N}-30^{\circ} \mathrm{N}\right) \quad \ldots \ldots \ldots 202$

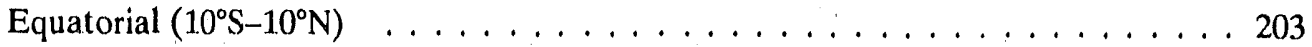

South Subtropics $\left(30^{\circ} \mathrm{S}-10^{\circ} \mathrm{s}\right) \ldots \ldots \ldots$

South Temperate $\left(60^{\circ} \mathrm{S}-30^{\circ} \mathrm{S}\right) \ldots \ldots \ldots \ldots \ldots$

South Folar $\left(90^{\circ} \mathrm{S}-60^{\circ} \mathrm{S}\right) \ldots \ldots \ldots \ldots \ldots \ldots$

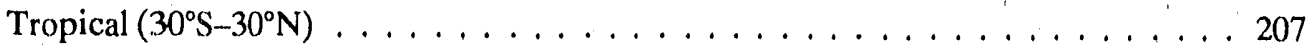

Northern Hemisphere $\left(0^{\circ}-90^{\circ} \mathrm{N}\right) \quad \ldots \ldots \ldots \ldots$

Southern Hemisphere $\left(0^{\circ}-90^{\circ} \mathrm{S}\right) \ldots \ldots$

United States National and Regional Temperatures

National . . . . . . . . . . . . . . . . . . . . . . . . . 210

Regional

W'est Region

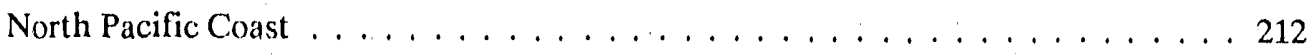

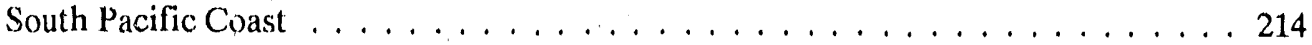

North Cascades . . . . . . . . . . . . . . . . . . . . . . . . . 216

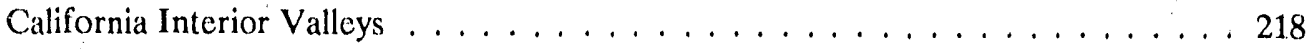

East Slope North Cascades . . . . . . . . . . . . . . . . . . . . . . . . 220

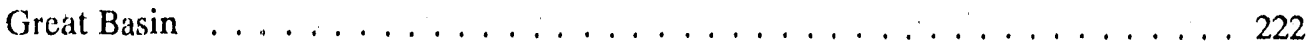

Southern Desert . . . . . . . . . . . . . . . . . . . . . . . . . . . . . . 224

Northern Rockies . . . . . . . . . . . . . . . . . . . . . . . 226

Southern Rockies . . . . . . . . . . . . . . . . . . . . . . . . . 228

Central Region

Northern Steppes . . . . . . . . . . . . . . . . . . . . . . . . 230

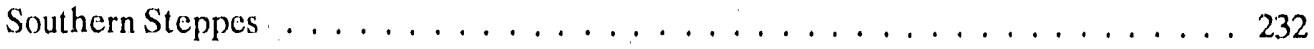

TRENDS'90 


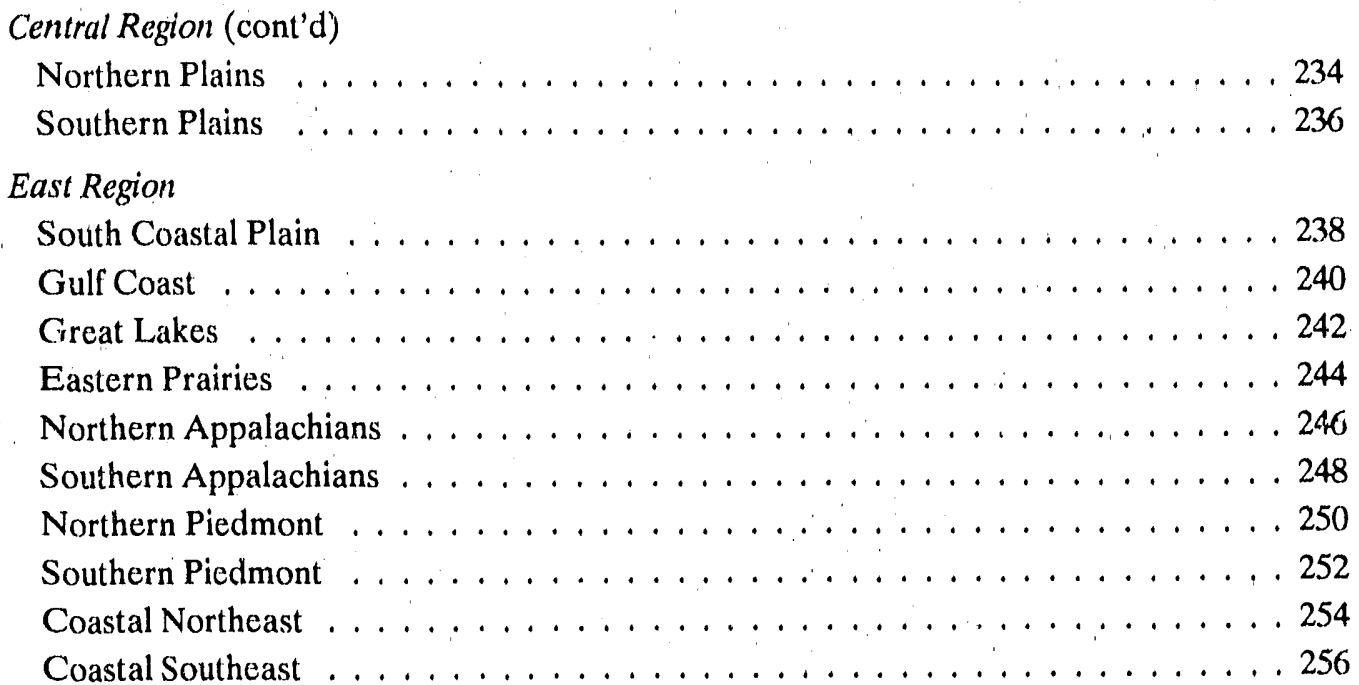

APPENDIXES

Appendix A

Carbon Dioxide Information Analysis Center $\ldots \ldots \ldots \ldots \ldots \ldots$ A $\ldots \ldots \ldots$

\section{Appendix B}

Numeric Data Packages Supporting TRENDS $90 \ldots \ldots \ldots$. . . . . . . B-1

Appendix $:$

Acronyms and Abbreviations $\ldots \ldots \ldots \ldots \ldots \ldots$ C-1 


\section{Abstract}

Boden, T. A., P. Kanciruk, and M. P. Farrell. 1990. TRENDS '90: A

Compendium of Data on Global Change. ORNL/CDIAC-36. Carbon Dioxide Information Analysis Center, Oak Ridge National Laboratory, Oak Ridge, Tennessee, 286 pages.

This document is a source of frequently used global change data. This first issue includes estimates for global and national $\mathrm{CO}_{2}$ emissions from the burning of fossil fuels and from the production of cement, historical and modern records of atmospheric $\mathrm{CO}_{2}$ and methane concentrations, and several long-term temperature records. Included are tabular and graphical presentations of the data, discussions of trends in the data, and references to publications that provide further information. Data are presented in a two-page format, each dealing with a different data set.

All data are available in digital form from the Carbon Dioxide Information Analysis Center.

Keywords: Air pollution, ambient temperature, atmospheric chemistry, carbon cycle, carbon dioxide, climates, earth atmosphere, geophysical surveys, global aspects, greenhouse effect, meteorology, methane, monitoring regional analysis, temperature monitoring, and temperature surveys. 
One of the goals of the Carbon Dioxide Information Analysis Center (CDIAC) at Oak Ridge National Laboratory is to provide ready access to data and information pertinent to global changes. CDIAC has attempted to achieve this goal by providing reports, numeric data packages (NDPs), computer model packages (CMPs), and other information center products and services. To date, these activities have been well received and frequently used by a diverse international audience. This new document, TRENDS' '9(), is our effort to widely distributu data critical to climate change issues.

TRENDS' 90 is intended to provide a quick reference for important data. The presentation of the data in TRENDS' $O 0$ differs from that in traditional CDIAC NDPs. For TRENDS' '90, we provide a graphical presentation of data accompanied by an explanation of current trends. TRENDS '9() also provides critical background information, references, and briof tabular summaries of the data. Detailed NDPS for most data sets cited in TRENDS '9() can be obtained from CDIAC:

We intend to publish TRENDS annually. For some data bases compiled by CDIAC (e.g., $\mathrm{CO}_{2}$ emissions), TRENDS will be the first presentation of the data for the year. This inangural issue includes data on atmospheric carbon dioxide $\left(\mathrm{CO}_{2}\right)$ concentrations; estimates of global and national $\mathrm{CO}_{2}$ emissions from fossil fuel burning, coment production, and gas flaring; atmospheric methane $\left(\mathrm{CH}_{4}\right)$ concentrations; and temperature data. Future issues of TRENDS may include data for atmospheric concentrations of other trace. 
gases, land use data, oceanographic data, precipitation records, and output from computer models (i.e., general circulation models, vegetation models, $\mathrm{CO}_{2}$ and $\mathrm{CH}_{4}$ emission models, ocean models, and carbon cycle models).

The direction and format of future issues of TRENDS will be largely determined by the feedback we receive on this first issue. We encourage you to comment on this issue and suggest data to include in future issues.

The data in TRENDS ' 90 are most properly referenced by citing the principal investigators as well as the section (e.g., Atmospheric Methane Concentrations) and subsection (c.g., Amsterdam Island) in which the data are found. The following sample citation for the atmospheric $\mathrm{CH}_{4}$ concentrations from the NOAA/GMCC llask sampling program at Amsterdam Island is recommended:

Steele, L.P., P.P. Tans, P.M. Lang,

R.C. Martin, and K.A. Masaric. 1990.

Atmospheric Methane Concentrations, Amsterdam Island, p. 148-49. IN Boden, T.A., P. Kanciruk, and M.P. Farrell, TRENDS '90: A Compendium of Data on Global Change, ORNL/CDIAC-36. Carbon Dioxide Information Analysis Center, ()ak Ridge National Laboratory, ()ak Ridge, Tennessee.

CDIAC ack 'owledges the support of the international science community in supplying data for creating its NDPS and TRENDS' $(0$. CDIAC ensures the quality of the data upon receipt. However, some of the atmospheric $\mathrm{CO}_{2}$ and $\mathrm{CH}_{4}$ data are considered preliminary. Users should note table foot notes to avoid misrepresentations of the accuracy of these data. The applications and limitations for most data sets in TRENDS ' 90 are documented in greater detail in CDIAC NDPs.

Data supporting TRENDS ' 90 as well as all of our NDPs are available from CDIAC in machine-readable form. If you have any questions concerning data contained in this document or would like to discuss a particular aspect of the data's application, please contact CDIAC directly, so that your inquiry can be addressed by one of our technical staff.

Dala requests and comments or suggestions concerning TRENDS may be sent to:

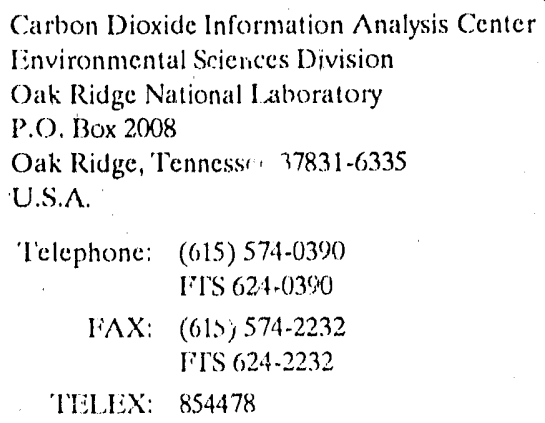

ISlectronic Mail:

BITNET:CDP(IIORNISTC.

INITRNET: CDP@STCIO.CID.ORNL CIOV OMNEI: CDIAC

On behalf of CDIAC, we weleome you to our newest publication. We hope you find it useful.

- Michael P. Farrell, Director Carbon Dioxide Information Analysis and Rescarch Program - Paul Kancink, Director Carbon Dioxide Information Analysis Center 


\section{Acknowledgments}

We gratefully acknowledge those who have contributed their data for inclusion in this document and thereby have made it possible for us to share data with researchers, policymakers, and students. We applaud the willingness of these individuals to allow the Carbon Dioxide Information Analysis Center (CDIAC) to archive and distribute their data.

Our deepest thanks go to Cheryl Buford and Marvel Burtis. Were it not for Cheryl's specialized electronic publishing design, composition, and production skills and Marvel's diligent support efforts, this document could not have been completed. We also thank Rosemary Adams, Dave Ball, John Holbrook, Mitchell Williamson, Jaime Payne, and Tammy White for graphics assistance; Bill Emanuel and Mac Post for suggestions and comments on the graphics; David Fowler for establishing document format; Bob Cushman for comments on document format and content; Gay Marie Logsdon and an editorial 
team from the Environmental Sciences

Division Publications Office for their suggestions; and Frances Littleton for her assistance in document preparation.

We especially thank Tom Gross, a program manager within the Carbon Dioxide Research Program, for his many years of support of CDIAC activities. Tom's continuing belief in the importance of international exchange of scientific information has been a mainstay for CDIAC progress.

CDIAC is supported by the U.S.

Department of Energy's Atmospheric and Climate Research Division, Carbon Dioxide Research Pringram.

CDIAC is housed in the Environmental Sciences Division (ESD) at Oak Ridge National Laboratory (ORNL). TRENDS ' 90 is ESD Publication No. 3430. ORNL is operated by Martin Marietta Energy Systems, Inc., for the U.S. Department of Energy under contract DE-AC05-84OR21400. 
Atmospheric Carbon Dioxide Concentrations

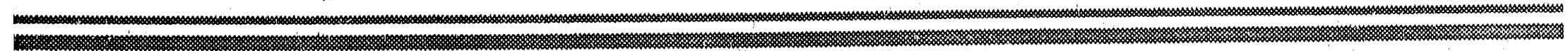




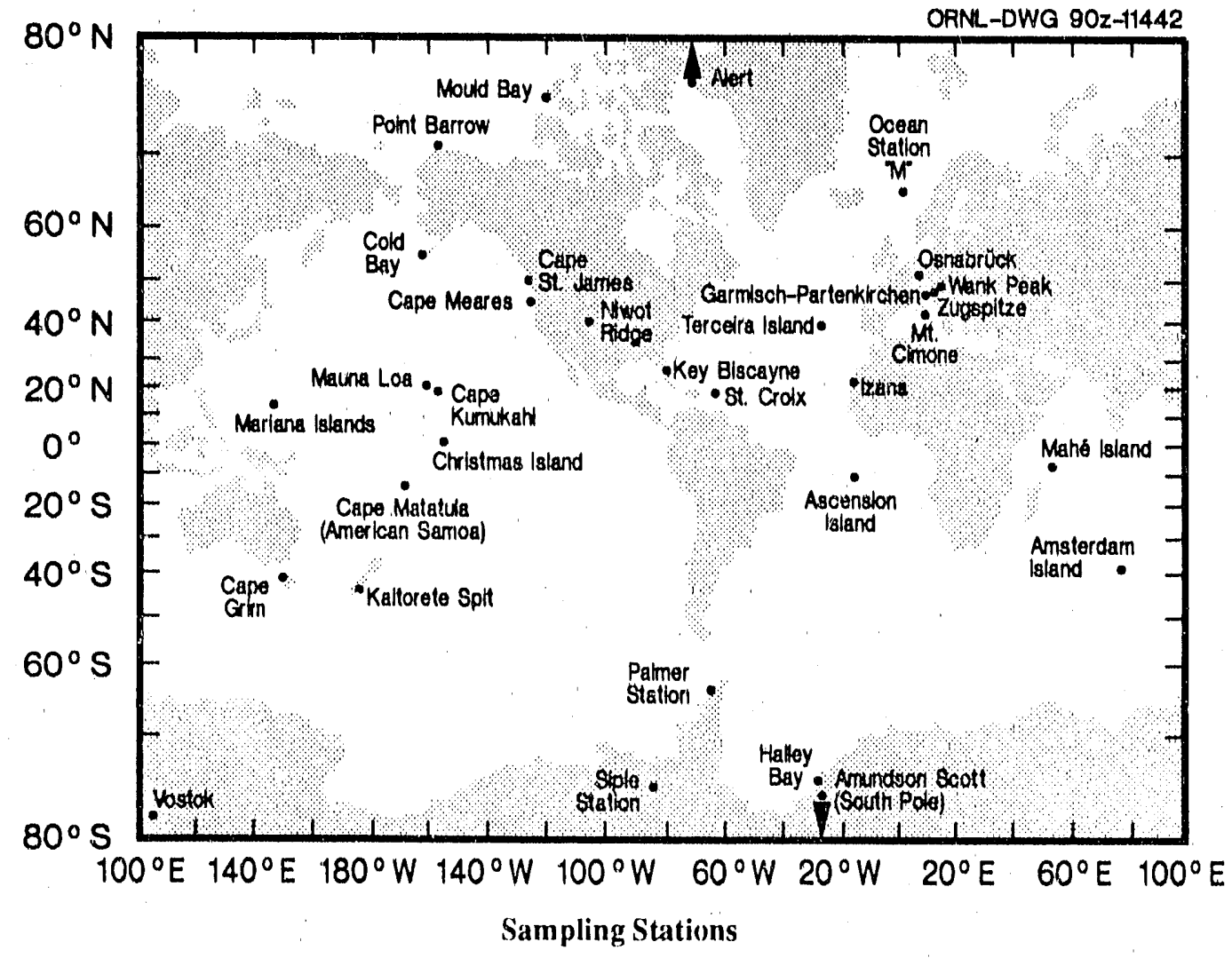




\section{Introduction}

Precise records of past and present atmospheric $\mathrm{CO}_{2}$ concentrations are critical to studies attempting to model and understand the global carbon cycle and possible $\mathrm{CO}_{2}$-induced climate change. Attempts to determine past levels of atmospheric $\mathrm{CO}_{2}$ concertrations have been made using a variety of techniques, including direct measurements of trapped air in polar ice cores, indirect determinations from carbon isotopes in tree rings, spectroscopic data, and carbon and oxygen isotopic changes in carbonate sediments in deep-ocean cores. The modern period of precise atmospheric $\mathrm{CO}_{2}$ measurements began during the International Geophysical Year (1958) with Keeling's (Scripps Institution of Oceariography) pioncering determinations at Mauna Loa, Hawaii, and the South Pole. The Mauna Loa record remains the single most valuable $\mathrm{CO}_{2}$ time series. Since Kecling's initial efforts, other agencies and organizations have implemented programs to monitor background levels of atmospheric $\mathrm{CO}_{2}$ concentrations. Two of the larger programs are the National Oceanic and Atmospheric Administration's Climate Monitoring and Diagnostics Laboratory (CMDL-formerly Geophysical Monitoring for Climate Change) flask and continuous monitoring networks and the World Meteorological Organization's (WMO's) Background Air Pollution Monitoring Network (BAPMoN).

In the following section, two historical atmospheric $\mathrm{CO}_{2}$ records derived from ice cores and 39 records of monthly and annual atmospheric $\mathrm{CO}_{2}$ concentrations from 30 globally distributed sites (see map on facing page) are provided. Collectively, these records document the atmospheric $\mathrm{CO}_{2}$ record during the past 160,000 years. For the modern record it seemed appropriate to present Keeling's Mauna Loa record first. because it represents the longest continuous modern record available. Most records are indicative of background air conditions in a particular region or location. Some records (c.g., Osnabritick) were collected for other purposes, such as determining local ambient levels of $\mathrm{CO}_{2}$ for growth chamber studies. The data presented on the pages that follow represent a significant portion, although not all, of the modern and historical atmospheric $\mathrm{CO}_{2}$ record and provide irrefutable evidence that atmospheric levels of $\mathrm{CO}_{2}$ concentrations have risen over the past three decades (see figure to right).

The data presented in this section were made available to the Carbon Dioxide Information Analysis Center (CDIAC) by the principal investigator(s) listed for each data record, and CDIAC acknowledges their kind cooperation. We urge readers to credit the principal investigators and their organizations when using these data. Users are cncouraged to contact CDIAC before using data for specific model or research exercises. Some of the data are considered preliminary and subject to adjustment (values could change by several parts per million). All the data presented here are available in digitized form from CDIAC. 


\section{Atmospheric $\mathrm{CO}_{2}$}

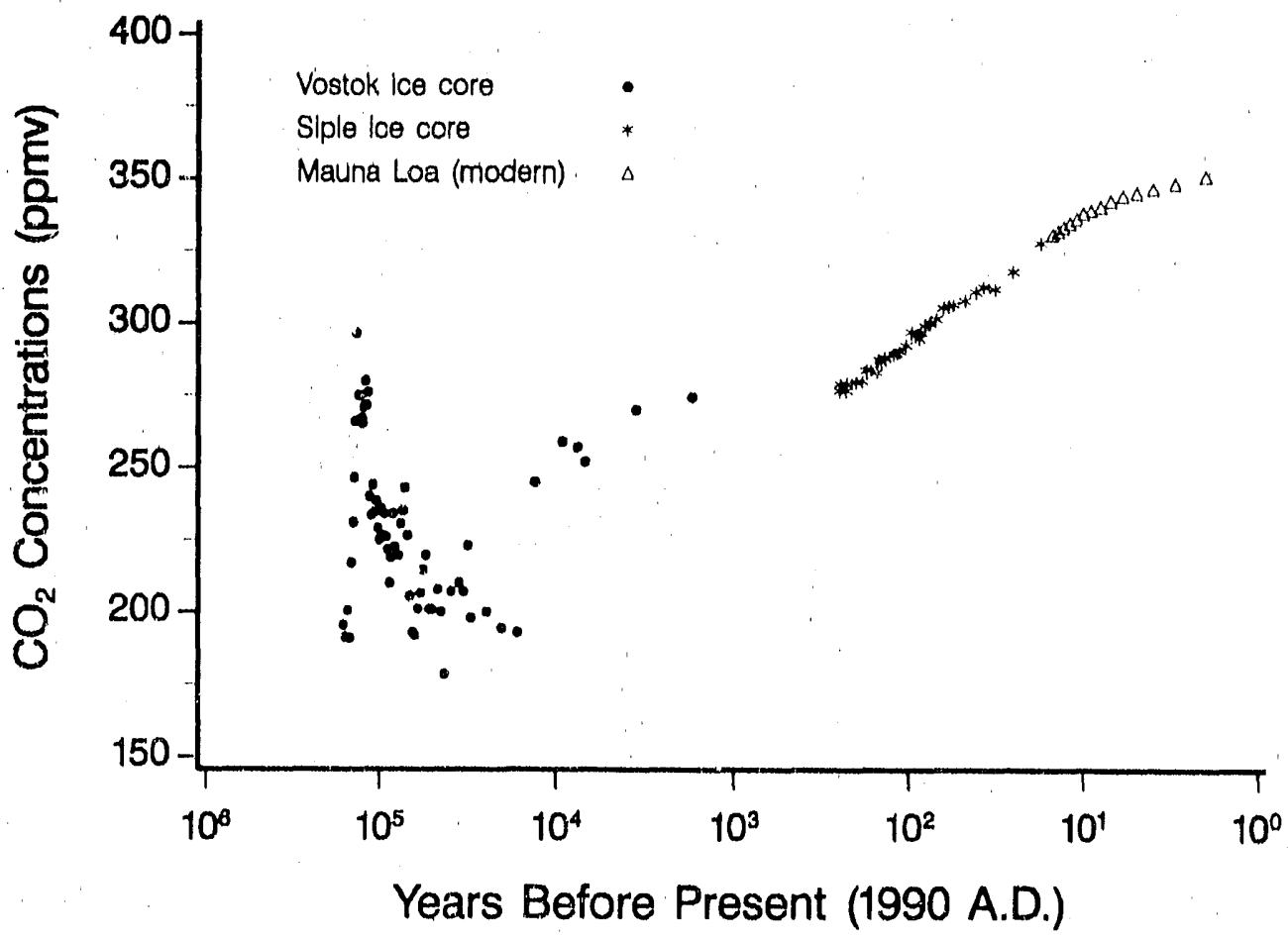

Annual atmospheric $\mathrm{CO}_{2}$ concentrations during the past 160,000 years (derived from the Vostok and Siple lice cores and Keeling's Mauna Loa record). 


\section{Vostok}

\begin{tabular}{|c|}
\hline BACKGROUND \\
\hline Principal investigators \\
\hline J. M. Bamola \\
\hline $\begin{array}{l}\text { D. Rayriaud } \\
\text { C. Lorius }\end{array}$ \\
\hline $\begin{array}{l}\text { Laboratoire de Glaciologie } \\
\text { et de Géophysique de l'Environnement }\end{array}$ \\
\hline $\begin{array}{l}38402 \text { Saint Martin d'Heres Cedex } \\
\text { France }\end{array}$ \\
\hline Y. S. Korotkevich \\
\hline Arctic and Antarctic Rescarch Institute \\
\hline Beringa Street 38 \\
\hline Leningrad 199226 \\
\hline U.S.S.R. \\
\hline Sponsoring agencies \\
\hline $\begin{array}{l}\text { Commission of the European Communitics } \\
\text { CNRS/PIREN }\end{array}$ \\
\hline Terres Australes et Antarctiques \\
\hline Francaises \\
\hline Soviet Antarctic Expeditions \\
\hline Method-Gas extraction and measurements \\
\hline $\begin{array}{l}\text { were performed with the "Grenoble } \\
\text { analytical setup" (Barnola et al. 1983) which }\end{array}$ \\
\hline \\
\hline $\begin{array}{l}\text { released during the crushing in a } \\
\text { pre-evacuated sampling loop, and analyzing }\end{array}$ \\
\hline $\begin{array}{l}\text { the } \mathrm{CO}_{2} \text { concentrations by gas chromatog- } \\
\text { raphy. For further details on the experi- }\end{array}$ \\
\hline $\begin{array}{l}\text { mental procedures and the dating of the } \\
\text { successive ice layers at Vostok, see Barnola } \\
\text { et al. (1987) and Lorius et al. (1985). }\end{array}$ \\
\hline $\begin{array}{l}\text { Calibration gases used-For each ice } \\
\text { sample measurement, the analytical system is } \\
\text { calibrated with a standard mixture of } \mathrm{CO}_{2} \text { in } \\
\text { nitrogen and oxygen. }\end{array}$ \\
\hline $\begin{array}{l}\text { Data availability-Contact CDIAC for } \\
\text { details on data and see Barnola et al. (1987). }\end{array}$ \\
\hline
\end{tabular}

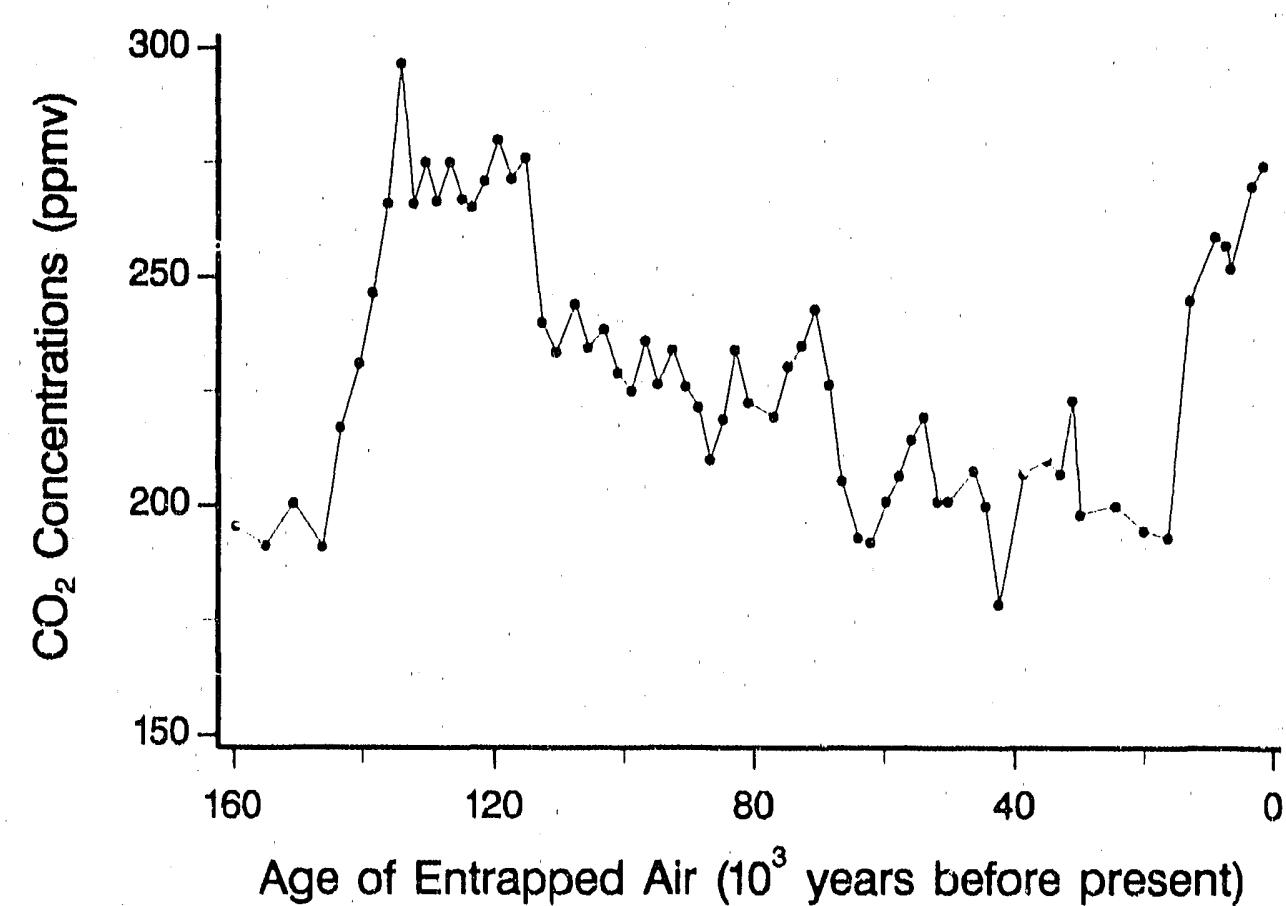

Atmospheric $\mathrm{CO}_{2}$ derived from the Vostok ice core.

Vostok

Antarctica

$78^{\circ} 28^{\prime} \mathrm{S}, 106^{\circ} 48^{\prime} \mathrm{E}$

$3488 \mathrm{~m}$ above $M S L$

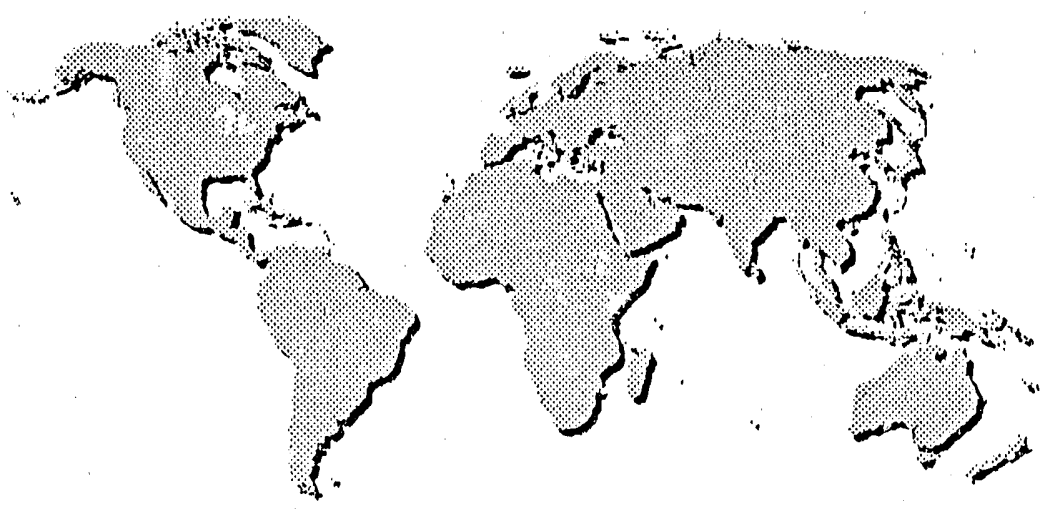

$\phi$ 


\section{Atmospheric $\mathrm{CO}_{2}$ from Ice Cores}

\section{TRENDS}

An atmospheric $\mathrm{CO}_{2}$ record over the past $160 \mathrm{kyr}$ has been obtained from the $2083-\mathrm{m}$ long ice core recovered by the Soviet Antarctica Expeditions at Vostok (East Antarctica). This $\mathrm{CO}_{2}$ record is probably the purest available, covering the last climatic cycle (Barnola et al, 1987). The Vostok ice core data have been compared with other ice core data (Delmas et al. 1980; Neftel et al. 1982) for the past 30-40 kyr and there is good agreement between these records, with all showing low $\mathrm{CO}_{2}$ values $(-200$ ppmv) during the Last Glacial Maximum and increased atmospheric $\mathrm{CO}_{2}$ concentrations associated with the glacial-Holocene transition. Barnola et al. (1987) found that over the 160,000 -year time scale there is a high correlation between $\mathrm{CO}_{2}$ concentrations and Antarctic climate, with significant oscillatory behavior of $\mathrm{CO}_{2}$ between high levels during interglacial periods and low levels during glacial periods. Barnola et al. (1987) reported that long-term $\mathrm{CO}_{2}$ changes are dominated by marked glacial-interglacial oscillations between $\sim 190-200$ and $260-280$ ppmv and that a period of $\sim 20 \mathrm{kyr}$ similar to the orbital precession period appears in the decreasing $\mathrm{CO}_{2}$ trend covering most of the last glaciation and is supported by spectral analysis. 


\section{Atmospheric Concentrations of Carbon Dioxide from Ice Cores}

\begin{tabular}{|c|c|c|c|c|c|c|c|}
\hline $\begin{array}{l}\text { Depth } \\
\text { (m) }\end{array}$ & $\begin{array}{l}\text { Age of } \\
\text { the ice } \\
\text { (yr BP) }\end{array}$ & $\begin{array}{l}\text { Mean } \\
\text { age of } \\
\text { the air } \\
\text { (yr BP) }\end{array}$ & $\begin{array}{c}\mathrm{CO}_{2} \\
\text { concentration } \\
\text { (ppmiv) }\end{array}$ & $\begin{array}{l}\text { Depth } \\
\text { (m) }\end{array}$ & $\begin{array}{l}\text { Age of } \\
\text { the ice } \\
\text { (yr BP) }\end{array}$ & $\begin{array}{l}\text { Mean } \\
\text { age of } \\
\text { the alr } \\
\text { (yr BP) }\end{array}$ & $\begin{array}{c}\mathrm{CO}_{2} \\
\text { concentration } \\
\text { (ppmv) }\end{array}$ \\
\hline 126.4 & 4,050 & 1,700 & 274.5 & 1274.2 & 87,980 & 84,700 & 218.8 \\
\hline 173.1 & 5,970 & 3,530 & 270.0 & 1299.3 & 89,940 & 86,680 & 210.0 \\
\hline 250.3 & 9,320 & 6,800 & 252.0 & 1322.5 & 91,760 & 88,520 & 221.5 \\
\hline 266.0 & 10,040 & 7,500 & 257.0 & 1349.0 & 93,860 & 90,630 & 226.0 \\
\hline 302.6 & 11,870 & 9,140 & 259.0 & 1374.8 & $\$ 5,910$ & 92,700 & 234.0 \\
\hline 375.6 & 16,350 & 12,930 & 245.0 & 1402.5 & 98,130 & 94,940 & 226.5 \\
\hline 426.4 & 20,330 & 16,250 & 193.0 & 1425.5 & 100,000 & $96,81 \rho$ & 236,0 \\
\hline 474.2 & 24,280 & 20,090 & 194.5 & 1451.5 & 102,210 & 98,950 & 225.0 \\
\hline 525.1 & 28,530 & 24,390 & 200.0 & 1476.1 & 104,410 & 101,040 & 229.0 \\
\hline 576.0 & 32,680 & 29,720 & 198.0 & 1499.6 & 106,610 & 103,130 & 238.5 \\
\hline 602.3 & 34,770 & 30,910 & 223.0 & 1526.3 & 109,240 & 105,620 & 2.34 .5 \\
\hline 625.6 & 36,600 & 32,800 & 207.0 & 1547.0 & 111,250 & 107,650 & 244.0 \\
\hline 651.6 & 38,600 & 34,870 & 210.0 & 1575.2 & 113,850 & 110,510 & 233.5 \\
\hline 700.3 & 42,320 & 38,660 & 207.0 & 1598.0 & 115,850 & 112,700 & 240.0 \\
\hline 748.3 & 45,970 & 42,310 & 178.5 & 1626.5 & 118,220 & 115,290 & 276.0 \\
\hline 775.2 & 48,000 & 44,350 & 200.0 & 1651.0 & 120,170 & 117,410 & 271.5 \\
\hline 800.0 & 49,850 & 46,220 & 207.7 & 1676.4 & $12,2,100$ & 119,500 & 280.0 \\
\hline 852.5 & 53,770 & 50,150 & 201.0 & 1700.9 & 123,900 & 121,430 & 271.0 \\
\hline 874.3 & 55,450 & 51,770 & 201.0 & 1726.8 & 125,730 & 123,380 & 265.3 \\
\hline 902.2 & 57,660 & 53,860 & 219.5 & 1747,3 & 127,150 & 124,880 & 267.0 \\
\hline 926.8 & 59,670 & 55,780 & 214.5 & 1774.1 & 129,020 & 126,770 & 275.0 \\
\hline 951.9 & 61,790 & 57,800 & 206.5 & 1802.4 & 131,030 & 128,780 & 266.5 \\
\hline 975.7 & 63,880 & 59,770 & 201.0 & 1825.7 & 132,700 & 130,460 & 275.0 \\
\hline 1002.5 & $6 \times 5,230$ & 62,080 & 192.0 & 1850.5 & 134,510 & 132,280 & 266.0 \\
\hline 1023.5 & 68,040 & 63,960 & 193.0 & 1875.9 & 136,450 & 134,170 & 296.5 \\
\hline 1052,4 & 70,470 & 66,540 & 205.5 & 1902,0 & 138,660 & 136,170 & 266.0 \\
\hline 1074.8 & 72,330 & 68,490 & 226.5 & 1928.0 & 141,170 & 138,410 & 246.5 \\
\hline 1101.4 & 74,500 & 70,770 & 243.0 & 1948.7 & 143,440 & 140,430 & 231.0 \\
\hline 1124.2 & 76,330 & 72,690 & 235.0 & 1975.3 & 146,860 & 143,370 & 217.0 \\
\hline 1148.7 & 78,270 & 74,720 & 230.5 & 1998.0 & 150,330 & 146,340 & 191.0 \\
\hline 1175.0 & 80,320 & 76,860 & 219.5 & 2025.7 & 154,980 & 150,700 & 200.5 \\
\hline 1225.7 & 84,220 & 80,900 & 222.5 & 2050.3 & 159,100 & 154,970 & 191.3 \\
\hline 1251.5 & 86,220 & 82,920 & 234.0 & 2077.5 & $163,670^{\circ}$ & 159,690 & 195.5 \\
\hline
\end{tabular}




\section{Atmospheric $\mathrm{CO}_{2}$ from Ice Cores}

\section{REFERENCES}

Barnola, J.M., D. Raynaud, A. Neftel, and H. Oeschger. 1983. Comparison of $\mathrm{CO}_{2}$ measurements by two laboratories on air bubbles in polar ice. Nature 303:410-13. Barnola, J.M., D. Raynaud, Y.S.

Korotkevich, and C. Lorius. 1987. Vostok ice core provides 160,000 -year record of atmospheric $\mathrm{CO}_{2}$. Nature 329:408-14.

Delmas, R.J., J.-M. Ascencio, and M. Legrand. 1980. Polar ice evidence that atmospheric $\mathrm{CO}_{2} 20,000$ yr BP was $50 \%$ of present. Nature 284:155-57.

Lorius, C., J. Jouzel, C. Ritz, L. Merlivat, N.I. Barkov, Y.S. Korotkevich, and V.M. Kotly:kov. 1985. A 150,000-year climatic record from Antarctic ice. Nature 316:591-96.

Neftel, A., H. Oeschger, J. Schwander, B. Stauffer, and R. Zumbrunn. 1982. Ice core measurements give atmospheric $\mathrm{CO}_{2}$ content during the past $40,000 \mathrm{yr}$. Nature 295:220-23.

Neftel, A., E. Moor, H. Oeschger, and B. Stauffer. 1985. Evidence from polar ice cores for the increase in atmospheric $\mathrm{CO}_{2}$ in the past two centuries. Nature 315:45-47. Raynaud, D., and J.M. Barnola. 1985. An Antarctic ice core reveals atmospheric $\mathrm{CO}_{2}$ variations over the past few centuries. Nature 315:309-11.

Schwander, J., and B. Stauffer. 1984. Age difference between polar ice and the air trapped in its bubbles. Nature 311:45-47. 


\section{Siple Station}

\begin{tabular}{|c|}
\hline BACKGROUND \\
\hline Princlpal investigators \\
\hline A. Neftel H. Friedll \\
\hline E. Moor $\quad$ H. Lötscher \\
\hline H. Oeschger U. Siegenthaler \\
\hline B. Stauffer \\
\hline Physics Institute \\
\hline University of Bern \\
\hline CH-3012 Bern \\
\hline Switzerlana \\
\hline Sponsoring agencies \\
\hline Swiss National Foundation \\
\hline National Science Foundation \\
\hline Department of Polar Programs \\
\hline U.S. Department of Energy \\
\hline Carbon Dioxide Research Program \\
\hline University of Bern \\
\hline Period of record $-1734-1983$ \\
\hline $\begin{array}{l}\text { Method-Measurements were made on a } \\
200 \text {-m ice core drilled in the Antarctic } \\
\text { summer of } 1983-84 \text { at Siple Station in West } \\
\text { Antarctica. The gases from ice samples were } \\
\text { extracted by a dry-extraction system, in which } \\
\text { bubbles are crushed mechanically to release } \\
\text { the trapped gases, and then analyzed for } \mathrm{CO}_{2} \\
\text { by infrared laser absorption spectroscopy or } \\
\text { by gas chromatography. For further details, } \\
\text { see Neftel et al. (1985) and Friedli et al. } \\
(1984) \text {. }\end{array}$ \\
\hline $\begin{array}{l}\text { Calibration Gases used-The analytical } \\
\text { system is calibrated for each ice sample } \\
\text { measurement with a standard mixture of } \mathrm{CO}_{2} \\
\text { in nitrogen and oxygen. }\end{array}$ \\
\hline $\begin{array}{l}\text { Data availability - These data are availablo } \\
\text { from CDIAC and the principal investigators } \\
\text { and have been published in Neftel et al. } \\
\text { (1985) and Friedli et al. (1986). }\end{array}$ \\
\hline
\end{tabular}

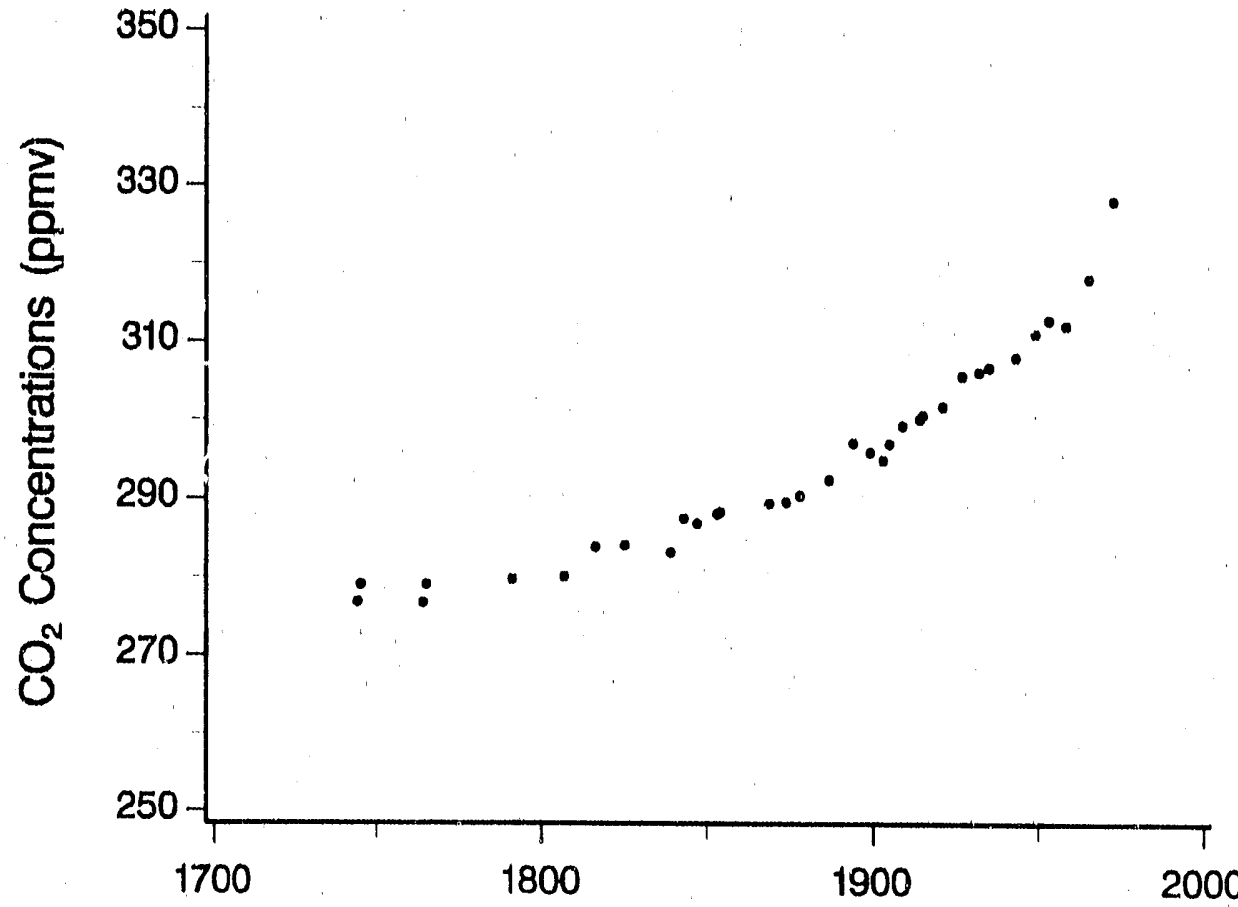

Atmospheric $\mathrm{CO}_{2}$ concentrations derived from the Siple ice core.

Siple Station

West Antarctica

$75^{\circ} 55^{\prime} S, 83^{\circ} 55^{\prime} \mathrm{W}$
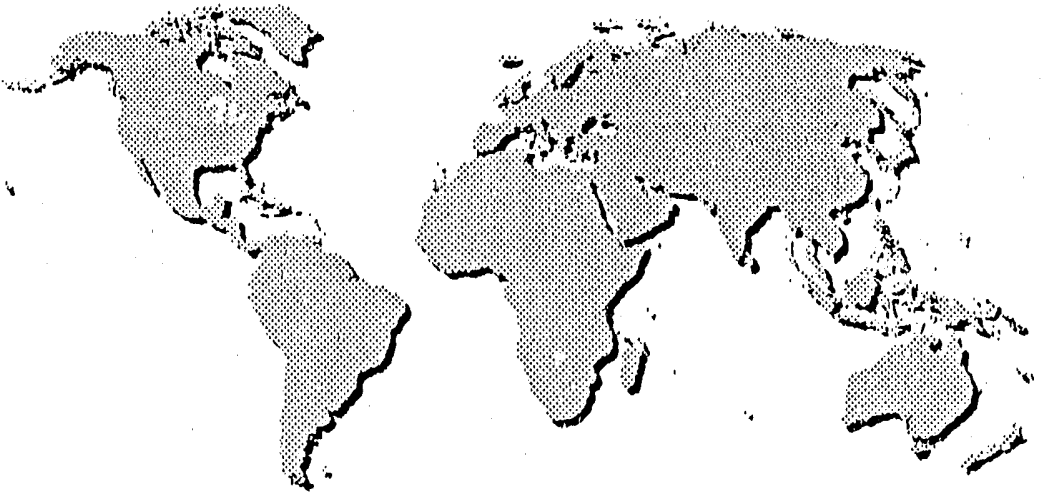


\section{Atmospheric $\mathrm{CO}_{2}$ from Ice Cores}

\section{TRENDS}

An atmospheric $\mathrm{CO}_{2}$ record for the past 200 years has been obtained from the Siple ice core. At shallow depths atmospheric air still circulates through the open pores (Friedli et al. 1986). The enclosed air is younger than the surrounding ice, because the enclosure of air in bubbles occurs only between depths of 64 and $76 \mathrm{~m}$. Based on porosity measurements, the time lag between the mean age of the gas and the age of the ice was determined to be 95 years and the duration of the close-off process to be 22 years (Schwander and Stauffer 1984). Neftel et al. (1985) concluded that the atmospheric $\mathrm{CO}_{2}$ concentration circa 1750 was $280 \pm 5$ ppmy and has increased by $22,5 \%$ since then to 345 ppmv in 1984 , essentially because of human factors. Friedli et al. (1986) also reported graphically that the pre-industrial (pre-1800) $\mathrm{CO}_{2}$ concentration was $\sim 280$ ppmv. 


\section{Siple Station}

\section{Atmospheric Concentrations of Carbon Dioxide from Ice Cores*}

$\begin{array}{ccccc}\begin{array}{c}\text { Depth } \\ (\mathbf{m})\end{array} & \begin{array}{c}\text { Samples } \\ \text { measured }\end{array} & \begin{array}{c}\text { Date of } \\ \text { ice } \\ \text { (yr A.D.) }\end{array} & \begin{array}{c}\text { Date } \\ \text { alr enclosed } \\ \text { (yr A.D.) }\end{array} & \begin{array}{c}\mathbf{C O}_{2} \\ \text { concentration in } \\ \text { cxtracted air } \\ \text { (ppmv) }\end{array} \\ 68.2-68.6 & 8 & 1891 & 1962-1983 & 328 \pm 3.5 \\ 72.4-72.7 & 11 & 1883 & 1954-1976 & 318 \pm 3.0 \\ 76.2-76.6 & 11 & 1876 & 1947-1969 & 312 \pm 3.0 \\ 82.0-83.0 & 28 & 1867 & 1938-1960 & 311 \pm 3.0 \\ 92.0-93.0 & 25 & 1850 & 1921-1943 & 306 \pm 3.0 \\ 102.0-103.0 & 26 & 1832 & 1903-1925 & 300 \pm 3.0 \\ 111.0-112.0 & 26 & 1812 & 1883-1905 & 297 \pm 3.0 \\ 128.0-129.0 & 47 & 1782 & 1842-1864 & 288 \pm 3.0 \\ 147.0-147.2 & 10 & 1743 & 1814-1836 & 284 \pm 3.0 \\ 162.0-162.3 & 9 & 1723 & 1794-1819 & 280 \pm 3.0 \\ 177.0-177.3 & 10 & 1683 & 1754-1776 & 279 \pm 3.0 \\ 187.0-187.3 & 10 & 1663 & 1734-1756 & 279 \pm 3.0\end{array}$

"Data published in Neftel et al, (1985).

\section{Atmospheric Concentrations of Carbon Dioxide from Ice Cores*}

$\begin{array}{cccccc}\begin{array}{c}\text { Average } \\ \text { depth }\end{array} & \begin{array}{c}\text { Gas age } \\ \text { (m) }\end{array} & \begin{array}{c}\mathbf{C O}_{2} \\ \text { Concentration } \\ \text { (ppmv) }\end{array} & \begin{array}{c}\text { Average } \\ \text { depth } \\ (\mathbf{m})\end{array} & \begin{array}{c}\text { Gas age } \\ \text { (yr A.D.) }\end{array} & \begin{array}{c}\text { CO2 } \\ \text { concentration } \\ \text { (ppmv) }\end{array} \\ 187.70 & 1744 & 276.8 & 116.82 & 1887 & 292.3 \\ 177.50 & 1764 & 276.7 & 110.20 & 1899 & 295.8 \\ 168.30 & 1791 & 279.7 & 108.80 & 1903 & 294.8 \\ 154.89 & 1816 & 283.8 & 107.20 & 1.905 & 296.9 \\ 142.75 & 1839 & 283.1 & 105.25 & 1909 & 299.2 \\ 140.75 & 1843 & 287.4 & 101.80 & 1915 & 300.5 \\ 138.20 & 1847 & 286.8 & 98.80 & 1921 & 301.6 \\ 134.47 & 1854 & 288.2 & 95.17 & 1927 & 305.5 \\ 126.80 & 1869 & 289.3 & 9077 & 193.5 & 306.6 \\ 123.80 & 1874 & 289.5 & 86.80 & 1943 & 307.9 \\ 121.80 & 1878 & 290.3 & 81.22 & 1953 & 312.7\end{array}$

\footnotetext{
*Data published in Friedli et al. (1986).
} 


\section{Atmospheric $\mathrm{CO}_{2}$ from Ice Cores}

\section{REFERENCES}

Barnola, J.M., D. Raynaud, A. Neftel, and H. Oeschger. 1983. Comparison of $\mathrm{CO}_{2}$ measurements by two laboratories on air bubbles in polar ice. Nature 303:410-13. Barnola, J.M., D. Raynaud, Y.S.

Korotkevich, and C. Lorius. 1987. Vostok ice core provides 160,000 -year record of atmospheric $\mathrm{CO}_{2}$. Nature 329:408-14. Friedli, H., E. Moor, H. Oeschger, U. Siegenthaler, and B. Stauffer. 1984. Ratios in $\mathrm{CO}_{2}$ extracted from Antarctic ice. Geophysical Research Letters 11:1145-48. Fricdli, H., H. Lötscher, H. Oeschger, U. Siegenthaler, and B. Stauffer. 1986. Ice core recond of ${ }^{13} \mathrm{C} /{ }^{12} \mathrm{C}$ ratio of atmospheric $\mathrm{CO}_{2}$ in the past two centuries. Nature 324:237-38.

Lorius, C., J. Jouzel, C. Ritz, L. Meriivat, N.I. Barkov, Y.S. Korotkevich, and V.M. Kotlyakov. 1985. A 150,000-year climatic record from Antarctic ice, Nature 316:591-96.

Neftel, A., H. Oeschger, J. Schwander, B. Stauffer, and R. Zumbrunn. 1982. Ice core measurements give atmospheric $\mathrm{CO}_{2}$ content during the past $40,000 \mathrm{yr}$. Nature 295:220-23.

Neftel, A., E. Moor, H. Oeschger, and B. Stauffer. 1985. Evidence from pclar ice cores for the increase in atmospheric $\mathrm{CO}_{2}$ in the past two centuries. Nature 315:45-47. Raynaud, D., and J.M. Barnola. 1985. An Antarctic ice core reveals atmospheric $\mathrm{CO}_{2}$ variations over the past few centuries. Nature 315:309-11.

Schwander, J., and B. Stauffer. 1984. Age difference between polar ice and the air trapped in its bubbles. Nature 311:45 47 . 


\section{Mauna Loa}

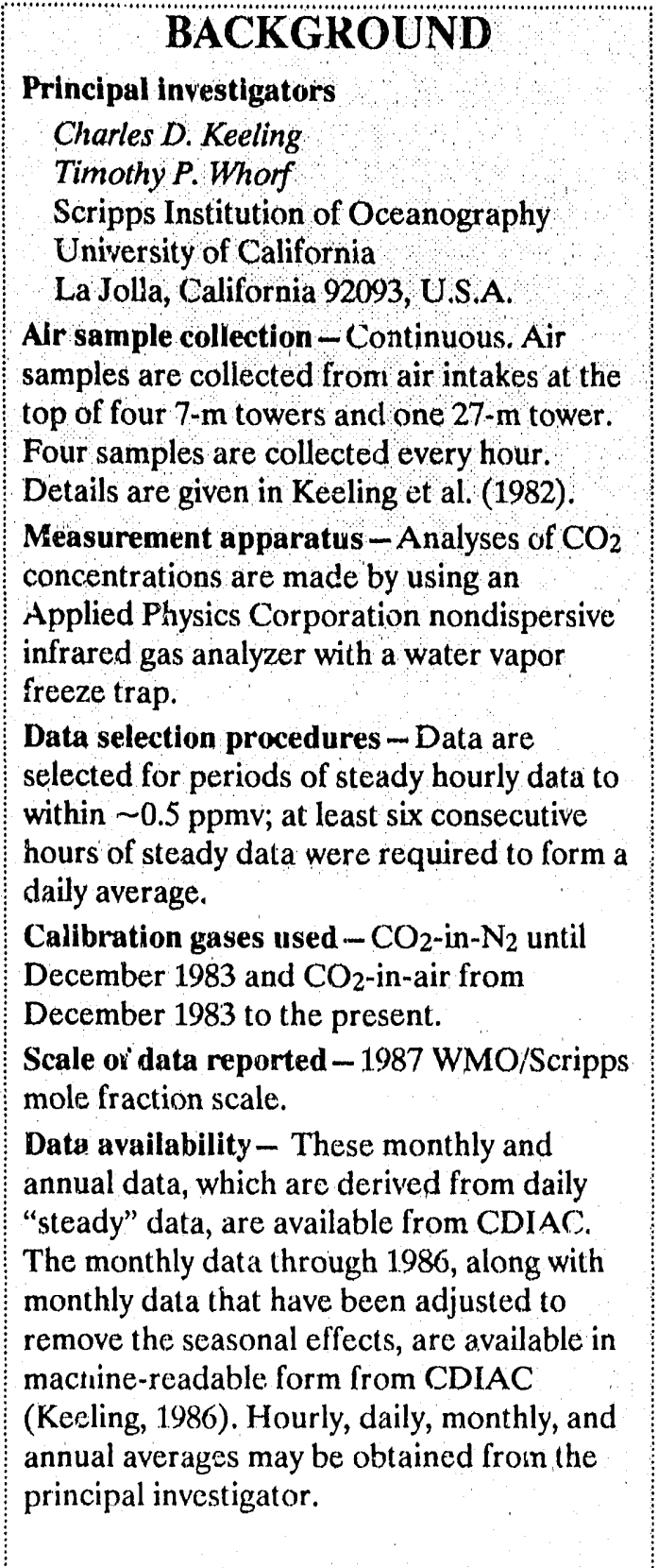

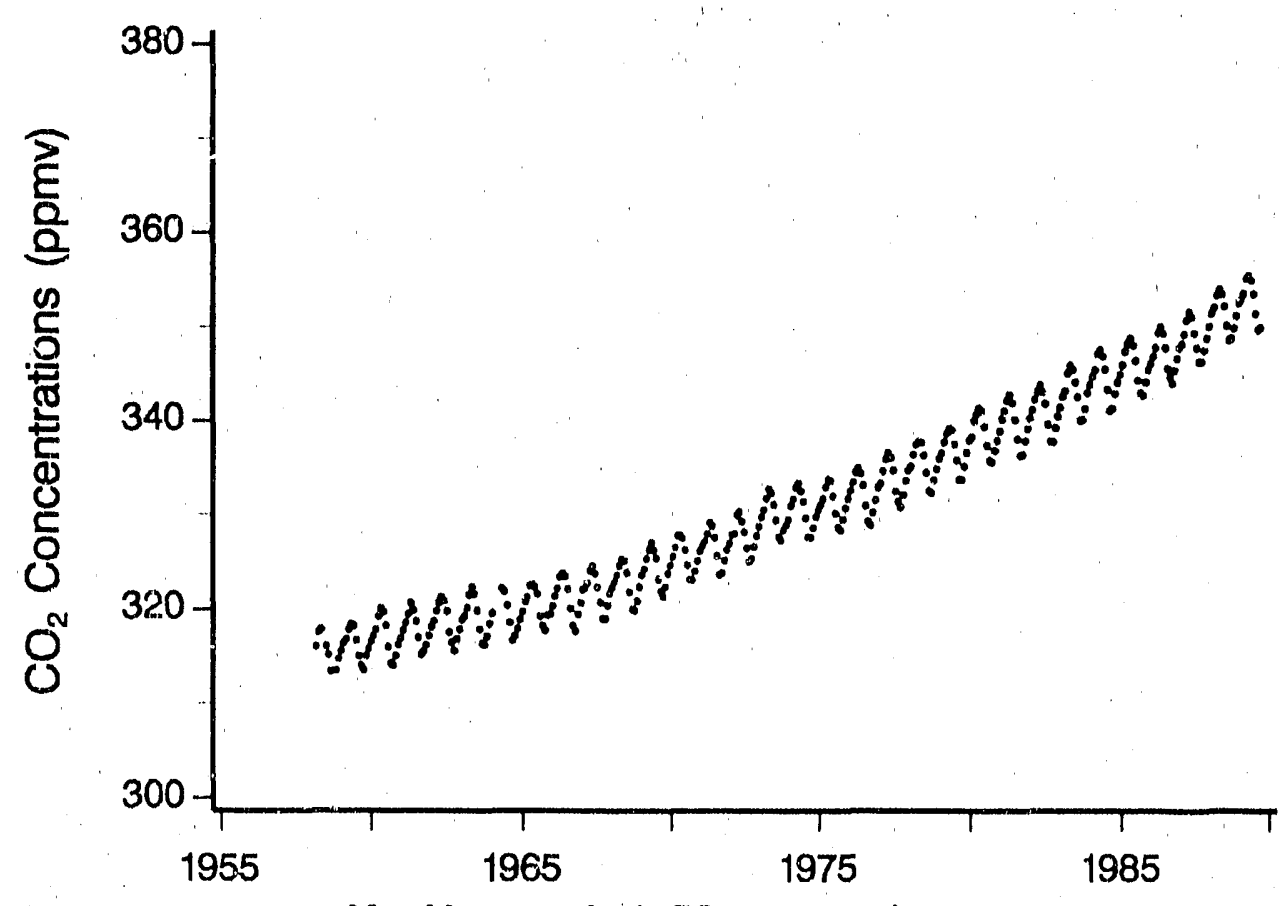

Monthly atmospheric $\mathrm{CO}_{2}$ concentrations.

Mauna Loa Observatory Hawaii, U.S.A.

Barren lava field of an active volcano $19^{\circ} 32^{\prime} \mathrm{N}, 155^{\circ} 35^{\prime} \mathrm{W}$ $3397 \mathrm{~m}$ above $M S L$ 


\section{TREND}

The Mauna Loa atmospheric $\mathrm{CO}_{2}$ measurements constitute the longest continuous record of atmospheric $\mathrm{CO}_{2}$ concentrations available in the world. The Mauna Loa site is considered one of the most favorable locations for measuring undisturbed air because possible local influences of vegetation or human activities on atmospheric $\mathrm{CO}_{2}$ concentrations are considered minimal and any influences from volcanic vents may be excluded from the records. The methods and equipment used to obtain these measurements have been essentially unchanged over the 31-year record.

Because of the favorable site location, continuous monitoring, and careful selection and scrutiny of the data, the Mauna Loa record is considered to be a precise record and a reliable indicator of the regional trend in the concentrations of atmospheric $\mathrm{CO}_{2}$ in the middle layers of the troposphere. The Mauna Loa record shows a 12 percent increase in the mean annual concentration in 31 years, from 315 parts per million by volume of dry air (ppm) in 1958 to 352 in 1989 (Keeling et al. 1989). 


\section{Atmospheric Concentrations of Carbon Dioxide*}

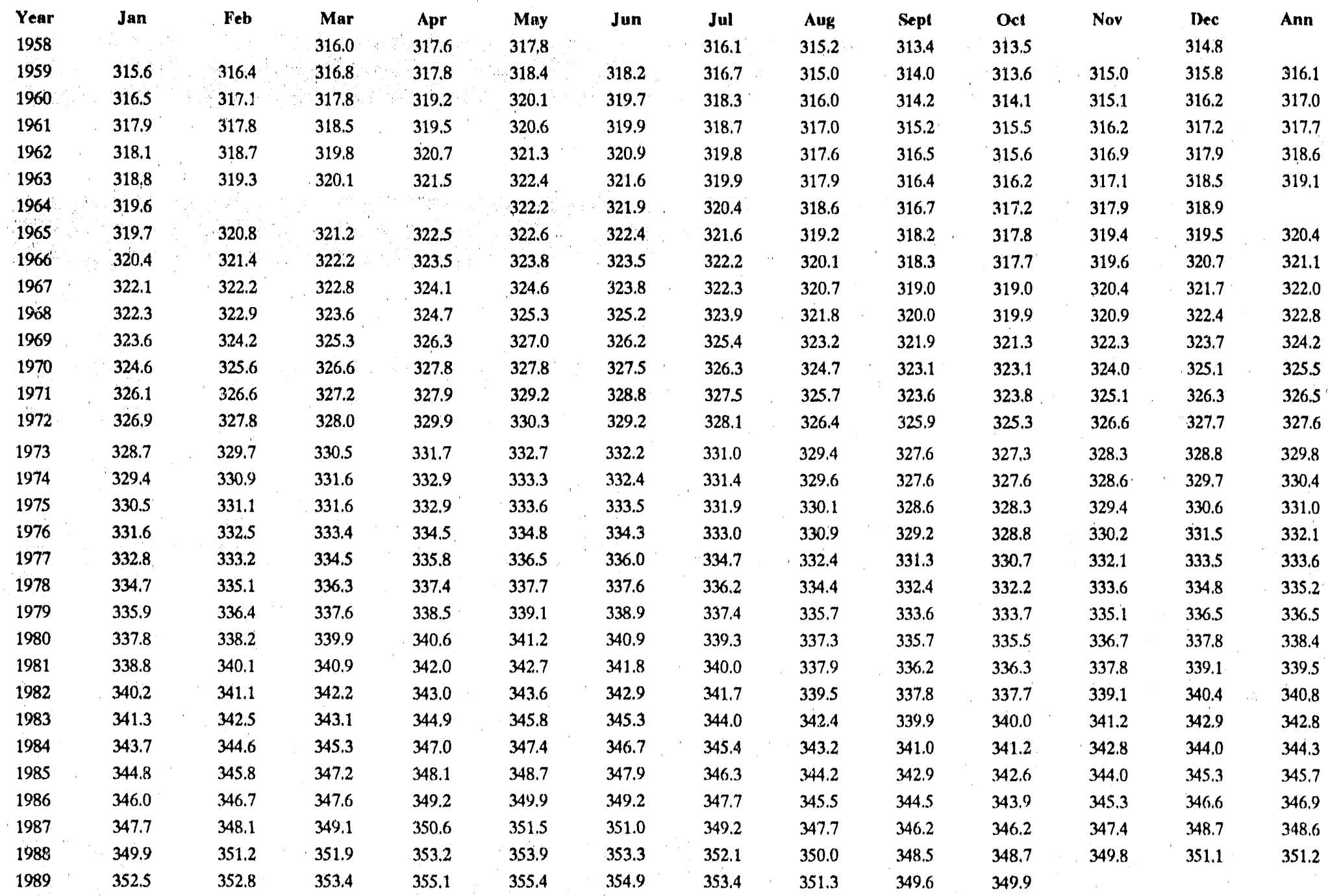

*Atmospheric $\mathrm{CO}_{2}$ in parts per million by volume (ppmv). Annual averages based on monthly means. All numbers have been rounded to the nearest tenth. 


\section{Atmosphoreric ( ()$_{2}$}

\section{REFLRENCES}

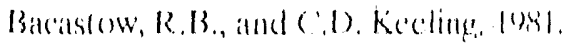

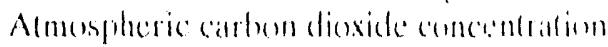
and the ohserved anderme frastion.

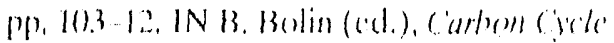

Mondelling, Sc(o)l'b lo. dohn Wiley and

Sons, New York.

Basastow, R.B., (..D. Kecling, and 'T.P.

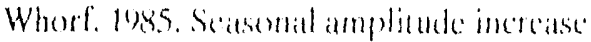

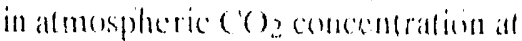

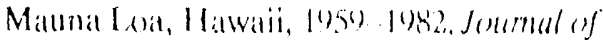

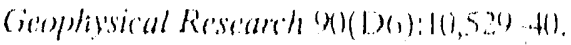

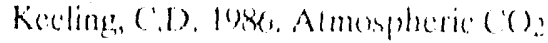

concentrations -.. Matuma lona ()hecervaters.

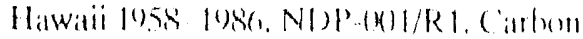

bioxide Information Analysis ('enter ()ath

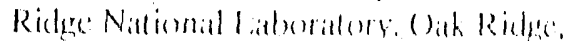

P'ennessece.

Kecling, ('D., R.B. Barraslew, A.I:

Banturidge, ('A. likelahl, lt., P.K.

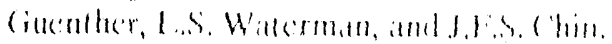

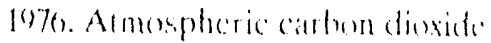

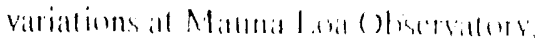

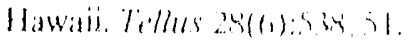

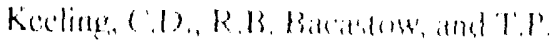

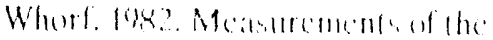

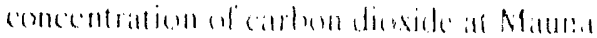

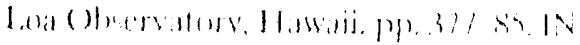

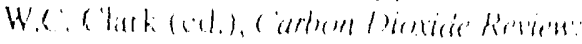

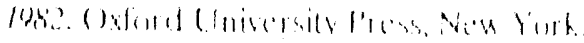

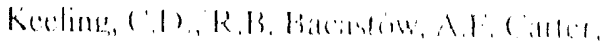

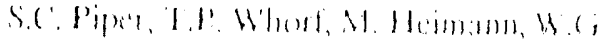

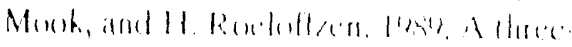

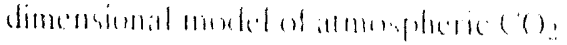

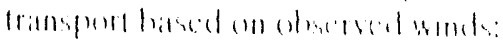

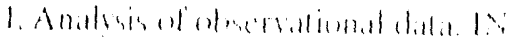

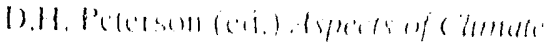

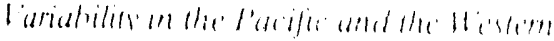

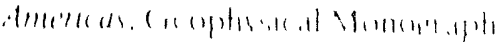
in lail : 


\section{American Samoa}

\section{BACKGROUND \\ Principal investigator \\ Charles D. Keeling \\ Scripps Institution of Oceanography \\ University of California \\ La Jolla, California 92093, U.S.A.}

Air sample collection -- Air samples are collected in 5-L evacuated glass flasks exposed in triplicate weekly.

Measurement apparatus - Flask samples are measured for $\mathrm{CO}_{2}$ concentration at Scripps Institution of Oceanography by using an Applied Physics Corporation nondispersive infrared gas analyzer with water vapor freeze trap.

Data selection procedures - Concentrations of replicate flask samples must agrec within $0.40 \mathrm{ppm} v$ to be accepted.

Calibration gases used $-\mathrm{CO}_{2}-\mathrm{in}-\mathrm{N}_{2}$ un' il May 1983 and $\mathrm{CO}_{2}$-in-air from May 1983 to the present.

Scale of data reported - 1985 WMO/Scripps mole fraction scale.

Data availability - These monthly and annual values, as well as the individual flask concentrations, may be obtained from the principal investigator. The monthly and annual values are available from CDIAC.

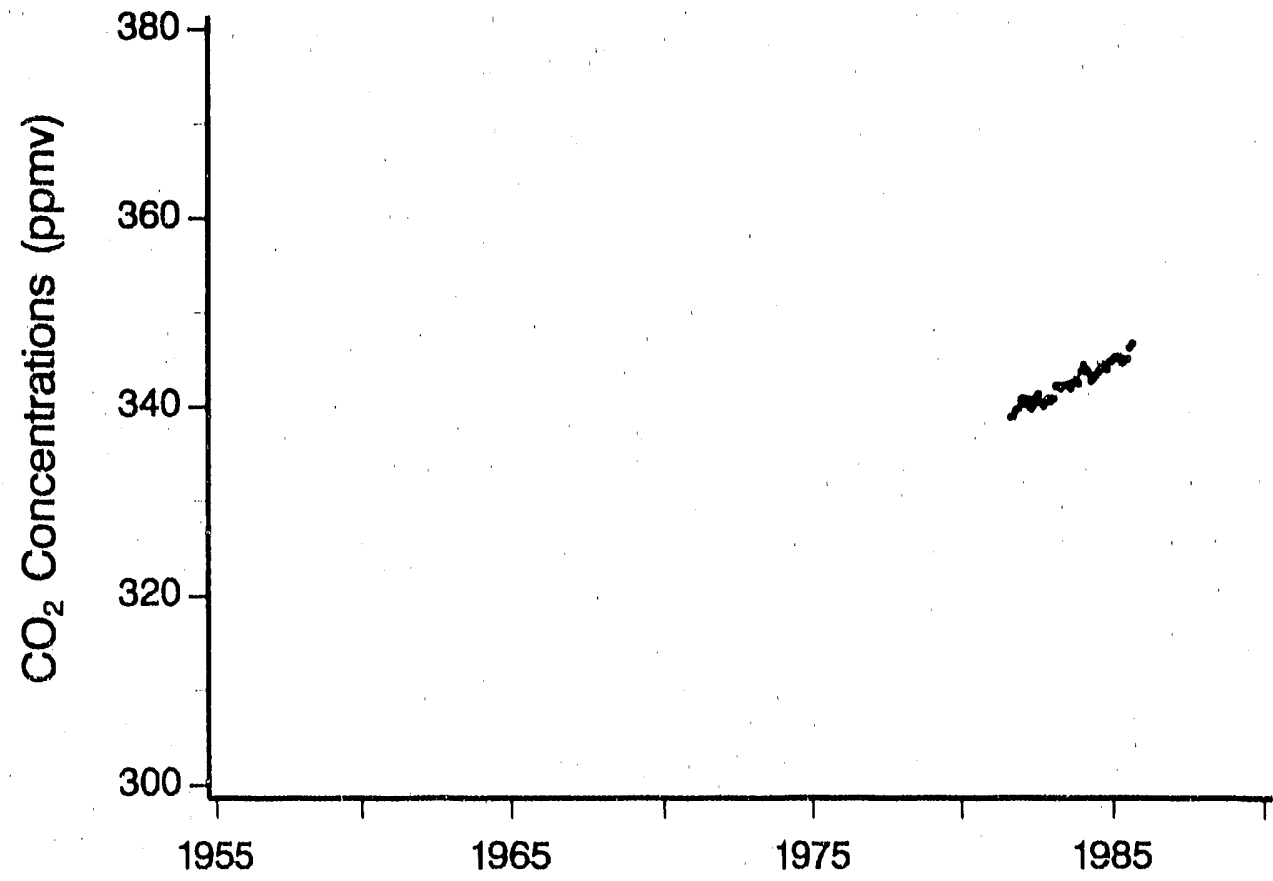

Monthly atmospheric $\mathrm{CO}_{2}$ concentrations.

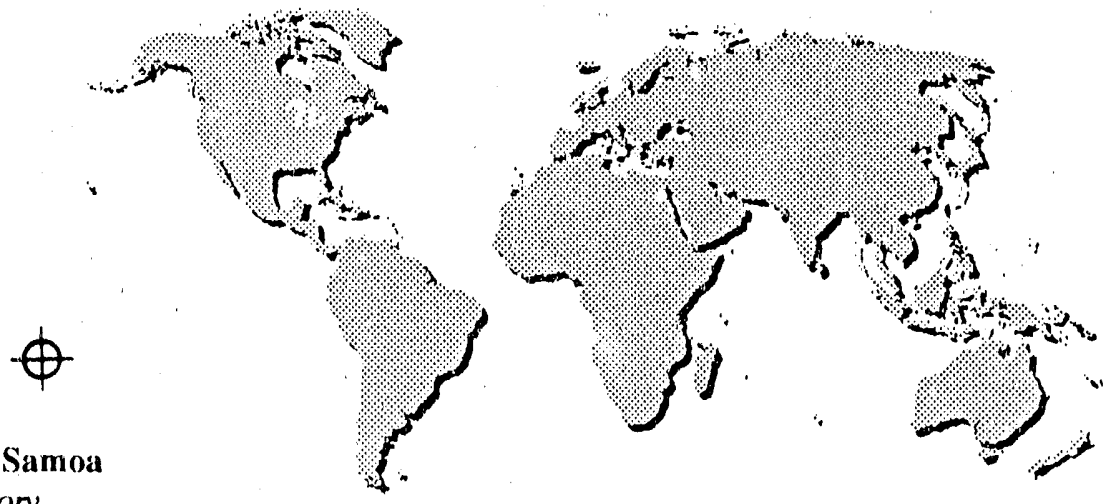

American Samoa

U.S. Territory

Rocky coastal promontory

$14^{\circ} 15^{\prime} \mathrm{S}, 170^{\circ} 34^{\prime} \mathrm{W}$

$30 \mathrm{~m}$ above $M S L$ 


\section{Atmospheric $\mathrm{CO}_{2}$}

\section{TREND}

A monitoring project to observe the sea-level climate and atmospheric constituents of the tropical Southern Hemisphere was established by NOAA at Cape Matatula, American Samoa, in 1973. NOAA operates both a continuous monitoring program (Waterman et al. 1989) and a flask sampling (Conway et al. 1988) program at Cape Matatula. Scripps Institution of Oceanography (SIO) has also collected flask samples at American Samoa independently of NOAA since 1981.

Since 1981, the annual average concentration of $\mathrm{CO}_{2}$, based on flask samples collected by SIO, has risen from 339.2 ppmv to 345.3 ppmv in 1985. This represents an annual growth rate of 1.2 ppmv per year at American Samoa. For comparison, Conway et al. (1988) reported an annual growth rate of 1.35 ppmv at American Samoa for 1981-1984 on the basis of flask data from the NOAA/CMDL flask sampling prograrn. 


\section{American Samoa}

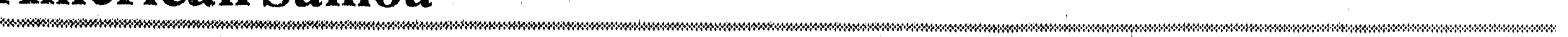

$\begin{array}{llllllllllllll}\text { Year } & \text { Jan } & \text { Feb } & \text { Mar } & \text { Apr } & \text { May } & \text { Jun } & \text { Jul } & \text { Aug } & \text { Sept } & \text { Oct } & \text { Nov } & \text { Dec } & \text { Ann } \dagger \\ 1981 & & & & & & & & & 338.8 & 338.9 & 339.5 & 339.7 & 339.2 \\ 1982 & 340.6 & 340.8 & 340.1 & 340.7 & 339.7 & 340.0 & 340.9 & 341.2 & 340.3 & 340.0 & 340.4 & 340.8 & 340.5 \\ 1983 & 340.5 & 340.8 & 342.1 & 342.2 & 341.9 & 342.2 & 342.2 & 342.3 & 341.9 & 342.5 & 342.8 & 342.4 & 342.0 \\ 1984 & 343.6 & 344.3 & 343.9 & 343.5 & 342.7 & 343.0 & 343.3 & 343.7 & 344.4 & 344.0 & 343.9 & 344.6 & 343.7 \\ 1985 & 344.8 & 345.1 & 345.2 & 345.2 & 344.6 & 344.8 & 345.0 & 346.2 & 346.6 & & & & 345.3\end{array}$

*Average monthly concentration, accepted data. Atmospheric $\mathrm{CO}_{2}$ concentrations in parts per million by volume (ppmv). $\uparrow$ Annual averages based on available monthly means. 


\section{Atmospheric $\mathrm{CO}_{2}$}

$1 e^{*}$

in't

19.2

10.5

12.1

13.7

1.5 .3

\section{REFERENCES}

Bacustow, R.B. 197\%. Dip in the atmosplacric (C) $)_{2}$ level cluring the mid-19(r)'s. Iomernal of (isophysical Resisearch 8(0:3100) 14 .

Bacastow, R.B., and (.,D). Keoling, 1981. Almospheric carbori dioxide concentration and the obscrved airborne fraction. pp).

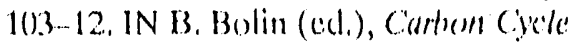
Modelling, SC. SPli 16. John Wiley and Sinns, New York.

Conway, T.J., P. Tans, L.S. Walcrman, K.W. Thoning, K.A. Masarice, and R.H. Cammon. 1988. Atmospherie caibon diexide meatsurements in the remote global troposplicre, 1083 - 19844. Tellas (H) (B) $: 81 \ldots 115$.

Keeling, (.D. D. 196(). The concentration and isotopic abundance of canbon dioxide in the atmosphere. Tellas 12:2(x)-2(1)3.

Keeling, C.D., R.B. Bacastow, A.F. Carter, S.C. Piper, T.P. Whotf, M. Heimann, W. (i. Mook, and H. Kocloffacen. 1989. A threedimensional model of almogheric ( $\left.{ }^{\prime}\right)_{2}$ transport based on observe. winds:

1. Analysis of observational dala. IN D.H. Peterson (ed.) Aspects of Climate Variability in the Pacific: and the Hestern Americase Cicophysical Monograph $55: 16,5-2.235$.

Watcrman, L.S., D.W. Nelson, W.D. Komhyr, T.B. Harris, K.W. Thoning, and P.P. Tans, 1989. Atmospheric carbon dioxide meastrements at Cape Matalula, American Samoa, 1976-1987. Jommal of (ieophysical Research (94(D12): 14817-2). 


\section{Point Barrow}

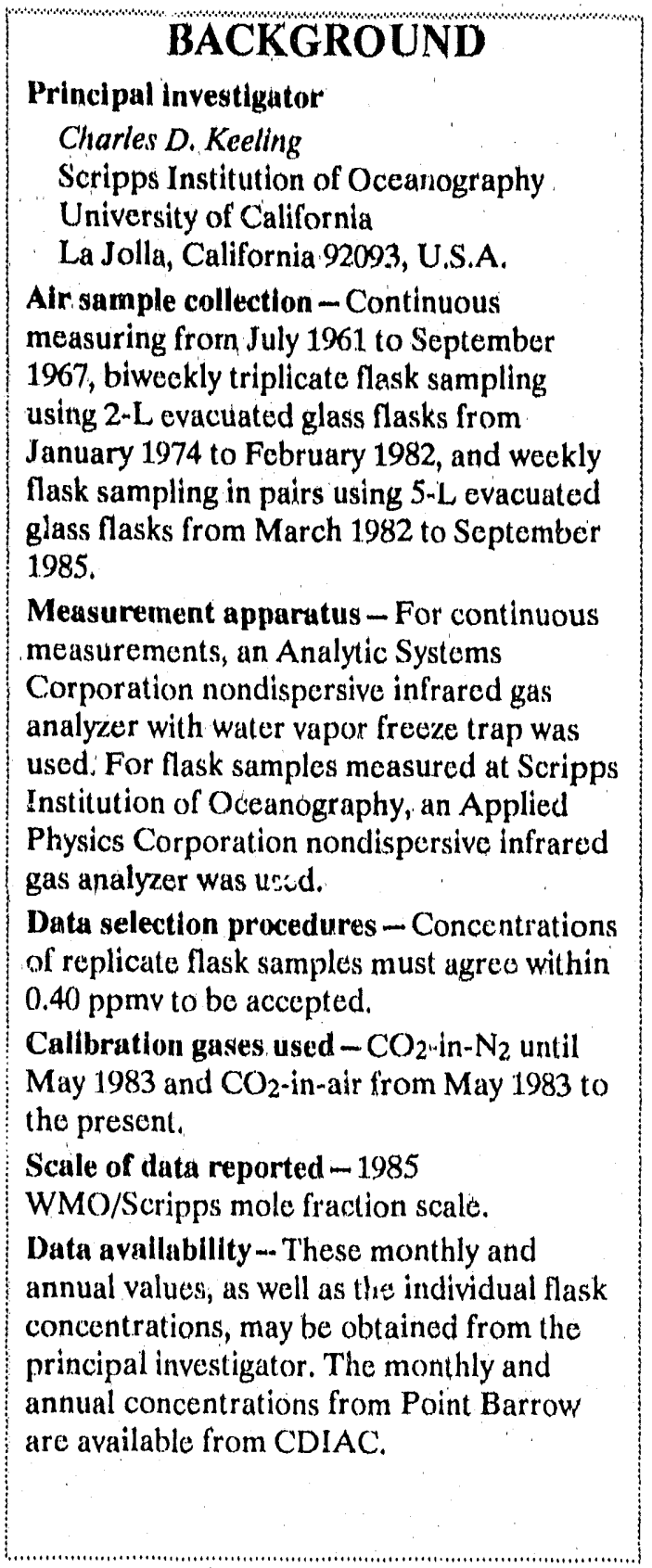

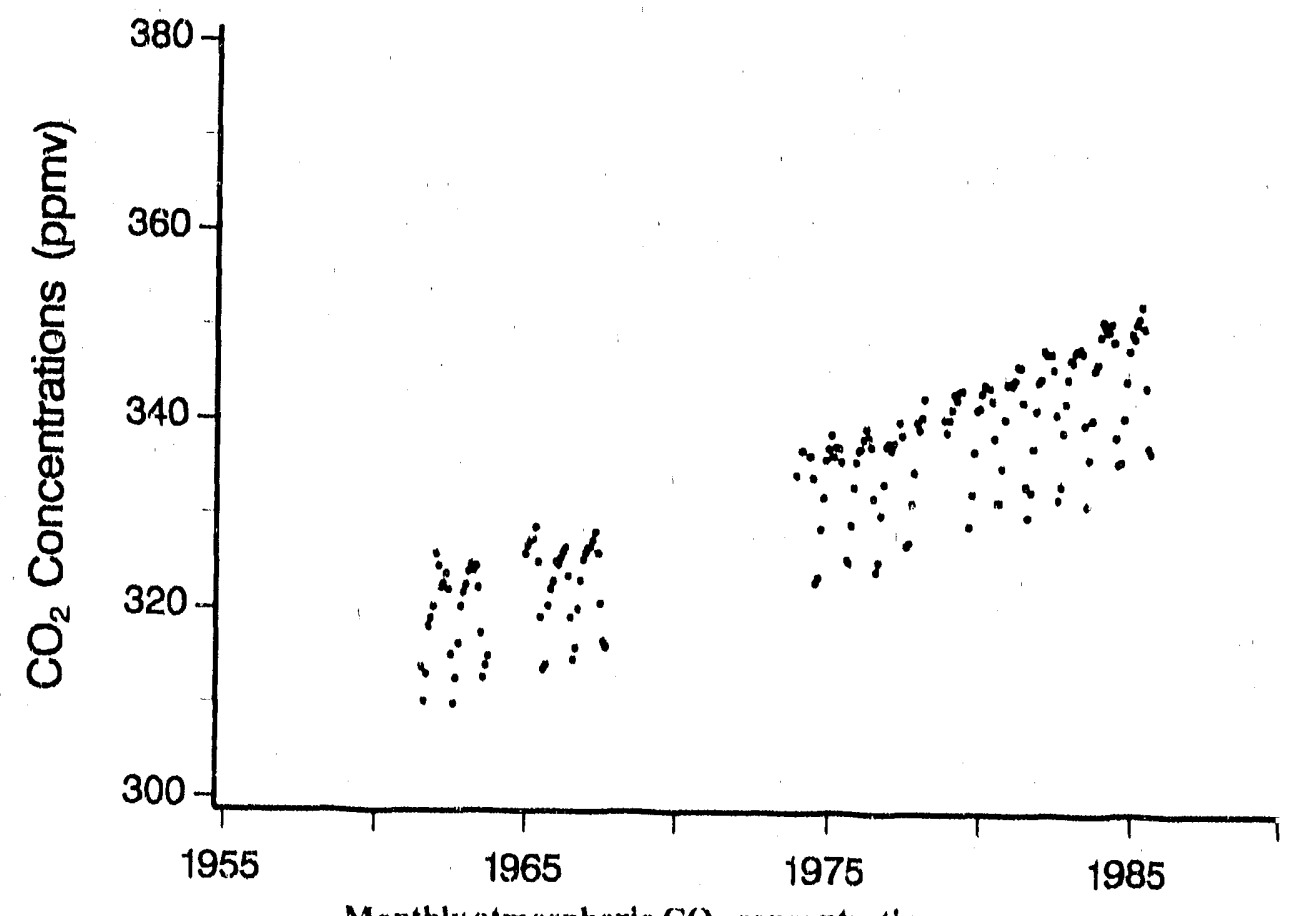

Monthly atmospheric $\mathrm{CO}_{2}$ concentrations.

Point Barrow

Alaska, U.S.A.

On the coast of the

Arctic ocean

$71^{\circ} 19^{\prime} \mathrm{N}, 156^{\circ} 36^{\prime} \mathrm{W}$

$11 \mathrm{~m}$ above MSL 


\section{Atmospheric $\mathrm{CO}_{2}$}

\section{TREND}

Carbon dioxide was first measured at Barrow, Alaska, by Kelley and co-workers from the University of Washington during the 1960s (Kelley 1969). Their measurements with a continuously operating analyzer began in July 1961. From 1962 (which marks the first full year of monitoring atmospheric $\mathrm{CO}_{2}$ concentrations at Point Barrow, Alaska) to 1985 (which represents the last full year of data available at the time this report was compiled) the annual $\mathrm{CO}_{2}$ concentration rose from 319.7 to $346.7 \mathrm{ppmv}$. The Point Barrow record is considered to be very accurate and indicative of maritime air masses. 


\section{Atmospheric Concentrations of Carbon Dioxide*}

\begin{tabular}{|c|c|c|c|c|c|c|c|c|c|c|c|c|c|}
\hline Year & Jan & Feb & Mar & Apr & May & Jun & Jul & Aug & Sept & Oct & Nov & Dec & Ann $\dagger$ \\
\hline 1961 & & & & & & & 313.8 & 310.2 & 313.1 & 318.1 & 319,0 & 320.2 & 315.7 \\
\hline 1962 & 325.8 & 324.5 & 322.2 & 322.7 & 323.7 & 322.0 & 315.1 & 309.9 & 312.6 & 316.3 & 320.2 & 321.7 & 319.7 \\
\hline 1963 & 322.5 & 323.9 & 324.7 & 324.0 & 324.5 & 322.2 & 317.4 & 312.7 & 314.0 & 315,0 & & & 320.1 \\
\hline \multicolumn{14}{|l|}{1964} \\
\hline 1965 & 325.8 & 326.7 & 327.2 & 327.3 & 328.6 & 324.9 & 319.1 & 313.6 & 314.1 & 320.3 & 32.2 .1 & 322.9 & 322.7 \\
\hline 1966 & 325.0 & 324.7 & 325.4 & 326.0 & 326.5 & 323.5 & 319.1 & 314.7 & 315.9 & 320.0 & 323.0 & 325.2 & 322.4 \\
\hline 1967 & 325.9 & 326.4 & 326.5 & 327.2 & 328.1 & 325.9 & 320.6 & 316.6 & 316.0 & & & & 323.7 \\
\hline 1968 & & & & & & & & & & & & & \\
\hline \multicolumn{14}{|l|}{1969} \\
\hline \multicolumn{14}{|l|}{1970} \\
\hline \multicolumn{14}{|l|}{1971} \\
\hline \multicolumn{14}{|l|}{1972} \\
\hline \multicolumn{14}{|l|}{1973} \\
\hline 1974 & 334.3 & & 336.9 & & & 336.3 & 334.0 & 322.9 & 323.5 & 328.6 & 331.9 & 335.9 & 331.6 \\
\hline 1975 & 337.1 & 338.6 & 336.3 & 337.3 & 337.2 & 335.8 & & 325.4 & 325.1 & 329.1 & 333.1 & 335.8 & 333.7 \\
\hline 1976 & 337.0 & 337.2 & 338.2 & 339.3 & 338.4 & 337.4 & 332.0 & 324.2 & 325.2 & 330.2 & 333.5 & 337.5 & 334.2 \\
\hline 1977 & 337.8 & 337.1 & 337.8 & & 340.0 & 338.6 & & 326.9 & 327.2 & 331.4 & 334.7 & 340.0 & 335.1 \\
\hline 1978 & 339.2 & 340.5 & 342.5 & & & & & & & & 340.3 & 339.0 & 340.3 \\
\hline 1979 & 340.3 & 341.4 & 343.0 & 342.4 & 343.3 & 343.4 & & & 329.0 & 332.4 & 336.9 & 341.3 & 339.3 \\
\hline 1980 & 341.5 & 343.1 & 344.0 & & 343.7 & 342.3 & 338.4 & 331.6 & 331,6 & 335.2 & 340,4 & 344.1 & 339.6 \\
\hline 1981 & 344.2 & 344.0 & 344.5 & 346.0 & 345.9 & 342.2 & 333.3 & 330.0 & 332.7 & 337.3 & 341.3 & 344.3 & 340.5 \\
\hline 1982 & 344.6 & 347.7 & 347.3 & 347.3 & 347.3 & 345.7 & 340.9 & 331.9 & 333,3 & 339.0 & 342.1 & 344.7 & 342.6 \\
\hline 1983 & 346.7 & 346.5 & 347.5 & 347.8 & 347.9 & 347.5 & 339.9 & 331.3 & 336.2 & 340.4 & 345.7 & 346.3 & 343,6 \\
\hline 1984 & 349.2 & 350.8 & 350.2 & 349.7 & 350.5 & 348.6 & 338.5 & 335.7 & 335.9 & 340.5 & 344.4 & 347.7 & 345.1 \\
\hline 1985 & 349.5 & 349.0 & 350.5 & 351.1 & 352.4 & 350.1 & 343.8 & 337.4 & 336.9 & & & & 346.7 \\
\hline
\end{tabular}

*Average monthly concentration, accepted data. Atmospheric $\mathrm{CO}_{2}$ concentrations in parts per million by volume (ppmv).

†Annual averages based on available monthly means. 


\section{Atmospheric $\mathrm{CO}_{2}$}

\section{REFERENCES}

bacastow, R. B. 19\%(1). Dip in the

IIt atmosplueric (.) level during the mid-1)(r)'s. Jomrnal of (ienplepsical Reserearch 8():31(x)- 14.

Bacastow, R.B., and ('.D. Kocling, 1)81. Almospherice carbon diexide concentration and the observed airberne fraction. P). 10.3 12. IN B. Bulin (ed.), Curbem Cyele Modelling, SC (c)Pli 16. Juhn Wiley and Solls, Now York.

Keeling, (․). 1984. Almosipheric and aceanographic moasturements needed for establishment of a dala base for carlom diexide from fossil liuels. ppr. 11- 2.2. IN The l'olemeial Eifferess of carben) Dionicle Indenced Climatic Changess in

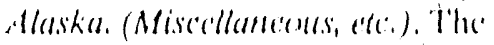
Procecedings of a conference bairbintis,

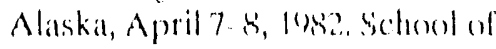
Agrriculeure and i and Resonteres Management, Lniversily ol Alaskat, Pairlounks.

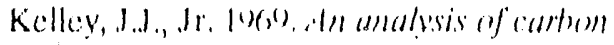

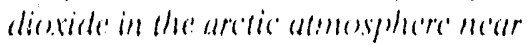

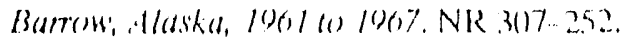

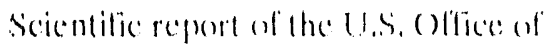
Naveal Research, Washingrton D.C. Pelc,som, l, T., W.1), Kumbyr, T, B, Marris, and 1..S. Waterman. I082. Almospheric: cartem dioxick meatsidrements at Barrows, Alaska, 1073 1970. Tellas 34:10(1) 175.

Pelcrson, I.T, W.I), Komhyr, I.s.

Walcrmin, R.H, (iammon, K.W. Thoming, and T.J, Conwaly, IOSO. Almospherice (.0) variallons at Barrow, Alaskal, 10\%.3. 11882.

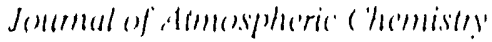
$1: 4(1) 1510$. 


\section{BACKGROUND \\ Principal investigator \\ Charles D. Keeling \\ Scripps Institution of Oceanography \\ University of California \\ La Jolla, Callifornia 92093, U.S.A.}

Air sample collection - Biweekly flask sampling, except for the continuous in situ measurements between 1960) and 1963 (Keeling et al، 1976a and 1976b; Bacastow and Keeling 1981). Five-liter evacuated glass flasks are exposed as triplets biweekly. From 1957 until October of 1963, 5-L glass flasks were exposed as singlets or pairs biweekly.

Measurement apparatus - Air samples obtained by flask sampling (as well as those obtained from continuous monitoring) are analyzed for $\mathrm{CO}_{2}$ concentration at Scripps Institution of Oceanography by using an Applied Physics Corporation nondispersive infrared gas analyzer with a water vapor freeze trap.

Data selection procedures - Concentrations of replicate flask samples must agree within 0.40 pprnv to be accepted.

Calibration gases used $-\mathrm{CO}_{2}$-in- $\mathrm{N}_{2}$ until March 1.983 and $\mathrm{CO}_{2}$-in-air from March 1983 to the present.

Scale of data reported -1985

WMO/Scripps mole fraction scale.

Data availability - These monthly and annual values, as well as the daily concentrations, may be obtained from the principal investigator. The monthly anci annual data are available from CDIAC and have been published in Keeling et al. (1989).

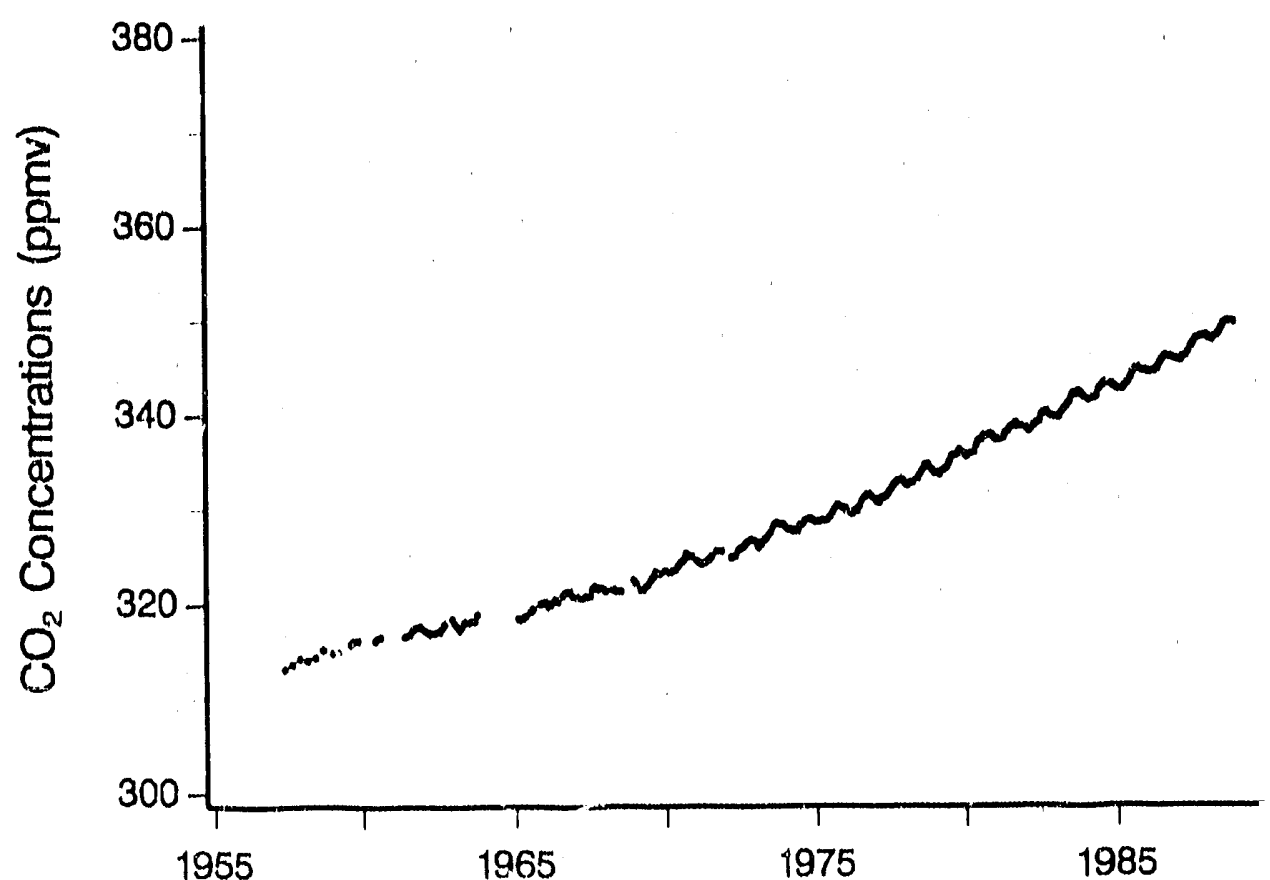

Monthly atmospheric $\mathrm{CO}_{2}$ concentrations.

South Pole

Antarctica

Ice- and snow-covered platean

$89^{\circ} 59^{\prime} \mathrm{S}, 24^{\circ} 48^{\prime} \mathrm{W}$

$2810 \mathrm{~m}$ above $M S L$ 


\section{Atmospheric $\mathrm{CO}_{2}$}

\section{TREND}

Precise measurements of atmospheric $\mathrm{CO}_{2}$ at the South pole have been obtained by Scripps Institution of Oceanography (SIO) since 1957. This record is based primarily on biweekly flask sampling. Since 1975, NOAA has also conducted continuous in situ measurements of atmospheric $\mathrm{CO}_{2}$ at the South Pole (Gillette et al, 1987) as part of the CMDL program.

The $\mathrm{SIO} \mathrm{CO}_{2}$ record from the South Pole shows that annual averages of atmospheric $\mathrm{CO}_{2}$ concentrations have risen from 313.7 ppmv in 1957 to 348.9 ppmv in 1988 . This represents an annual increase of $\sim 11 \mathrm{ppmv} /$ year. Keeling et al. (14/6a) reported that the seasonally adjusted concentration of atmospheric $\mathrm{CO}_{2}$ from the South Pole rose $3.7 \%$ between 1957 and 1971. Gillette et al. (1987) reported a mean annual $\mathrm{CO}_{2}$ increase of $1.32 \mathrm{ppmv}$ for 6 years $(1975-78,1980-82)$ from the South Pole. 
South Pole

\section{Atmospheric Concentrations of Carbon Dioxide*}

\begin{tabular}{|c|c|c|c|c|c|c|c|c|c|c|c|c|c|}
\hline Year & Jan & Feb & Mar & Apr & May & Jun & Jul & Aug & Sept & Oct & Nov & Dec & Annt \\
\hline 1957 & $\cdots$ & & ' & & $\therefore \quad$ & 313.2 & $\therefore$ & & 313.7 & $\cdots$ & & 314.3 & 313.7 \\
\hline 1958 & & & 314.1 & & & 314.4 & & & 315.2 & & & $\therefore$ & 314.5 \\
\hline 1959 & 314.9 & 315.0 & 314.9 & & & $\vdots$ & & 315.8 & 316.1 & & 316.2 & & 315.5 \\
\hline 1960 & & & & & & 316.2 & 316.5 & 316.6 & & & & & 316.4 \\
\hline 1961 & & & & & 316.5 & 316.7 & 316.8 & 317.2 & 317.5 & 317.6 & 317.7 & 317.5 & 317.2 \\
\hline 1962 & 317.3 & 317.1 & 316.9 & 317.0 & 317.0 & 317.1 & 317.1 & 317.5 & 317.9 & : & $\cdot$ & 318.5 & 317.3 \\
\hline 1963 & 318.0 & 317.7 & 317.3 & 317.7 & 318.1 & 318.1 & 318.1 & 318.2 & 318.2 & 318.9 & & & 318.0 \\
\hline 1964. & & & & & & & & & & & . & & \\
\hline 1965 & & 318.5 & 318.4 & 318.5 & 318.7 & & 319.2 & 319.5 & & & 320.0 & 320.1 & 319.1 \\
\hline 1966 & 320.2 & 319.8 & 319.9 & 320.2 & 320.5 & 320.3 & & 320.9 & 321.2 & 321.3 & 321.4 & 320.9 & 320.6 \\
\hline 1967 & & 320.8 & & 320.7 & 320.8 & 320.8 & 320.9 & 3217 & 321.9 & 321.6 & 321.7 & 321.6 & 321.3 \\
\hline 1968 & 321.4 & & & 321.5 & 321.3 & 321.3 & 321.3 & & & & & 322.5 & 321.6 \\
\hline 1969 & 322.2 & & 321.5 & 321.5 & 321.8 & 322.0 & 322.5 & 322.8 & 323.4 & 323.2 & 323.2 & & 322,4 \\
\hline 1970 & 323.5 & 323.4 & 323.3 & 323.5 & 323.6 & 324.0 & 324.3 & 324.6 & 325.3 & 325.0 & 325.1 & & 324.1 \\
\hline 1971 & 324.6 & 324.4 & 324.2 & 324.3 & 324.5 & 324.7 & 325.0 & & 325,6 & & 325.6 & $\therefore$ & 324.8 \\
\hline 1972 & & & 324.9 & 325.0 & 325.1 & 325.7 & 326.0 & 326.0 & 326.4 & 326.6 & 326.8 & 326,7 & 325.9 \\
\hline 1973 & 326.6 & 326.0 & 326.2 & 326.7 & 326.9 & 327.3 & 327.6 & 328.2 & 328.5 & 328.5 & 328.4 & 328.4 & 327.4 \\
\hline 1974 & 328.1 & 327.9 & 327.9 & 327.7 & 327.8 & 327.7 & 328.3 & 328.5 & 328.8 & 328.9 & 329.0 & 328.8 & 328.3 \\
\hline 1975 & 328.7 & 328.7 & 328.7 & 328.8 & 328.8 & 328.9 & 329.2 & 329.7 & 330.1 & 330.4 & 330.3 & 330.1 & 329.4 \\
\hline 1976 & 330.1 & 329.8 & 329.7 & 329.5 & 329.8 & 329.8 & 330.3 & 330.9 & 331.2 & 331.5 & 331.6 & 331.3 & 330,5 \\
\hline 1977 & 331.1 & 330.8 & 330.7 & 331.2 & 331.2 & 331.5 & 331.9 & 332.3 & 332.7 & 332.9 & 333.1 & 333.0 & 331.9 \\
\hline 1978 & 332.7 & 332.5 & 332.7 & 332.8 & & 333.2 & 333.7 & 334.1 & 334.6 & 334.7 & 334.4 & 334.1 & 333.6 \\
\hline 1979 & 333.8 & 333.9 & 333.7 & 334.0 & 334.2 & 334.4 & 335.0 & 335.6 & 335.7 & 335.8 & 336.2 & 335.9 & 334.8 \\
\hline 1980 & 335.9 & 335.6 & & 335.9 & 336,0 & 336.7 & 337.3 & 337.4 & 337.7 & 337.7 & 337.8 & 337.9 & 336.9 \\
\hline 1981 & 337.6 & 337.3 & 337.3 & 337.4 & 337.5 & 338.0 & 338.2 & 338.6 & 338.7 & 339.0 & 338.7 & 338.7 & 338.1 \\
\hline 1982 & & 338.5 & 338.2 & 338.5 & 338.8 & 339.0 & 339.2 & 339.9 & 340.1 & 340.2 & 339.9 & 339.8 & 339.3 \\
\hline 1983 & 339.7 & 339.7 & 339.7 & 340.1 & 340.5 & 340.8 & $341: 2$ & 341.7 & 342.2 & 342.1 & 342.4 & 342.2 & 341.0 \\
\hline 1984 & 341.9 & & 341.5 & 341.7 & 341.7 & 341.9 & 342.6 & 343.0 & 343.3 & 343.3 & 343.1 & 343.0 & 342.5 \\
\hline 1985 & 342.8 & 342.6 & 342.6 & 342.6 & 343.0 & 343.3 & 343.8 & 344.4 & 344.7 & 344.8 & 344.6 & 344.5 & 343.6 \\
\hline 1986 & 344.5 & 344.4 & 344.4 & 344.5 & 344.5 & 344.9 & 345.4 & 345.8 & 346.1 & 346.0 & 346.0 & 345.9 & 345.2 \\
\hline 1987 & 345.8 & 345.7 & 345.6 & 346.0 & 346.1 & 346.5 & 347.1 & 347.5 & 347.9 & $348: 0$ & 348.1 & 348.2 & 346.9 \\
\hline 1988 & 348.2 & 347.9 & 347.8 & 348.1 & 348.2 & 348.5 & 349.0 & 349.5 & 349.7 & 349.8 & 349.8 & 349.7 & 348.9 \\
\hline 1989 & 349.8 & & & & & & & & & & & & \\
\hline
\end{tabular}

*Entries express averages of daily values (in ppm) adjusted to the 15 th of each month. All numbers have been rounded by CDIAC to the nearest tenth. †Annual averages based on available monthly means. 


\section{Atmospheric $\mathrm{CO}_{2}$}

\section{REFERENCES}

Bacastow, R.B., and C.D. Keeling. 1981.

Atmospheric carbon dioxide concentration and the observed airborne fraction.

pp. 103-12. IN B. Bolin (ed.), Carbon Cycle

Modelling, SCOPE 16. John Wiley and Sons, New York.

317.2

317.3

318.0

319.1

320.6

321.3

321.6

322.4

324.1

Bacastow, R.B., J.A. Adams, Jr., C.D.

Keeling, D.J. Moss, T.P. Whorf, and C.S.

Wong. 1980. Almospheric carbon dioxide, the Southern Oscillation, and the weak 1975 El Niño. Science 210:66-68.

Brown, C.W., and C.D. Kecling. 1965. The concentration of atmospheric carbon dioxide in Antarctica. Journal of Geophysical Research 70:6077-85.

324.8

325.9

Gillette, D.A., W.D. Komhyr, L.S. Waterman, L.P. Stecle, and R.H. Gammon. 1987. The

327.4

328.3

329.4

330.5

331.9

333.6

334.8

336.9

3.38 .1

339.3

341.0

342.5

343.6

345.2

346.9

348.9 NOAA/GMCC continuous $\mathrm{CO}_{2}$ record at the South Pole, 1975-1982. Joumal of Geophysical Research 92(D4):4231-40). Keeling, C.D., J.A. Adams, Jr., C.A. Ekdahl, Jr., and P.R. Guenther, 1976a. Atmospheric carbon dioxide variations at the South Pole. Tellus 28:552-64.

Keeling, C.D., J.A. Adams, Jr., and C.A. Ekdahl, Jr. 1976b. Antarctic Carbon Dioxide Project, Report 5. Scripps Institution of Oceanography, La Jolla, California.

Kecling, C.D., R.B. Bacastow, A.F. Carter, S.C. Piper, T.P. Whorf, M. Heimann, W.G. Mook, and H. Roeloffen. 1989. A threedimensional model of atmospheric $\mathrm{CO}_{2}$ transport based on observed winds: 1. Analysis of observational dala. pp. 165 235. IN D.H. Peterson (ed.), Aspects of Climate Variability in the Pacific and the Westem Americas. (ieophysical Monograph, No. 55. Socicty of Exploration (icophysics, Tulsa, ()K. 


\section{Amundsen Scott}

\begin{tabular}{|c|}
\hline BACKGROUND \\
\hline Princlpal investigators \\
\hline Kin' W. Thoning \\
\hline Dale A. Gillette \\
\hline Walter D. Komhyr \\
\hline Pieter Tans: \\
\hline Lee S. Waterman \\
\hline Environmental Research Laboratories \\
\hline National oceanic and Atmospheric \\
\hline $\begin{array}{l}\text { Administration } \\
\text { Boulder, Colorado } 80303-3328, \text { U.S.A. }\end{array}$ \\
\hline $\begin{array}{l}\text { Alr sample collection-Air samples are } \\
\text { collected from a sample line } 13.5 \text { meters } \\
\text { above the snow surface and dried before } \\
\text { entering the analyzer. Details given in } \\
\text { Gillette et al. (1987). }\end{array}$ \\
\hline $\begin{array}{l}\text { Measurement apparatus - URAS-2T semi- } \\
\text { automatic nondispersive infrared gas ana- } \\
\text { lyzer manufactured by Hartmann and Braun. }\end{array}$ \\
\hline $\begin{array}{l}\text { Data selection procedures - Some data are } \\
\text { rejected immediately for various reasons } \\
\text { (e.g., lack of calibration data and linstrument } \\
\text { problems) using records kept by South Pole } \\
\text { personnel. After the initial selection process, } \\
\text { data are analyzed for short-term minute- } \\
\text { to-minute and hour-to-hour variations. } \\
\text { Algorithms have been written to remove } \\
\text { these short-term variations. For further } \\
\text { details see Gillette et al. (1987). }\end{array}$ \\
\hline Calibration gases used - $\mathrm{CO}_{2}$-in-air. \\
\hline $\begin{array}{l}\text { Scale of data reported - SIO X85 mole } \\
\text { fraction scale. }\end{array}$ \\
\hline $\begin{array}{l}\text { Data availability - These monthly } \mathrm{CO}_{2} \\
\text { concentrations from the South Pole are } \\
\text { available from CDIAC. They are also } \\
\text { available from the principal investigator at } \\
\text { NOAA/CMDL and WMO. }\end{array}$ \\
\hline
\end{tabular}

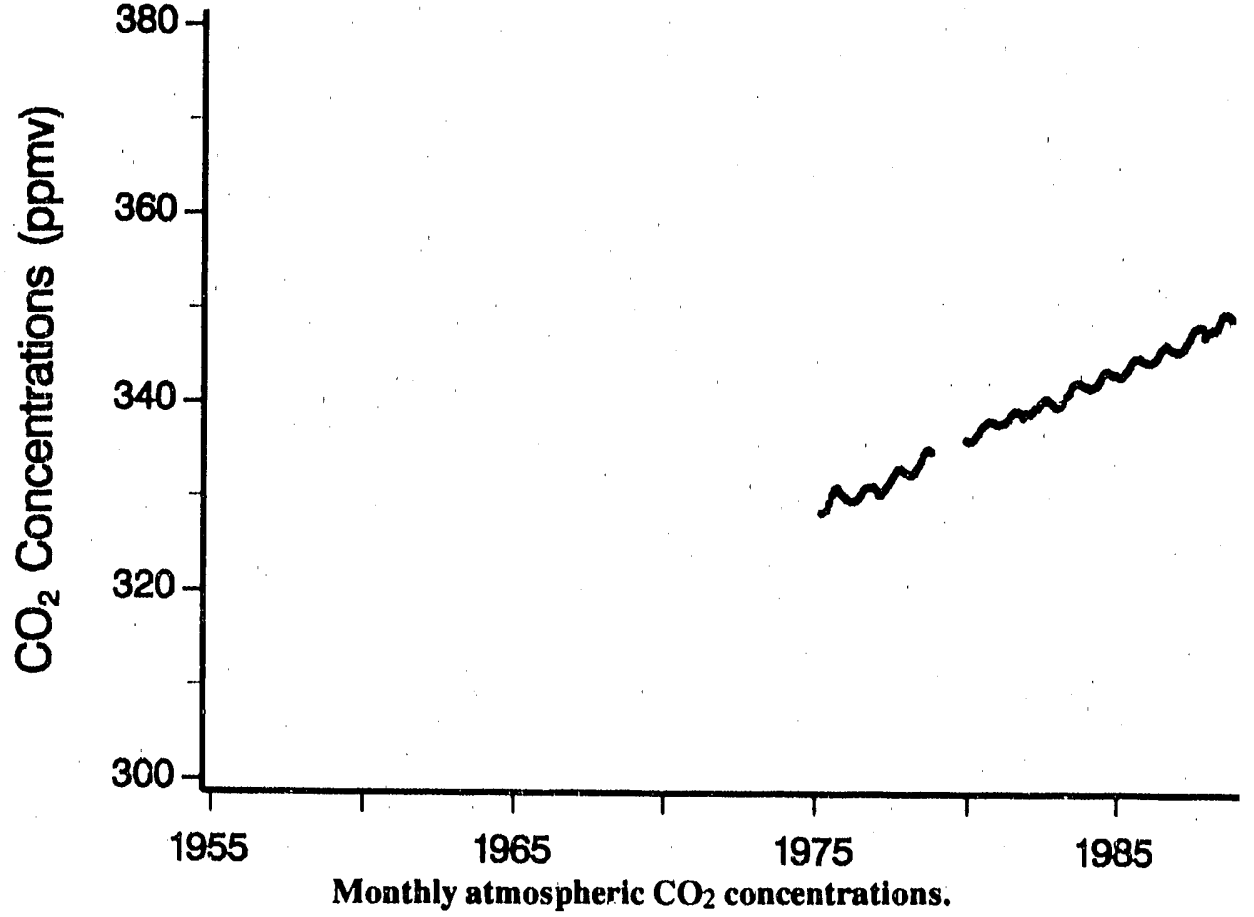

Amundsen Scott

South Pole, Antarctica

Ice and snow-covered plateau

$89^{\circ} 59^{\prime} S, 24^{\circ} 48^{\prime} W$

$2810 \mathrm{~m}$ above MSL 


\section{Atmospheric $\mathrm{CO}_{2}$}

\section{TREND}

The South Pole Observatory (SPO) is one of four baseline atmuspheric monitoring stations operated by the Climate Monitoring and Diagnostics Laboratory (CMDL) program of the National Oceanic and Atmospheric Administration (NOAA). The other three sites are located at Barrow, Alaska; Cape Matatula, American Samoa; and Mauna Loa Observatory, Hawaii. The remoteness of SPO makes it an ideal sampling location because it is removed from significant human-induced sources of $\mathrm{CO}_{2}$.

Continuous measurements of atmospheric $\mathrm{CO}_{2}$ concentrations have been made at SPO since 1957 by the Scripps Institution of Oceanography (SIO). The SIO program is based primarily on biweekly flask sampling, except for the continuous in situ measurements between 1960 and 1963. Since 1975, CMDL has also made continuous meas arements of atmospheric $\mathrm{CO}_{2}$ at the South Pole independently of SIO. Gillette et al. (1987) reported that, except for 1976, the continuous data from SPO for 1975-1982 showed good agreement with the SIO and CMDL flask data collected at the South Pole and with the results of the Australian

Commonwealth and Scientific and Industrial Research Organization aircraft monitoring program.

Gillette et al (1987) found the average growth rate of $\mathrm{CO}_{2}$ at the South Pole for $1975-1982$ to be $1,32 \pm 0.66 \mathrm{ppm}$ per year and the amplitude of the seasonal cycle to range from $1.59 \pm 0.36$ before 1979 to $1.02 \pm$ $0.18 \mathrm{ppm}$ after 1979 . For comparison, Conway et al. (1988) reported a growth rate of $1.22 \mathrm{ppm}$ per year for the flask sampling data from the South Pole for 1981-1984. 


\section{Amundsen Scott}

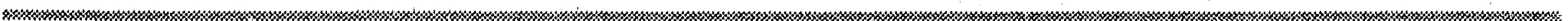

\section{Atmospheric Concentrations of Carbon Dioxide*}

\begin{tabular}{|c|c|c|c|c|c|c|c|c|c|c|c|c|}
\hline Year & Jan & Feb & Mar & Apr & May & Jun & Jul & Aug & Sept & Oct & Nov & Dec \\
\hline 1975 & & & & & 328.4 & 328.7 & 329.4 & 330.3 & 330.9 & 331.1 & 330.7 & 330,3 \\
\hline 1976 & 330.1 & 329.8 & 329.7 & 329.6 & 329.7 & 329.9 & 330.3 & 330.7 & 331.1 & 331.1 & 331.1 & 331.2 \\
\hline 1977 & 330.9 & 330.4 & 330.3 & 330.7 & 331.1 & 331.4 & 331.8 & 332.3 & 332.8 & 333.1 & 333.1 & 332.8 \\
\hline 1978 & 332.7 & 332.5 & 332.4 & 332.6 & 333.0 & 333.4 & 333.9 & 334.6 & 335.0 & 335.1 & 334.9 & \\
\hline \multicolumn{13}{|l|}{1979} \\
\hline 1980 & 336.2 & 336.0 & 336.0 & 336.2 & 336.6 & 336.9 & 337.4 & 337.7 & 337.9 & 338.1 & 338.0 & 338.0 \\
\hline 1981 & 337.8 & 337.8 & 337.9 & 337.9 & 338.1 & 338.3 & 338.8 & 339.0 & 339.2 & $339: 2$ & 339.0 & 338.6 \\
\hline 1982 & 339.0 & 338.0 & 338.9 & 339.2 & 339.6 & 339.6 & 340.0 & 340.3 & 340.5 & 340.5 & 340.2 & 340.0 \\
\hline 1983 & 339.7 & 339.6 & 339.7 & 340.1 & & 340.9 & 341.2 & 341.9 & 342.1 & 342.2 & 342.2 & 342.0 \\
\hline 1984 & 341.9 & 341.9 & 341.7 & 341.7 & 341.9 & 342.1 & 342.5 & 343.1 & 343.4 & 343.4 & 343.2 & 343.0 \\
\hline 1985 & 343.1 & 342.9 & 342.8 & 343.0 & 343.3 & 343.6 & 344.1 & 344.5 & 344.8 & 344.8 & 344.8 & 344.6 \\
\hline 1986 & 344.5 & 344.4 & 344.4 & 344.5 & 344.6 & 344.9 & 345.4 & 345.8 & 346.0 & 346.2 & 346.0 & 345.8 \\
\hline 1987 & 345.7 & 345.5 & 345.5 & 345.7 & 346.0 & 346.4 & 346.9 & 347.5 & 347.9 & 348.0 & 348.2 & 348.1 \\
\hline $1988+$ & 347.1 & 347.5 & 347.6 & 347.8 & 347.9 & 348.1 & 348.6 & 349.3 & 349.5 & 349.6 & 349.4 & 349.1 \\
\hline
\end{tabular}

*Atmospheric $\mathrm{CO}_{2}$ in parts per million by volume (ppmv). All numbers have been rounded to the nearcst tenth.

$\dagger$ All 1988 data are preliminary and may change by several tenths of a ppmv based on re-calibrations of the reference gases used for measurements. 


\section{REFERENCES}

Conway, T.J., P. Tans, L.S. Waterman, K.W. Thoning, K.A. Masarie, and R.H. Gammon، 1988. Atmospheric carbon dioxide measurements in the remote global troposphere, 1981-1984. Tellus 40(B):81-115.

Gillette, D.A., and A.T. Steele. 1983. Selection of $\mathrm{CO}_{2}$ concentration data from whole-air sampling at three locations' between 1968 and 1974. Joumal of Geophysical Research 88:1349-59. Gillette, D.A., W.D. Komhyr, L.S. Waterman, L.P. Steele, and R.H. Gammon. 1987. The NOAA/GMCC continuous $\mathrm{CO}_{2}$ record at the South Pole, 1975-1982. Joumal of Geophysical Research 92(D4):4231-40.

Komhyr, W.D., L.S. Waterman, and W.R. Taylui. 1983. Semiautomatic nondispersive infrared analyzer apparatus for $\mathrm{CO}_{2}$ air sample analyses. Joumal of Geophysical Research 88:1315-22.

Komhyr, W.D., T.B. Harris, and

L.S. Waterman. 1985. Calibration of nondispersive infrared $\mathrm{CO}_{2}$ analyzers with $\mathrm{CO}_{2}$-in-air reference gases. Joumal of Atmospheric and Oceanic Technology 2:82-88.

Thoning, K.W., P. Tans, T.J. Conway, and L.S. Waterman. 1987. NOAA/GMCC calibrations of $\mathrm{CO}_{2}$-in-air reference gases: 1979-85. NOAł Technical Memorandum ERL ARL-150. Environmental Research Laboratory, Boulder, Coloradc.

World Meteorological Organization. 1989.

Provisional daily atmospheric carbon dioxide concentrations as measured at BAPMON sites for the years 1980 and 1987. WMO/TD-No, 306. Geneva. 


\section{Cape Matatula (American Samoa)}

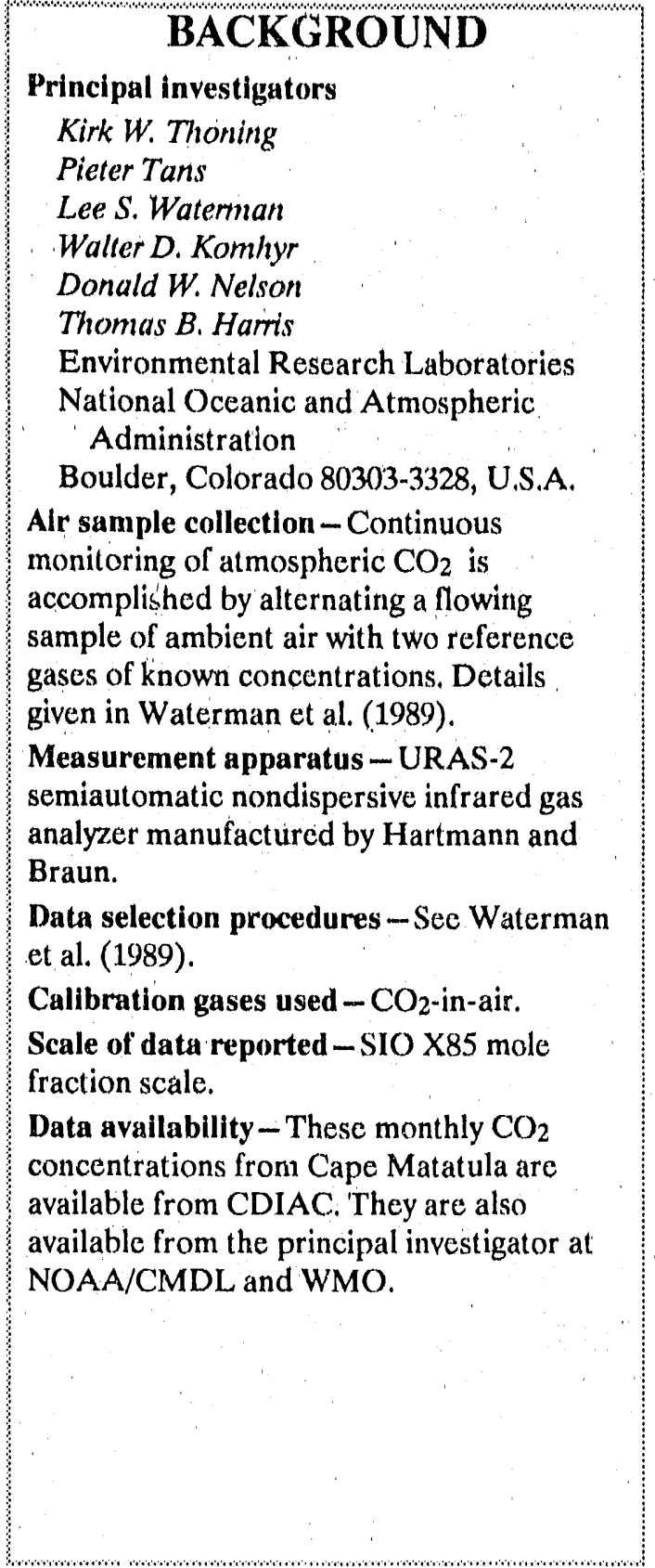

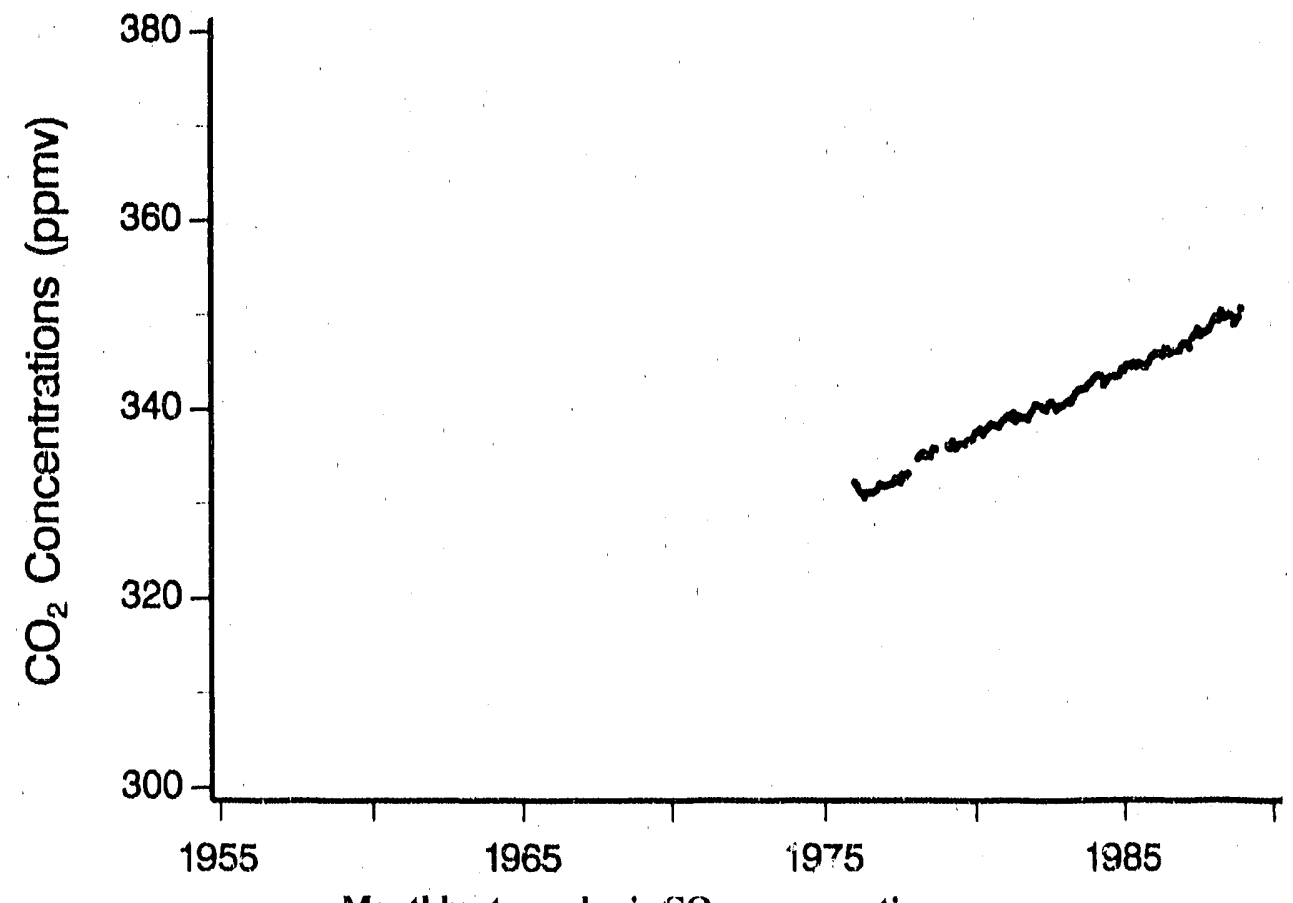

Monthly atmospheric $\mathrm{CO}_{2}$ conceni ations.

Cape Matatula

American Samoa, U.S.A.

Island rocky promontory

$14^{\circ} 15^{\prime} \mathrm{S}, 170^{\circ} 34^{\prime} \mathrm{W}$

$42 \mathrm{~m}$ above MSL 


\section{TREND}

Continuous measurements of atmospheric $\mathrm{CO}_{2}$ concentration in the Southern Hemisphere were initiated by C.D. Keeling of Scripps Institution of Occanography (SIO) at Little America, Antarctica, in 1958. A monitoring project to observe the sea-level climate and atmospheric constituents of the tropical Southern Hemisphere was established by the National Oceanic and Atmospheric Administration (NOAA) at Cape Matatula, American Samoa, in 1973. Discrete samples of atmospheric air have been collected in glass flasks at regular intervals at Cape Matatula since that time and have been reported by Komhyr et al. (1985) and Con- ay et al. (1988). An observatory building was erected in 1975, and continuous $\mathrm{CO}_{2}$ monitoring has been conducted since December 1975. The continuous $\mathrm{CO}_{2}$ monitoring program at Cape Matatula, American Samoa, represents one of four baseline atmospheric monitoring stations operated by the Climate Monitoring and Diagnostics Laboratory (CMDL) program of NOAA. The other three sites are located at Barrow, Alaska; Mauna Loa Observatory, Hawaii; and South Pole Station, Antarctica.

Waterman ef al. (1989) found that the average growth rate of $\mathrm{CO}_{2}$ at Cape Matatula for 1976-1987 was 1.44 ppmv per year. For comparison, Conway et al. (1988) reported a growth rate of $1.35 \mathrm{ppmv}$ per year for the flask sampling data from American Samoa for 1981-1984. 


\section{Cape Matatula (American Samoa)}

\section{Atmospheric Concentrations of Carbon Dioxide*}

$\begin{array}{lcccccccccccc}\text { Year } & \text { Jan } & \text { Feb } & \text { Mar } & \text { Apr } & \text { May } & \text { Jun } & \text { Jul } & \text { Aug } & \text { Sept } & \text { Oct } & \text { Nov } & \text { Dec } \\ 1976 & 332.2 & 331.9 & 331.3 & 331.1 & 330.7 & 331.2 & 331.1 & 331.2 & 313.3 & 331.5 & 332.0 & 331.9 \\ 1977 & 331.8 & 332.0 & 332.1 & 332.1 & 332.6 & 332.7 & 332.2 & 333.0 & 332.8 & 333.2 & & \\ 1978 & & 334.8 & 335.2 & 335.3 & 335.0 & 335.2 & 335.0 & 335.8 & 335.8 & & & \\ 1979 & & 336.1 & 335.7 & 336.6 & 335.8 & 336.0 & 336.3 & 336.3 & 336.3 & 336.6 & 336.7 & 336.9 \\ 1980 & 337.4 & 337.6 & 337.9 & 337.3 & 337.8 & 338.0 & 338.4 & 338.3 & 338.2 & 338.1 & 338.5 & 338.8 \\ 1981 & 339.0 & 339.3 & 339.0 & 339.5 & 338.7 & 339.3 & 339.0 & 339.1 & 339.11 & 338.9 & 339.4 & 339.8 \\ 1982 & 340.4 & 340.4 & 340.3 & 340.2 & 340.0 & 339.9 & 340.6 & 340.7 & 340.36 & 339.9 & 340.3 & 340.2 \\ 1983 & 340.4 & 340.6 & 340.8 & 340.7 & 341.2 & 341.7 & 341.9 & 342.1 & 342.05 & 342.2 & 342.5 & 342.8 \\ 1984 & 343.1 & 343.4 & 343.5 & 343.4 & 342.5 & 342.9 & 343.2 & 343.3 & 343.39 & 343.4 & 343.5 & 344.1 \\ 1985 & 343.1 & 344.5 & 344.6 & 344.4 & 344.8 & 344.5 & 344.8 & 344.7 & 344.41 & 344.4 & 344.8 & 345.3 \\ 1986 & 345.5 & 345.8 & 345.8 & 345.8 & 345.6 & 346.3 & 346.3 & 345.8 & 346.01 & 346.1 & 346.1 & 346.1 \\ 1987 & 346.7 & 346.9 & 346.8 & 346.5 & 347.5 & 347.8 & 348.4 & 347.7 & 347.98 & 348.1 & 348.3 & 348.8 \\ 1988 \dagger & 349.2 & 349.7 & 349.4 & 350.3 & 349.6 & 349.7 & 349.9 & 349.8 & 348.94 & 349.3 & 349.8 & 350.6\end{array}$

*Atmospheric $\mathrm{CO}_{2}$ in parts per million by volume (ppmv). All numbers have been rounded to the nearest tenth.

†All 1988 data are preliminary and may change by several tenths of a ppmv based on re-calibrations of the reference gases used for measurements. 


\section{Atmospheric $\mathrm{CO}_{2}$}

Ide*

lec

11,9

36.9

38.8

39.8

H).2

12.8

H.1

45.3

$+6.1$

48.8

50.6

sed

\section{RETERENCES}

Conway, T..., P. Tans, L.S. Walcrman, K.W. Thoning, K.A. Masaric, and R.H. (iammon, 1988. Almospheric carbon dioxide measurements in the remote global troposiphere, 1981-1984. T't'lless 40)(B):81-115.

Kombyr, W.D., R.H. (iammon, T.B. Hatris, L.S. Watcrman, T.J. Conway, W.R, Taylor, and K.W. Thoning, 1985. Cilobal atmospheric $\left(\mathrm{CO}_{2}\right.$ distributions and variations from 1968-82 NOAA/CMCC: $\mathrm{CCO}_{2}$ flask sample data. Jommonl of

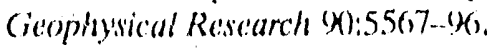

Kombyr, W.D., T,B, Harris, L.S. Watcrman, J.F.S. C.hin, and K.W. Thoning, 1989).

Almospheric carbon dioxide at Matuna Loa ()hervalory: I. NO)AA/(iMCC:

mensurements with a nondispersive infrared analyzer, 1974-1985. Joumal of Geophysical Re'se'urch 94(D) (1):8533-47.

Thoning, K.W., P. Tans, 'T'J. Conway, and L.S. Waterman, 1987. NOAd/CiMCC calibrations of $\mathrm{CO}_{2}$-in-air reference gases: 1979.. 85. N()AA Technical Memorandum ERL ARL-1.5(). Environmental Research Laboratory, Boulder, Colorado.

Thoning, K.W. 1989) Solection of N()AA/ GMCC $\mathrm{CO}_{2}$ dialia from Mauma Loa ()bservatory. pp, 1-26. IN W.P. Elliot (ed.), The Statistical Treatmont of $\mathrm{CO}_{2}$ Records. N()AA Technical Memorandum ERL AR1.-173. Air Resesures Laboratury, Silver Spring, Maryland.

Walceman, L.S., D.W. Nelson, W.D.

Kombyr, 'T.B. Harris, K.W. 'Thoning, and P.P. T'ins. 198') Atmospherice citron dioxide measurements al Cane Matatula, American Samoit, 1976-1987. Joumal of (itophwical Resceurch 94(D12):14817-20. 


\section{Mauna Loa}

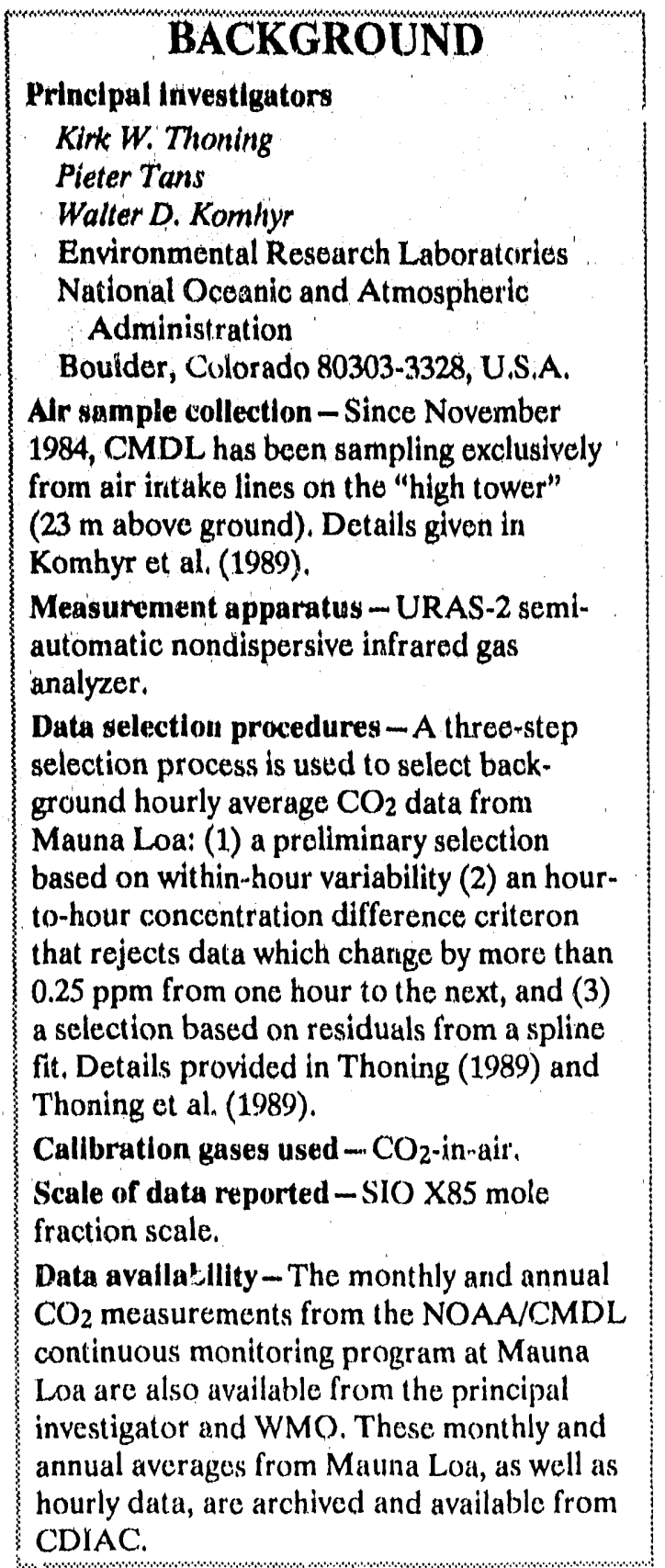

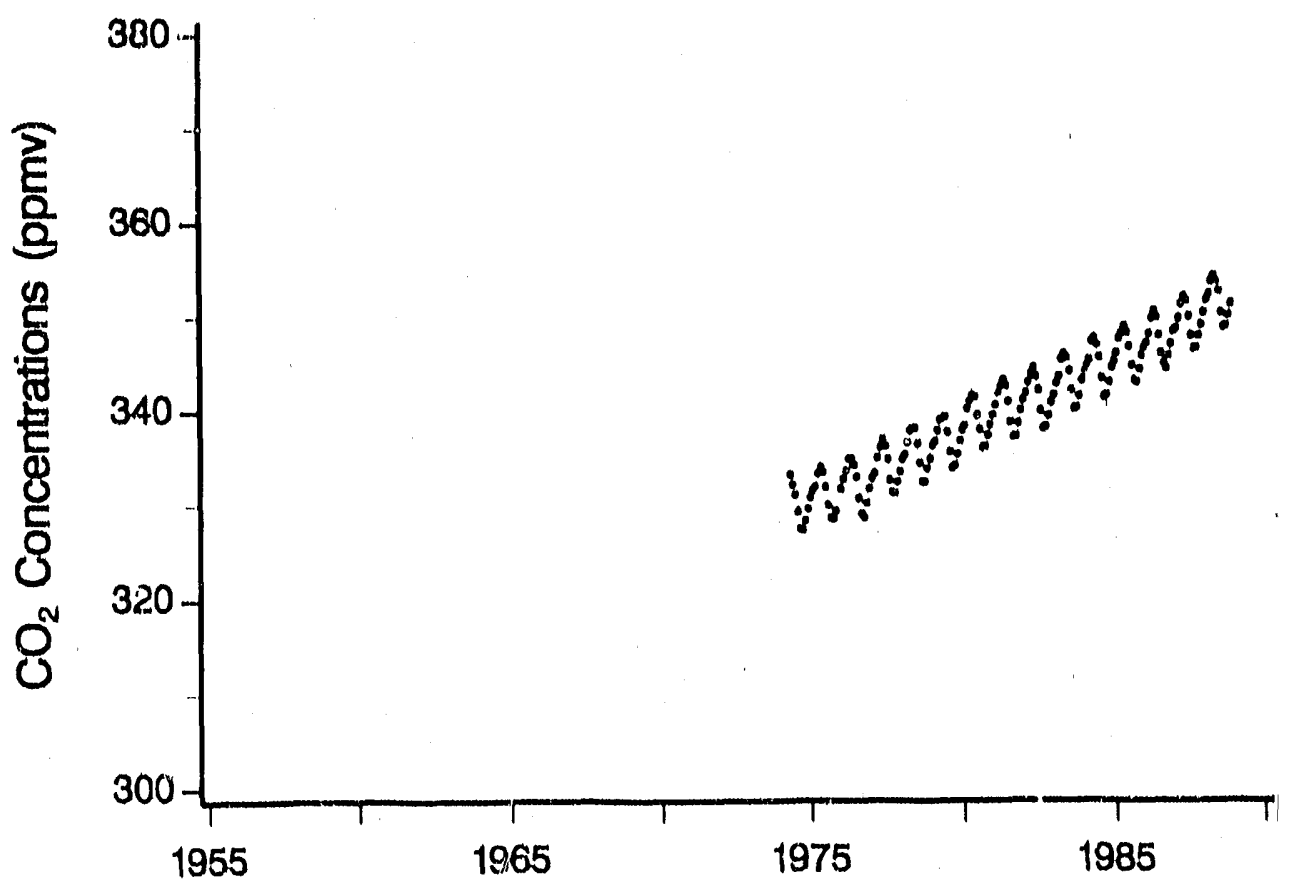

Monthly atmospheric $\mathrm{CO}_{2}$ concentrations.

Mauna Lou

Hawaii, U.S.A.

Barren volcanic mountain

slope

$19^{\circ} 5^{\prime} \mathrm{N}, 1.55^{\circ} 6^{\prime} \mathrm{W}$

$3.397 \mathrm{~m}$ above MSL 


\section{Atmospheric $\mathrm{CO}_{2}$}

\section{TREND}

Continuous measurements of atmos" pheric $\mathrm{CO}_{2}$ concentrations have been made. at the Mauna Loa Observatory (MLO) since 1958 by Scripps Institution of Oceanography (SIO). Since 1974, the National Oceanic and Atmosphoric Administration's Climate Monitoring and Diagnostics Laboratory (NOAA/CMDL) program has also mado continuous measurements of atmospheric $\mathrm{CO}_{2}$ at MLO independently of SIO. MLO is one of four baseline atmospheric monitoring stations operated by NOAA/CMDL. The other three sites are located at Point Barrow, Alaska; Cape Matatula, American Samoa; and South Pole Station, Antarctica. The SIO and CMDL records of atmos" pheric $\mathrm{CO}_{2}$ measurements at MLO constitute somes of the most important $\mathrm{CO}_{2}$ records for studies of the global carbon cycle and $\mathrm{CO}_{2}$-induced climate change.

Komhyr et al. (1989) reported that the average difference of corresponding monthly mean $\mathrm{CO}_{2}$ values for the $\mathrm{CMDL}$. and SIO data sets was $0.15 \pm 0.18$ ppmv. Thoning et al. (1989) found that the average growth rate of $\mathrm{CMDL}$ continuous $\mathrm{CO}_{2}$ data from MLO for 1974-1985 was $1.42 \pm 0.02$ ppmv per year and that the amplitude of the seasonal cycle was increasing at a rate of $0.05 \pm 0.02$ ppmv. For comparison, Conway et al. (1988) reported a growth rate of 1.21 ppmv per ycur for the flask sampling data from MLO for 1981-1984. 
Atmospheric Concentrations of Carbon Dioxide*

\begin{tabular}{|c|c|c|c|c|c|c|c|c|c|c|c|c|c|}
\hline Year & Jan & Feb & Mar & $\mathrm{Apr}$ & May & Jun & Jul & Aug & Sept & Oct & Nor & Dec & Ann \\
\hline 1974 & & & & & 333.2 & 332.1 & 331.0 & 329.2 & 327.4 & 327.3 & 328.3 & 329.5 & 329.7 \\
\hline 1975 & 330.7 & 331,4 & 331.8 & 333.5 & 333.9 & 333.4 & 331.8 & 329.9 & 328,6 & 328.5 & 329.3 & & 331.1 \\
\hline 1976 & 331.7 & 332.7 & 3.33 .5 & $334.8^{\prime}$ & 334.8 & 334.1 & 332,9 & 330.6 & 329.0 & 328.6 & 330,1 & 331.6 & 332.0 \\
\hline 1977 & 332.7 & 333.2 & 334,9 & 336,0 & 336,8 & 336.1 & 334.8 & 332.5 & 331.3 & 331.2 & 332.4 & 333.5 & 333.8 \\
\hline 1978 & 334.7 & 335.2 & 336.5 & 337,8 & 338,0 & 338.0 & 336.4 & 334.3 & 332.4 & 332.3 & 333.8 & 334.8 & 333.4 \\
\hline 1979 & 336.2 & 336.7 & 337.8 & 339,0 & 339,0 & 339.2 & 337.6 & 335.5 & 333.8 & 334.0 & 335.3 & 3.36 .7 & 336.7 \\
\hline 1980 & 337.8 & 338.3 & 340.1 & 340,9 & 341.5 & 341.3 & 339.4 & 337.8 & 336,0 & 336.0 & 337.2 & 338.3 & 338.7 \\
\hline 1981 & 339,4 & 340.5 & 341.7 & 342.5 & 343,0 & 342.5 & 340.8 & 338.6 & 337.0 & 337.1 & 338.5 & 339.9 & 340.1 \\
\hline 1982 & 340.9 & 341.7 & 342.8 & 343.7 & 344.3 & 343.4 & 342.0 & 339.8 & 337.9 & 338.1 & 339.3 & 340.7 & 341.2 \\
\hline 1983 & 341.5 & 342.7 & 343.4 & 345.2 & 345,8 & 345.4 & 344.0 & 342,0 & 340,0 & 340.2 & 341.4 & 343.0 & 342.8 \\
\hline 1984 & 343.9 & 344.6 & 345.2 & 347.1 & 347,5 & 346.8 & 345.4 & 343,2 & 341.3 & 341.5 & 342.8 & 344.4 & 344.5 \\
\hline 1985 & 345.0 & 345.9 & 347.5 & 348.0 & 348.7 & 348.1 . & 346.6 & 344.6 & 343.0 & 342.9 & 344,2 & 345.6 & 345.8 \\
\hline 1986 & 346.5 & 347.0 & 347.9 & 349,6 & 350.4 & 349.7 & 347.8 & 345.9 & 344.8 & 344.3 & 345.7 & 346.9 & 347.2 \\
\hline 1987 & 348.2 & 348.5 & 349.6 & 351.1 & 351.9 & 351.5 & 349.8 & 347.7 & 346.4 & 346.5 & 347.7 & 348.9 & 349.0 \\
\hline 19884 & 350.2 & 351.5 & 352.1 & 353.5 & 354.0 & 353.5 & 352.5 & 350.2 & 348.7 & 348.8 & 349.9 & 351.1 & 351.3 \\
\hline
\end{tabular}

*Atmospheric $\mathrm{CO}_{2}$ in parts per million by volume (ppmv). Annual averages based on monthly means. All numbers have been rounded to the nearest tenth.

tAll 1988 data are preliminary and may change by several tenths of a ppmv based on re-calibrations of the reference gases used for measurements. 


\section{Atmospheric $\mathrm{CO}_{2}$}

\section{REFERENCES}

Conway, T.J., P. Tans, L.S. Watcrman, K.W. Thoming, K.A. Masaric, and R.H.

Gammon. 1983. Almospheric carbon dioxide measurements in the remote global troposphere, 1981 1084. Tellas 4()$(B): 81 \ldots 115$.

Komhyr, W.D., r.B. Harris, L.S. Walerman, J.F.S. Chin, and K.W. Thoning, loke. Atmospheric carbon dioxide at Mauna Loa ()bscrvaiory 1. NOAA/C MCC: measurements with a nondispersive infrared analyacr, 1974 1985. Jommal of Geophysical Research 94(D6):85.53 47. Thoning, K.W., P. Yans, T.I. Conway, and L.S. Watcrman. 198\% NOAA/C $\mathrm{NCC}$ calibrations of $\mathrm{CO}_{2}$-in-air reference gases: 1979 8.5. NOAA Technical Memorandum ERL ARL-150). Linvirommental Research Laboratory, Boulder, colorado. 'Thoning, K.W. 198\%. Sclection of NOAACBMC : C(1) dialit from Mauna Loa observatory. pp. 1-26. IN W.P. Lellioll (ed.), The Sibtistical Treatment of $\mathrm{C}^{\circ} \mathrm{O}_{2}$ Records. NOAA Technical Memotandum ERI, AR1.-173. Air Resoures Laboratory, Silver Spring, Maryland. Thoning, K.W., P.P. Tans, and W.D. Kombyr. 1989. Almospheric carben

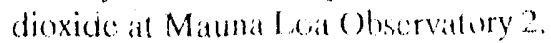
Analysis of the NOAA C MMC C datit.

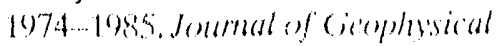
Research $)+(100): 85+406.5$.

World Metcorologeicat (organization. 1's,s?.

Provisional alaily amosepheric carbon dienide concentrationss as meanumed at BaPMoN sites for the verars losis and los. WM()/T') - No. 3(k). (icmevat. 


\section{Point Barrow}

\begin{tabular}{|c|}
\hline BACKGROUND \\
\hline Principal investigators \\
\hline Kirk W. Thoning \\
\hline Pieter Tans \\
\hline James T. Peterson \\
\hline Walter D. Komhyr \\
\hline Thomas B. Harris \\
\hline Lee S, Waterman \\
\hline Environmental Research Laboratories \\
\hline National Oceanic and Atmospheric \\
\hline Administration \\
\hline Boulder, Colorado $80303-3328$, U.S.A. \\
\hline $\begin{array}{l}\text { Air sample collection - See Komhyr and } \\
\text { Harris (1977). }\end{array}$ \\
\hline $\begin{array}{l}\text { Measurement apparatus - URAS-2T } \\
\text { semiautomatic nondispersive infrared gas } \\
\text { analyzer manufactured by Hartmand and } \\
\text { Braun. }\end{array}$ \\
\hline $\begin{array}{l}\text { Data selection procedures - Data are } \\
\text { rejected based on instability of the } \mathrm{CO}_{2} \\
\text { concentration within consecutive hours. } \\
\text { When hour-to-hour change exceeds } \\
0.25 \text { ppm, values for both hours are deleted } \\
\text { from the data set. Details about data } \\
\text { selection are provided in Peterson et al. } \\
\text { (1982, 1986), Thoning et al.(1987), and } \\
\text { Thoning et al. (1989). }\end{array}$ \\
\hline 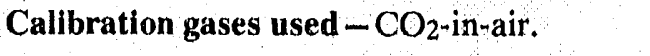 \\
\hline $\begin{array}{l}\text { Scale of data reported - SIO X85 mole } \\
\text { fraction scale. }\end{array}$ \\
\hline $\begin{array}{l}\text { Data availability - These monthly data from } \\
\text { Point Barrow are available from CDIAC. } \\
\text { They are also available from the principal } \\
\text { investigator at NOAA/CMDL and WMO. }\end{array}$ \\
\hline
\end{tabular}

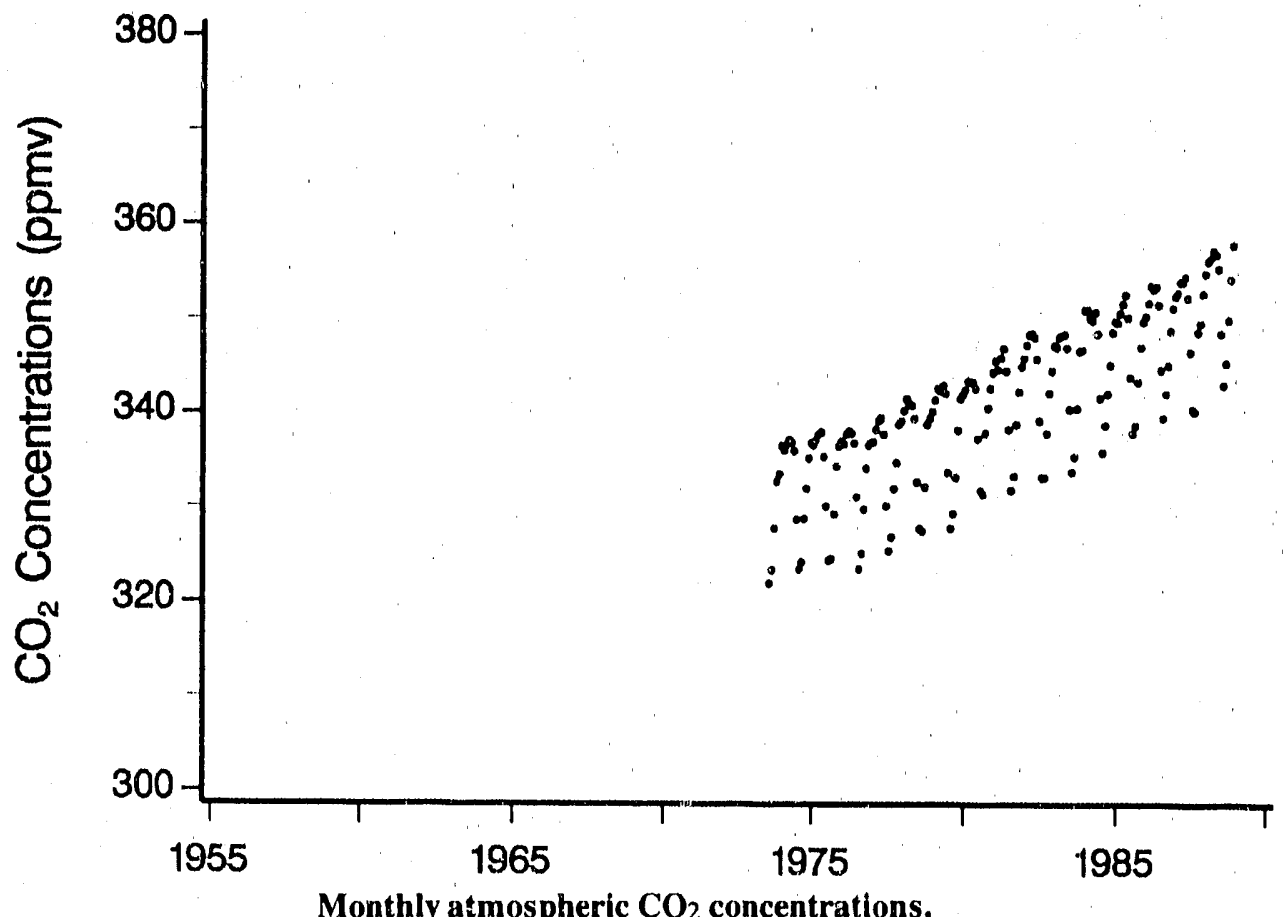

Point Barrow

Alaska, U.S.A.

Coastal seashore

$71^{\circ} 19^{\prime} \mathrm{N}, 156^{\circ} 36^{\prime} \mathrm{W}$

$11 \mathrm{~m}$ above $M S L$ 


\section{Atmospheric $\mathrm{CO}_{2}$}

\section{TREND}

The Air Resources Laboratories of NOAA established a program to conduct continuous measurements of atmospheric $\mathrm{CO}_{2}$ concentration at Point Barrow, Alaska, in 1973. The continuous $\mathrm{CO}_{2}$ monitoring program at Point Barrow represents one of four baseline atmospheric monitoring stations operated by the Climate Monitoring and Diagnostics Laboratory (CMDL) program of the National Oceanic and Atmospheric Administration (NOAA). The other three sites are located at American Samoa; Mauna Loa Observatory, Hawaii; and South Pole Station, Antarctica.

Peterson et al. (1982) reported that concentrations of $\mathrm{CO}_{2}$ at Point Barrow for 1973-1979 rose 4-5 ppmv and exhibited a seasunal cycle of 15.2 ppmv. Conway et al. (1988) reported a growth rate of $1.26 \mathrm{ppmv}$ per year for the flask sampling data from Point Barrow for 1981-1984. Peterson et al. (1982) reported a slight decrease in absolute concentrations for 1976 in comparison with 1975. Atmospheric $\mathrm{CO}_{2}$ concentrations at Point Barrow show an annual seasonal cycle with yearly minimum values recorded in late August and annual maximum values recorded in late April. 


\section{Point Barrow}

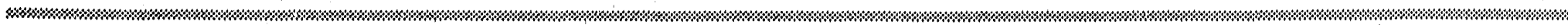

Atmospheric Concentrations of Carbon Dioxide*

\begin{tabular}{|c|c|c|c|c|c|c|c|c|c|c|c|c|}
\hline Year & Jan & Feb & Mar & Apr & May & Jun & Jul & Aug & Sept & Oct & Nov & Dec \\
\hline 1973 & & & & & & & & 322.0 & 323.4 & 327.8 & 332.7 & 333.5 \\
\hline 1974 & 336.5 & 336.0 & 336.7 & 337.1 & 336.9 & 335.9 & 328.7 & 323.5 & 324.2 & 328.8 & 332.0 & 335.2 \\
\hline 1975 & 336.8 & 336.6 & 337.1 & 337.7 & 337.9 & 335.4 & 330.1 & 324.9 & 324.6 & 329.3 & 334.3 & 336.5 \\
\hline 1976 & 337.0 & 336.7 & 337.7 & 338.0 & 337.8 & 336,8 & 331.0 & 323.5 & 325.1 & 329.8 & 334.1 & 336.6 \\
\hline 1977 & 336.8 & 336.9 & 338.2 & 339.5 & 339.4 & 337.7 & 330.1 & 325.4 & 326.8 & 332.0 & 334.7 & 338.8 \\
\hline 1978 & 339.1 & 340.2 & 341.5 & 341.0 & 340.8 & 339.4 & 332.6 & 327.7 & 327.4 & 332.1 & 338.8 & 339.4 \\
\hline 1979 & 340.1 & 341.3 & 342.5 & 342.4 & 342.9 & 342.0 & 333.6 & 327.7 & 329.3 & 333.1 & 338.1 & 341.5 \\
\hline 1980 & 341.9 & 342.4 & 343.4 & 343,3 & 343.2 & 342.6 & $337: 3$ & 331,8 & 331.4 & 337.9 & 340.5 & 342.6 \\
\hline 1981 & 344.3 & 345.5 & 344.6 & 345.8 & 346.8 & 344.4 & 338.2 & 331.8 & 333.3 & 338.8 & 342.2 & 344.9 \\
\hline 1982 & 345.8 & 347.2 & 348.3 & 348.4 & 348.0 & 345.7 & 339.2 & 333.2 & 333.2 & 337.9 & 342.1 & 344.5 \\
\hline 1983 & 347.1 & 347.0 & 348.0 & 348.2 & 348.3 & 347.0 & 340.4 & 333.8 & 335.4 & 340.5 & 346.5 & 346.7 \\
\hline 1984 & 350.9 & 350.9 & 350.0 & 349.8 & 350.7 & 348.2 & 341.6 & 335.8 & 338.7 & 342.0 & 345.0 & 348.5 \\
\hline 1985 & 349.7 & 349.5 & 350.5 & 351.5 & 352.5 & 350.1 & 343.8 & 337.8 & 338.7 & 343.3 & 346.9 & 349.7 \\
\hline 1986 & 350.2 & 351.6 & 353.4 & 353.1 & 353.3 & 351.4 & 344.5 & 339.5 & 342.0 & 345.0 & 348.7 & 351.1 \\
\hline 1987 & 352.4 & 352.7 & 353.9 & 353.9 & 354.4 & 352.2 & 346.5 & 340.4 & 340.2 & 348.6 & 349.5 & 352.6 \\
\hline $1988 \dagger$ & 354.8 & 356.1 & 356.4 & 357.2 & 356.8 & 355.3 & 348.4 & 343.0 & 345.3 & 349.8 & 354.2 & 357.8 \\
\hline
\end{tabular}

*Atmospheric $\mathrm{CO}_{2}$ in parts per million by volume (ppmv). All nu. bers have been rounded to the nearest tenth.

†All 1988 data are preliminary and may change by several tenths of a ppmv based on re-calibrations of the reference gases used for measurements. 


\section{Atmospheric $\mathrm{CO}_{2}$}

\section{REFERENCES}

Komhyr, W.D., and T.B. Harris, 1977.

Measurements of atmospherie $\mathrm{CO}_{2}$ at the U.S. (jMCC baseline stations, pp.9-19. IN Report and Proceedings of WMO Air Pollution Measurement Techniques Conference (APOME'T), Special Environmental Report No. 10, WMO.No. 4(6), World Meteorological Organization, Geneva.

Komhyr, W.D., T.B. Harris, 1..S. Waterman, J.F.S. Chin, and K.W. Thoning. 1989.

Atmospheric carbon dioxide at Mauna Loa Observatory: 1. N()AA/GMCC measurements with a nondispersive infrared analyzer, 1974-1985.Journal of Ceophysical Research 94(D6):8533-47.

Peterson, J.T., W.D. Komhyr, T.B. Harris, and L..S. Walcrman. 1982. Almospheric carbon dioxicie measurements al Barrow, Alaska, 197:--1979. Tellus 34:166-75.

Peterson, J.T., W.D. Komhyr, L.S.

Watcrman, R.H. Gammon, K.W. Thoning, and T.J. Conway, 1986. Atmospheric $\mathrm{CO}_{2}$ variations at Barrow, Alaska, 1973-1982. Journal of Atmospheric Chemistry $4: 491-.510$.

Thoning, K.W., P. Tans, T.J. Conway, and L.S. Watcrman, 1987. NOAA/CIMC' calibrations of $\left.\mathrm{C}^{\circ}\right)_{2}$-in-air reference gases: 1979-85. NOAA Technical Memorandum ERL ARL-1.50. Envirommental Research Laboratory, Boulder, Colorado. Thening, K.W., P.P. Tans, and W.D. Komhyr. 1989. Almospheric carbon dioxide at Matuna Loa ()teservatory 2. Analysis of He NCAA CBMC C data, 1974 ..1985.

Journal of (icephlysical Researsh y. (D) 6$): 8.549-6.5$. 


\section{Amsterdam Island}

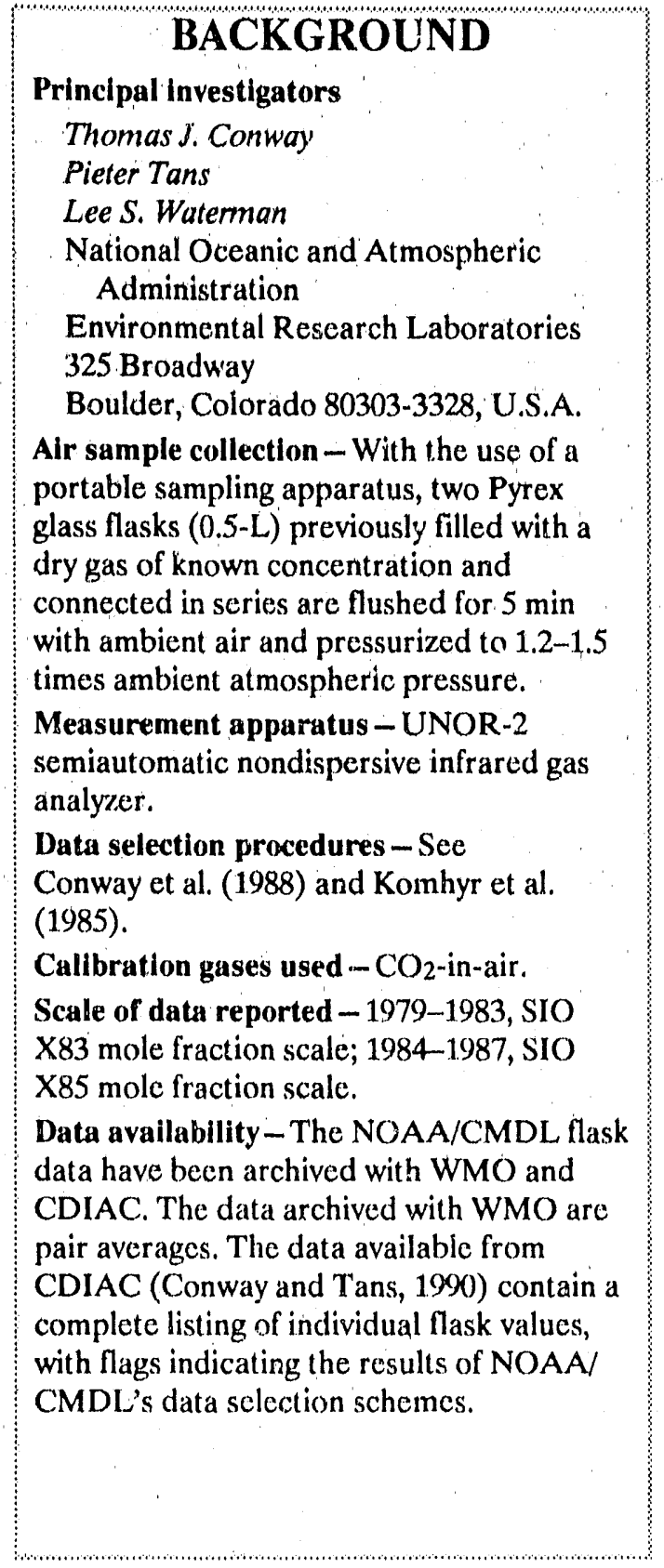

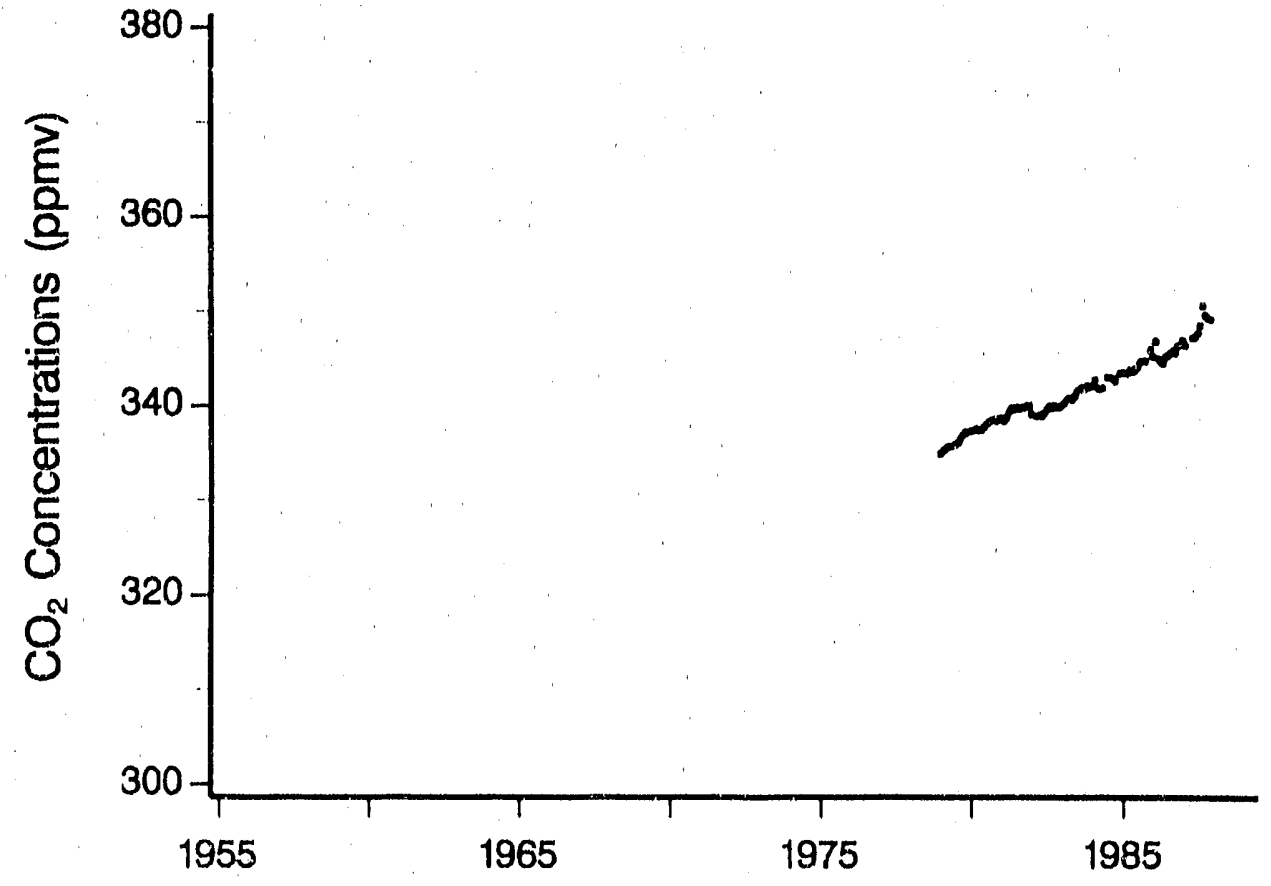

Monthly atmospheric $\mathrm{CO}_{2}$ concentrations.

Amsterdam Island Indian Ocean

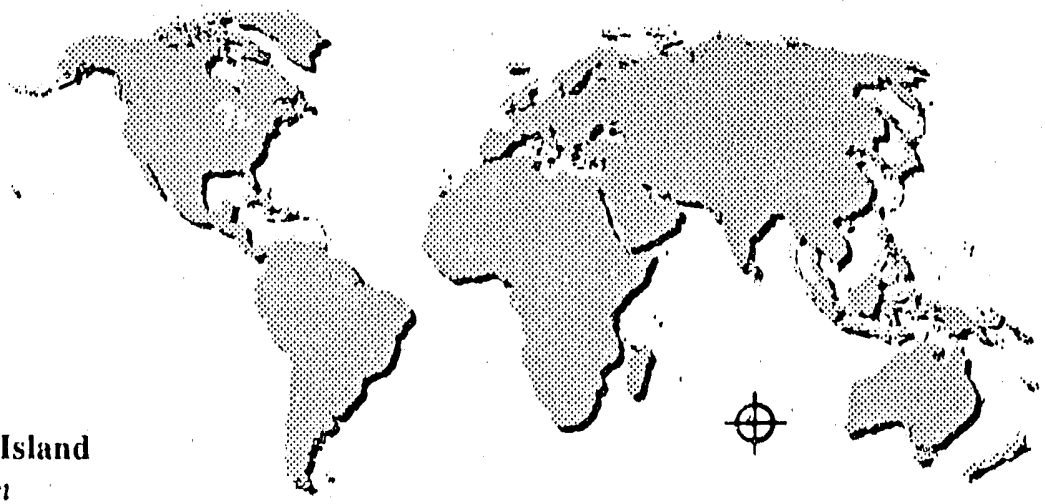

Island seashore

$37^{\circ} 52^{\prime} S, 77^{\circ} 32^{\prime} E$

$150 \mathrm{~m}$ above $M S L$ 


\section{TREND}

The sampling site on Amsterdam Island is operated in cooperation with the French Centre des Faibles Radioactivities. Except during the summer (December-February), when this island is within the wind regime of the westerlies, the monthly mean concentrations from Amsterdam Island can be considered as representative of the back. ground subantarctic atmosphere (Gaudry et al. 1983).

The NOAA flask data from Amsterdam Island have shown an increase in the annual value from $335.9 \mathrm{ppmv}$ in 1979 to $348.2 \mathrm{ppmy}$ in 1987. Conway et al. (1988) reported a 1.33-ppmv mean annual growth rate at Amsterdam Island for 1981-1984. Conway et al. (1988) found a global growth rate of 1.22 ppmv per year over the same time frame for all NOAA/CMDL flask sampling sites. Ascencio-Parvy et al. (1983) found a 0.11 ppmv-per-month increase in atmospheric $\mathrm{CO}_{2}$ concentrations at Amsterdam Island from October 1980 to November 1983. Both Conway et al. (1988) and Ascencio-Parvy et al. (1983) found considerable variability within each year and suggested that the growth rate minimum in 1982 and the growth rate maximum in 1983 may be due partly to the $1982 / 1983$ El Niño event.

Atmospheric $\mathrm{CO}_{2}$ concentrations at Amsterdam Island show a seasonal pattern, with the annual drawdown typically occurring in December-January and the annual buildup occurring in May-June. Conway et al. (1988) found the average peak-to-peak amplitude for Amsterdam Island to be 0.84 ppmv. 


\section{Amsterdam Island}

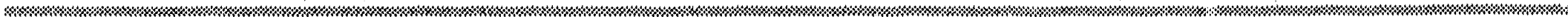

Atmospheric Concentrations of Carbon Dioxide*

$\begin{array}{lccccccccccccc}\text { Year } & \text { Jan } & \text { Feb } & \text { Mar } & \text { Apr } & \text { May } & \text { Jun } & \text { Jul } & \text { Aug } & \text { Sept } & \text { Oct } & \text { Nov } & \text { Dec } & \text { Ann } \\ 1979 & 334.8 & 335.1 & 335.3 & 335.5 & 335.6 & 335.7 & 335.8 & 336.0 & 336.4 & 336.8 & 337.1 & 337.1 & 335.9 \\ 1980 & 337.2 & 337.3 & 337.4 & 337.3 & 337.3 & 337.6 & 337.9 & 338.1 & 338.3 & 338.4 & 338.5 & 338.5 & 337.8 \\ 1981 & 338.6 & 338.3 & 338.6 & 339.2 & 339.6 & 339.5 & 339.7 & 339.6 & 339.7 & 339.7 & 339.9 & 339.9 & 339.4 \\ 1982 & 339.0 & & 338.8 & 338.9 & 338.8 & 339.1 & 339.5 & 339.8 & 339.7 & 339.9 & 339.8 & 339.8 & 339.4 \\ 1983 & 339.9 & 340.2 & 340.5 & 340.7 & 340.6 & 340.9 & 341.4 & 341.6 & 341.8 & 341.7 & 342.0 & 341.9 & 341.1 \\ 1984 & 342.0 & 342.6 & 341.8 & 341.7 & 341.8 & & 342.9 & 342.9 & 342.8 & 342.5 & & 343.3 & 342.4 \\ 1985 & 343.4 & & 343.3 & 343.7 & 343.5 & 343.7 & 344.0 & 344.5 & 344.6 & 344.6 & & 345.8 & 344.1 \\ 1986 & 345.1 & 346.7 & 344.9 & 344.6 & 344.4 & 345.0 & 345.2 & 345.4 & 345.7 & 345.5 & 346.2 & & 345.3 \\ 1987 & 346.8 & 346.3 & & & 347.1 & 347.2 & 347.6 & 348.4 & 350.5 & 349.5 & 349.2 & 349.1 & 348.2\end{array}$

*Atmospheric $\mathrm{CO}_{2}$ in parts per million by volume (ppmv). Annual averages based on monthly means. All numbers have been rounded to the aearest tenth. 


\section{Atmospheric $\mathrm{CO}_{2}$}

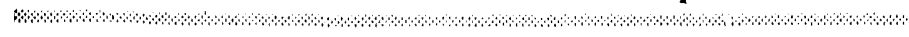

de*

Inn

35.9

37.8

39.4

39.4

41.1

42,4

44.1

45.3

48.2

$d(1)$

\section{REHERENCES}

Ascencion-Parry, J.M., A. (iaudry, and (i. Lambert. 1984, Year-10-year CO2 variations at Amsterdam 1sland in 1980)-1983. Goophysical Rosecurch Letters 11:1215-17. Conway, T.J and P. Tans. 1(x). Atmospheric $\mathrm{CO}_{2}$ concentrations - The NOAA/CiMC (' flatsk sampling netwerk. NDP.(0)5/R1. Carbon Dioxide Information Analysis (enter. ()ak Ridge National Laboratory. ()atk Ridge, Tennessees.

Conway, T.J., P. Tans, L.S. Walcrman, K.W. Thoning, K.A. Masaric, and R.H. (iammon. 1988. Almospheric carbon dioxide measurements in the remole global troposphere, 1981 1984t. To:llus $40(B): 81 \cdots 115$.

Ciaudry, A., J.M. Ascencio, and (3. Lambert. 1983. Preliminary study of $\left(\mathrm{C}_{2}\right.$ variations at Amsterdam Island (Territoire des Terres Australes ol Antarctiyues Francaises). Jourral of (iecophysical Research 88:1323\%2!.

Komhyr, W.D., R.H. ( iammon, T.B. Harris, L.S. Waterman, 'T'J, Conway, W.R. Taylor, and K.W. Thoning. 1985. (ilobal atmosphacric (C) de distributions and vartiations from 1\%(8 82 N()AA/CiMCC (C) flask sample data. Journal of (itophingsical Research $(1): 5567 \%$ ).

Thoning, K.W., P. Tans, 'T.I. Conway, and L.S. Watcrman. 1987. N()AA/GMCC calibrations of $(\mathrm{C})_{2}$-in-itir reference gases: 1979 85. N()AA Technical Memorandum ERL ARL-1.50. Environmental Research Laboratory, Boulder, Coloriado. World Metcoroleggical (Organization. 1989.

Provisional daty atmospheric carbon dioxide concentrations as messusered at BAPMoN sites for the vears 1956 and 1989. WM()/TI) - No. 3)K. (icnevit. 


\section{Amundsen Scott (South Pole)}

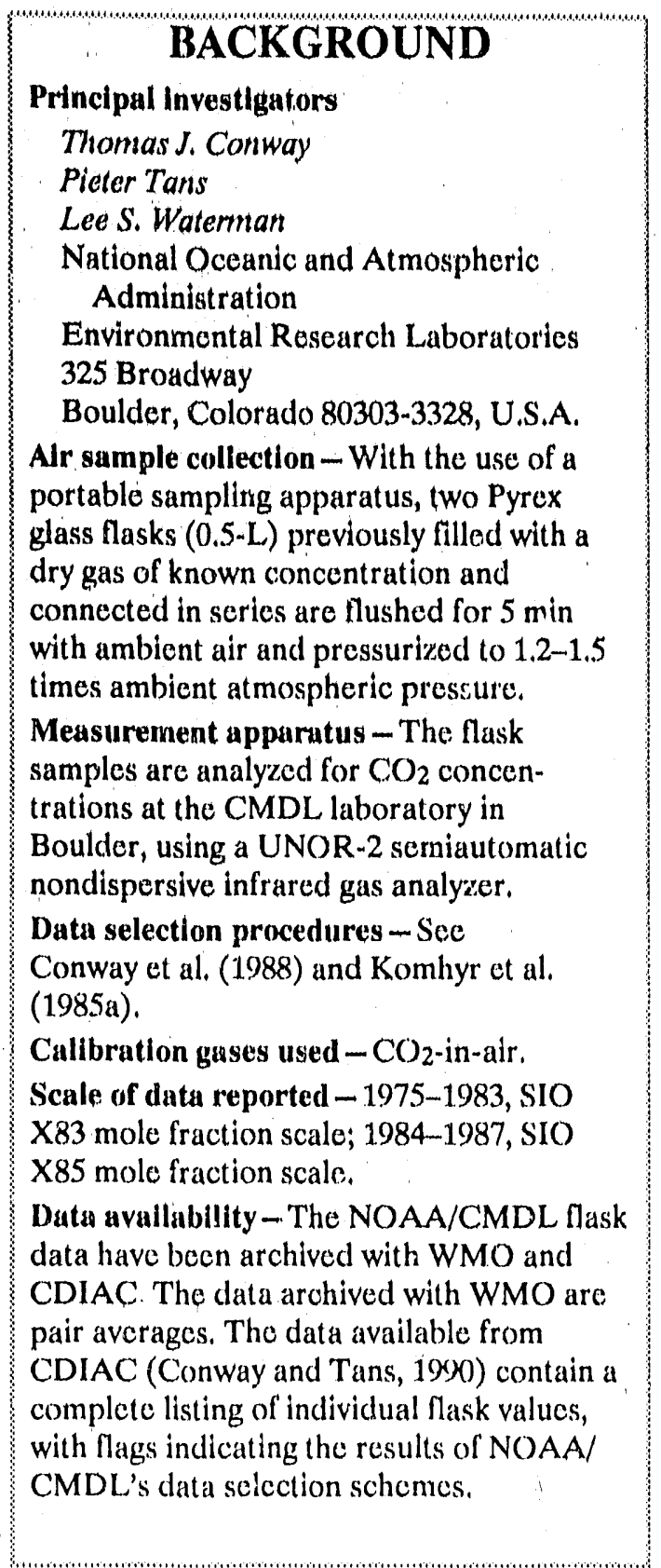

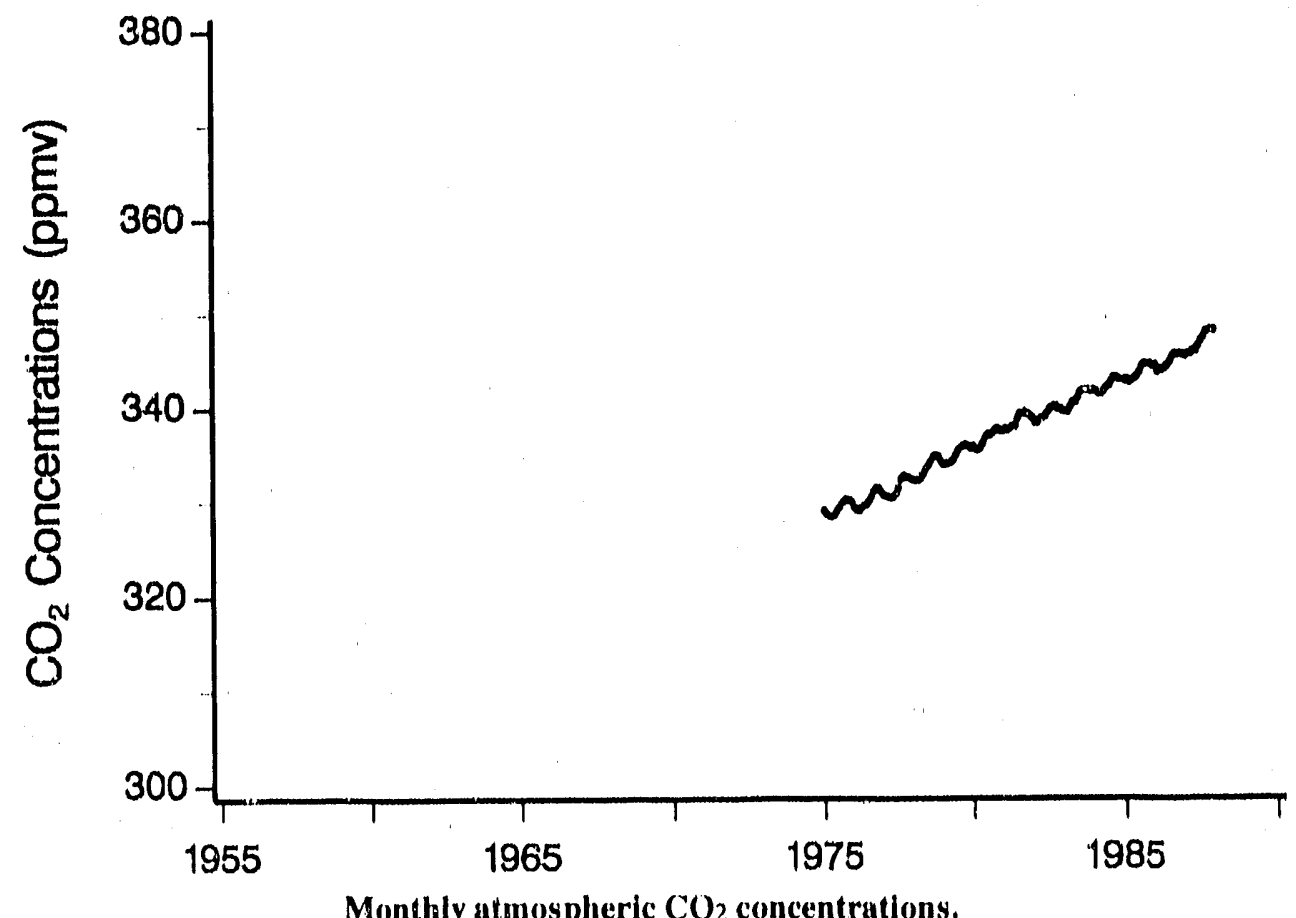

Amundsen Scott

Antarctica

Ice and snow covered

plateall

$89^{\circ} 59^{\prime} \mathrm{S}, 24^{\circ} 48^{\prime} \mathrm{W}$

$2810 \mathrm{~m}$ above MSL

Monthly atmospheric $\mathrm{CO}_{2}$ concentrations.

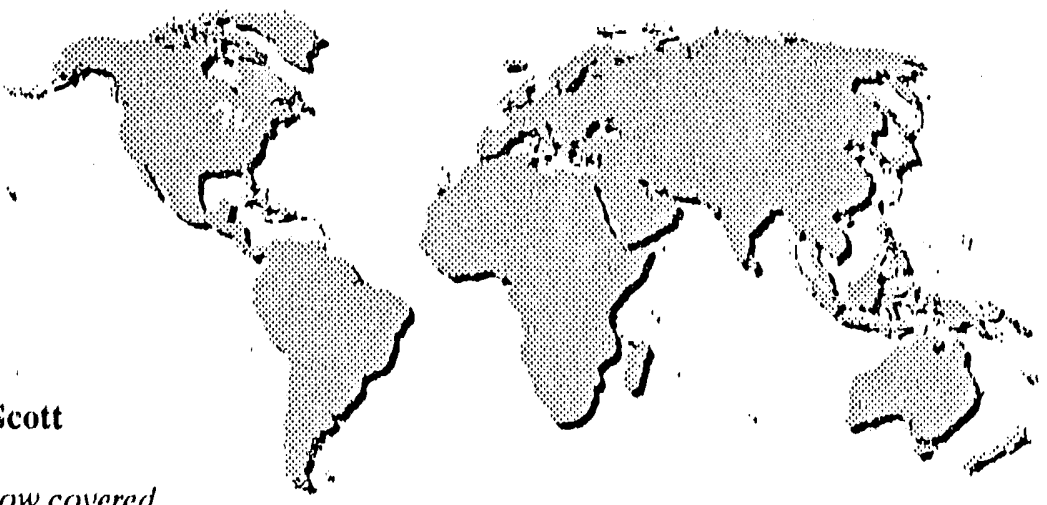




\section{Atmospheric $\mathrm{CO}_{2}$}

\section{TREND}

The sampling site at Amundsen Scott is operated in cooperation with the National Science Foundation.

The NOAA/CMDL flask data from Amundsen Scott show an increase in the annual value from $329.4 \mathrm{ppmv}$ in 1975 to 346.8 ppmv in 1987. Conway ot al. (1988) reported a 1.22-ppmv mean annual growth rate for both Amundsen Scott and all the NOAA/CMDL flask sampling sites, collectively, for 1981-1984.

Atmospheric $\mathrm{CO}_{2}$ concentrations at Amundsen Scott show a seasonal pattern with tho annual drawdown typically occurring in December-January and the annual buildup occurring in June-July. Conway et al, (1988) reported the peak-to-peak seasonal amplitude for Amundsen Scott to be 1.25 ppmy for 1981-1984. 


\section{Amundsen Scott (South Pole)}

\section{Atmospheric Concentrations of Carbon Dioxide}

\begin{tabular}{|c|c|c|c|c|c|c|c|c|c|c|c|c|c|}
\hline Yeur & Jan & Feh & Mar & Apr & May & Jun & Jul & Aug & Sept & Oct & NoY & Dec & Ann \\
\hline 1975 & 329.1 & 328,8 & 328.6 & 328.5 & 328.6 & 329.0 & 329.4 & 329.8 & 330.1 & 330.3 & 330.2 & 330,0 & 329.4 \\
\hline 1976 & 329.5 & 329.2 & 329.1 & 329,4 & 329.6 & 329.8 & 330,1 & 330.6 & 331.2 & 331.5 & 331.5 & 331.1 & 330.2 \\
\hline 1977 & 330,8 & 330.7 & 330.6 & 330.5 & 330,6 & 330.9 & 331.5 & 332.4 & 332.8 & 332.7 & 332.6 & 332.5 & 331.5 \\
\hline 1978 & 332.4 & 332.3 & 332.3 & 332.6 & 333.0 & 333.5 & 333,9 & 334.3 & 334.8 & 334.9 & 3.34 .8 & 334.3 & 333,6 \\
\hline 1979 & 334,0 & 334,0 & 334.1 & 334.2 & 334.4 & 334.9 & 335.4 & 335.7 & 335.9 & $336,(0)$ & 335.9 & 335.7 & 335.0 \\
\hline 1980 & 335,9 & 335.6 & 335.5 & 335.7 & 336,2 & 336.8 & 337.1 & 337,1 & 3377.3 & 337.6 & 337.7 & 337.5 & 336.7 \\
\hline 1981 & 337.5 & 337.7 & 337.6 & 337.8 & 338.0 & 338,0 & 338.8 & 339.3 & 339.3 & 339.4 & 339.3 & 339.1 & 338.5 \\
\hline 1982 & 338.9 & 338.4 & 338.4 & 338.7 & 338.9 & 339,0 & 339.4 & 339.8 & 340,0 & 340.1 & 339.8 & 339.8 & 339.3 \\
\hline 1983 & 339.6 & 339.5 & 339.5 & 340,0 & 340.5 & 340.5 & 341,0 & 341.6 & 341.7 & 341.8 & 341.8 & 341.7 & 340.8 \\
\hline 1984 & 341.8 & 341.7 & 341.5 & 341,4 & 341.6 & 342,0 & 342,2 & 342.7 & 343.1 & $34.3,1$ & 342.9 & 342.9 & 342.3 \\
\hline 1985 & 342.8 & 342.9 & 342,6 & 342.8 & 343.0 & 343.3 & 34.3 .7 & 344.3 & 344.5 & 344.5 & 344.5 & 344.3 & 343.6 \\
\hline 1986 & 344.4 & 343.7 & 344,0 & 343.9 & 344.1 & 344,4 & 344.8 & 345.3 & 345,6 & 345.5 & 345,6 & 345.5 & 344.7 \\
\hline 1987 & 345.4 & 345.6 & 345,6 & 345.9 & 345.9 & 346,4 & 347,0 & 347.3 & 347,9 & $348 .(1)$ & 348,1 & 3483.1 & 346,8 \\
\hline
\end{tabular}

"Atmospheric $\mathrm{CO}_{2}$ in parts per million by volume (ppmv), Annual averages based on monthly means. All numbers have been rounded to the nearest tenth. 


\section{Atmospheric (C)2}

\section{REILRLNCES}

Conwaly, T., I. P. T'uns, I.As, Walcrman, K.W. I'honing, K.A. Masiarice, and R.H.

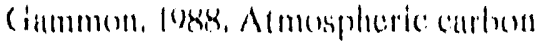
dioxide measurements in llae remole gelobul

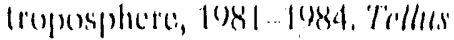
4(1)(13):81 ...115.

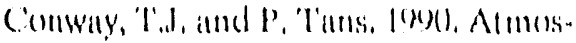

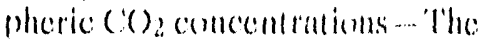
IVC)AA/CiMC ( : Plask silmpling! network.

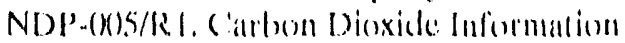
Analysis (Cenler, ()ak Kiclges Nallimal laboralory, ( )ak Ridger, T'ennessece. Kombyr, W, D), R, II, ( iammom, 'l',B, Harris,

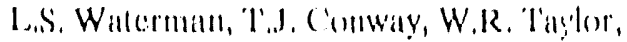
and K.W. 'Thoming, 196.5n, Cilohial almosplerice (C) 2 distribulions and

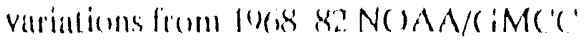

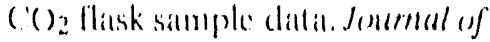

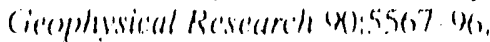
kimhyr, W.1), 'T.B, Harris, and I,.s'. Walcrman, lessib, c allibation al

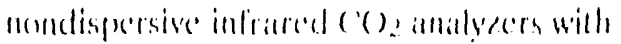

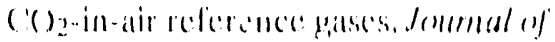

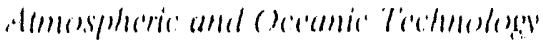
2.:3. 8 .

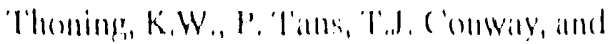

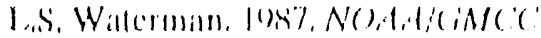

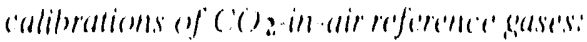

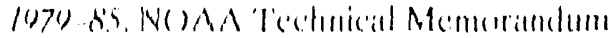

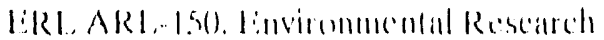

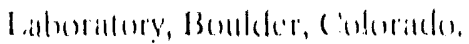

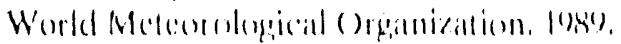

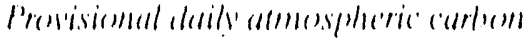

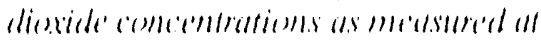

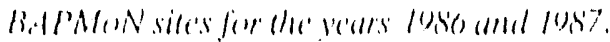

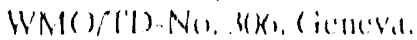




\section{Ascension Island}

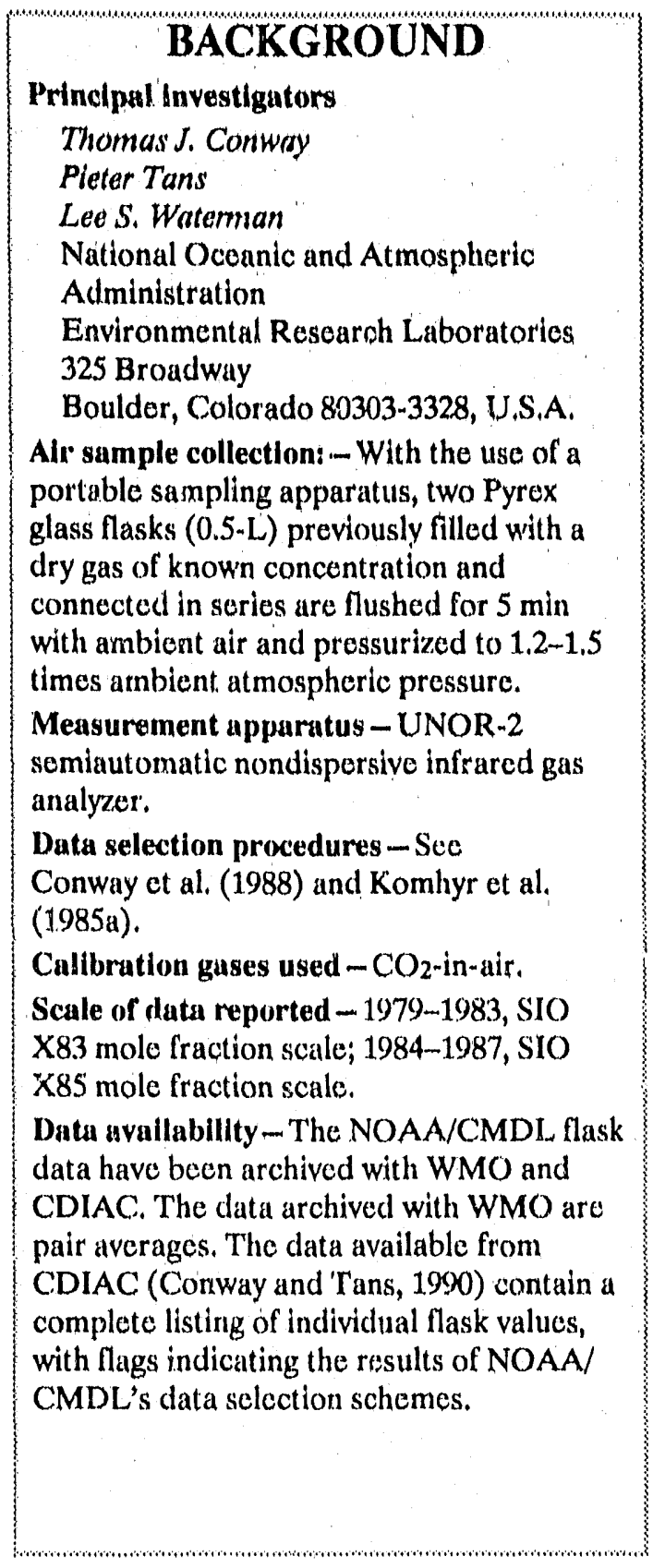

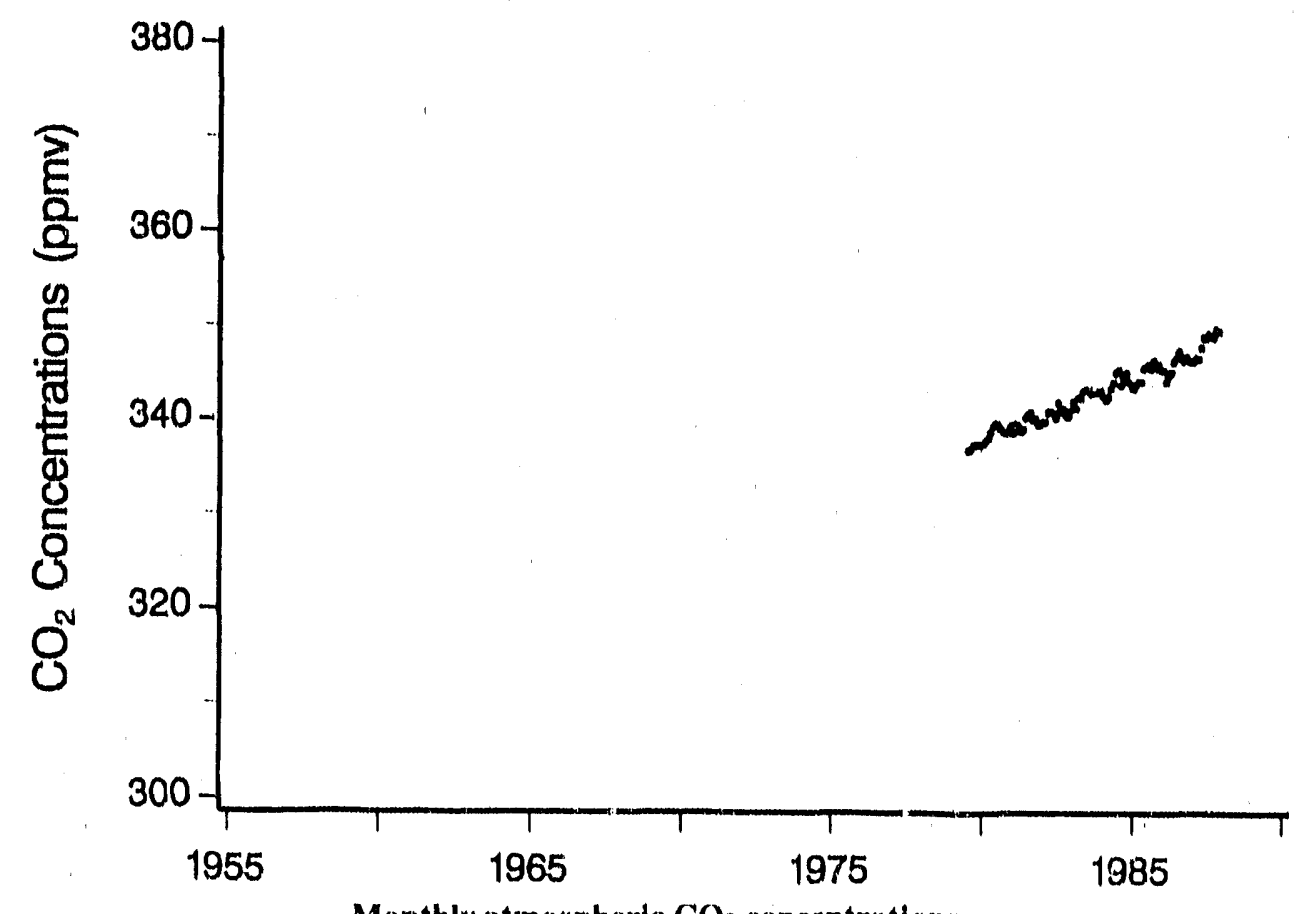

Monthly atmospheric $\mathrm{CO}_{2}$ concentrations.

Ascension Island South Allantic

Island seashore $7^{\circ} 55^{\prime} S, 14^{\circ} 25^{\prime} \mathrm{W}$ $54 \mathrm{~m}$ above $M S L$ 


\section{Atmospheric $\mathrm{CO}_{2}$}

\section{TREND}

The sampling site on the Ascension Island is operated in cooperation with the United States Air Force and Pan American World Airways.

The NOAA/CMDL flask data from Ascension Island show an increase in the annual value from $338.8 \mathrm{ppmv}$ in 1980 to 348.1 ppmv in 1987. Conway et al. (1988) reported a 1.30-ppmv mean annual growth rate at Ascension Island for 1981-1984 in comparison with a global growth rate of 1.22 ppmv per year over the same time frame for all NOAA/CMNL flask sampling sites.

Atmospheric $\mathrm{CO}_{2}$ concentrations at Ascension Island show a seasonal pattern, with the annual drawdown typically occurring in December-January and the annual buildup occurring in May-June. Conway et al. (1988) found that the seasonality at Ascension Island does not appear to be affected by transport of northern air and reported the peakto-trough seasonal amplitude for Ascension Island to be 2.00 ppmv for 1981-1984. 


\section{Ascension Island}

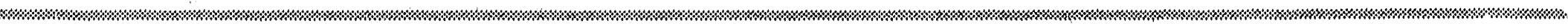

\begin{tabular}{|c|c|c|c|c|c|c|c|c|c|c|c|c|c|}
\hline Year & Jan & Feb & Mar & Apr & May & Jun & Jul & Aug & Sept & Oct & Nov & Dec & Ann \\
\hline 1979 & & & & & & & & 337.0 & 337.1 & 337.5 & 337.6 & 337.6 & \\
\hline 1980 & 337.6 & 337.7 & 338.0 & 338,3 & 338.9 & 339.5 & 339.8 & 339.7 & 339.3 & 339.0 & 338.8 & 338.8 & 338.8 \\
\hline 1981 & 339.5 & 338.8 & 339.7 & 339.6 & 339.0 & 339.2 & 340.4 & 340.7 & 340.9 & 340.2 & 340.3 & 339.7 & 339.8 \\
\hline 1982 & 339.7 & 340.0 & 340.0 & 341.0 & 341.0 & 341.0 & 340.4 & 342.0 & 341.1 & 341.4 & 340.7 & 340.6 & 340.7 \\
\hline 1983 & 341.2 & 342.1 & 341.4 & 342.5 & 342.5 & 343.2 & 343.4 & 343.3 & 343.0 & 343.4 & 343.1 & 343.1 & 342.7 \\
\hline 1984 & 343.2 & 342.7 & 342.3 & 342.6 & 343.5 & 344.1 & 345.2 & 345.4 & 343.9 & 344.6 & 345.1 & 344.2 & 343.9 \\
\hline 1985 & 343.9 & 343.5 & 343.9 & 344.2 & 344.2 & 345.6 & 345.8 & 346.0 & 345.6 & 346.4 & 345.7 & 346.0 & 345.1 \\
\hline 1986 & 345.5 & 345.4 & 344.2 & 344.8 & 345.2 & 346.3 & 346.7 & 347.4 & 346.8 & 346.4 & 346.8 & 346.5 & 346.0 \\
\hline 1987 & 346.3 & 346.3 & 346.7 & 346.6 & 347.8 & 348.9 & 348.8 & 349.2 & 349.0 & 348.9 & 349.7 & 349,5 & 348.1 \\
\hline
\end{tabular}

${ }^{*}$ Atmospheric $\mathrm{CO}_{2}$ in parts per million by volume (ppmv). Annual averages based on monthly means. All numbers have been rounded to the nearest tenth. 


\section{Atmospheric $\mathrm{CO}_{2}$}

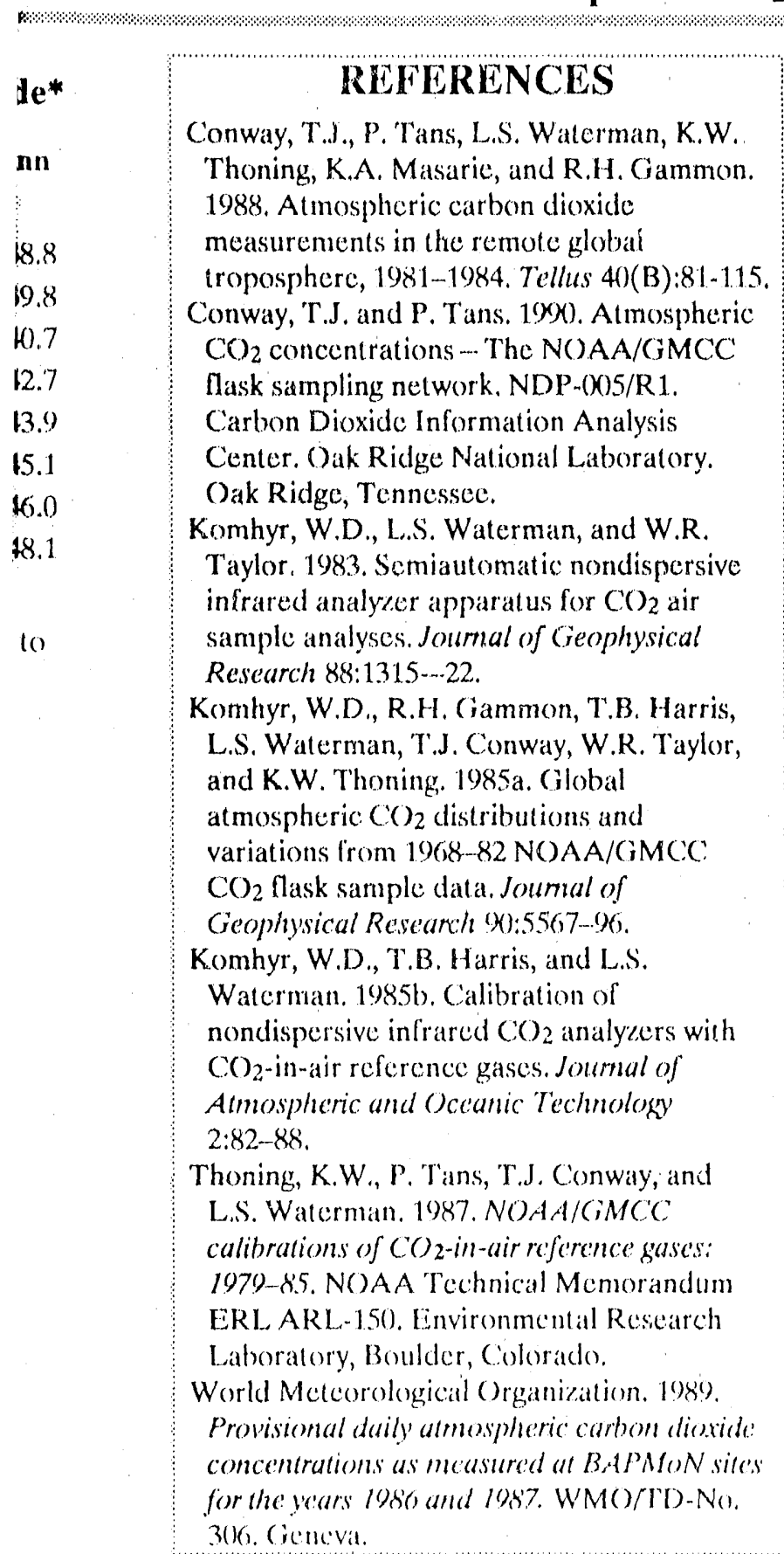




\section{Cape Grim}

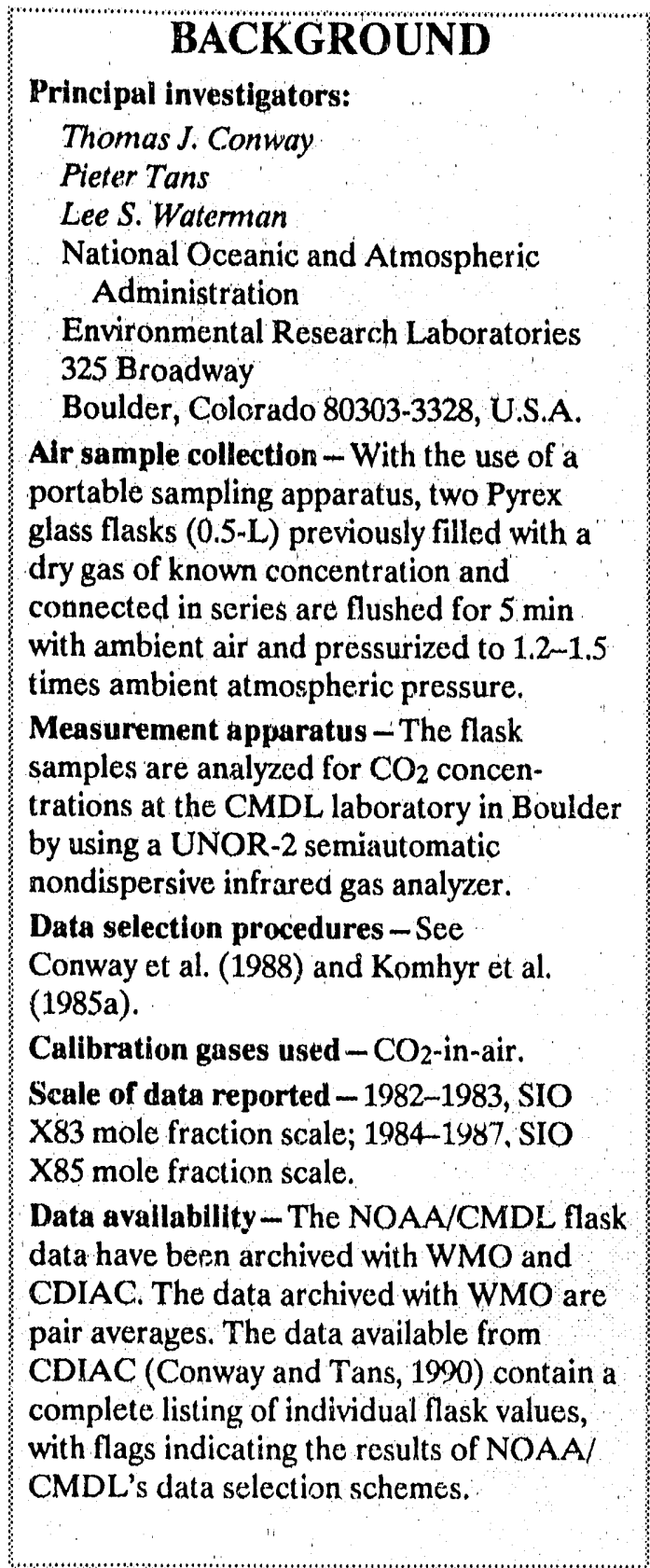

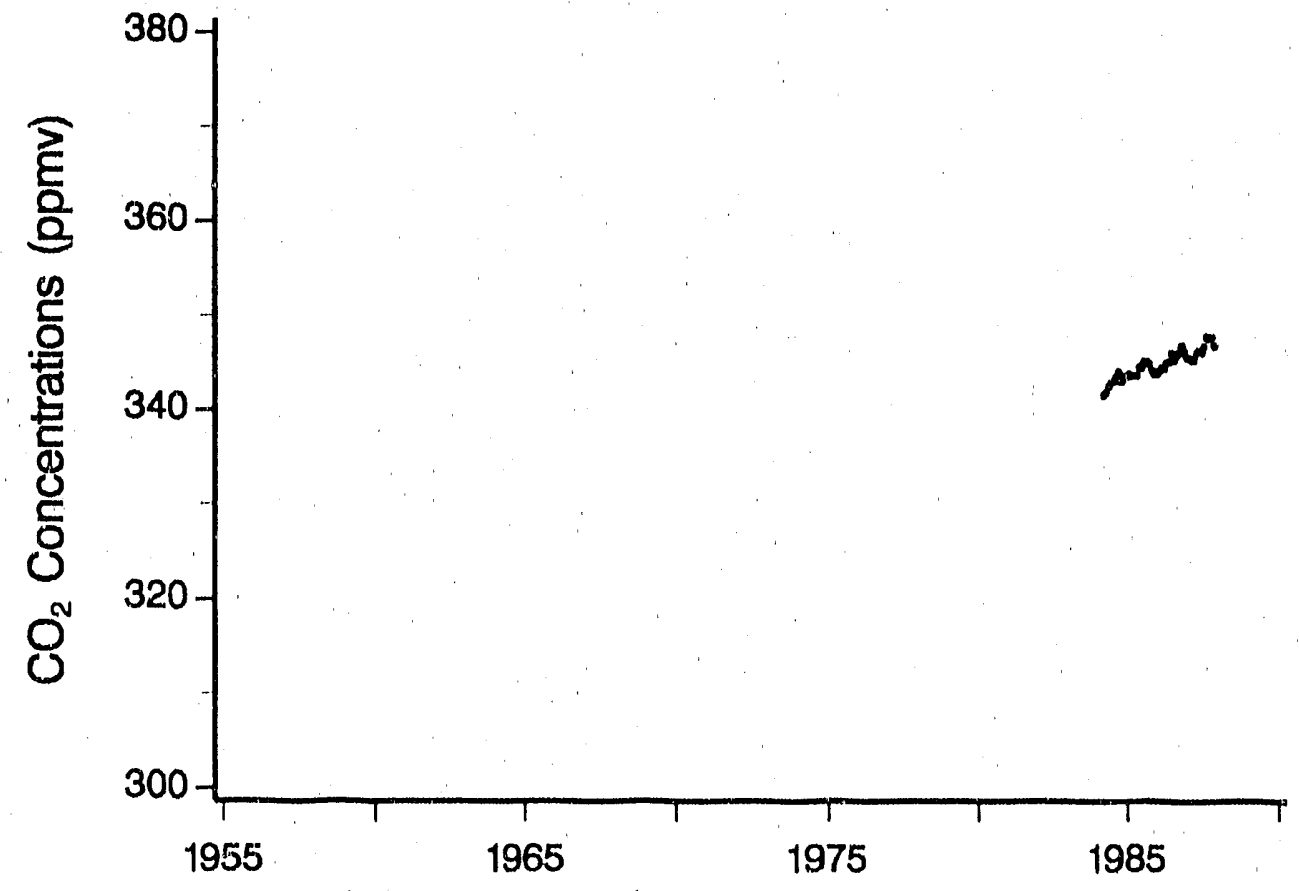

Monthly atmospheric $\mathrm{CO}_{2}$ concentrations.

Cape Grim

Tasmania, Australia

Promontory seashore

$40^{\circ} 41^{\prime} S, 144^{\circ} 41^{\prime} E$

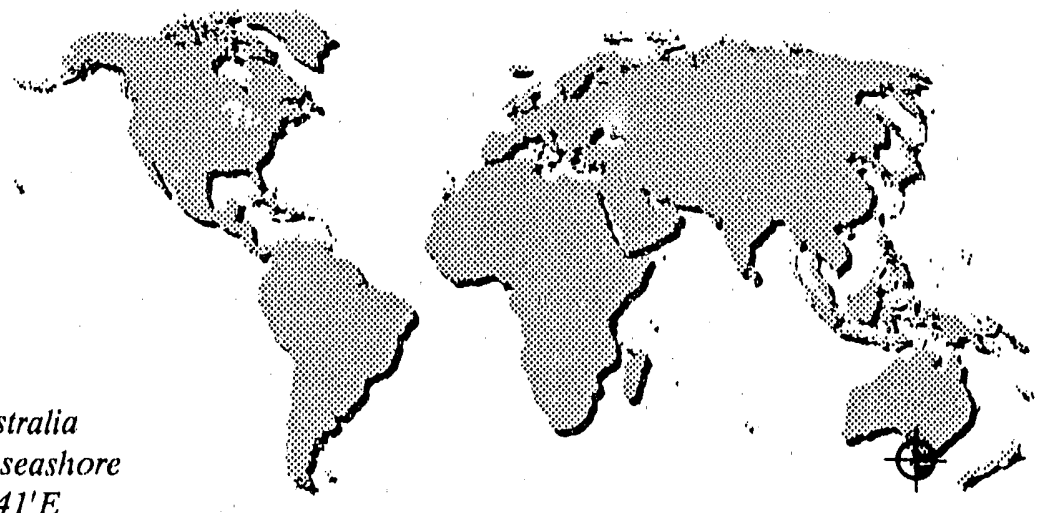

$94 \mathrm{~m}$ above MSL 


\section{Atmospheric $\mathrm{CO}_{2}$}

\section{TREND}

The sampling site at Cape Grim, Tasmania, is operated in cooperation with Graeme Pearman and Paul Fraser of the Commonwealth Scientific and Industrial Research Organization's (CSIRO's) Division of Atmospheric Research. Cape Grim replaced Kaitorete Spit, New Zealand, after it was established that Cape Grim was. a more suitable site for representative measurements at this latitude (Conway et al. 1988). From the outset of this cooperative program, samples have been taken in 0.5-L flasks. However, two sampling procedures have been used. One of the procedures is used at all the NOAA/CMDL flask sampling sites and is detailed in Komhyr et al. (1985a) and Conway et al. (1988). The second procedure differs in that the air samples are dried by passage through a glass column packed with anhydrous, granular magnesium perchlorate. This procedure is detailed in CSIRO (1989). Data derived from both procedures are given in the accompanying table.

From 1984-1987, annual average concentrations of $\mathrm{CO}_{2}$ at Cape Grim, calculated on the basis of undried air samples have risen from 342.9 to 346.3 ppmv. This represents an annual increase of 0.85 ppmv at Cape Grim in comparison with the increase of 1.22 ppmv per year reported by Conway et al. (1988) for all NOAA' CMDL flask sampling sites from 1981-1984. 


\section{Cape Grim}

\section{Atmospheric Concentrations of Carbon Dioxide*}

\begin{tabular}{|c|c|c|c|c|c|c|c|c|c|c|c|c|c|}
\hline \multirow[b]{2}{*}{ Year } & \multicolumn{12}{|c|}{ Air samples collected undried with the portable batter-powered sampling unit } & \multirow[b]{2}{*}{ Ann } \\
\hline & Jan & Feb & Mar & Apr & May & Jun & Jul & Aug & Sept & Oct & Nor & Dec & \\
\hline 1984 & & & & 341.5 & 341.8 & 342,4 & 342.8 & 342.9 & 343.4 & 343.9 & 342.7 & 343.4 & 342.9 \\
\hline 1985 & 343.4 & 343.7 & 343.5 & & 343.5 & 344.4 & 344.3 & 345.0 & 345.0 & 344.8 & 344.1 & 343.7 & 344.1 \\
\hline 1986 & 343.7 & 344.0 & 344.3 & 344.3 & 344.9 & 345.0 & 345,9 & 345.2 & 345.7 & 346.0 & 346.7 & 346.1 & 345.2 \\
\hline 1987 & 345.5 & 345.4 & 345.2 & 345.2 & 346.0 & 346.2 & 346.0 & 346.6 & 347.7 & 347.5 & 347.6 & 346.7 & 346.3 \\
\hline \multicolumn{14}{|c|}{ Data from dried samples taken through the sampling stack } \\
\hline 1984 & & & & 341.3 & 341.6 & 341.9 & 342.9 & & 343.2 & 343.0 & 342.9 & 342.7 & 342,4 \\
\hline 1985 & 342.5 & 342.5 & 342.7 & 342.8 & 342,8 & 343.2 & 343.9 & 344.4 & 344.4 & 344.3 & 344.1 & 344.0 & 343.5 \\
\hline 1986 & 343.8 & 343.9 & 344.1 & 343.9 & 344.2 & 344.5 & 344.9 & 345.0 & 345.2 & 345.7 & 345.7 & 345.3 & 344.7 \\
\hline 1987 & 345.0 & 344,9 & 345.1 & & 345.8 & 346.0 & 346.5 & 347.2 & 347.7 & 347.8 & 348.0 & 347.8 & 346.5 \\
\hline
\end{tabular}

*Atmospheric $\mathrm{CO}_{2}$ in parts per million by volume (ppmv). Annual averages based on monthly means. All numbers have been rounded to the nearest tenth. 


\section{Atmospheric $\mathrm{CO}_{2}$}

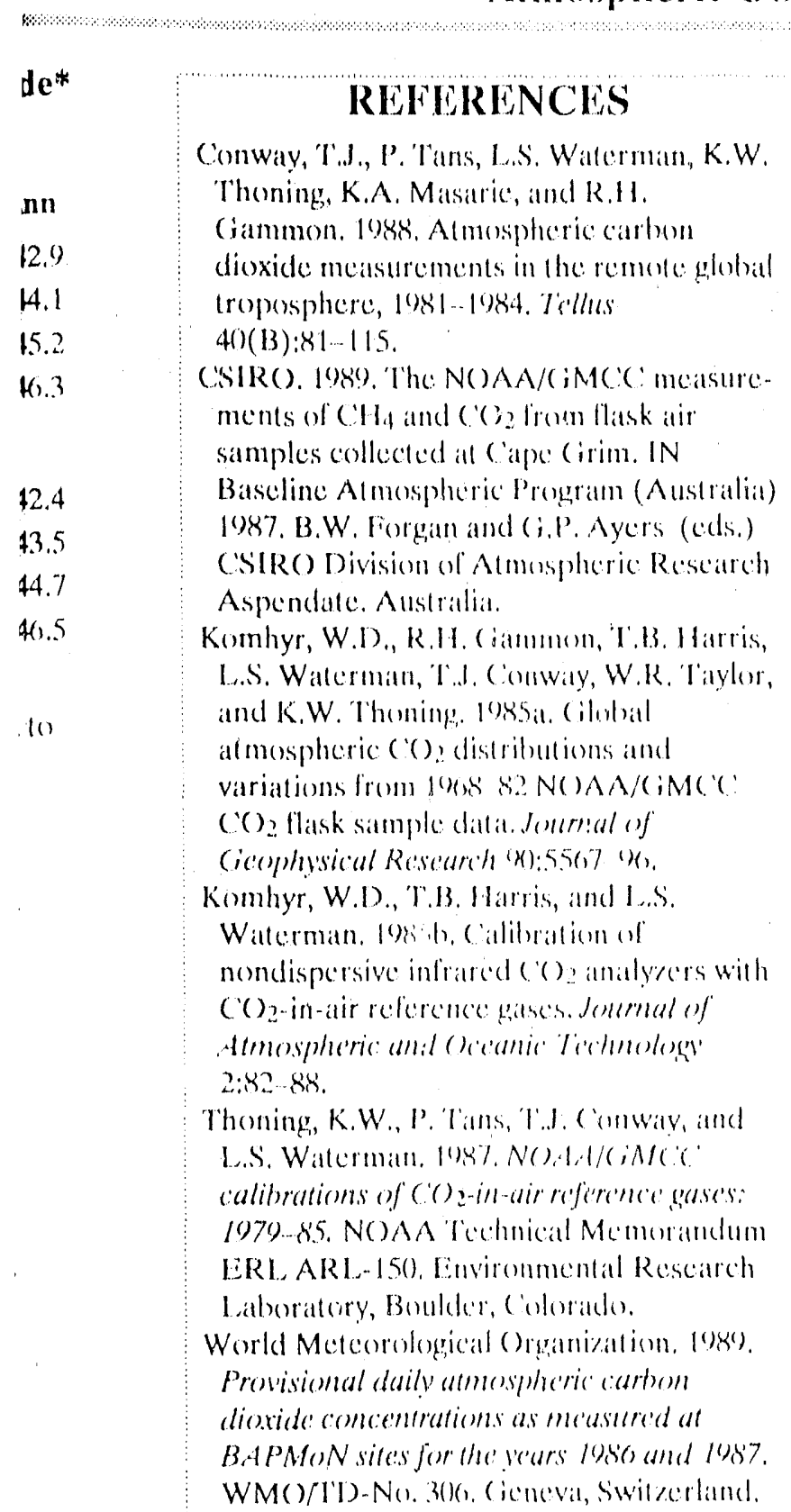




\section{Cape Kumukahi}

BACKGROUND
Principal investigators
Thomas $J$. Conway
Pieter Tans
Lee S. Waterman
National Oceanic and Atmospheric
Administration
Environmental Research Laboratories
325 Broadway
Boulder, Colorado 80303-3328, U.S.A.
Alr sample collection - With the use of a
portable sampling apparatus, two Pyrex
glass flasks (0.5-L) previously filled with a
dry gas of known concentration and
connected in series are flushed for 5 min
with ambient air and pressurized to $1.2-1.5$
times ambient atmospheric pressure.
Measurement apparatus - The flask
samples are analyzed for CO
concentrations at the CMDL laboratory in
Boulder by using a UNOR-2 semiautomatic
nondispersive infrared gas analyzer.
Data selection procedures - See
Conway et al. (1988) and Komhyr et al.
(1985a).
Calibration gases used - CO 2 -in-air.
Scale of data reported - 1976-1983, SIO
X83 mole fraction scale; 1984-1987, SIO
X85 mole fraction scale.
Data availability - The NOAA/CMDL flask
data have been archived with WMO and
CDIAC. The data archived with WMO are
pair averages. The data available from
CDIAC (Conway and Tans, 1990) contain a
complete listing of individual flask values,
with flags indicating the results of NOAAy
CMDL's data selection schemes.

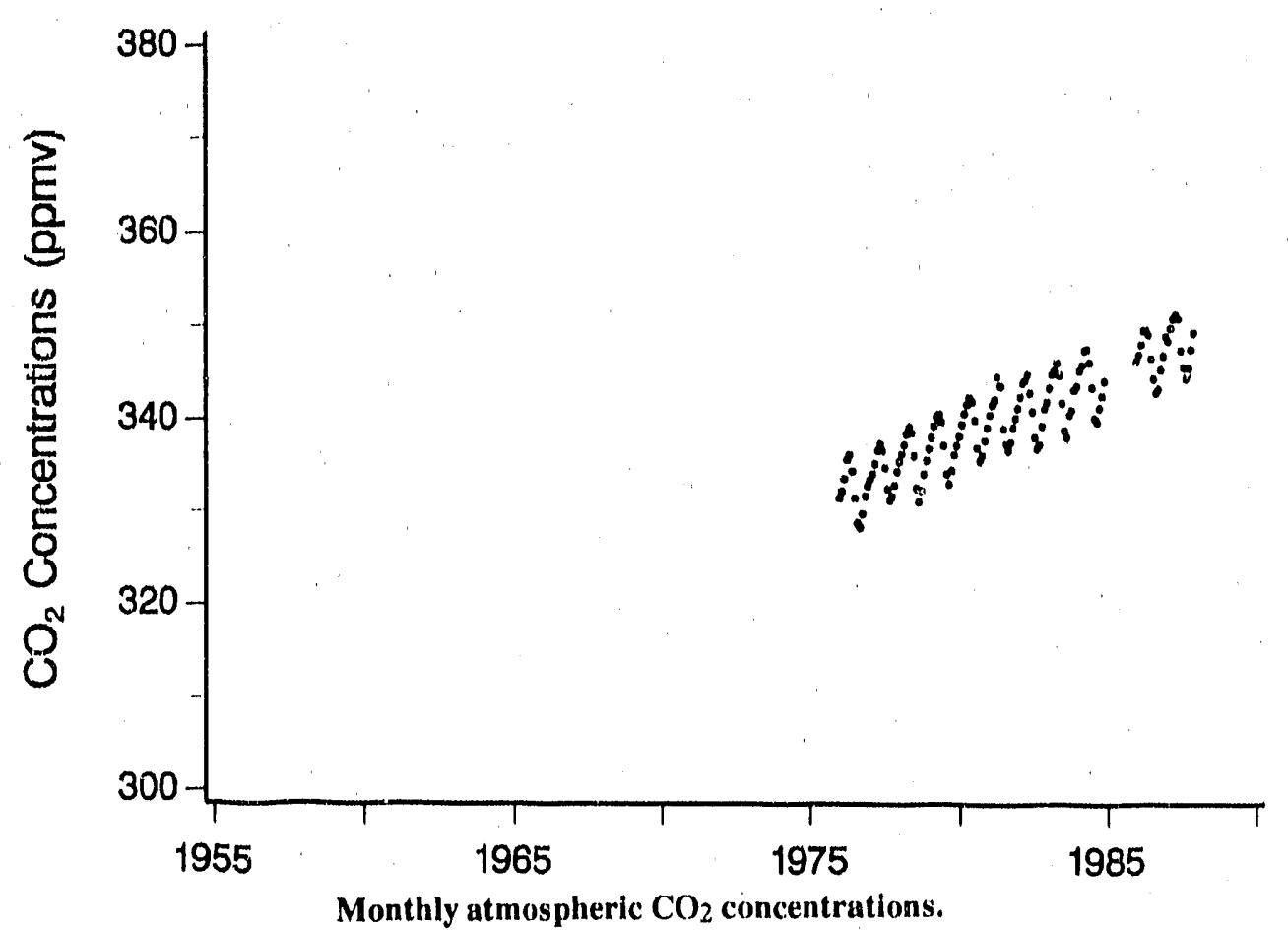

Cape Kumukahi Hawaii, U.S.A Hawail, U.S.A.
Island seashore $19^{\circ} 31^{\prime} \mathrm{N}, 154^{\circ} 49^{\prime} \mathrm{W}$ 3 m above MSL

\section{TREND}

The sampling site at Cape Kumukahi is operated in cooperation with the United States Air Forco and Pan Amorican World Airways. Airways

The NOAA/CMDL flask data from Cape Kumukahi show an increase in the annual value from $332.3 \mathrm{ppmv}$ in 1976 to 348.5 ppmv in 1987. Conway et al. (1988) reported a 1.15-ppmv mean annual growth rate at Cape Kumukahi for 1981-1984 in comparison with a global growth rate of $122 \mathrm{ppm}$ ison wh h alobal grow the per year over the same time frame for NOAA/CMDL flask sampling sites.

Atmospheric $\mathrm{CO}_{2}$ concentrations at Cape Kumukahi show a seasonal pattern with the annual drawdown typically occurring in July and the annual buildup occurring in December-January. Conway et al. (1988) reported the peak-to-trough seasonal amplitude for Cape Kumukahi to be 8.87 ppmv for 1981-1984.

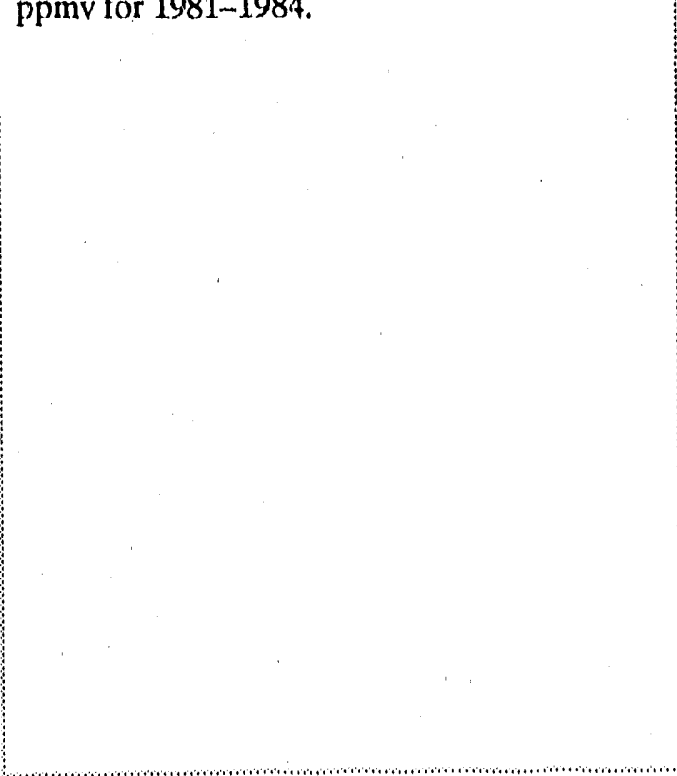




\section{Cape Kumukahi}

\section{Atmospheric Concentrations of Carbon Dioxide*}

$\begin{array}{cccccccccccccc}\text { Year } & \text { Jan } & \text { Feb } & \text { Mar } & \text { Apr } & \text { May } & \text { Jun } & \text { Jul } & \text { Aug } & \text { Sept } & \text { Oct } & \text { Nov } & \text { Dec } & \text { Ann } \\ 1976 & 331.6 & 332.3 & 333.7 & 335.8 & 336.3 & 334.5 & 331.6 & 328.9 & 328.4 & 329.9 & 331.8 & 332.9 & 332.3 \\ 1977 & 333.6 & 334.2 & 335.3 & 336.8 & 337.5 & 336.8 & 334.9 & 332.6 & 331.4 & 331.8 & 333.0 & 334.5 & 334.4 \\ 1978 & 335.6 & 336.4 & 337.4 & 338.6 & 339.3 & 338.7 & 336.2 & 332.7 & 331.2 & 332.4 & 334.2 & 335.7 & 335.7 \\ 1979 & 337.0 & 338.2 & 339.4 & 340.4 & 340.7 & 339.9 & 337.3 & 334.2 & 333.1 & 334.6 & 336.3 & 337.3 & 337.4 \\ 1980 & 338.3 & 339.6 & 340.8 & 341.8 & 342.5 & 342.1 & 340.1 & 337.1 & 335.7 & 336.3 & 337.9 & 339.3 & 339.3 \\ 1981 & 340.7 & 341.8 & 342.3 & 344.8 & 343.8 & 343.8 & 339.2 & 337.5 & 336.8 & 337.7 & 339.3 & 340.3 & 340.7 \\ 1982 & 341.4 & 342.6 & 344.1 & 344.4 & 345.0 & 343.0 & 341.0 & 338.2 & 337.0 & 337.4 & 339.4 & 341.3 & 341.2 \\ 1983 & 342.0 & 343.5 & 345.0 & 345.4 & 346.2 & 344.9 & 341.9 & 338.9 & 338.2 & 3411.6 & 341.1 & 343.3 & 342.6 \\ 1984 & 343.7 & 345.4 & 346.0 & 347.6 & 347.7 & 346.3 & 343.6 & 340.3 & 339.9 & 341.4 & 342.7 & 344.3 & 344.1 \\ 1985 & & & & & & & & & & & & & \\ 1986 & 346.4 & 347.1 & 348.2 & 349.7 & 349.7 & 349.3 & 346.7 & 344.5 & 343.0 & 343.4 & 345.5 & 347.0 & 346.7 \\ 1987 & 349.1 & 348.6 & 350.0 & 351.0 & 351.4 & 351.0 & 347.6 & 345.8 & 344.6 & 345.7 & 347.7 & 349.5 & 348.5\end{array}$

*Atmospheric $\mathrm{CO}_{2}$ in parts per million by volume (ppmv). Annual averages based on monthly means. All numbers have been rounded to the nearest tenth. 


\section{Almosphoric ( $\mathrm{O}_{2}$}

\section{REFLRENCHS}

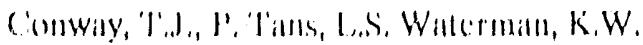
Thoning, K.A, Masillte, and K.Il, ( iammon,

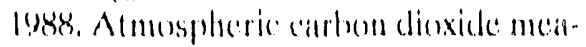

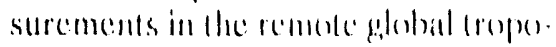

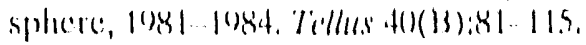

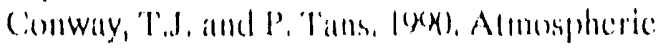

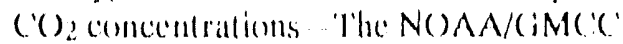
llask sampling network. NI)]'-(x)5/RI. Carbon Dioxide luformalion Analysis Concer. ()ak Ridge Natimal laboralory. () alk Riclge, Jennesisece.

komhyr, W.Y), I...S. Walloman, and W.R.

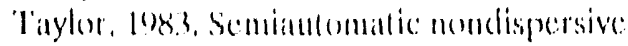

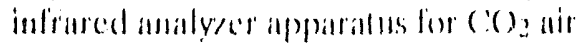

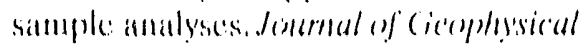

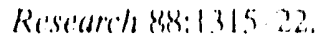

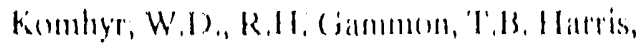
1...S. Watcrman, 'T'.l. Comwaly, V. R. 'latylur,

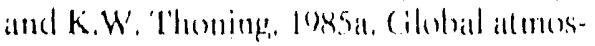
pherice ( $(3$, distributioms and vartations.

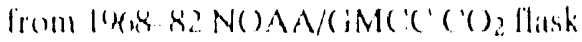

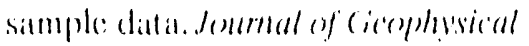

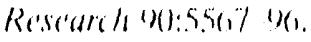

Komhyr, W.D, T'B, Harris, and I,.s.

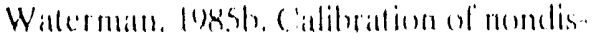

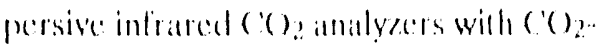

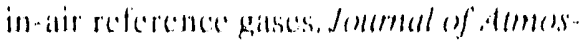

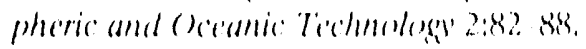

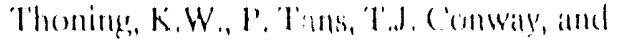

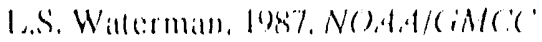

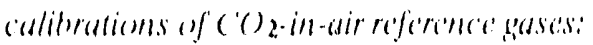
1070) 65. N() A A l'echnical Memorimelum

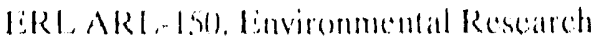

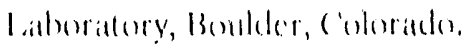

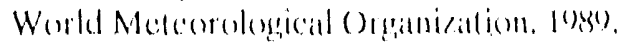

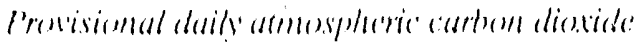

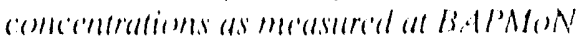

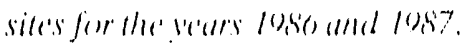

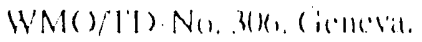




\section{Cape Matatula (American Samoa)}

\begin{tabular}{|c|}
\hline 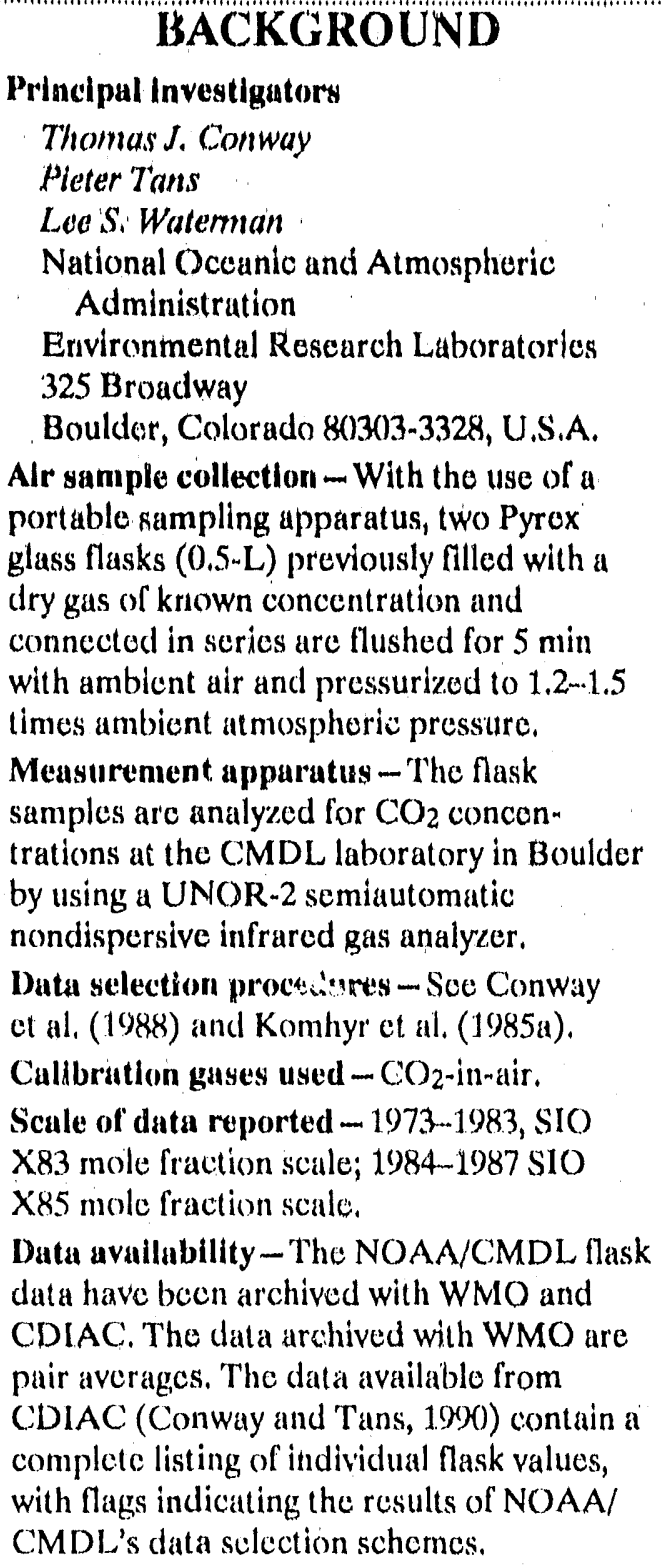 \\
\hline \\
\hline
\end{tabular}

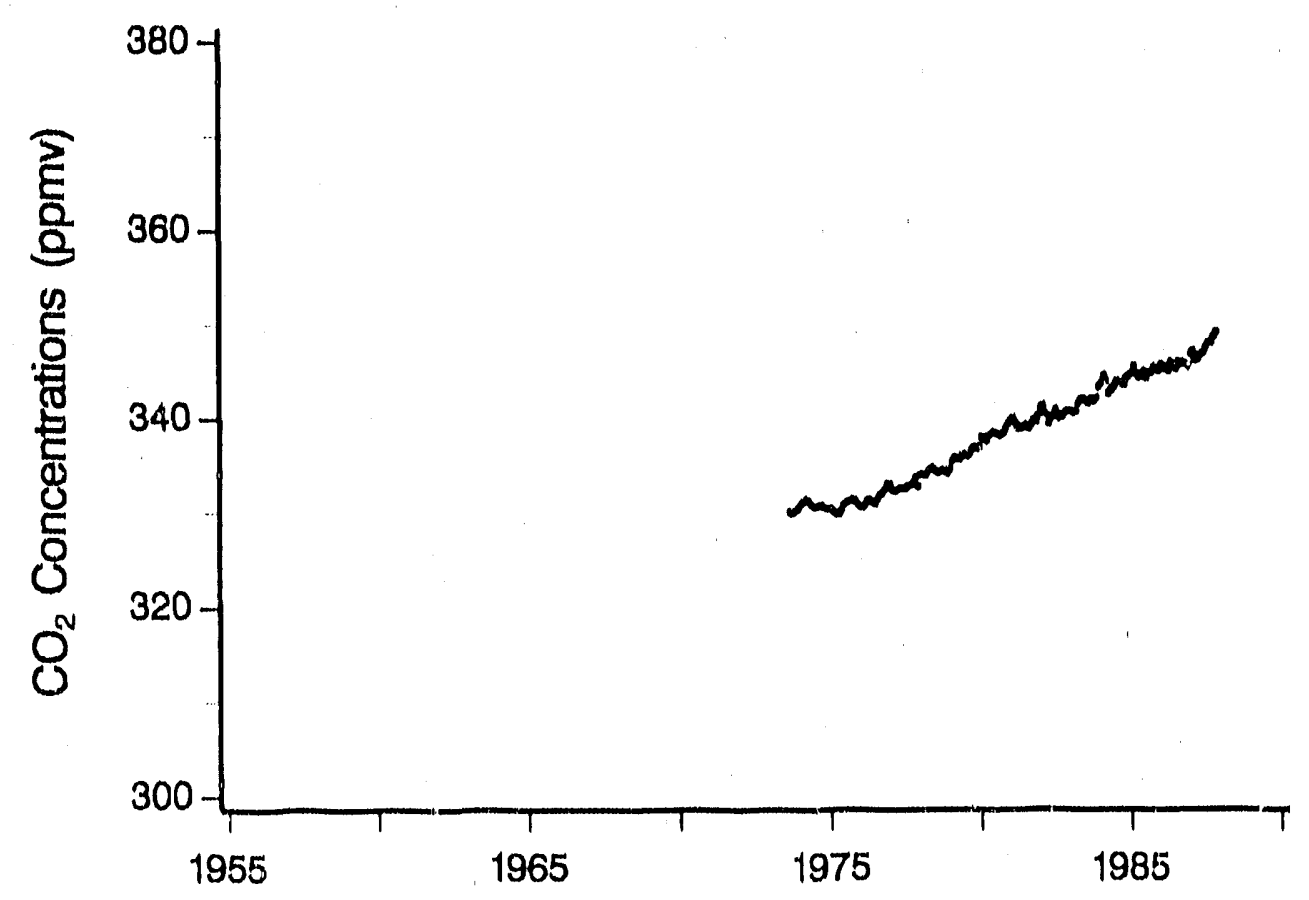

Monthly atmospheric $\mathrm{CO}_{2}$ concentrations.

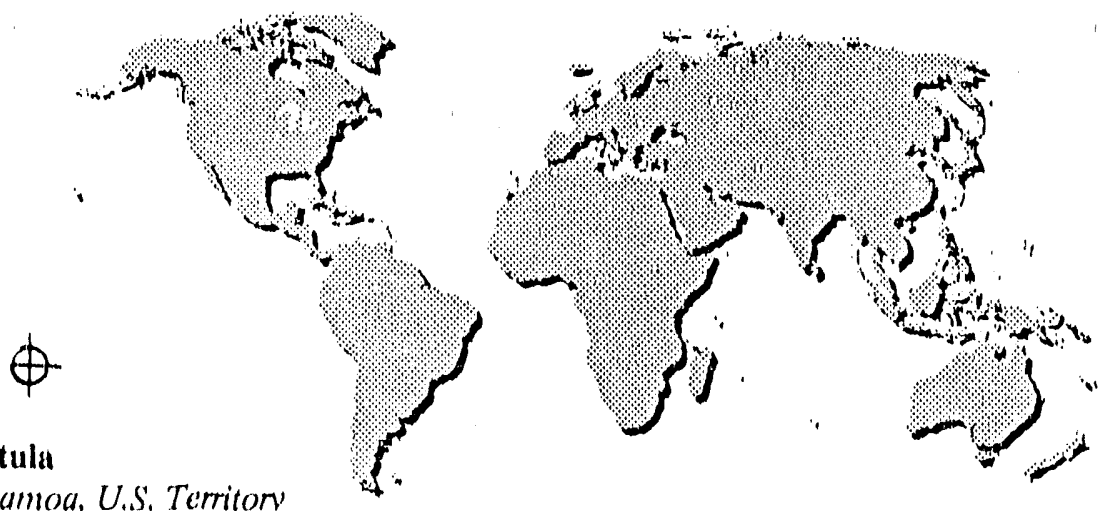

American Samoa, U.S. Territory South Pacific:

Island rocky promontory

$14^{\circ} 15^{\prime} \mathrm{S}, 170^{\circ} .34^{\prime} \mathrm{W}$

$42 \mathrm{~m}$ above MSL 


\section{Atmospheric $\mathrm{CO}_{2}$}

Mw

\section{TREND}

The NOAA/CMDL flask data from Amorican Samoa show an increase in the annual value from $330.9 \mathrm{ppm}$ in 1974 to 347.1 ppmv in 1987. Conway et al. (1988) reported a 1.35-ppmv mean annual growth rato at American Samoa for 1981-1984 in comparison with a global growth rato of 1.22 ppme per year over the same time frame for all NOAA/CMDL, flask sampling sites. Conway et al. (1988) reported the peak-to-trough seasonal at..plitude for American Samoa to be 1,40 ppinv for 1981-1984 


\section{Cape Matatula (American Samoa)}

\begin{tabular}{|c|c|c|c|c|c|c|c|c|c|c|c|c|c|}
\hline \multirow[b]{2}{*}{ Year } & \multirow[b]{2}{*}{ Jan } & \multirow[b]{2}{*}{ Feb } & \multirow[b]{2}{*}{ Mar } & \multirow[b]{2}{*}{ Apr } & \multirow[b]{2}{*}{ May } & \multirow[b]{2}{*}{ Jun } & \multirow[b]{2}{*}{ Jul } & \multicolumn{6}{|c|}{ Atmospheric Concentrationc. of Carbon Dioxide* } \\
\hline & & & & & & & & Aug & Sept & Oet & Nor & Dec & Ann \\
\hline 1973 & & & & & & & & & 330.1 & 330.0 & 330,1 & 330.3 & \\
\hline 1974 & 330.6 & 331,0 & 331.2 & 331.4 & 331.2 & 330.9 & 330.7 & 330.7 & 330.8 & 330.8 & 330.6 & 330.5 & 330.9 \\
\hline 1975 & 330.4 & 330.4 & 330.1 & 329.9 & 329.9 & $33(0,3$ & 3.30 .9 & 331.1 & 331.2 & 331.4 & 331.3 & 331.0 & 330.7 \\
\hline 1976 & 330.7 & 330.6 & 330.8 & 331.3 & 331.4 & 331.1 & 331.0 & 331.5 & 331.9 & 332.1 & 332.5 & 333.1 & 331,5 \\
\hline 1977 & 333.0 & 332.4 & 332.3 & 332.5 & 332,6 & 332.6 & 332.6 & 332.8 & 332.9 & 332.9 & 333.1 & 333.7 & 332,8 \\
\hline 1978 & 334,0 & 334.0 & 334.0 & 334.3 & 334.6 & 334.7 & 334.5 & 334.3 & 334.3 & 334.5 & 334.4 & 334,2 & 334.3 \\
\hline 1979 & 334,6 & 335.4 & 335.8 & 335.7 & 335.7 & 336.0 & 336.1 & 336.0 & 336.2 & 336.7 & 336,9 & 336.8 & 336,0 \\
\hline 1980$)$ & 337.0 & 338.0 & 338.0 & 337.6 & 338.1 & 338.3 & 338.5 & 338.4 & 338.3 & 338.2 & 338.4 & 338.9 & 338.1 \\
\hline 1981 & 339.4 & 339.7 & 340.0 & 339.4 & 338.9 & $3,38.9$ & 339.1 & 339.2 & 338.9 & 339.2 & 339.7 & 339.6 & 339.3 \\
\hline 1982 & 340.2 & 341.1 & 341.2 & 340.4 & 339.4 & 339.9 & 340.2 & 340.8 & 340.0 & 340.1 & 340.3 & 340.6 & 340.4 \\
\hline 1983 & 340.7 & 340.7 & 340.6 & 340.7 & 341.5 & 341.9 & 342.0 & 341.8 & 341.6 & 342,0 & 341.8 & 342.1 & 341.5 \\
\hline 1984 & 343.3 & 343.6 & 344.4 & 343,9 & 342.6 & 342.9 & 343.2 & 343.8 & 343.8 & 343,6 & 343.5 & 344.2 & 343.5 \\
\hline 1985 & 344.4 & 344.6 & 345.4 & 344.7 & 344.3 & 344,4 & 344.9 & 344.2 & 344.8 & 344.8 & 345.3 & 345,0 & 344.7 \\
\hline 1986 & 345.4 & 345.6 & 345.5 & 345.1 & 345.0 & 345.9 & 345.6 & 345.2 & 345.9 & 345.6 & 345.8 & 345.7 & 34.5 .5 \\
\hline 1987 & 345.5 & 346.8 & 347.0 & 346.1 & 346.2 & 346.6 & 346,9 & 347.4 & 347.9 & 347.9 & 348.5 & 349.0 & 347.1 \\
\hline
\end{tabular}

"At mospheric $\mathrm{CO}_{2}$ in parts per million by volume (ppmy). Annual averages based on monthly means. All numbers have been rounded to the nearest tenth. 


\section{Atmospheric $\mathrm{CO}_{2}$}

\section{REFERENCES}

Conway, T.J., P. Tans, L.S. Waterman, K.W. Thoning, K.A. Masaric, and R.H. Cammon. 1988. Atmospheric carbon dioxide mea. surements in the remole global tropesphere, 1981-1984. Tellus 40(B):81-115.

Conway, T.J. and P. Tans. 19y). Afmospheric C $)_{2}$ concentrations -. The NOAA/C BMC: flask sampling network. NDP (KI,5/R I. Carbon Dioxide Information Analysis Center. Oak Ridge National lab tory. Oak Ridge, T'ennessee.

Komhyr, W.D., L.S. Walcrman, and W.R. Taylor. 1983. Scmiautomatic nondispersive infrered analyzer apparalus for $\mathrm{C}^{\mathrm{C}} \mathrm{O}_{2}$ air sample analyses. Joumal of (ieopleysical Research 88:1315 22.

Komhyr, W.D., R.H. Ciammon, T.B. Marris, L.S. Waterman, T.J. Conway, W.R. Taylor, and K.W. Thoning. 1985 a cilobal atmospheric $\mathrm{CO}_{2}$ distributions and variations from 1968-82 NOA A/GMC C CO $)_{2}$ Mask sample data. Jouma ne fophysical Research (x):5567.96.

Komhyr, W.D., T.B. Harris, and I...s.

Waterman, 1985b, Calibration of nondispersive infrared $\left(\mathrm{C}_{2}\right.$ ana!yeers with $(\mathrm{C})$... in-air refercnee gases. Journal of Atmospheric and Oceanic Techmology $2: 8288$. Thoning, K.W., P. Tans, T.J. Conway, and L.S. Waterman. 1987. NOAA/CIMCC calibrations of $\mathrm{CO}_{2-i n-a i r}$ reference gases: 1979-85. NOAA Technis al Memorandum ERL ARL-150. Environmental Rescarch Laboratory, Boulder, Colonado. World Meteorological ()rganizarion. 1989.

Provisional daily atmosphatic carbon dioxide concentrations as measured at BAPMoN sites for the years 1980 and 1987. WMO/TO-No. 3(k) (ien'va. 


\section{Cape Meares}

\begin{tabular}{|c|}
\hline BACKGROUND \\
\hline Principal investlgators \\
\hline Thoma: J. Conway \\
\hline Pieter Tans \\
\hline Lee S. Waterman \\
\hline National Oceanic and Atmospheric \\
\hline Administration \\
\hline Environmental Research Laboratories \\
\hline 325 Broadway \\
\hline Boulder, Colorado 80303-3328, U.S.A. \\
\hline $\begin{array}{l}\text { Air sample collection - With the use of a } \\
\text { portable sampling apparatus, two Pyrex glass } \\
\text { flasks (0.5-L) previously filled with a dry gas } \\
\text { of known concentration and connected in } \\
\text { series are flushed for } 5 \text { min with ambient air } \\
\text { and pressurized to } 1.2-1.5 \text { times ambient } \\
\text { atmospheric pressure. }\end{array}$ \\
\hline $\begin{array}{l}\text { Measurement apparatus - The flask } \\
\text { samples are analyzed for } \mathrm{CO}_{2} \text { concen- } \\
\text { trations at the CMDL laboratory in Boulder } \\
\text { by using a UNOR-2 semiautomatic } \\
\text { nondispersive infrared gas analyzer. }\end{array}$ \\
\hline $\begin{array}{l}\text { Data selection procedures - See } \\
\text { Conway et al. (1988) and Kombyr et al. } \\
\text { (1985a). }\end{array}$ \\
\hline Calibratlon gases used - $\mathrm{CO}_{2}$-in-air. \\
\hline $\begin{array}{l}\text { Scale of data reported }-1982-1983 \text {, SIO } \\
\text { X83 mole fraction scale, } 1984-1987 \text {, SIO } \\
\text { X85 mole fraction scale. }\end{array}$ \\
\hline $\begin{array}{l}\text { Data availability - The NOAA/CMDL flask } \\
\text { data have been archived with WMO and } \\
\text { CDIAC. The data archived with WMO are } \\
\text { pair averages. The data available from } \\
\text { CDIAC (Conway and Tans, 1990) contain a } \\
\text { complete listing of individual flask values, } \\
\text { with flags indicating the results of NOA } \\
\text { CMDIs data selection schemes. }\end{array}$ \\
\hline
\end{tabular}

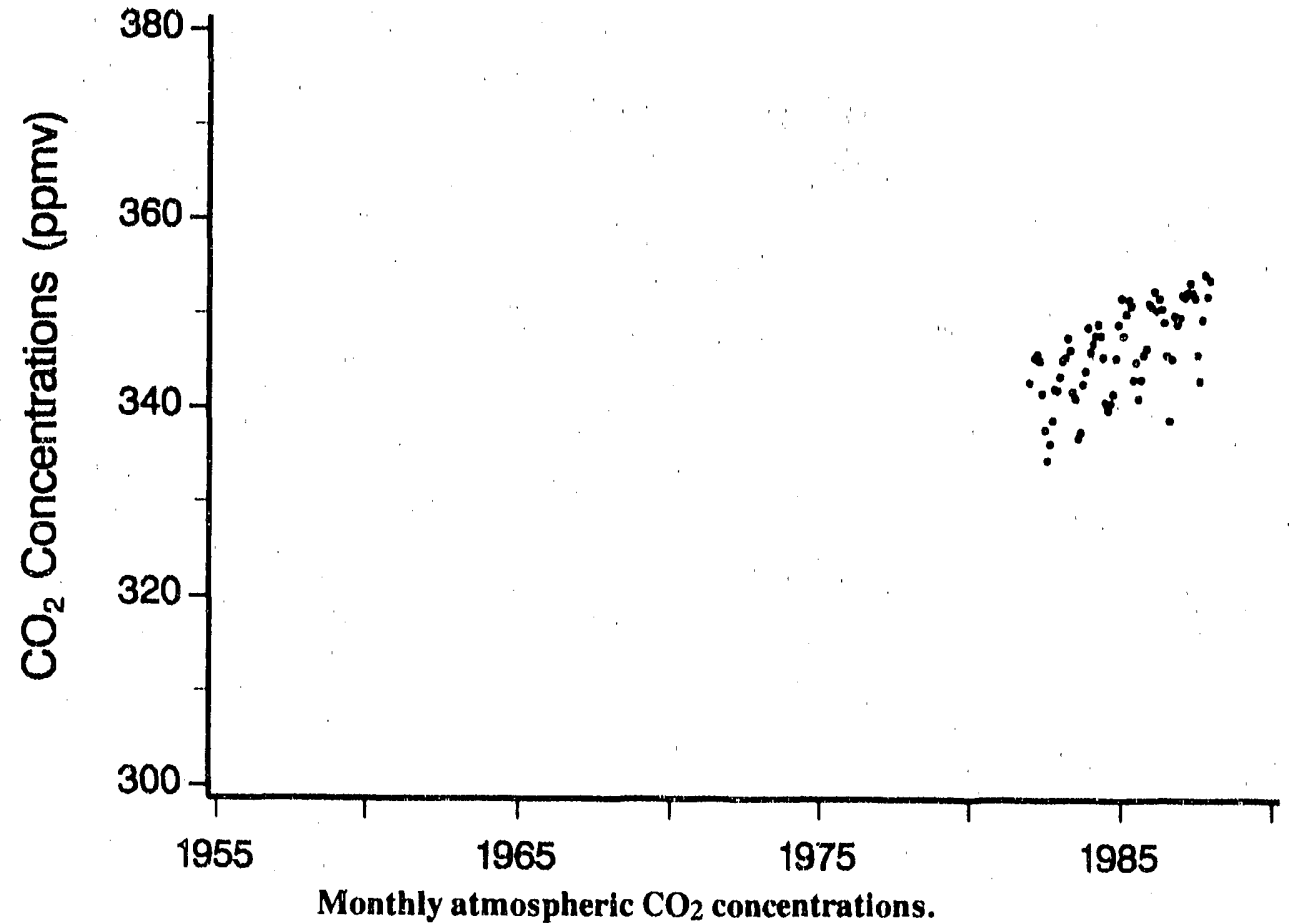

Cape Meares

Oregon, U.S.A.

Promontory seashore

$45^{\circ} 29^{\prime} \mathrm{N}, 120^{\circ} 00^{\prime} \mathrm{W}$

$30 \mathrm{~m}$ above MSL 


\section{Atmospheric $\mathrm{CO}_{2}$}

\section{TREND}

The sampling site at Cape Meares is operated in cooperation with the Oregon Graduate Institute of Science and Technology. The NOAA/CMDL flask data from Cape Meares show an increase in the annual value from $341.0 \mathrm{ppmv}$ in 1982 to $350.9 \mathrm{ppmv}$ in 1987. This represents an increase of -1.7 ppmv per year in comparison with a global growth rate of $1.22 \mathrm{ppm} v$ per year reported by Conway et al. (1988) for all NOAA/CMDL flask sampling sites for 1981-1984.

Atmospheric $\mathrm{CO}_{2}$ concentrations at Cape Meares show a seasonal pattern, with the annual minimum recorded during August and the annual maximum recorded during January-April. 


\section{Cape Meares}

\section{Atmospheric Concentrations of Carbon Dioxide*}

$\begin{array}{lccccccccccccc}\text { Year } & \text { Jan } & \text { Feb } & \text { Mar } & \text { Apr } & \text { May } & \text { Jun } & \text { Jul } & \text { Aug } & \text { Sept } & \text { Oct } & \text { Nov } & \text { Dec } & \text { Ann } \\ 1982 & 342.7 & & 345.3 & 345.7 & 345.0 & 341.5 & 337.7 & 334.5 & 336.2 & 338.7 & 342.0 & 341.9 & 341.0 \\ 1983 & 343.3 & 345.0 & 345.3 & 347.4 & 346.1 & 341.7 & 341.0 & 336.8 & 337.4 & 342.5 & 343.9 & 348.5 & 343.2 \\ 1984 & 345.9 & 346.8 & 347.7 & 348.9 & 347.7 & 345.4 & 340.6 & 339.8 & 340.5 & 341.5 & 345.3 & 348.9 & 344.9 \\ 1985 & 351.7 & 347.7 & 350.0 & 351.5 & 350.9 & & 344.9 & 341.0 & 343.0 & 345.6 & 346.3 & 351.1 & 347.9 \\ 1986 & 350.8 & 352.4 & 350.4 & 351.6 & 350.5 & 349.1 & 345.6 & 338.7 & 345.2 & 349.8 & 348.9 & 349.6 & 349.5 \\ 1987 & 352.0 & 351.8 & 352.3 & 353.3 & 352.2 & 351.7 & 345.7 & 342.9 & 349.4 & 354.2 & 351.9 & 353.6 & 350.9\end{array}$

*Atmospheric $\mathrm{CO}_{2}$ in parts per million by volume (ppmv). Annual averages based on monthly means. All numbers have been rounded to the nearcst tenth. 


\section{Atmospheric $\mathrm{CO}_{2}$}

\section{REFERENCES}

Conway, T.J., P. Tans, L.S. Walerman, K.W. Thoning, K.A. Masarie, and R.H. Gammon. 1988. Atmospheric carbon dioxide measurements in the remote global troposphere, 1981-1984. Tellas 41)(B):81-115.

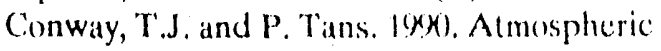
C( $)_{2}$ concentrations - 'The NOAA/GMC. llask sampling ne(work. NDP-(X)S/R . Carbon Dioxide Information Analysis Center. ()ak Ridge National l aboralory. ()ak Ridge, Tennessec.

Komhyr, W.D., L.S. Walcerman, and W.R. Taylor. 1983. Semiatumatic nondispersive infrared analyeer apparalus for ('( $)_{2}$ air sample analyses. Jourmal of (icenthysical Resecurch 8xi1315. 22.

Komhyr, W.D., R.H. (iammon, T.B. Hatris, L..S. Watcrman, T.J. ('onwaly, W.R. Taylor, and K.W. Theming, losita, (ilubat ammos. pheric: ( ()$_{2}$ dist ributions and variations

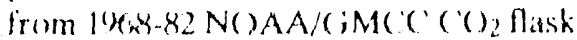
simple data. Journul of (iveophysical Researsh $(x): 5.50,7,2)$.

Kombyr, W.D., T.B. Hamis, and I...S. Watcrman. lossh. (aliluation of nondispersive infrared (') analyors with (')?in-air reference gatses Jomat of almos-

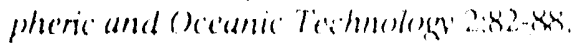
Thoning, K.W., l'. 'Tams, T.l. C'onway, and

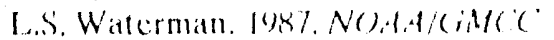

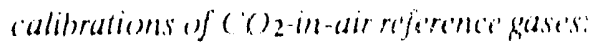
1970-85. N()AA Technical Memor molum ERL. ARL-150. Environmental Re ated Laboratory, Bumlder, Colorido.

World Metcorological ()rganizalion. lose.

Prowisional daily atmospheric artum dionilla concentrations as measured at BAPAfoN sites for the years loso and Ios7. WM()/TD-Ne. 3ki. cienceva. 


\section{Christmas Island}

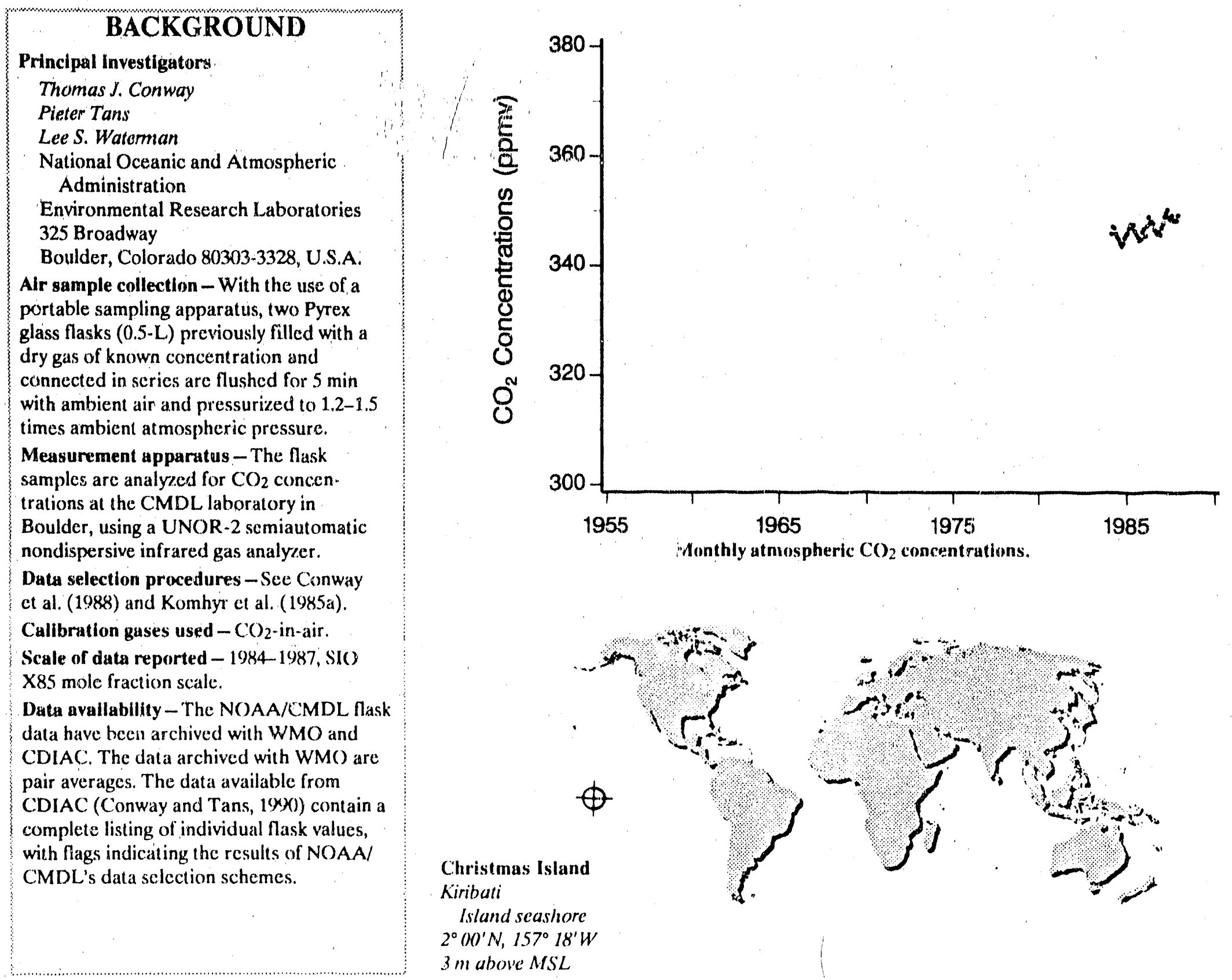




\section{Atmospheric $\mathrm{CO}_{2}$}

\section{TREND}

The sampling site on Christmas Island is operated in cooperation with the Scripps Institution of Oceanography.

The NOAA/CMDL flask data from Christmas Island show an increase in the annual value from $345.1 \mathrm{ppmv}$ in 1984 to 348.4 ppmv in 1987. From 1984-1987, the annual average $\mathrm{CO}_{2}$ concentration at Christmas Island showc'd a 0.83 ppmv per year increase. Conway et al. (1988) found a global growth rate of 1.22 ppmv per year for all NOAA/CMDL flask sampling sites from 1981-1984.

Based on the few years of data available, atmospheric $\mathrm{CO}_{2}$ concentrations at Christmas Island show variable seasonal patterns. From 1985-1987, annual minimum values were measured in October, February, and January, respectively. For the same time period, the annual high was recorded during either April or May of each year. 


\section{Christmas Island}

\section{Atmospheric Concentrations of Carbon Dioxide*}

$\begin{array}{llllllllllllll}\text { Year } & \text { Jan } & \text { Feb } & \text { Mar } & \text { Apr } & \text { May } & \text { Jun } & \text { Jul } & \text { Aug } & \text { Sept } & \text { Oct } & \text { Nov } & \text { Dec } & \text { Ann } \\ 1984 & & & 345.6 & 346.9 & 346.7 & 345.6 & 345.0 & 344.6 & 343.9 & 343.4 & 343.9 & 344.9 & 345.1 \\ 1985 & 345.4 & 345.8 & 346.7 & 347.4 & 346.9 & 347.3 & 346.2 & 345.6 & 345.1 & 344.5 & 344.7 & 346.0 & 346.0 \\ 1986 & 346.5 & 345.2 & 347.0 & 348.6 & 347.5 & 347.8 & 347.4 & 346.3 & 346.0 & 345.5 & 345.9 & 345.4 & 346.6 \\ 1987 & 346.7 & 347.4 & 348.7 & 349.4 & 350.0 & 348.6 & 348.3 & 349.0 & 348.1 & 348.1 & 348.1 & 349.1 & 348.4\end{array}$

"Atmospheric $\mathrm{CO}_{2}$ in parts per million by volume (ppmv). Annual averages based on monthly means. All numbers have been rounded to the ncarest tenth. 


\section{Atmospheric $\mathrm{CO}_{2}$}

\section{REFERENCLS}

C'omway, 'T.J., I'. 'Ians, L..S. Wallerman, K.W.

Thoming, K,A. Masaris, and R.H. (Bammon. 1988. Almosplocic carbon dioxide measurements in the remote global troposphere,

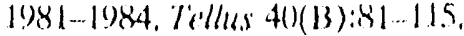

Conway, 'T.J. and P. Tans. $I(x)$. Almospheric (C) 2 concentrations ... 'The NOAA/CiMC'C llask sampling nelwork. ND)!'-(x)5/R1. Carbon Dioxide Information Analysis Center. ()ak Ridge Natiomal l aboratory. ()ak Ridge, Tennessiec.

Komhyr, W.D., L.,i. Walcrmatl, and W.R. Taylor, log?. Semiantomalle nondispersive infrared analyerer apparallus for ( ( () a at

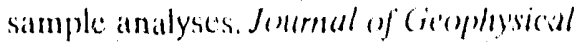
Resererch wo:1315 32.2.

Kumbyr, W.D., R.H. ( iammon, 'T.B. Hatris, L.S. Walcrman, Y.J. ( 'onway, W.R. Taylor, and K.W. Thonimg. 1985a. (ilobal atmospheric (') 2 distributions and

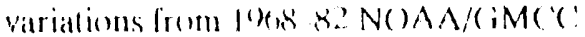
(') ( ) llask simple dalia. Journal of

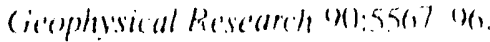

Komhyr, W.I)., T.P. Harris, and I ..S.

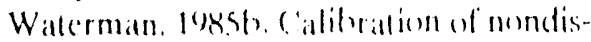

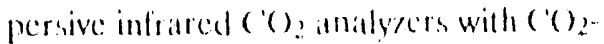
in-air reforence gatses. Jemertal af demos."

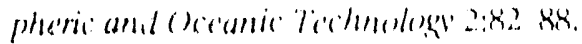

Thonink, K.W., P. Tann, I'.J. ('onway, and

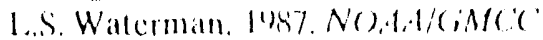

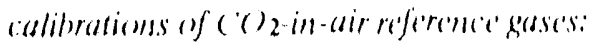
1979 6.5. NOAA Technical Memorandum BRI. ARL. 1.S1, linvinommental Rescarch Laboratory, Boulder, ( ollorado.

World Moleorolegrical ()eganization. 1984).

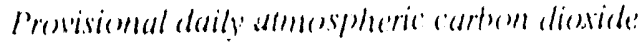
comocentrations as measured at BrtlMoN sites' forthe veses lose and 1987. WM1(3/T)-No. 3ki. (icmeval. 


\section{Cold Bay}

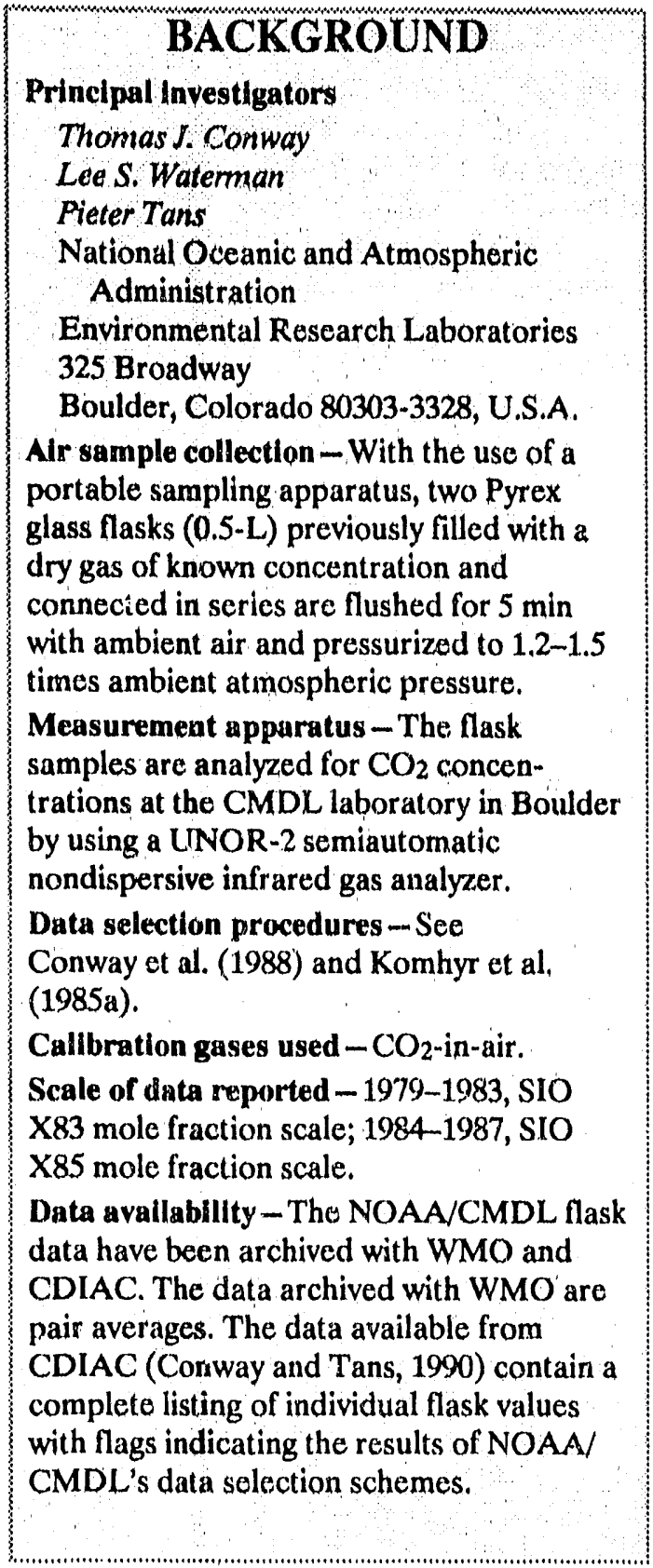

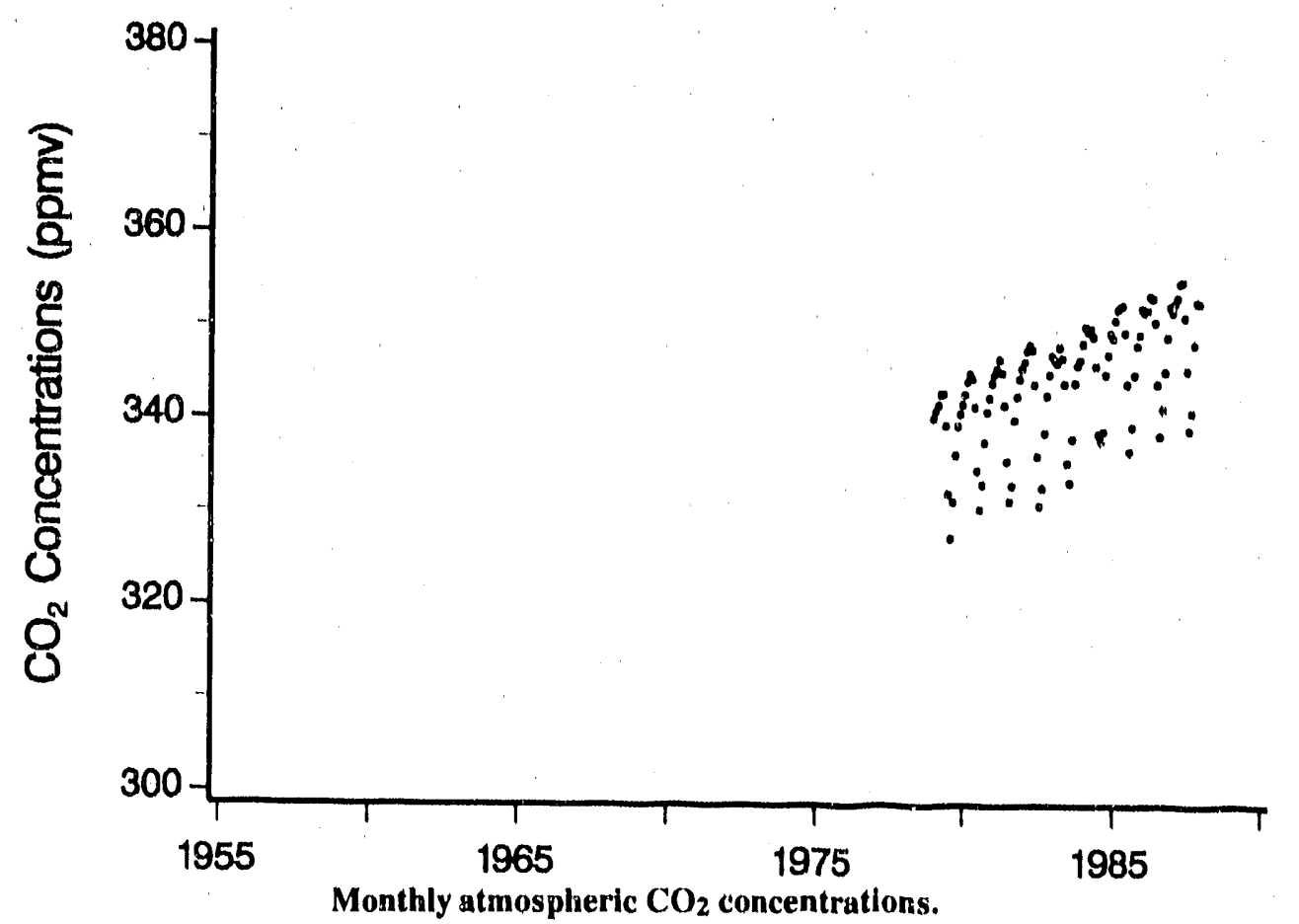

Cold Bay

Alaska, U.S.A.

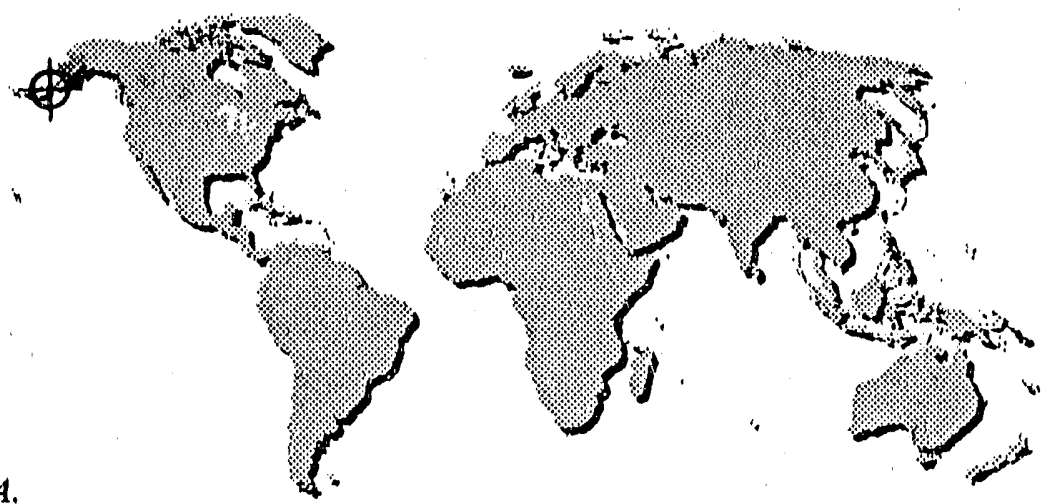

Treeless peninsula

$55^{\circ} 12^{\prime} \mathrm{N}, 162^{\circ} 43^{\prime} \mathrm{W}$

$11 \mathrm{~m}$ above $M S L$ 


\section{TREND}

These daia are from the NOAA/CMDL flask sampling program. The sampling site at Cold Bay, Alaska, is operated in cooperation with the National Weather Service. The NOAA/CMDL flask data from Cold Bay show an increase in tho annual value from $337.7 \mathrm{ppmv}$ in 1979 to 349.6 ppmv in 1987. Conway et al. (1988) reported a 1.44-ppmv mean annual growth rate at Cold Bay for 1981-1984 in comparison with a global growth rate of $1.22 \mathrm{ppmv}$ per year over the same time frame for all NOAA/CMDL flask sampling sites.

Atmospheric $\mathrm{CO}_{2}$ concentrations at Cold Bay show a seasonal pattern, with the annual drawdown typically in June and the annual buildup occurring in November. Conway et al. (1988) found the average peak-to-trough amplitude for Cold Bay to be 14.27 ppmv from 1981-1984. 


\section{Cold Bay}

Atmospheric Concentrations of Carbon Dioxide*

\begin{tabular}{|c|c|c|c|c|c|c|c|c|c|c|c|c|c|}
\hline Year & Jan & Feb & Mar & Apr & May & Jun & Jul & Aug & Sept & Oct & Nov & Dec & Ann \\
\hline 1979 & 340.1 & 340.9 & 341.5 & 342.7 & 342.7 & 339.3 & 332.0 & 327,2 & 331.1 & 336.1 & 339.2 & 340.5 & 337.7 \\
\hline 1980 & 341.5 & 342.6 & 344.0 & 344.8 & 344.3 & 341.3 & 334.5 & 330.3 & 333.0 & 337.5 & 340.8 & 342.3 & 339.7 \\
\hline 1981 & 343.9 & 344.8 & 345.4 & 346.4 & 345.2 & 341.5 & 335.5 & 331.2 & 332.9 & 339.9 & 342.4 & 344.3 & 341.1 \\
\hline 1982 & 345.4 & 346.1 & 347.3 & 347.9 & 347.4 & 343.7 & 336.0 & 330.7 & 332.6 & 338.5 & 342.5 & 344.8 & 341.9 \\
\hline 1983 & 346.8 & 346.4 & 346.0 & 347.7 & 346.5 & 343.8 & 335.3 & 333.2 & 337.9 & 343.9 & 345.8 & 346.3 & 343.3 \\
\hline 1984 & 348.1 & 349.9 & 349.4 & 349.7 & 348.9 & 345.7 & 338.4 & 337.7 & 338.7 & 344.8 & 346.9 & 349.2 & 345.6 \\
\hline 1985 & 348.7 & 350.6 & 351.8 & 352.0 & 352.2 & .349 .3 & 343.8 & 336.6 & 339.2 & 344.8 & 347.9 & 349.1 & 347.2 \\
\hline 1986 & 351.9 & 351.5 & 351.7 & 353.2 & 353.0 & 350.4 & 343.8 & 338.2 & 341.1 & 345.1 & 348.8 & 352.1 & 348,8 \\
\hline 1987 & 351.5 & 352.5 & 353.1 & 354.6 & 354.8 & 351.0 & 345.3 & 338.9 & 340.8 & 348.1 & 352,6 & 352.5 & 349.6 \\
\hline
\end{tabular}

* Atmospheric $\mathrm{CO}_{2}$ in parts per million by volume (ppmv). Annual averages based on monthly means. All numbers have been rounded to the nearest tenth. 


\section{Atmospheric $\mathrm{CO}_{2}$}

\section{REFERENCES}

C'unway, 'T.J, l'. 'T'uns, I,S, Wuterman, K,W. I'honing, K.A. Masarie, and R, I. Gammon. 1088, Almospheric carhom dioxido measurements in the remole global

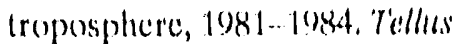
4()(B) :81-115.

Conway, 'T.J. and P. 'I'uns, IP(X). Atmospheric $\mathrm{C}()_{2}$ concentrations - The NOAA/GMCC. Flask simpling network. NDP-(X)S/R1, Carbon Dioxide Information Analysis Center, (Oak Ridge National Laboratory. ()ak Ridge, T'ennessee.

Komhyr, W.D., L.S. Watcrman, and W.R. Taylor, 1983. Semiantomatic nondispersive infrared analyeer apparalus for $\mathrm{C}^{\prime} \mathrm{C}_{2}$ air sample analyses. Journal of (ienphysuical Research 88:1315-22.

Komhyr, W.D., R.H. ( Eammon, T'.B, Harris, L.S, Watcrmatn, 'T',J, C'onway, W.R. ' l'alylor, and K.W. 'Thoning, lo8,5a. Cilobal almospheric $C_{2}$ distributions and variations from lox-82 NC AA/C CMC C ( ' ( ) $)_{2}$ flask

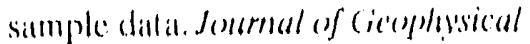
Rescarch (x):55, $50.5 .5 \%$.

Komhyr, W.D., T. B, Marris, and L...S. Walcrman. 1985\%, calibralion of nomdis-

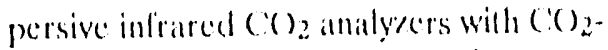
in-air reference gitses. Jommal of atmos-

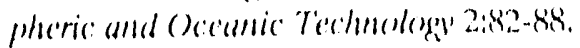
'Thoning, K.W., P. 'Tams, T'.J. Conwaty, and L...S, Wallematr. 1987. NOAd/CiN/C.: calibrations of $\left(C_{2}\right.$-in-air reference gessces: 1970 8.5. N()AA T'echnical Memoranclum LRL ARL-1.50. Enbirmmmental Restarch Lahoralory, Boulder, Colorado. World Meteorolengeal onganization. 1989).

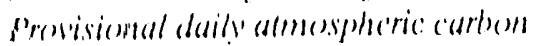

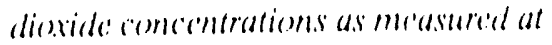

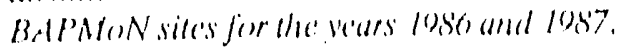

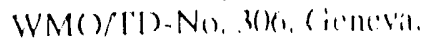




\section{Halley Bay}

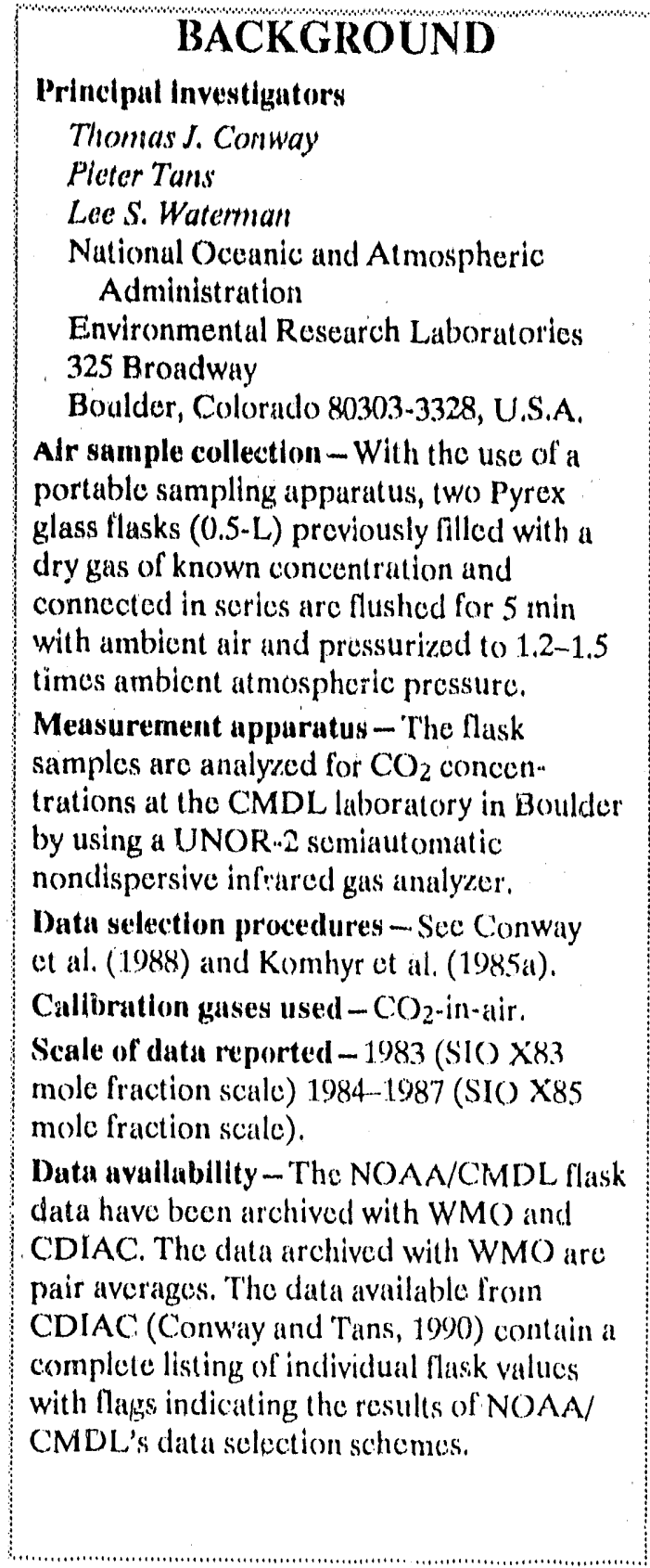

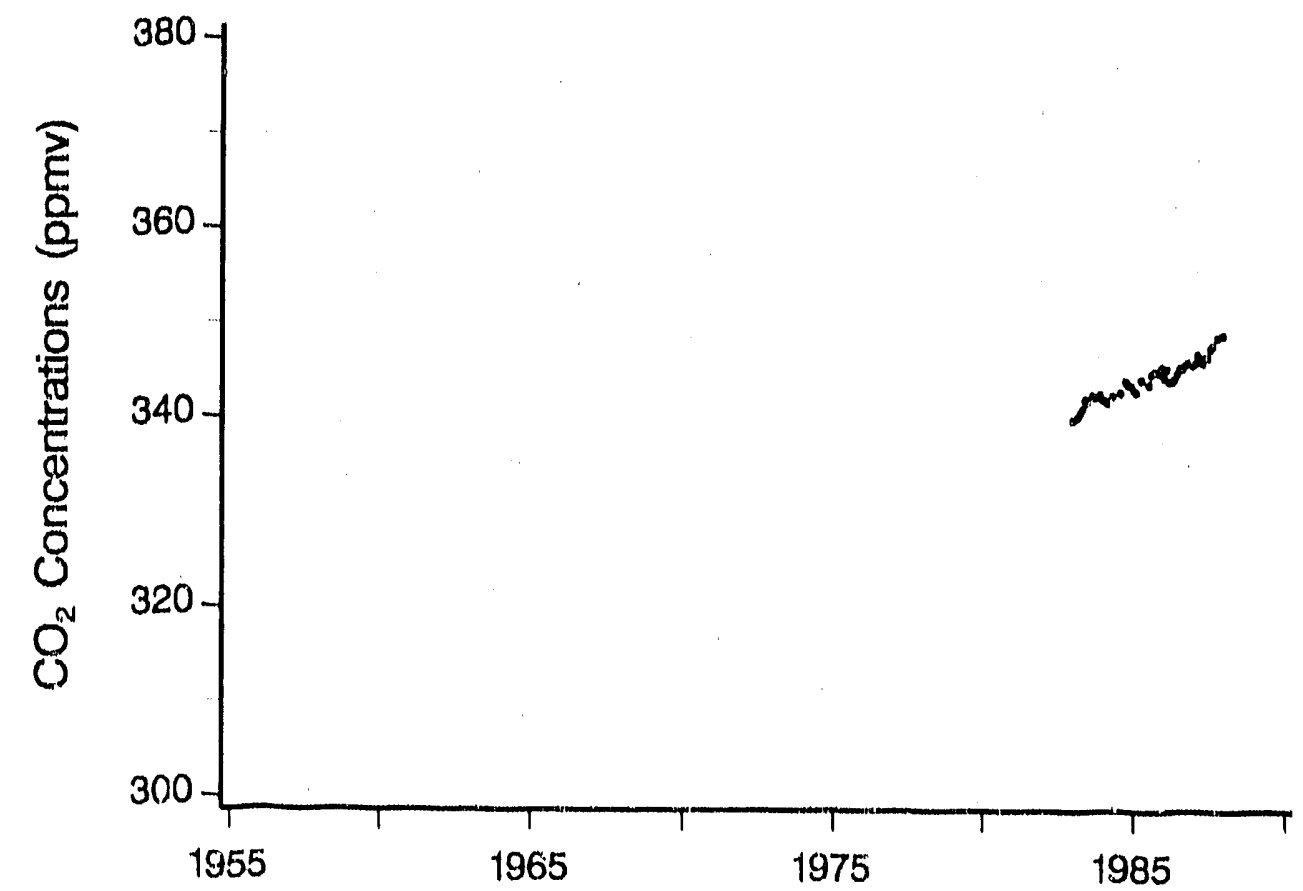

Monthly atmospherie $\mathrm{CO}_{2}$ concentrations.

Halley Bay Antarcticas

Barren seashore $75^{\circ} 40^{\prime} S, 27^{\circ} 00^{\prime} W$ 3 III abowe $M S L$ 


\section{Cold Bay}

$\begin{array}{lllllllllllllll}\text { Year } & \text { Jan } & \text { Feb } & \text { Mar } & \text { Apr } & \text { May } & \text { Jun } & \text { Jul } & \text { Aug } & \text { Sept } & \text { Oct } & \text { Nov } & \text { Dec } & \text { Ann } \\ 1979 & 340.1 & 340.9 & 341.5 & 342.7 & 342.7 & 339.3 & 332.0 & 327.2 & 331.1 & 336.1 & 339.2 & 340.5 & 337.7 \\ 1980 & 341.5 & 342.6 & 344.0 & 344.8 & 344.3 & 341.3 & 334.5 & 330.3 & 333.0 & 337.5 & 340.8 & 342.3 & 339.7 \\ 1981 & 343.9 & 344.8 & 345.4 & 346.4 & 345.2 & 341.5 & 335.5 & 331.2 & 332.9 & 339.9 & 342.4 & 344.3 & 341.1 \\ 1982 & 345.4 & 346.1 & 347.3 & 347.9 & 347.4 & 343.7 & 336.0 & 330.7 & 332.6 & 338.5 & 342.5 & 344.8 & 341.9 \\ 1983 & 346.8 & 346.4 & 346.0 & 347.7 & 346.5 & 343.8 & 335.3 & 333.2 & 337.9 & 343.9 & 345.8 & 346.3 & 343.3 \\ 1984 & 348.1 & 349.9 & 349.4 & 349.7 & 348.9 & 345.7 & 338.4 & 337.7 & 338.7 & 344.8 & 346.9 & 349.2 & 345.6 \\ 1985 & 348.7 & 350.6 & 351.8 & 352.0 & 352.2 & 349.3 & 343.8 & 336.6 & 339.2 & 344.8 & 347.9 & 349.1 & 347.2 \\ 1986 & 351.9 & 351.5 & 351.7 & 353.2 & 353.0 & 350.4 & 343.8 & 338.2 & 341.1 & 345.1 & 348.8 & 352.1 & 348.8 \\ 1987 & 351.5 & 352.5 & 353.1 & 354.6 & 354.8 & 351.0 & 345.3 & 338.9 & 340.8 & 348.1 & 352.6 & 352.5 & 349.6\end{array}$

*Atmospheric $\mathrm{CO}_{2}$ in parts per million by volume (ppmv). Annual averages based on monthly means. All numbers have been rounded to the nearest tenth. 


\section{Atmospheric $\mathrm{CO}_{2}$}

\section{REFERENCES}

Conway, T.J., P. Tans, L.S. Waterman, K.W. Thoning, K.A. Masaric, and R.H.

Gammon. 1988. Atmospheric carbon dioxide measurements in the remote global troposphere, 1981--1984. Tellus 40)(B):81-115.

Conway, T.J. and P. Tans. 1900. Atmospheric $\mathrm{CO}_{2}$ concentrations - The NOAA/GMCC nask sampling network. NDP-(X)5/R1. Carbon Dioxide Information Analysis Center. Oak Ridge National Laboratory. ()ak Ridge, Tennessec. Komhyr, W.D., L.S. Watcrman, and W.R. Taylor. 1983. Semiautomatic nondispersive infrared analyzer apparatus for $\mathrm{CO}_{2}$ air sample analyses. Joumal of Geophysical Research 88:1315-22.

Komhyr, W.D., R.H. Gammon, T.B. Harris, L.S. Waterman, T.J. Conway, W.R. Taylor, and K.W. Thoning, 1985a. Global atmospheric $\mathrm{CO}_{2}$ distributions and variations from $1468-82$ NOAA/CMCC C $)_{2}$ flask sample data. Joumal of Geophysical Research $90: 5567-55 \% 6$.

Komhyr, W.D., T.B. Harris, and L.S. Waterman. 1985b. Calibration of nondis. persive infrared $\mathrm{CO}_{2}$ analyzers with $\mathrm{CO}_{2}-$ in-air reference gases. Joumal of Amospheric and Oceanic Technology 2:82-88. Thoning, K.W., P. Tans, T.J. Conway, and L.S. Waterman. 1987. NOAA/CMCC calibrations of $\mathrm{CO}_{2}$-in-air reference gases: 1979-85. NOAA Technical Memorandum ERL ARL-150. Envirommental Rescarch Laboratory, Boulder, Colorado.

World Meteorological Organization. 1989. Provisional daily atmospheric carbon dioxide concentrations as measured at BAPMoN sites for the years 1980 and $198 \%$. WM()/lT)-No, 3(Kr. (ieneva. 


\section{Halley Bay}

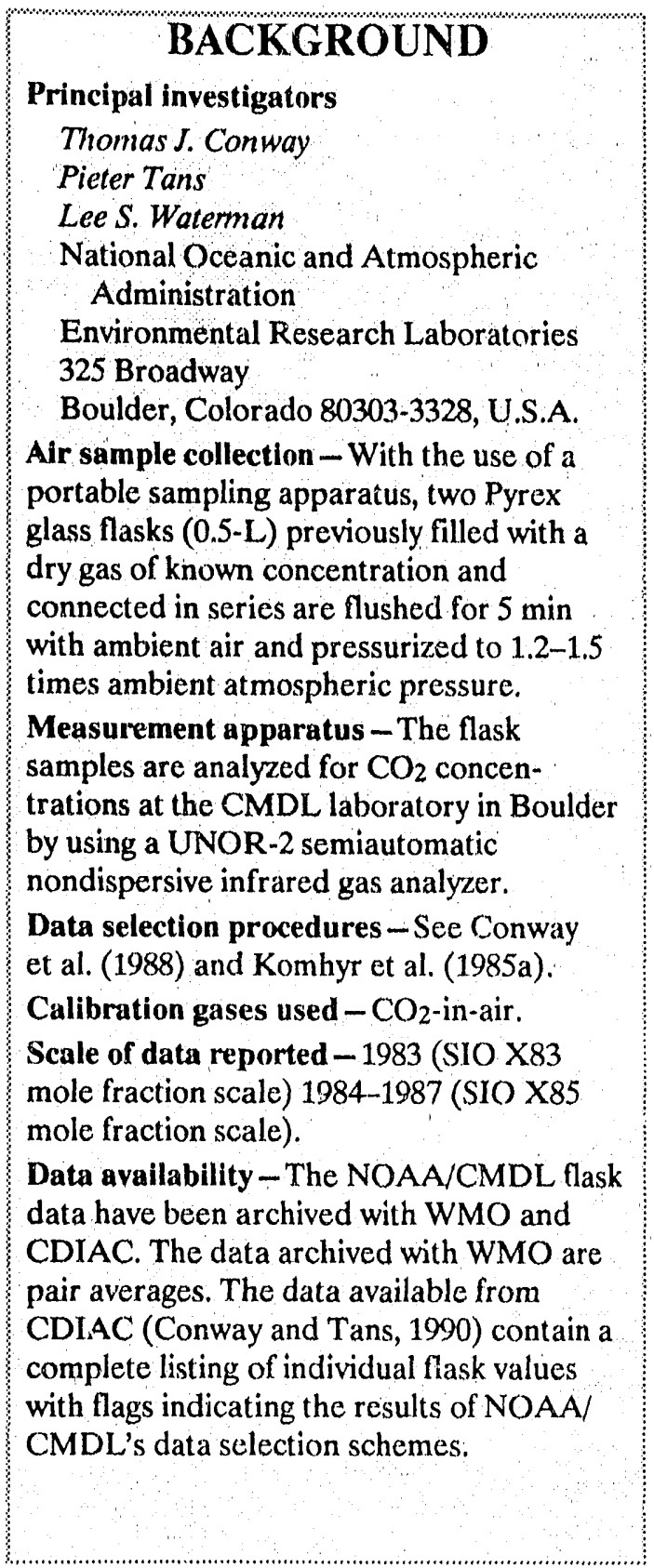

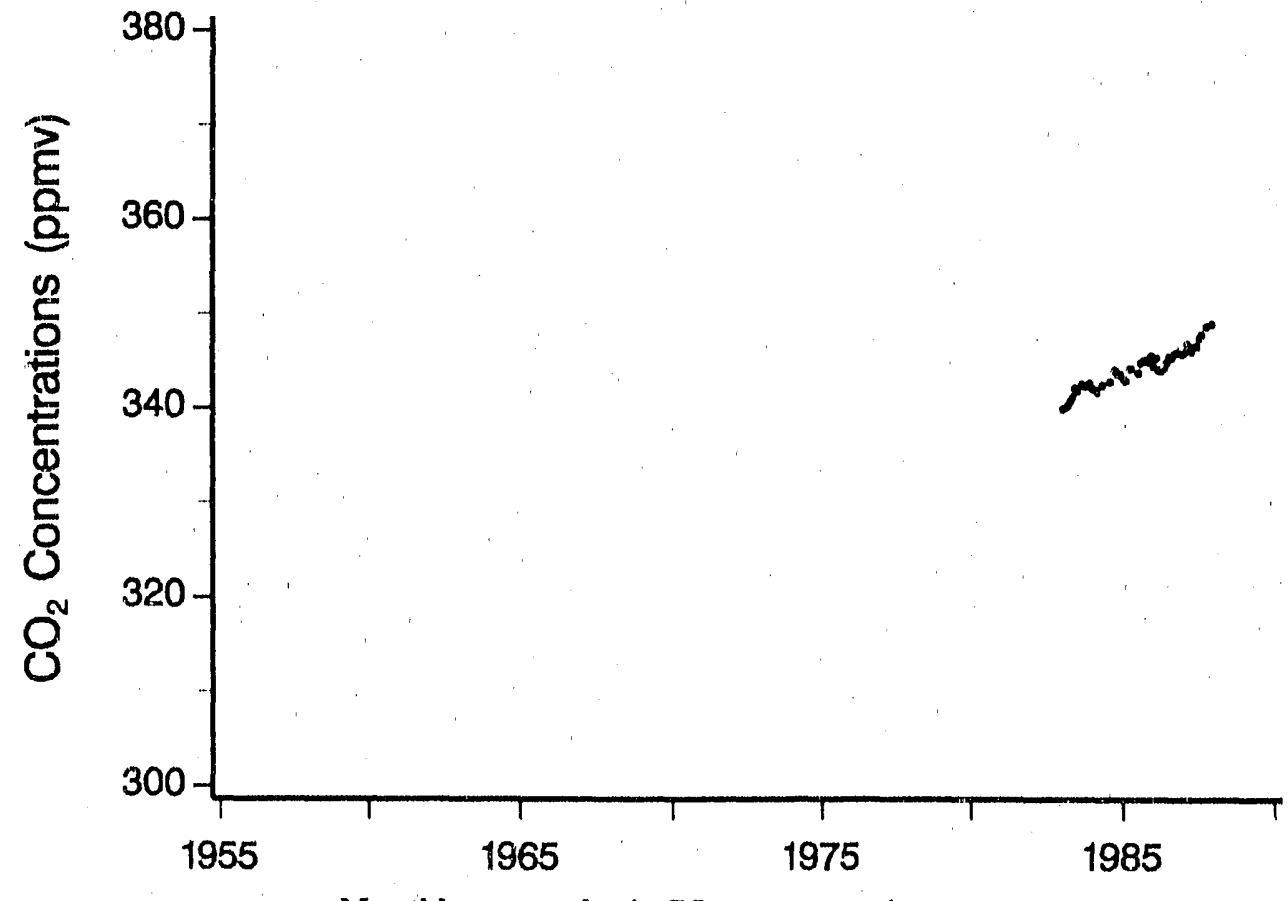

Halley Bay

Antarctica

Barren seashore

$75^{\circ} 40^{\prime} \mathrm{S}, 27^{\circ} 00^{\prime} \mathrm{W}$

$3 \mathrm{~m}$ above $M S L$

Monthly atmospheric $\mathrm{CO}_{2}$ concentrations.

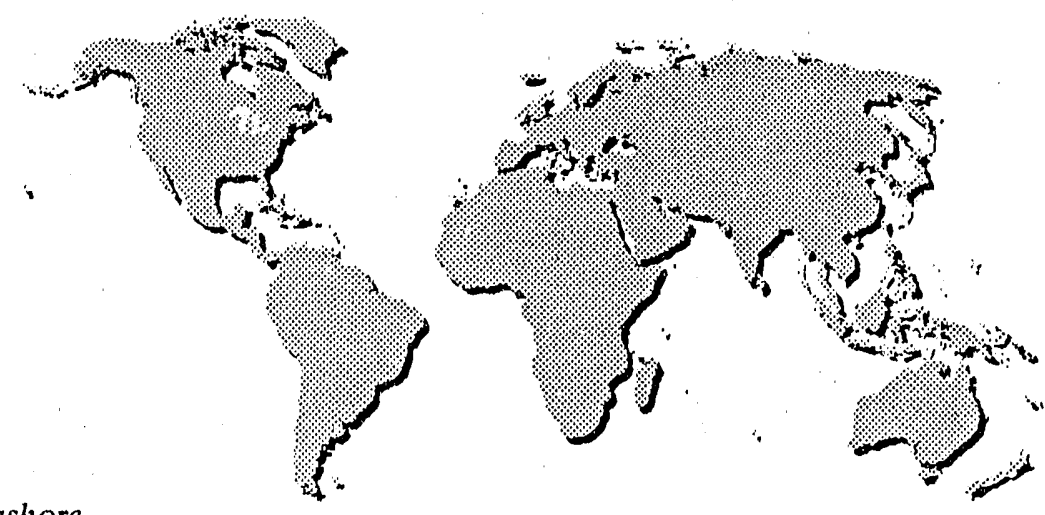




\section{Atmospheric $\mathrm{CO}_{2}$}

\section{TREND}

These data are from the NOAA/CMDL flask sampling program. The sampling site at Halley Bay is operated in cooperation with the British Antarctic Survey. The NOAA/CMDL flask data from Halley Bay show an increase in the annual vaiue from 341.3 ppmv in 1983 to 345.0 ppmv in 1986. By simply dividing the difference between the 1983 and 1986 annual averages by 4 , this represents a growth rate of 0.93 ppmv per year at Halley Bay. For comparison, Conway et al. (1988) reported a global growth rate of 1.22 ppmv per year for all NOAA/CMDL. flask sampling sites for 1981-1984.

Atmospheric $\mathrm{CO}_{2}$ concentrations at Halley Bay show a seasonal pattern, with the annual minimum measurements recorded during January-April and the annual maximum during October-December. Conway et al, (1988) found the average peak-to-trough amplitude for Halley Bay to be 1.26 ppmv. 


\section{Halley Bay}

\section{Atmospheric Concentrations of Carbon' Dioxide}

\begin{tabular}{|c|c|c|c|c|c|c|c|c|c|c|c|c|c|}
\hline Year & Jan & Feb & Mar & Apr & May & Jun & Jul & Aug & Sept & Oct & Nov & Dec & Ann \\
\hline 1983 & 339.8 & 339.9 & 340.1 & 340.5 & 341.0 & 342.0 & 341.7 & & 342.4 & 342.2 & 342.3 & 342.5 & 341.2 \\
\hline 1984 & 342.0 & 341.9 & 341.6 & & 342.3 & & & 342.7 & & 343.9 & 343.5 & 343.5 & 342.1 \\
\hline 1985 & 343.0 & 342.8 & & 344.1 & & & 343.6 & 344.7 & 344.9 & 345.0 & 344.8 & 345.4 & 344.3 \\
\hline 1986 & 344.3 & 345.2 & 343.9 & 343.9 & 344.2 & 344.7 & 345.3 & 345.2 & 345.6 & 345.8 & 345.7 & 345.6 & 345.0 \\
\hline 1987 & 345.8 & 346.7 & & 345.9 & 346.4 & 346.4 & 347.3 & 347.7 & & 348.5 & & 348.8 & \\
\hline
\end{tabular}

*Atmospheric $\mathrm{CO}_{2}$ in parts per million by volume (ppmv). Annual averages based on monthly means. All numbers have been rounded to the nearest tenth. 


\section{Atmospheric $\mathrm{CO}_{2}$}

\section{REFERENCES}

Conway, T.J., P. Tans, L.S. Waterman, K.W. 'Thoning, K.A. Masaric, and R.H.

Gammon. 1988. Almospheric carbon dioxide measurements in the remote global troposphere, 1981-..1984, 7ellus $40(B): 831 \ldots 115$.

Conway, T.J. and P. Tans. IOXX). Atmosipheric $\mathrm{C}_{2} \mathrm{O}_{2}$ concentrations -. The NOAA/CMCC: flask sampling network. NDP-(X)5/R 1. Carbon Dioxide Informalion Analysis (enter. Oak Ridge National Laboratory. Oak Ridge, 'Tennessee. Komhyr, W.D., L.S. Waterman, and W.R. Taylor. 1983. Semiautomatic nondispersive infrared analyzer apparatus for (C) a air sample analyses. Jouma! of (icophysical Research $88: 1315 \ldots 22$.

Komhyr, W.I), R.H. (iammon, T.B. Harris, L.S. Watcrman, T.J, Conway, W.R. Taylor, and K.W. Thoning. 1085a. Cilotal atmospheric $\left(\mathrm{C}_{2}\right.$ distributions and variations

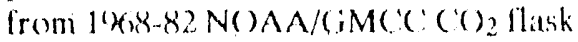
sample dat a. Jenermal of cieophysical Resecarch (x):5507 7.55\%).

Komhyr, W.D., T.B. Harris, and I..S. Watcrman. ly85h, ('alibration of nondis. persive infrared ( $\mathrm{C}_{2}$ analyzers with $\mathrm{C}_{2} \mathrm{O}_{2}$. in-ait relerence gatses. Jentrmal of atmon-

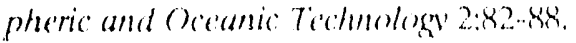
Thoning, K.W., I. Tans, T.l. Conwaly, and 1.S. Witlorman. lyst. NodA/C M/C calibrations of (') 2 -in-air reference geases: 1970.5.5. No AA Technical Memorandum ERL, ARI, 150). Finvirommental Research Laboratory, Bonder, Colomado.

World Metcorological () reanization. 1989).

Pronisiomal daily atmospheric cambon dionide concentrations as mécsured at Bal'MoN sifes forthe lears loseo and lost. WM()/l') No sur. (icmevis. 


\section{Kaitorete Spit}

\begin{tabular}{|c|}
\hline BACKGROUND \\
\hline Principal Investigators \\
\hline Thomas J, Conway \\
\hline Pieter Tans \\
\hline Lee S. Waterman \\
\hline National Oceanic and Atmospheric \\
\hline Administration \\
\hline Environmental Research Laboratories \\
\hline 325 Broadway \\
\hline Boulder, Colorado $80303-3328$, U.S.A. \\
\hline $\begin{array}{l}\text { Alr sample collection - With the use of a } \\
\text { portable sampling apparatus, two Pyrex } \\
\text { glass flasks ( } 0.5-\mathrm{L}) \text { previously filled with a } \\
\text { dry gas of known concentration and } \\
\text { connected in series are flushed for } 5 \mathrm{~min} \\
\text { with ambient air and pressurized to } 1.2-1.5 \\
\text { times ambient atmospheric pressure. }\end{array}$ \\
\hline $\begin{array}{l}\text { Measurement apparatus - The flask } \\
\text { samples are analyze d for } \mathrm{CO} 2 \\
\text { concentrations at the CMOL laboratory in } \\
\text { Boulder by using a UNOR-2 semiautomatic } \\
\text { nondispersive infrared gas analyzer. }\end{array}$ \\
\hline $\begin{array}{l}\text { Data selection procedures - See Conway } \\
\text { et al. (1988) and Komhyr et al. (1985a). }\end{array}$ \\
\hline Calibration gases used- $\mathrm{CO}_{2}$-in-air. \\
\hline $\begin{array}{l}\text { Scale of data reported-1983, SIO X83 } \\
\text { mole fraction scale; } 1984-1987 \text {, SIO X85 } \\
\text { mole fraction scale. }\end{array}$ \\
\hline $\begin{array}{l}\text { Data availability - The NOAA/CMDL flask } \\
\text { data have been archived with WMO and } \\
\text { CDIAC. The data archived with WMO are } \\
\text { pair averages. The data available from } \\
\text { CDIAC (Conway and Tans, 1990) contain a } \\
\text { complete linting of individual flask values } \\
\text { with flags indicating the results of NOAA/ } \\
\text { CMDL's data selection schemes. }\end{array}$ \\
\hline
\end{tabular}

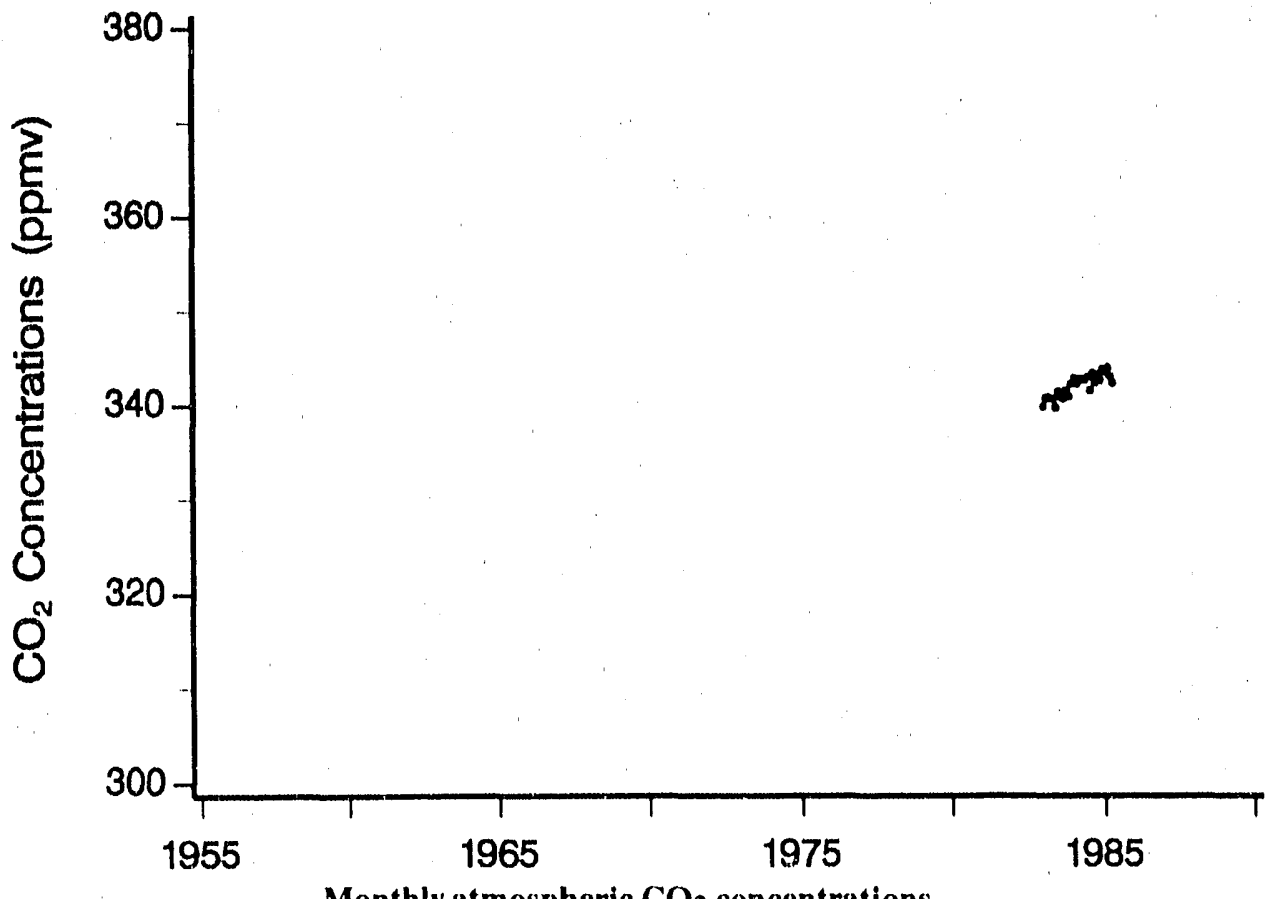

Kaitorete Spit New Zealand

Treeless spit $43^{\circ} 50^{\prime} \mathrm{S}, 172^{\circ} .38^{\prime} \mathrm{W}$

$3 \mathrm{~m}$ above $M S L$. 


\section{Atmospheric $\mathrm{CO}_{2}$}

\section{TREND}

These data are from the NOAA/CMDL flask sampling program. The sampling site at Kaitorete Spit was operated in cooperation with the National Center for Atmospheric Research. Sampling at Kaitorete Spit was discontinued in 1985 after it was established that the Cape Grim site was a more suitable site for representative measurements at that latitude.

The NOAA/CMDL flask data from Kaitorete Spit show an increase in the annual value fron. $340.7 \mathrm{ppmv}$ in 1983 to 342.6 ppmv in 1984. Conway et al. (1988) reported a global growth rate of $1.22 \mathrm{ppmv}$ per year for all NOA \&/CMDL flask sampling sites from 1981-1984. 


\section{Kaitorete Spit}

\section{Atmospheric Concentrations of Carbon Dioxide*}

$\begin{array}{llllllllllllll}\text { Year } & \text { Jan } & \text { Feb } & \text { Mar } & \text { Apr } & \text { May } & \text { Jun } & \text { Jul } & \text { Aug } & \text { Sept } & \text { Oct } & \text { Nov } & \text { Dec } & \text { Ann } \\ 1983 & 339.7 & 340.6 & 340.7 & 340.6 & 340.5 & 339.6 & 341.3 & 340.7 & 340.6 & 341.4 & 340.8 & 342.1 & 340.7 \\ 1984 & 342.7 & 342.1 & 342.6 & 342.6 & 342.5 & 342.8 & 341.4 & 343.2 & 342.2 & 343.0 & 342.5 & 343.6 & 342.6 \\ 1985 & 343.4 & 343.8 & 342.9 & 342.2 & & & & & & & & \end{array}$

*Atmospheric $\mathrm{CO}_{2}$ in parts per million by volume (ppmv). Annual averages based on monthly means. All numbers have been rounded to the nearest tenth.
Atmospheric $\mathrm{CO}_{2}$

\section{REFLRLNCLS}

Conway, T.J., P. Tans, L.S. Wiltermat1, K.W

Thoning, K.A. Masaltric, and R.11.

Gamment 1088. Almospheric carbon

dioxide measurements in the remote global

tropesphere, 1981-1984. Te?his

$40(B): 81 \cdots 115$,

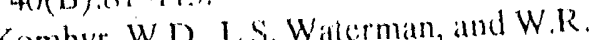

Komhyr, W.D., L... Wa werman, and W.R.

Taylor. 1983. Semiatutomatie nomdispers

infrared analyzer apparal us for $\mathrm{CO}_{2}$ air

sample atnalyses. Journal of Cienphysical

Research 88:131522

Kombr, W R RH Gammon, T.B. Harn is,

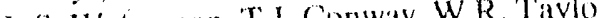

and K.W. Thoning. 1985.5a (ilobal

atmospheric (C) distributions and

variations from 1 \& 8 . $82 \mathrm{NC}$ ) AA/( $3 \mathrm{M}$

$\mathrm{CO}_{2}$ llask sample data. Jollmalof

(jeophwsical Resesarth (x):5507...

Komhyr, W.D., T.B. Harris, and L....

Watcroman. 1985b. Catibration of"

nondispersive infrared $(C)_{2}$ analyzers with

(C)-in-air reforence gases folmal of

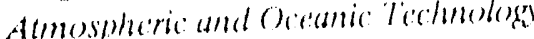

2.82 . 84

The K.W P Tans, T I cenway, and

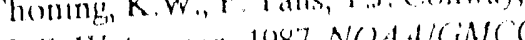

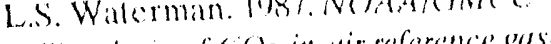

calibrations of $\left(\mathrm{CO}_{2}\right.$-intair refereme gases: 1979-85. NOAA Technical Memorandum FRL ARL 1 150) Fnvirunmental Researd Baboratory Boulder collorado.

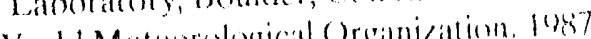

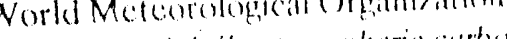

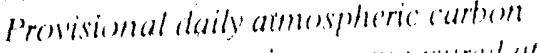

aidoxidr concontrutionts as mécestered BAPMON sites for the year 1985.5.

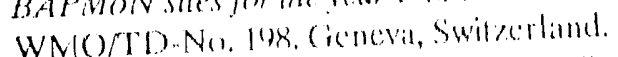

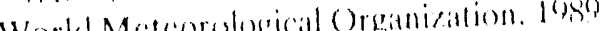

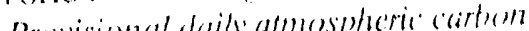

Provisional alaity atmonphore catrom

dioxide concentrutions as metastred at

BAPMON sites for the veders losion solnt loh't

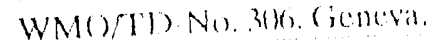




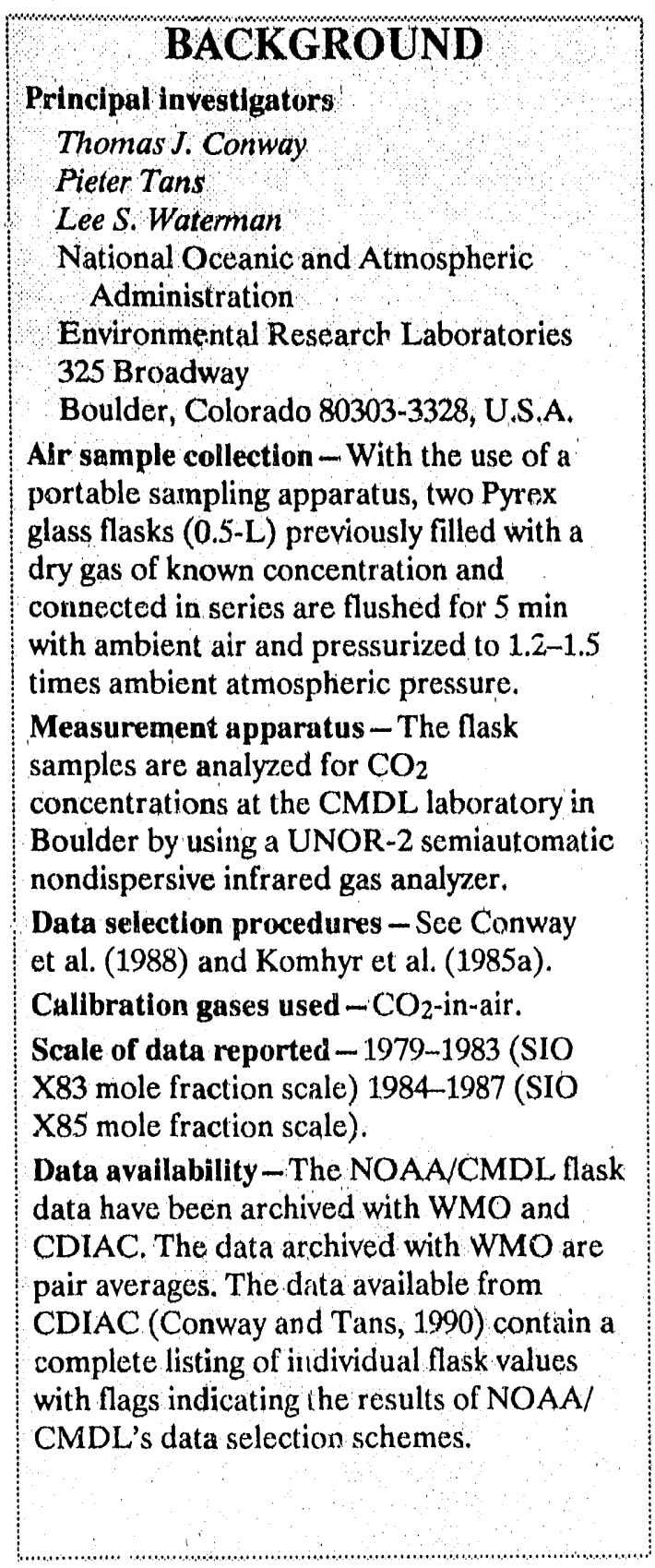

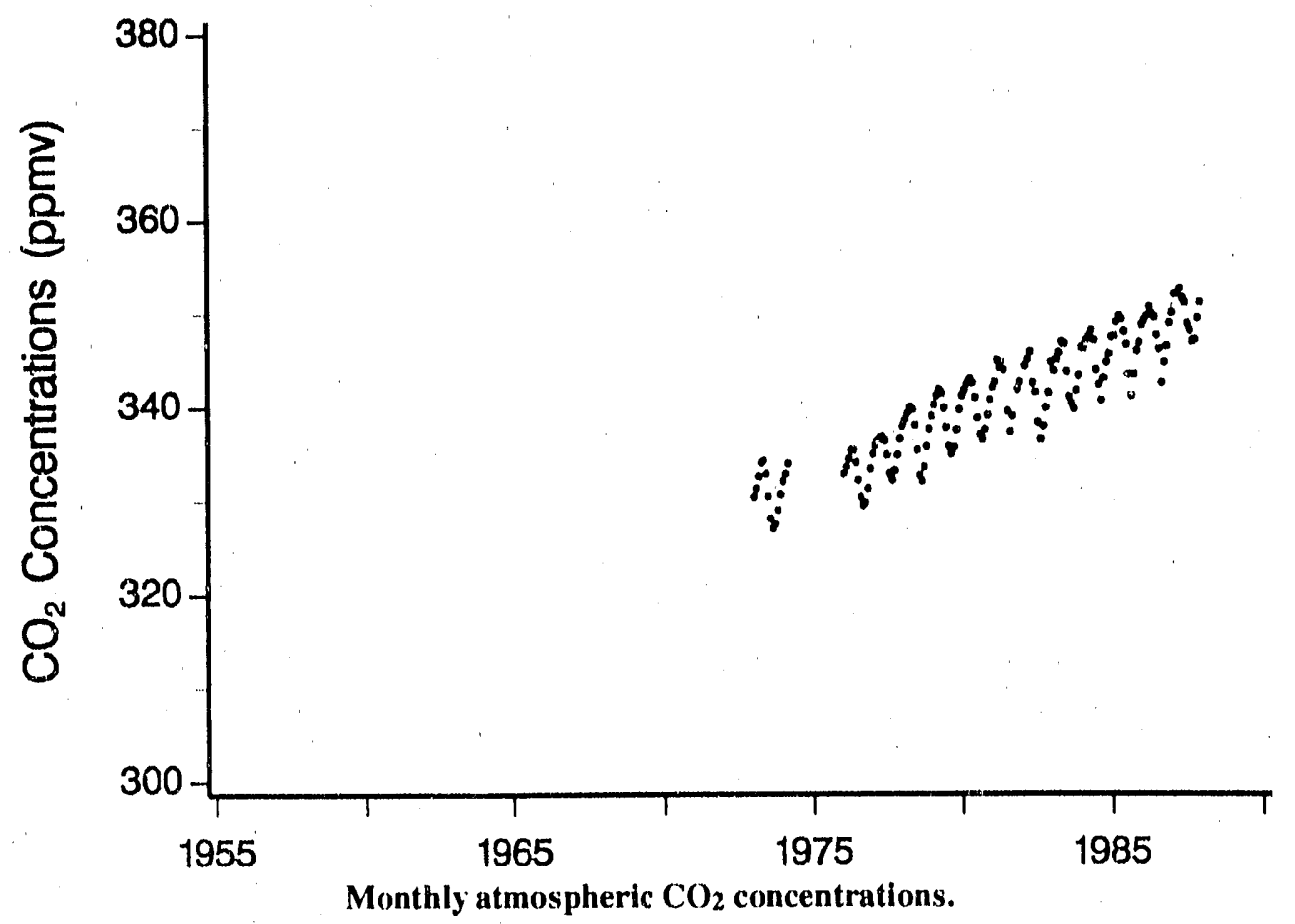

Key Biscayne

Florida, U.S.A.

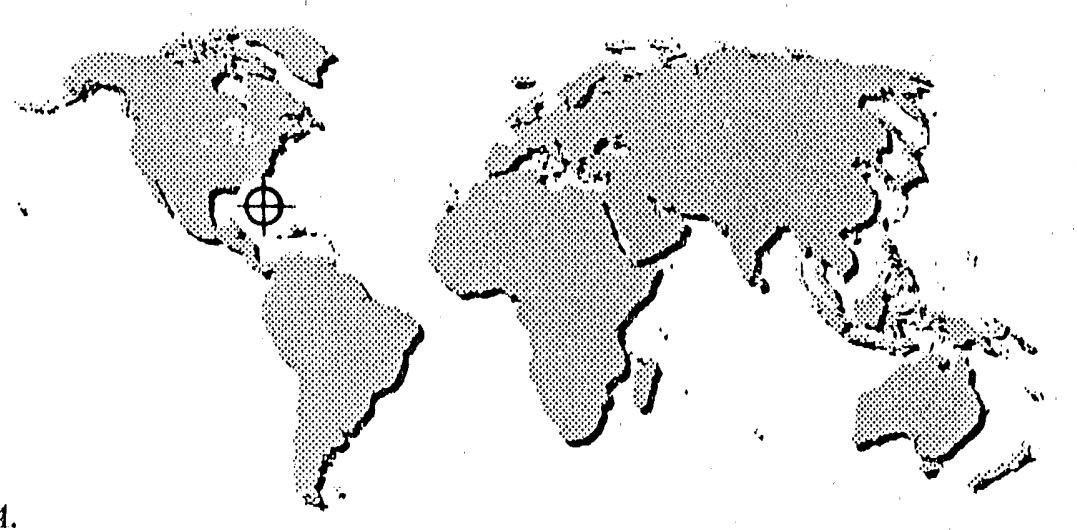

Coastal island seashore

$25^{\circ} 40^{\prime} \mathrm{N}, 80^{\circ} 10^{\prime} \mathrm{W}$

$3 \mathrm{~m}$ above $M S L$ 


\section{Atmospheric $\mathrm{CO}_{2}$}

\section{TREND}

These data are from the NOAA/CMDL flask sampling program. The sampling site at Key Biscayne, Florida, is operated in cooperation with the Sea-Air-Interaction Laboratory.

The NOAA/CMDL flask data from Key Biscayne show an increase in the annual value from $330.7 \mathrm{ppmv}$ in 1973 to 350.2 ppmv in 1987. Conway et al. (1988) reported a 1.11-ppmv mean annual growth rate at Key Biscayne for 1981-1984 in comparison with a global growth rate of 1.22 ppmv per year over the same time frame for all NOAA/CMDL flask sampling sites.

Atmospheric $\mathrm{CO}_{2}$ concentrations at Key Biscayne show a seasonal pattern, with the annual drawdown occurring in July and the annual buildup occurring in December. Conway et al. (1988) found the peak-totrough amplitude for the seasonal cycle at Key Biscayne to be 7.28 ppmv for the 1981-1984. 
Atmospheric Concentrations of Carbon Dioxide*

$$
\begin{aligned}
& \text { Yea } \\
& 197 \\
& 197 \\
& 1975 \\
& 197 \\
& 197 \\
& 1978 \\
& 1979 \\
& 198 \\
& 198 \\
& 198 \\
& 1983 \\
& 198 \\
& 1985 \\
& 1986 \\
& 1987
\end{aligned}
$$

\section{Jan}

330.4 332.1

332.9

335.0

337.9

339.0

341.2

342.1

342.7

344.8

346.4

347.5

348.8

350.1

\begin{tabular}{ccc} 
Feb & Mar & Apr \\
\hline 331.3 & 332.6 & 334.1 \\
\hline 332.9 & 334.0 & \\
& & \\
333.6 & 334.5 & 335.4 \\
335.9 & 336.4 & 336.7 \\
338.6 & 339.3 & 340.0 \\
340.2 & 341.2 & 341.9 \\
341.8 & 342.5 & 343.0 \\
342.7 & 345.0 & 344.2 \\
& 344.4 & 345.1 \\
343.9 & 345.1 & 345.8 \\
346.3 & 347.2 & 347.6 \\
347.6 & 349.1 & 349.8 \\
349.3 & 349.8 & 350.7 \\
352.1 & 352.2 & 352.7
\end{tabular}

Ma

May Jun

$334.3 \quad 332.9$

Jul

330.5

Aug

Sept

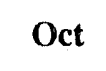

Oct
327.5

Nov

Dec

329.0

330.7

Ann

330.7

$335.4 \quad 334.1$

332.2

330.4

\section{5}

$329.8 \quad 331.3$

$\begin{array}{ll}336.8 & 336.4 \\ 339.7 & 338.0\end{array}$

$341.5 \quad 339.9$

335.4

337.8

$\begin{array}{lll}342.6 & 341.0 & 338.8\end{array}$

344.8

345.9

347.0

348.2

344.0

342.6

346.8
347.2

347.2

341.6
343.8

344.0
346.7
347.7

$\begin{array}{lll}350.0 & 349.6 & 347.7\end{array}$

351.2
332.9
332.7

335.8

335.8
337.0

339.5

338.3

341.1

342.4

343.5

346.2

348.2

332.2
332.1

332.1

335.5

337.3

$336.5 \quad 337.9$

$340.4 \quad 339.8$

340.7

341.2

342.6

347.0

*Atmospheric $\mathrm{CO}_{2}$ in parts per million by volume (ppmv). Annual averages based on monthly means. All numbers have been rounded to the nearest tenth.

\section{REFERENCES}

Conway, T.J., P. Tans, L.S. Watcrman, K.W.

"honing, K.A. Masiaric, and R.H.

Gammon. 198s, Atmospheric carbon

dioxide measurements in the remote global troposphere, 1981-1984. Tellis

$4(B): 81 \ldots 115$.

Conway, T.J. and P. Tans. 1990. Atmos-

pheric $(\mathrm{C}) 2$ concentrations - The

NOAA/GMCC flask sampling network.

NDP-(K) $5 /$ R 1. Cartoon Dioxide Information

Analysis Center. Oak Ridge National

Lathoratory. ()ak Ridge, Tennessec.

Komhyr, W.D., L.S. Waterman, and W.R.

Taylor. 1983. Semiautomatic nondispersive infrared analyser apparatus for $\mathrm{CO}_{2}$ air sample analyses.s. Journal of (iecophysical Research 88:1315-22.

Komhyr, W.D., R.H. ( Gammon, 'T.B. Harris,

L..S. Walcrman, T.J. Conway, W.R. Taylor, and K.W. Thoning. 1985a. (3lohal at mospheric $\mathrm{C}_{2}$ distributions and variations from 1968- $\$ 2$ NOAA/GMC( $(\mathrm{C})_{2}$ flask sample datia. fommal of Cieophysical Research (x):5567 .55\%).

Komhyr, W.D., T.B. Harris, and L.S.S.

Watcrman fos 5 h, Calibration of nondisWerive ing persive infrared (y in-air reference gasses joumal of Atmos-

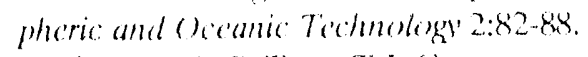
Thoning, K.W. P. 'Tam, T.l. Conway, and L.S. Watcrman. 1987. NOAA/GiMCC calibrations of $\left(\mathrm{O}_{2}\right.$-in-air werence greses: 1979) 85. NOAA Technical Memorandum ERI ARI 1SO Lncironmental Rescarch Latoratury, Boulder, Coldorader.

World Metcorolegical () regantation. 19889. Provisionat etaily atmospheric cattem

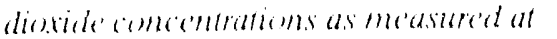

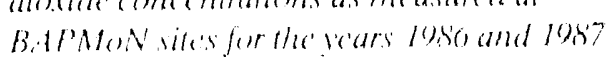

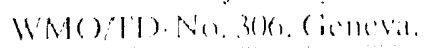




\section{Mahé Island (Seychelles)}

\begin{tabular}{|c|}
\hline BACKGROUND \\
\hline Principal investigators \\
\hline Thomas S. Conway \\
\hline Pieter Tans \\
\hline Lee S. Waterman \\
\hline National Oceanic and Atmospheric \\
\hline Administration \\
\hline Environmental Research Laboratories \\
\hline 325 Broadway \\
\hline Boulder, Colorado 80303-3328, U.S.A. \\
\hline $\begin{array}{l}\text { Air saniple collection - With the use of a } \\
\text { portable sampling apparatus, two Pyrex } \\
\text { glass flasks ( } 0.5-\mathrm{L}) \text { previously filled with a } \\
\text { dry gas of known concentiation and } \\
\text { connected in set ies are flushed for } 5 \mathrm{~min} \\
\text { with ambient ail and pressurized to } 1.2-1.5 \\
\text { times ambient atmospheric pressure. }\end{array}$ \\
\hline $\begin{array}{l}\text { Measurement apparatus - The flask } \\
\text { samples are analyzed for } \mathrm{CO}_{2} \text { concen- } \\
\text { trations at the CMDL laboratory in Buulder } \\
\text { by using a UNOR-2 semiautomatic } \\
\text { nondispersive infrared gas analyzer. }\end{array}$ \\
\hline $\begin{array}{l}\text { Data selection procedures - See Conway } \\
\text { et al. (1988) and Komhyr et al. (1985a). }\end{array}$ \\
\hline Calibration gases used- $\mathrm{CO}_{2}$-in-air. \\
\hline $\begin{array}{l}\text { Scale of data reported }-1980-1983, \text { SIO } \\
\text { X83 mole fraction scale; } 1984-1987, \text { SIO } \\
\text { X85 mole fraction scale. }\end{array}$ \\
\hline $\begin{array}{l}\text { Data availability - The NOAA/CMDL flask } \\
\text { data have been archived with WMO and } \\
\text { CDIAC. The data archived with WMO are } \\
\text { pair averages. The data available from } \\
\text { CDIAC (Conway and Tans, } 1990 \text { ) contain a } \\
\text { complete listing of individual flask values } \\
\text { with flags indicating the results of NOAA/ } \\
\text { CMDL's data selection schemes. }\end{array}$ \\
\hline
\end{tabular}

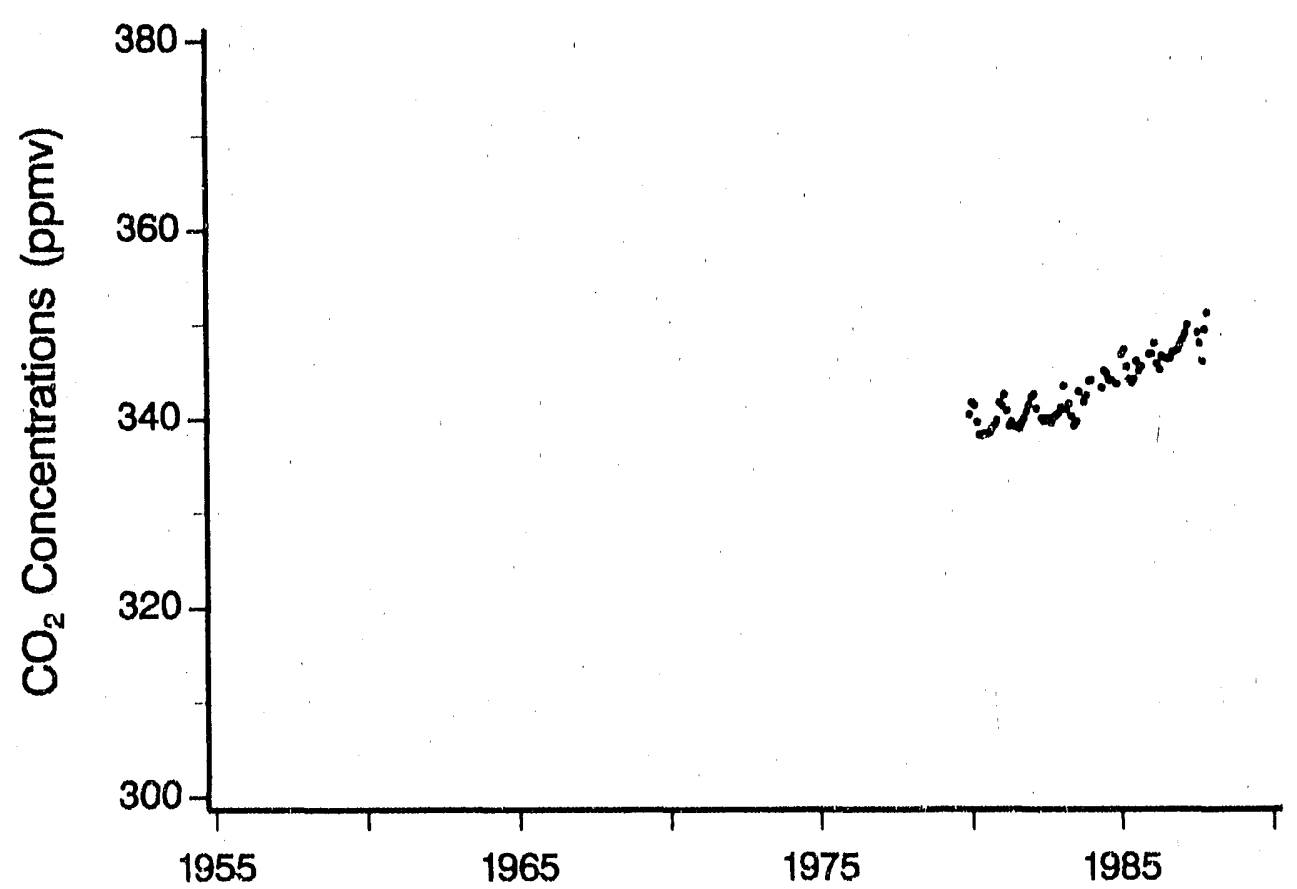

Mahé Island

Seychelles

Island seashore

$4^{\circ} 40^{\prime} S, 55^{\circ} 10^{\prime} E$

$3 \mathrm{~m}$ above MSL 


\section{TREND}

These data are from the NOAA/CMDL flask sampling program. The Seychelles sampling site on Mahe Island is operated in cooperaticn with the Physical Science Liboratory at New Mexico State University.

The NOAA/CMDL flask data from the Stychelles show an increase in the annual value from 339.3 ppinv in 1980 to 346,3 ppmv in 1986. Conway et al. (1988; reported a 1.21-ppmv mean annual growth rate at Seychelles for 1981-1984 compared to a global growth rate of $1.22 \mathrm{ppmv}$ per year over the same time frame for all NOAA/CMDL flask sampling sites.

Atmospheric $\mathrm{CO}_{2}$ concentrations at Seychelles show a seasonal pattern with the annual drawdown typically occurring in May and the annual buildup occurring in November-January. Conway et al. (1988) reported the peak-to-peak seasonal amplitude for Seychelles to be 2.85 ppmv for 1981-1984. 


\section{Atmospheric Concentrations of Carbon Dioxide*}

$\begin{array}{rccccccccccccc}\text { Year } & \text { Jan } & \text { Feb } & \text { Mar } & \text { Apr } & \text { May } & \text { Jun } & \text { Jul } & \text { Aug } & \text { Sept } & \text { Oct } & \text { Nov } & \text { Dec } & \text { Ann } \\ 1980 & 340.3 & 341.6 & 341.3 & 339.5 & 338.2 & 338.1 & 338.3 & 338.3 & 338.4 & 338.8 & 339.2 & 339.7 & 339.3 \\ 1981 & 341.6 & 341.3 & 342.4 & 340.7 & 339.1 & 339.5 & 339.1 & & 338.8 & 339.4 & 339.9 & 340.6 & 340.2 \\ 1982 & 341.3 & 342.1 & 342.4 & 340.9 & & 339.9 & 339.6 & 339.9 & 339.9 & 339.4 & 340.0 & 340.2 & 340.5 \\ 1983 & 340.4 & 341.0 & 343.3 & 340.8 & 341.4 & 340.1 & 339.1 & 339.5 & 342.7 & & 341.6 & 342.3 & 341.1 \\ 1984 & 343.8 & 343.9 & & & & 343.1 & 344.9 & 344.6 & 343.9 & 343.9 & & 343.5 & 344.0 \\ 1985 & & 346.6 & 347.1 & 345.3 & 344.0 & 343.6 & 344.0 & 345.9 & 344.9 & 345.3 & & & 345.2 \\ 1986 & 346.6 & 346.7 & 347.8 & 345.6 & 345.0 & 346.4 & 346.2 & 346.1 & 346.2 & 346.8 & 346.9 & 347.1 & 346.3 \\ 1987 & 347.7 & 348.2 & 348.8 & 349.7 & & & & 348.9 & 347.8 & 345.9 & 349.2 & 351.0 & \end{array}$

*Atmospheric $\mathrm{CO}_{2}$ in parts per million by volume (ppmv). Annual averages based on monthly means. All rumbers have been rourded to the nearest tenth.

\section{RHIVIRLNGS}

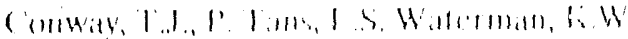

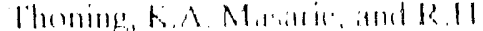

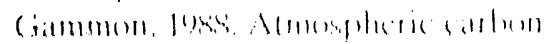

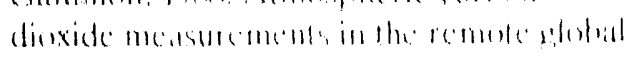

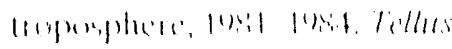

(1)(13):81 $11 \%$

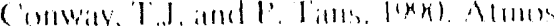

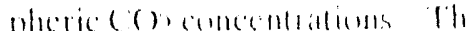

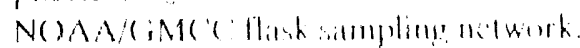

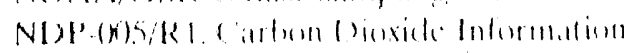

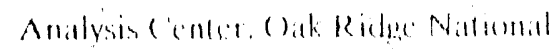

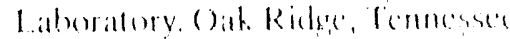

Kumber, W.D. I \& Wallermian, and W R

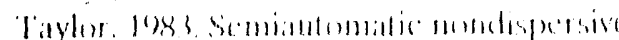

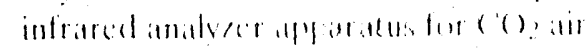

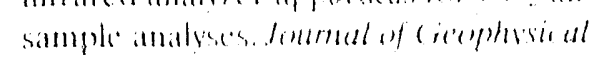

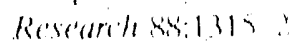

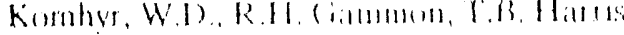

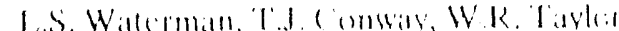

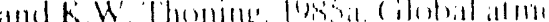

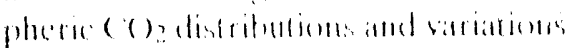

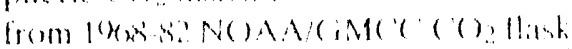

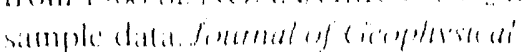

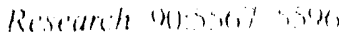

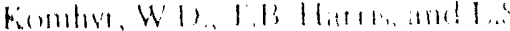

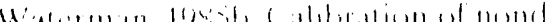

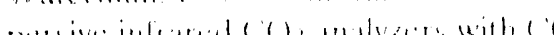

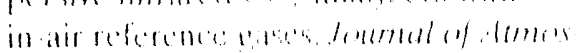

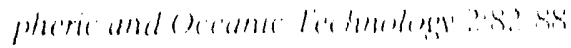

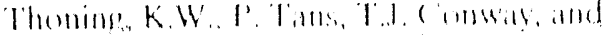

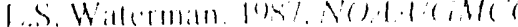

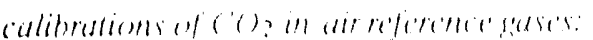

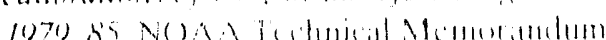

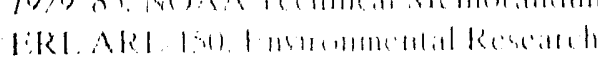

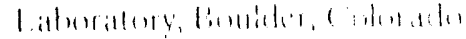

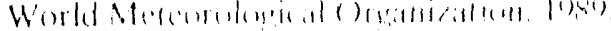

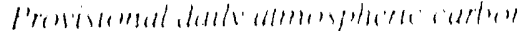

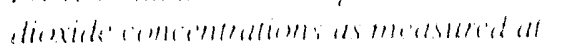

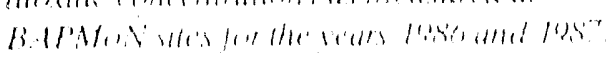

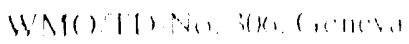




\section{Mariana Islands}

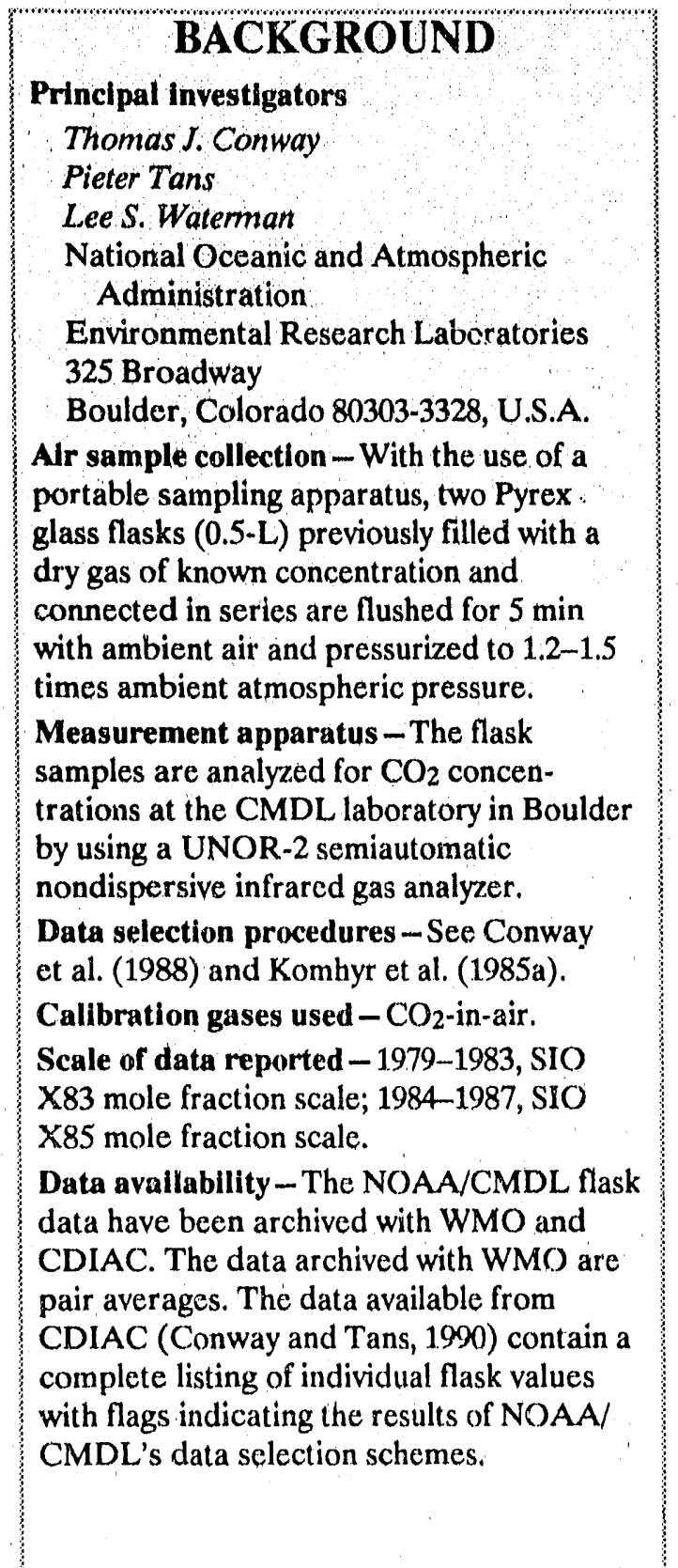

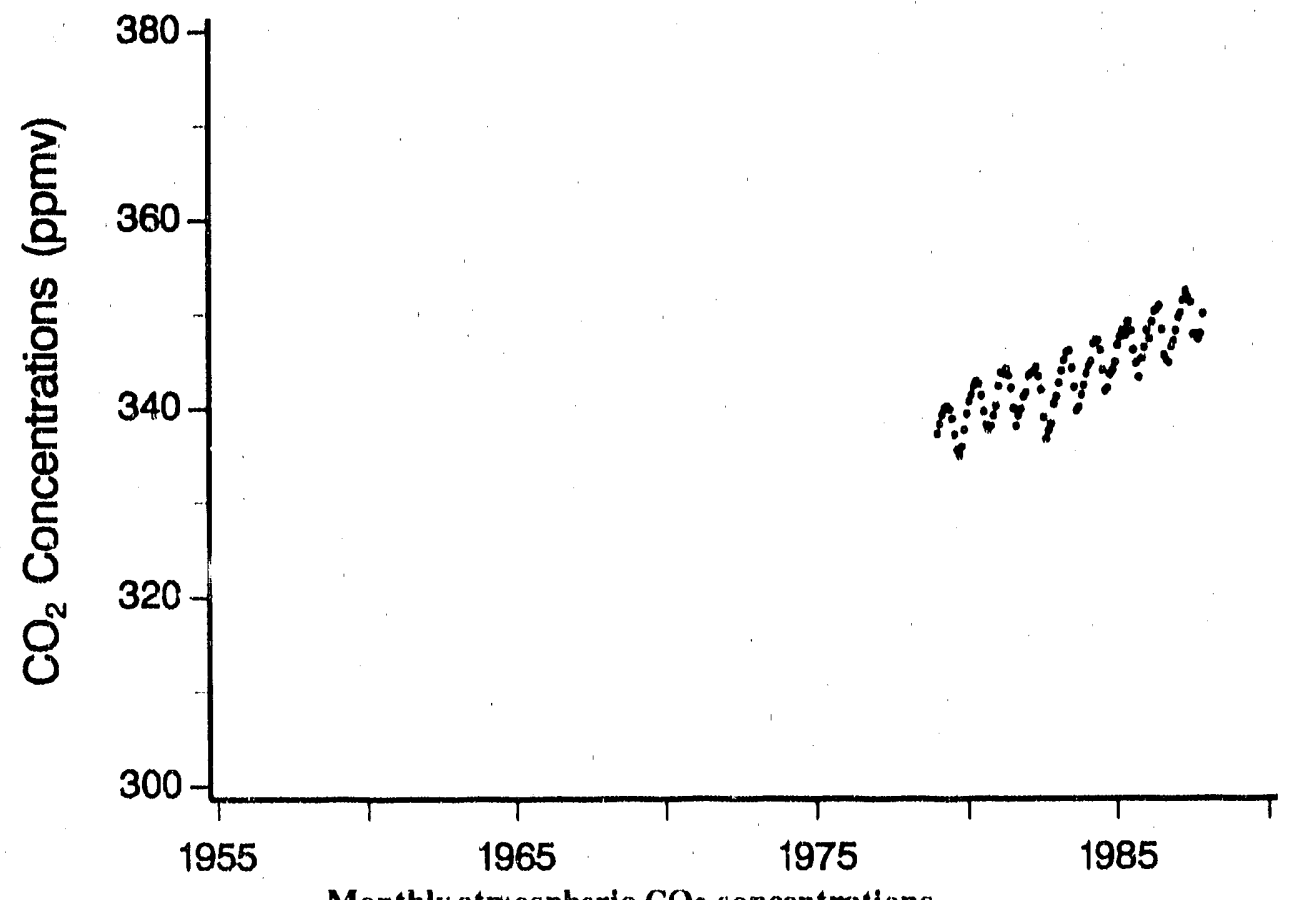

Mariana Islands

Guam, U.S. Territory

South Pacific

Island seashore

$13^{\circ} 26^{\prime} N, 144^{\circ} 47^{\prime} E$

$2 \mathrm{~m}$ above $\mathrm{MSL}$

Monthly atniospheric $\mathrm{CO}_{2}$ concentrations.

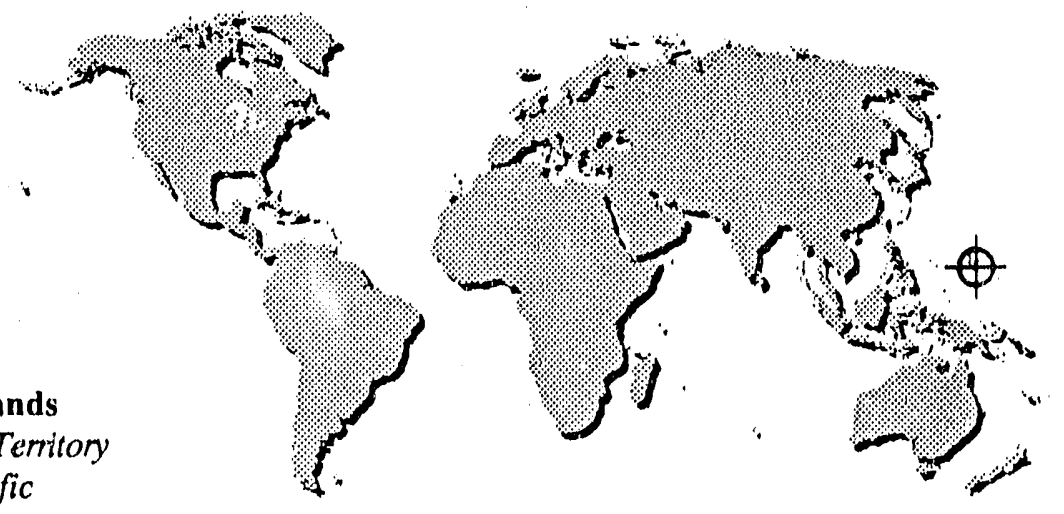




\section{TREND}

These data are from the NOAA/CMDL flask sampling program. The sampling site on the Mariana Islands is operated in cooperation with the University of Guam. The NOAA/CMDL flask data from Guam show an increase in the annual value from 337.7 ppm in 1979 to $349.4 \mathrm{ppm}$ in 1987. Conway et al. (1988) reported a 1.01-ppm mean annual growth rate at Guam for 1981-1984 compared to a global growth rate of $1.22 \mathrm{ppm}$ per year over the same time frame for all NOAA/CMDL flask sampling sites.

Atmospheric $\mathrm{CO}_{2}$ concentrations at Guam show a seasonal pattern with the annual drawdown typically occurring in July-August and the annual buildup occurring in January. Conway et al. (1988) found the average peak-to-peak amplitude for Guam from 1981-1984 to be $6.45 \mathrm{ppm}$. 
Atmospheric Concentrations of Carbon Dioxide*

$\begin{array}{rccccccccccccc}\text { Year } & \text { Jan } & \text { Feb } & \text { Mar } & \text { Apr } & \text { May } & \text { Jun } & \text { Jul } & \text { Aug } & \text { Sept } & \text { Oct } & \text { Nov } & \text { Dec } & \text { Ann } \\ 1979 & 337.1 & 338.1 & 339.1 & 339.8 & 340.0 & 339.7 & 338.7 & 337.0 & 335.4 & 334.8 & 335.7 & 337.5 & 337.7 \\ 1980 & 339.2 & 340.5 & 341.2 & 342.1 & 342.6 & 342.3 & 341.1 & 339.4 & 338.0 & 337.5 & 337.9 & 339.0 & 340.1 \\ 1981 & 340.0 & 342.1 & 343.5 & 343.4 & 343.9 & 343.2 & 341.9 & 339.8 & 337.9 & 339.0 & 339.7 & 341.0 & 341.3 \\ 1982 & 341.4 & 343.2 & 343.4 & 343.6 & 344.1 & 343.1 & 341.7 & 338.8 & 336.5 & 337.4 & 338.1 & 340.2 & 341.0 \\ 1983 & 341.0 & 342.4 & 343.7 & 344.8 & 345.7 & 345.8 & 344.0 & 342.0 & 339.5 & 339.9 & 341.2 & 342.2 & 342.7 \\ 1984 & 343.4 & 344.2 & 344.7 & 346.6 & 347.0 & 346.9 & 345.9 & 343.8 & 341.6 & 341.9 & 343.3 & 343.8 & 344.4 \\ 1985 & 344.6 & 346.4 & 347.3 & 348.0 & 347.4 & 348.9 & 347.9 & 345.9 & 344.5 & 343.0 & 345.0 & 346.2 & 346.3 \\ 1986 & 348.0 & 347.1 & 348.9 & 350.0 & 350.2 & 350.6 & 348.1 & 345.4 & 344.9 & 344.6 & 346.3 & 346.9 & 348.1 \\ 1987 & 348.0 & 349.4 & 349.9 & 351.2 & 352.2 & 351.5 & 351.0 & 347.6 & 347.7 & 347.1 & 347.7 & 349.8 & 349.4\end{array}$

*Atmospheric $\mathrm{CO}_{2}$ in parts per million by volume (ppmv). Annual averages based on monthly means. All numbers have been rounded to the nearest tenth.

\section{REFERENCES}

Conway, T.J., P. T'ans, L.s.'. Watcrminn

Thoning, K.A. Masaric, and R.H.

Gammon. 1988. Atmosphotic carbon

dioxide measurements in the remote global troposphere, 1981- 1984. Te!llus

4)(B):81-115.

Conway, T.J and P. Tiuns, $1(x)$. Almos-

pheric $C()_{2}$ concentrations - The

NOAA/GMCC flask samọling network.

NDP $4(x) 5 / \mathrm{K}$.. Carbon Dioxide Information

Analysis Center. Oak Ridge National

Lahoratory. ()ak Ridge, Tennessee.

Komhyr, W.D., L.S. Waterman, and W.R.

Taylor, 1983. Semiautomatic nondispersive infrared analyser apparatus for $\mathrm{CO}(\mathrm{C}) \mathrm{air}$ sample analyses. Joumal of (jeophysical Rescarch 8\%:1315 22

Komhyr, W.D., R.H. (iammon, T.B. Harris, L.S. Waterman, T'.J. Sonway, W.R. Taylor, and K.W. Thoning. 1985a (ilobal atmospheric $\mathrm{CO}_{2}$ distributions and variations from 1968-82 NOAA/CiMC(: (C) 2 llask sample datit. Ienrrat of Genphysical Research (⿻):550: $5.5 \%)$

Kombyr, W.D., T.B. Harris, and L.S.

Waterman. 1985h. Calibration of nondispersive infrared ( $(0)$ analyzers with $\mathrm{CO}_{2}$ peringe infired

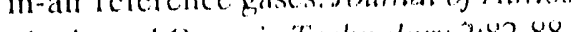

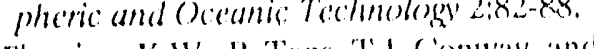
rhoning, K.W., P'. Tans, T'.J. Conwaly, and L.S. Watcrman. 1987. NOAA/GBACC calibrations of (:) 2-in-air reference gasests. 1979)...5. NOAA Technical Memorandum ERLARI-1511. Lenvingmeral Rescarch Laboratory, Boulder, Coloriado.

World Metcorological ( )rganization. 1984) Provisional denily atmosphereric cartom

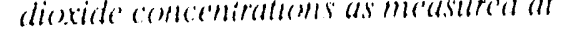

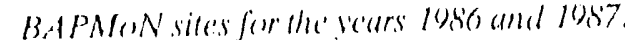
WM()/TD)-No. 3)(K. Ciencriat. 


\section{Mauna Loa}

\section{BACKGROUND \\ Principal Investigators: \\ Thomas J. Conway \\ Pieter Tans \\ Lee S. Waterman \\ National Oceanic and Atmospheric Administration \\ Environmental Research Laboratories 325 Broadway \\ Boulder, Colorado 80303-3328, U.S.A.}

Air sample collection - With the use of a portable sampling apparatus, two Pyrex glass flasks $(0.5-\mathrm{L})$ previously filled with a dry gas of known concentration and connected in series are flushed for $5 \mathrm{~min}$ with ambient air and pressurized to $1.2-1.5$ times ambient atmospheric pressure.

Measurement apparatus -. The flask samples are analyzed for $\mathrm{CO}_{2}$ concentrations at the CMDL laboratory in Boulder by using a UNOR-2 semiautomatic nondispersive infrared gas analyzer.

Data selection procedures - See Conway et al. (1988) and Komhyr et al. (1985a).

Calibrataun gases used $-\mathrm{CO}_{2}$-in-air.

Scale of data reported - 1969-1983, SIO

X83 mole fraction scale; $1984-1987$, SIO

X85 mole fraction scale.

Data availability - The NOAA/CMDL flask data have been archived with WMO and CDIAC. The data archived with WMO are pair averages. The data available from CDIAC (Conway and 'Tans, 1990) contain a complete listing of individual flask values with flags indicating the results of NOAA/ CMDL's data selection schemes.

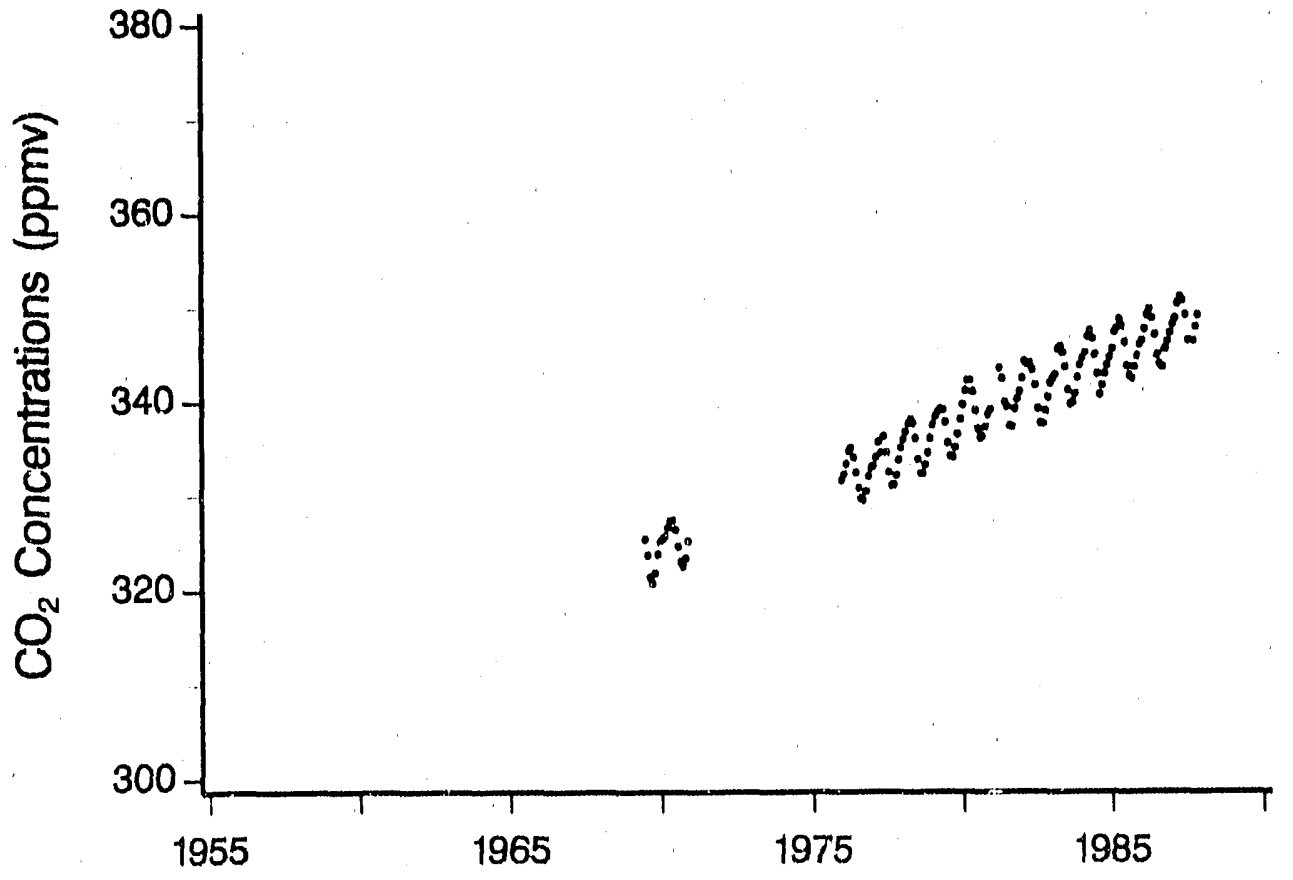

Monthly atmospheric $\mathrm{CO}_{2}$ concentrations.

Mauna Loa Hawaii, U.S.A.

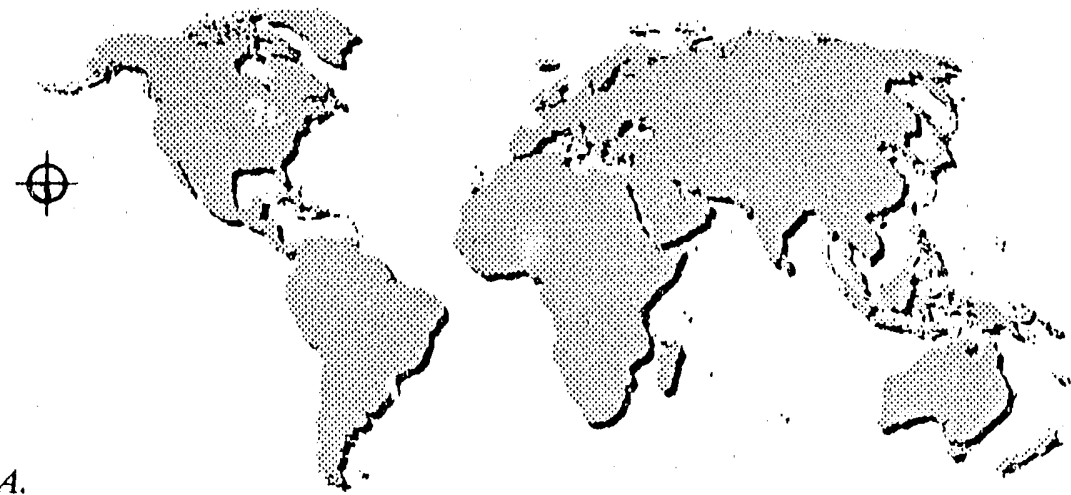

Barren volcanic slope $19^{\circ} 32^{\prime} \mathrm{N}, 155^{\circ} 35^{\prime} \mathrm{W}$ $3397 \mathrm{~m}$ above $\mathrm{MSL}$ 


\section{Atmospheric $\mathrm{CO}_{2}$}

\section{TREND}

These data are from the NOAA/CMDL flask sampling program. The NOAA/ CMDL flask data from Mauna Loa show an increase in the annual value from 325.2 npmv in 1970 to 348.3 ppmv in 1987. Conway et al. (1988) reported a 1.21-ppmv mean annual growth rate at Mauna Loa for 1981-1984 compared to a global growth rate of 1.22 ppmv per year over the same time frame for all NOAA/CMDL flask sampling sites.

Atmospheric $\left.\mathrm{C}_{2}\right)_{2}$ concentrations at Mauna Loa show a seasonal pattern with the annual drawdown occurring in July and the annuai buildup occurring in January. Conway et al. (1988) reported the peakto-peak seasonal amplitude for Mauna Loa to be $6.67 \mathrm{ppmv}$ for 1981-1984. 
Atmospheric Concentrations of Carbon Dioxide*

\begin{tabular}{|c|c|c|c|c|c|c|c|c|c|c|c|c|c|}
\hline Year & Jan & Feb & Mar & Apr & May & Jun & Jul & Aug & Sept & Oet & Nov & Dec & Ann \\
\hline 1969 & & & & & & & 325.4 & 323.7 & 321.4 & 320.7 & 321.8 & 323.8 & \\
\hline 1970 & 325.1 & 325.4 & 325.7 & 326.6 & 327.3 & 327.4 & 326.4 & 324.6 & 323.0 & 322.5 & 323.4 & 325.2 & 325.2 \\
\hline 1971 & & & & & & & & & & & & & \\
\hline 1972 & & & & & & & & & & & & & \\
\hline 1973 & & & & & & & & & & & & & \\
\hline 1974 & & & & & & & & & & & & & \\
\hline 1975 & & & & & & & & & & & & & \\
\hline 1976 & 331.6 & 332.2 & 333.3 & 334.7 & 335.0 & 334.0 & 332.4 & 330.8 & 329.7 & 329.5 & 330.4 & 332.0 & 332.1 \\
\hline 1977 & 332.9 & 333.1 & 334.0 & 335.6 & 336.5 & 336.2 & 334.5 & 332.4 & 331.0 & 331.1 & 332.1 & 333.7 & 333.6 \\
\hline 1978 & 335.0 & 335.9 & 336.7 & 337.6 & 338.0 & 337.6 & 336.0 & 333.8 & 332.3 & 332.3 & 333.2 & 334.5 & 335.2 \\
\hline 1979 & 336.0 & 337.4 & 338.3 & 338.8 & 339.1 & 339.0 & 337.7 & 335.5 & 334.1 & 334.0 & 335.0 & 336.4 & 336.8 \\
\hline 1980 & 338.0 & 339.5 & 341.0 & 342.1 & 342.1 & 340.9 & 338.9 & 337.0 & 336.0 & 336.2 & 337.2 & 338.5 & 339.0 \\
\hline 1981 & 339.0 & & & & 343.4 & 342.3 & 339.8 & 339.3 & 337.3 & 337.2 & 339.1 & 340.1 & 339.7 \\
\hline 1982 & 340.9 & 342.3 & 344.1 & 343.8 & 343.9 & 343.2 & 341.6 & 339.1 & 337.6 & 337.5 & 338.9 & 340.3 & 341.1 \\
\hline 1983 & 341.8 & 342.3 & 342.7 & 345.4 & 345.7 & 345.0 & 343.5 & 341.1 & 339.6 & 339.8 & 340.7 & 342.4 & 342.5 \\
\hline 1984 & 343.7 & 344.4 & 345.0 & 346.7 & 347,3 & 346.5 & 344.8 & 342.8 & 340.6 & 341.6 & 342.8 & 343.7 & 344.2 \\
\hline 1985 & 344.5 & 345.4 & 347.2 & 347.6 & 348.5 & 347.8 & 346.1 & 343.6 & 342.6 & 342.3 & 343.5 & 344.7 & 34.5 .3 \\
\hline 1986 & 345.9 & 346.3 & 347.5 & 349.0 & 349.6 & 348.7 & 346.9 & 344.8 & 343.8 & 343.5 & 345.4 & 346.2 & 346.4 \\
\hline 1987 & 347.1 & 348.0 & 348.6 & 350.2 & 350.9 & 350.5 & 349.0 & 346.3 & 346.3 & 346.3 & 347.8 & 349.0 & 348.3 \\
\hline
\end{tabular}

*Atmospheric $\mathrm{CO}_{2}$ in parts per million by volume (ppmv). Annual averages based on monthly means. All numbers have been rounded to the nearest tenth.

\section{REHLRENCES}

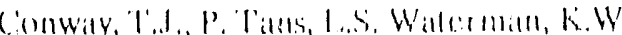
Theming, K.A. Massitric, and R.11

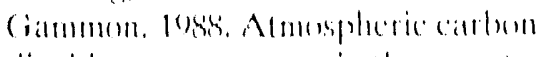

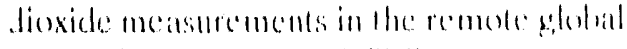

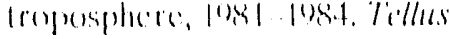

$$
40(13): 81115
$$

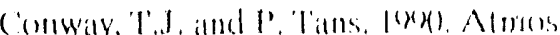
pheric (c)e concentrations: The

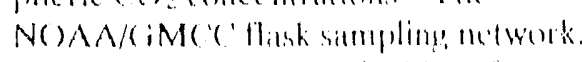

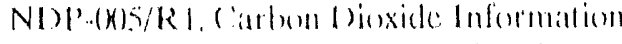
Analysis ('ontet. ()ikk Ridge Nitlonil

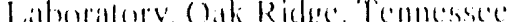

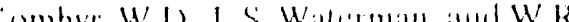

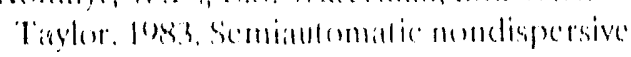

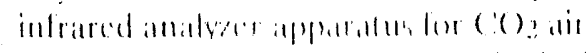

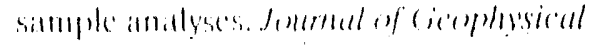
Reserurch

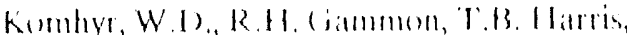

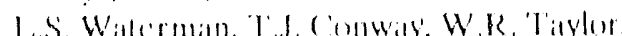

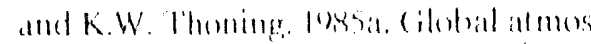
pherie (') : distributions and vatriations

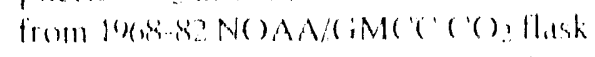

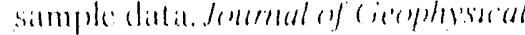

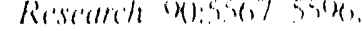

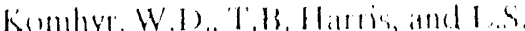

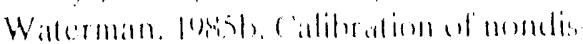

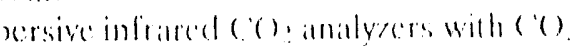

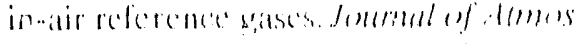

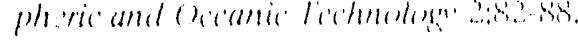

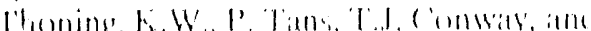

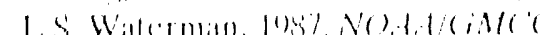

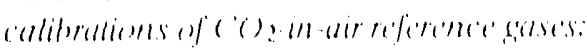

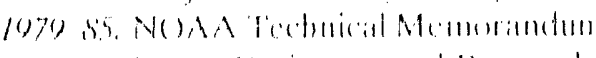

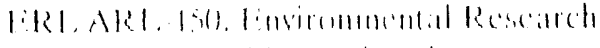

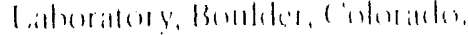

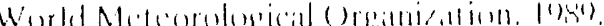

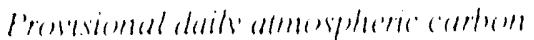

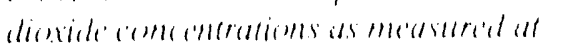

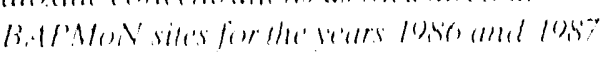

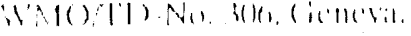




\section{Mould Bay}

\begin{tabular}{|c|}
\hline BACKGROUND \\
\hline Principal investigators \\
\hline Thomas J. Conway \\
\hline Pieter Tans \\
\hline Lee S. Waterman \\
\hline $\begin{array}{l}\text { National Oceanic and Atmospheric } \\
\text { Administration }\end{array}$ \\
\hline Environmental Research Laboratories \\
\hline 325 Broadvay \\
\hline Boulder, Colorado $80303-3328$, U.S.A. \\
\hline $\begin{array}{l}\text { Air sample collection-With the use of a } \\
\text { portable sampling apparatus, two Pyrex } \\
\text { glass flasks }(0.5-\mathrm{L}) \text { previously filled with a } \\
\text { dry gas of known concentration and } \\
\text { connected in series are flushed for } 5 \text { min } \\
\text { with ambient air and pressurized to } 1.2-1.5 \\
\text { times ambient atmospheric pressure. }\end{array}$ \\
\hline $\begin{array}{l}\text { Measurement apparatus - The flask } \\
\text { samples are analyzed for } \mathrm{CO}_{2} \text { concen- } \\
\text { trations at the } \mathrm{CMDL} \text { laboratory iri Boulder } \\
\text { by using a UNOR-2 semiautomatic } \\
\text { nondispersive infrared gas analyzer. }\end{array}$ \\
\hline $\begin{array}{l}\text { Data selection procedures - See Conway } \\
\text { et al. (1988) and Komhyr et al. (1985a). }\end{array}$ \\
\hline Calibration gases used- $\mathrm{CO}_{2}$-in-air. \\
\hline $\begin{array}{l}\text { Scale of data reported-1980-1983, SIO } \\
\text { X83 mole fraction scale; } 1984-1987 \text {, SIO } \\
\text { X85 mole fraction scale. }\end{array}$ \\
\hline $\begin{array}{l}\text { Data availability - The NOAA/CMDL flask } \\
\text { data have been archived with WMO and } \\
\text { CDIAC. The data archived with WMO are } \\
\text { pair averages. The data available from } \\
\text { CDIAC (Conway and Tans, } 1990 \text { ) contain a } \\
\text { complete listing of individual flask values } \\
\text { with flags indicating the results of NOAA/ } \\
\text { CMDL's data selection schemes. }\end{array}$ \\
\hline
\end{tabular}

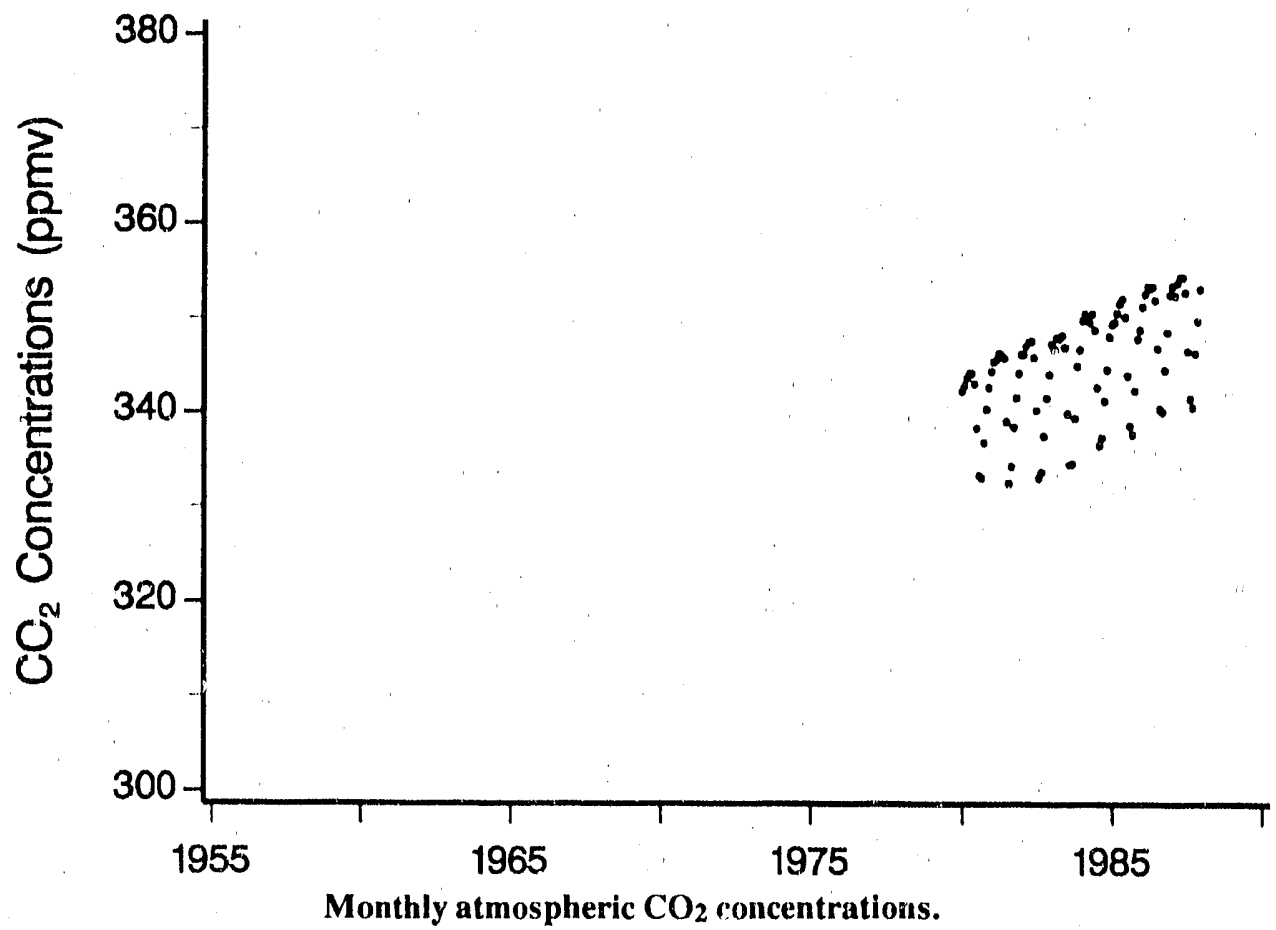

Mould Bay

Northwest Territories, Canada Island tundra

$76^{\circ} 14^{\prime} \mathrm{N}, 119^{\circ} 20^{\prime} \mathrm{W}$

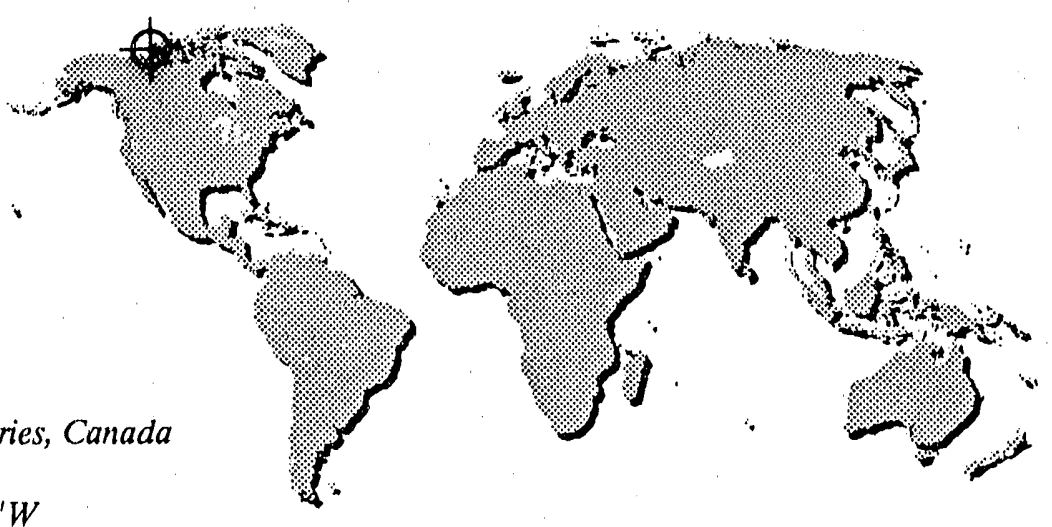

$15 \mathrm{~m}$ above $M S L$ 


\section{Atmospheric $\mathrm{CO}_{2}$}

\section{TREND}

These data are from the NOAA/CMDL flask sampling program. The sampling site at Mould Bay is operated in cooperation with the Atmospheric Environment Service of Environment Canada.

The NOAA/CMDL flask data from Mould Bay show an increase in the annual value from $340.3 \mathrm{ppmv}$ in 1980 to 349.8 ppmv in 1987. Conway et al. (1988) reported identical 1.22-ppmv annual growth rates at Mould Bay alone and for all the NOAA/ CMDL flask sampling sites for the period 1981-1984.

Atmospheric $\mathrm{CO}_{2}$ concentrations at Mould Bay show a seasonal pattern with the annual drawdown occurring in July and the annual buildup occurring in NovemberDecember. Conway et al. (1988) reported the peak-to-peak seasonal amplitude for Mould Bay to be 15.15 ppmr for 1981-1984. 
Atmospheric Concentrations of Carbon Dioxide*

$\begin{array}{lllllllllllllll}\text { Year } & \text { Jan } & \text { Feb } & \text { Mar } & \text { Apr } & \text { May } & \text { Jun } & \text { Jul } & \text { Aug } & \text { Sept } & \text { Oct } & \text { Nov } & \text { Dec } & \text { Ann } \\ 1980 & 342.1 & 342.7 & 343.5 & 344.0 & 34 . & 342.9 & 338.2 & 333.2 & 333.0 & 336.7 & 340.2 & 342.5 & 340.3 \\ 1981 & 344.2 & 345.2 & 345.4 & 346.1 & 345.9 & 345.6 & 338.9 & 332.4 & 334.2 & 338.3 & 341.4 & 344.0 & 341.8 \\ 1982 & 346.0 & 346.0 & 346.9 & 347.3 & 347.4 & 345.7 & 340.1 & 333.0 & 333.6 & 337.4 & 341.4 & 343.9 & 342.4 \\ 1983 & 347.1 & 346.6 & 347.8 & 347.7 & 348.0 & 346.8 & 339.8 & 334.4 & 334.5 & 339.3 & 344.8 & 346.5 & 343.6 \\ 1984 & 349.6 & 350.3 & 350.0 & 349.4 & 350.3 & 348.6 & 342.5 & 336.4 & 337.2 & 341.1 & 344.4 & 347.9 & 345.6 \\ 1985 & 349.2 & 349.4 & 350.4 & 351.4 & 351.9 & 350.0 & 343.8 & 338.5 & 337.6 & 342.2 & 347.7 & 348.6 & 346.7 \\ 1986 & 351.1 & 352.4 & 353.2 & 353.0 & 353.2 & 351.8 & 346.7 & 340.3 & 340.0 & 344.4 & 348.4 & 352.4 & 348.6 \\ 1987 & 353.3 & 352.3 & 353.6 & 354.2 & 354.2 & 352.6 & 346.4 & 341.4 & 340.5 & 346.2 & 349.6 & 353.0 & 349.8\end{array}$

${ }^{*}$ Atmospheric $\mathrm{CO}_{2}$ in parts per million by volume (ppmv). Annual averages based on monthly means. All numbers have been rounded to the nearest tenth.

\section{REFERENCES}

Conway, T.J., P. Taths, L.S. Watterman, K.W Thoning K A Masirice and R.H.

Gammon. 1988. Almospheric carbon

dioxide measurements in the remote global tropesphere, 1081 1984. Tellis: $4(1)(B): 81-115$

Conwaly, 'T.l. and P. 'Tans. I(M) Almus-

pheric (C) 2 concentrutions The

NOAA/GMCC llisk simpling network.

NDP-(K) $5 /$ R I. Carbon Dioxide Information

Analysis (enter. Oak Ridge National

Laboratory. ()ak Ridge, 'Tennessise.

Komhyr, W.D. L.S. Watcrman, and W.R.

Taylor. 1983 Semiatulomatic nondispersive

infrated analyzer anparat us for (C) 2 air

sample analyses. Journal of (ienophysical

Re'se'arch $88: 1315: 22$

Komhyr, W.D., R.H. ( iammon, 'T'B. Harris, L.S. Waterman, T'I. Conwaly, W.R. I'aylor, and K.W. Thoming. logsat (ilobal atmospheric $\mathrm{C}\left(\mathrm{O}_{2}\right.$ distributions and vartiations from 1968-42 NOAA/CiMC'('() 2 llask sample datat Iommal of (iecophsical

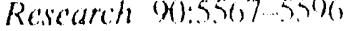

Kombyr, W.D., TB. Hlirris, ind L. Watcrom logest Calibration of nondisin-air reference gases. Joumal of ttmos

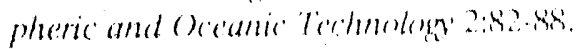
Thoning, K.W., P. Tatus, T'J. C'onway, and

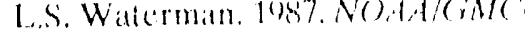

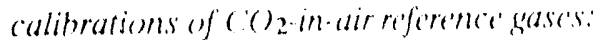
1070) 85 NOAA lectmical Memorandum

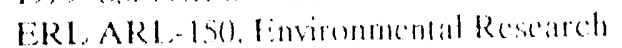
Laboratory, Bunder, Colduade.

World Meteorological (n)

Provisiomal duils atmespepheric cartom

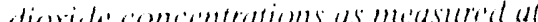

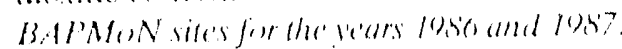

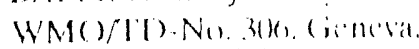




\section{Niwot Ridge}

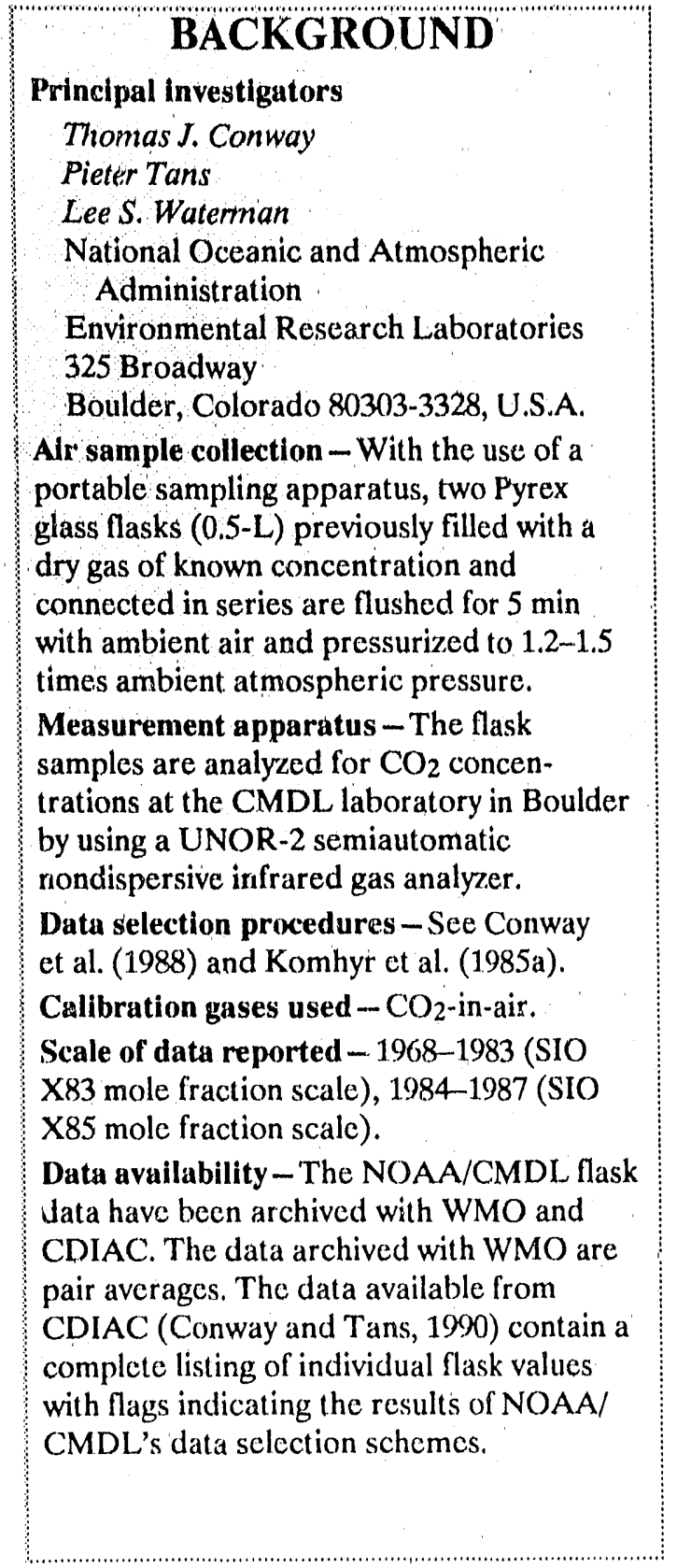

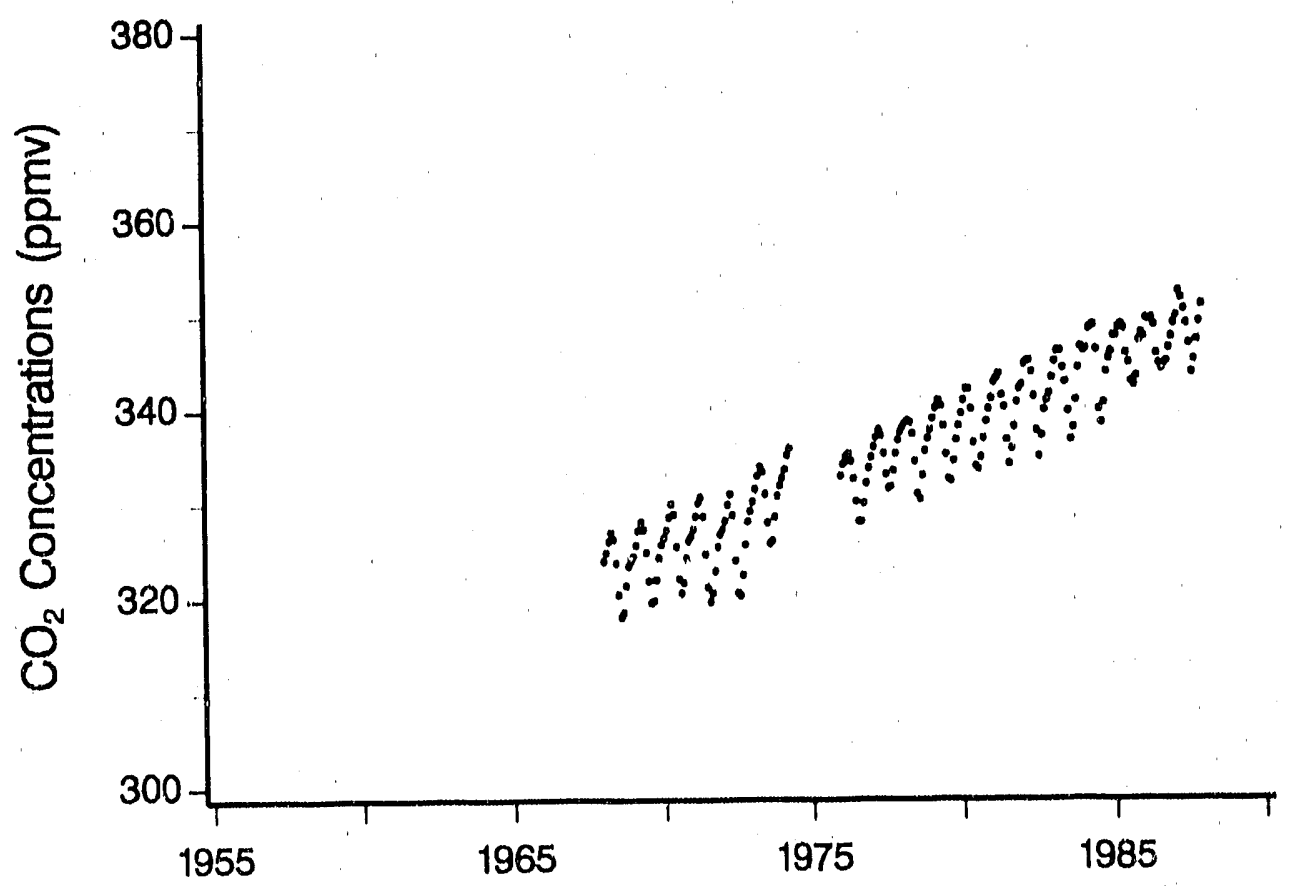

Monthly atmospheric $\mathrm{CO}_{2}$ concentrations.

Niwot Ridge

Colorado, U.S.A.

Alpine mountain

$40^{\circ} 03^{\prime} \mathrm{N}, 105^{\circ} 38^{\prime} \mathrm{W}$

$3749 \mathrm{~m}$ above $\mathrm{MSL}$ 


\section{Atmospheric $\mathrm{CO}_{2}$}

\section{TREND}

These data are from the NOAA/CMDL flask sampling program. The sampling site at Niwot Ridge is operated in cooperation with the University of Colorado.

The NOAA/CMDL flask data from Niwot Ridge show an increase in the annual value from $323.1 \mathrm{ppmv}$ in 1968 to 348.6 ppmv in 1987. Conway et al. (1988) reported a 1.57 -ppmv mean annual growth rate at Niw'ot Ridge for 1981-1984 compared to a global growth rate of 1.22 ppmv per year over the same time frame for all NOAA/ CMDL flask sampling sites.

Atmospheric $\mathrm{CO}_{2}$ concentrations at Niwot Ridge show a seasonal pattern with the annual drawdown occurring in June and the annual buildup occurring in NovemberDecember. Conway et al. (1988) reported the peak-to-peak seasonal amplitude for Niwot Ridge to be 10.49 ppmv for 1981-1984. 


$\begin{array}{lccccccccccccc}\text { Year } & \text { Jan } & \text { Feb } & \text { Mar } & \text { Apr } & \text { May } & \text { Jun } & \text { Jul } & \text { Aug } & \text { Sept } & \text { Oct } & \text { Nov } & \text { Dec } & \text { Ann } \\ 1968 & 323.9 & 324.8 & 326.0 & 326.9 & 326.2 & 323.7 & 320.4 & 318.0 & 318.5 & 321.3 & 323.4 & 323.9 & 323.1 \\ 1969 & 324.4 & 325.6 & 327.1 & 328.0 & 327.2 & 324.8 & 321.8 & 319.5 & 319.7 & 321.9 & 324.2 & 325.6 & 324.1 \\ 1970 & 326.3 & 327.1 & 328.5 & 329.9 & 328.8 & 325.4 & 322.0 & 320.5 & 321.6 & 324.2 & 326.0 & 326.5 & 325.6 \\ 1971 & 327.2 & 328.6 & 330.0 & 330.6 & 328.6 & 324.6 & 321.1 & 319.6 & 320.5 & 322.8 & 325.4 & 326.7 & 325.4 \\ 1972 & 327.2 & 328.1 & 329.8 & 330.9 & 328.7 & 323.9 & 320.5 & 320.2 & 322.4 & 325.6 & 328.0 & 329.1 & 326.2 \\ 1973 & 330.1 & 331.4 & 332.8 & 333.8 & 333.2 & 330.9 & 327.9 & 325.7 & 326.0 & 328.5 & 330.7 & 331.8 & 330.2 \\ 1974 & 332.6 & 333.5 & 335.0 & 335.7 & & & & & & & & & \\ 1975 & & & & & & & & & & & & & \\ 1976 & 332.8 & 334.0 & 334.8 & 335.1 & 334.3 & 332.5 & 330.1 & 328.0 & 328.0 & 329.9 & 332.0 & 333.6 & 332.1 \\ 1977 & 334.7 & 335.8 & 336.8 & 337.6 & 337.0 & 335.1 & 332.9 & 331.4 & 331.6 & 333.3 & 335.1 & 336.5 & 334.8 \\ 1978 & 337.4 & 337.9 & 338.3 & 338.6 & 338.4 & 337.2 & 334.3 & 330.9 & 330.3 & 332.8 & 335.4 & 336.7 & 335.7 \\ 1979 & 337.6 & 338.8 & 339.9 & 340.7 & 340.1 & 338.0 & 335.0 & 332.4 & 332.2 & 334.3 & 336.5 & 338.0 & 336.9 \\ 1980 & 339.3 & 340.7 & 341.9 & 341.9 & 339.8 & 336.2 & 333.8 & 333.5 & 334.7 & 336.7 & 338.5 & 339.8 & 338.0 \\ 1981 & 340.9 & 342.6 & 343.0 & 343.5 & 341.2 & 340.0 & 336.5 & 334.0 & 335.6 & 337.9 & 340.5 & 341.9 & 339.8 \\ 1982 & 342.3 & 344.5 & 344.8 & 344.9 & 343.7 & 341.1 & 337.5 & 334.8 & 337.0 & 339.7 & 340.7 & 341.4 & 341.0 \\ 1983 & 343.1 & 344.8 & 345.9 & 345.9 & 344.1 & 342.6 & 339.5 & 336.5 & 337.8 & 340.7 & 344.1 & 346.3 & 342.6 \\ 1984 & 345.9 & 346.1 & 348.2 & 348.4 & 348.6 & 346.0 & 339.7 & 338.3 & 340.4 & 343.7 & 345.1 & 345.8 & 344.7 \\ 1985 & 347.5 & 347.5 & 348.4 & 348.7 & 348.3 & 345.7 & 344.7 & 342.7 & 342.3 & 343.2 & 347.0 & 347.8 & 346.2 \\ 1986 & 347.4 & 349.3 & 349.2 & 349.3 & 348.6 & 345.6 & 344.5 & 344.0 & 344.5 & 344.8 & 346.2 & 347.4 & 346.5 \\ 1987 & 348.8 & 349.6 & 352.2 & 351.5 & 350.3 & 348.8 & 346.7 & 343.6 & 345.0 & 347.1 & 349.0 & 350.8 & 348.6\end{array}$

*Atmospheric $\mathrm{CO}_{2}$ in parts per million by volume (ppmv). Annual averages based on monthly means. All numbers have been rounded to the nearest tenth.

\section{REFTRENCLS}

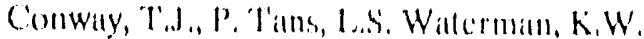
Thoning, K.A. Malsitrice, and R,H.

Gamminn. 1988. Almuspheric cartron

diexide meatsurements in the remole gllubal

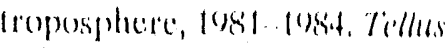

$4(1)(B): 81 \ldots 115$

Conwaly, 'T.J. and P'. 'T'ans, I(x) A(mon. pheric ( ()$_{2}$ concentritions... The

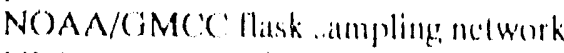
NDP-(K).5/R1, Carbon Dioxide Information Analysis (enter. ()ak Ridge National

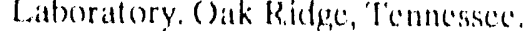

Komhyr, W.D., L..S. Wittermin, and W.R.

Taylor. IOR.3. Semiantumatio nondispersive

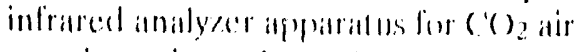
sample analysces. Iourmal of (irophlysical Rescearch ss:1.315? ?...

Komhyr, W.D., R.H. (iammon, T.B. Hurris I..S. Watermiar, T.I. Comwily, W.R. T'inylor, and K.W. Thoming. I MSSa (ilobal al monspheric (') (listributions and vartations

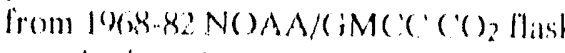

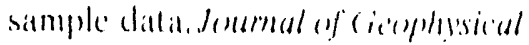

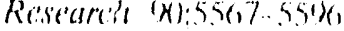

K'omhyr, W.D., T.B. Haurris, and I.S.

Watermim. 1985t. ( 'alihratien of nondispersive infrated (C) antilyeres with ( ( () 2 in-air reference gatses . Iournal of dtmos pheric and (ocennic Techmolenge 2:82-88.

Thoning, K.W., P'. Tans, T.I. ('onwaly, and L.s. Watermatn. 1987. No datcime'

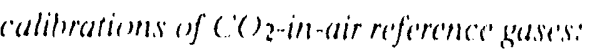
1970 -8.5. No A A Fechnical Memorandum ERL, AR1, 15). Enviromencontal Rescarch Lathoratory, Bonder, Colorado.

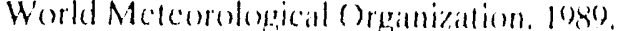
Provisiomal duily atmosphlaric cantom dienvide comcentrations as measured at

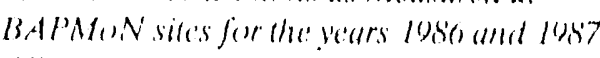

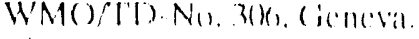




\section{Ocean Station "M"}

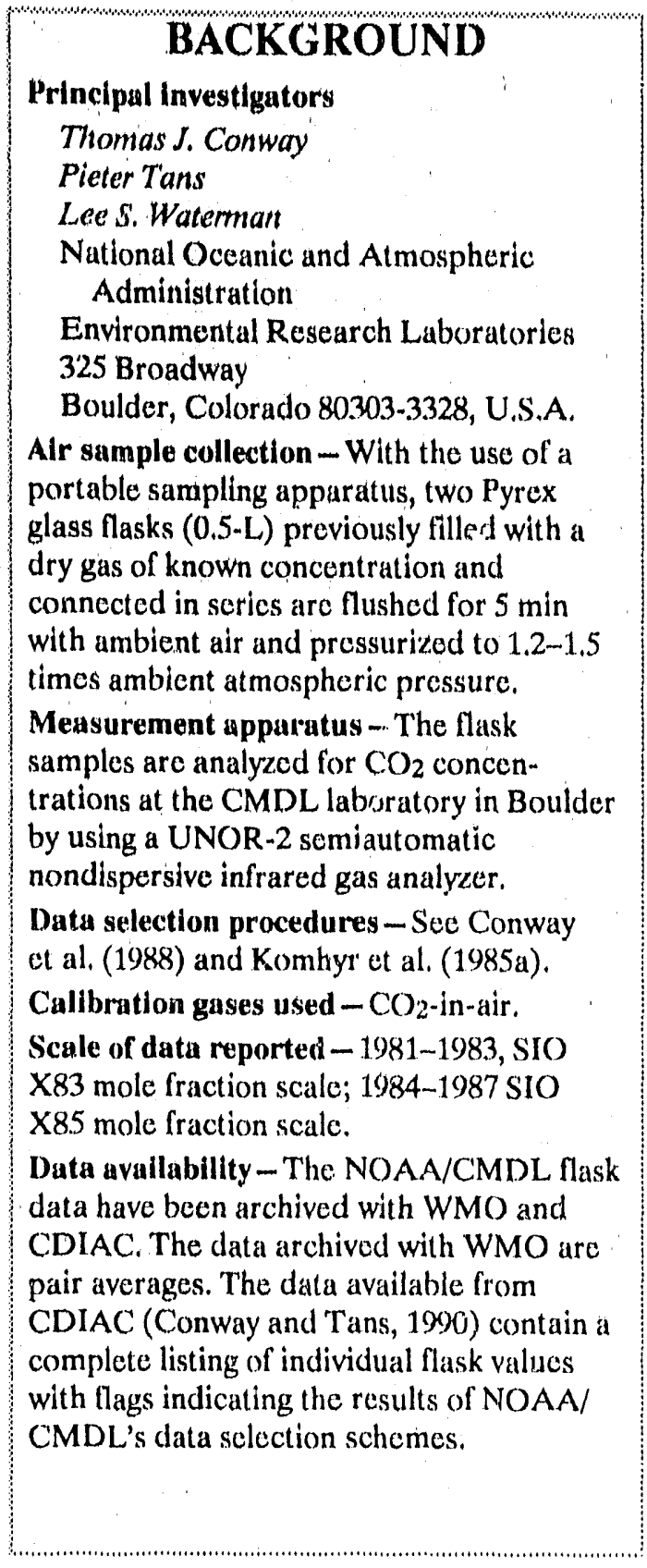

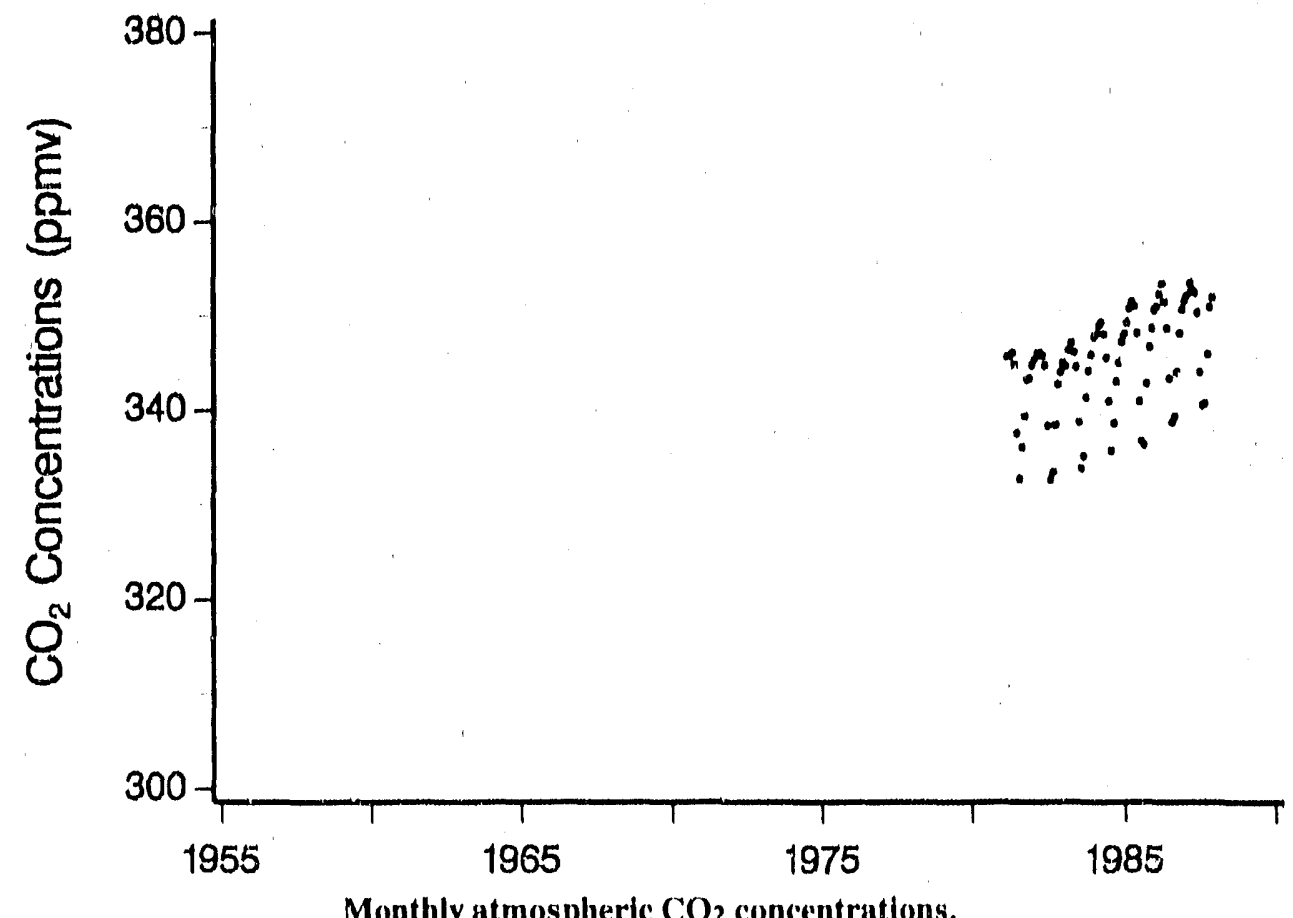

Ocean Station "M"

North Atlantic

Open oce'an

Monthly atmospheric $\mathrm{CO}_{2}$ concentrations.

$\left.66^{\circ} 0()^{\prime} N, 2^{\circ} 0\right)^{\prime} E$

o $m$ above $M S L$ 


\section{TREND}

These data are from the NOAA/CMDL flask sampling program. The Ocean Station " $\mathrm{M}$ " sampling site is operated in cooperation with the Norway Meteorological Institute.

The NOAA/CMDL flask data from Ocean Station "M" show an increase in the annual value from $341.6 \mathrm{ppmv}$ in 1981 to 348.9 ppmv in 1987. Conway of al. (1988) reported a 0.92 ppmv mean annual growth rate at Occan Station "M" for 1981-1984 in comparison with a global growth rate of 1.22 ppmv per year o ser the same time frame for all NOAA/CMDL flask sampling. sites.

Atmospheric $\mathrm{CO}_{2}$ concentrations at Occan Station "M" show a seasonal pattern with tho annual drawdown occurring in November and the annual buildup occurring in June, Conway et al. (1988) reported the peak-to-trough seasonal amplitude for Ocean Station " $M$ " to be 14.43 ppmv for 1981-1984. 


\section{Ocean Station "M"}

Atmospheric Concentrations of Carbon Dioxide*

\begin{tabular}{|c|c|c|c|c|c|c|c|c|c|c|c|c|c|}
\hline Year & Jan & Feb & Mur & Apr & May & $\operatorname{IIm}$ & Jul & Aug & Sept & Oct & Nov & Dec & Ann \\
\hline 1981 & & & 345.6 & 345.6 & 346.0 & 344.8 & 337.5 & 332.7 & 336.0 & 339.3 & 343.2 & 343.3 & 341.6 \\
\hline 1982 & $3: 4,7$ & 345.3 & 346.0 & 346.0 & 345.7 & 344.7 & 338.3 & 332.6 & 333.4 & 338.4 & 342.7 & 344.0 & 341.8 \\
\hline 1983 & 345.0 & 344.6 & 346.3 & 347.1 & 346.1 & 344.5 & 338.7 & 333.8 & 335.1 & 341.3 & 344.1 & 345.8 & 342.7 \\
\hline 1984 & 347.7 & 347.9 & 348.9 & 349,2 & 348,0 & 345.5 & 340,9 & 335.7 & 338.6 & 343.0 & 3450 & 347.2 & 344.8 \\
\hline 1985 & 348.0 & 349.2 & 350.7 & 351.4 & 351.0 & 348.1 & 340.9 & 336.7 & 336.3 & 342.8 & 346.6 & 348.6 & 345.9 \\
\hline 1986 & 350.5 & 350.9 & 352.2 & 353.3 & 351.4 & 348.6 & 343.3 & 338.7 & 339.3 & 344.0 & 348.1 & 350.6 & 347.6 \\
\hline 1987 & 351.5 & 352.1 & 353.4 & 352.7 & 352.4 & 350.3 & 344,0 & 340.5 & 340.7 & 345.9 & 350.9 & 351.9 & 348,9 \\
\hline
\end{tabular}

*Atmospheric $\mathrm{CO}_{2}$ in parts per million by volume (ppmv). Annual a'strages based on monthly means. All numbers have been rounded to the nearest tenth.

\section{REFLRLNCIS}

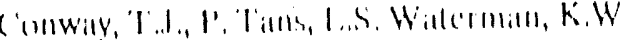

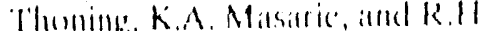

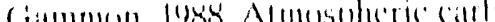

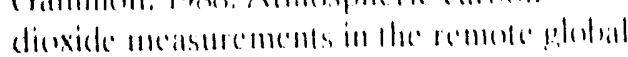

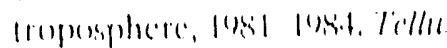

4)(13): 181 - 115

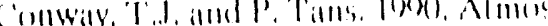

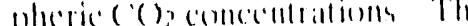

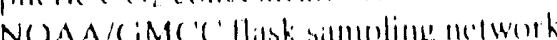

Nor

Amalysis ('onler, ()isk Ridene Nattionlat

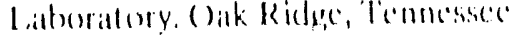

Komhyr, W.1 ), I..S. Wallerman, and W.R.

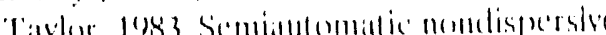

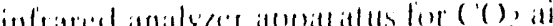

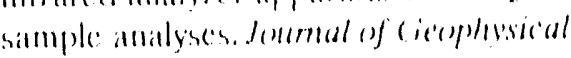

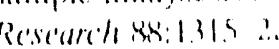

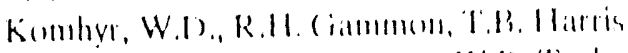

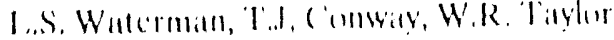

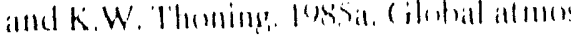

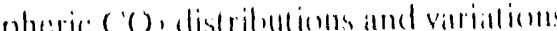

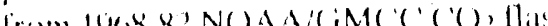

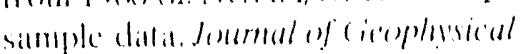

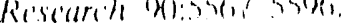

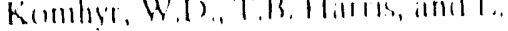

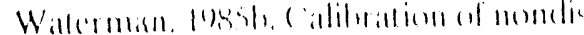

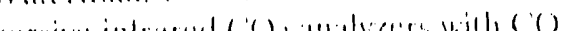

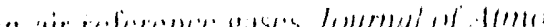

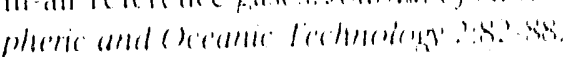

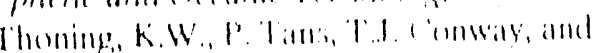

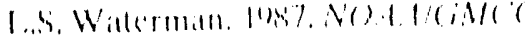

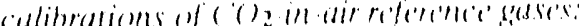

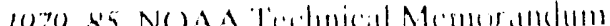

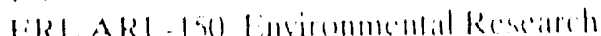

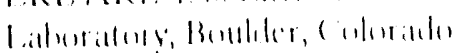

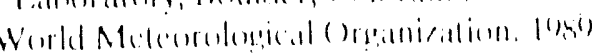

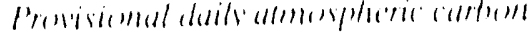

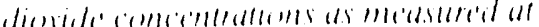

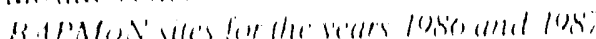

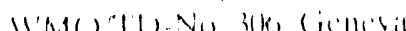




\section{Palmer Station (Anver Island)}

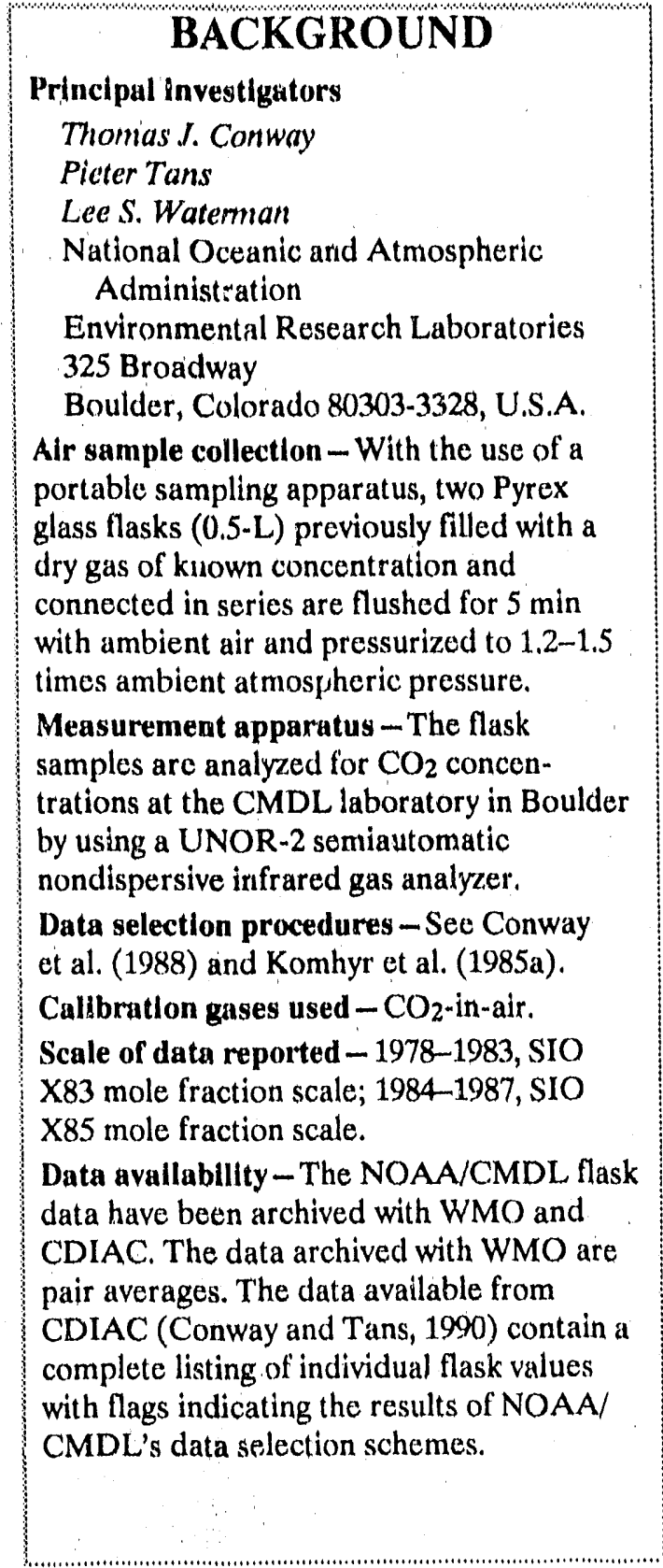

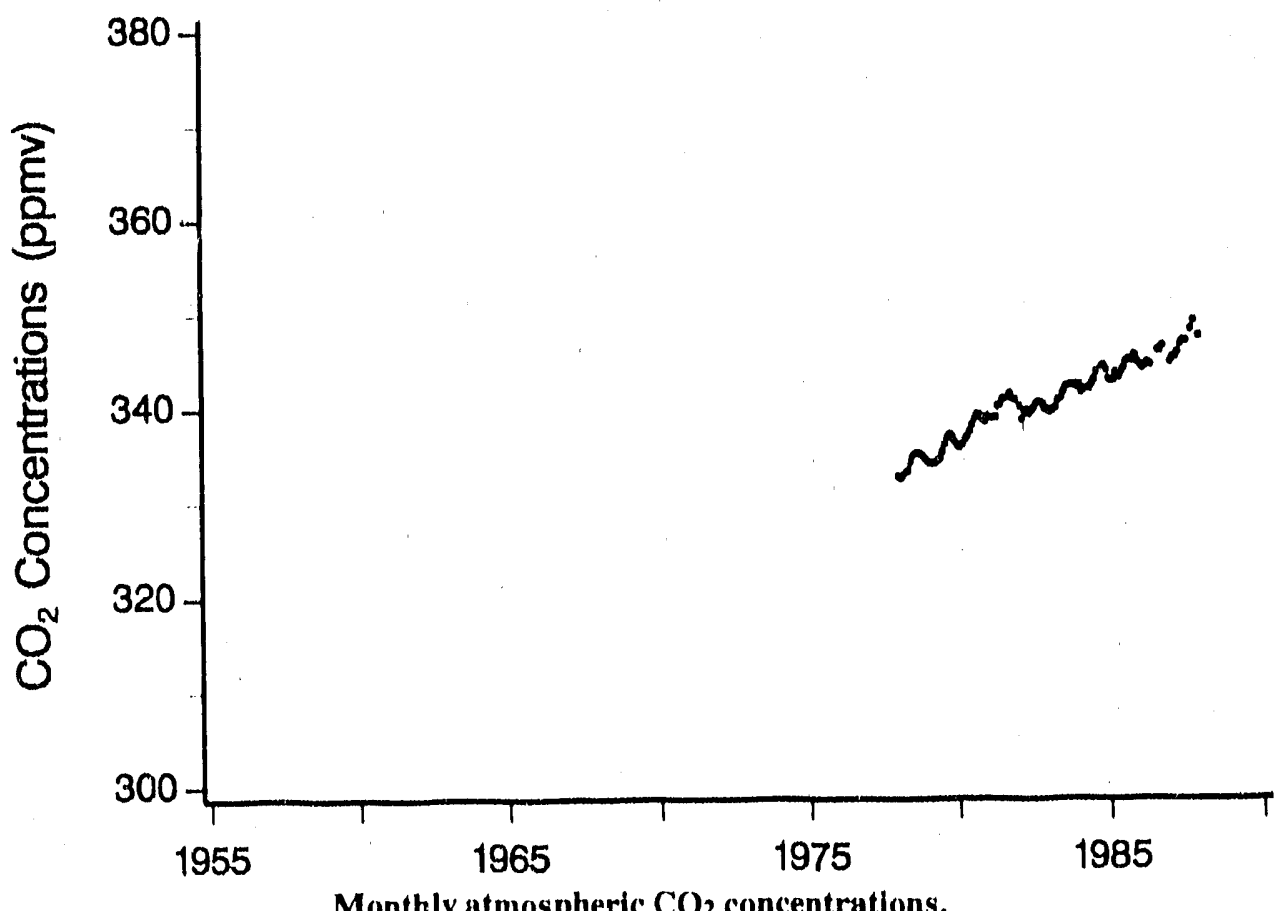

Palmer Station

Anver Island, Antarctica

Barren island seashore $64^{\circ} 55^{\prime} \mathrm{S}, 64^{\circ} 00^{\prime} \mathrm{W}$

$33 \mathrm{~m}$ above $M S L$

Monthly atmospheric $\mathrm{CO}_{2}$ concentrations.

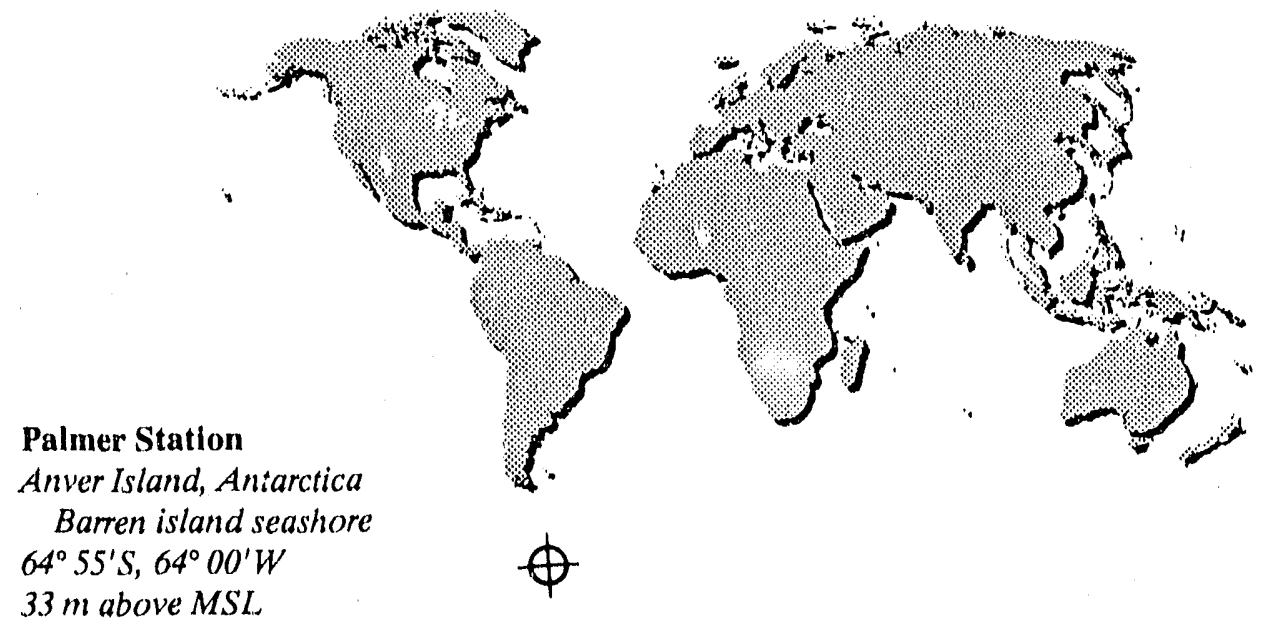




\section{Atmospheric $\mathrm{CO}_{2}$}

\section{TREND}

These data are from the NOAA/CMDL flask sampling program. The sampling site at Palmer Station on Anver Island is operated in cooperation with the Washington State University Laboratory for Atmospheric Research.

The NOAA/CMDL flask data from Palmer Station show an increase in the annual value from 333.9 pomv in 1978 to 343.9 ppmv in 1985. Conway et al. (1988) reported a 0.86 -ppmy mean annual growth rate at Palmer Station for 1981-1984 compared to a global growth rate of 1.22 ppmv per year over the same time frame for all NOAA/CMDL flask sampling sites.

Atmospheric $\mathrm{CO}_{2}$ concentrations at Palmer Station show a seasonal pattern with the annual drawdown typically occurring in December-January and the annual buildup occurring in May-July. Conway et al. (1988) reported the peak-to-peak seasonal amplitude for Palmer Station to be 1.30 ppmv for 1981-1984. 
Atmospheric Concentrations of Carbon Dioxide*

$\begin{array}{lllllllllllllll}\text { Year } & \text { Jan } & \text { Feb } & \text { Mar } & \text { Apr } & \text { May } & \text { Jun } & \text { Jul } & \text { Aug } & \text { Sept } & \text { Oct } & \text { Nov } & \text { Dec } & \text { Anu } \\ 1978 & 332.6 & 332.4 & 332.7 & 333.0 & 333.2 & 334.1 & 334.8 & 335.0 & 335.1 & 335.0 & 334.8 & 334.5 & 333.9 \\ 1979 & 334.2 & 334.0 & 334.0 & 334.0 & 334.2 & 334.5 & 335.2 & 336.0 & 336.7 & 337.0 & 336.8 & 336.2 & 335.2 \\ 1980 & 335.8 & 335.7 & 335.9 & 336.4 & 336.8 & 337.3 & 338.0 & 338.7 & 339.1 & 339.0 & 338.6 & 338.4 & 337.5 \\ 1981 & 338.9 & 338.7 & & 338.8 & 340.0 & 340.2 & 340.7 & 340.8 & 340.9 & 341.3 & 340.8 & 340.7 & 340.2 \\ 1982 & & 340.0 & 338.6 & 339.3 & 339.6 & 339.2 & 339.5 & 339.9 & 340.3 & 340.4 & 340.3 & 339.7 & 339.7 \\ 1983 & 339.7 & 339.4 & 339.6 & 339.8 & 340.6 & 340.8 & 341.4 & 342.0 & 342.1 & 342.2 & 342.2 & 342.0 & 341.0 \\ 1984 & 342.2 & 341.4 & 341.7 & 341.8 & 341.8 & 342.2 & 342.7 & 343.5 & & 343.9 & 344.2 & 343.8 & 342.7 \\ 1985 & 342.8 & 342.7 & 342.7 & 343.5 & 343.0 & 343.5 & 344.0 & 344.7 & 344.9 & 344.8 & 345.3 & 344.6 & 343.9 \\ 1986 & 344.4 & 344.0 & 344.2 & 344.5 & 344.3 & & & 345.8 & 345.8 & 346.3 & & 34.9 & 344.4 \\ 1987 & 344.6 & 345.1 & 345.2 & 345.7 & 346.5 & 346.9 & 346.9 & & 348.1 & 349.0 & & 347.4 & 346.5\end{array}$

*Atmospheric $\mathrm{CO}_{2}$ in parts per million by volume (ppmv). Annual averages based on monthly means. All numbers have been rounded to the vearest tenth.

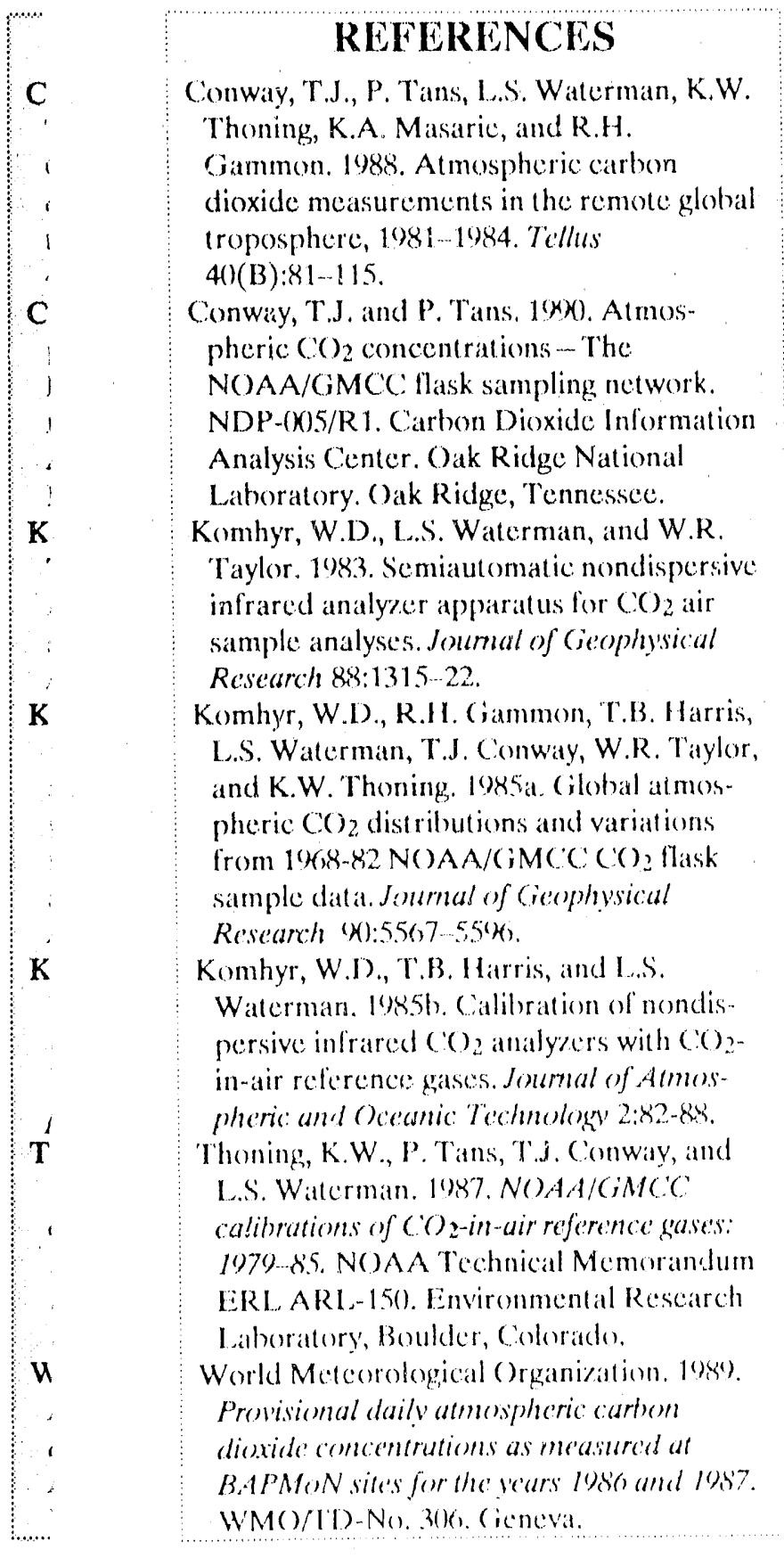




\section{Point Barrow}

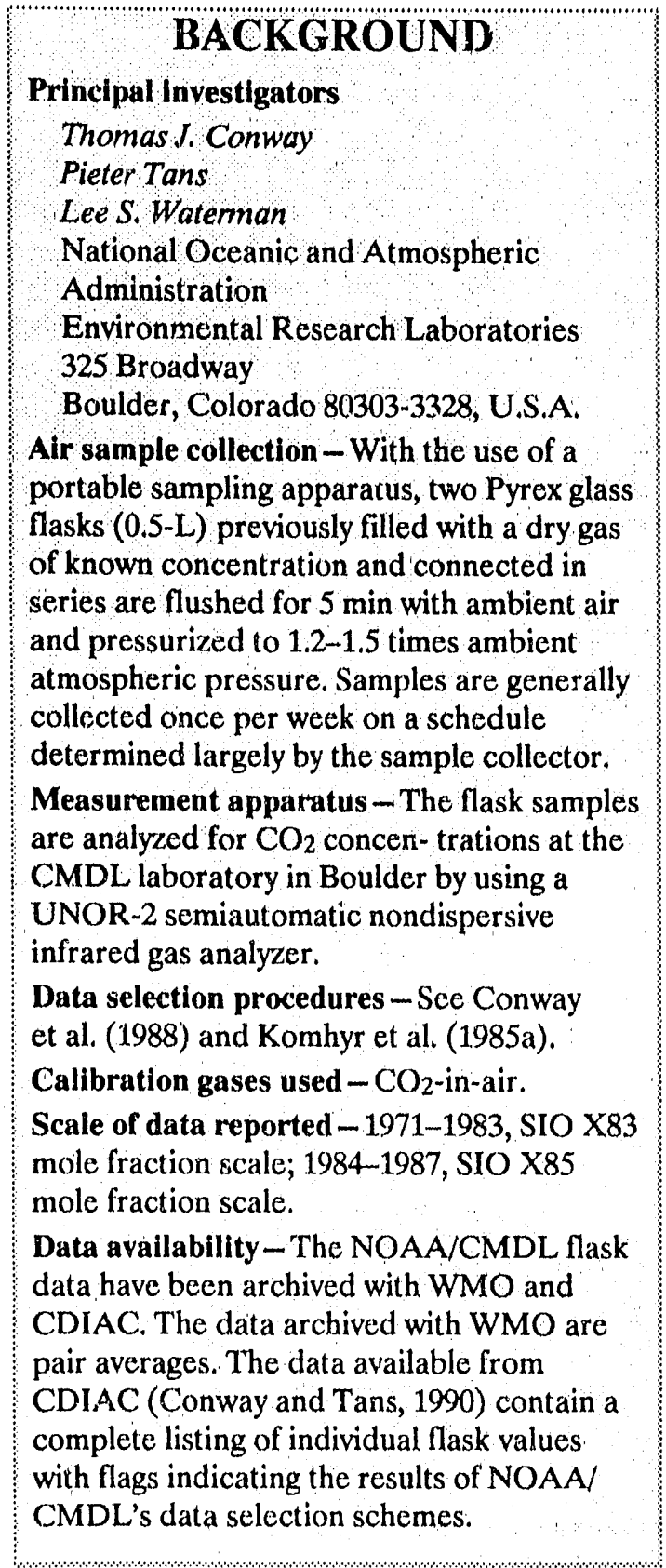

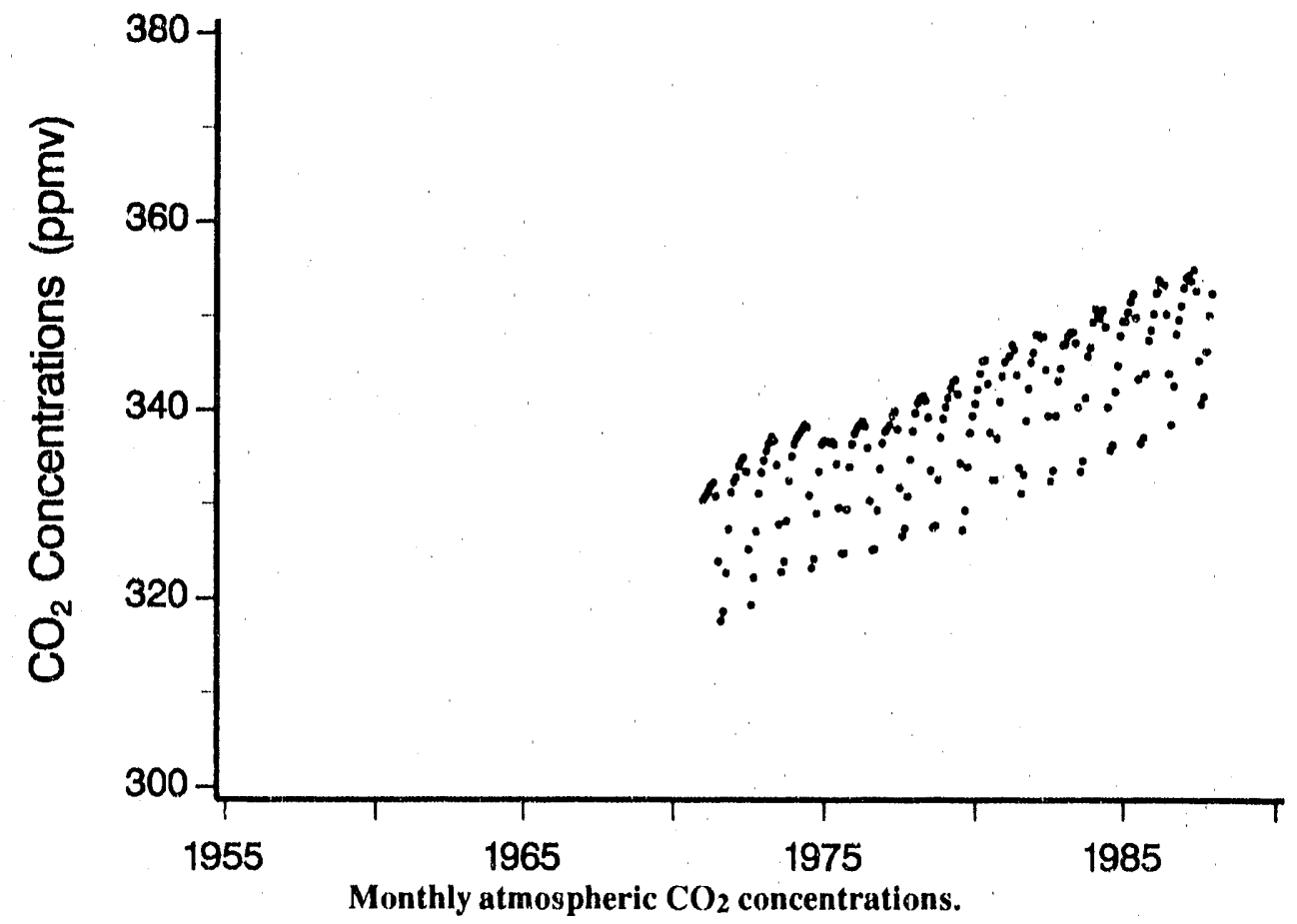

Point Barrow

Alaska, U.S.A.

Arctic coastal seashore

$71^{\circ} 19^{\prime} \mathrm{N}, 156^{\circ} 36^{\prime} \mathrm{W}$

$11 \mathrm{~m}$ above $M S L$ 


\section{Atmospheric $\mathrm{CO}_{2}$}

\section{TREND}

These data are from the NOAA/CMDL flask , ampling program. The NOAA/ CMDL flask data from Point Barrow show an increase in the annual value from 327.3 ppmv in 1971 to 349.7 ppmv in 1987. Conway et al. (1988) reported a 1.26-ppmv mean annual growth rate at Point Barrow for 1981-1984 compared to a global growth rate of 1.22 ppmv per year over the same time frame for all NOAA/CMDL lask sampling sites.

Atmospheric $\mathrm{CO}_{2}$ concentrations at Point Barrow show a seasonal pattern with the annual drawdown occurring in June and the annual buildup occurring in November. Conway et al. (1988) found the average peak-to-peak amplitude for Point Barrow to be 15.65 ppmy for the years 1981-1984. 


\section{Atmospheric Concentrations of Carbon Dioxide*}

$\begin{array}{cccccccccccccc}\text { Year } & \text { Jan } & \text { Feb } & \text { Mar } & \text { Apr } & \text { May } & \text { Jun } & \text { Jul } & \text { Aug } & \text { Sept } & \text { Oct } & \text { Nov } & \text { Dec } & \text { Ann } \\ 1971 & 330.3 & 330.7 & 331.2 & 331.8 & 332.1 & 330.7 & 323.8 & 317.5 & 318.5 & 322.6 & 327.2 & 331.1 & 327.3 \\ 1972 & 333.2 & 333.7 & 333.9 & 334.5 & 334.8 & 333.3 & 325.1 & 319.2 & 322.1 & 327.0 & 331.0 & 333.2 & 330.1 \\ 1973 & 334.5 & 335.5 & 336.3 & 337.0 & 336.6 & 334.0 & 327.7 & 322.7 & 323.8 & 328.1 & 332.3 & 334.9 & 331.9 \\ 1974 & 336.2 & 336.9 & 337.3 & 337.7 & 338.2 & 338.0 & 330.8 & 323.1 & 324.1 & 328.9 & 333.3 & 335.7 & 333.3 \\ 1975 & 336.6 & 336.5 & 336.4 & 336.5 & 336.2 & 334.1 & 329.5 & 324.7 & 324.7 & 329.3 & 333.8 & 336.2 & 332.8 \\ 1976 & 337.3 & 337.9 & 338.3 & 338.6 & 338.1 & 335.8 & 330.2 & 325.0 & 325.1 & 329.2 & 333.6 & 336.3 & 333.8 \\ 1977 & 337.5 & 337.8 & 338.2 & 339.2 & 339.7 & 337.8 & 331.6 & 326.5 & 327.3 & 330.7 & 334.6 & 337.6 & 334.8 \\ 1978 & 339.5 & 340.6 & 341.1 & 341.3 & 340.8 & 339.0 & 333.4 & 327.4 & 327.6 & 332.4 & 336.9 & 338.9 & 336.5 \\ 1979 & 340.1 & 341.1 & 342.1 & 342.8 & 343.0 & 341.5 & 334.2 & 327.1 & 329.2 & 333.8 & 337.4 & 339.2 & 337.6 \\ 1980 & 340.5 & 342.0 & 343.7 & 345.0 & 345.1 & 342.6 & 337.4 & 332.4 & 332.4 & 336.8 & 340.7 & 343.4 & 340.2 \\ 1981 & 344.9 & & 345.5 & 346.7 & 346.2 & 343.5 & 333.7 & 331.0 & 333.0 & 338.7 & 342.1 & 344.9 & 340.9 \\ 1982 & 345.9 & 347.8 & 347.8 & 347.5 & 347.6 & 344.1 & 339.2 & 332.3 & 333.4 & 339.2 & 342.9 & 344.2 & 342.7 \\ 1983 & 346.7 & 346.8 & 347.6 & 348.0 & 348.0 & 346.9 & 340.1 & 333.3 & 334.4 & 341.1 & 345.5 & 346.4 & 343.7 \\ 1984 & 349.1 & 350.5 & 349.8 & 349.5 & 350.4 & 348.6 & 340.1 & 335.6 & 336.1 & 341.8 & 344.5 & 347.7 & 345.3 \\ 1985 & 349.2 & 349.2 & 350.2 & 351.3 & 352.1 & 349.6 & 343.1 & 336.3 & 336.9 & 343.7 & 347.2 & 348.3 & 346.4 \\ 1986 & 350.0 & 352.2 & 353.6 & 352.8 & 353.1 & 350.0 & 343.7 & 338.3 & 342.4 & 347.9 & 349.4 & 350.9 & 348.6 \\ 1987 & 352.8 & 353.9 & 354.1 & 353.5 & 354.7 & 352.5 & 345.1 & 340.5 & 341.3 & 346.1 & 349.9 & 352.6 & 349.7\end{array}$

*Atmospheric $\mathrm{CO}_{2}$ in parts per million by volume (ppmv). Annual averages based on monthly means. All numbers have been rounded to the nearest tenth.

\section{REFERENCLS}

Conway, T.J, P. Tinns, L.S. Wattermall, K.W. Thoning, K.A. Masiarie, and R.H.

Ciammon. 1988. Atmospheric carthen

dioxide measurenents in the remote global troposphere, 1981 jedet. Tellus

$$
\text { 4)(13):81-11.5. }
$$

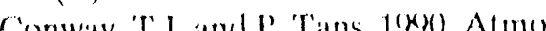

pheric $(C)$ concentrationis .... The

NOAA/GMC(C llask sampling nelwonk.

NDP-(K)S/R1. Carbon Dioxide Information

Analysis (enter. ()ak Ridge Nattional

Laboratory. Oak Ridege, Tennessece.

Kombyr, W.D., L.S. Wallerman, and W.R.

Taylor. 1983. Semiantomatic nondispersive infrarced antalyeer appartalus for (c) a air sample analyses Joumal of (ienphysical Resceurch 88:1315\%2?

Kombyr, W.D., R.H. (iammon, T.B. Harris, LS. Watcrman, T.J. Conwaty, W.R. Taylor, and K.W. Thoning. 198, ia. (ilobal at mosspheric $(C)_{2}$ distributions and varriations

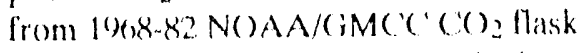
sample datia. Jomornal of (ierophusical

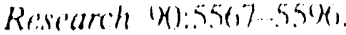

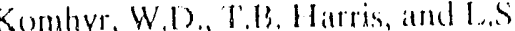
Watcrman losest calibration of nondispersive infrared ( ()$_{2}$ antalyzers will (C) in-air reference grisecs. Journal of Almospheric and (cecanic Technology' 2:82.88. Theming, K.W., P. T'ans, 'T..J. ('onwaty, and

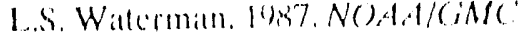
calibrations of (C) ain air reference

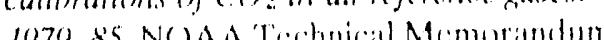
ERL, ARL-1.50. Enviremenental Resc:arch Latoratory, Boulder, Colderate.

World Mcteorological ()eganization. 1080)

Provisional daily atmosphateric carben

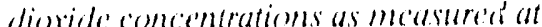

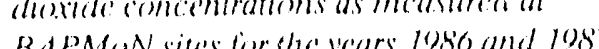

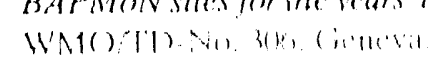




\section{St. Croix}

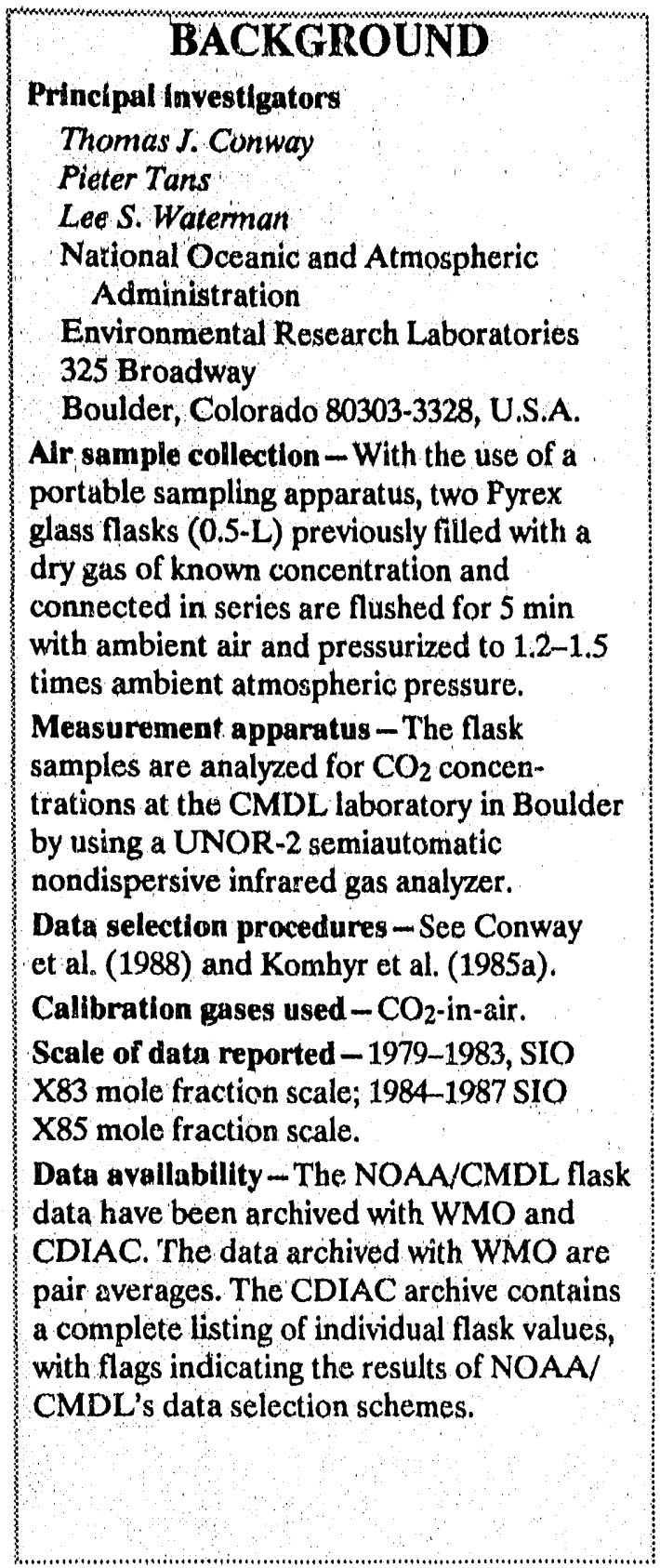

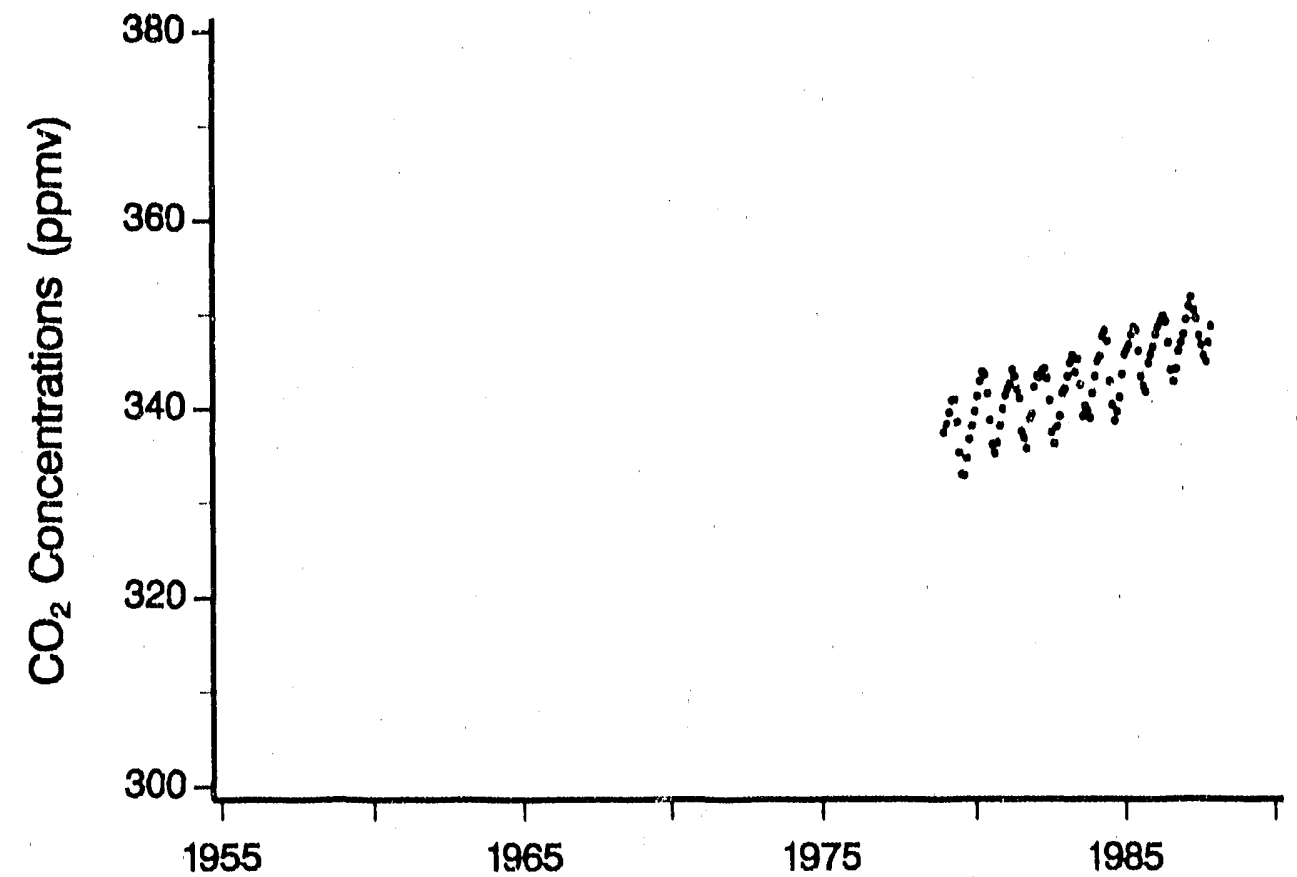

Monthly atmospheric $\mathrm{CO}_{2}$ concentrations.

St. Croix

Vingin Lslands, U.S. Territory

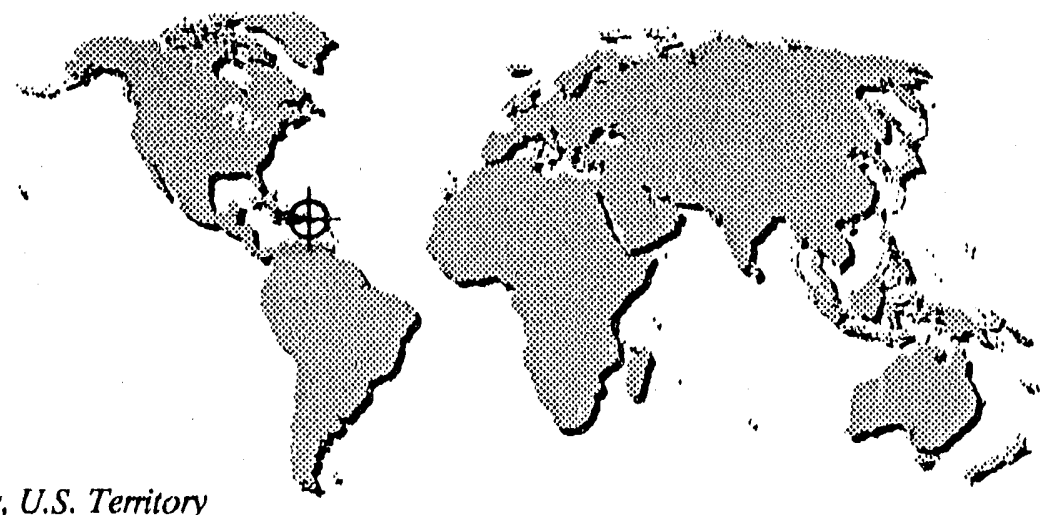

Island seashore

$17^{\circ} 45^{\prime} \mathrm{N}, 64^{\circ} 45^{\prime} \mathrm{W}$

$3 m$ above $M S L$ 


\section{TREND}

These data are from the NOAA/CMDL flask sampling program. The sampling site at St. Croix is operated in cooperation with Fairleigh Dickinson University. The NOAA/CMDL flask data from St. Croix, Virgin Islands, show an increase in the annual value from 337.1 ppenv in 1979 to $348.1 \mathrm{ppmv}$ in 1987. The 1987 annual. average was based on 147 flask samples. Conway et al. (1988) reported a $0.96 \mathrm{ppmv}$ mean annual growth rate at St. Croix, Virgin Islands, for 1981-1984. Conway et al. (1988) found a global growth rate of 1.22 ppmv per year over the same time frame for all NOAA/CMDL flask sampling sites.

Atmospheric $\mathrm{CO}_{2}$ concentrations at $\mathrm{St}$. Croix, Virgin Islands, show a seasonal pattern with the annual drawdown typically occurring in July and the annual buildup occurring in December-January. Conway et al. (1988) found the average peak-to-peak amplitude at St. Croix, Virgin Islands, during 1981-1984 to be 8.73 ppmv. Unlike the data from a majority of stations in the NOAA/CMDL flask sampling network during 1981-1984, the data from St. Croix did not show a growth rate minimum in 1982 and a growth rate maximum in 1983.

Instead, the data from St. Croix exhibited large oscillations in growth rate throughout the data record. 


\section{Atmospheric Concentrations of Carbon Dioxide*}

$\begin{array}{rrrrrrrrrrrrrr}\text { Year } & \text { Jan } & \text { Feb } & \text { Mar } & \text { Apr } & \text { May } & \text { Jun } & \text { Jul } & \text { Aug } & \text { Sept } & \text { Oct } & \text { Nov } & \text { Dec } & \text { Ann } \\ 1979 & 337.3 & 338.2 & 339.4 & 340.7 & \mathbf{3 4 0 . 8} & \mathbf{3 3 8 . 4} & 335.2 & 332.9 & 332.8 & 334.6 & 336.6 & 338.0 & 337.1 \\ 1980 & 339.5 & 341.1 & 342.7 & 343.7 & 343.4 & 341.4 & 338.6 & 336.0 & 335.1 & 336.2 & 338.0 & 339.8 & 339.6 \\ 1981 & 341.2 & 341.9 & 342.4 & 343.9 & 343.2 & 341.8 & 340.9 & 337.4 & 336.7 & 335.6 & 338.7 & 339.2 & 340.2 \\ 1982 & 342.1 & 343.3 & 343.1 & 343.8 & 344.0 & 343.0 & 340.7 & 337.3 & 336.1 & 337.9 & 339.0 & 341.4 & 341.0 \\ 1983 & 341.9 & 343.2 & 344.6 & 345.4 & 343.6 & 345.0 & 342.3 & 339.0 & 340.1 & 339.6 & 338.8 & 341.4 & 342.1 \\ 1984 & 343.2 & 344.8 & 345.3 & 347.4 & 348.0 & 346.9 & 342.7 & 340.2 & 338.5 & 339.5 & 341.0 & 343.4 & 343.4 \\ 1985 & 345.5 & 346.0 & 346.5 & 347.6 & 348.4 & 348.1 & 345.9 & 343.2 & 342.2 & 341.6 & 344.6 & 345.5 & 345.4 \\ 1986 & 346.3 & 347.6 & 348.4 & 349.0 & 349.6 & 349.0 & 346.8 & 343.9 & 342.7 & 344.0 & 345.9 & 346.8 & 346.9 \\ 1987 & 347.7 & 349.2 & 350.6 & 351.6 & 350.2 & 349.3 & 347.5 & 346.5 & 345.4 & 344.8 & 345.8 & 348.5 & 348.1\end{array}$

*Atmospheric $\mathrm{CO}_{2}$ in parts per million by volume (ppmv). Annual averages based on monthly means. All numbers have been rounded to the nearest tenth.

\section{RLEERENCLS}

Comw',y, T.,., P. Tims, L.S. Watcrman, K,W. Thouing, K.A. Masiaris, and R.11. Gimmon, 1988, Almespheric carbon

dioxide measurements in the remole polobal troposphere, 1981 1984. Te'llus $40)(B): 81 \ldots 115$

Conway, 'T', and P. Tans, $1(x)$. Almos. pheric $(C) 2$ concentrations -...The NOAA/GMCC flask sampling network. NDP-(KIS/R I. Carbon Dioxide Information Analysis Center. Oak Ridge Nutional Laboratory, Oak Ridge, Ternessec.

Komhyr, W.D, L,S. Waterman, and W.R. Taylor. 1983. Semiautematic nendispersive infrared analyzer apparatus for $\left(\mathrm{CO}_{2}\right.$ air sample analyses. Journal of Geophysical Resectarch 88:1315 22

Komhyr, W.D., R.H. (jammon, T.B. Harris, L.S. Watterman, 'T.J. Conway, W.R. Thyler, and K.W. Theming. 1985at. (ilobal almospheric (C) distributions and variations

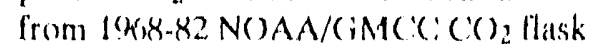
simple data. Journat of (ienoplessical Resecterch (x):5567\%55\%

Kombyr, WD, T'B, Harris, and L s. Watcrman. 19855. Calibration of nondispersive infrared $(C) 2$ analyzers with $(C)$ in-iar reference grateses. Joumal of Almos-

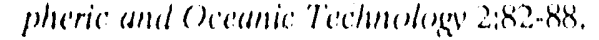
Thoning, K.W., P'. 'T'ans, T.J. Conway, and

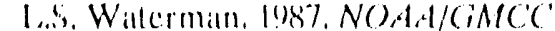

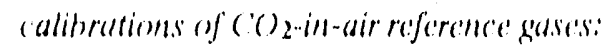
1979) 8'S. N()AA Techuical Memorandunn ERL ARL - 1.50. Linvironmental Research Laborritory, Boulder, C'oldorater.

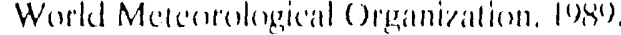

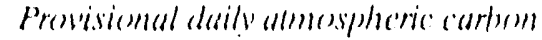

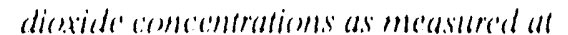

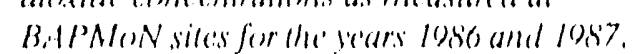

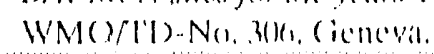




\section{Terceira Islands (Azores)}

\section{BACKGROUND \\ Principal invest/gators \\ Thomas J. Conway \\ Pleter Tans \\ Lee S. Watermsan \\ National Oceanic and Atmospheric Administration \\ Environmontal Research Laboratories 325 Broadway \\ Boulder, Colorado 8033)3-3328, U.S.A.} Alr sample collection - With the use of a portable sampling apparatus, two Pyrex glass flasks $(0.5-\mathrm{L})$ previously filled with a dry gas of known concentration and connected in scries are flushed for $5 \mathrm{~min}$ with ambient air and pressurized to 1.2-1.5 times ambient atmospheric pressure.

Meusurement apparatus - The Ilask samples are analyzed for $\mathrm{CO}_{2}$ concentrations at the CMDL laboratory in Boulder by using a UNOR-2 somlautomatic noridispersive infrared gas analyzer.

Data selection procedures - See Conway et al. (1988) and Komihyr et al. (1985a).

Callbration gases used $-\mathrm{CO}_{2}$-in-air.

Scale of datu reported - 1979-1983, SIO X83 mole fraction scale; 1984-1987, SIO X85 mole fraction scale.

Data availabillty - The NOAA/CMDL flask data have been archived with WMO and CDIAC. The data archived with WMO are pair averages. The data available from C.DIAC (Conway and Tans, 1990) contain a complete listing of individual flask values with flags indicating the results of NOAA/ CMDL's data selection schemes.

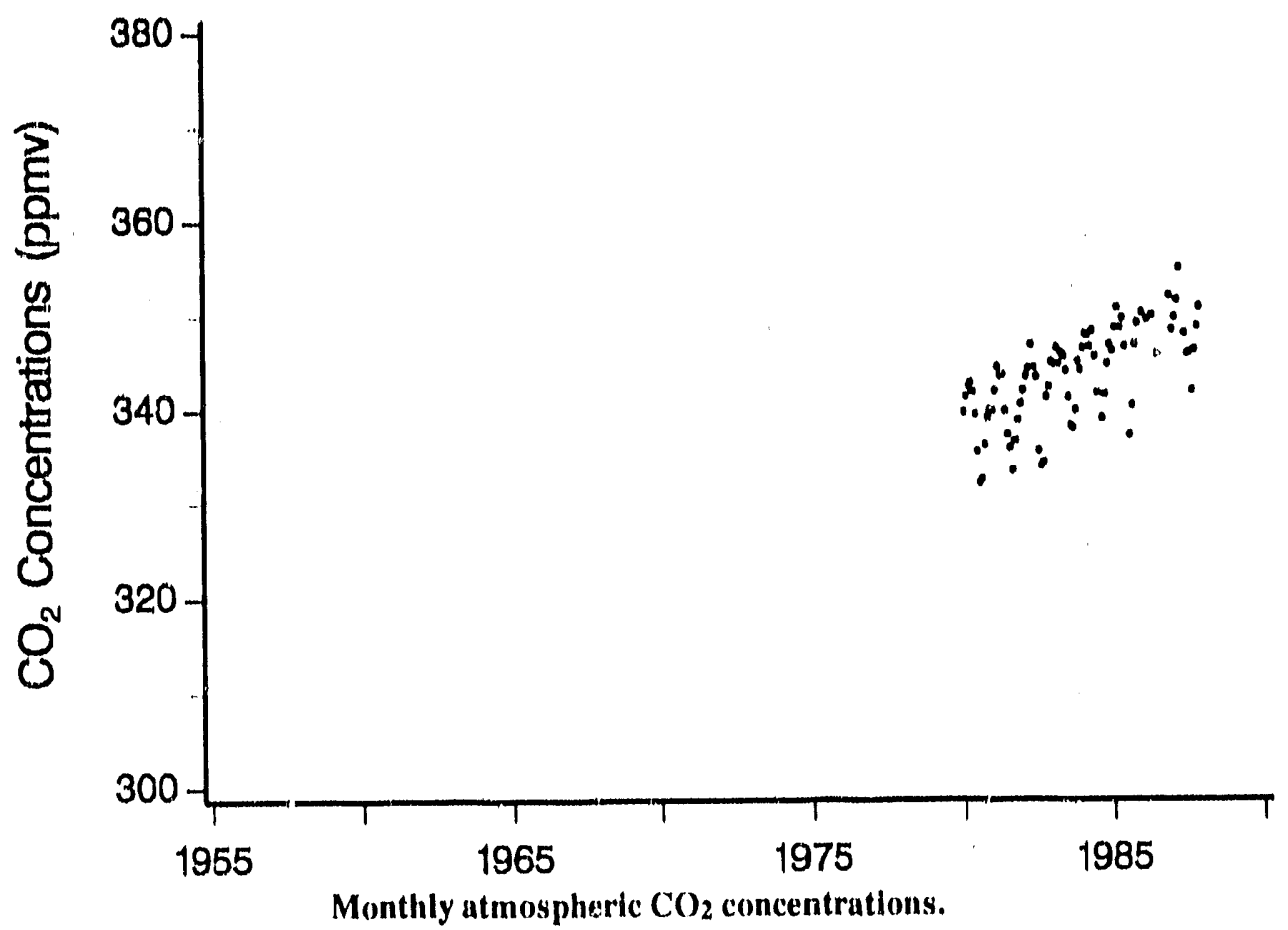

Terceira Islands Azores

Island seashore $38^{\circ} 45^{\prime} \mathrm{N}, 27^{\circ} 05^{\prime} \mathrm{W}$ 3) $m$ above $M S L$ 


\section{Atmospheric $\mathrm{CO}_{2}$}

\section{TREND}

These data are from the NOAA/CMDL flask sumpling program. The Terceira Islands sampling site is operated in cooperation with the 7th Weather Wing of the United States Air Force. The NOAA/ CMDL flask data from the Azoros show an increase in the annual value from 338.4 ppmv in 1980 to 348.2 ppmv in 1987. The 1987 annual average was based on 55 flask samples. Conway el al. (1988) reported a 1.65-ppmv mean annual growth rate at the Azores sampling site for 1981-1984 compared to a global growth rate of 1.22 ppun per year over the same time frame for all NOAA/CMDL flask sampling sittes.

Conway et al. (1988) found the average peak-t()-peak amplitude at the Terceira Islands sampling site during 1981-1984 to bo 10.15 ppmv. Unlike the majority of stations in the NOAA/CMDL flask sampling network during 1981-1984, the data from the Azores did not show a growth rate mininum in 1982 and a growth rate maximum in 1983. Instead, the data from the Terceira Islands sampling site exhibited large ascillations in growth rate throughout the data record. 


\section{Terceira Island (Azores)}

Atmospheric Concentrations of Carbon Dioxide*

\begin{tabular}{|c|c|c|c|c|c|c|c|c|c|c|c|c|c|}
\hline Year & Jan & Feb & $\operatorname{Mar}$ & Apr & May & Jun & JuI & Aug & Sept & Oct & Nor & Dec & Ann \\
\hline 1980 & 339.5 & 341.2 & 342.3 & 342.6 & 341.7 & 339.3 & 335.4 & 332.0 & 332,4 & 336.1 & 339,0 & 339.8 & 338.4 \\
\hline 1981 & 339.7 & 341.8 & 344.3 & 343.4 & 343.5 & 339.7 & 337.2 & 335.8 & 333.3 & 336.5 & 338.7 & 340,4 & 339.5 \\
\hline 1982 & 341.8 & 343.3 & 344.1 & 346.6 & 344.2 & 343.2 & 335.4 & 333.8 & 334.2 & 341.1 & 342.2 & 344.8 & 341.2 \\
\hline 1983 & 344.6 & 346.3 & 344.6 & 345.8 & 345.4 & 343.9 & 341.1 & 338.1 & 337.9 & 339.8 & 344.9 & 344,0 & 343.0 \\
\hline 1984 & 346.3 & 347.8 & 347.6 & 346.4 & 348.1 & 345.4 & 341.6 & & 338.9 & 341.4 & 344.6 & 346.6 & 345.0 \\
\hline 1985 & 346.0 & 348.4 & 350.5 & 348.4 & 349.4 & 346.4 & & 337.1 & 340.2 & 346.6 & 348.9 & & 346.2 \\
\hline 1986 & 350,0 & & 349.3 & & 349.7 & & 345.6 & & & & & 351.8 & \\
\hline 1987 & 348.2 & 349.5 & 351.3 & 354.7 & & 347.8 & 345.7 & 345.8 & 341.8 & 346.1 & 348.6 & 350.6 & 348.2 \\
\hline
\end{tabular}

${ }^{*}$ Atmospheric $\mathrm{CO}_{2}$ in parts per million by volume (ppmv). Annual averages based on monthly means. All numbers have been rounded to the nearest tenth.

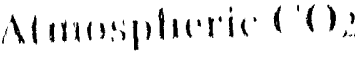

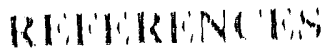

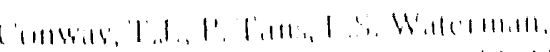

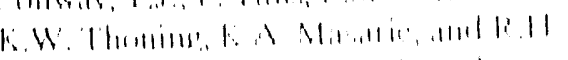

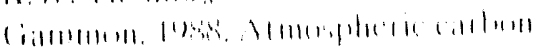

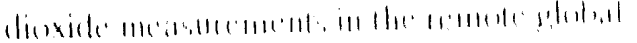

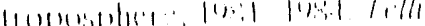

. In)(13).

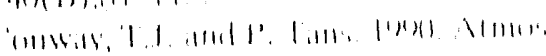

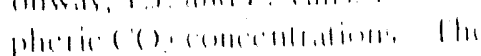

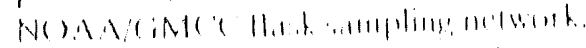

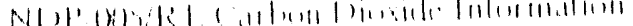

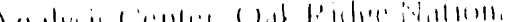

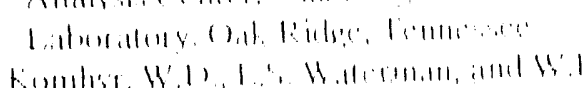

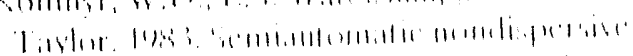

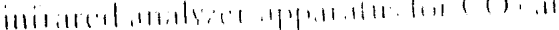

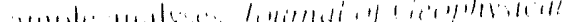

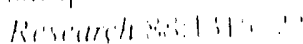

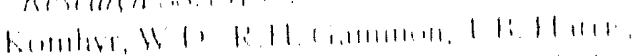

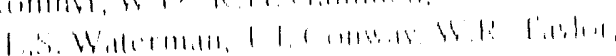

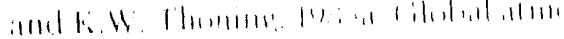

1.4.

form lon

.

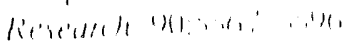

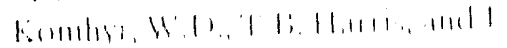

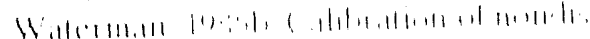

(n)

Fin a

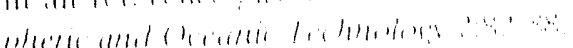

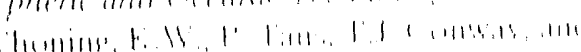

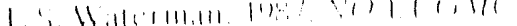

1.

1400 (2)

tere

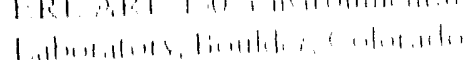

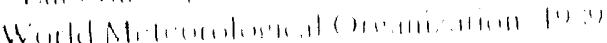

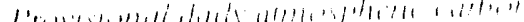

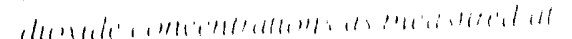

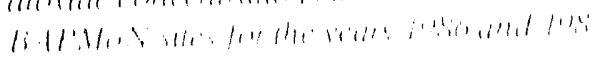

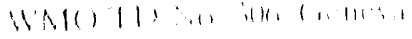




\section{Izaña}

\begin{tabular}{|c|}
\hline BACKGROUND \\
\hline Principal investigators \\
\hline Alberto Linés Escardo \\
\hline Beatriz Navascues \\
\hline Carmen Rus \\
\hline Instituto Nacional de Meteorologia \\
\hline Ciudad Universitaria \\
\hline Madrid, Spain \\
\hline Rainer Schmitt \\
\hline Zentralamt \\
\hline Frankfurterstraße 135 \\
\hline D- 6050 Offenbach \\
\hline F.R.G. \\
\hline $\begin{array}{l}\text { Air sample collection - Air samples are } \\
\text { collected continuously through an 18-m-high } \\
\text { air intake. Greater details about the mea- } \\
\text { surement methodology and calibrations are } \\
\text { given in Navascues et al. (1988). }\end{array}$ \\
\hline $\begin{array}{l}\text { Measurement apparatus - Siemens } \\
\text { ULTRAMAT } 3 \text { semiautomatic } \\
\text { nondispersive infared gas analyzer. }\end{array}$ \\
\hline $\begin{array}{l}\text { Data selection procedures - Data are } \\
\text { accepted whon, during } 0.5 \mathrm{~h} \text {, the standard } \\
\text { deviation of individual measurements taken } \\
\text { every } 10 \mathrm{~s} \text { does not exceed } 0.075 \mathrm{ppm} \text {. }\end{array}$ \\
\hline $\begin{array}{l}\text { Calibration gases used- }-\mathrm{CO}_{2} \text {-in- } \mathrm{N}_{2} \text { and } \\
\mathrm{CO}_{2} \text {-in-air. }\end{array}$ \\
\hline $\begin{array}{l}\text { Scale of data reported }-\mathrm{CO}_{2} \text { concentrations } \\
\text { are given relative to an internal scale based } \\
\text { on three primary } \mathrm{CO}_{2} \text {-in- } \mathrm{N}_{2} \text { tanks and a set } \\
\text { of } \mathrm{CO}_{2} \text {-in-synthetic tanks. }\end{array}$ \\
\hline $\begin{array}{l}\text { Data availability - In addition to being } \\
\text { available from the principal investigators, } \\
\text { these monthly and annual data are provided } \\
\text { to and have been reported by the WMO } \\
\text { (1987). These same data are also available } \\
\text { from CDIAC. }\end{array}$ \\
\hline
\end{tabular}

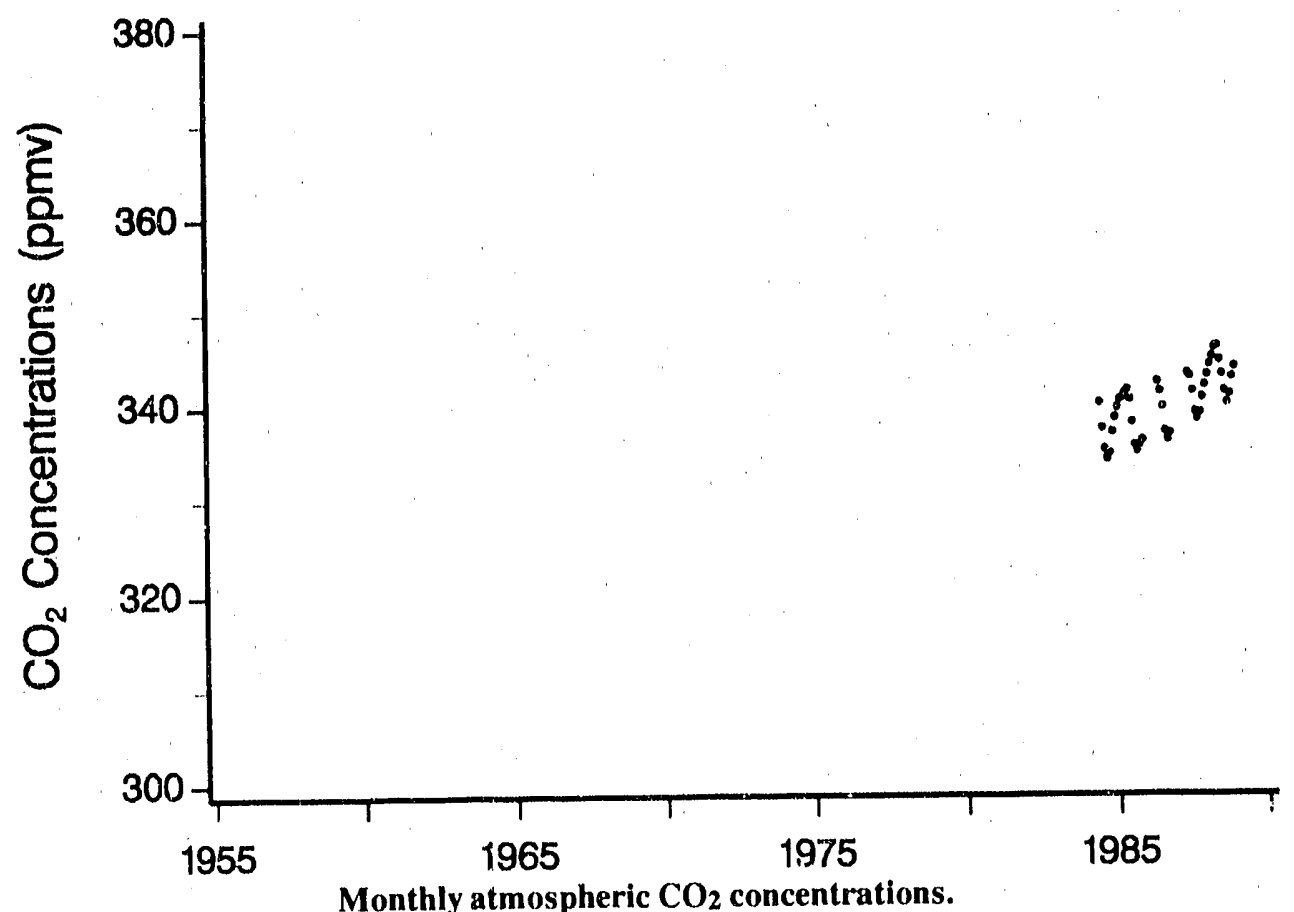

Izaña Observatory

Canary Islands, Spain

Top of a mountain plateau

on a volcanic island

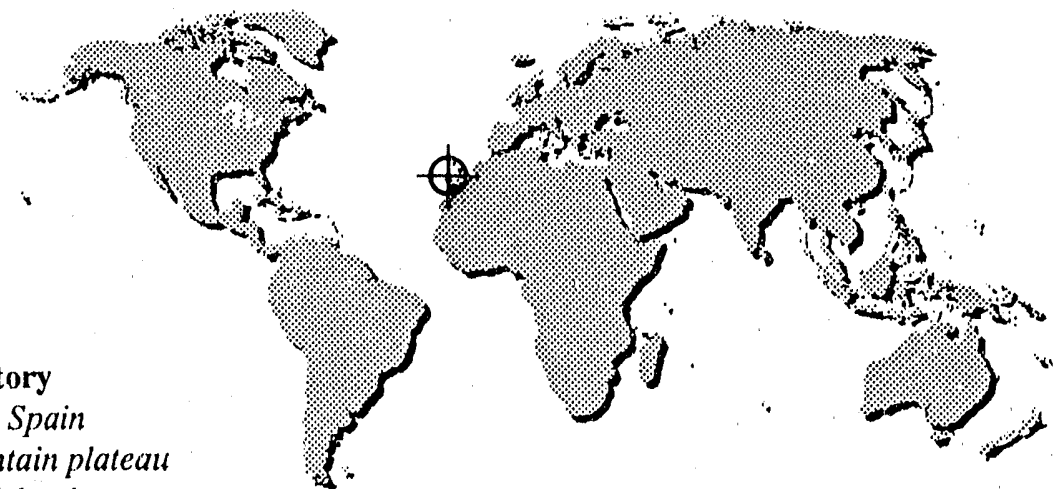

$28^{\circ} 18^{\prime} \mathrm{N}, 16^{\circ} 29^{\prime} \mathrm{W}$

$2367 \mathrm{~m}$ above $M S L$ 


\section{TREND}

The Izaña Baseline Station at Tenerife, Canary Islands, has been making meteorological observations since 1916. In 1983 the governments of Spain and the Federal Republic of Germany signed an agreement to set up a baseline station on the Canary Islands. Since June 1984, the Izaña station has served as the Spanish contribution to the WMO BAPMoN network.

The climate of the Canary Islands is affected by three major factors: circulation forced by trade winds, Saharan air invasions, and oceanic disturbances (Navascués et al. 1988). All of these factors influence the measurements of atmospheric $\mathrm{CO}_{2}$ recorded at Izaña. Changes of air mass are strongly reflected in the concentration records of $\mathrm{CO}_{2}, \mathrm{CH}_{4}$, and $\mathrm{O}_{3}$. Saharan air invasions normally occur in August, when there is a high-pressure system to the northeast of the Islands. These invasions carry dry, dust-laden air that has been depleted of $\mathrm{CO}_{2}$; Schmitt et al. (1988) also reported that the transport of Sahara dust results in an increase of optical thickness and an ozone depletion.

The mean annual atmospheric $\mathrm{CO}_{2}$ concentration at the Izaña Baseline Station has risen from $336.6 \mathrm{ppmv}$ in 1984 to 343.3 ppmv in 1988. Atmospheric $\mathrm{CO}_{2}$ concentrations from Izaña exhibit both diurnal and seasonal patterns. Annual maximum values occur in May, and annual minimum values occur in September. 


\section{Izaña}

Atmospheric Concentrations of Carbon Dioxide*

$\begin{array}{llllllllllllll}\text { Year } & \text { Jan } & \text { Feb } & \text { Mar } & \text { Apr } & \text { May } & \text { Jun } & \text { Jul } & \text { Aug } & \text { Sept } & \text { Oct } & \text { Nov } & \text { Dec } & \text { Ann } \\ 1984 & & & & & & 340.0 & 337.3 & 335.0 & 334.0 & 334.7 & 336.9 & 338.4 & 336.6 \\ 1985 & 339.4 & 340.3 & 340.4 & 341.0 & 341.3 & 340.3 & 337.9 & 335.5 & 334.8 & 335.4 & 336.0 & & 338.4 \\ 1986 & & & & & 342.1 & 341.1 & 339.5 & 336.9 & 336.0 & 336.7 & & & 338.1 \\ 1987 & & & & & 343.0 & 342.7 & 341.2 & 339.0 & 338.2 & 338.9 & 340.5 & 341.8 & 340.7 \\ 1988 & 342.9 & 344.0 & 344.8 & 345.8 & 345.9 & 344.4 & 342.9 & 341.2 & 339.9 & 340.8 & 342.7 & 343.8 & 343.3\end{array}$

*Atmospheric $\mathrm{CO}_{2}$ in parts per million by volume (ppmv). Annual averages based on monthly means. All numbers have been rounded to the nearest tenth.

\section{REFERENCLS}

Navascués, B., ( . J. Rus, A.S. Pastor, and

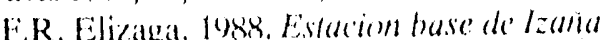

Tenerife 1984t 198s. Ministerio de

Transportes, Instituto Nitcional de Meteorologia, Madrid.

Schmitt, R., and I. Levin. 1985. Baseline

station Tenerife: Terchnical realization of the

$\mathrm{CO}_{2}$ monituring syvem and first rowelse of atmospheric measurements. Procecedings of

atmospheric me'dstrements. Pro

Atmospheric Carbon Dioxide.

Measurement Technigues, Lake

Arrowhead, California, Novernter 4 8 .

Schenith, R, B Schreiber, and I. Levin. 1988.

Effects of long-range transport on

atmospheric trace constituents at the

baseline station Tencrife (Canary lstands).

Journal of Atmospheric Chemistry 7:335.51

World Metcorological () rganization. 1987.

Provisionol dats atmospheric carton dioxide concentrations as measured at

BAPMON site's for the ve'ar 1085.

WM(JT) No, les. cicneval. 


\section{Mt. Cimone}

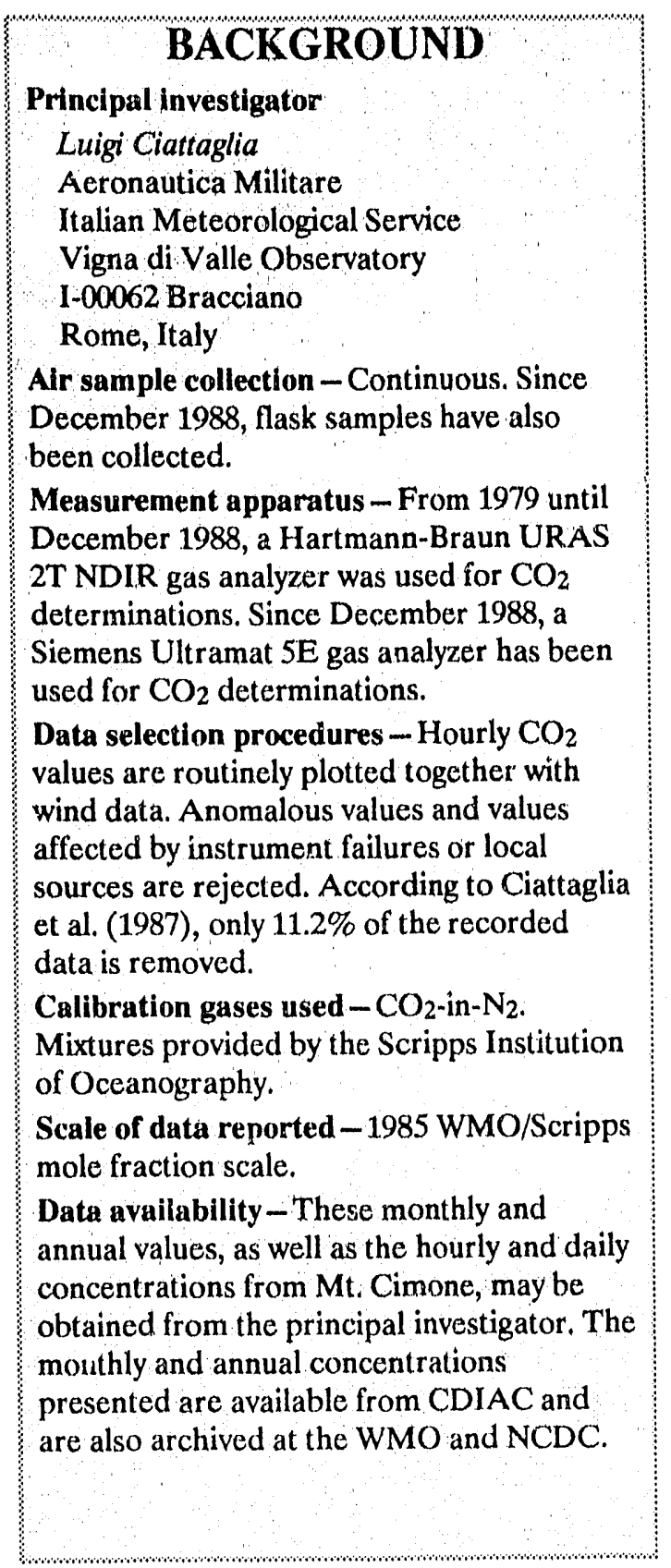

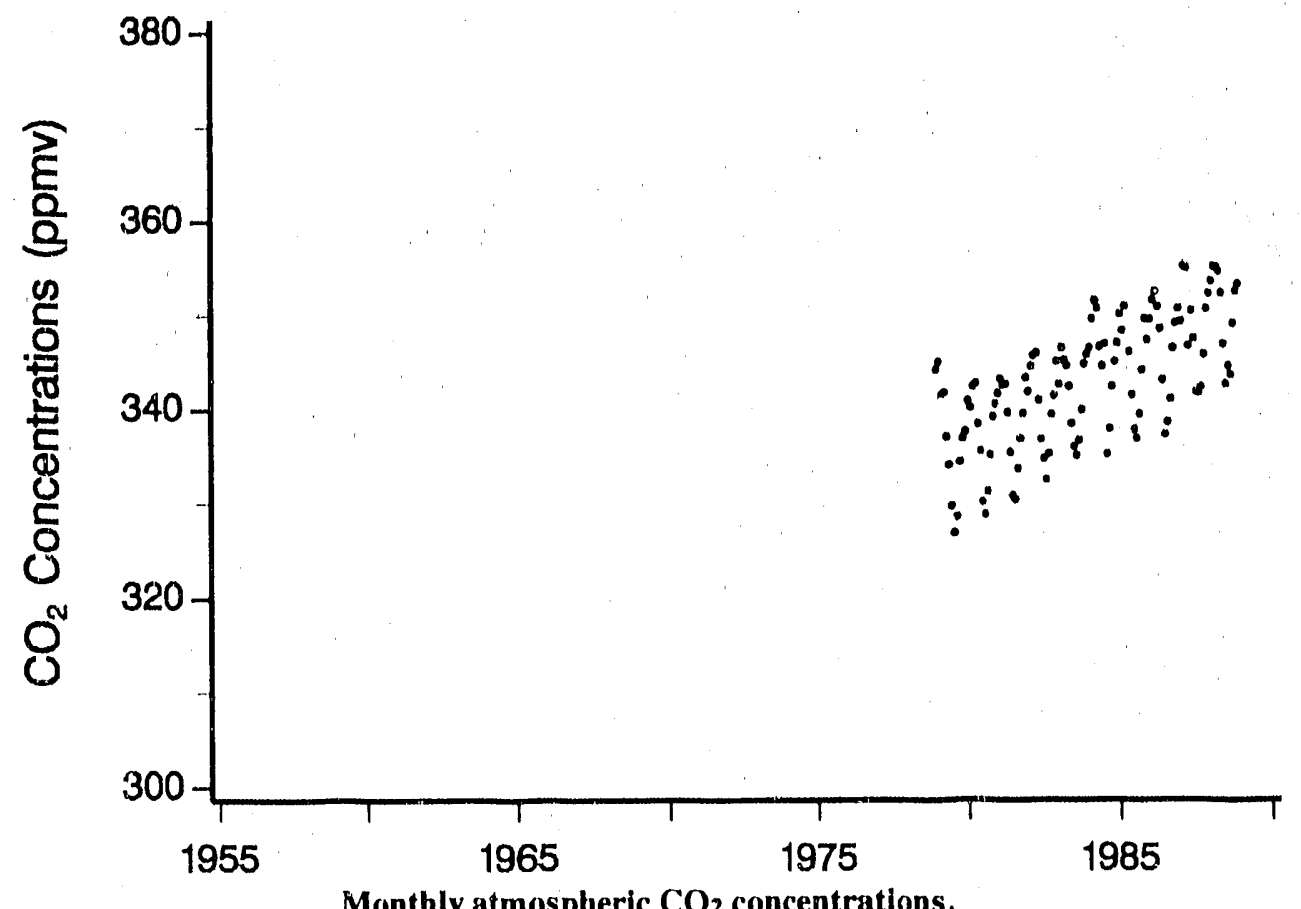

Mt. Cimone

Italy

Mountain top

$44^{\circ} 11^{\prime} \mathrm{N}, 10^{\circ} 42^{\prime} \mathrm{E}$

$2165 \mathrm{~m}$ above $M S L$ 


\section{Atmospheric $\mathrm{CO}_{2}$}

\section{TREND}

Mt. Cimone observatory, a station of the Italian Metcorological Service, has been participating in the WMO-BAPMON program since 1978. The atmospheric $\mathrm{CO}_{2}$ record from Mt. Cimone represents the longest continuous record available for the Mediterranean area. From 1979 to 1988, the annual mean atmospheric $\mathrm{CO}_{2}$ concentration at Mt. Cimone rose from 336.38 ppmv to 350.17 ppmv. This represents an increase of approximately $\sim 1.4$ ppmv per year. Ciattaglia reported a trend of 1.7 ppmv per year for the period March 1979-June 1985. Ciattaglia et al. (1987) also found the seasonal oscillation for this same time period to have an amplitude of 13 ppmv. This seasonal amplitude is attrib. utable to photosynthetic depletion from vegetation below the timberline at Mt. Cimone and to the relationship between $\mathrm{CO}_{2}$ concentrations and wind direction. Ciattaglia et al. (1987) found a relationship between the behavior of selected $\mathrm{CO}_{2}$ data with prevailing winds [i.c., SW $\left.\left(180^{\circ} \rightarrow 29\right)^{\circ}\right)$ and $\mathrm{NE}\left(0^{\circ}-90^{\circ}\right)$ winds] and episodes of Sahara dust transport. During winter, NE winds continue the high $\mathrm{CO}_{2}$ concentrations measured on site, while SW winds are characterized by lower concentrations. During summer, the situation is reversed. During the cold season, Saharan transports are characterized by low $\mathrm{CO}_{2}$ and by small record variability. When these episodes occur during hot periods, $\mathrm{CO}_{2}$ concentrations show values above average. 


\section{Mt. Cimone}

\section{Atmospheric Concentrations of Carbon Dioxide*}

$\begin{array}{lccccccccccccc}\text { Year } & \text { Jan } & \text { Feb } & \text { Mar } & \text { Apr } & \text { May } & \text { Jun } & \text { Jul } & \text { Aug } & \text { Sept } & \text { Oct } & \text { Nov } & \text { Dec } & \text { Ann } \\ 1979 & 344.1 & 344.8 & 341.3 & 341.7 & 337.0 & 334.0 & 329.7 & 326.8 & 328.6 & 334.3 & 336.8 & 337.5 & 336.4 \\ 1980 & 340.7 & 340.0 & 342.3 & 342.6 & 338.3 & 335.5 & 330.1 & 328.8 & 331.2 & 335.1 & 339.1 & 340.4 & 337.0 \\ 1981 & 341.5 & 343.1 & 342.4 & 342.5 & 339.5 & 335.3 & 330.8 & 330.3 & 333.6 & 336.8 & 339.4 & 343.2 & 338.2 \\ 1982 & 341.7 & 344.4 & 345.5 & 345.8 & 340.8 & 336.7 & 334.7 & 332.4 & 335.2 & 339.3 & 341.3 & 344.9 & 340.2 \\ 1983 & 342.5 & 346.3 & 345.0 & 344.4 & 342.3 & 338.3 & 335.9 & 335.0 & 336.6 & 339.8 & 344.6 & 345.6 & 341.4 \\ 1984 & 346.3 & 349.4 & 351.3 & 350.5 & 346.4 & 344.4 & 346.7 & 335.1 & 337.8 & 342.3 & 344.9 & 346.8 & 345.2 \\ 1985 & 349.9 & 348.2 & 350.7 & & & 345.9 & 341.4 & 337.7 & 336.8 & 339.3 & 344.0 & 349.4 & 347.2 \\ 1986 & 349.4 & 351.4 & 352.3 & 350.7 & 348.4 & 343.0 & 337.2 & 338.5 & 340.9 & 346.3 & 349.0 & 350.5 & 346.5 \\ 1987 & 349.2 & 355.0 & 354.8 & 346.5 & 350.3 & 347.4 & 341.7 & 341.6 & 342.2 & 345.7 & 350.5 & 352.1 & 348.1 \\ 1988 & 353.5 & 355.0 & 355.0 & 354.5 & 352.2 & 346.8 & 342.6 & 344.5 & 343.6 & 349.0 & 352.4 & 353.2 & 350.2\end{array}$

*Atmospheric $\mathrm{CO}_{2}$ in parts per million by volume (ppmv). Annual averages based on monthly means. All numbers have been rounded to the nearest tenth.

\section{RLIFLRLNCLis}

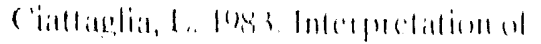

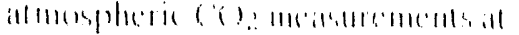

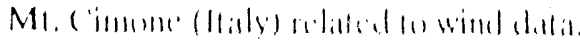

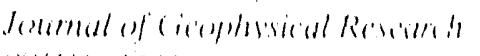

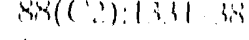

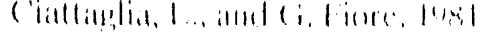

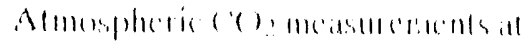

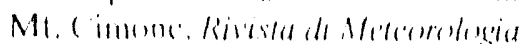

lerementicices $41: 253$

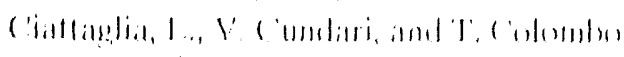

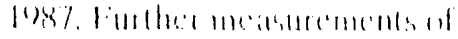

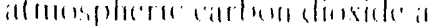

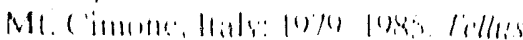
$39(13): 13$ ?

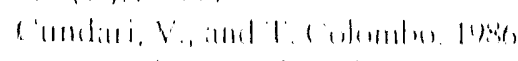

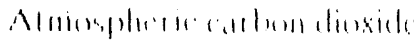

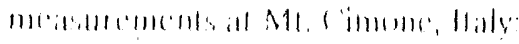

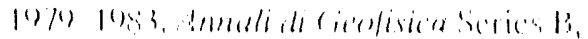
$4(1): 1<20$

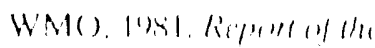

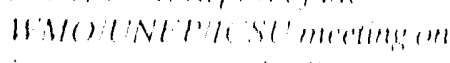

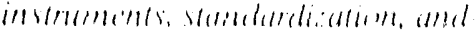

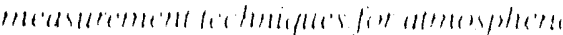

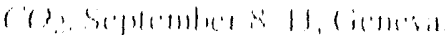




\section{Cape Grim}

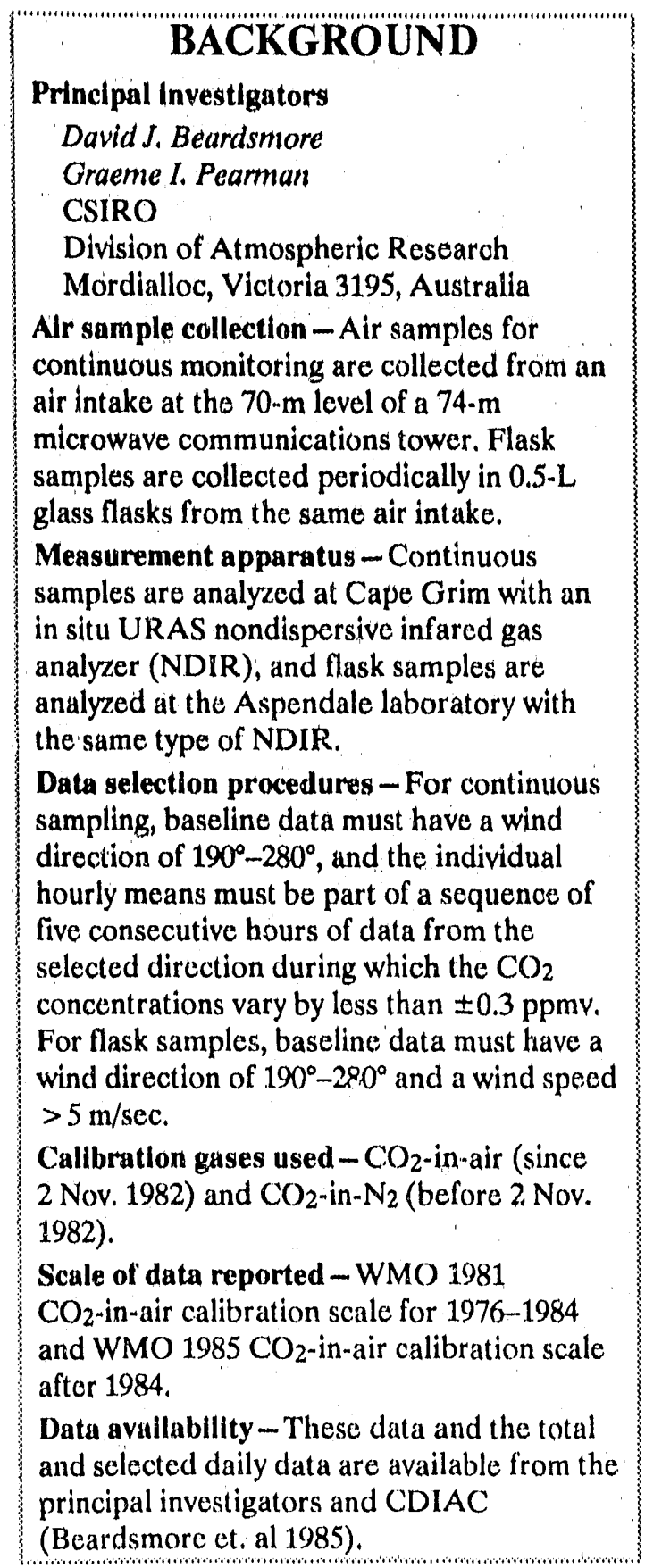

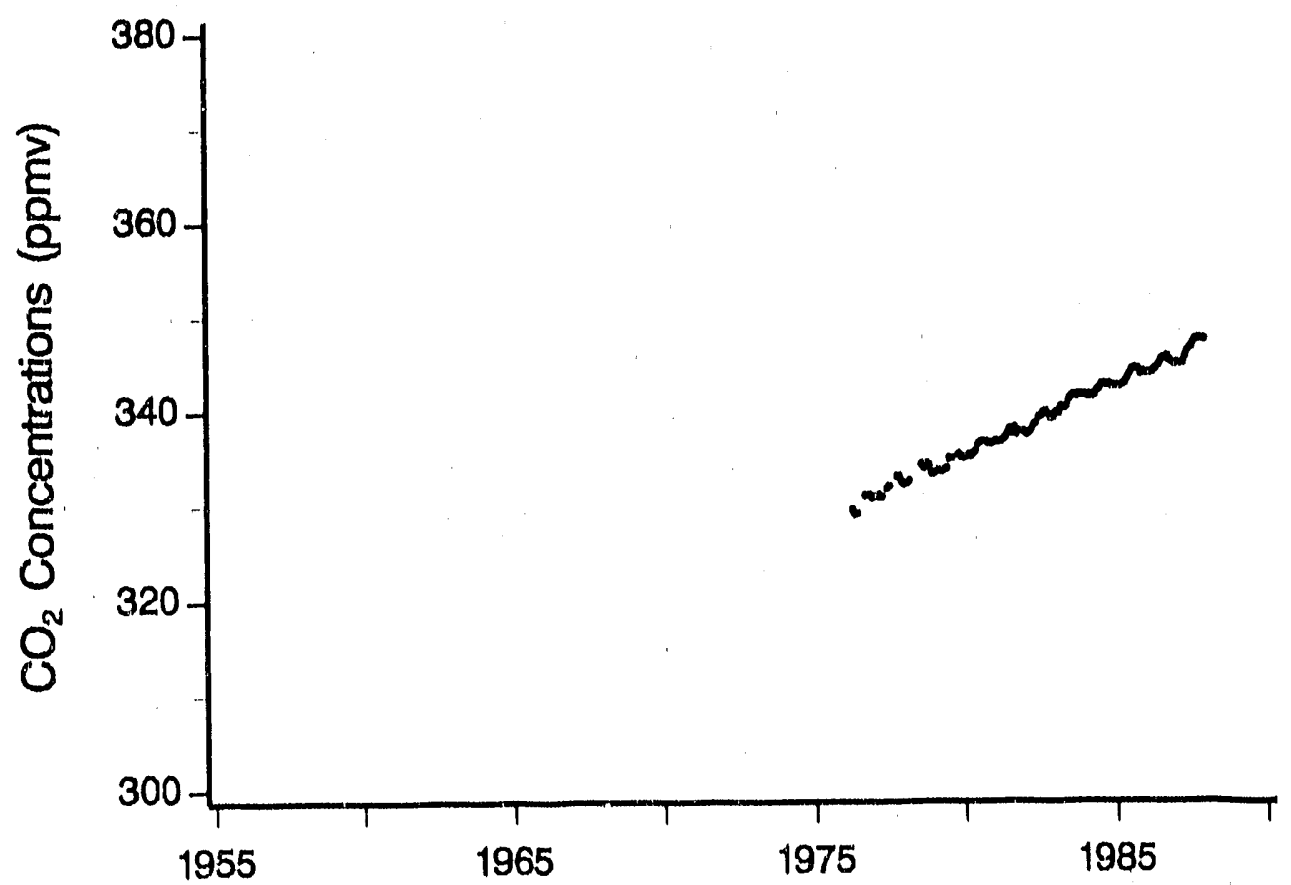

Monthly atmospheric $\mathrm{CO}_{2}$ concentrations.

Cape Grim

Tasmania, Australia

Promontory seashore $40^{\circ} 41^{\prime} S, 144^{\circ} 41^{\prime} E$

$94 \mathrm{~m}$ above $M S L$ 


\section{Atmospheric $\mathrm{CO}_{2}$}

\section{TREND}

The Australian Bascline Atmospheric Observatory at Cape Grim is part of the Australian contribution to the UNEP/WMO Background Air Pollution Network. It is a station that undertakes a comprehensive program of observations of the constituents of the background atmosphere for the purposes of (1) identifying trends in constituents that may be of climatic significance; (2) describing the distribution of constituents both temporally and spatially in conjunction with other stations of the network for the purpose of improving understanding of biogeochemical cycles; and (3) using the data in studies of largescale atmospheric dynamics (Beardsmore and Pearman 1987).

The annual average "baseline" atmospheric $\mathrm{CO}_{2}$ concentration at Cape Grim, Tasmania, has risen from 329.97 ppmv in 1976 to 346.06 ppmv in 1987. Beardsmore and Pearman (1987) found that the mean rate of $\mathrm{CO}_{2}$ concentration increase over the period April 1976 to December 1984 at Cape Grim was 1.49 ppmv per year, but they also reported a strong interannual variability in this rate of increase.

The seasonal cycle of atmospheric $\mathrm{CO}_{2}$. concentrations at Cape Grim is very apparent in the baseline in situ data. Beardsmore and Pearman (1987) found the mean scasonal amplitude to be 0.92 ppmv. 


\section{Cape Grim}

\begin{tabular}{|c|c|c|c|c|c|c|c|c|c|c|c|c|c|}
\hline Year & Jun & Feb & Mar & Apr & May & Jun & Jul & Aug & Sept & Oct & Nov & Dec & Ann \\
\hline 1976 & & & & 329,4 & 328.9 & 329.0 & & & 330.9 & & 330.9 & 330.6 & 330.0 \\
\hline 1977 & 330.8 & 330.7 & 331.0 & 330.8 & & 331.7 & 331.9 & & & 332.9 & 332.9 & 332.3 & 331.7 \\
\hline 1978 & 332.1 & 332.2 & 332.4 & & & & & 334.1 & 333.8 & 334.2 & 334,0 & 333,2 & 333.2 \\
\hline 1979 & 333.2 & 333.3 & 333.5 & 333,4 & 333.5 & 333.7 & 334.7 & 334.8 & & & 335.1 & 334.8 & 334,0 \\
\hline 1980 & 334,8 & 334.9 & 335.0 & 335.0 & 335.3 & 335.6 & 336.2 & 336.4 & 336.5 & 336.5 & 336,4 & 336.3 & 335.7 \\
\hline 1981 & 336.4 & 336.5 & 336.5 & 336.6 & 336.8 & 337.2 & & 337.7 & 337.9 & & & & 337.0 \\
\hline 1981 & & & & & & & 337.8 & 337.4 & 337.4 & 337.3 & 337.6 & 337.5 & 337.5 \\
\hline 1982 & 337.5 & $\mathbf{3 3 7 . 3}$ & 337.4 & 337.7 & 338.2 & 338.4 & 339.0 & 339.1 & 339.5 & 339.6 & 339.4 & 339.0 & 338.5 \\
\hline 1983 & 339.0 & 339.5 & 339.5 & 340.1 & 340,0 & 340.3 & 340.9 & 341,3 & 341,4 & 341.3 & 341.4 & 341.4 & 340.5 \\
\hline 1984 & 341.4 & 341.3 & 341.3 & 341.2 & 341.4 & 341.8 & 342.1 & 342.5 & 342.5 & 342.4 & 342.1 & 342.3 & 341,9 \\
\hline 1985 & 342.4 & 342,3 & 342.3 & 342.5 & 342.7 & 343.2 & 343.6 & 344.0 & 344.2 & 344.1 & 343.6 & 343,8 & 343.2 \\
\hline 1986 & 343.7 & 343.7 & 343.7 & 343.8 & 344.0 & 344.3 & 344.7 & 345.1 & 345.2 & 345.4 & 345.0 & 344.9 & 344.5 \\
\hline 1987 & 344.7 & 344.8 & 344.7 & 344.8 & 345.4 & 346.0 & 346.3 & 346.9 & 347.3 & 347.3 & 347.4 & 347.3 & 346.1 \\
\hline
\end{tabular}

"The monthly and annual means provided are selected baseline data that have been rounded by CDIAC to the nearest tenth. In 1981, the in situ equipment in the permanent laboratory was installed. For 1981, two sets of values are given. The first set is derived from the in situ equipment (Mark I) in the temporary laboratory, and the second set (Mark II), from the permanent laboratory. Atmospheric $\mathrm{CO}_{2}$ measurements in parts per million by volume (ppmv).
Atmosplueric ('()2

\section{RLILRENCWS}

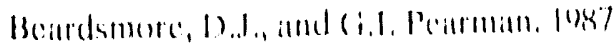

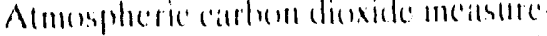

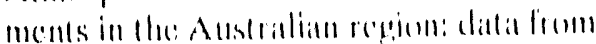

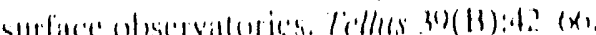

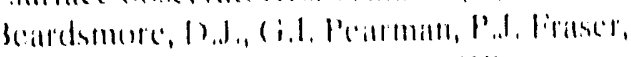

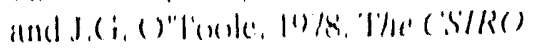

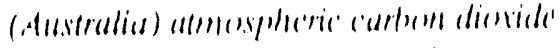
momitoring pronerems: the first sir ve'ters of

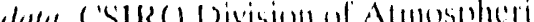

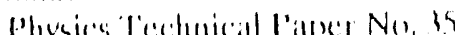

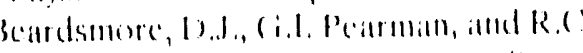

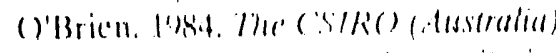

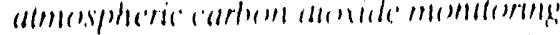

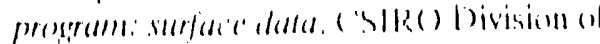

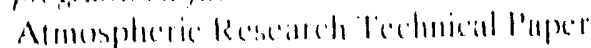
N(1) (1.

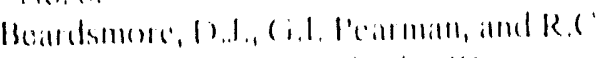

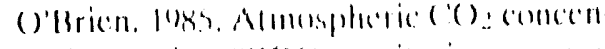

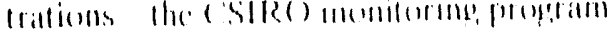

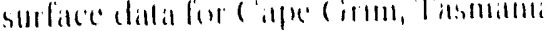

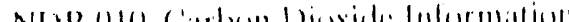

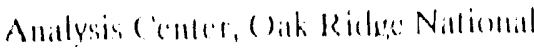

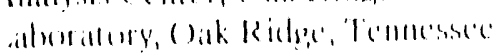

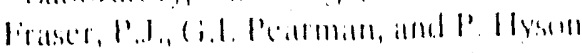

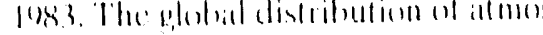

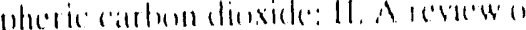

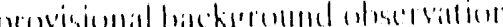

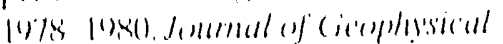

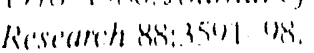

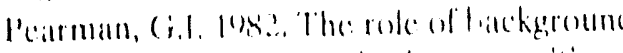

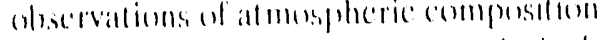

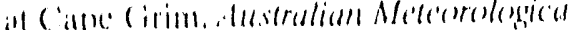

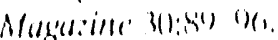

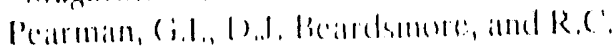

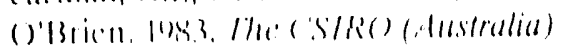

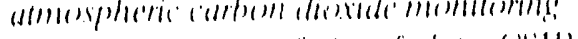

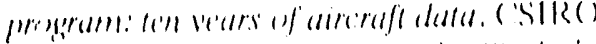

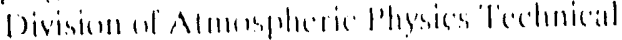
Palper Nor.ts. 


\section{Alert}

BACKGROUND
Principal investlgators
Neil B.A. Trivett
Kaz Higichi
Victoria Hudec
Atmospheric Environment Service
Downsview, Ontario M3H 5T4
Canada
C.S. Wong
Marine Carbon Research Centre
Institute of Ocean ?ciences
Sidney, British Columbia
Canada
Air sample collection - Once every week a
pair of evacuated 2-L flasks are exposed
around noon local time by Atmospheric
Environment Service (AES) personnel to
obtain samples of the ambient air.
Measurement apparatus - The flask samples
were analyzed for CO2 concentrations at the
Institute of Ocean Sciences (IOS) by using a
URAS 2T nondispersive infrared gas
analyzer (NDIR). Since 1988, AES has been
collecting and analyzing the data with URAS
3E and UNOR 4N NDIR.
Data selection procedures - Two flask
samples are collected per daily sample, From
cach flask, two aliquots are analyzed. The
flask data are given primary and secondary
classifications according to criteria described
in Trivett and Higuchi (1989).
Calibration gases used - CO2-in-air.
Scale of data reported - WMO 1983 scale.
Data avallabillty - The daily "good" flask
data, along with these monthly and annual
averages, have been archived and are
available from CDIAC. Monthly and annual
means have also been reported by WMO
(1989).

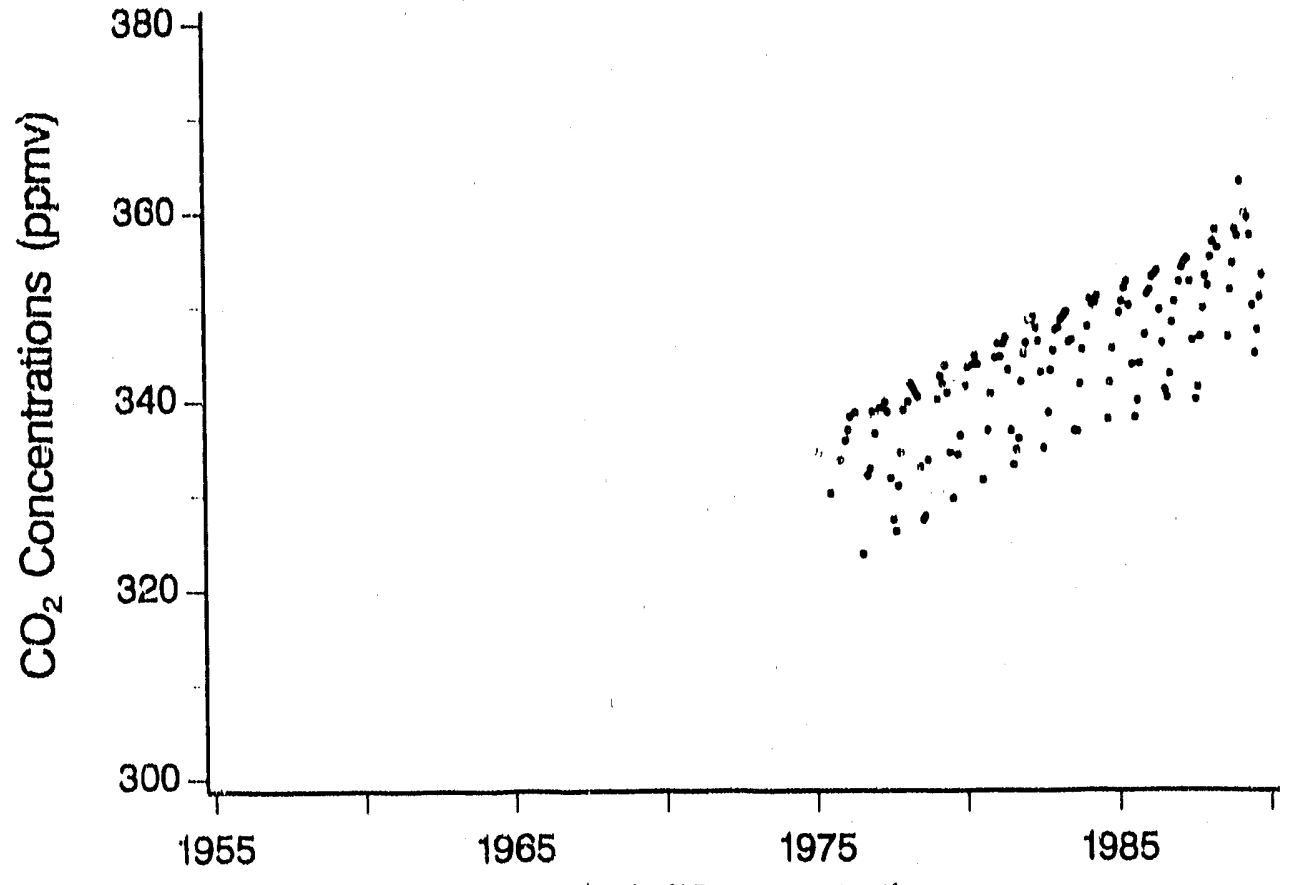

Monthly atmospheric $\mathrm{CO}_{2}$ concentrations.

Alert

Northwest Territories, Canada

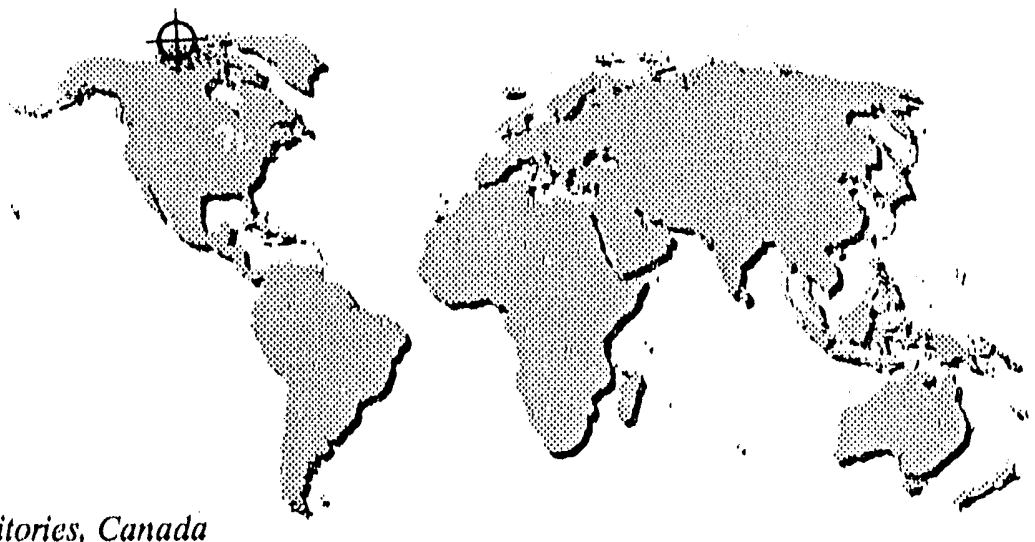

Tundra

$82^{\circ} 31^{\prime} \mathrm{N}, 62^{\circ} 18^{\prime} \mathrm{W}$

$142 \mathrm{~m}$ above $M S L$ 


\section{Atmospheric $\mathrm{CO}_{2}$}

\section{TREND}

These data are from the Canadian monitoring program, which began in 1969 at Ocean Weather Station "p" as a joint effort between Scripps Institution of Oceanography and the Institute for Ocoan Sciences at Sidney, British Columbia (see Wong et al, 1984). The sampling site at Alert, Northwest Territories, was established in 1975 by the Atmospheric Environment Service as a result of the Stockholm Conference in 1974. At the samo time, a station was established on Sable Island off the coast of Nova Scotia. Alert is located about $800 \mathrm{~km}$ from the North Pole on the northern tip of Ellesmere Island. Currently, both continuous and grab flask sampling programs are conducted at Alert.

The flask data from Alert show an increaso in the annual atmospheric $\mathrm{CO}_{2}$ concontration from $331.7 \mathrm{ppmv}$ in 1975 to 354.3 ppmv in 1989. Trivett and Higuchi (1989) reported a mean annual rate of increase, obtained from the slope of a least squares regression line through the annual averages, for Alert to be $1.49 \mathrm{ppmv}$ pe" year. For comparison, Conway et al. (1988) reported a 1.22 ppmv mean annual growth rate at the nearest NOAA/CMDL site (Mould Bay, Northwest Territories) for 1981-1984. Wong et al. (1984) reported a mean annual $\mathrm{CO}_{2}$ concentration of 338.73 ppmv for Alert in 1980 .

Atmospheric $\mathrm{CO}_{2}$ concentrations at Alert show a seasonal pattern with the annual drawdown measured during the late summer (August-September) and the annual maximum measurements recorded during the early spring (April-May). 


\section{Atmospheric Concentrations of Carbon Dioxide*}

\begin{tabular}{|c|c|c|c|c|c|c|c|c|c|c|c|c|c|}
\hline Year & Jan & Feb & Mar & Apr & May & Jun & Jul & Aug & Sept & Oct & Nov & Dec & Ann \\
\hline 1975 & & & & & & & 330.0 & & & & 333.5 & & 331.7 \\
\hline 1976 & 335.6 & 336.7 & 338.1 & & 338.5 & & 329.6 & 323.6 & & 331.9 & 332.6 & 338.6 & 333.9 \\
\hline 1977 & 336.3 & & 339.0 & & 339.6 & 338.6 & 331.6 & 327.2 & 326.0 & 330.8 & 334.3 & 338.8 & 334.2 \\
\hline 1978 & & 339.7 & 341.6 & 341.2 & 340.7 & 340.2 & 332.8 & 327.2 & 327.6 & 333.5 & & & 336.1 \\
\hline 1979 & & 339.9 & 342.4 & 341.6 & 343.5 & 340.6 & 334.3 & 329.5 & & 334.1 & 336.1 & & 338.0 \\
\hline 1980 & 341.3 & 343.3 & & 343.6 & 344.5 & 343.6 & & 331.4 & & 336.6 & 340.5 & & 340.6 \\
\hline 1981 & 344.3 & 345.8 & 344.4 & 345.8 & 346.4 & 343.0 & 336.6 & 333.0 & 334.6 & 335.8 & 341.8 & 344.7 & 341.4 \\
\hline 1982 & 345.9 & 348.3 & 348.3 & 348.6 & 347.5 & 346.1 & 342.8 & 334.8 & & 338.5 & 343.0 & 345.1 & 344.4 \\
\hline 1983 & 347.3 & 347.5 & 348.4 & 348.7 & 349.2 & 346.0 & 346.2 & 336.6 & 336.5 & 341.5 & 345.2 & & 344.8 \\
\hline 1984 & 347.6 & 350.5 & 350.0 & 350.1 & 350.8 & & & 337.4 & 337.8 & 341.7 & 345.3 & & 346.7 \\
\hline 1985 & & 349.1 & 350.3 & 351.7 & 352.4 & 349.9 & 343.6 & 338.0 & 339.8 & 343.8 & & 346.8 & 346.5 \\
\hline 1986 & 351.1 & 351.5 & 352.9 & 353.1 & 353.5 & 349.4 & 345.9 & 340.9 & 340.1 & 342.6 & 348.1 & 350.3 & 348.3 \\
\hline 1987 & & 352.4 & 353.9 & 354.5 & 354.8 & 352.4 & 346.2 & 339.9 & 341.2 & 346.6 & 349.6 & 353.0 & 349.5 \\
\hline 1988 & 352.0 & 355.0 & 356.6 & 357.9 & 356.0 & & & & 346.6 & 351.6 & 354.4 & 358.0 & 354.2 \\
\hline 1989 & 357.3 & 363.1 & & 359.7 & 359.3 & 357.4 & 350.0 & 344.9 & 347.4 & 350.9 & 353.2 & & 354.3 \\
\hline
\end{tabular}

*Atmospheric $\mathrm{CO}_{2}$ in parts per million by volume (ppmv). Annual averages based on monthly means. All numbers have been rounded to

\section{REFERENCES}

Conway, T.J., P. Tans, L.S. Waterman, K.W Thoning, K.A. iviasarie, and R.H.

Gammon 3088 . Atmospheric carbon

dioxide measurements in the remote global troposphere, 1981-1984. Tellus

$40(B): 81-115$.

Higuchi, K., and S.M. Daggupaty. 1985. On variability of at mospheric $\mathrm{CO}_{2}$ at station. Alert. Atmospheric Environment 19:2039-44.

Komhyr, W.D., R.H (iammon, T.B. Harris, L.S. Waterman, T.J. Conway, W.R. Taylor, and K.W. Thoning, 1985. (;lobal atmospheric $\mathrm{CO}_{2}$ distributions and variations from 1968-82 NOAA/GMCC

$\mathrm{CO}_{2}$ flask sample data. Joumal of

(icophysical Research 90:5567-.96.

Trivell, N.B.A., and K. Higuchi. 1989.

Trends and seasonal cycles of atmospheric $\mathrm{CO}_{2}$ over Alert, Sable Island, and Cape St. James, as analyzed by forward stepwise regression technique. pp. 27-42. IN The Statistical Treatment of $\mathrm{CO}_{2}$ Data Records, W.P. Elliott, (ed.). Air Resources

Laboratory, Silver Spring Maryland.

Wong, C.S., Y.H. Chan, J.S. Page, R.D.

Bellegay, and K.(i. Peltit. 1984. Trends of at mospheric $\mathrm{CO}_{2}$ over Cinadian WMO background stations al Ocean Weather Station P. Sable Island, and Alerl. Joumal of Geophysical Research 89:9527-39.'

World Metcorological Organization. 1989

Provisional daily atmospheric carbon

dioxide concentrations as measured at

BAPMON sites for the years 1986 and 1987. WMO/TD-No. 306. Gencva. 


\section{Cape St. James}

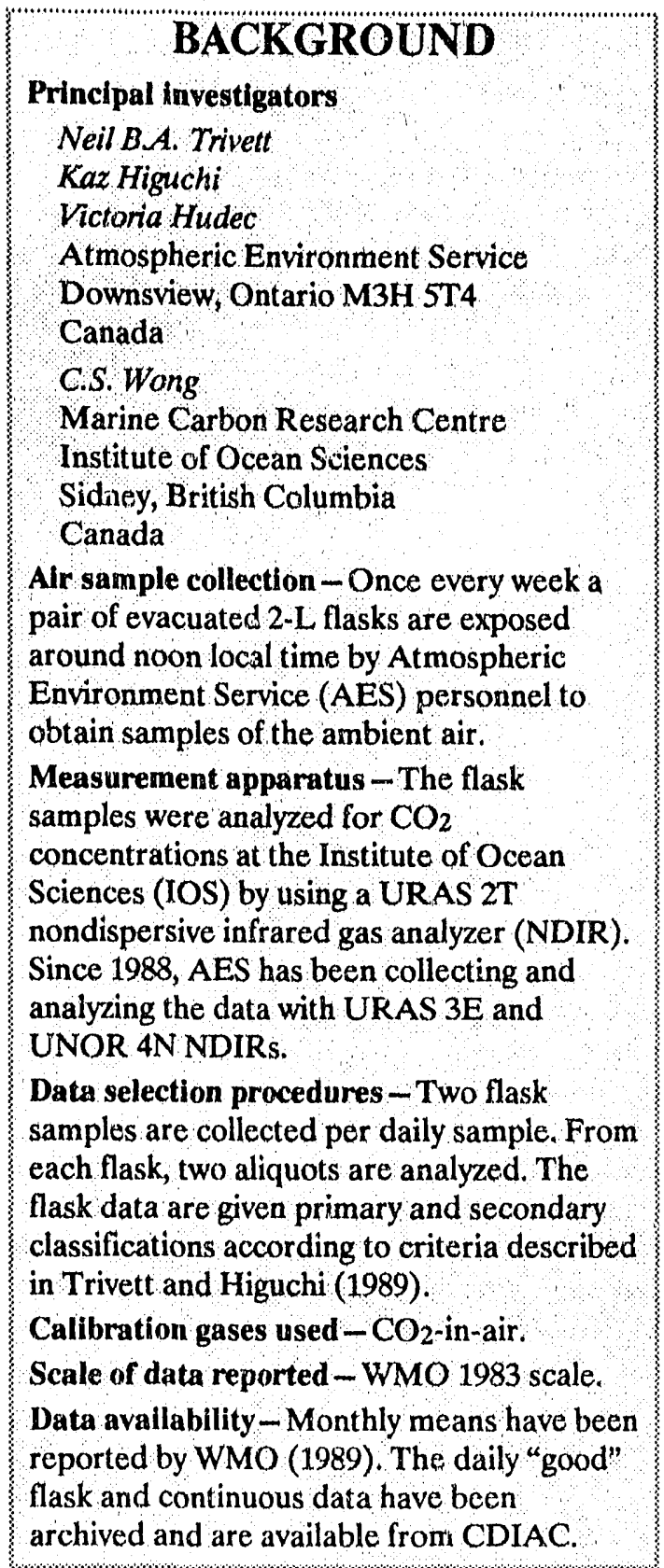

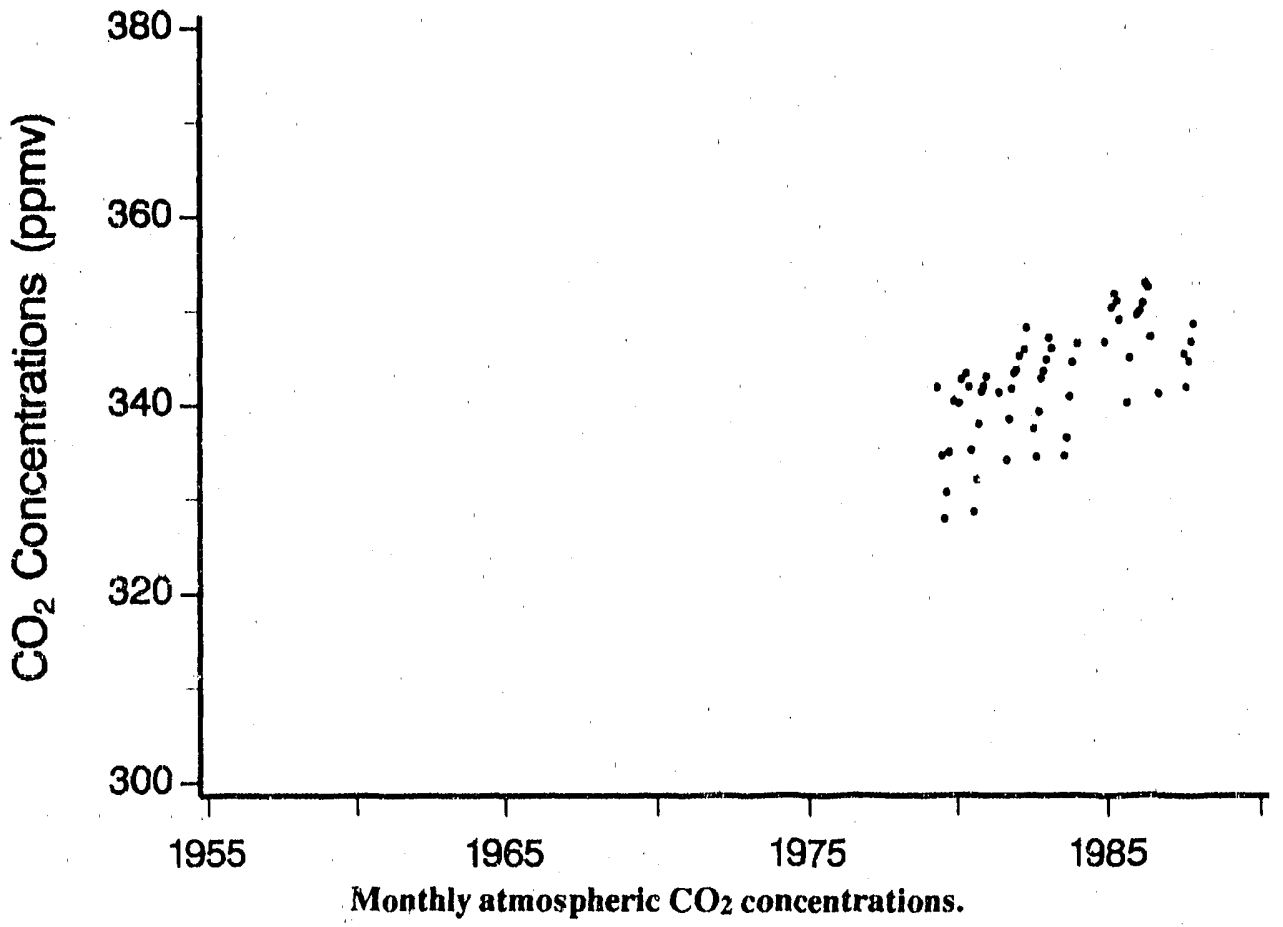

Cape St. James

British Columbia, Canada

Island seashore

$51^{\circ} 56^{\prime} \mathrm{N}, 131^{\circ} 01^{\prime} \mathrm{W}$

$89 \mathrm{~m}$ above MSL 


\section{TREND}

These data are from the Canadian monitoring program, which began in 1969 at Ocean Weather Station "P" as a joint effort between Scripps Institution of Oceanography and the Institute for Ocean Sciences at Sidney, British Columbia (see Wong et al. 1984). Following the Stockholm Conference in 1974, the Atmospheric Environment Service (AES) established two stations at Sable Island, Nova Scotia, and Alert, Northwest Territories. The sampling site at Cape St. James on Queen Charlotie Islands was established in 1978 as a replacement for Ocean Station "P," which was taken out of service in 1982.

The flask data from Cape St. James show an increase in the annual atmospheric $\mathrm{CO}_{2}$ concentration from $335.2 \mathrm{ppmv}$ in 1979 to $353.4 \mathrm{ppmv}$ in 1989. However, these annual estimates are derived from monthly means, which for some years are few in number and are based on few flask samples. For Cape St. James, Trivett and Higuchi (1989) reported a mean ainual rate of increase, obtained from the slope of a least squares regression line through the annual averages, to be 1.43 ppmv per year. For comparison, Conway et al. (1988) reported a 1.22-ppmv mean annual growth rate at all NOAA/ CMDL flask sites for 1981-1984. Wong et al. (1984) reported a mean annual increase of 1.4 ppmv based on data for 1975-1981 from Ocean Station "P," Sable Island, and Alert. 


\section{Cape St. James}

\section{Atmospheric Concentrations of Carbon Dioxide*}

\begin{tabular}{|c|c|c|c|c|c|c|c|c|c|c|c|c|c|}
\hline Year & Jan & Feb & Mar & Apr & May & Jun & Jul & Aug & Sept & Oct & Nov & Dec & Ann \\
\hline 1979 & & & & & 341.7 & & 336.1 & 327.8 & 330.6 & 334.8 & & 340.2 & $335: 2$ \\
\hline 1980 & & 340.0 & 342.5 & & 343.1 & 341.7 & 334.0 & 328.5 & 331.9 & 337.8 & 341.2 & & 337.9 \\
\hline 1981 & 342.8 & & & & & & & & 334.0 & 338.3 & 341.6 & 343.2 & 340,0 \\
\hline 1982 & 343.5 & 345.0 & & 345.7 & 348.0 & & & 337.3 & 334.3 & 339.1 & 342.6 & 342.7 & 342.0 \\
\hline 1983 & 344.6 & 346.9 & 345.8 & & & & & 334.4 & 336.3 & 341.2 & 345.2 & & 342.1 \\
\hline 1984 & & & & & & & & $\ldots$ & & & & 346.5 & 346.5 \\
\hline 1985 & & & 350.4 & 351.6 & 351.5 & 348.7 & & & 340.1 & 344.9 & & & 347.9 \\
\hline 1986 & 349.3 & 349,8 & 350.8 & $352: 3$ & 352.3 & 347.0 & & & 341.0 & 345.7 & & & 348.5 \\
\hline 1987 & & & & & & & 345.3 & 341.8 & 344.5 & 346.6 & 348.5 & & 345.3 \\
\hline 1988 & 354.0 & 353.6 & 354.4 & 355.9 & 355.7 & 353.0 & 349.7 & 341.5 & & 351.0 & 353.4 & 354.2 & 352.4 \\
\hline 1989 & 356.8 & 356.6 & 357.3 & 358.3 & & 355.9 & 348.5 & 347.2 & 348.4 & 351.9 & & & 353.4 \\
\hline
\end{tabular}

*Atmospheric $\mathrm{CO}_{2}$ in parts per million by volume (ppmv). Annual averages based on monthly means. All numbers have been rounded to the nearest tenth.

\section{REFERENCLS}

Conway, T.J., P. T'ans, L...S. Wallerman, K.W T'houing, K.A. Massitric, and R.IL

Gatmmon. 1488. Almosplacric carbon

dioxide measurements in the remote globat

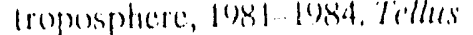

$$
4(1)(B): 81 \text { 1 } 15 .
$$

Hignchi, $K$ and S.M. Diagynpaly. 198.5. ()

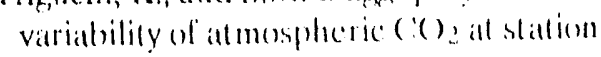
Alort demospheric Finviromment (1):2(1).31) 4.4

Komhyr, W.D., R.II. (iammonom, T.B. Hatris, LS. Watterman, T.J. Comwaty, W. R. Tayler, and K.W. Thoning. less (ilutial

almonpheric (') ? distributions and variations from 1\%(S \&: NCAA/C iMC

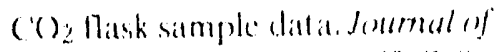

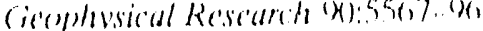

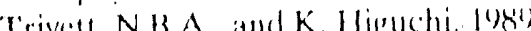

Trends and scasomat cyctes of atmospheric

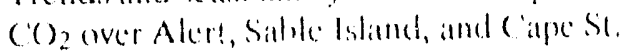
dames, as analyod by forwated stepwise

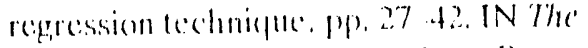

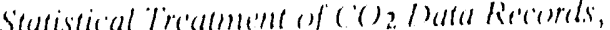

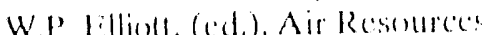

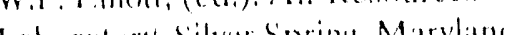

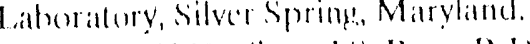

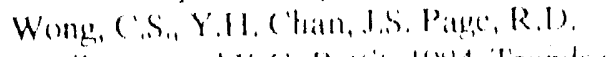

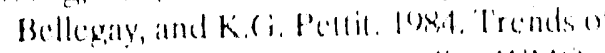

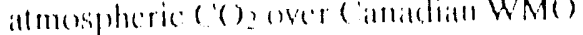

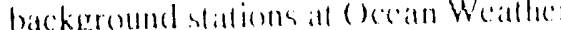
Station P'S Sathle lstand, innel Alcrt. Jentment

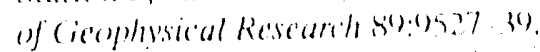

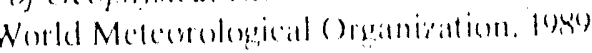

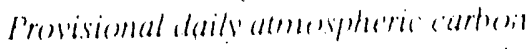

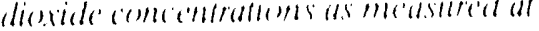

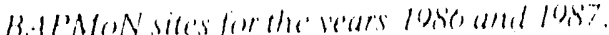

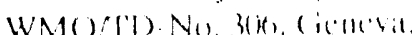




\section{Garmisch-Partenkirchen}

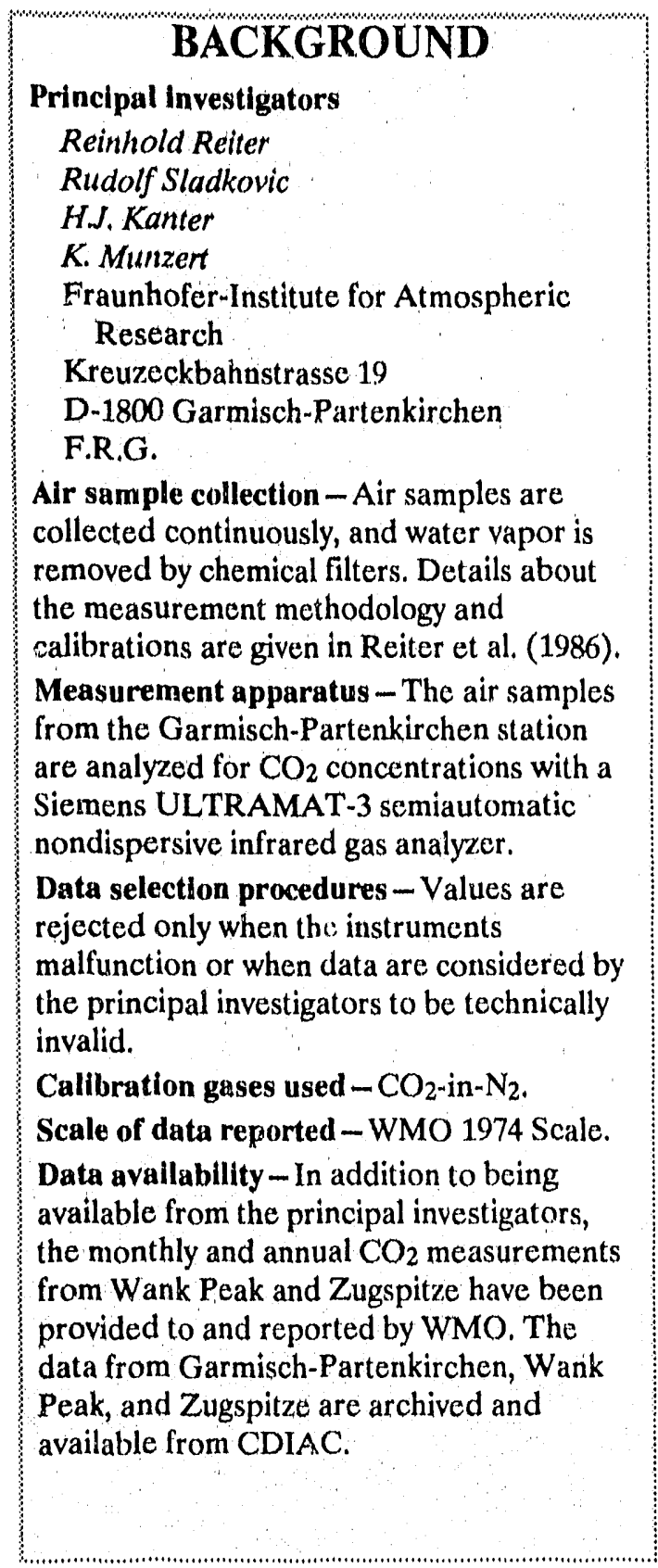

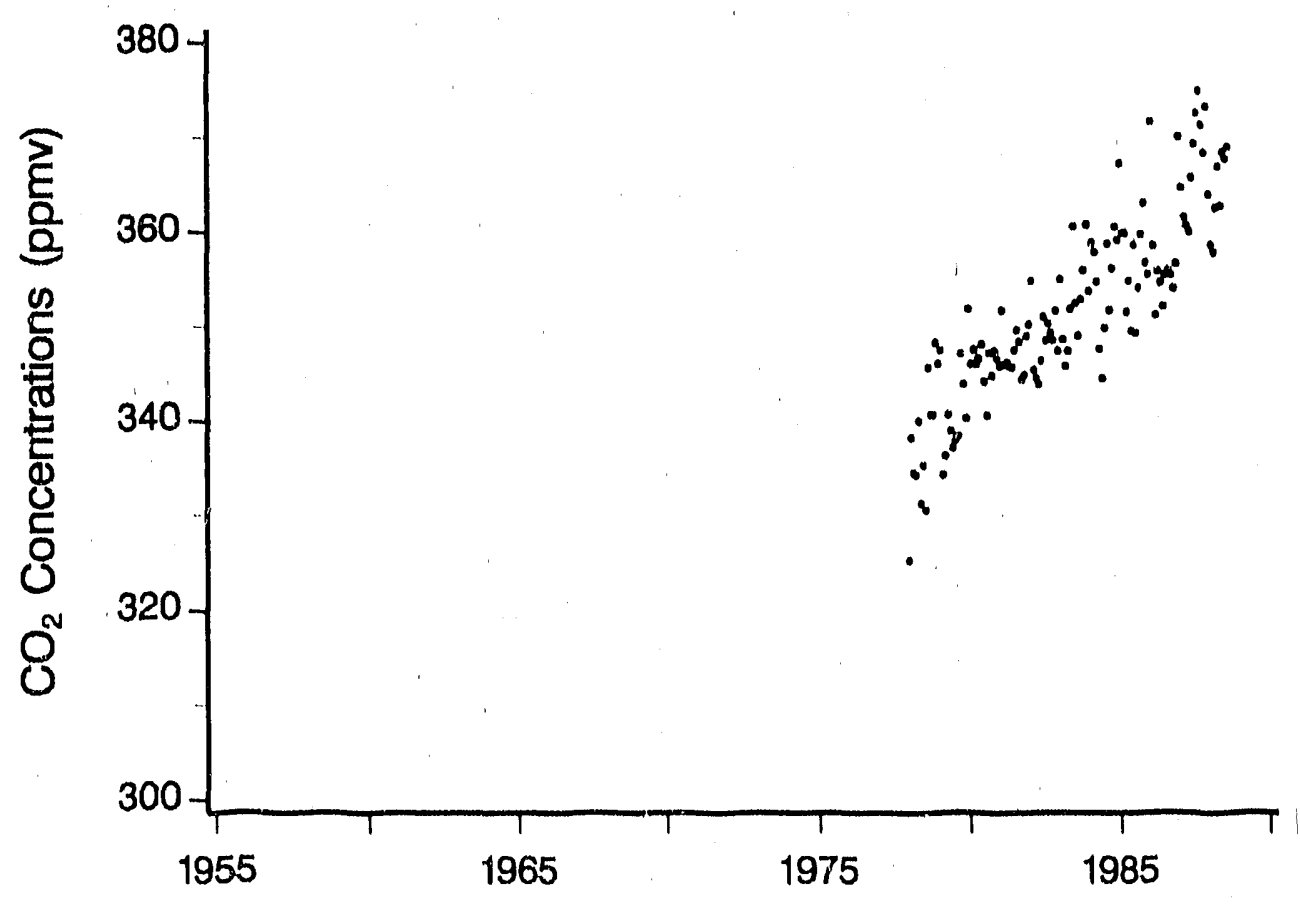

Monthly atmospheric $\mathrm{CO}_{2}$ concentrations.

Garmisch-Partenkirchen Federal Republic of Germany

Grassland valley $47^{\circ} 28^{\prime} \mathrm{N}, 11^{\circ} 03^{\prime} \mathrm{E}$ $740 \mathrm{~m}$ above $M S L$ 


\section{Atmospheric $\mathrm{CO}_{2}$}

\section{TREND}

These data are from the Federal Republic of Germany monitoring program. The monitoring site outside GarmischPartenkirchen is complemented by the Wank Peak and Zugspitze monitoring stations. Collectively, these three neighboring mountain stations provide reliable continuous $\mathrm{CO}_{2}$ measurements from three elevations. The mediumelevation station (Wank Peak) is a WMO-BAPMoN station with an extended program.

Because of local vegetation influences, the $\mathrm{CO}_{2}$ concentrations at Garmisch. Partenkirchen are higher and show greater seasonal amplitudes than the concentrations measured at Wank Peak or Zugspitze. Annual atmospheric $\mathrm{CO}_{2}$ concentrations have risen at Garmisch-Partenkirchen from 337.0 ppmv in 1978 to $367.5 \mathrm{ppmv}$ in 1987. Reiter et al. (1986) reported a mean value of 353 ppmv in 1985 compared to an initial value of $337 \mathrm{ppmv}$ in 1978. Reiter et al. (1986) reported that the steepest increase of $\mathrm{CO}_{2}$ occurred in the valley from 1978 to 1980 but that the increase has since slowed. 
Atmospheric Concentrations of Carbon Dioxide*

$\begin{array}{cccccccccccccc}\text { Year } & \text { Jan } & \text { Feb } & \text { Mar } & \text { Apr } & \text { May } & \text { Jun } & \text { Jul } & \text { Aug } & \text { Sept } & \text { Oct } & \text { Nov } & \text { Dec } & \text { Ann } \\ 1978 & 325.2 & 338.1 & 334.4 & 334.2 & 339.9 & 331.2 & 335.2 & 330.5 & 345.5 & 340.6 & 340.5 & 348.1 & 337.0 \\ 1979 & 345.9 & 347.3 & 334.2 & 336.2 & 340.5 & 338.8 & 337.0 & 337.8 & 338.2 & 346.9 & 343.7 & 340.1 & 340.6 \\ 1980 & 351.6 & 345.8 & 347.3 & 345.8 & 346.4 & 347.9 & 344.0 & 340.4 & 347.0 & 344.6 & 347.2 . & 346.4 & 346.2 \\ 1981 & 345.6 & 351.5 & 345.8 & 346.0 & 345.6 & 345.5 & 347.3 & 349.4 & 348.2 & 344.2 & 344.7 & 348.8 & 346.9 \\ 1982 & 350.0 & 354.6 & 345.2 & 344.3 & 343.7 & 346.2 & 350.8 & 348.3 & 350.1 & 349.1 & 348.3 & 351.4 & 348.5 \\ 1983 & 347.2 & 354.7 & 348.4 & 345.6 & 347.2 & 351.6 & 360.3 & 352.2 & 348.8 & 352.6 & 355.7 & 360.5 & 352.1 \\ 1984 & 353.5 & 358.6 & 357.6 & 354.5 & 347.4 & 344.3 & 349.6 & 358.5 & 351.5 & 355.9 & 360.3 & 358.9 & 354.2 \\ 1985 & 367.0 & 359.6 & 359.6 & 351.3 & 354.6 & 349.3 & 358.4 & 349.1 & 353.9 & 359.5 & 362.8 & 356.5 & 356.8 \\ 1986 & 355.3 & 371.4 & 358.3 & 351.0 & 355.6 & 354.4 & 351.9 & 355.2 & 355.7 & 355.2 & 353.8 & 356.4 & 356.2 \\ 1987 & 369.8 & 364.4 & 361.3 & 360.4 & 359.8 & 365.5 & 369.1 & 372.3 & 374.7 & 371.1 & 368.2 & 373.1 & 367.5 \\ 1988 & 363.8 & 358.5 & 357.7 & 362.4 & 366.8 & 362.6 & 368.3 & 367.6 & 368.8 & & & & \end{array}$

*Atmospheric $\mathrm{CO}_{2}$ in parts per million by volume (ppmv). Annual averages based on monthly means. All numbers have been rounded to the nearest tenth.

\section{RLIERLNCLS}

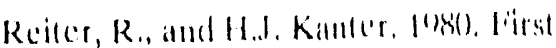
results of simultincous recordinges of the

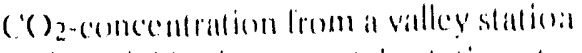

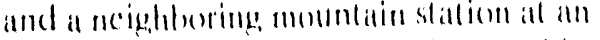

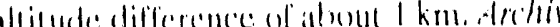

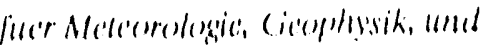

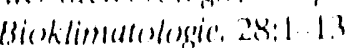

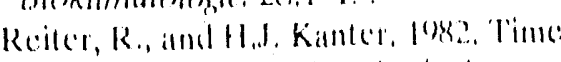

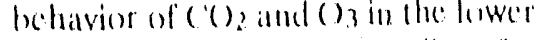
tropusphere: hitsed on recordinges from neighboring mountain slittions helween (1) 7 and 3,0$) \mathrm{km}$ Ast including the effects of

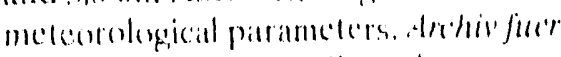

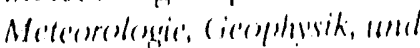

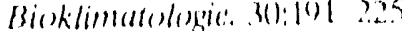

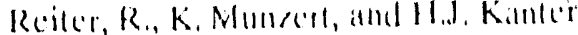

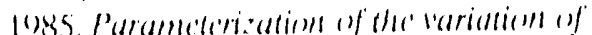
(.)

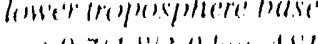

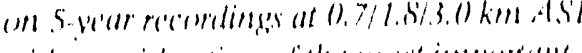

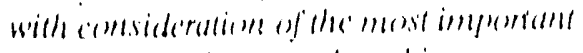

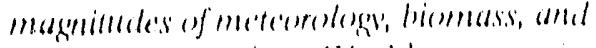

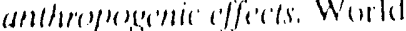

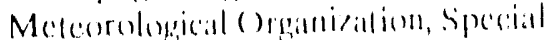

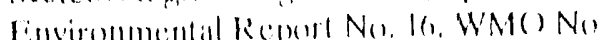

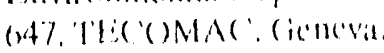

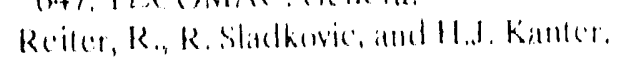

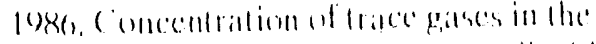

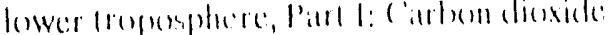

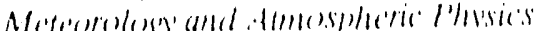
$35: 1872$ ? $2(x)$

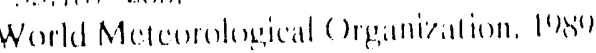

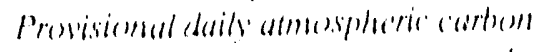

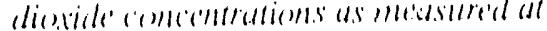

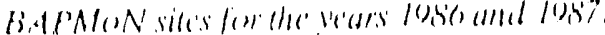

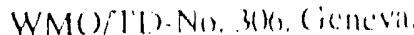




\section{Wank Peak}

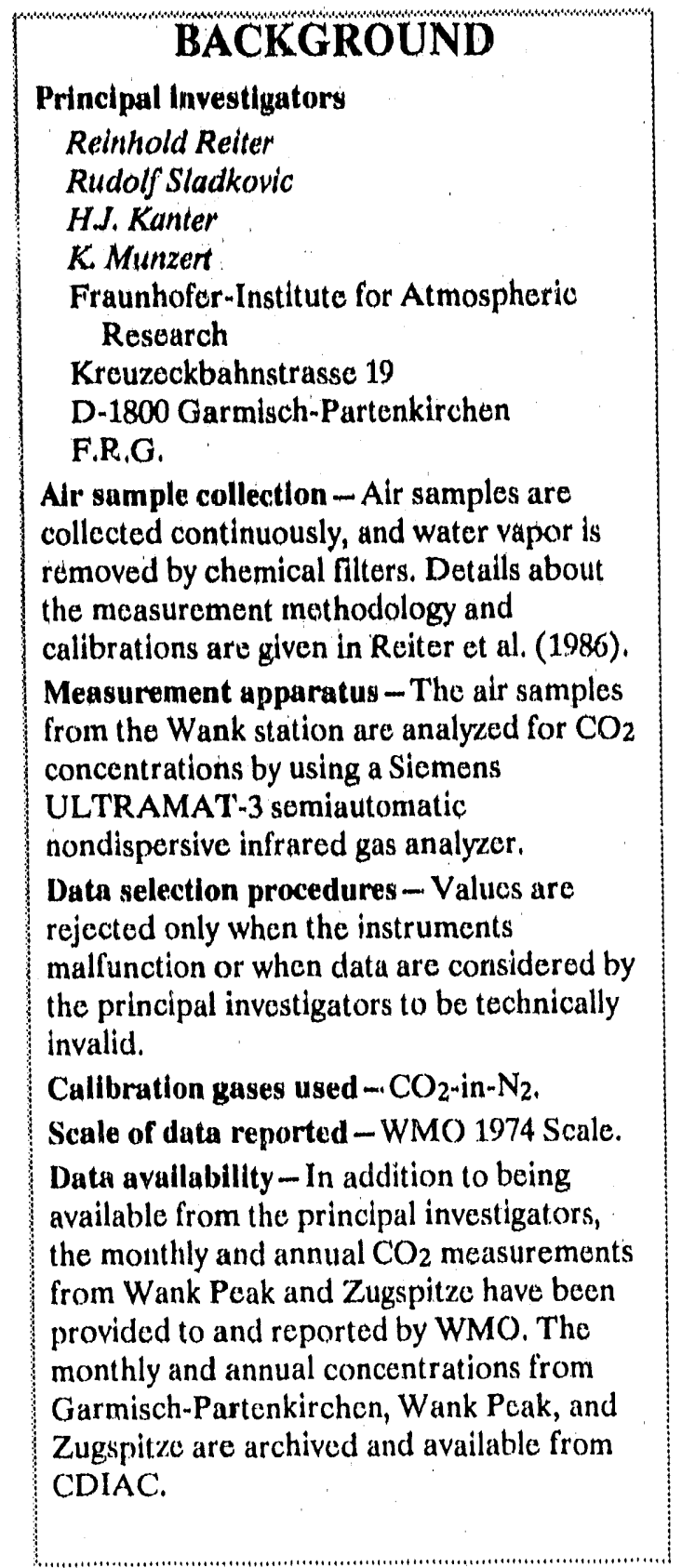

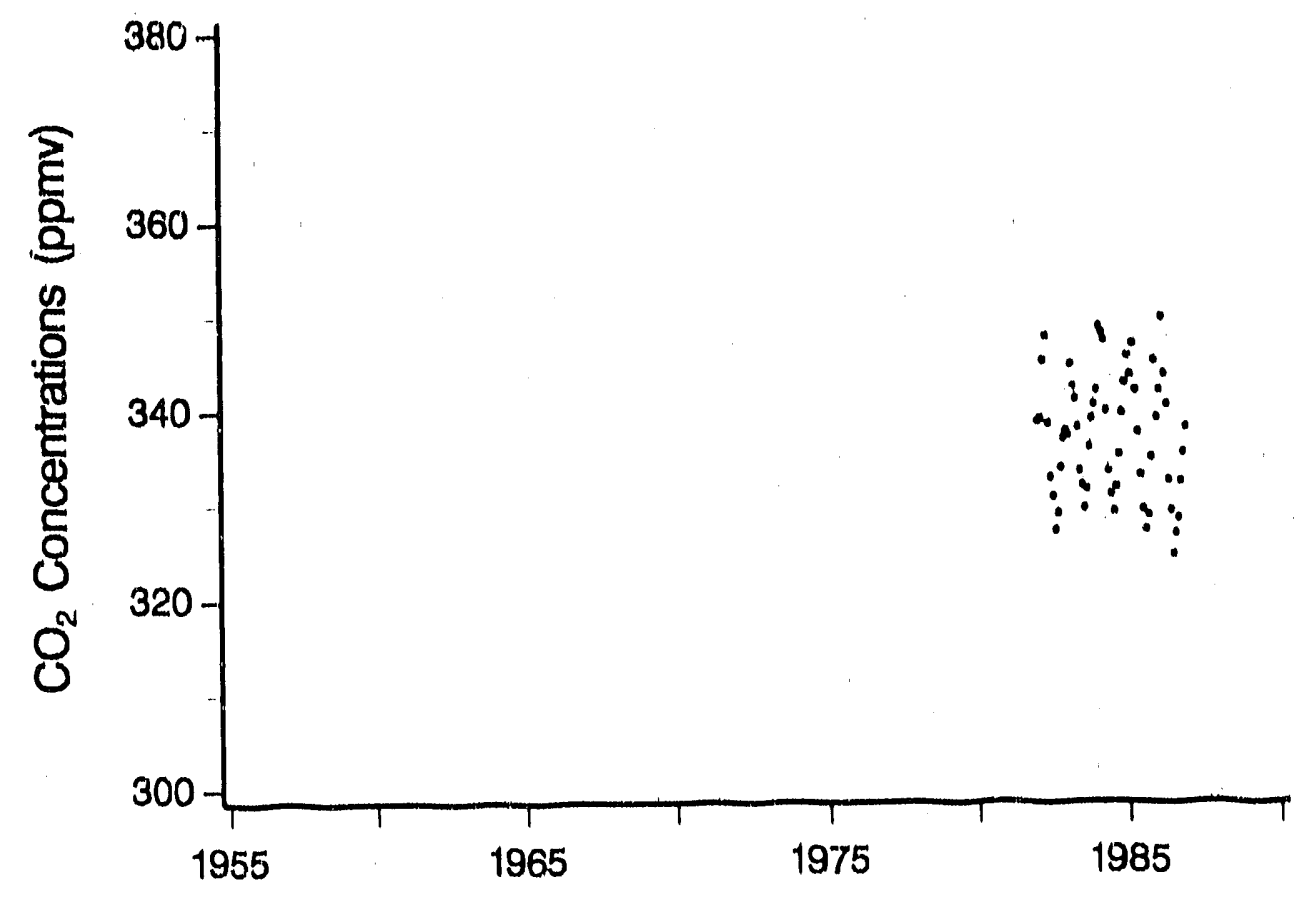

Monthly atmospheric $\mathrm{CO}_{2}$ concentrations.

Wank Peak

Federal Republic of Giemany

Mountain peak

$47^{\circ} 30^{\prime} \mathrm{N}, 11^{\circ} 08^{\prime} \mathrm{E}$

$1776 \mathrm{~m}$ above $M S L$ 


\section{Atmospheric $\mathrm{CO}_{2}$}

\section{TREND}

These data are from the Federal Ropublic of Germany monitoring program. The monitoring site at Wank Peak is a WMOBAPMoN station at which numerous atmospheric measurements, including $\mathrm{CO}_{2}$ concentrations, aro collected. This station is complemented by the nearby Garmisch. Partenkirchen and Zugspitze monitoring stations. The Wank Peak Mountain Observatory is located just above the timberline but surrounded by closed flat grass cover and isolated low alpine pines. Collectively, these three neighboring mountain stations provide reliable continuous $\mathrm{CO}_{2}$ measurements from three elevations.

Unlike the monitoring site at Garmisch. Partenkirchen, which is subject to considerable local vegetation influences, the $\mathrm{CO}_{2}$ measurements obtained at Wank Peak are not considered to be frequently influenced by vegetation or tourism. Reiter ot al. (1986) reported a slight increase in tho mean annual value from $331 \mathrm{ppmv}$ in 1978 to 339 ppmv in 1984. Reiter et al, (1986) also reported the mean annual amplitude to be greater at Wank Peak than at Zugspitze. 


\section{Wank Peak}

\section{Atmospheric Concentrations of Carbon Dioxide}

\begin{tabular}{|c|c|c|c|c|c|c|c|c|c|c|c|c|c|}
\hline Year & Jan & Feb & Mar & Apr & May & Jun & JuI & Allg & Sept & Oct & Nov & Dec & Ann \\
\hline 1982 & 338.8 & 339.1 & 345.2 & 347.8 & 338.6 & 332.9 & 330.9 & 327.3 & 329.1 & 333.9 & 337.0 & 337.8 & 336.5 \\
\hline 1983 & 337.3 & 344.8 & 342.4 & 341.1 & 338.1 & 333.5 & 332.0 & 329.6 & 331.6 & 336.0 & 339.0 & 340.5 & 337.2 \\
\hline 1984 & 342.0 & 348.7 & 348,1 & 347.3 & 339.8 & 333.5 & 331.0 & 329.2 & 331.8 & 335.2 & 339.6 & 342.8 & 339.1 \\
\hline 1985 & 345.6 & 343.6 & 346.9 & 342.0 & 337.6 & 333.1 & 329.5 & 327.4 & 328.9 & 335.0 & 345.2 & 339.2 & 337.8 \\
\hline 1986 & 342.1 & 349.8 & 343.8 & 340.6 & 332.6 & 329.4 & 324.8 & 327.0 & 328.6 & 332.5 & 335.5 & 338.2 & 335 \\
\hline
\end{tabular}

*Atmospheric $\mathrm{CO}_{2}$ in parts per million by volume (ppmy). Annual averages based on monthly means. All numbers have been rounded to the nearest tenth.

\section{RLWLKLNCLS}

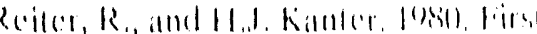

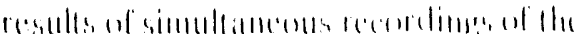

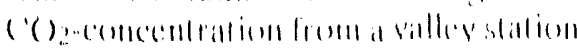

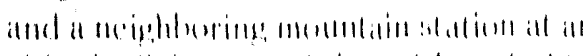

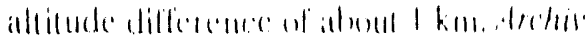

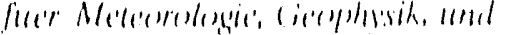

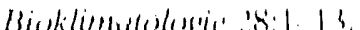

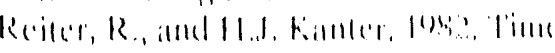

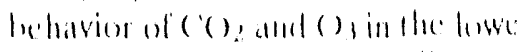

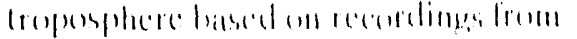

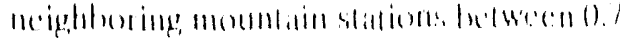

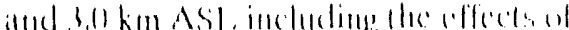

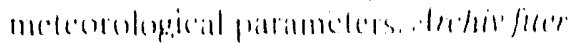

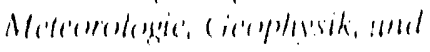

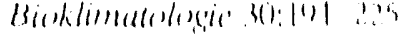

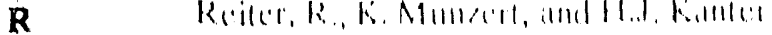

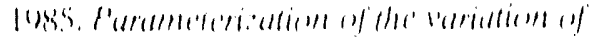

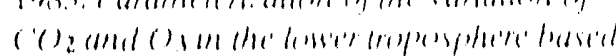

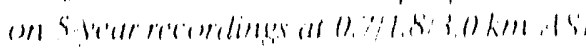

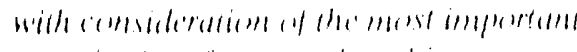

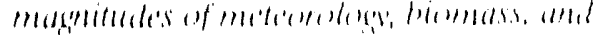

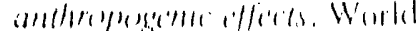

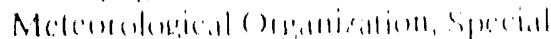

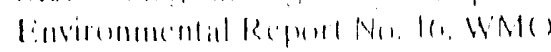

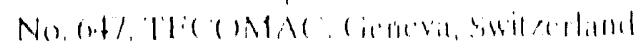
Reter, R., R.

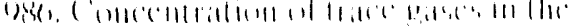

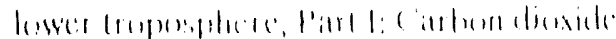

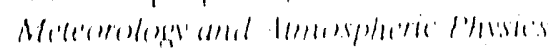

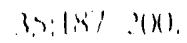

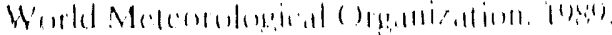

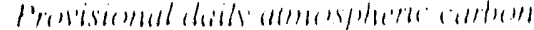

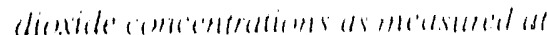

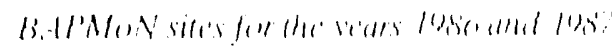

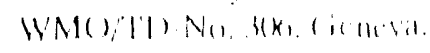




\section{Zugspitze}

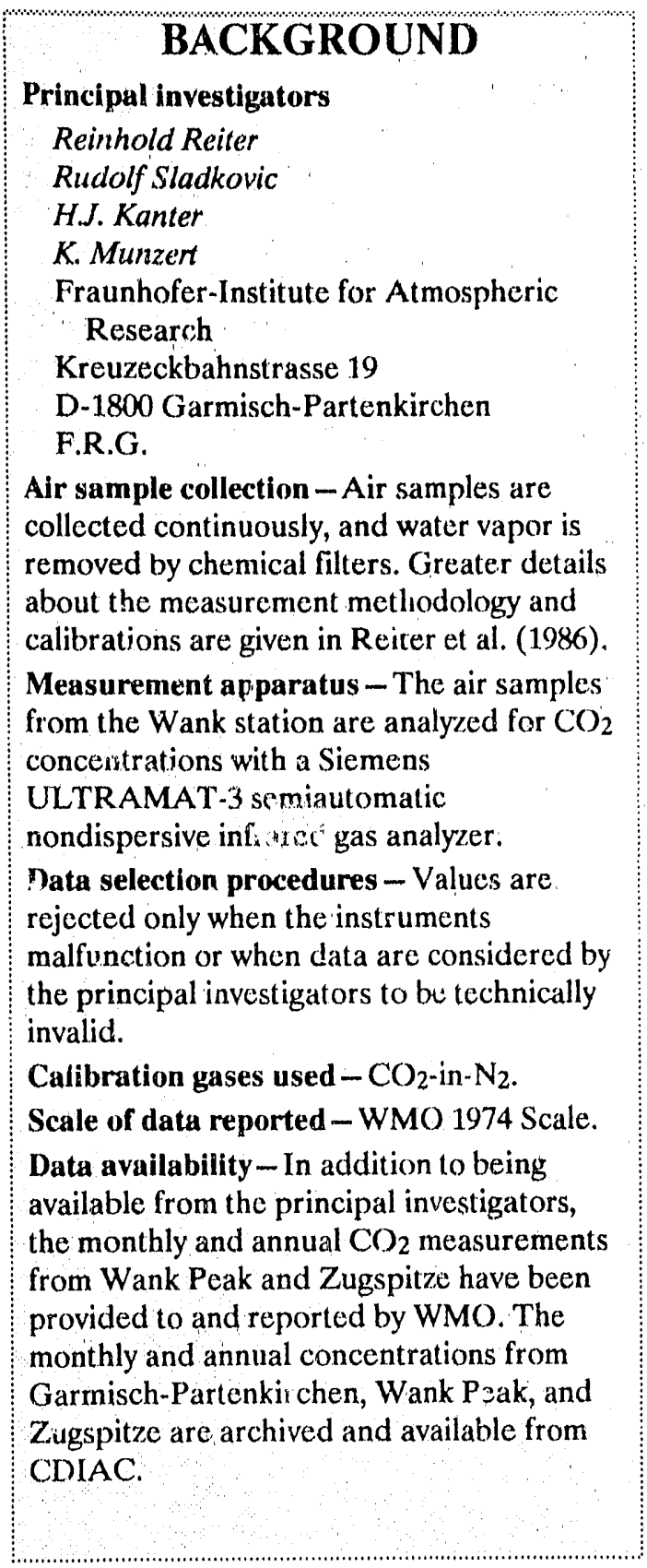

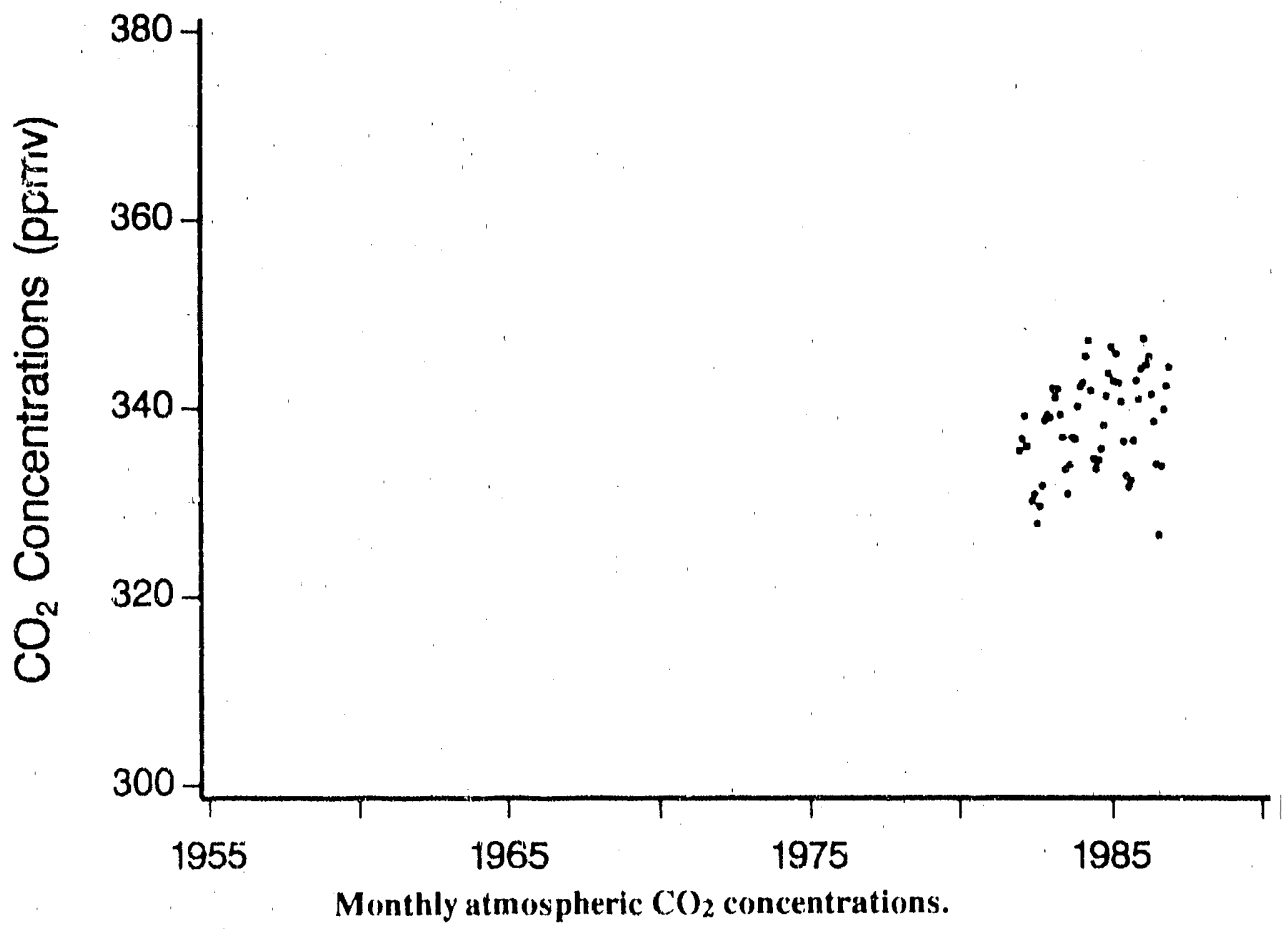

Zugspitze

Federal Republic of Germany

Monthly atmospheric $\mathrm{CO}_{2}$ concentrations.

Mountai, Jeak

$47^{\circ} 25^{\prime} \mathrm{N}, 10^{\circ} 59^{\prime} \mathrm{E}$

$2962 \mathrm{~m}$ above MSL 


\section{Atmospheric $\mathrm{CO}_{2}$}

\section{TREND}

The ie data are from the Federal Republic of Germany mcnitoring prograrn. The monitoring station at Zugspitze is complemented by the nearby GarmischPartenkirchen and Wank Peak monitoring stations. The station at Zugspitze is located above the timberline and approximately $250 \mathrm{~m}$ below the main peak of Zugspizze. A balcony, closed to all sides, on a very steep rock wall is used for the $\mathrm{CO}_{2}$ recordings. Collectively, these three neighboring mountain stations provide reliable continuous $\mathrm{CO}_{2}$ measurements from three elevations.

Unlike the monitoring sites at GarmischPartenkirchen and Wank Peak, which are subject to local influences (e.g., vegetation, automobile exhaust, and tourism), the $\mathrm{CO}_{2}$ measurements obtained at Zugspitze are considered to be free of regional contamination. Annual atmospheric $\mathrm{CO}_{2}$ concentrations have risen at Zugspitze from 334.0 ppmv in 1982 to 340.0 ppmv in 1986. Reiter et al. (1986) reported that the annual mean value of the $\mathrm{CO}_{2}$ concentration increases slowly in uneven annual steps and that the 10-day mean values vary greatly. Reiter et al. (1986) also reported that the maximum values at Zugspitze are recorded in April, while the minimum values are recorded between July and August. 


\section{Atmospheric Concentrations of Carbon Dioxide*}

$\begin{array}{llllllllllllll}\text { Year } & \text { Jan } & \text { Feb } & \text { Mar } & \text { Apr } & \text { May } & \text { Jun } & \text { Jul } & \text { Aug } & \text { Sept } & \text { Oct } & \text { Nov } & \text { Dec } & \text { Ann } \\ 1982 & 335.3 & 336.6 & 339.0 & 335.8 & & 330.0 & 330.7 & 327.6 & 329.4 & 331.6 & 338.5 & 339.1 & 334.0 \\ 1983 & 338.8 & 341.9 & 340.9 & 341.8 & 339.1 & 336.7 & 333.3 & 330.7 & 333.8 & 336.7 & 336.5 & 340.0 & 337.5 \\ 1984 & 342.1 & 342.5 & 345.3 & 347.0 & 341.7 & 334.5 & 333.4 & 334.3 & 335.5 & 338.0 & 341.1 & 343.5 & 339.9 \\ 1985 & 346.3 & 342.7 & 345.6 & 342.5 & 340.5 & 336.3 & 332.7 & 331.5 & 332.2 & 336.4 & 342.8 & 340.8 & 339.9 \\ 1986 & 344.0 & 347.2 & 344.4 & 345.3 & 341.3 & 338.4 & 333.9 & 326.4 & 333.7 & 339.7 & 342.2 & 344.2 & 340.0\end{array}$

*Atmospheric $\mathrm{CO}_{2}$ in parts per million by volume (ppmv). Annual averages based on monthly means. All numbers have been rounded to the nearest tenth.

\section{REFERENCES}

Reiter, R., and H.J. Kanter. Ios(). First results of simultancous recordinges of the (c)-concentration from a valley station and a neighboring, mountain stallion at an allitude difference of athout $1 \mathrm{~km}$ trih

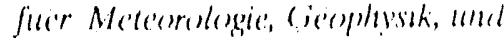

Bieklimalologic $32: 1 \ldots 13$

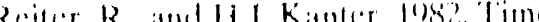

behavior of (') 2 and $)^{2}$ ) in the lower

troposplatere based an recordings from neighboring montutain stitions betwecen (). and .3.1) km Asil including the eflects ont meteorological parameters. Archinfuer

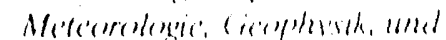

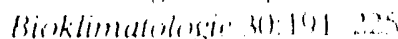

Reiter, R., K. Mundert, and H.I, Kanler.

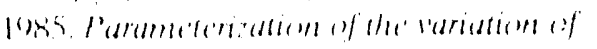

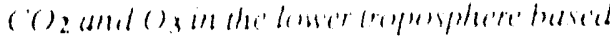

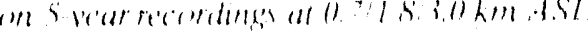

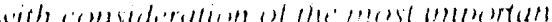

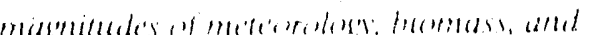

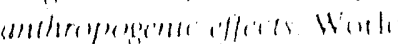

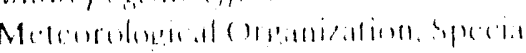

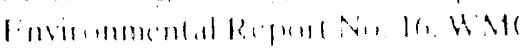

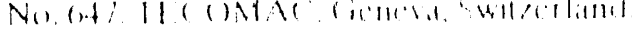

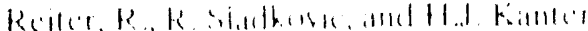

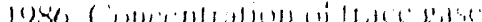

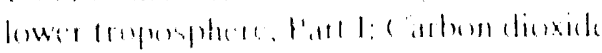

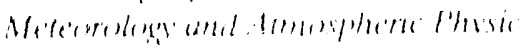
Bitis:.$(x)$.

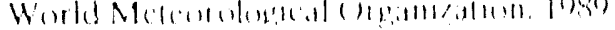

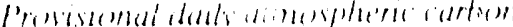

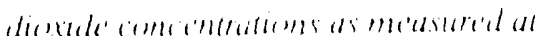

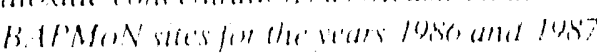

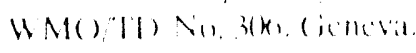




\section{Osnabrück}

\section{Principal investigators \\ Dieter Overdieck \\ Manfred Forstreuter \\ Universitat Osnabrück \\ Biologie/Chemie \\ Postfach 4469 \\ D-4500 Osnabrück \\ F.R.G.}

BACKGROUND

Alr sample collection - Continuous, every $144 \mathrm{~s}$.

Measurement apparatus - Air samples are analyzed for $\mathrm{CO}_{2}$ concentrations by using a Hartmann \& Braun URAS 2 T nondispersive infrared gas analyzer.

Data selection procedures - After digitizing, the data are reduced to half-hour means from which the monthly averages are calculated. Since the data at Osnabrück are collected for vegetative response rescarch, the data selection procedures are not as sophisticated as those at sites monitoring for climate analysis purposes.

Calibration gases used - $\mathrm{CO}_{2}-\mathrm{in}-\mathrm{N}_{2}$.

Scale of data reported - WMO 1985 Scale.

Data availability - Monthly means from Osnabrück have been archived and are available from CDIAC.

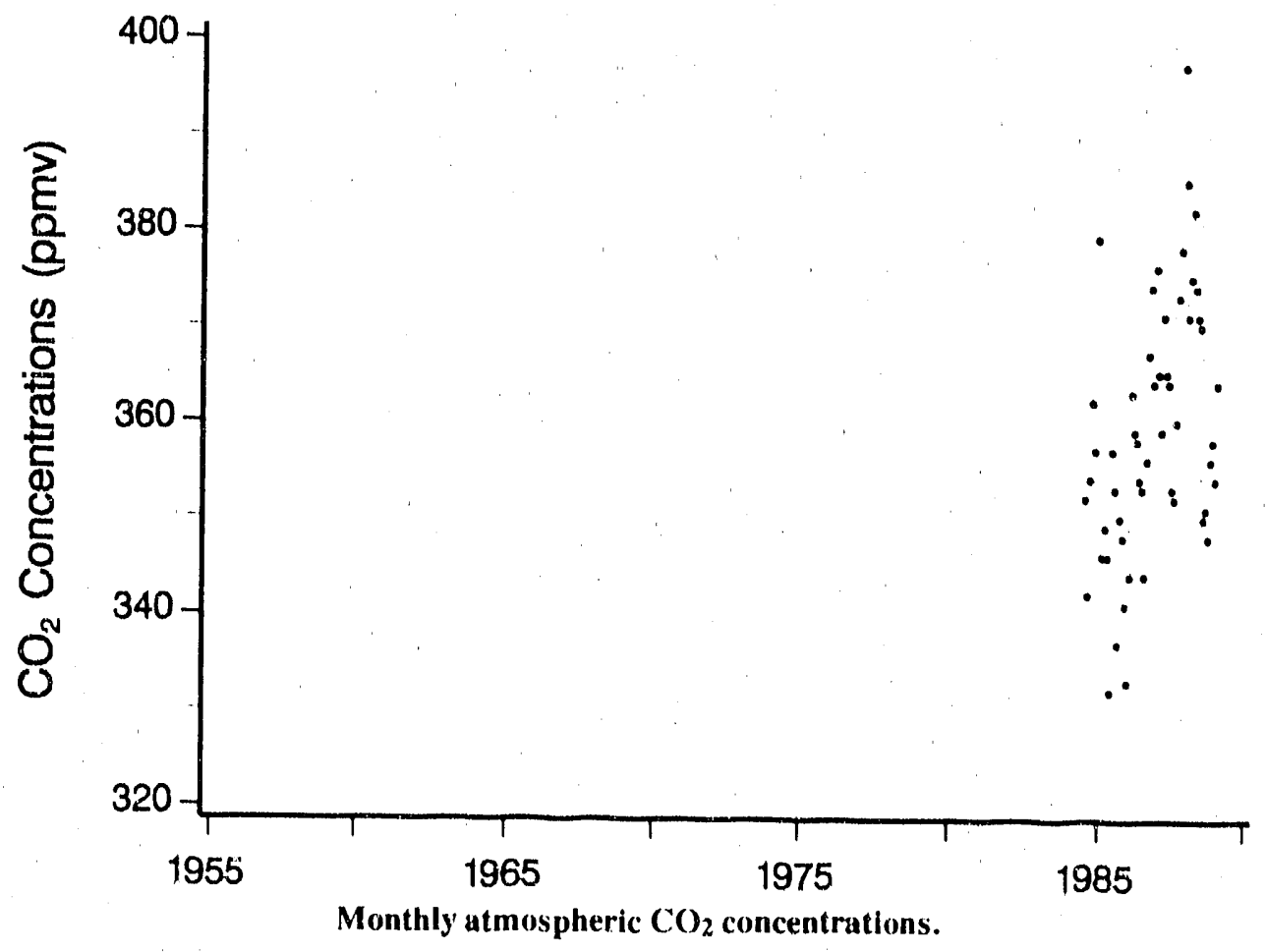

Osnabrück

Westerbery

Federal Republic of Germany

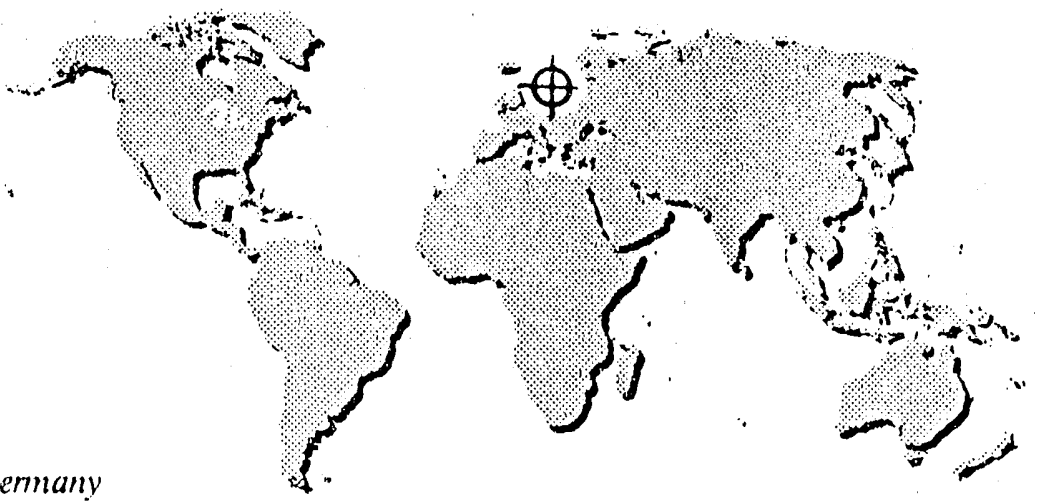

Urban (city of approximately 160,000$)$

$\therefore:^{\circ} 18^{\prime} \mathrm{N}, 8^{\circ} 2^{\prime} \mathrm{E}$

$95 \mathrm{~m}$ above MSL 


\section{Atmospheric $\mathrm{CO}_{2}$}

\section{TREND}

The $\mathrm{CO}_{2}$ monitoring conducted at Osnabrück is not part of the WMO BAPMoN network. The monitoring at Osnabrück is conducted for research examining the vegetative response to elevated levels of $\mathrm{CO}_{2}$. The monitoring of ambient air $\mathrm{CO}_{2}$ concentration levels provides the control data for long-term field experiments about the effects of tropospheric $\mathrm{CO}_{2}$ enrichment on single plants, grassland model-ecosystems, and other vegetation types. Because these measurements are subject to local sources of contamination and because of the purpose for which they are collected, these measurements are not indicative of the background air conditions near (Osnabrück. Despite the seasonal variability shown by these data, these measurements support the rising trend of atmospheric $\mathrm{CO}_{2}$ concentrations seen at other regional sites. 


\section{Osnabrüick}

Atmospheric Concentrations of Carbon Dioxide*

$\begin{array}{llllllllllllll}\text { Year } & \text { Jan } & \text { Feb } & \text { Mar } & \text { Apr } & \text { May } & \text { Jun } & \text { Jul } & \text { Aug } & \text { Sept } & \text { Oct } & \text { Nov } & \text { Dec } & \text { Ann } \\ 1984 & & & & & & & & 352 & 342 & 354 & 362 & 357 & \\ 1985 & 379 & 346 & 349 & 346 & 332 & 357 & 353 & 337 & 350 & 348 & 341 & & \\ 1986 & 333 & 344 & 363 & 359 & 358 & 354 & 353 & 344 & 356 & 367 & 374 & 364 & 356 \\ 1987 & 376 & 365 & 359 & 371 & 365 & 364 & 353 & 352 & 360 & 373 & 378 & 397 & 368 \\ 1988 & 385 & 371 & 375 & 382 & 374 & 371 & 370 & 350 & 351 & 348 & 356 & 358 & 366 \\ 1989 & 354 & 364 & & & & & & & & & & & \end{array}$

*Atmospheric $\mathrm{CO}_{2}$ in parts per million by volume (ppmv). Annual averages based on available monthly means.

\section{REILRLNCTIS}

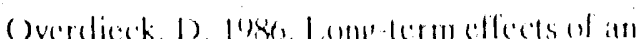

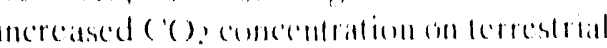

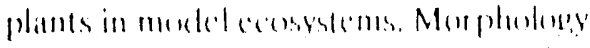

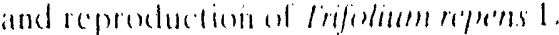

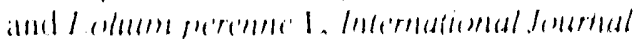

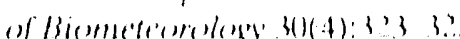

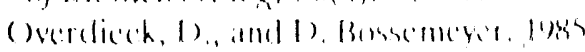

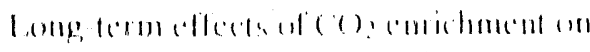

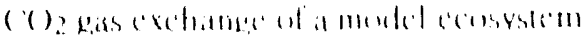

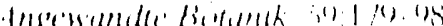

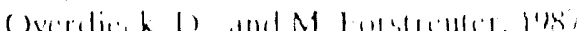

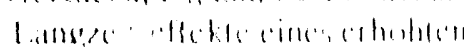

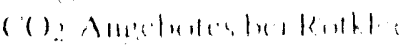

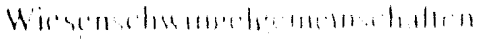

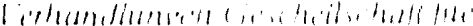

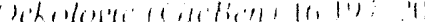

(1)

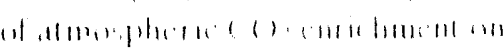

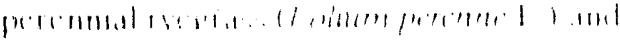

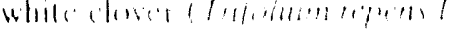

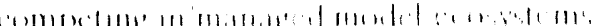

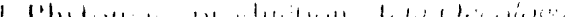

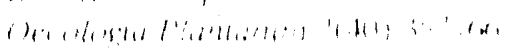

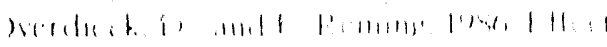

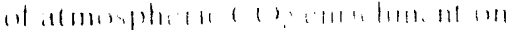

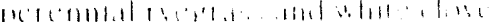

(1)

11 .

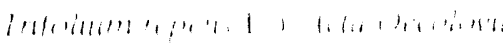

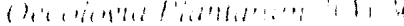

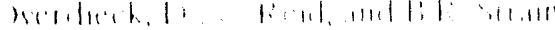

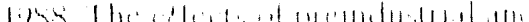

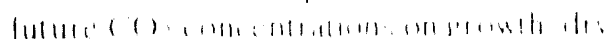

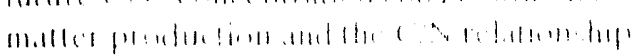

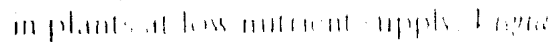

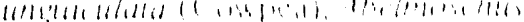

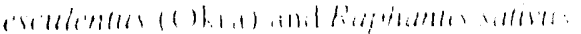

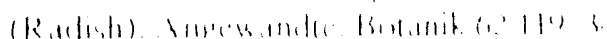




\section{Global and National $\mathrm{CO}_{2}$ Emissions from Fossil Fuel Burning, Cement Production, and Gas Flaring}




\section{Introduction}

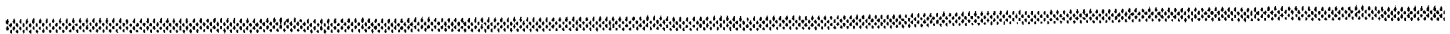

Atmospheric $\mathrm{CO}_{2}$ is produced both from natural sources and human activities. Of human activities, the most important source of $\mathrm{CO}_{2}$ is the release of carbon during the burning of fossil fuels. Since the Industrial Revolution, $\mathrm{CO}_{2}$ emissions from fossil fuel consumption have risen dramatically (see figure). In 1988, -5.9 gigatons of carbon was emitted to the atmosphere as a result of fossil fuel burning, cement manufacturing, and gas flaring. These cmission estimates, although small in compurison with the amounts of carbon stored in the oceans and terrestrial biosphere, represent a significant component of global carbon cycling and the greenhouse effect and, more important, quantify the largest human contribution to the global carbon budget.

Keeling (1973) was the first to establish a systematic method for estimating the amount of $\mathrm{CO}_{2}$ emitted from fossil fuel consumption. He used eilorgy data from the U.N. Department of International Economic and Social Affairs. Since 1973, both the energy data collection and the procedures for estimating $\mathrm{CO}_{2}$ emissions have been refined and improved (Marland and Rotty 1984; Marland et al. 1989; United Nations 1989).

The following section presents Keeling's 1860-1953 emission estimates along with more-recent global and national annual emission estimates calculated by Marland and Boden. These more recent estimates cover the period 1950-1988 and were calculated by using the methods of Marland and Rotty (1984). The data used for the calculations wero energy and population statistics from the U.N., cement manufacturing data from the U.S. Bureau of Mines, and gas flaring data from the U.N. and the U.S. Department of Energy.

For emphasis and brevity, national estimates are provided only for the 20 highest emitting countries in 1988 . The data are presented in descending order, with the highest emitting country, the United States, presented first. These 20 countries contributed $\sim 81.6 \%$ of all the 1988 world emissions from fossil fuel consumption. The top three countries, the United States, Soviet Union, and People's Republic of China, were responsible for over half $(51.0 \%)$ of the world emissions from fossil fuel burning in 1988. Spain, the twentieth highest emitting nation, contributed slightly less than $1 \%$ to this total.

\section{TRENDS '90}




\section{$\mathrm{CO}_{2}$ Emissions}

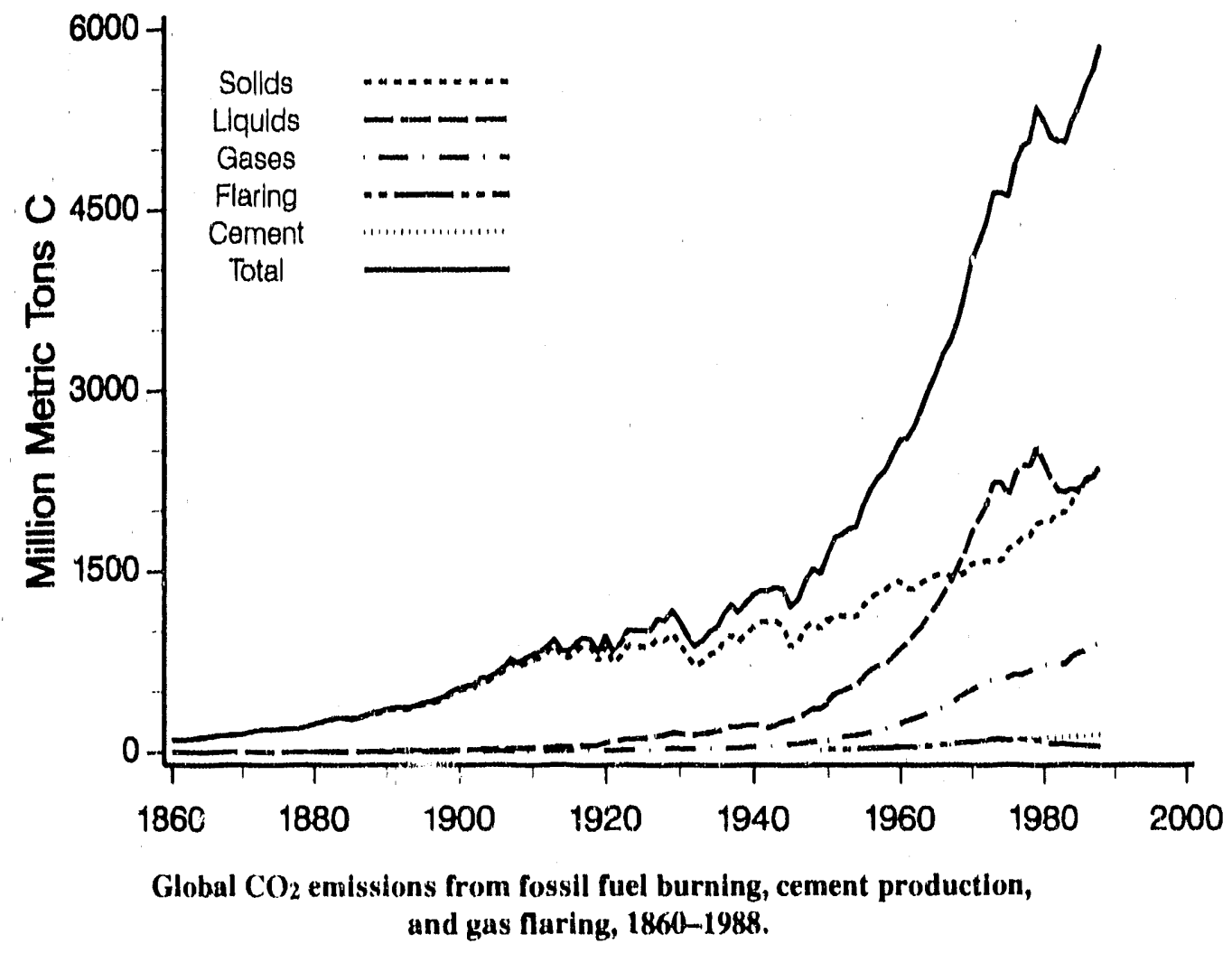




\section{Global}

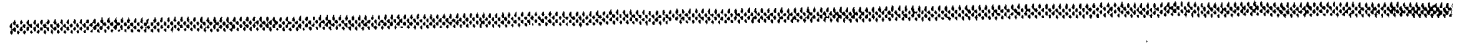

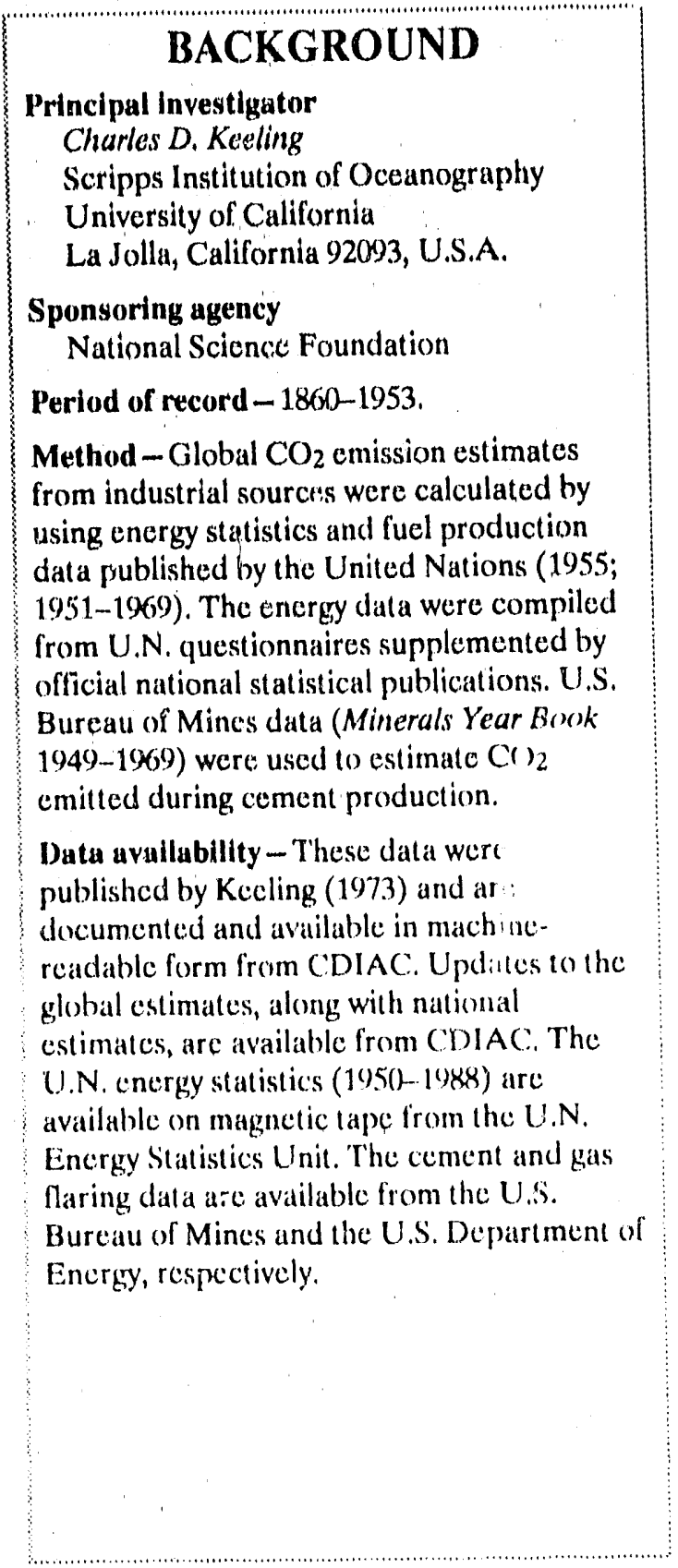

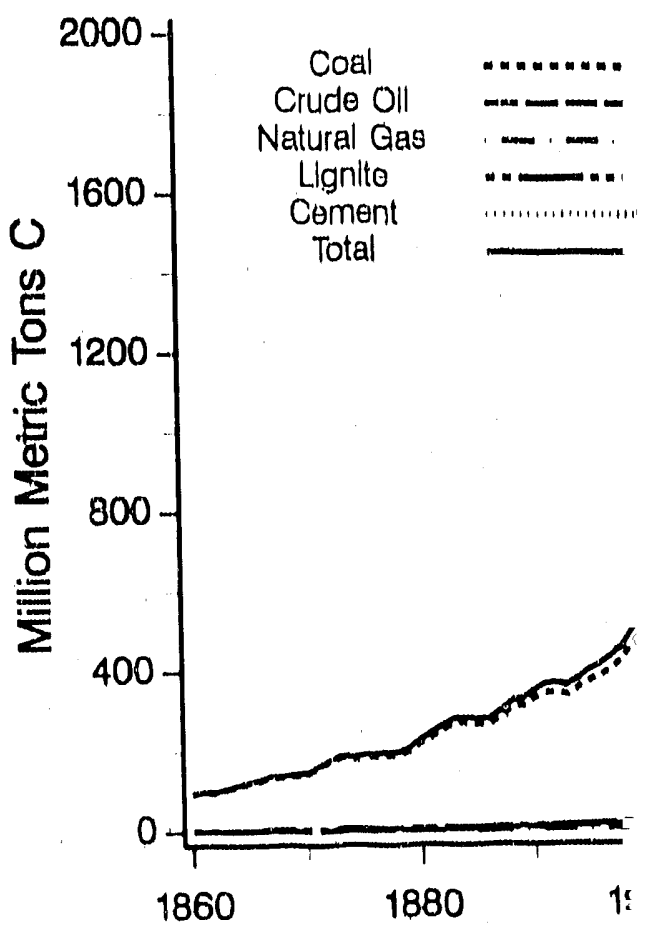

Annual $\left(\mathrm{C}_{2}\right.$ emissions from fossi

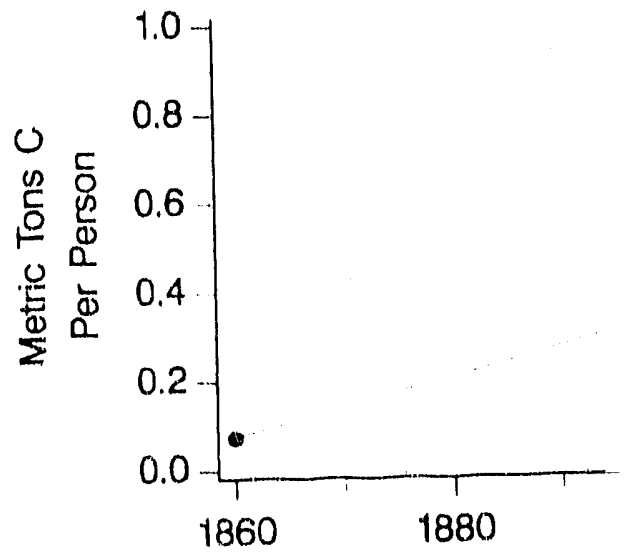

Global per capitn emis 


\section{$\mathrm{CO}_{2}$ Emissions}

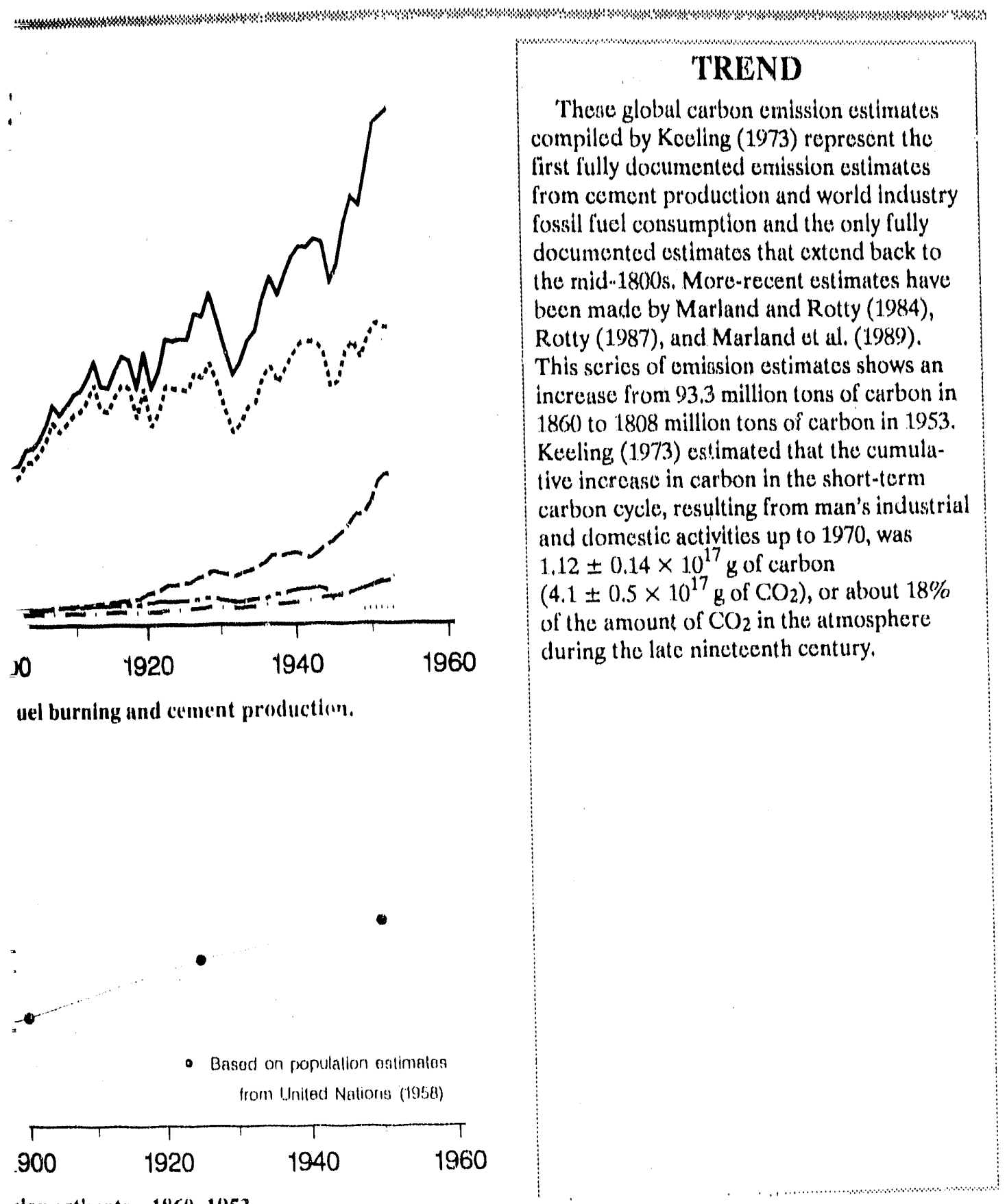

Ion estimates, 18601-1953. 


\section{Global}

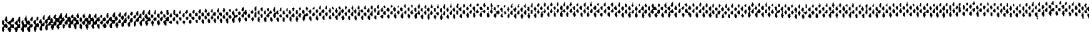

\begin{tabular}{|c|c|c|c|c|c|c|}
\hline Year & Conl & Idgnille & $\begin{array}{l}\text { Crucle } \\
\text { peiroleum }\end{array}$ & $\begin{array}{l}\text { Nuturn! } \\
\text { gus }\end{array}$ & $\begin{array}{l}\text { Cement } \\
\text { prodluctlont }\end{array}$ & 'I'olnI \\
\hline 1860 & 91.5 & 1.7 & 0.1 & 0.0 & NA & 93.3 \\
\hline 1861 & 96.7 & 1.8 & 0.2 & 0.0 & NA & 98.7 \\
\hline 1862 & 96.1 & 20 & 0.3 & 0.0 & NA & 98.4 \\
\hline 1863 & 103.5 & 2.1 & 0.3 & 0.0 & NA & 106,0 \\
\hline 1864 & 112.5 & 2.4 & 0.2 & 0.0 & NA & 115,1 \\
\hline 1865 & 119,0 & 2.6 & 0,3 & 0.0 & NA & 121.9 \\
\hline 1866 & 125.7 & 2.6 & 0.4 & 0,0 & NA & 1288.7 \\
\hline 1867 & 134.7 & 2.8 & 0.4 & 0.0 & NA & 137.9 \\
\hline 1868 & 133.3 & 3.0 & 0.4 & 0.0 & NA & 136.7 \\
\hline 1869 & 138.1 & 3.2 & 0.5 & 0.0 & NA & 141.8 \\
\hline 1870 & 141,0 & 3.4 & 0.6 & 0.0 & NA & 145.0 \\
\hline 1871 & 157.4 & 3.9 & 0.6 & 0.0 & NA & 161.9 \\
\hline 1872 & 170.9 & 4.3 & 0.7 & 0.0 & NA & 175,9 \\
\hline 1873 & 182.5 & 4.8 & 1,2 & 0.0 & NA & 188.4 \\
\hline 1874 & 177.3 & 5.3 & 1.2 & 0.0 & NA & 183.8 \\
\hline 1875 & 182.8 & 5.3 & 1.1 & 0.0 & NA & 189.2 \\
\hline 1876 & 184.9 & 5.5 & 1.2 & 0.0 & NA & 191.6 \\
\hline 1877 & 188.8 & 5.5 & 1.7 & 0.0 & NA & 196,0 \\
\hline 1878 & 188.9 & 5.7 & 1.9 & 0.0 & NA & 196.5 \\
\hline 1879 & 199.1 & 6.0 & 2.5 & 0.0 & NA & 207.6 \\
\hline $1880^{\circ}$ & 217.5 & 6.4 & 3.2 & 0.0 & NA & 227.1 \\
\hline 1881 & 234,0 & 6.8 & 3.4 & 0.2 & NA & 244.4 \\
\hline 1882 & 251.3 & 7.1 & 3.8 & 0.3 & NA & 262.5 \\
\hline 1883 & 268.8 & 7.6 & .3 .2 & 0.4 & NA & 280.0 \\
\hline 1884 & 269.9 & 7.8 & 3.6 & 0.6 & NA & 282.1 \\
\hline 1885 & $26,3.8$ & 8.0 & 3.8 & 0.8 & NA & 276.4 \\
\hline 1886 & 264.4 & 8.3 & 5.0 & 1.0 & NA & 278.7 \\
\hline 1887 & 282.8 & 8.6 & 5.0 & 1.3 & NA & 297.7 \\
\hline 1888 & 305.8 & 9.2 & 5.5 & 1.5 & NA & 321.9 \\
\hline 1889 & 310.5 & 9.8 & 6.5 & 1.7 & NA & 328.5 \\
\hline 1890 & 328.9 & 10.8 & 8.1 & 2.0 & NA & 349.7 \\
\hline 1891 & 342.2 & 11.5 & 9.6 & 2.0 & NA & 365.4 \\
\hline 1892 & 345.5 & 11.7 & 9.4 & 2.1 & NA & 368.7 \\
\hline 1893 & 337.6 & 12.2 & 9.7 & 2.2 & $\mathrm{NA}$ & 301.6 \\
\hline 1894 & 352.9 & 12.5 & 9,4 & 2.3 & NA & 377.1 \\
\hline 1895 & 371.7 & 13.6 & 10.9 & 2.4 & NA & 398.6 \\
\hline 1896 & 382.4 & 14.5 & 12.1 & 2.7 & NA & 411.6 \\
\hline 1897 & 400.0 & 15.7 & 12.8 & 3.0 & NA & 431.5 \\
\hline 1898 & 421.5 & 16.7 & 13.2 & 3.2 & NA & 454.6 \\
\hline 1899 & $4(12.2$ & 17.7 & 13.8 & 3.5 & NA & 497.3 \\
\hline 1900 & 485.6 & 19.8 & 15.8 & 3.7 & NA & $\$ 24.9$ \\
\hline 1901 & 497.2 & 21.3 & 17.7 & 4.1 & NA & 540.3 \\
\hline 1902 & .508 .5 & 20,9 & 19.1 & 4.4 & NA & 552.9 \\
\hline 1903 & 559.5 & 21.7 & 20.5 & 4.7 & NA & 606.4 \\
\hline 1904 & $56,3,0$ & 22.6 & 23.0 & 4.9 & NA & 613.4 \\
\hline 1905 & 594.2 & 24.1 & 22.7 & 5.6 & NA & 646,6 \\
\hline 1906 & 641.6 & 25.8 & 22.5 & 0.1 & $N A$ & 6.96 .1 \\
\hline
\end{tabular}


Global Carbon Dioxide Emission Estimates*

\begin{tabular}{|c|c|c|c|c|c|c|c|}
\hline Year & Total & Gas & Liquid & Solld & Cement & $\begin{array}{c}\text { Gas } \\
\text { naring }\end{array}$ & $\begin{array}{l}\text { Per } \\
\text { capila }\end{array}$ \\
\hline 1950 & 1638 & 97 & 423 & 1077 & 18 & 23 & 0.7 \\
\hline 1951 & 1775 & 115 & 479 & 1137 & 20 & 24 & 0.7 \\
\hline 1952 & 1803 & 124 & 504 & 1127 & 22 & 26 & 0.7 \\
\hline 1953 & 1848 & 131 & 533 & 1132 & 24 & 27 & 0.7 \\
\hline 1954 & 1871 & 138 & 557 & 1123 & 27 & 27 & 0.7 \\
\hline 1955 & 2050 & 150 & 625 & 1215 & 30 & 31 & 0.7 \\
\hline 1956 & 2185 & 161 & 679 & 1281 & 32 & 32 & 0.8 \\
\hline 1957 & 2278 & 178 & 714 & 1317 & 34 & .35 & 0.8 \\
\hline 1958 & 2238 & 192 & 732 & 1344 & 36 & 35 & 0.8 \\
\hline 1959 & 2471 & 214 & 790 & 1390 & 40 & 36 & 0.8 \\
\hline 1960 & 2586 & 235 & $850^{\circ}$ & 1419 & 43 & 39 & 0.9 \\
\hline 1961 & 2602 & 254 & 905 & 1356 & 45 & 42 & 0.9 \\
\hline 1962 & 2708 & 277 & 981 & 1358 & 49 & 44 & 0.9 \\
\hline 1963 & 2855 & 300 & 1053 & 1404 & s1 & 47 & 0.9 \\
\hline 1964 & 3016 & 328 & 11.38 & 1442 & 57 & 51 & 0.9 \\
\hline i965 & 3154 & 351 & 1221 & 1468 & 59 & 55 & 1.0 \\
\hline 1966 & 3314 & 380 & 1325 & 1485 & 63 & 60 & 1.0 \\
\hline 1967 & 3420 & 410 & 1424 & 1455 & 65 & 66 & 1.0 \\
\hline 1968 & 3596 & 445 & 1552 & 1456 & 70 & 73 & 1.0 \\
\hline 1969 & 3809 & 487 & 1674 & 1494 & 74 & 80 & 1.1 \\
\hline 1970 & 4090 & 515 & 1838 & 1571 & 78 & 87 & 1.1 \\
\hline 1971 & 4241 & 553 & 1946 & 1571 & 84 & 88 & 1.1 \\
\hline 1972 & 4409 & 582 & 2056 & 1587 & 89 & 95 & 1.2 \\
\hline 1973 & 4647 & 607 & 2240 & 1594 & 95 & 110 & 1.2 \\
\hline i974 & 4655 & 616 & 2244 & 1591 & 96 & 108 & 1.2 \\
\hline 1975 & 4628 & 620 & 2131 & 1686 & 95 & 95 & 1.1 \\
\hline 1976 & 4894 & 644 & 2313 & 1723 & 103 & 111 & 1.2 \\
\hline 1977 & 5034 & 645 & 2390 & 1786 & 108 & 105 & 1.2 \\
\hline 1978 & 5082 & 673 & 2383 & 1802 & 116 & 107 & 1.2 \\
\hline 1979 & 5365 & 713 & 2535 & 1899 & 119 & 100 & 1.2 \\
\hline 1980 & 5263 & 724 & 2409 & 1921 & 120 & 89 & 1.2 \\
\hline 1981 & 5129 & 734 & 2272 & 1930 & 121 & 72 & 1.1 \\
\hline 1982 & 5093 & 732 & 2178 & 1993 & 121 & 70 & 1.1 \\
\hline 1983 & 5084 & 735 & 2163 & 1998 & 125 & 63 & 1.1 \\
\hline 1984 & 5260 & 796 & 2191 & 2088 & 128 & 57 & 1.1 \\
\hline 1985 & 5379 & 826 & 2172 & 2196 & 130 & 55 & 1.1 \\
\hline 1986 & 5561 & 842 & 2277 & 2253 & 136 & 53 & 1.1 \\
\hline 1987 & 5680 & 888 & 2290 & 2313 & 142 & 48 & 1.1 \\
\hline 1988 & 5893 & 919 & 2392 & 2385 & 150 & 48 & 1.2 \\
\hline
\end{tabular}

"Emission estimates rounded and expressed in million metric tons of carbon; per capita estimates rounded and expressed in metric tons of carbon. 


\section{REFERENCES}

Keeling, C.D. 1973. Industrial production of carbon dioxide from fossil fucls and limestone. Tellus 25:174-198.

Marland, G., and R.M. Rotly. 1984. Carbon dioxide emissions from fossil fuels: $A$ procedure for estimation and results for 1950-1982. Tellus 36(B):232-61.

Marland, C., T.A. Boden, R.C. Griffin, S.F. Huang, P. Kanciruk, and T.R. Nelson. 1989. Estimates of $\mathrm{CO}_{2}$ omissions from fossil fuel buming and cenem mamufacturing based on the United Nations e'neryy statistics and the U.S. Bureau of Mines cement mantacturing data. ORNL/CDIA(-25, NDP-()3). ()ak Ridge National Laboratory, ()ak Ridge, Tennessec.

Rotty, R.M., and (i. Marland. 1986. Fossil fucl combustion: recent amounts, patterns, and trends of (C)2. pp. 484-500. IN I.R. Trabalka and D).E. Reichle (eds.), The Changing Carbon Cycle: A Cilobal Analysis, springer-Verlag.

United Nations, 1989. Enengy Statistics Yearbook 1987. United Nations Department of International Economic and Social Affairs, Statistical ()ffice, New York.

U.S. Burcat of Mines. 1988. Minerals Yearbook. Vol. I, Melals, Mincrals, and Fucls. Washington, D.C

U.S. Department of Energy. 1988. International Energn Anmual. D()E! EIA-()219(88). Fnergy Information Administration, Washinglon, D.C:

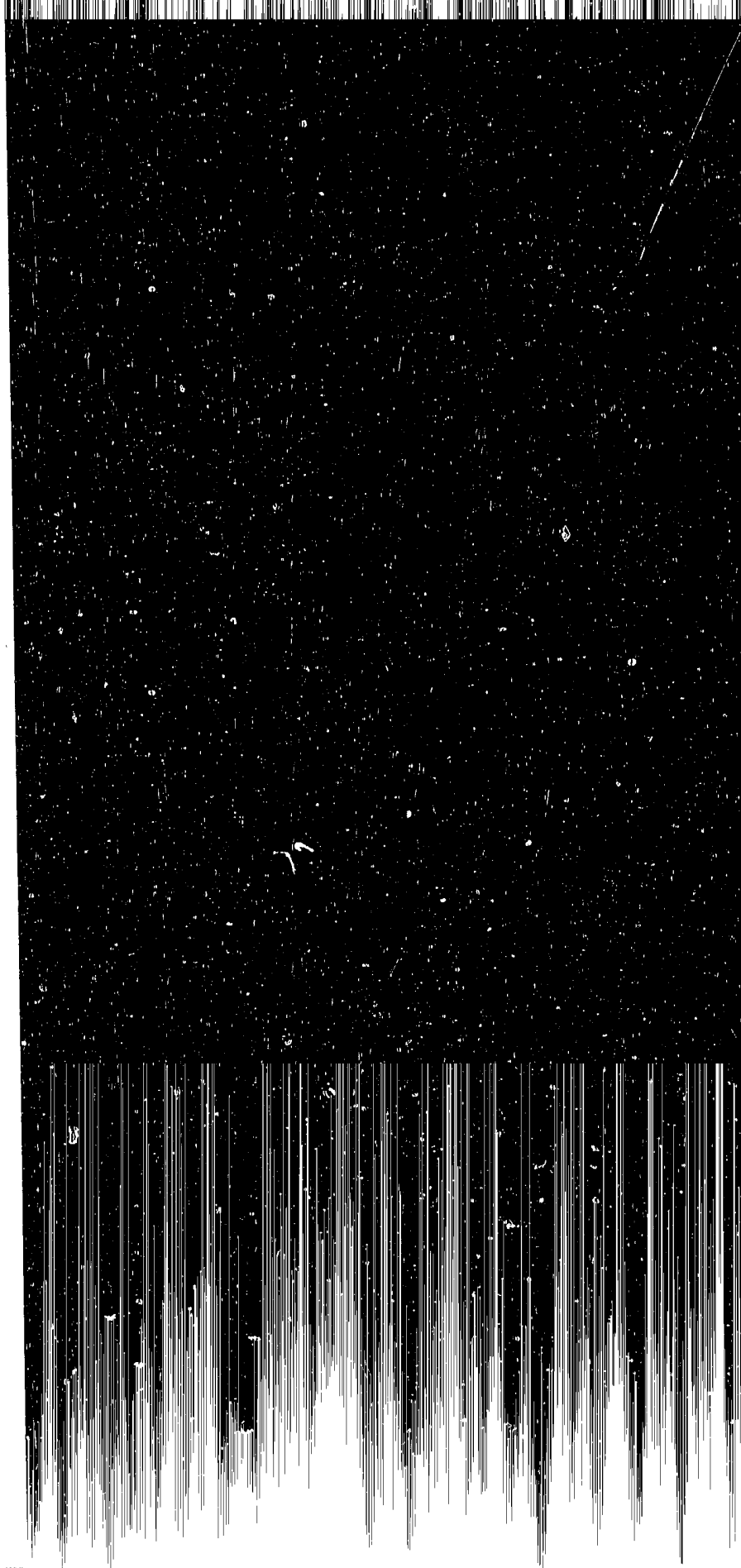




\section{United States}

\begin{tabular}{|c|}
\hline BACKGROUND \\
\hline $\begin{array}{l}\text { Principal investigator } \\
\text { Gregg Marland } \\
\text { Environmental Sciences Division } \\
\text { Oak Ridge National Laboratory } \\
\text { Oak Ridge, Tennessee } 37831-6335 \\
\text { U.S.A. }\end{array}$ \\
\hline $\begin{array}{l}\text { Sponsoring agency } \\
\text { U.S. Department of Energy } \\
\text { Carbon Dioxide Research Program }\end{array}$ \\
\hline Period of record - 1950-1988. \\
\hline $\begin{array}{l}\text { Method - Global } \mathrm{CO}_{2} \text { emission estimates } \\
\text { derived primarily from the U.N. energy } \\
\text { statistics were calculated by using the } \\
\text { methods of Marland and Rotty. (1984). The } \\
\text { energy data were compiled from U.N. } \\
\text { questionnaires supplemented by national } \\
\text { statistical publications. Data from the U.S. } \\
\text { Bureau of Mines were used to estimate } \mathrm{CO}_{2} \\
\text { emitted during cement production. } \\
\text { Emissions from gas flaring were derived } \\
\text { primarily from U.N. data but were } \\
\text { supplemented with data from the U.S. } \\
\text { Department of Energy and with a few global } \\
\text { and national estimates provided by Gregg } \\
\text { Marland. }\end{array}$ \\
\hline $\begin{array}{l}\text { Data availability - Global and national } \mathrm{CO}_{2} \\
\text { emission estimates, along with the data used } \\
\text { in calculating these estimates, are } \\
\text { documented and available from CDIAC } \\
\text { (Marland et al. 1989). The U.N. energy } \\
\text { statistics are available on magnetic tape } \\
\text { from the U.N. Energy Statistics Unit. The } \\
\text { cement and gas flaring data are available } \\
\text { from the U.S. Bureau of Mines and the U.S. } \\
\text { Department of Energy, respectively. }\end{array}$ \\
\hline
\end{tabular}
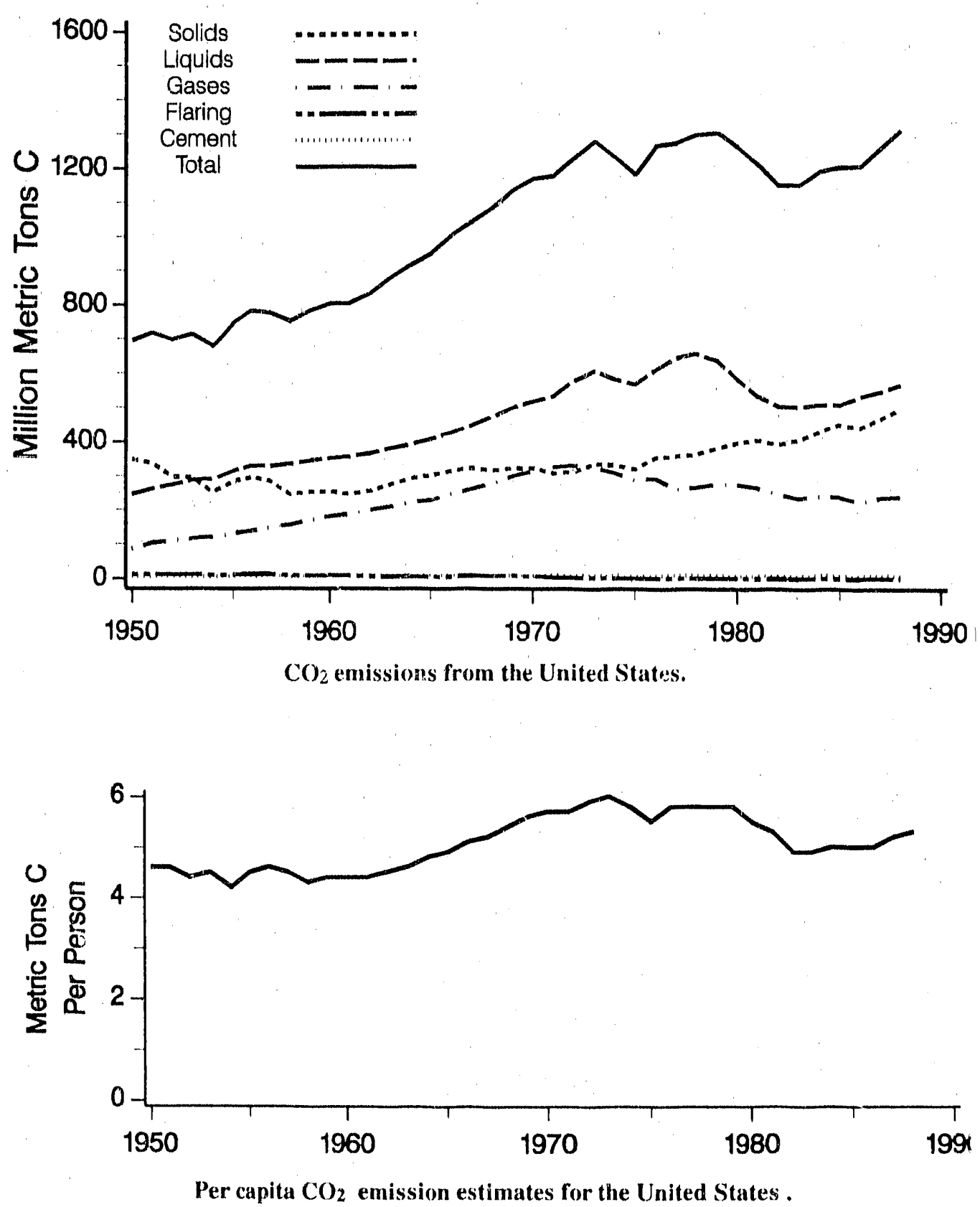


\section{United States}

\section{Carbon Dioxide Emission Estimates*}

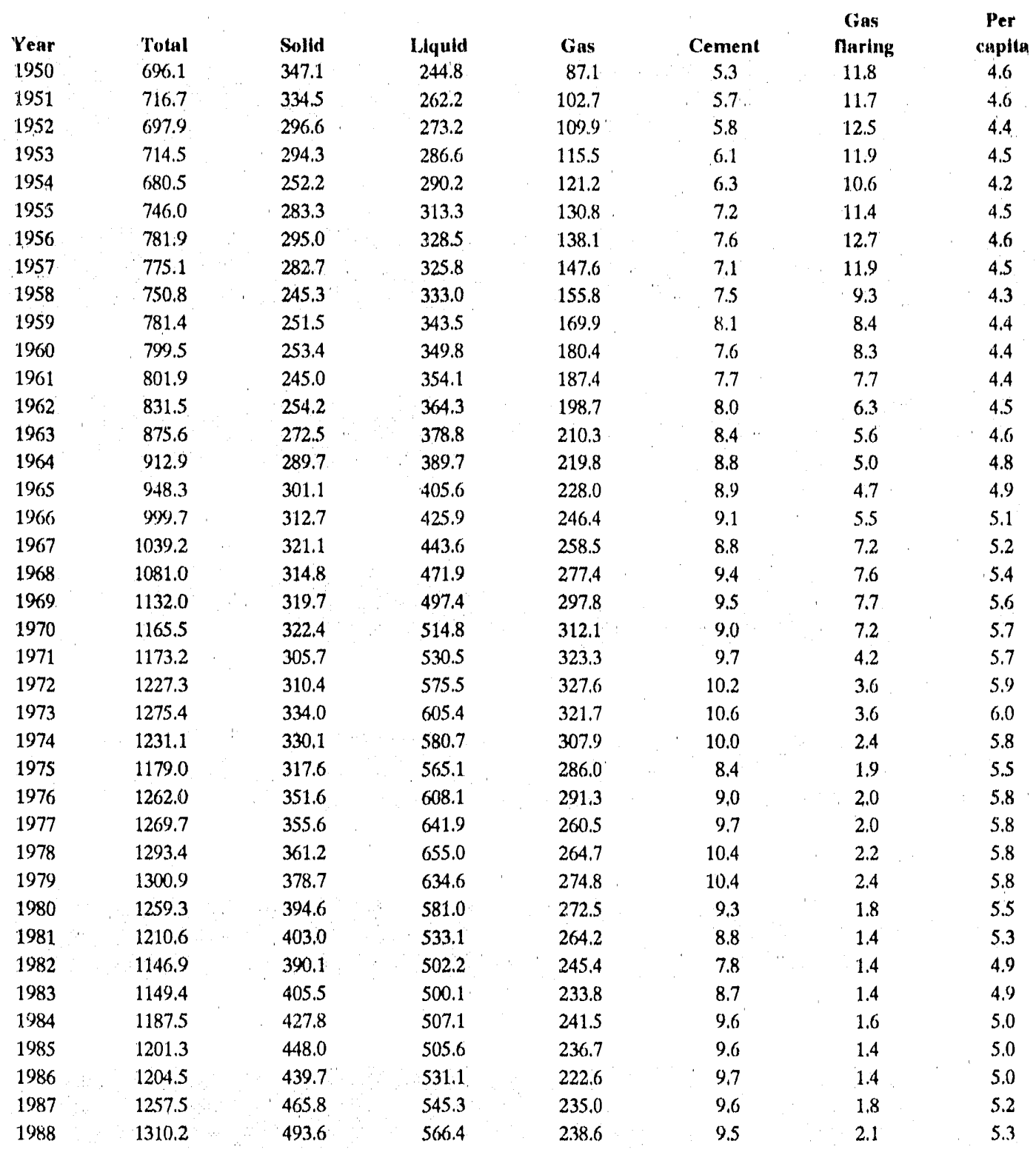

expressed in metric tons of carbon. 


\section{Union of Soviet Socialist Republics}

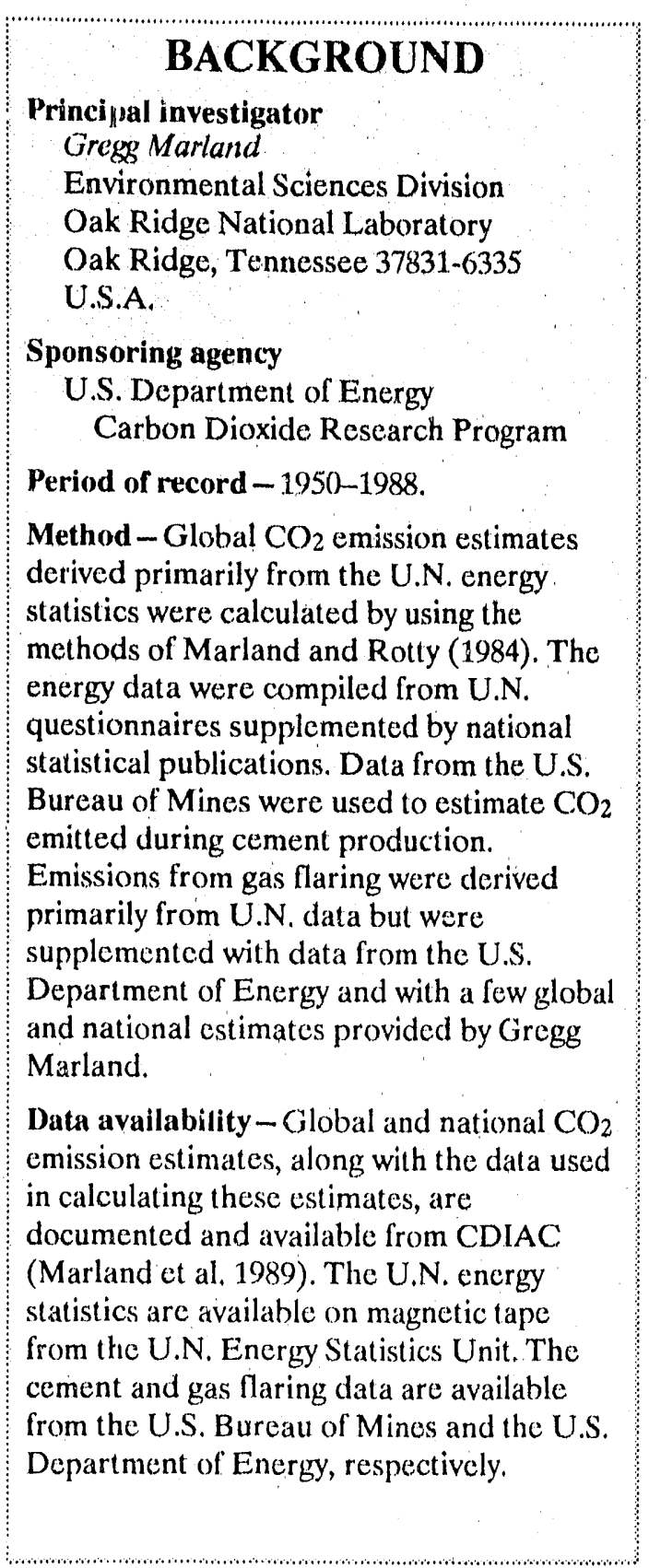

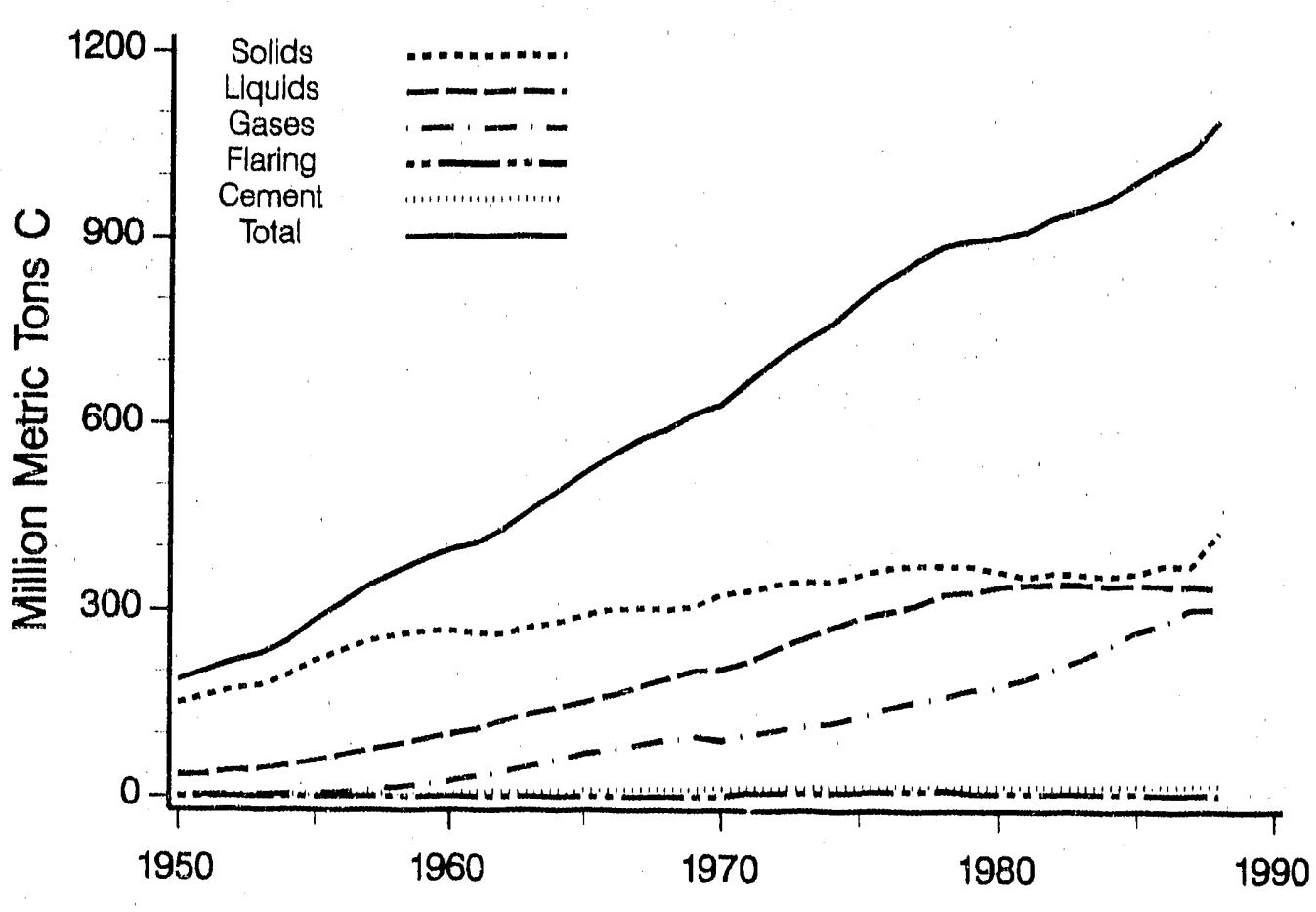

$\mathrm{CO}_{2}$ emissions from the Union of Soviet Socialist Republics.

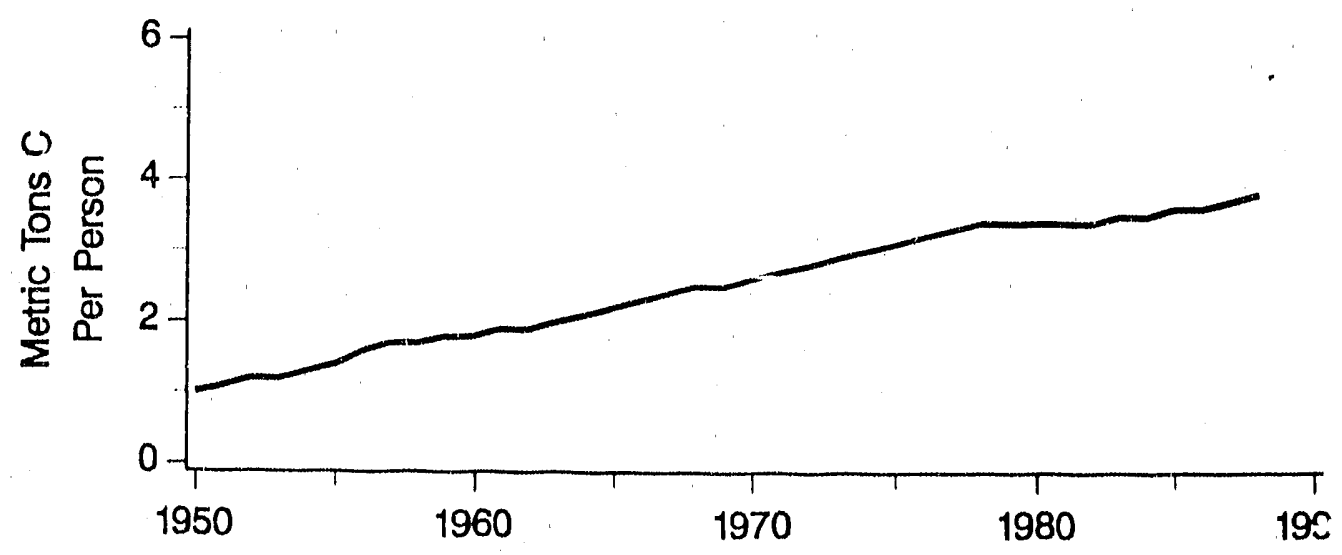

Per capita $\mathrm{CO}_{2}$ emission estimates for the Union of Soviet Socialist Republics. 


\section{$\mathrm{CO}_{2}$ Emissions}

\section{TREND}

$\mathrm{CO}_{2}$ emissions from the U.S.S.R. increased $4.7 \%$ from 1987 to 1988 , continuing the virtually unbroken trend of $4.5 \%$ annual growth that has been maintained since 1950 . During that interval, the U.S.S.R. share/contribution has increased from 11 to $18 \%$ of total global emissions. Recent growth has resulted largely from rapid exploitation of huge natural gas resources, and $28 \%$ of Soviet emissions now come from natural gas. Since 1950, the contribution of coal has shrunk from 80 to $39 \%$ of total emissions, and both coal and petroleum have been static over the last decade. Per capita emissions continue to grow and are now 31\% higher than in 1973 and $13 \%$ higher than in 1979. Gas flaring data for the U.S.S.R. are poor and partly estimated, but gas flaring contributes only a small fraction of total emissions - only $0.4 \%$ in 1988.

Note - Growth rates were calculated (before rounding) by performing a linear regression of $\log \mathrm{CO}_{2}$ emissions versus time and calculating the slope of the regression line. 
Carbon Dioxide Emission Estimates*

\begin{tabular}{|c|c|c|c|c|c|c|c|}
\hline Year & Total & Sollid & Llquild & Gas & Cement & $\begin{array}{l}\text { Gas } \\
\text { naring }\end{array}$ & $\begin{array}{l}\text { Per } \\
\text { capit }\end{array}$ \\
\hline 1950 & 185.8 & 148.6 & 32.7 & 31 & 1,4 & $0.0^{\circ}$ & 1.0 \\
\hline 1951 & 201.4 & 161.1 & 35.2 & 3.4 & 1.7 & 0.0 & 1.1 \\
\hline 1952 & 215.7 & 170,6 & 39.7 & 3.4 & 1.9 & 0.0 & 1.2 \\
\hline 1953 & 228.1 & 178.4 & 43.9 & 3.7 & 2.2 & 0.0 & 1.2 \\
\hline 1954 & 249.1 & 193.8 & 48.7 & 4.0 & 2.6 & 0.0 & 1.3 \\
\hline 1955 & 282.8 & 217.9 & 57.1 & 4.8 & 3.1 & 0.0 & 1.4 \\
\hline 1956 & 310.1 & 234.1 & 66.2 & 6.5 & 3.4 & 0.0 & 1.6 \\
\hline 1957 & 338.9 & 250.4 & 74.5 & 10.1 & 3.9 & 0.0 & 1.7 \\
\hline 1958 & 361.7 & 258.9 & 83.3 & 15.0 & 4.5 & 0.0 & 1.7 \\
\hline 1959 & 380.3 & 264.9 & 91.0 & 19.2 & 5.3 & 0.0 & 1.8 \\
\hline 1960 & 396.1 & 266.0 & 99.5 & 24.4 & 6.2 & 0.0 & 1.8 \\
\hline 1961 & 408.5 & 262.1 & 107.8 & 31.6 & 6.9 & 0.0 & 1.9 \\
\hline 1962 & 428.8 & 261.1 & 120.5 & 39,4 & 7.8 & 0.0 & 1.9 \\
\hline 1963 & $459.6^{\circ}$ & 271.0 & 132.1 & 48.2 & 8.3 & 0.0 & 2.0 \\
\hline 1964 & 488.7 & 279.5 & 141.7 & 58.7 & 8.8 & 0.0 & 2.1 \\
\hline 1965 & 518.5 & 289.5 & 151.2 & 68.0 & 9.8 & 0.0 & 2.2 \\
\hline 1966 & 547.7 & $299 . j$ & 161.9 & 75.4 & 10.9 & 0.0 & 2.3 \\
\hline 1967 & 572.5 & 302.2 & 176.4 & 82.6 & 11.5 & 0.0 & 2.4 \\
\hline 1968 & 588.7 & 299.4 & 187.9 & 89.5 & 11.9 & 0.0 & 2.5 \\
\hline 1969 & 613.1 & 303.8 & 201.3 & 95.8 & 12.2 & 0.0 & 2.5 \\
\hline 1970 & 628.2 & 323.3 & 203.2 & 88.8 & 13.0 & 0.0 & 2.6 \\
\hline 1971 & 666.8 & 330.1 & 216.7 & 100.5 & 13.6 & 5.9 & 2.7 \\
\hline 1972 & 701.2 & 340.1 & 235.6 & 105.7 & 14.2 & 5.7 & 2.8 \\
\hline 1973 & 730.5 & 343.8 & 253.4 & 111.7 & 14.9 & 6.8 & 2.9 \\
\hline 1974 & 757.8 & 344.9 & 271.4 & 118.4 & 15.7 & 7.4 & 3.0 \\
\hline 1975 & 795.9 & 355.3 & 286.4 & 129.3 & 16.6 & 8.2 & 3.1 \\
\hline 1976 & 828.3 & 365.4 & 294.7 & 142.2 & 16.9 & 9.2 & 3.2 \\
\hline 1977 & 857.3 & 371.3 & 306.2 & 152.6 & 17.3 & 9.9 & 3.3 \\
\hline 1978 & 882.5 & 370.0 & 324.5 & 160.1 & 17.3 & 10.6 & 3.4 \\
\hline 1979 & 890.6 & 370.0 & 327.6 & 170.5 & 16.7 & 5.8 & 3.4 \\
\hline 1980 & 895.5 & 359.6 & 335.8 & 177.3 & 17.0 & 5.8 & 3.4 \\
\hline 1981 & 906,0 & 352.3 & 340.2 & 190.5 & 17.3 & 5.8 & 3.4 \\
\hline 1982 & 929.4 & 358.9 & 342.4 & 205.5 & 16.8 & $5 . \%$ & 3.4 \\
\hline 1983 & 941.4 & 356.6 & 340.9 & 220.9 & 17.4 & 5.6 & 3.5 \\
\hline 1984 & 959.3 & 354.0 & 338.8 & 243.2 & 17.7 & 5.6 & 3.5 \\
\hline 1985 & 987.6 & 358.4 & 340.2 & 265.3 & 17.8 & 5.9 & 3.6 \\
\hline 1986 & 1014.2 & 372.4 & 339.2 & 279.1 & 18.4 & 5.2 & 3.6 \\
\hline 1987 & 1036.4 & 371.3 & 339.2 & 302.4 & 18.7 & 4.8 & 3.7 \\
\hline $198 \%$ & 1086.0 & 425.3 & 334.4 & 302.6 & 18.9 & 4.8 & 3.8 \\
\hline
\end{tabular}

\section{REFERENCES}

Koeling, ( D. . 1973. Industrial production of carbon dioxide from fossil fuels and limestone. Te'llus 25:174-198

Marland, G., and R.M. Rolly. 1984. Carhon dioxide comissions from fossil fuels: A procedure for estimation and results for 195(1)-1982. Telllus 36(B):232-61)

Marland, G., T.A. Bodden, R.C. (iriffin, S.F. Huang, P. Sanciruk, and T.R. Nelson, 1989. Estimates of $\mathrm{CO}_{2}$ cmissions from

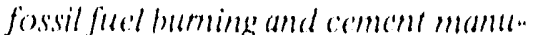
fasturing based on the United Nations. entergy statistics and the U.S. Burrem of Minces cement mamufacturing data. ()RNL/( DIAC(-25, NDP-(1)3(). ()ak Ridge National Laboratory, ()ak Ridge. Tennessee:

Rotly, R.M., and (i. Marlind 1980. Fonsil lucl combustion: recent imounts, pallerns, and trends of $\left(\mathrm{C}_{2}, \mathrm{mp}, 484 \mathrm{~s}, 50(1 \mathrm{~N}\right.$ J.R. Iratbalka and D.E. Reichle (cols.)

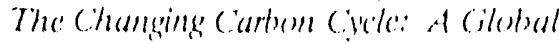
Analwsis, springer-Verlag

United Nattions, 1989. Encrgy' Stutistic: Yecarbook 1957. United Nations Department of Intermational Econtimic and Social Affairs, Statistical office. New York.

U.S. Burcau of Mines. 1988. Mineruls Yearbook. Vol. 1, Metals, Minerals, and Fudeds. Washingt on, D.C.

U.S. Department of Encrgy, 1988. International Energy Annual. D)( DE/ LIA-()219(88). Energy Information Administration, Washington, D.C. 


\section{People's Republic of China}

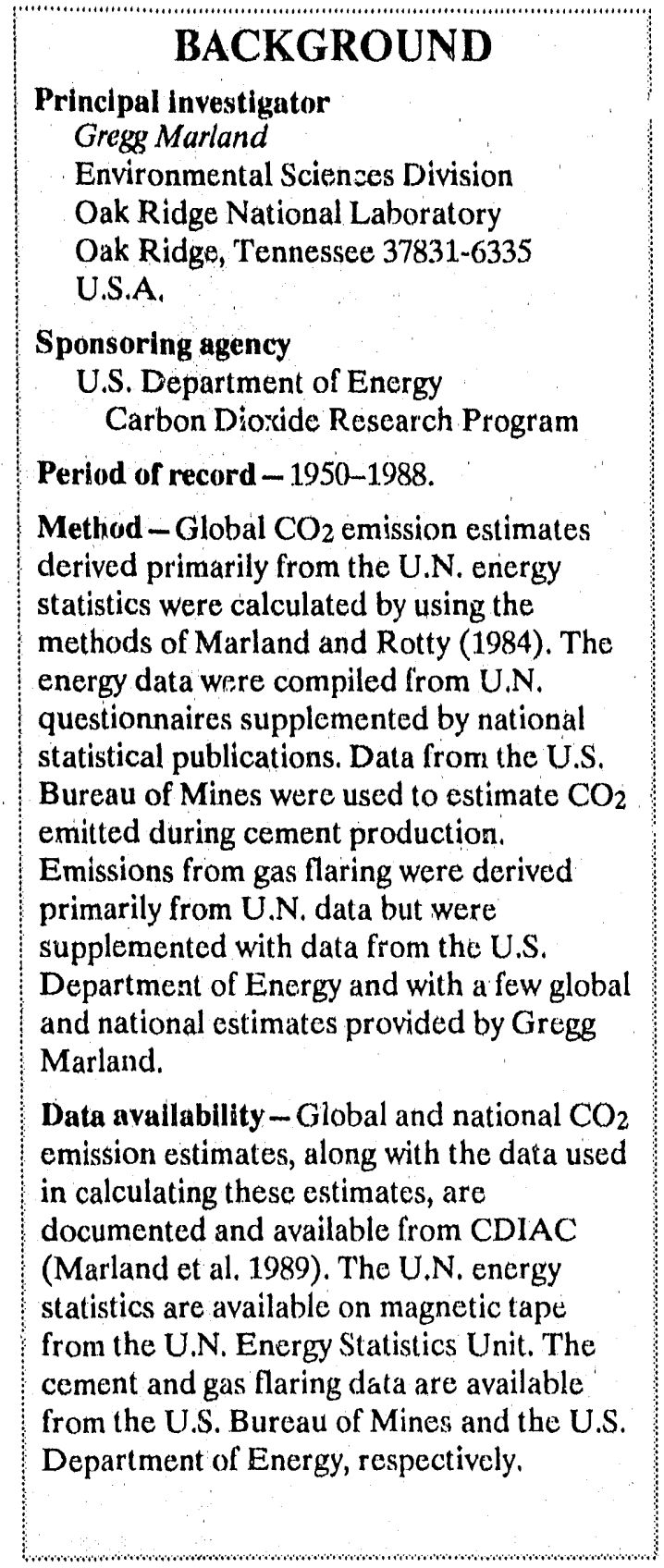

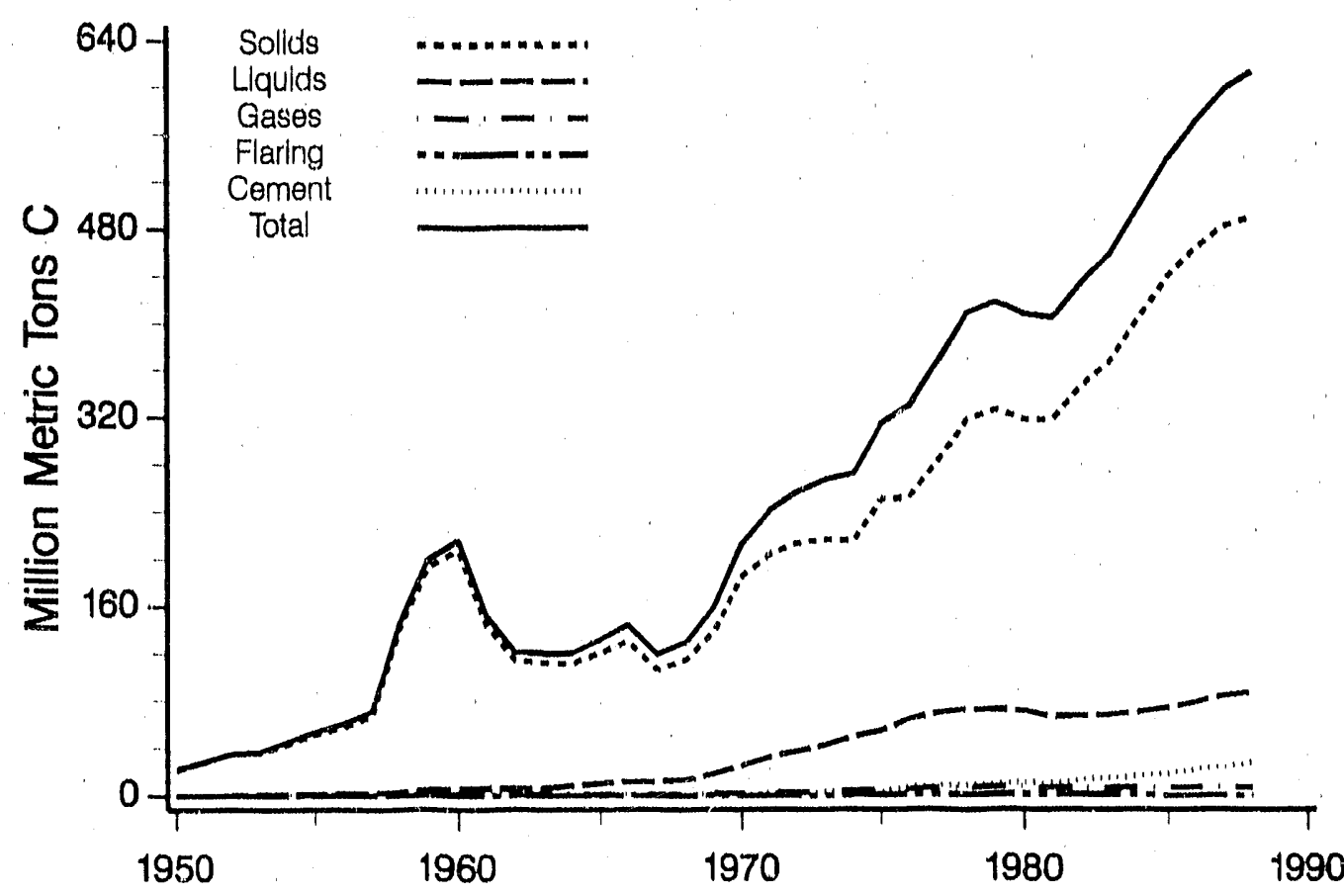

$\mathrm{CO}_{2}$ emissions from the People's Republic of China.

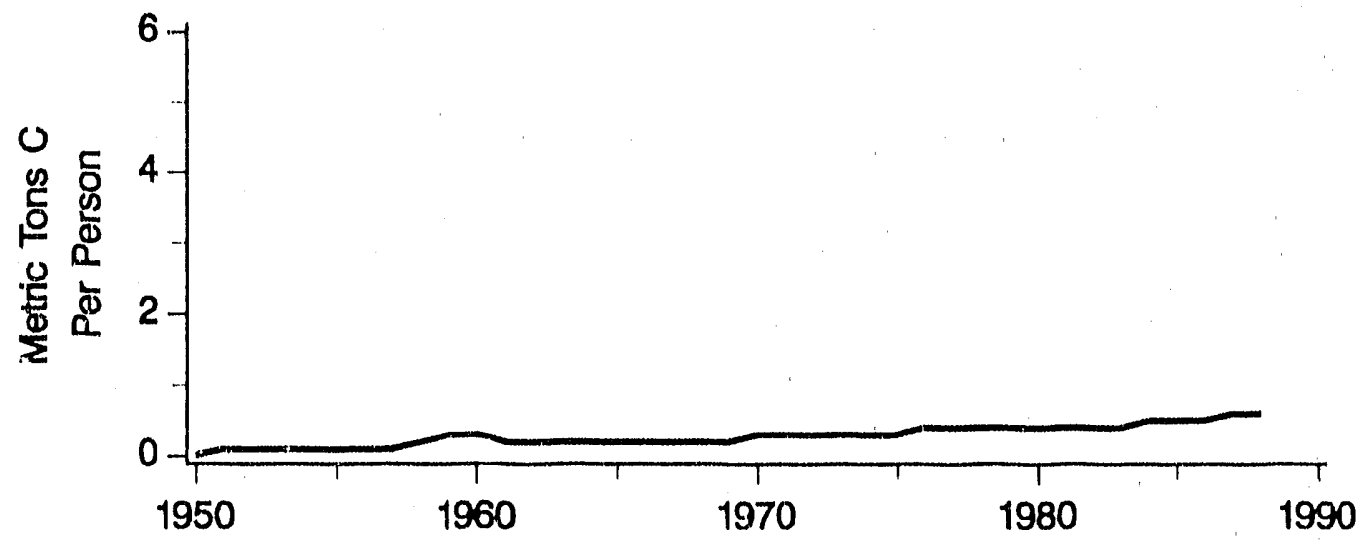

Per capita $\mathrm{CO}_{2}$ emission estimates for the People's Republic of China. 


\section{$\mathrm{CO}_{2}$ Emissions}

\section{TREND}

Chinese emissions of $\mathrm{CO}_{2}$ have grown phenomenally since 1950, when China stood tenth among nations. Per capita emissions increased by a factor of 14.2 over this interval, and, combined with a doubling of population, total $\mathrm{CO}_{2}$ emissions in 1988 were 28.1 times the 1950 level. Growth has been largely in the use of coal, which accounted for $99 \%$ of the total in 1950 and still $80 \%$ in 1988. Liquid fuels now contribute $14 \%$ of emissions, but growth has been stalled since about 1978. The anomalous peak in the data for 1958-1961 is common in Chinese data. These years are part of the period of "The Great Leap Forward," and it is not clear whether the anomaly represents a real event in $\mathrm{CO}_{2}$ emissions or a data residual. Growth from 1967 to 1988 has been fairly regular at $7.2 \%$ per year with a minor offset in 1980-1981.

Note-Growth rates were calculated (before rounding) by performing a linear regression of $\log \mathrm{CO}_{2}$ emissions versus time and calculating the slope of the regression line. 


\section{People's Republic of China}

\section{Carbon Dioxide Emission Estimates*}

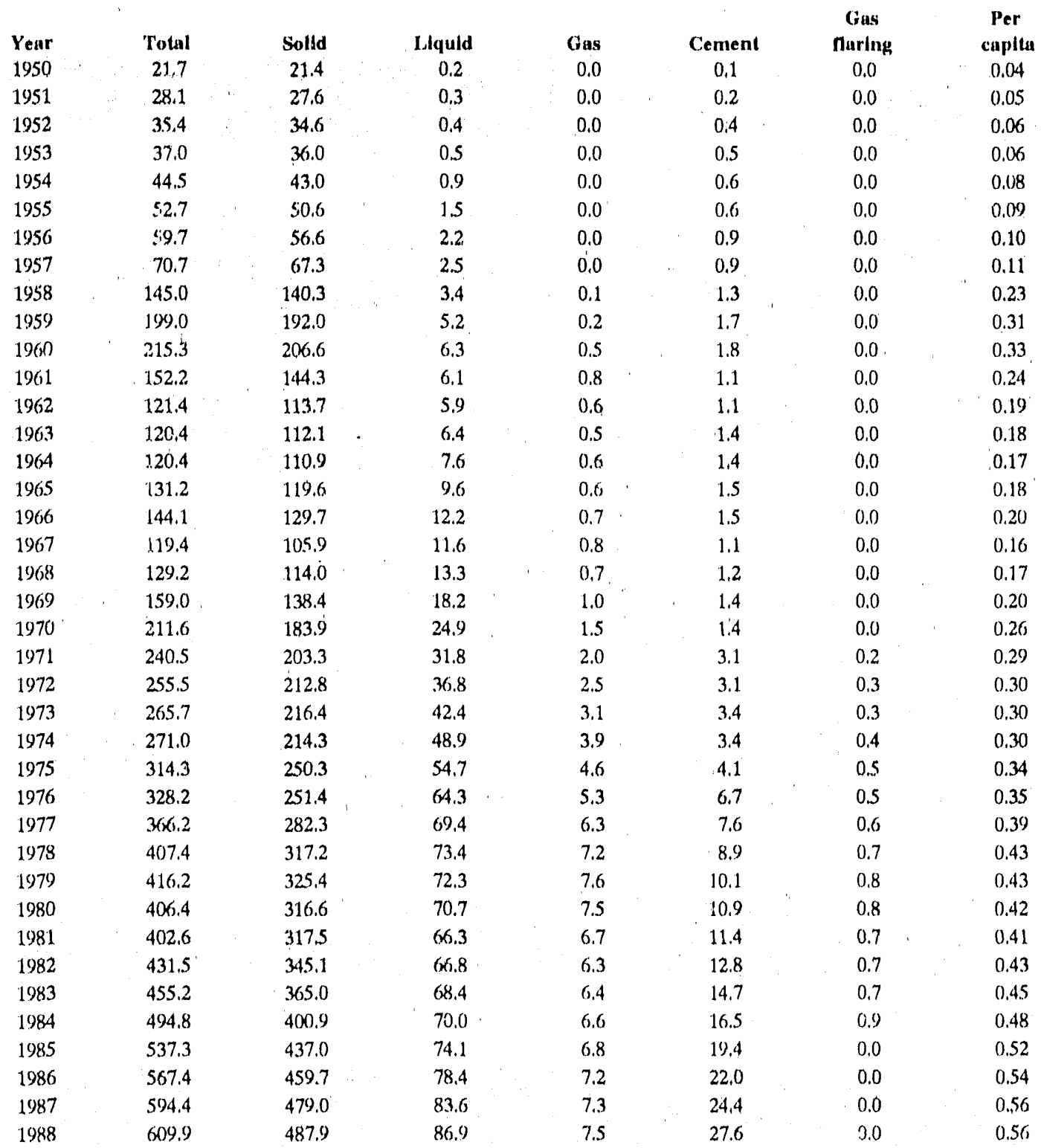




\section{$\mathrm{CO}_{2}$ Emissions}

\section{REFERENCES}

Keeling, C.L. 1973. Industrial production of carbon dioxide from fossil fucls and limestone. Tellus 5:174-198.

Marland, G., and R.M. Rotty. 1984. Carbon dioxide emissions from fossil fuels: A procedure for estimation and results for 1950-1982. Tellus 36(B):232-61.

Marland, G., T.A. Boden, R.C. Griffin, S.F. Huang, P. Kanciruk, and T.R. Nelson. 1989. Estimates of $\mathrm{CO}_{2}$ emissions from fossil fuel buming and cement mamufacturing, based on the United Nations energy siatistics and the U.S. Bureau of Mines cement manufacturng data. ORNL/CDIAC-25, NDP-()30. Oak Ridge National Laboratory, Oak Ridge, Tennessee.

Rotty, R.M., and G. Marland. 1986. Fossil fuel combustion: recent aniounts, patterns, and trends of $\mathrm{CO}_{2} . \mathrm{pp}, 484-500$. IN J.R. Trabalka and D.E. Reichle (eds.), The Changing Carbon Cycle: A Gbobal Analysis, Springer-Verlag.

United Nations. 1989. Enengy Statistics Yearbook 1987. United Nations Department of 'nternational Economic and Social Affairs, Statistical Office, New York.

U.S. Bureau of Mines. 1988. Mincrals Yearbrin. Vol. 1, Metals, Minerals, and Futels. Washington, D.C.

U.S. Department of Energy. 1988. International Energy Anmlal. D()E/ EIA-10219(88). Encrgy Information Administration, Washington, D.C. 


\section{Japan}

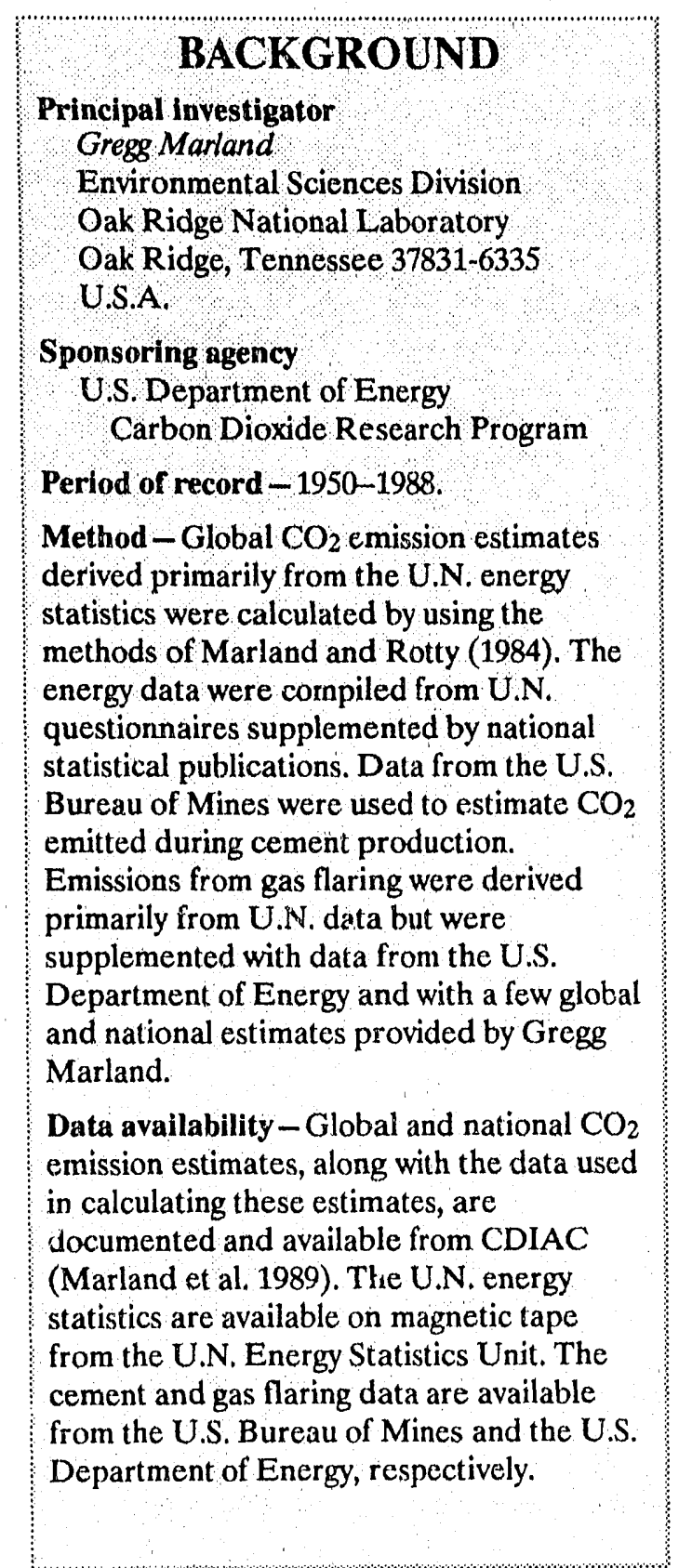
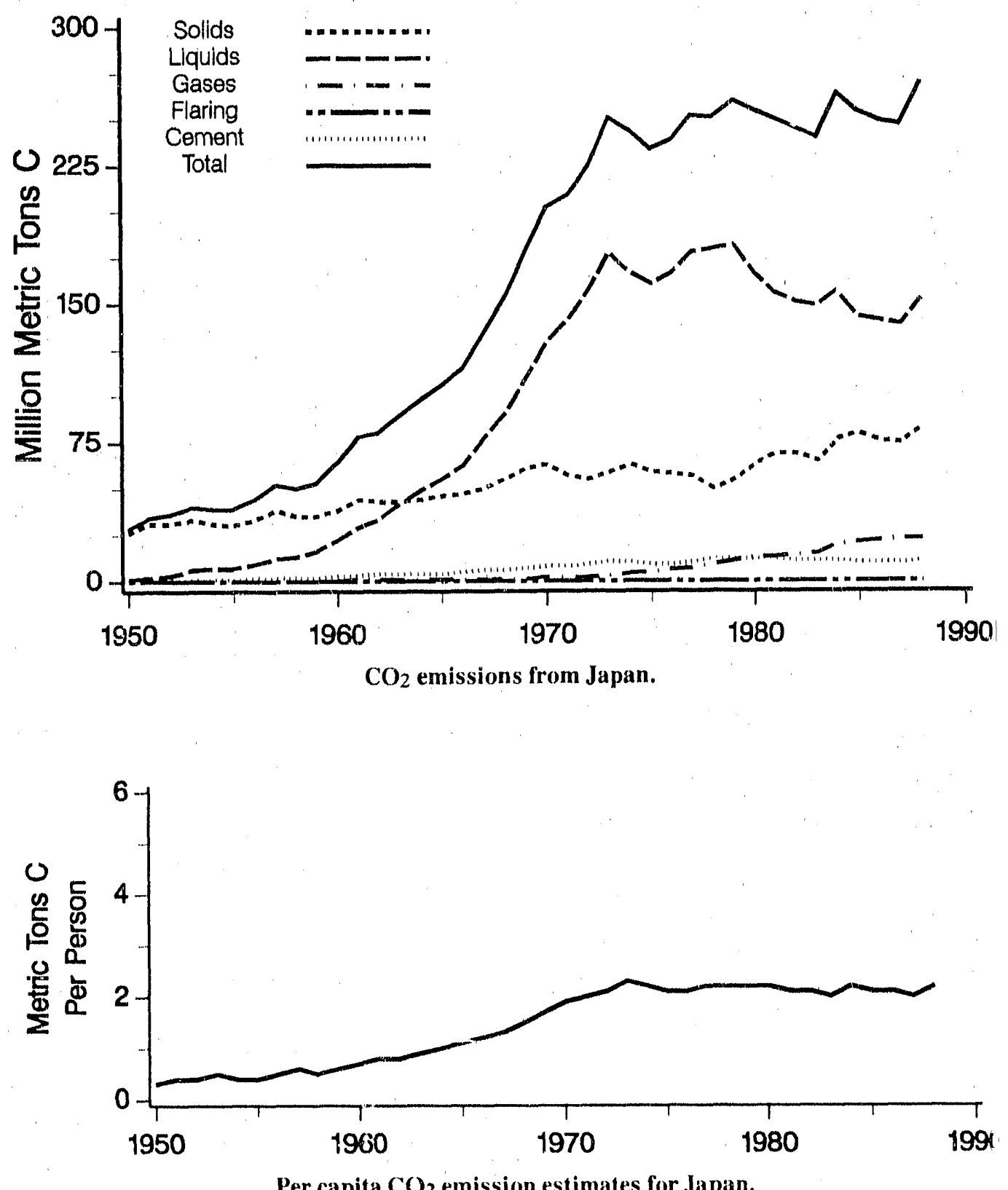


\section{$\mathrm{CO}_{2}$ Emissions}

\section{TREND}

The history of $\mathrm{CO}_{2}$ emissions from Japan is remarkable for the abrupt change that occurred in 1973. With postwar growth at $9.6 \%$ per year from 1950 to 1973 , total emissions have been virtually constant since 1973. Rising consumption of liquid petroleum products halted in 1973, and constant $\mathrm{CO}_{2}$ emissions reflect the increasing contributions of coal and natural gas as the petroleum share has shrunk from $71 \%$ in 1973 to $57 \%$ in 1988 . Japan is the world's largest consumer of liquified natural gas aixu' imported over 39 billion cubic meters in 1987. Per capita emissions are approac hing levels comparable to the 1973 maximum although they are 7 times larger than the very low value that prevailed in 1950 .

Note-Growtn rates were calculated (before rounding) by performing a linear regression of $\log \mathrm{CO}_{2}$ emissions versus time and calculating the slope of the regression line. 
Carbon Dioxide Emission Estimates*

\begin{tabular}{|c|c|c|c|c|c|c|c|}
\hline Year & Total & Solid & Liquild & Gas & Cement & $\begin{array}{l}\text { Gas } \\
\text { Flaring }\end{array}$ & $\begin{array}{l}\text { Per } \\
\text { Cappltt. }\end{array}$ \\
\hline $\begin{array}{l}\text { rear } \\
1950\end{array}$ & 28.3 & 26.4 & 1.2 & 0.0 & 0.6 & 0.0 & 0.3 \\
\hline 1951 & 34.0 & 30,6 & 2.5 & 0.0 & 0.9 & 0.0 & 0.4 \\
\hline 1952 & 35.9 & 31.4 & 3.5 & 0.0 & 1.0 & 0.0 & 0.4 \\
\hline 1953 & 40.2 & 32.9 & 6.0 & 0.0 & 1.2 & 0.0 & 0.5 \\
\hline 1954 & 39.3 & 31.2 & 6.5 & 0.0 & 1.5 & 0.0 & 0.4 \\
\hline 1955 & 39.1 & 30.1 . & 7.5 & 0.0 & 1.4 & 0.0 & 0.4 \\
\hline 1956 & 44.2 & 33.5 & 8.8 & 0.1 & 1.8 & 0.0 & 0.5 \\
\hline 1957 & 51.8 & 37.5 & 12.0 & 0.2 & 2.1 & 0.0 & 0.6 \\
\hline 1958 & 49.8 & 34.9 & 12.6 & 0.3 & 2.0 & 0.0 & 0.5 \\
\hline 1959 & 53.0 & 34.7 & 15.6 & 0.3 & 2.3 & 0.0 & 0.6 \\
\hline 1960 & 63.9 & 38.4 & 22.0 & 0.4 & 3.1 & 0.0 & 0.7 \\
\hline 1961 & 77.7 & 44.4 & 29.4 & 0.6 & 3.4 & 0.0 & 0.8 \\
\hline 1962 & 80.4 & 42.6 & 33.2 & 0.7 & 3.9 & 0.0 & 0.8 \\
\hline 1953 & 89.2 & 42.9 & 41.2 & 1.0 & 4.1 & 0.0 & 0.9 \\
\hline 1964 & 98.5 & 44.2 & 48.7 & 1.1 & 4.5 & 0.0 & 1.0 \\
\hline 1965 & 106.0. & 45.8 & 54.8 & 1.0 & 4.4 & 0.0 & 1.1 \\
\hline 1966 & $115.0^{\circ}$ & 47.1 & 61.7 & 1.3 & 5.2 & 0.0 & 1.2 \\
\hline 1967 & 134.2 & 50.1 & 77.1 & 1.2 & 5.8 & 0.0 & 1.4 \\
\hline 1968 & 154.0 & 55.3 & 91.2 & 1.2 & 6.5 & 0.0 & 1.5 \\
\hline 1969 & 179.0 & 61.0 & 109.7 & 1.3 & 7.0 & 0.0 & 1.8 \\
\hline 1970 & 202.4 & 63.3 & 129.3 & 2.1 & 7.8 & 0.0 & 2.0 \\
\hline 1971 & 209.5 & 57.0 & 142.2 & 2.2 & 8.1 & 0.0 & 2.0 \\
\hline 1972 & 224.9 & 55.3 & 158.4 & 2.2 & 9.0 & 0.0 & 2.1 \\
\hline 1973 & 250.7 & 59.3 & 177.8 & 2.9 & 10.6 & 0.0 & 2.3 \\
\hline 1974 & 244.1 & 63.3 & 166.9 & 3.9 & 9.9 & 0.0 & 2.2 \\
\hline 1975 & 233.7 & 58.9 & 161.2 & 4.7 & 8.9 & 0.0 & 2.1 \\
\hline 1976 & 239.3 & 57.6 & 166.7 & 5.6 & 9.3 & 0.0 & 2.1 \\
\hline 1977 & 251.6 & 56.6 & 178.3 & 6.7 & 9.9 & 0.0 & 2.2 \\
\hline 1978 & 250.7 & 49.9 & 179.8 & 9.4 & 11.5 & 0.0 & 2.2 \\
\hline 1979 & 260.2 & 54.7 & 182.3 & 11.2 & 11.9 & 0.0 & 2.2 \\
\hline 1980 & 254.9 & 62.8 & 167.0 & 13.1 & 12.0 & 0.0 & 2.2 \\
\hline 1981 & 249.9 & 68.9 & 156.2 & 13.3 & 11.5 & 0.0 & 2.1 \\
\hline 1982 & 244.6 & 68.5 & 151.5 & 13.6 & 11.0 & 0.0 & 2.1 \\
\hline 1983 & 239.9 & 65.2 & 149.1 & 14.6 & 11.0 & 0.0 & 2.0 \\
\hline 1984 & 264.3 & 76.9 & 157.1 & 19.6 & 10.7 & 0.0 & 2.2 \\
\hline $1985^{\prime}$ & 254.2 & 80.5 & 142.8 & 21.0 & 9.9 & 0.0 & 2.1 \\
\hline 1986 & 248.9 & 76.3 & 140.7 & 22.1 . & 9.7 & 0.0 & 2.1 \\
\hline 1987 & 246.9 & 75.2 & 139.4 & 22.5 & 9,7 & 0.0 & 2.0 \\
\hline 1988 & 269.8 & 82.9 & 152.8 & 23.5 & 10.5 & 0.0 & 2.2 \\
\hline
\end{tabular}

\section{REFERENCES}

Keeling, C.D. 1973. Industrial production of carbon dioxide from fossil fucls and limestone. Tellus 25:174-198.

Marland, $C$. , and R.M. Rotty. 1984. Carbon dioxide emissions from fossil fuels: $\mathrm{A}$

procedure for estimation and results for 1950-1982 Te'llus 36(B):232-61

Marland, G., T.A. Boden, R.C. Griffin, S.F. Huang, P. Kanciruk, and T.R. Nclson. 1989. Estimates of $\mathrm{CO}_{2}$ emissions from

fossil fuel burning and cement manu-

facturing, based on the United Nations

enengy statistics and the U.S. Bureau of

Mines cement manufacturing data.

ORNL/CDIAC-25, NDP-(3)3): ()ak Ridge National Laboratory, Oak Ridge,

Tennessece.

Rotty, R.M. and G. Marland. 1986. Fossil fuel combustion: recent amounts, patterns, and trends of $\mathrm{CO}_{2}$. pp. 484-500. IN

J.R. Trabalka and D.E. Reichle (eds.),

The Changing Carton Cycle: A Global

Analysis, Springer-Verlag.

United Nations. 1989. Energy Statistics

Yearbook 1987. United Nations

Department of International Economic and Social Affairs, Statistical office, New York.

U.S. Bureau of Mines. 1988. Minerals Yearbook. Vol. I, Metals, Minerals, and Futels. Washington, D.C

U.S. Department of Energy. 1988. International Energy Annual. DOE/ EIA-0219(88). Energy Information Administration, Washington, D.C 


\section{Federal Republic of Germany}

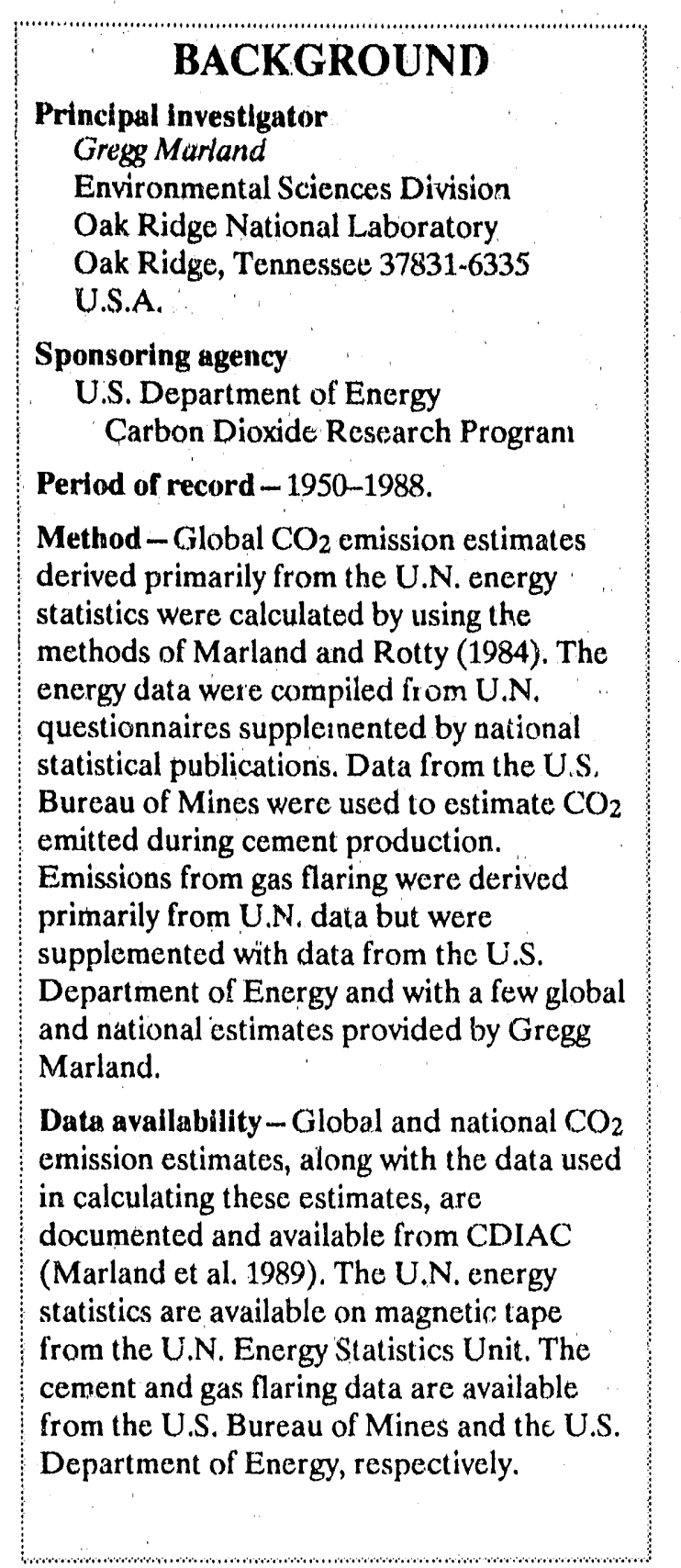

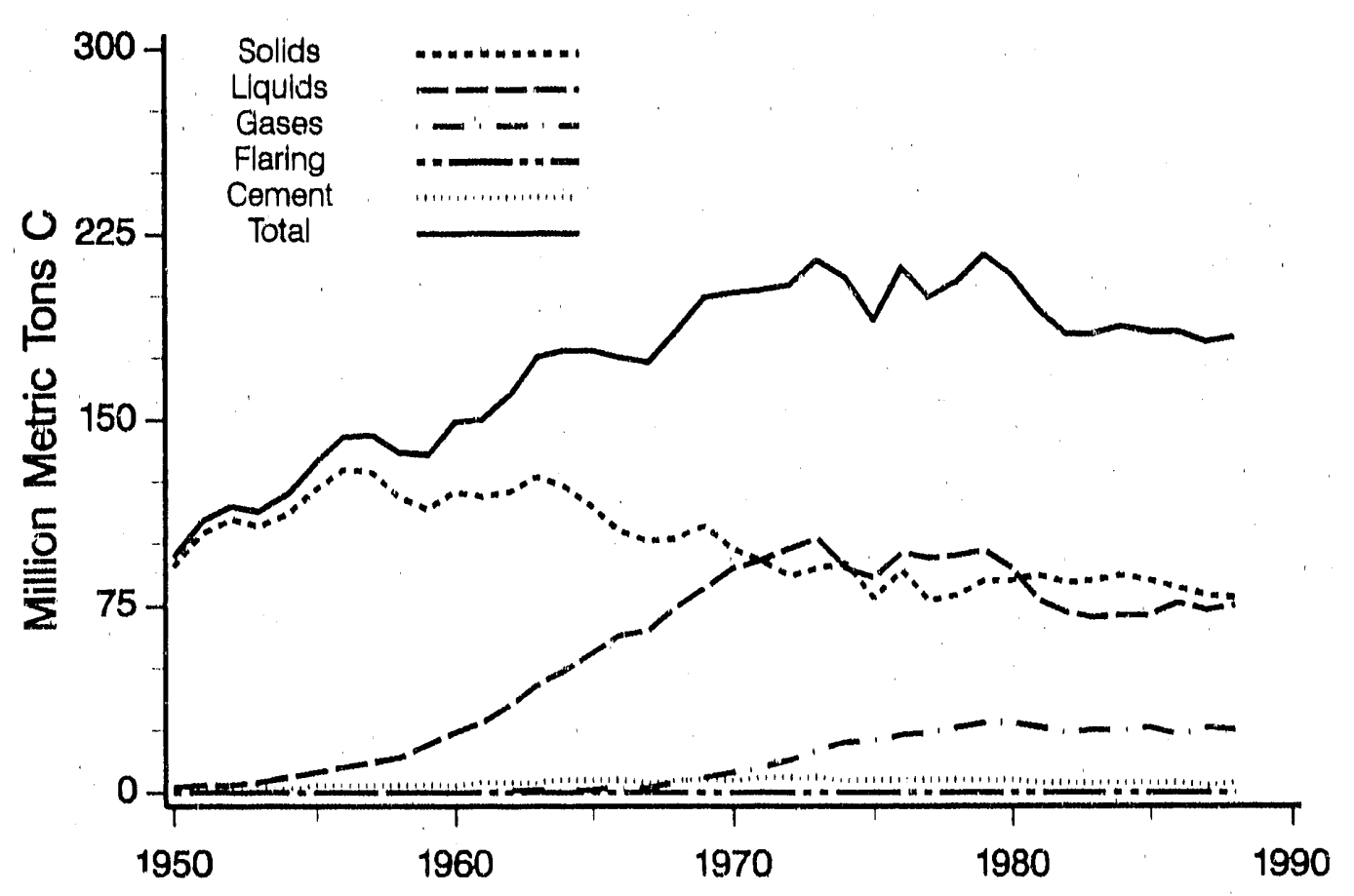

$\mathrm{CO}_{2}$ emissions from the Federal Republic of Germany.

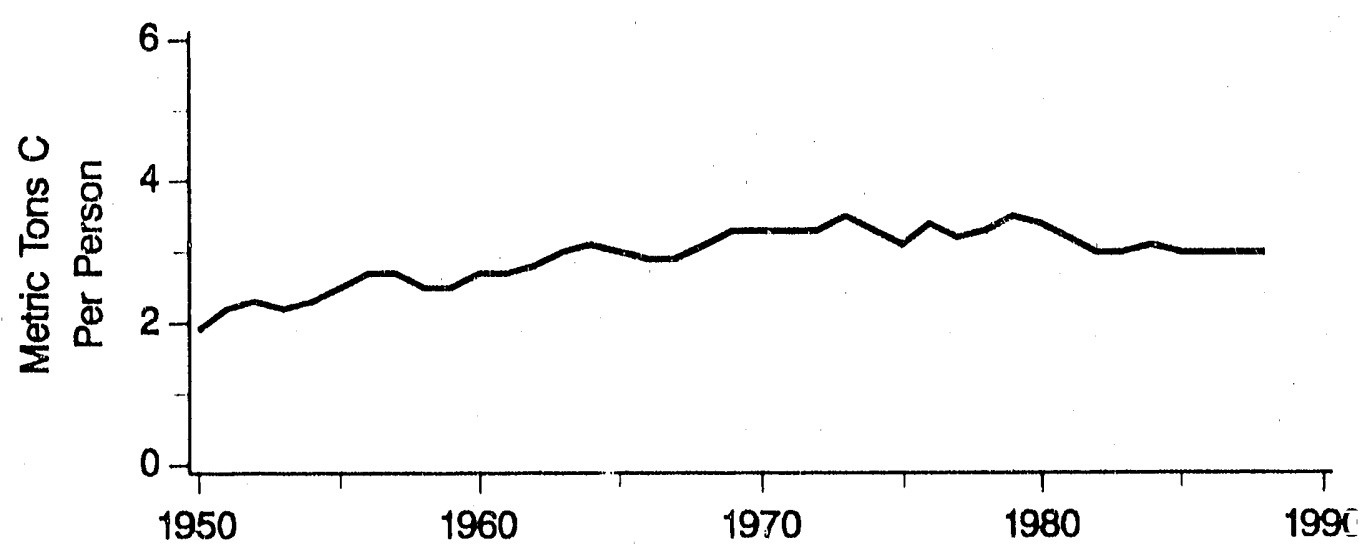

Per capita $\mathrm{CO}_{2}$ emission estimates for the Federal Republic of Germany. 


\section{$\mathrm{CO}_{2}$ Emissions}

\section{TREND}

Emissions of $\mathrm{CO}_{2}$ from the Federal Republic of Germany rose slightly in 1988 to 182.7 million metric tons of carbon.' This slight increase maintains the generally constant trend which has prevailed since 1982. Per capita emissions also remained generally constant and are now near the 1963 value and 14\% below the 1979 high. Although the largest fraction of emissions $(43 \%)$ is from burning of solid fuels, the use of coal has been in general decline since a maximum in 1956, at which time $91 \%$ of total emissions was from coal burning. Natural gas burning first contributed over $1 \%$ of total emissions in 1966 and is now $14 \%$ of the total, a share that has been fairly constant since 1978 .

Note-Growth rates were calculated (before rounding) by performing a linear regression of $\log \mathrm{CO}_{2}$ emissions versus time and calculating the slope of the regression line. 


\section{Federal Republic of Germany}

\section{Carbon Dioxide Emission Estimates*}

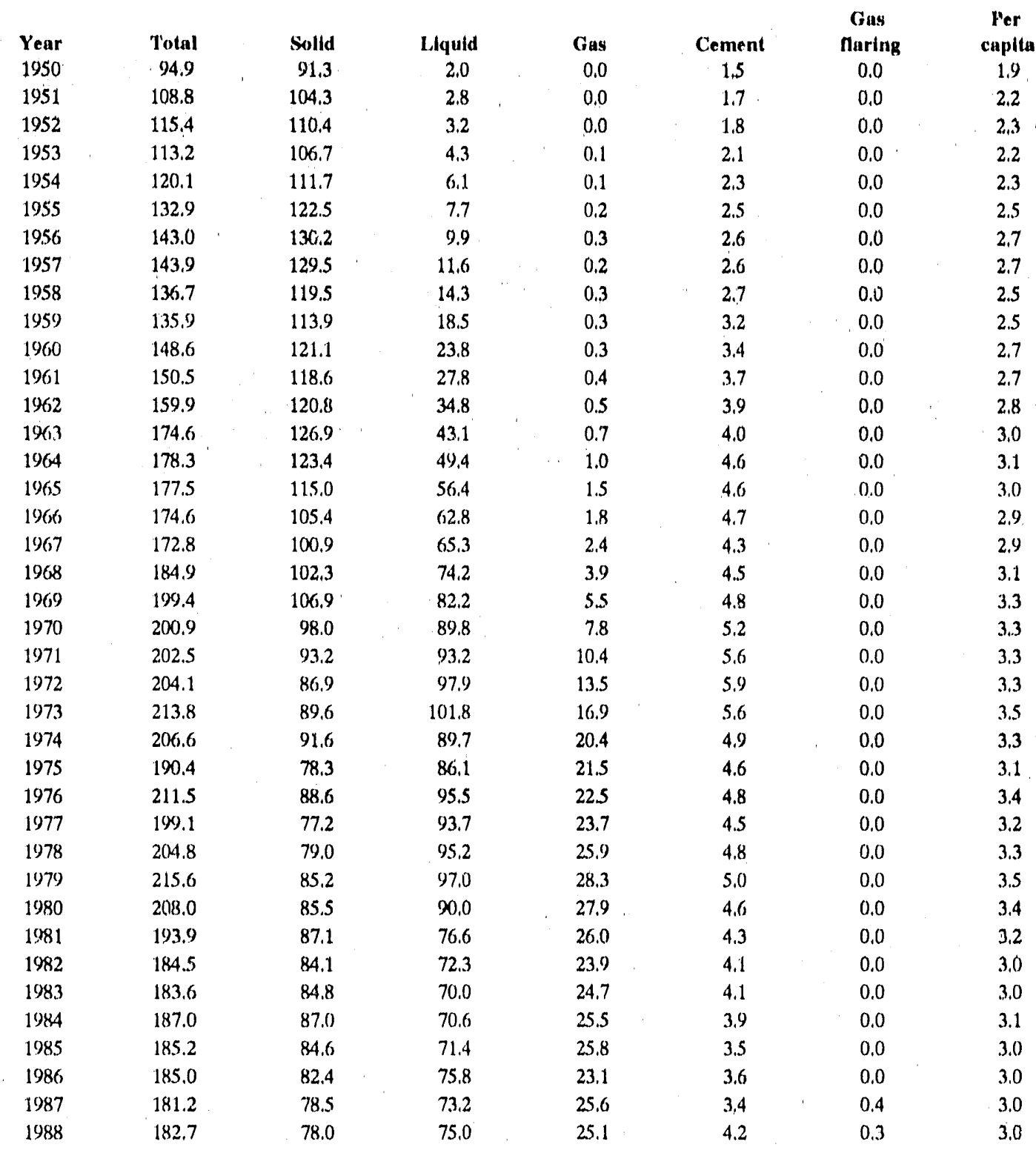

- Emission estimates rounded and expressed in million metric tons of carbon; per capita estimates rounded and 


\section{India}

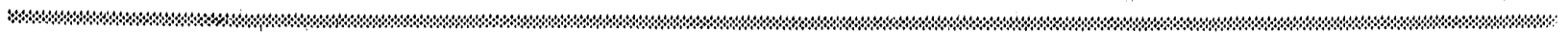

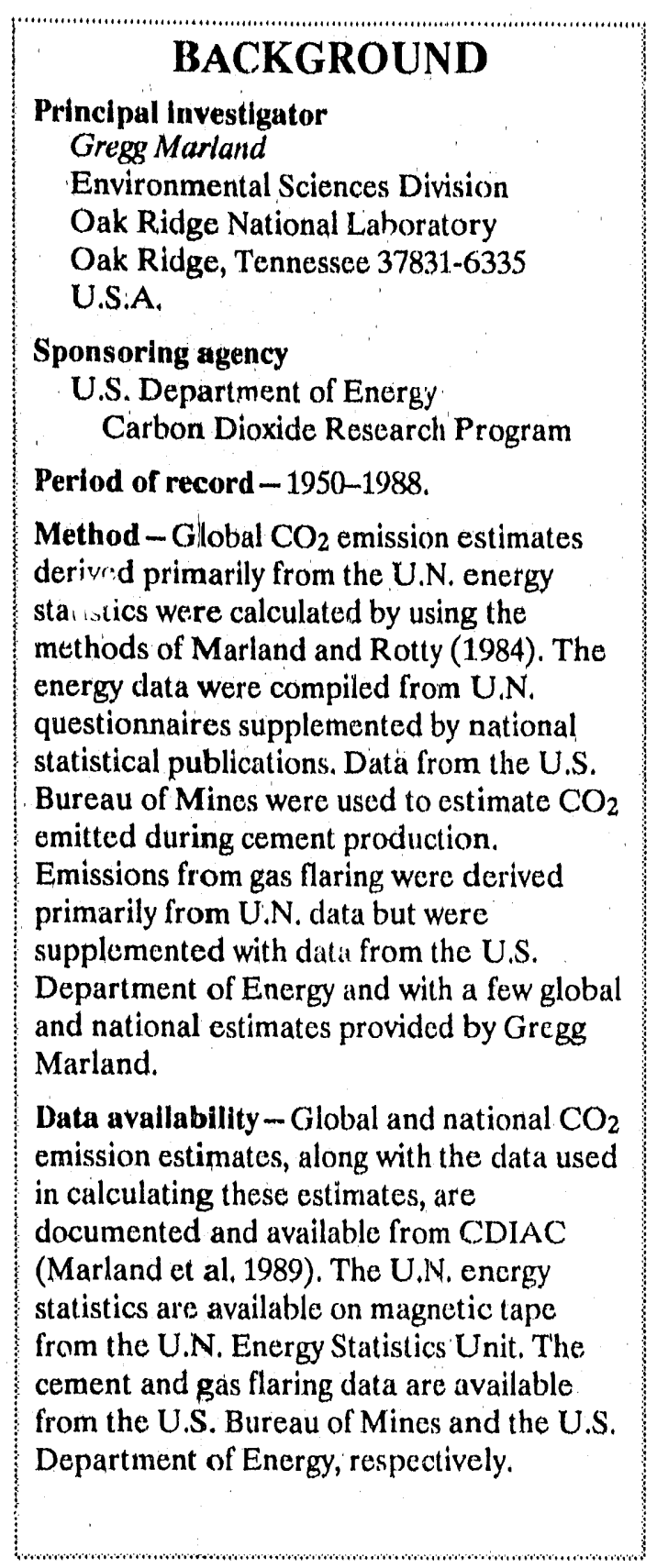
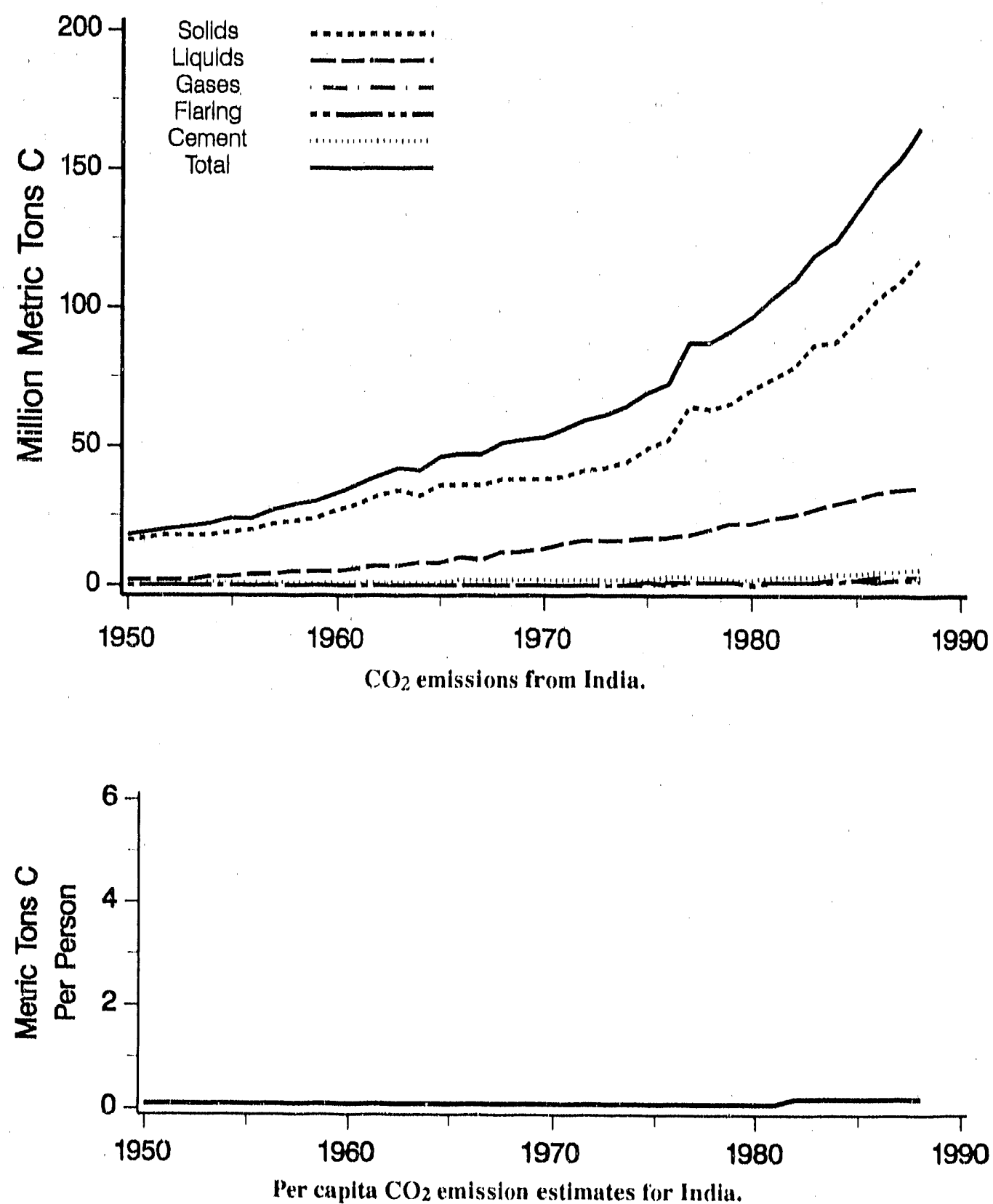


\section{$\mathrm{CO}_{2}$ Emissions}

\section{TREND}

India has experienced dramatic recent growth in $\mathrm{CO}_{2}$ emissions. Emissions have grown $5.6 \%$ per year since 1950 as India climbed from 13th to 6 th place as a national contributor. Total smissions increased 8.9 times over this interval and per capita emissions increased 3.9 times. Emissions in India continue to be largely from coal burning. Coal contributed $87 \%$ of emissions in 1950 and $72 \%$ in 1988 as the oil fraction increased from 11 to $22 \%$. Indian emissions data reveal little impact from the oil price increases that affected emissions in the United States and western Europe so dramatically in the late 1970s and early 1980s. Per capita emissions in 1988 were less than $4 \%$ of the U.S. value.

Note-Growth rates were calculated (before rounding) by performing a linear regression of $\log \mathrm{CO}_{2}$ emissions versus time and calculating the slope of the regression line. 


\section{India}

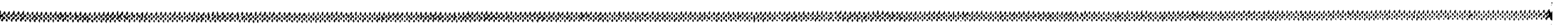

\section{Carbon Dioxide Emission Estimates*}

\begin{tabular}{|c|c|c|c|c|c|c|c|}
\hline Yenr & 'Total & Solld & Llyuid & Gas & Cement & $\begin{array}{l}\text { Gas } \\
\text { Maring }\end{array}$ & $\begin{array}{c}\text { Por } \\
\text { capila }\end{array}$ \\
\hline 1950 & 18.4 & 16.0 & 2.0 & 0.0 & 0.4 & 0.0 & 0.1 \\
\hline 1951 & 19.2 & 16.6 & 2.1 & 0.0 & 0.4 & 0.0 & 0.1 \\
\hline 1952 & 20.3 & 17.7 & 2.1 & 0.0 & 0.5 & 0.0 & 0.1 \\
\hline 1053 & 20.6 & 18.0 & 2.1 & 0.0 & 0.5 & 0.0 & 0.1 \\
\hline 1954 & 21.7 & 18.5 & 2.6 & 0.0 & 0.6 & 0.0 & 0.1 \\
\hline 1955 & 23.5 & 19,4 & 3.5 & 0.0 & 0.6 & 0.0 & 0.1 \\
\hline 1956 & 24.4 & 19.9 & 3.8 & 0.0 & 0.7 & 0.0 & 0.1 \\
\hline 1957 & 27,3 & 22.2 & 4.3 & 0.0 & 0,8 & 0.0 & 0.1 \\
\hline 1958 & 28.6 & 23.1 & 4.6 & 0.0 & 0.8 & 0.0 & 0.1 \\
\hline 1959 & 30.2 & 24.3 & 5.0 & 0.0 & 0.9 & 0.0 & 0.1 \\
\hline 1960 & 33.2 & 26.8 & 5.3 & 0.0 & 1.1 & 0.0 & 0.1 \\
\hline 1961 & 35.9 & 29.0 & 5.8 & 0.0 & 1.1 & 0.0 & 0.1 . \\
\hline 1962 & 39.5 & 31.5 & 6.8 & 0.0 & 1.2 & 0.0 & 0.1 \\
\hline 1963 & 42.4 & 33.7 & 7.4 & 0.0 & 1.3 & 0.0 & 0.1 \\
\hline 1964 & 41.4 & 32.3 & 7.7 & 0.0 & 1.3 & 0.1 & 0.1 \\
\hline 1965 & 45.6 & 35.5 & 8.4 & 0.1 & 1.4 & 0.2 & 0.1 \\
\hline 1966 & 47.2 & 35.7 & 9.7 & 0.1 & 1.5 & 0.2 & 0.1 \\
\hline 1967 & 47.4 & 36,3 & 8.9 & 0.1 & 1.6 & 0.4 & 0.1 \\
\hline 1968 & 51.5 & 37.7 & 11.5 & 0.2 & 1.6 & 0.4 & 0.1 \\
\hline 1969 & 52.4 & 37.6 & 12.4 & 0.3 & 1.8 & 0.3 & 0.1 \\
\hline 1970 & 53,3 & 37.7 & 13.1 & 0.3 & 1.8 & 0.4 & 0.1 \\
\hline 1971 & 56.2 & 38.7 & 14.7 & 0.3 & 2.0 & 0.4 & 0.1 \\
\hline 1972 & 59.4 & 41.0 & 15.6 & 0.3 & 2.1 & 0.3 & 0.1 \\
\hline 1973 & 61.1 & 42.0 & 16.4 & 0.3 & 2.0 & 0.4 & 0.1 \\
\hline 1974 & 63.6 & 44.4 & 16.4 & 0.4 & 1.9 & 0.5 & 0.1 \\
\hline 1975 & 69.1 & 49.2 & 16.7 & 0.5 & 2.2 & 0.5 & 0.1 \\
\hline 1976 & 72.2 & 51.5 & 17.1 & 0.6 & 2.5 & 0.5 & 0.1 \\
\hline 1977 & 86.5 & 64.2 & 18.4 & 0.7 & 2.6 & 0.6 & 0.1 \\
\hline 1978 & 87.0 & 62.9 & 20.2 & 0.7 & 2.7 & 0.5 & 0.1 \\
\hline 1979 & 90.8 & 64.8 & 22.2 & 0.8 & 2.5 & 0.6 & 0.1 \\
\hline 1980 & 95.5 & 69.7 & 22.4 & 0.7 & $2.4^{\prime}$ & 0.3 & 0.1 \\
\hline 1981 & 102.7 & 74.1 & 24.1 & 0.8 & 2.8 & 0.9 & 0.1 \\
\hline 1982 & 109.2 & 78.4 & 25.5 & 1.2 & 3.1 & 1.0 & 0.2 \\
\hline 1983 & 118.5 & 85.7 & 26.7 & 1.4 & 3.4 & 1.2 & 0.2 \\
\hline 1984 & 122.5 & 86.8 & 28,6 & 1.7 & 3.9 & 1.4 & 0.2 \\
\hline 1085 & 134.3 & 94.8 & 31.4 & 2.0 & 4.5 & 1.6 & 0.2 \\
\hline 1986 & 143.6 & 101.5 & 32.9 & 2.8 & 5.0 & 1.4 & 0.2 \\
\hline 1987 & 152.1 & 108.5 & 33.7 & 3.2 & 5.0 & 1.7 & 0.2 \\
\hline 1988 & 163.8 & 117.4 & 35.3 & 3.5 & 5.5 & 2.0 & 0.2 \\
\hline
\end{tabular}

" Bmission estimates rounded and expressed in million metric cons of carbon; per capita estimates rounded and expressed in metric tons of carbon. 


\section{$\mathrm{CO}_{2}$ Emissions}

\section{REFERENCLS}

Keoling, C..D. 1973. Industrial production of earbon dioxide from fossil fucls and limestone. Tellas 25:174-.11)8.

Marland, (i., and R.M. Rotty, 1984, Cambon dioxide omissions from fossil fucls: $A$ procedure fere estimation and results for 1950-1082. Tollus 36(B):232-61.

Marland, C., 'T'A, Boden, R.C , Griflin, S.F. Huang, P. Kanciruk, and T'R. Nelson, 1989. Estimates of $\mathrm{CO}_{2}$ (mmissions fromm fossil finel burning and co'me'nl mantufacturing, based ont the Unied Natioms encryy statistic:s and the U.S. Burcall of

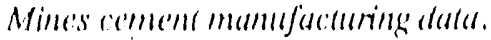
()RNI./(I)IA(:-25, ND)'-(1)3(), ()ak Ridge National Liburatory, ()ak Ridge, Tennessec.

Rolly, R.M., and (i. Marland. 1986. Fonsil fuel combustion: recent amorunts, palterns,

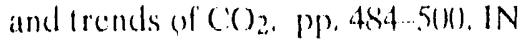
I.R. Trabalka and D. B. Reichle (eds.), The Chonging Carbon Cirle: a cilolul Anolvisis, Springer. Verlity.

Uniled Nations. 1989). Enterne Shatisticas Yearbook los7. United Nations Department of International Econemic: and Sincial Alfairs, Statistical offices, Now York.

U.S. Burcau of' Mines. I)\&8. Mincrals' Yearbene. Vell. 1, Melals, Mineruls, and fikels. Washington, D.C:

U.S. Depratment of Energy. 1988. International Energe Ammual. DO()E/

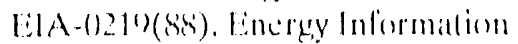
Administration, Washimstom, D). 


\section{United Kingdom}

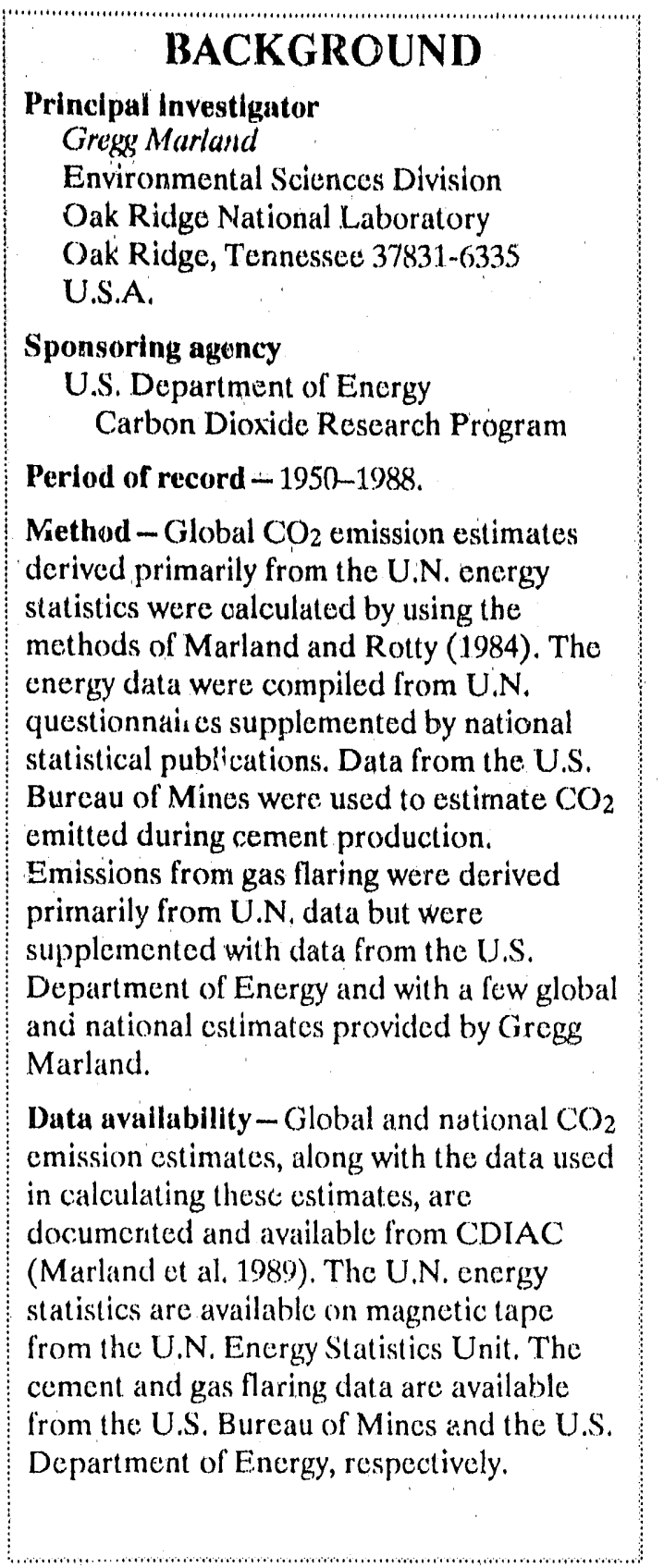
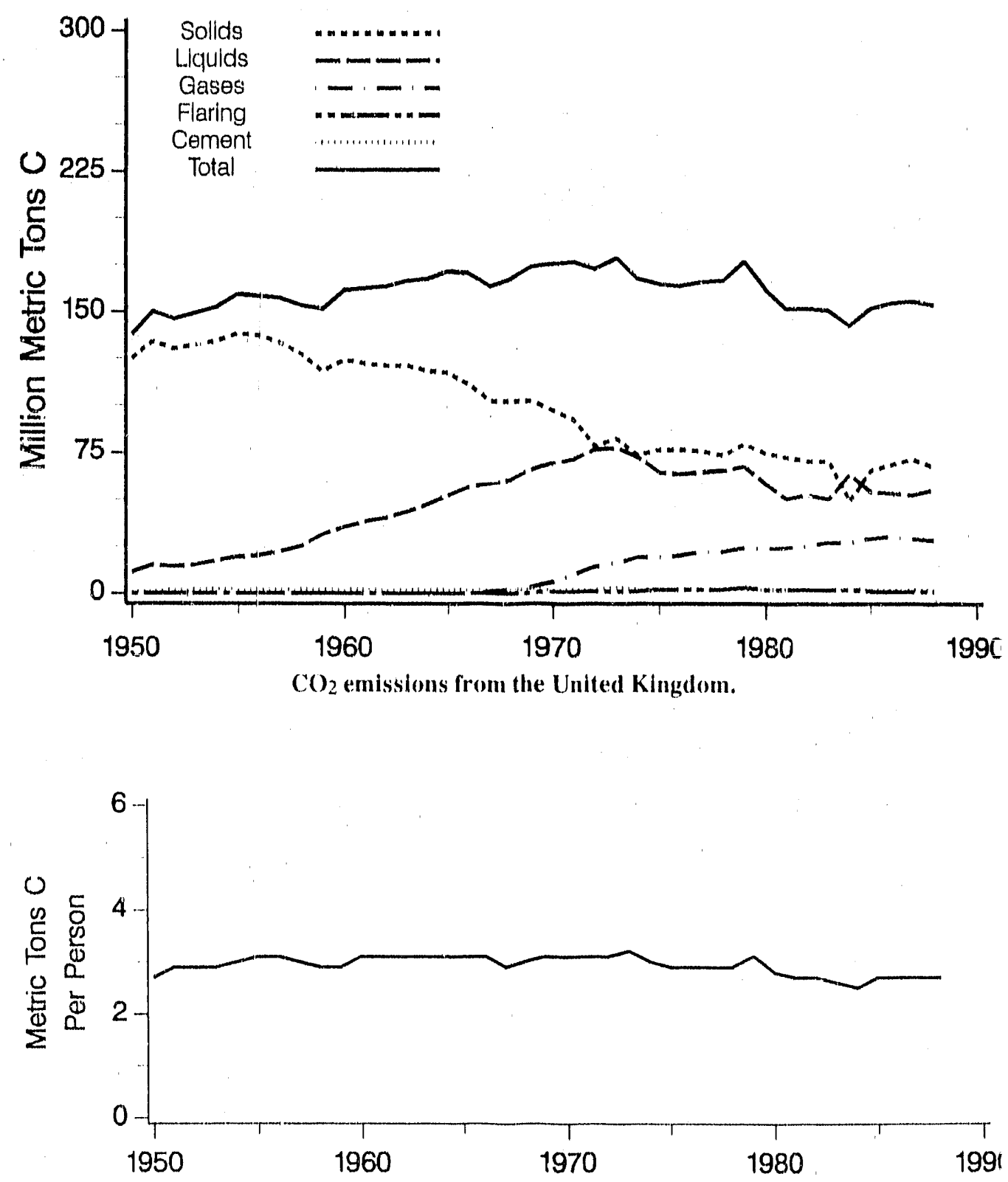

Per capita $\left(\mathrm{CO}_{2}\right.$ emission estimates for the United Kingdom. 


\section{$\mathrm{CO}_{2}$ Emissions}

\section{TREND}

$\mathrm{CO}_{2}$ emissions in the United Kingdom dropped from 155.0 to 152.5 million metric tons during 1987-1988. This decline differs from the general increasing trend observed during the previous three years (1984-1987) but conforms to the longer trend in which emissions declined 19\% from 1979 to 1984. After at least 23 years of increases in emissions from liquid fuels and generally declining emissions from coal burning, 1974 was the year in which emissions from both fuels began to decline simultaneously. Emissions from natural gas grew rapidly in the late 1960s and early 1970s and have continued to increase. Naturai gas burning now accounts for nearly $20 \%$ of total emissions of $\mathrm{CO}_{2}$. Total emissions were only $10.5 \%$ higher in 1988 than in 1950 , by far the smallest ircrease among the top 20 nations. Over this interval the United Kingdom dropped from third to seventh in rank among $\mathrm{CO}_{2}$-emitting nations.

Note-Growth rates were calculated (before rounding) by performing a linear regression of $\log \mathrm{CO}_{2}$ emissions versus time and calculating the slope of the regression line. 
Carbon Dioxide Emission Estimates*

\begin{tabular}{|c|c|c|c|c|c|c|c|}
\hline Year & Total & Solid & Liquid & Gas & Cement & $\begin{array}{c}\text { Gas } \\
\text { naring }\end{array}$ & $\begin{array}{c}\text { Per } \\
\text { capila }\end{array}$ \\
\hline 1950 & 138.0 & 125.3 & 11.4 & 0.0 & 1.3 & 0.0 & 2.7 \\
\hline 1951 & 150.3 & 134.2 & 14.6 & 0.0 & 1.4 & 0.0 & 2.9 \\
\hline 1952 & 145.7 & 129.7 & 14.5 & 0.0 & 1.5 & 0.0 & 2.9 \\
\hline 1953 & 148.9 & 132.1 & 15.3 & 0.0 & 1.6 & 0.0 & 2.9 \\
\hline 1954 & 152.4 & 133.5 & 17.1 & 0.0 & 1.7 & 0.0 & 3.0 \\
\hline 1955 & $15 \% 0$ & 138.0 & 19.2 & 0.0 & 1.7 & 0.0 & 3.1 \\
\hline 1956 & 158.2 & 136.6 & 19.8 & 0.0 & 1.8 & 0.0 & 3.1 \\
\hline 1957 & 157.2 & 133.2 & 22.3 & 0.0 & 1.7 & 0.0 & 3.0 \\
\hline 1958 & 153.2 & 126.7 & 24.9 & 0.0 & 1.6 & 0.0 & 2.9 \\
\hline 1959 & 150.5 & 117.5 & 31.2 & 0.0 & 1.7 & 0.0 & 2.9 \\
\hline 1960 & 160.8 & 123.7 & 35.2 & 0.0 & 1.8 & 0.0 & 3.1 \\
\hline 1961 & 162.0 & 122.3 & 37.7 & 0.0 & 2.0 & 0.0 & 3.1 \\
\hline 1962 & 163.2 & 120.7 & 40.5 & 0.1 & 1.9 & 0.0 & 3.1 \\
\hline 1963 & 166.1 & 121,3 & 42.8 & 0.1 & 1.9 & 0.0 & 3.1 \\
\hline 1964 & 167.3 & 117.7 & 47.2 & 0.1 & 2.3 & 0.0 & 3.1 \\
\hline 1965 & 171.2 & 116.6 & 51.8 & 0.5 & 2.3 & 0.0 & 3.1 \\
\hline 1966 & 170,0 & 111.4 & 55.9 & 0.5 & 2.3 & 0.0 & 3.1 \\
\hline 1967 & 162.8 & 101.7 & 57.9 & 0.8 & 2.4 & 0.0 & 2.9 \\
\hline 1968 & 166.8 & 102.2 & 60.3 & 1.7 & 2.4 & 0.1 & 3.0 \\
\hline 1969 & 172.8 & 101.6 . & 65.0 & 3.3 & 2.4 & 0.4 & 3.1 \\
\hline 1970 & $: 75.4$ & 97.4 & 68.6 & 6.3 & 2.3 & 0.8 & 3.1 \\
\hline 1971 & 176.1 & 91.6 & 71.0 & 10.2 & 2.4 & 0.9 & 3.1 \\
\hline 1972 & 172.2 & 77.8 & 76.5 & 14.4 & 2.5 & 1.1 & 3.1 \\
\hline 1973 & 178.1 & 81.7 & 76.8 & 15.6 & 2.7 & 1.3 & 3.2 \\
\hline 1974. & 167.2 & 72.7 & 72.0 & 18.6 & 2.4 & 1.5 & 3.0 \\
\hline 1975 & 164.1 & 76.3 & 64.4 & 19.5 & 2.3 & 1.6 & 2.9 \\
\hline 1976 & 163.0 & 75.9 & 63.1 & 20.2 & 2.1 & 1.6 & 2.9 \\
\hline 1977 & 164.6 & 74.9 & 64.3 & 21.6 & 2.1 & 1.7 & 2.9 \\
\hline 1978 & 165.7 & 73.5 & 65.4 & 22.2 & 2.2 & 2.3 & 2.9 \\
\hline 1979 & 175,6 & 78.7 & 66.9 & 24.3 & 2.2 & 3.4 & 3.1 \\
\hline 1980 & 160.6 & 74.4 & 57.8 & 24.1 & 2.0 & 2.2 & 2.8 \\
\hline 1981 & 151.1 & 72,3 & 50.4 & 24.5 & 1.7 & 2.2 & 2.7 \\
\hline 1982 & 150.7 & 69.6 & 51.7 & 25.5 & 18 & 2.0 & 2.7 \\
\hline 1983 & 150.1 & 70.2 & 49.7 & 26.5 & 1.8 & 2.0 & 2.6 \\
\hline 1984 & 142.4 & 48.5 & 63.1 & 27.2 & 1.8 & 1.8 & 2.5 \\
\hline 1985 & 151.3 & 64.7 & 54.0 & 29.5 & 1.8 & 1.4 & 2.7 \\
\hline 1986 & 153.6 & 68.1 & 53.1 & 29.5 & 18 & 10 & 2.7 \\
\hline 1987 & 155.0 & 71.0 & 51.8 & 29.3 & 1.8 & 1.1 & 2.7 \\
\hline 1988 & 152.5 & 66.7 & 55.0 & 27.8 & 1.8 & 1.1 & 2.7. \\
\hline
\end{tabular}

\section{REFERENCES}

Keeling, C.D. 1973. Industrial production of carbon dioxide from fossil fuels and limestone: Tellus 25:174-198.

Marland, G. and R.M. Rotty, 1984. Carbon. dioxide emissions from fossil fucls: A procedure for estimation and results for 1950-1982. To'llas 36(B):232-61.

Marland, G., T.A. Boden, R.C. Griffin, S.F. Huang, P. Kanciruk, and T.R. Nelson. 1989. Estimates of $\mathrm{CO}_{2}$ emissions. from fossil fuel buming and cement mamufacturing, based on the United Nations energy statistics and the U.S. Bureau of

Mines cement manuf acturing data.

ORNL/CDIAC-25, NDP-(130). (oak Ridge National Laboratory, Oak Ridge, Tennessee.

Rotty, R.M, and G. Marland. 1986. Fossil fuel combustion: recent amounts, patterns, and trends of $\mathrm{CO}_{2} . \mathrm{pp}, 484-5(\mathrm{~K})$. IN J.R. Trabalka and D.E. Reichle (eds.) The Changing Carbon Cycle: A Glohal Analysis, Springer-Verlag.

United Nations. 1989. Enerny Statistics Yearbook 1987. United Nations

Department of International Economic and Social Affairs, Statisticaloffice, New York.

US. Bureau of Mines. 1988. Mincrals Yearbook. Vol. I, Meteds, Minerals, and Fuels. Washington, D.C.

U.S. Department of Energy. 19ess. Intemational Energy Ammal. D()E: E1A-(1219(88). Encruy Information Ariministration, Washington, D.C. 


\section{Poland}

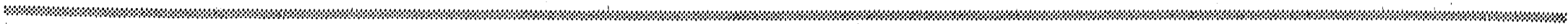

BACKGROUND
Principal investigator
Gregg Marland
Environmental Sciences Division
Oak Ridge National Laboratory
Oak Ridge, Tennessee 37831-633.5
U.S.A.
Sponsoring agency
U.S. Department of Energy
Carbon Dioxide Research Program
Period of record-1950-1988.
Method-Global CO2 emission estimates
derived primarily from the U.N. energy
statistics were calculated by using the
methods of Marland and Rotty (1984). The
energy data were compiled from U.N.
questionnaires supplemented by national
statistical publications. Data from the U.S.
Bureau of Mines were used to estimate CO
emitted during cement production.
Emissions from gas flaring were derived
primarily from U.N. data but were
supplemented with data from the U.S.
Department of Energy and with a few global
and national estimates provided by Gregg
Drom the U.S. Bureau of Mines and the U.S.
Data availability - Global and national CO
femission estimates, along with the data used
in calculating these estimates, are
(Maristics are available on magnetic tape
from the U.N. Energy Statistics Unit. The
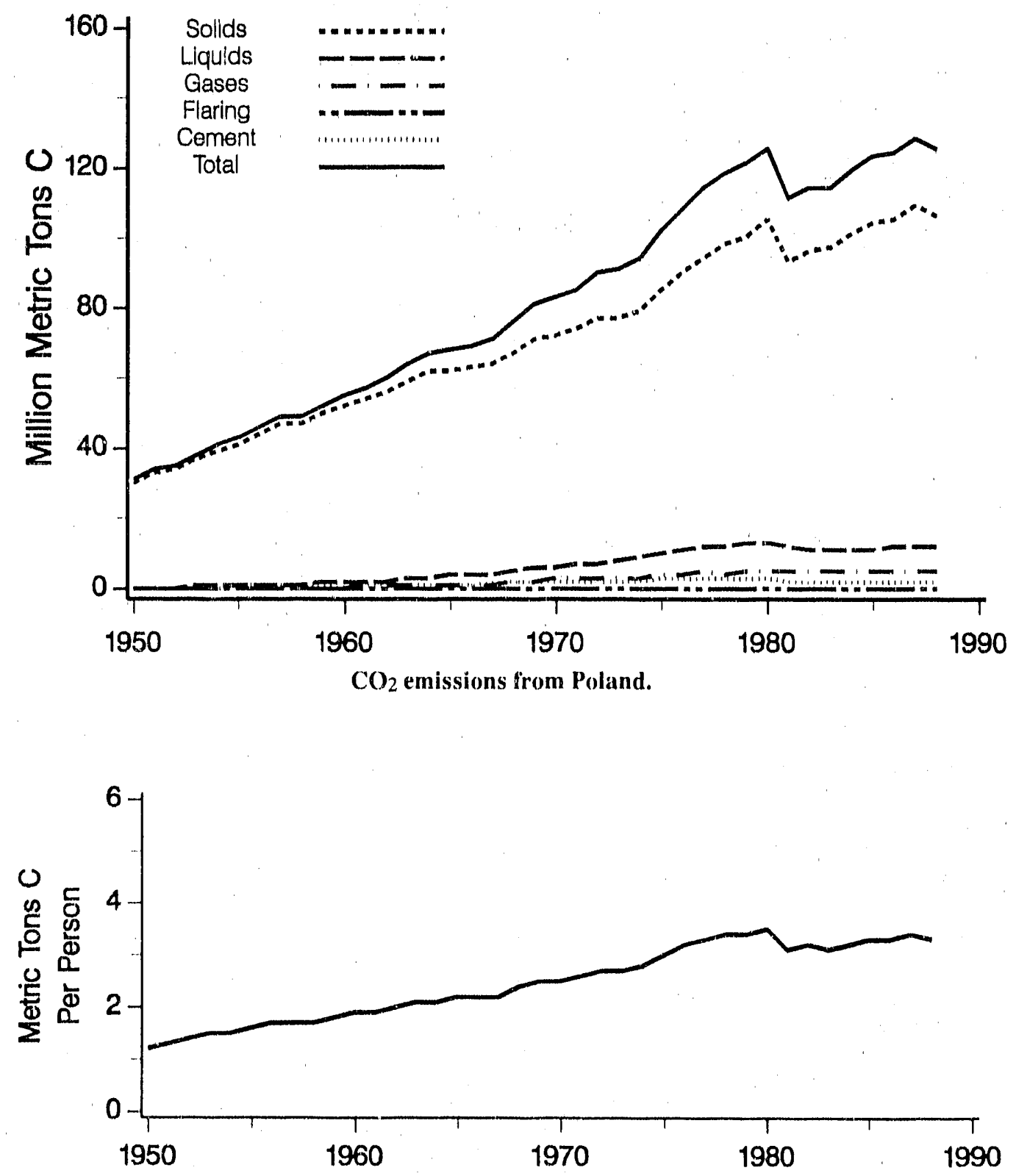

Per capita $\mathrm{CO}_{2}$ emission estimates for Poland. 


\section{$\mathrm{CO}_{2}$ Emissions}

\section{TREND}

$\mathrm{CO}_{2}$ emissions from Poland climbed at a remarkably steady rate of $4.4 \%$ per year until 1980, when they dropped abruptly (11.6\%). $\mathrm{CO}_{2}$ emissions crept back up throughout the 1980s and in 1987 they exceeded the previous high in 1980.

Emissions are predominantly from coal burning, $97 \%$ in 1950 and still $85 \%$ in 1988. The drop following 1980 is apparent in rates of liquid fuel burning but was predominantly in coal consumption. Total emissions increased over 4 times from 1950 to 1988, with per capita emissions accounting for most of the rise, increasing 2.65 times.

Note-Growth rates were calculated (before rounding) by performing a linear regression of $\log \mathrm{CO}_{2}$ emissions versus time and calculating the slope of the regression line. 


\section{Carbon Dioxide Emission Estimates*}

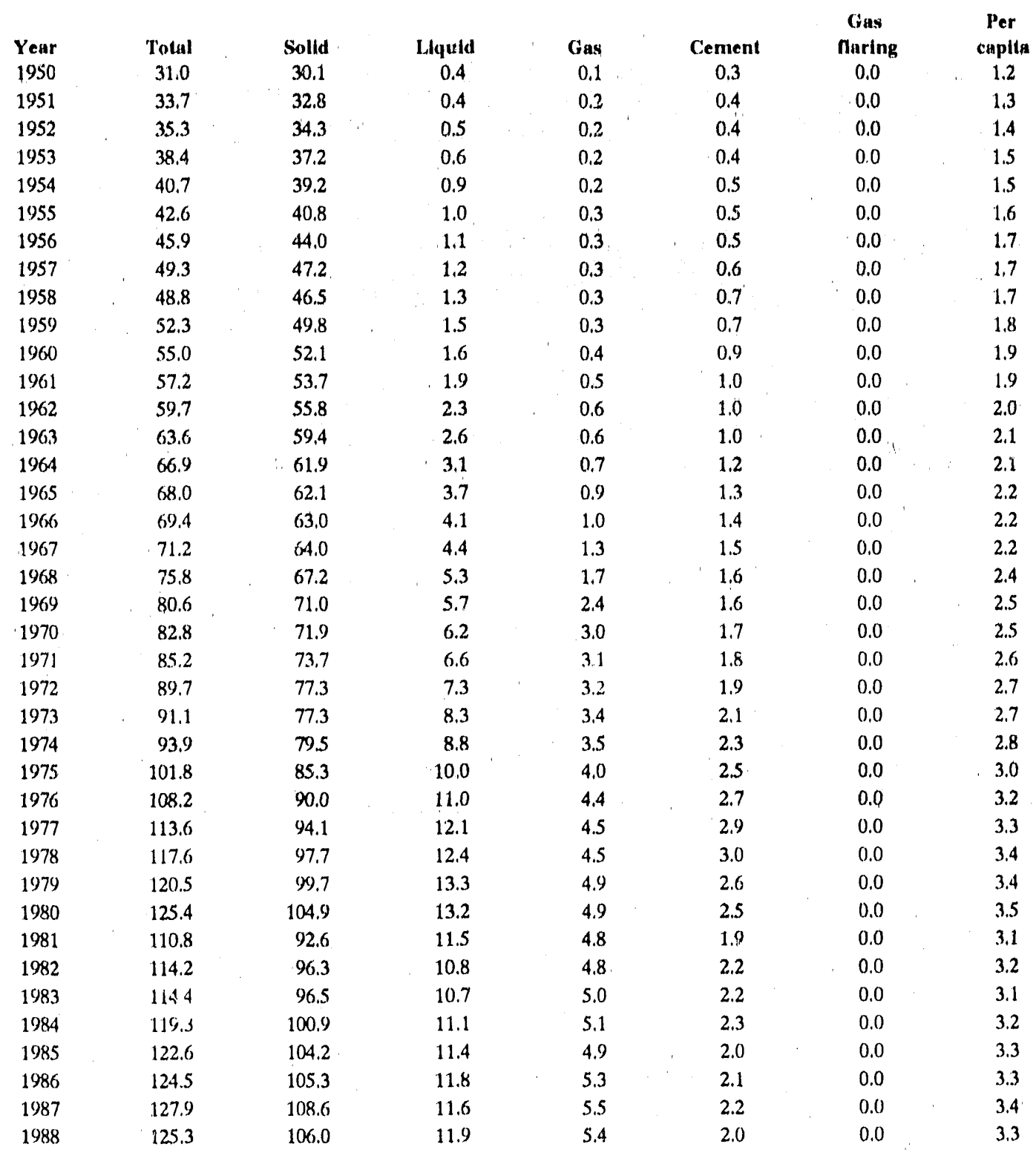

* Emission estimates rounded and expressed in million metric tons of carbon; per capita estimates rounded and expressed in metric tons of carbon. 


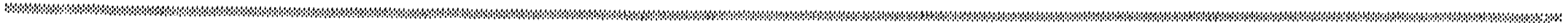

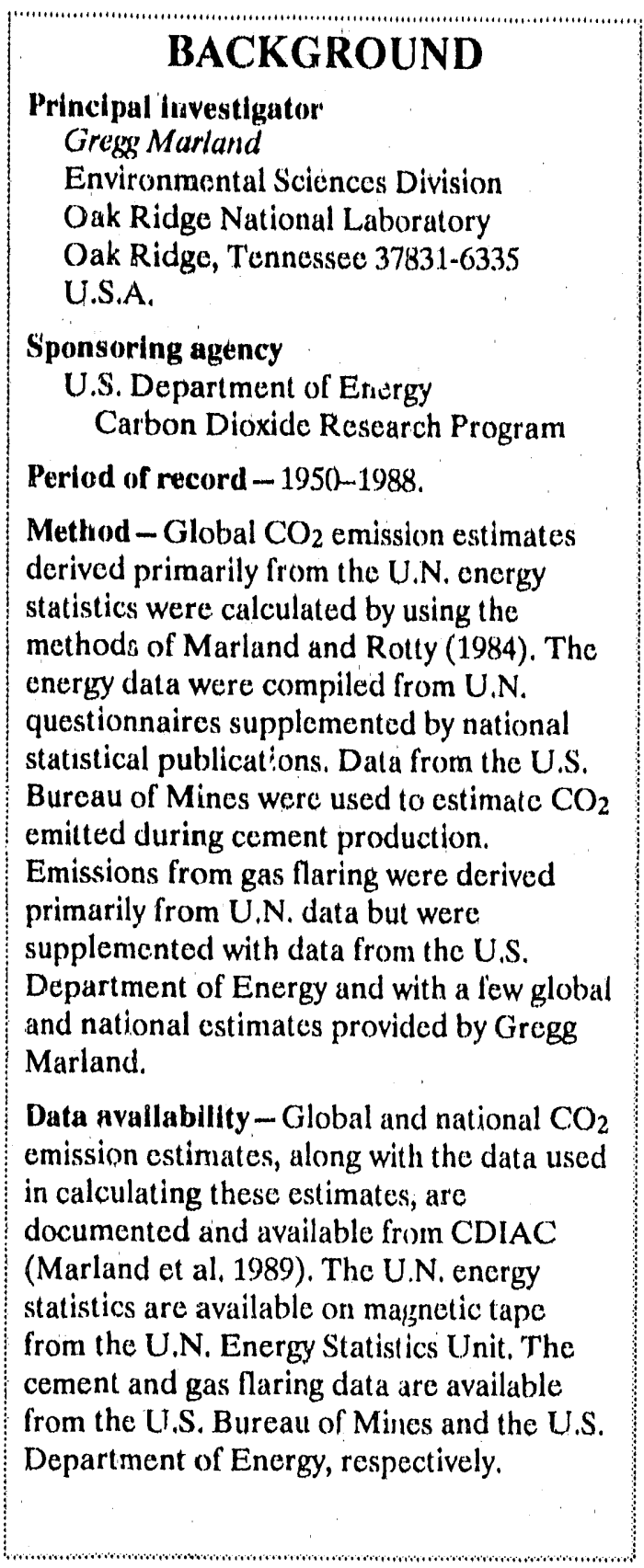
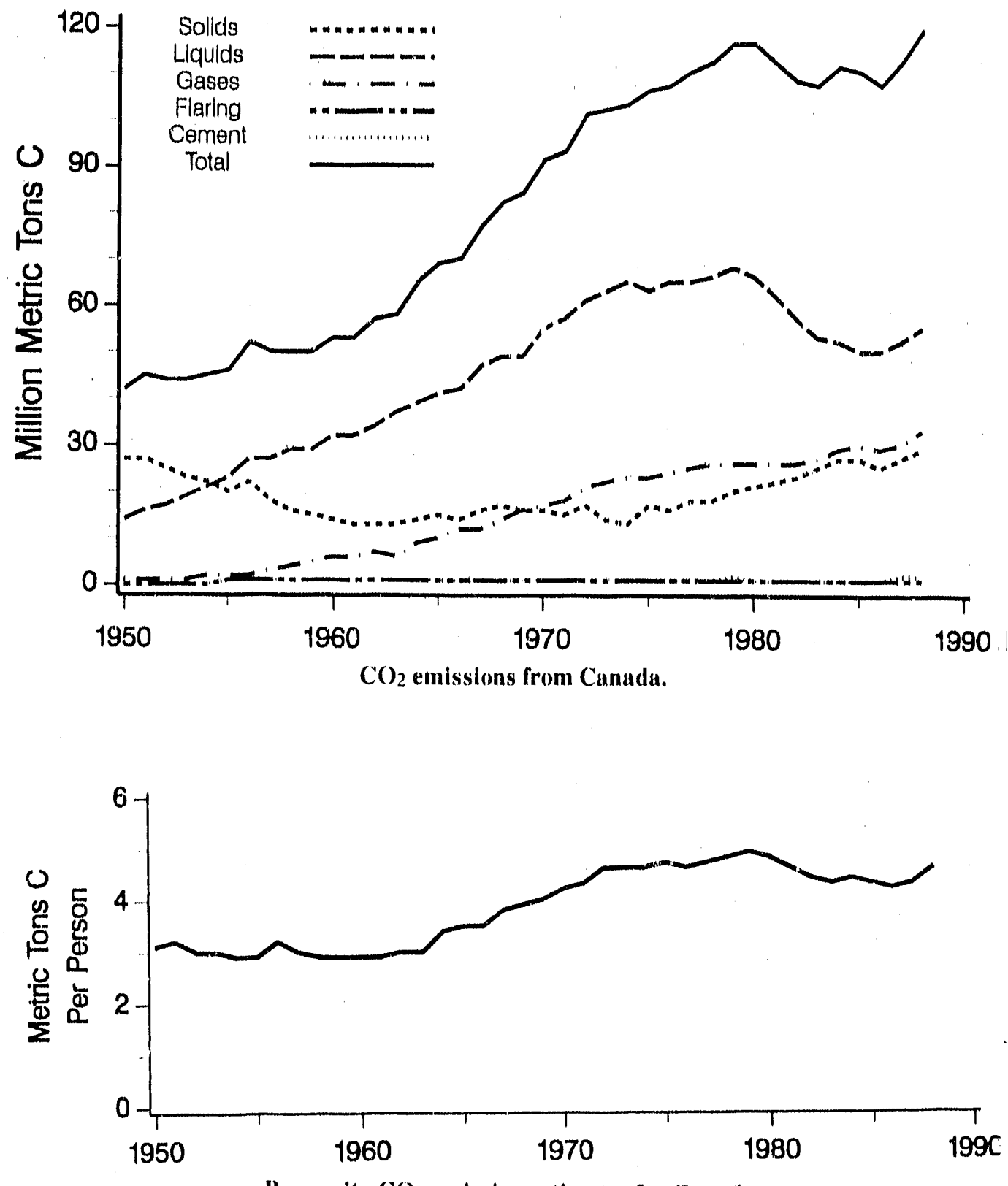

Per capita $\mathrm{CO}_{2}$ emission estimates for Canada. 


\section{$\mathrm{CO}_{2}$ Emissions}

\section{TREND}

Driven by a $6.0 \%$ per year increase in cmissions from liquid fuels, total $\mathrm{CO}_{2}$ cmissions from Canada increased by a factor of 2.4 from 1950 to 1974. Continuing growth until 1979 was maintained by continuing expansion of natural gas consumption and an upturn in coal consumption. The post-1979 drop was comparable to that observed in the United States, and the pattern from 1980 to 1986 was erratic but basically at a constant level. During the past 2 years, emissions have increased by $4.6 \%$ and $6.6 \%$, respectively. Emissions from coal burning comprised $63 \%$ of the total in 1950 but declined in both absolute and relative terms until 1974. Sirice emissions from liquid fuels turned down in 1974, emissions from coal have turned back up, growing at an average rate of $5.0 \%$ per year. In 1988 , coal contributed $24 \%$ of total emissions, barely half of the liquid fuel contribution and marginally less than natural gas. Per capita $\mathrm{CO}_{2}$ emissions from Canada peaked in 1979 at 4.9 metric tons of carbon per e pita, a value exceeded only by the German Democratic Republic and the United States among the major $\mathrm{CO}_{2}$ emitting nations.

Note-Growth rates were calculated (before rounding) by performing a linear regression of $\log \mathrm{CO}_{2}$ emissions versus time and calculating the slope of the regression line. 
Carbon Dioxide Emission Estimates*

\begin{tabular}{|c|c|c|c|c|c|c|c|}
\hline Year & Total & Sollid & Llyuld & Gins & Coment & $\begin{array}{l}\text { Cuas } \\
\text { nuring }\end{array}$ & $\begin{array}{c}\text { Per } \\
\text { conplta }\end{array}$ \\
\hline 1950 & 42.3 & 26.6 & 14.3 & 1.0 & 0.4 & $0.0^{\circ}$ & 3.1 \\
\hline 1951 & 44.6 & 26.7 & 16.5 & 1,1 & 0.4 & 0.0 & 3.2 \\
\hline 1952 & 43.7 & 24.7 & 17.4 & 1.2 & 0.4 & 0.0 & 3,0 \\
\hline 1953 & 44.0 & 22.8 & 19.1 & 1.3 & 0.5 & 0.3 & 3,0 \\
\hline 1954 & 44.7 & 22,0 & 20.5 & 1.6 & 0.5 & 0.0 & 2.9 \\
\hline 1955 & 40,4 & 19.9 & 23,4 & 2.0 & 0.5 & 0.6 & 2.9 \\
\hline 1956 & 52.0 & 21.6 & 26.5 & 2.3 & 0.6 & 0.9 & 3.2 \\
\hline 1457 & 50.0 & 17.9 & 27.3 & 3.0 & 0.7 & 1.1 & 3.0 \\
\hline 1958 & 49.8 & 15,7 & 28.5 & 3.7 & 0.8 & 1.1 & 2.9 \\
\hline 1959 & 50.5 & 14.7 & 29.4 & 4.7 & 0.8 & 0.9 & 2.9 \\
\hline 1960 & 52.7 & 13,6 & 31.6 & 5.9 & 0.7 & 0.9 & 2.9 \\
\hline 1961 & 53.0 & 12.5 & 32,4 & 6.3 & 0.8 & 1.1 & 2.9 \\
\hline 1962 & 56.6 & 12,9 & 34.5 & 7.1 & 0.8 & 1.3 & 3.0 \\
\hline 1963 & 57.7 & 12.8 & 36.6 & 6.1 & 0.9 & 1.2 & 3.0 \\
\hline 1964 & 64.9 & 14.3 & 39.2 & 9.3 & 1.0 & 1.2 & 3.4 \\
\hline 1965 & 68.9 & 14.9 & 41,4 & 10.4 & 1,0 & 1.1 & 3.5 \\
\hline 1966 & 70.1 & 14,4 & 41.9 & 11.6 & $1 . !$ & 1.2 & 3.5 \\
\hline 1967 & 77.0 & 15.7 & 46.8 & 12.3 & 1.0 & 1.1 & 3.8 \\
\hline 1968 & 81.7 & 16.6 & 48,9 & 14.0 & 1.0 & 1.2 & 3.9 \\
\hline 1969 & 83.7 & 16.2 & 49.3 & 15.9 & 1.0 & 1.2 & 4.0 \\
\hline 1970 & 90.6 & 10.1 & 55.1 & 17.1 & 1.0 & 1.3 & 4.2 \\
\hline 1971 & 93.5 & 15.3 & 57.4 & 18.4 & 1.1 & 1.2 & 4.3 \\
\hline 1972 & 101.2 & 17.0 & 60.9) & 20.9 & 1.2 & 1.2 & 4.6 \\
\hline 1973 & 101.7 & 14.2 & 62.6 & 22.3 & 1.4 & 1.2 & 4.6 \\
\hline 1974 & 103.1 & 13.2 & 64.7 & 22.8 & 1.4 & 1.0 & 4.6 \\
\hline 1975 & 105.8 & 16.7 & 6.3 .5 & 23.4 & 1.4 & 0.7 & 4.7 \\
\hline 1976 & 106,8 & 16.1 & 64.6 & 24.1 & 1.3 & 0.7 & 4.6 \\
\hline 1977 & 109.7 & 17.7 & 65,0 & 25.1 & 1.3 & 0.6 & 4.7 \\
\hline 1978 & 111.6 & 18.3 & 65.6 & 25.6 & 1.4 & 0.7 & 4.8 \\
\hline 1979 & 116,0 & 19.6 & 67.7 & 26.3 & 1.6 & 0.8 & 4.9 \\
\hline 1980 & 115.8 & 21.3 & 65.9 & 26.4 & 1.4 & 0.9 & 4.6 \\
\hline 1981 & 112.1 & 22.1 & 62.0 & 25.8 & 1.4 & 0.8 & 4.6 \\
\hline 1982 & 108.3 & 23.3 & 56.8 & 26.2 & 1.1 & 0.8 & 4.4 \\
\hline 198.3 & 106.8 & 24.9 & 53.0 & 27.0 & 1.1 & 0.8 & 4.3 \\
\hline 1984 & 110.6 & 27.2 & 52.2 & 28.8 & 1.2 & 1.2 & 4.4 \\
\hline 1985 & 109.6 & 26,8 & 50,0 & 30.1 & 1.4 & 1.4 & 4.3 \\
\hline 1986 & 107.1 & 24.8 & 50.5 & 29.0 & 1.4 & 1.3 & 4.2 \\
\hline 1987 & 112.0 & 27.1 & 52,4 & 29,6 & 1.7 & 1.3 & 4.3 \\
\hline 1988 & 119,4 & 28.9 & 54.9 & 32.5 & 1.7 & 1.4 & 4.6 \\
\hline
\end{tabular}

\section{REFLRENCLS}

Kecting, $(., D, 1973$, Industrial production af carbon dicxide from fossil fucls and

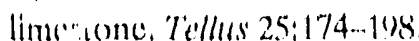

Marland, (i., and R.M. Rolly. 1984. Cantoon dioxide emissions from fousil fuels: $A$ procedure for estimition and results for

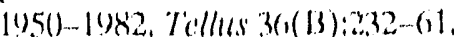

Marliand, (i, T.A. Buden, R,C. Ciriffin, S.F. Huang, P. Kanciruk, and T.R. Nelson. 1989. Estimates of $\mathrm{CO}_{2}$ cmissions from forsil forel burning and coment manu-

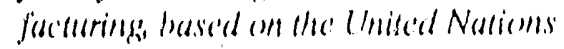

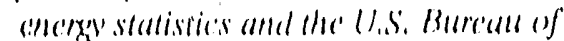

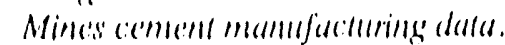

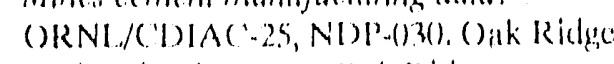
National Laboratlory, ()itk Ridere, Tennessee.

Rotty, R.M., and (i, Marlindl. I)\&6, Finsil luet combustion: recent innounts, pallerns, and trends of $(C), p p, 484,5(k)$, IN

J.R. Trablalkit and D.E. Reichle (cds.) The Chenging cartom cylle: al cilobal Analysis, Springer Vorlige.

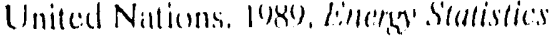

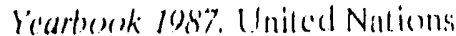
Department of International Economic and Soccial Allitirs, Śtutistical (office, New York.

U.S. Burcau of Mines. I) Ins. Mincrals

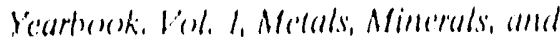
Firrls. Wishington, D)(

U.S. Department ol Energy. Ioss

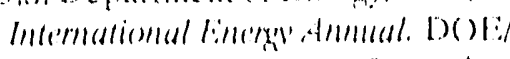

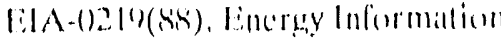
Administrattion, Waishunglom, D) 

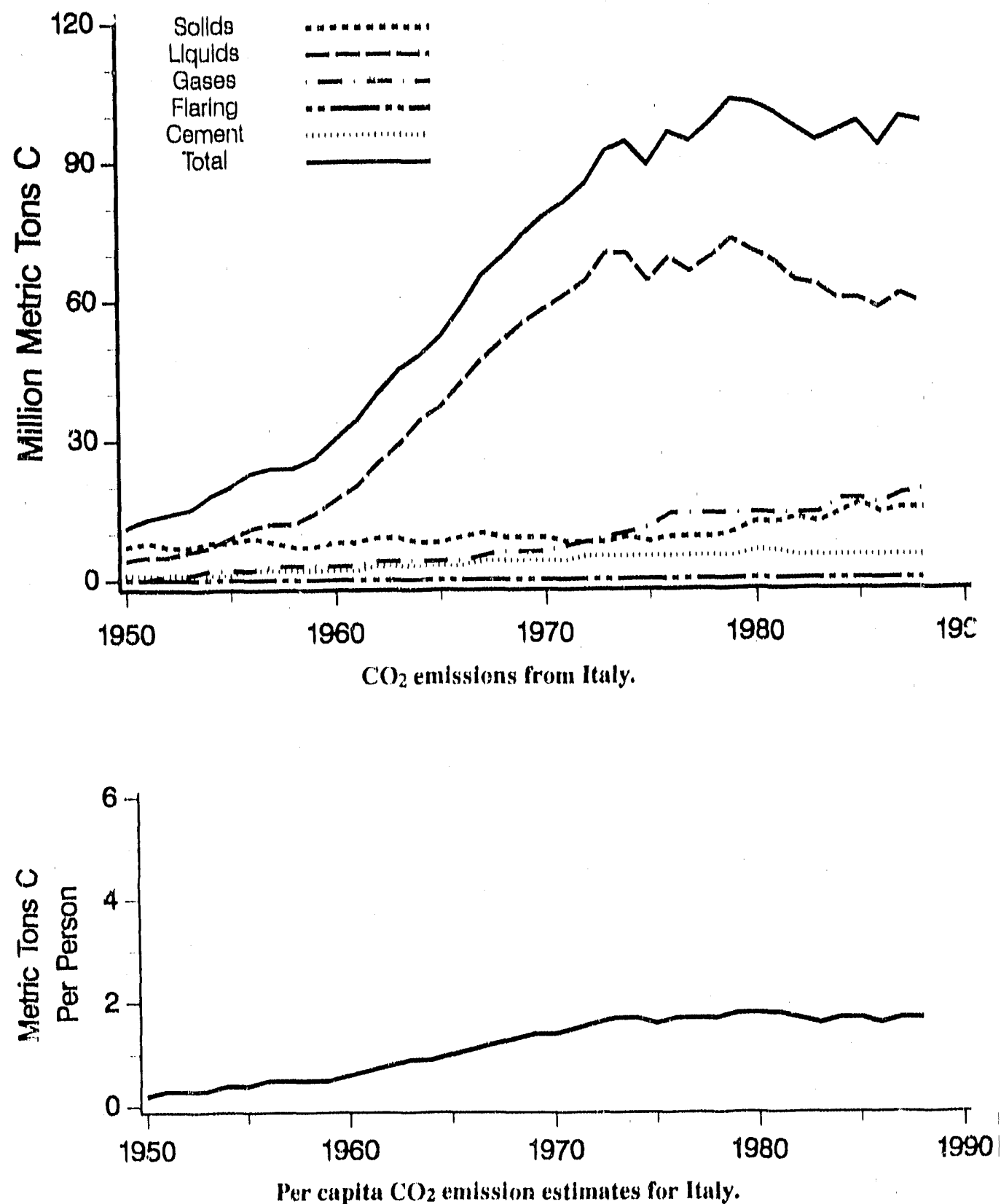


\section{$\mathrm{CO}_{2}$ Emissions}

\$4\$

\section{TREND}

As was the case for many industrialized nations, $\mathrm{CO}_{2}$ emissions from Italy rose steeply from 1950 until the growth was abruptly terminated in 1974. Since 1974, emissions from liquid fuels have vacillated but generally declined, dropping from 75 to $60 \%$ of a static, but vacillating, total. Significant increases in natural gas consumption and a slight upturn in coal burning have compensated for the drop in oil consumption. Coal usage was virtually constant from 1950 to 1974 and has nearly doubled since 1974. Per capita $\mathrm{CO}_{2}$ emissions grew rapidly from 1950 to 1974 , increasing by a factor of 7 , but have been nearly constint since 1974 .

Note-Growth rates were calculated (before rounding) by performing a linear regression of $\log \mathrm{CO}_{2}$ emissions versus time and calculating the slope of the regression line. 


\section{Italy}

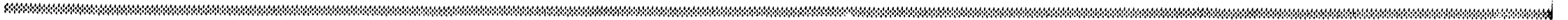

\section{Carbon Dioxide Emission Estimates*}

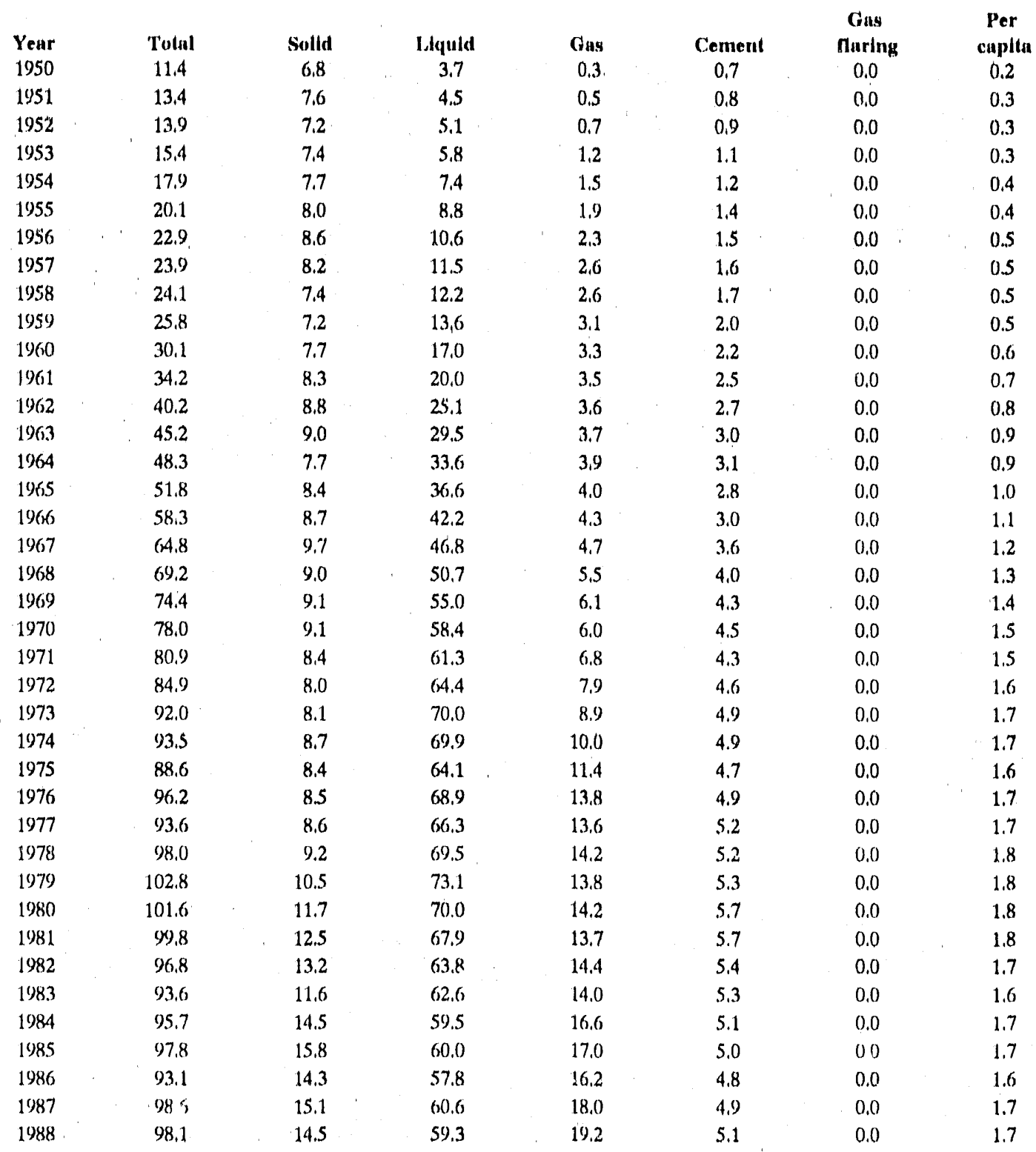

- Emission estimates rounded and expressed in million metric tons of carbon; per capita estimates rounded and 


\section{$\mathrm{CO}_{2}$ Emissions}

\section{REFERENCES}

Keeling, C.D. 1973. Industrial production of carbon dioxide from fossil fucls and limestone. Tellas 25:174 -198.

Marland, G., and R.M. Rotfy. 1984. Carbon dioxide emissions from fossil fuels: $A$ procedure for estimation and results for 1950-1982. Tellus 3i(B):232-61.

Marland, C., T.A. Boden, R.C.. Griffin, S.F. Huang, P. Kanciruk, and T.R. Nelson. 1989. Estimates of $\mathrm{CO}_{2}$ cmissions from fossil fuel buming and cement mantufacturing based on the United Nations energy statistics and the U.S. Burcau of Mines cement manufacturing data. ORNL/CDIAC (-25, NDP-()3). ()ak Ridge National Laboratory, Oak Ridge, Tennessee.

Rotty, R.M., and C. Marland. 1986. Fossil fuel combustion: recent amounts, patterns, and trends of (C). Pp. 484-50). IN J.R. Trabalka and D.E. Reichle (cds.), The Changing Carbon Cycle: A Cilobal Analysis, Springer Verlag.

United Nations. 1989. Enengy Statistics Yearbook 1987. United Nations Department of International Economic and Social Affars, Statistical office, New York.

U.S. Burcau of Mincs. 1988. Minerals Yearbook. Vol, I, Metals, Mincrals, and Fuels. Wathington, D.C.

U.S. Department of Energy. 1988. Intemational Enengy Anmual. D()E/ EIA-(0219(88). Encrgy Information Administration, Washington; D.C. 


\section{German Democratic Republic}

BACK GROUND
Principal investigator
Gregg Marland
Environmental Sciences Division
Oak Ridge National Laboratory
Oak Ridge, Tennessee $37831-6335$
U.S.A.
Sponsoring agency
U.S. Department of Energy
Carbon Dioxide Research Program
Period of record - 1950-1988.
Method - Global CO 2 emission estimates
derived primarily from the U.N. energy
statistics were calculated by using the
methods of Marland and Rotty (1984). The
energy data were compiled from U.N.
questionnaires supplemented by national
statistical publications. Data from the U.S.
Bureau of Mines were used to estimate CO
emitted during cement production.
Emissions from gas flaring were derived
primarily from. U.N. data but were
supplemented with data from the U.S.
Department of Energy and with a few global
and national estimates provided by Gregg
Marland.
Data availability - Global and national CO
emission estimates, along with the data used
in calculating these estimates, are
documented and available from CDIAC
(Marland et al. 1989). The U.N. energy
statistics are available on magnetic tape
from the U.N. Energy Statistics Unit. The

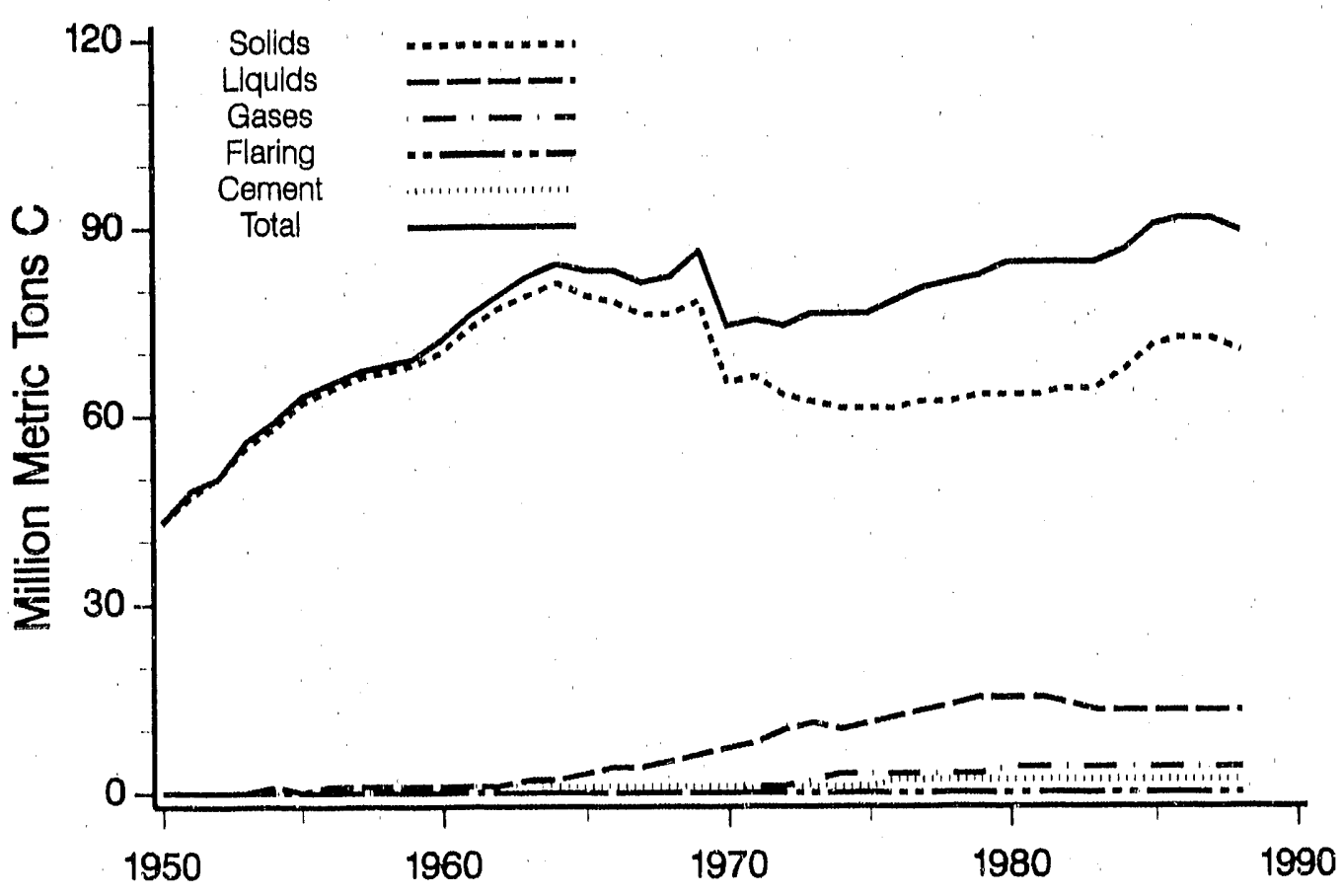

$\mathrm{CO}_{2}$ emissions from the German Democratic Republic.

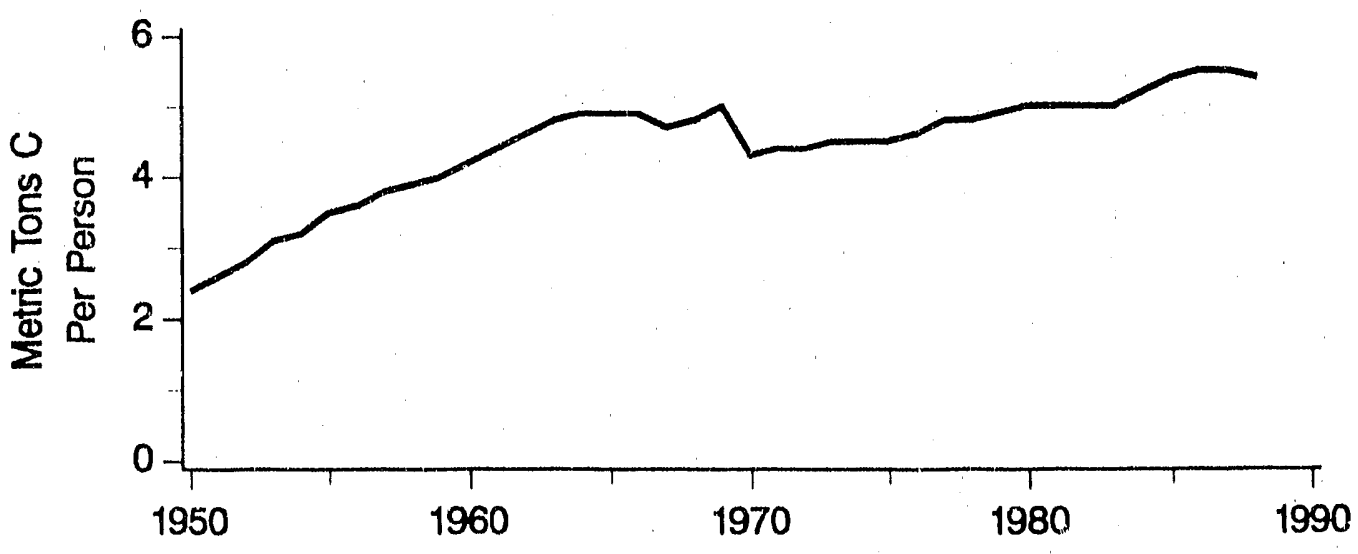

Per capita $\mathrm{CO}_{2}$ emission for the German Democratic Republic. 


\section{$\mathrm{CO}_{2}$ Emissions}

\section{TREND}

$\mathrm{CO}_{2}$ emissions from the German Democratic Republic grew steadily from 1950 to 1964 and then stalled for 5 years before dropping by $14 \%$ in 1970 . Emissions have grown slowly but steadily since 1970 . Per capita emissions have been consistently high and since 1982 have been the highest among the major economies of the world. The current level is 5.4 tons of carbon per capita, 2.3 times the 1950 value. Growth to 1970 was based largely on coal consumption, with coal contributing as much as $91 \%$ of emissions in 1969 and still over $79 \%$ in 1988. Petroleum became a significant contributor in the mid-1960s and, in spite of dropping slightly since 1980 , still contributes $14 \%$ of $\mathrm{CO}_{2}$ emissions.

Note - Growth rates were calculated (before rounding) by performing a linear regression of $\log \mathrm{CO}_{2}$ emissions versus time and calculating the slope of the regression line. 
Carbon Dioxide Emission Estimates*

\begin{tabular}{|c|c|c|c|c|c|c|c|}
\hline Year & Total & Solld & Liquild & Gas & Cement & $\begin{array}{c}\text { Gas } \\
\text { naring }\end{array}$ & $\begin{array}{l}\text { Per } \\
\text { capita }\end{array}$ \\
\hline 1950 & 43.5 & 43.3 & 0.0 & 0.0 & 0.2 & $0.0^{\circ}$ & 2.4 \\
\hline 1951 & 47.6 & 47.2 & 0.2 & 0.0 & 0.2 & 0.0 & 2.6 \\
\hline 1952 & 50.4 & 49.7 & 0.4 & 0.0 & 0.3 & 0.0 & 2.8 \\
\hline 1953 & 55.8 & 55.1 & 0.4 & 0.0 & 0.3 & 0.0 & 3.1 \\
\hline 1954 & 58.7 & 57.8 & 0.6 & 0.0 & 0.4 & 0.0 & 3.2 \\
\hline 1955 & 63.2 & 62.4 & 0.4 & 0.0 & 0.4 & 0.0 & 3.5 \\
\hline 1956 & 64.8 & 63.7 & 0.7 & 0.0 & 0.4 & 0.0 & 3.6 \\
\hline 1957 & 67.0 & .65 .6 & 0.8 & 0.0 & 0.5 & 0.0 & 3.8 \\
\hline 1958 & 68.2 & 67.0 & 0.7 & 0.0 & 0.5 & 0.0 & 3.9 \\
\hline 1959 & 68.8 & 67.5 & 0.7 & 0.0 & 0.6 & 0.0 & 4.0 \\
\hline 1960 & 71.9 & 70.3 & 0.9 & 0.0 & 0.7 & 0.0 & 4.2 \\
\hline 1961 & 75.7 & 73.8 & 1.1 & 0.0 & 0.7 & 0.0 & 4.4 \\
\hline 1962 & 79.3 & 77.1 & 1.4 & 0.0 & 0.7 & 0.0 & 4.6 \\
\hline 1963 & 81.6 & 79.0 & 1.8 & 0.0 & 0.7 & 0.0 & 4.8 \\
\hline 1964 & 84.1 & 80.8 & 2.5 & 0,0 & 0.8 & 0.0 & 4.9 \\
\hline 1965 & 82.6 & 78.7 & 3.0 & 0,0 & 0.8 & 0.0 & 4.9 \\
\hline 1966 & 83.1 & 78.2 & 3.9 & 0.0 & 0.9 & 0.0 & 4.9 \\
\hline 1967 & 80.8 & 75.6 & 4.2 & 0.0 & 1.0 & 0.0 & 4.7 \\
\hline 1968 & 81.8 & 75.6 & 5.1 & 0.1 & 1.0 & 0.0 & 4.8 \\
\hline 1969 & 85.6 & 78.2 & 6.3 & 0.1 & 1.0 & 0.0 & 5.0 \\
\hline 1970 & 73.8 & 65.0 & 7.4 & 0.3 & 1.1 & 0.0 & 4.3 \\
\hline 1971 & 75.1 & 65.7 & 7.8 & 0.5 & 1.2 & 0.0 & 4.4 \\
\hline 1972 & 74.5 & 62.6 & 9.8 & 0.9 & 1.2 & 0.0 & 4.4 \\
\hline 1973 & 75.6 & 62.1 & 10.5 & 1.6 & 1.3 & 0.0 & 4.5 \\
\hline 1974 & 75.6 & 61.1 & 10.5 & 2.7 & 1.4 & 0.0 & 4.5 \\
\hline 1975 & 75.9 & 60.7 & 11.1 & 2.8 & 1.4 & 0.0 & 4.5 \\
\hline 1976 & 77.9 & 61.3 & 12.0 & 3.0 & 1.5 & 0.0 & 4.6 \\
\hline 1977 & 79.9 & 62.0 & 13.2 & 3.0 & 1.6 & 0.0 & 4.8 \\
\hline 1978 & 80.7 & 62.2 & 14.0 & 2.9 & 1.7 & 0.0 & 4.8 \\
\hline 1979 & 82.4 & 62.9 & 14.9 & 3.0 & 1.7 & 0.0 & 4.9 \\
\hline 1980 & 83.7 & 63.1 & 15.3 & 3.6 & 1.7 & 0.0 & 5.0 \\
\hline 1981 & 84.0 & 63.2 & 15.1 & 4.0 & 1.7 & 0.0 & 5.0 \\
\hline 1982 & 84.1 & 64.2 & 14.5 & 3.9 & 1.6 & 0.0 & 5.0 \\
\hline 1983 & 83.5 & 64.3 & 13.4 & 4.2 & 1.6 & 0.0 & 5.0 \\
\hline 1984 & 86.0 & 67.1 & 13.2 & 4.2 & 1.6 & 0.0 & 5.2 \\
\hline 1985 & 90.2 & 71.4 & 13.4 & 3.9 & 1.6 & 0.0 & 5.4 \\
\hline 1986 & 91.1 & 72.1 & 13.1 & 4.3 & 1.6 & 0.0 & 5.5 \\
\hline 1987 & 91.1 & 72.3 & 12,8 & 4.3 & 1.7 & 0.0 & 5.5 \\
\hline 1988 & 89.3 & 70.5 & 12.8 & 4.2 & 1.7 & 0.0 & 5.4 \\
\hline
\end{tabular}

\section{REFERENCES}

Keeling C.D. 1973. Industrial production of carbon dioxide from fossil fucls and limestone. Tellus 25:174-198.

Marland, G., and R.M. Rotty. 1984. Carbon dioxide cmissions from fossil fuels: A procedure for estimation and results for 1950-1982. Telltws 36(B):232-61.

Marland, G., T.A. Boden, R.C. Griflin, S.F. Huang, P. Kanciruk, and T.R. Nelson. 1989. Estimates of $\mathrm{CO}_{2}$ emissions from fossil fuel buming and cement mamufacturing, based on the United Nations energy statistics and the U.S. Burean of Mines cement manufacturing data.

ORNL/CDIAC-25, NDP-()30. ()ak Ridge National Laboratory, Oak Ridge, Tennessece.

Rotty, R.M., and G. Marland. 1986. Fossil fucl combustion: recent amounts, patterns, and trends of $\left.\mathrm{CO}_{2}, \mathrm{pp}, 484-50 \mathrm{~K}\right)$. IN J.R. Trabalka and D.E. Reichle (eds.), The Changing Carton Cycle: A Gilobal Analysis, Springer-Verlag.

United Nations. 1989. Enerny Statistics Yearbook 1987. United Nations Department of International Economic and Social Affairs, Statistical Office, New York.

U.S. Burcau of Mincs. 1988. Minerals Yearbook. Vol. 1, Metals, Minerals, and Fuels. Washington, D.C.

U.S. Department of Energy. 1988 International Encrery Annual. D()E EIA-(1) 1 (O)(BY) Energy Inlormation Adminictration, Washington, $D$ 


\section{France}

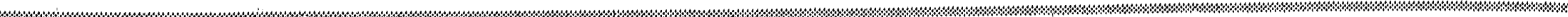

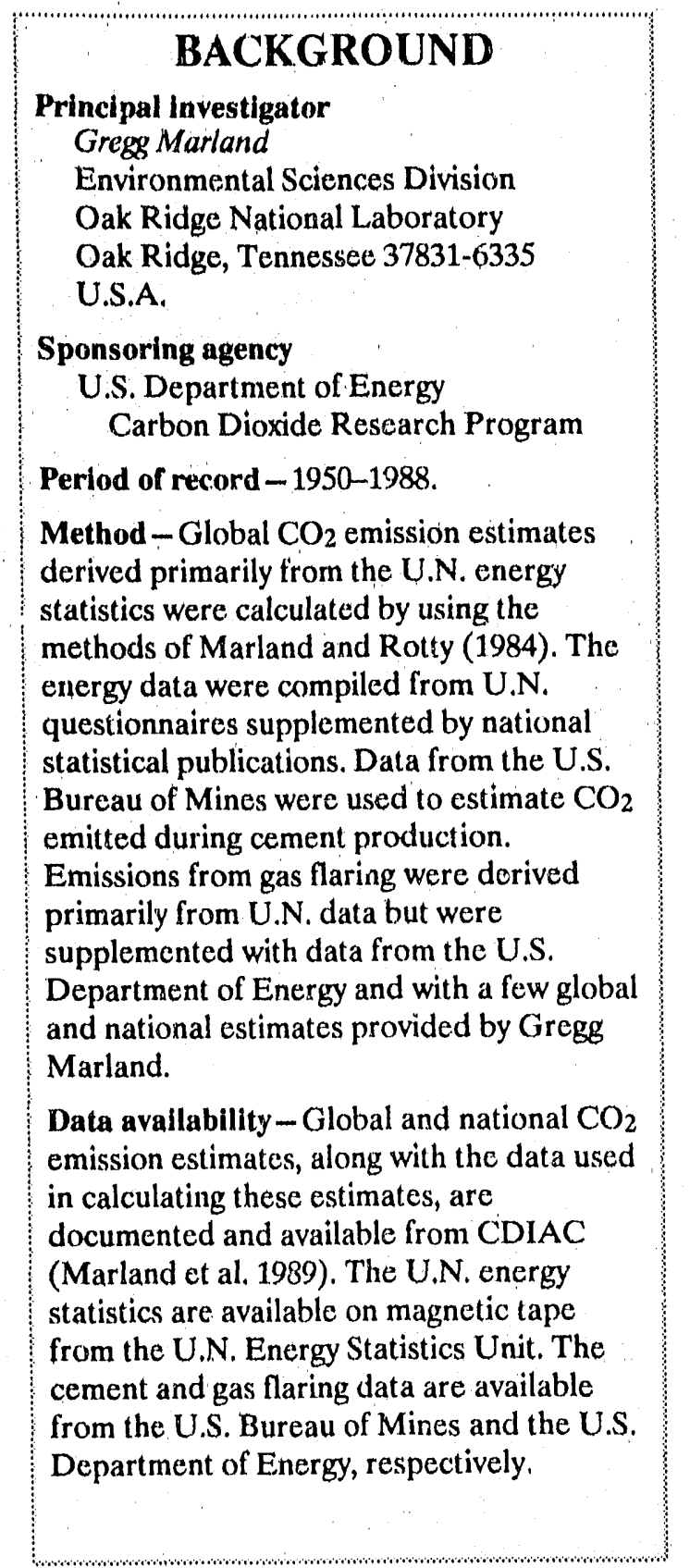
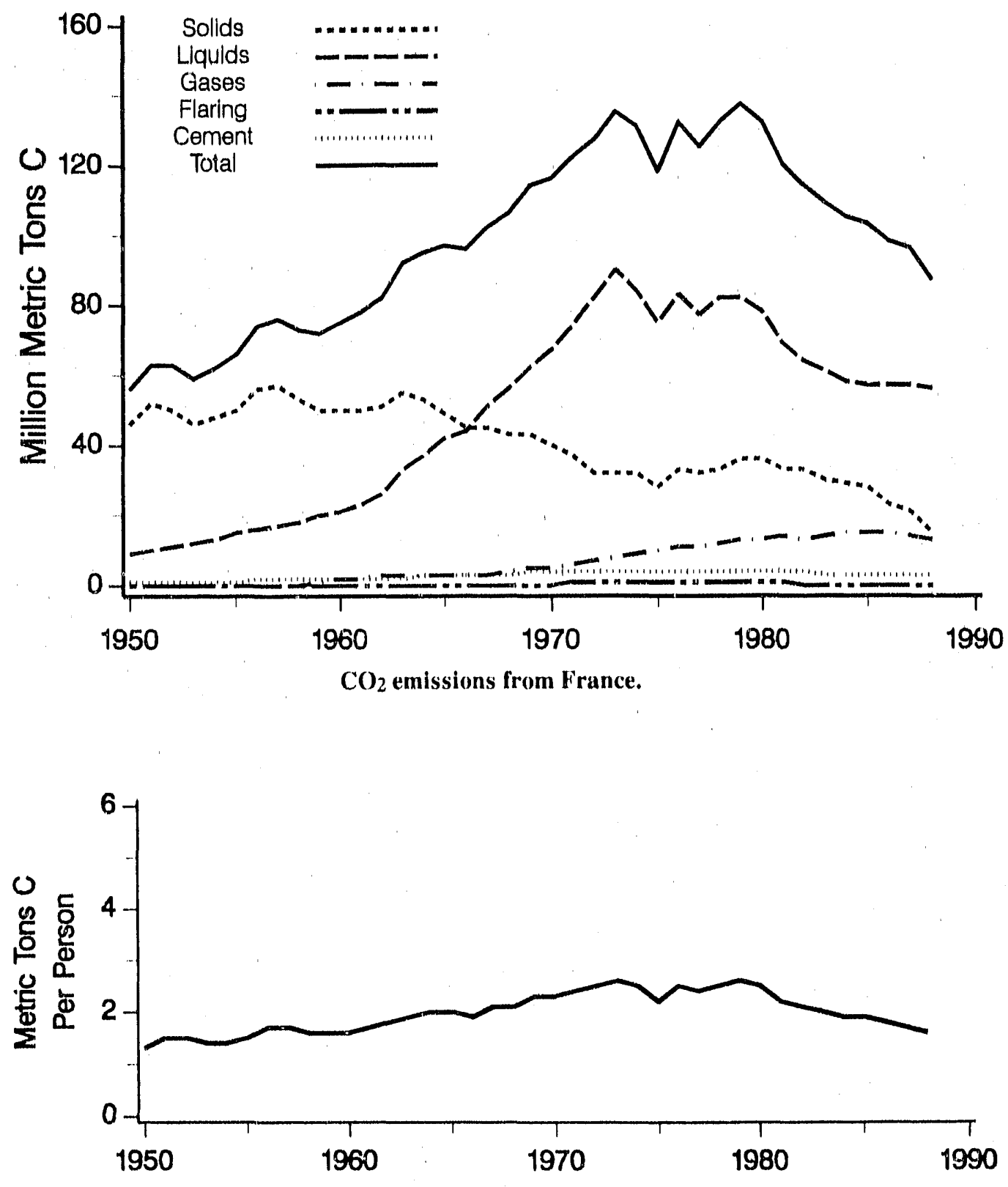


\section{$\mathrm{CO}_{2}$ Emissions}

\$

\section{TREND}

The $\mathrm{CO}_{2}$ emissions history of France is striking in the decline in emissions that has occurred since 1973, particularly since 1979. The country total since 1973 is virtually a reflection of the decrease in liquid fuel use, although a late 1970s bulge in emissions from solid fuels and continuing increased use of natural gas pushed the 1979 value above the 1973 total. $\mathrm{CO}_{2}$ emissions in 1950 were $83 \%$ from coal, but coal use declined steadily from 1963 to 1975 , and even the late 1970s bulge appears to have been $\mathrm{a}$ temporary reaction to world oil price increases. By 1988 only $18 \%$ of emissions were from coal, and natural gas was creeping toward $15 \%$. France made a major commitment to nuclear power and nuclear power generation grew rapidly from about 1975 until it contributed $76 \%$ of total electricity generation in 1987. France is a net exporter of electricity. Extensive use of nuclear power has clearly restrained $\mathrm{CO}_{2}$ emissions from France; per capita cmissions declined regularly from the 1973 maximum until the 1988 value, which is near that observed 33 years earlier. $\mathrm{CO}_{2}$ emissions in 1988 were $36 \%$ less than the 1979 maximum.

Note-Growth rates were calculated (before rounding) by performing a linear regression of $\log \mathrm{CO}_{2}$ emissions versus time and calculating the slope of the regression line. 


\section{Carbon Dioxide Emission Estimates*}

\begin{tabular}{|c|c|c|c|c|c|c|c|}
\hline Year & Totsl & solid & Llyuild & Gas & Cement & $\begin{array}{l}\text { Gus } \\
\text { narling }\end{array}$ & $\begin{array}{c}\text { Per } \\
\text { capitut }\end{array}$ \\
\hline 1950 & 55.8 & 46.1 & 8.6 & 0.1 & 1.0 & $0.0^{\circ}$ & 1.3 \\
\hline 1951 & 6.3 .0 & 51,6 & 10.2 & 0.2 & 1.1 & 0.0 & 1.5 \\
\hline 1952 & 62.5 & 50.2 & 11,0 & 0.2 & 1.2 & 0.0 & 1.5 \\
\hline 1953 & 59,1 & 46.0 & 11.7 & 0.1 & 1.3 & 0,0 & 1.4 \\
\hline 1954 & 62.3 & 47.5 & 13.3 & 0.2 & 1.3 & 0.0 & 1.4 \\
\hline 1955 & 65.8 & 49.5 & 14.7 & 0.2 & 1.4 & 0,0 & 1.5 \\
\hline 1956 & 73,9 & 55,7 & 16.5 & 0.2 & 1.6 & 0.0 & 1.7 \\
\hline 1957 & 76.4 & 57.3 & 17.1 & 0.3 & 1.7 & 0.0. & 1.7 \\
\hline 1958 & 73.3 & 52.7 & 18.4 & 0.4 & 1.8 & 0.0 & 1.6 \\
\hline 1959 & 72.2 & 49.8 & 19.8 & 0.8 & 1,9 & 0.0 & 1.6 \\
\hline 1960 & 74.8 & 49.9 & 21.4 & 1.6 & 1.9 & 0.0 & 1.6 \\
\hline 1961 & 77.7 & 50.1 & 23.3 & 2.2 & 2.1 & 0,0 & 1.7 \\
\hline 1962 & 82.5 & 51.4 & 26.2 & 2.5 & 2.3 & 0.0 & 1.8 \\
\hline 1963 & 92.2 & 54.5 & 32.6 & 2.6 & 2.5 & 0.0 & 1.9 \\
\hline 1964 & 95.3 & 52.5 & 37.1 & 2.7 & 2.9 & 0.0 & 2.0 \\
\hline 1965 & 97.1 & 49.2 & 42,1 & 2.7 & 3.0 & 0.0 & 2.0 \\
\hline 1966 & 95.7 & 45.4 & 44.2 & 2.9 & 3.2 & 0,0 & 1.9 \\
\hline 1967 & 102.3 & 44,7 & 51.1 & 3.3 & 3.3 & 0.0 & 2.1 \\
\hline 1968 & 105.7 & 42.8 & 55,6 & 3.9 & 3.5 & 0.0 & 2.1 \\
\hline 1969 & 113.6 & 42.9 & 62.5 & 4.5 & 3.7 & 0.0 & 2.3 \\
\hline 1970 & 116.2 & 40.3 & 66.8 & 5.1 & 3.9 & 0.0 & 2.3 \\
\hline 1971 & 122.1 & 36.7 & 73.9 & 6.1 & 3.9 & 1.5 & 2,4 \\
\hline 1972 & 126.8 & 32.4 & 81.7 & 7.2 & 4.1 & 1.4 & 2.5 \\
\hline 1973 & 135.5 & 31,9 & 89.6 & 8.5 & 4.2 & 1.4 & 2.6 \\
\hline 1974 & 130.8 & 31,9 & 84.3 & 8.8 & 4.4 & 1,3 & 2.5 \\
\hline 1975 & 118.2 & 28.0 & 75.1 & 9.8 & 4.0 & 1.2 & 2.2 \\
\hline 1976 & 132.3 & 33,0 & 83.4 & 10.6 & 4.0 & 1.3 & 2.5 \\
\hline 1977 & 125.2 & 32.2 & 76.8 & 11.0 & 3.9 & 1.3 & 2.4 \\
\hline 1978 & 132.1 & 33.4 & 81.6 & 12.0 & 3.8 & 1.3 & 2.5 \\
\hline 1979 & 136,9 & 36.3 & 82.4 & 13,2 & 3.9 & 1.0 & 2.6 \\
\hline 1980 & 132.1 & 36.3 & 77.7 & 13.4 & 4.0 & 0.8 & 2.5 \\
\hline 1981 & 120.5 & 33.2 & 69.2 & 13.7 & 3.8 & 0.5 & 2.2 \\
\hline 1982 & 114.4 & 33.2 & 64.2 & 13.2 & 3.6 & 0.3 & 2.1 \\
\hline 1983 & 108.7 & 30.1 & $6(x), 8$ & 14.5 & 3.3 & 0.0 & 2.0 \\
\hline 1984 & 104.7 & 28.6 & 58.4 & 14.6 & 3.1 & 0.0 & 1.9 \\
\hline 1985 & 103,3 & 27.8 & 57,0 & 15.2 & 3.2 & 0.0 & 1.9 \\
\hline 1986 & 98.2 & 23.0 & 56.7 & 15.2 & 3.2 & 0.0 & 1.8 \\
\hline 1987 & 96.1 & 21,2 & 57.3 & 14.4 & 3.2 & 0.0 & 1.7 \\
\hline 1988 & 87.3 & 15.5 & 55.6 & 13.0 & 3.3 & 0.0 & 1.6 \\
\hline
\end{tabular}

\section{RELIERLNCHS}

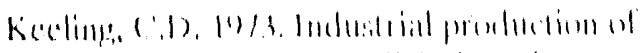

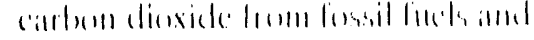

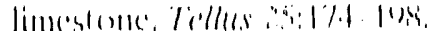

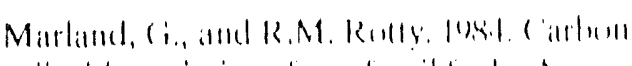

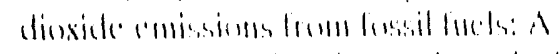

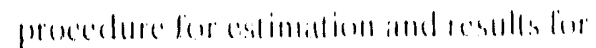

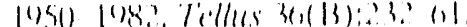

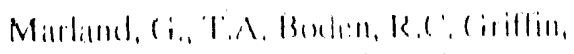

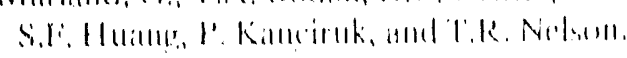

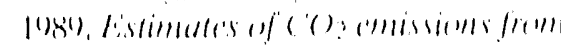

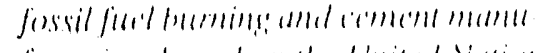

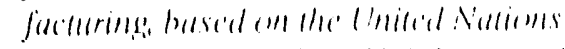

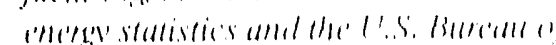

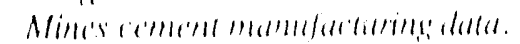

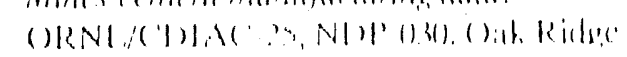

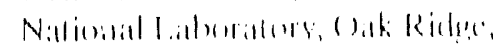
Tentenciser.

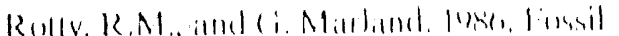

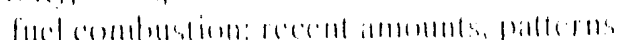

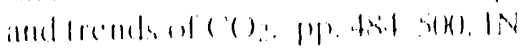

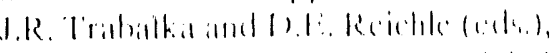

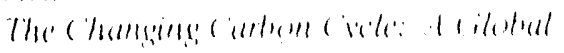

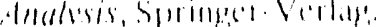

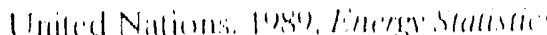

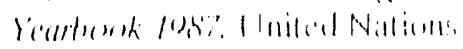

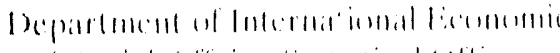

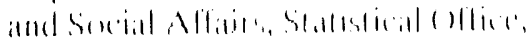
Now' Yolt.

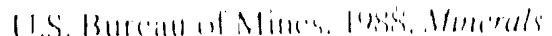

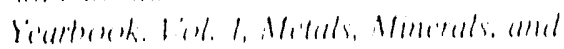

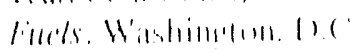

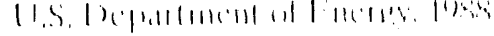

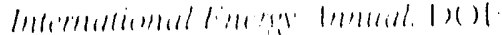

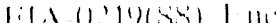

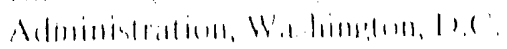




\section{Mexico}

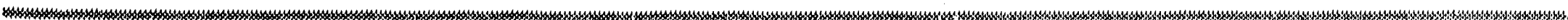

\section{BACKGROUND}

Principt' Investigator

Gregg Marland

Environmental Sciences Division

Oak Ridge National Laboratory

Oak Ridge, Tennessee 37831-6335

U.S.A.

\section{Sponsoring agency}

\section{U.S. Department of Energy}

Carbon Dioxido Research Program

Period of record - 1950-1988.

Method-Global $\mathrm{CO}_{2}$ emission estimates derived primarily from the U.N. energy statistics were calculated by using the methods of Marland and Rotty (1984). The energy data were compiled from U.N. questionnaires supplemented by national statistical publications. Data from the U.S. Bureau of Mines were used to estimate $\mathrm{CO}_{2}$ emitted during cement production.

Emissions from gas flaring were derived pximarily from U.N. data but were supplemented with data from the U.S. Department of Energy and with a few global and national estimates provided by Gregg Marland.

Data avallabillty - Global and national $\mathrm{CO}_{2}$ emission estimates, along with the data used in calculating these estimates, are documented and available from CDIAC (Marland et al. 1989). The U.N. energy statistics are available on magnetic tape from the U.N. Energy Statistics Unit. The cement and gas flaring data are available from the U.S. Bureau of Mines and the U.S. Department of Energy, respectively.
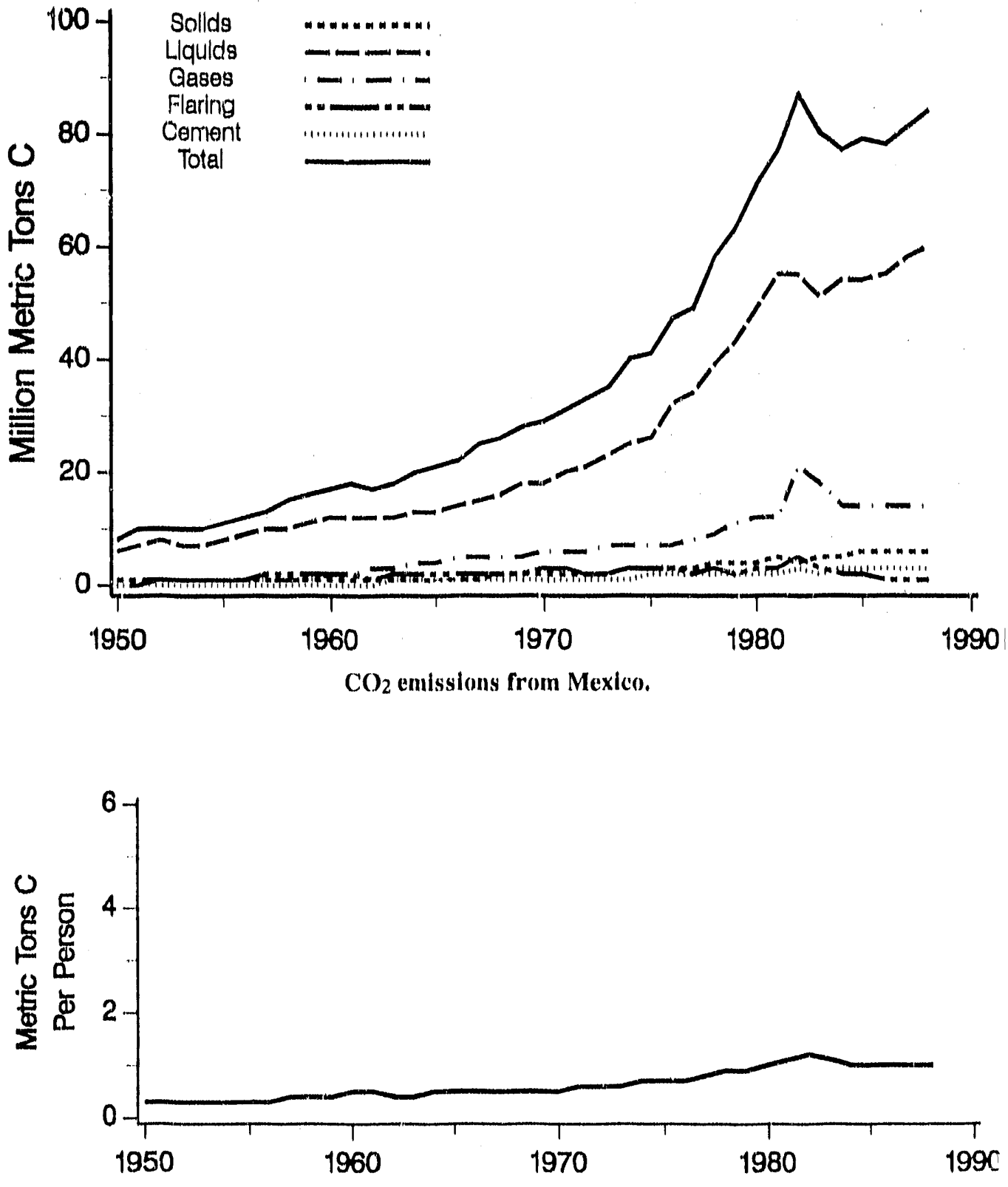

Per capita $\mathrm{CO}_{2}$ emission estimates for Mexico. 


\section{$\mathrm{CO}_{2}$ Emissions}

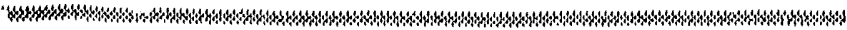

\section{TREND}

$\mathrm{CO}_{2}$ umissions from Mexico graw exponentially at a rate of $6.9 \%$ per year from 1950 to 198 ? but tumbled abruptly after 1982. Emissions growth was largely based on increasing oll production, and even in $1988,71.6 \%$ of emissions were from petroleum products, the highest fraction of any of the major emitting countries. For capita emissions also peaked in 1982 and were $16 \%$ lower by 1988 . The impact of the oil prico dislocations of tho late 1970s and early $1980 \mathrm{~s}$ is also reflected in a $74.5 \%$ decrease in emissions from gas flaring after 1982. Consumption of natural gas has become increasingly important in Mexico and now contributes $16.2 \%$ of $\mathrm{CO})_{2}$ emissions. regression of $\log \mathrm{CO}_{2}$ emissions yersus time and calculating the slope of the regression line. 


\section{Carbon Dioxide Emission Estimates*}

\begin{tabular}{|c|c|c|c|c|c|c|c|}
\hline Year & 'lotul & Sulld & Ilyuld & Gus & Cement & $\begin{array}{l}\text { Cus } \\
\text { nurlug }\end{array}$ & $\begin{array}{l}\text { Per } \\
\text { chuplta }\end{array}$ \\
\hline 19.50 & 8.3 & 0.5 & 6.5 & 0.4 & 0,2 & 0.7 & 0.3 \\
\hline 1951 & 9.5 & 0.6 & 7.3 & 0.5 & 0.2 & 1.0 & 0,3 \\
\hline 1952 & 10.2 & 0.7 & 7.7 & 0.5 & 0.2 & 1.0 & 0.3 \\
\hline 195.3 & 10.0 & 0,8 & 7.5 & 0.6 & 0.2 & 1.0 & 0,3 \\
\hline 1954 & 9.9 & 0.7 & 7,3 & 0.6 & 0.2 & 1.0 & 0.3 \\
\hline 1055 & 10.8 & 0.7 & 7.9 & 0.6 & 0.3 & 1.3 & 0.3 \\
\hline 1956 & 11.5 & 0.8 & 8.5 & 0.7 & 0.3 & 1.2 & 0.3 \\
\hline 1957 & 13.5 & 0.8 & 10.0 & 0.7 & 0,3 & 1.7 & 0.4 \\
\hline 1958 & 14.8 & 0.8 & 10.3 & 1.3 & 0.3 & 2,0 & 0.4 \\
\hline 1959 & 15.9 & 0.9 & 10.9 & 1.4 & 0.4 & 2.4 & 0.4 \\
\hline 1960 & 17.2 & 1,0 & 11.7 & 1.7 & 0.4 & 2.4 & 0.5 \\
\hline 1961 & 17.8 & 1.0 & 12.3 & 2.2 & 0.4 & 2.0 & 0.5 \\
\hline 1962 & 17.4 & 1,0 & 11.5 & 3.2 & 0.5 & 1.2 & 0.4 \\
\hline 1963 & 18.1 & 1.1 & 11.7 & 3.2 & 0.5 & 1.6 & 0.4 \\
\hline 1964 & 20.3 & 1.2 & 12.7 & 3.7 & 0,6 & 2.1 & 0.5 \\
\hline 196.5 & 20.5 & 1.1 & 12.9 & 4.3 & 0.6 & 1.6 & 0.5 \\
\hline 1060 & 22.1 & 1.2 & 13.7 & 4.6 & 0.7 & 1.8 & 0,5 \\
\hline 1967 & 24,6 & 1.4 & 15.4 & 5.4 & 0.8 & 1.6 & 0.5 \\
\hline 969 & 25.6 & 1.6 & 16.2 & 5.4 & 0.8 & 1.6 & 0.5 \\
\hline 1969 & 27,9 & 1.7 & 18.3 & 5.3 & 0.9 & 1.7 & 0.5 \\
\hline 1970 & 28.9 & 1.9 & 17,8 & 5.6 & 1.0 & 2.6 & 0.5 \\
\hline 1971 & 31.1 & 2.1 & 19.7 & 5.5 & 1.0 & 2.8 & 0.6 \\
\hline 1972 & .32 .5 & 2.2 & 20.6 & 6.2 & 1.2 & 2.3 & 0.6 \\
\hline 197.3 & 35.3 & 2.5 & 22.6 & 6.9 & 1.3 & 2.0 & 0.6 \\
\hline 1974 & 39.5 & 3.0 & 23.1 & 7.2 & 1.4 & 2.7 & 0.7 \\
\hline 1975 & 40.7 & 3.1 & 26.0 & 7.1 & 1.6 & 2.9 & 0.7 \\
\hline 1976 & 47.5 & 3.2 & 32.4 & 7.1 & 1.7 & 3.1 & 0.7 \\
\hline 1977 & 49.3 & 3.4 & 34.5 & 7.7 & 1.8 & 1.9 & 0.8 \\
\hline 1978 & $\$ 7.6$ & 3.9 & 39,4 & 9.5 & 1.9 & 2.9 & 0.9 \\
\hline 1979 & 62.5 & 4,3 & 42,6 & 11.2 & 2.1 & 2.3 & 0.9 \\
\hline 1980 & 71.0 & 4.3 & 49,4 & 12.4 & 2.2 & 2.7 & 1.0 \\
\hline 1981 & 77.1 & 4.6 & 54.5 & 12.3 & 2,4 & 3.2 & 1.1 \\
\hline 1982 & 86.9 & 4.5 & 54.5 & 20.6 & 2.6 & 4.7 & 1.2 \\
\hline 1983 & 79.7 & 5.0 & 50.9 & 18.4 & 2.3 & 3.1 & 1.1 \\
\hline 1984 & 77.4 & 5.1 & 53.6 & 14.2 & 2.5 & 2,0 & 1.0 \\
\hline 1985 & 78.6 & 5.6 & 54.1 & 14.4 & 2.8 & 1.7 & 1,0 \\
\hline 1986 & 77.6 & 5.5 & 54,8 & 13.5 & 2.7 & 1.1 & 1.0 \\
\hline 1987 & 81.5 & 5.7 & 57.9 & 13,6 & 3,1 & 1.2 & 1.0 \\
\hline 1988 & 83.7 & 5.9 & 59.9 & 13.5 & 3.1 & 1.2 & 1.0 \\
\hline
\end{tabular}

- IImlssion estimates rounded and expressed in million metric tons of carboni per caplta estimates rounded and expressed in metric tons of curbon. 


\section{South Africa}

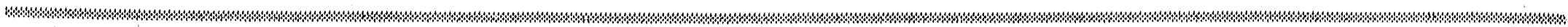

\begin{tabular}{|c|}
\hline BACKGROUND \\
\hline $\begin{array}{l}\text { Principal Investlgator } \\
\text { Greggy Marland } \\
\text { Environmental Sciences Division } \\
\text { Oak Ridge National Laboratory } \\
\text { Oak Ridge, Tennessee 37831-6335 } \\
\text { U.S.A. }\end{array}$ \\
\hline $\begin{array}{l}\text { Sponsoring agency } \\
\text { U.S. Department of Energy } \\
\text { Carbon Dioxide Research Program }\end{array}$ \\
\hline Period of record-1.950-1988. \\
\hline $\begin{array}{l}\text { Method - Global } \mathrm{CO}_{2} \text { emission estimates } \\
\text { derived primarily from the U.N. energy } \\
\text { statistics were calculated by using the } \\
\text { methods of Marland and Rotty (1984). The } \\
\text { energy data were compiled from U.N. } \\
\text { questionnaires supplemented by national } \\
\text { statistical publications, Data from the U.S. } \\
\text { Bureau of Mincs were used to estimate } \mathrm{CO}_{2} \\
\text { emitted during cement production. } \\
\text { Emissions from gas flaring were derived } \\
\text { primarily from U.N. data but were } \\
\text { supplemented with data from the U.S. } \\
\text { Department of Energy and with a few global } \\
\text { and national estimates provided by (Gregg } \\
\text { Marland. }\end{array}$ \\
\hline $\begin{array}{l}\text { Datu uvallability - Global and national } \mathrm{CO}_{2} \\
\text { emission ostimates, along with the data used } \\
\text { in calculating these estimates, are } \\
\text { documented and available from CDIAC } \\
\text { (Marland et al. 1989). The U.N. energy } \\
\text { statistics are available on magnetic tape } \\
\text { from the U.N. Encrgy Statistics Unit. The } \\
\text { cement and gas flaring data are available } \\
\text { from the U.S. Bureau of Mincs and the U.S. } \\
\text { Department of Energy, respectively. }\end{array}$ \\
\hline
\end{tabular}
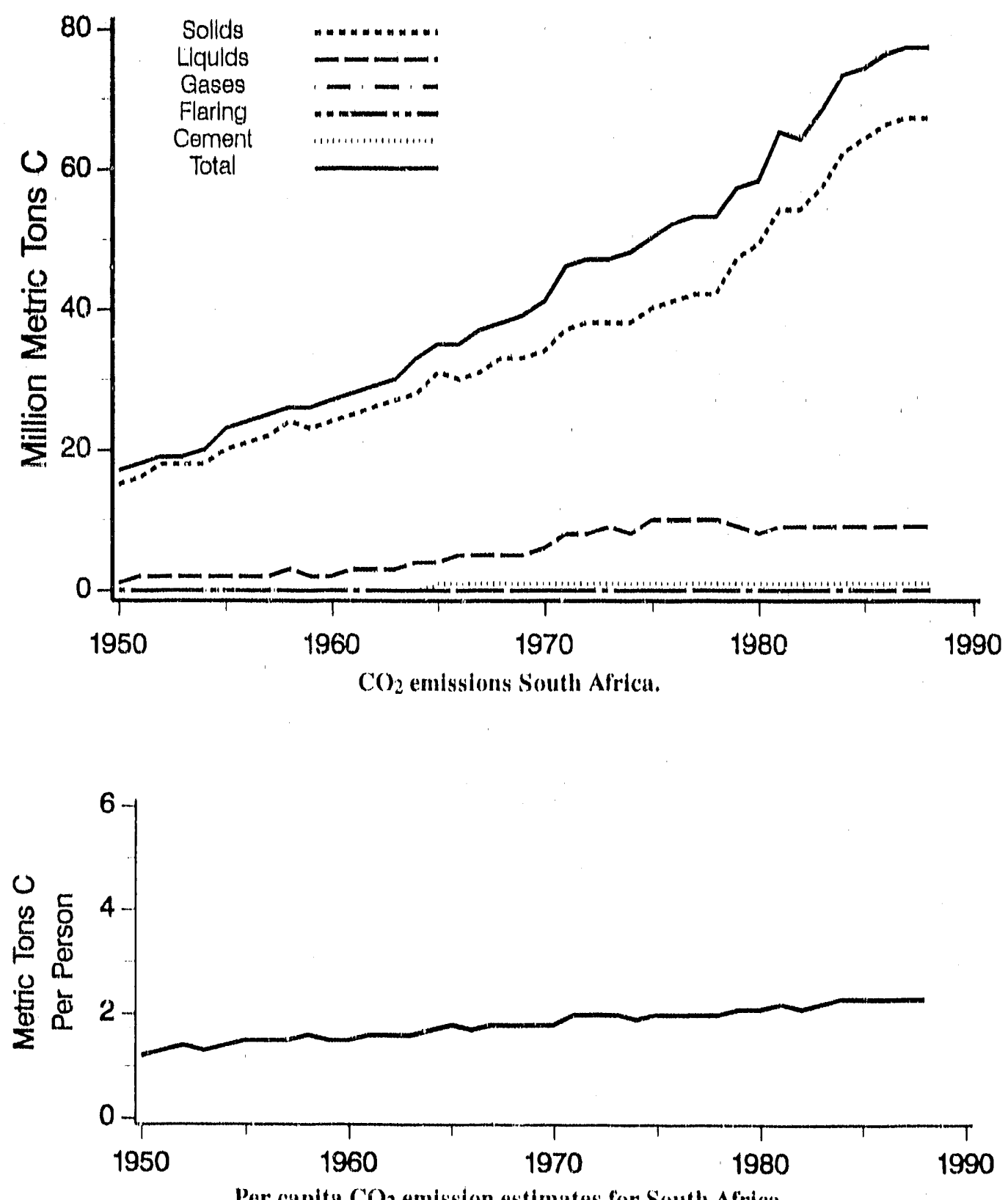


\section{$\mathrm{CO}_{2}$ Emissions}

\section{TREND}

With a domestic economy powered by coal, $\mathrm{CO}_{2}$ emissions from South Africa have risen 4.7 -fold since 1950 , with $85-90 \%$ of emissions from coal. With no natural gas, another $12 \%$ is currently from oil consumption, and the remainder is from cement manufacture. The oil price problems so evident in other countries appear to have left only minor impact on South African $\mathrm{CO}_{2}$ emissions. Per capita emissions have approximately doubled since 1950 .

It is appropriate to note that emissions shown here are by primary fuel, Consequently, when liquid fuels are produced from coal, the emissions will still appear in these tabulations as $\mathrm{CO}_{2}$ from solid fuels.

Note-Growth rates were calculated (before rounding) by performing a linear regression of $\log \mathrm{CO}_{2}$ emissions versus time and calculating the slope of the regression line. 


\section{Carbon Dioxide Emission Estimates*}

\begin{tabular}{|c|c|c|c|c|c|c|c|}
\hline Year & Total & Sollia & Liquid & Gas & Cement & $\begin{array}{l}\text { Gas } \\
\text { naring }\end{array}$ & $\begin{array}{l}\text { Per } \\
\text { capitt }\end{array}$ \\
\hline 1950 & 16.6 & 15.0 & 1.4 & 0.0 & 0.3 & & 1.2 \\
\hline 1951 & 17.8 & 16.0 & 1.5 & 0.0 & 0.3 & 0.0 & 1.3 \\
\hline 1952 & 19.5 & 17.6 & 1.6 & 0.0 & 0.3 & 0.0 & 1.4 \\
\hline 1953 & 19.5 & 17.5 & 1.7 & 0.0 & 0.3 & 0.0 & 1.3 \\
\hline 1954 & 20.3 & 18.1 & 1.8 & 0.0 & 0.3 & 0.0 & 1.4 \\
\hline 1955 & 22.8 & 20.4 & 2.1 & 0.0 & 0.3 & 0.0 & 1.5 \\
\hline 1956 & 24.0 & 21.4 & 2.3 & 0.0 & 0.3 & 0.0 & 1.5 \\
\hline 1957 & 247 & 22.1 & 2.2 & 0.0 & 0.3 & 0.0 & 1.5 \\
\hline 1958 & 26.5 & 23.6 & 2.5 & 0.0 & 0.4 & 0.0 & 1.6 \\
\hline 1959 & 26.0 & 23.3 & 2.4 & 0.0 & 0.4 & 0.0 & 1.5 \\
\hline 1960 & 26.9 & 24.1 & 2.5 & 0.0 & 0.4 & 0.0 & 1.5 \\
\hline 1961 & 28.1 & 24.9 & 2.8 & 0.0 & 0.4 & 0.0 & 1.6 \\
\hline 1962 & 29.0 & 25.6 & 3.0 & 0.0 & 0.4 . & 0.0 & 1.6 \\
\hline 1963 & 30.1 & 26.6 & 3.2 & 0.0 & 0.4 & 0.0 & 1.6 \\
\hline 1964 & 32.8 & 28.2 & 4.2 & 0,0 & 0.5 & 0.0 & 1.7 \\
\hline 1965 & 35.2 & 30.6 & 4.1 & 0.0 & 0.5 & 0.0 & 1.8 \\
\hline 1966 & 35.3 & 30.0 & 4.7 & 0.0 & 0.5 & 0.0 & 1.7 \\
\hline 1967 & 36.8 & 31.1 & 5.2 & 0.0 & 0.5 & 0.0 & 1.8 \\
\hline 1968 & 37.9 & 32.6 & 4.7 & 0,0 & 0.6 & 0.0 & 1.8 \\
\hline 1969 & 39.3 & 33.2 & 5.4 & 0.0 & 0.7 & 0.0 & 1.8 \\
\hline 1970 & 40.8 & 34.1 & 6.0 & 0.0 & 0.8 & 0.0 & 1.8 \\
\hline 1971 & 45.9 & 36.7 & 8.4 & 0.0 & 0.8 & 0.0 & 2.0 \\
\hline 1972 & 46.8 & 38.0 & 8.0 & 0.0 & 0.8 & 0.0 & 2.0 \\
\hline 1973 & 47.1 & 37.7 & 8.5 & 0.0 & 0.9 & 0.0 & 2.0 \\
\hline 1974 & 47.9 & 38.5 & 8.4 & 0.0 & 1.0 & 0.0 & 1.9 \\
\hline 1975 & 50.1 & 39.5 & 9.6 & 0.0 & 1.0 & 0.0 & 2.0 \\
\hline 1976 & 5.2 .3 & 41.1 & 10.3 & 0.0 & 1.0 & 0.0 & 2.0 \\
\hline 1977 & 52.8 & 41.9 & 9.9 & 0.0 & 0.9 & 0.0 & 2.0 \\
\hline 1978 & 53.0 & 42.3 & 9.7 & 0.0 & 0.9 & 0.0 & 2.0 \\
\hline 1979 & 56.9 & 46.8 & 9,2 & 0.0 & 0.9 & 0.0 & 2.1 \\
\hline 1980 & 58.2 & 49.3 & 7.9 & 0.0 & 1.0 & 0.0 & 2.1 \\
\hline 1981 & 64.5 & 54.4 & 9.0 & 0.0 & 1.1 & 0.0 & 2.2 \\
\hline 1982 & 63.5 & 53.9 & 8.6 & 0.0 & 1.1 & 0.0 & 2.1 \\
\hline 1983 & 67.6 & 57.3 & 9.2 & 0.0 & 1.1 & 0.0 & 2.2 \\
\hline 1984 & 72.6 & 62.4 & 9.1 & 0.0 & 1.1 & 0.0 & 2.3 \\
\hline 1985 & 73.7 & 63.6 & 9.1 & 0.0 & 1.0 & 0.0 & 2.3 \\
\hline 1986 & 75.7 & 65.6 & 9.2 & 0.0 & 0.9 & 0.0 & 2.3 \\
\hline 1987 & 76.8 & 66.6 & 9.3 & 0.0 & 0.9 & 0.0 & 2.3 \\
\hline 1988 & 77.5 & 67.0 & 9.4 & 0.0 & 1.1 & 0.0 & 2.3 \\
\hline
\end{tabular}

\section{REFERENCES}

Keeling, C.D. 1973, Industrial production of carbon dioxide from fossil fucls and limestone. Tellus 25:174-198.

Marland, G., and R.M. Rotty. 1984. Carbon dioxide cmissions from fossil fuels: A procedure for estimation and results for 1950-1982. Telllus 36(B):232-61

Marland, (i., T.A. Boden, R.C. Griffin, S.F. Huang, P. Kanciruk, and T.R. Nelson. 1989. Estimates of $\mathrm{CO}_{2}$ emissions from fossil fuel buming and cement mamufacturing, based on the United Nations enteryy statistics and the U.S. Burean of Mines cement manufacturing data. (ORNL/CDIAC-25, NDP-()3). ()ak Ridge National Laboratory, Oak Ridge, Tennessece.

Rotty, R.M., and G. Marland. 1986. Fossil fucl combustion: recent amounts, patterns, and trends of $\mathrm{CO}_{2} . \mathrm{pp} .484-500$. IN J.R. Trabalka and D.E. Reichle (eds.), The Changing Carbon Cycle: A Cilobat Analysis, Springer-Vorlag.

United Nations. 1989. Enenzy Statistics Yearbook 1987. United Nations

Department of International Economic and Social Affairs, Statistical office, New York.

U.S. Bureau of Mines. 1988. Minerals Yearbook. Vol. 1, Metals, Minerals, and Fuels. Washington, D.C.

U.S. Department of Energy, 1088 International Energy Annual. DOE EIA-(2)19(88). Encrgy Information Administration, Washington, D.C. 


\section{Australia}

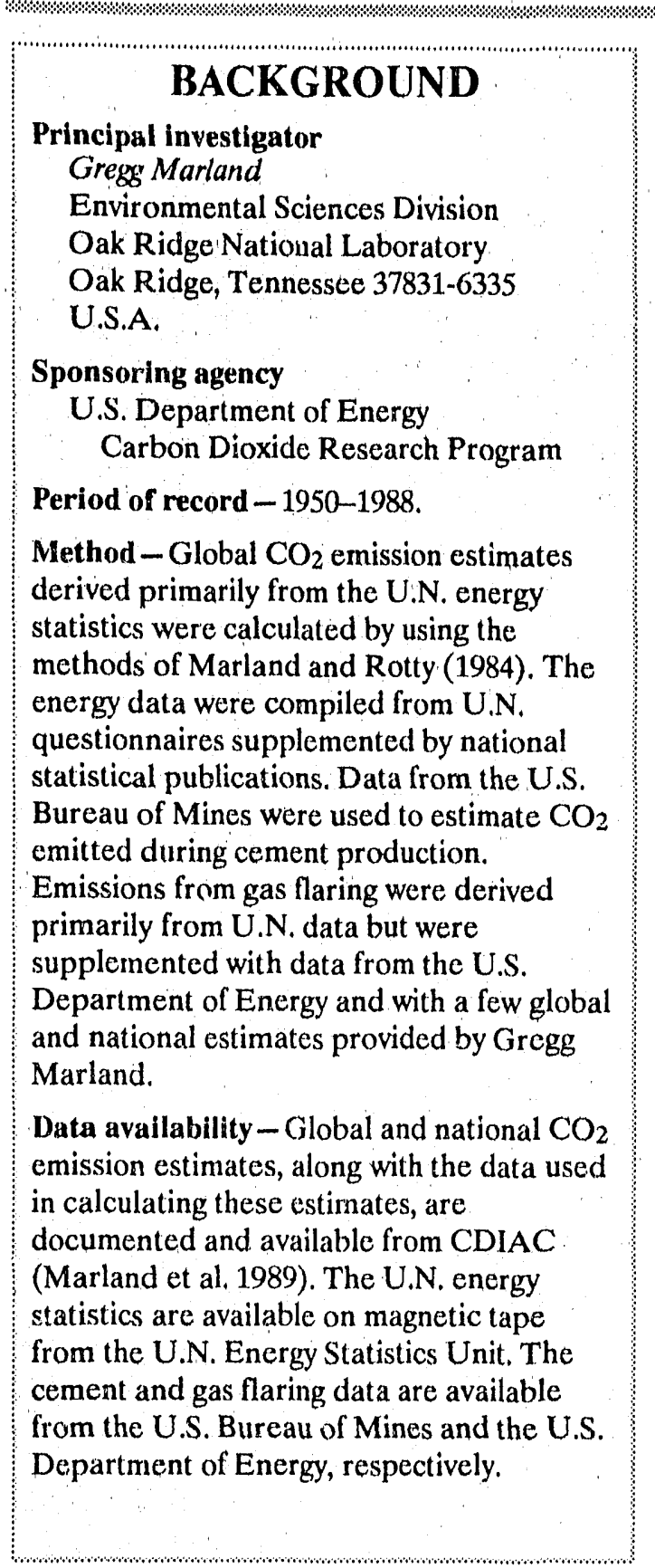
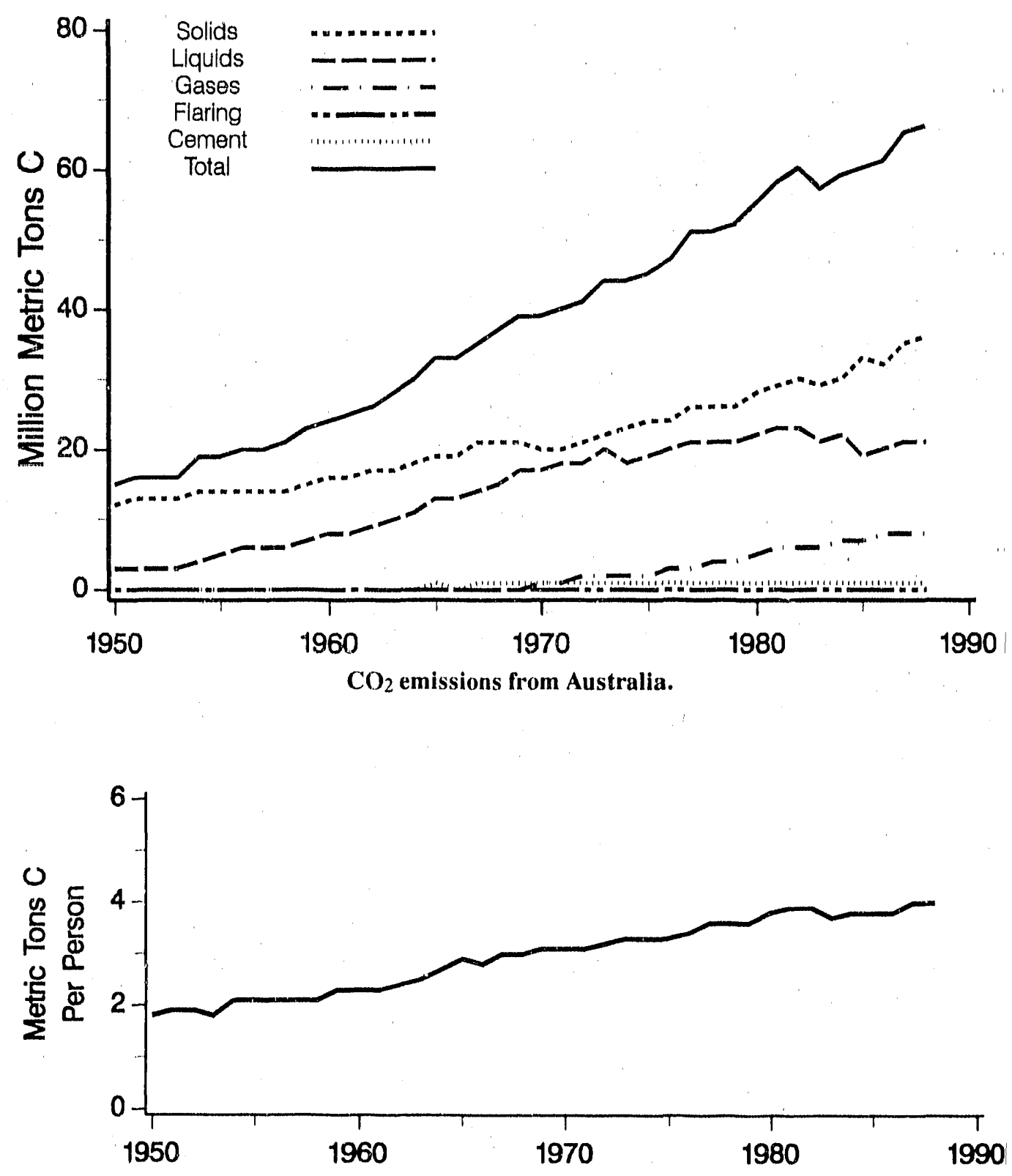

Per capita $\mathrm{CO}_{2}$ emission estimates for Australia. 


\section{$\mathrm{CO}_{2}$ Emissions}

\section{TREND}

Australian $\mathrm{CO}_{2}$ emissions have increased by a factor of 4.4 since 1950 , with a 2.2 -fold increase resulting from growing per capita emissions and a 2.0 -fold increase in population. Emissions from both solid and liquid fuels have grown (although emissions from liquid fuels have been nearly constant since 1981), and since 1969 a steep growth in gas consumption has occurred. Total emissions have grown at an almost linear rate of 1.34 million tons of carbon per year. Coal remains the major contributor at $54 \%$ cf the total. A small drop in emissions in 1983 is the only indication of the global trauma in oil prices that marks the post-1973 period.

Note - Growth rates were calculated (before rounding) by performing a linear regression of $\log \mathrm{CO}_{2}$ emissions versus time and calculating the slope of the regression line. 


\section{Australia}

\section{Carbon Dioxide Emission Estimates*}

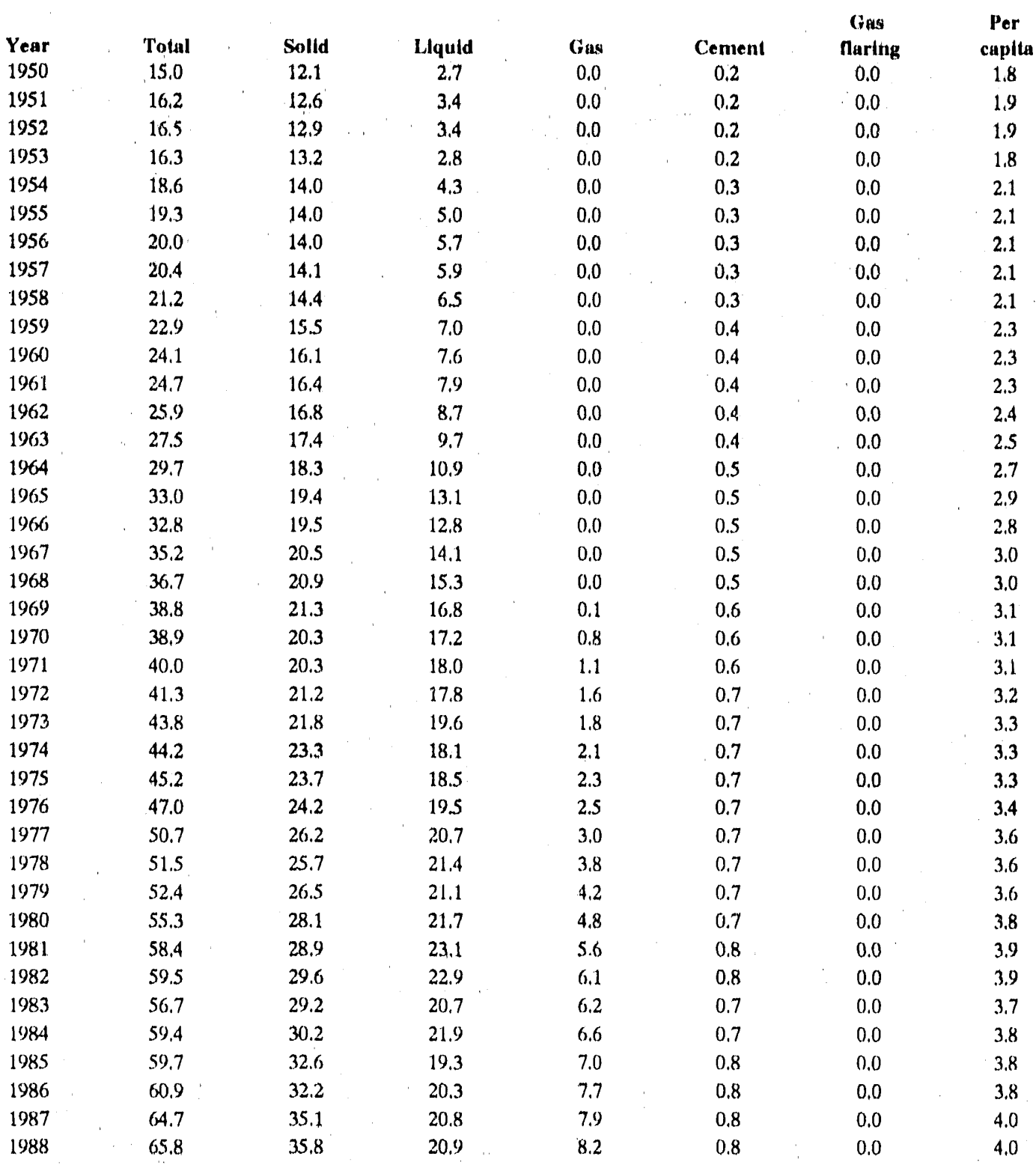

- Emission estimates rounded and expressed in million metric tons of carbon; per capita cstimates rounded and expressed in metric tons of carbon. 


\section{Czechoslovakia}

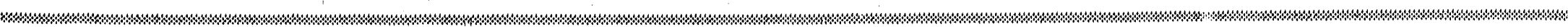

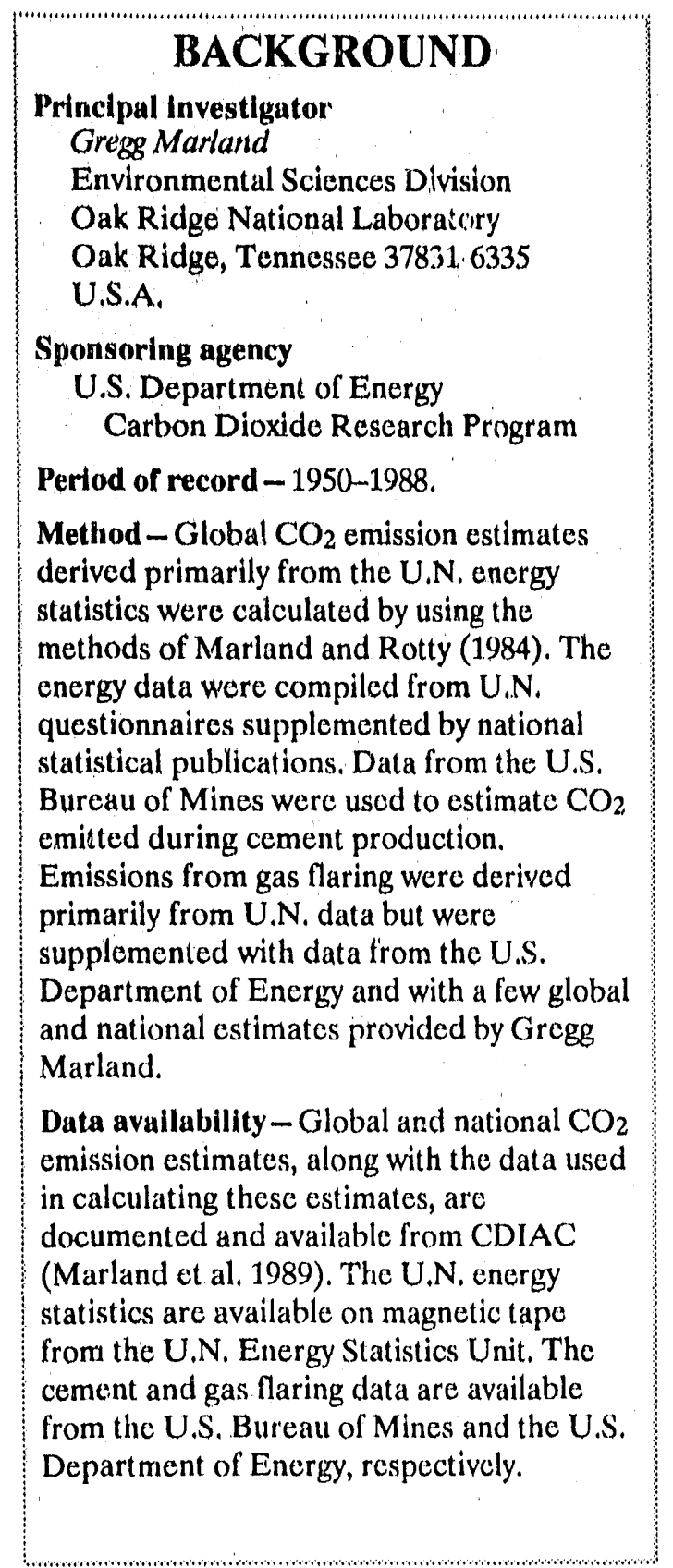
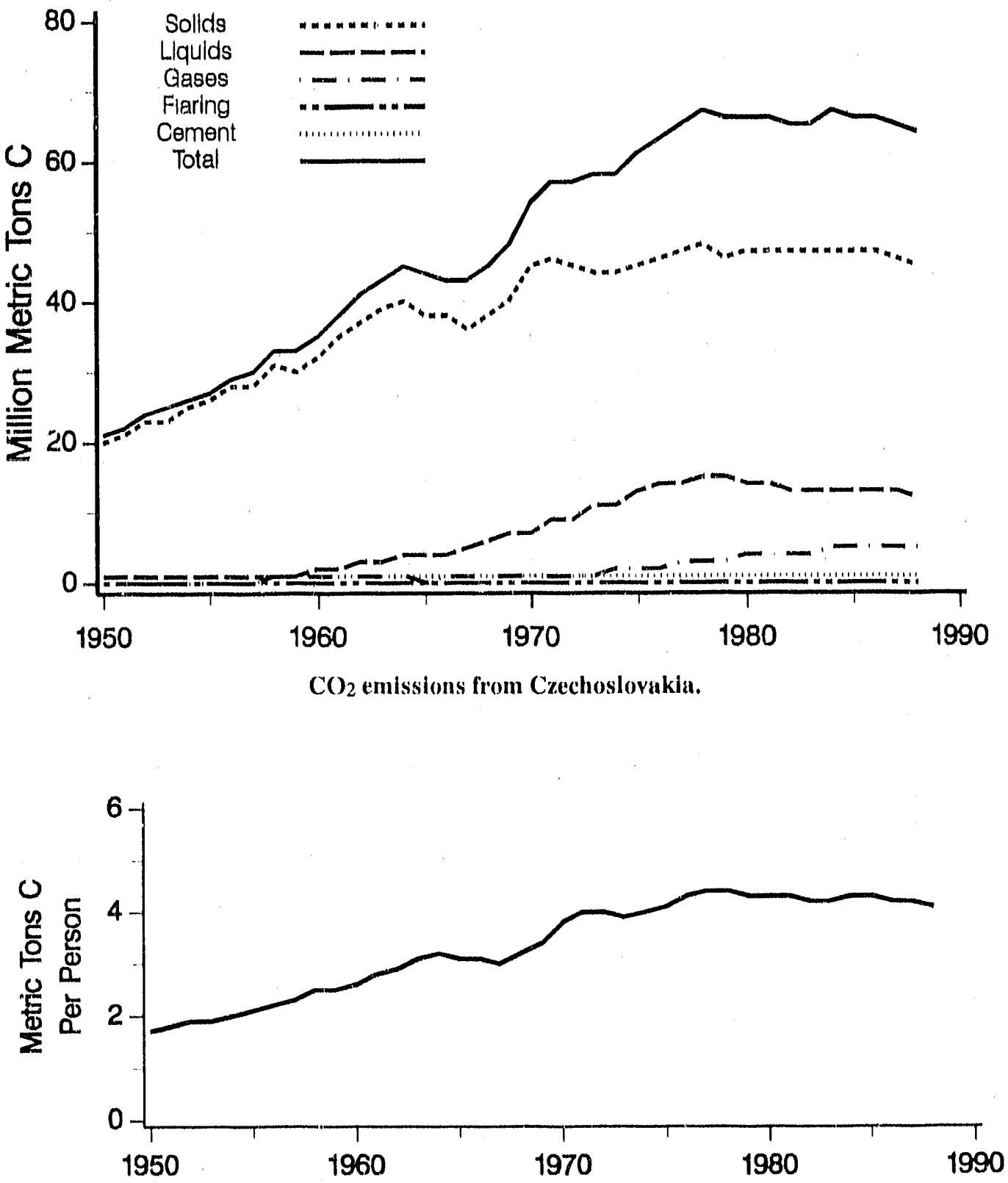

Per capita $\mathrm{CO}_{2}$ emission estimates for Czechoslovakia. 


\section{$\mathrm{CO}_{2}$ Emissions}

\section{TREND}

Aside from a hiatus from 1965 to 1967 , $\mathrm{CO}_{2}$ emissions from Czechoslovakia grew continuously from 1950 until 1978. Growth after 1970 was based on an increasing share from potroleum products as consumption of the dominant fuel, coal, has been virtually constant since 1970. Coal contributed over $88 \%$ of total emissions in 1964 , but this share dropped to $71.2 \%$ by 1988 . Population growth has not been an important factor in Czechoslovakia, as reflected in the fact that per capita emissions have followed the same pattern as total emissions, albeit at a slightly smaller growth rate. Natural gas first became a $1 \%$ contributor to $\mathrm{CO}_{2}$ in 1957 and has now grown to $8.2 \%$, with much of that growth occurring in the last decade.

Note-Growth rates were calculated (before rounding) by performing a linear regression of $\log \mathrm{CO}_{2}$ emissions versus time and calculating the slope of the regression line. 
Carbon Dioxide Emission Estimates*

\begin{tabular}{|c|c|c|c|c|c|c|}
\hline Year & Totulul & Sollid & LAquild & Gins & Coment & $\begin{array}{l}\text { Gus } \\
\text { flurling }\end{array}$ \\
\hline 1950 & 20,8 & 20.0 & 0.5 & 0,0 & 0.3 & 0,0 \\
\hline 1951 & 22.1 & 21.3 & 0.5 & 0,0 & 0,3 & 0.0 \\
\hline 1952 & 23.6 & 22.7 & 0.6 & 0.1 & 0.3 & 0.0 \\
\hline 1953 & 24.5 & 2.3 .5 & 0.6 & 0.1 & 0,3 & 0,0 \\
\hline 1954 & 26.2 & 24,9 & 0.8 & 0.1 & 0,3 & 0.0 \\
\hline 1955 & 27.1 & 25.9 & 0.8 & 0,1 & 0.4 & 0.0 \\
\hline 1956 & 29,1 & 27.7 & 0.9 & 0.1 & 0.4 & 0.0 \\
\hline 1957. & 30.3 & 28.4 & 1.1 & 0.4 & 0.5 & $0,0$. \\
\hline 1958 & 33.1 & 30.8 & 1.1 & 0.6 & 0.6 & 0.0 \\
\hline 1959 & 33.2 & 30.5 & 1.4 & 0.7 & 0.6 & 0.0 \\
\hline 1960 & 35.4 & 32.2 & 1.8 & 0.7 & 0.7 & 0,0 \\
\hline 1961 & 38.4 & 34.6 & 2.3 & 0.7 & 0.7 & 0,0 \\
\hline 1962 & 40.9 & 36.6 & 2.9 & 0.6 & 0.8 & 0.0 \\
\hline 1963 & 43.0 & 38.6 & 3.2 & 0.6 & 0.7 & 0.0 \\
\hline 1964 & 44.8 & 39.5 & 4.0 & 0.5 & 0.7 & 0.0 \\
\hline 196,5 & 43.6 & 38.2 & 4.2 & 0.5 & 0.8 & 0.0 \\
\hline $1966_{3}$ & 43.4 & 37.6 & 4.4 & 0.5 & 0.8 & 0.0 \\
\hline 1967 & 43.3 & 36.5 & 5.3 & 0.6 & 0.9 & 0.0 \\
\hline 1968 & 45.3 & 38.0 & 5.6 & 0.8. & 0.9 & 0,0 \\
\hline 1969 & 48.1 & 39.5 & 6.7 & 1.0 & 0.9 & 0.0 \\
\hline 1970 & 54,3 & 44.8 & 7.5 & 1.1 & 1.0 & 0.0 \\
\hline 1971 & 57.0 & 46,0 & 8.6 & 1.2 & 1.1 & 0.0 \\
\hline 1972 & 57.4 & 4.5 & 9.5 & 1.3 & 1,1 & 0.0 \\
\hline 1973 & 57.6 & 44.3 & 10.8 & 1.5 & 1.1 & 0.0 \\
\hline 1974 & 58,3 & 44.0 & 11.3 & 1.8 & 1.2 & 0.0 \\
\hline 1975 & 61.1 & 45.2 & 12.6 & 2.0 & 1.3 & 0.0 \\
\hline 1976 & 63.4 & 46.3 & 13.6 & 2.2 & 1.3 & 0.0 \\
\hline 1977 & 6.5 .4 & 46,8 & 14.5 & 2.8 & 1.3 & 0.0 \\
\hline $1978^{\circ}$ & 67.3 & 47.9 & 14,9 & 3.2 & 1.4 & 0.0 \\
\hline 1979 & 6.5 .7 & 45,9 & 14.9 & 3.5 & 1.4 & 0.0 \\
\hline 1980 & 66.1 & 46.5 & 14.1 & 4,0 & 1,4 & 0.0 \\
\hline 1981 & 65.5 & 46.7 & 13.8 & 3.6 & 1.4 & 0.0 \\
\hline 1982 & 64.9 & 46.5 & 12.9 & 4.1 & 1.4 & 0.0 \\
\hline 1983 & 65.1 & 47.1 & 12.5 & 4.1 & 1.4 & 0.0 \\
\hline 1984 & 66.6 & 47.2 & 13,4 & 4.5 & 1.4 & 0.0 \\
\hline 1985 & 66.0 & 46.9 & 13.1 & 4.5 & 1.4 & 0.0 \\
\hline 1986 & 65.8 & 46.9 & 12.5 & 5.1 & 1,4 & 0,0 \\
\hline 1987 & 65.3 & 46.2 & 12.6 & 5.2 & 1.4 & 0.0 \\
\hline 1988 & 63.7 & 45.4 & 11.7 & 5.2 & 1.4 & 0.0 \\
\hline
\end{tabular}

\section{REFERENCES}

Koc:ling, C,D, 1973, Industrial production of carbon dioxide from fossull fucls and limestono. Telliss 25:174-198.

Marland, $G_{1}$ and R.M. Rolly, 1984, Carbon dicoxide emissions from fossil fuals: A

procedure for estimation and results for

195(1)-1982. To!llus 36(B):232-61.

Marland, G, T,A, Boden, R.C., Griflin,

S.F. Huang, P. Kanciruk, and 'T,R. Nolsom,

108(9), Estimates of $\mathrm{CO}_{2}$ emissions from

fossil fuc! burming and ceme'nt mannu-

facturing basc'd on the United Nations

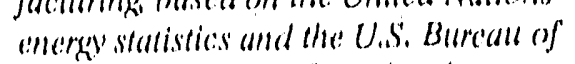

Minc's cementm manmfucturing data.

(ORNL/CDIAC -25, NDP-(1)3(). ().ak Ridge

National Laboratory, Oak Ridge,

Tennessece.

Rotty, R.M., und G, Marlund, 1986. Fonsil

fuci combustion: recent amounts, palterns and trends of $(\mathrm{CO})_{2}$. pp. 484--5(K). IN

J.R. Trabalka and D.E. Reichle (eds.),

The Changing Cabron Cycle: A Globul

Anculwsis, Springer-Vorlag.

United Nations, 1089, Energy' Statistics

Yearbook 1987, United Nations

Department of International Economic

and Social Affuirs, Slatistical office,

New York.

U.S. Burcau of Mines, 1988. Minerals

Yearbook Vol. L, Metals, Mincrals, and

Fuels. Washington, D.C.

U.S. Department of Energy, 1988.

International Einergy Anmulal, DO)

EIA.(1219(88). Energy Information

Administration, Washington, D.C. 


\section{Romania}

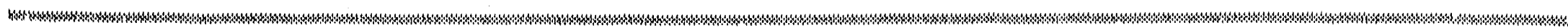

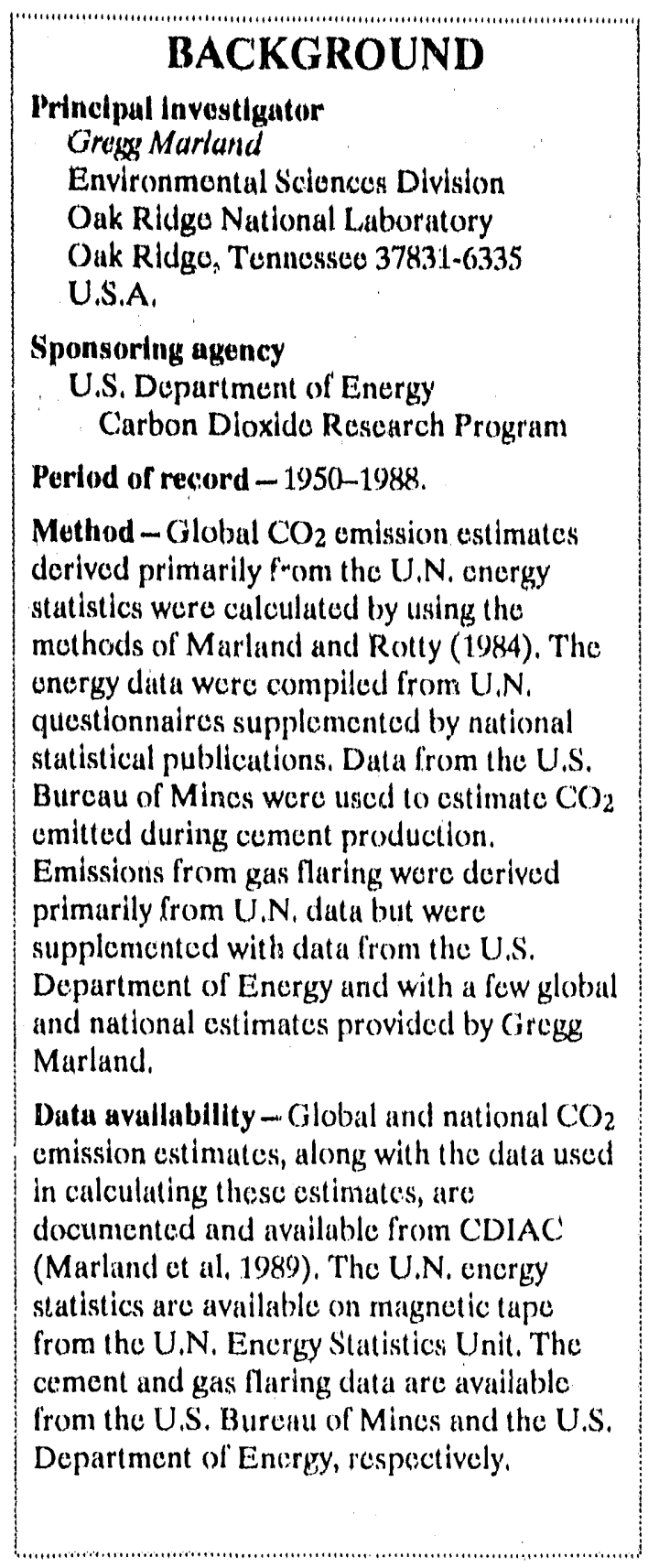
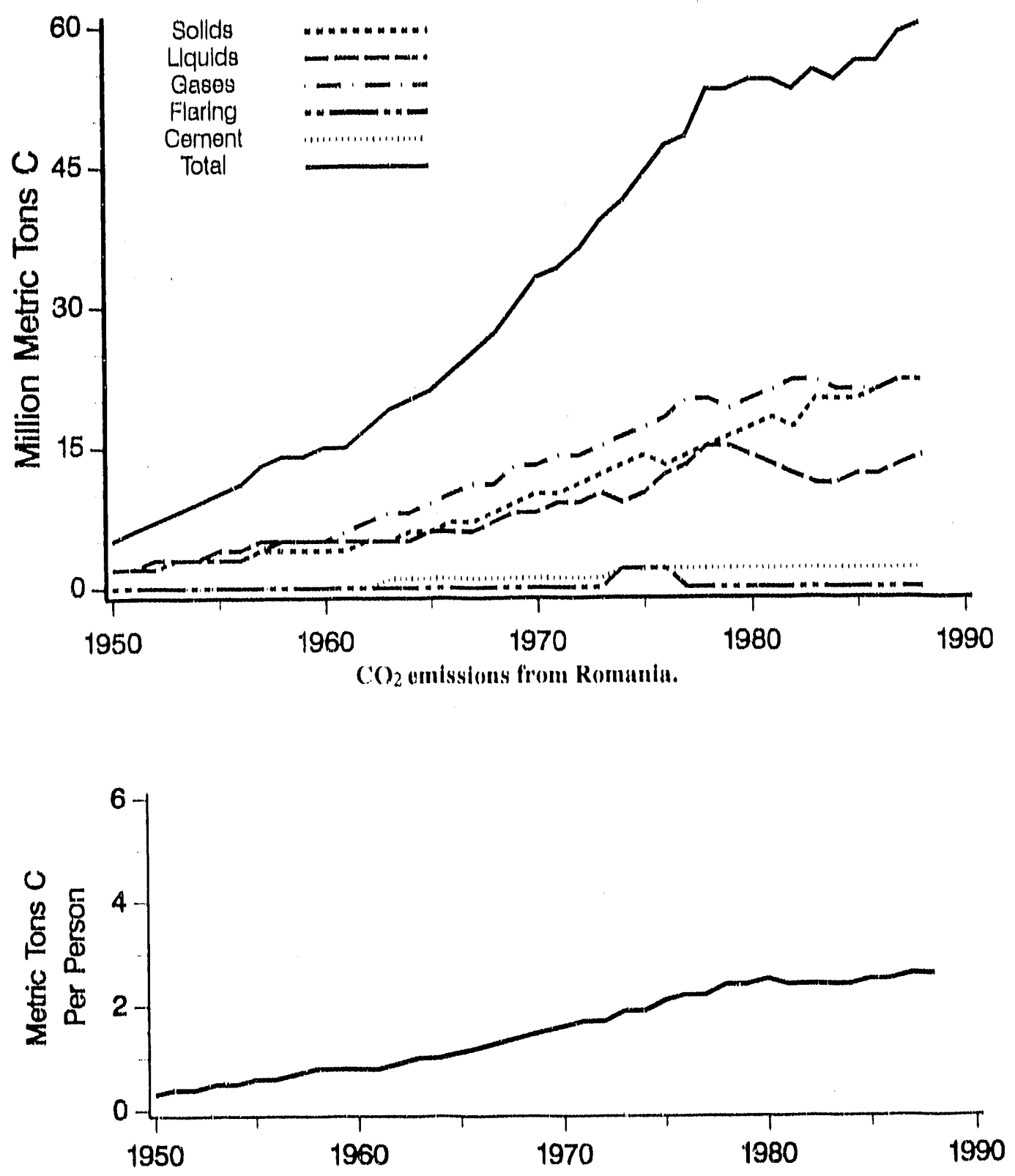

Per capita $\mathrm{CC}_{2}$ emission estimates for Romania. 


\section{$\mathrm{CO}_{2}$ Limissions}

\section{TREND}

Broad growth in the consumption of all three fuel types from 1950 to 1978 has supported $\mathrm{CO}_{2}$ emissions growth in Romanla by a factor of 11,3 from 195()-1988. Per capila emissions grew by a factor of 8,0 from 1950 to 1987 and were at an all-time high in 1988. Romania is the only top-20 emitter for which gas fuels are the major contributor, a situation that has existed since 1959. Emissions from gas flaring aro proportionally very small. Currently, $36,8 \%$ of Romanian emissions are from natural gas, $36.0 \%$ from solid fuels, and only $23.3 \%$ from liquid fucls. Emissions have shown slow but positive growth since 1978.

Note-Growlh rates were calculated (bofore rounding) by performing a linear regression of $\log \mathrm{CO}_{2}$ emissions versus time and calculating the slope of the regression line. 


\section{Romania}

\section{Carbon Dioxide Emission Estimates"}

\begin{tabular}{|c|c|c|c|c|c|c|c|}
\hline Yeiur & 'I'otul & Solla & Mlyuild & Ous & Coment & $\begin{array}{l}\text { Gas } \\
\text { Muring }\end{array}$ & $\begin{array}{l}\text { Per } \\
\text { caplin }\end{array}$ \\
\hline $19.50^{\circ}$ & 5.3 & 1.8 & 1.7 & 1.7 & 0.1 & 0,0 & 0.3 \\
\hline 1951 & 6.2 & 2.0 & 2.1 & 1.8 & 0.2 & 0.0 & 0,4 \\
\hline 1052 & 7.3 & 2.4 & 2.6 & 2.1 & 0.2 & 0.0 & 0.4 \\
\hline 1953 & 8,4 & 2.6 & 2.9 & 2.6 & 0,3 & 0,0 & 0.5 \\
\hline 1954 & $\varphi, 2$ & 2.8 & 3.4 & 2.7 & 0.2 & 0,0 & 0.5 \\
\hline 1955 & 10.0 & 3.1 & 3.8 & 2.9 & 0.3 & 0.0 & 0.6 \\
\hline 1956 & 11.1 & 3.3 & 4.3 & 3.3 & 0.3 & 0.0 & 0.6 \\
\hline 1957 & 12.5 & 3.5 & 4.7 & 3,9 & 0,3 & 0.0 & 0.7 \\
\hline 1958 & 13.6 & 3.7 & 5.1 & 4.5 & 0.3 & 0.0 & 0.8 \\
\hline 1959 & 13.8 & 3.9 & 4.6 & 5.0 & 0.4 & 0.0 & 0.8 \\
\hline 1960 & 14.6 & 4.2 & 4.6 & 5.5 & 0.4 & 0.0 & 0.8 \\
\hline 1961 & 15.2 & 4.4 & 4.5 & 5.9 & 0.4 & 0,0 & 0.8 \\
\hline 1962 & 17.4 & 5.1 & 4.9 & 6.9 & 0.5 & 0.0 & 0.9 \\
\hline 1963 & 19.0 & 5.5 & 5.3 & 7.6 & 0.6 & 0.0 & 1.0 \\
\hline 1964 & 19.7 & 5.7 & 5.1 & 8.2 & 0,6 & 0,0 & 1.0 \\
\hline 196.5 & 21.5 & 6.1 & 5.5 & 9.1 & 0.7 & 0.0 & 1.1 \\
\hline 1960 & 23.0 & 6.6 & 5.7 & 9.8 & 0,8 & 0.0 & 1.2 \\
\hline 1967 & 25.1 & 7.2 & 6.6 & 10.8 & 0.9 & 0.0 & 1.3 \\
\hline 1968 & 27.3 & 8.1 & 6,8 & 11.4 & 1.0 & 0.0 & 1.4 \\
\hline 1969 & 30.4 & 9.2 & 7.6 & 12.6 & 1.0 & 0.0 & 1.5 \\
\hline 1970 & 32.6 & 10.2 & 8.1 & 13.0 & 1.1 & 0.1 & 1.6 \\
\hline 1071 & .34 .3 & 10.4 & 8.7 & 13.9 & 1.2 & 0.2 & 1.7 \\
\hline 1972 & 36,0 & 11.0 & 0,1 & 14.2 & 1.3 & 0.4 & 1.7 \\
\hline 1973 & 39.5 & 12.4 & 10.3 & 15.1 & 1.3 & 0.4 & 1.9 \\
\hline 1974 & 41,0 & 12.8 & 9.5 & 15.6 & 1.5 & 1.6 & 1.9 \\
\hline 1975 & 44.2 & 13.5 & 10.3 & 16.9 & 1.6 & 1.9 & 2.1 \\
\hline 1976 & 47.4 & 13.4 & 11.6 & 18.5 & 1.8 & 2.1 & 2.2 \\
\hline 1077 & 48.4 & 13.7 & 12.9 & 19.6 & 1.5 & 0.4 & 2.2 \\
\hline 1978 & 52.7 & 15.3 & 14.7 & 20.2 & 2.0 & 0.4 & 2.4 \\
\hline 1979 & 5.3 .2 & 16.4 & 14.8 & 19.5 & 2.1 & 0,4 & 2.4 \\
\hline 1980 & 54.5 & 17.2 & 14.5 & 20.2 & 2.1 & 0.4 & 2.5 \\
\hline 1981 & 54.1 & 17.7 & 12.7 & 21.3 & 2.0 & 0.5 & 2.4 \\
\hline 1982 & 53.4 & 16.8 & 12.5 & 21,6 & 2.0 & 0.5 & 2.4 \\
\hline 1983 & 54.8 & 19.6 & 11.4 & 21.5 & 1.9 & 0.5 & 2.4 \\
\hline 1984 & 54.5 & 19.6 & 11.1 & 21.4 & 1,9 & 0.5 & 2.4 \\
\hline 1985 & 55.9 & 20.3 & 12.0 & 21.5 & 1.7 & 0.5 & 2.5 \\
\hline 1986 & 56,4 & 20.6 & 12.0 & 21.4 & 1.9 & 0.5 & 2.5 \\
\hline 1987 & $S(9) .2$ & 21.6 & 13.3 & 21.9 & 1,9 & 0.5 & 2.6 \\
\hline 1988 & 60.2 & 21.7 & 14.0 & 22.1 & 1.9 & 0.5 & 2.0 \\
\hline
\end{tabular}

- Emlssion estimates rounded and expressed li million metric tons of curbon; per capita estimates rounded and 


\section{$\mathrm{CO}_{2}$ Emissions}

\section{REFERENCES}

Keeling, C.D, 1973. Industrial production of carbon dioxide from fossil fucls and limestone. Tellus 25:174-198.

Marland, G., and R.M. Rotty. 1984. Carbon dioxide emissions from fossil fuels: $A$ procedure for estimation and results for 1950-1982. Tellus 36(B):232-61.

Marland, C., T.A. Boden, R.C. Griffin, S.F. Huang, P. Kanciruk, and T.R. Nelson. 1989. Estimates of $\mathrm{CO}_{2}$ emissions from fossil fuel burning and cement mamufacturing, bascd on the United Nations energy statistics and the U.S. Bureat of Mine's cement manufacturing data.

ORNL/CDIA(-25, NDP-()30). ()ak Ridge National Laboratory, ()ak Ridge, Tennessee.

Rotty, R.M., and (;. Marland. 1986. Fossil fucl combustion: recent amounts, patterns, and trends of $\left(\mathrm{C}_{2}\right.$. PP. $484.500 .1 \mathrm{~N}$ J.R. Trahalka and D.L. Reichle (eds.), The Changing Comber Cyele: A Cilobal Analyais, Springer-Verlag.

United Nations. 198\%, Energy Statistics Yearbook 1987. I nited Nations Department of International Economic and Social Alfairs, Statistical office, New York.

U.S. Bureatu of Mincs. 1988. Mincrals Yearbook. Vel. I, Metals, Mincrals, and Fuels. Washingtom, D.C.

U.S. Department of Energy. $198 \mathrm{~s}$. International Energy Ammual. D)( )I:EIA-()219(BS). Encrey Information Administration, Washington, b) 


\section{Republic of Korea}

BACKGROUND
Principal investigator
Gregg Marland
Environmental Sciences Division
Oak Ridge National Laboratory
Oak Ridge, Tennessee 37831-6335
U.S.A.
Sponsoring agency
U.S. Department of Energy
Carbon Dioxide Research Program
Period of record-1950-1988.
Method - Global CO 2 emission estimates
derived primarily from the U.N. energy
statistics were calculated by using the
methods of Marland and Rotty (1984). The
energy data were compiled from U.N.
questionnaires supplemented by national
statistical publications. Data from the U.S.
Bureau of Mines were used to estimate CO
emitted during cement production.
Emissions from gas flaring were derived
primarily from U.N. data but were
supplemented with data from the U.S.
Department of Energy and with a few global
and national estimates provided by Gregg
Marland.
Data availability - Global and national CO
emission estimates, along with the data used
in calculating these estimates, are
documented and available from CDIAC
(Marland et al 1989). The U.N. energy
statistics are available on magnetic tape
from the U.N. Energy Statistics Unit. The
cement and gas flaring data are available
from the U.S. Bureau of Mines and the U.S.
Department of Energy, respectively.
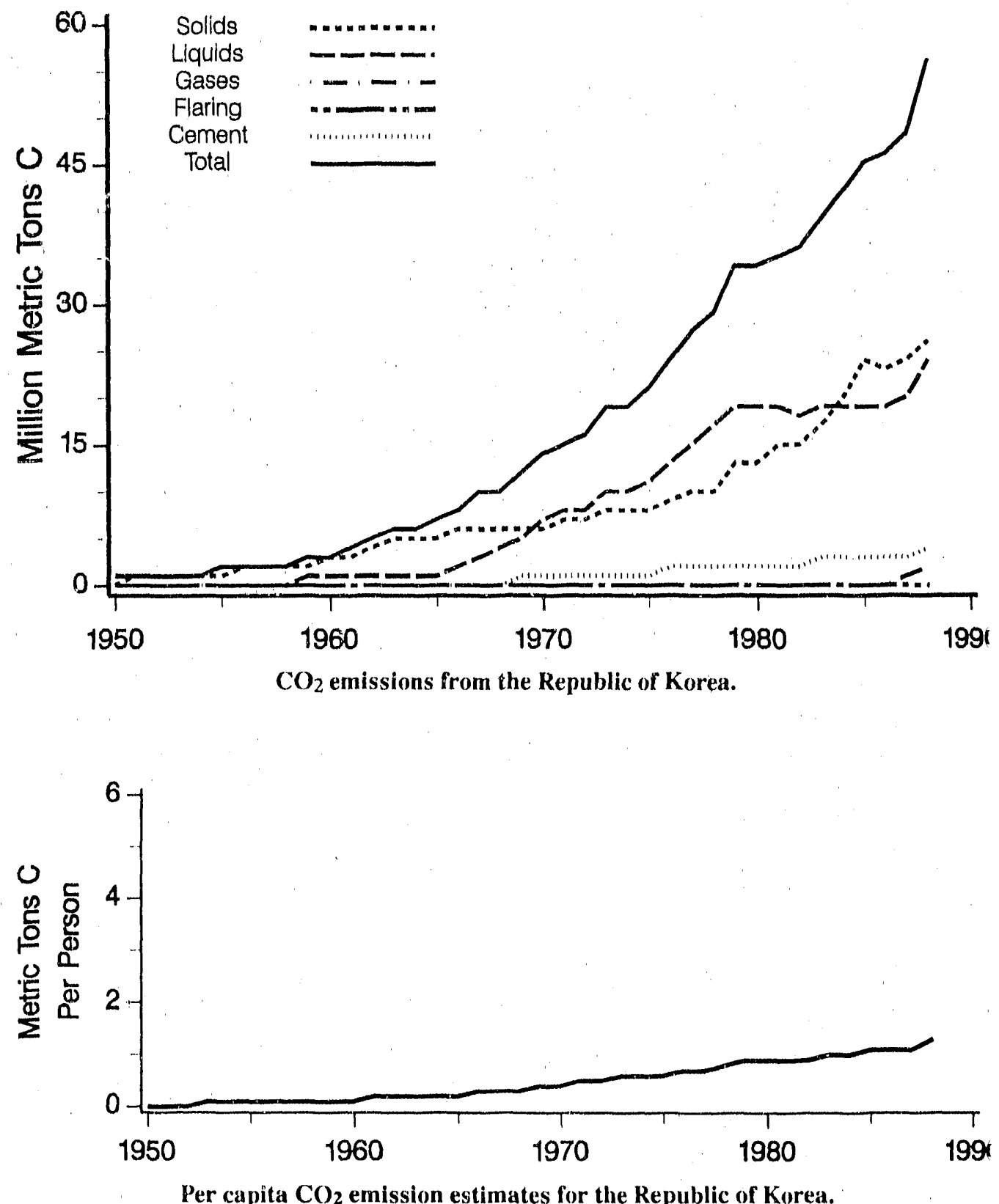


\section{$\mathrm{CO}_{2}$ Emissions}

\section{TREND}

Even though minor offsets in the growth of $\mathrm{CO}_{2}$ emissions from the Republic of Korea may have occurred during the late 1970 s, the last 38 years have been dominated by growth that averaged $11.4 \%$ per year and totaled almost 93 times as much $\mathrm{CO}_{2}$ in 1988 as in 1950. Per capita emissions have. increased by a factor of 44.3. Initial growth was based on coal, but oil consumption grew rapidly from 1965 to 1979 and was the major source of $\mathrm{CO}_{2}$ emissions from 1970 until 1983, at which time oil use was static and coal use was growing rapidly again. Natural gas became a significant contributor of $\mathrm{CO}_{2}$ for the first time in 1987 as the Republic of Korea increased imports of liquid natural gas. The indication is that emissions from liquid fuels were starting to increase again after 1985.

Note-Growth rates were calculated (before rounding) by performing a linear regression of $\log \mathrm{CO}_{2}$ emissions versus time and calculating the slope of the regression line. 


\section{Carbon Dioxide Emission Estimates*}

\begin{tabular}{|c|c|c|c|c|c|c|c|}
\hline Year & Total & Solld & Liquild & Gas & Cement & $\begin{array}{l}\text { Gas } \\
\text { haring }\end{array}$ & $\begin{array}{c}\text { Per } \\
\text { capita }\end{array}$ \\
\hline 1950 & 0.6 & 0.5 & 0.1 & 0.0 & 0.0 & 0.0 & 0.0 \\
\hline 1951. & 0.8 & 0.7 & 0.2 & 0.0 & 0.0 & 0.0 & 0.0 \\
\hline 1952 & 1.0 & 0.8 & 0.2 & 0.0 & 0.0 & 0.0 & 0.0 \\
\hline 1953 & 1.3 & 1.0 & 0.3 & 0.0 & 0.0 & 0.0 & 0.1 \\
\hline 1954 & 1.4 & 1.1 & 0.3 & 0.0 & 0.0 & 0.0 & 0.1 \\
\hline 1955 & 1.8 & 1.5 & 0.3 & 0.0 & 0.0 & 0.0 & 0.1 \\
\hline 1956 & 2.1 & 1.7 & 0.4 & 0.0 & 0.0 & 0.0 & 0.1 \\
\hline 1957 & 2.3 & 1.8 & 0.4 & 0.0 & 0.0 & 0.0 & 0.1 \\
\hline 1958 & 2.5 & 2.0 & 0.5 & 0.0 & 0.0 & 0.0 & 0.1 \\
\hline 1959 & 3.1 & 2.5 & 0.6 & 0.0 & $0.0^{\circ}$ & 0.0 & 0.1 \\
\hline 1960 & 3.5 & 2.8 & 0.6 & 0.0 & 0.1 & 0.0 & 0.1 \\
\hline 1961 & 4.0 & 3.3 & 0.6 & 0.0 & 0.1 & 0.0 & 0.2 \\
\hline 1962 & 4.8 & 3.8 & 0.8 & 0.0 & 0.1 & 0.0 & 0.2 \\
\hline 1963 & 5.8 & 4.6 & 1.1 & 0.0 & 0.1 & 0.0 & 0.2 \\
\hline 1964 & 6.1 & 5.1 & 0.9 & 0.0 & 0.2 & 0.0 & 0.2 \\
\hline 1965 & 6.9 & 5.4 & 1.2 & 0.0 & 0.2 & 0.0 & 0.2 \\
\hline 1966 & 8.3 & 6.2 & 1.8 & 0.0 & 0.3 & 0.0 & 0.3 \\
\hline 1967 & 9.7 & 6.5 & 2.9 & 0.0 & 0.3 & 0.0 & 0.3 \\
\hline 1968 & 10.2 & 5.5 & 4.2 & 0.0 & 0.5 & 0.0 & 0.3 \\
\hline 1969 & 11.7 & 5.5 & 5.5 & 0.0 & 0.7 & 0.0 & 0.4 \\
\hline 1970 & 14.2 & 6.4 & 7.0 & 0.0 & 0.8 & 0.0 & 0.4 \\
\hline 1971 & 15.4 & 6.5 & $7.9^{\circ}$ & 0.0 & 0.9 & 0.0 & 0.5 \\
\hline 1972 & 16.0 & 6.8 & 8.4 & 0.0 & 0.9 & 0.0 & 0.5 \\
\hline 1973 & 19.1 & 7.9 & 10.0 & 0.0 & 1.1 & 0.0 & 0.6 \\
\hline 1974 & 19.4 & 8,2 & 10.0 & 0.0 & 1.2 & 0.0 & 0.6 \\
\hline 1975 & 20.8 & 8.5 & 11.0 & 0.0 & 1.4 & 0.0 & 0.6 \\
\hline 1976 & 23.9 & 9.3 & 12.9 & 0.0 & 1.6 & 0.0 & 0.7 \\
\hline 1977 & 27.0 & 10.2 & 14.9 & 0.0 & 1.9 & 0.0 & 0.7 \\
\hline 1978 & 29.3 & 10.4 & 16.9 & 0.0 & 2.1 & 0.0 & 0.8 \\
\hline 1979 & 34.1 & 12.6 & 19.3 & 0.0 & 2.2 & 0.0 & 0.9 \\
\hline 1980 & 34.3 & 13.4 & 18.8 & 0.0 & 2.1 & 0.0 & 0.9 \\
\hline 1981 & 35.4 & 14.5 & 18.8 & 0.0 & 2.1 & 0.0 & 0.9 \\
\hline 1982 & 36.3 & 15.4 & 18.5 & 0.0 & 2.4 & 0.0 & 0.9 \\
\hline 1983 & 38.5 & 16.6 & 19.0 & 0.0 & 2.9 & 0.0 & 1.0 \\
\hline 1984 & 41.9 & 20.4 & 18.7 & 0.0 & 2.8 & 0.0 & 1.0 \\
\hline 1985 & 45.3 & 23.8 & 18.6 & 0.0 & 2.8 & 0.0 & 1.1 \\
\hline 1986 & 46.0 & 23.5 & 19.3 & 0.0 & 3.2 & 0.0 & 1.1 \\
\hline 1987 & 48.4 & 23.7 & 20.0 & 1.2 & 3.5 & 0.0 & 1.1 \\
\hline 1988 & 55.8 & 25.8 & 24.5 & 1.6 & 3.9 & 0.0 & 1.3 \\
\hline
\end{tabular}

\section{REFERENCES}

Keeting, (D) 1973. Industrial preduction of carton dioxide from fossil fucls and

limestonc. Ti'llus 25:174-11)8

Marland, (i., and R.M. Rosty, 1984. Carbon dioxide cmissions from fossil fucks: $A$ procedure for estimation and results for

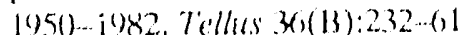

Marland, (i., T.A. Buden, R.C. (iriffin, S.F. Huang, P. Kanciruk, and 'T.R. Nelson. 198') Essimutes of ( $\left(\mathrm{O}_{2}\right.$ c'missions from fossil fuci burning and reme'nt mamufacturing, iassed on the Unitcol Nations. enersy statistics and the U.S. Butrean of Mines cemenu muntufucturing datu. ORNI/(CD)A ( - 25, NDPP.(1) (1). ()itk Ridge: Natlionall Laboraltory, ()ak Ridge. Tennesisee.

Rolly, RM and (i. Marlind, IOSk, Fonsil fucl combustion: recent amounts, patterns,

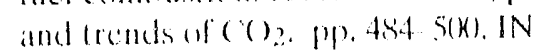
J.R. Tratralkat and D.P. Reichle (cds.)

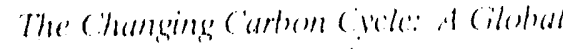
Analusis, Springer Verlate

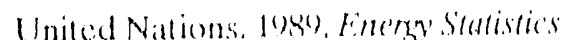
rearbook 1958. I Iniled Nations Department of Intermational Ecomemis: and Social Aflatirs, Stat istical office, New York.

HS Burcau of Mines. INese. Mimerals

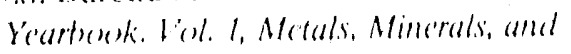
Fucks. Wathington, 1).(')

1)s. Department of Encrey. Inse

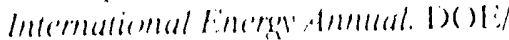

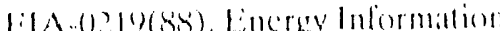
Administration, Washinglon, D). ( 


\section{Brazil}

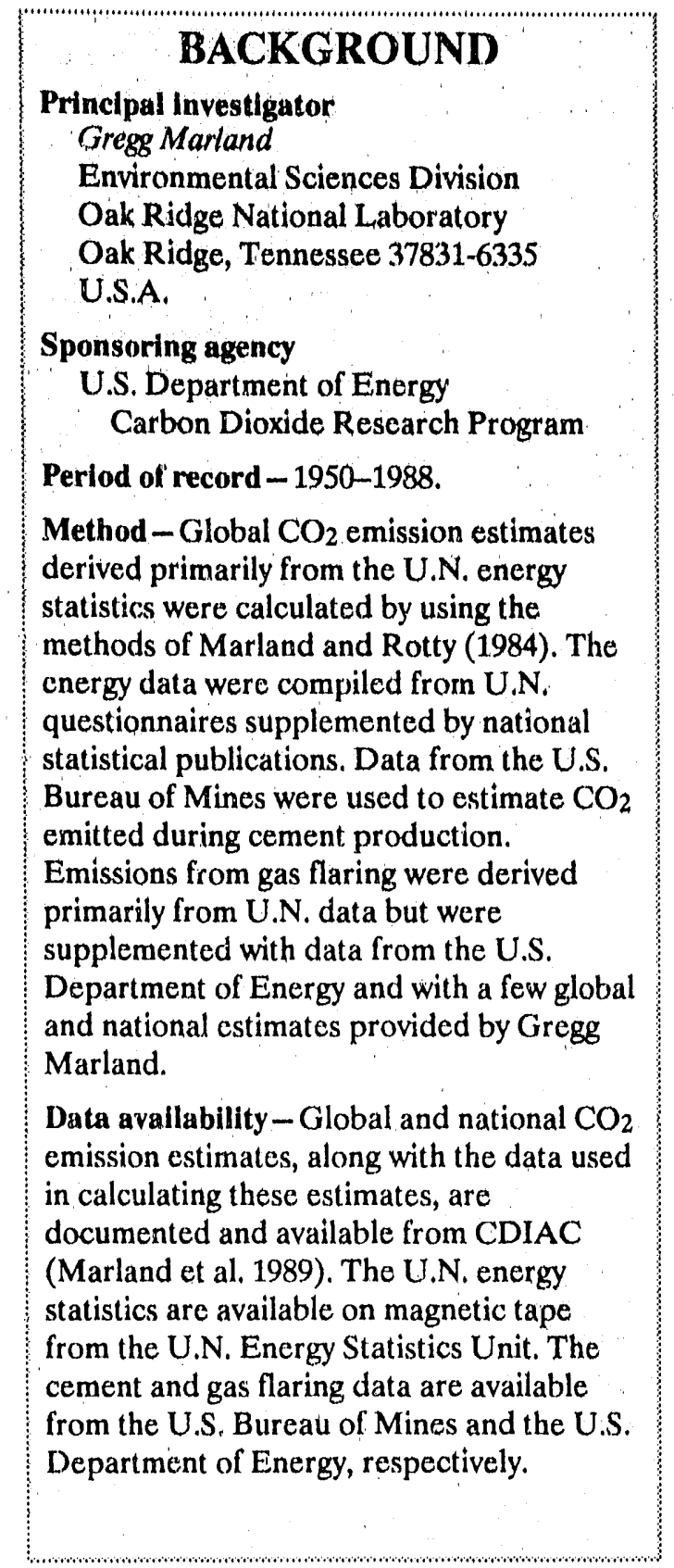
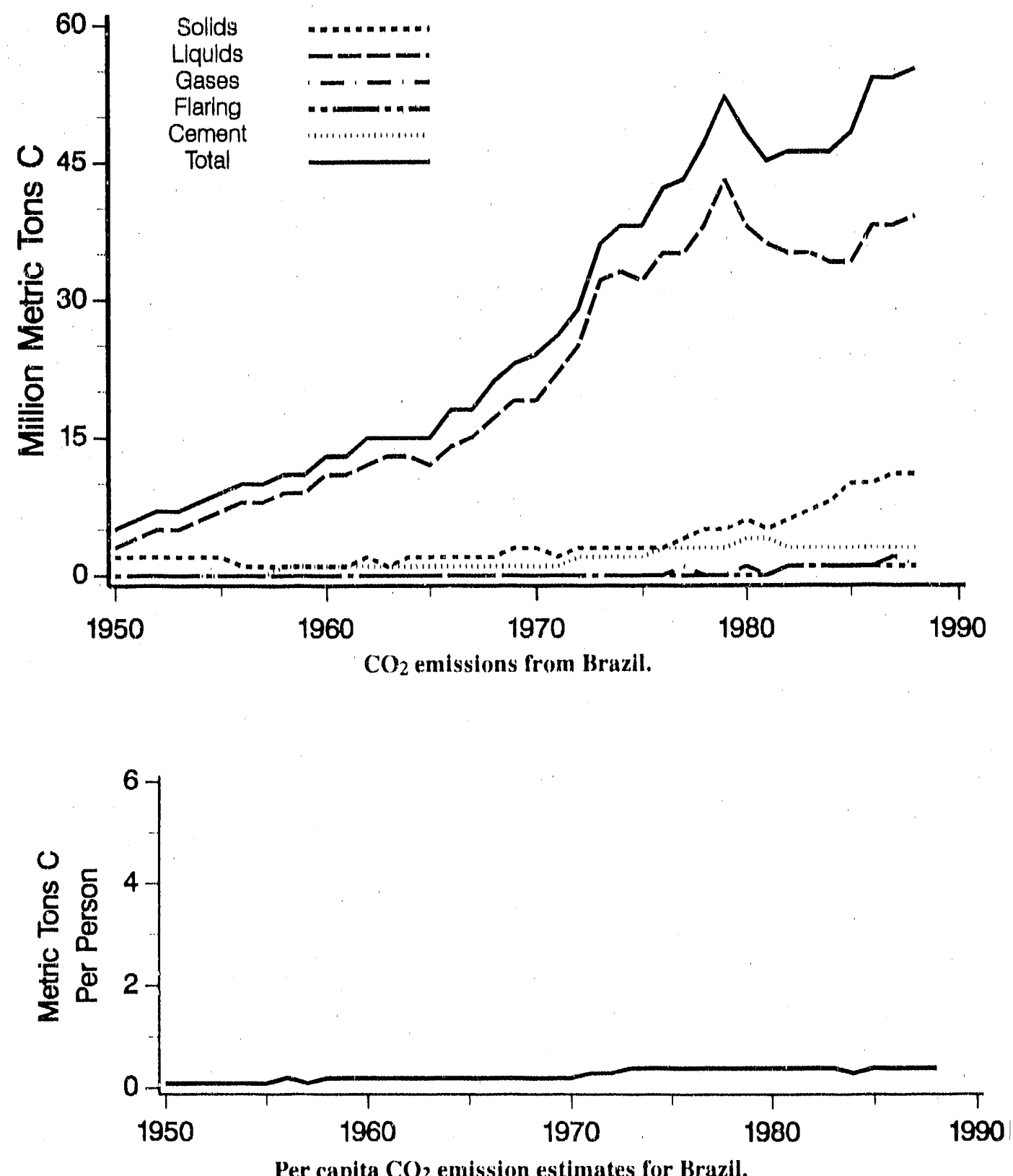


\section{$\mathrm{CO}_{2}$ Emissions}

\section{TREND}

$\mathrm{CO}_{2}$ emissions from Brazil grew rapidly from 1950 to 1979 (almost tenfold) but dropped sharply after 1979. Emissions have now increased steadily since 1982 and reached an all-time high in 1988.

Historically, emissions have come largely from consumption of liquid fuels, but since 1973 , when $87 \%$ of emissions were from liquid fuels, emissions from solid fuels have played an increasing role. In 1988, emissions were $70.8 \%$ from liquids and $19.2 \%$ from solids. Emissions from gas fuels have remained small (2.7\% in 1988) but trebled from 1981 to 1988 . Until 1974 more gas was flared than used.

Note - Growth rates wore calculated (before rounding) by performing a linear regression of $\log \mathrm{CO}_{2}$ emissions versus time and calculating the slope of the regression line. 
Carbon Dioxide Emission Estimates*

\begin{tabular}{|c|c|c|}
\hline Year & Total & Solld \\
\hline 1950 & 5.4 & 1.8 \\
\hline 1951 & 5,9 & 1.7 \\
\hline 1952 & 6.8 & 1,7 \\
\hline 1953 & 6.9 & 1.6 \\
\hline 1954 & 8.1 & 1.6 \\
\hline 1955 & 9.3 & 1.6 \\
\hline 1956 & 10.0 & 1.4 \\
\hline 1957 & 9.8 & 1.4 \\
\hline 1958 & 10.7 & 1.1 \\
\hline 1959 & 10.7 & 1.1 \\
\hline 1960 & 12.8 & 1.4 \\
\hline 1961 & 13,4 & 1.3 \\
\hline 1962 & 14.7 & 1.6 \\
\hline 1963 & 15.2 & 1.5 \\
\hline 1964 & 15.5 & 1.7 \\
\hline 1965 & $15.4^{\circ}$ & 1.9 \\
\hline 1966 & 17.6 & 2.3 \\
\hline 1967 & 18.1 & 2.2 \\
\hline 1968 & 21.1 & 2.4 \\
\hline 1969 & 23.0 & 2.6 \\
\hline 1970 & 23,6 & 2.6 \\
\hline 1971 & 26.4 & 2.5 \\
\hline 1972 & 29.2 & 2.6 \\
\hline 1973 & 36.5 & 2.5 \\
\hline 1974 & 38,4 & 3.0 \\
\hline 1975 & 38.2 & 3.4 \\
\hline 1976 & 41.6 & 3.2 \\
\hline 1977 & 43.0 & 4.1 \\
\hline 1978 & 46.5 & 4.9 \\
\hline 1979 & 52.3 & 5.1 \\
\hline 1980 & 48.2 & 5.5 \\
\hline 1981 & 45,3 & 5,4 \\
\hline 1982 & 45.8 & 6.1 \\
\hline 1983 & 45.9 & 6.6 \\
\hline 1984 & 46.4 & 7.9 \\
\hline 1985 & 48.4 & 9.6 \\
\hline 1986 & 53.5 & 9.7 \\
\hline 1987 & $54: 3$ & 10.5 \\
\hline 1988 & 55,2 & 10.6 \\
\hline
\end{tabular}

- Emission estimates rounded an expressed in metric tons of carbon.

\begin{tabular}{ccc} 
L.quld & Gas & Cement \\
$\mathbf{3 . 4}$ & 0.0 & 0.2 \\
4.0 & 0.0 & 0.2 \\
4.9 & 0.0 & 0.2 \\
5.1 & 0.0 & 0.3 \\
6.2 & 0.0 & 0.3 \\
7.3 & 0.0 & 0.4 \\
8.1 & 0.0 & 0.4 \\
7.9 & 0.0 & 0.5 \\
9.0 & 0.0 & 0.5 \\
8.9 & 0.0 & 0.5 \\
10.6 & 0.0 & 0.6 \\
11.3 & 0.0 & 0.6 \\
12.2 & 0.0 & 0.7 \\
12.8 & 0.0 & 0.7 \\
12.8 & 0.0 & 0.8 \\
12.5 & 0.0 & 0.8 \\
14.2 & 0.0 & 0.8 \\
14.7 & 0.0 & 0.9 \\
17.5 & 0.0 & 1.0 \\
18.9 & 0.0 & 1.1 \\
19.4 & 0.0 & 1.2 \\
22.2 & 0.0 & 1.3 \\
24.6 & 0.1 & 1.5 \\
31.7 & 0.1 & 1.8 \\
32.9 & 0.3 & 2.0 \\
31.8 & 0.3 & 2.4 \\
35.5 & 0.3 & 2.6 \\
35.4 & 0.5 & 2.9 \\
38.0 & 0.4 & 3.0 \\
43.1 & 0.5 & 3.4 \\
38.2 & 0.6 & $\mathbf{3 . 7}$ \\
35.6 & 0.5 & $\mathbf{3 . 5}$ \\
35.1 & 0.6 & 3.5 \\
34.8 & 0.8 & $\mathbf{2 . 8}$ \\
33.8 & 1.0 & 2.7 \\
33.8 & 1.3 & 2.8 \\
38.2 & 1.5 & $\mathbf{3 . 4}$ \\
38.3 & 1.5 & $\mathbf{3 . 5}$ \\
39.1 & 1.5 & $\mathbf{3 . 4}$ \\
\hline & & \\
\hline
\end{tabular}

\section{REFERENCES}

Keeling, C.D. 1973. Industrial production of carbon dioxide from fossil fuels and limestone. Tellus 25:174-198.

Marland, G., and R.M. Rotty. 1984. Carbon dioxide emissions from fossil fuels: A procedure for estimation and results for 1950-1982. Tellus 36(B):232-61.

Marland, G., T.A. Boden, R.C. Griffin S.F. Huang, P. Kanciruk, and T.R, Nelson 1989. Estimates of $\mathrm{CO}_{2}$ emissions from fossil fuel burning and cement manufacturing, based on the United Nations energy statistics and the U.S. Bureau of Mines cement manufacturing data. ORNL/CDIAC-25, NDP-(130. Oak Ridge National Laboratory, Oak Ridge, Tennessee.

Rotty, R.M., and G. Marland. 1986. Fossil fuel combustion: recent amounts, patterns, and trends of $\mathrm{CO}_{2}, \mathrm{pp}, 484-500$. IN

J.R. Trabalka and D.E. Reichle (eds.), The Changing Carbon Cycle: A Global Analysis, Springer-Verlag.

United Nations. 1989. Energy Statistlics

Yeurbook 1987. United Nations

Department of international Economic and Social Affairs, Statistical Office, New York.

U.S. Bureau of Mines. 1988. Minerals Yearbook. Vol. 1, Metals, Minerals, and Fuels. Washington, D.C

U.S. Department of Energy. 1988. International Energy Annual. DOE/ EIA-0219(88). Energy Information Administration, Washington, D.C 


\section{Spain}

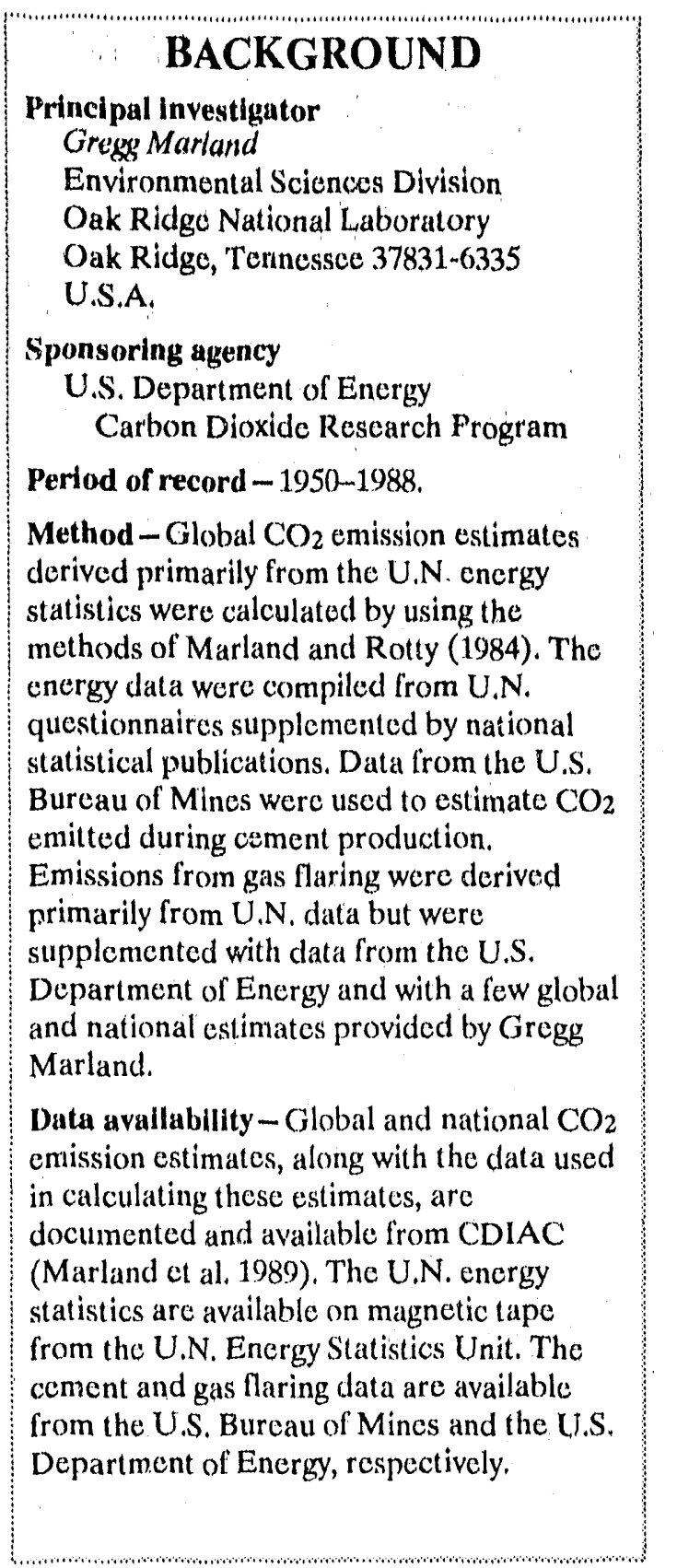
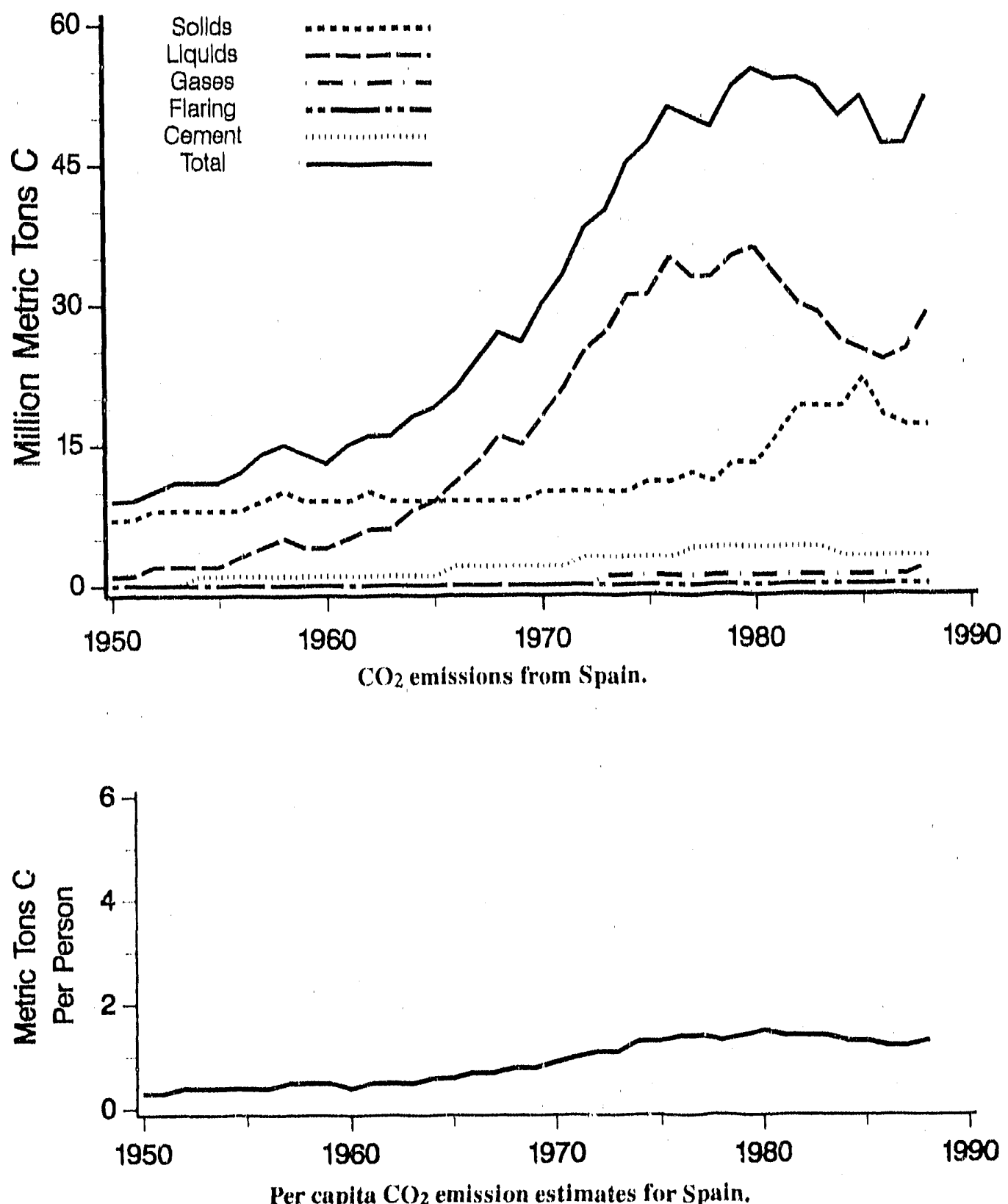


\section{$\mathrm{CO}_{2}$ Emissions}

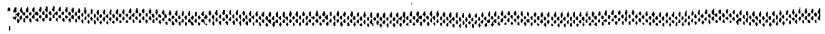

\section{TREND}

Spain has experienced a $19.3 \%$ drop in $\mathrm{CO}_{2}$ emissions from liquid fuels from 1980 to 1988 , a drop that occurs in both total and per capita emissions, Emissions from coal grew fram 1978 until 1985, balancing some of the loss in liquid fuel burning. Liquild fuels have been the dominant source of $\mathrm{CO}_{2}$ from Spain since 1966 , contributing $56.7 \%$ of emissions in 1988 after a high of $69.7 \%$ in 1974. Coal was the dominant $\mathrm{CO}_{2}$ source prior to 1966 and still contributed $33,1 \%$ in 1988. Per capita emissions remain low, in contrast with those of other Western European nations, at a rate of 1.3 metric tons of carbon per capita per year, a value little changed from 1973.

Note - Growth rates were calculated (before rounding) by performing a linear regression of $\log \mathrm{CO}_{2}$ emissions versus time and calculating the slope of the regression line. 


\section{Spain}

\section{Carbon Dioxide Emission Estimates*}

\begin{tabular}{|c|c|c|c|c|c|c|c|}
\hline Yeur & 'Tolthl & Solld & Llyuld & Gas & Cement & $\begin{array}{c}\text { Gas } \\
\text { nuring }\end{array}$ & $\begin{array}{l}\text { Por } \\
\text { cenpitu }\end{array}$ \\
\hline 1950 & 9.1 & 7.3 & 1.4 & 0.0 & 0.3 & 0.0 & 0.3 \\
\hline 1951 & 9.1 & 7.3 & 1.5 & 0.0. & 0.4 & 0.0 & 0.3 \\
\hline 1952 & 10.3 & 8.0 & 1.9 & 0.0 & 0.4 & 0.0 & 0.4 \\
\hline 1953 & 10.7 & 8.3 & 2.0 & 0.0 & 0.4 & 0.0 & 0.4 \\
\hline 1954 & 10.9 & 8.3 & 2.1 & 0,0 & 0.5 & 0.0 & 0.4 \\
\hline 1955 & 11.1 & 8.2 & 2.3 & 0.0 & 0.6 & 0,0 & 0.4 \\
\hline 1956 & 11.6 & 8.1 & 2.8 & 0.0 & 0.6 & 0.0 & 0.4 \\
\hline 1957 & 13.8 & 9.2 & 3.9 & 0.0 & 0.7 & 0.0 & 0.5 \\
\hline 1958 & 15.3 & 10,0 & 4.7 & 0.0 & 0.7 & 0.0 & 0.5 \\
\hline 1959 & 14.3 & 9.0 & 4.5 & 0.0 & 0.8 & 0.0 & 0.5 \\
\hline 1960 & 13.4 & 8.8 & 3.9 & 0.0 & 0.8 & 0.0 & 0.4 \\
\hline 1961 & 14.7 & 9.2 & 4.6 & 0.0 & 0.9 & 0.0 & 0.5 \\
\hline 1962 & 16.5 & 9.5 & 6.0 & 0.0 & 1.0 & 0.0 & 0.5 \\
\hline 1963 & 16.1 & 9.5 & 5.6 & 0.0 & 1.1 & 0.0 & 0.5 \\
\hline 1964 & 17.6 & 9.0 & 7.5 & 0.0 & 1.2 & 0.0 & 0.6 \\
\hline 1965. & 19.5 & 9.5 & 8.7 & 0.0 & 1.3 & 0.0 & 0.6 \\
\hline $19(6)$ & 21.3 & 8.8 & 10.8 & 0.0 & 1.6 & 0.0 & 0.7 \\
\hline 1967 & 23.7 & 8.8 & 13.0 & 0.0 & 1.8 & 0.0 & 0.7 \\
\hline 1968 & 26.6 & 9.0 & 15.5 & 0.0 & 2.0 & 0,0 & 0.8 \\
\hline 1969 & 26.5 & 9.0 & 15.2 & 0.0 & 2.2 & 0.0 & 0.8 \\
\hline 1970 & 30.2 & 10.0 & 17.9 & 0.0 & 2.3 & 0.0 & 0.9 \\
\hline 1971 & 33.4 & 9.6 & 21.2 & 0.2 & 2.3 & 0.0 & 1.0 \\
\hline 1972. & 37.6 & 9.9 & 24.5 & 0.4 & 2.7 & 0.0 & 1.1 \\
\hline 1973 & 40.0 & 9.6 & 26.8 & 0.6 & 3.0 & 0.0 & 1.1 \\
\hline 1974 & 45,1 & 10.1 & 31.4 & 0.6 & 3.0 & 0.0 & 1.3 \\
\hline 1975 & 46.6 & 11.3 & 31.3 & 0.7 & 3.3 & 0.0 & 1.3 \\
\hline 1976 & 50.6 & 11.1 & 33.1 & 0.9 & 3.4 & 0.0 & 1.4 \\
\hline 1977 & 49.8 & 12.2 & 33.0 & 0.8 & 3.8 & 0.0 & 1.4 \\
\hline 1978 & 49.4 & 11.2 & 33.2 & 0.8 & 4.1 & 0.0 & 1.3 \\
\hline 1979 & 53.0 & 13.1 & 35.2 & 1.0 & 3.8 & 0.0 & 1.4 \\
\hline 1980 & 54.5 & 13.4 & 36.2 & 1.1 & 3.8 & 0.0 & 1.5 \\
\hline 1981 & 54.5 & 16.0 & 33.4 & 1.2 & 3.9 & 0.0 & 1.4 \\
\hline 1982 & 54.5 & 18.9 & 30.2 & 1.3 & 4.0 & 0.0 & 1.4 \\
\hline 1983 & 53.2 & 19.0 & 28.7 & 1.3 & 4.2 & 0.0 & 1.4 \\
\hline 1984 & 49.8 & 19.1 & 25.9 & 1.3 & 3.5 & 0.0 & 1.3 \\
\hline 1985 & 51.8 & 21.8 & 25.2 & 1.5 & 3.3 & 0,0 & 1.3 \\
\hline 1986 & 47.1 & 18.0 & 24,4 & 1.4 & 3.3 & 0.0 & 1.2 \\
\hline 1987 & 46.9 & 17.1 & 25.0 & 1.5 & 3.2 & 0.0 & 1.2 \\
\hline 1988 & 51.5 & 17,1 & 29.2 & 1.9 & 3.3 & 0.0 & 1.3 \\
\hline
\end{tabular}

- Imission estimates rounded and expressed in million metric tons of carbon; per capita ustimates rounded and 
Atmospheric Methane Concentrations

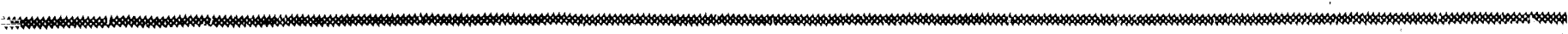
4. 


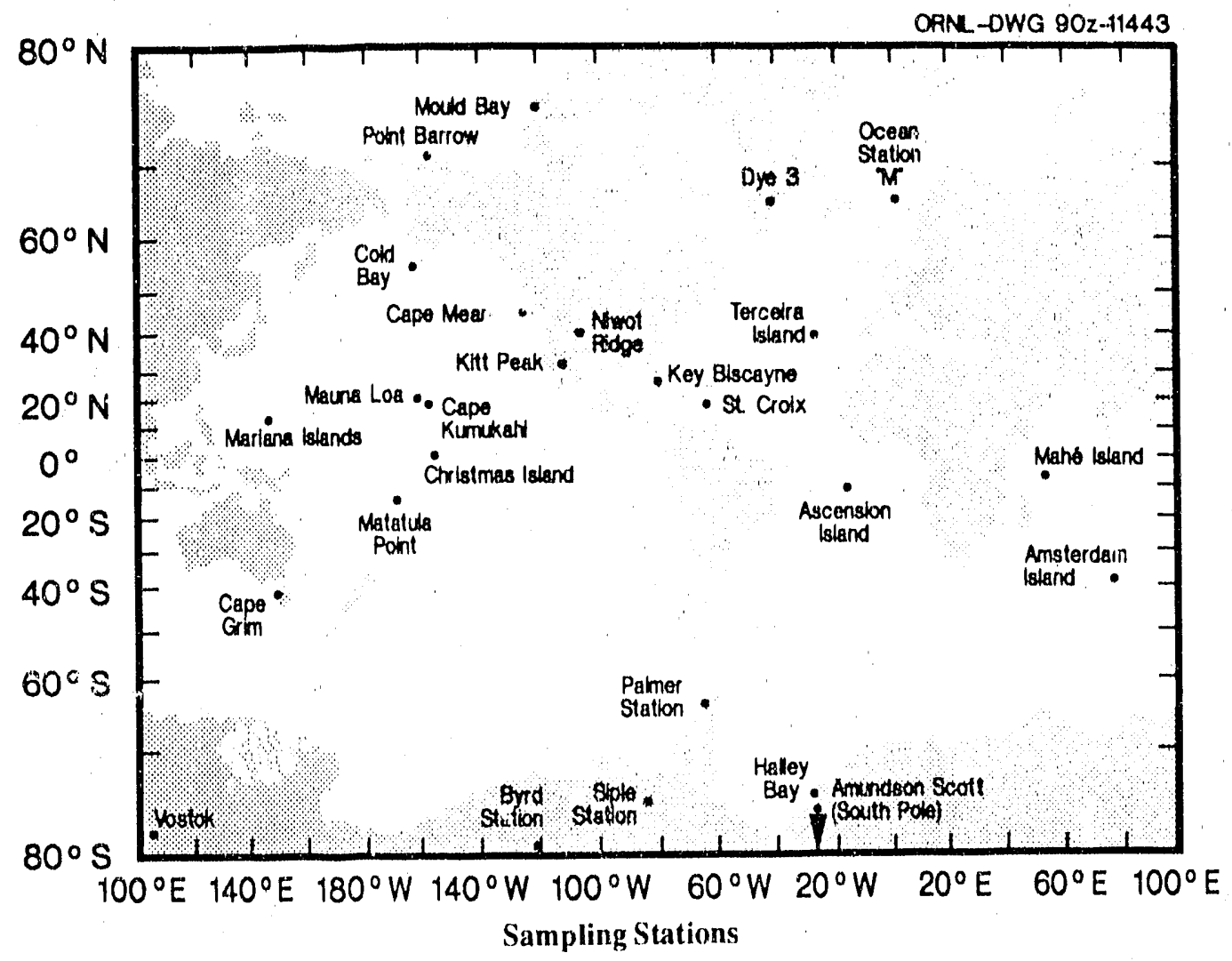




\section{Introduction}

Methane $\left(\mathrm{CH}_{4}\right)$ is recognized as one of the most important radiatively active trace gases with significant potential to contribute to climatic change within the next century. The mos? important methane sources are enteric fermentation in ruminants; anaerobic decay of organic matter in rice paddies, natural wetlands, and landfills; coal mining; natural gas production and distribution; oil exploration and production; and biomass burning. There is compelling evidence that the concentration of $\mathrm{CH}_{4}$ in the atmosphere is rising rapidly and that present levels are approximately double those of a few hundred years ago (see figure to right). Precise records of past and present $\mathrm{CH}_{4}$ concentrations are critical to studies attempting to determine the potential effects that greenhouse gases would have on climate.

Past concentrations of atmospheric $\mathrm{CH}_{4}$ have been determined by analyzing air bubbles trapped in ice from both Greenland and Antarctica. Since 1978, when the modern $\mathrm{CH}_{4}$ record begins, several systematic investigations have found on average a 1-2\% increase in $\mathrm{CH}_{4}$ concentrations per year. Most of these measurements have been made in the troposphere by using the method of gas chromatography with a flame ionization detector. Other measurements have relied upon an optical absorption technique that uses the sun as a source of infrared radiation and yields an average atmospheric abundance along the entire path length traversed through the atmosphere.

The following pages provide $\mathrm{CH}_{4}$ concentrations derived from ice cores, global monthly averages derived from 7 monitoring sites, and monthly atmospheric $\mathrm{CH}_{4}$ concentration records from 21 globally distributed sites (see figure on facing page). These latter data were collected as part of the National Oceanic and Atmospheric Administration's Climate Monitoring and Diagnostics Laboratory (NOAA/CMDL) program.

We urge e eaders to credit the principal investigators and their organizations when using these data. In addition, users are encouraged to contact CDIAC before applying the data in specific model or research exercises. Some of the data that are presented are considered preliminary and are subject to change by several parts per billion. All the data presented here are available in digitized form from CDIAC. 


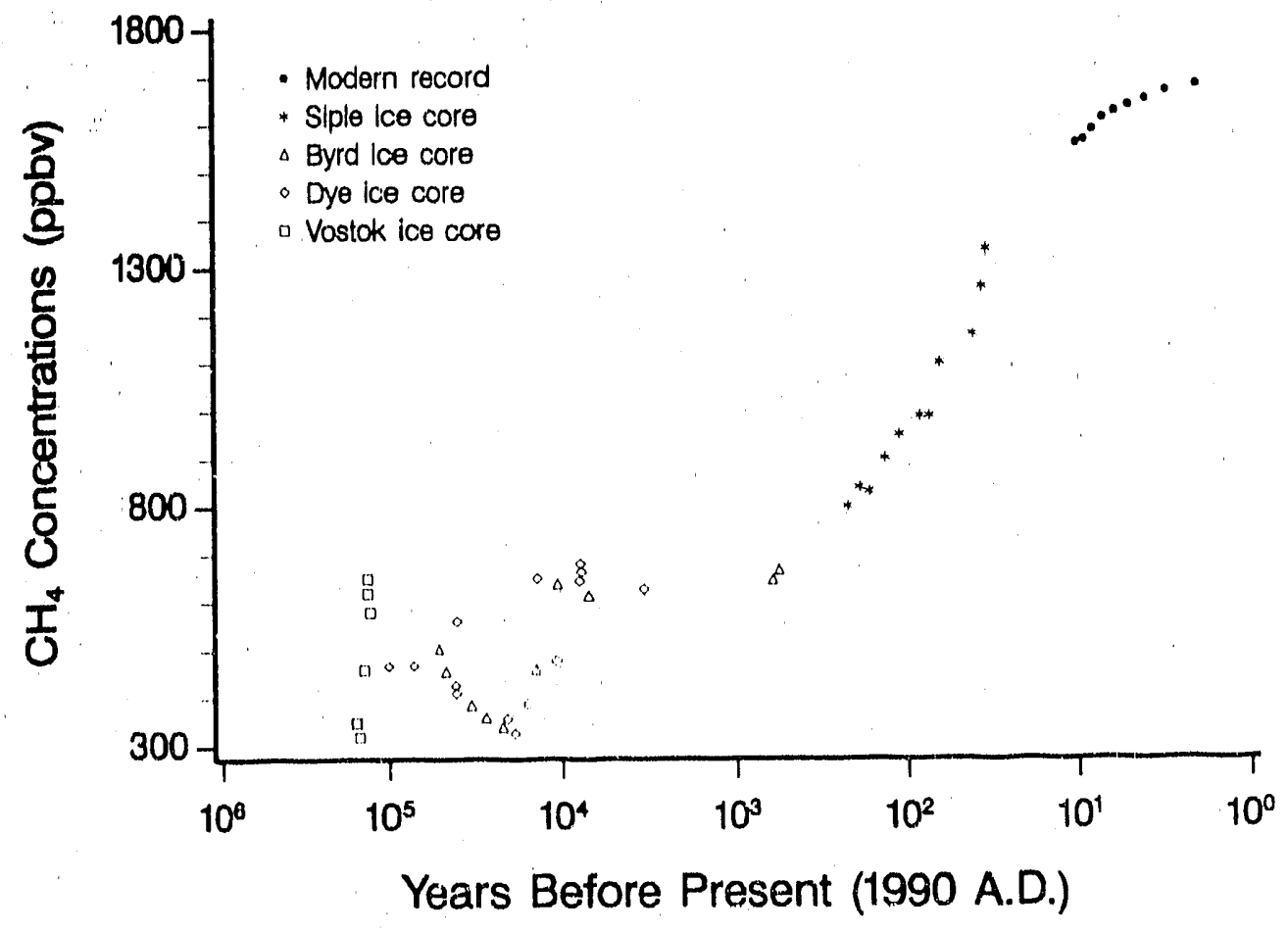

Annual atmospheric $\mathrm{CH}_{4}$ concentrations during the past 160,000 years (derived from ine corts and the NOAA/CMDL nask sampling network). 


\section{Vostok}

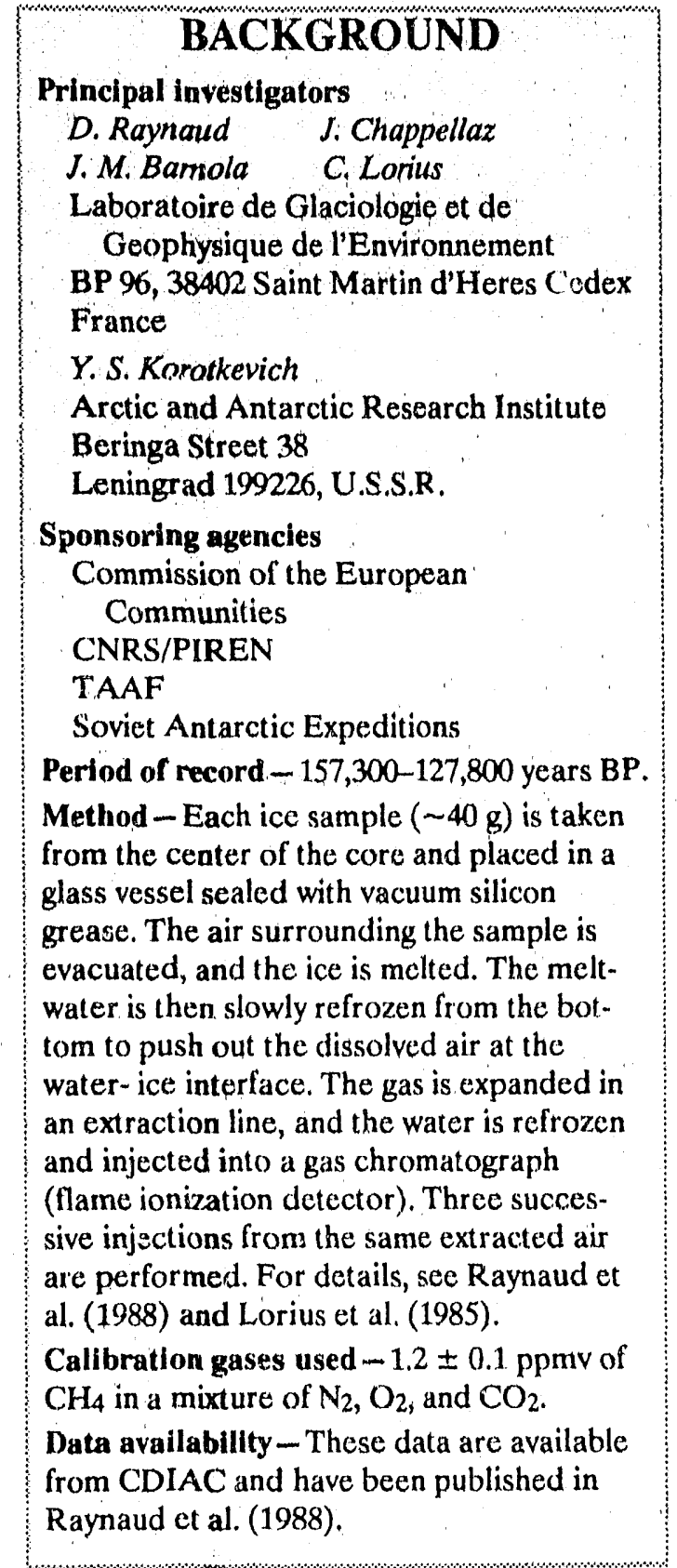

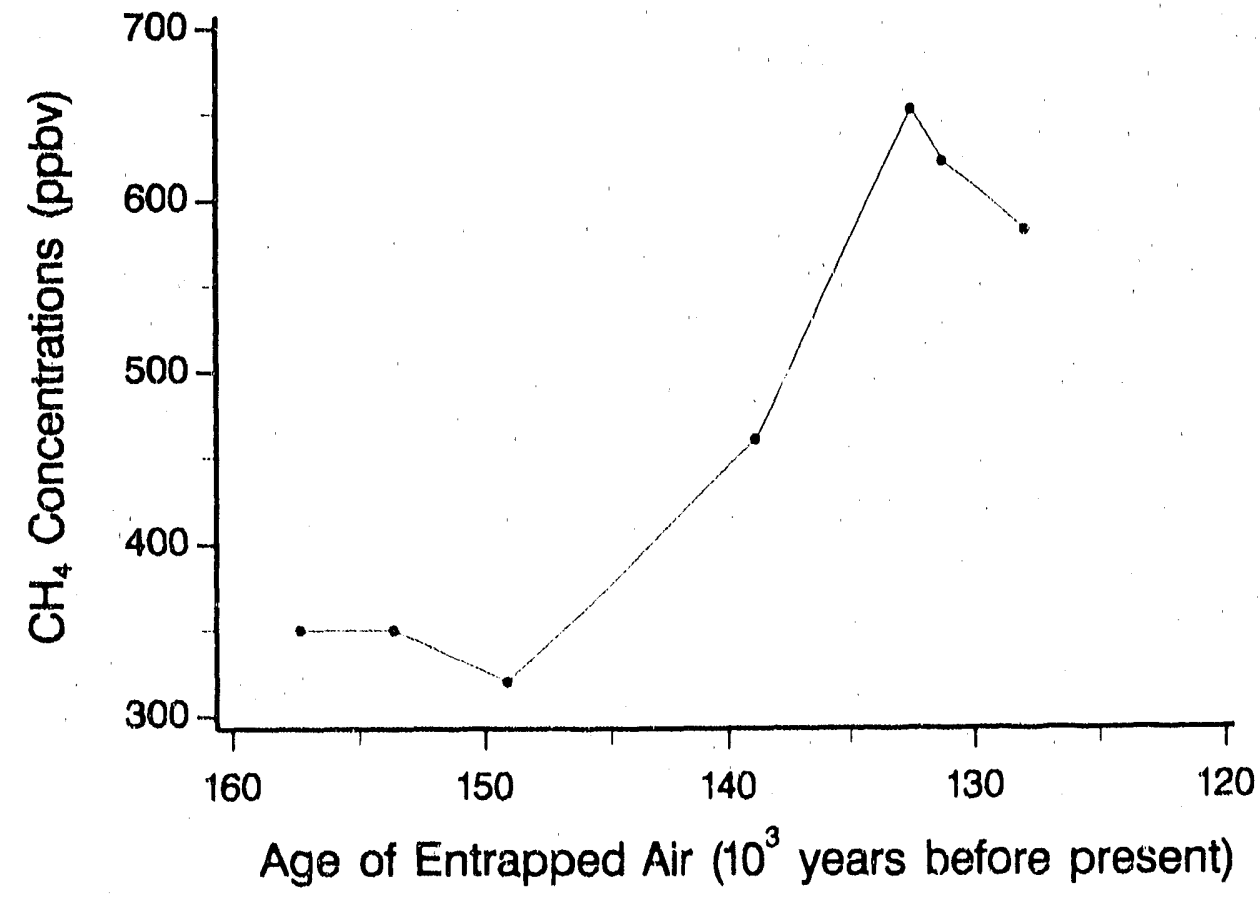

Concentrations of atmospheric $\mathrm{CH}_{4}$ from ice cores.

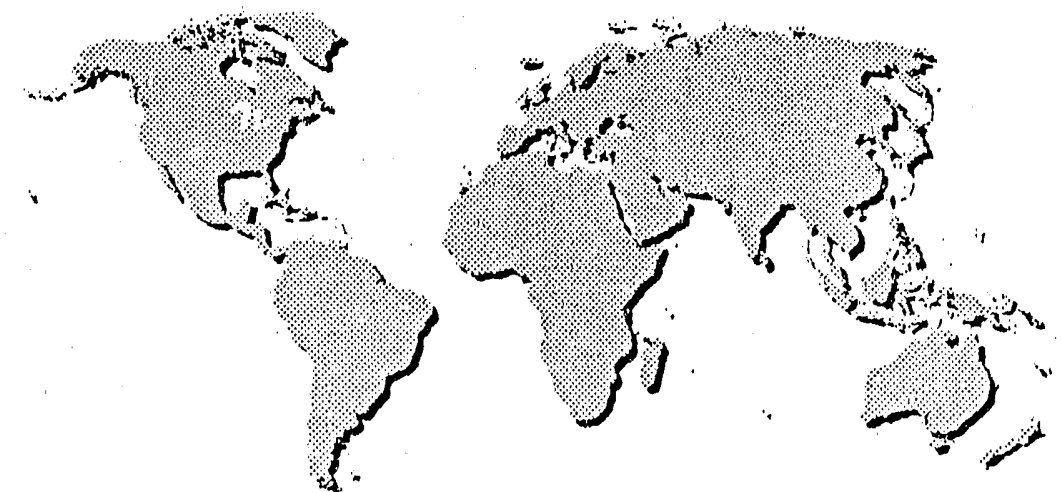

Vostok

Antarctica

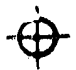




\section{Atmospheric $\mathrm{CH}_{4}$ from Ice Cores}

\section{TRENDS}

Using a 2083-m-long ice core recovered by the Soviet Antarctic Expeditions at Vostok (East Antarctica), the investigators have determined atmospheric $\mathrm{CH}_{4}$ concentrations for the past 160,000 years.

On the basis of an analysis of the Vostok ice core, Raynaud et al. (1988) reported that $\mathrm{CH}_{4}$ concentrations increased from 0.34 to 0.62 ppmv between the end of the penultimate ice age and the following interglacial, about $160 \times 10^{3}$ to $120 \times 10^{3}$ years BP. The mean $\mathrm{CH}_{4}$ concentration from the Vostok core is in good agreement with results published for coruparable periods from other cores. 
Atmospheric Methane from Ice Cores

\begin{tabular}{|c|c|c|c|c|}
\hline $\begin{array}{c}\text { Depth } \\
(\boldsymbol{m})\end{array}$ & $\begin{array}{l}\text { Ant of } \\
\text { thy ince } \\
\text { (y) BP) }\end{array}$ & $\begin{array}{l}\text { Mean } \\
\text { age of } \\
\text { the gas } \\
\text { (yr BP) }\end{array}$ & $\begin{array}{c}\mathrm{CH}_{4} \\
\text { concentration } \\
(\mathrm{ppmv})^{*}\end{array}$ & $\begin{array}{c}\text { Mean } \\
\text { CH}_{4} \\
\text { concentration } \\
( \pm 2 \sigma) \dagger \\
(\text { ppmv })\end{array}$ \\
\hline 1789.2 & 130,0850 & 127,800 & $\begin{array}{l}0.58,0.60,0.57 \\
0.58,0.59,0.58\end{array}$ & $0.68(0,04)$ \\
\hline 1834.7 & 133,360 & 131,100 & $0.64,0.60,0.62$ & $0.62(0.02)$ \\
\hline 1852.3 & 134,650 & 132,400 & $0.67,0.64,0.64$ & $0.65(0.04)$ \\
\hline 1932.1. & 141,600 & 138,800 & $0.44,0.46,0.47$ & $0.46(0.03)$ \\
\hline 2016.4 & 153,420 & 149,100 & $0.30,0.32,0.33$ & $0.32(0.03)$ \\
\hline 2042.5 & 157,790 & 153,600 & $0.35,0.34,0.35$ & $0.35(0.01)$ \\
\hline 2063.7 & 161,350 & 157,300 & $\begin{array}{l}0.37,0.34,0.34 \\
0.35,0.38,0.34\end{array}$ & $0.35(0.04)$ \\
\hline
\end{tabular}

Three concentrations are given because three successive injections into the gas chromatograph from the same extracted air are performed.

tThis symbol $a$ signifies standard deviation.

\section{REFERENCES}

Barnola, J.M., D. Raynaud, A. Neftel, and $\mathrm{H}$. Oeschger. 1983. Comparison of $\mathrm{CO}_{2}$ measurements by two laboratories on air bubbles in polar ice. Nature 303:410-13.

Barnola, J.M., D. Raynaud, Y.S.

Korotkevich, and C. Lorius, 1987. Vostok ice core provides $16(x),(0)(0)$-year record of atmospheric $\mathrm{CO}_{2}$. Nature 329:41)8-14.

Lorius, C., J. Jouzel, C. Ritz, L. Merlivat, N.I. Barkov, Y.S. Korotkevich, and V.M. Kotlyakov. 198. A 150,(0)(0)-year climatic record from Antarctic ice. Nature

316:591-206.

Raynaud, D, J Chappellay J M Barnola, YS. Korotkevich, and C. Lorius. 1988. Climatic and $\mathrm{CH}_{4}$ cycle implications of glaciat-interglacial $\mathrm{CH}_{4}$ change in the Vostok ice core. Nature 333:655-57. Schwander, J., and B. Stauffer. 1984. Age. difference between polar ice and air trapped in its bubbles. Nature 311:45-47. Stauffer, B., E. Lochbronner, H. Oeschger, and J. Schwander. 19x8. Methare

concentration in the glacial atmosphere was only half that of the preindustrial Holocene. Nuture 3.2:812-14 


\section{Byrd Station}

\begin{tabular}{|c|}
\hline BACKGROUND \\
\hline $\begin{array}{l}\text { Princlpal investigators } \\
\text { B. Stauffer } \\
\text { E. Lochbronner } \\
\text { H. Oeschger } \\
\text { J. Schwander } \\
\text { A. Neftel } \\
\text { Physics Institute } \\
\text { University of Bern } \\
\text { Sidlerstraße } 5 \\
\text { CH-3012 Bern, Switzerland }\end{array}$ \\
\hline $\begin{array}{l}\text { Sponsoring agencies } \\
\text { Swiss Nitional Science Foundation } \\
\text { University of Bern }\end{array}$ \\
\hline $\begin{array}{l}\text { Period of record }-3,400-100,000 \text { years BP. } \\
\text { Method - For extracting the air from an ice } \\
\text { sample, a } 500 \text { - to } 800-\mathrm{g} \text { sample of ice is } \\
\text { placed in a glass cylinder. The cylinder is } \\
\text { evacuated for } 20 \text { min to further clean the } \\
\text { sample surface, and the ice sample is melted } \\
\text { in } 30-40 \text { min. The air released during } \\
\text { melting is dried and collected continuously } \\
\text { by condensation at } 15-20^{\circ} \mathrm{K} \text {. The air } \\
\text { collected is then analyzed for } \mathrm{CH}_{4} \text { concen- } \\
\text { tration by using a gas chromatograph } \\
\text { equipped with a flame ionization detector. } \\
\text { For details on the gas extraction and ice } \\
\text { core dating techniques, see } \mathrm{Stauffer} \mathrm{et} \mathrm{al.} \\
\text { (1988) and Harnmer et al. (1985), } \\
\text { respectively. }\end{array}$ \\
\hline $\begin{array}{l}\text { Calibration gases used-A standard gas } \\
\text { mixture of } \mathrm{N}_{2}, \mathrm{O}_{2}, \mathrm{Ar}, \text { and } \mathrm{CO}_{2} \text { with a } \mathrm{CH}_{4} \\
\text { concentration of } 980 \pm 30 \mathrm{ppbv} \text { is used. }\end{array}$ \\
\hline $\begin{array}{l}\text { Data avallability - These data are available } \\
\text { from CDIAC and have been published in } \\
\text { Stauffer ct al. (1988). }\end{array}$ \\
\hline
\end{tabular}

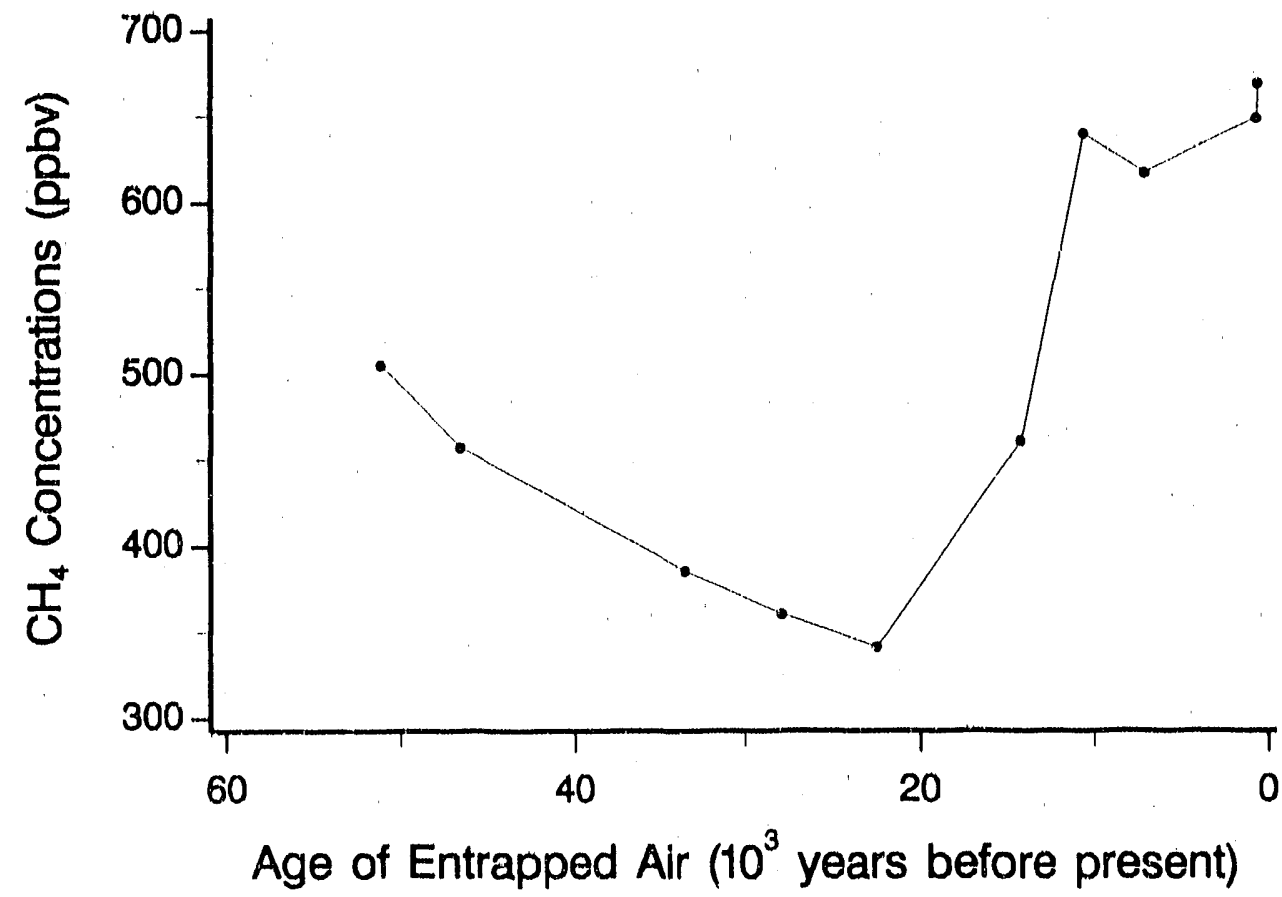

Concentrations of atmospheric $\mathrm{CH}_{4}$ from ice cores.

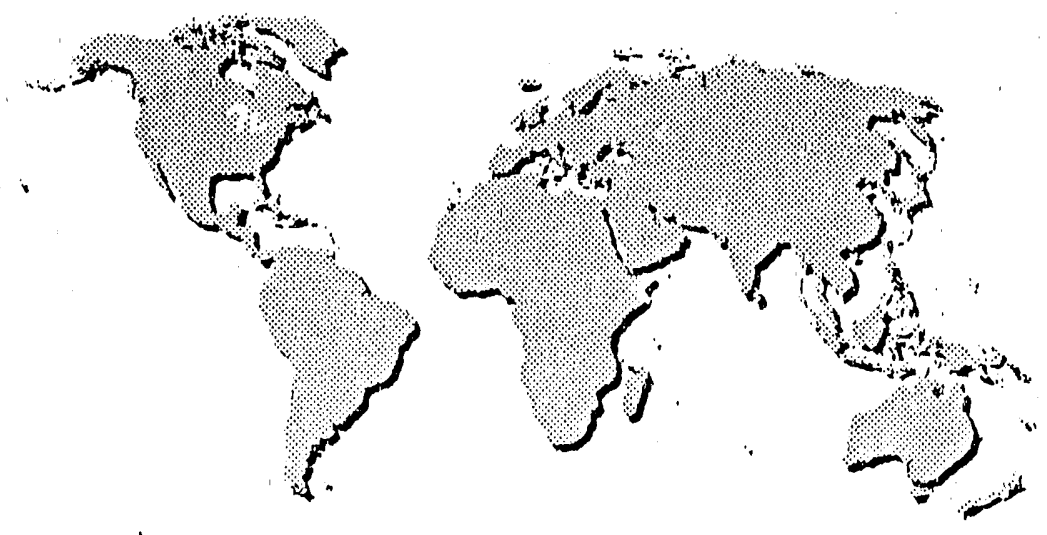

Byrd Station

Antarctica

$79^{\circ} .59^{\prime} \mathrm{S}, 120^{\circ} 01^{\prime} \mathrm{W}$ 


\section{Atmospheric $\mathrm{CH}_{4}$ from Ice Cores}

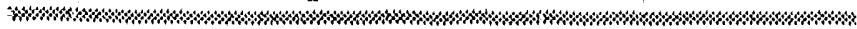

\section{TRENDS}

The 2184-m core from Byrd Station was drilled in 1967 1968 by the U.S. Cold Regions Research and Engineering Laboratory. Schwander and Stauffer (1984) reported a difference of 240 years between the age of the ice core from Byrd Station and the mean age of the air trapped in its bubbles.

Stauffer et al. (1988) reported that measurements on ice cores from Byrd Station (Antarctica) and Dye 3 (Greenland) show that the atmospheric $\mathrm{CH}_{4}$ concentration was only -350 ppbv during the last glaciation, in comparison with a mean preindustrial level of $\sim 650 \mathrm{ppbv}$ and a present value of $1650 \mathrm{ppbv}$. 
Atmospheric Methane from Ice Cores

$\begin{gathered}\text { Depth } \\ (\mathbf{m})\end{gathered}$
147.22
153.82
750.04
999.63
1200.6
1395.9
1501.3
1601.1
1795.7
1853.3

$\mathrm{CH}_{4}$ concentrution

In extracted air

(ppby)*

$667 \pm 25$

$647 \pm 25$

$615 \pm 25$

$638 \pm 25$

$460 \pm 25$

$341 \pm 27$

$360 \pm 25$

$385 \pm 25$

$457 \pm 27$

$505 \pm 31$

*For a 500-g sample, the $\mathrm{CH}_{4}$ concentration rose $40 \pm 10$ ppbv because of $\mathrm{CH}_{4}$ contamination (Stauffer et al. 1988). These results have been corrected

accordingly. The precision of their analyses, including

extraction, is within \pm 25 ppby the accuracy is further

cxtraction, is within $\pm 25 \mathrm{ppbv}$; the accuracy is further

uncertainty of $3 \%$ in the methane concentration.

\section{REFERENCLS}

Barnoli, J.M., D. Raynuad, A. Neffel, and

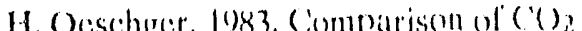
measurements by lwo laborateries on air bubbles in polar ice. Nettere' 3(10.34110) 13.

Hammer, C.U., H.B. Clathien, and ( $\therefore($. Langway, Ir, 1085. The Byrd ice core: continuous acidity measurenenents and solid electrical conductivity measurements.

Proceedinges of the Symposium on Snow and lee Chemistry and the Atmespluere. pp. 214. IN W.P. Adams (ced.), almolls of Ciluciology).

Lorius, C., J, Jouzel, C. Ritz, L, Merlivat, N.I. Barkow, 'Y.S. Korrolkevich, and

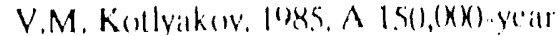

climatic record from Antarctic ice. Nanere $316,501 \ldots)$

Nefiel, A., H. ()eschger, J. Sichwander,

B. Stauffer, and R. Zumblirumin. IN82. I I core measurements give at mospherice (' $(1)$ : content during he patst al), (x)k) yr. Neture' $295,22023$.

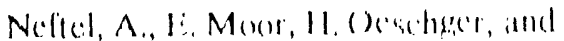

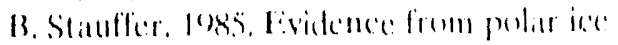
cores for the increane in allmonpherice (c): in the past two contul ve vature 315.4547

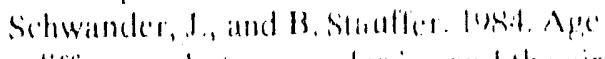
difference between polate ice and hate atr

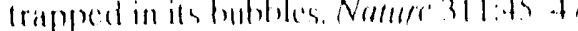

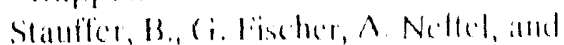

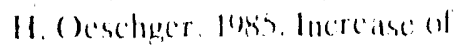

almospherie methatere reorded in

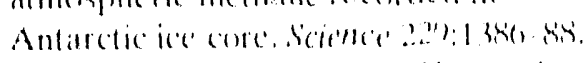

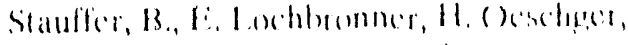
and J. Sichwinder. 10s'. Methitne

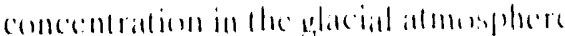

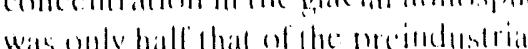
Holecence Nuture 332:81? 1.4. 


\section{Dye 3}

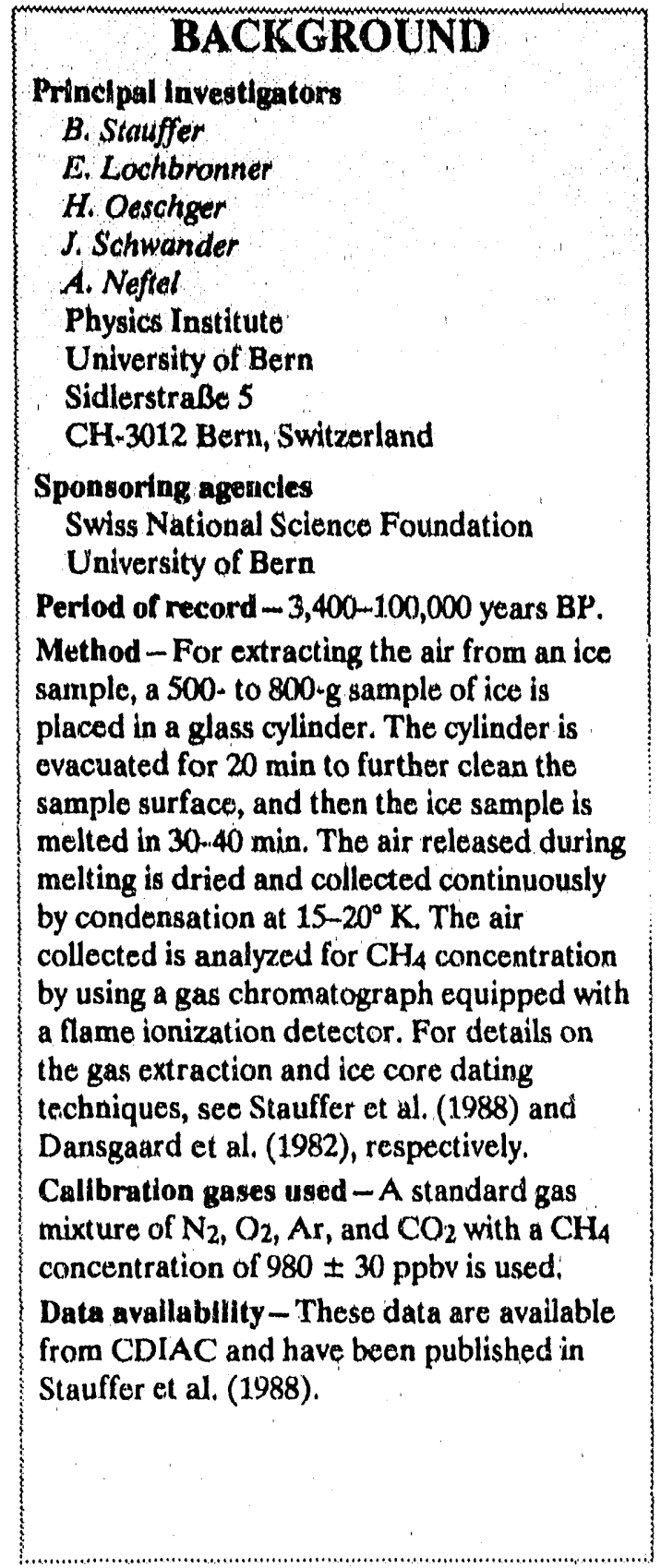

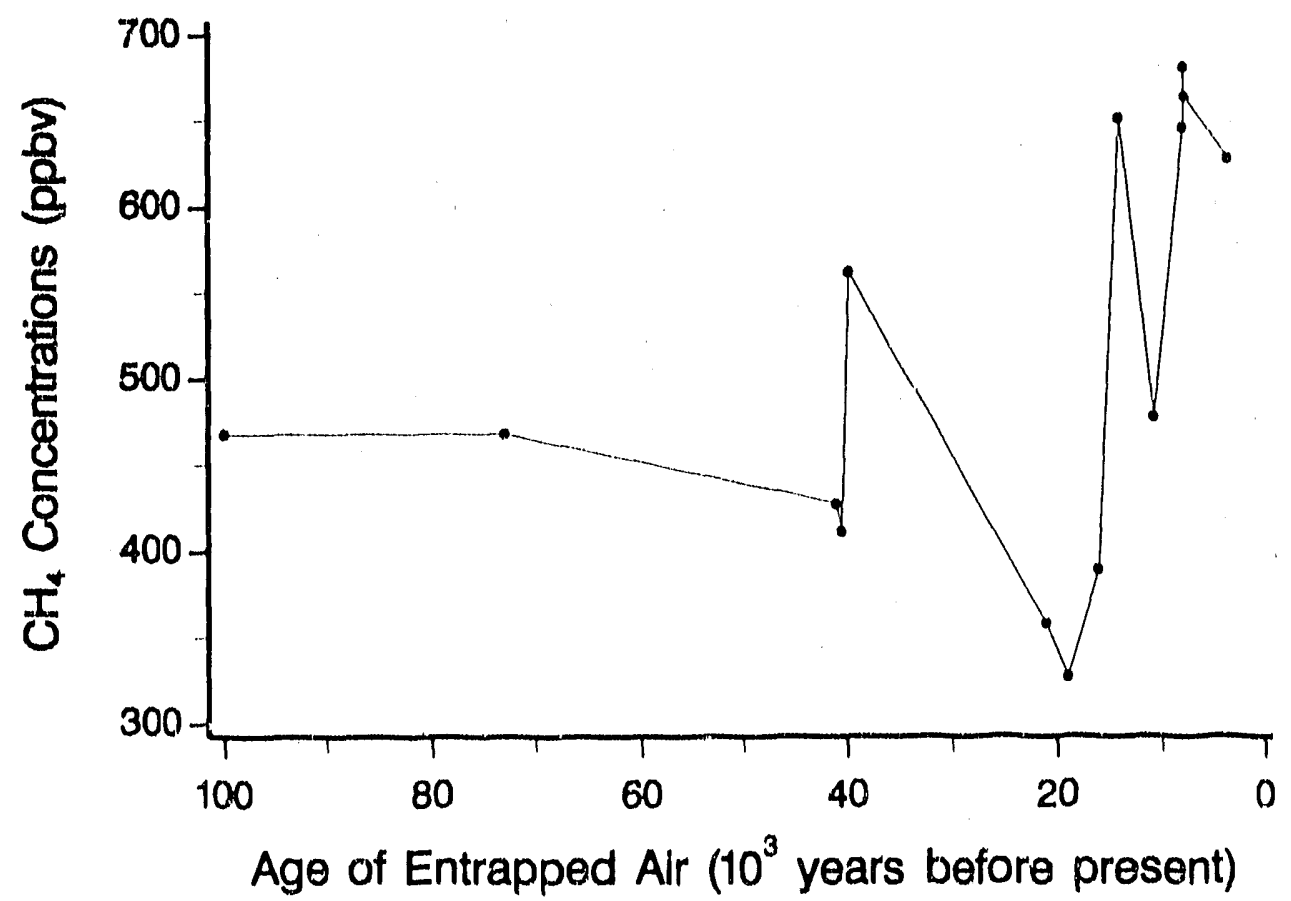

Dye 3

Concentrations of atmospheric $\mathrm{CH}_{4}$ from ice cores.

Greenland

$65^{\circ} 11^{\prime} \mathrm{N}, 43^{\circ} 50^{\prime} \mathrm{W}$

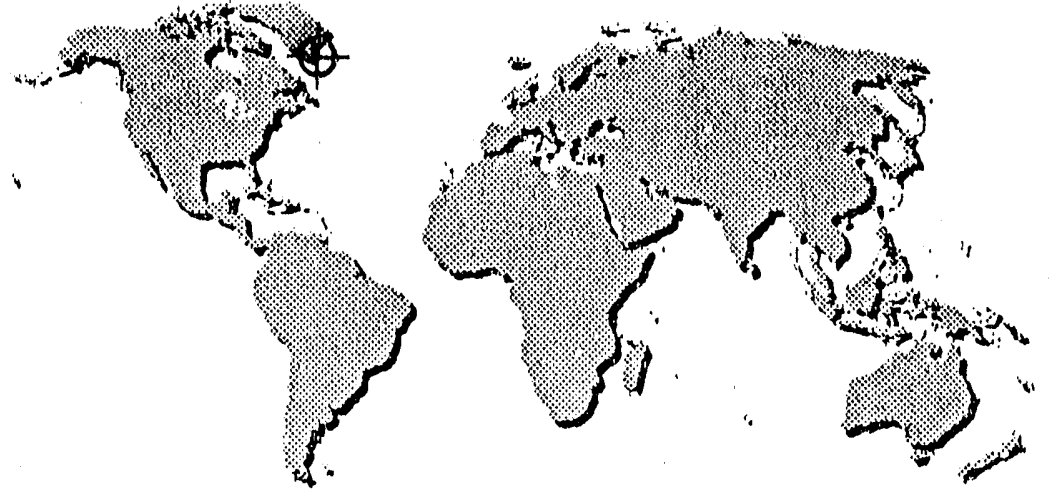


Atmospheric $\mathrm{CH}_{4}$ from Ice Cores

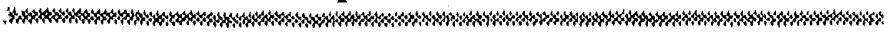

\section{TRENDS}

The Greenland core was drilled at Dyo 3 during the summer months 1979-1981 as part of an international collaboration between the United States, Denmark, and Switzerland (i.e., the Greenland Ice Sheot Program). Fourteen samples were measured from the $2037 . \mathrm{m}$ core. Schwander and Stauffer (1984) determined that the difference between the mean age of the ice and the mean age of the air trapped in its bubbles was 90 years.

On the basis of analyses of the ice core from Dye 3. Stauffer et al. (1988) reported a decline in the $\mathrm{CH}_{4}$ concentration from 500 ppbv around 60,000 yearrs BP to 350 ppbv around 20,000 yearrs BP followed by a rapid increase to the Holocene value of 650 ppbv. Present values are now $\sim 1650$ ppbv. 


\section{Dye 3}

\section{Atmospheric Methane from Ice Cores}

$\begin{array}{ccc}\begin{array}{c}\text { Depth } \\ \text { (m) }\end{array} & \begin{array}{c}\text { Air enclosed } \\ \text { (yr BP) }\end{array} & \begin{array}{c}\text { CH4 concentration } \\ \text { In extracted alr } \\ \text { (ppbv)* }\end{array} \\ 11.85 .03 & 3,400 & 627 \pm 25 \\ 1670.91 & 7,700 & 663 \pm 30 \\ 1675.26 & 7,800 & 680 \pm 27 \\ 1681.40 & 7,900 & 645 \pm 37 \\ 1789.00 & 10,800 & 477 \pm 25 \\ 1808.39 & 14,000 & 650 \pm 32 \\ 1818.90 & 16,000 & 389 \pm 32 \\ 1828.90 & 19,000 & 327 \pm 30 \\ 1836.81 & 21,000 & 358 \pm 41 \\ 1896.83 & 39,800 & 561 \pm 31 \\ 1898.33 & 40,500 & 411 \pm 32 \\ 1899.33 & 41,000 & 427 \pm 33 \\ 1951.77 & 73,000 & 468 \pm 25 \\ 1990.22 & 100,000 & 468 \pm 25\end{array}$

*For a 500-g sample, the $\mathrm{CH}_{4}$ concentration rose $40) \pm 10$ ppbr because of $\mathrm{CH}_{4}$ contamination 'Stauffer et al. 1988). These results have been corrected accordingly. The precision of their analyses, including extraction, is within $\pm 25 \mathrm{ppbv}$; the accuracy is further limited by the standard gas, which gives an additional uncertainty of $3 \%$ in the methane concentration. 


\section{Atmospheric Methane from Ice Cores}

\begin{tabular}{ccc}
$\begin{array}{c}\text { Depth } \\
(\mathbf{m})\end{array}$ & $\begin{array}{c}\text { Air enclosed } \\
\text { (yr BP) }\end{array}$ & $\begin{array}{c}\text { CH4 concentration } \\
\text { in extracted air } \\
(\mathbf{p p b v )}\end{array}$ \\
1185.03 & 3,400 & $627 \pm 25$ \\
1670.91 & 7,700 & $663 \pm 30$ \\
1675.26 & 7,800 & $680 \pm 27$ \\
1681.40 & 7,900 & $645 \pm 37$ \\
1789.00 & 10,800 & $477 \pm 25$ \\
1808.39 & 14,000 & $650 \pm 32$ \\
1818.90 & 16,000 & $389 \pm 32$ \\
1828.90 & 19,000 & $327 \pm 30$ \\
1836.81 & 21,000 & $358 \pm 41$ \\
1896.83 & 39,800 & $561 \pm 31$ \\
1898.33 & 40,500 & $411 \pm 32$ \\
1899.33 & 41,000 & $427 \pm 33$ \\
1951.77 & 73,000 & $468 \pm 25$ \\
1990.22 & 100,000 & $468 \pm 25$ \\
\hline
\end{tabular}

*For a 500-g sample, the $\mathrm{CH}_{4}$ concentration rose $40 \pm 10$ ppbv because of $\mathrm{CH}_{4}$ contamination (Stauffer $40 \pm 10 \mathrm{ppbv}$ because of $\mathrm{CH}_{4}$ contamination (

et al. 1988). These results have been corrected
accordingly. The precision of their analyses, including extraction, is within \pm 25 ppbv; the accuracy is further limited by the standard gas, which gives an additional uncertainty of $3 \%$ in the methane concentration.

\section{REFERENCES}

Barnola, J.M., D. Raynaud, A. Neftel, and H. Oeschger. 1983. Comparison of $\mathrm{CO}_{2}$ measurements by two laboratories on air bubbles in polar ice. Nature $303,410-13$. Dansgaard, W., H.B. Clausen, N.

Gundestrup, C.U. Hammer, S.F. Johnsen, P.M. Kristinsdottir, and N. Reeh. 1982. A New Greenland deep ice core. Science 218:1273-77.

Lorius, C., J. Jouzel, C. Ritz, L. Merlivat,

N.I. Barkov, Y.S. Korotkevich, and

V.M. Kotlyakov, 1985. A 150,000-year

climatic record from Antarctic ice. Nature 316:591-96.

Neftel, A., H. Oeschger, J. Schwander,

B. Stauffer, and R. Zumbrunn, 1982. Ice

core measurements give atmospheric $\mathrm{CO}_{2}$ content during the past 40,000 yr. Nature 295:220-23.

Neftel, A, E. Moor, H. Oeschger, and

B. Stauffer. 1985. Evidence from polar ice cores for the increase in atmospheric $\mathrm{CO}_{2}$ in the past two centuries. Nature 315:45-47.

Schwander, J., and B. Stauffer. 1984. Age. difference between polar ice and the air trapped in its bubbles. Nature 311:45-47. Stauffer, B., G. Fischer, A: Neftel, and

H. Oeschger. 1985. Increase of

atmospheric methane recorded in

Antarctic ice core Science 229:1386-88. Antaufer, B., E. Lochbronner, H. Oeschger, and J. Schwander. 1988. Methane concentration in the glacial atmosphere was only half that of the preindustrial Holocene. Nature 332:812-14. 


\section{Siple Station}

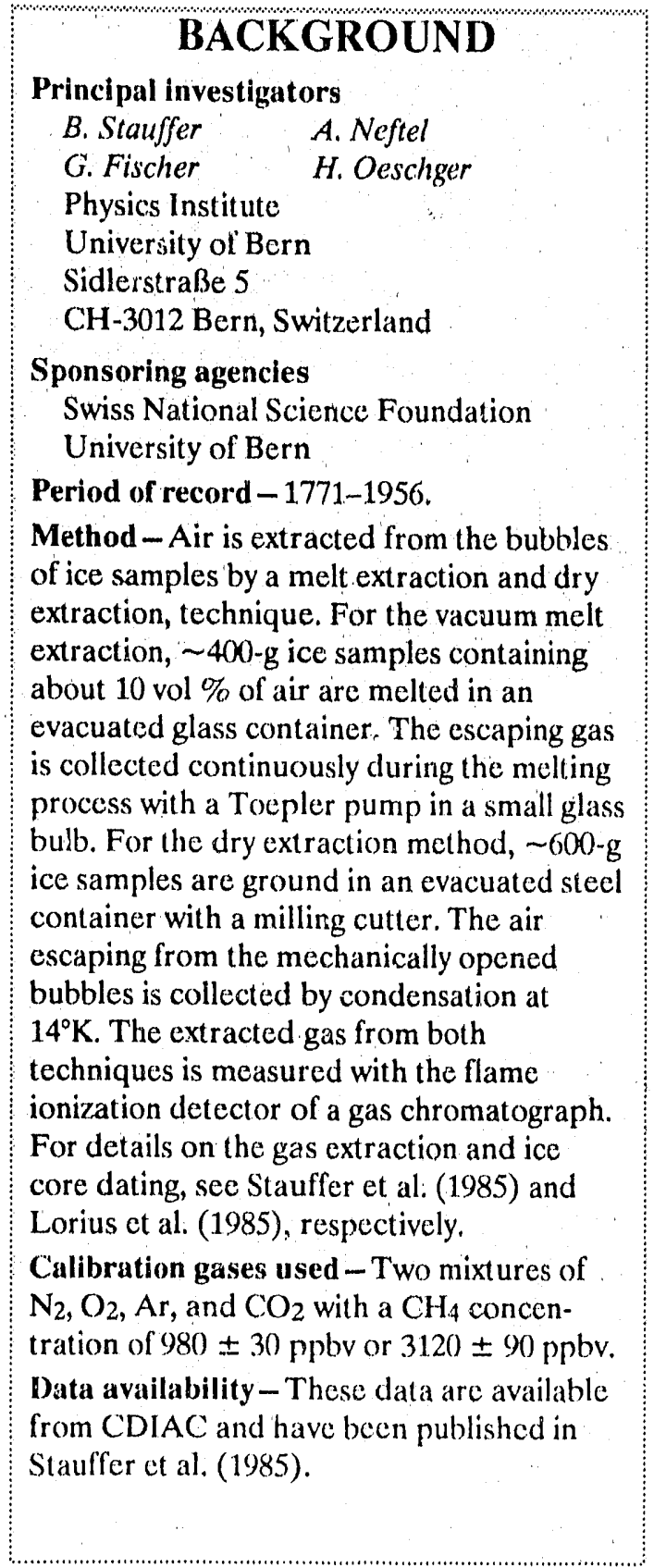

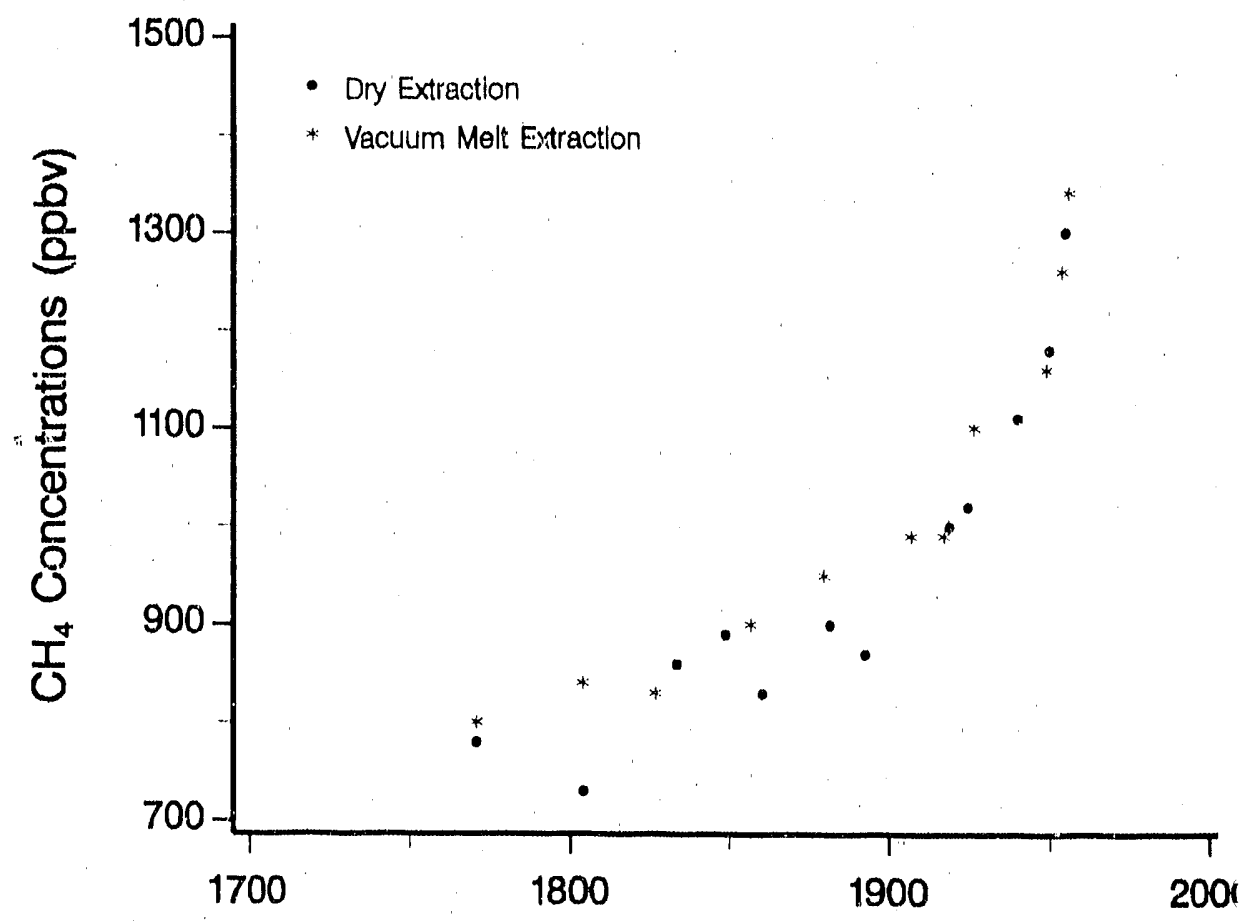

Siple Station

Antaractica

$75^{\circ} 55^{\prime} \mathrm{S}, 83^{\circ} 55^{\prime} \mathrm{W}$

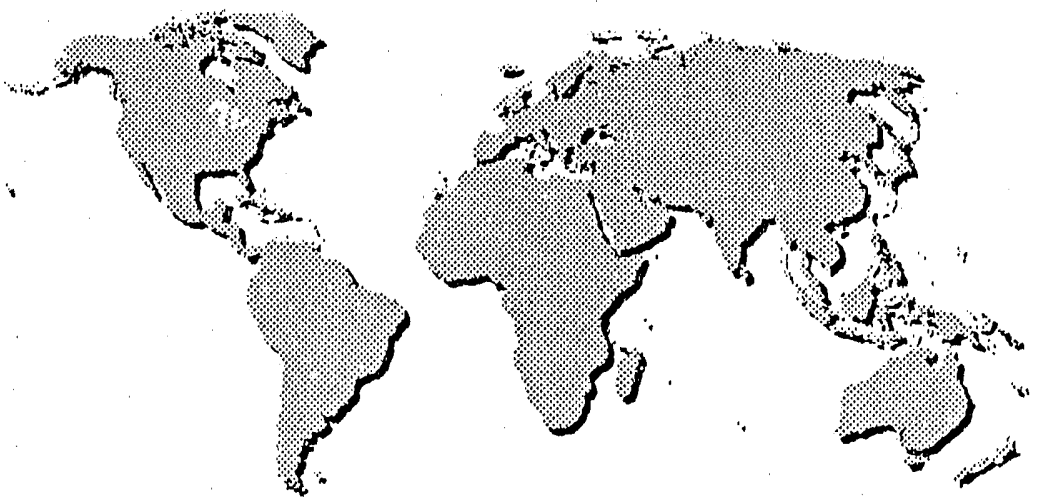




\section{Atmospheric $\mathrm{CH}_{4}$ from Ice Cores}

\section{TRENDS}

The ice core from Siple Station was drilled in the Antarctic summer of 1983-1984 to a depth of $200 \mathrm{~m}$ by the Polar Ice Coring Office (Nebraska) and the Physics Institute at the University of Bern. Schwander and Stauffer (1984) reported a difference of 95 years between the mean age of the ice and the air trapped in its bubbles. Samples from Siple Station in western Antarctica are well suited for investigating changes of atmospheric composition in the recent past, having an excellent time resolution because of the high rates of accumulation (Stauffer et al. 1985).

Measurements of the $\mathrm{CH}_{4}$ concentrations in air extracted by two different methods from ice samples from Sipic Station allow the reconstruction of the history of the increase of atmospheric $\mathrm{CH}_{4}$ during the past 200 years. Determinations of $\mathrm{CH}_{4}$ concentrations on the 12 ice samples measured by dry extraction show that atmospher: $: \mathrm{CH}_{4}$ concentrations increased from $0.78 \pm 0.09$ ppmv in 1771 to $1.30 \pm 0.07$ ppmv in 195.5 . Determinations on the 11 ice samples measured by vacuum melt extraction show increases from $0.80 \pm 0.06$ ppmv in 1771 to $1.34 \pm 0.08$ ppmv in 1956 . 
Atmospheric Methane from Ice Cores

$\begin{array}{r}\text { Depth } \\ \text { (m) }\end{array}$


78.6
82.6
88.0
96.4
100
113
119
130
136
144
160
177

Dept

Gas age

(yr A.D.)

$\mathrm{CH}_{4}$ concentration

\section{in extracted air}

(ppmv)*

\section{Dry extraction}

Vacuum melt extraction

$\begin{array}{ll}1956 & 1.34 \pm 0.08 \\ 1954 & 1.26 \pm 0.08 \\ 1949 & 1.16 \pm 0.08 \\ 1927 & 1.10 \pm 0.07 \\ 1917 & 0.99 \pm 0.06 \\ 1907 & 0.99 \pm 0.06 \\ 1880 & 0.95 \pm 0.06 \\ 1857 & 0.90 \pm 0.06 \\ 1827 & 0.83 \pm 0.06 \\ 1804 & 0.84 \pm 0.06 \\ 1771 & 0.80 \pm 0.06\end{array}$

*The error limits are the estimated precisions of the measurements

\section{REFERENCES}

\section{Barnola JM D. Raynaud, A Neftel, and} H. Oeschger. 1983. Comparison of $\mathrm{CO}_{2}$ measurements by two laboratories on air bubbles in polar ice. Nature 303:410-13. Dansgaard, W., H.B. Clausen,

N. Gundestrup, C. U. Hammer,

S.F. Johnsen, P.M. Kristinsdottir, and

N. Reeh. 1982. A New Greenland deep ice core. Science 218:1273-77.

Lorius, C. J. Jouzel, C. Ritz, L. Merlivat,

N.I. Barkov, Y.S. Korotkevich, and

V.M. Kotlyakov. 1985. A 150,000-year

climatic record from Antarctic ice. Nature 316:591-96.

Neftel, A., H. Oeschger, J. Schwander,

B. Stauffer, and R. Zumbrunn. 1982. Ice

core measurements give atmospheric $\mathrm{CO}_{2}$

content during the past $40,000 \mathrm{yr}$. Nature 295:220-223.

295:220-223.
Neftel, A., E. Moor, H. Oeschger, and

B. Stauffer. 1985. Evidence from polar ice cores for the increase in atmospheric $\mathrm{CO}_{2}$ in the past two centuries. Nature 315:45-47. Schwander, J., and B. Stauffer. 1984. Age

difference between polar ice and the air trapped in its bubbles. Nature 311:45-47. Stauffer, B., G. Fischer, A. Neftel, and H. Oeschger. 1985. Increase of $\mathrm{H}$. Oeschger. 1985 . Increase of
atmospheric methane recorded in atmospheric methane recorded in
Antarctic ice core. Science 229:1386-88. Stauffer, B., E. Lochbronner, H. Oeschger, and J. Schwander. 1988. Methane

concentration in the glacial atmosphere

was only half that of the preindustrial

Holocene. Nature 332:812-14. 


\section{Global}

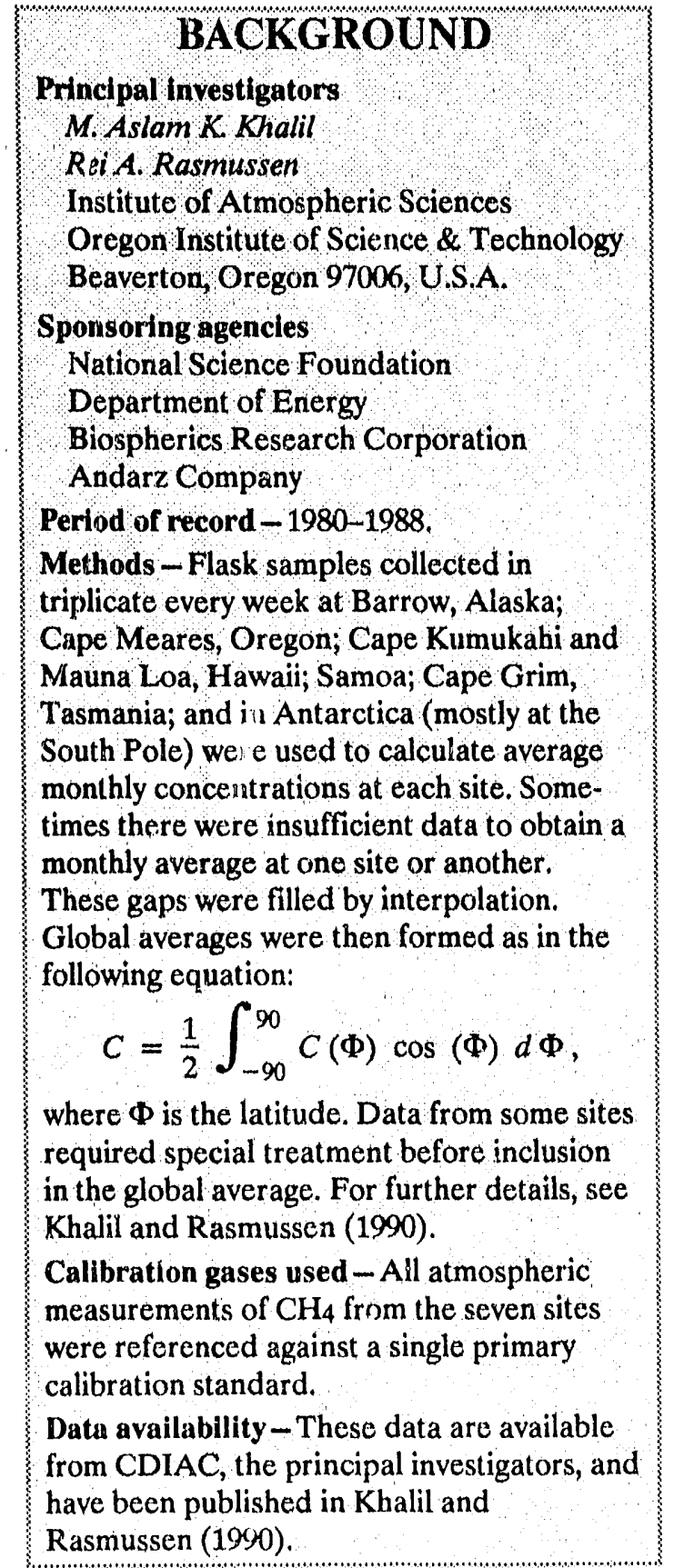

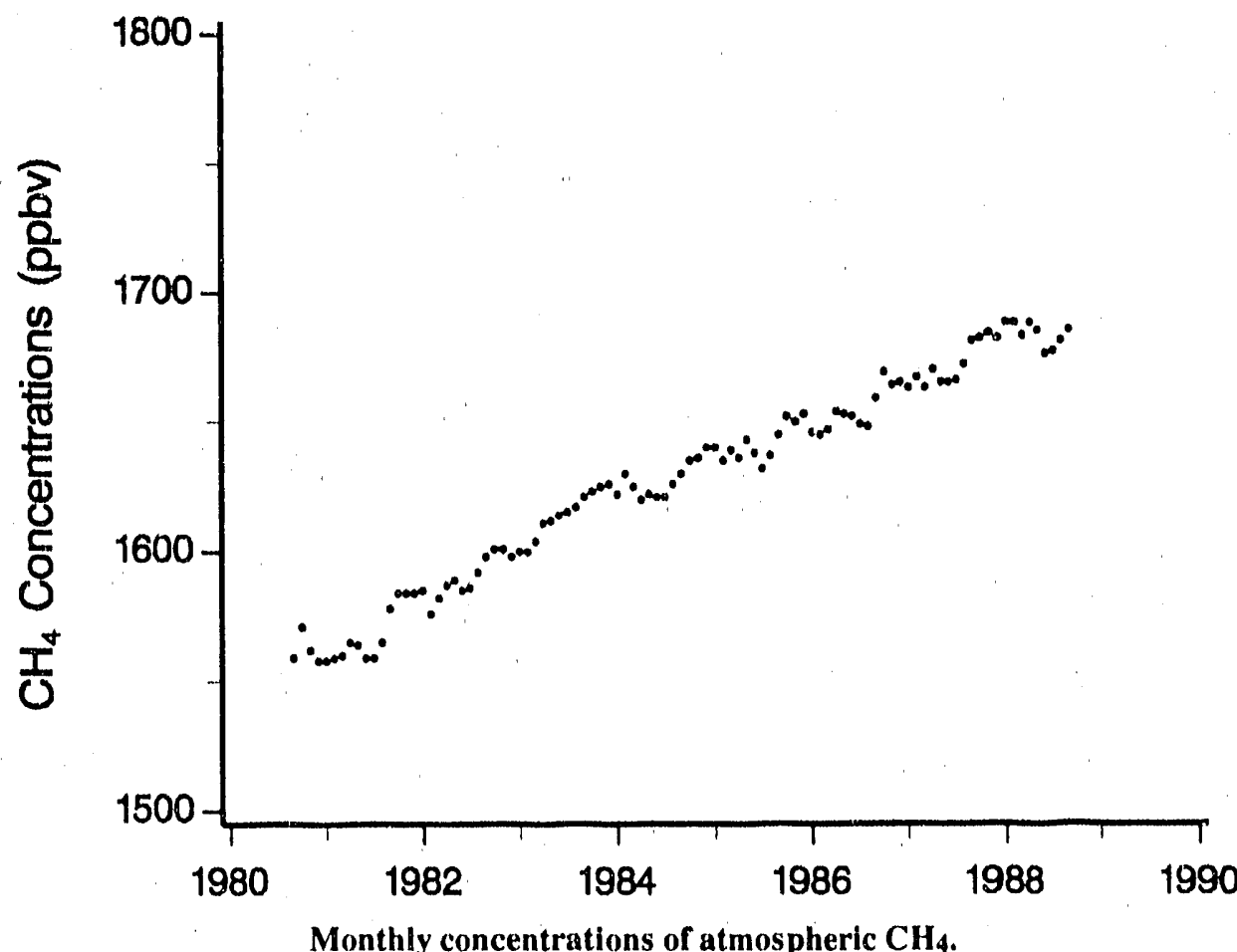

Barrow

Alaska, U.S.A.

Cape Grim

Tasmania, Australia

Cape Kumukahi

Hawaii, U.S.A.

Cape Matatula American Samoa

Cape Meares

Oregon, U.S.A.

Mauna Loa

Hawaii, U.S.A.

South Pole

Antarctica

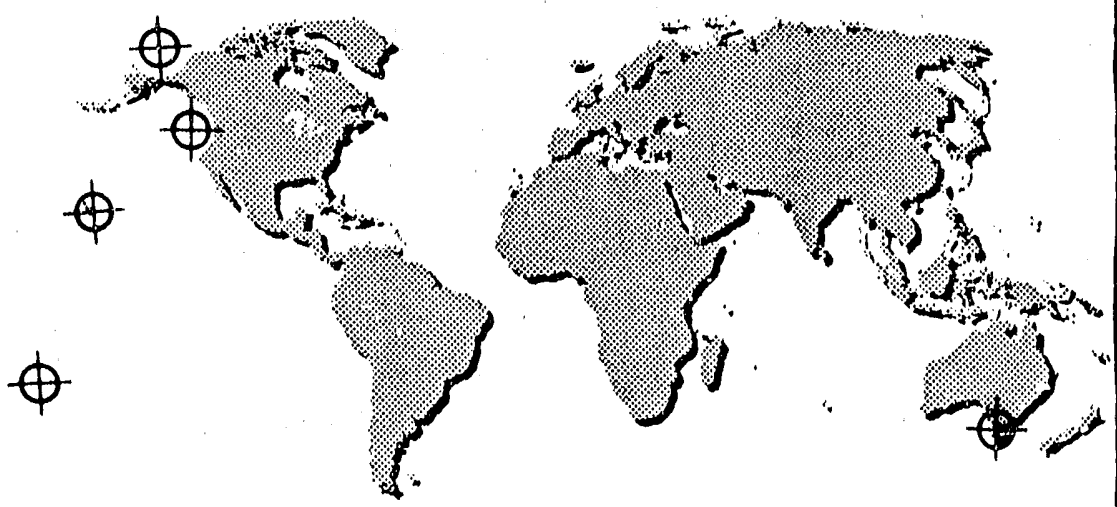




\section{Atmospheric $\mathrm{CH}_{4}$}

\section{TRENDS}

According to Khalil and Rasmussen (1990), "this record shows that methane concentration increased at an average rate of $16.6 \pm 0.4 \mathrm{ppbv} /$ year or $\sim 1.02 \pm$ $0.02 \% /$ year over 8 years. This trend has not been constant according to our record but has varied berween $12 \pm 2$ and $23 \pm 2$ ppbv/year over 2-year periods after seasonal variations are removed."

Earlier work by Rasmussen and Khalil (1981) and Kha'il and Rasmussen (1983) reported annual global increases of nearly $2 \%$ and $1.3 \%$ per year, respectively. Blake and Rowland (1988) showed trends of $1 \%$ per year, and Steele et al. (1987) reported even slower increases, slightly less than $0.8 \%$ per year. 


\section{Concentrations of Atmospheric Methane*}

$\begin{array}{llllllllllllll}\text { Year } & \text { Jan } & \text { Feb } & \text { Mar } & \text { Apr } & \text { May } & \text { Jun } & \text { Jul } & \text { Aug } & \text { Sept } & \text { Oet } & \text { Nov } & \text { Dec } \\ 1980 & & & & & & & & & & 1559 & 1571 & 1562 & 1558 \\ 1981 & 1558 & 1559 & 1560 & 1565 & 1564 & 1559 & 1559 & 1565 & 1578 & 1584 & 1584 & 1584 \\ 1982 & 1585 & 1576 & 1582 & 1587 & 1589 & 1585 & 1586 & 1592 & 1598 & 1601 & 1601 & 1598 \\ 1983 & 1600 & 1600 & 1604 & 1611 & 1612 & 1614 & 1615 & 1617 & 1621 & 1623 & 1625 & 1626 \\ 1984 & 1622 & 1630 & 1625 & 1620 & 1622 & 1621 & 1621 & 1626 & 1630 & 1635 & 1636 & 1640 \\ 1985 & 1640 & 1635 & 1639 & 1636 & 1643 & 1638 & 1632 & 1637 & 1645 & 1652 & 1650 & 1653 \\ 1986 & 1646 & 1645 & 1647 & 1654 & 1653 & 1652 & 1649 & 1648 & 1659 & 1669 & 1664 & 1665 \\ 1987 & 1663 & 1667 & 1663 & 1670 & 1665 & 1665 & 1666 & 1672 & 1681 & 1682 & 1684 & 1682 \\ 1988 & 1688 & 1688 & 1683 & 1688 & 1685 & 1676 & 1677 & 1681 & 1685 & & & \end{array}$

"Methane concentrations expressed in parts per billion by volume (ppbv).

\section{REFERENCES}

Blake, D.R., and F.S. Rowland, 1988. Continuing worldwide increase in tropospheric methane, 1978 to 1987 Science 239:1129-31.

Khalil, M.A.K., and R.A. Rasmussen, 1983. Sources, sinks, and seasonal cycles of at mospheric methane. Jourmal of

Geophysical Research 88.5131-44.

Khalil, M.A.K., and R.A. Rasmussen, 1990 Atmospheric methane: recent global

trends. Environmental Science \&

Technology 24:549-5?.

Rasmussen, R.A. and M.A.K. Khalil. 1981. Atmospheric methane $\left(\mathrm{CH}_{4}\right)$ : trends and seasonal cycles. Joumal of Geophysical Research 86.9826-32

Stecle, L.P., P.J. Fraser, R.A. Rasmussen, M.A.K. Khalil, T.J. Conway, A.J. Crawford, R.H. Gammon, K.A. Masarie, and

K.W. Thoning. 1987. The global

distribution of methane in the troposphere.

Joumal of Atmospheric Chemistry 5:125-71. 


\section{Amsterdam Island}

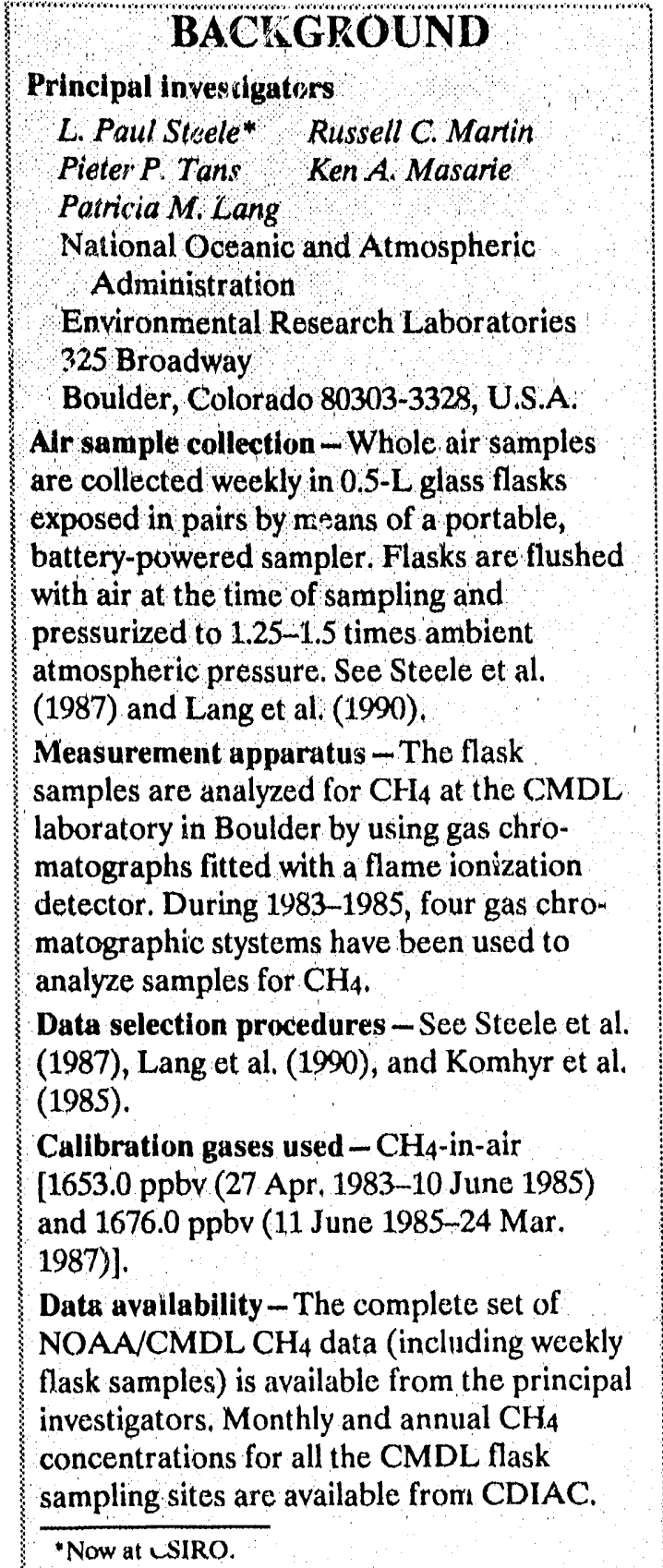

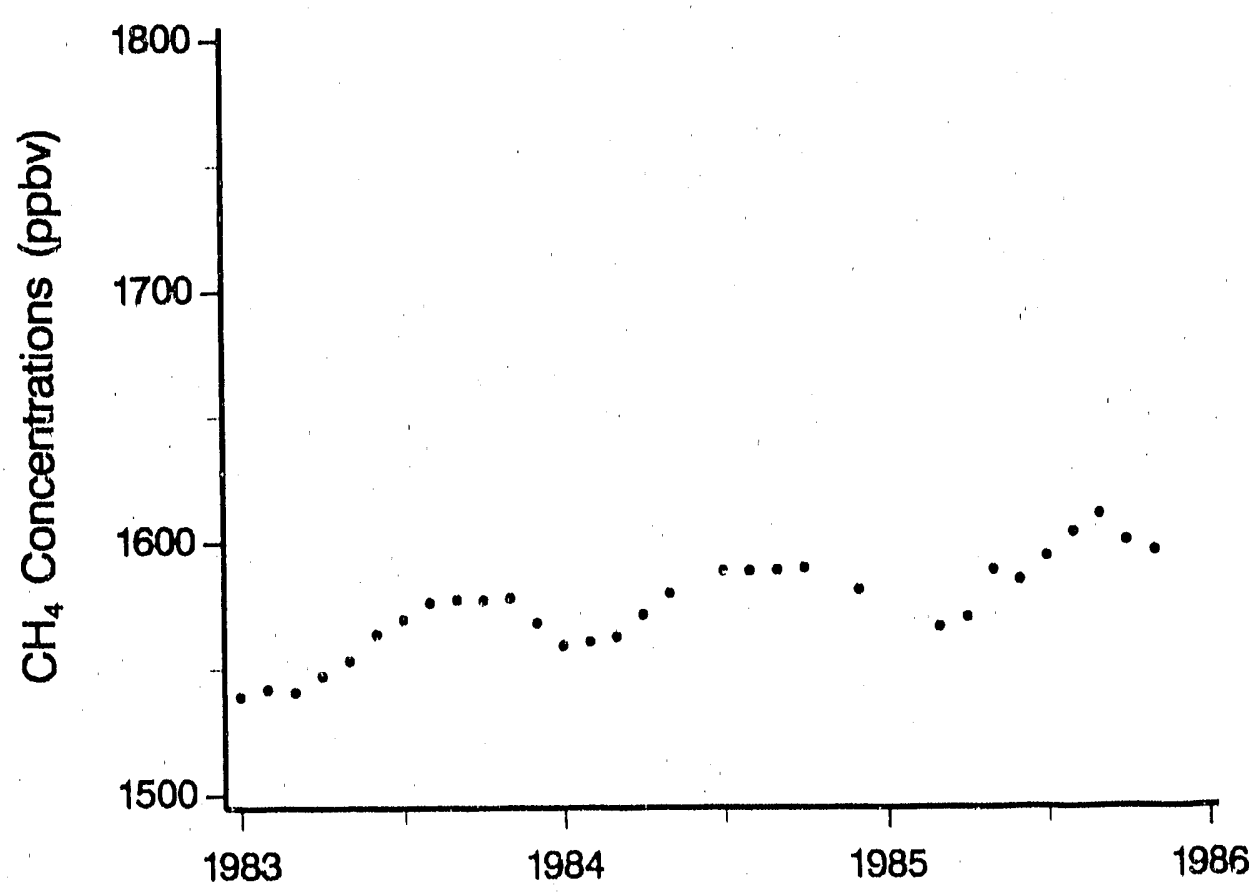

Monthly concentrations of atmospheric $\mathrm{CH}_{4}$.

Amsterdam Island

French Territory, Indian Ocean

Island seashore

$37^{\circ} 57^{\prime} S, 77^{\circ} 32^{\prime} E$

$1.50 \mathrm{~m}$ above MSL 


\section{Atmospheric $\mathrm{CH}_{4}$}

\section{TREND}

The sampling site on Amsterdam Island is operated in cooperation with the French Centre des Faibles Radioactivities. The annual concentration of $\mathrm{CH}_{4}$ at Amsterdam Island rose from $1561.1 \mathrm{ppbv}$ in 1983 to 1590.5 ppbv in 1985 . Steele et al. (1987) found that even with only 2 years of data, is pattern of unmistakable growth in $\mathrm{CH}_{4}$ concentration was seen at four sites (not including Amsterdam Island) in the Southern Hemisphere. The seasonal pattern seen at Amsterdam Island is typical for the Southern Hemisphere and repeats from year to year. 


\section{Amsterdam Island}

\section{Concentrations of Atmospheric Methane*}

$\begin{array}{cccccccccccccc}\text { Year } & \text { Jan } & \text { Feb } & \text { Mar } & \text { Apr } & \text { May } & \text { Jun } & \text { Jul } & \text { Aug } & \text { Sept } & \text { Oct } & \text { Nov } & \text { Dec } & \text { Ann } \\ 1983 & 1539.3 & 1542.1 & 1540.9 & 1547.4 & 1553.4 & 1563.9 & 1569.6 & 1576.3 & 1577.4 & 1577.2 & 1578.0 & 1568.1 & 1561.1 \\ 1984 & 1559.2 & 1560.7 & 1562.6 & 1571.3 & 1579.7 & & 1588.7 & 1588.7 & 1588.9 & 1589.8 & & 1581.0 & 1586.0 \\ 1985 & & & 1566.3 & 1570.1 & 1588.8 & 1584.8 & 1594.1 & 1603.6 & 1610.7 & 1600.1 & 1596.2 & & 1590.5\end{array}$

* Methane concentrations expressed in parts per billion by volume (ppbv). Monthly averages calculated as arithınetic means of individual flask concentrations that are indicative of background conditions. Annual averages based on monthly means.

\section{REFERENCES}

Fraser, PJ MAK Khatil, R.A.

Rasmussen, and A.J ( rawford. MS1.

Trends of atmospherie: mithane in the

Southern Hemisphere, Cotophysical

Re'search Lefters 8illki, fort.

Fraser, P.I., M.A.K. Khatil, R.A.

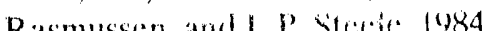

Troposplesie methane in the mid fall il tedes

of the Southern Hemisphere. Jomernal of

Atmospheric Chemistry 1:125.15.

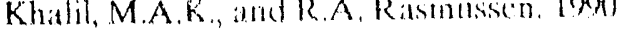

Almospheric mothante: recent glothat

Arends Envrommental Sicience and

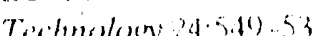

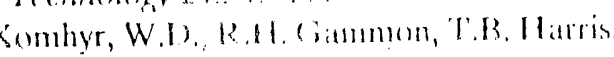

L.S. Watcrman, T.L. Conway, W.R. Taylur

and K.W. Thoning, luss (ilotral

ammosperic (o) distributions and

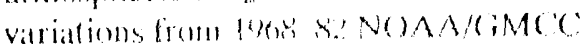

(O) flask sample diati formmol of

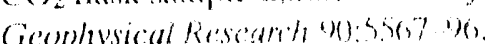

Lang, P.M., L.P. Storte, R. . Martin, and

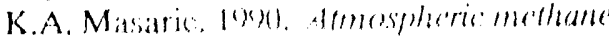
data for the prefiod los z. loss from the

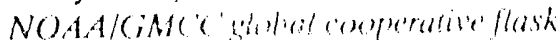

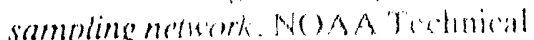

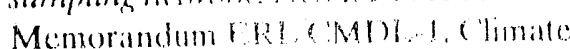

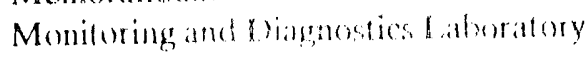
Boulder, Colmonisho.

Steck, L.P., P'. Fraser, R.A. Rasmussen,

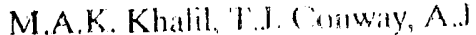

Crawford R.II ciammonn K.A. Masitric,

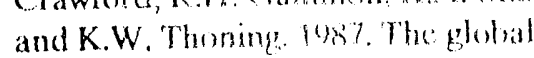

distribution of methane is the troposphere.

Joumal of Atmospheric Chemistry $5: 125.71$ 


\section{Amundsen Scott (South Pole)}

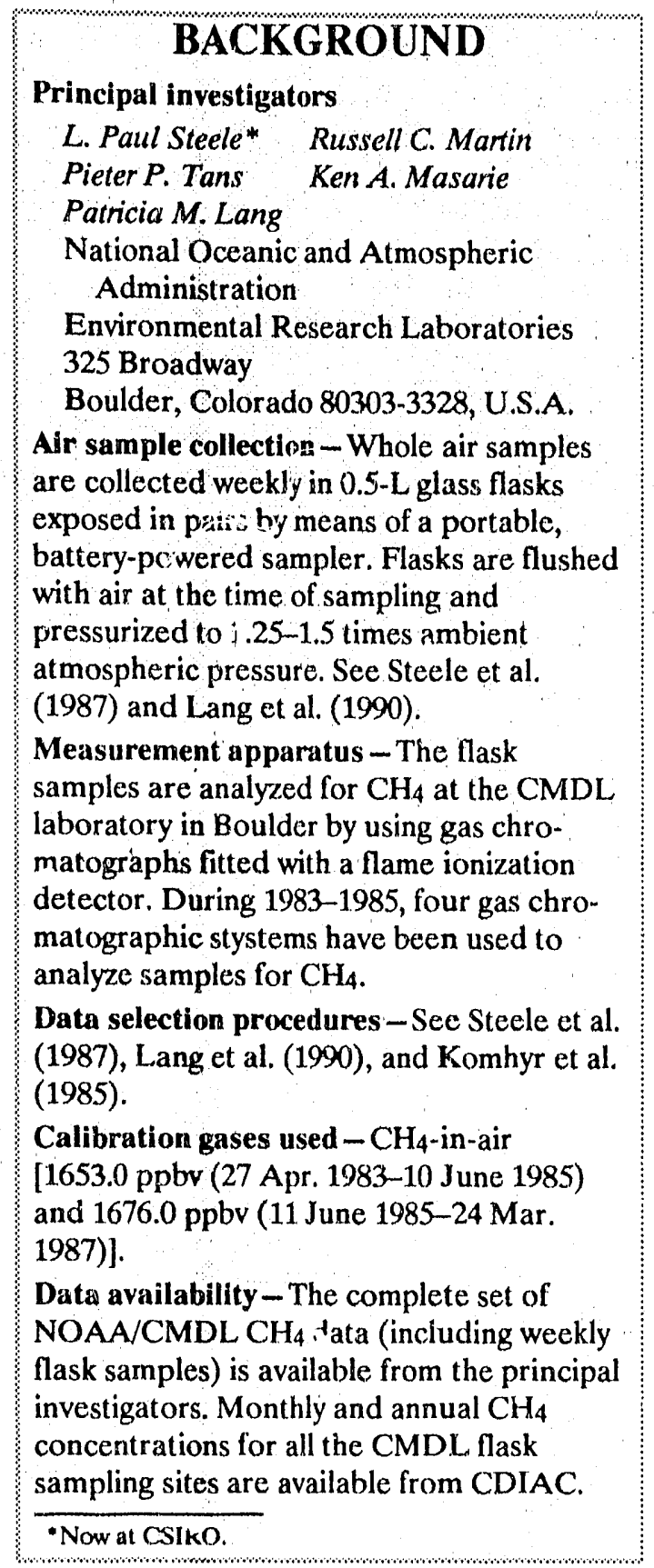

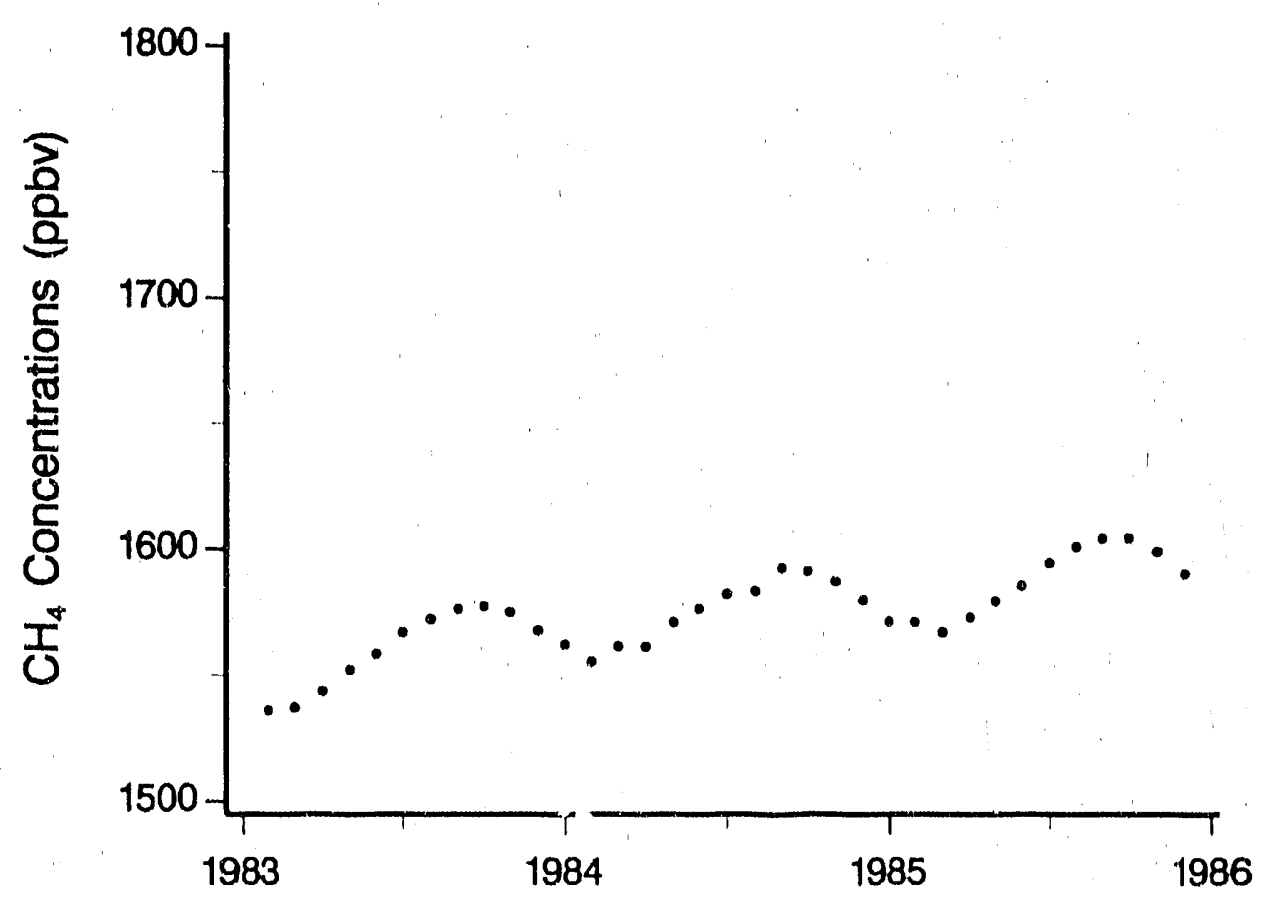

Monthly concentrations of atmospheric $\mathrm{CH}_{4}$.

Amundsen Scott

South Pole, Antarctica

Ice and snow covered plateau

$89^{\circ} 59^{\prime} \mathrm{S}, 24^{\prime \prime} 48^{\prime} \mathrm{W}$

$2810 \mathrm{~m}$ above $\mathrm{MSL}$ 


\section{TREND}

The average annual $\mathrm{CH}_{4}$ concentration at the South Pole increased from $1560.3 \mathrm{ppbv}$ in 1983 to 1586.7 ppbv in 1985 . Steele et al. (1987) reported an average growth rate of 23.1 ppbv per year at the South Pole on the tasis of a 12-1nonth running means fitted to a quadratic function. The NOAA/CMDL $\mathrm{CH}_{4}$ data record from Amundsen $\mathrm{Scott}$ is remarkably similar to the $\mathrm{CH}_{4}$ data records from the other southernmost sites in the CMDL network, except for Kaitorete Spit. Steele et al. (1987) reported that within the limits of the measurement precision, both the absolute concentration and the phase and amplitude of the seasonal cycle are indistinguishable at these Southerm Hemisphere sites. 


\section{Amundsen Scott (South Pole)}

Concentrations of Atmospheric Methane*

$\begin{array}{cccccccccccccc}\text { Year } & \text { Jan } & \text { Feb } & \text { Mar } & \text { Apr } & \text { May } & \text { Jun } & \text { Jul } & \text { Aug } & \text { Sept } & \text { Oct } & \text { Nov } & \text { Dec } & \text { Ann } \\ 1983 & & 1536.1 & 1537.1 & 1543.7 & 1552.1 & 1558.4 & 1566.9 & 1572.3 & 1576.4 & 1577.4 & 1575.1 & 1567.8 & 1560.3 \\ 1984 & 1562.1 & 1555.4 & 1561.5 & 1561.4 & 1571.1 & 1576.5 & 1584.2 & 1583.5 & 1592.7 & 1591.2 & 1587.2 & 1579.9 & 1575.4 \\ 1985 & 1571.3 & 1571.1 & 1567.0 & 1572.9 & 1579.3 & 1585.4 & 1594.4 & 1600.9 & 1604.1 & 1504.3 & 1599.0 & 1590.2 & 1586.7\end{array}$

*Methane concentrations expressed in parts per billion by volume (ppbv). Monthly averages calculated as arithmetic means of individual flask concentrations that are indicative of background conditions. Annual averages based on monthly means.

\section{REITRINAES}

Firaser, P.J, M.A.K. Khalil, K.A.

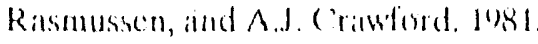
Trends of almospheric ane thate in the

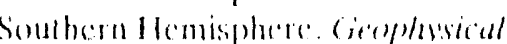

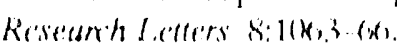
Fraser, P.J., M.A K. Khallit, R.A Ritsmussen, and L.P. Stcele. Irot. Tropespheric methane in the mid lat itudes

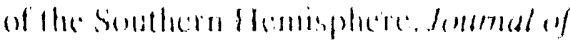

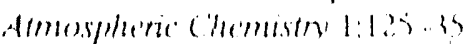

Khalil, M.A.K., and R.A. Rasmuss(n) I Ixy).

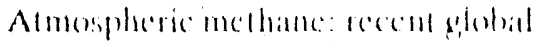

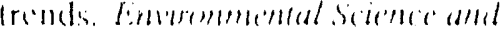

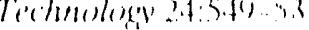

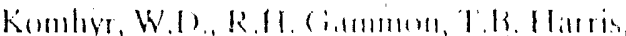

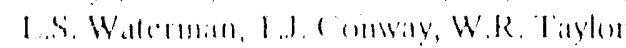

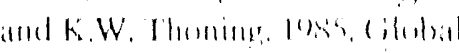

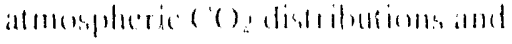
vartitions from l'k

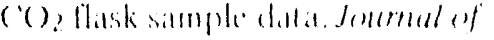

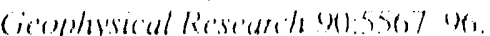

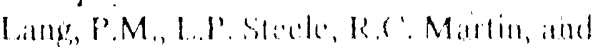

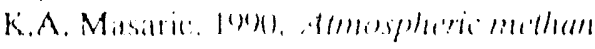

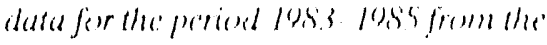

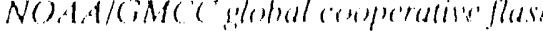
sampling ne'werth. N()AA Trechnical Memurandum ERI, ( MI) I. Clinnate Monitoring and Diagnostics lathratory,

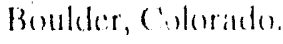

Stcele, L.P., P'J. Fratier, R.A. Ratsmussen, M.A.K. Khalil, 'I'J, Conway, A.J

Crawford, R.H. (iammon, K.A. Malsarice, and K.W. Thening. 1987. The glothal

distribution of methane in the troposphere Journal of almospheric: ('he'mistry 5:12571 


\section{Ascension Island}

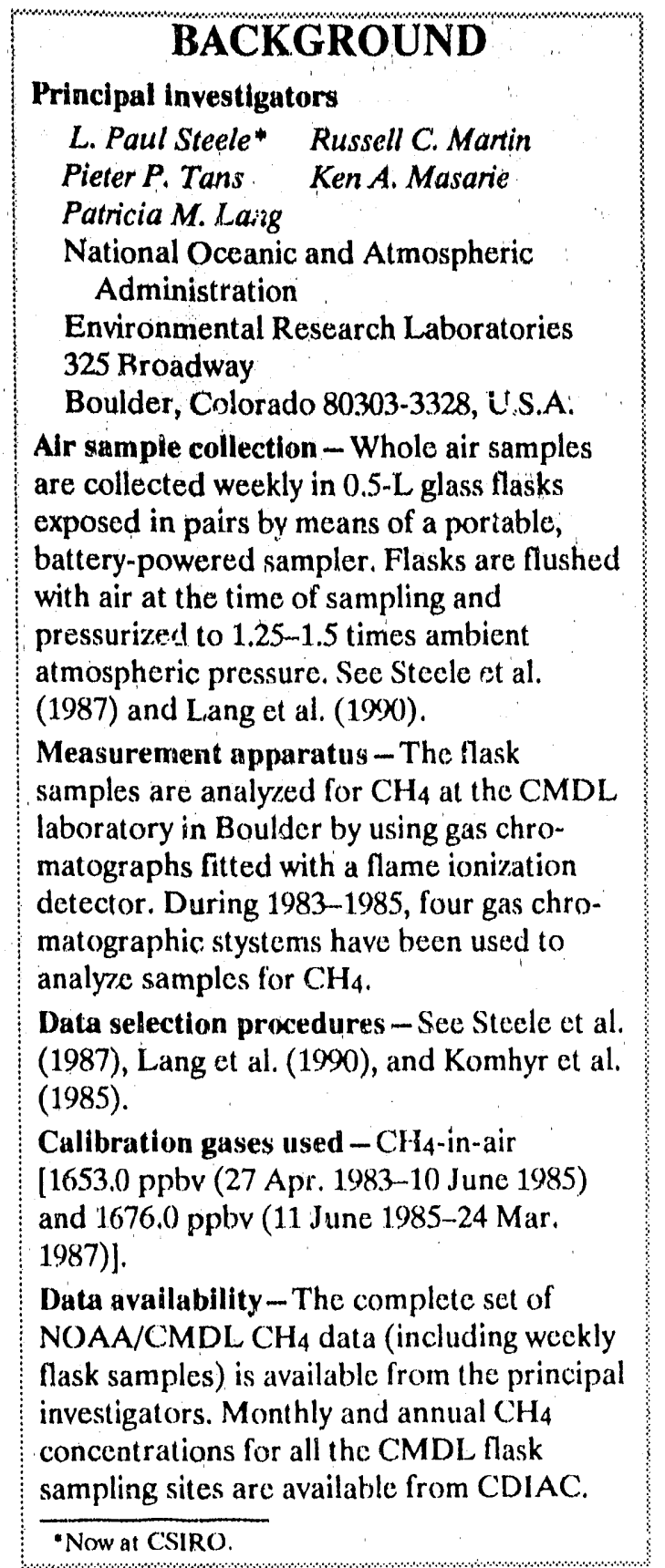

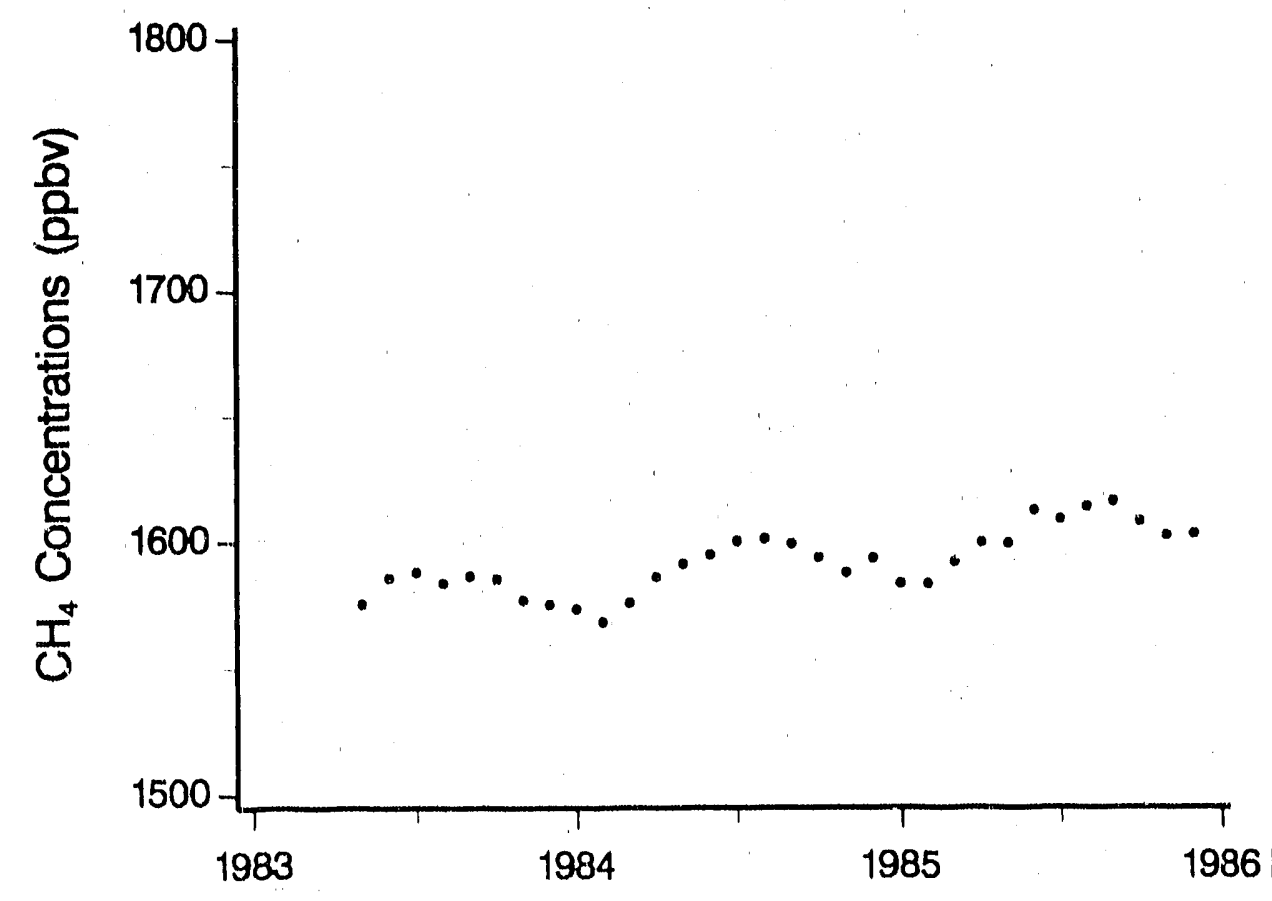

Monthly concentrations of atmospheric $\mathrm{CH}_{4}$.

Ascension Island United Kingdom

Island seashore $7^{\circ} 55^{\prime} S, 14^{\circ} 25^{\prime} \mathrm{W}$ $54 \mathrm{~m}$ above $M S L$ 


\section{TREND}

The sampling site on Ascension Island is operated in cooperation with the U.S. Air Force and Pan American World Airways.

The average annual $\mathrm{CH}_{4}$ concentration at Ascension Island rose from $1582.3 \mathrm{ppbv}$ in 1983 to $1601.9 \mathrm{ppbv}$ in 1985 . Stcele et al. (1987) calculated an average growth rate of 14.1 ppbv for Ascension Island by fitting a linear regression to 12 -month running means. With respect to latitude, this site is located between the sites at American Samoa and the Seychelles. According to Steelc et al. (1987), the $\mathrm{CH}_{4}$ concentration data from Ascension Island show a clear seasonal cycle, but the phase of the cycle is different from that observed at sites in mid and polar latitudes of the Southerr: Hemisphere. Stecle et al. (1987) also reported that this site does not appear to be influenced during any season by air originating north of the Intertropical Convergence Zone. 


\section{Ascension Island}

\section{Concentrations of Atmospheric Methane}

$\begin{array}{cccccccccccccc}\text { Year } & \text { Jan } & \text { Feb } & \text { Mar } & \text { Apr } & \text { May } & \text { Jun } & \text { Jul } & \text { Aug } & \text { Sept } & \text { Oct } & \text { Nov } & \text { Dec } & \text { Ann } \\ 1983 & & & & & 1575.6 & 1586.0 & 1588.2 & 1584.0 & 1586.7 & 1585.6 & 1577.2 & 1575.4 & 1582.3 \\ 1984 & 1573.6 & 1568.4 & 156.0 & 1586.2 & 1591.5 & 1595.0 & 1600.5 & 1601.5 & 1599.3 & 1593.9 & 1587.8 & 1593.6 & 1588.9 \\ 1985 & 1583.5 & 1583.4 & 1592.1 & 1599.6 & 1599.4 & 1612.4 & 1608.9 & 1613.9 & 1616.0 & 1607.9 & 1602.3 & 1603.0 & 1601.9\end{array}$

*Methane concentrations expressed in parts per billion by volume (ppbv). Monthly averages calculated as arithmetic means of individual flask concentrations that are indicative of hackground conditions. Annual averages based on monthly means.

\section{REITRENCH}

Frisse, P.J, M.A.K. Khalil, R.A

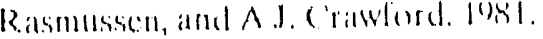

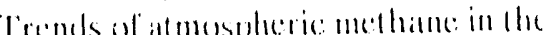

Southern Hemisphere (ienphlysical

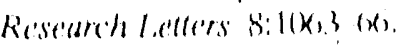

Frisiser, P.J., M.A.K. K.thitil, R.A

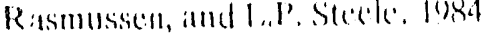

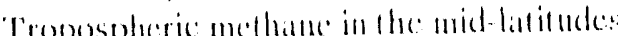

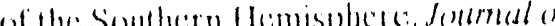

Almospherw: (chemistry 1:125 35.

Khalil, M.A.K., and R.A. Ratsmuss(n). I(x)).

Almospheric methane: recent plobal

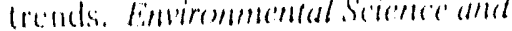

Ticholum 24.54) 53

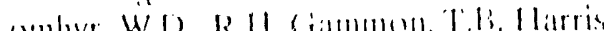

LS Watcman, T I. Comwity, W.R. Taylor

and K.W. Theming. less. (iluhal

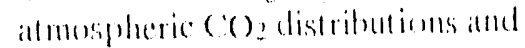

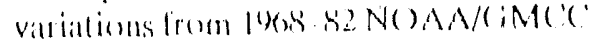

(C) flisk simple dials. Ioumal of

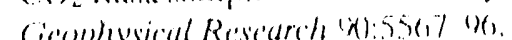

L.ang, P.M., L..P. Sterke, R.C. Martin, and

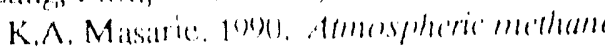

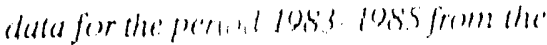

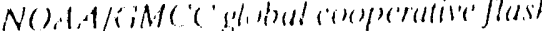

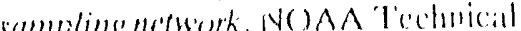
Memoriundum LIRI, ('MI) 1. 1. ('limbitc Monitoring and Didg!nestics latheratory, Boulder, colurado

Stede, L.P', P.I. Fraser, R.A. Rismussen,

MA.K Khalil, TJ Conwaty, A.J.

Cirawlord R

and K.W. Thening, 1987. The global

distribution of methane in the troposphere.

Joumal of Atmospheseric ('He'mistry 5:125-71. 


\section{Cape Grim}

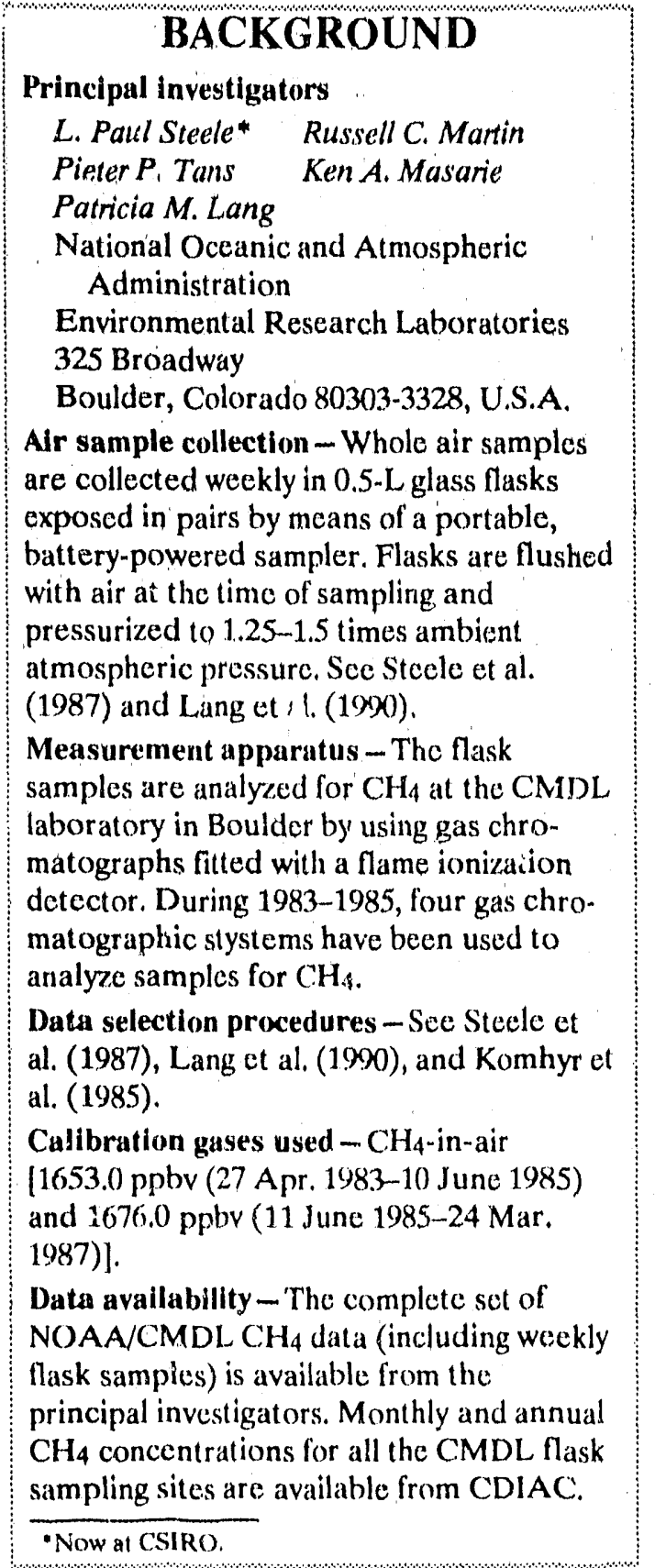

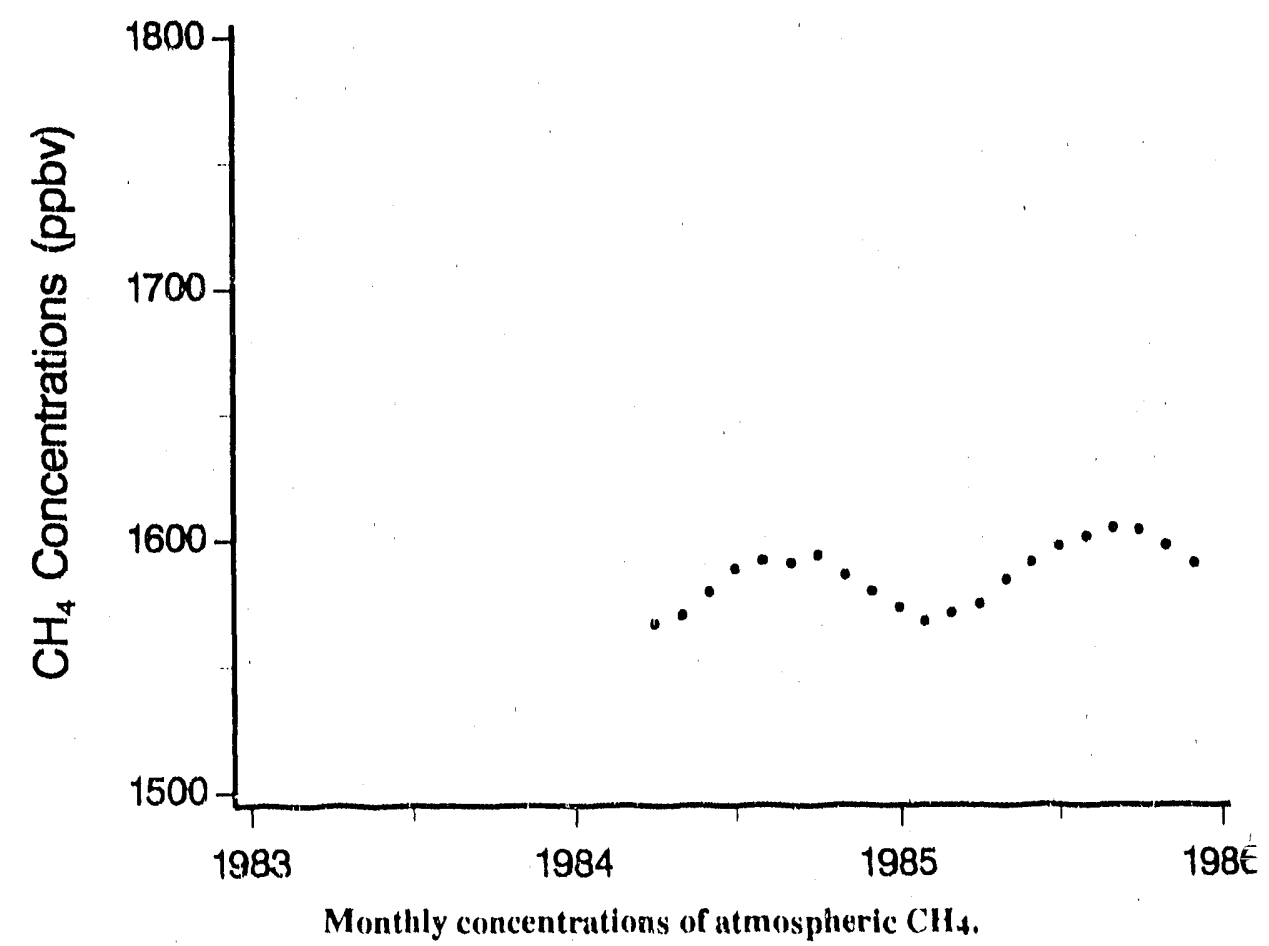

Cape Grim

Tasmania, Australia

Promontory seashore $40^{\circ} 41^{\prime} \mathrm{S}, 144^{\circ} 41^{\prime} \mathrm{E}$

$94 \mathrm{~m}$ above MSL 


\section{Atmospheric $\mathrm{CH}_{4}$}

\section{TREND}

The sampling site at Cape Grim, Tasmania, is operated in cooperation with the Commonwealth Scientific and Industrial Research Organization (CSIRO), which has been making $\mathrm{CH}_{4}$ measurements at Cape Grim since 1978. Fraser et al. (1986) reported an average growth rate of 18.2 ppby per year at Cape Grim for the 7-year period 1978-1984. NOAA/CMDL has been making $\mathrm{CH}_{4}$ measurements at Capo Grim since 1984. The NOAA/CMDL data show that the avrrage annual concentration at Cape Grim rose from 1583.1 ppbvin 1984 to 1588.1 in 1985.

The CH record from Cape Grim is comparable to those from other Southern Hemisphere sites. Fraser et al. (1986) found no significant difference in either tha: scasonal cycle or the long-term growth in concentration for $\mathrm{CSIRO} \mathrm{CH}_{4}$ measurements taken from flask samples collected at Cape Grim and Mawson, Antarclica, for the period 1980-1984. Steele et al. (1987) found that the NOAA/C.MDL $\mathrm{CH}_{4}$ data record from Cape Grim is remarkably similar to four of the five southernmost GMCC sites. The exception to this finding is the monitoring site at Kaitorete Spit, New Zealand. 


\section{Cape Grim}

Concentrations of Atmospheric Methane*

$\begin{array}{cccccccccccccc}\text { Year } & \text { Jan } & \text { Feb } & \text { Mar } & \text { Apr } & \text { May } & \text { Jun } & \text { Jul } & \text { Aug } & \text { Sept } & \text { Oct } & \text { Nov } & \text { Dec } & \text { Ann } \\ 1984 & & & & 1566.9 & 1570.3 & 1579.5 & 1588.8 & 1591.8 & 1591.1 & 1594.0 & 1585.9 & 1579.7 & 1583.1 \\ 1985 & 1573.2 & 1567.5 & 1570.9 & 1574.6 & 1584.2 & 1591.1 & 1597.4 & 1601.3 & 1604.4 & 1603.8 & 1597.6 & 1590.6 & 1588.1\end{array}$

*Methane concentrations expressed in parts per billion by volume (ppbv). Monthly averages calculated as arithmetic means of individual flask concentrations that are indicative of background conditions. Annual averages based on monthly means.

\section{RETERENCES}

Frasier, P.J, M.A.K. Khillil, R.A

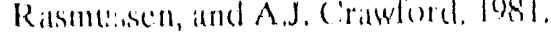
Trends of atmesphere ic methine in the Southern Hemisphere (imphissical

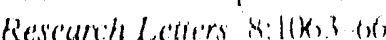

Friser, P.J., M.A.K. Khalil, R.A.

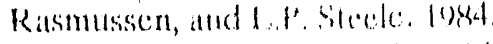

Iropespherice methatme in the mid latitudes

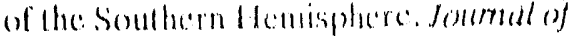

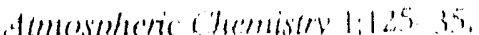

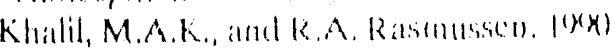

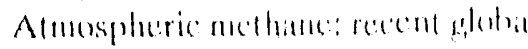

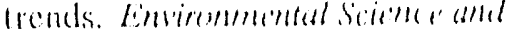

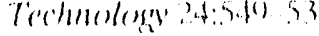

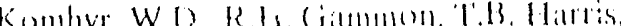

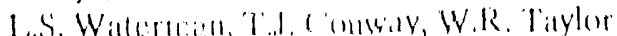

and K.W. Thuminge. lisis. (ilobal

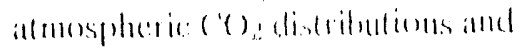

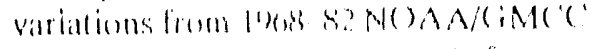

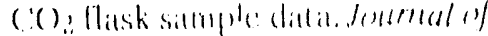

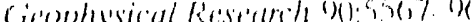

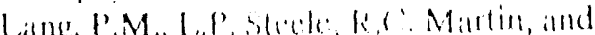

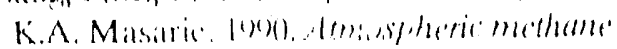

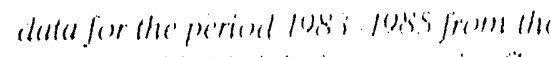

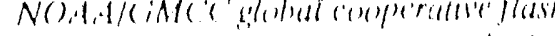

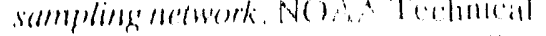

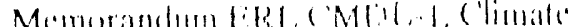

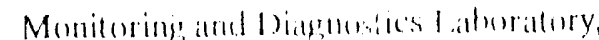
Boulder, Conturation.

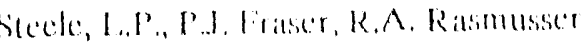
M.A.K. Khall, T.J Comwily, A.J

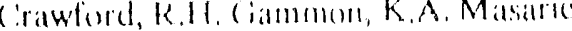

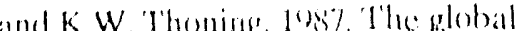

distritution of and thane in the eropespotere

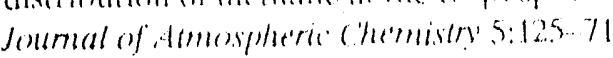




\section{Cape Kumukahi}

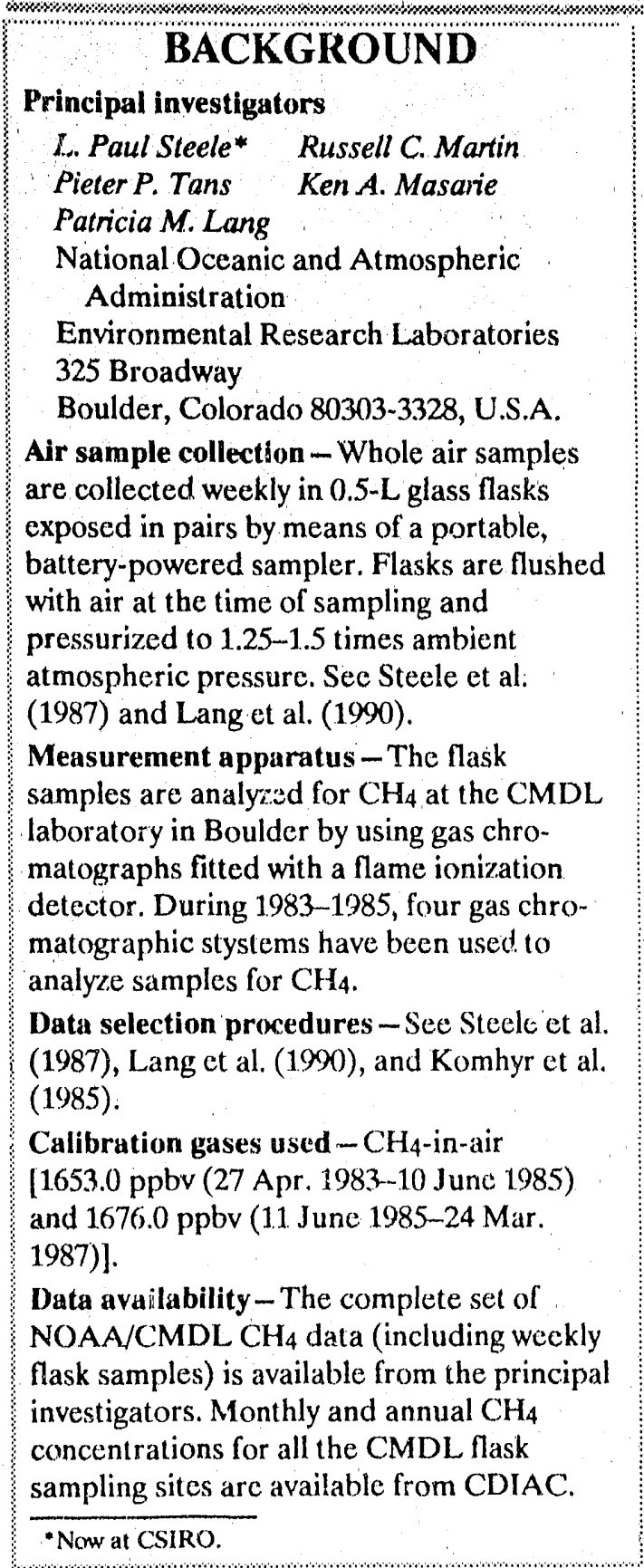

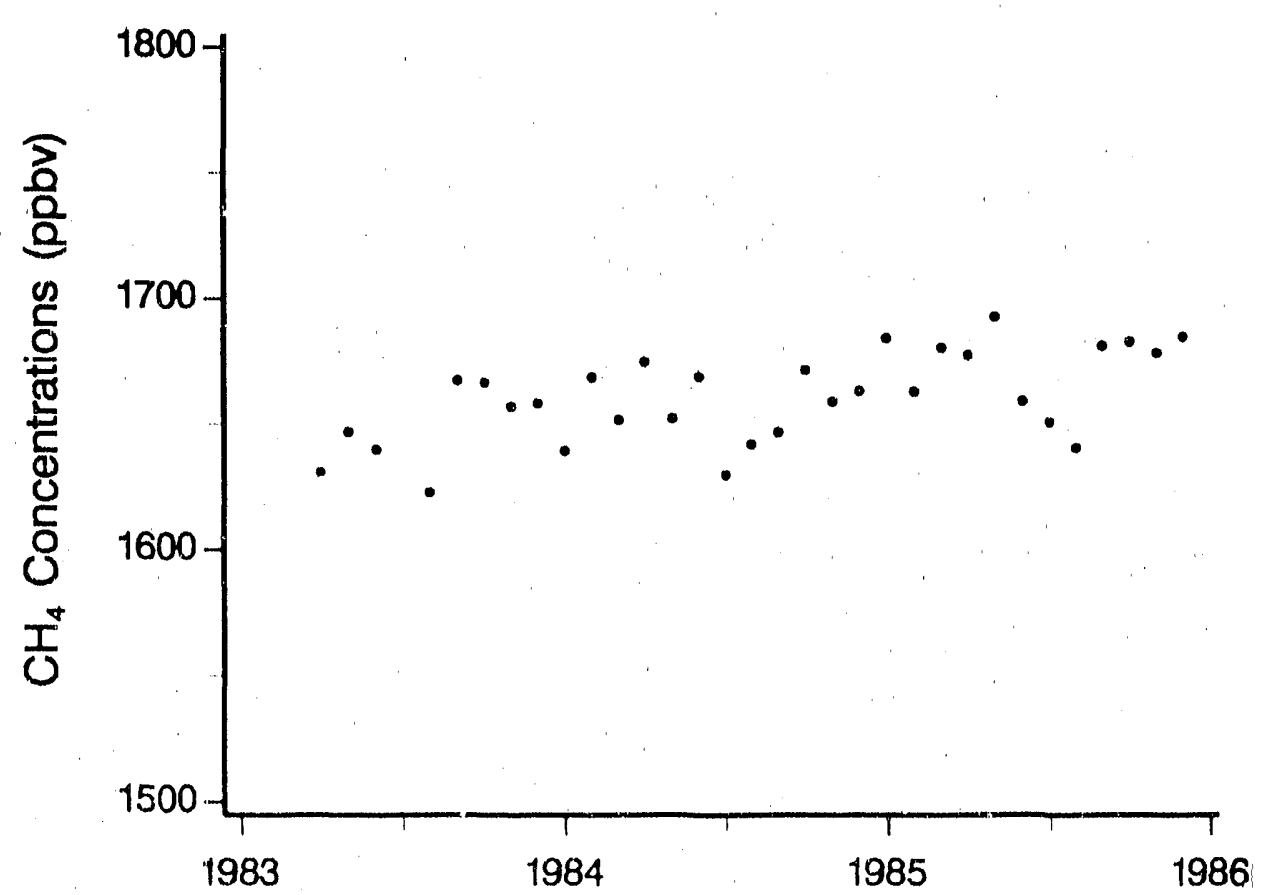

Cape Kumukahi

Hawaii, U.S.A.

Island seashore

$19^{\circ} 31^{\prime} \mathrm{N}, 154^{\circ} 49^{\prime} \mathrm{W}$

$3 \mathrm{~m}$ above $M S L$

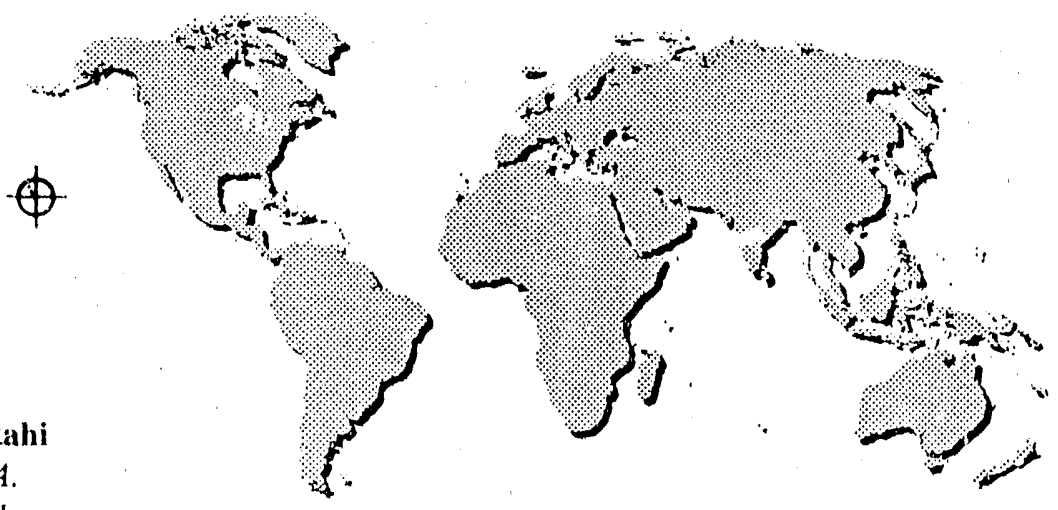




\section{Atmospheric $\mathrm{CH}_{4}$}

w

\section{TREND}

The average annual $\mathrm{CH}_{4}$ concentration from Cape Kumukahi, Hawaii, rose from $1648.6 \mathrm{ppbv}$ in 1983 to $1672.8 \mathrm{ppbv}$ in 1985. Steele et al. (1987) fitted a linear regression to the 12-month running means from Cape Kumukahi and calculated an average annual growth rate of $7.9 \mathrm{ppbv}$. Steele et al. (1987) also compared the $\mathrm{CH}_{4}$ data from $\mathrm{Cupe}$ Kumukahi with those from Mauna Loa and found a significant vertical gradient in $\mathrm{CH}_{4}$ concentration, with the long-term average concentrations from Mauna Loa being lower than those at Cape Kumukahi. Steele et al. (1987) found that (1) both sites exhibited a major scasonal minimum in the northern summer of 1984 (2) that the fitted cubic spline functions for both sites show evidence that two minimums and two maximums occur each year at times consistent with those reported by Khalil and Rasmussen (1983). 


\section{Cape Kumukahi}

\section{Concentrations of Atmospheric Methane*}

$\begin{array}{cccccccccccccc}\text { Year } & \text { Jan } & \text { Feb } & \text { Mar } & \text { Apr } & \text { May } & \text { Jun } & \text { Jul } & \text { Aug } & \text { Sept } & \text { Oct } & \text { Nov } & \text { Dec } & \text { Ann } \\ 1983 & & & & 1630.9 & 1647.0 & 1640.0 & & 1623.0 & 1667.5 & 1666.6 & 1657.2 & 1658.4 & 1648.6 \\ 1984 & 1639.5 & 1668.7 & 1651.9 & 1674.9 & 16.3 & 1669.0 & 1630.0 & 1642.0 & 1646.7 & 1671.5 & 1658.8 & 1663.1 & 1655.7 \\ 1985 & 1684.2 & 1662.9 & 1680.3 & 1677.3 & 1692.5 & 1658.9 & 1650.7 & 1640.4 & 1680.9 & 1682.5 & 1678.1 & 1684.5 & 1672.8\end{array}$

*Methane concentrations expressed in parts per billion by volume (ppbv). Monthly averages calculated as arithmetic means of individual flask concentrations that are indicative of background conditions. Annual averages based on monthly means.

\section{REFERENCES}

Fraser, P.J., M.A.K Khalil, R.A. Rasmussen, and A.J. Crawford. 1981. Trends of atmospherie methane in the Southern Hemisphere. Geophysical Research Letters 8:1(K,3-(k).

Fraser, P.J., M.A.K. Khalil, R.A.

Rasmussen, and L.P. Stecle. 1984.

Tropospheric netharie in the mid-latitudes

of the Southern Hemisphere. Journal of Atmospheric Chemisty 1:125 35 .

Khalil, M.A.K., and R.A. Rasmussen. 1983.

Sources, sinks, and seasonal cycles of

at mospheric methane. Joumal of

(icophysical Rescurch 88:39)13 18.

Khalil, M.A.K. and R.A. Rasimussen. $(\%)$

Almospheric methims: recent globial

tronds. Eisvirommental Sicience d

Technology 2.4:54') 53.

Kombyr W.D. R.H. (Bammon, T.B. Harris, L.S. Watcrman, T.J Conway, W.R. Taylor,

and K.W. Thoning. 1945. (ilohal

at mospheric $\mathrm{CO}_{2}$ distributions and variations from 1968 S $82 \mathrm{NO}$ A A / BMCC

$\mathrm{CO}_{2}$ flask sample dat a. Joumal of Cicophysical Research (x):55(77. 1)6.

Lang, P.M. L.P. Stcele, R.C. Martin, and

K.A. Masaric 1(Wא). A(mospheric methane data for the period 1983.1985 from the NOAA/CiMC'C global coopcrative flask sampling network. N(OAA Technical

Memorandum ERL ( MDL-1. Climate

Monitoring and Diagnostics Laboratory,

Boulder, Colorado.

Steele, L.P., P.J. Fraser, R.A Rasmussen,

M.A.K. Khalil, ' $\Gamma J$. Conway, A.J

Crawford, R.H. Gammon, K.A. Masarie,

and KW Thoning. 1987. The global

distribution of methane in the troposphere.

Joumal of Atmospheric Chemistry 5:125-71. 


\section{Cape Meares}

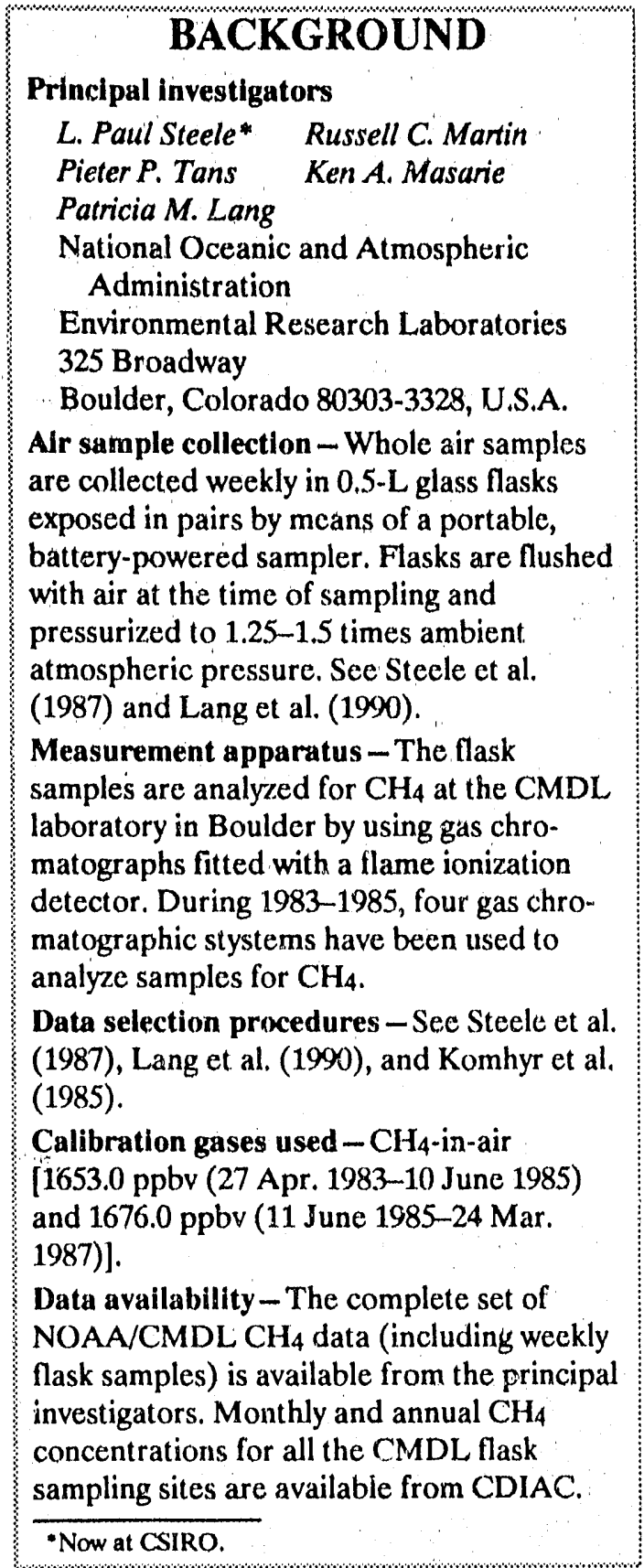

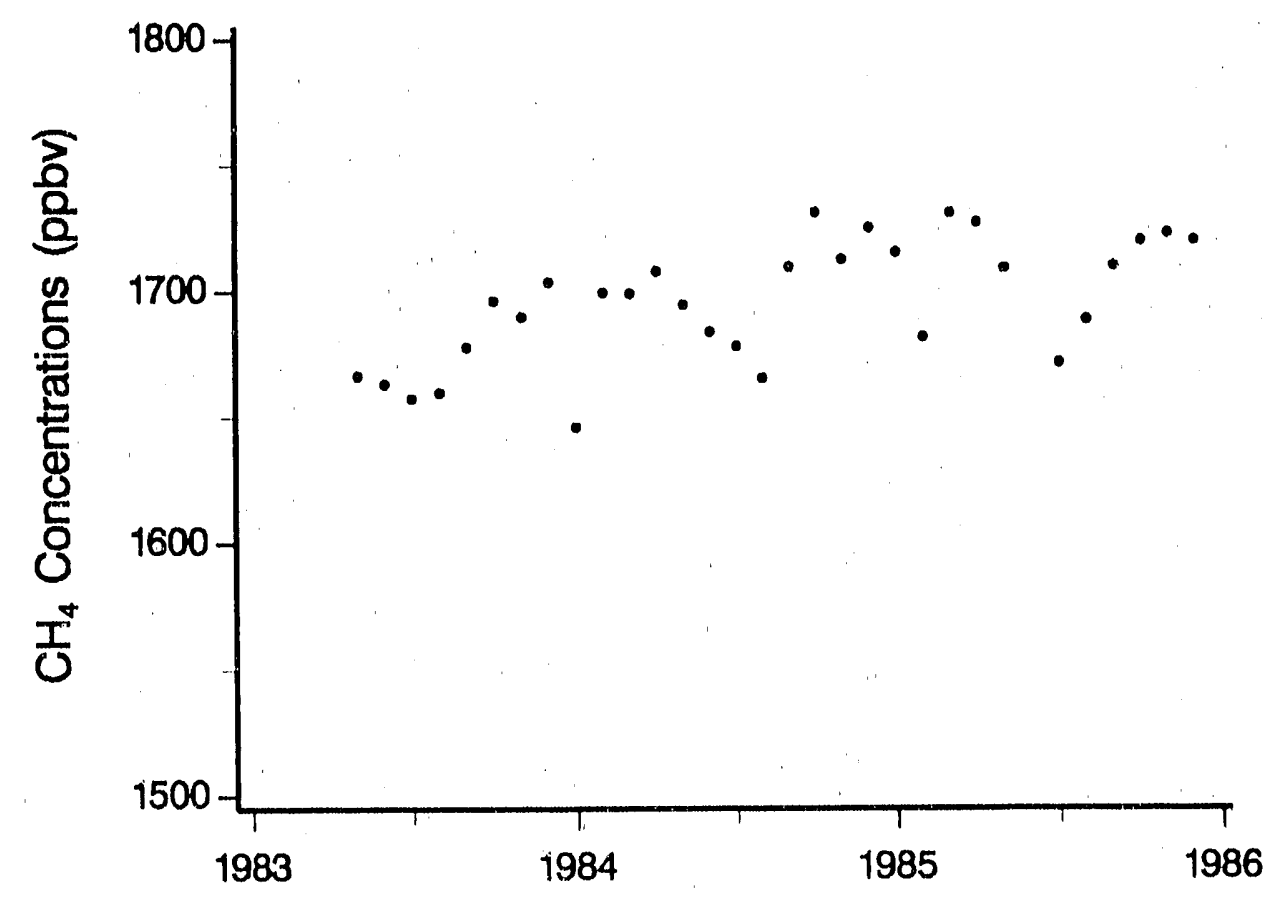

Monthly concentrations of atmospheric $\mathrm{CH}_{4}$.

Cape Meares

Oregon, U.S.A.

Promontory seashore

$45^{\circ} 00^{\prime} \mathrm{N}, 124^{\circ} 00^{\prime} \mathrm{W}$

$30 \mathrm{~m}$ above $\mathrm{MSL}$ 


\section{Atmospheric $\mathrm{CH}_{4}$}

\section{TREND}

The sampling site at Cape Meares, Oregon, is operated in cooperation with the Oregon Graduate Institute of Science and Technology. The annual average concentration of $\mathrm{CH}_{4}$ at Cape Meares rose from 1676.7 ppbv in 1983 to $1708.3 \mathrm{ppbv}$ in 1985. Steele et al. (1987) reported an annual average growth rate of $24.8 \mathrm{ppbv}$ for Cape Meares, which was calculated by fitting a linear regression to 12-month running mean values. Khalil and Rasmussen (1983), on the basis of in situ measurements of $\mathrm{CH}_{4}$ over a 3-year period at Cape Meares, found that 2 minimums and 2 maximums may occur each year, with the major minimum in the northern summer and the maximum concentrations in spring and fall. Steelo et al. (1987) reported that all five of the northernmost CMDL stations, including Cape Meares, exhibited major seasonal minimums during the northern summer. of both 1983 and 1984. 


\section{Cape Meares}

Concentrations of Atmospheric Methane*

$\begin{array}{cccccccccccccc}\text { Year } & \text { Jan } & \text { Feb } & \text { Mar } & \text { Apr } & \text { May } & \text { Jun } & \text { Jul } & \text { Aug } & \text { Sept } & \text { Oct } & \text { Nov } & \text { Dec } & \text { Anı } \\ 1983 & & & & & 1666.4 & 1663.2 & 1657.4 & 1659.7 & 1677.7 & 1696.1 & 1689.7 & 1703.5 & 1676.7 \\ 1984 & 1646.0 & 1699.3 & 1698.9 & 1707.8 & 1694.5 & 1683.7 & 1678.0 & 1665.3 & 1709.3 & 1730.9 & 1712.3 & 1724.8 & 1695.9 \\ 1985 & 1715.1 & 1681.4 & 1730.5 & 1726.7 & 1708.5 & & 1671.0 & 1688.1 & 1709.3 & 1719.3 & 1722.3 & 1719.5 & 1708.3\end{array}$

* Methane concentrations expressed in parts per billion by volume (ppbv). Monthly averages calculated as arithmetic means of individual flask concentrations that are indicative of background conditions. Annual averages based on monthly means.

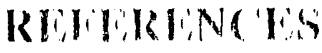

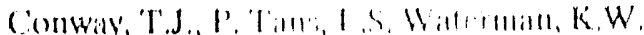

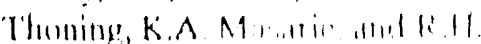

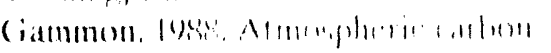

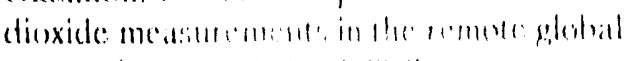

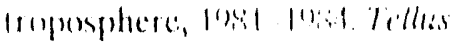

4113:81..113

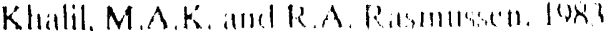

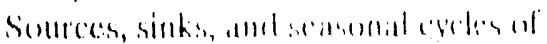

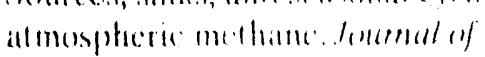

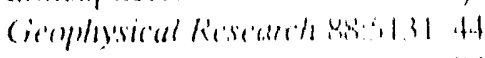

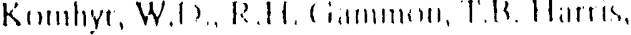

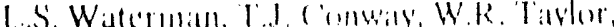

and k.W. Thonime lome dital al

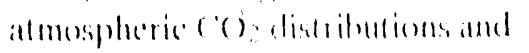

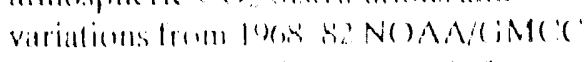

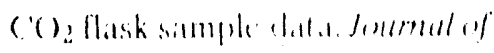

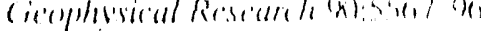

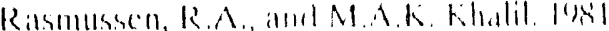

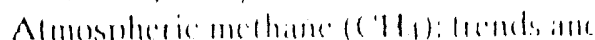

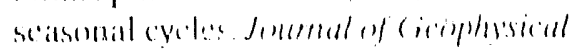

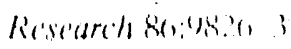

Ratimussen, R.A., and M A.R. Khalil. MRit.

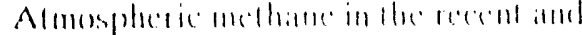

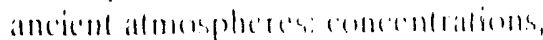

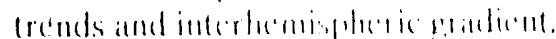

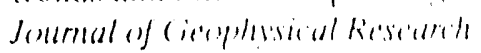

s(y:11s(x) (x).

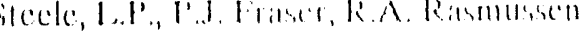

M.A.K. Khatil, T.J. 'omwily, A.I

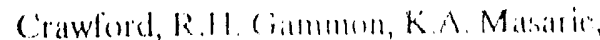

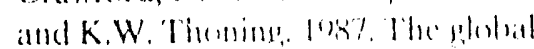

distribution of me thatne in the trepesphere

Jomental of atmospheric ( hemusisy $5: 12571$ 


\section{Christmas Island}

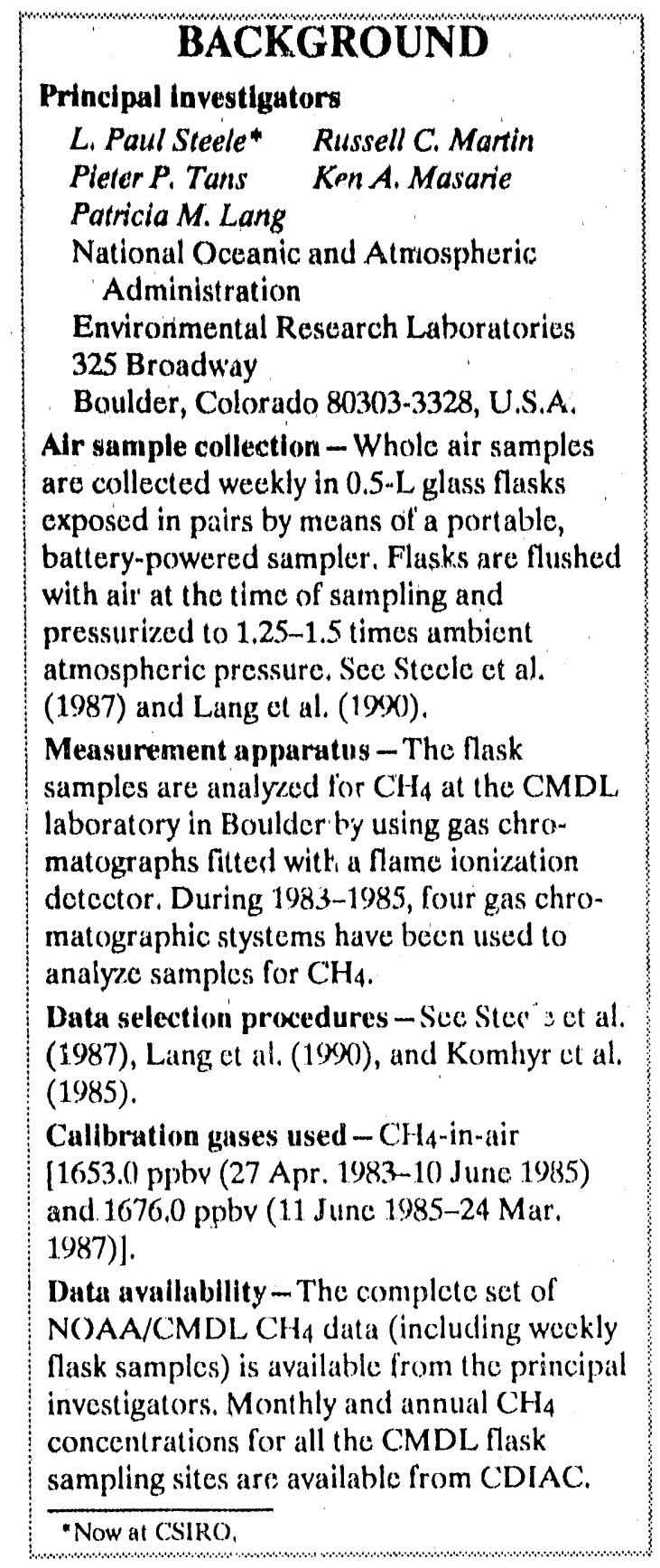

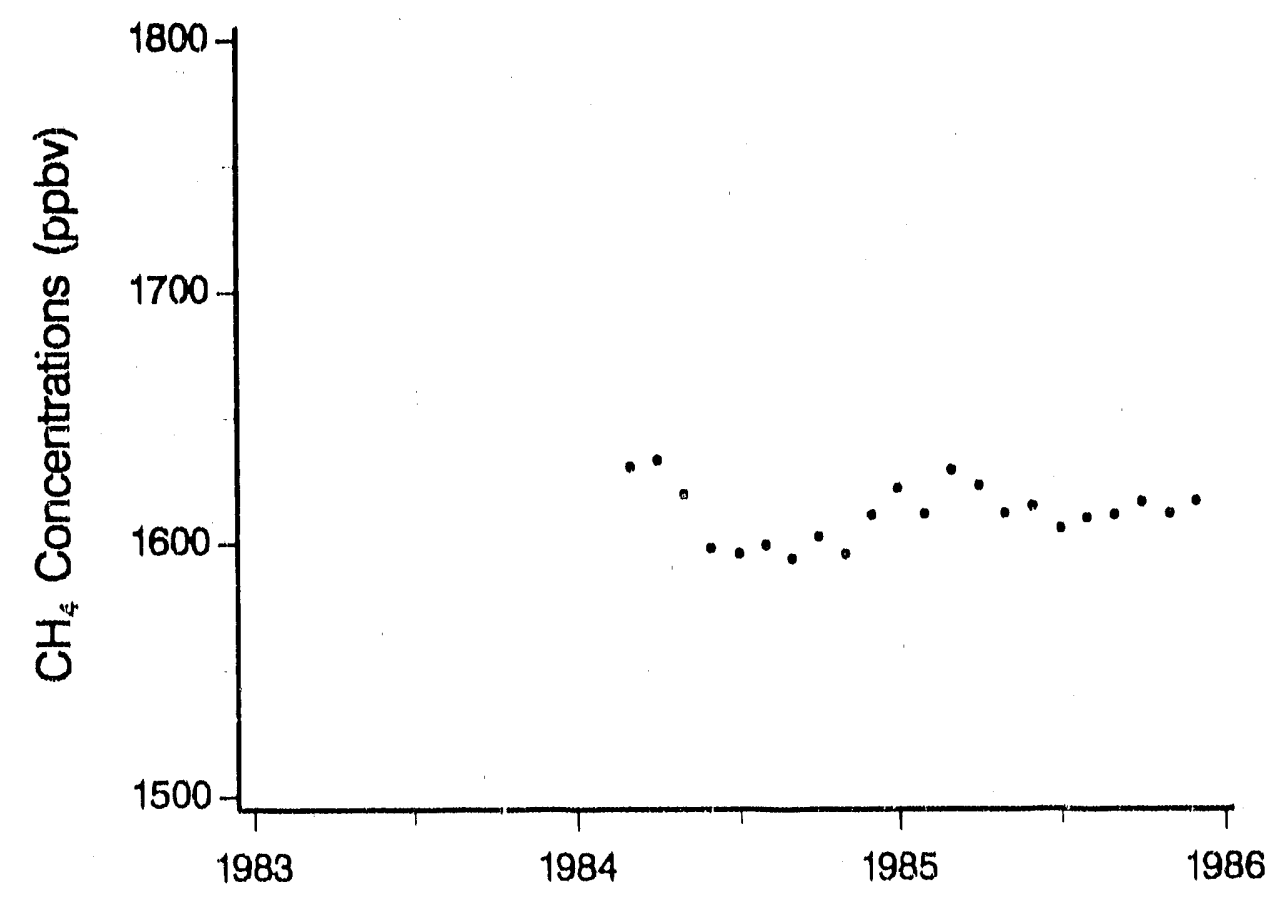

Monthly concentrations of atmospheric $\mathrm{CH}_{4}$.

Christmas Island Kiribati

Island seashore $2^{\circ} 00^{\prime} \mathrm{N}, 157^{\circ} 19^{\prime} \mathrm{W}$ $3 \mathrm{~m}$ above MSL 


\section{TREND}

The sampling site at Christmas Island is operated in cooperation with Scripps Institution of Oceanography. The annual average concentration of $\mathrm{CH}_{4}$ at Christmas Island rose from $16(07.9$ ppbv in 1984 to 1615.2 ppov in 1985. Becaltse of the climatology of the convergence zone of surface winds in the central Pacific Ocean, atmospheric $\mathrm{CH}_{4}$ concentrations from Christmas Island should be typical of those found in southern tropical latitudes. Stecle et al. (1987) reported that the $\mathrm{CH}_{4}$ concentrations from Christmas Island during the austral ninter and spring of 1984 were strongly consistent with measurements made at similar times al several locations in the Southern Hemisphere. The elevated concentrations during March and April 1984 were alnost certianly caused by the influence of air from north of the Intertropical convergence Zone, and the elevated concentrations in the first few months of 1985 may be caused by the southward movement of the convergence zone or by an irregular intrusion of northern air (Stecle et al. 1987). 


\section{Christmas Island}

Concentrations of Atmospheric Methane*

$\begin{array}{cccccccccccccc}\text { Year } & \text { Jan } & \text { Feb } & \text { Mar } & \text { Apr } & \text { May } & \text { Jun } & \text { Jul } & \text { Aug } & \text { Sept } & \text { Oct } & \text { Nov } & \text { Dec } & \text { Ann } \\ 1984 & & & 1630.3 & 1633.0 & 1619.4 & 1598.1 & 1595.9 & 1599.3 & 1594.0 & 1602.6 & 1595.7 & 1611.1 & 1607.9 \\ 1985 & 1621.6 & 1611.5 & 1628.8 & 1622.7 & 1611.8 & 1614.5 & 1605.7 & 1699.9 & 1611.1 & 1616.2 & 1611.6 & 1616.6 & 1615.2\end{array}$

"Methane concentrations expressed in parts per billion by volume (ppbv). Monthly averages calculated as arithmetic means of individual flask concentrations that are indicative of background conditions. Annual averages based on monthly means.

\section{RLILRLNCHS}

Litithe, l'.J., M.A.k. Kihalil, K.A.

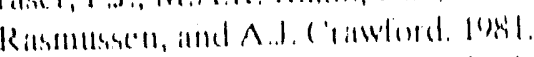

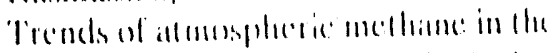

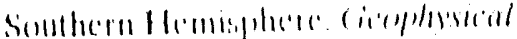

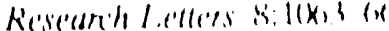

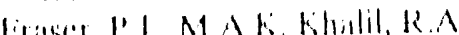

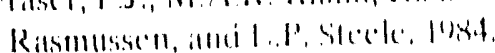

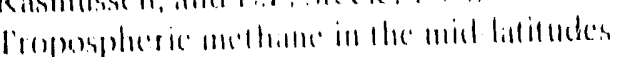

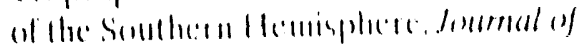

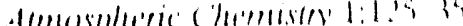

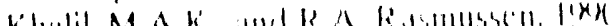

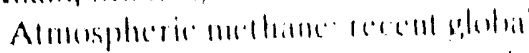

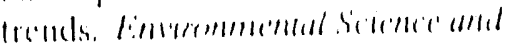

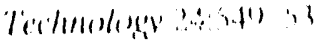

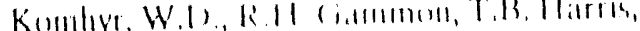

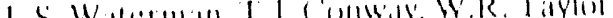

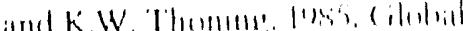

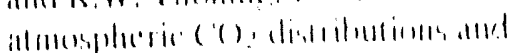

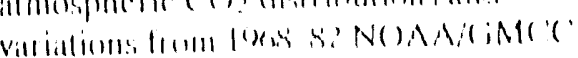

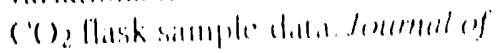

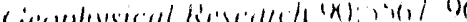

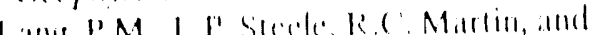

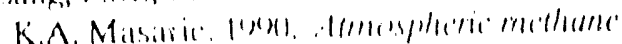

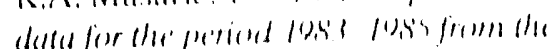

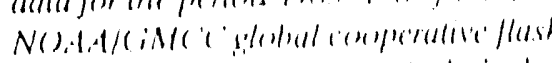

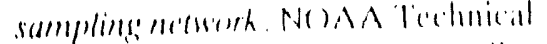

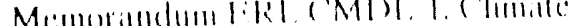

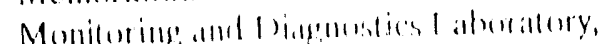
Boulder, colmonder.

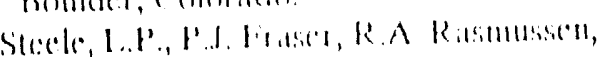
M.A.K. Khatil, T.J. (')IIW'ly, A.J

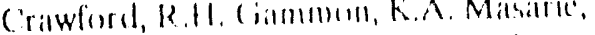

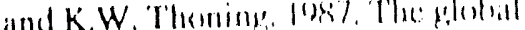

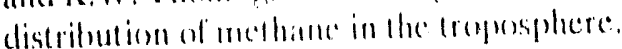

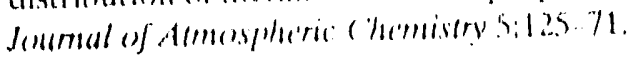




\section{Cold Bay}

\section{BACKGROUND \\ Principal Investigators \\ L. Paul Steele* Russell C. Martin \\ Pieter P. Tans Ken A. Massanie \\ Patricia M. Lang \\ National Oceanic and Atmospheric Administration \\ Environmental Research Laboratories 325 Broadway \\ Boulder, Colorado 80303-3328, U.S.A.}

Air sumple collection - Whole air samples are collected weekly in $0.5 \mathrm{~L}$ glass flasks exposed in pairs by means of a portable, battery-powered sampler. Flasks are flushed with air at the time of sampling and pressurized to 1.25-1.5 times ambiont atmospheric pressure. Sec Stecle et al. (1987) and Lang et al. (1990).

Measurement apparatus - The flask samples are analyzed for $\mathrm{CH}_{4}$ at the $\mathrm{CMDL}$ laboratory in Boulder by using gas chro" matographs fitted with a flame ionization detector. During 1983-1985, four gas chromatographic stystems have been used to analyze samples for $\mathrm{CH}_{4}$.

Data selection procedures - See Stecle et al. (1987), Lang et al. (1990), and Komhyr et al. (1985).

Calibration gases used $-\mathrm{CH}_{4}$-in-air [1653.0 ppbv (27 Apr. 1983-10 June 1985) and 1676.0 ppbv (11 Junc 1985-24 Mar. 1987)].

Data availability - The complete set of NOAA/CMDL CH 4 data (including weekly flask samples) is available from the principal investigators. Monthly and annual $\mathrm{CH}_{4}$ concentrations for all the CMDL flask sampling sites are available from CDIAC.

- Now at CSIRO.

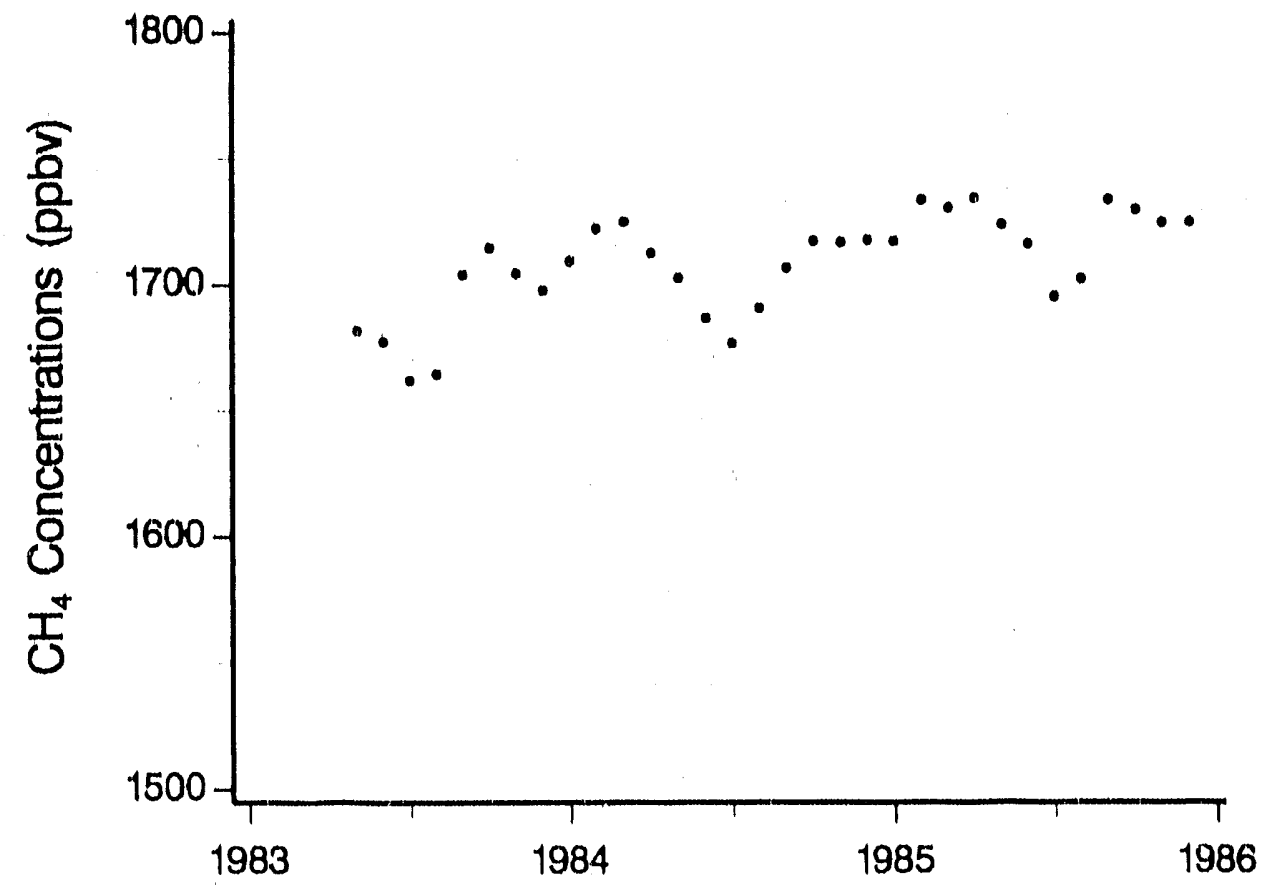

Monthly concentrations of atmospheric $\mathrm{CH}_{4}$.

Cold Bay

Alaska, U.S.A.

Treeless' peninsula

$55^{\circ} 12^{\prime} \mathrm{N}, 162^{\circ} 43^{\prime} \mathrm{W}$

$25 \mathrm{~m}$ above $M S L$ 


\section{Atmospheric $\mathrm{CH}_{4}$}

\section{TREND}

The sampling site at Cold Bay, Alaska, is operated in cooperation with the National Weather Service. The average annual $\mathrm{CH}_{4}$ concentration at Cold Bay rose from 1688.3 ppbv in 1983 10 1721.9 ppbv in 1985. Steele et al. (1987) reported the average annual growth rate for Cold Bay to be 13.0 ppbv. Steele et al. (1987) also found that the $\mathrm{CH}_{4}$ data from the five northernmost CDML sites, including Cold Bay, exhibited major seasonal minimums during the northern summers of both 1983 and 1984. Secondary minimums were also apparent but not as well defined. 
Concentrations of Atmospheric Methane

\begin{tabular}{|c|c|c|c|c|c|c|c|c|c|c|c|c|c|}
\hline Year & Jan & Feb & Mar & Apr & May & Jun & Jul & Aug & Sept & Oct & Nov & Dec & Ann \\
\hline 1983 & & & & & 1681.7 & 1677.5 & 1662.0 & 1664.5 & 1704.0 & 1714.7 . & 1704,5 & 1697.8 & \\
\hline 1984 & 1709.5 & 1722.3 & 1725.0 & 1712.5 & 1702.7 & 1686.6 & 1676.7 & 1690.6 & 1706.5 & 1717.2 & 1716.7 & 1717.7 & \\
\hline 1985 & 1717.1 & 1733.4 & 1730.3 & 1734.2 & 1723.5 & 1715.8 & 1695.0 & $1701: 9$ & 1733.4 & 1729.4 & 1724.4 & 1724.5 & \\
\hline
\end{tabular}

* Methane concentrations expressed in parts per billion by volume (ppbv). Monthly averages calculated as arithmetic means of individual flask concentrations that are indicative of background conditions. Annual averages based on monthly means.

\section{REFERENCES}

Fraser, P.J., M.A.K. Khalil, R.A Rasmussen, and A.J. Crawford. 1981. Trends of atmospheric methane in the

Southern Hemisphere. Geophysical

Reseurch Letters 8:1(K),3-60.

Fraser, P.J., M.A.K. Khalil, R.A

Rasmussen, and L.P. Steelc. 1984

Tropospheric methane in the mid-latitudes of the Southern Hemisphere. Joumal of Atmospheric Chemistry 1:125-35.

Khalil, M.A.K., and R.A. Rasnussen. 19(x).

Atmospheric methane: recent global

trends. Environmental Science and Technology 24:549-53.

Komhyr, W.D., R.H. ( Gammon, T.B. Harris, L.S. Waterman, T.J. Conway, W.R. Taylor, and K.W. Thoning. 1's S5. (ilobal atmospheric $\mathrm{CO}_{2}$ distributions and varialions from 1)6 \&2 NOAA/( IMC COn flask sample data. Journal of (implyasical Researth (x):5.567 () .

Lang, P.M., L.P. Stede, R.C.. Martin, and K.A. Masarie. 19x). Atmospheric methane duis for the periol 1983-1085 from the NOAA/CiMCC yllobal cooperative flask sampling network. NOAA Technical Memorandum ERL (MDL 1. ('limate Monitoring and Diagnostics, Lathoratory, Boulder, Colorado.

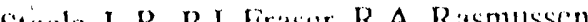

M.A.K. Khalil, Y.J. Conway, A.J.

Crawford, R.H. Gammon, K.A. Masarie, and K.W. Thoning. 1987. The global

distribution of methane in the Iroposphere.

Journal of Amospheric Chemistry 5:125..71. 


\section{Halley Bay}

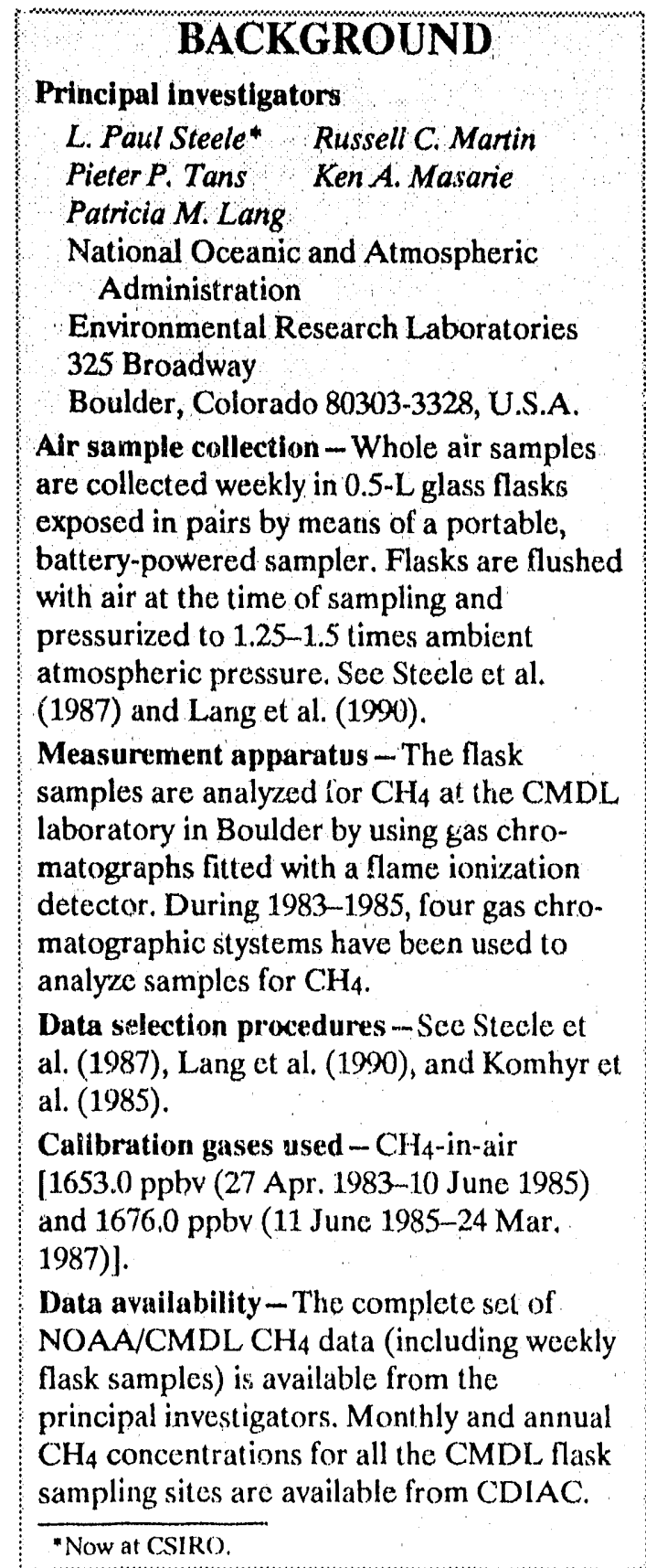

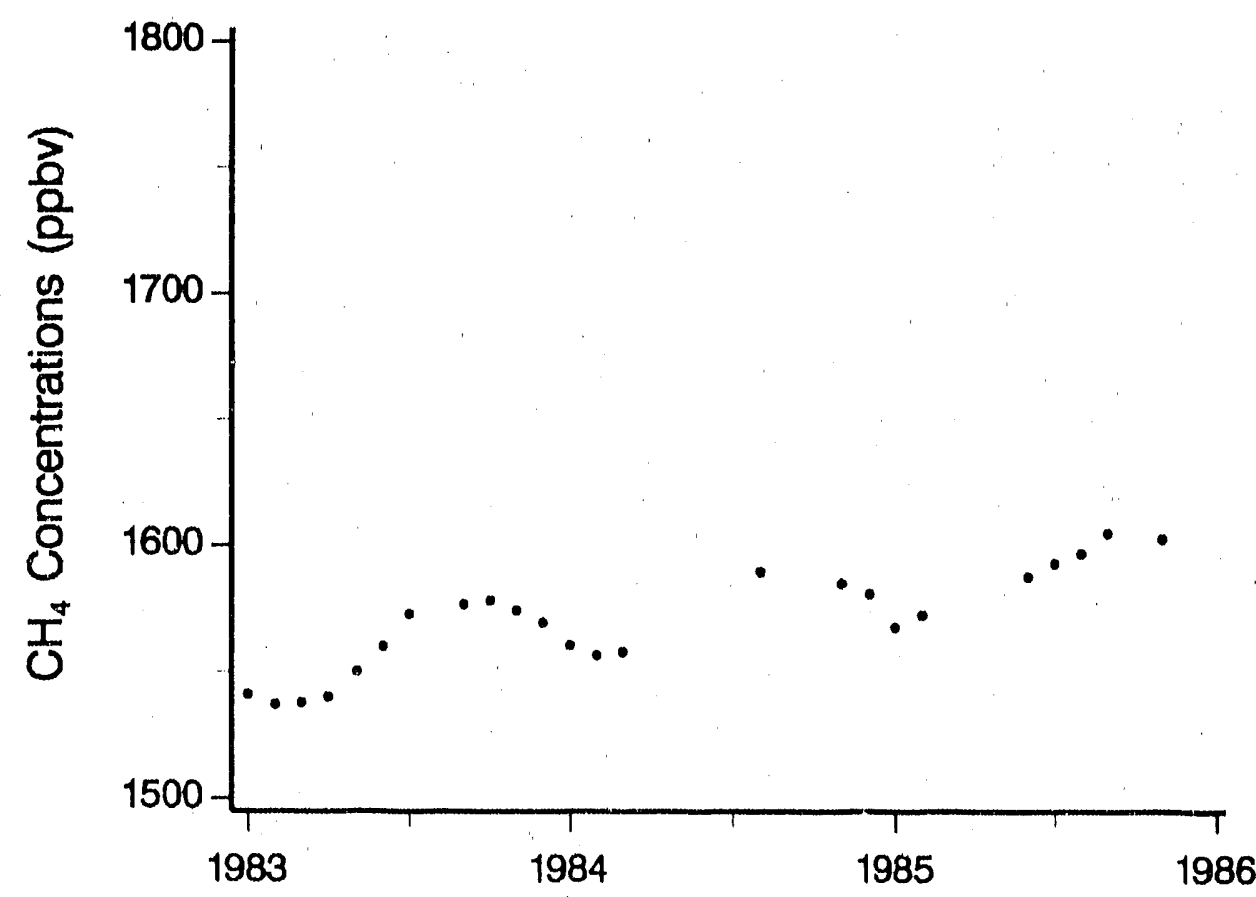

Monthly concentrations of atmospheric $\mathrm{CH}_{4}$.
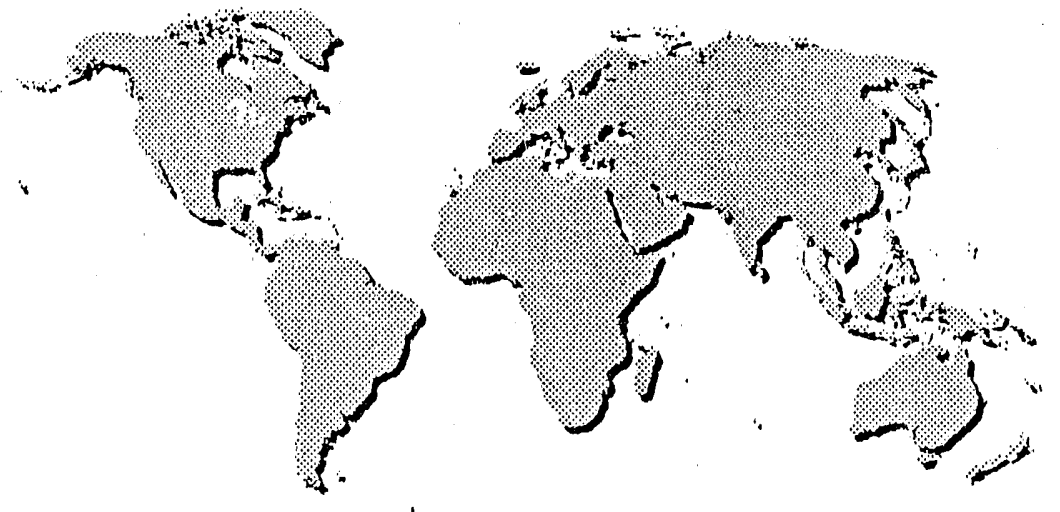

Halley Bay

Antarctica

Barren seashore $75^{\circ} 40^{\prime} \mathrm{S}, 25^{\circ} 30^{\prime} \mathrm{W}$ $3 \mathrm{~m}$ above $M S L$ 


\section{TREND}

The sampling site at Halley Bay is operated in cooperation with the British Antarctic Survey. The average annual $\mathrm{CH}_{4}$ concentration at Halley Bay rose from 1558.1 ppbv in 1983 to 1589.3 ppbv in 1985. Steele et al. (1987) reported the $\mathrm{CH}_{4}$ data from Halley Bay were similar to the data from the other CMDL sites in the Southern Hemisphere, except for Kaitorete Spit, New Zealand. Furthermore, the $\mathrm{CH}_{4}$ data from Halley Bay exhibit the same phase and amplitude of the seasonal cycle observed at the other Southern Hemisphere sites. 


\section{Halley Bay}

Concentrations of Atmospheric Methane*

$\begin{array}{cccccccccccccc}\text { Year } & \text { Jan } & \text { Feb } & \text { Mar } & \text { Apr } & \text { May } & \text { Jun } & \text { Jul } & \text { Aug } & \text { Sept } & \text { Oct } & \text { Nov } & \text { Dec } & \text { Ann } \\ 1983 & 1541.1 & 1537.2 & 1537.9 & 1540.2 & 1550.2 & 1560.2 & 1573.1 & & 1576.8 & 1578.4 & 1574.4 & 1569.6 & 1558.1 \\ 1984 & 1560.7 & 1556.7 & 1558.0 & & & & & 1589.7 & & & 1585.0 & 1580.9 & 1571.8 \\ 1985 & 1567.7 & 1572.5 & & & & 1587.7 & 1592.9 & 1596.7 & 1604.9 & & 1602.6 & & 1589.3\end{array}$

*Methane concentrations expressed in parts per billion by volume (ppbv). Monthly averages calculated as arithmetic means of individual flask concentrations that are indicative of background conditions. Annual averages based on monthly means.

\section{Armospheric CH4}

\section{RLIERENCHS}

Fraser, P.J., M.A.K. Khalil, R.A

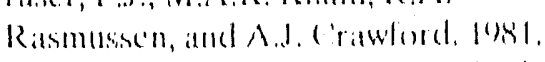

Trends of atmo:phleric methine in the

Southern Hemisphere. (ior)physical

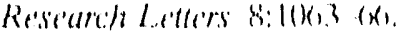

Friser, P. MAK Khalil, R.A

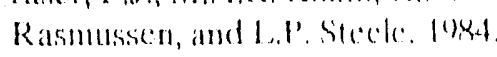

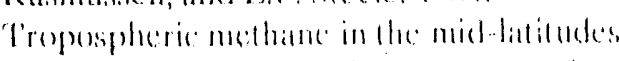

of the Southern Hemisphere. Solumal of

Almospheric (hemiston 1:125 35

Khalit, M.A.K. and R.A. Rasmussen, f(rk).

Almospheric methame:; Hecoul p!lubal

trends. Emirommentul Sirtenterend

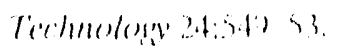

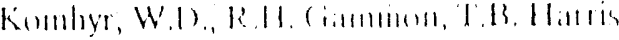

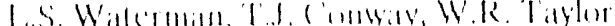

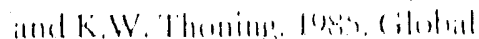

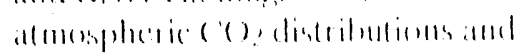

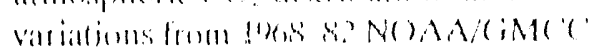

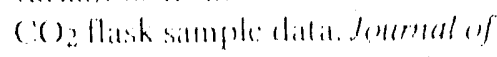

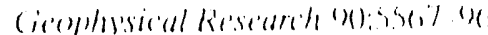

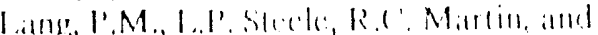

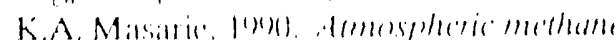

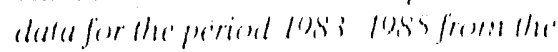

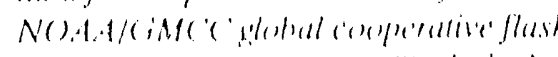

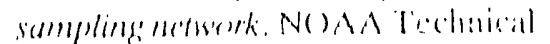

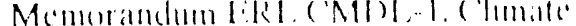
Monituring and biangusties laboratury

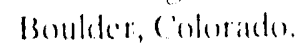

Stecte, I.P., P.J. Fritser, R.A. Rasmusisen, M.A.K. Khallil, 'T.J. Conwaly, A.I

Crawford, R.H. Cianmmon, K.A. Malsitric, and K.W. Thoning. 1's'7. The gotohal

distribution of me thane in the tropesphere Joumal of Atmospheric Che'mistry 5:125-71. 


\section{Key Biscayne}

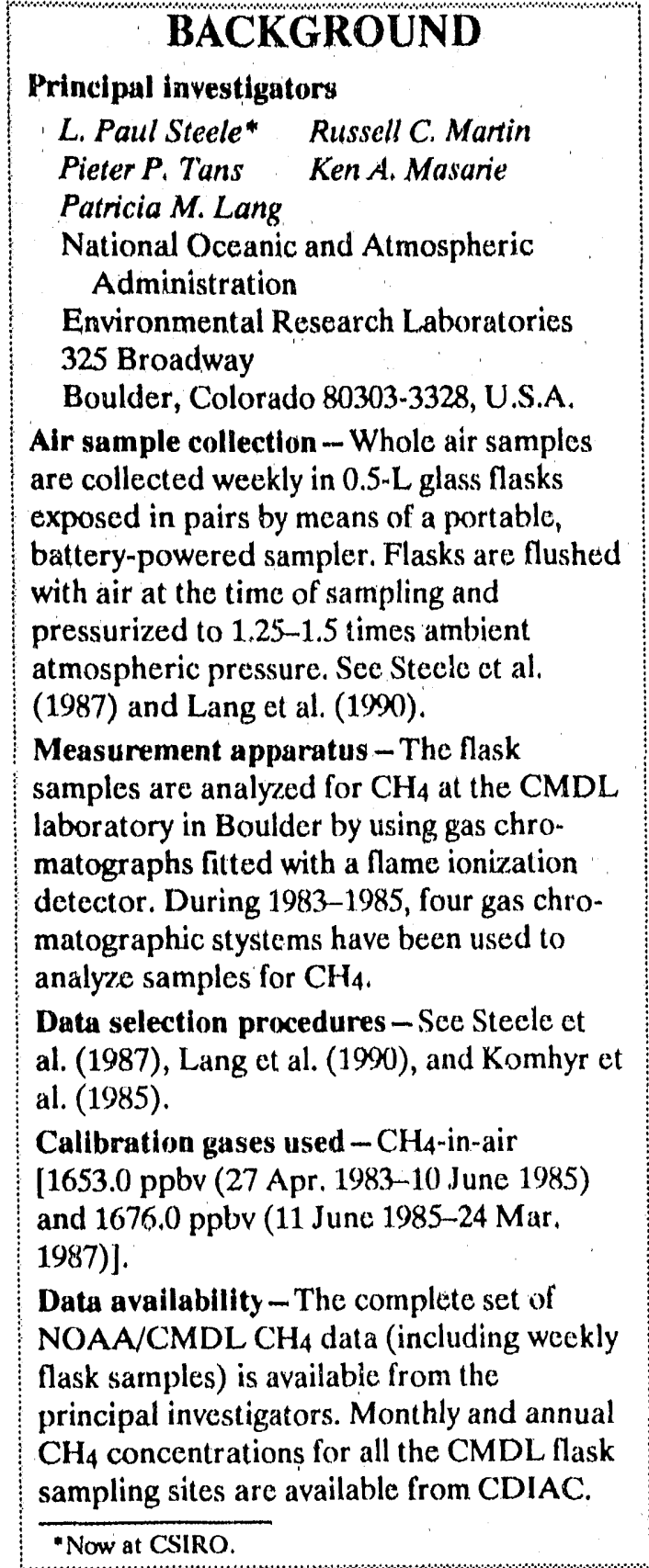

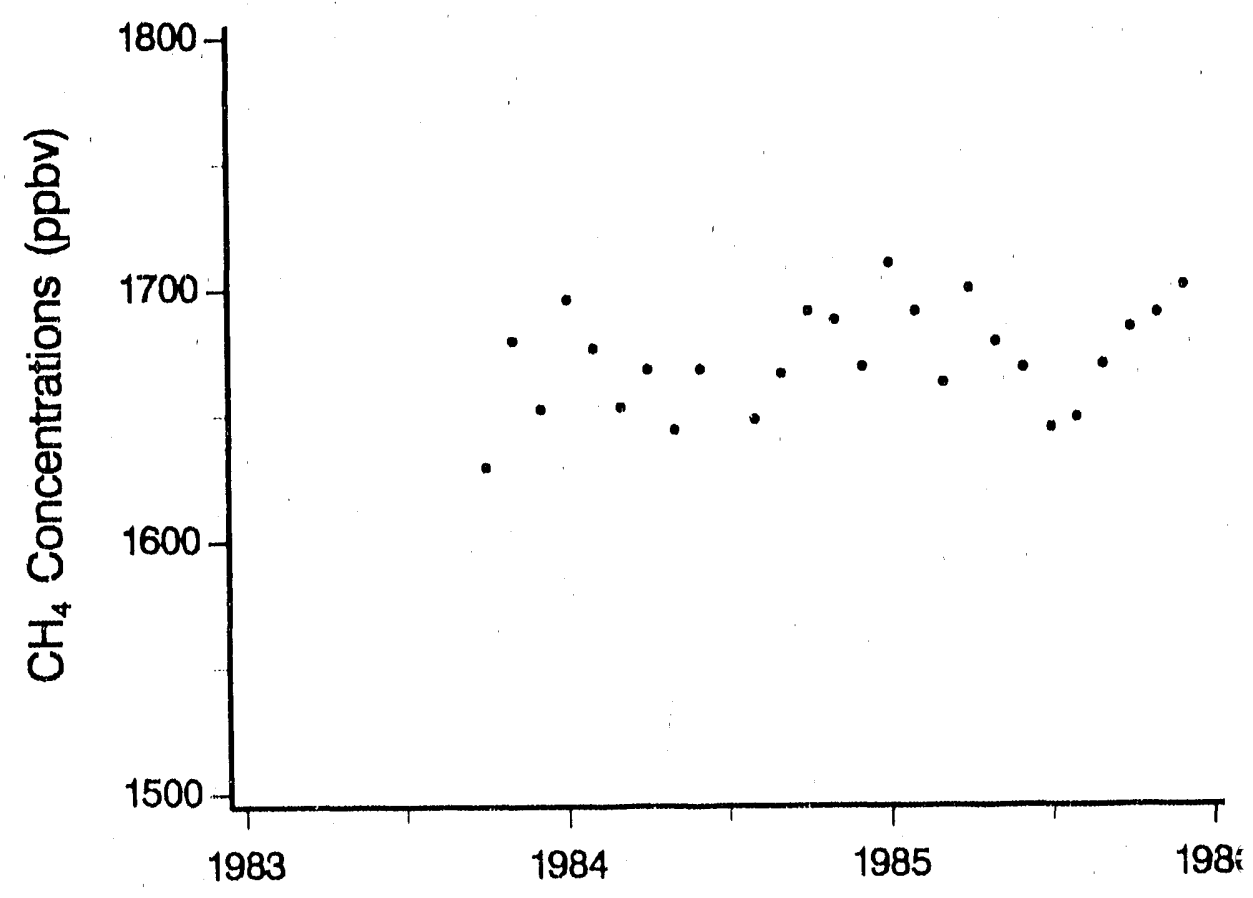

Monthly concentrations of atmospheric $\mathrm{CH}_{4}$.

Key Biscayne

Florida, U.S.A.

Coastal island seashore

$25^{\circ} 40^{\prime} \mathrm{N}, 80^{\circ} 12^{\prime} \mathrm{W}$

$3 \mathrm{~m}$ above $M S L$ 


\section{Atmospheric $\mathrm{CH}_{4}$}

\section{TREND)}

The average annual $\mathrm{CH}_{4}$ concentration at Key Biscayne rose from 1653.9 ppby in 1983 to 1678.8 ppbv in 1985. Steel et al. (1987) reported that it is difficult to interpret the $\mathrm{CH}_{4}$ data from Key Biscayne because of changes in sampling frequency, the proximity of the station to urban Miami, and the large degree of scatter shown by the Key Biscayne record. Steele ot al. (1987) reported that despite these difficulties, the $\mathrm{CH}_{4}$ data from Key Biscayne do indicale a seasonal minimum in the northern summer of 1984 and that the annual mean concentration calculated for 1984 fits neatly into the latitudinal gradient with other northern C.MDL sites. However, because of these difficullies and questions concerning the suitability of the site for monitoring background measurements, NOAA/CMDL replaced the southern Florida site and began monitoring at Midway Island in 1985. The site at Midway Island is at a comparable latitude $\left(28^{\circ} \mathrm{N}, 177^{\circ} \mathrm{W}\right)$ to the Key Biscayne site and is believed to be suitable for obtaining backgrourid measurements. 


\section{Key Biscayne}

Concentrations of Atmospheric Methane*

\begin{tabular}{|c|c|c|c|c|c|c|c|c|c|c|c|c|}
\hline Jan & Feb & Mar & Apr & Miuy & Jun & Jul & Aug & Sept & Oet & Nov & Dec & Ann \\
\hline 883 & & & & & & & & & 1629.5 & 1679.7 & 1652.5 & 1653,9 \\
\hline 1696.0 & 1676.5 & 1653.2 & 1668.0 & 1644.0 & 16683.0 & & 1648.0 & 1666.2 & 1690.8 & 1687.3 & 1668.6 & 1669.7 \\
\hline 1709.8 & 1690.7 & 1662.3 & 1699,6 & 1678.5 & 16688.1 & 1644.3 & 1648.4 & 1669.4 & 1684.0 & 1689.7 & 1700.8 & 1678.8 \\
\hline
\end{tabular}

* Methane concentrations expressed in parts per billion by volume (ppbv). Monthly averages calculated as arithmetic means of individual flask concentrations that are indicative of background conditions. Annual averages based on monthly means.

\section{RIIIRENETS}

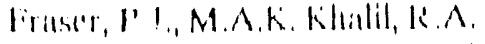

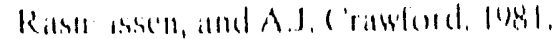

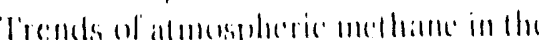

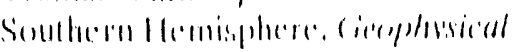

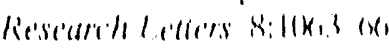

lraser, I', ., M.A.K. Khalil, R.A.

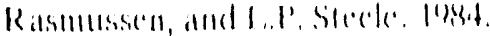

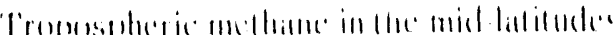

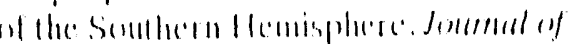

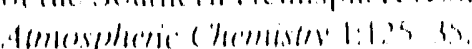

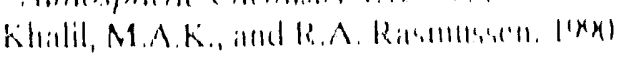

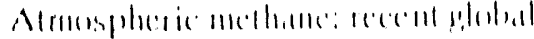

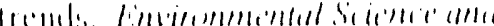

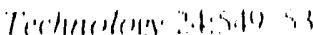

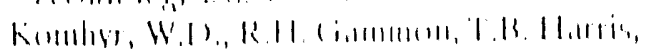

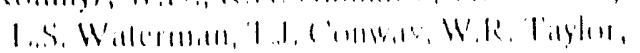

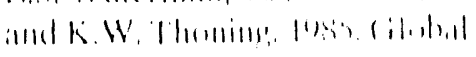

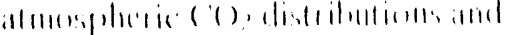

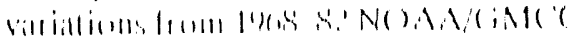

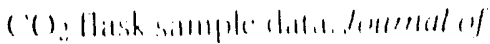

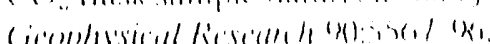

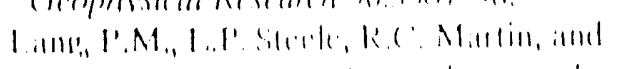

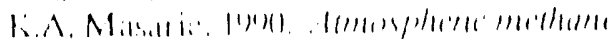

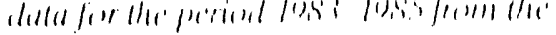

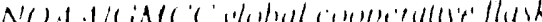

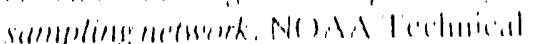

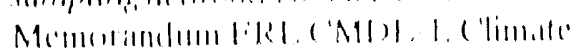

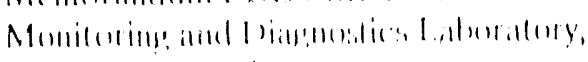

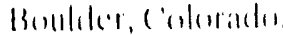

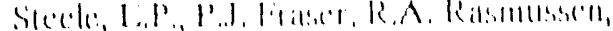

MA K Khalil, T.J. ('onsaly, A...

Cratwford, R.H. (iallumbur, K.A. Malsartic,

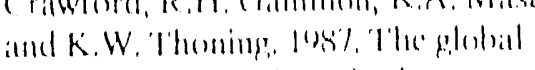

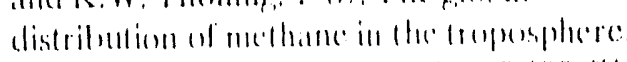

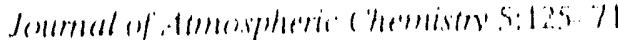




\section{Kitt Peak}

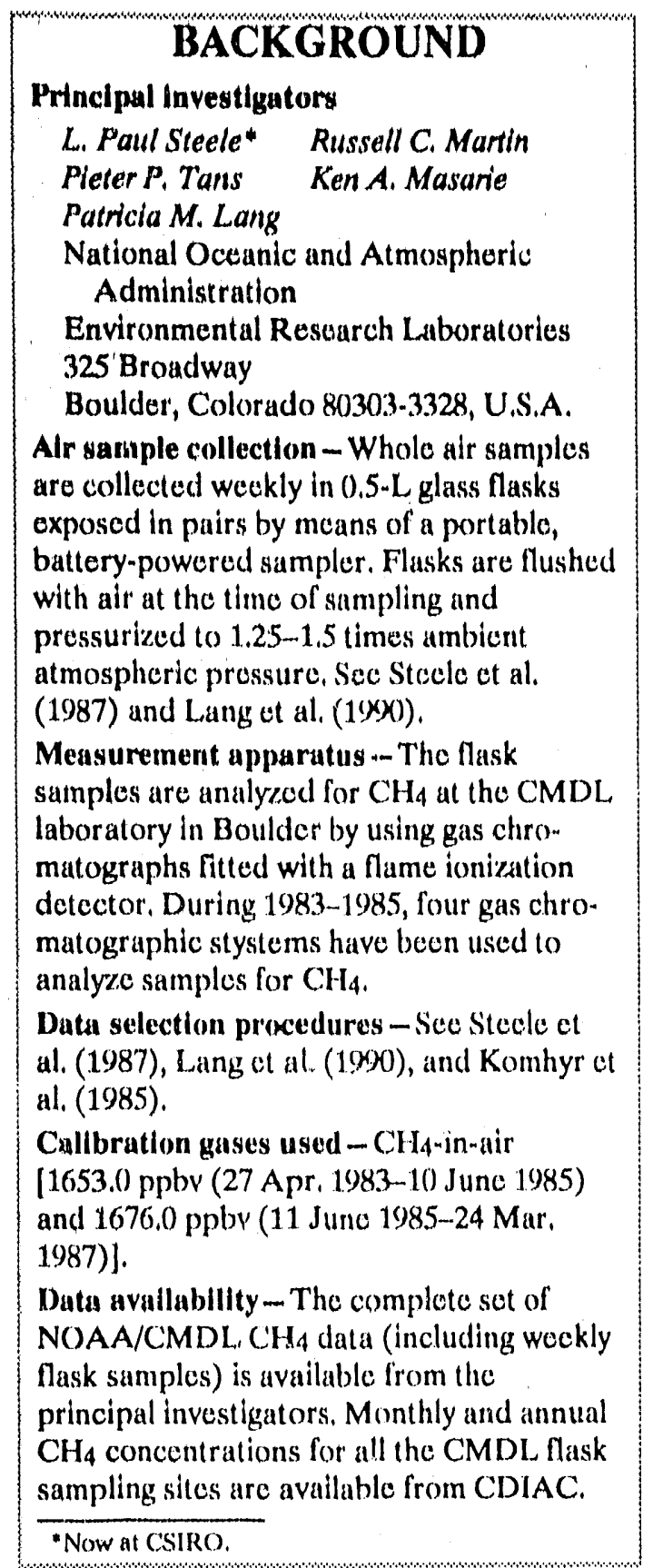

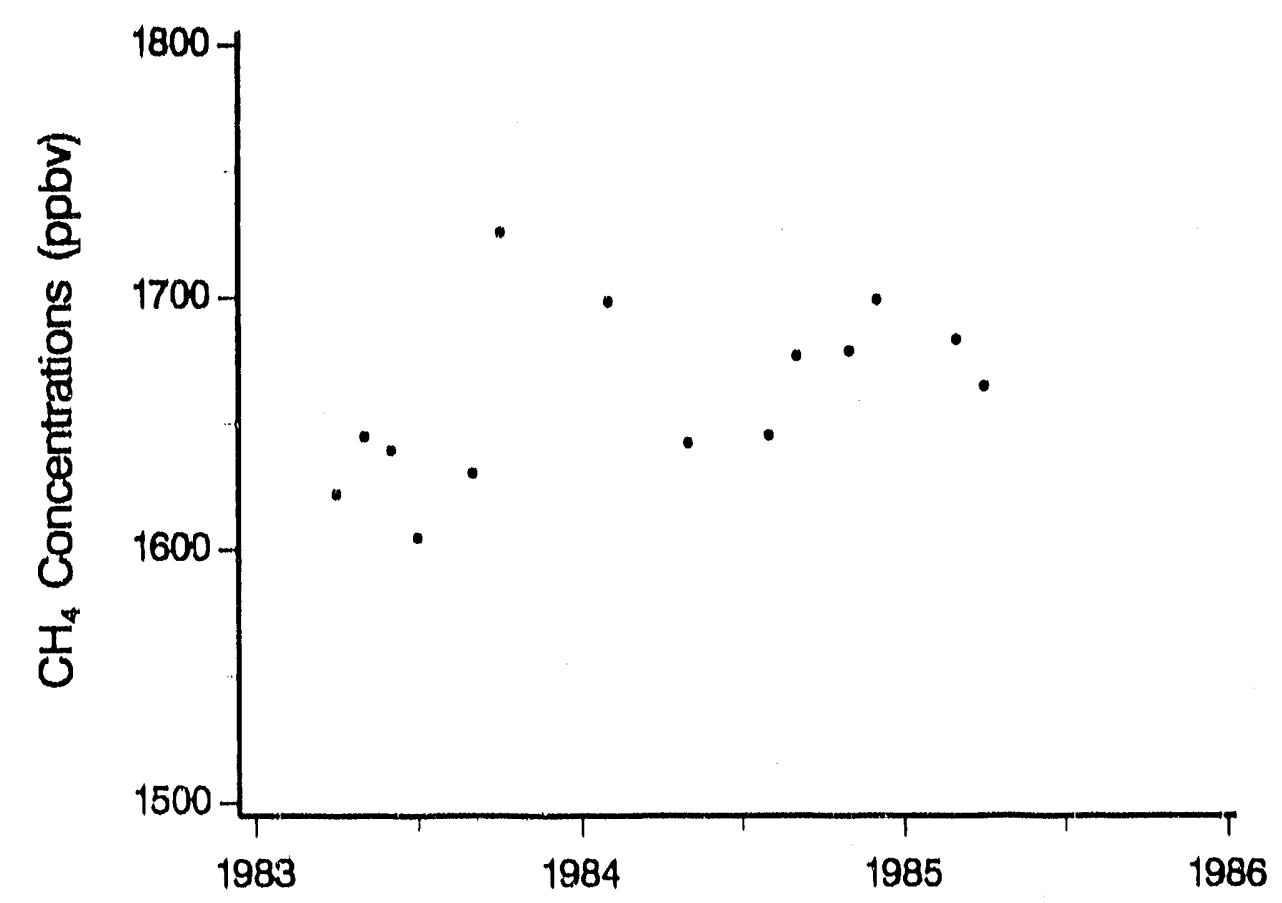

Kitt Peuk,

Arizona, U.S.A.

Arid mothtain top with

scattered vegetation

$32^{\circ}(0)^{\prime} N_{1} 112^{\circ}(0){ }^{\prime} \mathrm{W}$

$2083 \mathrm{~m}$ above $M S L$

Monthly concentrutions of atmospheric $\mathrm{CH}_{4}$. 


\section{Atmospheric $\mathrm{CH}_{4}$}

\section{TREND}

Sampling at Kitt Peak is conducted with the cooperation of the Kitt Pouk Observatory. Sampling is done only when a group from Battelle Pacific Northwest Laboratory is making dotorminations of total column $\mathrm{CH}_{4}$. Consequently, sumpling at Kitt Pouk has been sparse in comparison with othor sampling at CMDL stations (Stecle et al. 1987). Based on a limited number of sumples, the average annual $\mathrm{CH}_{4}$ concentration at Kitt Peak has risen from 1644.6 ppbr in 1983 to 1674.2 ppbr in 1985. 
Concentrations of Atmospheric Methane*

\begin{tabular}{|c|c|c|c|c|c|c|c|c|c|c|c|c|c|}
\hline Year & Jan & Feb & Mar & Apr & May & Jun & Jul & Aug & Sept & Oet & Nov & Dec & Ann \\
\hline 1983 & & & & 1622,0 & 1644.9 & 1639.4 & 1604,9 & & 1630.5 & 1726.0 & & & 1644.6 \\
\hline 1984 & & 1698.5 & & & 1642.5 & & & 1645.5 & 1677.0 & & 1678.9 & 1699.3 & 1673.6 \\
\hline 1985 & & & 1683.4 & 1664.9 & & & & & & & & & 1674.2 \\
\hline
\end{tabular}

*Methane concentrations expressed in parts per billion by volume (ppbv). Monthly averages calculated as arithmetic means of individual flask concentrations that are indicative of background conditions. Annual averages based on monthly means.

\section{REFERENCES}

Frister, M..., M.A.K. Khillil, R.A

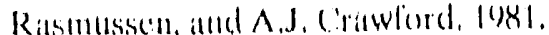
Trereds of atmospheric methame in the Southerallemisphere, (iecophysical

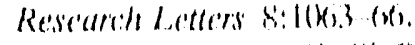

Fritser, P'.,., M.A.K. Khialil, R,A

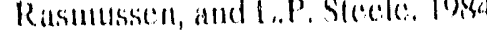

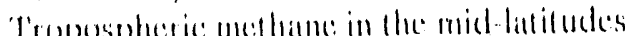
of the Southere Hemisphere. Jonertul of

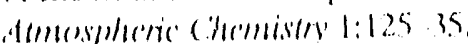

Khalil, M.A.K., and R.A. Rasmusiscu, (r)x).

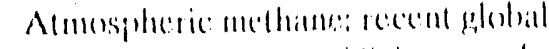

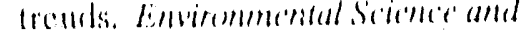

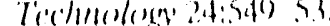

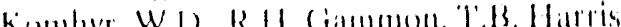

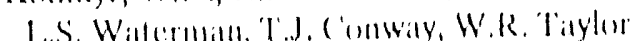

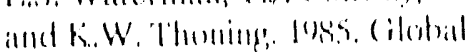

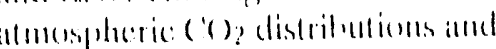
vartitlums from l')

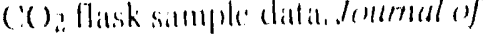

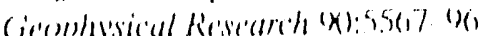

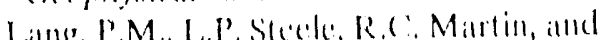

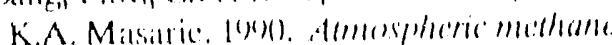
dested for the previod losis los's from the

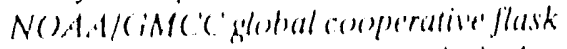

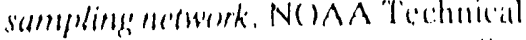
Mememanlem liRL ( MDL-L (limate Menitoring and Diemestic's Laturatery,

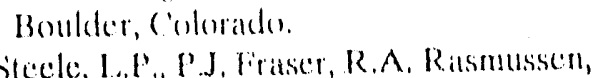

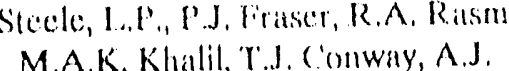
Crawford, R.H. Gatmmon, K.A. Mitsitrie, and K.W. Thoning. 1)87. The global

distribution of methese in the tropsisthere. Jourrial

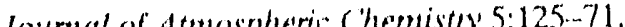




\section{Mahé Island (Seychelles)}

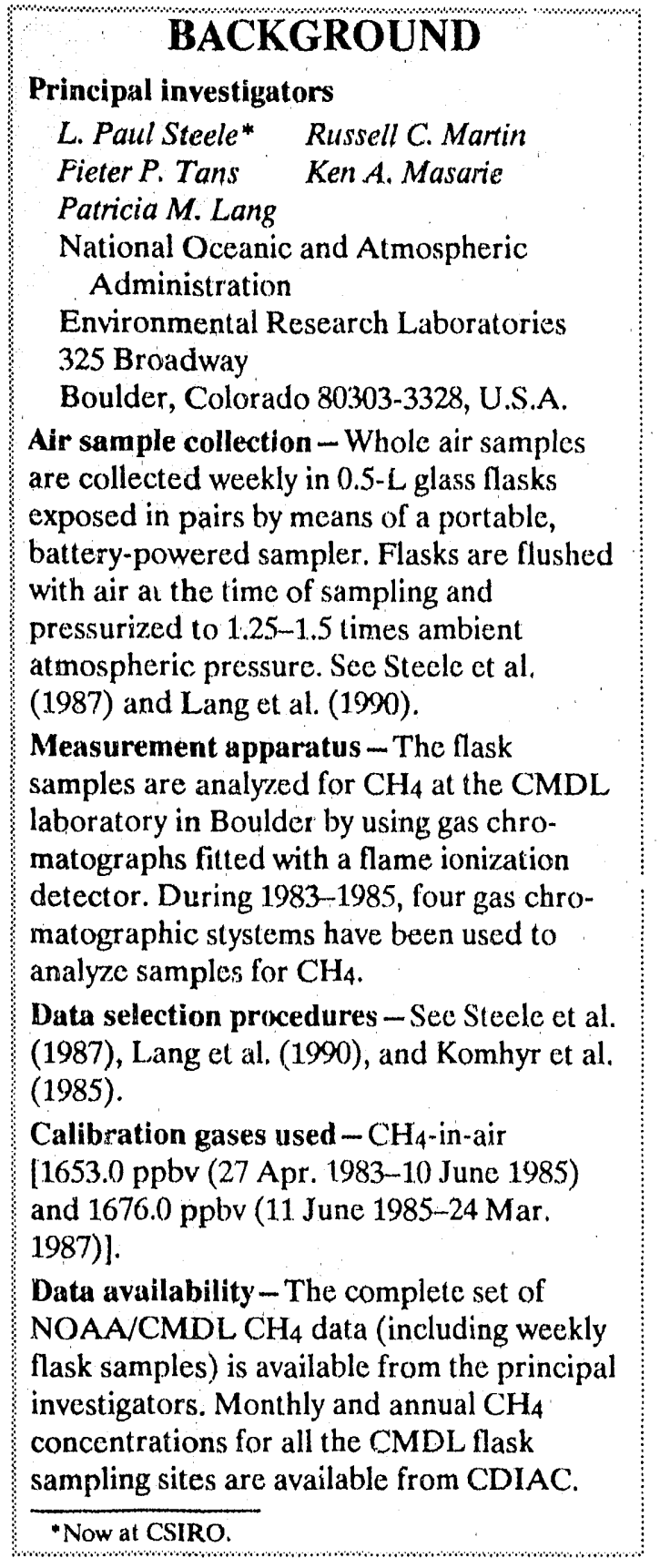

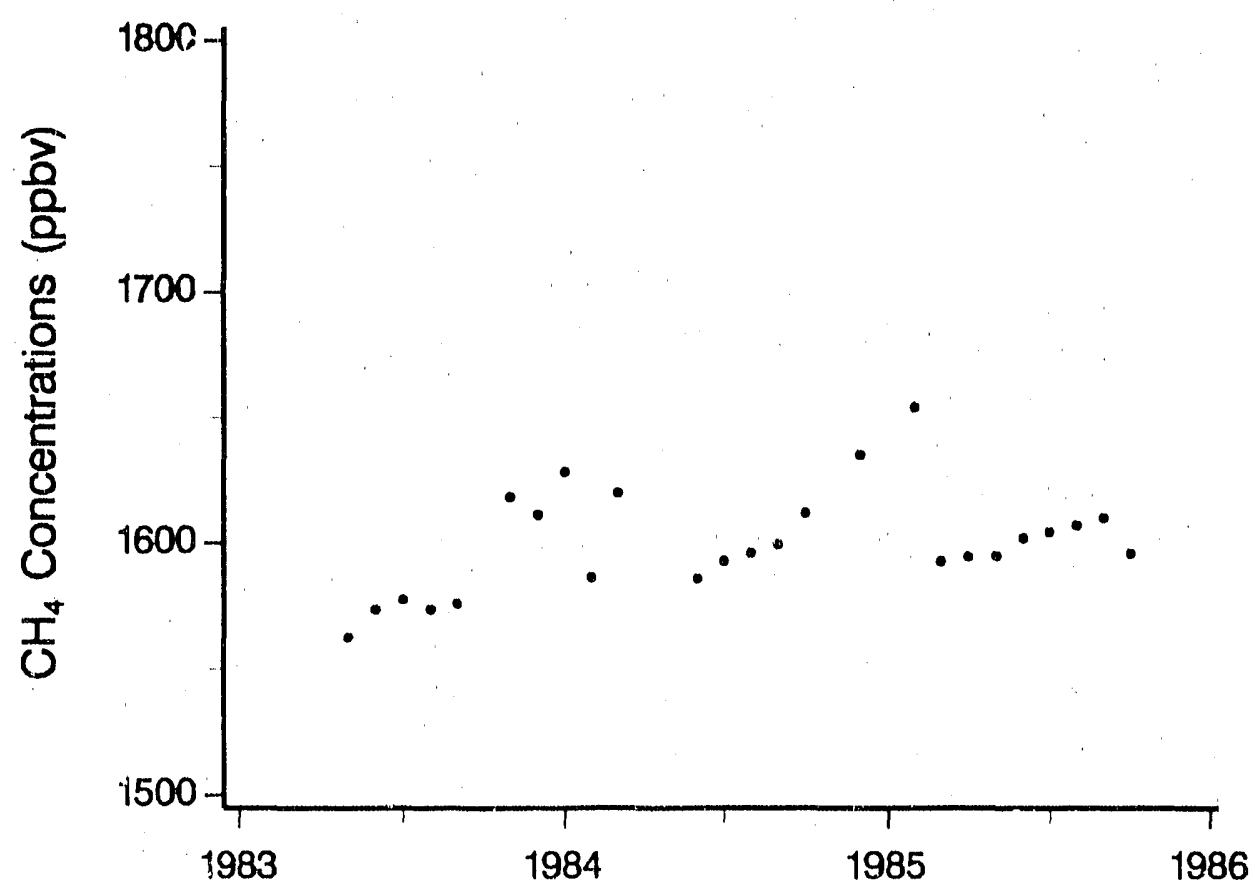

Mahé Island Seychelles

Island seashore $4^{\circ} 40^{\prime} S, 55^{\circ} 10^{\prime} E$ $3 \mathrm{~m}$ above $M S L$ 


\section{Atmospheric $\mathrm{CH}_{4}$}

\section{TREND}

The monitoring station at Mahe Island in the Indian Ocean is operated in cooperation with the Physical Science Laboratory of New Mexico State University. The annual average $\mathrm{CH}_{4}$ concentration at Mahe Island increased from $1.584 .9 \mathrm{ppbv}$ in 1983 to $1606.0 \mathrm{ppbv}$ in 1985. Stecle et al. (1987) also reported that the NOAA/CMDL $\mathrm{CH}_{4}$ and $\mathrm{CO}_{2}$ records from the Seychelles show parallel seasonality.

The Seychelles and the corresponding $\mathrm{CH}_{4}$ measurements are influenced by monsoons and the seasonal migration of the surface wind convergence zone. Stecle et al. (1987) reported that during the austral winter this convergence zone is normally found to the north of Mahe Island, bringing southeast monsoon winds and typically

Southern Hemisphere $\mathrm{CH}_{4}$ concentrations to the Mahe Island site. During the austral summer, however, the convergence zone has migrated far to the south of the Seychelles, bringing the site under the predominant influence of the northwest monsoon winds and higher $\mathrm{CH}_{4}$ concentrations (Steele et al. 1987). 
Concentrations of Atmospheric Methane*

\begin{tabular}{|c|c|c|c|c|c|c|c|c|c|c|c|c|c|}
\hline Year & Jan & Feb & Mar & Apr & May & Jun & jul & Aug & Sept & Oct & Nov & Dec & Ann \\
\hline 1983 & & & & & 1562.7 & 1573.8 & 1577.7 & 1573.8 & 1576.1 & & 1618.5 & 1611.4 & 1584.9 \\
\hline 1984 & 1628.4 & 1586.5 & 1620.0 & & & 1586.0 & 1.593 .0 & 1596.1 & 1599.4 & 1611.9 & & 1635.1 & 1606 \\
\hline 1985 & & 1653.9 & 1592.6 & 1594.4 & 1594.8 & 1601.8 & 1604.3 & 1606.9 & 1609.9 & 1595.8 & & & 1606 \\
\hline
\end{tabular}

*Methane concentrations expressed in parts per billion by volume (ppbv). Monthly averages calculated as arithmetic means of individual flask concentrations that are indicative of background conditions. Annual averages based on monthly means.

\section{REFERENCES}

Fraser, P.J., M.A.K. K'halil, R.A Rasmussen, and A.I. Crawlord. 1981. Trends of at mospherice methane in the Southern Hemisphere. (ieophysical

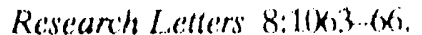

Fraser, PJ MAK Khalil, R.A.

Rasmussen, and L.P. Sterke. 1984

Tropospheric methane in the mid-latitudes of the Southern Hemisphere. Journal of

Almospheric Chemistry 1:125-3.5.

Khalil, M.A.K., and R.A. Rasinussen, $1(x)$

Atmospheric methane: recent global

trends. Environmental Sicience and

Technologe 24:549) 53.

Komhyr, W.D., R.II. (iammon, T.B. Marris,

LS Watermin, T.J. conway, W R. Taylor,

and K.W. Thoning, 1985. Cilobial

atmospheric ( ()$_{2}$ distrilustions and

variations from 6 (6) $82 \mathrm{NO}$ A A A IMCC

(C) 2 flask sample dat a. Journal of

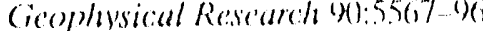

Lang, P.M., L.P. Stecle, R.C., Martin, and K A Mararie 104) demospherie methane data for the period 1985.105.5 from the

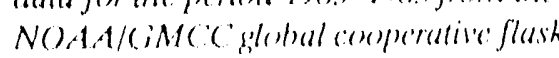
sampling netwerk. N()^A Technical Memorandum ERI, (MD) - 1. Climate

Monitoring and Diarnostics Laboratory, Boulder, Colorado.

Stecle, L.P., P.J.firaser, R.A. Rasmussen, M.A.K. Khalil, T.J. Conway, A.J. Crawford, R.H. ( Gammon, K.A. Masarice and K.W. Thoning. 1987. The global distribution of methane in the tronosphere Joumal of Atmospheric Chomistry 5:125.71. 


\section{Mariana Islands (Guam)}

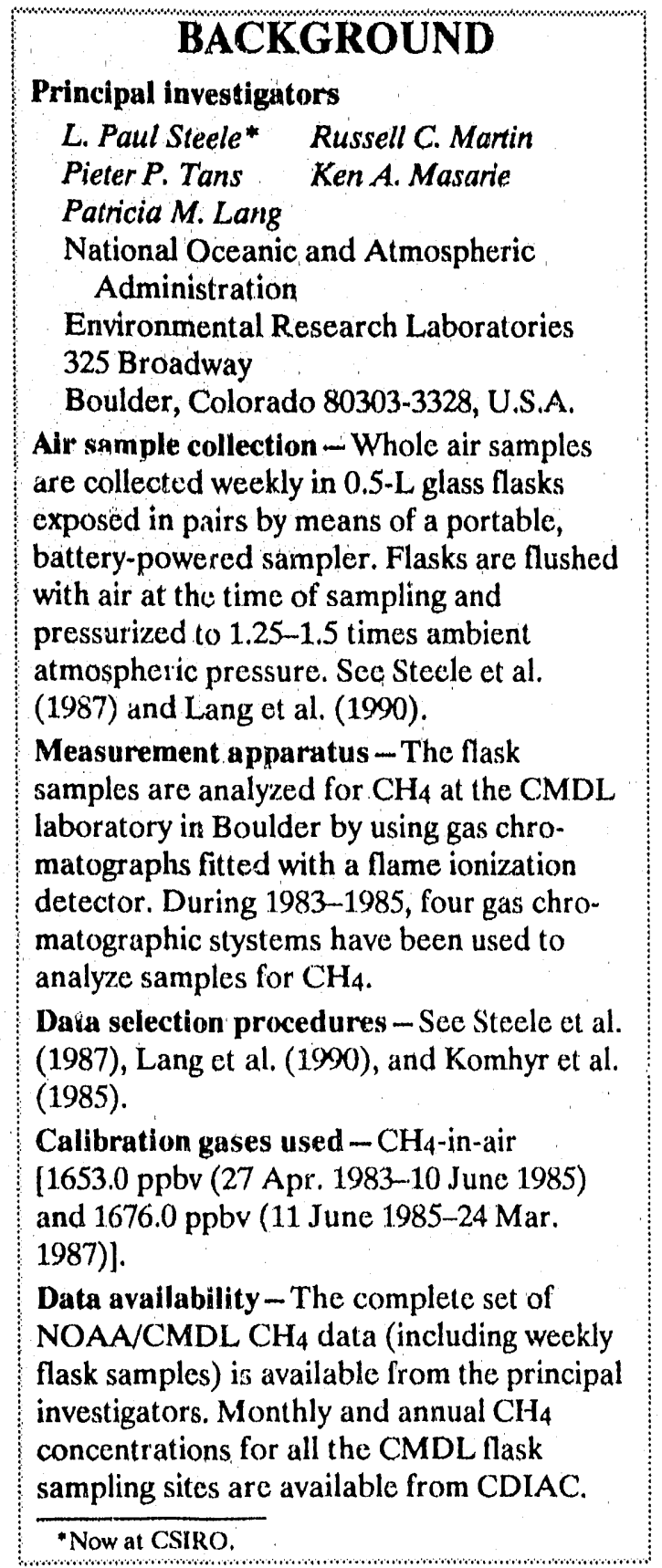

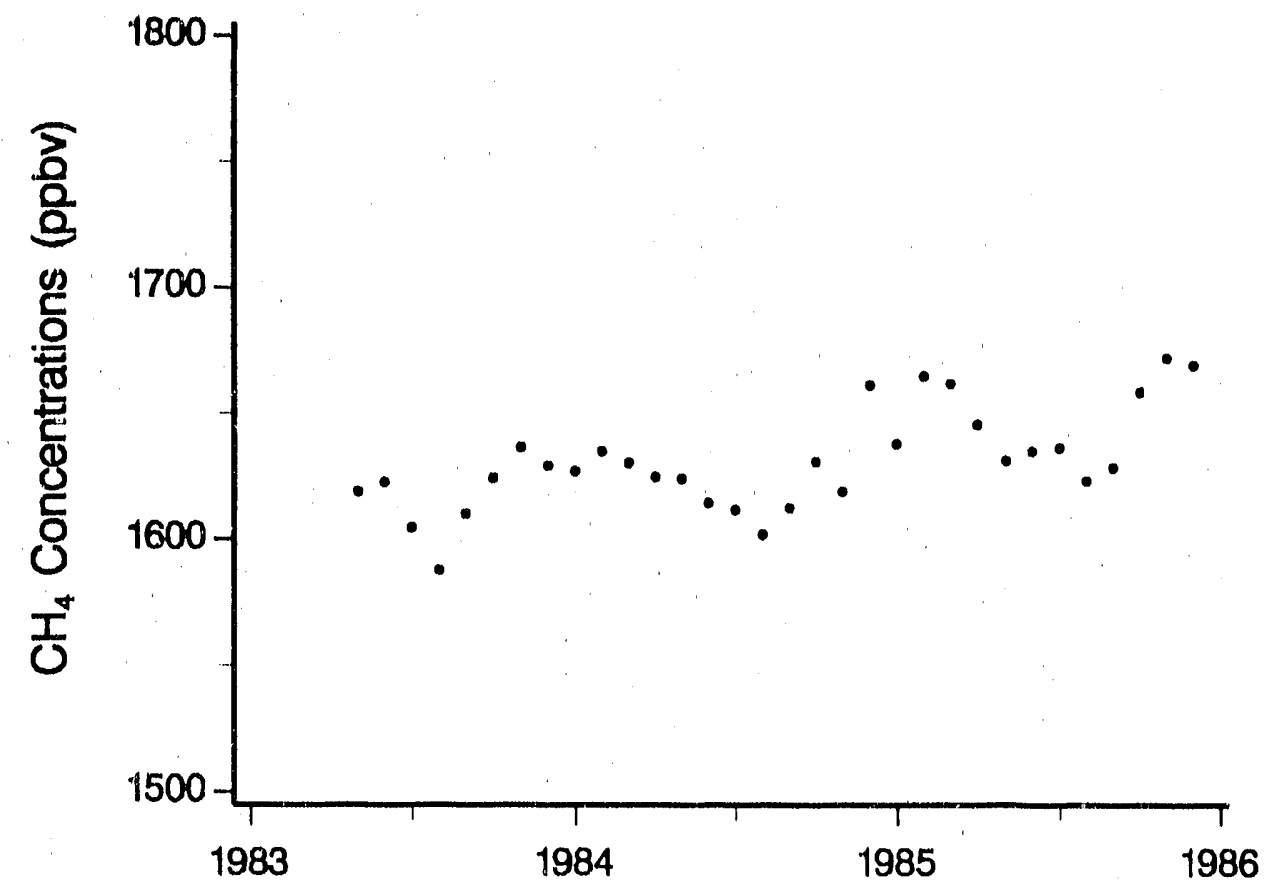

Mariana Islands Guam, U.S. Territory

Island seashore $13^{\circ} 26^{\prime} \mathrm{N}, 144^{\circ} 47^{\prime} \mathrm{E}$ $2 \mathrm{~m}$ above $M S L$ 


\section{Atmospheric $\mathrm{CH}_{4}$}

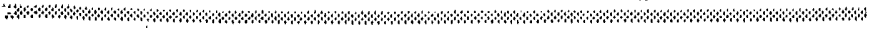

\section{TREND}

The sampling site at the Mariana Islands is operated in cooperation with the University of Guam. Annual atmospheric $\mathrm{CH}_{4}$ concentrations at the Guam site rose from $1616.8 \mathrm{ppbv}$ in 1983 to $1646.9 \mathrm{ppbv}$ in 1985. Stcele ct al. (1987) fitted a lincar regression to the 12 -month running means from the Mariana Islands site and calculated an annual average growth rate of 11.4 ppbv. Steele et al. (1987) also found a pronounced minimum in the methane concentrations for Guam in the late northern summer of both 1983 and 1984 but found no evidence of a secondary minimum in either year. 
Mariana Islands (Guam)

Concentrations of Atmospheric Methane*

$\begin{array}{cccccccccccccc}\text { Year } & \text { Jan } & \text { Feb } & \text { Mar } & \text { Apr } & \text { May } & \text { Jun } & \text { Jul } & \text { Aug } & \text { Sept } & \text { Oct } & \text { Nov } & \text { Dec } & \text { Ann } \\ 1983 & & & & & 1618.9 & 1622.8 & 1604.7 & 1587.8 & 1610.2 & 1624.3 & 1636.5 & 1629.2 & 1616.8 \\ 1984 & 1627.1 & 1635.0 & 1630.4 & 1624.8 & 1624.1 & 1614.5 & 161.1 .7 & 1601.9 & 1612.5 & 1630.9 & 1618.9 & 1661.1 & 1624.4 \\ 198.5 & 1637.9 & 1664.7 & 1661.7 & 1645.5 & 1631.1 & 1634.9 & 1636.2 & 1623.0 & 1.628 .4 & 1658.2 & 1671.8 & 1668.9 & 1646.9\end{array}$

* Methane concentrations expressed in parts per billion by volume (ppbv). Monthly averages calculated as arithmetic means of individual flask concentrations that are indicative of background conditions. Annual averages based on monthly means.

\section{REITERTER}

Firisicr, P..., M.A.K. Khillil, K.A.

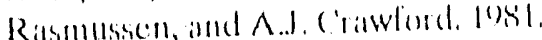

Trends of at monspheric methane in the

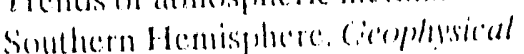

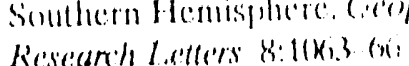

Researsh lotters b:llki.3 on:

Fraiscr, P'J., M.A.K. K'halli, R.A.

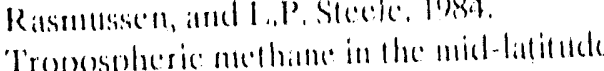

Troperspherice on the

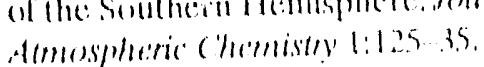

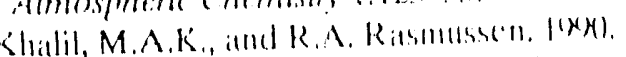

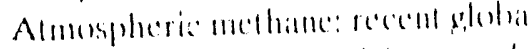

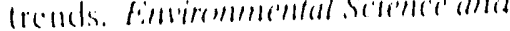

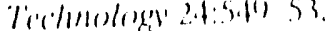

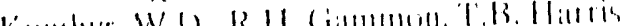

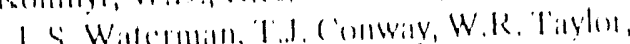

and K.W. Thuming. less c cilubial

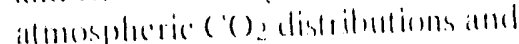

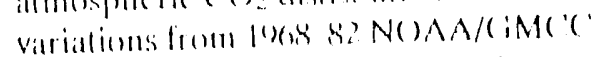

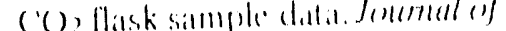

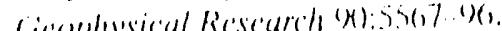

L.ans, I.M., L.P. Silcelle, R.C. Martin, and

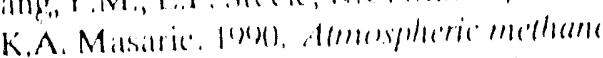

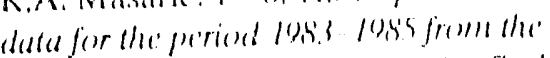

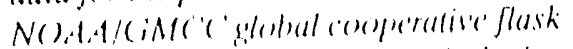

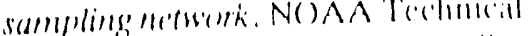

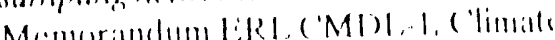

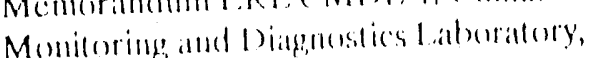

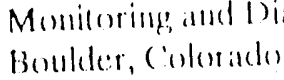

Stecke, L.P', P'J firase', R.A. Ratsmussern,

M.A.K. Khitli, T.J. Conwaly, A.J.

crawford, R.11 (jammon, K.A. Masarice

and K.W Thoming. 198\%. The global

distribution of methane in the tropesphere.

distribution of methane in the tropesphere.
Joumal of almospheric (hemistry $5: 125-71$. 


\section{Matatula Point (American Samoa)}

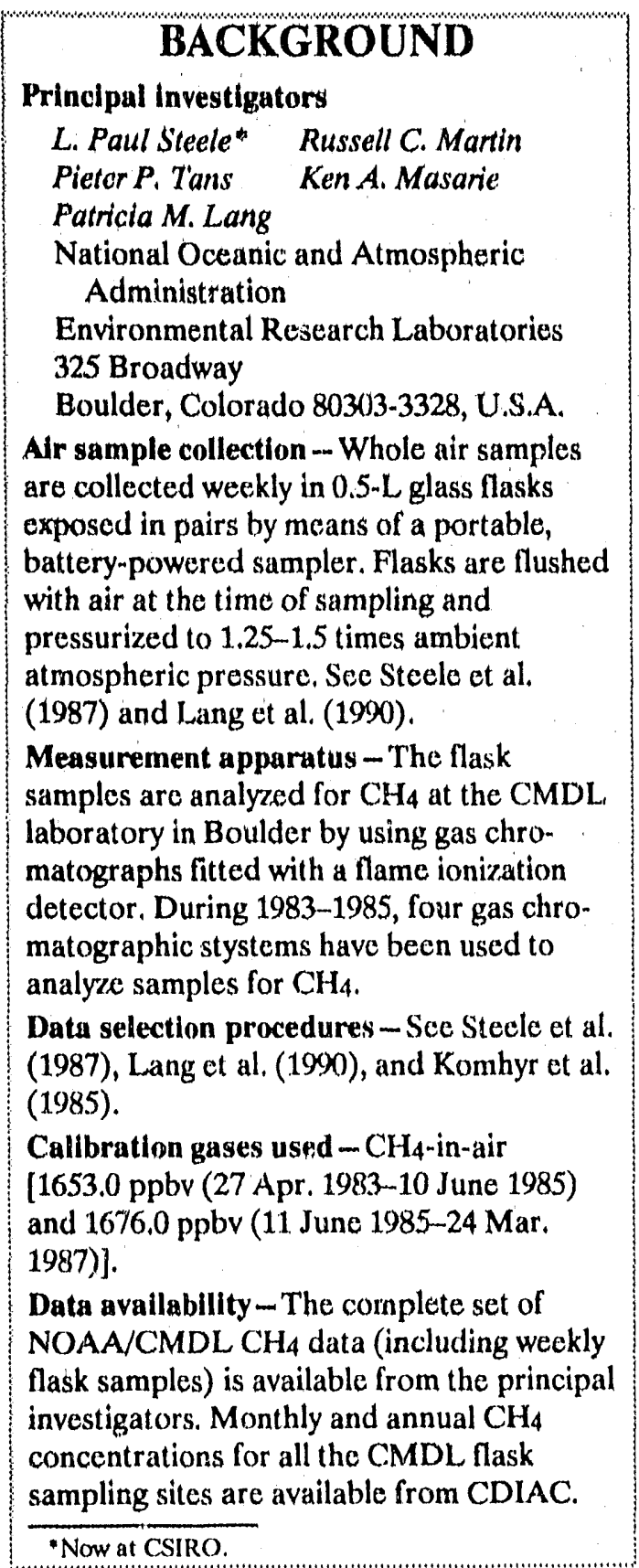

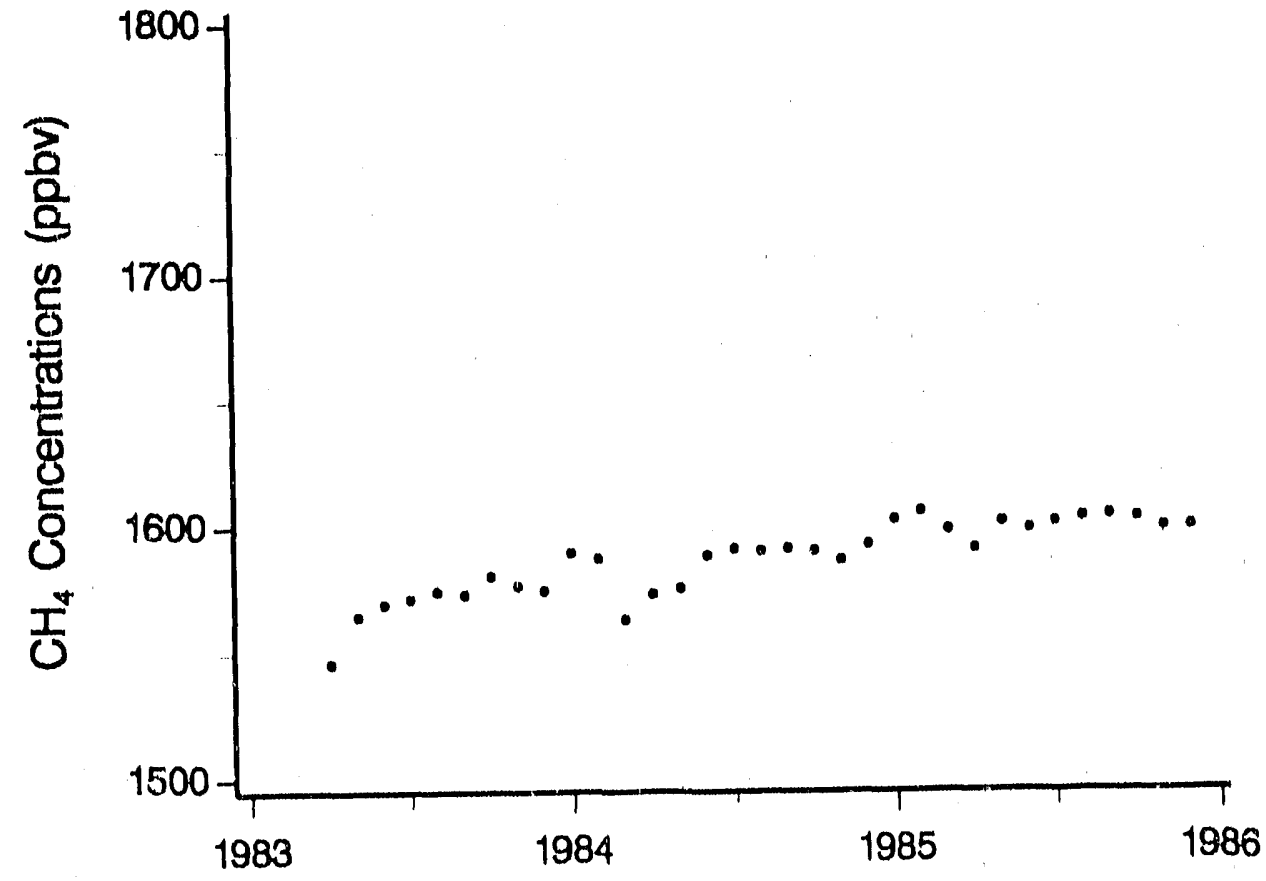

Monthly concentrations of atmospheric $\mathrm{CH}_{4}$.

Matatula Point

American Samoa, U.S. Territory

Island rocky promontory

$14^{\circ} 15^{\prime} \mathrm{S}, 170^{\circ} 34^{\prime} \mathrm{W}$

$42 \mathrm{~m}$ above $M S L$ 


\section{TREND}

The average annual $\mathrm{CH}_{4}$ concentration from American Samou has increased from 1570.1 ppbv in 1983 to 1600.2 ppbv in 198.5. steole at al. (1987) reported that the $\mathrm{CH}_{4}$ concentrations from American Samoa showed a longuterm increase in $\mathrm{CH}_{4}$ but no apparont scasonal variation. Stecle et al. (1987), using 12-month running means (to remove scasonal variations) fitted to a lincar regression, calculated the average growth rate for American Samoa to be 14.0 ppbe per year. Halter et al. (1988) found compelling evidence to support the idea that American Samoa is influcnced by significant intrusions of air from the Northern Hemisphere and that these intrusions oceur more frequently during the austral summer and autumn. Stecle et al. (1987) suggessted that since $\mathrm{CH}_{4}$ concentrations north of the Intertropical Convergence Zone (ITCZ) are always higher than those in the Southern Hemisphere, intrusions of air reaching American Samou from north of the ITCZ will always have the effect of increasing the $\mathrm{CH}_{4}$ concentrations observed at American Samoa. The absence of any clear seasonal variation in concentration at American Samoa is probably due to the opposing effects of seasonal transport of $\mathrm{CH}_{4}$-rich air from north of the ITCZ during those times when the seasonal minimum in $\mathrm{CH}_{4}$ concentration normally oceurs in the Southern Hemisphere (Steele et al. 1987). 


\section{Matatula Point (American Samoa)}

Concentrations of Atmospheric Methane*

\begin{tabular}{|c|c|c|c|c|c|c|c|c|c|c|c|c|c|}
\hline Year & JuII & Peb & Mar & $A p r$ & May & Jun & Jul & Aug & Sept & Oet & Nov & Dec & Ann \\
\hline 1083 & & & & 1546.1 & 1564.6 & 1.569 .4 & 15716 & 1574.3 & 1573.1 & 1580.5 & 1576.7 & 1574.6 & \\
\hline 1984 & 15805 & 1587.2 & $156,3,1$ & 1573.1 & 157.5 .4 & 1588.5 & 1.591 .0 & 1590.1 & 15) & 1590.0 & 1586.3 & 1592.3 & 884 \\
\hline 985 & $16(1) 2.2$ & $16,(15,8$ & 1597.9 & $15(x) .5$ & $16(x) 1,0$ & 1598,1 & $1(x) 1.0$ & $16(x) 2,6$ & $1(x) 3.5$ & $16(1) 2,3$ & 1598.7 & $1.5(x), 0)$ & \\
\hline
\end{tabular}

* Methane concentrutions expressed in parts per billlon by volume (ppov). Monthly averages calculatod as arithmetic means of individual flask concentrations that are indicative of background conditions. Annual averages based on monthly means.

\section{RliliRYiNG Wis}

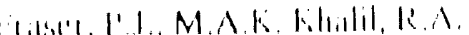

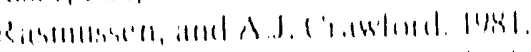

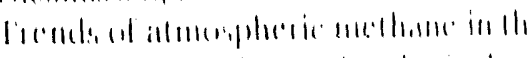

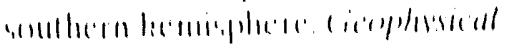

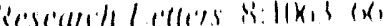

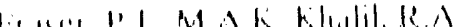

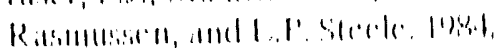

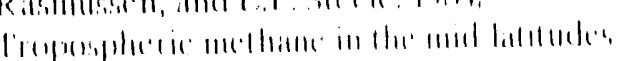

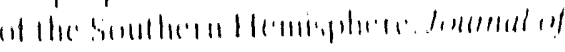

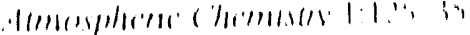

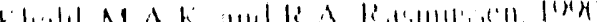

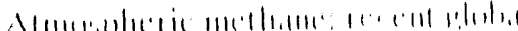

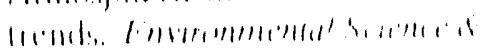

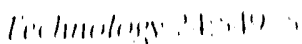

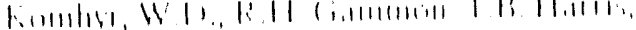

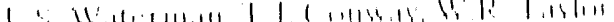

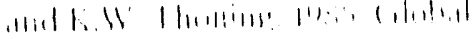

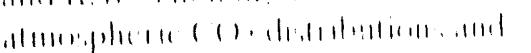

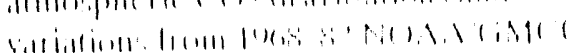

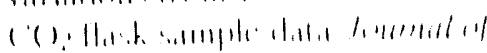

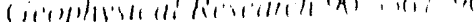

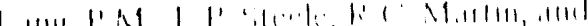

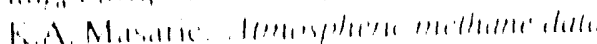

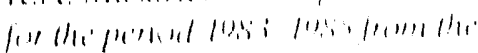

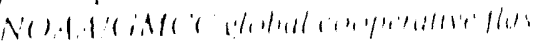

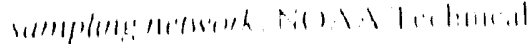

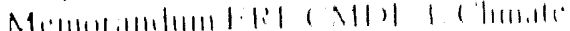

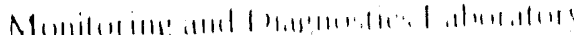

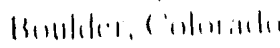

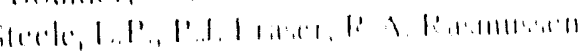

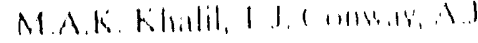

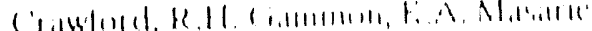

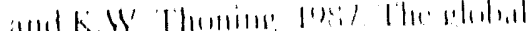

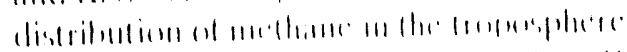

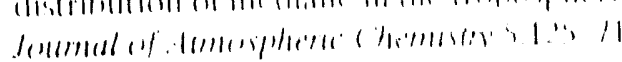




\section{Mauna Loa}

\section{BACKGROUND \\ Princlpal investigators \\ L. Paul Steele* Russell C. Martin \\ Pieter P. Tans Ken.A.Masarie \\ Patricia M. Lang \\ National Oceanic and Atmospheric Administration \\ Environmental Research Laboratories 325 Broadway \\ Boulder, Colorado 80303-3328, U.S.A.}

Air sample collection - Whole air samples are collected weekly in $0.5-\mathrm{L}$ glass flasks cxposed in pairs by means of a portable, battery-powered sampler. Flasks are flushed with air at the time of sampling and pressurized to 1.25-1.5 times ambient atmospheric pressure. Sce Stecle et al. (1987) and Lang et al. (199()).

Measurement apparatus - The flask samples are analyzed for $\mathrm{CH}_{4}$ at the $\mathrm{CMDL}$ laboratory in Boulder by using gas chromatographs fitted with a flame ionization detector. During 1983-1985, four gas chromatographic stystems have been used to analyre samples for $\mathrm{CH}_{4}$.

Data selection procedures - Sec Stecele ct al. (1987), Lang et al. (1990), and Komhyr et al. (1985).

Calibration gases used - $\mathrm{CH}_{4}$-in-air [1653.0 ppbv (27 A pr. 1983-10) June 1985) and 1676.0 ppbv (11 June 1985-24 Mar. 1987)].

Data availability - The complete set of NOAA/CMDL CH4 data (including weekly flask samples) is available from the principal investigators. Monthly and annual $\mathrm{CH}_{4}$ concentrations for all the CMDL flask sampling sites are available from CDIAC.

- Now at CStro

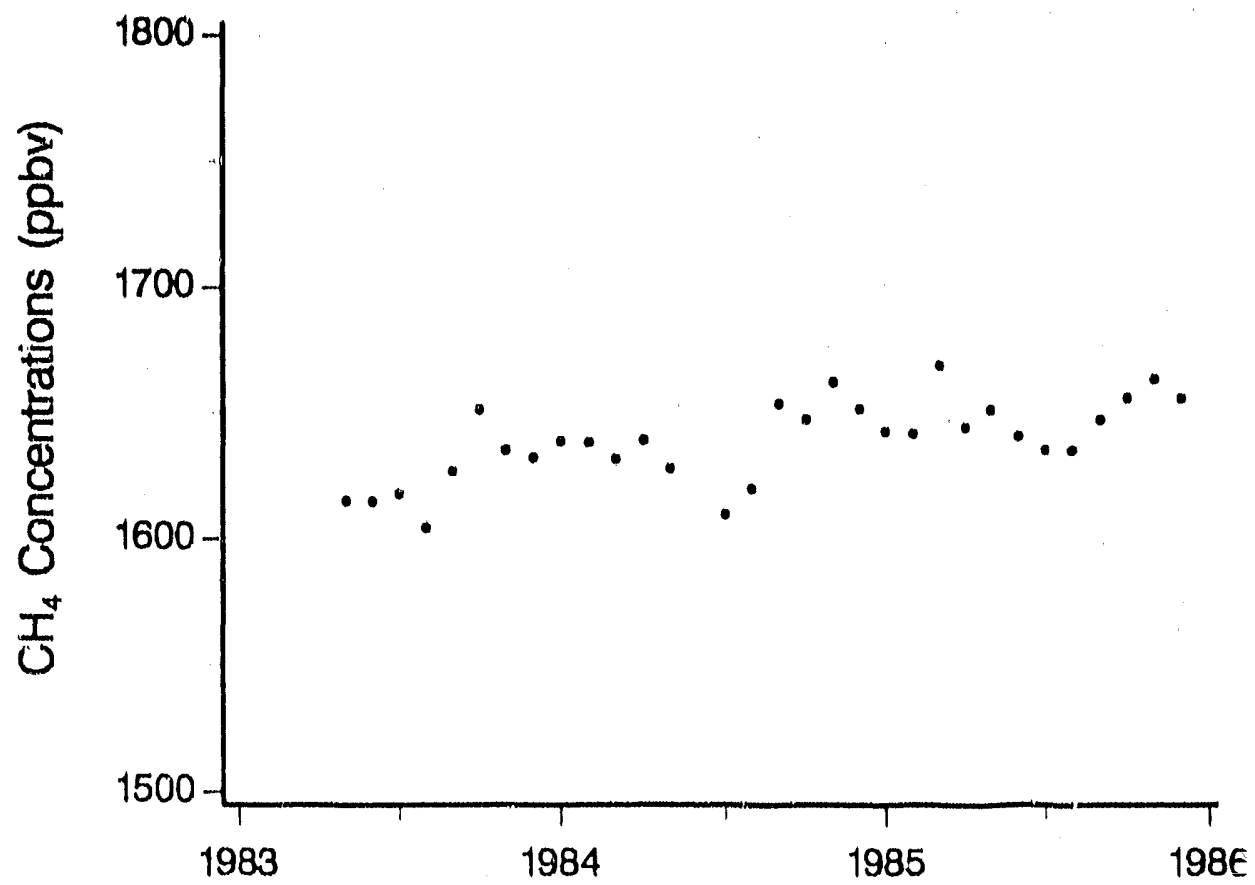

Monthly concentrations of atmospheric $\mathrm{CH}_{4}$.

Mauna Loa

Hawaii, USA

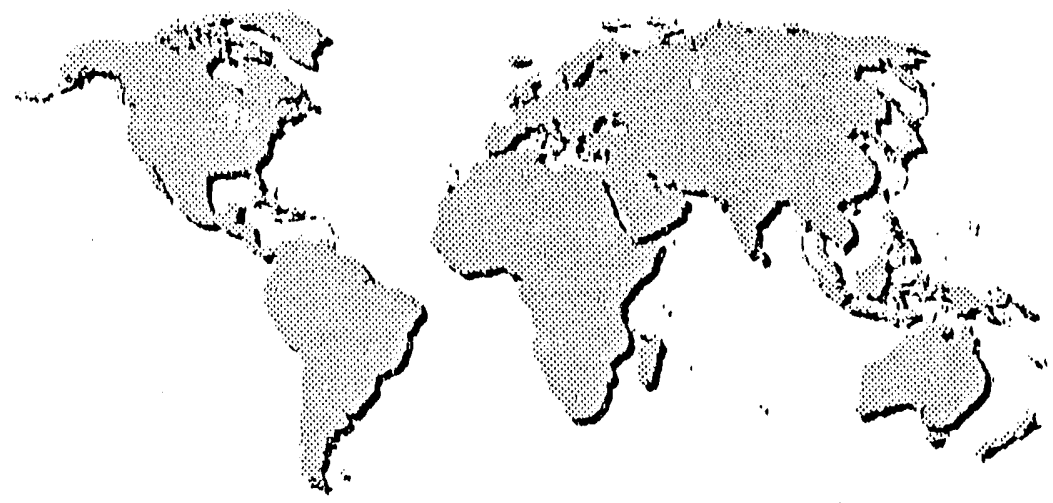

Barren volcanic mountain slope: $10^{\circ} .32^{\prime} \mathrm{N}, 1.55^{\circ} .35^{\prime} \mathrm{W}$ $3.397 \mathrm{~m}$ above $\mathrm{MSL}$ 


\section{Atmospheric $\mathrm{CH}_{4}$}

\section{TREND}

The average annual $\mathrm{CH}_{4}$ concentration at Mauna Loa increased from $1620.3 \mathrm{ppbv}$ in 1983 to 1648.5 ppbv in 1985. By fitting the 12-month running means to a linear regression to remove seasonal variation, Stecle et al. (1987) found the annual average growth rate for Mauna Loa to be 12.0 ppby per year. Stecle et al. (198'7) also compared the $\mathrm{CH}_{4}$ data from Mauna Lola with those from Cape Kumukahi and found a significant vertical gradient in $\mathrm{CH}_{4}$ coneentration, with the longaterm average concentrations from Mauna Loa being lower than those al Cape Kumukahi. Stecle et al. (1987) found that (1) both sites exhibited a major seasonal minimum in the northern summer of 1984 and (2) the fitted cubie spline functions for both sites show evidence that two minimums and two maximums oecur ench year at times consistent wilh those reported by Khalil and Rasmussen $(I(\mathcal{N}))$. 
Concentrations of Atmospheric Methane*

\begin{tabular}{|c|c|c|c|c|c|c|c|c|c|c|c|c|}
\hline an & Feb & Mar & Apr & May & Jun & Jul & Aug & Sept & Oct & Nov & Dec & Ann \\
\hline & & & & 1615.3 & 1614.9 & 1618.0 & 1604.5 & 1626.9 & 1651.4 & 1635.3 & 1632.4 & 1620.3 \\
\hline 1638.8 & 1638.4 & 16318 & 639.2 & 1628.0 & & 1609.8 & 1619.9 & 1653.7 & 1647.4 & 1662.2 & 1651.5 & 1638.2 \\
\hline 1642.7 & 1641.7 & 1668.8 & 1644.3 & 1651.2 & 1640.6 & 1635.1 & 1635.1 & 1647.1 & 1655.9 & 1663.4 & 1655.8 & 1648.5 \\
\hline
\end{tabular}

${ }^{*}$ Methane concentrations expressed in parts per billion by volume (ppbv). Monthly averages calculated as arithmetic means of individual flask concentrations that are indicative of background conditions. Annual averages based on monthly means.

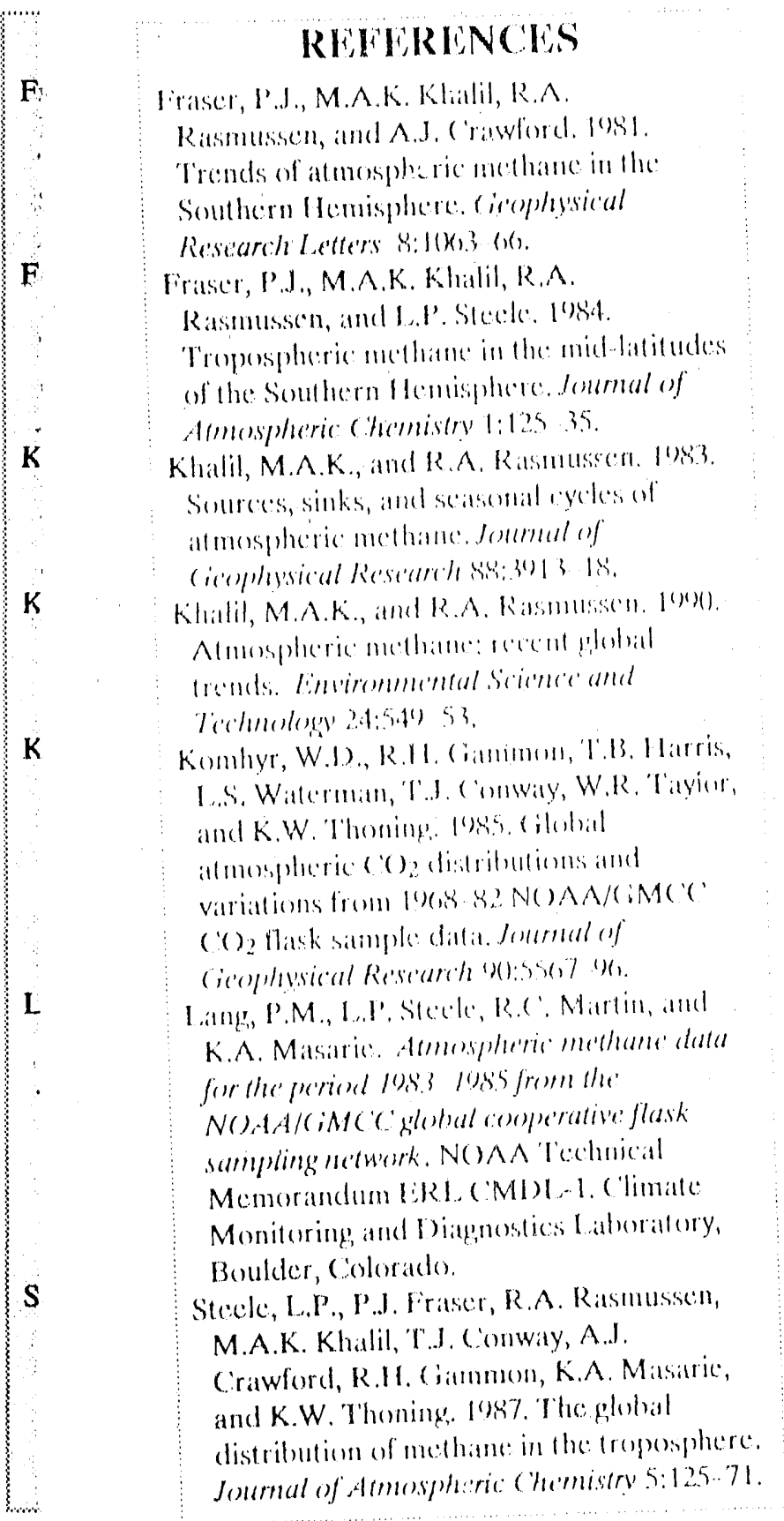




\section{Mould Bay}

\section{BACKGROUND \\ Principal investigators \\ L. Paul Steele* Russell C. Martin \\ Pieter P. Tans . Ken A. Masarie \\ Patricia M. Lang \\ National Oceanic and Atmospheric Administration \\ Environmental Research Laboratories 325 Broadway \\ Boulder, Colorado 80303-3328, U.S.A.}

Air sample collection - Whole air samples are collected weekly in $0.5-\mathrm{L}$ glass flasks exposed in pairs by means of a portable, battery-powered sampler. Flasks are flushed with air at the time of sampling and pressurized to 1.25-1.5 times ambient atmospheric pressure. See Steele et al. (1987) and Lang et al. (1990).

Measurement apparatus - The flask samples are analyzed for $\mathrm{CH}_{4}$ at the $\mathrm{CMDL}$ laboratory in Boulder by using gas chromatographs fitted with a flame ionization detector. During 1983-1985, four gas chromatographic stystems have been used to analyze samples for $\mathrm{CH}_{4}$.

Data selection procedures - Sce Stecle et al. (1987), Lang et al. (1990), and Komhyr et al. (1985).

Calibration gases used- $\mathrm{CH}_{4}$-in-air [1653.0 ppbv (27 Apr. 1983-10 June 1985) and 1676.0 ppbv (11 June 1985-24 Mar. 1987)].

Data availability - The complete set of NOAA/CMDL $\mathrm{CH}_{4}$ data (including weckly flask samples) is available from the principal investigators. Monthly and annual $\mathrm{CH}_{4}$ concentrations for all the CMDL flask sampling sites are available from CDIAC.

Now at CSIRO.

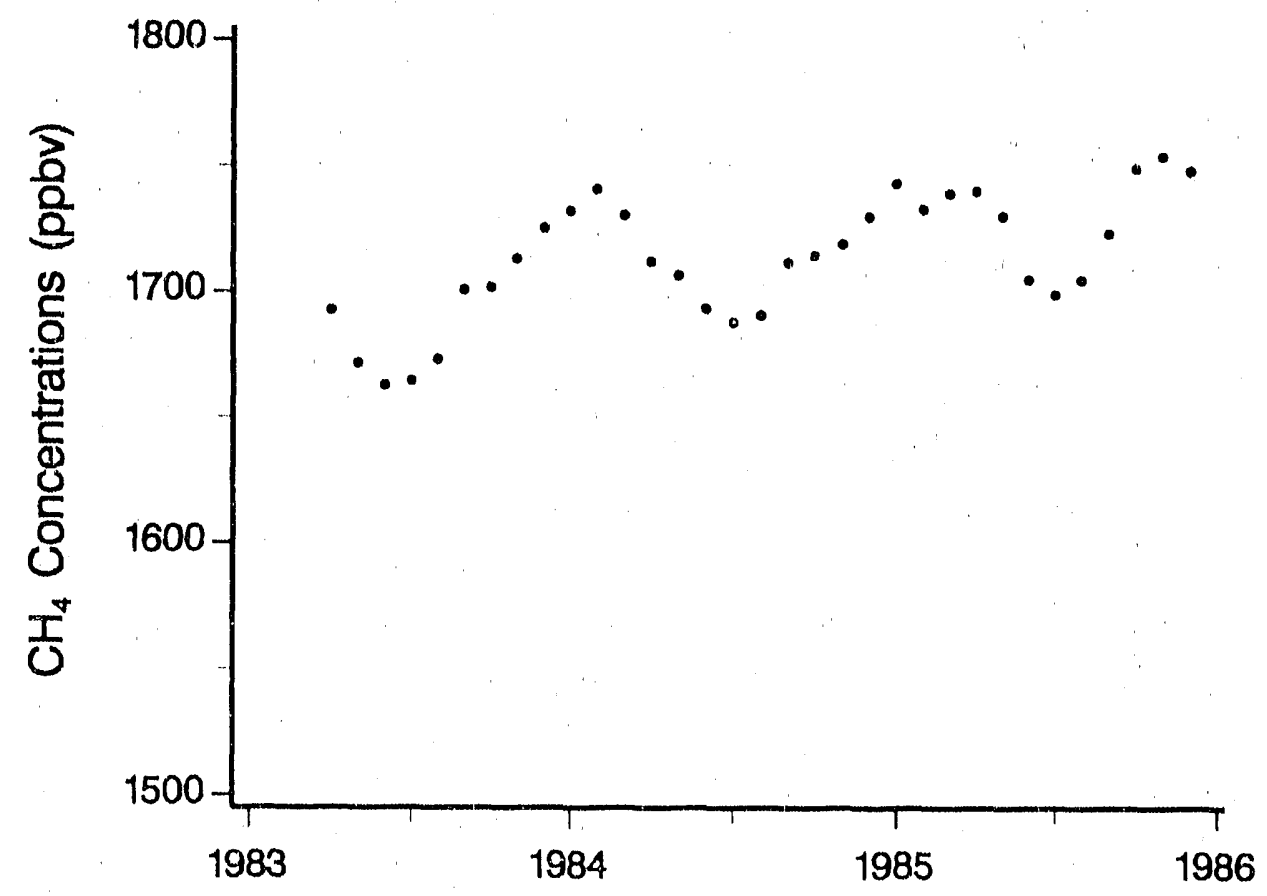

Monthly concentrations of atmospheric $\mathrm{CH}_{4}$.

Mould Bay

Northwest Territories, Canada

Island seashore

$76^{\circ} 14^{\prime} \mathrm{N}, 119^{\circ} 20^{\prime} \mathrm{W}$

$15 \mathrm{~m}$ above $\mathrm{MSL}$ 


\section{TREND}

The sampling site at Mould Bay is operated in cooperation with the Canadian Atmospheric Environment Service. The annual $\mathrm{CH}_{4}$ concentrations at Mould Bay have risen from 1689.4 ppbv in 1983 to $1730.2 \mathrm{ppbv}$ in 1985. After fitting a linear regression to the 12 -month running means to remove the seasonal variations, Steele et al. (1987) calculated the average annual growth rate for Mould Bay to be $12.2 \mathrm{ppbv}$. Steele et al. (1987) also reported that the five northernmost CMDL stations, including Mould Bay, cxhibit major scasonal minimums during the northern summer months of both 1983 and 1984. Stecle et al. (1987) found the degree of scalter for the $\mathrm{CH}_{4}$ data from Mould Bay was much less than the other four northernmost sites and suggested that this reduced scatter may be a reflection of greater distances between the Mould Bay site and significant sources of $\mathrm{CH}_{4}$. 


\section{Mould Bay}

Concentrations of Atmospheric Methane*

$\begin{array}{cccccccccccccc}\text { Year } & \text { Jan } & \text { Feb } & \text { Mar } & \text { Apr } & \text { May } & \text { Jun } & \text { Jul } & \text { Aug } & \text { Sept } & \text { Oct } & \text { Nov } & \text { Dec } & \text { Ann } \\ 1983 & & & & 1692.5 & 1671.4 & 1662.7 & 1664.3 & 1673.0 & 1700.6 & 1701.6 & 1713.0 & 1725.1 & 1689.4 \\ 1984 & 1732.0 & 1740.5 & 1730.1 & 1711.8 & 1706.3 & 1693.0 & 1687.5 & 1690.3 & 171.3 & 1714.1 & 1718.5 & 1729.5 & 1713.7 \\ 1985 & 1742.7 & 1732.4 & 1738.6 & 1739.5 & 1729.7 & 1704.4 & 1698.4 & 1704.3 & 1722.7 & 1748.5 & 1753.5 & 1747.7 & 1730.2\end{array}$

* Methane concentrations expressed in parts per billion by volume (ppbv). Monthly averages calculated as arithmetic means of individual flask concentrations that are indicative of background conditions. Annual averages based on monthly means.

\section{REIERENCTS}

Friaser, P'.J, M.A.K. Kihialil, R.A.

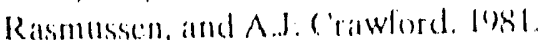

Trends of atmospteric ancthance in the

Southern Hemisphere. (icenthesical

Reseureh Letters 8: Ilxis (x)

Fras'r, P.J., M.A.K. Khillil, R.A.

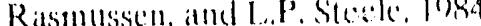

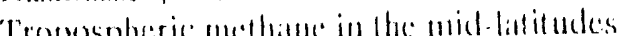

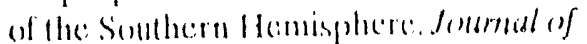

Almospheric (hemistry 1:125 is

K'halil, M.A.K., and R.A. Kinsmus,sen, I (x)

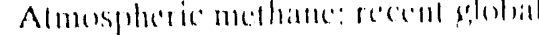

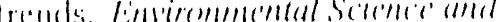

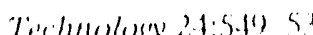

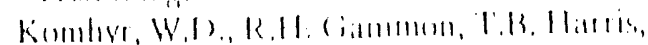

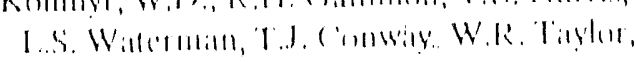

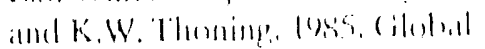

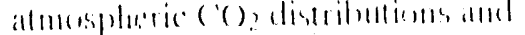

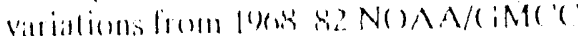

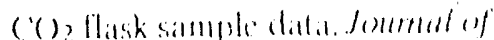

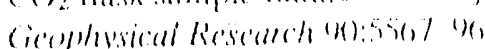

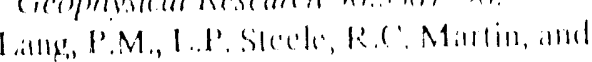

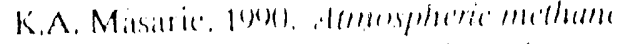

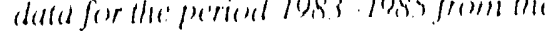

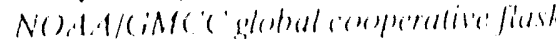

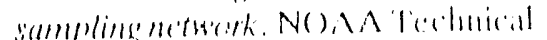

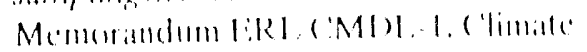

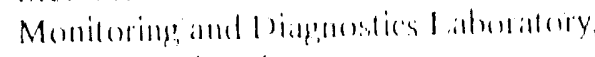
Buslder, colutitlo.

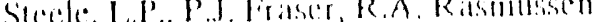
MAK K'halil 'IJ.J. ('onwaly, A.J

Crawford, R.II (iammum, K.A. Masurice,

and K.W. Yhoming. 10827. The globlat

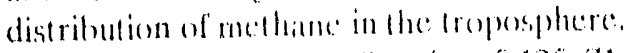

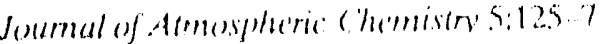




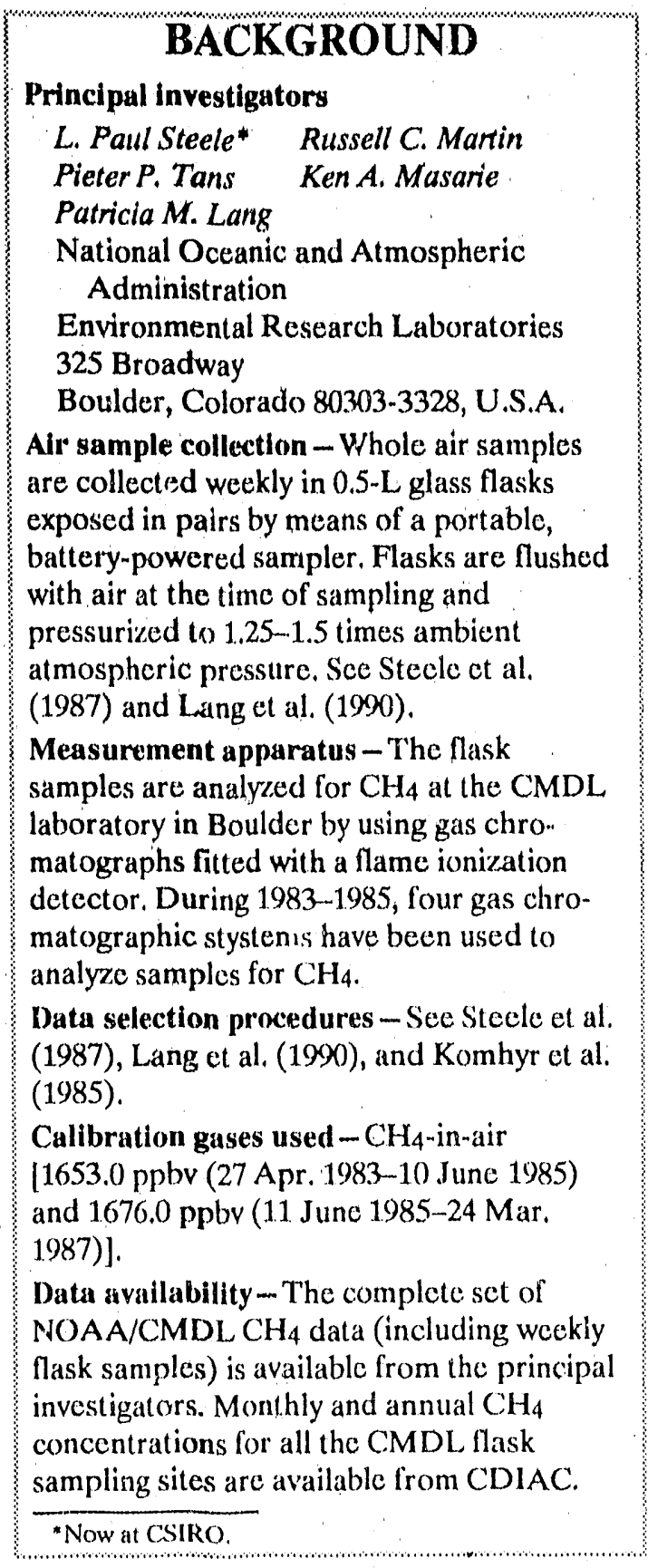

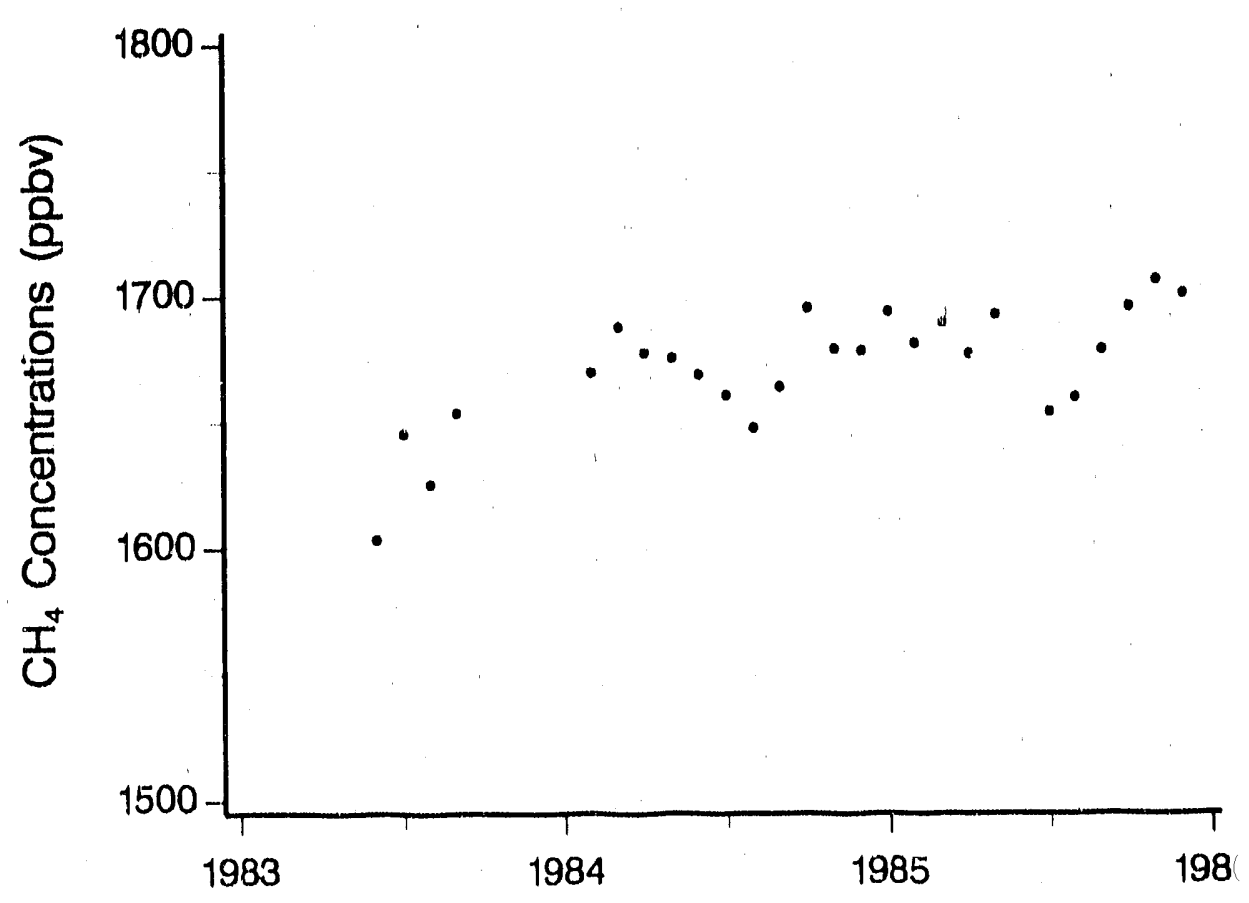

Monthly concentrations of atmospheric $\mathrm{CH}_{4}$.

Niwot Ridge

Colorado, U.S.A.

Alpine mountain

$40^{\circ} 03^{\prime} \mathrm{N}, 105^{\circ} 38^{\prime} \mathrm{W}$

3749 m above $M S L$ 


\section{Atmospheric $\mathrm{CH}_{4}$}

\section{TREND}

The Niwot Ridge station is operated in cooperation with the University of

Colorado's INSTAAR. The average annual $\mathrm{CH}_{4}$ concentration at Niwot Ridge has risen from 1632.2 ppbv in 198.3 to 1684.3 ppbv in 1985. Steele et al. (1987) compared the $\mathrm{CH}_{4}$ data from Niwot Ridge and the Azores site, because both have similar latitudes, and found that for extended periods of time the $\mathrm{CH}_{4}$ concentrations at the high-altitude site of Niwot Ridge are lower than those at the Azores site. Steele et al. (1987) also found a difference of $17 \mathrm{ppbv}$ when comparing the 1984 annual mean values for the two sites. 


\section{Niwot Ridge}

Concentrations of Atmospheric Methane*

\begin{tabular}{|c|c|c|c|c|c|c|c|c|c|c|c|c|c|}
\hline Year & Jan & Feb & Mar & Apr & May & Jun & Jul & Aug & Sept & Oct & Nov & Dec & Ann \\
\hline 1983 & & & & & & 1603.5 & 1645.6 & 1625.7 & 1653.8 & & & & 1632.2 \\
\hline 10 & & 1669.8 & 1688.0 & 1677.8 & 1675.6 & 1669.0 & 1660.9 & 1647.8 & 1664.1 & 1695.3 & 167 & 1678.4 & 1673.3 \\
\hline 1985 & 1693.6 & 1681.2 & 1689.3 & 1676.9 & 1692.4 & & 1653.8 & 1659.5 & 1678.3 & 1695.3 & 1706.0 & 1700.5 & 1684.3 \\
\hline
\end{tabular}

* Methane concentrations expressed in parts per billion by volume (ppbv). Monthly averages calculated as arithmetic means of individua lask concentrations that are indicative of background conditions. Annual averages based on monthly means.

\section{RLIERLNCIS}

Fraice, P..J, M.A.K. K'hialil, R.A

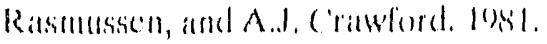

Trends of allmospheric methates in the Somberm Hemisphere. (ierophesiral

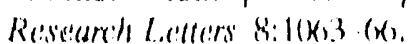

Friscr, P..., M.A.K. Khillil, R.A

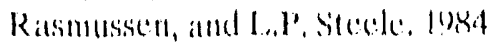

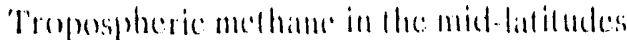
af the Southern llemisphere. Ionernal of demospheric Chemistrey 1:125-35.

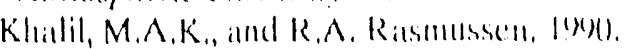

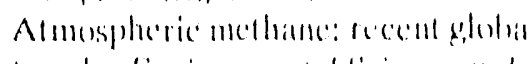

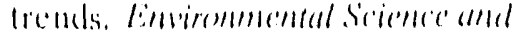

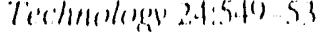

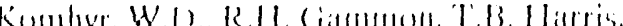

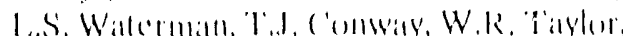
and K.W. Theming, loss (ilutial almosplueric (') () distributioms and

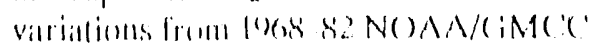

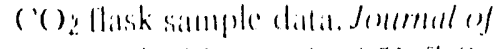

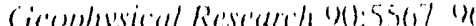

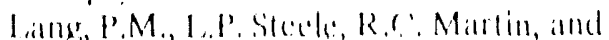

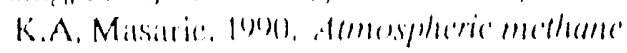

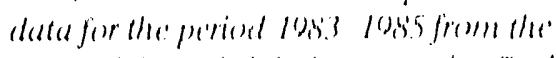

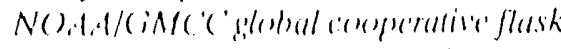
sampling ne'tremk. N()AA Terthnicial Memurandum LRL. ('Ml)L.L. ('limbe

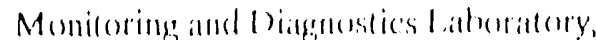
Bunder, colcratu.

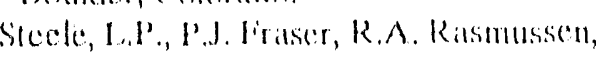
M.A.K. Khitlil, 'IJJ, Conwaty, A.J.

('rawford, R.II, (iamumon, K.A. Malsaric and K.W. 'Thoninge. 1987. The glohel

distribution of methane in the troposphere. Joumal of Almospheric Chomistry 5:125-71 


\section{Palmer Station (Anvers Island)}

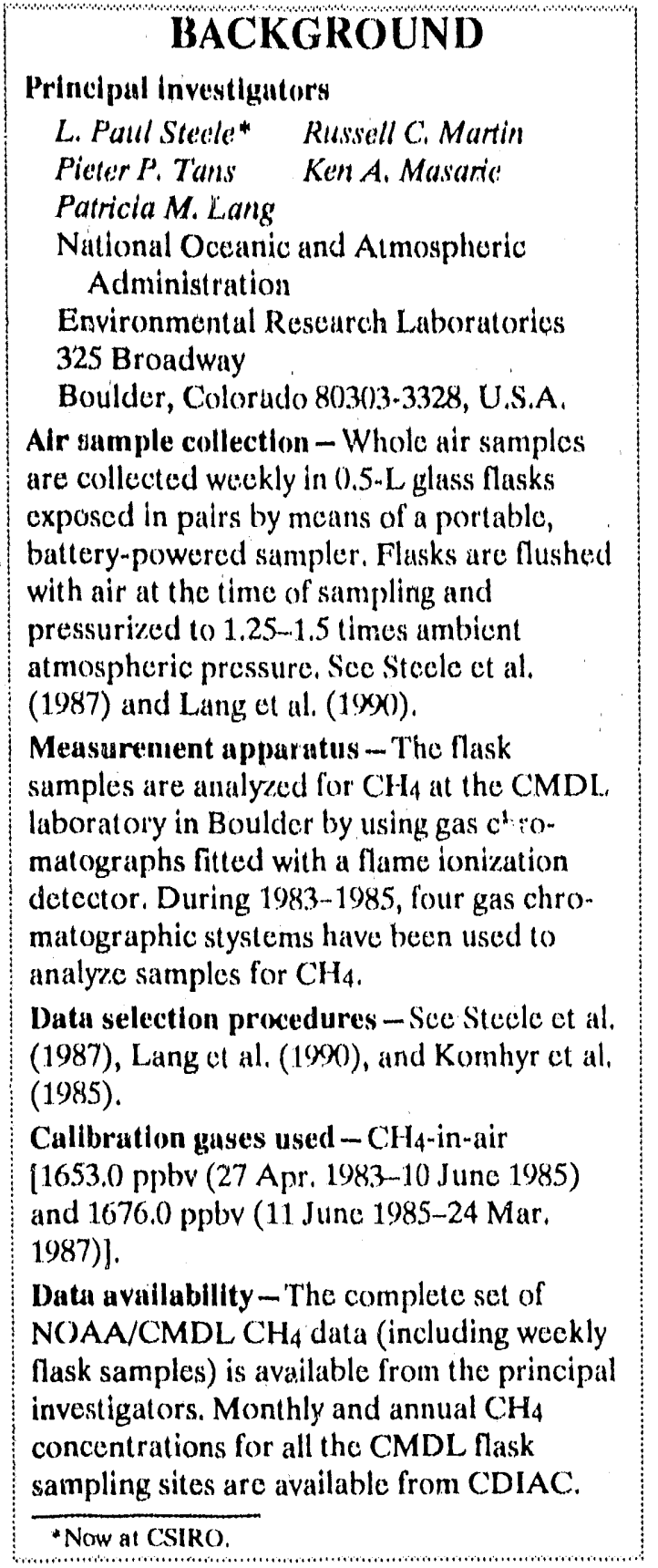

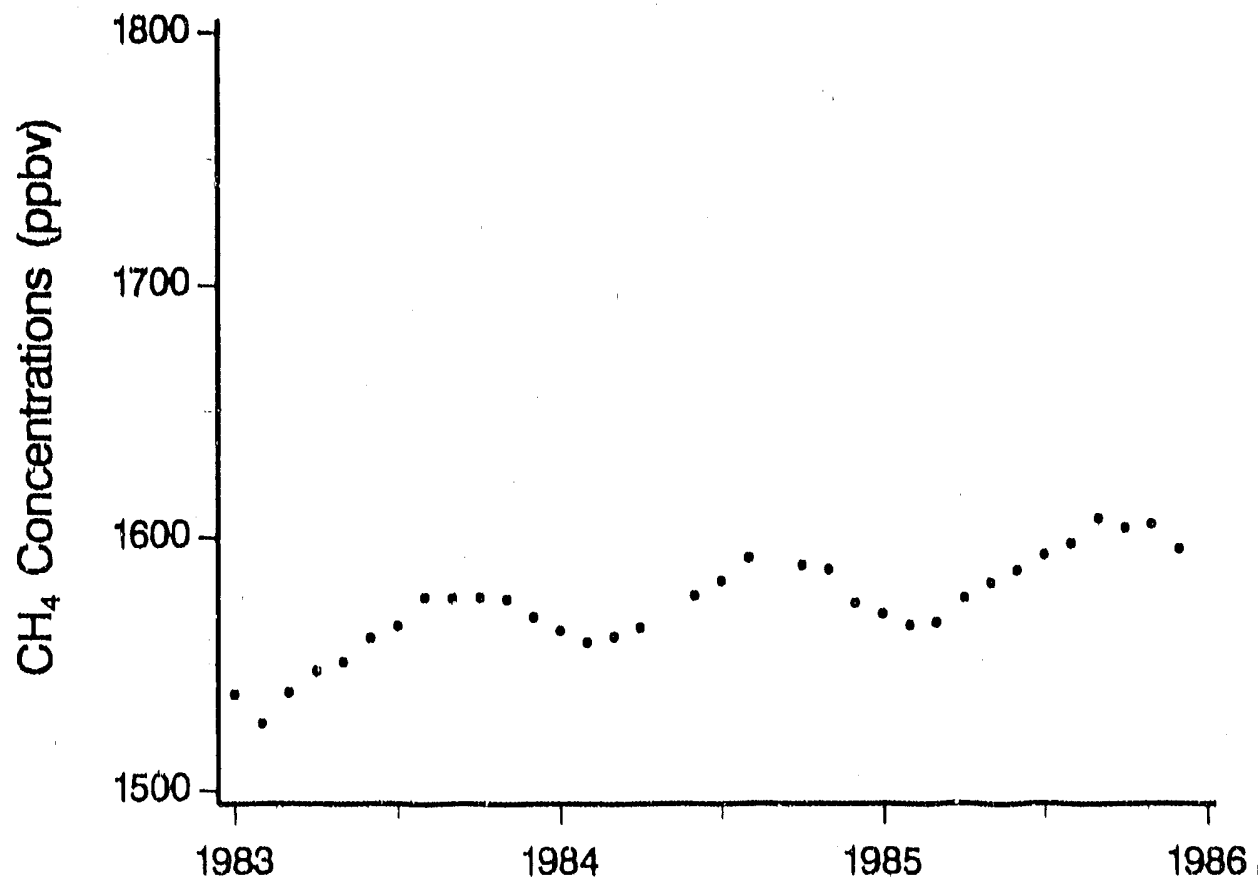

Monthly concentrations of atmospheric $\mathrm{CH}_{4}$.

\section{Palmer Station}

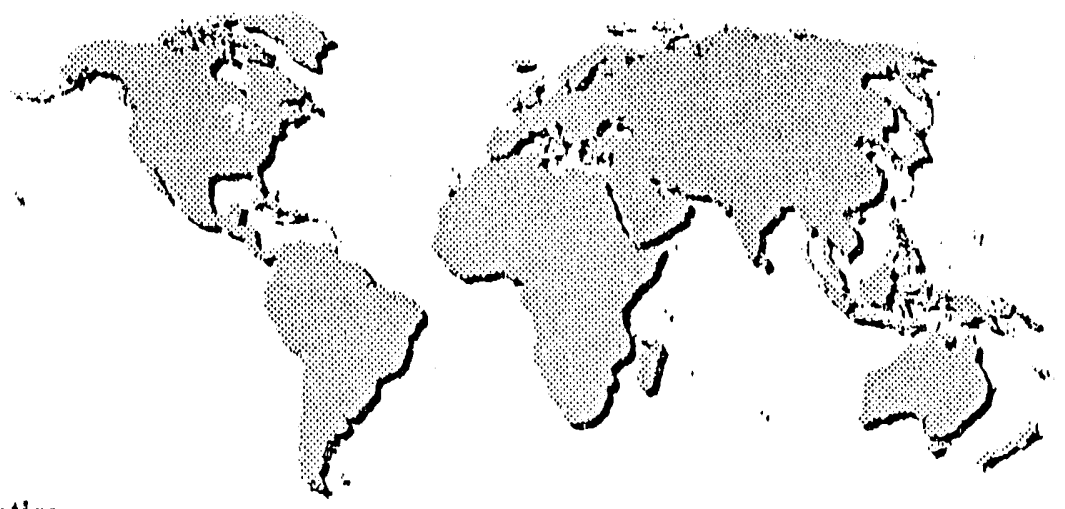

Anvers Island, Antarctica

Barren island seashore $\left.64^{\circ} 55^{\prime} \mathrm{S}, 64^{\circ} \mathrm{ON}\right)^{\prime} \mathrm{W}$ $33 \mathrm{~m}$ above $\mathrm{MSL}$ 


\section{Atmospheric $\mathrm{CH}_{4}$}

\section{TRENI)}

The Palmer Station site is operaled in cocopreration with the Laboralory for Almospheric Research at Washington State Universily. The annual average $\mathrm{CH}_{4} \mathrm{conn}$. eentration from P'almor Station increased from 1558.4 potov in 1983 to 1587.5 pplovin 1985. Using 12-month running means (10 remove seasonal variations) fillod to a quadratic function, Stecle et al. (1987) found the average growth rate all Palmer Station to be 26.0 ppope per year.

Stecke et al. (1987) made direct comparisons of the NOAA/C:MDL ( $\mathrm{H}_{4}$ data with in silu measurements of $\mathrm{CH}_{4}$ it Palmer Station made by Robinson ol al. (1984) during 1982 1983 and found that the 1983 data from both records exhibit a seasonal cycle that is similat in phase and amplitude. However, the concentrations reported by Rubinson et al. (198.4) were -30 ppov lower than those reported by Stecle at al. (1987). Robinson et al. (1984) also reported no increasing trend in $\mathrm{CH}_{4}$ at Palmer Station. The finding differs from the lindings of Fraser ot al. (1984) and stecle ot al. (1987). 


\section{Palmer Station (Anvers Island)}

Concentrations of Atmospheric Methane*

$\begin{array}{cccccccccccccc}\text { Yeur } & \text { Jan } & \text { leb } & \text { Mar } & \text { Apr } & \text { May } & \text { Jun } & \text { Jul } & \text { Aug } & \text { Sept } & \text { Oet } & \text { Nov } & \text { Dec } & \text { Ann } \\ 1983 & 1538.1 & 1526.6 & 1538.9 & 1547.4 & 1550.9 & 1560.4 & 1565.2 & 1576.5 & 1576.1 & 1576.4 & 1575.7 & 1568.7 & 1558.4 \\ 1984 & 1563.3 & 1558.7 & 1560.9 & 1564.4 & & 1577.1 & 1582.9 & 1592.1 & & 1589.1 & 1587.3 & 1574.2 & 1570.0 \\ 1985 & 1569.8 & 1565.4 & 1566.5 & 1576.1 & 1582.2 & 1587.0 & 1593.1 & 1597.7 & 1607.6 & 160) 3.8 & 16(6) 5.3 & 1595.5 & 1587.5\end{array}$

* Methane concentrations expressed in parts per billion by volume (pphv). Monthly averages calculated as arithmelic means of individual flask concentrations that are indicative of background conditions. Annual averages based on mont hly means.

\section{RLWHRLNCWS}

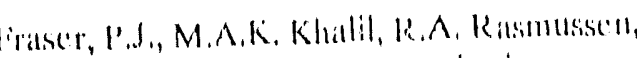

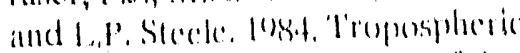
methene in the mich lintitudes of the

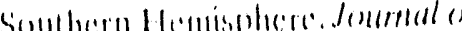

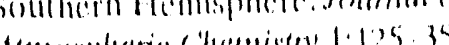

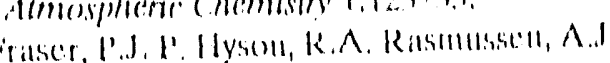

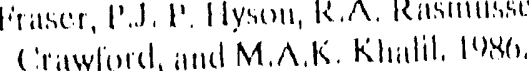

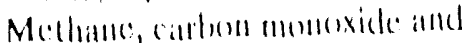

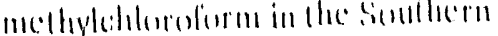

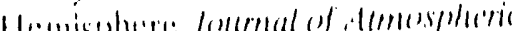

('Mensistry $4: 3$, th

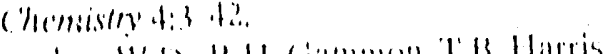

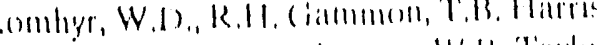

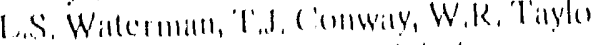

and K.W. Thenning. Jess, (ilatril

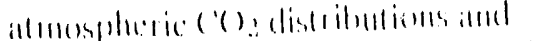

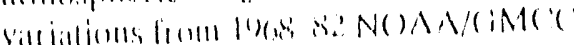

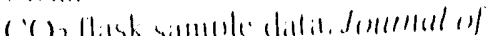

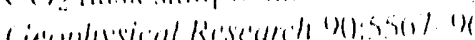

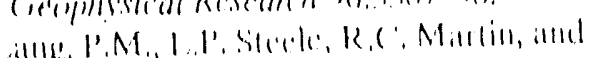

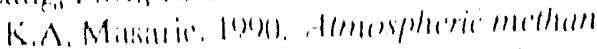

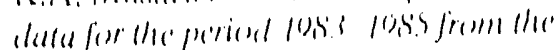

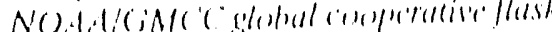

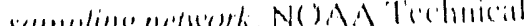

Menter

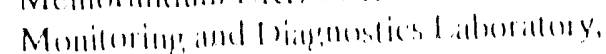

Bundere colloride.

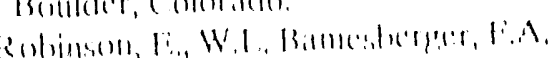

Monzlit, A.s. Wisyld and s.t: Waylell.

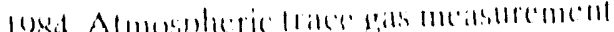

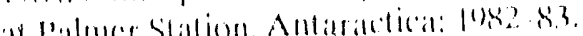

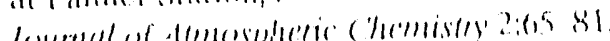

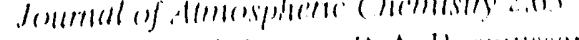

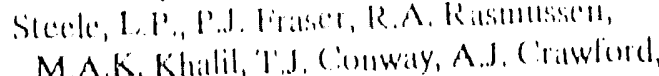

M.A.K. Khalli, 'I'J. C. Mwaly, A.J. ('Titwlon,

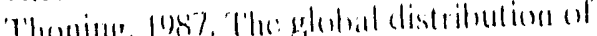

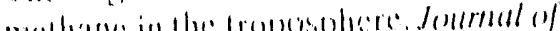

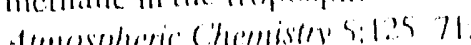




\section{Point Barrow}

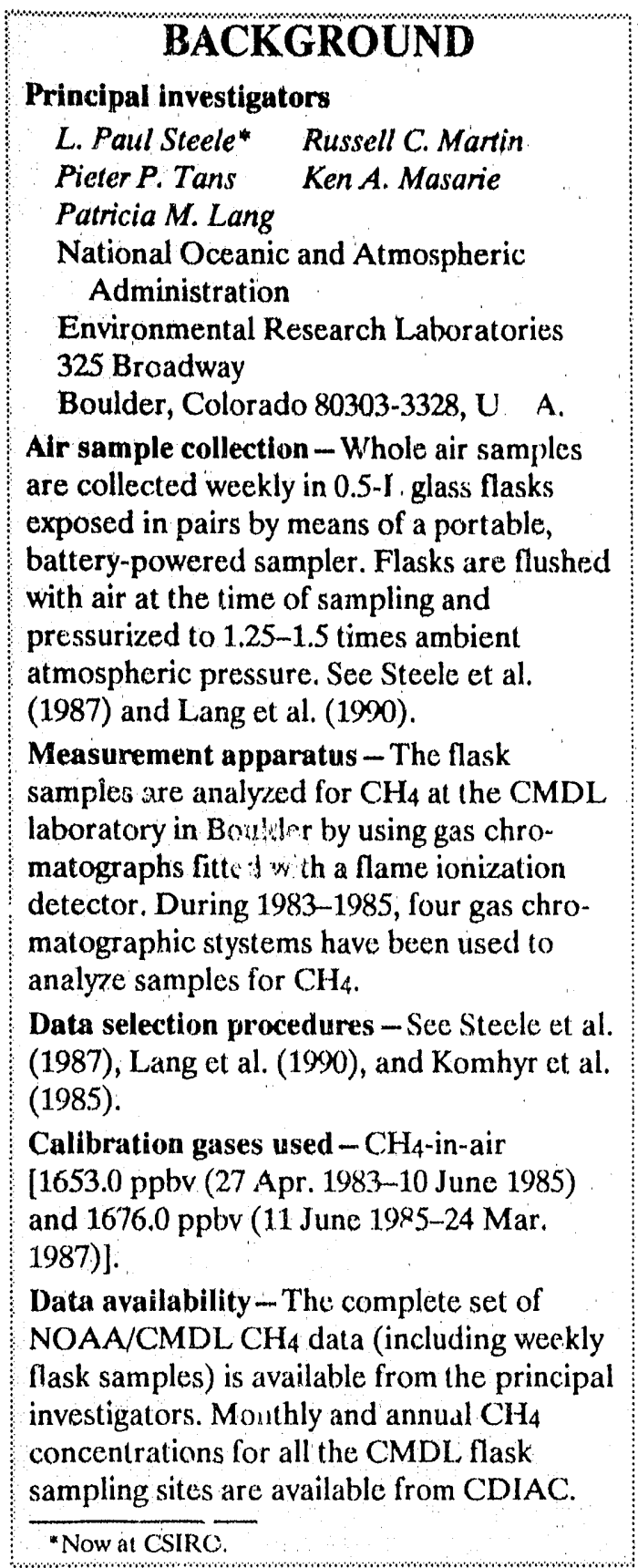

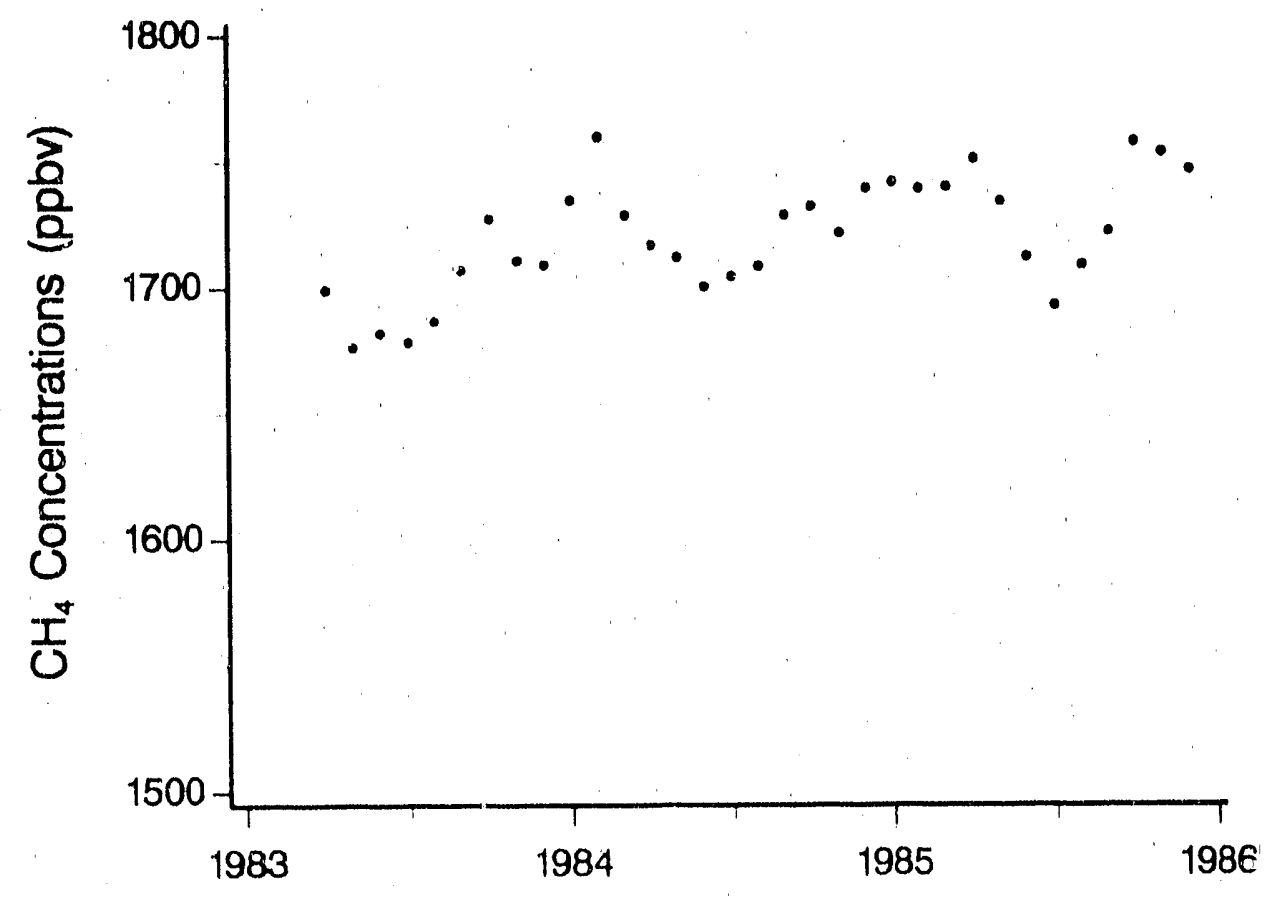

Monthly concentrations of atmospheric $\mathrm{CH}_{4}$.

Point Barrow Alaska, U.S.A. Arctic c xtal seashore $71^{\circ} 19^{\prime} \mathrm{N}, 156^{\circ} 36^{\prime} \mathrm{W}$ $11 \mathrm{~m}$ above $M S L$ 


\section{Atmospheric $\mathrm{CH}_{4}$}

\section{TREND}

The sampling site at Point Barrow was est. blished as a CMDL station in 1973 for the purpose of measuring atmospheric $\mathrm{CO}_{2}$ concentrations. Analyses of flask samples for $\mathrm{CH}_{4}$ concentrations began in 1983. The average annual $\mathrm{CH}_{4}$ concentration at Point Barrow rose from 1697.5 ppbv in 1983 to 1733.0 ppbv in 1985. Steele et al. (1987) reported an average annual growth rate of 15.7 ppbv for Point Barrow and observed that all of the northernmost CMDL sites (Cape Mcares, Oregon; Cold Bay, Alaska; Ocean Station "M," North Atlantic; Point Barrow, Alaska; and Mould Bay, Canada) exhibited major seasonal minimums during the northern summers of both 1983 and 1984 . 
Concentrations of Atmospheric Methane*

$\begin{array}{cccccccccccccc}\text { Year } & \text { Jan } & \text { Feb } & \text { Mar } & \text { Apr } & \text { May } & \text { Jun } & \text { Jul } & \text { Aug } & \text { Sept } & \text { Oct } & \text { Nov } & \text { Dec } & \text { Ann } \\ 1983 & & & & 1699.2 & 1676.4 & 1682.1 & 1678.4 & 1686.9 & 1707.0 & 1727.5 & 1710.8 & 1709.1 & 1697.5 \\ 1984 & 1734.7 & 1759.9 & 1728.7 & 1716.9 & 1711.9 & 1700.3 & 1704.4 & 1708.3 & 1728.6 & 1732.1 & 1721.4 & 1739.3 & 1723.9 \\ 1985 & 1741.6 & 1738.9 & 1739.7 & 1750.7 & 1733.8 & 1711.7 & 1692.4 & 1708.5 & 1721.7 & 1757.3 & 1753.0 & 1746.2 & 1733.0\end{array}$

* Methane concentrations expressed in parts per billion by volume (ppbv). Monthly averages calculated as arithmetic means of individual flask concentrations that are indicative of background conditions. Annual averages based on monthly means.

\section{REFERENCES}

Fraser, PJ MAK Khalil, R.A.

Rasmusscen, and A.J, Crawford. 1981

Trends of atmospheric methane in the

Southern Semisphere. (ietophysical

Research Leetters 8:10k,3-6xi.

Frascer, P.J., M.A.K. Khalil, R.A

Rasmussen, and L.P. Stecle. 19834.

Tropospheric methane in the mid-latitudes

of the Southern Hemisphere. Journat of

Atmospheric Chemistry 1:125-35.

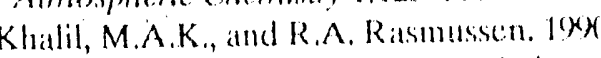

Atmospheric melhane: recent global

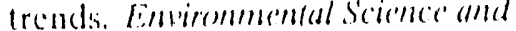

Tercluologen 24:549).53.

Kumber W. R.H Giammon, T.B. Harris,

LS Watcrman, T.J. conway, W.R. Taylor,

and K.W. Thouning, lisks cilubal

atmospherie (C) 2 distributions and

vartiations from l')

(c) flask simule ditia Joirmul of

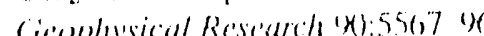

Lang, P.M., L.P. Sicele, R.C. Martin, and

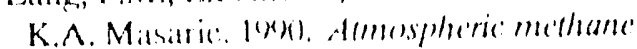
duta for the peried 1989.1085 from the

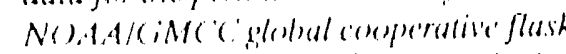
sampling netwerk. NOAA Technical Memerandum RRL ( MDL L ( Climate

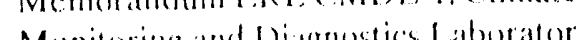
Boulder, Coldrialo.

Stecle, L.P., P.J. Fraser, R.A. Rasmussen, M.A.K. Khalil, T.J. Conway, A.J.

Crawford, R.H. (iammon, K.A. Masaric,

and K.W. Thoming. 1987. The global

distribution of me thane in the troposphere.

distribution of mes basc

Journal of Atmosphicric Chernistry 5:125-71. 


\section{St. Croix}

\section{BACKGROUND \\ Principal investigators \\ L. Paul Steele* Russeil C. Martin \\ Pieter P. Tans Ken A. Masarie \\ Patricia M. Lang \\ National Oceanic and Atmospheric Administration}

Environmental Research Laboratories 325 Broadway

Boulder, Colorado 80303-3328, U S.A.

Air sample collection - Whole air samples are collected weekly in $0.5-\mathrm{L}$ glass flasks exposed in pairs by means of a portable, battery-powered sampler. Flasks are flushed with air at the time of sampling and pressurized to 1.25 1.5 times ambient atmospheric pressure. Sec Stecle et al. (1987) and Lang et al. (1990).

Measurement apparatus - The flask samples are analyzed for $\mathrm{CH}_{4}$ at the CMDL laboratory in Boulder by using gas chromatographs fitted with a flame ionization detector. During 1983-1985, four gas chromatographic stystems have been used to analyze samples for $\mathrm{CH}_{4}$.

Data selection procedures - See Steele et al. (1987), Lang et al. (1990), and Komhyr et al. (1985).

Calibration gases used- $\mathrm{CH}_{4}$-in-air [1653.0 ppbv (27 Apr. 1983-10 June 1985) and $1676.0 \mathrm{ppbv}$ (11 June 1985-24 Mar. 1987)].

Data availability - The complete set of NOAA/CMDL CH4 data (including weekly flask samples) is available from the principal investigators. Monthly and annual $\mathrm{CH}_{4}$ concentrations for all the CMDL flask sampling sites are available from CDIAC.

- Now at CSIRO.

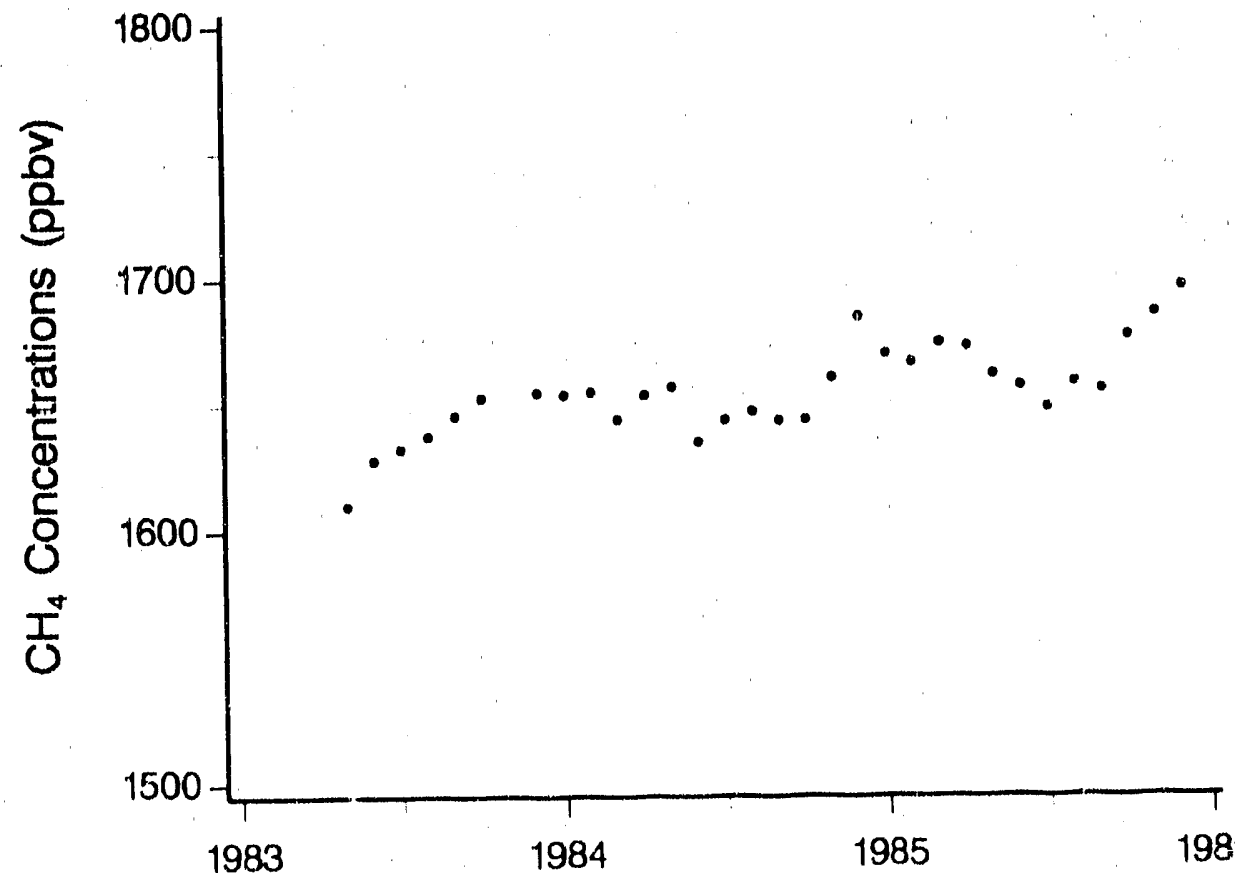

Monthly concentrations of atmospheric $\mathrm{CH}_{4}$.

St. Croix

U.S. Vingin Islands

Island seashore $17^{\circ} 45^{\prime} \mathrm{N}, 64^{\circ} 45^{\prime} \mathrm{W}$ 3 m above $M S L$ 


\section{Atmospheric $\mathrm{CH}_{4}$}

.

\section{TREND}

The sampling site at St. Croix is operated in cooperation with Fairleigh Dickinson University. The annual average $\mathrm{CH}_{4}$ concentration at St. Croix rose from $1637.2 \mathrm{ppbv}$ in 1983 to $1667.9 \mathrm{ppbv}$ irs $28 \mathrm{~s}$. By fitting a linear regression to the 12-month running mean values, Steele et al. (1987) calculated an average growth rate of 11.7 ppbv per year at St. Croix. 
Concentrations of Atmospheric Methane*

$\begin{array}{cccccccccccccc}\text { Year } & \text { Jan } & \text { Feb } & \text { Mar } & \text { Apr } & \text { May } & \text { Jun } & \text { Jul } & \text { Aug } & \text { Sept } & \text { Oct } & \text { Nov } & \text { Dec } & \text { Ann } \\ 1983 & & & & & 1609.9 & 1628.0 & 1632.5 & 1637.4 & 1645.5 & 1652.5 & & 1654.5 & 1637.2 \\ 1984 & 1653.6 & 1654.5 & 1643.8 & 1653.5 & 1656.5 & 1635.0 & 1643.5 & 1646.8 & 1643.4 & 1643.4 & 1660.0 & 1684.1 & 1651.5 \\ 1985 & 1669.2 & 1665.9 & 1673.6 & 1672.1 & 1661.1 & 1656.2 & 1647.9 & 1657.8 & 1654.8 & 1676.2 & 1685.0 & 1695.5 & 1667.9\end{array}$

*Methane concentrations expressed in parts per billion by volume (ppbv). Monthly averages calculated as arithmetic means of individual flask concentrations that are indicative of background conditions. Annual averages based on monthly means.

\section{REFLRLNCWA}

Erate, H.J., M.A.K. Khallil, R.A

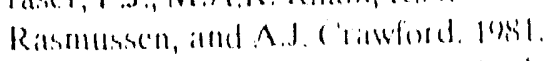

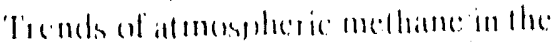

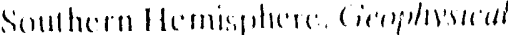

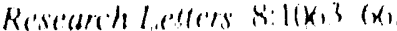

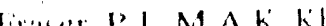

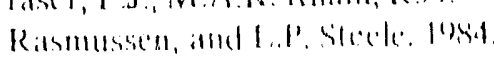

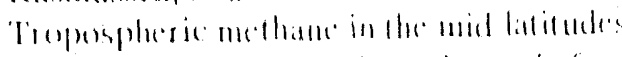

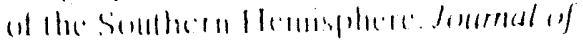

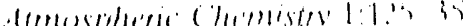

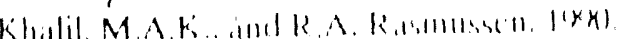

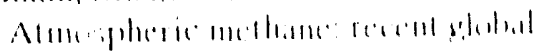

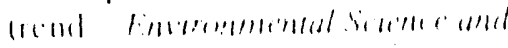

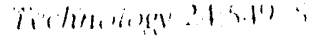

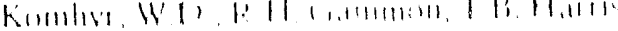

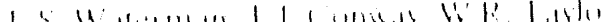

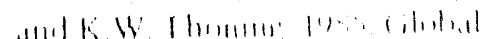

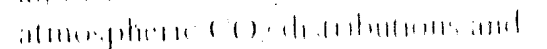

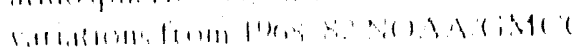

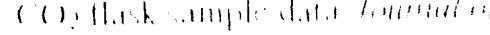

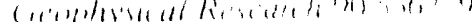

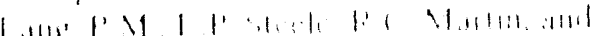

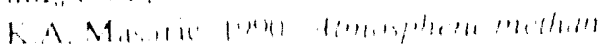

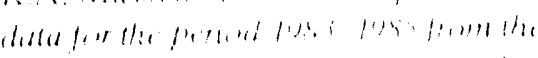

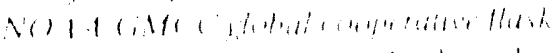

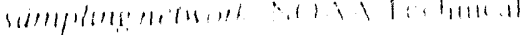

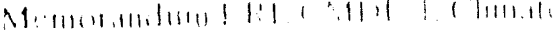

19

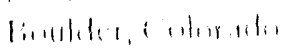

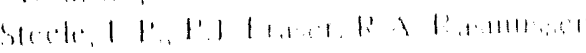

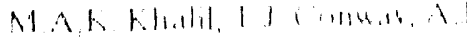

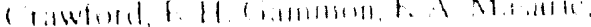

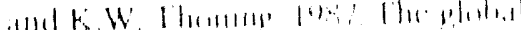

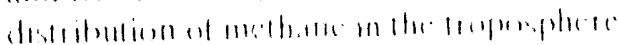

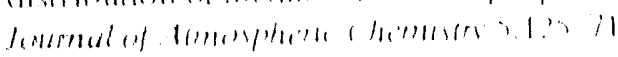




\section{Terceira Island (Azores)}

\section{BACKGROUND \\ Principal investigators \\ L. Paul Steele* Russell C. Martin Pieter P. Tans Ken A. Masarie \\ Patricia M. Lang \\ National Oceanic and Atmospheric Administration \\ Environmental Reșearch Laboratories 325 Broadway \\ Boulder, Colorado 801303-3328, U.S.A.}

Air sample collection - Whole air samples are collected weekly in 0.5 -L glass flasks exposed in pairs by means of a portable, battery-powered sampler. Flasks are flushed with air at the time of sampling and pressurized to 1.25 1.5 times ambient atmospheric pressure. Sec Steele et al. (1987) and Lang et al. (1900)).

Messurement apparatus - The flask samples are analyzed for $\mathrm{CH}_{4}$ at the CMDL. laborat ory in Boulder by using gas chromatographs fitted with a llame ionization detector. During 1987-1985, four gas chromatographic stystems have been used to analyze samples for $\mathrm{CH}_{4}$.

Data selection procedures - See Sitede et al. (1987), Lang et al. (1990), and Komhyr et al. (1985).

Calibration gases used- $-\mathrm{CH}_{4}$-in-air [1653.0 ppby (27 Apr. 198.3 10 June 1985) and $16 \%$ pphe (11 June 1985-24 Mar. 1987)].

Data availability - The complete set of NOAA/CMDL $\mathrm{CH}_{4}$ data (including weckly flask samples) is available from the principal investigators. Monthly and anmual $\mathrm{CH}_{4}$ concentrations for all the CMDI. flask sampling sites are available from CDIAC.

- Now at CSIRO.

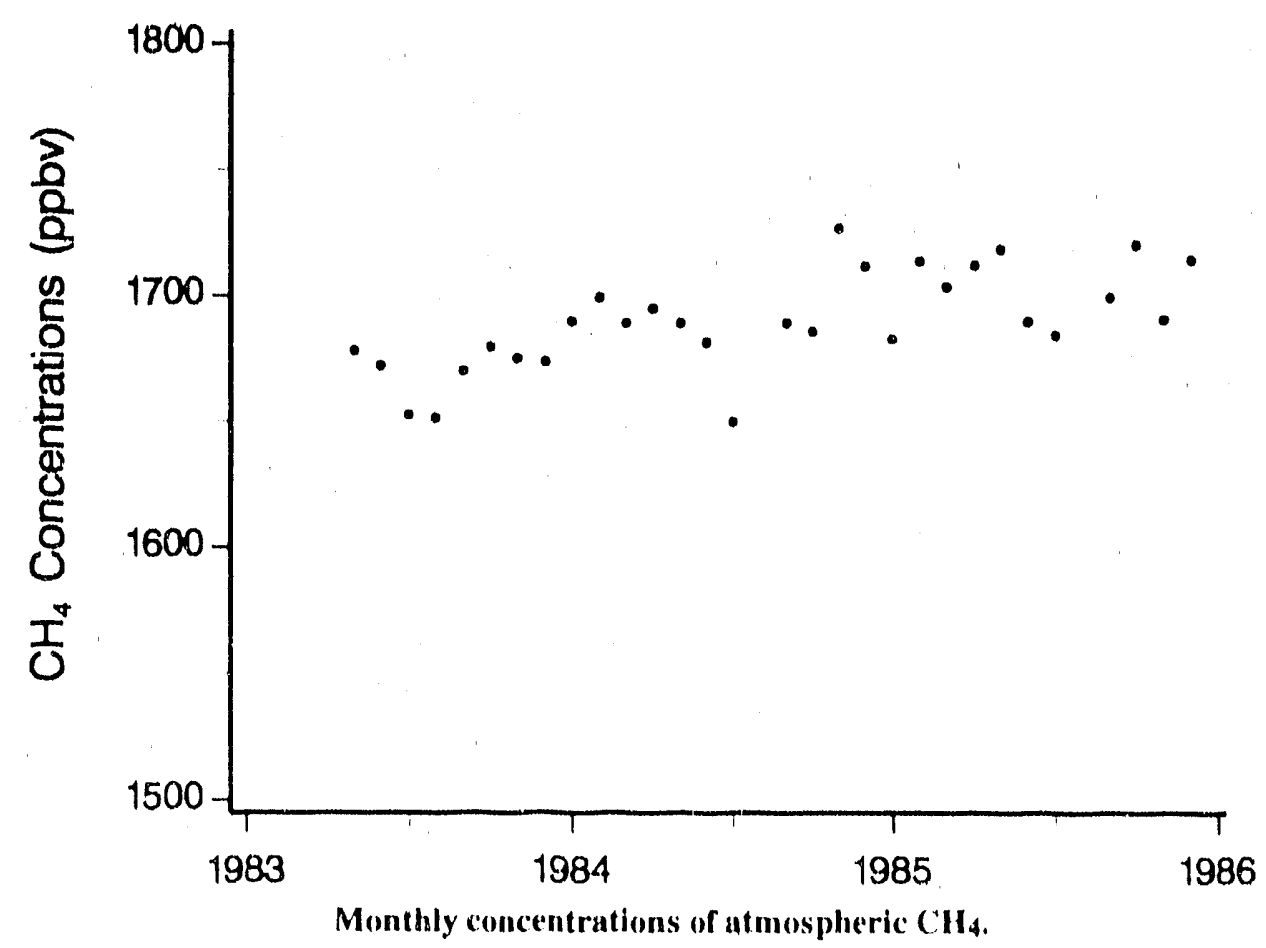

Terceira Island Azores, North Atlantic.

Island seiashore $38^{\circ} 45^{\prime} \mathrm{N}, 27^{\circ} 05^{\prime} \mathrm{W}$ $30 \mathrm{~m}$ above $\mathrm{MSL}$ 


\section{Atmospheric $\mathrm{CH}_{4}$}

\section{TREND}

The average annual $\mathrm{CH}_{4}$ concentration at the Azores rose from $1669.0 \mathrm{ppbv}$ in 1983 to 1702.3 ppbv in 1985. By fitting a linear regression to the 12 -month running means, Steele et al. (1987) reported an average annual CH4 growth rate of 17.0 ppbv for the Azores. Stcole et al. (1987) also compared the methane data from the Azores and Niwot Ridge sites and found that the longterm averages for concentrations at the high-altitude site of Niwot Ridge were lower than those at the Azores. When comparing the annual mean values for 1984, stecle et al. (1987) found the difference between the two sites to be 17 pptov.

The Azores sampling site is operated in cooperation with the 7 th Weather Wing of the United States Air Force. 


\section{Terceira Island (Azores)}

Concentrations of Atmospheric Methane*

$\begin{array}{cccccccccccccc}\text { Year } & \text { Jan } & \text { Feb } & \text { Mar } & \text { Apr } & \text { May } & \text { Jun } & \text { Jul } & \text { Aug } & \text { Sopt } & \text { Oct } & \text { Nov } & \text { Dec } & \text { Ann } \\ 1983 & & & & & 1678.0 & 1672.0 & 1652.5 & 1651.3 & 1670.0 & 1679.5 & 1675.0 & 1673.5 & 16699.0 \\ 1984 & 1689.9 & 1699.2 & 1689.1 & 16(95.0 & 1689.0 & 1681.5 & 1649.8 & & 1689.1 & 1685.7 & 1726.5 & 1711.5 & 1691.5 \\ 1985 & 1682.7 & 1713.4 & 1703.2 & 1711.7 & 1718.1 & 16899.4 & 1683.9 & & 1698.9 & 1719.9 & 16(3) .2 & 1713.9 & 17(12.3\end{array}$

* Methane concentrations expressed in parts per billion by volume (ppbv). Monthly averages calculated as arithmetic meanss of individual flask concentrations that are indicative of background conditions. Annual averages based on monthly means.

\section{Almosplaceric ( H.t}

\section{RERHRLNEIS}

Firiser, I'.I., M.A.K. Khialit, R.A

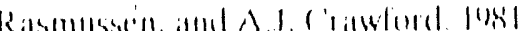

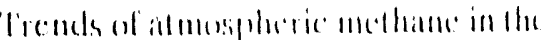

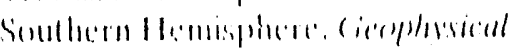

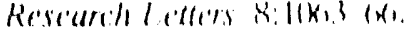

Fraser, P.J., M.A.K. Khallil, R.A

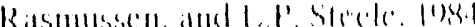

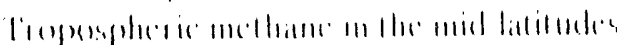

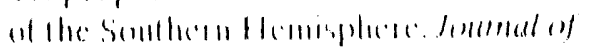

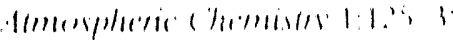

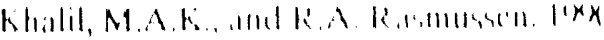

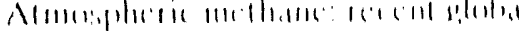

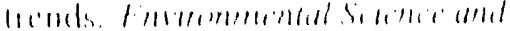

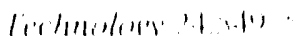

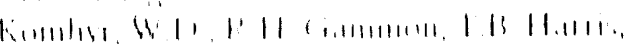

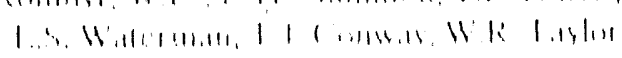

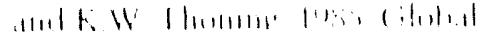

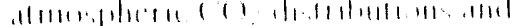

(2)

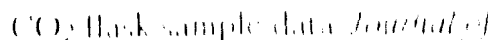

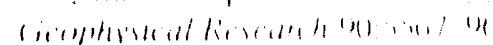

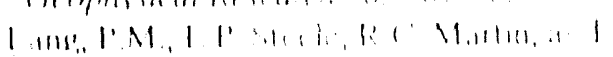

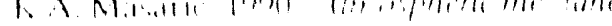

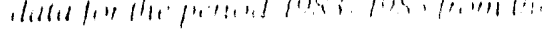

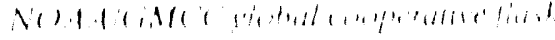

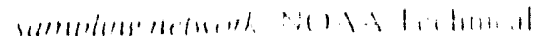

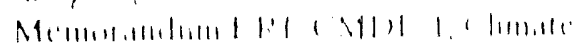

A

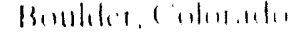

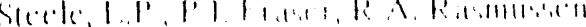

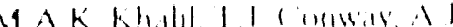

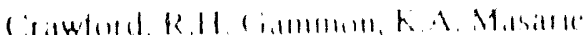

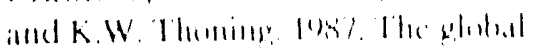

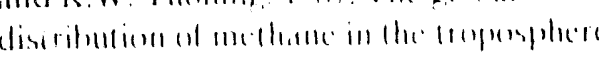

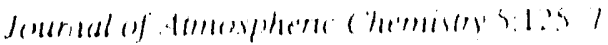




\section{Temperature Records}




\section{Introduction}

During the past 20 years, much attention has been given to the potential climatic effects of increasing concontrations of at mospheric greenhouse gases. This is not surprising because these potential climatic effocts coudd have far-reaching environmental, economb, and social consequences. Much of the work that has been porformed during this period hats involved (1) climate modeling or empirical analyses attempting to attributc elimatic changes to various astronomical and atmosphoric factors and (2) assombly and oxamination of new geological, historical, and instrumental data. From these studies, researchers have gained important now insights into the possible climatic response to the increasing concentrations of $\left(\mathrm{C}_{2}\right.$ and other trace gases, together with a better understanding of the sensitivity of the overall climale system to both human and natural porturbations.

In order to isolate the "greenhouse signal," or that part of the climale change that is indicative of increased concentrations of greenhouse gases, it is imperative that we have: long-term observational records that can be used to identify the climate shanges that have aldendy oceurred. Fortunately, for the past eentury many climatic variubles (c.g. surfite air temperature) hate been measured at a large number of moteorological stations, mostly at land locallions in the Northern Hemisphere. It is also imperativi: that these observational records have sufficient spatial coverage. Although local and regional varialions in lemperalture are important in assessing the impacts of climate and climate change on secis:ty, larger-scalc averages are most likely to indicate detectable changesi in climate that result from changes in atmospherie trace gats concentrations, Researchers have compiled and analyod several time series of harge-scale average surface air temperatures largely on the hasis of land-based data and dalla from a fiw fixed-position wealler ships. To determine large-scale tropospleric and st ratespheric temperatures, radiosonde and rocketsonde data have typically been used. Many of these series

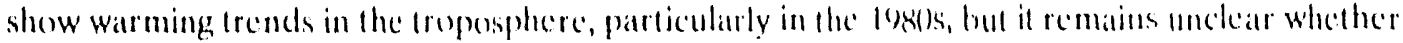

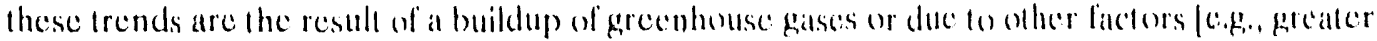

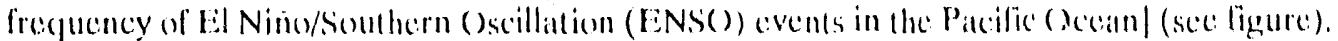

The following pages provide several long-term records of lemperallures and femperallure:

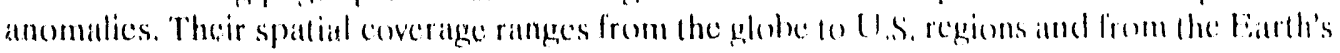
surface 10 the low stratesphere. The first two recorde are gled al and hemispheric temperalure anomalies. These records are followed by annual and seasonal temperature anomalies for the surface, troposphere, fropopatuse, and low stratosplecese. (ilohal anomaly estimales are presented lirst followed by northern and southern zonal averinges and averages fer catch hemisphere. Finally, seasenal and annual lemperatures for the l'nited states are presented with mational estimates first followed by estimates for the sub-repgons that comprise he andergegated West, Contral, and Eastern regions. These records represent only a fraction of the long-term records available; however, lhey are lrequendly relerenced in studies addessing, polential grocenhouse: gits-induced climate changes. All the data presented in this section were mate available to the

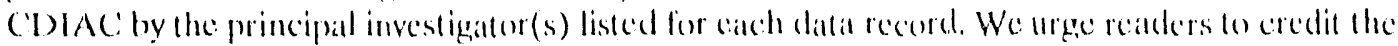
principal investigators and the ir organizattons when using lhese data. Isers arse catutioned lo pay

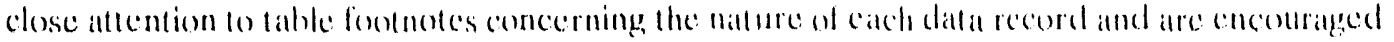

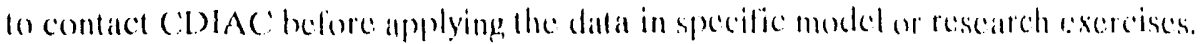

TRliNI)S ()( ) 


\section{Introduction}

During the past 20 years, much attention has been given to the potential climatic effects of increasing concentrations of atmospheric greenhouse gases. This is not surprising because these potential climatic effects could have far-reaching environmental, economic, and social consequences. Much of the work that has been performed during this period has involved (1) climate modeling or empirical analyses attempting to attribute climatic changes to various astronomical and atmospheric factors and (2) assembly and examination of new geological, historical, and instrumental data. From these studies, researchers have gained important new insights into the possible climatic response to the increasing concentrations of $\mathrm{CO}_{2}$ and other trace gases, together with a better understanding of the sensitivity of the overall climate system to both human and natural perturbations.

in order to isolate the "greenhouse signal," or that part of the climate change that is indicative of increased concentrations of greenhouse gases, it is imperative that we have long.term observational records that can be used to identify the climate changes that have alrcady occurred. Fortunately, for the past century many climatic variables (e.g., surface air temperature) have been measured at a large number of meteorological stations, mostly at land locations in the Northern Hemisphere. It is also imperative that these observational records have sufficient spatial coverage. Although local and regional variations in temperature are important in assessing the impacts of climate and climate change on society, large-scale averages are most likely to indicate detectable changes in climate that result from changes in atmospheric trace gas concentrations. Researchers have compiled and analyzed several time series of large-scale average surface air temperatures largely on the basis of land-based data and data from a few fixed-position weather ships. To determine large-scale tropospheric and stratospheric temperatures, radiosonde and rocketsonde data have typically been used. Many of these series show warming trends in the troposphere, particularly in the $1980 \mathrm{~s}$, but it remains unclear whether these trends are the result of a buildup of greenhouse gases or due to other factors [e.g., greater frequency of El Niño/Southern Oscillation (ENSO) events in the Pacific Ocean] (see figure).

The following pages provide several long-term records of temperatures and temperature anomalies. Their spatial coverage ranges from the globe to U.S. regions and from the Earth's surface to the low stratosphere. The first two records are global and hemispheric temperature anomalies. These records are followed by annual and seasonal temperature anomalies for the surface, troposphere, tropopause, and low stratosphere. Global anomaly estimates are presented first followed by northern and southern zonal averages and averages for each hemisphere. Finally, seasonal and annual temperatures for the United States are presented with national estimates first followed by estimates for the sub-regions that comprise the aggregated West, Central, and Eastern regions. These records represent only a fraction of the long-term records available; however, they are frequently referenced in studies addressing potential grecnhouse gas-induced climate changes. All the data presented in this section were made available to the CDIAC by the principal investigator(s) listed for each data record. We urge readers to credit the principal investigators and their organizations when using these data. Users are cautioned to pay close attention to table footnotes concerning the nature of each data record and are encouraged to contact CDIAC before applying the data in specific model or rescarch exercises.

TRENDS '9() 


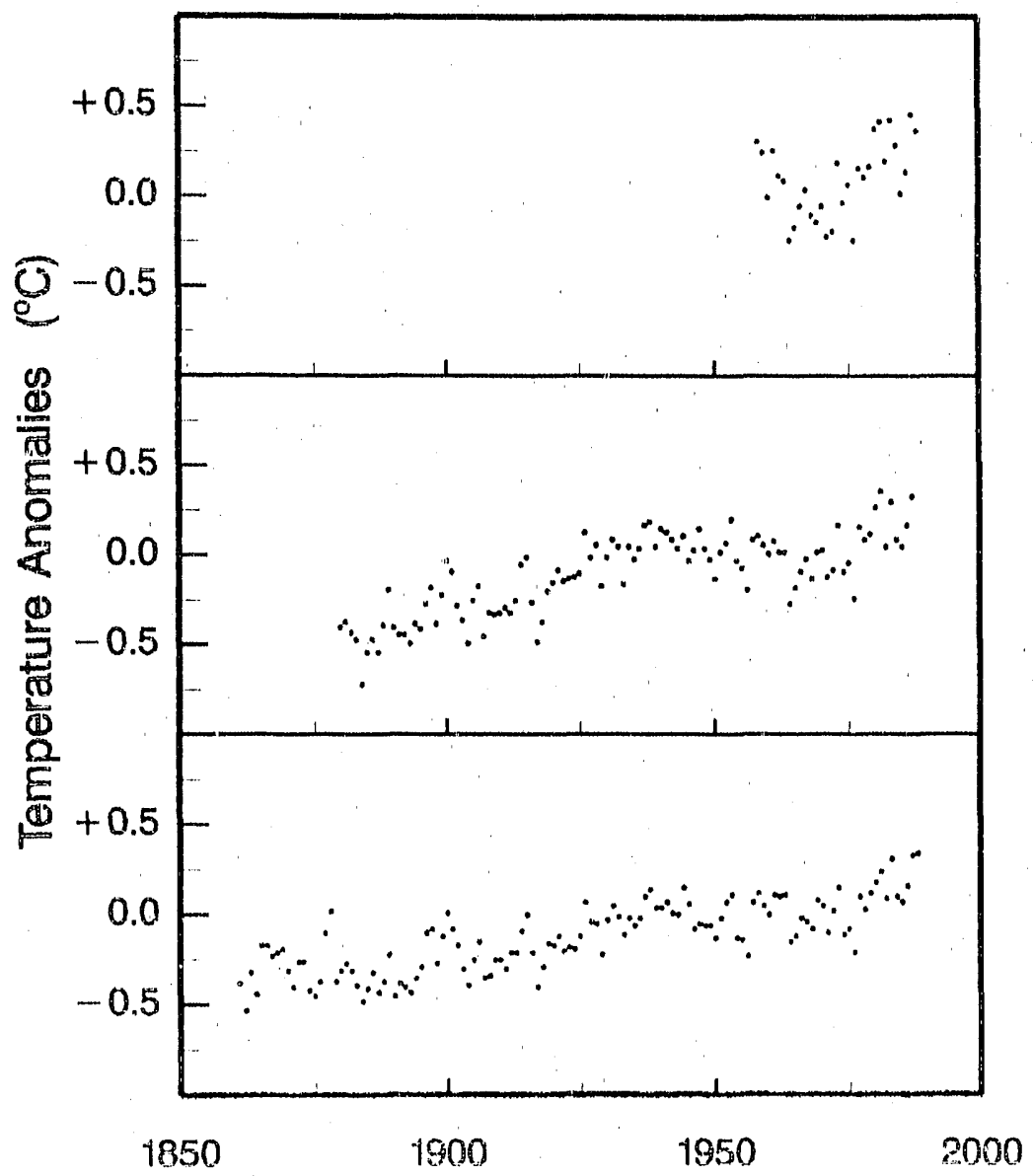

Annual global temperature anomalies (Angell's surface data [see pg. 199] are shown in the upper box; Hansen and Lebedeff's data [see pg. 197] are shown in the middle box; and Jones, Wigley, and Wright's data [see pg. 195] are shown in the lower box). 


\section{BACKGROUND}

\section{Principal investigators}

$P . D$. Jones

T. M. L. Wiglev

P. B. Wright

Climatic Research Unit

School of Environmental Sciences

University of East Anglia

Norwich, United Kingdom NR4 7TJ

\section{Sponsoring agency}

U.S. Department of Energy

Carbon Dioxide Research Program

Period of record $-1861-1988$ (relative to a 1950-1979 reference period).

Method - These estimates were compiled by Jones et al. (1986a, b, c) and Jones (1988) and are based on corrected land and marine data. Land data were derived from metcorological data and fixed-position weather ship data that were corrected for nonclimatic errors, such as station shifts and/or instrument changes. The marine data were from the Comprehensive Ocean-Atmosphere Data Set (COADS) compilation, which extends (with updates) to 1986. Updates to 1988 were based on hemispheric sea surface temperature (SST) estimates produced by the United Kingdom Meteorological Office. Both SSTs and marine air temperatures were corrected, but only SST data were used in the combined land-marine data set.

Data availability - These data are available from the Climatic Research Unit at the University of East Anglia and are also documented and available from CDIAC (Jones et al. 1990).
ENSO-uncorrected

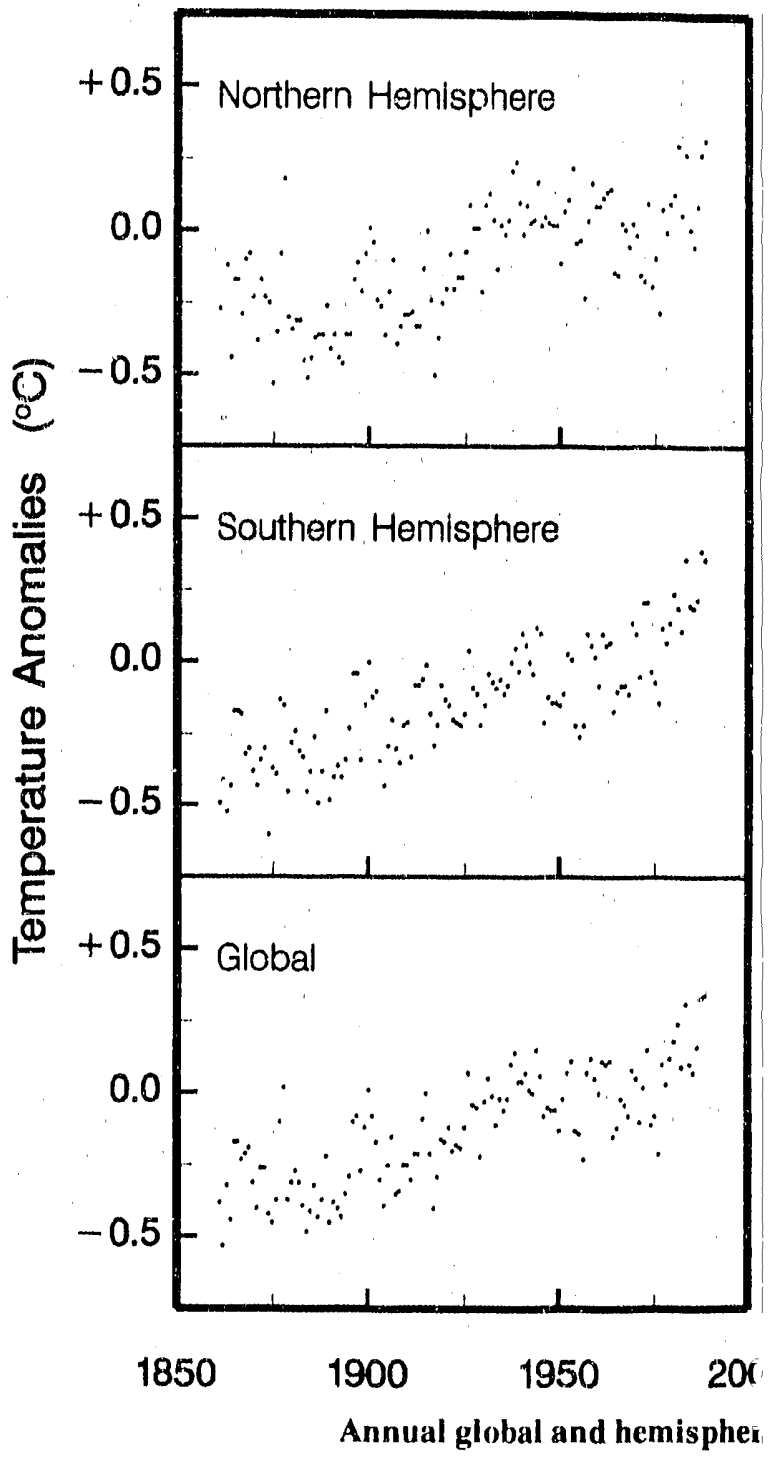




\section{ENSO-substracted}

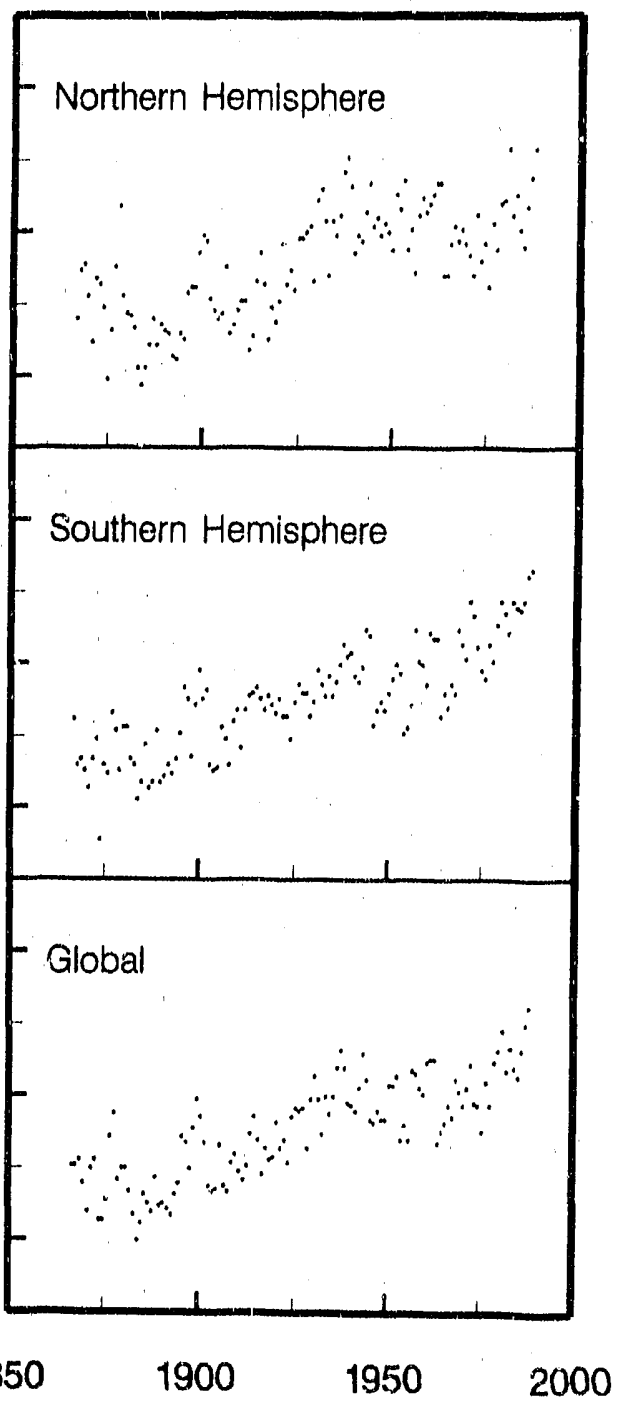

\section{TRENDS}

These global and hemispheric annual variations show little trend during the nineteenth century, marked warming to 1940, relatively steady conditions to the mid-1970s, followed by a rapid warming during the 1980s. Globally, in 1988 the mean temperature variation was $0.34^{\circ} \mathrm{C}$ above the mean for the 1950-1979 reference period and $0.01^{\circ} \mathrm{C}$ warmer than that of 1987.

Factoring out ENSO-related events from the global temperature anomaly series, 1988 was considerably warmer than 1987. Statistically, the decade of the 1980s over the globe has been significantly warmer ( $t$ value 1.90 ) than the mean of the 1950-1979 reference period (Jones 1988). 


\section{Annual Temperature Anomalies (rela}

\begin{tabular}{|c|c|c|c|c|c|c|c|c|c|c|c|c|c|}
\hline \multirow[b]{3}{*}{ Year } & \multirow[b]{2}{*}{$\begin{array}{l}\text { North- } \\
\text { ern }\end{array}$} & \multirow[b]{2}{*}{$\begin{array}{l}\text { South- } \\
\text { ern }\end{array}$} & \multirow[b]{3}{*}{ Global } & \multicolumn{3}{|c|}{ ENSO-subtracted $\dagger$} & \multirow[b]{3}{*}{ Year } & \multirow[b]{2}{*}{$\begin{array}{l}\text { North- } \\
\text { ern }\end{array}$} & \multirow[b]{2}{*}{$\begin{array}{l}\text { South- } \\
\text { ern }\end{array}$} & \multirow{3}{*}{ Global } & \multicolumn{3}{|c|}{ ENSO-subtracted $\dagger$} \\
\hline & & & & $\begin{array}{l}\text { North- } \\
\text { ern }\end{array}$ & $\begin{array}{l}\text { South- } \\
\text { ern }\end{array}$ & & & & & & $\begin{array}{l}\text { North- } \\
\text { ern }\end{array}$ & $\begin{array}{l}\text { South- } \\
\text { ern }\end{array}$ & \\
\hline & Hem. & Hem. & & & & Global & & Hem. & Hem & & Hem. & Hem. & Global \\
\hline 1861 & -0.27 & $-0,49$ & -0.38 & & & & 1904 & -0.36 & -0.43 & -0.39 & -0.30 & -0.37 & -0.33 \\
\hline 1862 & -0.65 & -0.41 & -0.53 & & & & 1905 & -0.21 & -0.29 & -0.25 & -0.28 & -0.36 & -0.32 \\
\hline 1863 & -0.12 & -0.52 & -0.32 & & & & 1906 & -0.10 & -0.20 & -0.15 & -0.12 & -0.22 & -0.17 \\
\hline 1864 & -0.44 & -0.43 & -0.44 & & & & 1907 & -0.39 & -0.30 & -0.35 & -0.35 & -0.26 & $-0,31$ \\
\hline 1865 & -0.17 & -0.17 & -0.17 & & & & 1908 & -0.33 & -0.35 & -0.34 & -0.32 & -0.35 & -0.33 \\
\hline 1866 & -0.17 & -0.17 & -0.17 & & & & 1909 & -0.29 & -0.22 & -0.25 & -0.27 & -0.20 & -0.23 \\
\hline 1867. & -0.29 & $-0 ; 18$ & -0.23 & -0.30 & -0.19 & -0.24 & 1910 & -0.29 & -0.21 & -0.25 & -0.24 & -0.16 & -0.20 \\
\hline 1868 & -0.10 & -0.32 & -0.21 & -0.13 & -035 & -0.24 & 1911 & -0.28 & -0.33 & -0.30 & -0.24 & -0.29 & -0.26 \\
\hline 1869 & -0.08 & -0.30 & -0.19 & -0.11 & -0.33 & -0.22 & 1912 & -0.33 & -0.08 & -0.21 & -0.41 & -0.16 & -0.29 \\
\hline 1870 & -0.23 & -0.38 & -0.31 & -0.22 & -0.37 & -0.30 & 1913 & -0.33 & $-0,08$ & -0.21 & -0.36 & -0.11 & -0.24 \\
\hline 1871 & -0.38 & -0.43 & -0.40 & -0.38 & -0.43 & -0.40 & 1914 & -0.13 & -0.06 & -0.09 & -0.17 & -0.10 & -0.13 \\
\hline 1872 & -0.17 & -0.34 & -0.26 & -0.16 & $-i) .33$ & -0.25 & 1915 & 0.00 & -0.01 & 0.00 & -0.07 & $0.0 \%$ & -0.07 \\
\hline 1873 & -0.23 & -0.30 & -0.26 & -0.18 & -0.26 & -0.22 & 1916 & -0.24 & -0.18 & -0.21 & -0.18 & -0.12 & -0.15 \\
\hline 1874 & -0.25 & -0.60 & -0.42 & -0.26 & -0.61 & -0.43 & 1917 & -0.50 & -0.29 & -0.40 & -0.37 & -0.16 & -0.27 \\
\hline 1875 & -0.53 & -0.37 & -0.45 & -0.51 & -0.35 & -0.43 & 1918 & -0.37 & -0.22 & -0.29 & -0.26 & -0.11 & -0.18 \\
\hline 1876 & -0.35 & -0.39 & -0.37 & -0.34 & -0.38 & -0.36 & 1919 & -0.25 & -0.08 & -0.16 & -0.31 & -0.14 & -0.22 \\
\hline 1877 & -0.08 & -0.13 & -0.10 & -0.12 & -0.17 & -0.14 & 1920 & -0.20 & -0.13 & -0.17 & -7.24 & -0.17 & -0.21 \\
\hline 1878 & 0.18 & -0.15 & 0.02 & 0.09 & 0.23 & -0.06 & .1921 & $-0,08$ & -0.15 & -0.12 & 0.04 & -0.12 & -0.09 \\
\hline 1879 & -0.30 & -0.45 & -0.37 & -0.22 & -0.37 & -0.29 & 1922 & -0.20 & -0.20 & -0.20 & -0.18 & -0.18 & -0.18 \\
\hline 1880 & -0.34. & -0.28 & -0.31 & -0.28 & -0.22 & -0.25 & 1923 & -0.16 & -0.21 & -0.18 & -0.13 & -0.18 & -0.15 \\
\hline 1881. & -0.31 & -0.24 & -0.27 & -0.29 & -0.22 & -0.25 & 1924 & -0.16 & -0.22 & -0.19 & -0.20 & -0.26 & -0.23 \\
\hline 1882 & -0.31 & -0.31 & -0.31 & -0.33 & -0.33 & -0.33 & 1925 & -0.07 & -0.18 & -0.12 & -0.02 & -0.13 & -0.07 \\
\hline 1883 & -0.45 & -0.33 & -0.39 & -0.47 & -0.35 & -0.41 & 1926 & 0.09 & 0.04 & 0.07 & -0.02 & -0.07 & -0.04 \\
\hline 1884 & -0.51 & -0.45 & -0.48 & -0.53 & -0.47 & -0.50 & 1927 & 0.01 & -0.09 & -0.04 & 0.00 & -0.10 & -0.05 \\
\hline 1885 & -0.44 & -0.38 & -0.41 & -0.47 & -0.41 & -0.44 & $1928^{\circ}$ & 0.01 & -0.11 & $-0 . C 5$ & 0.02 & -0.10 & -0.04 \\
\hline 1886 & -0.37 & -0.26 & $-0,32$ & -0.39 & -0.28 & -0.34 & 1929 & -0.21 & -0.22 & -0.22 & -0.17 & -0.18 & -0.18 \\
\hline 1887 & -0.36 & -0.49 & -0.43 & -0.30 & -0.43 & -0.37 & 1930 & 0.09 & -0.15 & -0.03 & 0.11 & -0.13 & -0.01 \\
\hline 1888 & -0.36 & -0.38 & -0.37 & -0.39 & -0.41 & -0.40 & 1931 & 0.13 & -0.04 & 0.05 & 0.15 & -0.02 & 0.07 \\
\hline 1889 & -0.26 & -0.17 & -0.22 & -0.32 . & -0.23 & -0.28 & 1932 & 0.04 & -0.07 & -0.01 & 0.04 & -0.07 & -0.01 \\
\hline 1890 & -0.41 & -0.48 & -0.45 & -0.34 & -0.41 & -0.38 & 1933 & -0.13 & -0.09 & -0.11 & -0.15 & -0.11 & -0.13 \\
\hline 1891 & -0.36 & -0.40 & -0.38 & -0.35 & -0.39 & -0.37 & 1934 & 0.02 & -0.06 & -0.02 & 0.04 & -0.04 & 0.00 \\
\hline 1892 & -0.44 & -0.35 & -0.40 & -0.43 & -0.35 & -0.39 & 1935 & -0.01 & -0.11 & -0.06 & -0.01 & -0.11 & -0.06 \\
\hline 1893 & -0.46 & -0.40 & -0.43 & -0.44 & -0.38 & -0.41 & 1936 & 0.04 & -0.08 & -0.02 & 0.06 & $-0 . \omega K$ & 0.00 \\
\hline 1894 & -0.36 & -0.34 & -0.35 & -0.35 & -0.33 & -0.34 & 1937 & 0.21 & 0.00 & 0.10 & 0.21 & 0.00 & 0.10 \\
\hline 1895 & -0.36 & -0.23 & -0.29 & -0.37 & -0.24 & -0.30 & 1938 & 0.24 & 0.05 & 0.14 & 0.26 & 0.07 & 0.16 \\
\hline 1896 & -0.17 & -0.04 & -0.10 & -0.21 & $-0,08$ & -0.14 & 1939 & 0.10 & -0.03 & 0.04 & 0.16 & 0.03 & 0.10 \\
\hline 1897. & -0.11 & -0.04 & -0.08 & -0.19 & -0.12 & -0.16 & 1940 & -0.01 & 0.10 & 0.04 & -0.07 & 0.04 & -0.02 \\
\hline 1898 & -0.21 & -0.34 & -0.27 & -0.19 & -0.32 & -0.25 & 1941 & 0.09 & 0.06 & 0.07 & -0.01 & -0.04 & -0.03 \\
\hline 1899 & -0.08 & -0.15 & -0.12 & -0.07 & -0.14 & -0.11 & 1942 & 0.03 & 0.00 & 0.01 & -0.03 & -0.06 & -0.05 \\
\hline 1900 & 0.01 & 0.00 & 0.01 & -0.01 & -0.02 & -0.01 & 1943 & 0.04 & -0.04 & 0.00 & 0.07 & -0.01 & 0.03 \\
\hline 1901 & -0.04 & -0.12 & -0.08 & -0.03 & -0.12 & -0.07 & 1944 & 0.17 & 0.12 & 0.15 & 0.17 & 0.12 & 0.15 \\
\hline 1902 & -0.24 & -0.10 & -0.17 & -0.23 & -0.09 & -0.16 & 1945 & 0.02 & 0.10 & 0.06 & 0.02 & 0.10 & 0.06 \\
\hline 1903 & -0.26 & -0.34 & -0.30 & -0.27 & -0.35 & -0.31 & 1946 & 0.05 & -0.21 & -0.08 & 0.05 & -0.21 & -0.08 \\
\hline
\end{tabular}

\section{TRENDS '90}


ive to a 1950-79 reference period mean)*

\begin{tabular}{|c|c|c|c|c|c|c|}
\hline \multirow[b]{3}{*}{ Year } & \multirow{3}{*}{$\begin{array}{l}\text { North- } \\
\text { ern } \\
\text { Hem. }\end{array}$} & \multirow[b]{2}{*}{$\begin{array}{l}\text { South- } \\
\text { ern }\end{array}$} & \multirow[b]{3}{*}{ Global } & \multicolumn{3}{|c|}{ ENSO-subtracica $\dagger$} \\
\hline & & & & $\begin{array}{l}\text { North- } \\
\text { ern }\end{array}$ & $\begin{array}{c}\text { South- } \\
\text { ern }\end{array}$ & \\
\hline & & Hem. & & Hem. & Hem. & Global \\
\hline 1947 & 0.03 & -0.12 & -0.05 & -0.01 & -0.16 & -0.09 \\
\hline 1948 & 0.02 & -0.14 & -0.06 & 0.03 & -0.13 & -0.05 \\
\hline 1949 & 0.02 & -0.14 & -0.06 & 0.00 & -0.16 & -0.08 \\
\hline 1950 & -0.11 & -0.15 & -0.13 & -0.06 & -0.10 & -0.08 \\
\hline 1951 & 0.07 & -0.11 & -0.02 & 0.13 & -0.05 & 0.04 \\
\hline 1952 & 0.11 & 0.03 & 0.07 & 0.08 & 0.00 & 0.04 \\
\hline 1953 & 0.22 & 0,01 & 0.11 & 0.18 & $-0,03$ & 0.07 \\
\hline 1954 & -0.04 & -0.22 & -0.13 & -0.06 & -0.24 & -0.15 \\
\hline 1955 & -0.03 & -0.26 & $-0: 14$ & 0.01 & -0.22 & -0.10 \\
\hline 1956 & -0.23 & -0.22 & -0.23 & -0.14 & -0.14 & -0.15 \\
\hline 957 & 0.04 & 0.10 & 0.07 & 0.06 & 0.12 & 0.09 \\
\hline 1958 & 0.17 & 0.06 & 0.12 & 0.12 & 0.01 & 0.08 \\
\hline 1959 & 0.09 & 0.02 & 0.05 & 0.07 & 0.00 & 0.03 \\
\hline 1960 & 0,09 & -0.08 & 0.00 & 0.10 & -0.07 & 0.01 \\
\hline 1961 & 0.12 & 0.10 & 0.11 & 0.13 & 0.11 & 0.12 \\
\hline 1962 & 0.14 & 0.06 & 0.10 & 0.17 & 0.09 & 0.13 \\
\hline 1963 & 0.15 & 0.07 & 0.11 & 0.17 & 0.09 & 0.13 \\
\hline 1964 & -0.14 & -0.17 & -0.15 & -0.15 & -0.18 & -0.16 \\
\hline 1965 & -0.15 & -0.10 & -0.12 & -0.15 & -0.10 & -0.12 \\
\hline 1966 & 0.03 & -0.08 & -0.02 & -0.04 & -0.15 & -0.09 \\
\hline 1967 & 0.01 & -0.08 & -0.04 & 0.02 & -0.07 & -0.03 \\
\hline 1968 & -0.05 & -0.11 & -0.08 & -0.03 & -0.10 & -0.07 \\
\hline 1969 & 0.03 & 0.14 & 0.08 & 0.01 & 0.12 & 0.06 \\
\hline 1970 & -0.01 & 0.10 & 0.05 & -0.04 & 0.07 & 0.02 \\
\hline 1971 & -0.15 & -0.05. & -0.10 & -0.08 & 0.02 & $-0,03$ \\
\hline 1972 & -0.17 & 0.21 & 0.02 & -0.15 & 0.22 & 0.03 \\
\hline 1973 & 0.10 & 0.21 & 0.15 & 0.06 & 0.17 & 0.11 \\
\hline 1974 & -0.19 & -0.03 & -0.11 & -0.10 & 0.06 & -0.02 \\
\hline 1975 & -0.09 & -0.07 & -0.08 & -0.04 & -0.02 & -0.03 \\
\hline 1976 & -0.28 & -0.14 & -0.21 & -0.19 & -0.05 & -0.12 \\
\hline 1977 & 0.08 & 0.12 & 0.10 & 0.03 & 0.07 & 0.05 \\
\hline 1978 & 0.00 & 0.07 & 0.03 & -0.06 & 0.01 & -0.03 \\
\hline 1979 & 0.10 & 0.14 & 0.12 & 0.10 & 0.14 & 0.12 \\
\hline 1980 & 0.13 & 0.24 & 0.18 & 0.11 & 0.22 & 0.16 \\
\hline 1981 & 0.30 & 0.19 & 0.24 & 0.29 & 0.18 & 0.23 \\
\hline 1982 & 0.063 & 0.11 & 0.09 & 0.06 & 0.11 & 0.09 \\
\hline 1983 & 0.27 & 0.36 & 0.31 & 0.13 & 0.22 & 0.17 \\
\hline 1984 & 0.01 & 0.20 & 0.10 & 0.01 & 0.20 & 0.10 \\
\hline 1985 & -0.05 & 0.19 & 0.07 & -0.05 & 0.19 & 0.07 \\
\hline 1986 & 0.09 & 0.22 & 0.16 & 0.09 & 0.22 & 0.16 \\
\hline 1987 & 0.27 & 0.39 & 0.33 & 0.19 & 0.31 & 0.25 \\
\hline 1988 & 0.32 & 0.36 & 0.34 & 0.29 & 0.33 & 0.31 \\
\hline
\end{tabular}

"Degrees Celsius.

tData corrected for the influences of El Niño/Southern Oscillation (ENSO).

\section{REFERENCES}

Jones, P.D. 1988. The influence of ENSO on global temperatures. Climate Monitor 17(3):80-89.

Jones, P.D., S.C.B. Raper, R.S. Bradley, H.F. Diaz, P.M. Kelly, and T.M.L. Wigley. 1986a. Northern Hemisphere surface air temperature variations: $1851-1984$. Joumal of Climate and Applied Meteorology' 25(2):161-79.

Jones, P.D., S.C.B. Raper, and T.M.L. Wigley. 1986b. Southern Hemisphere surface air temperature variations: 1851-1984. Joumal of Climate and Applied Meteorology 25(9):1213-30.

Jones, P.D., T.M.L. Wigley, and P.B. Wright. 1986c. Global temperature variations between 1861 and 1984. Nature 322:430-34. Jones, P.D., T.M.L. Wigley, and P.B. Wright. 1990. Global and hemispheric annual temperature variations between 1861 and 1988. NDP 022/R1, Carbon Dioxide Information Analysis Center, Oak Ridge National Laboratory, Oak Ridge, Tennessee.

Woodruff, S.D., R.J. Slutz, R.J. Jenne, and P.M. Steurer. 1987. A comprehensive ocean-atmosphere data set. Bulletin of the American Meteorological Society 80:1239-47. 


\section{Global and Hemispheric}

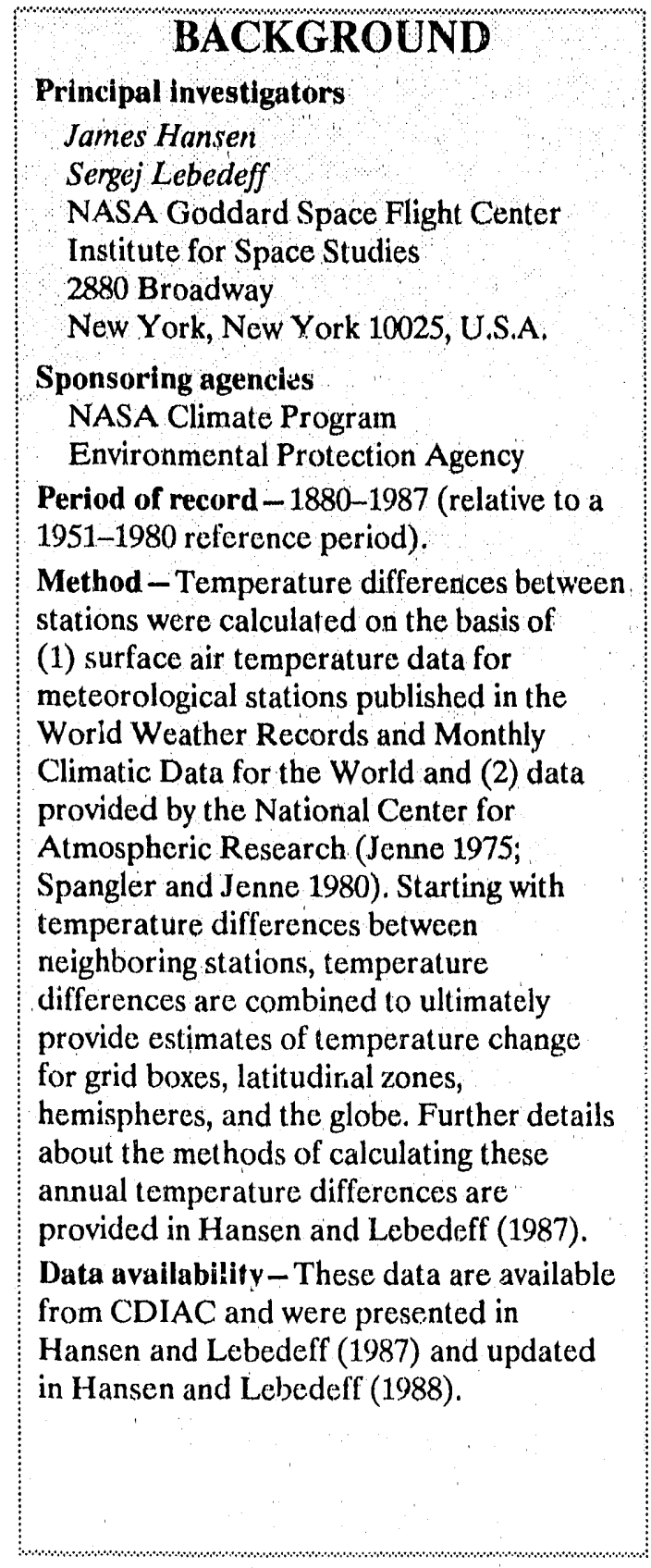

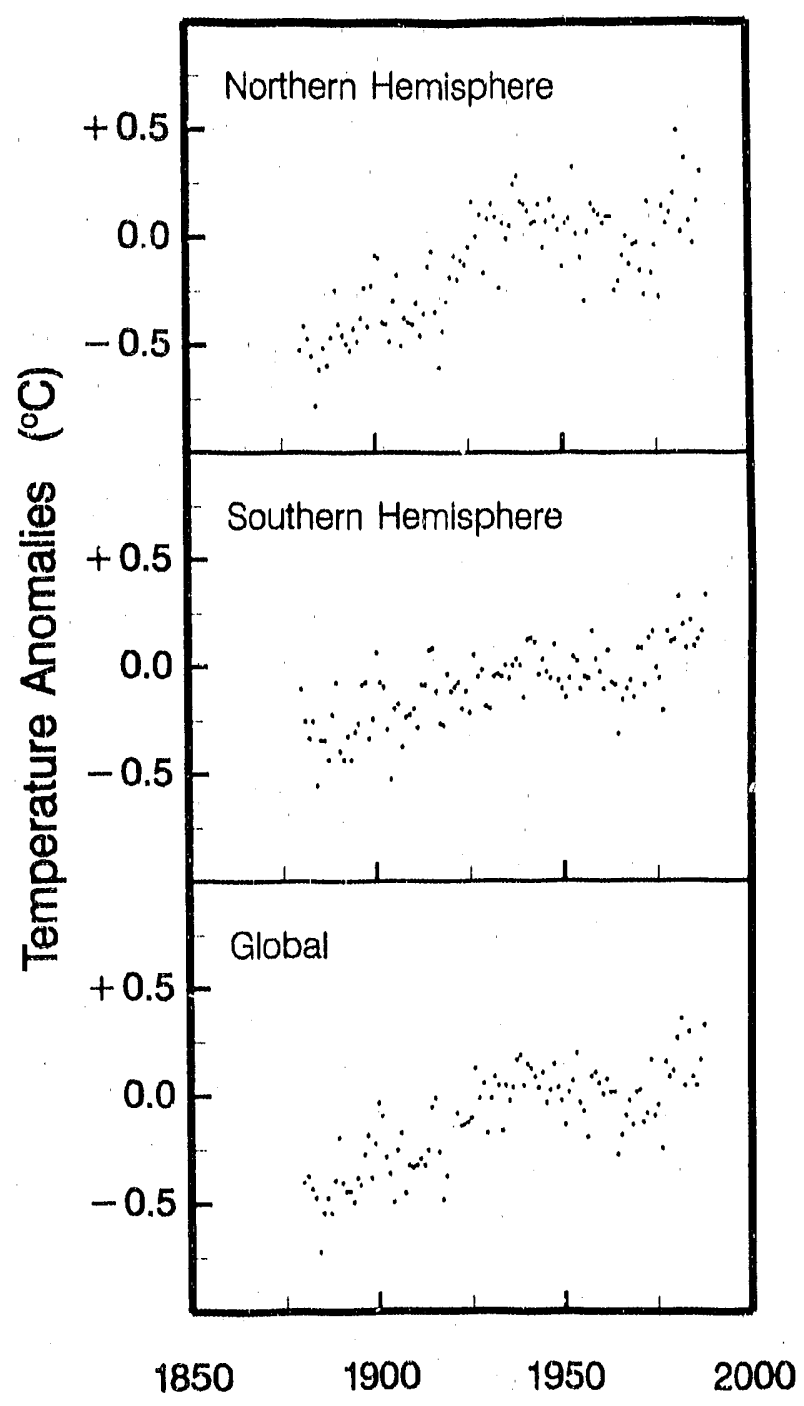

Annual surface air temperature anomalies. 


\section{Temperature Anomalies}

\section{TRENDS}

Hansen and Lebedeff (1987) reported "global temperature increases by about $0.5^{\circ} \mathrm{C}$ between 1880 and 1940 , decreases by about $0.2^{\circ} \mathrm{C}$ between 1940 and 1965 , and increases by about $0.3^{\circ} \mathrm{C}$ between 1965 and 1980. The northern hemisphere temperature change is rather similar to the global change, increasing by $0.6^{\circ} \mathrm{C}$ between 1880 and 1940 , decreasing by $0.3^{\circ} \mathrm{C}$ between 1940 and 1970 , and increasing by $0.3^{\circ} \mathrm{C}$ between 1970 and 1980. The southern hemisphere temperature change is noisier, but, especially if averaged over a 10-year interval or longer, it shows a more steady increase in temperature, with a warming of about $0.6^{\circ} \mathrm{C}$ between 1880 and 1980. The largest rate of warming is between 1965 and 1980."

Hansen and Lebedeff (1988) also reported that the global surface air temperatures in the 1980s are the warmest in the history of meteorological records and that the four warmest years on record are all in the 1980s, with the warniest years being 1981 and 1987. 


\section{Global and Hemispheric}

क\%क

\begin{tabular}{|c|c|c|c|c|c|c|c|}
\hline Year & Global & $\begin{array}{l}\text { Northern } \\
\text { llem. }\end{array}$ & $\begin{array}{l}\text { Southern } \\
\text { Hem. }\end{array}$ & Year & Global & $\begin{array}{l}\text { Northern } \\
\text { Uem. }\end{array}$ & $\begin{array}{c}\text { Southern } \\
\text { Ilem. }\end{array}$ \\
\hline 1880 & $-0,40$ & -0.52 & -0.10 & 1916 & -0.26 & -0.34 & $-0,11$ \\
\hline 1881 & -0.37 & -0.41 & -0.25 & 1917 & -0.48 & -0.60 & -0.26 . \\
\hline 1882 & $-0,43$ & -0.47 & -0.33 & 1918 & -0.37 & -0.43 & -0.27 \\
\hline 1883 & -0.47 & -0.55 & -0.25 & 1919 & -0.20 & -0.29 & -0.03 \\
\hline 1884 & -0.72. & -0.78 & -0.55 & 1920 & -0.15 & -0.18 & -0.11 \\
\hline 1885 & -0.54 & -0.61 & -0.34 & 1921 & -0.08 & -0.08 & -0.09 \\
\hline 1886 & -0.47 & -0.51 & -0.34 & 1922 & -0.14 & -0.19 & $-0,07$ \\
\hline 1887 & -0.54 & -0.59 & -0.43 & 1923 & -0.13 & -0.10 & -0.19 \\
\hline 1888 & -0.39 & -0.46 & -0.22 & 1924 & -0.12 & -0.12 & -0.11 \\
\hline 1889 & -0.19 & -0.24 & -0.07 & 1925 & -0.10 & -0.04 & -0.21 \\
\hline 1890 & -0.40 & -0.40 & -0.39 & 1926 & 0.13 & 0.17 & 0.06 \\
\hline 1891 & -0.44 & -0.45 & -0.43 & 1927 & -0.01 & 0.01 & -0.04 \\
\hline 1892 & -0.44 & -0.49 & -0.32 & 1928 & 0.06 & 0.11 & -0.01 \\
\hline 1893 & -0.49 & -0.52 & -0.43 & 1929 & -0.17 & -0.16 & -0.18 \\
\hline 1894 & -0.38 & -0.42 & -0.30 & 1930 & -0.01 & 0.09 & -0.19 \\
\hline 1895 & -0.41 & -0.48 & -0.26 & 1931 & 0.09 & 0.16 & -0.04 \\
\hline 1896 & -0.27 & -0.37 & -0.08 & 1932 & 0.05 & 0.10 & -0.03 \\
\hline 1897 & -0.18 & $-0,23$ & -0.07 & 1933 & -0.16 & -0.23 & -0.04 \\
\hline $1898^{\prime}$ & -0.38 & -0.41 & -0.33 & 1934 & 0.05 & 0.07 & 0.01 \\
\hline 1899 & -0.22 & -0.22 & -0.24 & 1935 & -0.02 & 0.00 & -0.05 \\
\hline 1900 & $-0,03$ & -0.08 & 0.07 & 1936 & 0.04 & 0.06 & 0.01 \\
\hline 1901 & -0.09 & -0.09 & -0.07 & 1937 & 0.17 & 0.25 & 0.04 \\
\hline 1902 & -0.28 & -0.39 & -0.09 & 1938 & 0.19 & 0.29 & 0.01 \\
\hline 1903 & -0.36 & -0.40 & -0.29 & 1939 & 0.05 & 0.17 & -0.14 \\
\hline 1904 & -0.49 & -0.48 & -0.52 & 1940 & 0.15 & 0.16 & 0.13 \\
\hline 1905 & -0.25 & -0.29 & -0.19 & 1941 & 0.13 & 0.13 & 0.14 \\
\hline 1906 & -0.17 & -0.17 & -0.17 & 1942 & 0.09 & 0.07 & 0.12 \\
\hline 1907 & -0.45 & -0.50 & -0.37 & 1943 & 0.04 & 0.08 & -0.03 \\
\hline 1908 & $-0: 32$ & -0.37 & -0.23 & 1944 & 0.11 & 0.16 & 0.04 \\
\hline 1909 & -0.33 & -0.39 & -0.22 & 1945 & -0.03 & -0.04 & -0.02 \\
\hline 1910 & -0.32 & -0.40 & -0.19 & 1946 & 0.03 & 0.08 & -0.05 \\
\hline 1911 & -0.29 & -0.30 & -0.28 & 1947 & 0.15 & 0.18 & 0.11 \\
\hline 1912 & -0.32 & -0.45 & -0.08 & 1948 & 0,04 & 0.10 & -0.06 \\
\hline 1913 & -0.25 & -0.35 & -0.08 & 1949 & -0.02 & 0.04 & -0.10 \\
\hline 1914 & -0.05 & -0.13 & 0.08 & 1950 & -0.13 & -0.13 & -0.14 \\
\hline 1915 & -0.01 & -0.06 & 0.09 & 1951 & 0.02 & 0.07 & -0.0 .5 \\
\hline
\end{tabular}

"Anomalies expressed in degrecs Celsius. 
Annual Temperature Anomalies*

$\begin{array}{rr}\text { Year } & \text { Global } \\ 1952 & 0.07 \\ 1953 & 0.20 \\ 1954 & -0.03 \\ 1955 & -0.07 \\ 1956 & -0.19 \\ 1957 & 0.09 \\ 1958 & 0.11 \\ 1959 & 0.06 \\ 1960 & 0.01 \\ 1961 & 0.08 \\ 1962 & 0.02 \\ 1963 & 0.02 \\ 1964 & -0.27 \\ 1965 & -0.18 \\ 1966 & -0.09 \\ 1967 & -0.02 \\ 1968 & -0.13 \\ 1969 & 0.02 \\ 1970 & 0.03 \\ 1971 & -0.12 \\ 1972 & -0.08 \\ 1973 & 0.17 \\ 1974 & -0.09 \\ 1975 & -0.04 \\ 1976 & -0.24 \\ 1977 & 0.16 \\ 1978 & 0.09 \\ 1979 & 0.12 \\ 1980 & 0.27 \\ 1981 & 0.36 \\ 1982 & 0.05 \\ 1983 & 0.30 \\ 1984 & 0.09 \\ 1985 & 0.05 \\ 1986 & 0.17 \\ 1987 & 0.33 \\ & \end{array}$

$\begin{array}{rr}\begin{array}{c}\text { Northern } \\ \text { IIem. }\end{array} & \begin{array}{c}\text { Southern } \\ \text { Hem. }\end{array} \\ 0.09 & 0.05 \\ 0.33 & 0.03 \\ 0.02 & -0.10 \\ -0.09 & -0.04 \\ -0.29 & -0.05 \\ 0.03 & 0.17 \\ 0.16 & 0.04 \\ 0.13 & -0.02 \\ 0.11 & -0.10 \\ 0.07 & 0.08 \\ 0.10 & -0.07 \\ 0.10 & -0.08 \\ -0.24 & -0.31 \\ -0.20 & -0.15 \\ -0.08 & -0.10 \\ 0.01 & -0.06 \\ -0.12 & -0.14 \\ -0.03 & 0.09 \\ -0.02 & 0.09 \\ -0.15 & -0.08 \\ -0.26 & 0.14 \\ 0.17 & 0.17 \\ -0.16 & 0.00 \\ -0.03 & -0.05 \\ -0.27 & -0.20 \\ 0.15 & 0.17 \\ 0.07 & 0.12 \\ 0.12 & 0.13 \\ 0.21 & 0.33 \\ 0.50 & 0.20 \\ 0.03 & 0.09 \\ 0.37 & 0.22 \\ 0.08 & 0.10 \\ -0.02 & 0.13 \\ 0.17 & 0.17 \\ 0.31 & 0.34 \\ & \end{array}$

\section{REFERENCES}

Hansen, J., and S. Lebedeff. 1987. Global trends of measured surface air temperatures. Joturnal of Geophysical Research 92:13345-72.

Hansen, J., a S. Lebedeff. 1988. Global surface air temperatures: update through 1987. Geophysical Research Letters 1.5:323-26.

Jenne, R. 1975. Data sets for meteorological research. NCAR-TN/JA-111. National Center fol Atmospheric Research. Boulder, Colorado.

Jones, P.D. 1988. The influence of ENSO on global temperatures. Climate Monitor 17(3):8()-89.

Jones, P.D., S.C.B. Raper, R.S. Bradley, H.F. Diaz, P.M. Kelly, and T.M.L. Wigley. 1986a. Northern Hemisphere surface air temperature variations: 1851-1984. Journal of Climate and Applied Meteorology 25(2):161-79.

Jones, P.D., S.C.B. Raper, and T.M.L.

Wigley. 1986b. Southern Hernisphere surface nir temperature variations: 1851-1984. Joumal of Climate and Applied Meteorology 25(9):1213-30.

Jones, P.D., T.M.L. Wigley, and P.B. Wright. 1986c. Global temperature variations between 1861 and 1984. Nature 322:430-34. Spangler, W.M.L., and R.L. Jenne. 1980),

World monthly surface station climatology. Computer data tape documentation.

National Center for Atmospheric Research, Boulder, Colorado. 


\section{Global $\left(90^{\circ} \mathrm{S}-90^{\circ} \mathrm{N}\right)$}

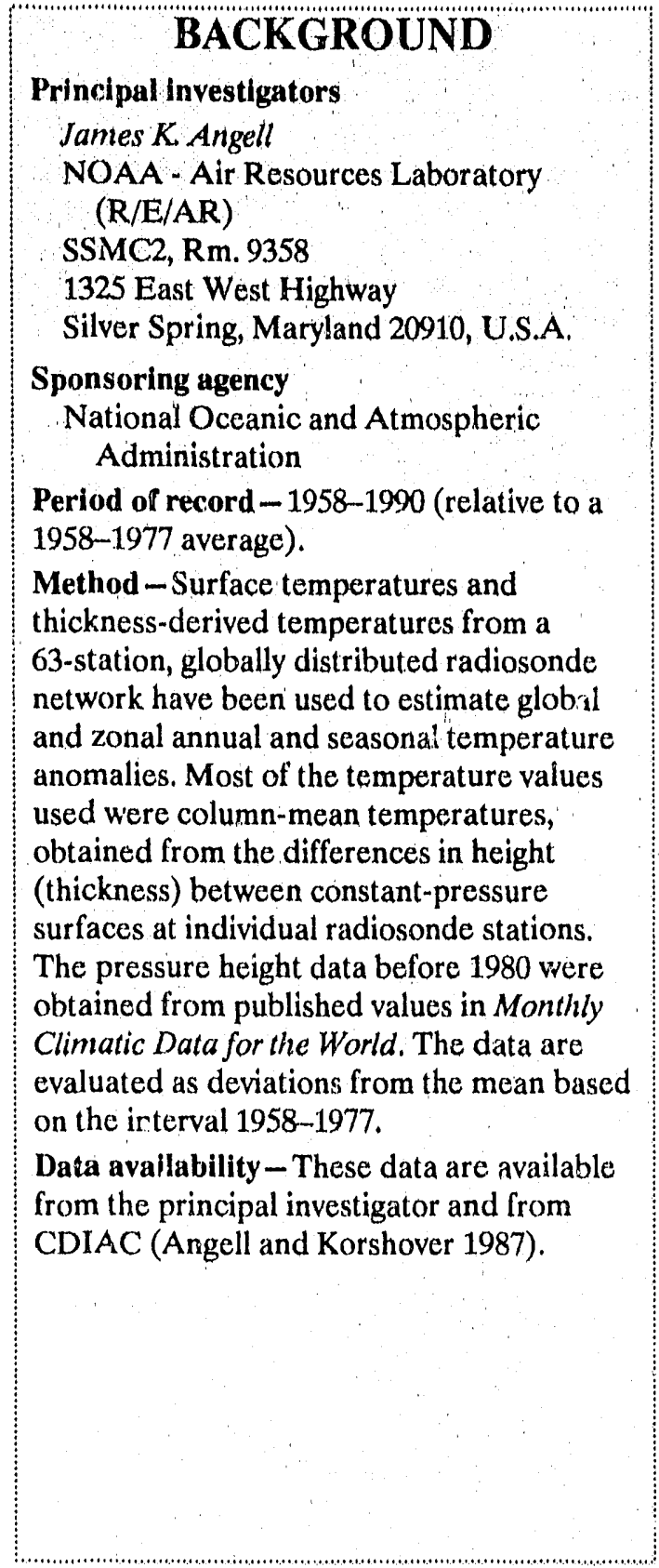

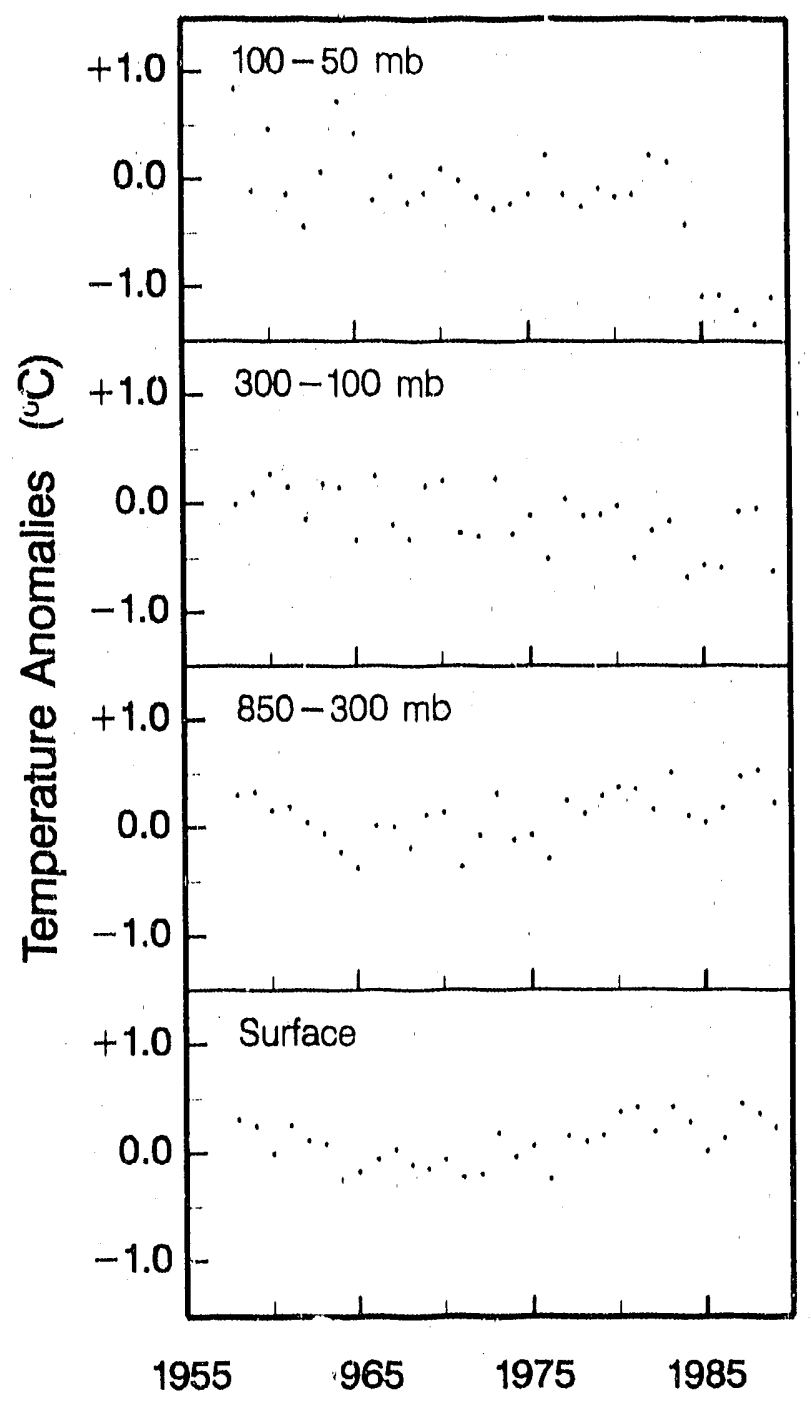

Global annual temperature anomalies, 1958-1989 (1989 value is provisional). 


\section{Temperature Anomalies}

\section{TRENDS}

Angell (1986) reported that, during the last quarter century, the surface and troposphere have warmed, the tropopause layer and the low stratosphere have cooled, and low-level warming and higher-level cooling havs been more pronounced in the Southern Hemisphere than the Northern Hemisphere. For the earth's surface and the troposphere ( $850-300 \mathrm{mb}$ ) Angell (1988) reported a global temperature increase of $0.08^{\circ} \mathrm{C} / 10$ year and $0.09^{\circ} \mathrm{C} / 10$ year over the 30-year interval 1958-1987. There was record surface warmth in the north polar and north temperate latitudes during the first half of 1990. 


\begin{tabular}{|c|c|c|c|c|c|c|c|c|c|c|c|c|c|c|c|c|c|c|c|c|}
\hline ear & Wint & Spr & Sum & Fall & Ann & Win & Spr & Sum & Fall & Ann & Win & Spr & Sum & Fall & Ann & Win & Spr & Sum & iall & Ann \\
\hline 958 & 0.70 & 0.26 & -0.04 & 0.33 & 0.31 & 0.39 & 0.21 & 0.27 & 0.32 & 0.30 & 0.11 & 0.26 & 0.11 & 0.03 & 0.00 & 0.39 & -0.02 & 0.17 & 0.22 & 0.15 \\
\hline 59 & 0.40 & 0.28 & 0.26 & 0.05 & 0.25 & 0.25 & 0.43 & 0.36 & 0.29 & 0.33 & -0.05 & 0.47 & 0.19 & -0.22 & 0.10 & 0.22 & 0.43 & 0.30 & 0.16 & 0.22 \\
\hline 960 & 0.10 & -0.05 & 0.03 & -0.07 & 0.00 & 0.28 & -0.04 & 0.27 & 0.13 & 0.16 & 0.46 & 0.15 & 0.35 & 0.15 & 0.28 & 0.28 & 0.01 & 0.24 & 10 & 0.11 \\
\hline 61 & 0.37 & 0.15 & 0.10 & 0.33 & 0.26 & 0.29 & 0.17 & 0.01 & 0.27 & 0.19 & 0.16 & 0.59 & 0.19 & -0.32 & 0.16 & 0.27 & 0.30 & 0.04 & 0.15 & 0.19 \\
\hline 1962 & 0.33 & 0.11 & -0.02 & 0.07 & 0.12 & 0.14 & -0.01 & -0.01 & 0.07 & 0.05 & -0.43 & -0.43 & -0.11 & 0.40 & -0.14 & 0.05 & -0.98 & -0.03 & 0.13 & 0.02 \\
\hline 963 & 0.11 & -0.10 & 0.02 & 0.32 & 0.09 & 0.07 & -0.14 & -0.11 & -0.03 & -0.05 & -0.21 & 0.21 & 0.38 & 0.39 & 0.19 & -0.05 & -0.10 & 0.02 & 0.12 & 0.00 \\
\hline 964 & -0.21 & -0.47 & -0.06 & -0.23 & -0.24 & -0.07 & -0.10 & -0.25 & -0.45 & -0.22 & 0.09 & 0.31 & 0,03 & 0.19 & 0.16 & 0.00 & -0.07 & -0.16 & -0.26 & -0.12 \\
\hline 965 & -0.21 & -0.21 & -0.17 & -0.09 & -0.17 & -0.58 & -0.47 & -0.40 & -0.04 & -0.37 & -0.35 & -0.46 & -0.35 & -0.15 & -0.33 & -0.47 & -0.44 & -0.34 & -0.09 & -0.34 \\
\hline 966 & -0.17 & 0.07 & -0.04 & -0.07 & -0.05 & -0.03 & 0.07 & 0.05 & 0.00 & 0.02 & 0.42 & 0.20 & 0.39 & 0.04 & 0.26 & 0.03 & 0.10 & 0.11 & -0.01 & 0.0 \\
\hline 967 & -0.08 & 0.08 & 0.05 & 0.10 & 0.04 & -0.13 & -0.03 & 0.06 & 0.12 & 0.01 & -0.13 & -0.33 & -0.14 & -0.14 & -0.19 & -0.13 & -0.08 & 0.02 & 0.05 & -0.04 \\
\hline 968 & -0.10 & 0.16 & -6.22 & -023 & -0.10 & -0.02 & -0.07 & -0.33 & -0.31 & -0.18 & 0.00 & -1.07 & .0 .36 & 0.15 & -0.31 & 0.02 & -0.26 & -0.31 & -0.1 & -0.19 \\
\hline 969 & -0.45 & -0.12 & -0.11 & 0.11 & -0.14 & -0.16 & 0.14 & $0.3 z$ & 0.18 & 0.12 & 0.42 & 0.58 & 0.01 & -0.32 & 0.17 & -0.03 & 0.12 & 0.18 & 0.06 & 0.08 \\
\hline 70 & & -0.09 & -0.15 & -0 & & & & & & & 0.05 & 0.28 & 6.35 & 0.20 & 0.22 & 0.08 & 0.13 & 0.18 & 0.11 & 0.13 \\
\hline 971 & -0.28 & -0.20 & -0.18 & -0.21 & -0.22 & -0.17 & -0.44 & -0.39 & -044 & -0.36 & -0.02 & -0.15 & -0.35 & -0.53 & -0.26 & -0.16 & -0.35 & -0.34 & -0.42 & -0.32 \\
\hline 972 & -0.38 & -0.30 & 0.14 & -0.2 & -0.19 & -0.49 & -0.13 & 0.18 & 0.16 & -0.07 & -0.4 & -0.54 & -0.23 & 0.10 & -0.29 & -0.50 & -0.30 & 0.08 & 0.0 & -0.17 \\
\hline 973 & 0.21 & 0.28 & 0.17 & 0.08 & 0.19 & 0.56 & 0.41 & 0.25 & 0.04 & 0.32 & 0.45 & 0.40 & 0.12 & -0.01 & 0.24 & 0.49 & 0.39 & 0.24 & 0.05 & 0.29 \\
\hline 974 & -0.14 & 0.04 & -0.02 & 0.02 & -0.03 & 0.01 & -12 & -0.11 & $-\cap .23$ & -0.11 & -0.44 & -0.26 & -0.30 & -0.08 & -0.27 & -0.14 & -0.12 & -0.14 & -0.15 & -0.14 \\
\hline 975 & 0.08 & 0.31 & 0.06 & -0.17 & 0.07 & -0.03 & 0.00 & -0.16 & -0.10 & -0.07 & -0.12 & 0.10 & -0.20 & -0.17 & -0.10 & -0.08 & 0.09 & -0.12 & -0.12 & -0.06 \\
\hline 976 & -0.22 & -0.42 & -0.12 & -0.21 & -0.24 & -0.15 & $-0,36$ & -0.27 & -0.38 & -1.29 & -0.54 & -0.66 & -0.53 & -0.25 & -0.50 & -0.25 & -0.44 & -0.39 & -0.32 & -0.35 \\
\hline 977 & -0.11 & 0.33 & 0.31 & 0.09 & 0.16 & 0.13 & 0.42 & 0.28 & 0.18 & 0.25 & 0.22 & 0.12 & -0.03 & -0.11 & 0.05 & 0.11 & 0.33 & 0.22 & 0.10 & 0.19 \\
\hline 978 & 0. & 0.06 & 0.11 & 0.15 & 0.10 & -0.03 & 0.30 & 0.21 & 0. & 0.13 & 0.16 & -0.03 & -0.27 & -0.24 & -0.10 & 0.02 & 0.21 & 0.08 & -0.01 & 0.08 \\
\hline 979 & -0.02 & 0.30 & 0.12 & 0.28 & 0.18 & 0.05 & 0.53 & 0.30 & 0.28 & 0.29 & 0.01 & 0.04 & -0.33 & -0.06 & -0.09 & 0.03 & 0.37 & 0.19 & 0.23 & 0.21 \\
\hline 980 & 0.53 & 0.56 & 0.29 & 0.15 & 0.38 & 0.37 & 0.39 & 0.5 & 0.21 & 0.37 & -0.41 & 0.28 & 22 & -0 . & -0.01 & 0.27 & 0.46 & 0.41 & 0.16 & 0.33 \\
\hline $98 i$ & 0.44 & 0.57 & 0.39 & 0.28 & 0.42 & 0.44 & 0.40 & 0.30 & 0.26 & 0.35 & -0.61 & -0.68 & -0.37 & -0.30 & -0.49 & 0.20 & 0.17 & 0.19 & 0.14 & 0.18 \\
\hline 982 & 0.33 & 0.10 & 0.22 & 0.16 & 0.20 & 0.33 & -0.05 & ט.29 & 0.05 & 0.16 & -0.17 & -0.35 & -0.08 & -0.37 & -0.24 & 0.19 & -0.07 & 0.21 & -0.02 & 0.08 \\
\hline 1983 & 0.57 & 0.51 & 0.32 & 0.32 & 0.43 & 0.41 & 0.87 & 0.52 & 0.22 & 0.51 & -0.39 & 0.18 & -0.05 & -0.33 & -0.15 & 0.29 & 0.68 & 0.36 & 0.15 & 0.37 \\
\hline 984 & 0.35 & 0.49 & 0.05 & 0.27 & 0.29 & 0.14 & 0.26 & 0.01 & 0.02 & 0.11 & -1.07 & -0.60 & -0.36 & -0.61 & -0.66 & -0.10 & 0.11 & -0.06 & -0.07 & -0.03 \\
\hline 1985 & -0.11 & 0.09 & 0.29 & -0.19 & 0.02 & 0.15 & 0.09 & 0.02 & -0.08 & 0.05 & -0.37 & -0.20 & -0.68 & -0.93 & -0.55 & 0.02 & 0.03 & -0.10 & -0.28 & -0.08 \\
\hline 986 & -0.02 & 0.36 & 0.14 & 0.09 & 0.14 & 0.33 & 0.14 & 0.12 & 0.12 & 0.18 & -0.97 & -0.53 & -0.39 & -0.44 & -0.58 & -0.02 & 0.03 & 0.03 & 0.01 & 0.01 \\
\hline 987 & 0.30 & 0.58 & 0.69 & 0.26 & 0.46 & 0.46 & 0.44 & 0.61 & 0. & 0.47 & -0.1 & -0 & 0.10 & 0. & -0.06 & 0.33 & 0.28 & 0.47 & 0.29 & 0.34 \\
\hline 1988 & 0.37 & 0.51 & 0.27 & 0.33 & 0.37 & 0.51 & 0.52 & 0.73 & 0.36 & 0.53 & -0.31 & -0.14 & 0.19 & 0.13 & -0.03 & 0.31 & 0.38 & 0.52 & 0.30 & 0.38 \\
\hline 989 & 0.37 & 0.27 & 0.21 & 0.10 & 0.24 & 0.15 & 0.18 & 0.30 & 0.30 & 0.23 & -0.7 & -0.49 & -0.54 & -0.61 & -0.61 & 0.01 & 0.04 & 0.10 & 0.07 & 0.05 \\
\hline 990 & 0.47 & 0.89 & & & & 0.25 & 0.60 & & & & -0.46 & -0.39 & & & & 0.13 & 0.43 & & & \\
\hline
\end{tabular}

*Temperature anomalies expressed (in relation to a 1958-1977 average) in degrees Celsius.

†Northern Hemisphere willter (Dec-Feb).

Note: Data for summer (Jun- ug) 1989 through spring (Mar-May) 1990 are provisional.

\section{TRENDS '90}




\section{Temperature Anomalies}

\section{ual and Seasonal Temperature Anomalies*}

$100-50 ~ m b$

Win Spr Sum Fall Ann Win Spr Sum Fall Ann $\begin{array}{lllllllllll}1.01 & 0 & 53 & 0.58 & 1.22 & 0.84 & 0.68 & 0.34 & 0.71 & 1.50 & 0.81\end{array}$

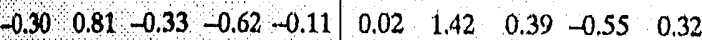
$\begin{array}{llllllllllllllll}1.04 & 0.51 & -0.05 & 0.36 & 0.47 & 1.23 & -0.01 & -0.78 & -0.32 & 0.03\end{array}$ $\begin{array}{llllllllll}-1.38 & -0.38 & 0.93 & 0.26 & -0.14 & -1.25 & -1.07 & 0.59 & -0.35 & -0.52\end{array}$ $\begin{array}{llllllllll}0.07 & -0.83 & -0.69 & -0.30 & -0.44 & -0.22 & -1.23 & -1.10 & -0.59 & -0.79\end{array}$ $\begin{array}{llllllllll}-0.43 & -0.52 & 0.54 & 0.70 & 0.07 & -0.63 & -1.40 & 0.76 & 1.40 & 0.03\end{array}$ $\begin{array}{lllllllllll}0.49 & 1.10 & 0.61 & 0.71 & 0.73 & 0.25 & 1.14 & 0.80 & 0.47 & 0.67\end{array}$ $\begin{array}{lllllllllllll}0.36 & 0.28 & 0.30 & 0.79 & 0.43 & -0.01 & 0.37 & 0.19 & 0.66 & 0.30\end{array}$ $\begin{array}{llllllllll}0.13 & -0.66 & -0.24 & 0.28 & -0.19 & -0.64 & -0.41 & 0.06 & 0.82 & -0.04\end{array}$ \begin{tabular}{lllll|llllll}
0.28 & 0.08 & -0.02 & -0.21 & 0.03 & 0.18 & 0.48 & -0.04 & -0.17 & 0.11
\end{tabular} $\begin{array}{lllllllllll}-0.48 & -0.12 & -0.11 & -0.12 & -0.21 & -0.81 & 0.04 & 0.00 & -0.19 & -0.24\end{array}$

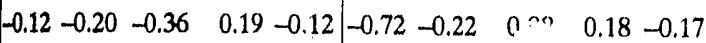
$\begin{array}{lllllllllll}0.06 & -0.05 & 0.50 & -0.10 & 0.10 & -0.08 & 0.09 & 0.5 & 0.47 & 0.26\end{array}$ $0.43-0.24-0.22-0.01-0.01 \quad 0.36-0.32-0.31-0.50-0.19$ $\begin{array}{llllllllll}0.04-0.02 & -0.22 & -0.43 & -0.16 & 0.42 & 0.28 & -0.53 & -0.31 & -0.04\end{array}$ $\begin{array}{llllllllllll}-0.14 & -0.30 & -0.36 & -0.28 & -0.27 & -0.12 & -0.73 & -0.57 & -0.43 & -0.46\end{array}$ $\begin{array}{lllllllllll}-0.16 & 0.06 & -0.37 & -0.39 & -0.22 & 0.09 & -0.04 & -0.43 & -0.75 & -0.28\end{array}$ $\begin{array}{llllllllllll}-0.15 & 0.05 & 0.15 & -0.53 & -0.12 & -0.29 & -0.22 & -0.20 & -0.38 & -0.27\end{array}$ $\begin{array}{lllllllllll}0.18 & 0.37 & -0.05 & 0.37 & 0.22 & 0.26 & 0.20 & 0.20 & -0.17 & 0.12\end{array}$ $\begin{array}{llllllllll}0.76 & -0.01 & -0.03 & 0.26 & -0.14 & -1.43 & -0.33 & -0.55 & 0.28 & -0.51\end{array}$ $\begin{array}{lllllllllllllll}0.30 & 0.06 & 0.02 & -0.76 & -0.25 & -0.79 & -0.46 & -0.26 & -0.61 & -0.53\end{array}$ $\begin{array}{llllllllll}0.22 & 0.24 & -0.24 & -0.53 & -0.08 & -0.13 & 0.19 & -0.29 & -0.81 & -0.26\end{array}$ $\begin{array}{llllllllll}-0.09 & -0.29 & -0.25 & -0.01 & -0.15 & -0.13 & -0.83 & -0.36 & 0.05 & -0.32\end{array}$ $\begin{array}{lllllllllll}0.15 & -0.15 & -0.61 & 0.06 & -0.14 & 0.29 & -0.35 & -0.48 & -0.11 & -0.16\end{array}$ $\begin{array}{lllllllllll}0.10 & 0.17 & 0.09 & 0.50 & 0.22 & -0.33 & -0.06 & -0.03 & 0.35 & -0.02\end{array}$ $\begin{array}{lllllllllll}0.62 & 0.12 & -0.29 & 0.17 & 0.16 & 0.19 & -0.13 & -0.41 & 0.01 & -0.09\end{array}$ $\begin{array}{lllllllllllll}0.10 & -0.46 & -0.59 & -0.70 & -0.41 & -0.30 & -0.43 & -0.49 & -0.67 & -0.47\end{array}$ $\begin{array}{lllllllllll}-0.98 & -1.04 & -1.35 & -0.96 & -1.08 & -0.78 & -0.81 & -1.11 & -0.95 & -0.91\end{array}$ $\begin{array}{lllllllllllll}-1.03 & -0.74 & -1.02 & -1.50 & -1.07 & -0.80 & -0.62 & -0.78 & -1.08 & -0.82\end{array}$ $\begin{array}{llllllllll}-0.90 & -1.29 & -1.17 & -1.53 & -1.22 & -0.73 & -0.92 & -1.26 & -1.53 & -1.11\end{array}$ $\begin{array}{llllllllll}1.45 & -1.41 & -1.17 & -1.32 & -1.34 & -1.15 & -0.99 & -0.96 & -0.86 & -0.99\end{array}$ $\begin{array}{llllllllll}0.87 & -1.08 & -1.00 & -1.41 & -1.09 & -0.64 & -0.82 & -0.92 & -1.28 & -0.92\end{array}$ $153-1.18$

\section{REFERENCES}

Angell, J.K. 1986. Annual and seasonal global temperature changes in the troposphere and low stratosphere, 1960-85. Monthly Weather Review 114:1922 -30. Angell, J.K. 1988. Variations and Trends in Tropospheric and Stratospheric Global Temperatures, 1958-87. Joumal of Climate 1:1296-1313.

Angell, J.K., and J. Korshover. 1983. Global temperature variations in the troposphere and stratosphere, 1958-1982. Monthly Weather Review 111:901-21.

Angell, J.K., and J. Korshover. 1983. Comparison of stratospheric warmings following Agung and Chichon. Monthly Weather Review 111:2129-35.

Angell, J.K., and J. Korshover. 1987. Annual and seasonal global temperature anomalies in the troposphere and low stratosphere, 1958-summer 1986. NDP-008/R1. Carbon Dioxide Information Analysis Center, Oak Ridge National Laboratory, Oak Ridge, Tennessee.

Hansen, J., and S. Lebedeff. 1987. Global trends of measured surface air temperature. Joumal of Geophysical Research 92:13345-72.

Jones, P.D., S.C.B. Raper, R.S. Bradley, H.F. Diaz, P.M. Kelly, and T.M.L. Wigley. 1986a. Northern Hemisphere surface air temperature variations: 1851-1984. Joumal of Climate and Applied Meteorology 25(2):161-79.

Jones, P.D., S.C.B. Raper, and T.M.L. Wigley, 1986b. Southern Hemisphere surface air temperature variations: 1851-1984. Joumal of Climate and Applied Meteorology 25(9):1213-30. 


\begin{tabular}{|c|c|c|c|c|c|c|c|c|c|c|c|c|c|c|c|}
\hline \multirow[b]{2}{*}{ Year } & \multicolumn{4}{|c|}{ Surfuce } & \multicolumn{6}{|c|}{$850-300) \mathrm{mb}$} & \multicolumn{5}{|c|}{$360-100 \mathrm{mb}$} \\
\hline & Wint & Spr & Sun & Fall & Ann & Win & Spr & Sum & Fall & Aisn & Win & Spr & Sum & Fall & Ann \\
\hline 1958 & -0.45 & -0.95 & 0.18 & 0.16 & -0.27 & -0.88 & -0.14 & 0.18 & 0.21 & -0.16 & 0,60 & 1.12 & -0.21 & 0.56 & 0.52 \\
\hline 1959 & 0.93 & 0.41 & 0.18 & 0.85 & 0.59 & 1.02 & 0.95 & 0.42 & 1.47 & 0.97 & -0.39 & 1.47 & 0.04 & -0.28 & 0.21 \\
\hline 1960 & -0.78 & 0.00 & 0.54 & -0.51 & -0.19 & -0.07 & 0.88 & 0.84 & 0.60 & 0.41 & 3.47 & -0.70 & -0.32 & 0.77 & 0.81 \\
\hline 1961 & 1.85 & -0.56 & 0.11 & 1.28 & 0.67 & 1.89 & -0.42 & -0.63 & 0.49 & 0.33 & 0.60 & 3.05 & 1.47 & 0.46 & 1.40 \\
\hline 1962 & 1.06 & 0.69 & 0.21 & 0.44 & $0.60^{\circ}$ & -0.14 & 0.22 & -0.07 & $-0,32$ & -0.08 & -2.63 & -1.68 & -0.81 & -0.18 & -1.33 \\
\hline 1963 & -0.08 & -0.09 & -0.39 & 0.19 & -0.09 & -0.04 & 0.25 & -0.25 & -0.21 & -0.06 & -0.11 & 0.28 & 0.53 & -0.53 & 0.04 \\
\hline 1964 & 0.15 & -0.55 & -0.18 & -0.60 & -0.30 & 0.07 & -0.56 & -0.70 & -0.70 & -0.47 & -2.91 & 1.51 & 0.04 & 0.74 & -0.13 \\
\hline 1965 & -0.55 & 0.18 & -0.10 & 0.54 & 0.02 & -0.21 & -0.39 & -0.88 & 0.84 & -0.16 & -1.09 & -1.61 & 0.04 & -0.38 & -0.76 \\
\hline 1966 & -3.41 & -1.44 & 0.00 & -0.96 & -1.45 & -1.47 & -0.42 & 0.11 & 0.21 & -0.39 & 2.49 & 0.42 & 0.81 & 0.49 & 1.05 \\
\hline 1967 & -0.28 & 1.35 & -0.66 & 0.78 & 0.30 & -0.46 & 0.07 & -0.39 & 0.42 & -0.09 & -1.40 & -3.89 & -0.21 & -1.47 & -1.74 \\
\hline 1968 & 0.00 & 0.58 & -0.25 & -0.91 & -0.15 & -0.18 & -0.32 & 0.00 & -0.42 & -0.23 & 1.36 & -4.34 & -0.49 & -0.42 & -0.97 \\
\hline 1969 & -0.70 & -0.48 & 0.01 & 0.58 & -0.15 & $\begin{array}{l}0.07 \\
\end{array}$ & 0.11 & 0.49 & 0.32 & 0.25 & 2.98 & 0.18 & 0.28 & -0.14 & 0.83 \\
\hline 1970 & 1.31 & 0.44 & -0.36 & -0.71 & 0.17 & 1.02 & -0.21 & 0.14 & -0.18 & 0.19 & 2.87 & 0.28 & -0.11 & 0.18 & 0.81 \\
\hline 1971 & -0.82 & 0.05 & 0.64 & -0.06 & -0.05 & -0.5 .3 & -0.21 & -0.11 & -1.30 & -0.54 & 0.32 & 0.53 & -0.18 & -0.73 & -0.02 \\
\hline 1972 & -0.11 & -0.29 & -0.20 & -0.75 & -0.34 & -0.25 & 0.07 & 0.21 & -0.35 & -0.08 & -3.15 & -0.46 & -0.49 & 0.32 & +0.9 .5 \\
\hline 1973 & 1.57 & -0.25 & 0.83 & -0.14 & 0.50 & 0.63 & -0.35 & 0.77 & 0.11 & 0.29 & 0.49 & 1.26 & -0.21 & 0.32 & 0.47 \\
\hline 1974 & 0.53 & 0.14 & -0.21 & 0.14 & 0.15 & 0.18 & 0.74 & 0.00 & -0.28 & 0.16 & -2.63 & 0.98 & -0.28 & 0.88 & -0.26 \\
\hline 1975 & -0.13 & 0.91 & -0.33 & -0.41 & 0.01 & -0.67 & 0.25 & -0.14 & -0.21 & -0.19 & -0.77 & 1.40 & 0.04 & -0.49 & 0.05 \\
\hline 1976 & 0.30 & 0.28 & -0.45 & -0.93 & -0.20 & -0.56 & -0.21 & -0.28 & 0.48 & -0.14 & -4.03 & -2.24 & -1.02 & -1.13 & -2.11 \\
\hline 1977 & 0.18 & -0.79 & 0.19 & -0.55 & -0.24 & 0.78 & 0.06 & 0.83 & -0.15 & 0.38 & 3.27 & 1.42 & -0.88 & -0.77 & 0.76 \\
\hline 1978 & 0.60 & 0.55 & -0.36 & -0.18 & 0.15 & 0.03 & 0.54 & 0.36 & -0.38 & $0: 14$ & -0.65 & 0.49 & -0.14 & -1.17 & $-0.3 ?$ \\
\hline 1979 & -0.46 & -0.23 & -0.91 & -0.18 & -0.45 & -0.39 & 0.16 & 0.25 & 0.00 & 0.01 & -0.36 & 0.54 & -0.10 & 0.09 & 0.04 \\
\hline 1980 & 1.12 & 0.30 & 0.00 & -0.84 & 0.15 & 0.38 & 0.35 & 0.17 & -0.40 & 0.13 & -2.36 & 1.15 & 0.09 & -0.23 & -0.34 \\
\hline 1981 & 1.85 & 0.48 & -0.45 & 1.10 & 0.75 & -0.27 & 0.76 & -0.22 & 0.56 & 0.21 & -1.72 & -0.90 & -0.02 & -0.63 & -0.82 \\
\hline 1982 & 0.80 & -0.06 & -0.19 & -1.71 & -0.29 & 0.25 & -0.38 & 0.18 & -0.71 & -0.17 & -0.45 & -0.33 & -0.12 & -1.09 & -0.50 \\
\hline 1983 & 0.38 & 0.52 & -0.08 & -0.34 & 0.12 & -0.46 & 0.48 & 0.56 & -0.01 & 0.14 & -4.43 & 0.23 & -0.65 & -1.28 & -1.53 \\
\hline 1984 & 1.18 & 0.49 & -0.10 & 0.17 & 0.44 & 0.10 & 0.40 & 0.07 & 0.58 & 0.29 & -3.25 & 1.61 & -0.18 & -0.93 & -0.69 \\
\hline 1985 & 0.13 & -0.33 & -0.54 & -0.51 & -0.31 & 0.43 & -0.78 & -0.86 & -0.04 & -0.31 & 3.75 & 1.71 & -0.02 & 0.04 & 1.37 \\
\hline 1986 & -0.10 & -0.19 & -0.02 & 0.81 & 0.13 & 0.38 & -0.59 & -0.01 & -0.34 & -0.14 & -1.43 & 0.20 & -0.89 & -1.02 & -0.79 \\
\hline 1987 & -1.21 & -0.73 & 0.00 & -0.58 & -0.63 & -0.47 & 0.32 & -0.02 & -0.40 & -0.14 & 1.73 & 0.26 & -0.24 & 0.61 & 0.59 \\
\hline 1988 & 0.54 & 1.06 & 0.44 & -0.45 & 0.40 & 0,10 & -0.09 & 0.95 & -0.11 & 0.21 & -0.22 & -1.35 & -0.37 & -1.09 & -0.76 \\
\hline 1989 & 1.99 & 1.42 & 0.69 & 0.06 & 1.04 & -0.49 & 0.58 & 0.27 & -0.27 & 0.02 & -3.62 & 1.09 & -0.52 & -0.61 & -0.92 \\
\hline 1990 & 0.92 & 3.98 & & & & 0.02 & 0.22 & & & & -3.87 & -5.98 & & & \\
\hline
\end{tabular}

*'Temperature anomalies (in relation to a 1958-1977 average) expressed in degrees Celsius.

†Northern Hemisphere winier (Dec-Feb).

Note: Data for summer (Jun-Aug) 1989 through spring (Mar-May) 1990 are provisional. 


\section{Annual and Seasonal Temperature Anomalies*}

\begin{tabular}{|c|c|c|c|c|c|c|c|c|c|c|c|c|c|c|}
\hline \multicolumn{5}{|c|}{ Surface-100 mb } & \multicolumn{5}{|c|}{$1(10-50 \mathrm{mb}$} & \multicolumn{5}{|c|}{$100-30 \mathrm{mb}$} \\
\hline Win & Spr & Fall & Sum & Ann & Win & Spr & Sum & Fall & Ann & "' in & Spr & Sum & Fall & Ann \\
\hline-0.48 & 0.02 & 0.09 & 0.28 & -0.02 & 2.60 & -1.60 & 0.23 & 2.77 & 1.00 & 2.35 & -2.47 & 0.31 & 3.92 & 1.03 \\
\hline 0.69 & 0.98 & 0.30 & 0.98 & 0.74 & -3.03 & 6.25 & 1.08 & -1.30 & 0.75 & -2.18 & 5.95 & 1.30 & -1.27 & 0.95 \\
\hline 0.60 & 0,38 & 0.53 & 0.09 & 0.40 & 6.05 & 4.16 & 0.28 & 2.12 & 3.15 & 9.25 & -0.41 & 0.09 & 2.95 & 2.97 \\
\hline 1.60 & 0.33 & -0.04 & 0.62 & 0.63 & 1.32 & 2.12 & -0.21 & 1.14 & 1.09 & 1.17 & 2.87 & 0.16 & 1.18 & 1.35 \\
\hline-0.49 & -0.30 & -0.19 & -0.16 & -0.29 & -5.08 & -4.23 & $-1,30$ & -0.09 & -2.68 & -6.31 & -4.86 & -1.67 & -0.20 & -3.26 \\
\hline-0.06 & 0.20 & -0.10 & -0.21 & -0.04 & -0.19 & -3.14 & 0.97 & -1.02 & -0.85 & 1.34 & -4.03 & 0.93 & -0.69 & -0.61 \\
\hline-0.58 & -0.08 & -0.45 & -0.36 & -0.37 & -4.29 & 2.28 & 0.13 & 0.35 & -0.38 & -4.55 & 3.35 & -0.07 & 0.06 & -0.30 \\
\hline-0.46 & -0.57 & -0.55 & 0.52 & -0.27 & -2.68 & -2.73 & -0.37 & -1.02 & -1.70 & -4.63 & -1.78 & -0.47 & -1.56 & -2.11 \\
\hline-0.91 & -0.40 & 0.25 & 0.08 & -0.25 & 3.18 & -0.71 & 0.33 & 0.09 & 0.72 & 1.49 & -0.55 & 0.06 & 0.17 & 0.28 \\
\hline-0.55 & -0.60 & -0.40 & 0.06 & -0.37 & -3.30 & -5.61 & 0.30 & -0.99 & -2.40 & -4.17 & -1.94 & 0.07 & -2.15 & -2.05 \\
\hline 0.19 & -1.06 & -0.15 & -0.50 & -0.38 & 0.25 & -4.63 & 0.10 & 0.08 & -1.05 & -3.96 & -2.19 & 0.29 & 0.41 & -1.36 \\
\hline 0.59 & 0.03 & 0.36 & 0.20 & 0.31 & 1.28 & -0.81 & -1.76 & -0.35 & -0.41 & -0.59 & -0.43 & 0.02 & -0.57 & -0.39 \\
\hline 1.48 & 0.01 & 0.00 & -0.19 & 0.33 & 2.76 & -0.24 & 0.69 & 1.62 & 1.21 & 3.03 & -0.39 & 0.75 & 0.02 & 0.85 \\
\hline-0.39 & 0.00 & 0.00 & -0.97 & -0.34 & 2.35 & -0.84 & 0.06 & -0.33 & 0.31 & 0.85 & -1.17 & -0.12 & -0.41 & -0.21 \\
\hline-0.87 & -0.11 & -0.01 & -0.27 & -0.32 & -2.06 & 0.76 & 0.06 & -0.46 & -0.43 & -1.91 & 1.88 & -0.11 & -0.02 & -0.04 \\
\hline 0.76 & 0.02 & 0.56 & 0.12 & 0.37 & 1.90 & -0.65 & -0.67 & -0.58 & 0.00 & 4.09 & -1.48 & -0.73 & -0.35 & 0.38 \\
\hline-0.39 & 0.69 & -0.10 & 0.05 & 0.06 & -2.47 & 2.85 & 0.02 & 1.42 & 0.46 & -0.97 & 3.05 & 0.01 & 0.63 & 0.68 \\
\hline-0.60 & 0.62 & -0.13 & -0.31 & -0.11 & 0.57 & 1.59 & -0.11 & -0.94 & 0.28 & 1.45 & 0.18 & 0.26 & 0.27 & 0.54 \\
\hline-1.19 & -0.58 & -0.47 & -0.10 & -0.59 & -4.38 & 1.40 & -0.15 & -0.66 & -0.95 & -1.62 & 1,26 & 0.03 & -0.49 & -0.21 \\
\hline 1.23 & 0.22 & 0.34 & -0.36 & 0.36 & 2.94 & 0.95 & 1.30 & 0.95 & 1.54 & 0.07 & 0.74 & 0.62 & 0.28 & 0.43 \\
\hline-0.018 & 0.52 & 0.13 & -0.52 & 0.01 & -1.10 & 0.30 & -1.09 & -2.42 & -1.03 & -0.91 & 0.15 & -0.91 & -0.88 & -0.64 \\
\hline-0.39 & 0.05 & -0.03 & $-0,01$ & -0.10 & 2.10 & 0.49 & -0.33 & 0.23 & 0.62 & 0.26 & 0.48 & -0.29 & -0.89 & -0.11 \\
\hline-0.09 & 0.52 & 0.20 & -0.24 & 0.10 & -0.12 & 0.87 & 0.10 & 0.41 & 0,32 & 1.05 & 0.83 & 0.06 & 0.05 & 0.50 \\
\hline-0.34 & 0.28 & -0.22 & 0.34 & 0.02 & -0.13 & -1.52 & -0.43 & -0.18 & -0.57 & 0.47 & -2.35 & -0.18 & -0.21 & -0.57 \\
\hline 0.17 & -0.20 & 0.03 & -0.91 & -0.23 & 1.11 & 0.42 & 0.52 & -1.08 & 0.24 & 0.92 & 0.96 & 0.54 & -1.90 & 0.13 \\
\hline-0.98 & 0.48 & 0.21 & -0.29 & -0.15 & -4.36 & -0.01 & -0.81 & -0.98 & -1.54 & -4.00 & 0.15 & -0.90 & -1.33 & -1.52 \\
\hline-0.47 & 0.68 & -0.01 & 0.19 & 0.10 & -1.73 & 1.01 & -0.45 & -0.76 & -0.48 & -1.37 & 0.72 & -0.22 & -0.42 & -0.32 \\
\hline 1.12 & -0.15 & -0.62 & -0.10 & 0.06 & 3.34 & $0.2 \%$ & -0.69 & -0.50 & 0.59 & 2.13 & 0.10 & -0.43 & -0.55 & 0.31 \\
\hline-0.12 & -0.32 & -0.24 & -0.30 & -0.25 & -1.54 & 1.10 & -0.62 & -1.67 & -0.68 & -0.79 & 0.86 & -0.41 & -1.11 & -0.36 \\
\hline-0.11 & 0.13 & -0.06 & -0.21 & -0.06 & 3.20 & -2.23 & -0.34 & 0.38 & 0.25 & 2.27 & -1.53 & -0.36 & 0.57 & 0.24 \\
\hline 0.07 & -0.18 & 0.57 & -0.39 & 0.02 & -1.48 & 0.03 & -0.81 & -1.35 & -0.90 & -0.72 & 0.36 & -0.58 & -0.98 & -0.48 \\
\hline-0.77 & 0.83 & 0.17 & -0.29 & -0.02 & -0.38 & 1.11 & -0.97 & -0.75 & -0.25 & 0.30 & 0.61 & -0.60 & -0.43 & -0.03 \\
\hline-0.69 & -0.53 & & & & -3.26 & -6.18 & & & & -1.54 & -3.47 & & & \\
\hline
\end{tabular}


Surface

$850-300 \mathrm{mb}$

$300-100 \mathrm{mb}$

\begin{tabular}{|c|c|c|c|c|c|c|c|c|c|c|c|c|c|c|}
\hline Year & Wint & Spr & Sum & Fall & Ann & Win & Spr & Sum & Fall & Ann & Win & Spr & Sum & Fall \\
\hline 1958 & 1.67 & 0.03 & 0.12 & 0.33 & 0.54 & 1.61 & 0.70 & -0.07 & 0.14 & 0.60 & -0.46 & -0.35 & 0.39 & 0.98 \\
\hline 1959 & 0.48 & 0.31 & 0.55 & -0.49 & 0.21 & 0.25 & 0.95 & 0.42 & 0.14 & 0.44 & 0.35 & 0.88 & & 0.28 \\
\hline $960^{\circ}$ & 0.52 & -0.88 & 0.10 & -0.34 & -0.15 & -0.04 & -0.70 & 0.14 & -0.07 & -0.17 & 0.84 & 0.60 & & 0.53 \\
\hline 961 & 0.92 & 0.82 & 0.25 & 0.21 & 0.55 & 0.42 & 0.56 & 0.21 & 0.67 & 0.47 & 0.53 & 0.42 & 0.53 & -0.28 \\
\hline 1962 & 0.94 & 0.39 & -0.09 & -0.31 & 0.23 & 0.46 & 0.56 & 0.18 & 0,04 & 0.31 & -0.70 & -0.21 & -0.28 & 0.28 \\
\hline 1963 & 0.26 & -0.11 & 0.03 & 0.97 & 0.29 & 0.53 & -0.18 & 0.21 & 0.81 & 0.34 & -0.53 & -0.14 & & 0.67 \\
\hline 964 & 0.12 & -0.83 & -0.19 & -0.17 & -0.27 & -0.04 & 0.32 & 0.21 & -0.07 & 0.11 & 0.14 & 0.07 & -0.07 & 0.18 \\
\hline 1965 & -0.47 & -0.32 & -0.20 & -0.60 & -0.40 & 0.18 & -0.35 & -0.39 & -0.49 & -0.26 & 0.56 & 0.14 & -0.39 & 0.25 \\
\hline 1966 & 0.39 & 0.37 & -0.36 & -0.05 & 0.09 & 0.00 & 0.04 & 0.18 & 0.56 & 0.20 & -0.25 & -0.46 & 0.77 & 0.00 \\
\hline 1967 & -0.47 & 0.48 & 0.64 & 0.85 & 0.38 & -0.35 & 0.46 & 0.46 & 0.60 & 0.29 & -0.07 & 0.42 & -0.88 & -0.67 \\
\hline 1968 & -0.42 & 1.07 & -0.31 & -0.16 & 0.05 & 0.74 & 0.42 & -0.67 & -0.28 & 0.05 & 0.00 & -0.84 & -0.32 & -0.04 \\
\hline 1969 & -2.27 & -0.93 & -0.10 & -0.03 & -0.83 & -0.98 & -0.49 & 0.07 & 0.14 & -0.32 & -0.46 & 0.25 & 0.21 & -0.32 \\
\hline 1970 & 0.00 & -1.29 & -0.23 & 0.21 & $-0,08$ & -0.42 & -0.35 & 0.07 & 0.18 & -0.13 & -0.39 & -0.42 & 0.32 & -0.21 \\
\hline 1971 & -0.67 & -0.35 & -0.25 & 0.65 & -0.16 & -0.53 & -0.60 & -0.21 & 0.14 & -0.30 & -0.04 & 0.04 & & -0.11 \\
\hline 1972 & -0.90 & -0.25 & -0.06 & -0.60 & -0.45 & -0.95 & -0.35 & -0.28 & -0.49 & -0.52 & 0.42 & -0.46 & -0.5 & -0.35 \\
\hline 1973 & -0.19 & -0.02 & 0.12 & -0.43 & -0.13 & 0.00 & -0.21 & -0.21 & -0.67 & -0.27 & 0.14 & 0.35 & 0.00 & -0.49 \\
\hline 1974 & -0.02 & -0.32 & -0.47 & -0.24 & -0.26 & -0.39 & $-0,81$ & -0.63 & -1.12 & -0.74 & -0.25 & -0.11 & -0.53 & -0.25 \\
\hline 1975 & 0.52 & 0.58 & 0.51 & 0.00 & 0.40 & -0.42 & 0.04 & 0.32 & -0.21 . & -0.07 & 0.07 & -0.21 & -0. & -0.21 \\
\hline 1976 & 0.02 & -0.80 & -0.05 & -0.82 & -0.41 & -0.25 & -1.09 & -0.46 & -1.03 & -0.71 & -0.14 & -0.46 & -1. & $-\{1.52$ \\
\hline 1977 & -0.96 & 0.53 & -0.08 & 0.17 & -0.09 & -0.96 & 0.44 & -0.11 & 0.14 & -0.12 & -0.12 & 0.51 & 0.05 & 13.14 \\
\hline 1978 & -0.20 & -0.53 & 0.07 & 0.10 & -0.14 & -0.66 & -0.22 & -0.05 & -0.13 & -0.27 & 0.42 & -0.30 & 0.16 & $\alpha .21$ \\
\hline 1979 & -0.54 & 0.33 & 0.16 & 0.01 & -0.01 & -0.43 & 0.73 & 0.22 & 0.44 & 0.24 & -0.28 & -0.25 & -0.31 & 0.10 \\
\hline 1980 & 0.65 & -0.14 & -0.47 & 0.03 & 0.02 & 0.21 & -0.31 & 0.29 & -0.24 & -0.01 & -0.51 & 0.92 & 0.84 & 0.46 \\
\hline 1981 & 1.06 & 1.06 & 0.31 & 0.40 & 0.71 & 0.73 & 0.71 & 0.37 & -0.03 & 0.45 & -0.76 & -0.79 & 0.01 & 0.23 \\
\hline 1982 & 0.21 & -0.22 & -0.05 & 0.28 & $0 .^{-}$ & -0.32 & -0.28 & -0.01 & 0.20 & -0.10 & 0.69 & 0.50 & 0.09 & -0.33 \\
\hline 1983 & 2.92 & 0.60 & 0.34 & 0.57 & 1.11 & 0.93 & 0.98 & 0.45 & 0.39 & 0.69 & -0.23 & -0.95 & -0.11 & 0.04 \\
\hline 1984 & 1.02 & 0.03 & 0.26 & -0.19 & 0.28 & 0.05 & -0.25 & 0.27 & -0.61 & -0.14 & -0.40 & -0.32 & 0.00 & 0.43 \\
\hline 1985 & -1.29 & -0.27 & -0.20 & -0.99 & -0.69 & -0.51 & -0.26 & -0.25 & -0.46 & -0.37 & 0.22 & 0.80 & 0.01 & 0.32 \\
\hline 1986 & 0.14 & 0.51 & -0.40 & -0.45 & -0.05 & -0.07 & 0.52 & -0.06 & 0.17 & 0.14 & 0.31 & -0.31 & -0.20 & -0.12 \\
\hline 1987 & 0.78 & -0.13 & 0.10 & -0.79 & -0.01 & 0.23 & 0.22 & 0.38 & -0.41 & 0.11 & -0.05 & -0.82 & 0.29 & 0.90 \\
\hline 1988 & 0.55 & 0.60 & 0.39 & 0.26 & 0.45 & -0.05 & 0.23 & 0.97 & 0.37 & 0.38 & -0.70 & 0.20 & -0.06 & -0.05 \\
\hline 1989 & 1.49 & 0.79 & 0.47 & 0.17 & 0.73 & 0.36 & 0.50 & 0.54 & 0.33 & 0.43 & 0.49 & 0.02 & -0.85 & -0.28 \\
\hline 1990 & 1.31 & 1.77 & & & & 0.53 & 1.03 & & & & 0.35 & 0.24 & & \\
\hline
\end{tabular}

* Temperature anomalies (in relation to a 1958-1977 average) expressed in degrees Celsius.

†Northern Hemisphere winter (Dec-Feb).

Note: Data for summer (Jun-Aug) 1989 through spring (Mar-May) 1990 are provisional. 
Temperature Anomalies

\section{Annual and Seasonal Temperature Anomalies*}

Surface-100 mb

$160-50 \mathrm{mb}$

$(00-3) \mathrm{mb}$

\begin{tabular}{|c|c|c|c|c|c|c|c|c|c|c|c|c|c|c|c|}
\hline Ann & Win & Spr & Fall & Sum & Ann & W/n & Spr & Sum & Fall & Ann & Win & Spr & Sum & Fall & Ann \\
\hline 0.14 & 1.16 & 0.36 & 0.06 & 0.36 & 0.49 & 1.40 & 1.22 & 0.89 & 1.93 & 1.36 & 0.36 & 0.83 & 1.37 & 1.94 & 1.13 \\
\hline 0.54 & 0.31 & 0.83 & 0.49 & 0.07 & 0.43 & 1.48 & 2.18 & 1.32 & 0.64 & 1.41 & 0.60 & 1.48 & 0.99 & 1.21 & 1.07 \\
\hline 0.56 & 0.25 & -0.44 & 0.16 & 0.02 & 0.00 & 1.19 & 1.33 & 1.00 & 0.37 & 0.97 & 0.69 & 1.02 & 0.77 & 0.34 & 0.71 \\
\hline 0.30 & 0.53 & 0.57 & 0.29 & 0.38 & 0.44 & -1.30 & 0.23 & 0.78 & -1.11 & -0.35 & -0.15 & -0.04 & 0.74 & $-0,33$ & 0.06 \\
\hline-0.23. & 0.28 & 0.36 & 0.03 & 0.06 & 0.18 & 0.53 & -0.23 & -0.80 & 0.23 & -0.07 & 1.27 & -0.53 & -1.02 & 0.11 & -0.04 \\
\hline 0.14 & 0.25 & -0.16 & 0.26 & 0.81 & 0.29 & -1.11 & 0.01 & 0.70 & 1.01 & 0.15 & 0.56 & -1.25 & 0.41 & 0.68 & 0.10 \\
\hline 0.08 & 0.03 & 0.07 & 0.08 & -0.03 & 0.04 & -0.09 & 0.56 & -0.16 & -0.91 & -0.15 & 0.70 & 1.40 & -0.22 & -0.70 & 0.30 \\
\hline 0.14 & 0.16 & -0.24 & -0.36 & -0.34 & -0.20 & -0.46 & 0.07 & -0.02 & 0.19 & -0.06 & -0.68 & 1.40 & 0.14 & 0.02 & 0.22 \\
\hline 0.02 & 0.01 & -0.02 & 0.22 & 0.33 & 0.14 & 0.59 & -0.85 & 0.24 & 0.80 & 0.20 & -0.16 & -0.50 & 0.27 & 0.90 & 0.13 \\
\hline-0.30 & -0.31 & 0.45 & 0.19 & 0.36 & 0.17 & 0.85 & 0.23 & -1.21 & -0.28 & -0.10 & 0.09 & 0.42 & -0.44 & -0.41 & -0.09 \\
\hline-0.30 & 0.38 & 0.25 & -0.53 & -0.21 & -0.03 & -0.99 & -0.74 & 0.18 & -0.10 & -0.41 & -1.58 & -0.91 & 0.12 & -0.35 & -0.68 \\
\hline-0.08 & -1.08 & -0.40 & 0.07 & 0.01 & -0.35 & -1.37 & 0.03 & -0.04 & 1.15 & -0.06 & -2.03 & -0.43 & -0.07 & -0.63 & -0.79 \\
\hline-0.18 & -0.34 & & 0.08 & 0.10 & -0.13 & 0.05 & 0.37 & 0.33 & -0.27 & 0.12 & -0.28 & 0.46 & 0.31 & -0.08 & 0.10 \\
\hline-0.01 & -0.44 & -0.42 & -0.15 & 0.17 & -0.21 & 0.03 & -0.78 & 0.00 & -0.11 & -0.22 & -0.75 & -0.96 & 0.02 & -0.50 & -0.55 \\
\hline-0.23 & -0.64 & & -0.30 & -0.48 & $-0.4 S$ & -0.33 & 0.12 & 0.30 & 0.19 & 0.07 & 1.26 & 0.27 & -0.45 & 0.13 & 0.30 \\
\hline 0.00 & 0.00 & & -0.11 & -0.59 & -0.19 & 0.56 & -0.94 & -0.60 & -0.38 & -0.34 & 0.49 & -1.5 & -0.58 & -0.89 & $-0,64$ \\
\hline-0.29 & -0.30 & & -0.56 & -0.78 & -0.55 & -0.09 & 0.46 & -0.07 & -0.38 & -0.02 & 0.66 & .54 & -0.14 & 0.11 & 0.29 \\
\hline-0.28 & -0.15 & & 0.11 & -0.29 & -0.07 & -0.16 & -0.09 & -0.29 & -0.82 & -0.34 & -0.66 & -0.62 & -0.12 & -0.09 & -0.37 \\
\hline-0.55 & -0.18 & & -0.53 & -0.88 & -0.62 & 0.04 & 0.38 & -0.58 & 0.27 & 0.03 & 0.72 & 0.43 & -0.35 & 0.29 & 0.27 \\
\hline 0.15 & -0.77 & & -0.04 & 0.14 & -0.05 & -0.17 & -0.08 & 0.42 & 0.17 & 0.09 & -0.25 & & 0.12 & -0.13 & -0.14 \\
\hline 0.02 & -0.34 & & 0.02 & -0.10 & & 0.24 & -1.35 & -0.78 & -0.29 & -0.55 & -0.58 & & -0.56 & -0.09 & -0.63 \\
\hline-0.19 & -0.36 & 0.45 & 0.09 & & 0.12 & 0.18 & 0.60 & -0.16 & 0.27 & 0.22 & 0.47 & 0.06 & 0.00 & -0.02 & 0.13 \\
\hline 0.43 & & & 0.27 & -0.07 & 0.10 & -0.21 & 1.02 & 0.03 & 1.08 & 0.48 & -0.93 & 0.41 & 0.39 & 0.79 & 0.17 \\
\hline-0.33 & & & 0.28 & & 0.32 & 0.52 & 0.04 & -0.09 & 0.53 & 0.25 & 0.45 & 0.36 & 0.11 & 0.83 & 0.44 \\
\hline 0.24 & -0.02 & -0.09 & 0.03 & 0.09 & 0.00 & 0.93 & 0.64 & 0.91 & & & 1.78 & 0.68 & 0. & 0.36 & 0.90 \\
\hline$=-0,31$ & & & 0.28 & & 0.53 & 0.28 & 0.1 .8 & -0.39 & & 0.01 & 0.51 & 0.23 & -0. & 0.31 & 0.12 \\
\hline-0.07 & 0.11 & -0.22 & 0.21 & -0.34 & -0.06 & 0.00 & & -0.79 & & 0.05 & 0.23 & 0.34 & -0.49 & 0.26 & 0.09 \\
\hline 0.34 & -0.48 & -0.03 & -0.18 & -0.37 & -0.27 & -0.44 & -1.09 & -0.65 & -0.01 & -0.55 & -0.26 & & -0.46 & -0.04 & -0.40 \\
\hline$-0,08$ & 0.05 & 0.34 & -0.15 & 0.00 & 0.06 & 1.07 & -0.26 & -0.39 & 0.26 & 0.17 & 0.80 & -0.09 & -0.28 & 0.19 & 0.16 \\
\hline 0.08 & 0.26 & -0.07 & 0.32 & -0.18 & 0.08 & -0.01 & -0.68 & 0.27 & 0.77 & 0.09 & 0.03 & -0.40 & -0.24 & 0.63 & 0.01 \\
\hline$-0.1 S$ & $-0,09$ & 0.29 & 0.64 & 0.26 & 0.28 & -1.36 & 0.68 & -0.23 & -0.10 & -0.25 & $-0,68$ & 0.47 & -0.23 & -0.10 & -0.14 \\
\hline \multirow[t]{2}{*}{-0.16} & 0.58 & 0.44 & 0.22 & 0.17 & 0.35 & 0.33 & -0.87 & -0.80 & -0.37 & -0.43 & 0.46 & -0.54 & -0.71 & -0.23 & -0.26 \\
\hline & 0.62 & 0.98 & & & -0.78 & -0.43 & & & & -0.55 & -0.40 & & & & \\
\hline
\end{tabular}


Surface

$850-300 \mathrm{mb}$

$300-100 \mathrm{mb}$

\begin{tabular}{|c|c|c|c|c|c|c|c|c|c|c|c|c|c|c|c|}
\hline Year & Wint & Spr & Sum & Fall & Ann & W/n & Spr & Sum & Fall & Ann & Win & Spr & Sum & Fall & Ann \\
\hline 1958 & 0.22 & 0.40 & 0.12 & 0,30 & 0.26 & $0>0:$ & 0.77 & & & & & 010 & 0.56 & 0.77 & 0.46 \\
\hline 959 & 0.05 & 0.08 & & & & & & & & & & .32 & & 0.70 & $\$ 1$ \\
\hline 1960 & 0.05 & 0.00 & 0.05 & -0.47 & -0.09 & 0.49 & 0.44 & 0.49 & 0.18 & 0.40 & 0.53 & 0.11 & 0.39 & -0.21 & 0.21 \\
\hline 961 & -0.07 & -0.24 & -0.17 & -0.38 & -0.22 & 0.18 & 0.11 & 0.00 & 0.04 & 0.08 & 0.11 & 0.28 & 0.56 & 0.25 & 0.30 \\
\hline 962 & -0.21 & -0.12 & -0.12 & 0.02 & -0.11 & 0.28 & -0.14 & -0.11 & 0.18 & 0.05 & 0.60 & & .25 & 0.25 & 0.36 \\
\hline 963 & 0.42 & & 0.10 & 0.34 & 0.26 & -0.07 & -0.25 & -0.21 & -0.21 & -0.19 & -0.11 & 0.18 & 11 & 0.46 & 0.16 \\
\hline 964 & -0.67 & -0.39 & -0.14 & -0.39 & -0.40 & 0.07 & 0.07 & -0.07 & -0.46 & -0.10 & 0.63 & 0.53 & 0.14 & -0.35 & 0.24 \\
\hline 965 & -0.15 & -0.38 & -0.18 & -0.08 & -0.20 & -0.91 & -0.53 & -0.60. & -0.25 & .0 .57 & -0.67 & $-0.49^{\prime}$ & -0.28 & 0.07 & -0.34 \\
\hline 966 & -0.35 & 0.09 & 0.06 & 0.08 & -0.03 & 0.14 & 0.32 & 0.25 & 0.14 & 0.21 & 1.02 & 0.56 & 0.67 & 0.24 & 0.62 \\
\hline 967 & -0.31 & -0.17 & -0.07 & -0.47 & -0.26 & 0.25 & -0.35 & 0.14 & -0.11 & -0.02 & 0.00 & 0.11 & 0.21 & 0.14 & 0.12 \\
\hline 968 & -0.29 & -0.37 & 0.02 & 0.01 & -0.16 & -0.46 & -0.60 & -0.39 & -0.32 & -0.44 & -0.49 & -0.95 & -1.02 & -0.91 & -0.84 \\
\hline 969 & 0.39 & 0.42 & 0.44 & 0.24 & 0.37 & -0.14 & & 0.28 & 0.04 & 0.07 & -0.56 & 0.39 & -0.46 & -0.42 & -0.200 \\
\hline 1970 & 0.55 & 0.19 & 0.28 & 0.00 & 0.26 & 0.11 & 0.18 & 0.25 & 0.07 & 0.15 & -0.21 & 0.35 & 0.39 & 0.28 & 0.20 \\
\hline 971 & -0.11 & 0.06 & -0.27 & -0.27 & -0.15 & -0.25 & -0.70 & -0.67 & -0.60 & -0.56 & -0.42 & -0.74 & -1.05 & -0.95 & -0.79 \\
\hline 972 & -0.19 & -0.32 & 0.27 & 0.30 & 0.02 & -0.67 & -0.35 & -0.04 & -0.11 & -0.29 & -0.98 & -0.77 & 0.00 & 0.21 & -0.39 \\
\hline 973 & 0.47 & 0.62 & 0.28 & 0.35 & 0.43 & 0.53 & 0.39 & 0.07 & 0.11 & 0.28 & 1.05 & 0.60 & 0.18 & -0.14 & 0.42 \\
\hline 1974 & 0.12 & 0.20 & -0.32 & 0.02 & 0.01 & -0.18 & -0.21 & -0.28 & -0.11 & -0.20 & -0.53 & -0.53 & -0.53 & -0.21 & -0.48 \\
\hline 1975 & 0.17 & 0.12 & -0.08 & 0.09 & 0.08 & -0.25 & 0.04 & -0.32 & 0.00 & -0.13 & -0.60 & -0.14 & -0.11 & 0.11 & -0.19 \\
\hline 1976 & 0.08 & -0.23 & 0.08 & 0.48 & 0.10 & -0.49 & -0.49 & -0.49 & -0.34 & -0.45 & -0.35 & -0.35 & -0.39 & -0.40 & -0.37 \\
\hline 1977 & 0.09 & & 0.40 & 0.71 & 0.41 & 0.31 & -0.13 & -0.20 & 0.19 & 0.04 & -0.05 & -0.15 & -0.17 & -0.69 & -0.27 \\
\hline 1978 & 0.44 & -0.14 & 0.43 & 0.63 & 0.34 & -0.01 & 0.08 & -0.02 & -0.16 & -0.03 & 0.00 & -0.64 & -0.70 & -0.76 & -0.53 \\
\hline 1979 & 0.19 & & 0.16 & 0.44 & 0.29 & -0.51 & -0.02 & -0.03 & 0.08 & -0.12 & -0.58 & 0.05 & -0.76 & -0.88 & -0.54 \\
\hline 1980 & 0.71 & 0.96 & 0.45 & 0.56 & 0.67 & 0.06 & 0.14 & 0.36 & 0.21 & 0.19 & -0.34 & 0.12 & 0.00 & -0.24 & -0.12 \\
\hline 1981 & 0.54 & 0.71 & 0.68 & 0.33 & 0.57 & 0.05 & -0.11 & 0.06 & 0.18 & 0.05 & -0.56 & -0.79 & -0.63 & -0.74 & -0.68 \\
\hline 1982 & 0.57 & 0.05 & 0.40 & 0.45 & 0.37 & -0.17 & -0.27 & 0.10 & -0.34 & -0.17 & -0.53 & -0.82 & -0.22 & -0.67 & -0.56 \\
\hline 1983 & -0.37 & -0.13 & 0.59 & 0.64 & 0.18 & -0.25 & & 0.10 & 0.04 & 0.00 & 0.35 & & 0.21 & & 0.05 \\
\hline 1984 & -0.19 & 0.48 & 0.11 & 0.36 & 0.19 & 0.05 & 0.07 & -0.35 & -0.19 & -0.11 & -1.02 & -0.87 & -0.71 & -1.23 & -0.96 \\
\hline 1985 & -0.17 & 0.02 & 0.22 & 0.34 & 0.10 & -0.05 & -0.19 & -0.28 & -0.51 & -0.26 & -0.74 & -0.53 & -0.97 & -1.03 & $-0,82$ \\
\hline 1986 & 0.07 & 0.21 & 0.28 & 0.27 & 0.21 & 0.25 & 0.07 & 0.11 & 0.10 & 0.13 & -0.77 & -1.02 & -0.60 & -0.47 & -0.72 \\
\hline 1987 & 0.46 & 0.42 & 0.76 & 1.07 & 0.68 & 0.23 & -0.15 & 0.48 & 0.69 & 0.31 & 0.35 & -0.35 & -0.16 & 0.22 & 0.02 \\
\hline 1988 & 0.37 & 0.47 & 0.18 & 0.02 & 0.26 & 0.59 & 0.52 & 0.81 & 0.52 & 0.61 & -0.38 & -0.21 & -0.04 & -0.25 & -0.22 \\
\hline 1989 & 0.14 & 0.14 & 0.30 & -0.02 & 0.14 & 0.07 & 0.06 & 0.24 & 0.45 & 0.21 & -0.42 & -0.92 & -0.45 & -0.22 & -0.50 \\
\hline 1990 & 0.31 & 0.14 & & & & -0.13 & 0.74 & & & & 0.76 & 0.30 & & & \\
\hline
\end{tabular}

"Temperature anomalies (in relation to a 1958-1977 average) expressed in degrees Celsius.

†Northern Hemisphere winter (Dec-Feb).

Note: Data for summer (Jun-Aug) 1989 through spring (Mar-May) 1990 are provisional. 


\section{Annual and Seasonal Temperature Anomalies*}

Surface-100 mb

$100-50 \mathrm{mb}$

$100-30 \mathrm{mb}$

\begin{tabular}{|c|c|c|c|c|c|c|c|c|c|c|c|c|c|c|}
\hline$V / n$ & Spr & all & Sum & Ann & NIn & Spr & Sum & Fall & Ann & Win & Spr & Sum & Fall & $\ln n$ \\
\hline 028 & 0,58 & 0.64 & 0.76 & 0.57 & 0.60 & 0.60 & -0.47 & 0.13 & 0.22 & 0.71 & 1.50 & & & \\
\hline & 0.47 & & 0.41 & 0.42 & 0.01 & -0.22 & 0.14 & -0.39 & -0.12 & 0.12 & -0.73 & & 0.33 & \\
\hline 0.43 & 0.07 & 0,39 & $-0,02$ & 0.22 & -0.41 & -0.48 & 0.14 & 0.71 & $-0,01$ & $-0,48$ & -0.21 & & 0.64 & 0.02 \\
\hline 0.12 & 0.17 & & 0.02 & 0.10 & (1) & -0.64 & 1.38 & 1.99 & 0.59 & -1.01 & & 154 & & 0.18 \\
\hline 0.27 & -0.03 & -0.03 & 0.17 & 0.10 & 0.63 & 0.08 & -0.49 & -0.15 & 0.02 & 0.83 & 0.39 & 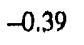 & 0.16 & 0.25 \\
\hline 0.00 & 0.08 & $-0,09$ & 0.03 & -0.04 & 0.05 & 0.81 & 1.99 & 0.86 & 0.93 & -0.33 & 0.84 & 1.81 & 1.12 & 0.86 \\
\hline 0.07 & 0,10 & -0.04 & -0.42 & -0.07 & 1.19 & 0.77 & 1.47 & 0.18 & 0.90 & 1.28 & 0.72 & 1.35 & 0.74 & 1.02 \\
\hline-0.73 & -0350 & -0.46 & -0.15 & -0.46 & 1.15 & 0.55 & 1.06 & 1.39 & 1.04 & 1.39 & 1.34 & 0.79 & 1.24 & 1.19 \\
\hline 0.25 & 0.34 & 0.31 & 0.15 & 0.26 & -0.09 & -0.08 & -0.27 & -0.08 & -0.13 & -0.71 & -0.53 & -0.34 & 0.46 & -0.28 \\
\hline 0.10 & -0.22 & 0.12 & -0.11 & -0.03 & 0.09 & 0.57 & -0.49 & -1.42 & -0.31 & 0.45 & 0.73 & -0.37 & -0.67 & 0.04 \\
\hline-0.44 & -0.64 & -0.46 & -0.40 & -0.49 & -0.34 & 1.16 & 0.00 & -0.11 & 0.18 & -0.03 & 1.04 & -0.02 & -0.53 & 0.12 \\
\hline-0.08 & -0.22 & 0.14 & $-0,03$ & -0.05 & -0.18 & 0.11 & -0.10 & 0.67 & 0.13 & -1.16 & -0.78 & -0.84 & 0.22 & -0.64 \\
\hline 0.11 & 0.22 & 029 & 0.11 & 0.18 & -0.83 & -0.57 & -0.06 & 0.03 & -0.36 & -0.94 & -0.20 & 0.40 & 0.42 & -0.08 \\
\hline-0.26 & -0.58 & -0.69 & -0.62 & -0.54 & -0.13 & $-0,05$ & -0.17 & 0,01 & $-0,09$ & $-0,46$ & $-0,32$ & 0.05 & -0.32 & -0.26 \\
\hline-0.66 & -0.44 & 0.02 & 0.03 & -0.26 & 0.56 & -0.55 & -1.62 & -0.48 & -0.52 & 0.20 & -0.41 & -1.61 & & -0.73 \\
\hline 0.64 & & 0.13 & 0.09 & 0.34 & -0.48 & -0.54 & -0.18 & -0.15 & -0.34 & -1.72 & -1.26 & & & -0.97 \\
\hline-0.21 & -0.24 & -0.34 & -0.11 & -0.23 & 0.18 & -0.77 & -0.58 & -0.55 & & 0.83 & -0.69 & & -1.16 & -0.38 \\
\hline-0.26 & & -0.23 & 0.04 & -0.11 & -0.20 & 0.39 & -0.22 & -0.09 & & -1.47 & 0.02 & & & -0.21 \\
\hline 0,36 & & -0.37 & -0.22 & -0.34 & 1.15 & 0.49 & 0.77 & -0.13 & & 1.29 & 0.05 & & & 0.28 \\
\hline 0.20 & & -0.11 & 0.09 & 0.04 & -1.57 & 1.00 & 0.30 & 1.06 & & -1.89 & & & & -0.94 \\
\hline 0.00 & & -0.08 & -0.16 & -0.09 & -0.89 & -0.66 & -0.76 & -0.77 & & -2.17 & -1.87 & & & -1.63 \\
\hline-0.41 & & 0.22 & 0.02 & -0.03 & -0.10 & 0.13 & -0.21 & $-r .24$ & & 0.06 & 0.11 & & & -0.25 \\
\hline 0.07 & & 22 & 0.19 & 0.19 & 0.28 & -0.52 & -0.27 & -0.20 & & -0.14 & & 0.07 & & -0.44 \\
\hline-0.01 & -0.12 & & 0.06 & 0.01 & -0.22 & -0.78 & -0.75 & -0.31 & -0.52 & 0.04 & -1.00 & & & -0.61 \\
\hline 0.22 & -0.33 & 0.07 & -0.29 & -0.19 & 0,04 & 0.28 & 0.71 & 0.90 & 0.48 & -0.67 & 0.43 & 0.89 & 1.14 & 0.45 \\
\hline-0.14 & & & 0.09 & 0.05 & 1.14 & -0.14 & -0.37 & 0.61 & 0.31 & 0.22 & & & 0.56 & -0.26 \\
\hline-0.22 & -0.07 & & -0.22 & -0.21 & 0.29 & -0.99 & -0.93 & -0.26 & & 0.35 & -0.75 & & $-0,32$ & -0.37 \\
\hline-0.20 & & -0.32 & -0.48 & -0.30 & -1.07 & -0.81 & -0.39 & 0.23 & -0.51 & -0.92 & -0.91 & & -0.13 & -0.62 \\
\hline-0.01 & & & 0.10 & -0.02 & -1.26 & -0.54 & -1.65 & -1.33 & & -0.89 & & & -0.96 & -0.98 \\
\hline 0.33 & -0.11 & 0.40 & 0.59 & 0.30 & -1.50 & -0.47 & -0.55 & -0.65 & & -0.99 & & & & -0.76 \\
\hline 0.34 & 0.42 & 0.48 & 0.25 & 0.37 & -1.66 & -1.50 & -1.21 & -1.81 & & -1.23 & & & -1.21 & -1.13 \\
\hline 0.05 & -0.19 & 0.10 & 0.22 & 0.05 & -0.69 & -0.70 & -0.05 & -0.40 & -0.46 & -0.39 & -0.68 & -0.42 & -0.42 & -0.48 \\
\hline 0.14 & 0.56 & & & & 0,04 & 0.91 & & & & -0.33 & -0.32 & & & \\
\hline
\end{tabular}




\section{Equatorial $\left(10^{\circ} \mathrm{S}-10^{\circ} \mathrm{N}\right)$}

Surfuce

$850-300 \mathrm{mb}$

$3(1)-100 \mathrm{ml}$

\begin{tabular}{|c|c|c|c|c|c|c|c|c|c|c|c|c|c|c|}
\hline Year & $v \ln t$ & Spr & Sum & Fall & Ann & Win & Spr & Sum & Fall & Ann & Win & Spr & Sum & Fall \\
\hline 1958 & 0.45 & -0.30 & -0.90 & 0.30 & -0.11 & 0.25 & -0.30 & -0.60 & -0.22 & -0.22 & 0.68 & -1.65 & -0.05 & 0.37 \\
\hline 1959 & 0.15 & -0.45 & -0.18 & 0.25 & -0.06 & -0.04 & -0.09 & -0.27 & -0.27 & -0.17 & -0.13 & -0.19 & -0.02 & -0.25 \\
\hline 1960 & -0.07 & -0.07 & 0.00 & 0.23 & 0.02 & -0.03 & -0.11 & 0.15 & 0.06 & 0.02 & 0.11 & -0.19 & 0.38 & 0.23 \\
\hline 1961 & 0.12 & 0.17 & 0.13 & 0.02 & 0.11 & -0.11 & -0.05 & -0.03 & -0.35 & -0.14 & -0.03 & $-0.1 ?$ & -0.55 & -0.03 \\
\hline 1962 & $-0,02$ & -0.18 & -0.12 & -0.13 & $-(0.11$ & -0.14 & -0.25 & -0.22 & 0.20 & -0.10 & 0.32 & 0.21 & -10.06 & 0.29 \\
\hline 1963 & -0.22 & -0.23 & 0.07 & 0.22 & -0.04 & -0.24 & -0.10 & 0.13 & 0.19 & -0.01 & -0.11 & 0.20 & -0.26 & -0.07 \\
\hline 1964 & -0.23 & -0.09 & -0.11 & -0.39 & -0.21 & 0.49 & 0.28 & -0.32 & -0.47 & $\neg) .01$ & 0.21 & 0.00 & -0.34 & -0.78 \\
\hline 1965 & -0.64 & -0.01 & -0.31 & 0.07 & -0.22 & -0.76 & -0.20 & -0.32 & 0.06 & -0.31 & -1.08 & -0.94 & -0.40 & 0.15 \\
\hline 1966 & -0.10 & 0.13 & 0.20 & -0.03 & 0.05 & 0.30 & 0.23 & 0.20 & -0.33 & 0.10 & 0.35 & 0.21 & 0.01 & -0.37 \\
\hline 1967 & -0.08 & -0.09 & -0.06 & -0.38 & -0.15 & -0.34 & -0.39 & -0.10 & -0.17 & -0.25 & -0.20 & -0.3 .3 & 0.21 & 0.00 \\
\hline 1968 & -0.13 & -0.20 & 0.08 & 0.09 & -0.04 & -0.17 & -0.35 & -0.11 & -0.19 & -0.21 & -0.57 & -1.01 & 0.15 & -0.26 \\
\hline 1969 & 0.17 & 0.36 & -0.01 & 0.32 & 0.21 & 0.19 & 0.68 & 0.25 & 0.24 & 0.34 & 0.30 & 0.92 & $-(0.1 .3$ & 0.39 \\
\hline 1970 & 0.38 & 0.14 & -0.11 & -0.37 & 0.01 & 0.55 & 0.62 & 0.38 & 0.43 & 0.50 & 0.41 & 1,30 & $0 \div 0$ & 0.57 \\
\hline 1971 & -0.14 & -0.20 & -0.33 & -0.47 & -0.29 & -0.21 & -0.55 & -0.43 & -0.57 & -0.44 & 0.06 & -0.82 & $-(1) .60$ & -0.76 \\
\hline 1972 & -0.10 & -0.24 & 0.19 & 0.24 & 0.02 & -0.55 & -0.13 & 0.45 & 0.64 & 0.10 & -0.85 & -0.46 & 0.18 & 0.45 \\
\hline 1973 & 0.59 & 0.37 & 0.16 & 0.36 & 0.37 & 1.15 & 0.64 & 0.39 & 0.35 & 0.63 & 1.13 & 0.87 & 0.76 & 0.37 \\
\hline 1974 & 0.03 & -0.30 & 0.26 & 0.12 & 0.03 & -0.37 & -0.02 & 0.08 & 0.16 & -0.04 & -0.29 & -0.02 & 0.35 & -0.20 \\
\hline 1975 & 0.13 & 0.19 & -0.10 & -0.27 & -0.01 & 0.18 & 0.20 & -0.02 & -0.06 & 0.08 & 0.15 & 0.18 & -0.10 & 0.28 \\
\hline 1976 & -0.31 & 0.08 & -0.20 & 0.07 & -0.09 & -0.18 & -0.34 & -0.16 & 0.37 & -0.08 & -0.02 & $-0,42$ & 0.15 & 0.55 \\
\hline 1977 & -0.02 & 0.43 & 0.37 & 0.33 & 0.28 & 0.45 & 0.32 & 0.44 & 0.47 & 0.42 & 0.36 & 0.16 & 0.26 & 0.33 \\
\hline 1978 & 0.51 & 0.26 & 0.30 & 0.39 & 0.37 & 0.50 & 0.78 & 0.11 & 0.05 & 0.36 & 0.10 & 0.35 & -0.29 & -0.36 \\
\hline 1979 & 0.54 & 0.60 & 0.54 & 0.61 & 0.57 & 0.52 & 0.22 & 0.50 & 0.42 & 0.42 & 0.36 & 0.09 & -0.01 & -0.51 \\
\hline 1980 & 0.40 & 0.49 & 0.06 & 0.33 & 0.32 & 0.35 & 0.44 & 0.57 & 0.50 & 0.47 & -0.84 & -0.60 & -0.11 & -0.44 \\
\hline 1981 & 0.13 & 0.43 & 0.15 & 0.07 & 0.20 & 0.31 & 0.45 & 0.09 & 0.37 & 0.31 & -0.89 & -0.91 & -0.73 & -0.54 \\
\hline 1982 & 0.26 & 0.28 & 0.62 & 0.33 & 0.37 & 0.53 & 0.24 & 0.57 & 0.21 & 0.39 & -0.56 & -0.98 & -0.40 & -0.86 \\
\hline 1983 & 0.52 & 0.58 & 0.61 & 0.14 & 0.46 & 1.21 & 1.21 & 0.77 & -0.10 & 0.77 & 0.06 & 0.31 & 0.21 & -0.47 \\
\hline 1984 & 0.63 & -0.01 & -0.32 & 0.13 & 0.11 & -0.04 & 0.08 & -0.04 & -0.07 & -0.02 & -0.86 & -0.89 & -0.99 & -1.20 \\
\hline 1985 & 0.56 & 0.06 & 0.05 & 0.28 & 0.24 & 0.26 & 0.08 & -0.19 & 0.11 & 0.07 & -1.04 & -1.13 & -1.34 & -1.25 \\
\hline 1986 & 0.35 & 0.39 & 0.29 & 0.22 & 0.31 & 0.20 & 0.02 & -0.05 & 0.37 & 0.14 & -0.90 & -0.77 & -0.81 & -0.64 \\
\hline 1987 & 0.81 & 1.37 & 1.41 & 0.87 & 1.12 & 0.77 & 0.80 & 0.96 & 0.91 & 0.86 & -0.02 & -0.19 & 0.23 & 0.30 \\
\hline 1988 & 1.03 & 0.74 & 0.24 & 0.57 & 0.65 & 1.15 & 0.62 & 0.77 & 0.24 & 0.70 & 0.22 & 0.33 & 0.73 & -0.64 \\
\hline 1989 & 0.23 & -0.08 & 0.12 & 0.56 & 0.21 & -0.26 & -0.30 & -0.12 & 0.23 & -0.11 & -1.45 & -1.18 & -0.52 & -0.28 \\
\hline 1990 & 0.70 & 0.72 & & & & 0.17 & 0.62 & & & & -0.96 & -0.40 & & \\
\hline
\end{tabular}

- Temperature anomulies (In relation to a 1958-1977 average) expressed in degrees Celsius.

†Northern Hemisphere winter (Dec-lieb).

Note: Data for summer (Jun-Aug) 1989 through spring (Mar-May) 1990 are provisional. 
Temperature Ar umalies

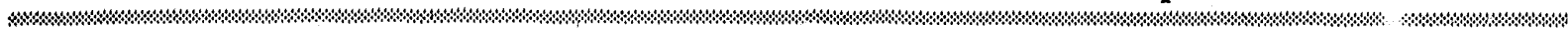

Annual and Seasonal Temperature Anomalies*

Surface-100 mb

\begin{tabular}{|c|c|c|c|c|c|c|c|c|c|c|c|c|c|c|c|}
\hline Ann & Win & Spr & Fall & Sum & Ann & Win & Spr & Sum & Fall & Ann & Win & Spr & Sum & Fall & Ann \\
\hline-0.16 & 0.37 & -1.43 & $-0,59$ & $-0,21$ & -0.47 & & & & & & & & & & \\
\hline-0.15 & -0.02 & -0.11 & -0.20 & -0.04 & -0.09 & -1.87 & -2.65 & -2.81 & 1.25 & -1.52 & & & & & \\
\hline 1.13 & -0.01 & -0.10 & 0.18 & 0.13 & 0.05 & 0.21 & -1.07 & -2.00 & -1.72 & -1.15 & -0.14 & -1.23 & -5.18 & -4.66 & -2.80 \\
\hline-0.18 & -0.06 & 0.01 & -0.28 & -0.21 & -0.14 & -5.23 & -2.29 & 0.83 & 2.63 & -1.02 & -4.97 & -4.80 & -0.56 & -1.47 & -2.95 \\
\hline 0.19 & -0.01 & -0.13 & -0.24 & 0.05 & -0.08 & 0.59 & -0.88 & -1.21 & -2.17 & -0.92 & -0.37 & -2.04 & -3.64 & -3.12 & -2.29 \\
\hline-0.06 & -0.20 & -0.05 & 0.02 & 0.13 & -0.03 & -1.45 & $-2.0 ?$ & -0.47 & 1.02 & -0.73 & -3.99 & -3.46 & 0.72 & $3.8 \%$ & -0.71 \\
\hline-0.23 & 0.37 & 0.19 & -0.28 & -0.49 & -0.05 & 1.38 & 2.27 & 1.70 & 1.50 & 1.71 & 0.62 & 1.99 & 1.49 & 0.64 & 1.19 \\
\hline-0.57 & $-0,81$ & -0.41 & -0.33 & 0.08 & -0.37 & 0.99 & 0.51 & -0.55 & -0.83. & 0.03 & 0.57 & -0.09 & -1.14 & -1.37 & -0.51 \\
\hline 0.05 & 0.15 & 0.21 & 0.12 & -0.29 & 0.05 & -1.86 & -1.97 & -0.48 . & 2.23 & -0.52 & -2.34 & -0.93 & 1.72 & 2.30 & 0.19 \\
\hline-0.08 & -0.31 & -0.32 & -0.01 & -0.15 & -0.20 & 1.49 & 2.12 & 0.33 & 0.23 & 1.04 & 2.04 & 2.03 & 0.88 & 0.14 & 1.27 \\
\hline-0.42 & -0.25 & -0.47 . & -0.01 & -0.15 & -0.22 & -0.30 & 14 & -0.91 & -1.16 & -0.31 & -1.06 & 0.09 & -0.95 & -0.48 & -0.60 \\
\hline 0.37 & 0.21 & 0.63 & 0.09 & 0.29 & 0.31 & -1.18 & -1.59 & 0.34 & 0.57 & -0.47 & -1.25 & -0.38 & 1.22 & 1.59 & 0.30 \\
\hline 0.74 & 0.49 & 0.69 & 0.37 & 0.40 & 0.49 & 0.28 & 0.20 & 0.39 & 0.69 & 0.39 & -0.70 & -0.55 & 0.10 & 0.65 & -0.13 \\
\hline-0.53 & -0.19 & -0.56 & -0.45 & -0.59 & -0.45 & 0.20 & -0.63 & 1.09 & 1.25 & 0.48 & 1.67 & 1.66 & 1.14 & -0.42 & 1.01 \\
\hline-0.17 & -0.54 & -0.22 & 0.36 & 0.52 & 0.03 & 1.84 & 1.26 & -0.82 & -2.22 & 0.02 & 1.80 & 0.54 & -1.36 & -0.72 & 0.07 \\
\hline 0.78 & 0.94 & 0.65 & 0.43 & 0.36 & 0.60 & -1.74 & -0.79 & 0.89 & 0.71 & -0.2 .3 & -1.80 & -0.22 & 0.51 & 0.37 & -0.29 \\
\hline-0.04 & -0.29 & -0.16 & 0.17 & 0.08 & -0.05 & 1.64 & 0.46 & -1.01 & -1.59 & -0.13 & 1.27 & -0.72 & -2.0 & -2.32 & -0.96 \\
\hline 0.13 & 0.17 & 0.19 & -0.05 & -0.01 & 0.08 & -0.78 & -0.53 & 0.76 & 1.24 & 0.17 & -0.54 & -0.11 & 0.26 & 1.44 & 0.26 \\
\hline 0.07 & -0.16 & -0.29 & -0.10 & 0.35 & -0.05 & 3.31 & 1.44 & 0.91 & $1 . \alpha^{\prime}$ & 1.72 & 2.51 & 0.50 & 0.48 & -1.53 & 0.49 \\
\hline 0.28 & 0.35 & 0.30 & 0.39 & 0.41 & 0.36 & -1.34 & -0.72 & -0.65 & $-1,21$ & -0.98 & $-3,83$ & $-1,59$ & -1.40 & 1.22 & -1.40 \\
\hline-0.05 & 0.43 & 0.58 & 0.06 & 0.01 & 0.27 & -0.52 & 0.52 & 2.34 & 1.41 & 0.94 & -0.03 & 0.80 & 1.19 & 0.60 & 0.64 \\
\hline-0.02 & 0.49 & 0.25 & 0.40 & 0.31 & 0.36 & 0.60 & -0.10 & -0.96 & -2.24 & -0.68 & -0.42 & -0.63 & -0.81 & -2.08 & -0.99 \\
\hline-0.50 & 0.16 & 0.34 & 0.34 & 0.24 & 0.27 & -0.79 & -1.93 & 0.05 & 1.60 & -0.27 & -1.14 & -2.53 & 0.69 & 1.37 & -0.40 \\
\hline-0.77 & -0.01 & 0.14 & -0.11 & 0.08 & 0.03 & 1.33 & 0.55 & -0.12 & -0.07 & 0.42 & 1.44 & -0.23 & -1.32 & -1.11 & -0.31 \\
\hline-0.70 & 0.23 & 0.03 & 0.36 & 0.00 & 0.16 & -0.98 & -0.41 & -0.32 & 1.92 & 0.05 & -2.76 & -2.23 & 0.44 & 2.42 & -0.53 \\
\hline 0.03 & 0.89 & 0.98 & 0.62 & $-0.0 \dot{s}$ & 0.61 & 1.55 & 1.19 & 0.60 & 0.76 & 1.03 & 0.87 & 0.55 & -0.87 & -1.10 & -0.14 \\
\hline-0.99 & $-0,16$ & -0.17 & -0.32 & -0.29 & -0.24 & 0.45 & -1.10 & -2.11 & $-2,44$ & -1.30 & -0.94 & -1.40 & -1.49 & -1.68 & -1.38 \\
\hline-1.19 & 0.02 & -0.19 & -0.41 & -0.16 & -0.19 & -2.86 & -1.42 & -0.05 & 0.38 & -0.99 & $-1,74$ & -0.76 & 0.13 & -0.27 & -0.66 \\
\hline-0.78 & -0.01 & -0.10 & -0.16 & 0.12 & -0.04 & -0.92 & -1.16 & -1.82 & -2.65 & -1.64 & $-1,01$ & -1.30 & -1.62 & -2.03 & -1.49 \\
\hline 0.08 & 0.68 & 0.72 & 0.69 & 0.88 & 0.74 & -2.55 & -3.27 & -3.70 & -1.43 & -2.74 & -2.25 & -2.46 & -2.20 & -0.89 & -1.95 \\
\hline 0.16 & 0.96 & 0.58 & 0.68 & 0.10 & 0.58 & $-1,38$ & -2.29 & -1.49 & -2.04 & -1.80 & -1.08 & -1.83 & $-1,1 \mathrm{~s}$ & -1.65 & -1.42 \\
\hline \multirow[t]{2}{*}{-0.86 . } & -0.44 & -0.46 & -0.17 & 0.17 & -0.23 & -0.68 & -1.58 & -1.89 & -2.31 & -1.62 & -0.83 & -1.27 & -1.45 & -1.77 & -1.33 \\
\hline & 0.01 & 0.41 & & & & -2.80 & -2.13 & & & & -2.02 & -1.33 & & & \\
\hline
\end{tabular}


Surface

$850-300 \mathrm{mb}$

M)(10) $\mathrm{mb}$

\begin{tabular}{|c|c|c|c|c|c|c|c|c|c|c|c|c|c|c|c|}
\hline Year & Wint & Spr & Sum & Fall & Ann & Win & Spr & Sum & Fall & Ann & W/n & Spr & Sum & Fall & Ann \\
\hline 1958 & 1.10 & 1.00 & -0.10 & 0.40 & 0.60 & 0.70 & 0.04 & 0.56 & 0.53 & 0.46 & $-0,14$ & 0,04 & 0.00 & -1.51 & $-0 ; 40$ \\
\hline 1959 & 0,47 & 0.50 & 0.67 & 0.52 & 0.54 & 0.21 & 0.07 & 0.32 & 0.28 & 0.22 & -0.63 & -0.21 & -0.53 & -0.56 & -0.48 \\
\hline 1960 & 0.34 & 0.20 & 0.01 & 0.37 & 0.23 & 0.46 & 0.07 & 0.56 & 0.32 & 0.35 & 0.53 & -0.18 & 0.00 & 0.18 & 0.13 \\
\hline 1961 & 0.06 & 0.15 & -0.08 & 0.26 & 0.10 & -0.04 & 0.49 & 0.18 & 0.11 & 0.19 & $-0,18$ & 0.39 & -0.11 & $-0,32$ & -0.06 \\
\hline 1962 & 0.08 & 0.04 & -0.04 & 0.26 & 0.09 & 0.18 & -0.28 & -0.04 & -0.04 & -0.05 & $-0,0 \%$ & 0.07 & 0.11 & 0.28 & 0.10 \\
\hline 1963 & -0.13 & 0.00 & -0.16 & -0.10 & -0.10 & -0.18 & -0.14 & 0.07 & -0.14 & -0.10 & -0.56 & 0.07 & 0.25 & 0.07 & -0.04 \\
\hline 1964 & -0.13 & -0.01 & -0.23 & 0.05 & -0.08 & 0.00 & 0.07 & -0.42 & -0.56 & -0.23 & 0.42 & 0.04 & -0.32 & -0.67 & -0.13 \\
\hline 1965 & -0.08 & -0.28 & -0.09 & -0.28 & -0.18 & -1.16 & -0.60 & -10.63 & -0.28 & -0.67 & -1.19 & -0.60 & -0.49 & 0.04 & -0.56 \\
\hline 1966 & -0.08 & -0.25 & -0.16 & -0.25 & -0.19 & 0,04 & -0.18 & 0.04 & -0.18 & -0.07 . & 0.25 & 0.42 & 0.00 & 0.11 & 0.20 \\
\hline 1967 & $0 .(6)$ & 0.09 & -0.16 & 0.10 & 0.03 & -0.28 & -0.04 & -0.07 & -0.18 & -0.14 & -0.42 & -0.42 & -0.25 & -0.32 & -0.35 \\
\hline 1968 & 0.17 & -0.72 & -0.60 & -0.21 & -0.34 & -0.23 & -0.35 & -0.14 & 0,07 & -0.16 & -0.11 & -0.67 & 0.04 & 0.14 & -0.15 \\
\hline 1969 & 0.12 & 0.28 & 0.02 & -0.03 & 0,10 & 0.28 & 0.60 & 0.53 & 0.32 & 0.43 & 0.14 & 0.98 & 0.39 & 0.35 & 0.47 \\
\hline $19 \%$ & 0.03 & -0.14 & -0.09 & -0.24 & -0.11 & 0.35 & 0.53 & 0.49 & 0.28 & 0.41 & 0.49 & 0.53 & 0.63 & 0.77 & 0.61 \\
\hline 1971 & -0.16 & -0.23 & -0.17 & -0.25 & -0.20 & -0.21 & -0.63 & -0.56 & -0.67 & -0.52 & 0.77 & -0.42 & -0.46 & -0.60 & -0.18 \\
\hline 1972 & -0.13 & -0.21 & 0.20 & $-0,06$ & -0.05 & -0.39 & 0.00 & 0.21 & 0.60 & 0.11 & 0.46 & -0.46 & 0.04 & 0.18 & 0.06 \\
\hline 1973 & 0.48 & 0.59 & 0.51 & 0.02 & 0.40 & 0.95 & 0.95 & 0.35 & 0.28 & 0.63 & 0.91 & 0.35 & 0.42 & 0.39 & 0.52 \\
\hline 1974 & -0.41 & -0.15 & 0.10 & -0.05 & $-0.1 \mathrm{~s}$ & 0.07 & 0.07 & -0.32 & -0.14 & -0.08 & -0.18 & -0.25 & -0.21 & 0.04 & -0.15 \\
\hline 1975 & -0.45 & 011 & 0.15 & -0.09 & -0.07 & -0.25 & -0.21 & -0.35 & -0.25 & -0.26 & -0.14 & 0.11 & -0.02 & -0.11 & -0.04 \\
\hline 1976 & -0.57 & -0.32 & -0.26 & -0.19 & -0.34 & -0.32 & -0.32 & -0.46 & -0.35 & -0.36 & -0.70 & -0.35 & -0.53 & 0.00 & -0.40 \\
\hline 1977 & 0.16 & 0.36 & 0.24 & 0.16 & 0.23 & 0.38 & 0.62 & 0.80 & 0.47 & 0.57 & -0.07 & 0.03 & -0.37 & 0.20 & -0.05 \\
\hline 1978 & -0.09 & 0.12 & -0.02 & 0.04 & 0.01 & 0.33 & 0.24 & 0.46 & 0.26 & 0.32 & 0.21 & -0.04 & 0.07 & 0.13 & 0.09 \\
\hline 1979 & -0.24 & 0.14 & 0.10 & 0.03 & 0.01 & 0.17 & 0.51 & 0.45 & 0.28 & 0.35 & 0.07 & 0.18 & -0.15 & -0.03 & 0.02 \\
\hline 1980 & 0.49 & 0.97 & 0.53 & 0.44 & 0.61 & 0.61 & 0.88 & 0.75 & 0.41 & 0.66 & -0.27 & $-(0.09$ & 0.23 & 0.31 & 0.05 \\
\hline 1981 & 0.01 & 0.26 & -0.31 & 0.55 & 0.13 & 0.53 & 0.23 & 0.28 & 0.21 & 0.31 & -0.19 & -0.22 & -0.46 & -0.34 & -0.30 \\
\hline 1982 & 0.38 & 0.87 & 0.51 & 0.38 & 0.54 & 0.62 & -0.04 & 0.33 & 0.35 & 0.32 & -10.07 & -0.01 & -0.20 & -0.05 & -0.08 \\
\hline 1983 & 0.47 & 0.76 & 0.58 & 0.79 & 0.65 & 0.78 & 1.22 & 0.40 & 0.03 & 0.61 & 0.41 & 0.59 & 0.02 & -0.10 & 0.23 \\
\hline 1984 & 0.40 & 0.71 & 0.81 & 0.84 & 0.69 & 0.42 & 0.89 & 0.26 & 0.31 & 0.47 & -1.24 & $-0,88$ & -0.91 & -0.82 & -0.96 \\
\hline 1985 & -0.24 & 0.29 & 0.57 & 0.20 & 0.21 & 0.39 & 0.53 & 0.12 & 0.4 .5 & 0.37 & -1.22 & -0.79 & -0.79 & -0.63 & -0.86 \\
\hline 1986 & -0.70 & 0.49 & 0.59 & 0.64 & 0.26 & 0.60 & 0.23 & 0.04 & 0.12 & 0.25 & -0.86 & $-0,10$ & -0.23 & -0.03 & -0.31 \\
\hline 1987 & 0.76 & 1.66 & 0.70 & 0.70 & 0.96 & 0.79 & 0.76 & 0.49 & 0.64 & 0.67 & -0.13 & -0.14 & 0.8 .3 & 1.03 & 0.40 \\
\hline 1988 & 0.39 & 0,23 & 0.40 & 0.73 & 0.44 & $0 . y$ & 0.99 & 0.92 & 0.16 & 0.77 & 0,49 & 0.47 & 0.66 & 0.23 & 0,46 \\
\hline 1989 & -0.29 & 0.37 & 0.22 & 0.04 & 0.09 & 0.05 & 0.16 & 0.27 & 0.14 & 0.16 & -0.58 & -0.51 & -0.15 & 0.15 & -0.27 \\
\hline 1990 & -0.07 & 0.59 & & & & 0.01 & 0.57 & & & & 0.03 & 0.20 & & & \\
\hline
\end{tabular}

*'Tempe rature anomalies (in relation to a 1958-1977 average) expressed in degrecs Celsius.

†Northern Hemisphere winter (Dec-Feb):

Note: Data for summer (Jun-Aug) 1989) through spring (Mar-May) 1990 are provisional. 
Temperature Anomalies

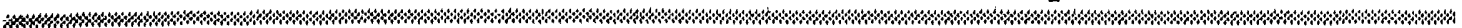

Annual and Seasonal Temperature Anomalies*

Surface-10 $10 \mathrm{mb}$

$10(0-50 \mathrm{mb}$

$100-30 \mathrm{mb}$

\begin{tabular}{|c|c|c|c|c|c|c|c|c|c|c|c|c|c|c|}
\hline$W / n$ & Spr & Fall & Sum & Ann & Win & Spr & Sum & Full & Ann & W/n & Spr & Sum & Fall & Ann \\
\hline 0.58 & 0.44 & 0.33 & $-0,48$ & 0.22 & & & & & & & & & & \\
\hline 0.07 & 0.08 & 0.19 & 0.13 & 0.12 & & & & & & & & & & \\
\hline 0.46 & 0.04 & 0.34 & 0.30 & 0.21 & & & & & & & & & & \\
\hline 0.05 & 0.41 & 0.07 & 0.04 & 0.12 & & & & & & & & & & \\
\hline 0.03 & -0.34 & -0.01 & 0.08 & $-0,08$ & & & & & & & & & & \\
\hline 0.26 & -0.07 & 0.14 & -0.09 & -0.07 & & & & & & & & & & \\
\hline 0,07 & 0.05 & -0.37 & -0.10 & -0.09 & 1.15 & 1.97 & 1.30 & 0.75 & 1.29 & 0.27 & 1.09 & 1.78 & -0.07 & 0.77 \\
\hline 0.99 & 2.55 & -0.51 & -0.21 & -0.57 & 1.58 & 0.33 & 1,20 & 1.63 & 1.19 & 0.43 & -0.26 & 0.78 & 2.13 & 0.77 \\
\hline 0.18 & -0.06 & -0.01 & $-0,13$ & -0.01 & -0.12 & 0.05 & -0.86 & 0.22 & -0.18 & -0.12 & -0.16 & -0.72 & 0.33 & -0.17 \\
\hline$=0.25$ & -0.10 & -0.13 & $-0,02$ & -0.13 & 1.00 & 0.41 & 0.94 & -0.10 & 0.56 & 0.39 & 0.67 & 0.14 & -0.21 & 0.25 \\
\hline 0.15 & $-0,48$ & 0.11 & -0.27 & -0.20 & -0.81 & 0.49 & 0.60 & 0.72 & 0.25 & -0.62 & 0.75 & 0.68 & 0.32 & 0.28 \\
\hline 0.22 & 0.71 & 0.41 & 0.27 & 0.40 & -0.16 & -0.04 & -1.20 & 0.19 & -0.30 & -0.42 & -0.81 & -1.41 & 0.65 & -0.50 \\
\hline 0.45 & 0.23 & 0.42 & 0.36 & 0.37 & -0.52 & -0.29 & 1.48 & i.10 & 0.19 & -0.77 & 0.24 & 1.51 & 1.16 & 0.54 \\
\hline 0.02 & -0.52 & -0.47 & -0.58 & -0.39 & 1.17 & 0.25 & -1.16 & -0.33 & -0.02 & 1.46 & -0.32 & -1.12 & -0.62 & -0.15 \\
\hline-0.27 & -0.08 & 0.25 & 0.40 & 0.08 & -0.14 & -0.56 & 0.42 & -0.35 & -0.16 & 0.05 & 0.06 & -0.74 & $-1,05$ & -0.42 \\
\hline 0.86 & 0.76 & 0.29 & 0.26 & 0.54 & -0.77 & -0.23 & -0.59 & -0.66 & -0.56 & -0.67 & -0.67 & -0.64 & -0.49 & -0.62 \\
\hline 0.07 & -0.04 & -0.23 & $-(1,0)$ & -0.11 & 0.40 & -0.10 & 0.50 & -0.03 & 0.19 & -0.18 & -0.07 & 1.05 & -0.44 & 0.09 \\
\hline 0.26 & 0.02 & -0.20 & -0.19 & -0.16 & $-0,38$ & 0.09 & -0.35 & 0.03 & -0.15 & -0.31 & 0.35 & -1.56 & -0.83 & -0.59 \\
\hline 0.34 & -0.33 & -0.44 & -0.25 & -0.34 & 0.72 & -0.06 & -0.18 & -0.18 & 0.08 & 0.27 & -0.34 & 0.91 & -0.30 & 0.14 \\
\hline 0.24 & 0.43 & 0,45 & 0,36 & 0.37 & -2.32 & -0.63 & -0.18 & -0.28 & & -2.91 & -0.63 & -0.08 & -0.88 & $-1,13$ \\
\hline 0.23 & 0.23 & 0.29 & 0.19 & 0.24 & -0.33 & -0.25 & -0.38 & -1.25 & -0.55 & -1.45 & -1.13 & -0.64 & -1.54 & -1.19 \\
\hline 0.05 & 0.38 & 0.26 & 0.17 & 0.22 & -0.82 & 0.19 & 0.05 & -0.30 & -0.22 & -1.80 & 0.41 & 0.43 & -1.03 & -0.50 \\
\hline 0.53 & 0.90 & 0.64 & 0.46 & 0.63 & -0.37 & -1.76 & -1.20 & -0.06 & -0.85 & 0.19 & -2.28 & -1.73 & -0.56 & -1.10 \\
\hline 0.18 & 0.10 & 0.05 & 0.17 & 0.13 & -0.41 & -0.82 & -0.12 & 0.46 & -0.22 & -0.22 & -0.45 & 1.23 & 0.49 & 0.26 \\
\hline 0.43 & 0.10 & 0.24 & 0.26 & 0.26 & -0.58 & 0.01 & 1.16 & 1.16 & 0.44 & -0.78 & 0.08 & 0.69 & $-0,09$ & -0.03 \\
\hline 0.66 & 1.01 & 0.39 & 0.15 & 0.55 & 0.99 & -10.99 & -0.03 & 0.87 & 0.21 & 0.66 & -0.73 & 0.47 & 1.56 & 0.49 \\
\hline 0.04 & 0,49 & 0.08 & 0.13 & 0.19 & 0.20 & -1.30 & 0.18 & -0.19 & -0.28 & -0.87 & -0.95 & $-0,20$ & -0.61 & -0.66 \\
\hline-0.07 & 0.17 & -0.12 & 0.17 & 0.04 & -1.36 & -1.61 & -1.75 & -1.15 & -1.47 & -1.10 & -1.44 & -1.36 & -1.20 & -1.28 \\
\hline 0.06 & 0.20 & 0.07 & 0.18 & 0.13 & -2.21 & -2.53 & -2.57 & -2.52 & -2.46 & -1.80 & -1.79 & -1.64 & -1.98 & -1.80 \\
\hline 0.58 & 0.71 & 0.60 & 0.76 & 0.66 & -1.49 & -1.42 & $-0,38$ & -0.32 & $-0,90$ & -1.34 & -1.28 & -0.70 & -0.80 & $-1,03$ \\
\hline 0.78 & 0.75 & 0.75 & 0.27 & 0,64 & -1.12 & -3.38 & -1.85 & -3.52 & -2.47 & -1.62 & -2.23 & -1.49 & -2.61 & -1.99 \\
\hline-0.14 & 0.05 & 0.17 & 0.12 & .0 .05 & -1.84 & -2.16 & -0.60 & -0.53 & -1.28 & -1.59 & -1.63 & -0.65 & -0.97 & -1.21 \\
\hline 0.00 & 0.49 & & & & -2.43 & -1.64 & & & & -1.43 & -1.45 & & & \\
\hline
\end{tabular}


Surface

$85(1-30) \mathrm{mb}$

$3(0)-1(K) \mathrm{mb}$

\begin{tabular}{|c|c|c|c|c|c|c|c|c|c|c|c|c|c|c|}
\hline Yeur & Wint & Spr & Sum & Falt & Ann & WIn & Spr & Sum & Fall & Ann & WIn & Spr & Sum & Fall \\
\hline 1958 & 0.63 & 0.70 & 0.73 & 0.70 & 0.69 & -0.12 & $-0,06$ & 0,33 & 0.89 & 0.26 & -0.34 & -0.68 & 0.08 & -0.45 \\
\hline 1959 & 1.10 & 0.63 & 0.78 & 0.68 & 0.80 & 0.47 & 0.00 & 1.11 & 1.19 & 0.69 & -0.47 & 0.51 & 0,53 & -0.35 \\
\hline $19 \times 0$ & 0,68 & 0.63 & 0.67 & 0.10 & 0.52 & 0.90 & 0.22 & 0.03 & 0,42 & 0.39 & -0.71 & $-0,41$ & 1,68 & 0.25 \\
\hline 1961 & $0.60)$ & 0.42 & 0.70 & 0.54 & 0.57 & 0.28 & 0.06 & 0.00 & 0.37 & 0.18 & -0.05 & 0.56 & -0.21 & -1.02 \\
\hline 1962 & 0.95 & 0.65 & 0.55 & 0.55 & 0.68 & 0.62 & 0.44 & 0.38 & 0.18 & 0,41 & -0.54 & -1.72 & 0.06 & 0.40 \\
\hline 1963 & 0.55 & 0.28 & 0.13 & 0.12 & 0.27 & 0.47 & 0.02 & -0.58 & -0.46 & -0.14 & -0.40 & 0.43 & 1.00 & 2.20 \\
\hline 1964 & $-0,45$ & -0.23 & 0,03 & 0.28 & $-0,09$ & -1.07 & $-0,36$ & $-0,95$ & -6.64 & -0.76 & 0.93 & 1.12 & 1,21 & 0.62 \\
\hline 1965 & 0.38 & -0.17 & $-0,08$ & 0.66 & 0.20 & -0.86 & -0.75 & 0.30 & 0.43 & -0.22 & 0.47 & 0.19 & -0.84 & -0.45 \\
\hline 1966 & 0.65 & 0.10 & -0.15 & 0.18 & 0.20 & -0.02 & -0.17 & -0.19 & -0.20 & -0.15 & 0.15 & 0.08 & 0.18 & 0.28 \\
\hline 1967 & -0.15 & -0.22 & -0.48 & 0,40 & -0.11 & -0.12 & 0.15 & 0.01 & 0.29 & 0.08 & 0.48 & 0.59 & -0.16 & $-0,06$ \\
\hline 19683 & 0.35 & 0,47 & -0.20 & -0.18 & 0.11 & 0.10 & 0.29 & -0.40 & -0.70 & -0.18 & 0.20 & & & 0.75 \\
\hline 1969 & -0.93 & -0.93 & -0.50 & -0.361 & -0.68 & -0.10 & & & & & & & -0.16 & -0.69 \\
\hline 1970 & -0.28 & -0.53 & -0.28 & & & & & & -0.46 & & & & & -0.38 \\
\hline 1971 & -0.55 & -0.53 & $-0,45$ & -0.65 & -0.55 & 0.43 & $-0,12$ & $-0,30$ & -0.36 & $-0,09$ & & 0.42 & -0.29 & -0.62 \\
\hline 1972 & -0.98 & -0.47 & -0.50 & -0.53 & $-0,62$ & -0.48 & & & 0.49 & 0,08 & & -0.57 & -0.39 & -0.37 \\
\hline 1973 & -0.63 & -0.32 & -0.50 & -0.47 & -0.48 & 0.57 & 0.58 & 0.34 & -0.40 & 0.27 & -0.59 & -0.12 & -0.69 & -0.14 \\
\hline 1974 & -0.74 & 0.20 & -0.17 & -0.75 & -0.37 & 0.78 & 0.58 & -0.14 & -0.19 & 0.26 & -0.37 & -1.18 & -0.90 & -0.74 \\
\hline 1975 & -0.75 & -0.50 & -0.32 & -0.50 & -0.52 & -0.06 & -0.03 & -0.32 & 0.07 & -0.09 & -0.11 & 0.06 & -0.08 & -0.41 \\
\hline 1976 & -0.97 & -0.62 & -0.08 & -0.28 & -0.49 & 0.38 & 0.35 & 0,26 & -0.90 & 0.02 & 0.12 & -0.63 & -0.51 & -0.50 \\
\hline 1977 & -0.55 & 0.05 & -0.13 & 0.08 & -0.14 & -0.38 & 0.87 & $-0,31$ & 0.00 & 0.05 & -0.26 & -0.04 & 0.63 & -0.24 \\
\hline 1978 & 0.15 & 0.12 & 0.00 & -0.15 & 0.03 & 0.15 & 0.11 & 0.77 & 0.16 & 0.30 & -0.19 & -0.32 & -0.26 & -0.18 \\
\hline 1979 & 0.00 & 0.12 & 0.48 & 0.05 & 0.16 & 0.49 & 1.23 & 1.10 & 0.36 & 0.80 & 0.25 & -0.05 & 0.25 & 0.45 \\
\hline 1980 & 0.03 & 0.23 & 0.29 & $-0.0^{\prime} 7$ & 0.12 & 0.43 & 0.74 & 0.61 & 0.25 & 0.51 & -0.22 & 0.33 & $-0,48$ & 0.03 \\
\hline 1981 & -0.13 & 0.28 & 0.31 & -0.20 & 0.07 & 0.93 & 0.73 & 0.71 & 0.42 & 0.70 & -0.78 & -0.82 & -0.89 & 0.00 \\
\hline 1982 & -0.02 & 0.28 & -0.02 & 0.02 & 0.07 & 0.83 & 0.64 & 0.77 & 0.32 & 0.64 & -0.28 & -0.06 & 0.01 & 0.80 \\
\hline 1983 & -0.67 & -0.32 & -0.4 .2 & -0.03 & -0.36 & -0.29 & 0.86 & 0.65 & 0.83 & 0.51 & & 0.50 & 0.00 & 0.38 \\
\hline 1984 & -0.43 & 0.14 & -0.45 & -0.11 & -0.21 & 0.23 & 0.23 & 0.02 & 0.25 & 0.18 & -0.71 & -0.56 & 0.80 & 0.15 \\
\hline 1985 & 0.06 & 0.4 .3 & 0.58 & -0.44 & 0.16 & 0.14 & 0.85 & 0.81 & 0.12 & 0.48 & -0.70 & -0.39 & -0.94 & -1.30 \\
\hline 1986 & -0.40 & 0.32 & -0.28 & -0.30 & -0.17 & 0.29 & 0.09 & 0.43 & 0.29 & 0.28 & -1.66 & -0.70 & -0.21 & 0.01 \\
\hline 1987 & -0.51 & 0.4 .5 & 0.56 & -0.11 & 0.10 & 0.72 & 0.6 .5 & 1.08 & 0.43 & 0.72 & -0.52 & -0.08 & -0.22 & 0.41 \\
\hline 1988 & -0.74 & -0.48 & -0.61 & 0.00 & -0.46 & 0.11 & 0.48 & -10.10 & 0.18 & 0.17 & -0.54 & -0.32 & 0.23 & 0.35 \\
\hline 1989 & -0.11 & -0.13 & -0.23 & -0.08 & -0.14 & 0.49 & 0.41 & 0.36 & 0.49 & 0.44 & -1.20 & -0.81 & $-0,82$ & -1.01 \\
\hline 1900 & 0.03 & -0.15 & & & & 0.55 & 0.38 & & & & -0.61 & 0.75 & & \\
\hline
\end{tabular}

"Temperature anomalles (in relation to a 1958-1977 average) expressed in degrees Celsius.

†Northern Hemisphere winter (Dec-lieb).

Note: Data for summer (Jun-Aug) 1989 through spring (Mar-May) 1900 are provisional. 


\section{Annual and Seasonal Temperature Anomalies*}

Surface-1(0) mb

$1(6)-50 \mathrm{mb}$

\begin{tabular}{|c|c|c|c|c|c|c|c|c|c|c|c|c|c|c|c|}
\hline Ann & Win & Spr & Full & Sum & Ann & Win & Spr & Sumı & Fall & Ann & Win & Spr & Sum & Fall & Ann \\
\hline-0.35 & -0.04 & -0.03 & 0.34 & 0.56 & 0.21 & & & & . & & & & & & \\
\hline 0.06 & 0.44 & 0.23 & 0.93 & 0.76 & 0.59 & & & & & & & : & & & \\
\hline 0.20 & 0.45 & 0.15 & 0.41 & 0.33 & 0.34 & & . & & & & & & & & \\
\hline-0.18 & 0.26 & 0.23 & $C .07$ & $-0,01$ & 0.14 & & & & & & & & & & \\
\hline$-0,45$ & 0.42 & 0,02 & 0.34 & 0.30 & 0.27 & & & & & & & & & & \\
\hline 0.81 & -0.10 & -0.17 & -0.11 & 0.23 & -0.04 & & & & & & & & & & \\
\hline 0,97 & -0.28 & $-0,01$ & -0.31 & -0.21 & -0.20 & 1,90 & 0.55 & -0.29 & 0.22 & 0.60 & 1,12 & 0.46 & 1,06 & 0,47 & 0.78 \\
\hline-0.16 & -0.36 & -0.44 & 0.01 & 0.17 & -0.16 & 0.89 & 0.92 & 1.0 .3 & 0.86 & 0.93 & 1.10 & 0.59 & 1.43 & 1.31 & 1.11 \\
\hline 0.17 & 0.18 & -0.07 & -0.09 & -0.03 & 0.00 & -0.28 & 0.08 & -1.14 & -0.88 & -0.56 & -0.94 & 1.03 & -1.45 & 0.77 & -0.15 \\
\hline 0.21 & -0.04 & 0.18 & -0.11 & 0.22 & 0.06 & 0.10 & -0.10 & 0.97 & 0.27 & 0.31 & 0.28 & 0.13 & -0.05 & 0.47 & 0.21 \\
\hline 0.01 & 0.16 & 0.13 & -0.37 & -0.29 & -0.09 & -0.63 & $-(1.67$ & 0.21 & -0.32 & -0.35 & 0.52 & 0.33 & -0.19 & -0.34 & 0.08 \\
\hline 0.18 & 0.17 & -0.04 & 0.35 & -0.15 & 0.08 & 1.04 & 0.47 & $0 .{ }^{4} 71$ & 0.37 & 0.65 & 0.61 & 0.98 & 1.57 & 0.63 & 0.95 \\
\hline-0.38 & -0.44 & $-0,38$ & -0.15 & -0.50 & -0.37 & 0.02 & 0.26 & 0.83 & -0.08 & 0.11 & 0.27 & 1.36 & 0.37 & 1.24 & 0.81 \\
\hline-0.15 & 0.12 & $-0,10$ & $-0,33$ & $-0,47$ & $-0,20$ & 0.00 & -0.40 & -0.40 & $-0,89$ & -0.42 & -0.20 & -1.53 & -1.14 & $-0,94$ & $-0,95$ \\
\hline$-0,36$ & -0.48 & -0.74 & $-0,09$ & 0.13 & -0.30 & -0.37 & -0.64 & 0.42 & 0.59 & 0.00 & 0.40 & 0.29 & 1.22 & 1.21 & 0.78 \\
\hline-0.39 & 0.11 & 0.28 & 0.17 & -0.36 & 0.05 & 0.92 & 0.82 & -1.39 & -0.45 & -0.03 & 1.23 & 0.04 & -1.50 & -0.52 & -0.19 \\
\hline$-0,80$ & 0.27 & 0.12 & -0.33 & -0.39 & -0.08 & $-1,77$ & -1.57 & -0.29 & -0.57 & $-1,05$ & -1.55 & -1.56 & -0.33 & -1.25 & -1.17 \\
\hline-0.14 & -0.18 & -0.14 & -0.24 & -0.12 & -0.17 & 0.18 & 0.01 & 1.64 & -1.76 & 0.02 & -0.39 & -0.71 & -0.45 & -2.10 & -0.91 \\
\hline-0.38 & 0.04 & -0.03 & -0.52 & -0.71 & -0.31 & -1.72 & -0.87 . & $-1,13$ & 0.90 & -0.71 & -2.05 & -0.75 & -0.38 & 0.73 & -0.61 \\
\hline 0.02 & -0.38 & 0.53 & -0.07 & -0.04 & 0.01 & -0.82 & -0.18 & 0,10 & 0.25 & -0.16 & -0.47 & -0.21 & -0.31 & 0.50 & -0.12 \\
\hline-0.24 & 0.07 & -0.09 & 0,36 & 0.04 & 0,10 & 0.10 & 0.30 & 0.31 & -0.50 & 0.05 & -0.29 & 0.08 & 0.22 & 0.49 & 0.13 \\
\hline 0.23 & 0.30 & 0.76 & 0.80 & 0.32 & 0.55 & 0.52 & 0.47 & 0.38 & 0.41 & 0.45 & 0.35 & 0.77 & 0.90 & 0.13 & 0.54 \\
\hline-0.09 & 0.23 & 0.56 & 0.31 & 0.16 & 0.32 & 0.77 & -0.11 & -0.91 & -0.85 & -0.28 & 0.76 & -0.28 & -1.25 & -0.39 & -0.29 \\
\hline-0.62 & 0.45 & 0.28 & 0.26 & 0.23 & 0.31 & -0.64 & 0.07 & -0.94 & 0.16 & $-0,34$ & -0.48 & -0.19 & $-0,99$ & 0.03 & -0.41 \\
\hline 0.12 & 0.44 & 0.42 & 0.49 & 0.37 & 0.43 & -0.22 & 0.53 & 0.13 & 1.05 & 0.37 & -0.53 & 0.36 & -0.09 & 0.39 & 0,03 \\
\hline 0.00 & -0.31 & 0.62 & 0.33 & 0.42 & 0.27 & 1.72 & 0.23 & 0.32 & 0.56 & 0.71 & 1.26 & 0.32 & 0.62 & 0.25 & 0.61 \\
\hline-0.08 & -0.09 & 0.03 & 0.12 & 0.17 & 0.06 & 0.42 & -0.66 & 0.14 & -0.31 & -0.10 & $-0,01$ & -0.42 & -0.14 & -0.47 & -0.26 \\
\hline-0.83 & 0.06 & 0.55 & 0.39 & -0.29 & 0.18 & -1.09 & -1.05 & -1.71 & -1.87 & -1.43 & -0.97 & -0.61 & -1.06 & -0.72 & -0.84 \\
\hline-0.64 & -0.26 & -0.05 & 0.17 & 0.13 & 0.00 & -1.44 & -0.99 & 0.24 & -0.93 & -0.78 & -0.84 & -0.65 & -0.099 & -0.15 & $-0,43$ \\
\hline-0.10 & 0.24 & 0.45 & 0.71 & 0.34 & 0.44 & -0.72 & -0.72 & -0.56 & -0.97 & -0.74 & -0.25 & 0.01 & -1.56 & $-0,90$ & -0.68 \\
\hline-0.07 & -0.18 & 0.14 & -0.11 & 0.19 & 0.01 & -1.98 & -1.97 & -1.53 & -2.21 & -1.92 & -1.45 & -1.42 & -1.34 & -1.56 & -1.44 \\
\hline \multirow[t]{2}{*}{-0.96} & 0.01 & 0.06 & 0.00 & 0.06 & 0.03 & -1.68 & -2.01 & $-(1.84$ & -0.86 & -1.35 & -1.18 & -1.38 & -0.63 & -0.50 & -0.92 \\
\hline & 0.21 & 0.37 & & & & $-1,23$ & -0.59 & & & & -0.69 & -0.42 & & & \\
\hline
\end{tabular}


Surface

$850-300 \mathrm{mb}$

$300)-100 \mathrm{mb}$

\begin{tabular}{|c|c|c|c|c|c|c|c|c|c|c|c|c|c|c|c|}
\hline Year & Wint & Spr & Sum & Fall & Ann & Win & Spr & Sunı & Fall & Ann & Win & Spr & Sum & Fall & Ann \\
\hline 1958 & 0.68 & 0.36 & -0.58 & -0.22 & 0.06 & 0.11 & 0.34 & 1.01 & -0.83 & 0.16 & 0.56 & 0.69 & -0.41 & -0.55 & 0.07 \\
\hline 1959 & -0.60 & 0.84 & -0.66 & -2.02 & -0.61 & -0.86 & 1.12 & -0.16 & -1.50 & -0.35 & 0.26 & 1.56 & 0.25 & -2.04 & 0.01 \\
\hline 1960 & -1.02 & -0.38 & -1.88 & -0.12 & -0.85 & -0.09 & -0.45 & -0.35 & -0.23 & -0.28 & -0.58 & 2.61 & -0.83 & -0.92 & 0.07 \\
\hline 1961 & -0.65 & 0.86 & -0.61 & 1.36 & 0.24 & 0.10 & 0.13 & 0.06 & 1.10 & 0.35 & 0.50 & 0.96 & 0.40 & -1.49 & 0.09 \\
\hline 1962 & -0.58 & -0.91 & -0.78 & -0.37 & -0.66 & -0.99 & -0.65 & -0.40 & 0.06 & -0.50 & -1.72 & -0.89 & -0.62 & 1.93 & -0.33 \\
\hline 1963 & -0.38 & -1.36 & 0.28 & 0.53 & -0.23 & -0.23 & -0.55 & -0.33 & -0.56 & -0.42 & 1.06 & 0.78 & 0.68 & -1.44 & 0.27 \\
\hline 1964 & 0.10 & -1.94 & 0.71 & -0.93 & -0.52 & 0.21 & -1.40 & 0.83 & -0.30 & -0.17 & -0.63 & -1.45 & -0.90 & 3.50 & 0.13 \\
\hline 1965 & -0.03 & -0.37 & -0.22 & -1.10 & -0.43 & 0.23 & -0.34 & -0.59 & -0.31 & -0.25 & 0.73 & -0.46 & 0.57 & -1.59 & -0.19 \\
\hline 1966 & 0.40 & 1.39 & 0.32 & 0.30 & 0.60 & 0.16 & 0.74 & -0.48 & -0.20 & 0.06 & -0.48 & 0.33 & 0.64 & -0.57 & -0.02 \\
\hline 1967 & 1.15 & -0.51 & 1.51 & -0.60 & 0.39 & 0.58 & -0.12 & 0.26 & 0.12 & 0.21 & 0.27 & -0.86 & 0.26 & 1.61 & 0.32 \\
\hline 1968 & -0.58 & 0.80 & -0.37 & -0.96 & -0.28 & 0.00 & 0.62 & -0.48 & -0.42 & -0.07 & 0.60 & -0.89 & -0.52 & 2.97 & 0.54 \\
\hline 1969 & 0.35 & 0.68 & -1.05 & 0.50 & 0.12 & -0.45 & -0.03 & -0.38 & 0.12 & -0.19 & 1.66 & 0.19 & 0.11 & -2.27 & -0.08 \\
\hline 1970 & -0.28 & -0.27 & -0.53 & 1.31 & 0.06 & -0.59 & 0.63 & -0.16 & 0.77 & 0.16 & -1.77 & 0.09 & 0.96 & 0.12 & -0.15 \\
\hline 1971 & 0.66 & 0.00 & 0.18 & -0.46 & 0.10 & 0.03 & 0.15 & -0.19 & 0.16 & 0.04 & -1.07 & 0.75 & 0.68 & 0.44 & 0.20 \\
\hline 1972 & 0.10 & -0.32 & 1.73 & -0.71 & 0.20 & 0.41 & -0.01 & 0.75 & 0.06 & 0.30 & -0.43 & -0.55 & -0.88 & 0.65 & -0.30 \\
\hline 1973 & -0.52 & 1.12 & 0.08 & 1.45 & 0.53 & -0.26 & 0.55 & 0.29 & 1.01 & 0.40 & -0.35 & -0.60 & 0.26 & -0.44 & -0.28 \\
\hline 1974 & -0.15 & 1.10 & 1.20 & 1.87 & 1.01 & 0.09 & -0.58 & 1.26 & 0.33 & 0.28 & 0.56 & 0.20 & 0.35 & 0.91 & 0.51 \\
\hline 1975 & 1.85 & 1.80 & G.75 & $\ldots 0.05$ & 1.09 & 0.89 & -0.28 & -0.37 & -0.12 & 0.03 & 0.58 & -0.26 & -0.28 & -0.81 & -0.19 \\
\hline 1976 & 0.57 & -1.59 & 0.00 & -0.05 & -0.27 & 0.54 & -0.38 & -0.34 & -0.51 & -0.17 & -0.32 & -1.20 & -0.65 & -0.17 & -0.59 \\
\hline 1977 & 1.03 & 1.13 & 1.93 & -1.30 & 0.70 & 1.15 & 0.70 & 1.30 & -0.24 & 0.73 & -0.34 & -1.05 & -0.24 & 0.02 & -0.40 \\
\hline 1978 & -1.00 & 0.50 & 0.04 & -0.10 & -0.14 & -0.96 & 1.06 & -0.44 & 0.34 & 0.00 & 1.50 & 1.07 & -1.06 & 1.08 & 0.65 \\
\hline 1979 & 0.31 & 0.73 & -0.53 & 1.20 & 0.43 & 0.52 & 0.81 & -1.17 & 0.20 & 0.09 & 0.87 & -0.12 & -1.85 & 0.95 & -0.04 \\
\hline 1980 & 0.70 & 1.36 & 1.75 & 0.06 & 0.97 & 0.79 & 0.54 & 0.86 & 0.67 & 0.72 & 1.76 & 0.84 & 1.54 & -1.58 & 0.64 \\
\hline 1981 & 0.25 & 0.82 & 2.88 & -0.10 & 0.96 & 0.44 & 0.03 & 0.77 & 0.28 & 0.38 & 0.75 & -0.18 & 0.98 & -0.24 & 0.33 \\
\hline 1982 & 0.33 & -1.26 & -0.06 & 0.71 & -0.07 & 0.72 & -0.79 & -0.20 & -0.17 & -0.11 & -0.11 & -1.07 & 0.56 & -1.07 & -0.42 \\
\hline 1983 & 0.77 & 2.57 & 0.54 & 0.00 & 0.97 & 0.60 & 1.18 & 0.90 & 0.21 & 0.72 & -1.19 & 0.60 & -0.62 & 0.22 & -0.25 \\
\hline 1984 & 0.18 & 2.66 & -0.08 & 0.96 & 0.93 & 0.14 & 0.67 & -0.23 & 0.29 & 0.22 & -1.17 & -1.72 & -0.47 & -1.03 & -1.10 \\
\hline 1985 & 0.77 & 0.30 & 1.59 & -0.54 & 0.53 & 0.90 & -0.21 & 0.67 & -0.30 & 0.27 & -1.25 & -0.06 & -0.04 & -3.36 & -1.18 \\
\hline 1986 & 0.92 & 0.70 & 0.68 & -0.50 & 0.45 & 1.06 & 0.43 & 0.52 & -0.29 & 0.43 & -2.50 & -0.72 & 0.34 & -1.72 & -1.15 \\
\hline 1987 & 0.21 & 0.10 & 1.19 & 0.19 & 0.42 & 0.52 & 0.39 & 0.54 & 0.05 & 0.38 & -2.12 & -1.47 & -0.49 & -4.97 & -2.26 \\
\hline 1988 & 0.75 & 1.98 & 1.56 & 1.20 & 1.37. & 0.49 & 0.60 & 1.04 & 1.46 & 0.90 & -1.67 & -1.32 & -0.43 & 3.42 & 0.00 \\
\hline 1989 & -0.52 & -0.40 & -0.01 & -0.24 & -0.29 & 0.84 & -0.11 & 0.78 & 0.59 & 0.53 & 0.54 & -0.11 & -0.39 & -3.35 & -0.83 \\
\hline 1990 & 0.16 & 0.46 & & & & 0.72 & 0.24 & & & & -0.80 & -0.88 & & & \\
\hline
\end{tabular}

* Temperature anomalies (in relation to a 1958-1977 average) expressed in degrees Celsius.

$\uparrow$ Northern Hemisphere winter (Dec-Feb).

Note: Data for summer (Jun-Aug) 1989 through spring (Mar-May) 1990 are provisional. 
Temperature Anomalies

\#\#\%

\section{Annual and Seasonal Temperature Anomalies*}

Surface-100 mib

100)-50 mb

$100-30 \mathrm{mb}$

\begin{tabular}{|c|c|c|c|c|c|c|c|c|c|c|c|c|c|c|}
\hline V/n & Spr & Fall & Sum & Ann & Win & Spr & Sum & Fall & Ann & Win & Spr & Sum & Fall & Ann \\
\hline 0.41 & 0.42 & 0.43 & -0.67 & 0.15 & -0.52 & 1.17 & 2.42 & 0.42 & 0.87 & -0.41 & -0.14 & 1.56 & 0.56 & 0.39 \\
\hline 0.57 & 1.18 & -0.14 & -1.71 & -0.31 & 1.38 & 1.61 & -1.02 & -6.63 & -1.17 & 0.88 & 1.04 & -0.75 & -5.10 & -0.98 \\
\hline 0,35 & 0.26 & -0.63 & -0.36 & -0.27 & -0.29 & 0.39 & 1,04 & 2.06 & 0.80 & 0.47 & 1.18 & 2.29 & 1.84 & 1.45 \\
\hline 0.06 & 0.44 & 0.06 & 0.78 & 0.34 & 1.43 & 0.28 & 1.66 & -6.10 & -0.68 & 1.07 & 0.57 & 1.12 & -3.09 & -0.08 \\
\hline 1.08 & -0.75 & -0.39 & 0.41 & -0.45 & 2.11 & -0.33 & 0.78 & 1.91 & 1.12 & 1.12 & -0.62 & 2.95 & 1.20 & 1.16 \\
\hline 0.04 & -0.39 & 0.00 & -0.57 & -0.23 & 1.79 & 1.39 & -1.13 & 0.81 & 0.72 & 1.14 & 0.57 & -1.31 & 0.47 & 0.22 \\
\hline 0.06 & -1.51 & 0.43 & 0.44 & -0.15 & -0.85 & $-1,30$ & -0.90 & 4.73 & 0,42 & $-0,41$ & $-1,04$ & -1.22 & $3: 37$ & 0.18 \\
\hline 0,30 & -0.38 & -0.27 & -0.73 & -0.27 & -1.34 & 1.27 & -1.42 & 3.99 & 0.63 & -1.14 & 0.28 & -1.22 & 2.79 & 0.18 \\
\hline 0.06 & 0.76 & -0.02 & -0.20 & 0.15 & -1.19 & -1.73 & 1.80 & -1.28 & -0.60 & -0.59 & -2.23 & 1.69 & 0.11 & -0.26 \\
\hline 0.63 & -0.35 & 0.47 & 0.26 & 0.25 & -0.34 & 0.14 & -1.61 & 1.03 & -0.20 & -0.17 & -0.23 & -0.81 & 1.50 & 0.07 \\
\hline 0.04 & 0.32 & -0.45 & 0.26 & 0.04 & 0.14 & 0.38 & -1.57 & 0.39 & -0.17 & -0.18 & 0.01 & 0.46 & 0.13 & 0.11 \\
\hline 0.15 & 0.18 & -0.38 & -0.35 & -0.10 & 1.00 & 0.39 & -2.00 & -3.30 & -0.98 & 0.44 & 0.59 & 0.04 & -2.14 & -0.27 \\
\hline 0.80 & 0.36 & 0.10 & 0.74 & 0.10 & -0.08 & -0.27 & 0.53 & -3.74 & -0.89 & 0.85 & -1.13 & 0.62 & -1.22 & -0.22 \\
\hline 0.05 & 0.22 & 0.06 & 0.16 & 0.10 & 0.26 & 1.21 & -1.44 & 0.34 & 0.09 & $0 . C 7$ & 0.23 & -1.55 & 0,05 & -0.30 \\
\hline 0.22 & 0.28 & 0.62 & 0.05 & 0.29 & -0.60 & -0.24. & -0.04 & -0.20 & -0.27 & -0.52 & 0.03 & -0.35 & -0.71 & -0.39 \\
\hline 0.03 & 0.45 & 0.27 & 0.94 & 0.42 & -0.51 & 0.47 & 0.07 & -0.94 & -0.23 & -0.53 & 0.11 & -0.96 & -0.70 & -0.52 \\
\hline 0.09 & 0.14 & 1.02 & 0.76 & 0.46 . & -0.22 & 0.86 & -1.55 & 0.13 & -0.20 & 0.01 & 1.52 & -1.28 & 0.55 & 0.20 \\
\hline 1.01 & 0.15 & -0.09 & -0.03 & 0.26 & 0.28 & -0.78 & -1.19 & -2.63 & -1.08 & -0.15 & -0.68 & 1.16 & -0.96 & -0.16 \\
\hline 0.40 & -0.72 & -0.32 & -0.35 & -0.25 & -0.46 & 0.31 & -0.40 & 0.98 & 0.20 & -0.81 & 1.41 & 0.77 & 0.84 & 0.55 \\
\hline 0.80 & 0.38 & 1.06 & -0.36 & 0.47 & 0,37 & 0.10 & -1.63 & 4.22 & 0.77 & 0.19 & -0.25 & -1.54 & 0.65 & -0.24 \\
\hline 0.42 & 0.97 & $-0,50$ & 0.44 & 0.12 & 0.28 & 3.27 & -0.19 & -3.94 & -0.15 & 0.32 & 1.21 & -0.13 & -2.64 & -0.31 \\
\hline 0.57 & 0.59 & -1.21 & 0.54 & 0.12 & -1.21 & -0.15 & -0.78 & -2.35 & -0.87 & 0.26 & 0.41 & -3.61 & -1.18 & -1.03 \\
\hline 1.11 & 0.78 & 1.16 & 0.16 & 0.80 & -0.34 & 2.29 & 1.59 & -3.69 & -0.04 & -0.04 & 1.50 & -0.75 & -1.41 & -0.18 \\
\hline 0.51 & 0.12 & 1.33 & 0.10 & 0.52 & 0.71 & 1.67 & -2.82 & -0.66 & -0.28 & 0.52 & 1.15 & -1.91 & -0.45 & -0.17 \\
\hline 0,38 & -0.93 & 0,08 & -0.23 & -0.18 & 1.63 & $-0,53$ & -4.65 & -3.49 & -1.76 & 1.10 & -0.32 & -6.27 & -2.35 & -1.96 \\
\hline 0.21 & 1.34 & 0.49 & 0.22 & 0.57 & 0.35 & 0.52 & -2.91 & -2.53 & -1.14 & 0.23 & -0.20 & -1.96 & -1.71 & -0.91 \\
\hline 0.07 & 0.47 & -0.28 & 0.11 & 0.06 & 0.26 & 0.45 & 0.45 & -2.03 & -0.22 & 0.21 & & & & \\
\hline 0.40 & -0.09 & 0.71 & -1.02 & 0.00 & -1.50 & -0.68 & -6.41 & -6.16 & -3.69 & & & & & \\
\hline 0.25 & 0.22 & 0.72 & -0.64 & 0.14 & -1.30 & 1.02 & 0.82 & $-1,95$ & -0.35 & & & & & \\
\hline 0.12 & -0.18 & 0.25 & -1.04 & -0.27 & -1.45 & -0.12 & -3.87 & -13.51 & -4.74 & & & & & \\
\hline 0.01 & 0.40 & 0.80 & 1.85 & 0.77 & -0.95 & -0.07 & -0.65 & 4.93 & 0.82 & & & & & \\
\hline 0.55 & -0.16 & 0.39 & -0.42 & 0.09 & -0.92 & 0.56 & -2.64 & $-7,17$ & -2.54 & & & & & \\
\hline 0.29 & 0.03 & & & & -0.63 & -0.25 & & & & & & & & \\
\hline
\end{tabular}




\section{Tropical $\left(30^{\circ} \mathrm{S}-30^{\circ} \mathrm{N}\right)$}

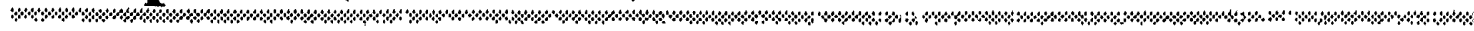

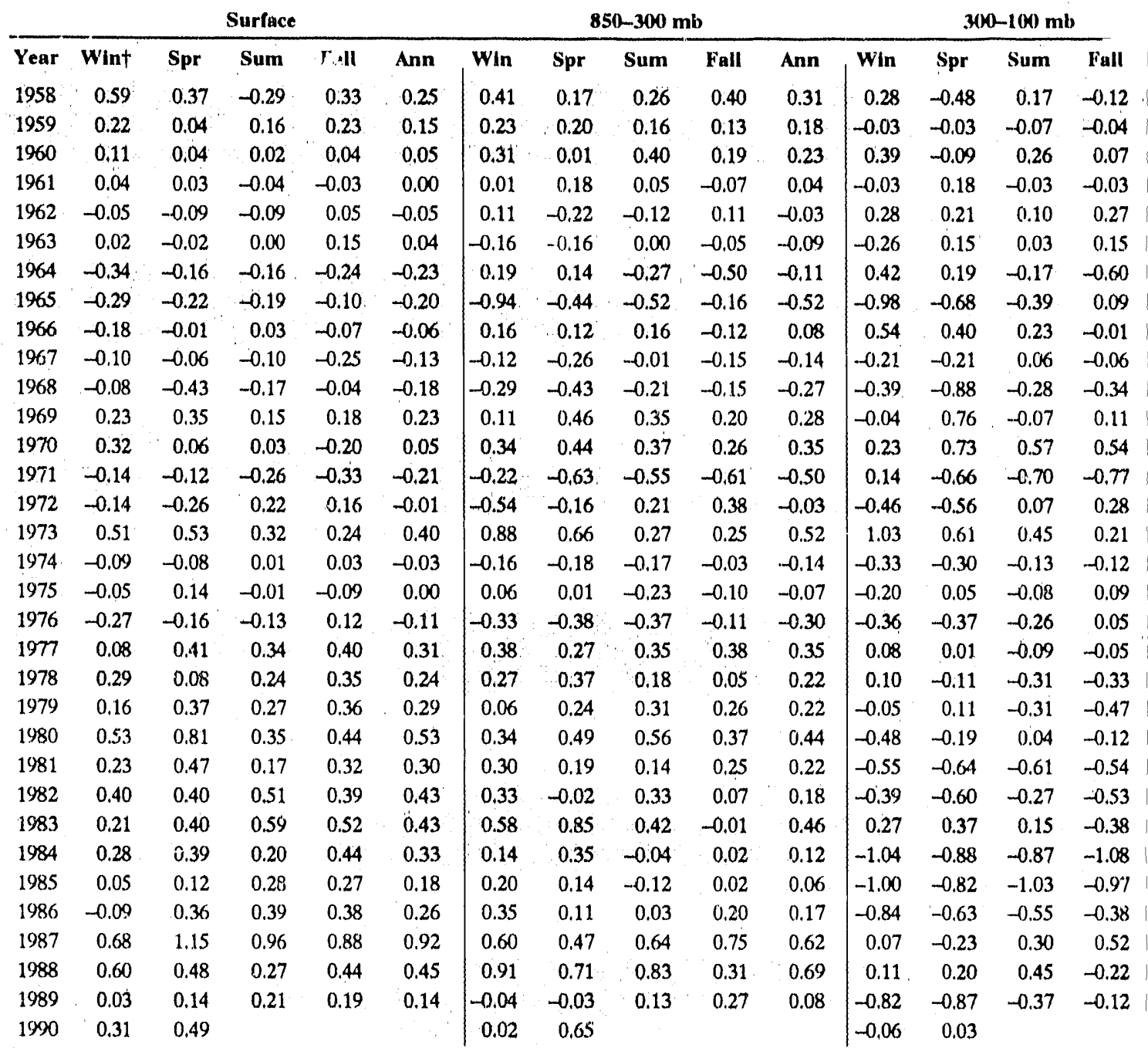

* Temperature anomalies (in relation to a 19.58-1977 average) expressed in degrees Celsius.

†Northern Hemisphere winter (Dec-Feb).

Note: Data for summer (Jun-Aug) 1989 through spring (Mar-May) 1990 are provisional. 


\section{Annual and Seasonal Temperature Anomalies*}

Surface-100 mb

$100-50 \mathrm{mb}$

$100-30 \mathrm{mb}$

\begin{tabular}{|c|c|c|c|c|c|c|c|c|c|c|c|c|c|c|c|}
\hline Ann & Win & Spr & Fall & Sum & Ann & Win & Spr & Sum & Fall & Ann & Win & Spr & Sum & Fall & Ann \\
\hline-0.04 & 0.41 & -0.22 & 0.13 & 0.20 & 0.13 & 0.60 & 0.60 & -0.47 & 0.13 & 0.22 & 0.71 & 1.50 & -0.19 & 0.33 & 0.59 \\
\hline-0.04 & 0.18 & 0.15 & 0.11 & 0.17 & 0.15 & -0.93 & -1.52 & -1.34 & 0.43 & -0.84 & 0.12 & -0.73 & -0.11 & 0.33 & -0.10 \\
\hline 0.16 & 0.29 & 0.00 & 0.30 & 0.14 & 0.18 & -0.10 & -0.78 & -0.93 & -0.51 & -0.58 & -0.31 & -0.72 & -2.54 & -2.01 & -1.40 \\
\hline 0.02 & 0.00 & 0.20 & -0.04 & -0.05 & 0.03 & -2.81 & -1.47 & 1.11 & 2.31 & -0.22 & -2.99 & -2.99 & 0.49 & -0.05 & -1.39 \\
\hline 0.22 & 0.12 & -0.10 & -0.09 & 0.10 & 0.01 & 0.61 & -0.40 & -0.85 & -1.16 & -0.45 & 0.23 & -0.83 & -2.02 & -1.48 & -1.03 \\
\hline 0.02 & -0.15 & -0.07 & 0.00 & 0.02 & -0.05 & -0.70 & -0.61 & 0.76 & 0.94 & 0.10 & -2.16 & -1.31 & 1.27 & 2.51 & 0.08 \\
\hline-0.04 & 0.17 & 0.11 & -0.23 & -0.46 & -0.10 & 1.24 & 1.67 & 1.49 & 0.81 & 1.30 & $0 . i 2$ & 1.27 & 1.54 & 0.44 & 0.99 \\
\hline-0.49 & -0.84 & -0.49 & -0.43 & -0.09 & -0.46 & 1.24 & 0.46 & 0.57 & 0.73 & 0.75 & 0.80 & 0.33 & 0.14 & 0.67 & 0.49 \\
\hline 0.29 & 0.16 & 0.16 & 0.14 & -0.09 & 0.09 & -0.69 & -0.67 & -0.54 & 0.79 & -1.28 & -1.06 & -0.54 & 0.22 & 1.03 & -0.09 \\
\hline-0.11 & -0.15 & -0.21 & -0.01 & -0.14 & -0.13 & 0.86 & 1.03 & 0.26 & -0.43 & 0.43 & 0.96 & 1.1 .4 & 0.22 & -0.25 & 0.52 \\
\hline-0.47 & -0.18 & -0.53 & -0.22 & -0.17 & -0.28 & -0.48 & 0.93 & -0.10 & -0.18 & 0.04 & -0.57 & 0.63 & -0.10 & -0.23 & -0.07 \\
\hline 0.19 & 0.12 & 0.35 & 0.21 & 0.18 & 0.22 & -0.51 & -0.51 & -0.32 & 0.48 & -0.22 & -0.94 & -0.66 & -0.35 & 0.82 & -0.28 \\
\hline 0.52 & 0.31 & 0.44 & 0.36 & 0.27 & 0.35 & -0.36 & -0.22 & 0.60 & 0.27 & 0.07 & -0.80 & -0.17 & 0.67 & 0.74 & 0.11 \\
\hline-0.50 & -0.14 & -0.55 & -0.54 & -0.60 & -0.46 & 0.41 & -0.14 & -0.08 & 0.31 & 0.13 & 0.89 & 0.34 & 0.02 & -0.45 & 0.20 \\
\hline$-0,17$ & -0.52 & -0.27 & 0.18 & 0.32 & -0.07 & 0.75 & 0.05 & -0.67 & -1.02 & -0.22 & 0.68 & 0.06 & -1.24 & -0.96 & -0.37 \\
\hline 0.58 & 0.81 & 0.63 & 0.32 & 0.24 & 0.50 & -1.00 & -0.52 & 0.04 & -0.03 & -0.38 & -1.40 & -0.72 & -0.16 & -0.22 & -0.63 \\
\hline-0.22 & -0.19 & -0.23 & -0.13 & -0.04 & -0.15 & 0.74 & $-0.14^{\prime}$ & -0.36 & -0.72 & -0.12 & 0.64 & -0.49 & -0.49 & -1.31 & -0.41 \\
\hline-0.04 & -0.12 & 0.07 & -0.16 & -0.05 & $-0.0^{\circ} 7$ & -0.45 & -0.02 & 0.06 & 0.39 & -0.01 & -0.44 & 0.09 & -0.44 & 0.09 & -0.18 \\
\hline-0.24 & -0.32 & -0.35 & -0.30 & -0.04 & -0.25 & 1.73 & 0.62 & 0.50 & 0.30 & 0.79 & 1.36 & 0.07 & 0.52 & -0.74 & 0.30 \\
\hline-0.01 & 0.26 & 0.23 & 0.24 & 0.29 & 0.26 & -1.74 & -0.12 & -0.18 & -0.48 & -0.64 & -2.66 & -0.56 & -0.88 & -0.30 & -1.10 \\
\hline-0.16 & 0.22 & 0.23 & 0.09 & 0.01 & 0.14 & -0.58 & -0.13 & 0.40 & -0.20 & -0.13 & -1.20 & -0.73 & -0.19 & -0.76 & -0.72 \\
\hline-0.18 & 0.04 & 0.23 & 0.29 & 0.17 & 0.18 & -0.11 & 0.07 & -0.37 & -0.93 & -0.34 & -0.72 & -0.04 & -0.23 & .1 .30 & -0.57 \\
\hline-0.19 & 0.25 & 0.50 & 0.40 & 0.30 & 0.36 & -0.29 & -1.40 & -0.47 & 0.45 & -0.43 & -0.36 & -2.08 & -0.32 & 0.19 & -0.64 \\
\hline-0.59 & 0.05 & 0.04 & 0.02 & 0.10 & 0.05 & 0.23 & -0.35 & -0.33 & 0.03 & -0.11 & 0.42 & -10.56 & -0.32 & -0.40 & -0.22 \\
\hline-0.45 & 0.15 & -0.07 & 0.22 & -0.01 & 0.07 & -0.51 & -0.04 & 0.52 & 1.33 & 0.33 & -1.40 & -0.57 & 0.67 & 1.16 & -0.04 \\
\hline 0.10 & 0.47 & 0.69 & 0.40 & 0.06 & 0.41 & 1.23 & 0.02 & 0.07 & 0.75 & 0.52 & 0.58 & -0.44 & -0.36 & 0,34 & 0.03 \\
\hline-0.97 & -0.11 & 0.08 & -0.18 & -0.13 & -0.09 & 0.31 & -1.13 & -0.95 & -0.96 & -0.68 & -0.49 & -1.03 & -0.81 & -0.87 & -0.80 \\
\hline-0.96 & -0.08 & -0.08 & -0.28 & -0.16 & -0.15 & -1.76 & -1.28 & -0.73 & -0.18 & -0.99 & -1.25 & -1.04 & -0.58 & -0.53 & -0.85 \\
\hline-0.60 & 0.01 & -0.03 & -0.02 & 0.13 & 0.02 & -1.46 & -1.41 & -2.01 & -2.17 & -1.76 & -1.23 & -1.30 & -1.51 & -1.66 & -1.43 \\
\hline 0.17 & 0.53 & 0.44 & 0.56 & 0.74 & 0.57 & -1.85 & -1.72 & -1.54 & -0.80 & -1.48 & -1.53 & -1.43 & -1.21 & -0.81 & -1.25 \\
\hline 0.14 & 0.69 & 0.58 & 0.64 & 0.21 & 0.53 & -1.39 & -2.39 & -1.52 & -2.46 & -1.94 & -1.31 & -1.72 & -1.20 & -1.82 & -1.51 \\
\hline \multirow[t]{2}{*}{-0.55} & -0.13 & -0.20 & 0.03 & 0.17 & -0.03 & -1.07 & -1.48 & -0.85 & -1.08 & -1.12 & -0.94 & -1.19 & -0.84 & -1.05 & -1.01 \\
\hline & 0.05 & 0.49 & & & & -0.87 & -0.95 & & & & -1.26 & -1.03 & & & \\
\hline
\end{tabular}


Surface

$850-3(10) \mathrm{mb}$

$300-100 \mathrm{mh}$

\begin{tabular}{|c|c|c|c|c|c|c|c|c|c|c|c|c|c|c|c|}
\hline Year & Wint & Spr & Sum & Fall & Ann & W/n & Spr & Sum & Fall & Ann & W/n & Spr & Sum & Fall & Ann \\
\hline 1958 & 0.63 & -0.06 & -0.04 & 0.29 & 0.21 & 0.53 & 0.42 & 0.18 & 0.34 & 0.37 & 0.16 & -0.15 & 0.27 & 0.74 & 0.26 \\
\hline 1959 & 0.36 & 0.12 & 0.18 & 0.00 & 0.16 & 0.42 & 0.67 & 0.31 & 0.38 & 0.45 & 0.25 & 0.61 & 0.33 & 0.24 & 0.36 \\
\hline 1960 & 0.05 & -0.30 & 0.14 & -0.32 & -0.11 & 0.13 & -0.08 & 0.38 & 0.05 & 0.12 & .1 .05 & 0.09 & 0.22 & 0.27 & 0.41 \\
\hline 1961 & 0.61 & 0.13 & 0.07 & 0.16 & 0.24 & 0.50 & 0.15 & -0.04 & 0.26 & 0.22 & 0.31 & 0.72 & 0.52 & 0.06 & 0.40 \\
\hline 1962 & 0.42 & 0.18 & -0.05 & -0.04 & 0.12 & 0.20 & 0.09 & -0.03 & 0.05 & 0.08 & -0.42 & -0.20 & -0.16 & 0.20 & -0.15 \\
\hline 1963 & 0.18 & -0.03 & -0.01 & 0.50 & 0.16 & 0.11 & -0.12 & -0.02 & 0.20 & 0.04 & -0.25 & 0.09 & 0.27 & 0.28 & 0,09 \\
\hline 1964 & -0.20 & -0.51 & -0.16 & -0.35 & -0.31 & 0.10 & 0.08 & -0.12 & -0.37 & -0.08 & -0.19 & 0.47 & -0.03 & -0.06 & 0.05 \\
\hline 1965 & -0.41 & -0.21 & -0.20 & -0.13 & -0.24 & -0.41 & -0.39 & -0.53 & -0.10 & -0.36 & -0.40 & -0.54 & -0.28 & 0.07 & -0.29 \\
\hline 1966 & -0.51 & -0.07 & -0.07 & -0.16 & -0.22 & -0.15 & 0.09 & 0.20 & 0.21 & 0.09 & 0.73 & 0.14 & 0.62 & 0.10 & 0.40 \\
\hline 1967 & -0.32 & 0.31 & 0.07 & 0.19 & 0.06 & -0.17 & -0.02 & 0.12 & 0.21 & 0.04 & -0.29 & -0.53 & -0.22 & -0.42 & -0.37 \\
\hline 1968 & -0.26 & 0.30 & -0.13 & -0.19 & -0.07 & 0.04 & -0.17 & -0.37 & -0.30 & $-0.20^{\circ}$ & -0.03 & -1.49 & & -0.43 & -0.61 \\
\hline 1969 & -0.71 & -0.19 & 0.11 & 0.22 & -0.14 & -0.33 & 0.01 & 0,24 & & & 0.21 & 0.40 & -0.06 & $-(0.21$ & 0.09 \\
\hline 1970 & 0.47 & 0.06 & -0.06 & -0.11 & 0.09 & 0.16 & 0.01 & 0.19 & 0.13 & 0.12 & 0.35 & 0.24 & 0.33 & 0.15 & 0.27 \\
\hline 1971 & $-(1,42$ & -0.12 & -0.12 & 0.04 & -0.16 & -0.38 & -0.56 & -0.38 & -0.47 & -0.45 & -0.09 & -0.28 & -0.46 & -0.60 & -0.36 \\
\hline 1972 & -0.40 & -0.28 & 0.07 & -0.19 & $-0,20$ & -0.67 & -0.24 & 0.00 & -0.15 & -0.27 & -0.85 & -0.56 & -0.23 & 0.08 & -0.39 \\
\hline 1973 & 0.4 .5 & 0.22 & 0.30 & 0.01 & 0.25 & 0.47 & 0.11 & 0.15 & -0.11 & 0.16 & 0.67 & 0.67 & 0.15 & -0.10 & 0.35 \\
\hline 1974 & 0.13 & -0.07 & -0.26 & -0.03 & -0.06 & -0.22 & -0.22 & -0.29 & -0.43 & -0.29 & -0.75 & -0.09 & -0.34 & -0.04 & -0.31 \\
\hline 1975 & 0.23 & 0.42 & 0.07 & -0.08 & 0.16 & -0.31 & 0.10 & -0.03 & -0.12 & -0.09 & -0.28 & 0.15 & -0.30 & -0.07 & -0.13 \\
\hline 1976 & 0.03 & -0.28 & -0.10 & -0.26 & -0.15 & -0.37 & -0.62 & -0.39 & -0.32 & -0.43 & -0.84 & -0.71 & -0.64 & -0.40 & -0.65 \\
\hline 1977 & -0.26 & 0.27 & 0.20 & 0.26 & 0.12 & -0.01 & 0.17 & 0.11 & 0.16 & 0.11 & 0.55 & 0.38 & -0.14 & -0.26 & 0.13 \\
\hline 1978 & 0.27 & -0.09 & 0.16 & 0.28 & 0.16 & -0.14 & 0.17 & 0.06 & -0.15 & -0.02 & 0.05 & -0.17 & -0.25 & -0.58 & -0.24 \\
\hline 1979 & -0.10 & 0.30 & 0.05 & 0.22 & 0.12 & -0.29 & 0.30 & 0.19 & 0.24 & 0.11 & -0.29 & 0.04 & -0.38 & -0.33 & -0.24 \\
\hline 1980 & 0.71 & 0.41 & 0.00 & 0.11 & 0.31 & 0.21 & 0.08 & 0.34 & 0.01 & 0.16 & -0.82 & 0.44 & 0.28 & -0.04 & -0.04 \\
\hline 1981 & 0.86 & 0.74 & 0.28 & 0.44 & 0.58 & 0.27 & 0.40 & 0.12 & 0.21 & 0.25 & -0.88 & -0.83 & -0.33 & -0.37 & -0.60 \\
\hline 1982 & 0.44 & -0.02 & 0.19 & 0.01 & 0.16 & -0.03 & -0.21 & 0.16 & -0.13 & -0.05 & -0.12 & -0.33 & -0.13 & -0.66 & -0.31 \\
\hline 1983 & 1.00 & 0.34 & 0.40 & 0.37 & 0.53 & 0.35 & 0.65 & 0.41 & 0.13 & 0.39 & -0.69 & -0.16 & -0.04 & -0.47 & -0.34 \\
\hline 1984 & 0.58 & 0.25 & 0.05 & 0.11 & 0.25 & 0.04 & 0.02 & -0.02 & -0.18 & -0.04 & $-1,16$ & -0.28 & -0.43 & -0.62 & -0.62 \\
\hline 1985 & -0.37 & -0.13 & -0.08 & -0.26 & -0.21 & -0.07 & -0.27 & -0.35 & -0.31 & -0.25 & 0.28 & 0.19 & -0.55 & -0.44 & -0.13 \\
\hline 1986 & 0.11 & 0.27 & 0.01 & 0.11 & 0.13 & 0.16 & 0.10 & 0.01 & 0.10 & 0.09 & -0.54 & -0.54 & -0.55 & -0.47 & -0.53 \\
\hline 1987 & 0.35 & 0.20 & 0.52 & 0.14 & 0.30 & 0.20 & 0.21 & 0.44 & 0.18 & 0.26 & 0.38 & -0.38 & 0.04 & 0.53 & 0.14 \\
\hline 1988 & 0.57 & 0.66 & 0.30 & 0.11 & 0.41 & 0.39 & 0.34 & 0.88 & 0.32 & 0.48 & -0.36 & -0.17 & 0.03 & -0.39 & -0.22 \\
\hline 1989 & 0.91 & 0.53 & 0.39 & 0.15 & 0.50 & 0.02 & 0.23 & 0.28 & 0.26 & 0.20 & -0.82 & -0.32 & -0.61 & -0.32 & -0.52 \\
\hline 1900 & 0.81 & 1.42 & & & & 0.17 & 0.73 & & & & -0.44 & -0.88 & & & \\
\hline
\end{tabular}

-Temperature anomalies (in relation to a 1958-1977 average) expressed in degrees Celsius.

†Northern Hemisphere winter (Dec-[eb).

Note: Data for summer (Jun-Aug) 1989 through spring (Mar-May) 1990 are provisional. 


\section{Annual and Seasonal Temperature Anomalies*}

Surface-100 mb

$10(1-50) \mathrm{mb}$

$100-30 \mathrm{mb}$

\begin{tabular}{|c|c|c|c|c|c|c|c|c|c|c|c|c|c|c|}
\hline Wha & Spr & Fall & Sum & Ann & W/n & Spr & Sum & Fall & Ann & Win & Spr & Sum & Fall & Ann \\
\hline 0,46 & 0.08 & 0.15 & 0.39 & 0.27 & 1.32 & 0.41 & 0.21 & 1.38 & 0.83 & 0.90 & 0.44 & 0.53 & 1.69 & 0.89 \\
\hline 0.38 & 0.58 & 0.29 & 0.32 & 0.39 & -0.32 & 1.25 & 0.20 & 0.07 & 0.30 & -0.15 & 1.49 & 0.61 & 0.36 & 0.58 \\
\hline 0.33 & $-0,08$ & 0,30 & 0.04 & 0,15 & 1.30 & 0,80 & 0.09 & 0.43 & 0.66 & 1.59 & 0,00 & $-0,57$ & 0.04 & 0.27 \\
\hline 0.47 & 0.30 & 0.08 & 0.20 & 0.26 & -1.22 & -0.16 & 0.82 & 0.92 & 0.09 & $-1,02$ & -0.73 & 0.69 & 0.30 & -0.19 \\
\hline 0.10 & 0.04 & -0.07 & 0.06 & 0.03 & -0.36 & -0.90 & -0.85 & -0.35 & -0.62 & $-0,41$ & -1.20 & $-1,36$ & -0.46 & -0.86 \\
\hline 0.04 & -0.06 & 0.04 & 0.27 & 0.07 & -0.63 & -0.59 & 0.98 & 0.62 & 0.10 & -0.37 & -1.39 & 1.02 & 1.13 & 0.10 \\
\hline 0.00 & 0.08 & -0.11 & -0.29 & -0.08 & -0.12 & 1.20 & 0.74 & 0.06 & 0.47 & 0.01 & 1,60 & 0.61 & 0.13 & 0.59 \\
\hline-0.40 & -0.41 & -0.42 & -0.06 & -0.32 & -0.05 & -0.16 & 0.19 & 0.22 & 0.05 & -0.44 & 0.60 & 0.04 & -0.07 & 0.03 \\
\hline-0.04 & 0.08 & 0.24 & 0.13 & 0.10 & 0.38 & -0.76 & -0.03 & 0.63 & 0.06 & -0.43 & -0.59 & 0.27 & 0.87 & 0.03 \\
\hline-0.21 & -0.38 & 0.04 & 0.07 & -0.12 & 0.01 & -0.31 & -0.46 & -0.69 & $-(1,36$ & -0.18 & 0.40 & -0.11 & -0.70 & -0.15 \\
\hline-0.03 & -0.39 & -0.36 & -0.31 & -0.27 & -0.45 & -0.44 & -0.07 & -0.25 & -0.30 & -1.37 & -10.31 & -0.08 & -0.31 & -0.52 \\
\hline-0.25 & -0.12 & 0.17 & 0.10 & $-0,03$ & -0.50 & -0.35 & -0.28 & 0.64 & -0.12 & -1.37 & -0.54 & -0.10 & 0.03 & -0.50 \\
\hline 0.30 & 0.08 & 0.22 & 0.13 & 0.18 & 0.24 & -0.07 & 0.27 & 0.31 & 0.19 & -0.02 & -0.07 & 0.38 & 0.23 & 0.13 \\
\hline-0.40 & -0.51 & $-0,43$ & -0.49 & -0.46 & 0.39 & -0.52 & 0.14 & 0.12 & 0,03 & 0.02 & -0.35 & 0.19 & -0.41 & $-0,14$ \\
\hline-0.80 & -0.39 & -0.04 & -0.13 & -0.34 & 0.04 & 0.19 & -0.57 & -0.54 & -0.22 & 0.47 & 0.36 & -0.93 & $-0,45$ & -0.14 \\
\hline 0.60 & 0.31 & 0.21 & -0.10 & 0.26 & 0.05 & -0.73 & -0.22 & -0.15 & -0.26 & -0.03 & -1.23 & -0.35 & $-0,48$ & -0.52 \\
\hline-0.34 & -0.22 & -0.25 & -0.33 & -0.29 & -0.10 & 0.45 & -0.38 & -0.34 & -0.09 & 0.55 & 0,34 & -0.55 & -0.28 & 0.02 \\
\hline-0.25 & 0.19 & -0.08 & -0.16 & -0.08 & -0.16 & 0.28 & -0.06 & -0.25 & -0.05 & -0.23 & -0.19 & 0.04 & 0.14 & -0.06 \\
\hline-0.49 & -0.70 & -0.57 & -0.32 & -0.52 & 0.22 & 0.76 & 0.19 & 0.14 & 0.33 & 0.82 & 0.45 & 0.02 & -0.37 & 0.23 \\
\hline 0.07 & 0.23 & 0.07 & 0.09 & 0.12 & -0.31 & 0.35 & 0.35 & 0.03 & 0.11 & -1.34 & -0.07 & -0.48 & -0.20 & -0.52 \\
\hline-0.05 & 0.11 & 0.01 & -0.17 & -0.03 & -0.49 & -0.53 & -0.31 & -0.52 & -0.46 & -1.05 & -0.90 & -0.52 & -0.52 & -0.75 \\
\hline-0.24 & 0.22 & 0.17 & 0.16 & 0.08 & 0.48 & 0.31 & -0.34 & -0.33 & 0.03 & 0.15 & 0.03 & -0.29 & -0.77 & -0.22 \\
\hline 0.08 & 0.24 & 0.25 & 0.04 & 0.15 & -0.12 & -0.01 & $-0,06$ & 0.63 & 0.11 & -0.37 & -0.63 & 0.28 & 0.42 & $-0,08$ \\
\hline 0.10 & 0.17 & 0.08 & 0.12 & 0.12 & 0.30 & -0.41 & -0.37 & 0.03 & -0.11 & 0,48 & -0.64 & -0.51 & -0.14 & -0.20 \\
\hline$-0,01$ & -0.17 & 0.10 & -0.22 & -0.08 & 0.3 .5 & 0.31 & 0.57 & 0.52 & 0.44 & 0.06 & 0.16 & 0.72 & 0.59 & 0.38 \\
\hline 0.28 & 0.43 & 0.29 & 0.09 & 0.27 & 0.00 & 0.21 & -0.29 & 0.16 & 0.03 & -0.45 & -0.18 & -0.72 & -0.12 & -0.37 \\
\hline-0.14 & -0.01 & -0.09 & -0.20 & -0.11 & -0.12 & -0.15 & -1.00 & -0.49 & -0.44 & -0.19 & -0.25 & -0.70 & -0.37 & -0.38 \\
\hline-0.04 & -0.14 & -0.34 & -0.33 & -0.21 & -0.42 & -0.83 & -0.47 & 0.05 & -0.42 & -0.33 & -0.69 & -0.37 & -0.19 & -0.40 \\
\hline-0.01 & $-0,02$ & -0.11 & 0.00 & -0.04 & -0.47 & -0.28 & -1.09 & -1.08 & -0.73 & -0.33 & -0.37 & -0.8 .5 & -0.78 & -0.58 \\
\hline 0.29 & 0.013 & 0.35 & 0.25 & 0.24 & -0.40 & -1.30 & -0.77 & -0.14 & -0.65 & -0.32 & -0.98 & -0.75 & -0.10 & -0.54 \\
\hline 0.26 & 0.30 & 0.58 & 0.12 & 0.32 & -1.48 & -0.65 & -0.86 & -1.20 & -1.05 & -0.94 & -0.45 & -0.69 & $-0.8 \delta$ & -0.74 \\
\hline 0.01 & 0.15 & 0.11 & 0.11 & 0.10 & -0.30 & -0.60 & -0.76 & -0.77 & -0.61 & -0.07 & .0 .52 & -0.72 & -0.58 & -0.47 \\
\hline 0.14 & 0.49 & & & & -1.26 & -1.22 & & & & -0.89 & -1.04 & & & \\
\hline
\end{tabular}


Surface

85(1-.3.) $\mathrm{mb}$

$3(k)-1(x) \mathrm{mb}$

\begin{tabular}{|c|c|c|c|c|c|c|c|c|c|c|c|c|c|c|}
\hline Year & Wint & Spr & Sum & Fall & Ann & W/n & Spr & Sum & Full & Ann & Win & Spr & Sum & Fall \\
\hline 1958 & 0.76 & 0.58 & -0.04 & 0.38 & 0.42 & 0.25 & 0,00 & 0.37 & 0.30 & 0.23 & 0.05 & $-0,37$ & -0.05 & -0.68 \\
\hline 1959 & 0.45 & 0.44 & 0.34 & 0.11 & 0.34 & 0.08 & 0.20 & 0.41 & 0.20 & (). 22 & -0.35 & 0.33 & 0.04 & -0.69 \\
\hline 1960 & 0.16 & 0.20 & -0.09 & 0.18 & 0.11 & 0.43 & 0.00 & 0.16 & 0.22 & 0.20 & -0.14 & 0.21 & 0.49 & 0.03 \\
\hline 1961 & 0.13 & 0.36 & 0.13 & 0.50 & 0.28 & 0.08 & 0.20 & 0.07 & 0.29 & 0.16 & 0.00 & 0.46 & -0.13 & -0.70 \\
\hline 1962 & 0.24 & 0.05 & 0.02 & 0.19 & 0.13 & 0.08 & -0.10 & 0.01 & 0.09 & 0.02 & -0.44 & $-11.66)$ & $-(0,(K)$ & 0.60 \\
\hline 1963 & 0.04 & -0.17 & 0.05 & 0.13 & 0.01 & 0.02 & -0.15 & $-0,20$ & -0.26 & -0.15 & -0.16 & 0,33 & 0.49 & 0.51 \\
\hline 1964 & -0.21 & -0.42 & 0.03 & -0.11 & -0.18 & -0.24 & -0.28 & -0.37 & -0.53 & -0.36 & 0.38 & 0.15 & $\left.0.0^{\circ}\right)$ & 0.44 \\
\hline 1965 & -0.01 & -0.21 & -0.15 & -0.04 & -0.10 & -0.76 & -0.54 & -0.26 & 0.01 & -0.39 & -0.30 & -0.37 & -10.42 & $-0,38$ \\
\hline 1966 & 0.24 & 0.20 & -0.02 & 0,02 & 0.11 & 0.088 & 0.05 & $-0,10$ & -0.22 & -0.05 & 0,11 & 0.26 & 0.17 & -0.03 \\
\hline 1967 & $0: 6$ & -0.14 & 0.03 & 0.00 & 0.01 & -0.00 & -0.05 & 0.01 & 0.03 & $-0,03$ & 0.03 & -0.14 & $-(0,06$ & 0.14 \\
\hline 1968 & 0.05 & 0.02 & -0.31 & -0.28 & -0.13 & -0.07 & 0.03 & -0.28 & -0.31 & -0.16 & 0.04 & -10.67 & -0.22 & 0.75 \\
\hline 1969 & -0.18 & -0.014 & -0.34 & 0.01 & -0.14 & 0.02 & 0.28 & 0.41 & 0.20 & 0.23 & 0.63 & 0.77 & 0,07 & -0.43 \\
\hline 1970 & -0.07 & -0.25 & -0.23 & -0.19 & -0.19 & 0.06 & 0.26 & 0.16 & 0.14 & 0.16 & $-0,25$ & 0.33 & 0.38 & 0.25 \\
\hline 1971 & -0.15 & -0.29 & -0.23 & -0.46 & -0.29 & 0.14 & -0.31 & -0.39 & -0.41 & $-0,27$ & $0.0 S$ & -0.01 & -0.24 & -0.46 \\
\hline 1972 & -0.37 & -0.32 & 0.22 & -0.28 & -0.19 & -0.31 & -0.01 & 0.36 & 0.48 & 0.13 & -0.10 & $-0 . . ; 1$ & -0.23 & 0.12 \\
\hline 1973 & -0.04 & 0.34 & 0.05 & 0.15 & 0.13 & 0.661 & 0.71 & 0.34 & 0.19 & 0.48 & 0.24 & 0.12 & 0.08 & 0.07 \\
\hline 1974 & -0.40 & 0.15 & 0.22 & 0.06 & 0.01 & 0.24 & -0.01 & 0.07 & -0.0 .3 & 0.07 & -0.14 & -0.45 &.-0.25 & -0.12 \\
\hline 1975 & -0.07 & 0.20 & 0.05 & -0.25 & -0.02 & 0.24 & -0.09 & $\cdot-(0.29$ & -0.09 & -0.06 & 0.04 & 0.04 & -0.10 & -0.26 \\
\hline 1976 & -0.47 & -0.56 & -0.15 & -0.15 & -0.33 & 0.08 & -0.11 & -0.15 & -0.44 & -0.16 & -0.25 & -0.60 & -0.43 & -0.10 \\
\hline 1977 & 0.04 & 0.40 & 0.42 & -0.08 & 0.20 & 0.27 & 0.67 & 0.45 & 0.20 & 0.40 & -0.11 & -0.15 & 0,09 & 0.05 \\
\hline 1978 & -0.06 & 0.21 & 0.06 & 0.01 & 0.06 & 0.08 & 0.42 & 0.36 & 0.21 & 0.27 & 0.27 & 0.12 & -0.29 & 0.10 \\
\hline 1979 & 0.06 & 0.31 & 0.20 & 0.33 & 0.23 & 0.39 & 0.75 & 0.41 & 0.32 & 0.47 & 0.31 & 0.04 & $-1) .28$ & $0.2 !$ \\
\hline 1980 & 0.36 & 0.71 & 0.58 & 0.19 & 0.46 & 0.54 & 0.70 & 0.69 & 0.42 & 0.59 & -0.01 & 0.12 & 0.16 & -0.22 \\
\hline 1981 & 0.02 & 0.39 & 0.51 & 0.11 & 0.26 & 0.61 & 0.40 & 0.47 & 0.32 & 0.45 & -0.35 & -0.53 & -0.41 & -0.24 \\
\hline 1982 & 0.22 & 0.22 & 0.26 & 0.31 & 0.25 & 0.69 & 0.11 & 0.43 & 0.23 & 0.37 & -0.23 & -0.37 & -0.04 & -0.07 \\
\hline 1983 & 0.15 & 0.67 & 0.25 & 0.28 & 0.34 & 0.47 & 1.10 & 0.63 & 0.31 & 0.63 & -0.09 & 0.52 & $-0,06$ & -0.20 \\
\hline 1984 & 0.13 & 0.73 & 0.05 & 0.43 & 0.34 & 0.23 & 0.50 & 0.05 & 0.22 & 0.25 & -0.99 & --0.92 & -0.28 & -0.60 \\
\hline 1985 & 0.16 & 0.30 & 0.661 & -0.12 & 0.25 & 0.37 & 0.44 & 0.39 & 0.16 & 0.34 & -1.02 & -0.59 & -0.81 & -1.41 \\
\hline 1986 & -0.16 & 0.45 & 0.27 & 0.07 & 0.16 & 0.51 & 0.18 & 0.24 & 0.15 & 0.27 & -1.41 & -0.52 & -0.23 & $-0,40$ \\
\hline 1987 & 0.25 & 0.95 & 0.85 & 0,37 & 0.61 & 0.72 & 0.67 & 0.77 & 0.52 & 0.67 & -0.57 & -0.35 & 0.16 & -0.30 \\
\hline 1988 & 0.18 & 0.37 & 0.23 & 0.54 & 0.33 & 0.64 & 0.69 & 0.58 & 0.40 & 0.58 & -0.26 & -0.12 & 0,35 & 0.66 \\
\hline 1989 & -0.18 & 0.00 & 0.02 & 0.04 & -0.03 & 0.28 & 0.12 & 0.32 & 0.35 & 0.27 & -0.75 & -0.66 & -0.39 & -0.89 \\
\hline $19 x$ & 0.13 & 0.35 & & & & 0.33 & 0.46 & & & & -0.49 & 0.10 & & \\
\hline
\end{tabular}

- Temperature anomalies (in relation to a 1958-1977 average) expressed in degrees Celsius.

†Northern Ilemisphere winter (1)ec-liab).

Note: Data for summer (Jun-Aug) 1989 through spring (Mar-May) 1900 are provisional. 
Annual and Seasonal Temperature Anoinalies*

Surface-1 (K) mb

$1(K()-50) \mathrm{mb}$

$1(00-30 \mathrm{mb}$

\begin{tabular}{|c|c|c|c|c|c|c|c|c|c|c|c|c|c|c|c|}
\hline Ann & Win & Spr & F'all & Sum & Ann & Win & Spr & Sum & Full & Ann & W/n & Spr & Sum & Fall & Ann \\
\hline-0.26 & 0.31 & $-0,11$ & 0.20 & 0.06 & 0.12 & & & & & & & & & & \\
\hline-0.17 & 0.07 & 0.28 & 0,32 & 0.01 & 0.17 & & & & & & & & & & \\
\hline 0.15 & 0.24 & 0,09 & 0.18 & 0.17 & 0.17 & & & & & & & & & & \\
\hline-0.09 & 0,07 & 0,29 & 0.01 & 0.11 & 0.12 & & & & & & & & & & \\
\hline$-0,14$ & -0.01 & -0.19 & 0.01 & 0.20 & 0.00 & & & & & & & & & & \\
\hline 0.29 & $-(1) ; 15$ & $-0,1.5$ & -0.01 & $-0,0.3$ & -0.09 & & & & & & & & & & \\
\hline 0.27 & 0.00 & -0.21 & -0.20 & -0.24 & $-0.16^{\prime}$ & 1.11 & 1,00 & 0.47 & 1.36 & 0.99 & 0.50 & 0.68 & 0,99 & 0.80 & 0.74 \\
\hline$-0,37$ & -0.54 & -0.46 & -0.27 & -0.12 & -0.35 & 0.77 & 0.71 & 0.42 & 1.36 & 0.82 & 0.42 & 0.14 & 0.34 & 1.38 & 0.57 \\
\hline 0.13 & 0.10 & 0.12 & -0.02 & -0.14 & 0.02 & $-0,64$ & -0.57 & -0.45 & $-0,06$ & -0.43 & -0.84 & -0.24 & -0.16 & 1.15 & -0.02 \\
\hline-0.01 & $-0,014$ & $-(1.09)$ & 0.00 & 0.04 & -0.02 & 0.56 & 0,48 & 0.42 & 0.27 & 0.43 & 0.54 & 0.57 & 0.04 & 0.36 & 0,38 \\
\hline-0.02 & 0.07 & $-(1.14$ & -0.26 & -0.07 & -0.10 & -0.50 & 0.19 & -0.14 & 0.00 & -0.11 & -0.24 & 0.38 & 0,08 & -0.07 & 0,04 \\
\hline 0.26 & 0.19 & 0.33 & 0.21 & 0.03 & 0.19 & 0.26 & -0.05 & -0.44 & -0.27 & -0.13 & $-0,07$ & 0,09 & 0.25 & 0.31 & 0.15 \\
\hline 0.17 & $-\left(0.0^{\prime}\right)$ & 0.19 & 0.17 & 0.12 & 0.10 & -0.13 & -0.02 & 0.72 & -0.50 & 0.02 & $-0,14$ & 0.25 & 0.75 & 0.71 & 0.39 \\
\hline-0.17 & 0.01 & -0.26 & -0.33 & $-0,42$ & -0.25 & 0.47 & 0.05 & -0.58 & -0.14 & -0.05 & 0.71 & -0.30 & -0.82 & -0.58 & $-0,25$ \\
\hline-0.19 & -0.33 & -0.28 & 0.19 & 0.19 & -0.06 & 0.04 & -0.23 & 0.14 & -0.32 & $-0,09$ & 0.36 & 0.21 & -0.13 & -0.19 & 0.06 \\
\hline 0.13 & 0.49 & 0.53 & 0.30 & 0.18 & 0.38 & -0.33 & 0.14 & -0.50 & -0.41 & -0.28 & -0.20 & -0.24 & -0.79 & -0.39 & $-0,40$ \\
\hline-0.24 & 0.00 & $-0,06$ & 0.01 & -0.02 & -0.02 & -0.22 & -0.34 & -0.36 & -0.44 & $-0,34$ & -0.36 & -0.41 & -0.32 & -0.86 & -0.49 \\
\hline-0.07 & 0.05 & 0.02 & -0.17 & -0.11 & -0.05 & -0.15 & -0.19 & 0.36 & -0.81 & -0.20 & -0.35 & -0.25 & -0.43 & $-0,90$ & $-0,48$ \\
\hline-0.35 & -0.10 & -0.29 & -0.39 & -0.32 & -0.28 & 0.14 & -0.02 & -0.30 & 0.61 & 0.11 & -0.31 & -0.05 & 0.39 & 0.03 & 0.02 \\
\hline$-0,0$ & 0.14 & 0.43 & 0.37 & 0.12 & 0.27 & -1.21 & -0.37 & $-0,41$ & 0.49 & $-0,38$ & -1.52 & -0.59 & -0.62 & 0.19 & -0.64 \\
\hline 0.0 & 0.10 & 0.31 & 0.14 & 0.15 & 0.18 & -0.12 & 0.65 & 0.34 & -1.01 & -0.04 & -0.53 & -0.02 & 0.04 & -0.69 & -0.30 \\
\hline 0.07 & 0.29 & 0.52 & 0.22 & 0.31 & 0.34 & -0.04 & 0.18 & -0.15 & -0.73 & -0.19 & -0.51 & 0.36 & -0.29 & $-0,84$ & -0.32 \\
\hline 0.01 & 0.47 & 0,67 & 0.57 & 0.27 & 0.50 & -0.06 & $-0,56$ & -0.43 & -0.65 & -0.43 & 0.12 & -1.03 & -1.00 & -0.32 & -0.56 \\
\hline-0.38 & 0.29 & 0.17 & 0.31 & 0.16 & 0.23 & -0.01 & 0.12 & -0.84 & 0.09 & -0.16 & 0,09 & -0.06 & -0.46 & -0.09 & -0.13 \\
\hline-0.18 & 0.39 & 0.02 & 0.32 & 0.17 & 0.23 & -0.16 & 0.02 & -0.40 & 0,48 & -0.02 & -0.71 & -0.28 & -0.77 & 0.11 & -0.41 \\
\hline 0.04 & 0.30 & 0.93 & 0.43 & 0.22 & 0.47 & 1.22 & 0.03 & -0.29 & 0.18 & 0.29 & 0.82 & -0.08 & -0.11 & 0.14 & 0.19 \\
\hline-0.70 & -0.06 & 0.22 & $-0,03$ & 0,07 & 0.05 & 0.33 & -0.76 & -0.17 & -0.91 & -0.38 & -0.42 & -0.62 & -10.29 & $-0,98$ & -0.58 \\
\hline-0.96 & 0.07 & 0.19 & 0.14 & -0.24 & 0.04 & -1.54 & -1.24 & -2.23 & -1.97 & -1.75 & -1.23 & -0.92 & -1.85 & -1.71 & -1.43 \\
\hline-0.64 & -0.03 & 0.07 & 0.17 & 0.02 & 0.06 & -1.59 & -1.20 & -0.94 & -1.92 & -1.41 & -1.27 & -0.86 & -0.71 & -1.37 & -1.05 \\
\hline-0.27 & 0.36 & 0.48 & 0.59 & 0.34 & 0.44 & -1.40 & -1.28 & -1.58 & -2.92 & -1.80 & -1.15 & -0.85 & -1.77 & -2.97 & -1.69 \\
\hline 0.16 & 0,36 & 0.46 & 0,46 & 0.48 & 0.44 & -1.42 & -2.18 & -1.48 & $-1,43$ & -1.63 & $-1,36$ & -1.53 & $-1,24$ & $-0,84$ & -1.24 \\
\hline \multirow[t]{2}{*}{-0.67} & $-0,03$ & -0.07 & 0.09 & 0.02 & 0.00 & -1.44 & -1.56 & -1.24 & -2.05 & -1.57 & -1.22 & $-1,12$ & -1.11 & -1.98 & -1.36 \\
\hline & 0.12 & 0.36 & & & & -1.79 & -1.14 & & & & -1.15 & -0.89 & & & \\
\hline
\end{tabular}




\section{National}

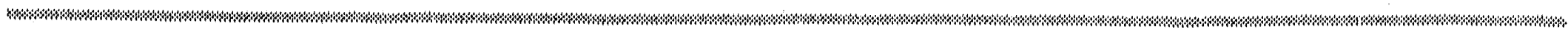

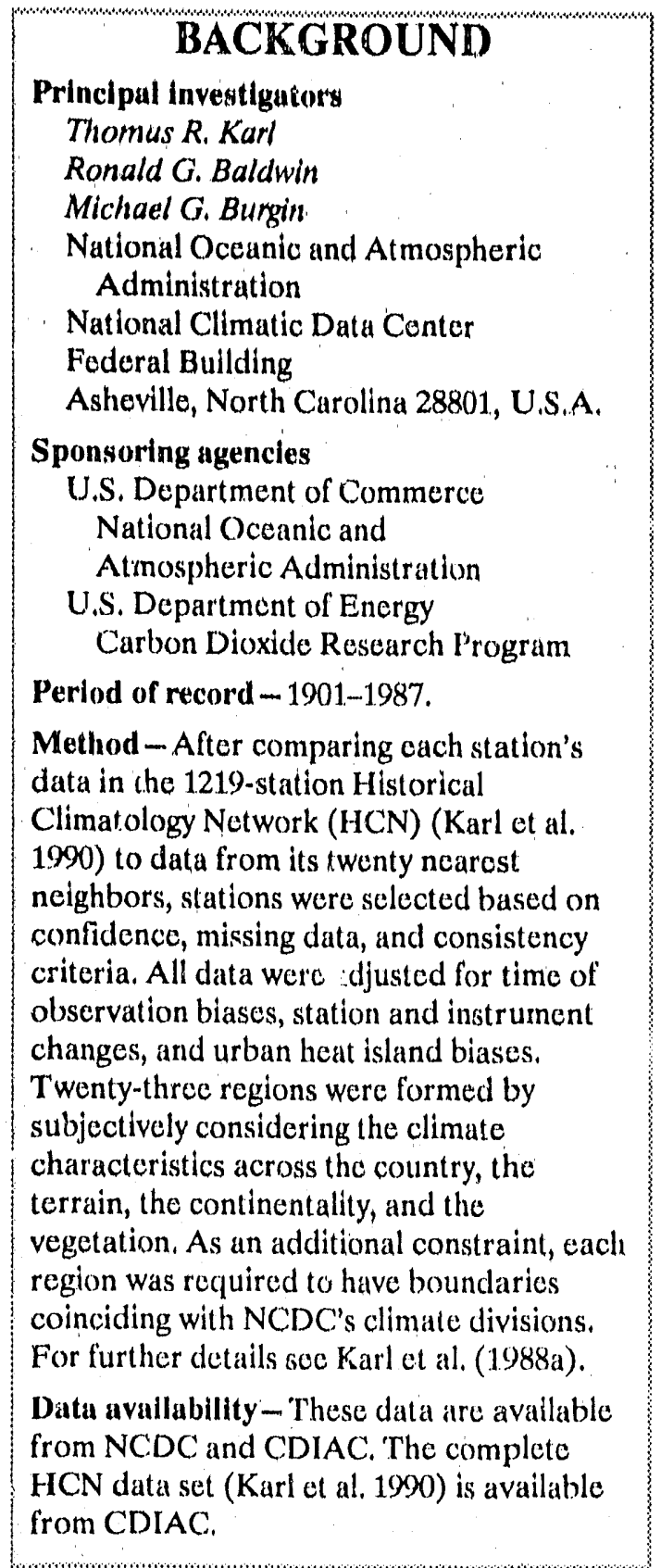

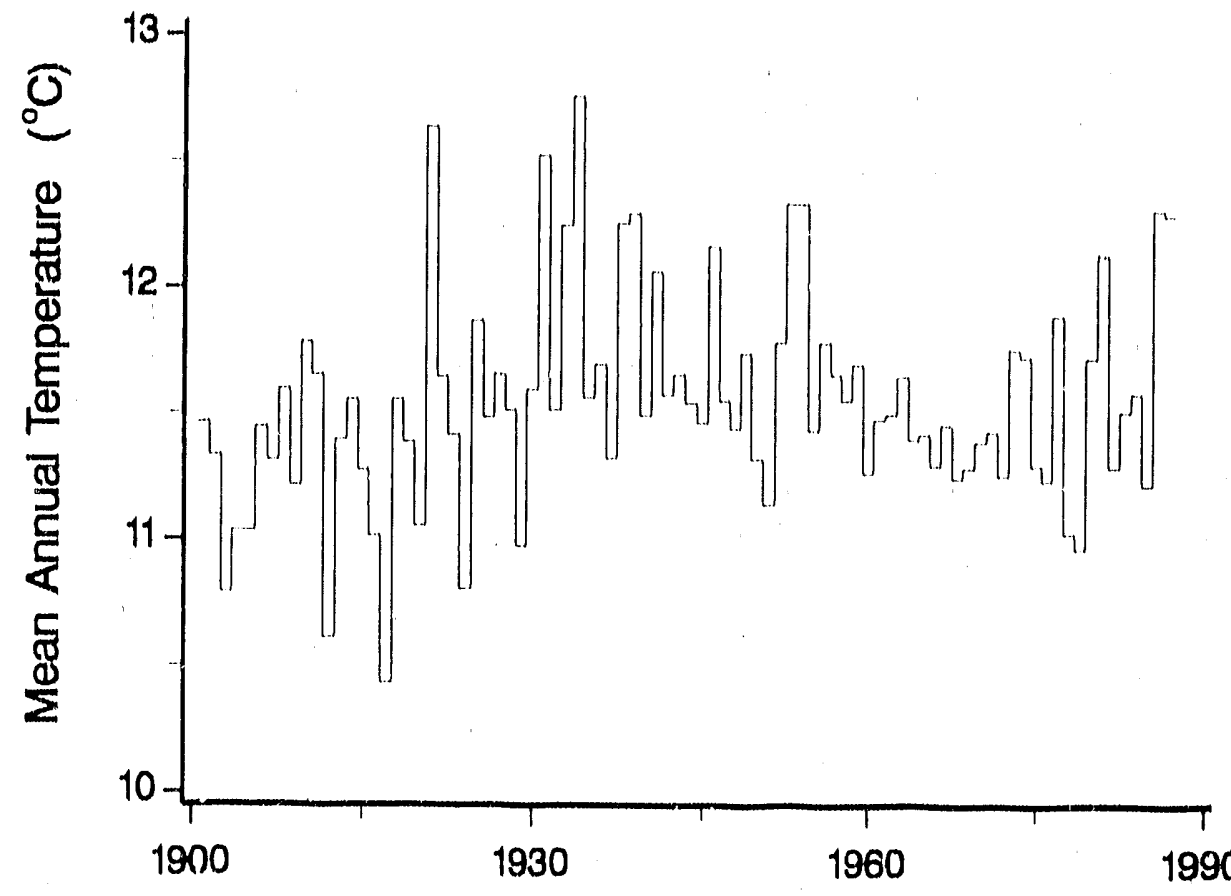

Annual calendar year average temperature.

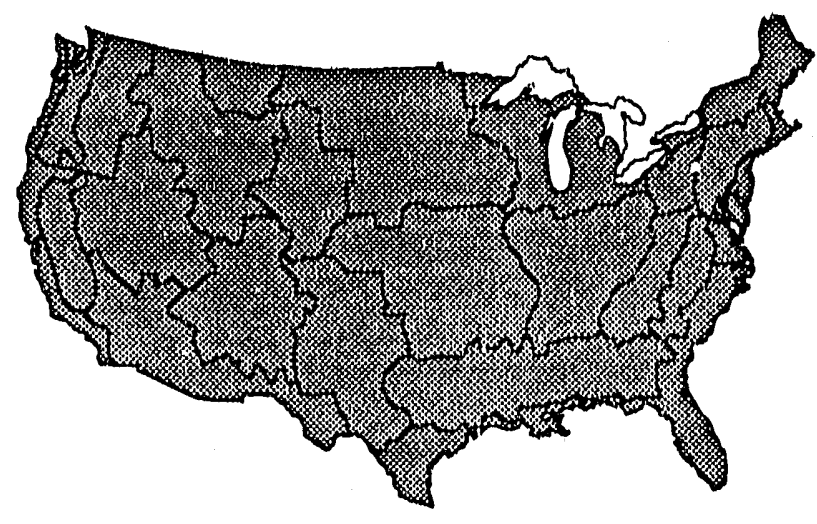

Nutional 


\section{U.S. National Temperatures}

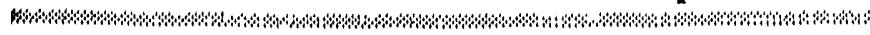

\section{TRENDS}

On the basis of regional seasonal temperatures (i.e., maximum, minimum, avorage, and diurnal range) for the United States, Karl et al. (1988a) concluded that the climate has changed during the recent century but that the changes for the mast part have not been monotonic. Instead, the changes are somewhat unsteady and sometimes occur over a relatively short period of time. If there are any monotonic trends in the data, it may be the decrease in the diurnal temperature range. 


\section{National}

w wh के

\begin{tabular}{|c|c|c|c|c|c|c|c|c|}
\hline Year & Ann" & W/n & Spr & Sum & Nall & Annt & Your & Antr \\
\hline 1901 & 11.46 & 0.55 & 10.59 & 22.92 & 12.36 & 14.61 & 1945 & 11.46 \\
\hline 1902 & 11.33 & $-0,21$ & 11,30 & 21.75 & 12,46 & 11.35 & 1946 & 12.16 \\
\hline 1903 & 10.79 & -0.57 & 10.94 & 21.23 & 11,70 & 10.82 & 1947 & 11.55 \\
\hline 1904 & 11.0 .3 & -0.82 & 10.74 & 21.31 & 12.56 & 10.95 & 1948 & 11.04 \\
\hline 1905 & 11.03 & -1.37 & 11,39 & 21.97 & 12.25 & 11.06 & 1940 & 11.74 \\
\hline 1906 & 11,44 & 0.88 & 10,27 & 21.77 & 12.15 & 11.27 & 1950 & 11.32 \\
\hline $190 \%$ & 11,31 & 1.51 & 10,43 & 21.32 & 12.07 & 11.33 & 1951 & 11.14 \\
\hline 1908 & 11.59 & 1.20 & 11.56 & 21.62 & 12.21 & 11.65 & 1952 & 11.78 \\
\hline 190, & 11.21 & 1.35 & 9.93 & 22.31 & $12.6 \% i$ & 11.57 & 1953 & 12.33 \\
\hline 1910 & 11.78 & $-1,60$ & 12.74 & 22.10 & 12.75 & 11.50 & 1954 & 12.33 \\
\hline 1911 & 11,65 & 1.02 & 11.53 & 22.3 .5 & $11.60)$ & $11,6.3$ & 1955 & 11,43 \\
\hline 1912 & 10.61 & -1.09 & $10 .(12$ & 21.40 & 11.96 & 10.57 & 1956 & 11.78 \\
\hline 1913 & 11.39 & 0.04 & 10.62 & 22.42 & 12.41 & 11.37 & 1957 & 11.05 \\
\hline 1914 & 11.55 & 0,83 & 11.17 & 22.51 & 12.91 & 11.85 & 1958 & 11.55 \\
\hline 1915 & 11.27 & $-0,39$ & 10,47 & 20,98 & 12,88 & 10.98 & 1059 & 11.69 \\
\hline 1916 & 11,01 & 0.30 & 10,89 & $21,(x)$ & 11.59 & 11.19 & 1960 & 11.26 \\
\hline 1917 & 10,43 & $-1,07$ & 9.10 & 21.85 & 11.79 & 10,42 & $19(11$ & 11.47 \\
\hline 1918 & 11.55 & -1.17 & 11.66 & 22.666 & 12.06 & 11.30 & 1962 & 11.49 \\
\hline 1919 & 11.38 & 1,14 & 10,99 & 22.51 & $12 .(X)$ & 11.60 & 196.3 & $11,(44$ \\
\hline 1920 & 11.05 & -0.28 & 9.88 & 21.58 & 12.26 & 10.86 & $15 \times 4$ & 11.39 \\
\hline 1921 & $12,6,3$ & 2.04 & 12,09 & 22.83 & 13.15 & 12.52 & 1965 & 11.41 \\
\hline 1922 & 11,64 & 0.22 & 10,93 & 22.58 & 1.3 .12 & 11.71 & $19(6)$ & 11.29 \\
\hline 1923 & 11.41 & 0.88 & 10.14 & 22.02 & 12.086 & 11.28 & 1967 & 11,45 \\
\hline 1924 & 10.80 & 0.83 & 9,69 & 21.98 & 12.32 & 11.21 & 19018 & 11.24 \\
\hline 1925 & 11,86 & 0.36 & 12.21 & 22.49 & 11.57 & 11.66 & $1 \%(6)$ & 11.28 \\
\hline 1926 & 11,48 & 1.16 & 10,61 & 22.14 & 12.17 & 11.52 & 1970 & 11.38 \\
\hline 1927 & $11,6.5$ & 1.39 & 11.12 & 21.28 & 13,30 & {$[1.71$} & 1971 & 11.42 \\
\hline 1928 & 11,51 & 0.27 & 10,97 & $\therefore 1.70$ & 12.28 & 11.31 & 1972 & 11.25 \\
\hline 1929 & 10,97 & -1.24 & 11.26 & 22.14 & 11.52 & 10,92 & 1973 & 11.75 \\
\hline 1930 & 11.59 & 0.96 & 11,26 & 22.64 & 12.03 & 11.72 & 1974 & 11.72 \\
\hline 1931 & 12.52 & 1.63 & 10.58 & 23.12 & 13,95 & 12.32 & 1975 & 11.29 \\
\hline 1932 & 11,51 & 2.06 & 10,45 & 22.65 & 11.175 & 11.78 & 1976 & 11.23 \\
\hline 19.33 & 12.24 & 0.33 & 10,91 & 23.14 & 13.36 & 11.93 & 1977 & 11.88 \\
\hline 1934 & 12.75 & 2.22 & 12.59 & 23.61 & 1.3 .20 & 12.93 & 1978 & 11.02 \\
\hline 193.35 & 11.36 & 1.30 & 10.70 & 22.61 & $11 .(x)$ & $11,0.5$ & 1979 & 10.96 \\
\hline 1936 & 11,60 & -1.78 & 11.87 & 23.72 & 12.22 & 11.51 & 1980 & 11.71 \\
\hline 1937 & 11.32 & $-0,26$ & 10,66 & 22,98 & 12,30 & 11.42 & 1981 & 12.12 \\
\hline 1938 & 12.25 & 1,43 & 11.78 & 22.64 & 12.85 & 12.18 & 1982 & 11.28 \\
\hline 1939 & 12.29 & 0,96 & 11.74 & 22.68 & 13.15 & 12.13 & 198.3 & 11.50 \\
\hline 1940 & 11.49 & 0.34 & 10.89 & 22.59 & 12,42 & 11.56 & 1084 & $11.5 \%$ \\
\hline 1941 & 12.06 & 1,01 & 11.28 & 22.3 .3 & 12.96 & 12.04 & 1085 & 11,21 \\
\hline 1942 & 11.57 & 0.76 & 11.29 & 22.30 & 12.58 & 11.73 & 1986 & 12.30 \\
\hline 194,3 & 11.65 & 1,08 & 10,78 & 22.87 & 11.98 & 11,68 & 1987 & 12,28 \\
\hline 1944 & 11.54 & 1.12 & 10,41 & 22.21 & 12.75 & 11.02 & & \\
\hline
\end{tabular}

"Calendar year mean (Jan-Dec).

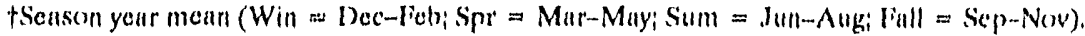

TRENDS '90) 


\section{Average Temperature $\left({ }^{\circ} \mathrm{C}\right), 1901-1987$}

\begin{tabular}{|c|c|c|c|c|}
\hline W/in & Spr & Sun & rull & Annt \\
\hline 0.53 & 11.30 & 21.69 & 12.60 & 11.53 \\
\hline 0.48 & 12.41 & 22.10 & 12.32 & 11.83 \\
\hline 1.21 & 10.40 & 22,21 & 12.98 & 11,72 \\
\hline$-(1,12$ & 11.01 & 22.31 & 12.52 & 11.43 \\
\hline$-(1.13$ & 11.41 & 22.62 & 12.92 & 11.71 \\
\hline 1.40 & 10,05 & 2.1 .42 & 12.613 & 11.38 \\
\hline 0.88 & 10.38 & 21,90 & 11.6 .3 & 11.19 \\
\hline 1.21 & $\mathrm{I}(1.52$ & 22,98 & 12.07 & 11.70 \\
\hline 2.28 & 10.88 & 22.71 & 13,42 & 12.32 \\
\hline 2.32 & 10.95 & 22.78 & 1.3 .24 & 12.32 \\
\hline 0,16 & 11.41 & 22,34 & 12.17 & 11.53 \\
\hline 0.32 & 10.88 & 22.46 & 12.57 & 11.56 \\
\hline $1 .(x)$ & 10.82 & 22.43 & 11.58 & 11,68 \\
\hline 1.27 & 10,62 & 22.2 .3 & 12.98 & 11.77 \\
\hline 0.21 & 11.32 & 2.2 .81 & 11.71 & 11.51 \\
\hline 0.49 & 101.10 & 22.42 & 1.3 .0 .5 & 11.51 \\
\hline 0.71 & 10.6 .5 & 22.42 & 11.95 & $11,4.3$ \\
\hline-0.11 & 10.91 & 21.88 & 12.91 & 11.40 \\
\hline-0.43 & 11.74 & 22.28 & 14.09 & 11.91 \\
\hline-0.57 & 10.83 & 22.09 & 12.25 & 11.15 \\
\hline 0.55 & 10,24 & 21.61 & 12.60 & 11.25 \\
\hline 0.0 .5 & 11.08 & 22,24 & 12.37 & 11.44 \\
\hline 0.9 .3 & 11.05 & 21.7 .3 & 12.11 & 11.45 \\
\hline 0.22 & 11.00 & 21.90 & 12.24 & 11.36 \\
\hline$-(1.21$ & 10.60 & 22.24 & 11,200 & 11.14 \\
\hline 0,132 & 10.50 & 22.60 & $12 .(x)$ & 11.36 \\
\hline 0.54 & 10.21 & 22.26 & 12.56 & $(1,34)$ \\
\hline$(0.81$ & 11.51 & 21.95 & 11.54 & $11,4,5$ \\
\hline$-0,0.5$ & 11.012 & 22,44 & 12.98 & $11 .(x)$ \\
\hline 1.012 & 11.77 & 22.07 & 12.01 & 11.72 \\
\hline 0.84 & 9.82 & $22 .(x)$ & 12.35 & $11 . .17$ \\
\hline 1.72 & 11.1 .5 & 21.82 & 10.84 & 11.18 \\
\hline-0.8 .3 & 12.29 & 22.79 & 12.76 & 11.76 \\
\hline-1.29 & $\{0,0) \mid$ & 22.12 & 12.64 & 11.16 \\
\hline-2.47 & 10.86 & 21.92 & 12.48 & $10,(1)$ \\
\hline 1.06 & 10.00 & $22 .(x)$ & 12.40 & 11.75 \\
\hline 1.77 & 11.81 & 22.0 .5 & 12.60 & 12,20 \\
\hline-0.25 & $10.1 \% 6$ & 21.87 & 12.06 & 11.16 \\
\hline 2.11 & 10.02 & 22.70 & 12.97 & $11,1) 8$ \\
\hline$-(10.40$ & 101,41 & 22.47 & 12.1 .4 & 11.1 .1 \\
\hline$-0,34$ & 12.48 & 22.14 & 11.84 & 11.5 .3 \\
\hline 0.76 & 12.40 & 22.72 & 12.21 & 12.013 \\
\hline 1.62 & 12.24 & $22 .(6)$ & 12.58 & 12.27 \\
\hline
\end{tabular}

\section{REFERENCES}

Karl, T.R, G, Kukla, and J. Gavin, 1984. Docroasing diurnal temperaturo range in the United States and Canada from 1941. through 1980. Journal of Climate and Applied Meteorology 23:1489-15(24,

Karl, T.R, G. Kukla, and J, Gavin, 1986. Relationship between decreased temperature range and precipitation trends in the United States and Canada, 1941-1980. Jotwmal of Climate and Applied Meteorologry 26:1878-86.

Karl, T.R., C.N. Williams, Jr., P.J. Young, and W.M. Wendland, 1986. A model to estimate the time of observation bias associaled with monthly moan maximum, minimum, and mean temporatures for the United States. Jomrinal of Climate and Applied Meteorology 25:145-60).

Karl, T.R., R.G. Baldwin, and M.G. Burgin. 1988a. Time series of regional seasonal averages of maximum, minimum, and average temperature, and diurnal temperature range across the United States: 1901-1984. Historical Climatology Sorios 4-5. National Climatic Data Center, National Occanic \& Atmospheric Administration, National Environmental Satellite, Data, and Information Service, Asheville, North Carolina.

Karl, T.R., H.F. Diaz, and Ci, Kukla, 1988 b. Urbanization: its detection and effect in the United States climate record, Joumal of Climare 1:10y9-1123.

Karl, T.R., C.N. Williams, Jr., and F.T. Quinlan, 199(). United States Historical Climatology' (HCN) serial temperature and precipitation data. NDP-()19/R1. Carbon Dioxide Information Analysis Center, Oak Ridge National Laboratory, ()ak Ridge, Tennessec. 


\section{North Pacific Coast}

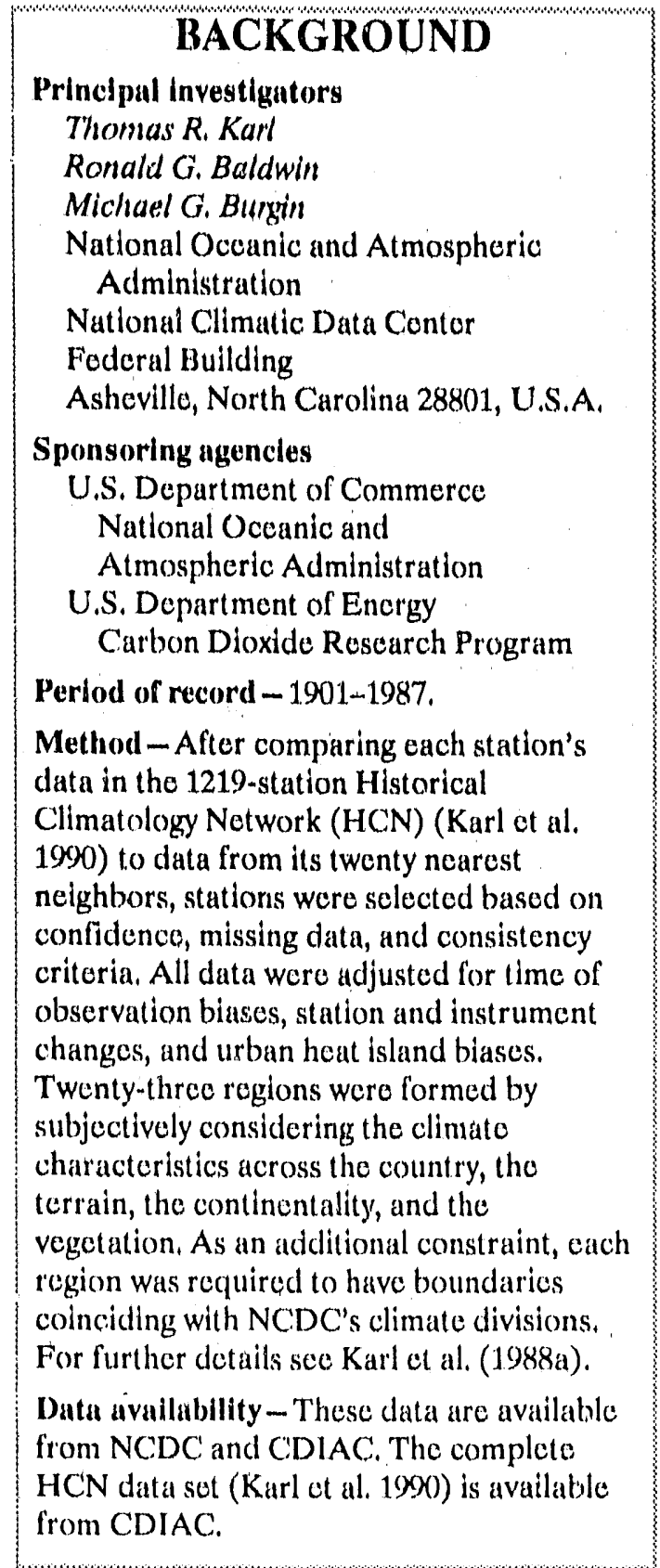

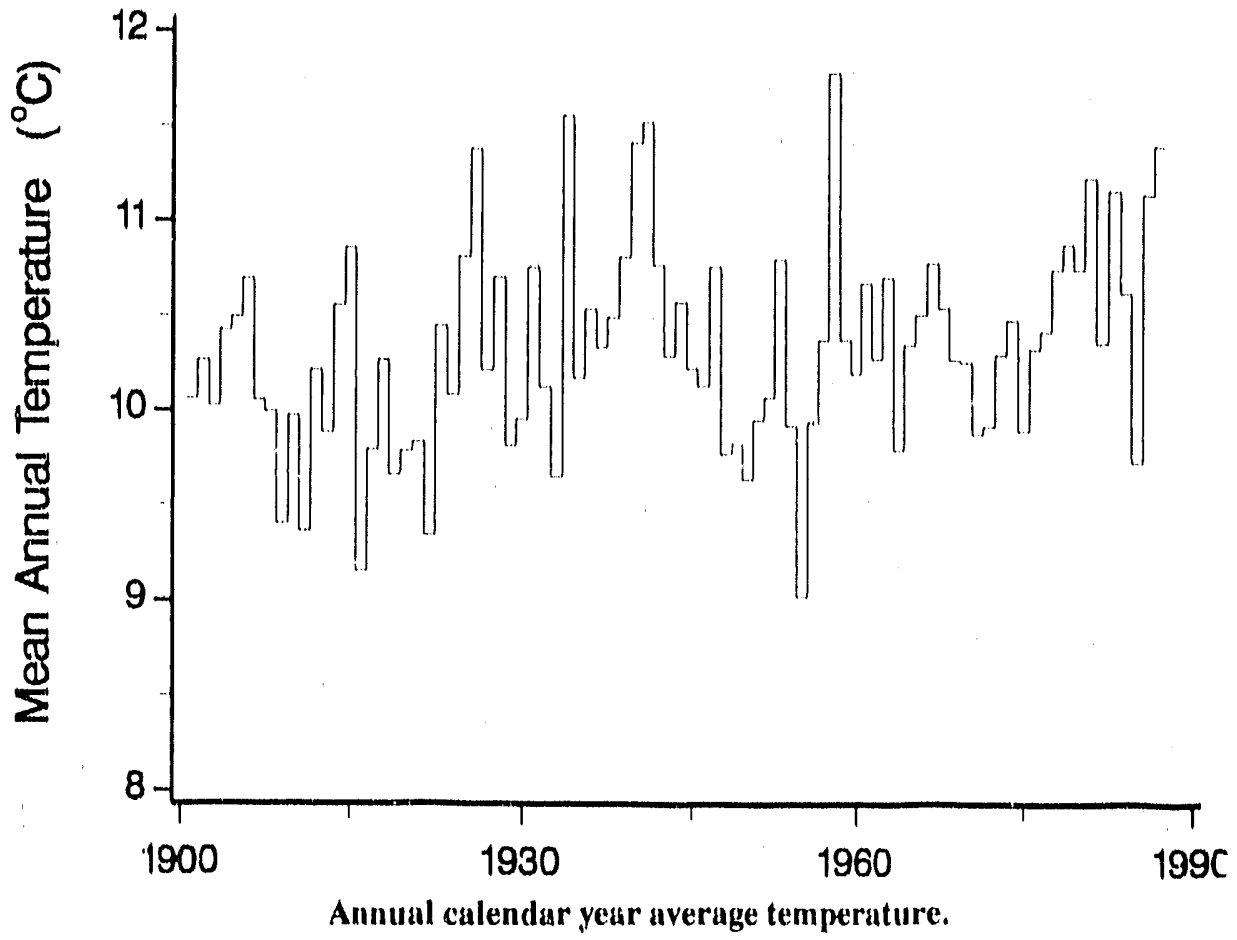




\section{U.S. Regional Temperatures}

\section{TRENDS}

On the basis of regional seasonal temperatures (i.e., maximum, minimum, average, and diurnal range) for the United States, Karl et al. (1988a) concluded that the climate has changed over the recent century but that the changes for the most part have not been monotonic. Instead, the changes are somewhat unsteady and sometimes occur over a relatively short period of time.

Karl et al. (1988a) also found a considerable amount of detailed information for each regional time series but reported that their salient features often could be summarized in time series plots for three aggregated regions: West, Central, and East. For the aggregated West region, which includes this subregion, Karl et al. (1988a) reported that, since the relatively cool period during the beginning decades of the century, annual mean temperatures have remained relatively constant with the exception of a number of multiyear climate fluctuations. 


\begin{tabular}{|c|c|c|c|c|c|c|c|c|}
\hline Year & Ann* & Win & Spr & Sum & Fall & Annt & Year & Ann \\
\hline 1901 & 10.06 & 5.67 & 8.79 & 14.51 & 11.74 & 10.18 & 1945 & 10.22 \\
\hline 1902 & 10.26 & 5.76 & 9.13 & 15.36 & 10.88 & 10.28 & 1946 & 10.13 \\
\hline 1903 & 10.02 & 5.18 & 8.33 & 15.40 & 10.95 & 9.96 & 1947 & 10.76 \\
\hline 1904 & 10.42 & 5.17 & 9.12 & 15.12 & 12.19 & 10.40 & 1948 & 9.77 \\
\hline 1905 & 10.49 & 5.89 & 10.46 & 15.49 & 10.41 & 10.56 & 1949 & 9.83 \\
\hline 1906 & 10.69 & 6.07 & 9.77 & 15.87 & 10.99 & 10.67 & 1950 & 9.64 \\
\hline 1907 & 10.05 & 4.49 & 9.13 & 15.05 & 11.47 & 10.03 & 1951 & 9.95 \\
\hline 1908 & 9.99 & 5.46 & 8.96 & 15.25 & 10.88 & 10.14 & $19 \$ 2$ & 10.07 \\
\hline 1909 & 9.40 & 3.90 & 8.54 & 14.76 & 10.80 & 9.50 & 1953 & 10.80 \\
\hline 1910 & 9.97 & 3.47 & 10.09 & 14.52 & 10.73 & 9.70 & 1954 & 9.92 \\
\hline 1911 & 9.36 & 4.41 & 8.38 & 14.92 & 10.11 & 9.46 & 1955 & 9.02 \\
\hline 1912 & 10.21 & 5.75 & 9.20 & 15.40 & 10.41 & 10.19 & 1956 & 9.94 \\
\hline 1913 & 9.88 & 4.14 & 8.72 & 15.80 & 10,77 & 9.86 & 1957 & 10.37 \\
\hline 1914 & 10.55 & 6.03 & 10.53 & 15.17 & 11.18 & 10.73 & 1458 & 11.78 \\
\hline 1915 & 10.85 & 5.02 & 10.85 & 16.27 & 10.68 & 10.70 & 1959 & 10.37 \\
\hline 1916 & 9.15 & 3.54 & 9.02 & 15.18 & 9.67 & 9.35 & 1960 & 10.19 \\
\hline 1917 & 9.79 & 3.32 & 7.97 & 15.03 & 11.60 & 9.48 & 1961 & 10.67 \\
\hline 1918 & 10.26 & 5.83 & 8.79 & 15.50 & 11.44 & 10.39 & 1962 & 10.27 \\
\hline 1919 & 9.66 & 5.15 & 9.16 & 14.63 & 10.13 & 9.77 & 1963 & 10.70 \\
\hline 1920 & 9.78 & 4.50 & 7.96 & 15.33 & 10.60 & 9.60 & 1964 & 9.79 \\
\hline 1921 & 9.83 & 5.56 & 8.74 & 15.02 & 10.73 & 10.01 & 1965 & 10.34 \\
\hline 1922 & 9.34 & 3.25 & 7.99 & 15.37 & 10.85 & 9.36 & 1966 & 10.50 \\
\hline 1923 & 10.44 & 3.88 & 9.32 & 16.14 & 11.84 & 10.29 & 1967 & 10.77 \\
\hline 1924 & 10.08 & 6.07 & 9.44 & 15.00 & 10.67 & 10.29 & 1968 & 10.53 \\
\hline 1925 & 10.81 & 5.32 & 9.92 & 15.61 & 10.89 & 10.44 & 1969 & 10.26 \\
\hline 1926 & 11.37 & 6.88 & 11.38 & 16.22 & 11.71 & 11.55 & 1970 & 10.25 \\
\hline 1927 & 10.21 & 5.46 & 8.69 & 16.06 & 11.31 & 10.38 & 1971 & 9.87 \\
\hline 1928 & 10.70 & 5.19 & 10.40 & 15.81 & 10.84 & 10.56 & 1972 & 9.91 \\
\hline 1929 & 9.81 & 3.18 & 8.80 & 15.74 & 11.21 & 9.73 & 1973 & 10.29 \\
\hline 1930 & 9.95 & 4.12 & 9.67 & 15.43 & 10.61 & 9.96 & 1974 & 10.47 \\
\hline 1931 & 10.75 & 6.52 & 10.59 & 15.77 & 10.40 & 10.82 & 1975 & 9.89 \\
\hline 1932 & 10.12 & 4.49 & 9.71 & 15.22 & 11.62 & 10.26 & 1976 & 10.32 \\
\hline 1933 & 9.65 & 3.41 & 8.49 & 15.01 & 10.65 & 9.39 & 1977 & 10.41 \\
\hline 1934 & 11.55 & 7.26 & 11.65 & 15.57 & 11.90 & 11.60 & 1978 & 10.74 \\
\hline 1935 & 10.17 & 5.91 & 8.66 & 15.56 & 10.37 & 10.12 & 1979 & 10.87 \\
\hline 1936 & 10.53 & 4.91 & 9.83 & 16.30 & 11.23 & 10.57 & 1980 & 10.74 \\
\hline 1937 & 10.33 & 3.37 & 9.75 & 15.86 & 12.20 & 10.29 & 1981 & 11.22 \\
\hline 1938 & 10.49 & 6.00 & 9.72 & 15.37 & 11.15 & 10.56 & 1982 & 10.35 \\
\hline 1939 & 10.81 & 5.23 & 9.88 & 15.52 & 11.80 & 10.61 & 1983 & 11.15 \\
\hline 1940 & 11.41 & 7.25 & 11.10 & 16.10 & 11.63 & 11.52 & 1984 & 10.61 \\
\hline 1941 & 11.52 & 7.16 & 11.26 & 16.42 & 11.56 & 11.60 & 1985 & 9.72 \\
\hline 1942 & 10.77 & 5.57 & 9.76 & 16.50 & 11.16 & 10.75 & 1986 & 11.13 \\
\hline 1943 & 10.29 & 5.06 & 9.43 & 15.07 & 11.85 & 10.35 & 1987 & 11.39 \\
\hline 1944 & 10.57 & 5.57 & 9.34 & 15.40 & 12.10 & 10.60 & & \\
\hline
\end{tabular}

* Calendar year mean (Jan-Dec).

†Season year mean (Win = Dec-Feb; Spr = Mar-May; Sum = Jun-Aug; Fall = Sep-Nov).

TRENDS '90 


\section{Average Temperature $\left({ }^{\circ} \mathrm{C}\right), 1901-1987$}

\begin{tabular}{rrrrr} 
Win & Spr & Sum & Fall & Ann† \\
\hline 5.80 & 9.17 & 15.28 & 10.48 & 10.18 \\
5.55 & 9.60 & 15.57 & 9.94 & 10.16 \\
4.92 & 10.89 & 15.82 & 11.07 & 10.67 \\
5.07 & 8.73 & 15.87 & 10.47 & 10.04 \\
2.24 & 10.01 & 15.02 & 11.58 & 9.71 \\
2.47 & 8.43 & 15.69 & 10.75 & 9.34 \\
5.80 & 8.85 & 15.54 & 11.03 & 10.30 \\
4.11 & 9.09 & 14.97 & 11.33 & 9.88 \\
6.49 & 9.32 & 15.31 & 11.93 & 10.76 \\
5.34 & 8.64 & 14.34 & 11.63 & 9.98 \\
4.83 & 7.39 & 14.47 & 9.80 & 9.12 \\
4.12 & 9.56 & 15.47 & 10.39 & 9.88 \\
3.71 & 10.18 & 15.52 & 11.56 & 10.24 \\
7.56 & 10.35 & 17.57 & 11.40 & 11.72 \\
6.11 & 9.61 & 15.72 & 10.76 & 10.55 \\
5.12 & 9.35 & 15.44 & 10.85 & 10.19 \\
6.43 & 9.63 & 16.75 & 10.01 & 10.71 \\
5.16 & 8.86 & 14.92 & 11.63 & 10.14 \\
5.91 & 9.49 & 15.36 & 12.16 & 10.73 \\
5.84 & 8.50 & 15.14 & 10.51 & 10.00 \\
4.60 & 9.17 & 15.63 & 11.63 & 10.26 \\
5.18 & 9.44 & 15.22 & 11.39 & 10.31 \\
6.39 & 8.52 & 16.64 & 12.21 & 10.94 \\
5.88 & 9.87 & 15.76 & 11.14 & 10.66 \\
2.95 & 9.93 & 15.92 & 11.11 & 9.98 \\
6.51 & 9.20 & 15.65 & 10.40 & 10.44 \\
4.87 & 8.78 & 15.63 & 10.52 & 9.95 \\
3.96 & 9.56 & 15.94 & 10.22 & 9.92 \\
4.70 & 9.66 & 15.06 & 10.58 & 10.00 \\
5.59 & 9.13 & 15.48 & 11.79 & 10.50 \\
5.32 & 8.50 & 15.11 & 10.95 & 9.97 \\
5.57 & 8.84 & 15.02 & 11.58 & 10.25 \\
6.12 & 9.26 & 15.98 & 10.48 & 10.46 \\
6.38 & 10.23 & 16.59 & 10.61 & 10.95 \\
3.47 & 10.50 & 16.19 & 11.96 & 10.52 \\
5.86 & 10.17 & 15.28 & 11.76 & 10.78 \\
7.04 & 10.47 & 16.16 & 11.43 & 11.29 \\
5.26 & 9.21 & 16.03 & 11.08 & 10.40 \\
6.87 & 10.91 & 16.27 & 11.31 & 11.36 \\
5.40 & 10.22 & 15.98 & 10.82 & 10.60 \\
3.77 & 9.51 & 16.51 & 8.99 & 9.69 \\
5.69 & 10.29 & 16.33 & 11.35 & 10.92 \\
6.09 & 11.10 & 16.20 & 12.54 & 11.48
\end{tabular}

\section{REFERENCES}

Karl, T.R., G. Kukla, and J. Gavin. 1984. Decreasing diurnal temperature range in the United States and Canada from 1941 through 1980. Joumal of Climate and Applied Meteorology 23:1489-1504.

Karl, T.R., G. Kukla, and J. Gavin. 1986. Relationship between decreased temperature range and precipitation trends in the United States and Canada, 1941-1980. Joumal of Climate and Applied. Meteorology 26:1878-86.

Karl, T.R., C.N. Williams, Jr., P.J. Young, and W.M. Wendlan'. 1986. A model to estimate the time of ubservation bias associated with monthly mean maximum, minimum, and mean temperatures for the United States. Joumal of Climate and Applied Meteorology 25:145-60.

Karl, T.R., R.G. Baldwin, and M.G. Burgin. 1988a. Time series of regional seasonal averages of maximum, minimum, and average temperature, and diumal temperature range across the United States: 1901-1984. Historical Climatology Series 4-5. National Climatic Data Center, National Oceanic \& Atmospheric Administration, National Environmental Satellite, Data, and Information Service, Asheville, North Carolina.

Karl, T.R., H.F. Diaz, and G. Kukla. 1988b. Urbanization: its detection and effect in the United States climate record. Jotumal of Climate 1:1099-1123.

Karl, T.R., C.N. Williams, Jr., and F.T. Quinlan. 1990. United States Historical Climatology $(H C N)$ serial temperature and precipitation data. NDP-019/R1. Carbon Dioxide Information Analysis Center, Oak Ridge National Laboratory, Oak Ridge, Tennessee. 


\section{South Pacific Coast}

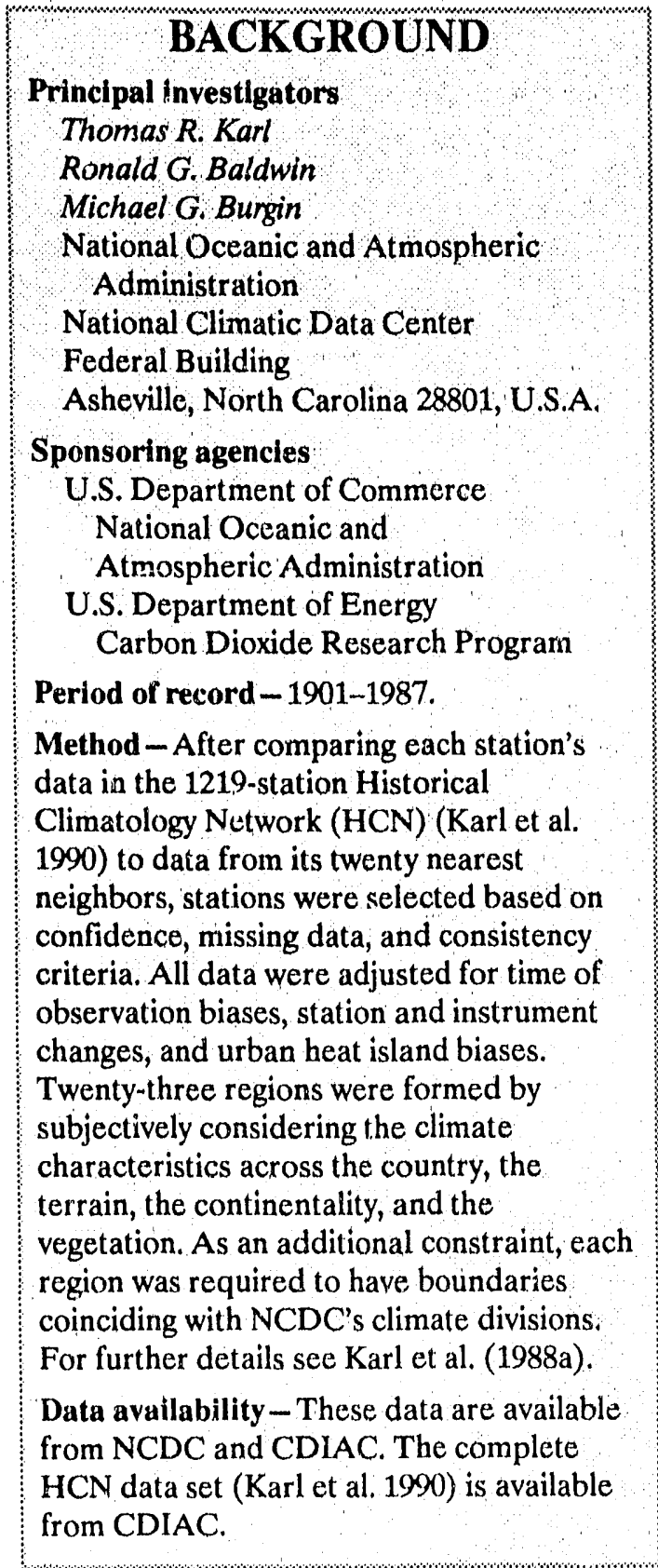
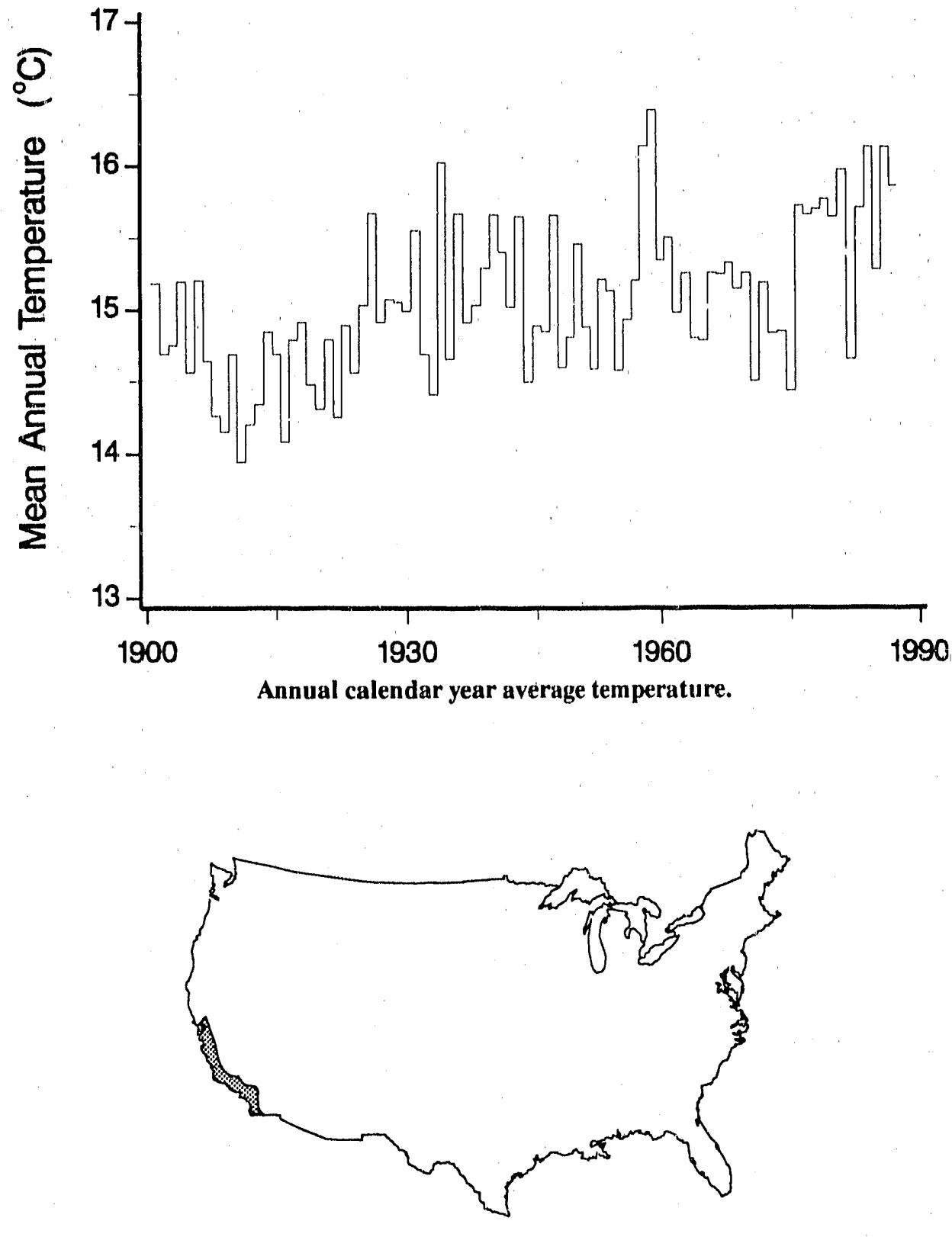

South Pacific Coast 


\section{U.S. Regional Temperatures}

\$कжक巾

\section{TRENDS}

On the basis of regional seasonal temperatures (i.e., maximum, minimum, average, and diurnal range) for the United States, Karl et al. (1988a) concluded that the climate has changed over the recent century but that the changes for the most part have not been monotonic. Instead, the changes are somewhat unsteady and sometimes occur over a relatively short period of time.

Karl et al. (1988a) also found a considerable amount of detailed information for each regional time series but reported that their salient features often could be summarized in time series plots for three aggregated regions: West, Central, and East. For the aggregated West region, which includes this subregion, Karl et al. (1988a) reported that, since the relativeiy cool period during the beginning decades of the century, annual mean temperatures have remained relatively constant with the exception of a number of multiyear climate fluctuations. 


\section{South Pacific Coast}

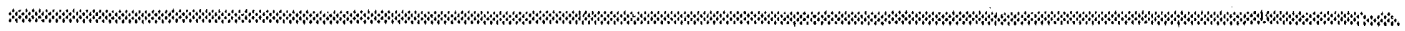

\begin{tabular}{|c|c|c|c|c|c|c|c|c|}
\hline Year & Ann* & Win & Spr & Sum & Fall & Annt & Year & Ann* \\
\hline 1901 & 15.18 & 11.63 & 13.42 & 19.24 & 16.42 & 15.18 & 1945 & 14.89 \\
\hline 1902 & 14.69 & 11.46 & 12.87 & 19.19 & 15.82 & 14.84 & 1946 & 14.85 \\
\hline 1903 & 14.75 & 10.13 & 12.54 & 19.12 & 16.8 .3 & 14.66 & 1947 & 15.66 \\
\hline 1904 & 15,19 & 11.06 & 13.74 & 19.07 & 17.07 & 15.24 & 1948 & 14.60 \\
\hline 1905 & 14.56 & 11.41 & 13,04 & 18.45 & 15.57 & 14.62 & 1949 & 14.81 \\
\hline 1906 & 15.20 & 11.52 & 13.14 & 19.64 & 16.41 & 15.18 & 1950 & 15.46 \\
\hline 1907 & 14.64 & 11.19 & 12.74 & 18.62 & 15.77 & 1458 & 1951 & 14.88 \\
\hline 1908 & 14.26 & 10.66 & 13,54 & 18.63 & 14.93 & 14.44 & 1952 & 14.59 \\
\hline 1909 & 14.15 & 10.23 & 12.25 & 18.66 & 15.50 & 14.16 & 1953 & 15.21 \\
\hline 1910 & 14.69 & 9.29 & 14.51 & 18.26 & 15.83 & 14.47 & 1954 & 15.13 \\
\hline 1911 & 13.94 & 10.32 & 12.76 & $18,1.5$ & 15.34 & 14.14 & 1955 & 14.58 \\
\hline 1912 & 14.20 & 10.99 & 11.64 & 18.45 & 15.53 & 14.15 & 1956 & 14.93 \\
\hline 1913 & 14.34 & 9.57 & 12.49 & 19.16 & 16.28 & 14.37 & 1957 & 15.20 \\
\hline 1914 & 14.84 & 10.81 & 14.08 & 18.28 & 16.48 & 14.91 & 1958 & 16.13 \\
\hline 1915 & 14.69 & 9.63 & 13.30 & 19.39 & 15.80 & 14.53 & 1959 & 16.38 \\
\hline 1916 & 14.08 & 10.55 & 14.09 & 18.18 & 14.15 & 14.24 & 1960 & 15.34 \\
\hline 1917 & 14.79 & 8.95 & 11.70 & 19.65 & 17.14 & 14.36 & $1 \% 61$ & 15.50 \\
\hline 1918 & 14.91 & 11.84 & 13.10 & 19.72 & 16.34 & 15.25 & 1962 & 14.98 \\
\hline 1919 & 14.48 & 10.19 & 12.93 & 19.15 & 15.29 & 14.39 & 1963 & 15.25 \\
\hline 1920. & 14.31 & 10.91 & 12.51 & 19.26 & 14.90 & 14.39 & 1964 & 14.80 \\
\hline 1921 & 14.79 & 10.03 & 12.57 & 19.57 & 16.32 & 14.62 & 1965 & 14.78 \\
\hline 1922 & 14.25 & 9.57 & 12.15 & 19.70 & 15.76 & 14.29 & 1966 & 15.25 \\
\hline 1923 & 14.89 & 10.72 & 13.50 & 18.65 & 16.98 & 14.96 & 1967 & 15.24 \\
\hline 1924 & 14.56 & 11.36 & 13.24 & 18.36 & 15.58 & 14.63 & 1968 & 15.32 \\
\hline 1925 & 15.03 & 10.81 & 13.61 & 19,13 & 15.48 & 14.76 & 1969 & 15.14 \\
\hline 1926 & 15.67 & 11.96 & 15.51 & 19.20 & 16.94 & 15.90 & 1970 & 15.25 \\
\hline 1927 & 14.91 & 10.75 & 13,46 & 18.84 & 16.51 & 14.89 & 1971 & 14.50 \\
\hline 1928 & 15.07 & 11.28 & 14.80 & 18.32 & 15.86 & 15.06 & 1972 & 15.18 \\
\hline 1929 & 15.05 & 9.48 & 12.74 & 20.01 & 16.95 & 14.79 & 1973 & 14.83 \\
\hline 1930 & 14.99 & 11.80 & 13.75 & 18.81 & 16.50 & 15.22 & 1974 & 14.84 \\
\hline 1931 & 15.55 & 11.26 & 15.74 & 20.00 & 15.66 & 15.66 & 1975 & 14.43 \\
\hline 1932 & 14.69 & 9.34 & 14.05 & 18.36 & 17,32 & 14.77 & 1976 & 15.71 \\
\hline 1933 & 14.41 & 8.68 & 12.76 & 18.28 & 17.00 & 14.18 & 1977 & 15.65 \\
\hline 1934 & 16.02 & 11.58 & 16.33 & 18.98 & 16.89 & 15.94 & 1978 & 15.69 \\
\hline 1935 & 14.66 & 11.08 & 13.03 & 19.14 & 15.66 & 14.73 & 1979 & 15.76 \\
\hline 1936 & 15.67 & 10.94 & 14.77 & 19.96 & 17.14 & 15.70 & 1980 & 15.64 \\
\hline 1937 & 14.91 & 8.41 & 13.73 & 19.51 & 17.40 & 14.76 & 1981 & 15.96 \\
\hline 1938 & 15.03 & 11.54 & 13.16 & 18.77 & 16.59 & 15.02 & 1982 & 14.65 \\
\hline 1939 & 15.29 & 10.56 & 13.74 & 18.81 & 17.92 & 15.26 & 1983 & 15.70 \\
\hline 1940 & 15.66 & 11.94 & 14.90 & 18.87 & 16.95 & 15.66 & 1984 & 16.12 \\
\hline 1941 & 15.40 & 12.06 & 14.60 & 18.87 & 16.68 & 15.55 & 1985 & 15.27 \\
\hline 1942 & 15.02 & 10.78 & 13.60 & 18.93 & 16.48 & 14.95 & 1986 & 16,12 \\
\hline 1943 & 15.65 & 11.81 & 14.79 & 18.66 & 17.47 & 15.68 & 1987 & 15.85 \\
\hline 1944 & 14.50 & 10,54 & 13.35 & 17.85 & 16.13 & 14.47 & & \\
\hline
\end{tabular}

* Calendar year mean (Jan-Dec).

†Season year mean (Win = Dec-Feb; Spr = Mar-May; Sum = Jun-Aug; Fall = Sep-Nov).

\section{TRENDS '90}


Average Temperature $\left({ }^{\circ} \mathrm{C}\right), 1901-1987$

\begin{tabular}{rrrrr}
\multicolumn{1}{c}{ Win } & Spr & Sum & Full & Ann† \\
11.13 & 12.73 & 19.12 & 16.79 & 14.94 \\
10.38 & 13.65 & 19.17 & 16.17 & 14.84 \\
11.03 & 15.06 & 20.03 & 16.71 & 15.71 \\
10.85 & 12.59 & 18.85 & 16.82 & 14.77 \\
7.48 & 13.93 & 19.28 & 17.89 & 14.65 \\
9.94 & 13.93 & 19.04 & 18.00 & 15.23 \\
11.37 & 13.69 & 18.65 & 17.04 & 15.19 \\
9.71 & 13.52 & 18.64 & 16.36 & 14.56 \\
11.34 & 12.87 & 19.01 & 17.05 & 15.07 \\
11.60 & 13.43 & 18.89 & 17.04 & 15.24 \\
9.65 & 13.36 & 18.56 & 16.57 & 14.54 \\
10.07 & 13.61 & 18.73 & 16.95 & 14.84 \\
10.79 & 13.70 & 20.24 & 16.14 & 15.22 \\
11.88 & 13.97 & 19.80 & 18.21 & 15.96 \\
12.17 & 15.51 & 20.49 & 17.93 & 16.53 \\
10.76 & 14.75 & 19.80 & 16.52 & 15.46 \\
11.64 & 13.77 & 20.24 & 16.46 & 15.53 \\
10.26 & 13.55 & 18.72 & 16.92 & 14.86 \\
11.92 & 13.15 & 18.73 & 17.47 & 15.32 \\
10.77 & 12.93 & 18.88 & 16.62 & 14.80 \\
11.03 & 13.43 & 18.11 & 17.10 & 14.92 \\
9.6 .3 & 14.77 & 19.14 & 17.03 & 15.14 \\
11.28 & 12.45 & 19.11 & 18.46 & 15.33 \\
11.15 & 14.39 & 19.08 & 16.77 & 15.35 \\
9.66 & 13.79 & 19.02 & 17.18 & 14.92 \\
12.19 & 14.06 & 19.10 & 16.57 & 15.48 \\
10.16 & 12.92 & 19.26 & 16.13 & 14.62 \\
9.78 & 15.21 & 19.59 & 15.72 & 15.08 \\
10.02 & 13.51 & 19.43 & 15.77 & 14.68 \\
10.34 & 13.45 & 19.28 & 16.49 & 14.89 \\
10.63 & 12.21 & 18.39 & 16.07 & 14.32 \\
11.85 & 13.58 & 19.64 & 17.64 & 15.68 \\
12.16 & 13.21 & 19.69 & 17.14 & 15.55 \\
12.32 & 15.07 & 19.54 & 17.08 & 16.00 \\
9.79 & 14.62 & 19.78 & 17.80 & 15.50 \\
12.64 & 13.78 & 18.95 & 17.03 & 15.60 \\
12.55 & 14.52 & 20.53 & 16.52 & 16.03 \\
11.28 & 12.97 & 18.56 & 16.37 & 14.80 \\
11.20 & 13.75 & $19.9)$ & 17.65 & 15.63 \\
11.64 & 15.75 & 20.34 & 17.32 & 16.26 \\
12.77 & 15.41 & 20.18 & 15.79 & 15.11 \\
11.58 & 15.71 & 19.29 & 17.79 .73 & 16.05 \\
& & & &
\end{tabular}

\section{REFERENCES}

Karl, T.R., G. Kukla, and J. Gavin, 1984.

Decreasing diurnal temperature range in the United States and Canada from 1941 through 1980. Journal of Climate and Applied Meteorology 23:1489-1504.

Karl, T.R., G. Kukla, and J. Gavin. 1986. Relationship between decreased temperature range and precipitation trends in the United States and Canada, 1941-1980. Joumal of Climate and Applied Meteorology 26:1878-86.

Karl, T.R., C.N. Williams, Jr., P.J. Young, and W.M. Wendland. 1986. A model to estimate the time of observation bias associated with monthly mean maximum, minimum, and mean temperatures for the United States. Joumal of Climate and Applied Meteorology 25:145-60.

Karl, T.R., R.G. Baldwin, and M.G. Burgin. 1988a. Time series of regional seasonal averages of maximum, minimum, and average temperature, and diumal temperature range across the United States: 1901-1984. Historical Climatology Series 4-5. National Climatic Data Center, National Oceanic \& Atmospheric Administration, National Environmental Satellite, Data, and Information Service, Asheville, North Carolina.

Karl, T.R., H.F. Diaz, and G. Kukla. 1988 b. Urbanization: its detection and effect in the United States climate record. Joumal of Climate 1:1099-1123.

Karl, T.R., C.N. Williams, Jr., and F.T. Quinlan. 1990. United States Historical Climatology (HCN) serial temperature and precipitation data. NDP-019/R1. Carbon. Dioxide Information Analysis Center, Oak Ridge National Laboratory, Oak Ridge, Tennessec. 


\section{North Cascades}

\begin{tabular}{|c} 
BACKGROUND \\
Principal investigators \\
Thomas R. Karl \\
Ronald G. Baldwin \\
Michael G. Burgin \\
National Oceanic and Atmospheric \\
Administration \\
National Climatic Data Center \\
Federal Building \\
Asheville, North Carolina 28801, U.S.A. \\
Sponsoring agencies \\
U.S. Department of Commerce \\
National Occanic and \\
Atmospheric Administration \\
U.S. Department of Energy \\
Carbon Dioxide Research Program
\end{tabular}

Period of record - 1901-1987.

Method-After comparing each station's data in the 1219-station Historical Climatology Network (HCN) (Karl et al. 1990) to data from its twenty nearest neighbors, stations were selected based on confidence, missing data, and consistency criteria. All data were adjusted for time of observation biases, station and instrument changes, and urban heat island biases. Twenty-three regions were formed by subjectively considering the climate characteristics across the country, the terrain, the continentality, and the vegetation. As an additional constraint, each region was required to have boundaries coinciding with NCDC's climate divisions. For further details see Karl et al. (1988a).

Data availability - These data are available from NCDC and CDIAC. The complete HCN data set (Karl et al. 1990) is available from CDIAC.
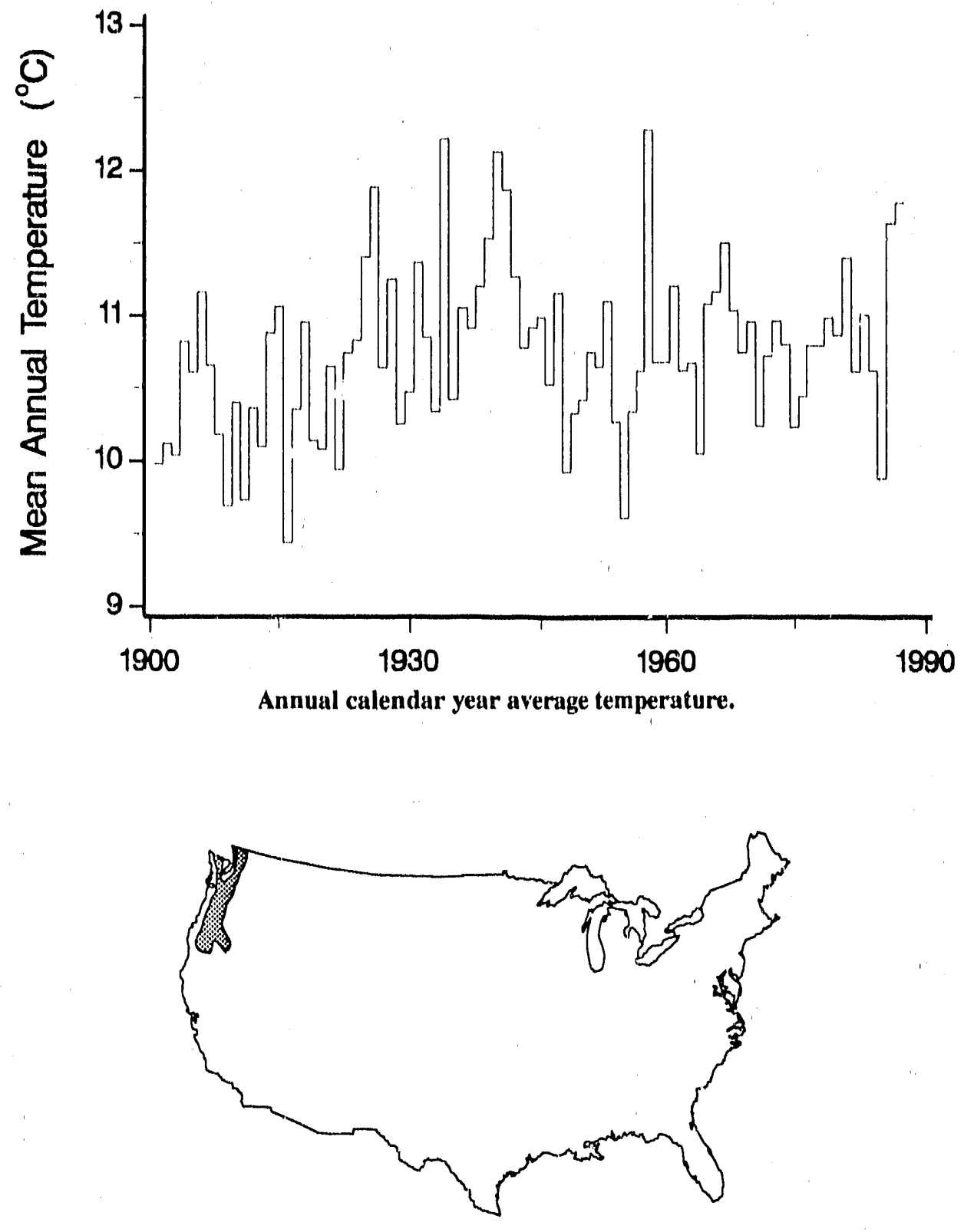

North Cascades 


\section{U.S. Regional Temperatures}

\section{TRENDS}

On the basis of regional seasonal temperatures (i.e., maximum, minimum, average, and diurnal range) for the United States, Karl et al. (1988a) concluded that the climate has changed over the recent century but that the changes for the most part have not been monotonic. Instead, the changes are somowhat unsteady and sometimes occur over a relatively short period of time.

Karl et al. (1988a) also found a considerable amount of detailed information for each regional time series but reported that their salient features often could be summarized in time series plots for three aggregated regions: West, Central, and East. For the aggregated West region, which includes this subregion, Karl et al. (1988a) reported that, since the relatively cool period during the beginning decades of the century, annual mean temperatures have remained relatively constant with the exception of a number of multiyear climate fluctuations. 


\section{North Cascades}

Whoph

\begin{tabular}{|c|c|c|c|c|c|c|c|c|}
\hline Yeur & Altn* & WIn & Spr & Sum & Fall & Arint & Yeur & Ann* \\
\hline 1901 & 9.98 & 4.72 & 9.23 & 15.69 & 10.95 & 10.15 & 1945 & $10 .(x)$ \\
\hline 1902 & 10,12 & 4.40 & 8.94 & 16.58 & 10.57 & 10,12 & 1946 & 10.53 \\
\hline 1903 & 10.04 & 3.73 & 8.77 & 16.90 & 10,84 & 10,06 & 1947 & 11.16 \\
\hline 1904 & 10.82 & 3.99 & 9.48 & 17.63 & 11,93 & 10.76 & 1948 & 9,93 \\
\hline 1905 & 10,61 & 4.58 & 10.54 & 17,80 & 9.90 & 10.70 & 1949 & 10,33 \\
\hline 1906 & 11.16 & 4.61 & 10.03 & 18.32 & 11.19 & 11.04 & 1950 & 10,42 \\
\hline 1907 & 10.66 & 4.02 & 9.63 & 17.20 & 11.66 & 10.63 & 1951 & 10.75 \\
\hline 1908 & 10.18 & 4.65 & 8.76 & 17.55 & 10.68 & 10.41 & 1952 & 10,65 \\
\hline 1909 & 9.69 & 2.78 & 8.94 & 16.57 & 11,02 & 9.83 & 1953 & 11.10 \\
\hline 1910 & 10.40 & 1.87 & 11,14 & 16,78 & 10.65 & 10.11 & 1954 & 10.27 \\
\hline 1911 & 9.73 & 3.00 & 8.93 & 17.52 & 9.74 & 9.79 & 1955 & 9,61 \\
\hline 1912 & 10.36 & 4,82 & 9,31 & 17.12 & 10,08 & 10.33 & 1956 & 10.34 \\
\hline 1913 & 10.10 & 2.80 & 9.13 & 17.80 & 10.66 & 10,10 & 1957 & 10.62 \\
\hline 1914 & 10.88 & 4.79 & 11.42 & 17.54 & $10.7 / 3$ & 11.12 & 1958 & 12.28 \\
\hline 1915 & 11.06 & 3,18 & 11.28 & 18.00 & 10.68 & 10.78 & 1959 & 10.68 \\
\hline 1916 & 9.44 & 2.88 & 9.28 & 16.74 & 9.61 & 9.6 .3 & 1960 & 10.68 \\
\hline 1917 & 10.35 & 2.49 & 7,95 & 17.78 & 11.57 & 9.9 .5 & 1961 & 11.20 \\
\hline 1918 & 10.95 & 5.44 & 9.23 & 18.29 & 11,94 & 11.22 & 1962 & 10,62 \\
\hline 1919 & 10.14 & 3.84 & 9.98 & 17.84 & 9.87 & 10.38 & 1963 & 10.67 \\
\hline 1920 & 10.08 & 2.59 & 8.41 & 17.80 & 10.13 & 9.73 & 1964 & 10.05 \\
\hline 1921 & 10.65 & 5.0 .5 & 9.67 & 17.33 & 11.22 & 10.82 & 1965 & 11.08 \\
\hline 1922 & 9,94 & 2.38 & 8.84 & 17.91 & 10.74 & 9.97 & 1966 & 11.16 \\
\hline 1923 & 10.74 & 3.20 & 9.71 & 17.84 & 11.64 & 10.60 & 1967 & 11.50 \\
\hline 1924 & 10.83 & 5.01 & 10.62 & 17.75 & $! 0.92$ & 11.07 & 1968 & 11.0 .3 \\
\hline 1925 & 11.40 & 4.68 & $10.8^{\circ} 7$ & 17.98 & 10.66 & 11.05 & 1969 & 10.74 \\
\hline 1926 & 11.88 & 5.63 & 12.19 & 18.76 & 11.54 & 12.02 & 1970 & 10.95 \\
\hline 1927 & 10.64 & 4.08 & 9,06 & 18.40 & 11.55 & 10.78 & 1971 & 10.24 \\
\hline 1928 & 11.25 & 3.86 & 11.43 & 18.08 & 11.25 & 11.15 & 1972 & 10.72 \\
\hline 1929 & 10.25 & 1.92 & 9.67 & $1 \%, 77$ & 10.91 & 10.07 & 197.3 & 10.96 \\
\hline 1930 & 10,47 & 3.40 & 10.66 & 17.6 .5 & 10.75 & 10.62 & 1974 & 10.80 \\
\hline 1931 & 11.36 & 5.01 & 11.70 & 18.1 .3 & 10.6 .5 & 11.37 & 1975 & 10.23 \\
\hline 1932 & 10.85 & 3.62 & 10.25 & 17.72 & 12.28 & 10.97 & 1976 & 10.44 \\
\hline 1933 & 10.34 & 2.45 & 9.03 & 17.70 & 10.71 & 9.97 & 1977 & 10.79 \\
\hline 1934 & 12.22 & 7.00 & 12.88 & 17.51 & 12.08 & 12.37 & 1978 & 10.79 \\
\hline 1935 & 10.42 & 4.59 & 8.95 & 17.55 & 1082 & 10.48 & 1979 & 10,98 \\
\hline 1936 & 11,05 & 3.81 & 10.89 & 18.17 & 11,08 & 10.99 & 1980 & 10.86 \\
\hline 1937 & 10.91 & 2.55 & 10.33 & 18.01 & 12.52 & 10.85 & 1981 & 11.39 \\
\hline 1938 & 11.20 & 4.91 & 10.45 & 18.07 & 11.51 & 11.24 & 1982 & 10.61 \\
\hline 1939 & 11.53 & 4.54 & 11.09 & 17.84 & 12,06 & 11.38 & 1983 & 11.00 \\
\hline 1940 & 12.1 .3 & 6.22 & 11.98 & 18.68 & 12.03 & 12.2 .3 & 1984 & 10.62 \\
\hline 1941 & 11.87 & 6.11 & 11.70 & 18.51 & 11.32 & 11.91 & 1985 & 9.88 \\
\hline 1942 & 11.27 & 4.51 & 10.16 & 18.52 & 11.76 & 11.24 & 1986 & 11.63 \\
\hline 1943 & 10.78 & 4.38 & 10.23 & 17.08 & 12.14 & 10.96 & 1987 & 11.77 \\
\hline 1944 & 10.92 & 4.00 & 9.70 & 17.63 & 12.22 & 10.89 & & \\
\hline
\end{tabular}

* Calendar year mean (Jari-Dec).

tSeason yeur mean (Win = Dec-lich; Spr = Mar-Muy; Sum = Jun-Aug; "all = Sep-Nov).

TRENDS' '90 
Average Temperature $\left({ }^{\circ} \mathrm{C}\right), 19() 1-1987$

\begin{tabular}{|c|c|c|c|c|}
\hline W/n & Spr & Sum & Full & AnIn' \\
\hline 5.03 & 9.72 & 17.98 & 11,07 & 10,05 \\
\hline 4.48 & 10,43 & 17,35 & 9.92 & 10.55 \\
\hline 4,28 & 11.82 & 16,74 & 11.49 & 11,088 \\
\hline 4.21 & 8.6 .5 & 17,47 & 10.44 & 10.19 \\
\hline 1.15 & 10.77 & 17,20 & 11.56 & 10.17 \\
\hline 2,07 & 9,00 & 18.08 & 11.35 & 10.12 \\
\hline 5.40 & 9.73 & 17.91 & 11.52 & 11,11 \\
\hline 319 & 9.92 & 17.56 & 11.32 & 10.50 \\
\hline 5.86 & 9.23 & 16,80 & 12.19 & 11,02 \\
\hline 4.75 & 9.40 & 15.94 & 11.38 & 10.37 \\
\hline 3.76 & 7.6 .3 & 16.70 & 10.41 & 9.62 \\
\hline 3.48 & 10,30 & 17,46 & 10,25 & 10,37 \\
\hline 2.88 & 10.66 & 17,07 & 11.29 & 10,47 \\
\hline 6.54 & 10.73 & 19,79 & 11.68 & 12.19 \\
\hline 5.56 & 9.80 & 17.74 & 10.65 & 10.94 \\
\hline 3.8 .3 & 9.57 & 17.98 & 11.32 & 10.68 \\
\hline 5.66 & 9.81 & 19,22 & 9,98 & 11.17 \\
\hline 3.92 & 9,35 & 17.05 & 11.79 & 10.53 \\
\hline 4.89 & 9.57 & $16.60)$ & 12.04 & 10.78 \\
\hline 4.34 & 8,69 & 16.83 & 10.46 & 10,08 \\
\hline 4.31 & 10.02 & 17,98 & 12.05 & 11.00 \\
\hline 4.15 & 10,40 & 17.45 & 11.80 & 10.95 \\
\hline 5.8 .7 & 8.86 & 19,42 & 12.51 & 11.65 \\
\hline 5.53 & 10.14 & 17.58 & 11.28 & 11.13 \\
\hline 2.62 & 10.52 & 17.82 & 11.21 & 10.54 \\
\hline 5.81 & 9.31 & 18,383 & 10.86 & 11,09 \\
\hline 4,12 & 9.00 & 17,69 & 10,29 & 10,28 \\
\hline 3.87 & 10,25 & 18.52 & 10.72 & 10.84 \\
\hline 3,96 & 10,19 & 17.38 & 10,81 & 10.59 \\
\hline 4.55 & 9.20 & 17,70 & 12.01 & 10.80 \\
\hline 4.87 & 8.44 & 16.73 & 11,00 & 10.20 \\
\hline 5.01 & 9.07 & 16.42 & 11.81 & 10.58 \\
\hline 4.20 & 9.31 & 18.37 & 10.53 & 10.60 \\
\hline 6.12 & 10,26 & 18.04 & 10,01 & 11,11 \\
\hline 2.44 & 10.65 & 17.64 & 11.86 & 10.64 \\
\hline 4.77 & 10.03 & 16.74 & 11.97 & 10,88 \\
\hline 5.83 & 10.38 & 17.89 & 11.50 & 11.40 \\
\hline 4.70 & 9.39 & 17.93 & 10.83 & 10,71 \\
\hline 5,83 & 10.92 & 17.08 & 11,04 & 11.22 \\
\hline 4.4 .5 & 10.08 & 17.34 & 10.39 & 10.56 \\
\hline 2.96 & 9,91 & 18.46 & 8.85 & 10,05 \\
\hline 4.48 & 10.84 & 18.166 & 11.35 & 11,33 \\
\hline 4.91 & 11.54 & 18.29 & 12.58 & 11.83 \\
\hline
\end{tabular}

\section{REFERENCES}

Karl, T.R., G. Kukla, and J, Gavin, 1984. Docreasing diurnal temperaturo range in the Uniled States and Canada from 1941 through 1980. Joumal of Cilmate and Applicd Meteorology 23:1489-1504. Karl, T.R., G. Kukla, and J, Gavirn, 1986. Rolationship between docreased temperature range and precipitation trends in the United States and Canada, 1941-1980. Jommal of Climate and Applied Mefeorology 26:1878-86.

Karl, T.R., C.N, Williams, Jr., P.J. Young, and W.M. Wendland, 19866. A miodel to estimate the time of observation bias associated with monthly mean maximum, minimum, and mean temperatures for the United States. Joumial of Climate and Applied Meteorology' 25:145-6().

Karl, T.R., R.G. Baldwin, and M.G, Burgin. 1988a. Time series of regional seasonal averages of maximum, minimum, and average temperature, and diumal temperature range across' the United States: 1901-1984. Historical Climatology

Series 4-5. National Climatic Data Center, National Oceanic \& Atmospheric Administration, National Environmental Satellitc, Data, and Information Service, Asheville, North Carolina.

Karl, 'T.R., H,F. Diaz, and G. Kukla, 1988 b. Urbanization: its delection and effect in the United States climate record. Journal of Climute 1:1(0) 1123 .

Karl, T.R., C.N. Williams, Jr., and

F.T. Quinlan, 1990. United States Historical Climatology (HCN) serial temperature and precipitation data. NDP-019/R1. Carbon Dioxide Information Analysis Center, ()ak Ridge National Laboratory, Oak Ridge, Tennessec. 


\section{California Interior Valleys}

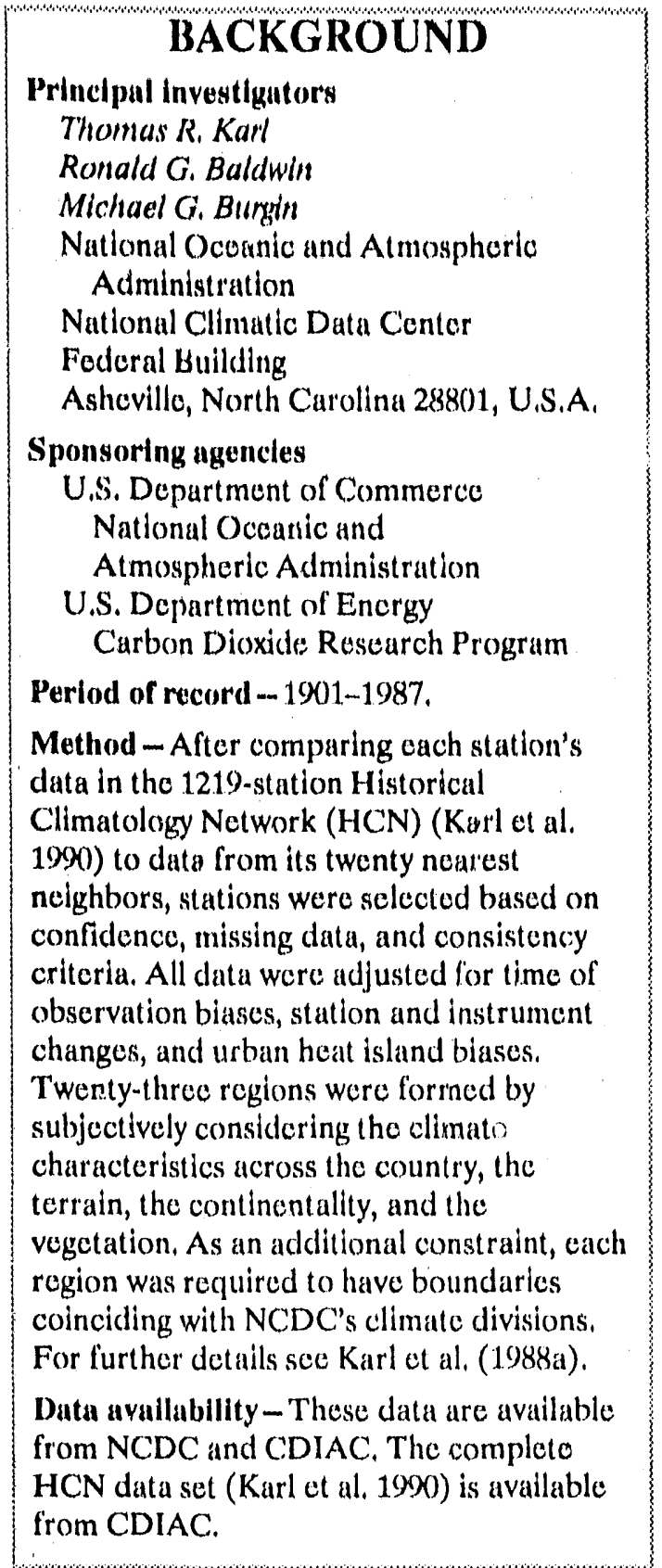
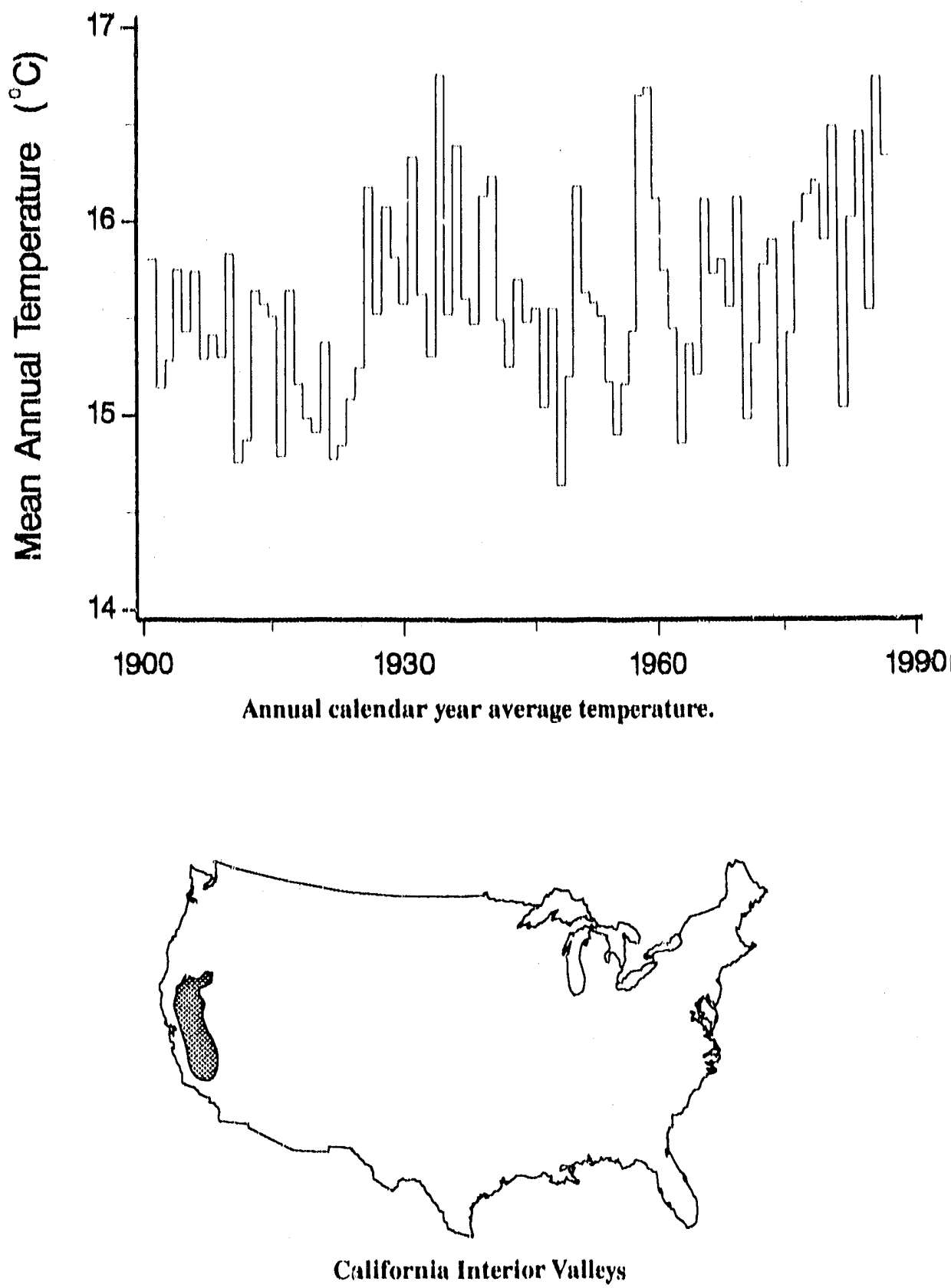


\section{TRENDS}

On the basis of rogional soasonal tomperatures ( 1,0, maximum, minimum, average, and diurnal runge) for the United States, Karl et al. (1988a) concluded that the climate has changed over the rocent century but that the changes for the most part have not been monotonic. Instead, the changes are somewhat unsteady and somotimes occur over a rolatively short period of time.

Karl et al. (1988a) also found a consid. erable amount of detailed information for each regional time series but reported that their salient foutures often could be summarized in time series plots for three aggregated regions: West, Central, and East. For the aggregated West region, which includes this subregiom, Karl et al. (1988a) reported that, since the relatively cool period during the beginning decades of the century, annual mean temperatures have remained relatively constant with the exception of a number of multiyear climate fluctuations. 
California Interior Valleys

\begin{tabular}{|c|c|c|c|c|c|c|c|c|}
\hline Yoar & Ann* & W/n & Spr & Sum & Full & Anint & Yeur & Ann* \\
\hline 1901 & 15.80 & 8.45 & 14,08 & 23.20 & 17.02 & 15.70 & 1945 & 15.55 \\
\hline 1902 & 15.14 & 8.50 & 13.14 & 23.35 & 15,90 & 15.22 & 1946 & 15.04 \\
\hline 1903 & 15.28 & 7.12 & 13.71 & 22.07 & 17.15 & 15.24 & 1947 & 15.55 \\
\hline 1904 & 15.75 & 8.27 & 14,93 & 24.05 & $\left.16,0^{\circ}\right)$ & 15.84 & 1948 & 14.64 \\
\hline 1905 & 15.4 .3 & 8.82 & 14.53 & 23.12 & 1.5 .54 & 15.50 & 1949 & 15.20 \\
\hline 1906 & 15.74 & 8.98 & 13.683 & 23.53 & 16.28 & 15.62 & 1950 & 16.18 \\
\hline 1907 & 15.29 & 8.67 & 13.72 & 22.27 & 16.34 & 15.25 & 1951 & 15.63 \\
\hline 1908 & 15.41 & 8.20 & 14,31 & 23.94 & 16.19 & 15.660 & $19 \$ 2$ & 15.58 \\
\hline 1909 & 15.30 & 8.06 & 13,86 & 22.86 & $1.6,02$ & 15.20 & 1953 & 1551 \\
\hline 1910 & 15.83 & 6.81 & $15,(x)$ & 23,32 & 16.48 & 15.65 & 1954 & 15.17 \\
\hline 1911 & 14.76 & 8.06 & 13,61 & 22.88 & 14.90 & 14,89 & 1955 & 14.90 \\
\hline 1912 & $14: 87$ & 8.61 & 13.06 & 22.844 & 15.04 & 14.89 & 1956 & 15.16 \\
\hline 1913 & 15.64 & 7.35 & 14.20 & 23.74 & 17,17 & 15.62 & 1957 & 15.43 \\
\hline 1914 & 15.57 & 8.64 & 15.34 & 22.72 & 15.86 & 15.64 & 1958 & 16.64 \\
\hline 1915 & 15.51 & 7,53 & 14.12 & 23,52 & 16.34 & 15,38 & $19 \$ 9$ & 16.68 \\
\hline 1916 & 14.74 & 8.17 & 14.58 & 22.49 & 14.47 & 14.93 & 1960 & 16.11 \\
\hline 1917 & 15.64 & 6.91 & 12.54 & 24.53 & 17.50 & 15.37 & 1961 & 15.74 \\
\hline 1918 & 15.16 & 8.46 & 13.78 & 23.88 & 15.67 & 15.44 & 1962 & 15.44 \\
\hline 1919 & 14.98 & 7.00 & 14.45 & 23.15 & 15,03 & 14.91 & 1963 & 14.85 \\
\hline 1920 & 14.91 & 8.25 & $13,4 \mathrm{~S}$ & 22.90 & 14.73 & 14.84 & $15 \times 64$ & 15.36 \\
\hline 1921 & 15.37 & 7.92 & 13.53 & 23,32 & 16.21 & 15.24 & 1965 & 15.20 \\
\hline 1922 & 14.77 & 7.16 & 13,12 & 23.29 & 15.65 & 14.80 & 1966 & 16.10 \\
\hline 1923 & 14.84 & 8.03 & 13.96 & 21.46 & 16.58 & 15.01 & 1967 & 15.72 \\
\hline 1924 & 15.08 & 8.11 & 14.66 & 32,69 & 15.22 & 15.17 & 1968 & 15.79 \\
\hline 1925 & 15.24 & 7,78 & 14.51 & 23,43 & 14.48 & 15,05 & 1269 & 15.55 \\
\hline 1926 & 16.17 & 7.77 & 16.54 & 24.26 & 16,33 & 16.23 & 1970 & 16.11 \\
\hline 1927 & 15.52 & 8.55 & 14,17 & 23.22 & 16,10 & 15.51 & 1971 & 14.97 \\
\hline 1928 & 16,07 & 8.28 & 15,97 & 23.80 & 16.35 & 16.10 & 1972 & 15.36 \\
\hline 1929 & 15.81 & 7.27 & 14.16 & 23.57 & 17.22 & 15.55 & 1973 & 15.76 \\
\hline 1930 & 15.57 & 9.42 & 14.47 & 23,35 & $15 .(x)$ & 15.81 & 1974 & 15.89 \\
\hline 1931 & 16.33 & 8.32 & 16.63 & 24.80 & 15.54 & 16.32 & 1975 & 14.73 \\
\hline 1932 & 15,62 & 7.50 & 14.59 & 23.30 & 17.86 & 15.81 & 1976 & 15.41 \\
\hline 1933 & 15.30 & 5,94 & 13.54 & 24.05 & 17,04 & 15.14 & 1977 & 15.98 \\
\hline 1934 & 16,75 & 8.37 & 17.25 & 23.52 & 17.22 & 16.59 & 1978 & 16.12 \\
\hline 1935 & 15.52 & 8.53 & 13,71 & 24.17 & 15.79 & 15.54 & 1979 & 16.19 \\
\hline 1936 & 16.39 & 9.00 & 15.52 & 24,32 & 17.23 & 16.51 & 1980 & 15.89 \\
\hline 1937 & 15,60 & 6.10 & 14.70 & 23.96 & 17.03 & 15.45 & 19881 & 16.47 \\
\hline 1938 & 15.47 & 8.39 & 13.91 & 23.67 & 16.05 & 15.50 & 1982 & 15.03 \\
\hline 1939 & 16.13 & 7,78 & 15.72 & 23,859 & 16.92 & 16.07 & 1983 & 16.00 \\
\hline 1940 & 16,23 & 9.46 & 15.53 & 24.05 & 15,77 & 16.20 & 1984 & 16.44 \\
\hline 1941 & 15.49 & 9.64 & 14.35 & 22.68 & 15.59 & 15.56 & 198.5 & 15.53 \\
\hline 1942 & 15.25 & 8.02 & 13.29 & 23,68 & 16.38 & 15,35 & 1086 & 16.72 \\
\hline 1943 & 15.70 & 8.31 & 14.98 & 22.27 & 16.97 & 15.6 .3 & 1987 & 16.32 \\
\hline 1944 & 15,48 & 8.15 & 14.19 & 22.58 & 17.00 & 15,48 & & \\
\hline
\end{tabular}

- Calendar year muan (Jan-iDec).

tSeasun year mean (Win = Doc-leb; Spr = Mar-May; Sum = Jun - Aug; Fall = Sep-Nov).

TRENDS 'O() 


\section{Average Temperature (C), 1901-1987}

\begin{tabular}{|c|c|c|c|c|}
\hline Win & Spr & Sum & linll & Annt \\
\hline 8.01 & 13.31 & 23.83 & 17.30 & 15.61 \\
\hline 7.2 .3 & 14,49 & 23,02 & 15.56 & 15.07 \\
\hline 7,32 & $16.2 !$ & 22,51 & 16.39 & 15,61 \\
\hline 7.99 & 12.29 & 22.48 & 16.05 & 14.70 \\
\hline 5.31 & 15.03 & 23.21 & 17.01 & 15.14 \\
\hline 7.36 & 15.19 & 23.77 & 17.31 & 15.91 \\
\hline 8.60 & 14.96 & 23.21 & 16.66 & 15.86 \\
\hline 7,39 & 14.58 & 22,99 & 17.12 & 15.52 \\
\hline 8.84 & 13.47 & 22.56 & 16.90 & 15.44 \\
\hline 8.24 & 15.16 & 22.63 & 15.54 & 15.39 \\
\hline 6.07 & 13.61 & 22.74 & 16.16 & 14.65 \\
\hline 7.89 & 14.39 & 23.11 & 15.59 & 15.34 \\
\hline 7,52 & 14.73 & 23.86 & 15.58 & 15.42 \\
\hline 8.38 & 14.59 & 24.36 & 18.09 & 16.35 \\
\hline 9.49 & 16.13 & 24.69 & 17.22 & 16.88 \\
\hline 8.12 & 15.14 & 25.21 & 16.36 & 16,200 \\
\hline 7.41 & 14,28 & 25,33 & 16.08 & 15.78 \\
\hline 6.66 & 14.5 .5 & 23.48 & 16.62 & 15.32 \\
\hline 8.47 & 13.14 & 22.49 & 16.47 & 15.14 \\
\hline 6.43 & 13.87 & 23,13 & 16.20 & 14.91 \\
\hline 8.57 & 14,83 & 22.660 & 16,25 & 15.58 \\
\hline 6.54 & 16.34 & $23,7 / 2$ & 17.07 & 15.91 \\
\hline 7.78 & 12.91 & 24.50 & $17 .(x)$ & 15.79 \\
\hline 8.22 & 1.5 .20 & 23.80 & 16.12 & 15.8 .3 \\
\hline 6.50 & 15.00 & 23.56 & 16.28 & 15.33 \\
\hline 9.38 & 15.01 & 24,04 & 16.44 & 16.22 \\
\hline 7.46 & 13.64 & 23,91 & 15.47 & 15.12 \\
\hline 6.53 & 1.5 .97 & 24.08 & 1.5 .11 & 15,42 \\
\hline 6.98 & 15.33 & 23.97 & 15.61 & 15.47 \\
\hline 8.07 & 14.71 & 23.97 & $1 / .23$ & $15 .(N)$ \\
\hline 7.16 & 13.36 & 22.50 & 15.83 & 14.71 \\
\hline 7,74 & 14,42 & 22.46 & 16.84 & 15,36 \\
\hline 7.94 & 14.20 & 24.38 & 16.74 & 15.81 \\
\hline 9.78 & 1.5 .55 & 23.93 & 16.71 & 16,49 \\
\hline 7.12 & 15.41 & 23.92 & 17.36 & 15.95 \\
\hline 8.97 & 14.64 & 22.85 & 17.14 & 15.90 \\
\hline 8.69 & 15.43 & 24.99 & 16.54 & 16,41 \\
\hline 7,70 & 14.20 & 22.88 & 15.69 & 15.14 \\
\hline 7.9$)$ & 14.40 & 23.37 & 17.53 & 15.82 \\
\hline 8.65 & 16.25 & 24.95 & 16.64 & $16,6,3$ \\
\hline 7.32 & 15.10 & 24.61 & 15.49 & 15.63 \\
\hline 9.16 & 16.23 & 24.47 & 16,54 & 16.60 \\
\hline 8.00 & 16,61 & 23.36 & 17.41 & 16.35 \\
\hline
\end{tabular}

\section{REFERENCES}

Karl, T.R., G. Kukla, and J. Gavin, 1984. Decreasing diurnal temperaturo range in the United States and Canada from 1941. through 1980. Joumal of Climate and Applied Meteorology 23:1489-1504. Karl, T.R., G. Kukla, and J, Gavin. 1986. Relationship between decreased temperature range and precipitation trends in the United States and Canada, 1941-1980. Joumal of Climate and Applied Meteorology 26:1878-86.

Karl, T.R., C.N. Williams, Jr., P.J. Young, and W.M. Wendland. 1986. A model to estimate the time of observation bias associated with monthly mean maximum, minimum, and mean temperatures for the United States. Joumal of Climate and Applied Meteorology 25:145-60).

Karl, T.R., R.G. Baldwin, and M.G. Burgin. 1988a. Time series of regional seasonal averages of maximum, minimum, and average temperature, and diurnal temperature range across the United States: 1901-1984. Historical Climatology Series 4-5. National Climatic Data Center, National Oceanic \& Atmospheric Administration, National Environmental Satellite, Data, and Information Service, Asheville, North Carolina.

Karl, T.R., H.F. Diaz, and G. Kukla, 1988 b. Urbanization: its detection and effect in the United States climate record, Joumal of Climate $1: 1099-1123$.

Karl, T.R., C.N. Williams, Jr., and F.T. Quinlan, 1900). United States Historical Climatology (HCN) serial temperature and precipitation data. NDP-(019/R1. Carbon Dioxide Information Analysis Center, ()ak Ridge National Laboratory, Oak Ridge, Tennessec. 


\section{East Slope North Cascades}

BACKGROUND
Principal investigators
Thomas R. Karl
Ronald G. Baldwin
Michael G. Burgin
National Oceanic and Atmospheric
Administration
National Climatic Data Center
Federal Building
Asheville, North Carolina 28801, U.S.A.
Sponsoring agencies
U.S. Department of Commerce
National Oceanic and
Atmospheric Administration
U.S. Department of Energy
Carbon Dioxide Research Program
Period of record - 1901-1987.
Method-After comparing each station's
data in the 1219-station Historical
Climatology Network (HCN) (Karl et al.
1990) to data from its twenty nearest
neighbors; stations were selected based on
confidence, missing data, and consistency
criteria. All data were adjusted for time of
observation biases, station and instrument
changes, and urban heat island biases.
Twenty-three regions were formed by
subjectively considering the climate
characteristics across the country, the
terrain, the continentality, and the
vegetation. As an additional constraint, each
region was required to have boundaries
coinciding with NCDC's climate divisions.
For further details see Karl et al. (1988a).
Data availability-These data are available
from NCDC and CDIAC. The complete
HCN data set (Karl et al. 1990) is available
from CDIAC.
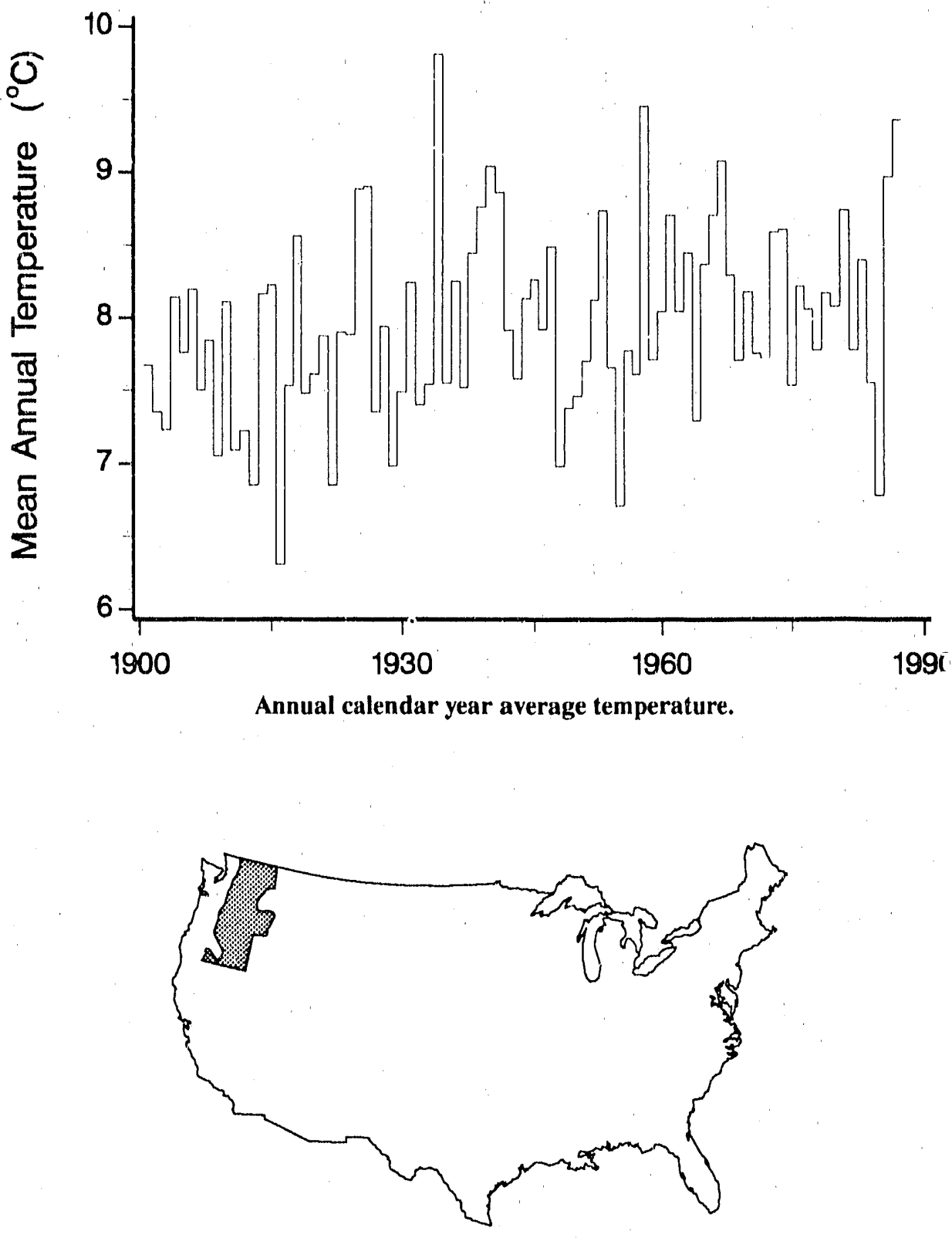

East Slope North Cascades 


\section{TRENDS}

On the basis of regional seasonal temperatures (i.e., maximum, minimum, average, and diurnal range) for the United States, Karl et al. (1988a) concluded that the climate has changed over the recent century but that the changes for the most part have not been monotonic. Instead, the changes are somewhat unsteady and sometimes, occur over a relatively short period of time.

Karl et al. (1988a) also found a considerable amount of detailed information for each regional time series but reported that their salient features often could be summarized in time series plots for three aggregated regions: Wist, Central, and East: For the aggregated West region, which includes this subregion, Karl et al. (1988a) reported that, since the relatively cool period during the beginning decades of the century, annual mean temperatures have remained relatively constant with the exception of a number of multiyear climate fluctuations. 


\section{East Slope North Cascades}

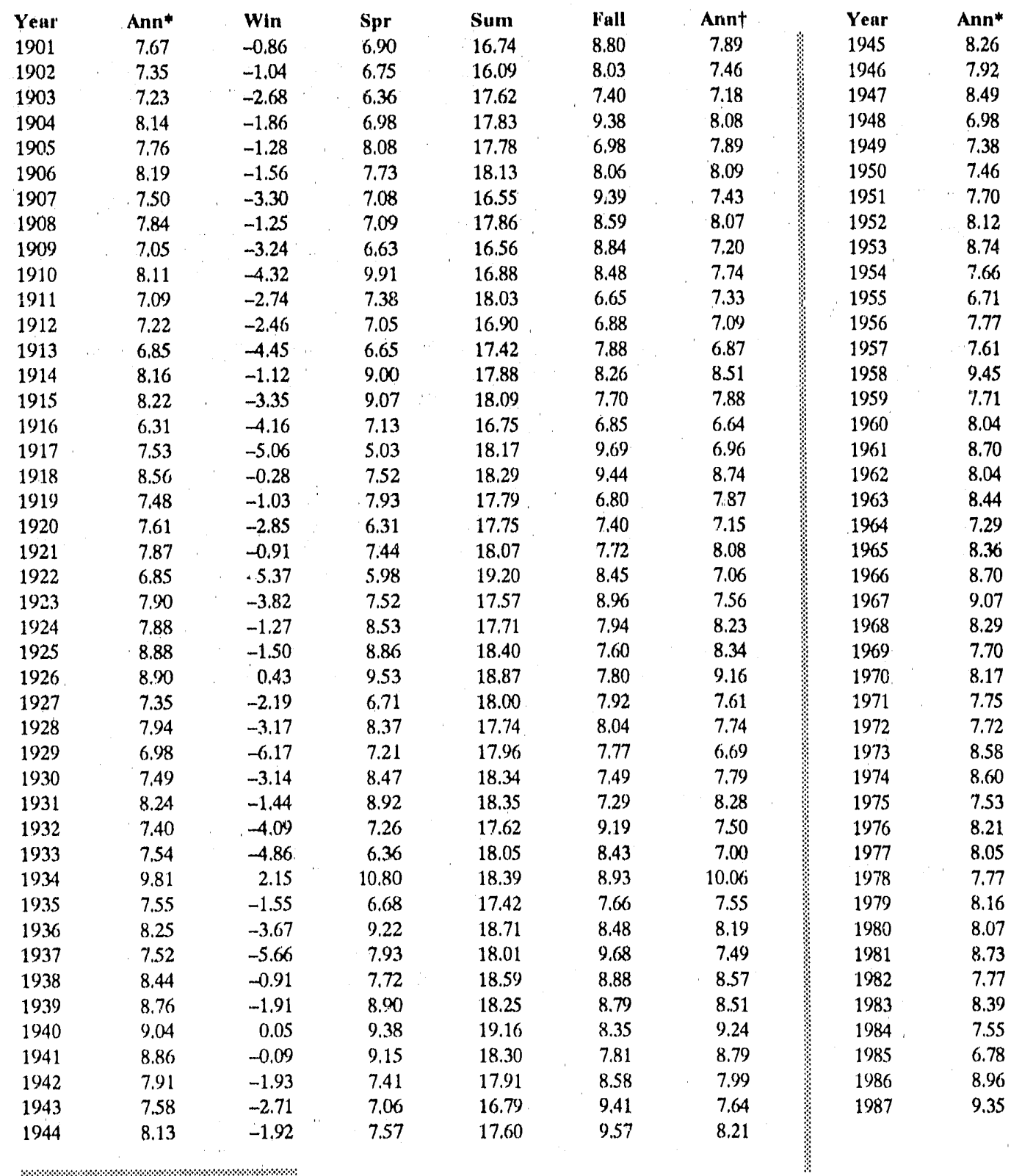

* Calendar year mean (Jan-Dec).

†Scason year mean $($ Win $=$ Dec-Feb; Spr $=$ Mar-May; Sum $=$ Jun-Aug; Fall $=$ Sep-Nov $)$. 


\section{Average Temperature $\left({ }^{\circ} \mathrm{C}\right), 1901-1987$}

\begin{tabular}{|c|c|c|c|c|}
\hline Win & Spr & Sum & Fall & Annt \\
\hline-0.80 & 7.14 & 18.19 & 8.24 & 8.19 \\
\hline-1.54 & 8.54 & 17.43 & 6.76 & 7.80 \\
\hline-1.17 & 9.57 & 16.96 & 8.64 & 8.50 \\
\hline-1.57 & 6.23 & 17.36 & 7.65 & 7.42 \\
\hline-7.38 & 8.57 & 17.75 & 9.12 & 7.01 \\
\hline-4.67 & 6.65 & 18.26 & 8.61 & 7.21 \\
\hline-0.53 & 7.15 & 18.03 & 8.12 & 8.19 \\
\hline-3.37 & 7.93 & 17,74 & 9.03 & 7.83 \\
\hline 1.21 & 7.00 & 16.42 & 9.68 & 8.58 \\
\hline-0.20 & 7.11 & 15.86 & 8.58 & 7.84 \\
\hline-2.01 & 4.81 & 17.34 & 7.18 & 6.83 \\
\hline-3.01 & 8.40 & 17.54 & 7.58 & 7.63 \\
\hline-3.87 & 8.46 & 16.97 & 8.24 & 7.45 \\
\hline 1.76 & 8.34 & 19.68 & 8.24 & 9.50 \\
\hline 60.56 & 7.32 & 17.46 & 7.25 & 7.87 \\
\hline-2.20 & 7.11 & 18.45 & 8.90 & 8.07 \\
\hline 0.32 & 7.70 & 20.31 & 6.63 & 8.74 \\
\hline-2.44 & 7.16 & 17.07 & 9.19 & 7.75 \\
\hline-0.07 & 7.61 & 17.22 & 10.08 & 8.71 \\
\hline-1.46 & 6.35 & 16.94 & 7.66 & 7.37 \\
\hline-1.35 & 7,30 & 18.06 & 8.90 & 8.23 \\
\hline-0.93 & 8.41 & 17.14 & 3.40 & 8.50 \\
\hline 1.36 & 6.48 & 19.81 & 9.81 & 9.36 \\
\hline-0.53 & 7.97 & 17.91 & 8.18 & 8.33 \\
\hline-4.62 & 8.16 & 18.14 & 8.20 & 7.47 \\
\hline-0.52 & 7.00 & 19.54 & 7.25 & 8.31 \\
\hline-1.00 & 6.96 & 18.33 & 7.11 & 7.85 \\
\hline-2.93 & 7.94 & 18.42 & 7.63 & 7.76 \\
\hline-2.14 & 8.40 & 18.27 & 7.99 & 8.13 \\
\hline-0.41 & 7.17 & 18.48 & 9.50 & 8.69 \\
\hline-2.03 & 6.18 & 17.55 & 8.43 & 7.53 \\
\hline-0.14 & 7.08 & 16.98 & 9.36 & 8.32 \\
\hline-1.47 & 7,36 & 19.27 & 7.17 & 8.08 \\
\hline-0.61 & 7,81 & 18.12 & 7.10 & 8.10 \\
\hline-5.27 & 8.23 & 18.69 & 8.78 & 7.61 \\
\hline-1.13 & 8.27 & 16.65 & 8.57 & 8.09 \\
\hline 1.10 & 8.06 & 17.66 & 8.62 & 8.86 \\
\hline$-1,17$ & 7.05 & 18.33 & 7.36 & 7.89 \\
\hline 0.60 & 8.58 & 17.33 & 8.39 & 8.72 \\
\hline-2.13 & 7.33 & 17.93 & 6.94 & 7.52 \\
\hline-4.58 & 8.04 & 19.04 & 4.80 & 6.82 \\
\hline-1.75 & 8.78 & 19.23 & 8.09 & 8.59 \\
\hline-0.74 & 9.89 & 18.48 & 10.05 & 9.42 \\
\hline
\end{tabular}

\section{REFERENCES}

Karl, T.R., G. Kukla, and J. Gavin. 1984. Decreasing diurnal temperature range in the United States and Canada from 1941. through 1980. Joumal of Climate and Applied Metcorology 23:1489-1504.

Karl, T.R., G. Kukla, and J. Gavin, 1986. Relationship between decreased temperature range and precipitation trends in the United States and Canada, 1941-1980. Joumal of Climate and Applied Meteorology 26:1878-86.

Karl, T.R., C.N. Williams, Jr., P.J. Young, and W.M. Wendland. 1986. A model to estimate the time of observation bias associated with monthly mean maximum, minimum, and mean temperatures for the United States. Joumal of Climate and Applied Meteorology 25:145-60.

Karl, T.R., R.G. Baldwin, and M.G. Burgin. 1988a. Time series of regional seasonal averages of maximum, minimum, and average termperature, and diumal temperature range across the United States: 1901 1984. Historical Climatology Series 4-5. National Climatic Data Center, National Oceanic \& Atmospheric Administration, National Environmental Satellite, Data, and Information Service, Asheville, North Carolina.

Karl, T.R., H.F. Diaz, and G. Kukla. 1988b. Urbanization: its detection and effect in the United States climate record. Joumal of Climate 1:1099-1123.

Karl, T.R., C.N. Williams, Jr., and F.T. Quinlan. 1990. United States Historical Climatology (HCN) serial temperature and precipitation data. NDP-019/R1. Carbon Dioxide Information Analysis Center, Oak Ridge National Laboratory, Oak Ridge, Tennessee. 


\section{Great Basin}

\begin{tabular}{l} 
BACKGROUND \\
Principal investigators \\
Thomas R. Karl \\
Ronald G. Baldwin \\
Michael G. Burgin \\
National Oceanic and Atmospheric \\
Administration \\
National Climatic Data Center \\
Federal Building \\
Asheville, North Carolina 28801, U.S.A. \\
Sponsoring agencies \\
U.S. Department of Commerce \\
National Oceanic and \\
Atmospheric Adrninistration \\
U.S, Department of Energy \\
Carbon Dioxide Research Program \\
Period of record - 1901-1987. \\
Method-After comparing each station's \\
data in the 1219-station Historical \\
Climatology Network (HCN) (Karl et al. \\
1990) to data from its twenty nearest \\
neighbors, stations were selected based on \\
confidence, missing data, and consistency \\
criteria. All data were adjusted for time of \\
observation biases, station and instrument \\
changes, and urban heat island biases. \\
Twenty-three regions were formed by \\
subjectively considering the climate \\
characteristics across the country, the \\
terrain, the continentality, and the \\
vegetation. As an additional constraint, each \\
region was required to have boundaries \\
coinciding with NCDC's climate divisions. \\
For further details see Karl et al. (1988a). \\
Data availability - These data are available \\
from NCDC and CDIAC. The complete \\
HCN data set (Karl et al. 1990) is available \\
from CDIAC. \\
\hline
\end{tabular}
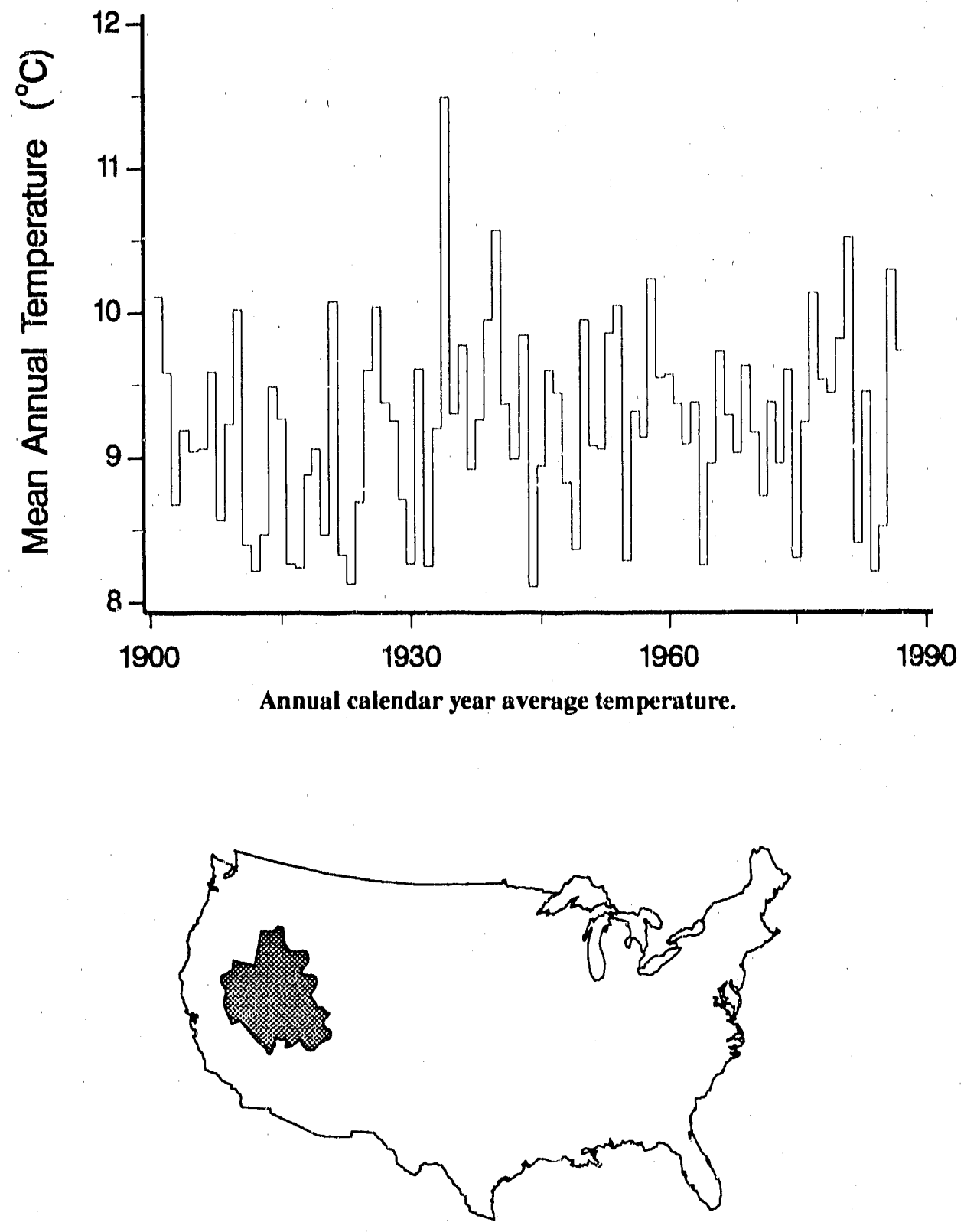

Great Basin 


\section{U.S. Regional Temperatures}

\section{TRENDS}

On the basis of regional seasonal temperatures (i.e., maximum, minimum, average, and diurnal range) for the United States, Karl et al. (1988a) concluded that the climate has changed over the recent century but that the changes for the most part have not been monotonic. Instead, the changes are somewhat unsteady and sometimes occur over a relatively short period of time.

Karl et al. (1988a) also found a consid. erable amount of detailed information for each regional time series but reported that their salient features often could be summarized in time series plots for three aggregated regions: West, Central, and East. For the aggregated West region, which includes this subregion, Karl et al. (1988a) reported that, since the relatively cool period during the beginning decades of the century, annual mean temperatures have remaincd relatively constant with the exception of a number of multiyear climate fluctuations. 


\section{Great Basin}

\begin{tabular}{|c|c|c|c|c|c|c|c|c|}
\hline Year & Ann* & Win & Spr & Sum & Fall & Annt & Year & Ann \\
\hline 1901 & 10.11 & -0.05 & 8.46 & 21.15 & 10.99 & 10.14 & 1945 & 8.94 \\
\hline 1902 & 9.59 & -0.22 & 8.23 & 20.65 & 9.60 & 9.57 & 1946 & 9.60 \\
\hline 1903 & 8.68 & -3.54 & 7.64 & 21.14 & 10,07 & 8.82 & 1947 & 9.45 \\
\hline 1904 & 9.19 & -1.58 & 8.33 & 20.40 & 9.61 & 9.19 & 1948 & 8.83 \\
\hline 1905 & 9.04 & -0.70 & 8.56 & 20.82 & 8.78 & 9.37 & 1949 & 8.37 \\
\hline 1906 & 9.06 & -2.44 & 7.72 & 20.15 & 8.73 & 8.54 & 1950 & 9.95 \\
\hline 1907 & 9.59 & 1.08 & 8.85 & 18.65 & 9.76 & 9.58 & 1951 & 9.08 \\
\hline 1908 & 8.57 & 0.50 & 7.49 & 19.59 & 8.04 & 8.91 & $19 \$ 2$ & 9.06 \\
\hline 1909 & 9.23 & -0.29 & 7.47 & 20.99 & 9.55 & 9.43 & 1953 & 9.86 \\
\hline 1910 & 10,02 & -4.24 & 11.04 & 21.11 & 10.43 & 9.59 & 1954 & 10.05 \\
\hline 1911 & 8.40 & -1.39 & 8.14 & 20.36 & 7.80 & 8.72 & 1955 & 8.29 \\
\hline 1912 & 8.22 & -1.58 & 7.18 & 19.75 & 7.19 & 8.14 & 1956 & 9.32 \\
\hline 1913 & 8.47 & -3.43 & 8.08 & 19.99 & 9.22 & 8.46 & 1957 & 9.14 \\
\hline 1914 & 9.49 & $-1,00$ & 9.93 & 20.18 & 9.71 & 9.70 & 1958 & 10.23 \\
\hline 1915 & 9.27 & $-2,82$ & 9.08 & 20,03 & 9.25 & 8.89 & 1959 & 9.55 \\
\hline 1916 & 8.27 & -1.60 & 8.78 & 19.37 & 7.50 & 8.51 & 1960 & 9.57 \\
\hline 1917 & 8.24 & -5.94 & 5.37 & 21.00 & 10.19 & 7.65 & 1961 & 9.37 \\
\hline 1918 & 8.88 & 0.00 & 7.92 & 21.01 & 8.82 & 9.44 & 1962 & 9.09 \\
\hline 1919 & 9.06 & -2.48 & 9.33 & 22.02 & 7.46 & 9,08 & 1963 & 9.38 \\
\hline 1920 & 8.47 & -2.22 & 7.01 & 20.12 & 8.38 & 8.32 & 1964 & 8.26 \\
\hline 1921 & 10.08 & -0.61 & 8.43 & 20.97 & 10.36 & 9.78 & 1965 & 8.96 \\
\hline 1922 & 8.33 & -3.62 & 6.17 & 21.56 & 9.71 & 8.45 & 1966 & 9.73 \\
\hline 1923 & 8.13 & -1.75 & 7.43 & 19.32 & 8.59 & 8.40 & 1967 & 9.29 \\
\hline 1924 & 8.69 & -2.63 & 7.98 & 21.26 & 9,06 & 8.92 & 1968 & 9.03 \\
\hline 1925 & 9.60 & $-2,3,3$ & 10.31 & 20.13 & 8.32 & 9.11 & 1969 & 9.63 \\
\hline 1926 & 10.04 & -0.45 & 10,10 & 21.51 & 9.97 & 10.28 & 1970 & 9.17 \\
\hline 1927 & 9.38 & -0.95 & 7.88 & 20.78 & 10.15 & 9.47 & 1971 & 8.73 \\
\hline 1928 & 9.25 & -1.99 & 9.43 & 20.10 & 9.46 & 9.25 & 1972 & 9.38 \\
\hline 1929 & 8.71 & -4.02 & 7.28 & 20.84 & 8.55 & 8,16 & 1973 & 8.96 \\
\hline 1930 & 8.27 & -0.46 & 8.54 & 20.82 & 7.20 & 9.03 & 1974 & 9.60 \\
\hline 1931 & 9.61 & -2.96 & 9.08 & 22.61 & 9.01 & 9.43 & 1975 & 8.31 \\
\hline 1932 & 8.25 & -4.84 & 8.35 & 20.39 & 9.93 & 8.46 & 1976 & 9.24 \\
\hline 1933 & 9.20 & -6.24 & 6.81 & 22.15 & 11.02 & 8.43 & 1977 & 10.13 \\
\hline 1934 & 11.49 & 2.22 & 12.57 & 21.81 & 10.41 & 11.75 & 1978 & 9.53 \\
\hline 1935 & 9.30 & -0.07 & 7.41 & 21.37 & 8.85 & 9.39 & 1979 & 9.44 \\
\hline 1936 & 9.77 & -0.97 & 9.76 & 21.33 & 8.54 & 9.67 & 1980 & 9.81 \\
\hline 1937 & 8.92 & -5.25 & 8.52 & 21.22 & 10,79 & 8.82 & 1981 & 10.51 \\
\hline 1938 & 9.26 & -0.25 & 7.77 & 20.70 & 8.96 & 9.30 & 1982 & 8.41 \\
\hline 1939 & 9.95 & $-2,41$ & 10.08 & 21.11 & 10.13 & 9.73 & 1983 & 9.45 \\
\hline 1940 & 10.57 & 1.10 & 10.26 & 22.33 & 9.50 & 10.80 & 1984 & 8.21 \\
\hline 1941 & 9.37 & 0.63 & 8.37 & 19,90 & 8.32 & 9.31 & 1985 & 8.52 \\
\hline 1942 & 8.99 & -1.81 & 7.01 & 21,01 & 9.71 & 8.98 & 1986 & 10.29 \\
\hline 1943 & 9.84 & 0.35 & 9.39 & 19.90 & 10.33 & 9.99 & 1987 & 9.73 \\
\hline 1944 & 8.11 & $-3,14$ & 6.78 & 19,26 & 9.78 & 8.16 & & \\
\hline
\end{tabular}

- Calendar year mean (Jan-Dec).

†Season year mean (Win $=$ Dec-Feb; Spr = Mar-May; Sum = Jun-Aug; Fall $=$ Sep-Nov).

TRENDS '90 


\section{Average Temperature $\left({ }^{\circ} \mathrm{C}\right), 1901-1987$}

\begin{tabular}{|c|c|c|c|c|}
\hline W/n & Spr & Sum & Fall & Annt \\
\hline-0.82 & 6.97 & 19.64 & 9.76 & 8.89 \\
\hline$-1,60$ & 9.42 & 21.46 & 8.19 & 9,37 \\
\hline-0.38 & 9.83 & 19,98 & 9.34 & 9,69 \\
\hline-0.95 & 7.28 & 20.59 & 9.23 & 9.04 \\
\hline-7.21 & 9.23 & $20.54^{\prime}$ & 10.58 & 8.29 \\
\hline-1.87 & 8.09 & 20.61 & 11.48 & 9.58 \\
\hline 0.04 & 8.33 & 20.45 & 9.33 & 9.54 \\
\hline-3.26 & 7.60 & 20.64 & 10.23 & 8,80 \\
\hline 0.93 & 7.11 & 20.52 & 11.39 & 9.99 \\
\hline-0.15 & 9.34 & 20.56 & 10.43 & 10.04 \\
\hline-4.86 & 6.77 & 20.40 & 9.90 & 8.05 \\
\hline-0.52 & 8.73 & 20.51 & 9.39 & 9.53 \\
\hline-1.41 & 7.87 & 20.81 & 8.53 & 8.95 \\
\hline 0.78 & 8.11 & 21.27 & 10.28 & 10.11 \\
\hline 0.51 & 8,21 & 21.84 & 9.14 & 9.93 \\
\hline-3.09 & 9.13 & 21.70 & 10.27 & 9.50 \\
\hline-0.45 & 8.29 & 22.15 & 7.65 & 9.41 \\
\hline-3.26 & 7.99 & 20.14 & 11.14 & 9.00 \\
\hline-1.03 & 7.70 & 19.91 & 11,47 & 9.51 \\
\hline-3.47 & 6.41 & 19.99 & 9.11 & 8.01 \\
\hline-0.04 & 7.10 & 19.33 & 9.98 & 9.09 \\
\hline-1.90 & 9.51 & 21.16 & 10.54 & 9.83 \\
\hline-1.23 & 7.35 & 20.93 & 10.96 & 9.50 \\
\hline-1.88 & 7.86 & 20.03 & 9.29 & 8.82 \\
\hline-0.94 & 8.80 & 20.83 & 9.08 & 9.44 \\
\hline 0.87 & 6.79 & 21.04 & 8.61 & 9.33 \\
\hline-1.04 & 7.56 & 21.41 & 7.83 & 8,94 \\
\hline-1.53 & 9.55 & 21.30 & 8.70 & 9.50 \\
\hline-4.00 & 7.52 & 20.82 & 9.44 & 8.45 \\
\hline-1.13 & 9.19 & 21.42 & 9.84 & 9.83 \\
\hline-2.50 & 6.02 & 19.70 & 9.26 & 8.12 \\
\hline-0.57 & 8.00 & 20.13 & 9,90 & 9.36 \\
\hline-1.41 & 7.56 & 22.14 & 10.81 & 9.77 \\
\hline 1.56 & 9.08 & 20.54 & 9.23 & 10.10 \\
\hline-3.70 & 8.75 & 20.97 & 10.23 & 9.05 \\
\hline 0.63 & 7.83 & 20.43 & 9.88 & 9.69 \\
\hline 0.98 & 8.68 & 21.85 & 10.43 & 10.48 \\
\hline-0.72 & 7.48 & 20.33 & 7.92 & 8.75 \\
\hline-0.15 & 7.10 & 20.10 & 10,26 & 9.33 \\
\hline-3.26 & 7.94 & 20.19 & 8.82 & 8.42 \\
\hline-3.98 & 9.00 & 21.47 & 7.86 & 8.59 \\
\hline 0.13 & 9.57 & 21.70 & 8.68 & 10.02 \\
\hline-1.39 & 9.77 & 20.74 & 10.39 & 9.87 \\
\hline
\end{tabular}

\section{REFERENCES}

Karl, T.R., G. Kukla, and J. Gavin. 1984. Decreasing diurnal temperature range in the United States and Canada from 1941 through 1980. Joumal of Climate and Applied Meteorology 23:1489-1504.

Karl, T.R., G. Kukla, and J. Gavin. 1986. Relationship between decreased temperature range and precipitation trends in the United States and Canada, 1941-1980. Joumal of Climate and Applied Meteorology 26:1878-86.

Karl, T.R., C.N. Williams, Jr., P.J. Young, and W.M. Wendland. 1986. A model to estimate the time of observation bias associated with monthly mean maximum, minimum, and mean temperatures for the United States. Joumal of Climate and Applied Meteorology 25:145-60.

Karl, T.R., R.G. Baldwin, and M.G. Burgin. 1988a. Time series of regional seasonal averages of maximum, minimum, and average temperature, and diumal temperature range across the United States: 1901-1984. Historical Climatology Series 4-5. National Climatic Data Center, National Oceanic \& Atmospheric Administration, National Environmental Satellite, Data, and Information Service, Asheville, North Carolina.

Karl, T.R, H.F. Diaz, and G. Kukla. 1988b. Urbanization: its detection and effect in the United States climate record. Joumal of Climate 1:1099-1123.

Karl, T.R., C.N. Williams, Jr., and F.T. Quinlan. 1990. United States Historical Climatology (HCN) serial temperature and precipitation data. NDP-019/R1. Carbon Dioxide Information Analysis Center, Oak Ridge National Laboratory, Oak Ridge, Tennessee. 


\section{Southern Desert}

BACKGROUND
Principal investigators
Thomas R. Karl
Ronald G. Baldwin
Michael.G. Burgin
National Oceanic and Atmospheric
Administration
National Climatic Data Center
Federal Building
Asheville, North Carolina 28801, U.S.A.
Sponsoring agencies
U.S. Department of Commerce
National Oceanic and
Atmospheric Administration
U.S. Department of Energy
Carbon Dioxide Research Program
Period of record - 1901-1987.
Method - After comparing each station's
data in the 1219-station Historical
Climatology Network (HCN) (Karl et al.
1990) to data from its twenty nearest
neighbors, stations were selected based on
confidence, missing data, and consistency
criteria. All data were adjusted for time of
observation biases, station and instrument
changes, and urban heat island biases.
Twenty-three regions were formed by
subjectively considering the climate
characteristics across the country, the
terrain, the continentality, and the
vegetation. As an additional constraint, each
region was required to have boundaries
coinciding with NCDC's climate divisions.
For further details see Karl et al. (1988a).
Data availability-These data are available
from NCDC and CDIAC. The complete
HCN data set (Karl et al. 1990) is available
trom CDIAC.
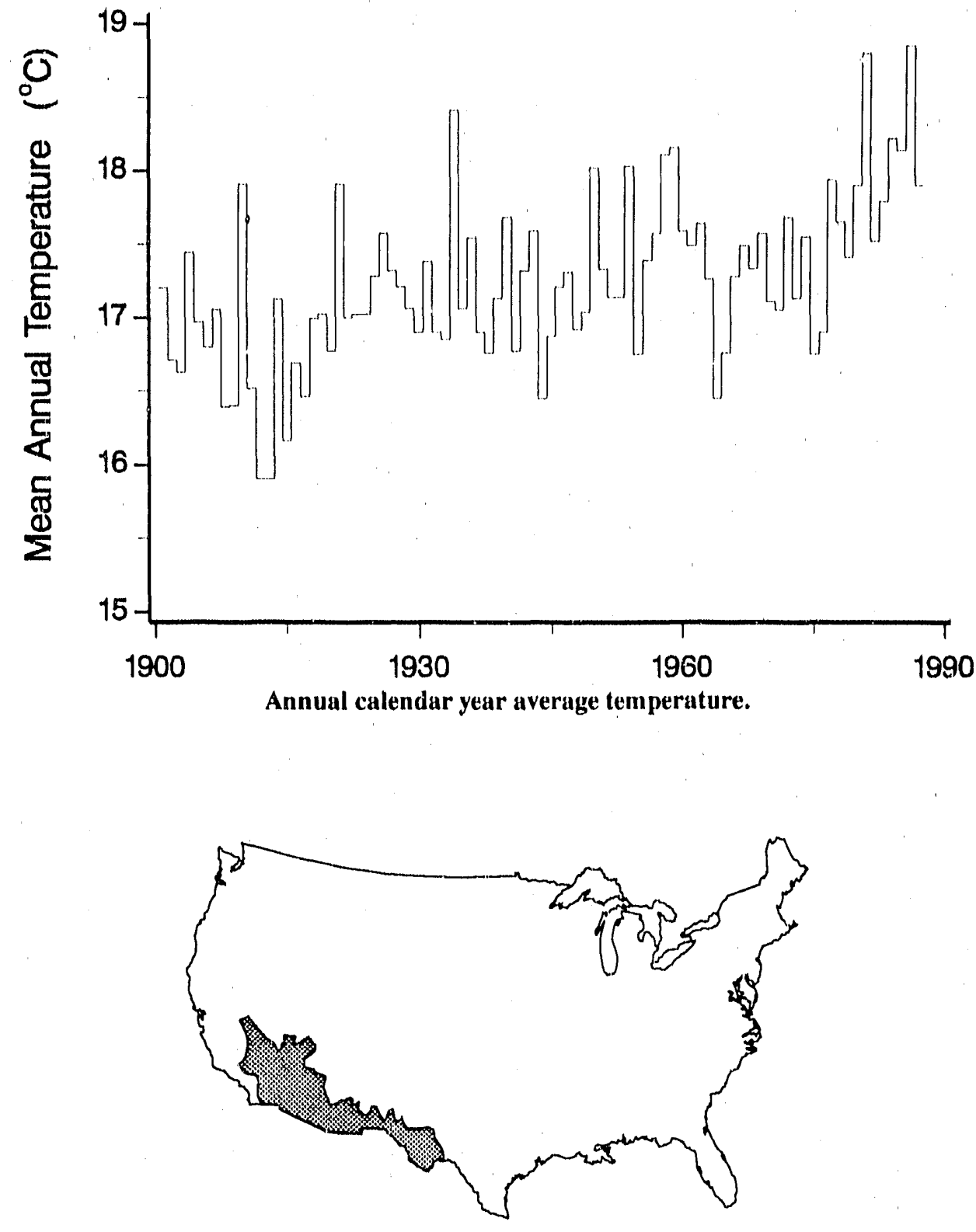

Southern Desert 


\section{U.S. Regional Temperatures}

\section{TRENDS}

On the basis of regional seasonal temperatures (i.e., maximum, minimum, average, and diurnal range) for the, United States, Karl et al. (1988a) concluded that the climate has changed over the recent century but that the changes for the most part have not been monotonic. Instead, the changes are somewhat unsteady and sometimes occur over a relatively short period of time.

Karl et al. (1988a) also found a considcrable amount of detailed information for each regional time series but reported that their salient features often could be summarized in time series plots for three aggregated regions: West, Central, and East. For the aggregated West region, which includes this subregion, Karl et al. (1988a) reported that, since the relatively cool period during the beginning decades of the century, annual mean temperatures have remained relatively constant with the exception of a number of multiyear climate fluctuations. 


\section{Southern Desert}

\begin{tabular}{|c|c|c|c|c|c|c|c|c|}
\hline Year & Ann* & Win & Spr & Sum & Fall & Alunt & Year & Ann* \\
\hline 1901 & 17.20 & 7,58 & 15.90 & 27.20 & 18.05 & 17,18 & 1945 & 16.87 \\
\hline 1902 & 16.71 & 7,30 & 15.81 & 26.74 & 17.24 & 16.77 & 1946 & 17.21 \\
\hline 1903 & 16.63 & 6.16 & 15,42 & 26.79 & 17.95 & 16.58 & 1947 & 17.31 \\
\hline 1904 & 17.44 & 7.52 & 17.82 & 27.09 & 17.44 & 17.47 & 1948 & 16,92 \\
\hline 1905 & 16.97 & 7.68 & 15.54 & 27.45 & 17.73 & 17.10 & 1949 & 17.04 \\
\hline 1906 & 16.80 & 7.03 & 15.70 & 26.58 & 16.93 & 16.56 & 1950 & 18.012 \\
\hline 1907 & 17.05 & 8.17 & 16,49 & 25.97 & 17.67 & 17,08 & 1951 & 17.33 \\
\hline 1908 & 16.39 & 7.13 & 16.10 & 26.24 & 16.53 & 16.50 & 19,52 & 17.14 \\
\hline 1909 & 16.40 & 7.33 & 15,00 & 27.11 & 17.42 & 16.72 & 1953 & 17.14 \\
\hline 1910 & 17.91 & 5.18 & 18.30 & 27.76 & 18.56 & $1 \%, 45$ & 1954 & 18.03 \\
\hline 1911 & 16.52 & 7.75 & 16.33 & 26,60 & 16,96 & 16.91 & 1955 & 16.75 \\
\hline 1912 & 15.90 & 5.92 & 14.86 & 26.42 & 16.14 & 15.84 & 1956 & 17.39 \\
\hline 1913 & 15.90 & 4,66 & 15.29 & 25.90 & 17.47 & 15.83 & 1957 & 17.57 \\
\hline 1914 & 17.12 & 6.71 & 16.93 & 26.78 & 18.39 & 17.20 & 1958 & 18.11 \\
\hline 1915 & 16.16 & 5.36 & 14.85 & 26.69 & 17.12 & 16.01 & 1959 & 18.16 \\
\hline 1916 & 16,69 & 7.41 & 17.05 & 26.46 & 16.22 & 16.78 & 1960 & 17.59 \\
\hline 1917 & 16.46 & 5.52 & 14,06 & 27.10 & 18.13 & 16.20 & $1 \% 61$ & 17.49 \\
\hline 1918 & 16.99 & 7,38 & 16,31 & 27.27 & 17.70 & 17.17 & 1962 & 17.64 \\
\hline 1919 & 17.02 & 6.10 & 16.98 & 27.52 & 16.89 & 16.87 & 1963 & 17.26 \\
\hline 1920 & 16.77 & 8.28 & $15.71)$ & 26,94 & 16.65 & 16.92 & 1904 & 16.45 \\
\hline 1921 & 17.91 & 7,34 & 16.95 & 27.57 & 18.54 & 17.60 & 1965 & 16.76 \\
\hline 1922 & 17.00 & 7,00 & 15.53 & 28.04 & 17.86 & 17.11 & 1966 & 17.28 \\
\hline 1923 & 17.02 & 8.09 & 16.58 & 26.20 & 17.65 & 17.15 & 1967 & 17.49 \\
\hline $19^{\prime} 24$ & 17,02 & 6,81 & 16.39 & 27.58 & 17.66 & 17.11 & 1968 & 17.33 \\
\hline 1925 & 17.28 & 7.20 & 17.56 & 26.72 & 16.70 & 17.14 & 1969 & 17.57 \\
\hline 1926 & 17.57 & 7.35 & 17.50 & 27,05 & 18.55 & 17.61 & 1970 & 17.11 \\
\hline 1927 & 17.32 & 8.16 & 16.69 & 26.64 & 18.07 & 17.39 & 1971 & 17.05 \\
\hline 1928 & 17.21 & 6.98 & 17,18 & 26.68 & 17.76 & 17.15 & 1972 & 17.68 \\
\hline 1929 & 17.06 & 6.42 & 16.2 .2 & 27.20 & 17.89 & 16.93 & 1973 & 17.13 \\
\hline 1930 & 16.90 & 7.94 & 16.26 & 27.16 & 16.94 & 17,08 & 1974 & 17.55 \\
\hline 1931 & 17.38 & 7.24 & 17.51 & 27,64 & 17.49 & 17,47 & 1975 & 16.75 \\
\hline 1.932 & 16,90 & 5.87 & 16.57 & 27.07 & 17.174 & 16.86 & 1976 & 16.90 \\
\hline 19,33 & 16.85 & 4.67 & 15.16 & 27.67 & 19.18 & 16.67 & 1977 & 17,94 \\
\hline 1934 & 18.41 & 8.11 & 19.56 & 27.43 & 18.25 & 18.34 & 1978 & 17.65 \\
\hline 1935 & 17,06 & 8.12 & 15.83 & 27.54 & 17.15 & 17.16 & 1979 & 17.41 \\
\hline 1936 & 17.54 & 7.28 & 17.92 & 27.79 & 17.27 & 17.57 & 1980 & 17.90 \\
\hline 1937 & 16.90 & 4.78 & 16,38 & 27.50 & 18.29 & 16.73 & 1981 & 18.80 \\
\hline 1938 & 16.76 & 8.41 & 15,93 & 26.34 & 16.54 & 16.80 & 1982 & 17.52 \\
\hline 1939 & 17.13 & 6.34 & 17.10 & 27.25 & 17.46 & 17.04 & 1983 & 17.79 \\
\hline 1940 & 17.68 & 8.35 & 17.69 & 27.73 & 17.12 & 17.72 & 1984 & 18,22 \\
\hline 1941 & 16.77 & 8.84 & 15.65 & 26.26 & 16.77 & 16.88 & 1985 & 18.14 \\
\hline 1942 & 17.32 & 7,43 & 15.64 & 27,70 & 17.97 & 17.18 & 1986 & 18.85 \\
\hline 1943 & 17.59 & 8,93 & 17.48 & 27.21 & 17.47 & 17.77 & 1987 & 17.90 \\
\hline 1944 & 16.45 & 6.52 & 15.52 & 26.37 & 17.25 & 16.41 & 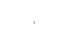 & \\
\hline
\end{tabular}

- Calendar year mean (Jan--Dec).

†Season year mean (Win $=\mathrm{Dec}-\mathrm{Feb} ; \mathrm{Spr}=\mathrm{Mar}-$ May; Sum $\Rightarrow$ Jun-Aug; lall $\Rightarrow$ Sep-Nov).

TRENDS '90 


\begin{tabular}{|c|c|c|c|c|}
\hline W/n & Spr & Sum & Inll & Anint \\
\hline 7.55 & 25.14 & 27.36 & 17.74 & 16.94 \\
\hline 6.39 & 17.18 & 27,92 & 16.50 & 17,00 \\
\hline 8.31 & 17.43 & 27,07 & 17.49 & 17.57 \\
\hline $6 .(6)$ & 15.85 & 24.52 & 17.37 & 16.86 \\
\hline 5.00 & 16.79 & 27.64 & 18,62 & 17.01 \\
\hline 7.73 & 17.63 & 27.34 & 18.54 & 17.81 \\
\hline 8.25 & 16.58 & $2 \% .50$ & 17.80 & 17.51 \\
\hline 7.32 & 16.03 & 27.41 & 18.05 & 17,20 \\
\hline 7.8 .3 & $15.7 \AA$ & 27.40 & 17.72 & 17,17 \\
\hline 8.14 & 17.46 & 27.40 & 18.60 & 17.92 \\
\hline 6.14 & 15.83 & 26.52 & 18.03 & 16.6 .3 \\
\hline 8.16 & 16.73 & 27.57 & 17.39 & 17.46 \\
\hline 9.13 & 16.13 & 28.14 & 16.69 & 17.52 \\
\hline 8.70 & 16.46 & 28.42 & 18.55 & 18.03 \\
\hline 8.67 & 17.83 & 28.47 & 18,02 & 18.25 \\
\hline 6.81 & 17.6 .3 & 28.58 & 18.00 & 17.75 \\
\hline 7.85 & {$[(6,9)$} & 28.0 .0 & 16.74 & 17.42 \\
\hline 7.68 & 16.28 & 27.29 & 18.85 & 17.53 \\
\hline 8.49 & $1 t i .28$ & 26.39 & 18.45 & 17.40 \\
\hline 6.15 & 15.37 & 26.97 & 17.06 & 16.39 \\
\hline 8.15 & 15.32 & 26.12 & 17.62 & 16.80 \\
\hline 5.98 & 17.20 & 27.58 & 18.15 & 17.23 \\
\hline 8.15 & 16.14 & 27.50 & 18.80 & 17.64 \\
\hline 8.10 & 16,43 & 26,188 & 17.87 & 17.34 \\
\hline 7.16 & 16.65 & 27.74 & 17.81 & 17.33 \\
\hline 8.54 & 15.67 & 27.95 & 16.74 & 17.22 \\
\hline 7.95 & 15.77 & 27.75 & 17.04 & 17.13 \\
\hline 7.64 & 18.10 & 27.92 & 16.82 & 17.62 \\
\hline 6.8 .5 & 15.70 & 27.70 & 17.62 & 16.99 \\
\hline 7.7 .5 & 17.53 & 27.69 & 18,03 & 17.75 \\
\hline 7.19 & 14.63 & 27.088 & 17.45 & 16.59 \\
\hline 8.46 & 16.1 .3 & 26.71 & 16.73 & 17.01 \\
\hline 8.00 & 15.34 & 28.36 & 19.04 & 17,69 \\
\hline 8.91 & 16.89 & 28.02 & 17.96 & 17.94 \\
\hline 6.57 & 16.89 & 27,30 & 18.19 & 17.23 \\
\hline 9.25 & 15.37 & 28.10 & 18.07 & 17.70 \\
\hline 10.32 & 17.68 & 29,05 & 18.46 & 18.88 \\
\hline 9.28 & 16.83 & 27.52 & 17.23 & 17.71 \\
\hline 8.39 & $15 .(10)$ & 27.37 & 19.25 & 17.65 \\
\hline 9.50 & 18.56 & 27.87 & $17,6.5$ & 18.39 \\
\hline 7.78 & 18.08 & 28.66 & 17.54 & 18.02 \\
\hline 10.48 & 19.17 & 28.87 & 17.36 & 18.97 \\
\hline 7.87 & 17.46 & 27.60 & 19.05 & 18.00 \\
\hline
\end{tabular}

\section{REFERENCES}

Karl, T.R., (1, Kukla, and J, Gavin, 1984. Decreasing diurnal temperature range in the United States and Canada from 1941 through 1980. Joumal of Climate and Applied Meteorology 23:1489-15(1)4. Karl, T.R., G. Kukla, and J, Gavin, 1986. Relationship between decreased temperature range and preclpitation trends In the United States and Canada, 1941-1980. Joumal of Climate and Applied Meteorology 26:1878-86.

Karl, T.R., C.N. Williums, Jr,, P.J. Young, and W.M. Wendland. 1986. A model to estimate the time of observation bias associated with monthly mean maximum, minimum, and mean temperatures for the United States. Joumal of Climate and Applied Meteorology 25:145-60.

K.arl, T.R., R.G. Baldwin, and M.G. Burgin. 1988a. Time series of regional seasonal averages of maxinum, minimum, and average temperature, and diurmal temperature range across the United States: 1901-1984. Historical Climatology Series 4-5. National Climatic Data Center, National Occanic \& Atmospheric Administration, National Environmental Satellite, Data, and Information Service, Asheville, North Carolina.

Karl, T.R., H.F. Diaz, and G. Kukla. 1988b. Urbanization: its detection and effect in the United States climate record. Journal of Climate 1:10999-1123.

Karl, T.R., C.N. Williams, Jr., and

F.T. Quinlan. 190). United States Historical Climatology ( $\mathrm{HCN}$ ) serial temperature and precipitation data. NDP-()19/R1. Carbon Dioxide Information Analysis Center, ()ak Ridge National Laboratory, Oak Ridge, Tennessee. 


\section{Northern Rockies}

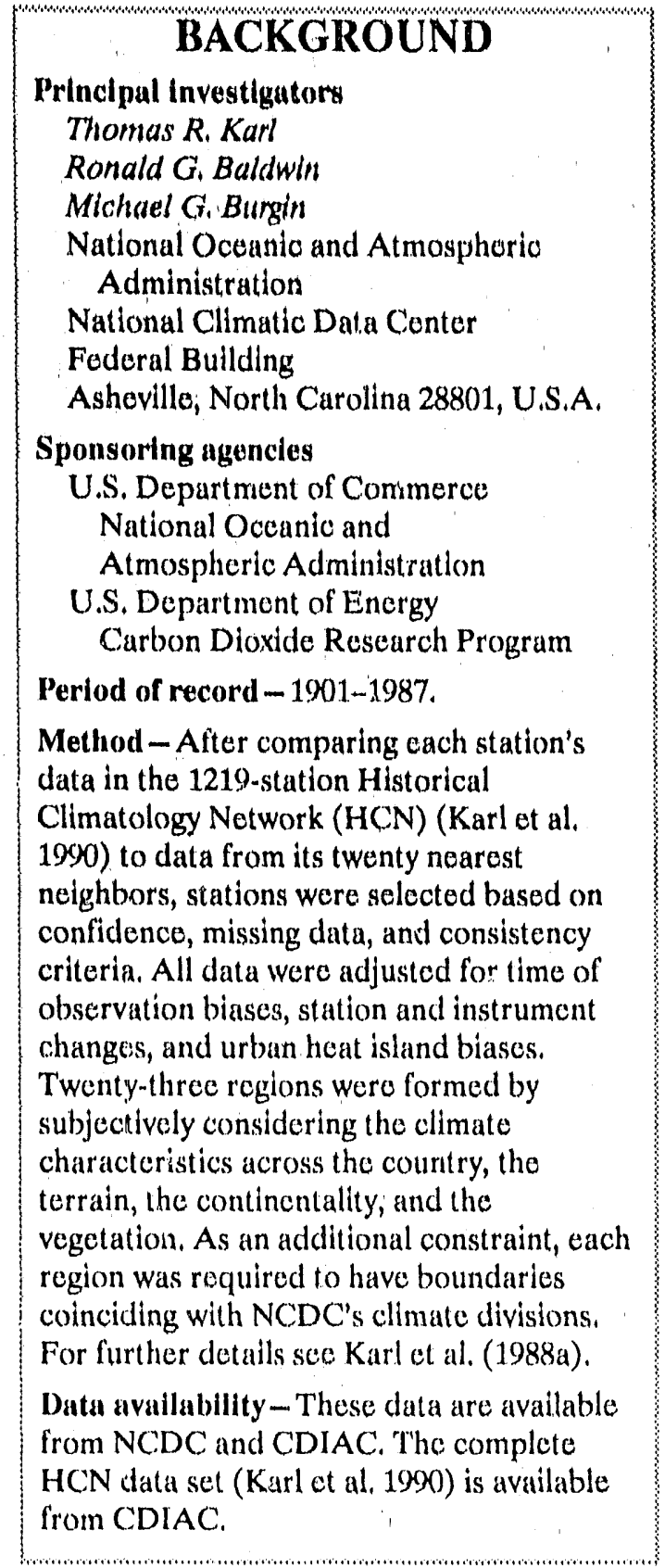

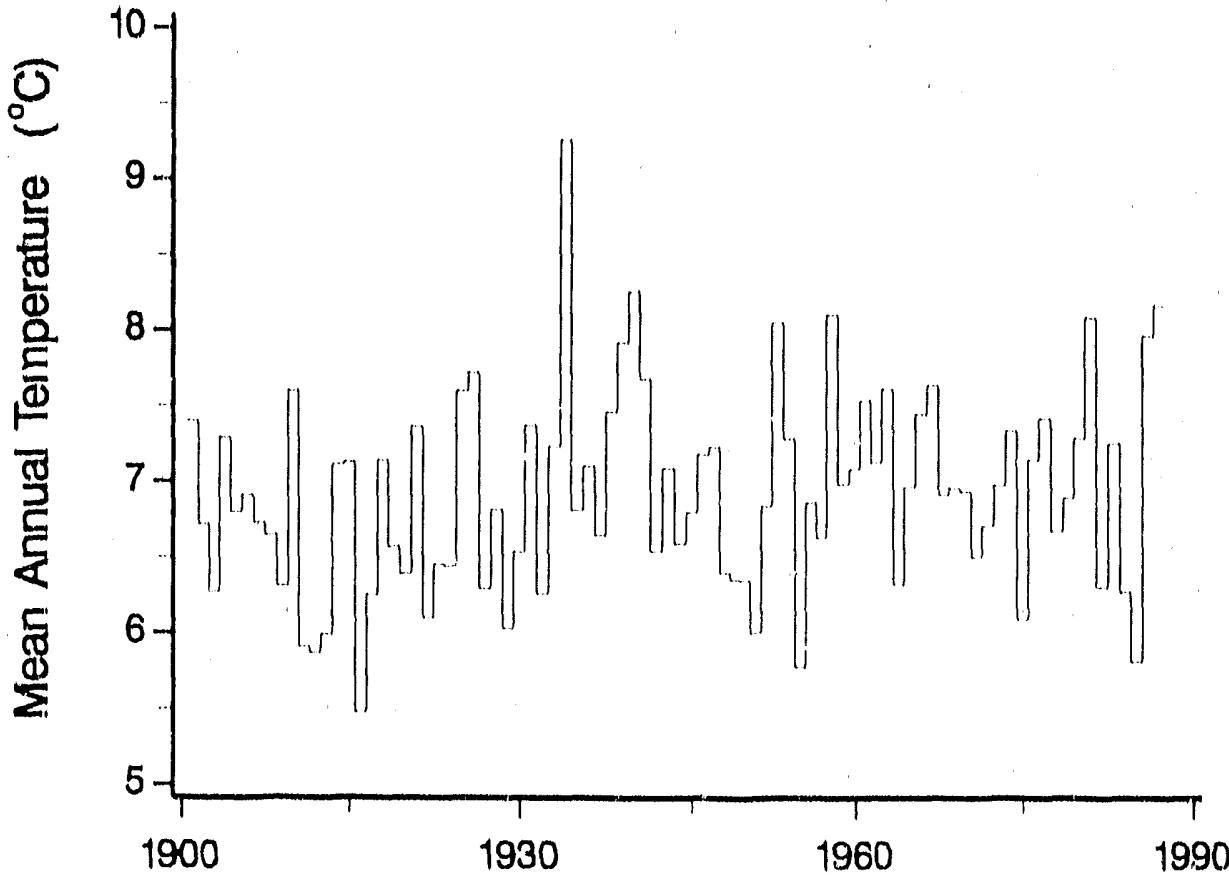

Annual calendar year average temperature.

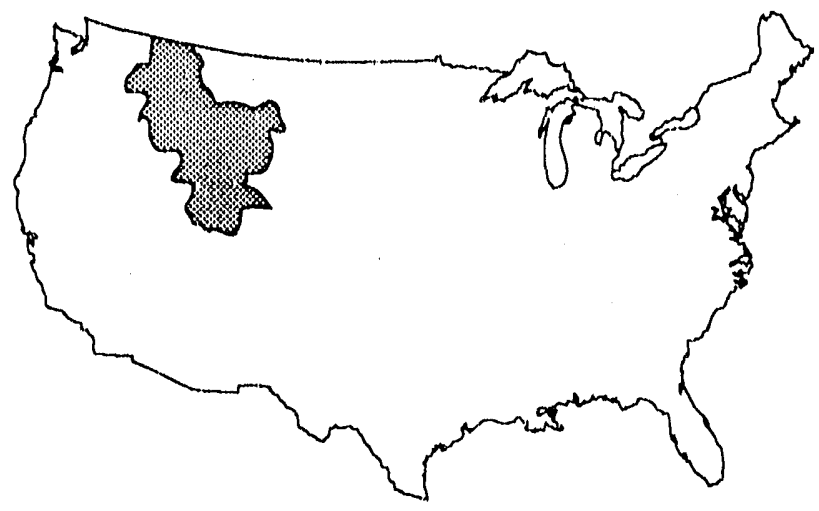

Northern Rockies 


\section{TRENDS}

On the basis of regional seasonal temperatures (i.e., maximum, minimum, average, and dilurnal range) for the United States, Karl et al. (1988a) concluded that the climate has changed over the recent century but that the changes for the nost part have not been monotonic. Instead, the changes are somewhat unsteady and sometimes occur over a relatively short period of time.

Karl et al. (1988a) also found a considerable amount of detailed information for cach regional time series but reported that their salient features often could be summarized in time series plots for three aggregated rogions: West, Central, and East. For the aggregated West region, which includes this subregion, Karl ot al. (1988:a) reported that, since the relatively cool period during tho beginning decades of the century, annual mean temperatures have remained relatively constant with the exception of a number of multiyear climate fluctuations. 


\section{Northern Rockies}

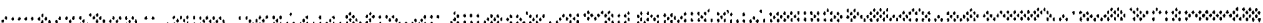

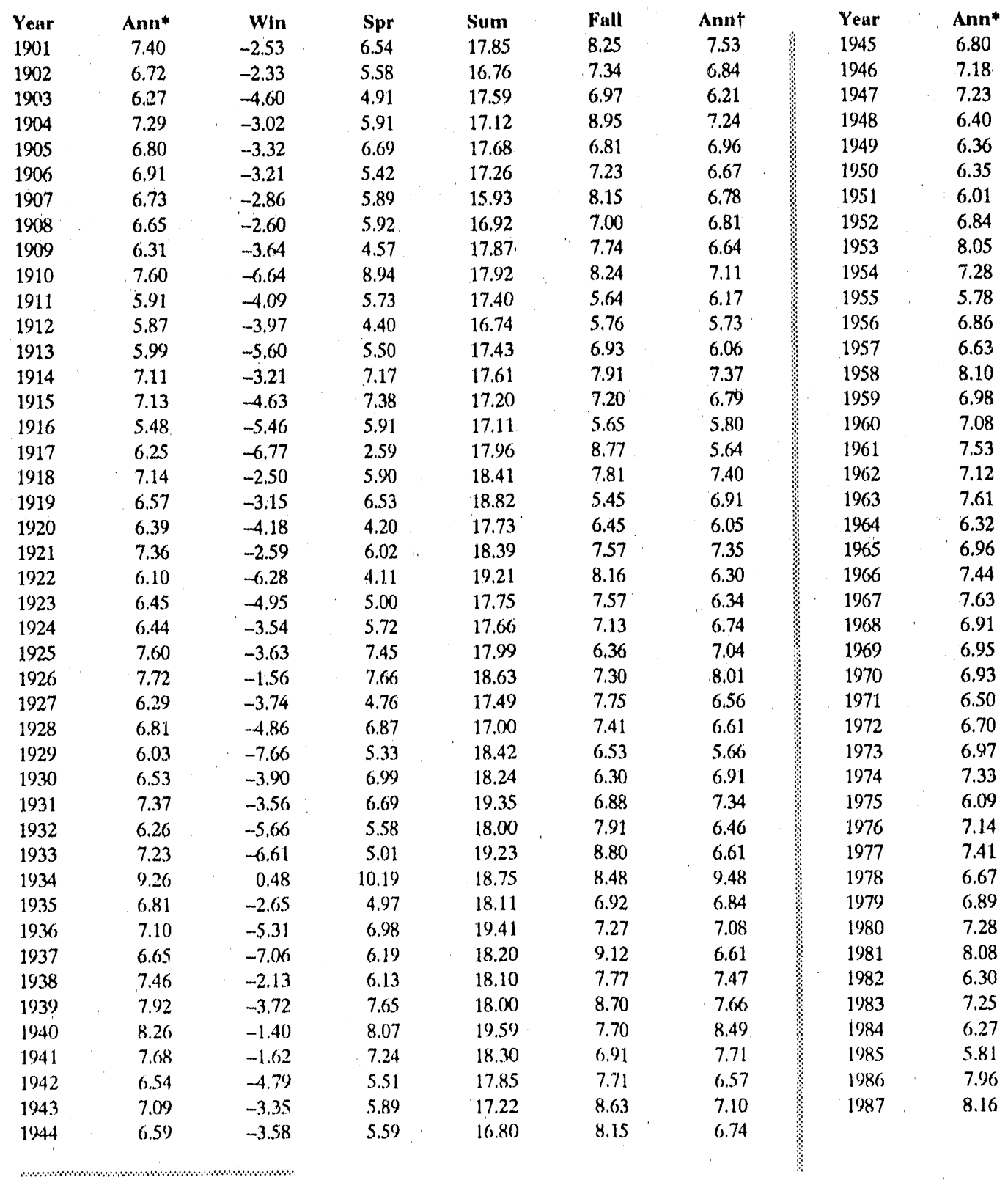

* Calendar year mean (Jan-1)ec).

tSeason year mean $($ Win $=$ Dec-Feb; Spr $=$ Mat-May; Sum = Jun-Aug; Fall $=$ Sep - Nov $)$. 


\section{Average Temperature $\left({ }^{\circ} \mathrm{C}\right)$, 1901-1987}

\begin{tabular}{|c|c|c|c|c|}
\hline Win & Spr & Sum & Full & Annt \\
\hline-2.88 & 5.32 & 17.55 & 7,28 & 6.81 \\
\hline-3.62 & 7.21 & 18.21 & 5.88 & 6.92 \\
\hline-2.71 & 7.24 & 17.50 & 7.40 & 7.36 \\
\hline-3.39 & 5.18 & 17.91 & 7.30 & 6.75 \\
\hline-8.77 & 7.37 & 17.92 & 8.02 & 6.14 \\
\hline-5.59 & 4.71 & 17.03 & 8.00 & 6.04 \\
\hline-2.45 & 5.25 & 16.89 & 6.44 & 6.53 \\
\hline-5.88 & 5.83 & 17.76 & 8.17 & 6.47 \\
\hline-0.51 & 5.38 & 17.73 & 9.50 & 8.03 \\
\hline-1.75 & 5.91 & 17.13 & 8.24 & 7.38 \\
\hline-4.72 & 3.70 & 17.76 & 6.38 & 5.78 \\
\hline-4.16 & 6.42 & 17.82 & 7.17 & 6.82 \\
\hline-4.70 & 6.10 & 17.70 & 6.78 & 6.47 \\
\hline-0.95 & 6.61 & 18.58 & 8.04 & 8.07 \\
\hline-2.17 & 5.91 & 18.23 & 6.53 & 7.13 \\
\hline-4.21 & 6.38 & 18.47 & 8.13 & 7.19 \\
\hline-1.82 & 6.36 & 20.23 & 5.68 & 7.61 \\
\hline-4.72 & 5.99 & 17.05 & 8.94 & 6.82 \\
\hline-2.37 & 6.36 & 17.69 & 9.82 & 7.87 \\
\hline-4.07 & 4.68 & 17.31 & 7.34 & 6.31 \\
\hline-2.81 & 4.98 & 17.33 & 7.90 & 6.85 \\
\hline-3.63 & 6.84 & 18.05 & 8.61 & 7.47 \\
\hline-1.67 & 5.34 & 18.56 & 8.96 & 7.80 \\
\hline-3.19 & 6.31 & 17.35 & 7.26 & 6.93 \\
\hline-4.99 & 6.56 & 17.89 & 7.26 & 6.68 \\
\hline-1.66 & 4.95 & 19.03 & 6.12 & 7.11 \\
\hline-3.27 & 5.51 & 18.32 & 5.94 & 6.63 \\
\hline-4.52 & 7.00 & 18.02 & 6.58 & 6.77 \\
\hline-5.02 & $5: 90$ & 18.13 & 7.25 & 6.56 \\
\hline-3.04 & 6.35 & 18.30 & 8.10 & 7.43 \\
\hline-3.90 & 4.01 & 17,15 & 6.73 & 6.00 \\
\hline-2.16 & 5.68 & $17: 16$ & 8.05 & 7.18 \\
\hline-2.76 & 6.27 & 18.70 & 7.53 & 7.43 \\
\hline-2.66 & 6.51 & 17.52 & 6.87 & 7.06 \\
\hline-7.34 & 6.46 & 18.29 & 8.00 & 6.35 \\
\hline$-2,42$ & 6.56 & 17.02 & 7.99 & 7.28 \\
\hline-0.74 & 7.20 & 17.99 & 8.27 & 8.18 \\
\hline-3.77 & 5.44 & 17.84 & 6.33 & 6.46 \\
\hline-1.46 & 6.01 & 17.95 & 7.99 & 7.62 \\
\hline-5.67 & 5.77 & 17.98 & 6.37 & 6.11 \\
\hline-6.64 & 7.10 & 18.56 & 4.51 & 5.88 \\
\hline-3.27 & 7.85 & 18.96 & 6.85 & 7.60 \\
\hline-2.47 & 8.57 & 17.89 & 8.86 & 8.22 \\
\hline
\end{tabular}

\section{REFERENCES}

Karl, T.R., G. Kukla, and J. Gavin. 1984. Decreasing diurnal temperature range in the United States and Canada from 1941 through 1980. Joumal of Climate and Applied Meteorology 23:1489-1504.

Karl, T.R., G. Kukla, and J. Gavin. 1986. Relationship between decreased temperature range and precipitation trends in the United States and Canada, 1941-1980. Joumal of Climate and Applied Meteorology 26:1878-86.

Karl, T'R., C.N. Williams, Jr., P.J. Young, and W.M. Wendland. 1986. A model to estimate the time of observation bias associated with monthly mean maximum, minimum, and mean temperatures for the United States. Joumal of Climate and Applied Meteorology 25:145-60.

Karl, T.R., R.G. Baldwin, and M.G. Burgin. 1988a. Time series of regional seasonal averages of maximum, minimum, and average temperature, and diumal temperature range across the United States: 1901-1984. Historical Climatology Series 4-5. National Climatic Data Center, National Oceanic \& Atmospheric Administration, National Environmental Satellite, Data, and Information Service, Asheville, North Carolina.

Karl, T.R., H.F. Diaz, and G. Kukla. 1988b. Urbanization: its detection and effect in the United States climate record. Joumal of Climate 1:1099-1123.

Karl, T.R., C.N. Williams, Jr., and F.T. Quinlan. 1990. United States Historical Climatology (HCN) serial temperature and precipitation data. NDP-019/R1. Carbon Dioxide Information Analysis Center, Oak Ridge National Laboratory, Oak Ridge, Tennessee. 


\section{Southern Rockies}

\begin{tabular}{l} 
BACKGROUND \\
Principal investigators \\
Thomas R. Karl \\
Ronald G. Baldwin \\
Michael G. Burgin \\
National Oceanic and Atmospheric \\
Administration \\
National Climatic Data Center \\
Federal Building \\
Asheville, North Carolina 28801, U.S.A \\
Sponsoring agencies \\
U.S. Department of Commerce \\
National Oceanic and \\
Atmospheric Administration \\
U.S. Department of Energy \\
Carbon Dioxide Research Program \\
Period of record - 1901-1987. \\
Method - After comparing each station's \\
data in the 1219-station Historical \\
Climatology Network (HCN) (Karl et al. \\
1990) to data from its twenty nearest \\
neighbors; stations were selected based on \\
confidence, missing data, and consistency \\
criteria. All data were adjusted for time of \\
observation biases, station and instrument \\
changes, and urban heat island biases. \\
Twenty-three regions were formed by \\
subjectively considering the climate \\
characteristics across the country, the \\
terrain, the continentality, and the \\
vegetation, As an additional constraint, each \\
region was required to have boundaries \\
coinciding with NCDC's climate divisions, \\
For further details see Karl et al. (1988a). \\
Data availability - These data are available \\
from NCDC and CDIAC. The complete \\
HCN data set: (Karl et al, 1990) is available \\
from CDIAC. \\
\hline
\end{tabular}

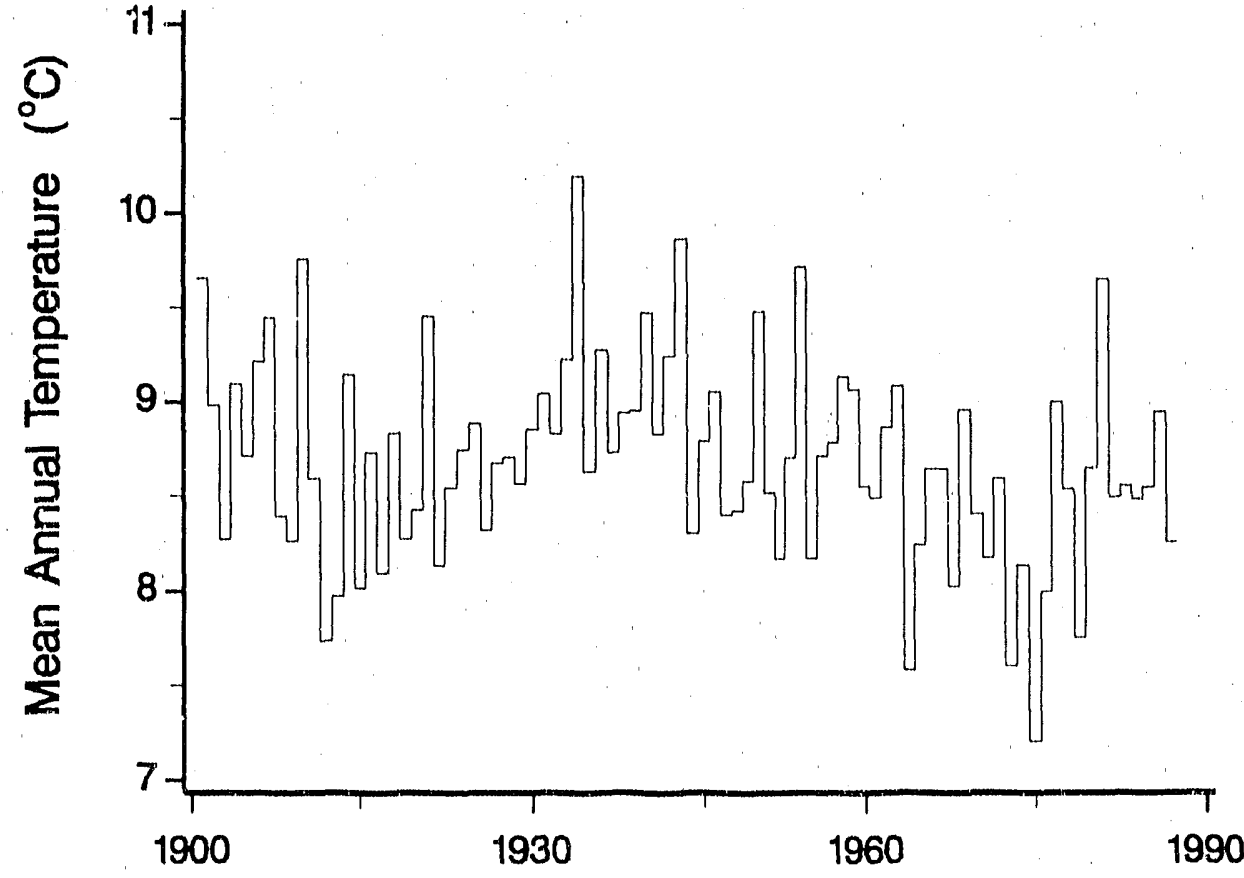

Annual calendar year average temperature.

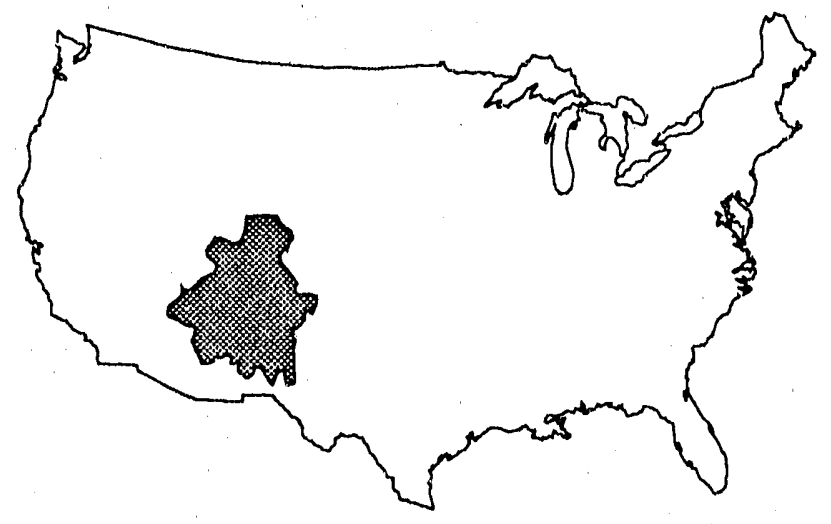

Southern Rockies 


\section{TRENDS}

On the basis of regional seasonal temperatures (i.e., maximum, minimum, average, and diurnal range) for the United States, Karl et al. (1988a) concluded that the climate has changed over the recent century but that the changes for the most part have not been monotonic. Instead, the changes are somewhat unsteady and sometimes occur over a relatively short period of time.

Karl et al. (1988a) also found a consid. erable amount of detailed information for each regional time series but reported that their salient features often could be summarized in time series plots for three aggregated regions: West, Central, and East. For the aggregated West region, which includes this subregion, Karl et al. (1988a) reported that, since the relatively cool period during the beginning decades of the century, annual mean temperatures have remained relatively constant with the exception of a number of multiyear climate fluctuations. 


\section{Southern Rockies}

\begin{tabular}{|c|c|c|c|c|c|c|c|c|}
\hline Year & Ann* & Win & Spr & Sum & Fall & Annt & Year & Ann" \\
\hline 1901 & 9.65 & -0.11 & 8.63 & 19.32 & 10.59 & 9.60 & 1945 & 8.79 \\
\hline 1902 & 8.98 & -0.91 & 8.47 & 19.37 & 9.56 & 9.12 & 1946 & 9.05 \\
\hline 1903 & 8.27 & -3.22 & 8,06 & 18.81 & 9,41 & 8.26 & 1947 & 8.40 \\
\hline 1904 & 9.09 & -1.52 & 9.67 & 18.68 & 9.40 & 9.06 & 1948 & 8.42 \\
\hline 1905 & 8.71 & -1.51 & 8.35 & 19.11 & 9.71 & 8.91 & 1949 & 8.58 \\
\hline 1906 & 9.21 & -2.24 & 8.97 & 18.65 & 9.56 & 8.73 & 1950 & 9,48 \\
\hline 1907 & 9.44 & 1.23 & 9.21 & 18.13 & 9.91 & 9.62 & 19.51 & 8.52 \\
\hline 1908 & 8.39 & -1.06 & $8: 46$ & 18.61 & 8.24 & 8.56 & 1952 & 8.17 \\
\hline 1909 & 8.26 & -1.82 & 6.32 & 19.67 & 9.92 & 8.52 & 1953 & 8.70 \\
\hline 1910 & 9.75 & -3.58 & 10.20 & 19.83 & 10.74 & 9.30 & 1954 & 9.71 \\
\hline 1911 & 8.59 & -0.45 & $9: 25$ & 18.06 & 9.02 & 8.97 & 1955 & 8.17 \\
\hline 1912 & 7.73 & -3.29 & 7.28 & 18.28 & 8.21 & 7.62 & 1956 & 8.71 \\
\hline 1913 & 7.97 & -3.98 & 7,63 & 18.76 & 9.64 & 8.01 & 1957 & 8.78 \\
\hline 1914 & 9.14 & -2.39 & 9.46 & 18.82 & 10.26 & 9.04 & 1958 & 9.13 \\
\hline 1915 & 8.01 & -3.19 & 7.42 & 18.24 & 9.07 & 7.89 & 1959 & 9.06 \\
\hline 1916 & 8.73 & -1.12 & 9.01 & 18.48 & 9.04 & 8.86 & 1960 & 8.55 \\
\hline 1917 & 8.09 & -2.96 & 5.22 & 18.43 & 10.25 & 7.74 & 1961 & 8.49 \\
\hline 1918 & 8.83 & -1.49 & 8.70 & 19.98 & 9.45 & 9.16 & 1962 & 8.86 \\
\hline 1919 & 8.27 & -3.54 & 8.42 & 18.98 & 8.64 & 8.13 & 1963 & 9.08 \\
\hline 1920 & 8.42 & -0.39 & 7.12 & 18.77 & 8.82 & 8.58 & 1964 & 7.58 \\
\hline 1921 & 9.45 & -1.42 & 8.58 & 18.52 & 10.55 & 9.06 & 1965 & 8.24 \\
\hline 192.2 & 8.13 & -1.64 & 7.02 & 19.26 & 8.71 & 8.34 & 1966 & 8.64 \\
\hline 1923 & 8.54 & -1.04 & 7.79 & 18.97 & 8.44 & 8.54 & 1967 & 8.64 \\
\hline 1924 & 8.74 & -1.23 & 7.19 & 19.81 & 9.95 & 8.93 & 1968 & 8.02 \\
\hline 1925 & 8.88 & -2.46 & 9.46 & 19.31 & 8.74 & 8.76 & 1969 & 8.95 \\
\hline 1926 & 8.32 & -2.49 & 7.73 & 18.53 & 10.15 & 8.48 & 1970 & 8.40 \\
\hline 1927 & 8.67 & -1.26 & 7.38 & 18.59 & 10.12 & 8.71 & 1971 & 8.17 \\
\hline 1928 & 8.70 & -2.59 & 8.76 & 19.00 & 9.71 & 8.72 & 1972 & 8.59 \\
\hline 1929 & 8.56 & -4.07 & 7.74 & 19.63 & 9.13 & 8.11 & 1973 & 7.60 \\
\hline 1930 & 8.85 & 0.11 & 8.24 & 19.60 & 8.67 & 9.15 & 1974 & 8.13 \\
\hline 1931 & 9.04 & -1.50 & 8.63 & 19.76 & 9.82 & 9.18 & 1975 & 7.20 \\
\hline 1932 & 8.83 & -2.81 & 8.24 & 19.41 & 9.88 & 8.68 & 1976 & 7.99 \\
\hline 1933 & 9.22 & -2.70 & 7.91 & 19.69 & 11.21 & 9.03 & 1977 & 8.99 \\
\hline 1934 & 10.19 & -0.06 & 10.89 & 19.94 & 9.95 & 10.18 & 1978 & 8.53 \\
\hline 1935 & 8.63 & -0.76 & 7.12 & 19.34 & 9.24 & 8.73 & 1979 & 7.75 \\
\hline 1936 & 9.27 & -0.92 & 9.05 & 20.09 & 9.09 & 9.33 & 1980 & 8.64 \\
\hline 1937 & 8.73 & -3.79 & 7.71 & 19.56 & 10,91 & 8.60 & 1981 & 9.64 \\
\hline 1938 & 8.94 & -0.40 & 7.69 & 19.32 & 9.13 & 8.93 & 1982 & 8.49 \\
\hline 1939 & 8.95 & $-3,02$ & 8.92 & 19.47 & 9.95 & 8.83 & 1983 & 8.55 \\
\hline 1940 & 9.47 & -0.68 & 9.10 & 19.90 & 9.93 & 9.56 & 1984 & 8.48 \\
\hline 1941 & 8.83 & -0.42 & 7.93 & 18.66 & 9.28 & 8.87 & 1985 & 8.54 \\
\hline 1942 & 9.24 & -1.68 & 8.24 & 19.68 & 10.41 & 9.16 & 1986 & 8.94 \\
\hline 1943 & 9.86 & 0.22 & 10.19 & 20.22 & 9.99 & 10.16 & 1987 & 8.25 \\
\hline 1944 & 8.30 & -2.77 & 6.66 & 19.15 & 9.6 .5 & 8.17 & & \\
\hline
\end{tabular}

"Calendar year mean (Jan-Dec).

tSeason year mean (Win $=$ Dec-leb; Spr = Mar-May; Sum =Jun-Aug; Fall $=$ Sep-Nov).

TRENDS'90 
Average Temperature $\left({ }^{\circ} \mathrm{C}\right), 1901-1987$

\begin{tabular}{|c|c|c|c|c|}
\hline W/n & Spr & Sum & Full & Annt \\
\hline-0.94 & 7.26 & 19.15 & 9,90 & 8.84 \\
\hline-1.97 & 8.84 & 19.46 & 8.89 & 8.80 \\
\hline-1.03 & 7.96 & 18.69 & 9.48 & 8.78 \\
\hline-2.54 & 6.73 & 18.94 & 9.31 & 8.11 \\
\hline-2.15 & 8.07 & 18.62 & 10.59 & 8.78 \\
\hline-0.91 & 8.59 & 17.96 & 10.92 & 9.14 \\
\hline-0.16 & 7.20 & 19.12 & 9.13 & 8.82 \\
\hline-2.18 & 6.88 & 19.20 & 9.20 & 8.27 \\
\hline-1.65 & 7.07 & 19.29 & 9.89 & 8.65 \\
\hline-0.17 & 8.81 & 18.74 & 11.04 & 9.60 \\
\hline-3.23 & 7.04 & 18.26 & 9.98 & 8.01 \\
\hline-0.89 & 8.30 & 19.09 & 9.26 & 8.94 \\
\hline 0.13 & 7.09 & 19.10 & 8.11 & 8.61 \\
\hline-0.84 & 7.20 & 19.79 & 9.69 & 8.96 \\
\hline 0.03 & 8.09 & 19.62 & 9.23 & 9.24 \\
\hline-3.07 & 8.43 & 19.55 & 10.02 & 8.73 \\
\hline-1.75 & 8.17 & 19.44 & 8.15 & 8.50 \\
\hline-1.84 & 7.21 & 18.43 & 10.60 & 8.60 \\
\hline-0.67 & 8.17 & 18.79 & 11.03 & 9.33 \\
\hline-4.07 & 6.34 & 18.61 & 9.19 & 7.52 \\
\hline-1.72 & 6.08 & 18.16 & 10.10 & 8.15 \\
\hline-3.00 & 8.75 & 19.16 & 9.81 & 8.68 \\
\hline-1.27 & 8.03 & 18.45 & 10.03 & 8.81 \\
\hline-1.80 & 6.45 & 18.14 & 9.16 & $7 .(y)$ \\
\hline-1.42 & 7.59 & 19.34 & 9.10 & 8.65 \\
\hline-0.15 & 6.57 & 19.07 & 8.63 & 8.53 \\
\hline-1.01 & 7.44 & 18.87 & 8.22 & 8.38 \\
\hline-1.78 & 9.05 & 18.71 & 8.39 & 8.59 \\
\hline-3.23 & 5.81 & 18.20 & 9.15 & 7.48 \\
\hline-3.09 & 7.95 & 18.95 & 9.47 & 8.32 \\
\hline-4.05 & 5.04 & 18.36 & 9.17 & 7.13 \\
\hline-2.23 & 6.81 & 18.33 & 8.63 & 7.88 \\
\hline-1.86 & 7.17 & 19.36 & 10.21 & 8.72 \\
\hline-0.53 & 7,58 & 18.98 & 9.79 & 8.95 \\
\hline-3.83 & $6 .(6)$ & 18.28 & 9.45 & 7.49 \\
\hline-0.52 & 5.15 & 19.42 & 9.50 & 8.39 \\
\hline 1.05 & 8.01 & 19.80 & 10.40 & 9.81 \\
\hline-0.72 & 7.54 & 18.83 & 9.29 & 8.74 \\
\hline-2.30 & 5.74 & 19.10 & 10.74 & 8.32 \\
\hline-1.80 & 7.76 & 19.04 & 9.16 & 8.54 \\
\hline-2.48 & 8.15 & 19.51 & 9.19 & 8.59 \\
\hline-0.63 & 8.57 & 19.28 & 8.48 & 8.93 \\
\hline-2.21 & 6.74 & 18.79 & 9.86 & 8.29 \\
\hline
\end{tabular}

\section{REFERENCES}

Karl, T.R., G. Kukla, and J. Gavin, 1984. Decreasing diurnal temperature range in the United States and Canada from 1941 through 1980. Joumal of Climate and Applied Meteorology 23:1489-1504. Karl, T.R., G. Kukla, and J. Gavin. 1986. Relationship between decreased temperature range and precipitation trends in the United States and Canada, 1941-1980. Joumal of Climate and Applied Meteorology 26:1878-86.

Karl, T.R., C.N. Williams, Jr., P.J. Young, and W.M. Wendland. 1986. A model to estimate the time of observation bias associated with monthly mean maximum, minimum, and mean temperatures for the United States. Joumal of Climate and Applied Meteorology 25:145-60.

Karl, T.R., R.G. Baldwin, and M.G. Burgin. 1988a. Time series of regional seasonal averages of maximum, minimum, and average temperature, and diumal temperature range across the United States: 1901-1984. Historical Climatology Series 4-5. National Clintatic Data Center, National Oceanic \& Atmospheric Administration, National Environmental Satellite, Data, and Information Service, Asheville, North Carolina.

Karl, T.R., H.F. Diaz, and G. Kukla. 1988b. Urbanization: its detection and effect in the United States climate record. Joumal of Climate 1:1099-1123.

Karl, T.R., C.N. Williams, Jr., and

F.T. Quinlan. 1990 . United States Historical Climatology (HCN) serial temperat tre and precipitation data. NDP-019/R 1. Carbon Dioxide Information Analysis Center, Oak Ridge National Laboratory, Oak Ridge, Tennessee. 


\section{Northern Steppes}

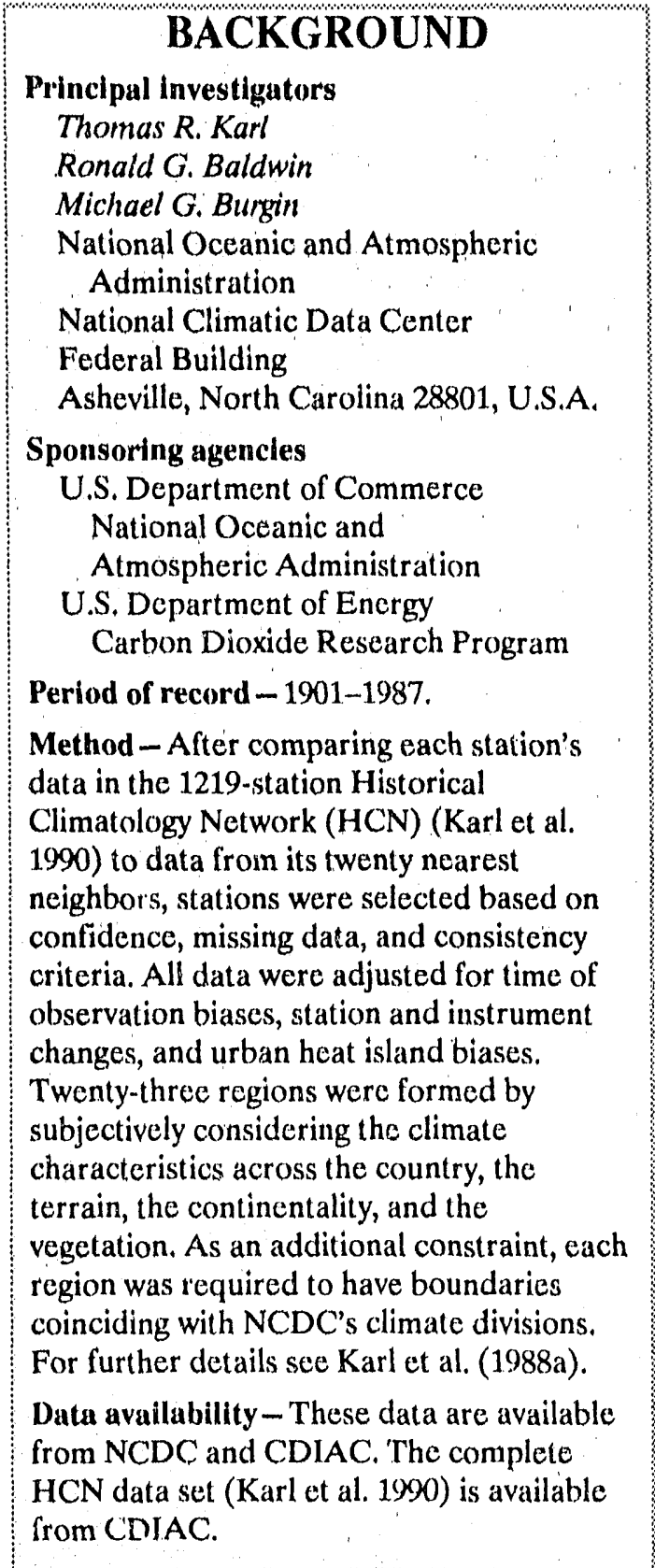

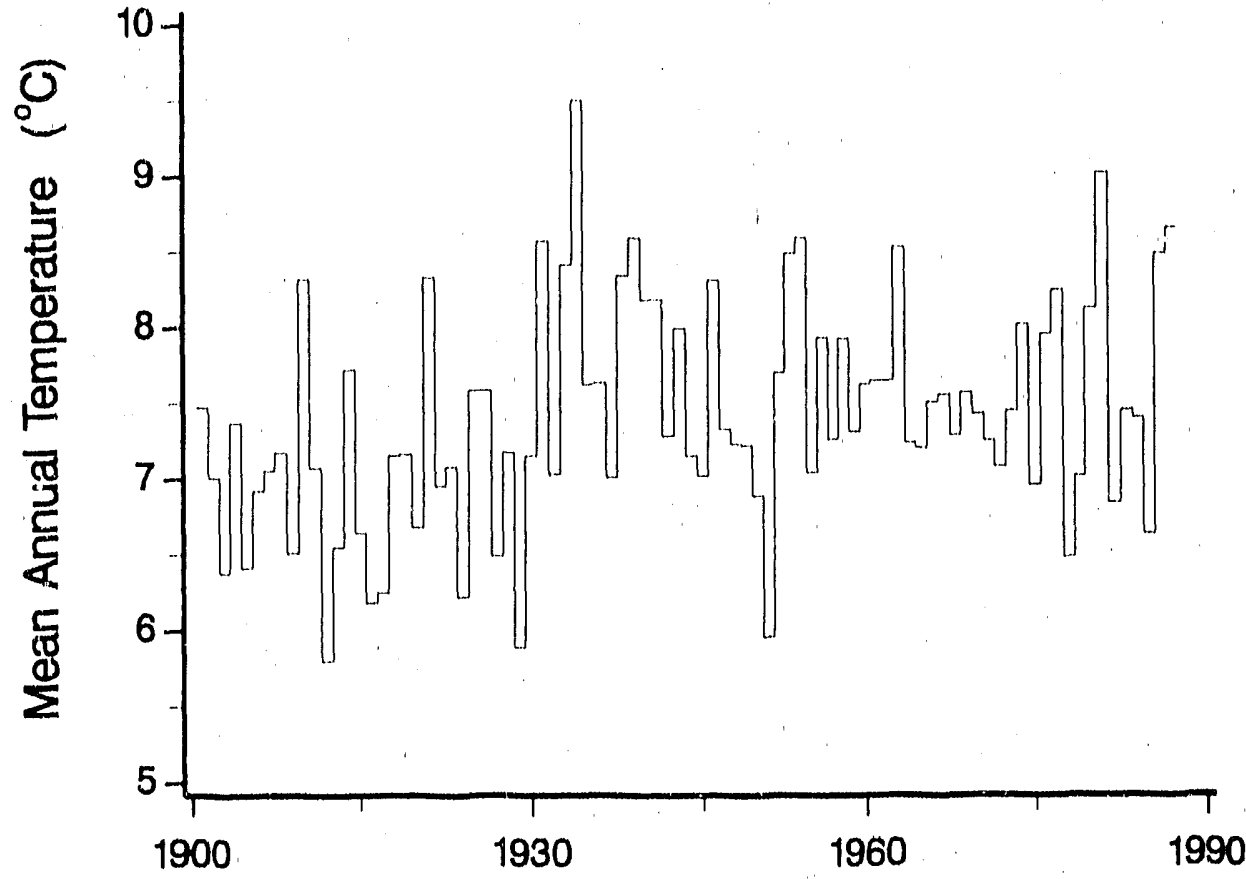

Annual calendar year average temperature.

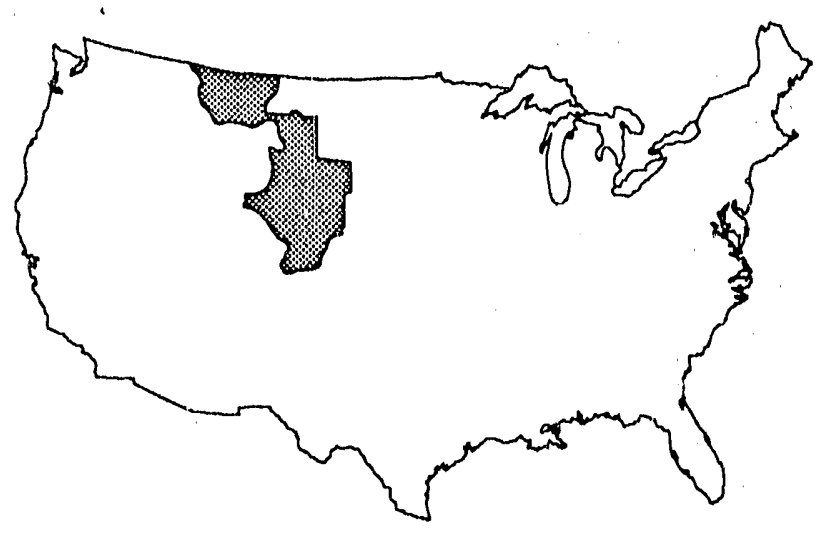

Northern Steppes 


\section{U.S. Regional Temperatures}

\section{TRENDS}

On the basis of regional seasonal temperatures (i.e., maximum, minimum, average, and diurnal range) for the United States, Karl et al. (1988a) concluded that the climate has changed over the recent century but that the changes have not been monotonic for the most part. Instead, the changes are somewhat unsteady and sometimes occur over a relatively short period of time. Karl et al. (1988a) also found a considerable amount of detailed information for each regional time series but reported that their salient features often could be summarized in time series plots for three aggregated regions: West, Central, and East. For the aggregated Central region, which includes this subregion, Karl et al. (1988a) reported that the annual average temperature time series can be divided into three epochs: a cool beginning until the 1920 s, followed by several decades of warm weather until about 1960, and a somewhat cooler period that was not as cool as earlier in the century. 


\section{Northern Steppes}

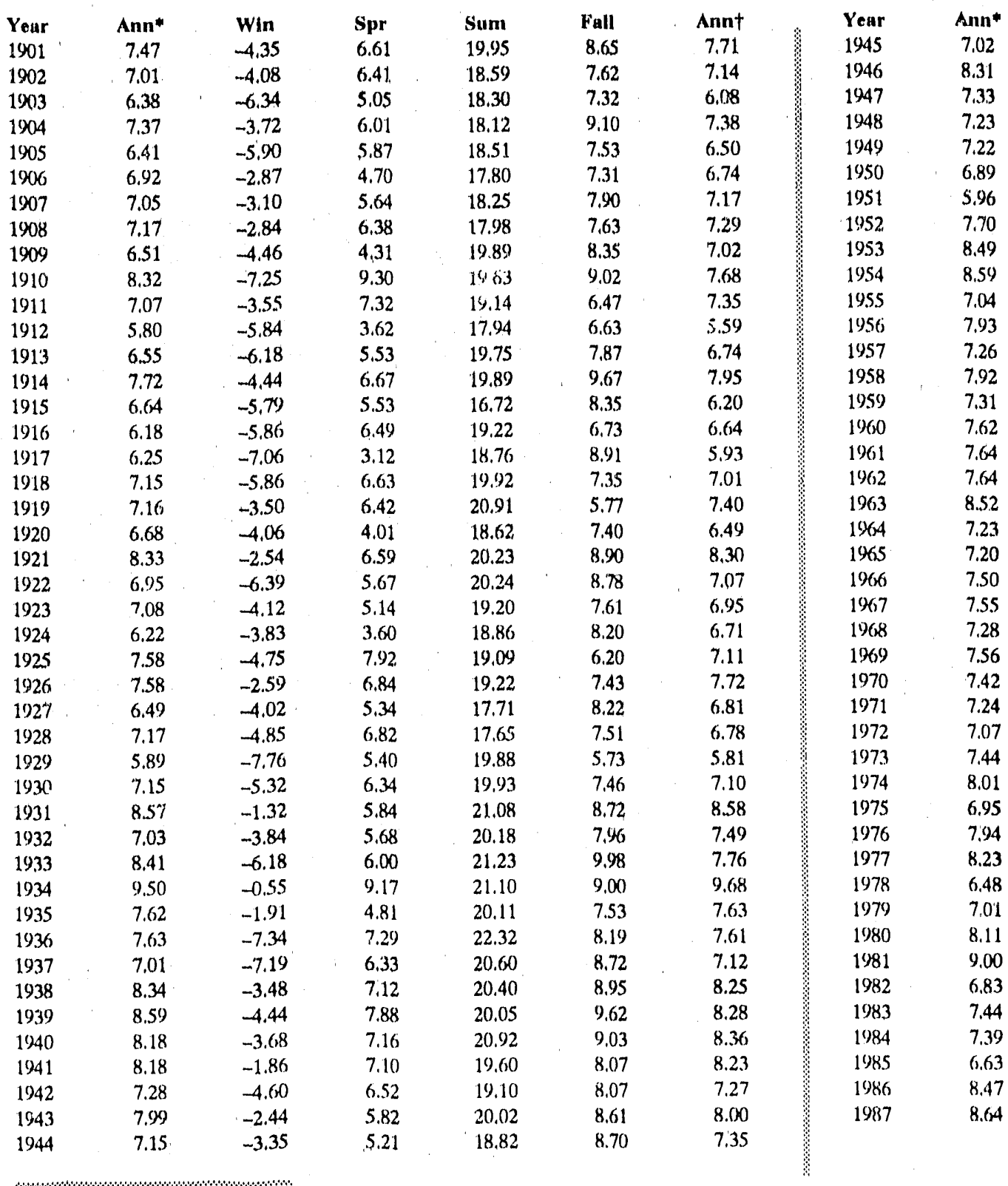

- Calendar year mean (Jan-Dec).

+Season year mean (Win = Dec-I Ieb; Spr = Mar-May; Sum = Jun-Aug; Fall $=$ Sep-Nov). 


\section{Average Temperature $\left({ }^{\circ} \mathrm{C}\right)$, 1901-1987}

\begin{tabular}{|c|c|c|c|c|}
\hline Win & Spr & Sum & Full & Annt \\
\hline-3.76 & 5.52 & 18.44 & 8.24 & 7.11 \\
\hline-2.89 & 8.15 & 19,69 & 6.84 & 7.95 \\
\hline-3.19 & 5.37 & 19.39 & 8.18 & 7,44 \\
\hline$-4,17$ & 6.28 & 19.52 & 8.35 & 7,49 \\
\hline-8.03 & 7.28 & 19.92 & 9.21 & 7.10 \\
\hline-4.37 & 4.36 & 18.18 & 8.36 & 6.63 \\
\hline-3.10 & 4.55 & 17.78 & 6.51 & 6,43 \\
\hline-4.63 & 5.86 & 20.38 & 7.95 & 7,39 \\
\hline-1.78 & 5.47 & 20.16 & 10.04 & 8.47 \\
\hline-1.22 & 5.53 & 20.31 & 9.27 & 8.47 \\
\hline-4.38 & 6.15 & 19.90 & 7.34 & 7.25 \\
\hline-4.27 & 6.32 & 20.13 & 8.63 & 7.70 \\
\hline-3.76 & 5.32 & 19.68 & 7.15 & 7,10 \\
\hline-1.06 & 5.93 & 19.03 & 8.99 & 8.22 \\
\hline-4.49 & 5.87 & 20.69 & 6.28 & 7,00 \\
\hline-4.04 & 6.57 & 20.22 & 8.95 & 7.92 \\
\hline-2.19 & 6.34 & 20.68 & 6.27 & 7.77 \\
\hline-5.65 & 6.71 & 18.80 & 9.42 & 7.32 \\
\hline-3.91 & 7.40 & 20.62 & 11,07 & 8.79 \\
\hline-4.04 & 5.51 & 19.69 & 7,94 & 7.27 \\
\hline-3.91 & 4.63 & 18.84 & 7.99 & 6.88 \\
\hline-4.80 & 7.02 & 19.91 & 8.50 & 7.66 \\
\hline-2.42 & 6.45 & 18.68 & 8.5 .5 & 7.82 \\
\hline-4.20 & 6.14 & 18.93 & 8.10 & 7.24 \\
\hline-5.31 & 6.93 & 19.55 & 7.67 & 7.21 \\
\hline-2.30 & 5.14 & 20.63 & 6.85 & 7.58 \\
\hline-4.23 & 6.07 & 20.07 & 7.21 & 7.28 \\
\hline-4.31 & 7.67 & 19.21 & 6.84 & 7.35 \\
\hline-5.31 & 5.36 & 19.94 & 7.77 & 7,07 \\
\hline-3.50 & 7.48 & 19.82 & 8.17 & $7.9)$ \\
\hline$-4,33$ & 4.68 & 19.36 & 7.650 & 6.83 \\
\hline-1.91 & 6.71 & 19.77 & 7.37 & 7.98 \\
\hline-3.24 & 7.86 & 20.35 & 8.59 & 8,39 \\
\hline-6.70 & 6.87 & 19.44 & 7.87 & 6.87 \\
\hline-8.71 & 6.42 & 19.42 & 8.31 & 6.36 \\
\hline-3.58 & 6.53 & 20,48 & 8.76 & 8.05 \\
\hline-0.66 & 8.19 & 19.91 & 9.41 & 9.21 \\
\hline-4.68 & 5.96 & 19.28 & 6.93 & 6.87 \\
\hline-0.97 & 4.95 & 20.38 & 8.47 & 8.21 \\
\hline-5.8 .5 & 5.98 & 20.29 & 0.91 & 0.83 \\
\hline-0.17 & 8.47 & 19.71 & 4.72 & 6.68 \\
\hline-3.16 & 8.27 & 20.29 & 7.22 & 8.15 \\
\hline-1.51 & 8.18 & 19.66 & 8.62 & 8.74 \\
\hline
\end{tabular}

\section{REFERENCES}

Karl, T,R, G, Kukla, and J. Gavin, 1984. Decreasing diurnal temperature range in the United States and Canada from 1941. through 1980. Joumal of Climate and Applied Meteorology 23:1489-1504:

Karl, T.R., G. Kukla, and J. Gavin. 1986. Relationship between decreased temperature range and precipitation trends in the United States and Canada, 1941-1980. Joumal of Climate and Applied Meteorology 26:1878-86.

Karl, T.R., C.N. Williams, Jr., P.J. Young, and W.M. Wendland. 1986. A model to estimate the time of observation bias associatod with monthly mean maximum, minimum, and mean temperatures for the United States. Joumal of Climate and Applied Meteorology 25:145-60.

Karl, T.R., R.G. Baldwin, and M.G. Burgin. 1988a. Time series of regional seasonal averages of maximum, minimum, and average temperature, and diumal temperature range across the United States: 1901-1984. Historical Climatology Series 4-5. National Climatic Data Center, National Oceanic \& Atmospheric Administration, National Environmental Satellite, Data, and Information Service, Asheville, North Carolina.

Karl, T.R., H.F, Diaz, and G. Kukla. 1988 b. Urbanization: its detection and effect in the United States climate record. Joumal of Climate 1:10(1)--1123.

Karl, T.R., C.N. Williams, Jr., and

F.T. Quinlan, 1990. United States Historical Climatology (HCN) serial temperature and precipitation data. NDP..019/R1, Carbon Dioxide Information Analysis Center, Oak Ridge National Laboratory, Oak Ridge, Tennessec. 


\section{Southern Steppes}

BACKGROUND
Principal investigators
Thomas R. Karl
Ronald G. Baldwin
Michael G. Burgin
National Oceanic and Atmospheric
Administration
National Climatic Data Center
Federal Building
Asheville, North Carolina 28801, U.S.A.
Sponsoring agencles
U.S. Department of Commerce
National Oceanic and
Atmospheric Administration
U.S. Department of Energy
Carbon Dioxide Research Program
Period of record - 1901-1987.
Method-After comparing each station's
data in the 1219-station Historical
Climatology Network (HCN) (Karl et al.
1990) to data from its twenty nearest
neighbors, stations were selected based on
confidence, missing data, and consistency
criteria. All data were adjusted for time of
observation biases, station and instrument
changes, and urban heat island biases.
Twenty-three regions were formed by
subjectively considering the climate
characteristics across the country, the
terrain, the continentality, and the
vegetation. As an additional constraint, each
region was required to have boundaries
coinciding with NCDC's climate divisions.
For further details see Karl et al. (1988a).
Data availability - These data are available
from NCDC and CDIAC. The complete
HCN data set (Karl et al. 1990) is available
from CDIAC.
a
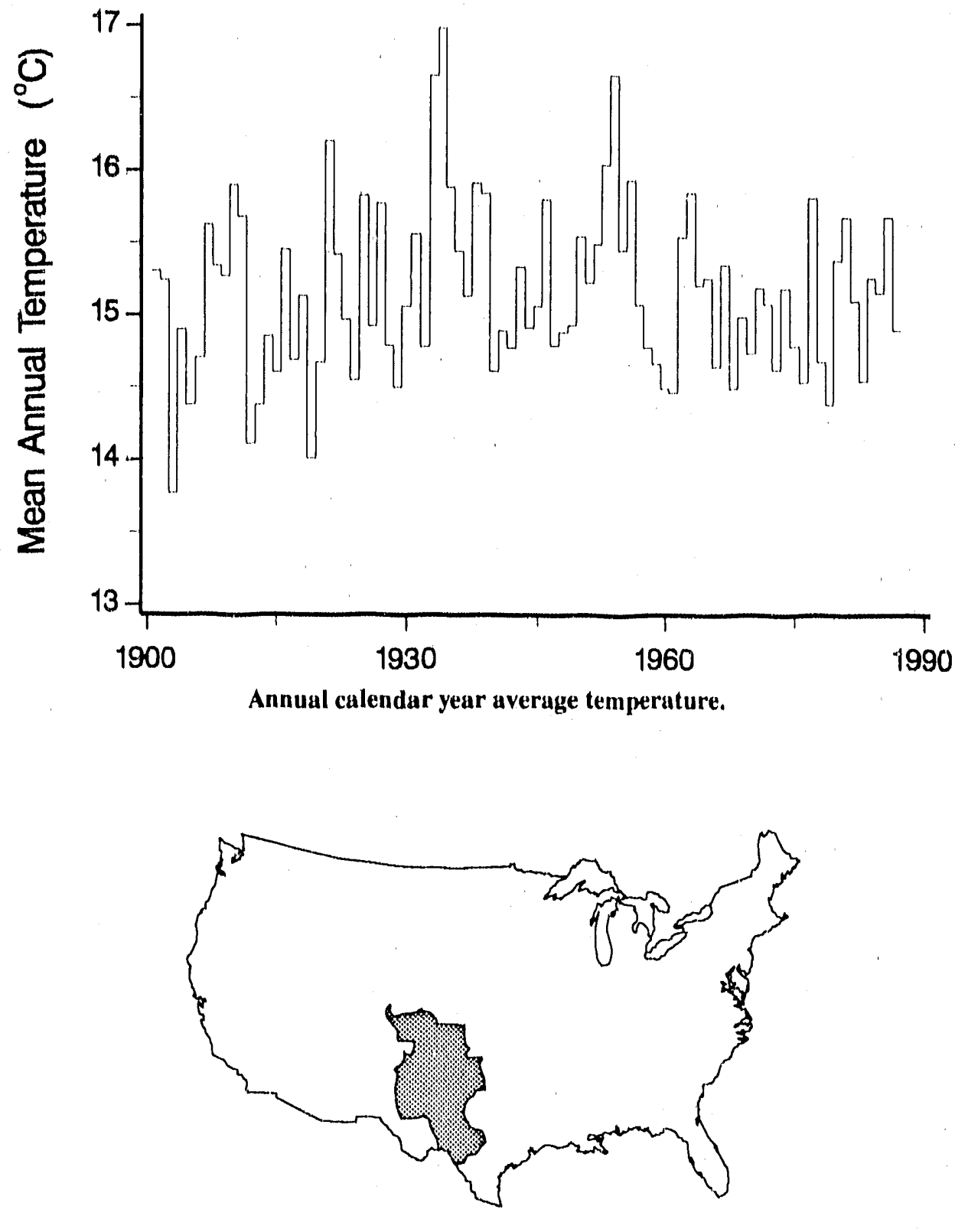

Southern Steppes 
U.S. Regional Temperatures

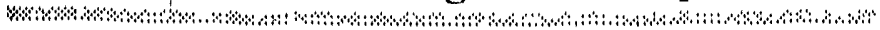

\section{TRENDS}

On the basis of regional seasonal temperatures (i.e., maximum, minimum, average, and diurnal range) for the United States, Karl ot al. (1988a) concluded that the climate has changed over the recent century but that the changes have not been monotonic for the most part. Instead, the changes are somewhat unsteady and sometimes occur over a relatively short period of time. Karl et al. (1988a) also found a considerable amount of detailed information for each regional time series but reported that their salient features often could bo summarized in time scrics plots for three aggregated regions: West, Central, and Eust. For the aggregated Central region, which includes this subregion, Karl et al. (1988a) reported that the annual average temperature time series can be divided into three epochs: a cool beginning until the 1920 s, followed by several decades of warm weather until about 1960), and a somewhat co. ler period that was not as cool as earlier in sile century. 


\section{Southern Steppes}

\begin{tabular}{|c|c|c|c|c|c|c|c|c|}
\hline Yeur & $A n n^{*}$ & W/n & Spr & SilIII & fiall & Annt & Yeur & Ann* \\
\hline 1001 & 15.30 & 4.33 & 14.27 & 20.51 & 16.47 & 15,39 & 1445 & $15.0 \mathrm{~K}$ \\
\hline $1 \% 12$ & 15.24 & 3.81 & 16,15 & 25.57 & 15.47 & 15.25 & 1946 & 15.80 \\
\hline $1 \%(1,3$ & 13.77 & 2.79 & 13.70 & 23.79 & 14.55 & 13,71 & 1947 & 14,79 \\
\hline $19(1) 4$ & 14.90 & 4.97 & 15.53 & 24,00 & 15.24 & 14,94 & 1948 & 14.88 \\
\hline 1905 & 14.38 & 1.64 & 15.30 & 25.13 & 16.013 & 14.5 .3 & 1949 & 14.93 \\
\hline 1906 & 14.70 & 4.21 & 14.13 & 24.23 & 14.42 & 14.25 & 1950 & 15.54 \\
\hline 1907 & 15.62 & 7.74 & 15.27 & 25.16 & 15.49 & 15.92 & 19,51 & 15.22 \\
\hline 1908 & 15.34 & $S .(x)$ & 15,94 & 24.82 & 14.98 & 15.21 & 1952 & 15.49 \\
\hline 1909 & 15.27 & 6.20 & $14,4,3$ & 26.09 & 16.24 & 15.74 & 1953 & 16.04 \\
\hline 1910 & $1.5,90$ & 2.73 & 16.16 & 26.31 & 16.73 & 15.48 & 1954 & 16,660 \\
\hline 1911 & 15.68 & 6.00 & 15.98 & 26.38 & 15.51 & 15.97 & 1955 & 15.45 \\
\hline 1912 & 14.11 & 1,98 & 13.67 & 24,97 & 15.27 & 13,98 & 1956 & 15.93 \\
\hline 1913 & 14.38 & 2.80 & 14.60 & 25.41 & 15.08 & 14.47 & 1957 & 15.07 \\
\hline 1914 & 14.85 & 4.41 & 14.31 & 25.17 & $16,00)$ & 14.97 & 1958 & 14.77 \\
\hline 1915 & $14.6(0)$ & 3,40 & $12 . \%$ & 24.10 & 16.26 & 14.18 & 1950 & 14.661 \\
\hline 1916 & $15,4.5$ & 5.75 & 15.88 & 25.74 & 15.02 & 15,60 & $1 \% 60$ & 14.49 \\
\hline 1917 & 14.60 & 4.6 .5 & 13.28 & 25.46 & 15.40 & 14.70 & 1961 & 14.46 \\
\hline 1918 & 15.13 & 3.42 & 15.6 .3 & 26.77 & 14.611 & 15.11 & 1962 & 15.53 \\
\hline 1919 & 14.01 & 2.95 & 14,08 & 24.11 & 1.5 .11 & 14,06 & 196.3 & 15.84 \\
\hline 1920 & 14.67 & 4.75 & 14.23 & 24.31 & 15.21 & 14.63 & 1964 & 15.20 \\
\hline 1921 & 16.20 & 5.83 & 15.54 & 25.52 & 17.05 & 15.99 & 1965 & 15.25 \\
\hline 1922 & 1.5 .42 & 4.8 .3 & 14,61 & 25.88 & 16.18 & 15.38 & 1966 & 14.64 \\
\hline 1923 & 14.97 & 6.37 & 13,98 & 25.73 & 14.56 & 15.16 & $15 \times 17$ & 15.34 \\
\hline 1924 & 14.55 & 4.18 & 12.75 & 25.96 & 16.42 & $14,8.3$ & 1968 & 14.49 \\
\hline 1925 & 15.82 & 3.89 & 17.49 & 26.46 & 14.80 & 15.66 & 1909 & 14.98 \\
\hline 1926 & 14,92 & 4.92 & 13.67 & 24,90 & $16.0^{\prime} 7$ & 14.89 & 1970 & 14.73 \\
\hline 1927 & 15.77 & 5.43 & 16.17 & 24.88 & 17.18 & 1.5 .91 & 1971 & 15.18 \\
\hline 1928 & 14.79 & 3,79 & 14.51 & 24.89 & 15.27 & 14.61 & 1972 & 15.07 \\
\hline 1929 & 14.50 & 2,83 & 1.5 .17 & 25,68 & 14.01 & 14.42 & 1073 & 14.62 \\
\hline 1930 & 15.06 & 4.31 & 15.33 & 25.82 & 15.49 & 1.5 .24 & 1974 & 15.18 \\
\hline 1931 & 15.56 & 4.78 & 13,02 & 25.8 .5 & 17.92 & 15.39 & 1975 & 14.78 \\
\hline 19.32 & 14.78 & 5.71 & 14,41 & 25.77 & 14.51 & 15.10 & 1976 & 14.53 \\
\hline 1933 & 16.65 & 3.88 & 15.86 & 26.49 & 18,01 & 16.06 & 1077 & 15,80 \\
\hline 19.34 & 16.98 & 6.84 & 16.34 & 27.98 & 17.48 & 17.16 & 1978 & 14.67 \\
\hline 193.5 & 15.88 & 0.67 & 15.60 & 26,23 & 15.55 & 16.01 & 1979 & 14.38 \\
\hline 1936 & 15.44 & 3.53 & 16.28 & 26.88 & 14.70 & 15.35 & 1080 & 15.37 \\
\hline 1937 & 15.13 & 3.85 & 14.97 & 26.63 & 15.65 & 15.27 & 1981 & 15.67 \\
\hline 1938 & $15.9 !$ & 5.41 & 16.02 & 25.84 & 15.86 & 15.78 & 1982 & 15.09 \\
\hline 1939 & 15.84 & 4.79 & 15.79 & 26.07 & 16.39 & 15.76 & 1983 & 14.54 \\
\hline 1940 & 14.61 & 3.40 & 14.98 & 24.76 & 15.47 & 14.65 & 1984 & 15.25 \\
\hline 1941 & 14.89 & 5.41 & 13.94 & 24.35 & 15.91 & 14.90 & $19 k 5$ & 15.15 \\
\hline 1942 & 14.77 & 4.24 & 14.50 & $25 .(10)$ & 15.40 & 14.81 & 1986 & 15.67 \\
\hline 1943 & 15.33 & 5.8 .3 & 14.86 & 26.57 & 14.78 & 15.51 & 1987 & 14.89 \\
\hline 1944 & 14.91 & 4.42 & 13.87 & 25.53 & 15.65 & 14.86 & & \\
\hline
\end{tabular}

- Calendar year mean (Jan-1)ec).

tSeason year mean $=($ Win $=1$ ec-leb; Spr $=$ Mur-May; Sum $=$ Jun-Augi Fall $=$ Sep-Nov $)$.

TRENDS '90) 


\section{Average Temperature $\left({ }^{\circ} \mathrm{C}\right), 1901-1987$}

\begin{tabular}{|c|c|c|c|c|}
\hline Wh & Spr & Sum & Full & Annt \\
\hline 4,48 & 15,03 & 24.77 & 16.07 & $15.06)$ \\
\hline 4.69 & 16.16 & 25.70 & 15.37 & 15,48 \\
\hline 4,47 & 13.57 & 25.54 & 16.40 & $1,5,00$ \\
\hline 3,10 & 15.07 & 25.61 & 15.21 & 14.75 \\
\hline 4,02 & 14.70 & 24.96 & 16,22 & 14,98 \\
\hline 6.3 .3 & 14,81 & 24.76 & 16,30 & 15.55 \\
\hline$\$, 0.3$ & 14,60 & 25.91 & 15.35 & 15,22 \\
\hline 6,82 & 14.03 & 20,95 & 14.59 & $15,(8)$ \\
\hline 6.07 & 15.45 & 26.81 & 16.07 & 16.10 \\
\hline 6.18 & 15.34 & 27.15 & 16.96 & 16,41 \\
\hline 5.09 & 15.9 .3 & 25.24 & 1.5 .98 & 15.56 \\
\hline 4.81 & 15.77 & 26,48 & 16.28 & 15,83 \\
\hline 6.62 & 13,60 & 25.82 & 14.05 & 15.02 \\
\hline 5.17 & $1,3,03$ & 2.5 .88 & 15,81 & 14,97 \\
\hline 4.06$)$ & 14,52 & 25.21 & 14.37 & 14.54 \\
\hline 3.30 & 14.13 & 25.45 & 10.08 & 14.74 \\
\hline $.3,87$ & 14.93 & 24.39 & 14.44 & 14.41 \\
\hline 4.21 & $15 .(\gamma)$ & 25.60 & 10.53 & 15.35 \\
\hline 3,86 & 16,88 & 26.56 & 17.49 & 16.19 \\
\hline 2.61 & $15,(0)$ & 26,24 & 15.77 & 14,93 \\
\hline $5 .(12$ & 1.3 .98 & 25.18 & 16.32 & 15,12 \\
\hline $.3,32$ & 15.13 & 25.45 & 15.61 & 14.88 \\
\hline 4.80 & 16.75 & 24.87 & 15.05 & 15.37 \\
\hline 3.97 & 13.94 & 24.73 & 15.1 .3 & 14,44 \\
\hline 5,35 & 13.41 & 25.72 & 14.78 & 14.81 \\
\hline $5,0.5$ & 13.65 & 25.40 & 14.33 & 14.61 \\
\hline 0,07 & 14.81 & 24.97 & 15.31 & 15,29 \\
\hline 5,64 & 16.48 & 24.93 & 14.49 & 15.39 \\
\hline $3 .(x)$ & 13.75 & 24,660 & 16.20 & 14.40 \\
\hline 4.76 & 16,87 & 25,12 & 14.42 & 15.29 \\
\hline $4,3,3$ & 14.17 & 24.84 & 14.98 & 14.58 \\
\hline 6.34 & 14.68 & 24.63 & $\left.13,0^{4}\right)$ & 14.68 \\
\hline 3.92 & 15.33 & 26.28 & 16.94 & 15.6 .3 \\
\hline 2.46 & 15.47 & 25,05 & 15.88 & 14,94 \\
\hline 1.94 & 14,62 & 24.74 & 15.31 & 14.15 \\
\hline$S .(x)$ & 13.86 & 27.10 & 15.21 & 15.29 \\
\hline 5.89 & 15.52 & 25.60 & 16.11 & 15,78 \\
\hline 4.10 & 15.23 & 25.45 & 15.77 & 15,14 \\
\hline 4.43 & 13.41 & 25.40 & 16.65 & 14,97 \\
\hline 2.58 & $14,6.5$ & 25.95 & 1.5 .08 & 14.56 \\
\hline 4.51 & 16.35 & $25,6,5$ & 15.6 .5 & 1.5 .54 \\
\hline 5.61 & $|6,2|$ & 25.413 & 1.5 .07 & 15,58 \\
\hline $4 . \%$ & 14.12 & 25.11 & 15.52 & 14.9 .3 \\
\hline
\end{tabular}

\section{REEERENCES}

Karl, T.R., G. Kukla, and J. Gavin, 1984. Decteasing diurnal temperature range in the United States and Canada from 1941 through 1980. Journal of Climate and Applied Muteorology 23:1489-1504.

Karl, T.R., G. Kukla, and J. Gavin, 1986. Relationship between decreased temperaturo range and precipitation trends in the United States and Canada, 1941-1980. Journal of Climate and Applied Mateorology 26:1878-86.

Karl, T.R., C.N. Williams, Jr, P.J. Young, and W.M. Wendland. 1986. A model to estimate the time of observation bias associated with monthly mean maximum, minimum, and mean temperatures for the United States. Journal of Climate and Applied Meleorology 25:145-60).

Karl, T.R., R.G. Baldwin, M.G. Burgin. 1988a. Time series of regional seasonal avernges of maximum, minimum, and average temperature, and diumal temperature range across the United States: 19()1-1984. Historical Climatology

Series 4-5. National Climatic Data Center. National Occanic \& Atmospheric Administration. National Environmental Satellite, Data, and Information Service. Asheville, North Carolina.

Karl, T.R., H.F. Diaz, and G. Kukla. 1988b. Urbanization: its delection and effect in the United States climate record. Joumal of Climate 1:10:99-1123.

Karl, T.R., C.N. Williams, Jr., and F.T. Ouinlan, 1990). United States' Historical Climatology ( $H C N$ ) serial temperature and precipitation data. NDP-019/R1. Carbon Dioxide Information Analysis Center. Oak Ridge National Laboratory. Oak Ridge, Tennessec. 


\section{Northern Plains}

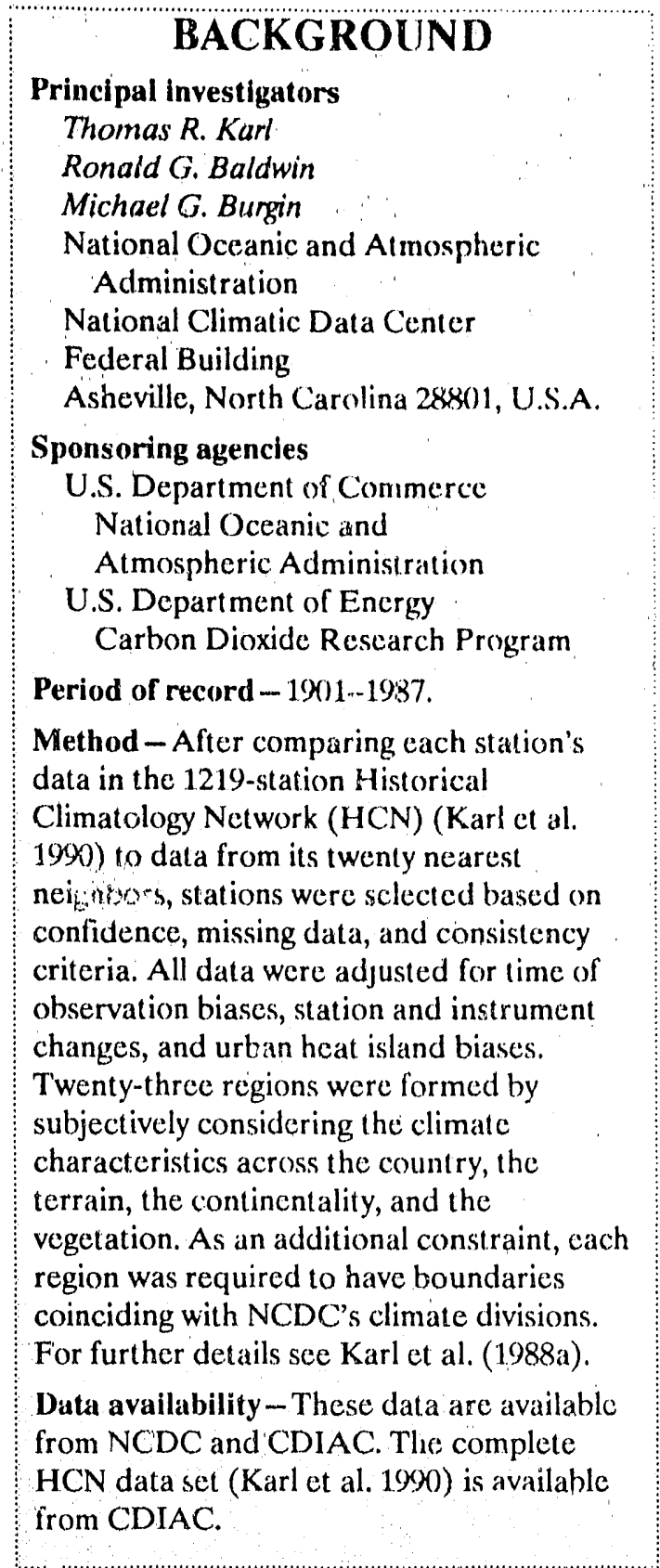
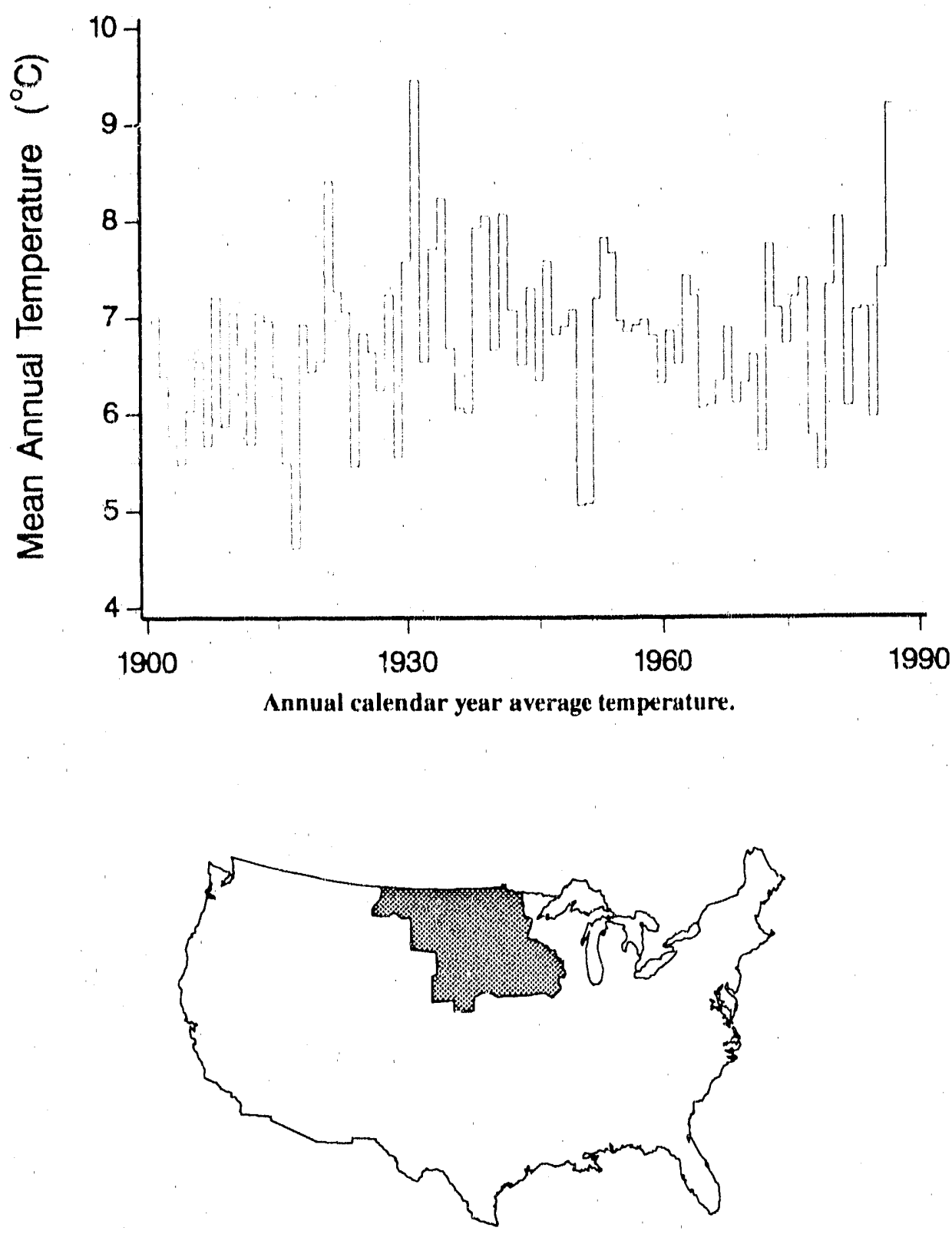

Northern Plains 


\section{U.S. Regional Temperatures}

\section{TRENDS}

On the basis of regional seasonal temperatures (i.e., maximum, minimum, average, and diurnal range) for the United States, Karl et al. (1988a) concluded that the climate has changed over the recent century but that the changes have not been monotonic for the most part. Instead, the changes are somewhat unsteady and sometimes occur over a relatively short period of time. Karl et al. (1988a) also found a considerable amount of detailed irformation for cach regional time series but reported that their salient features often could be summarized in time series plots for three aggregated regions: West, Central, and East. For the aggregated Central region, which includes this subregion, Karl et al. (1988a) reported that the annual average temperature time series can be divided into three epochs: a cool beginning until the 1920 s, followed by several decades of warm weather until about 1960, and a somewhat cooler period that was not as cool as earlier in the century. 


\section{Northern Plains}

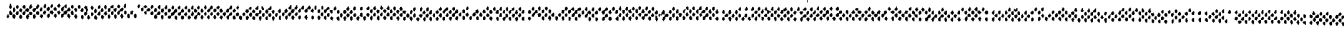

\begin{tabular}{|c|c|c|c|c|c|c|c|c|}
\hline Year & Ann* & Win & Spr & Sum & Fall & Ann $\dagger$ & Year & Ann* \\
\hline 1901 & 7.01 & -8.20 & 7.28 & 22.15 & 8.01 & 7.31 & 1945 & 6.34 \\
\hline 1902 & 6.39 & -8.70 & 7.60 & 19.11 & 7.89 & 6.47 & 1946 & 7.58 \\
\hline 1903 & 5.77 & -10.10 & 7,00 & 18.86 & 7.25 & 5.76 & 1947 & 6.82 \\
\hline 1904 & 5.48 & -12.20 & 5.39 & 18.74 & 9.14 & 5.27 & 1948 & 6.91 \\
\hline 1905 & 6.03 & -11.30 & 6.69 & 19.78 & 8.36 & 5.88 & 1949 & 7.08 \\
\hline 1906 & 6.54 & -6.80 & 5.69 & 19.65 & 8.18 & 6.68 & 1950 & 5.05 \\
\hline 1907 & 5.67 & -9.38 & 4.04 & 19.60 & 7.55 & 5.45 & 1951 & 5.07 \\
\hline 1908 & 7.21 & -5.98 & 6.69 & 19.40 & 9.34 & 7.36 & 1952 & $7.19^{\prime}$ \\
\hline 1909 & 5.87 & -8.28 & 4.53 & 20.91 & 8.20 & 6.34 & 1953 & 7.82 \\
\hline 1910 & 7.05 & -11.40 & 9.35 & 20.61 & 8.18 & 6.68 & 1954 & 7.601 \\
\hline 1911 & 6.71 & -8.72 & 8.20 & 20.92 & 5.83 & 6.56 & 1955 & 6.96 \\
\hline 1912 & 5.68 & -11.30 & 5.61 & 19.43 & 8.55 & 5.57 & 1956 & 6.84 \\
\hline 1913 & 7.04 & -8.43 & 5.74 & 21.43 & 8.77 & 6.88 & 1957 & 6.91 \\
\hline 1914 & 6.96 & -7.04 & 6.77 & 21.12 & 9.99 & 7.71 & 1958 & 6.97 \\
\hline 1915 & 6.38 & -9.33 & 6.37 & 17.62 & 9.01 & 5.92 & 1959 & 6.80 \\
\hline 1916 & 5.49 & -10.20 & 5.80 & 20.75 & 7.43 & 5.94 & 1960 & 6.31 \\
\hline 1917 & 4.61 & -12.60 & 4.66 & 19.53 & 7.28 & 4.71 & 1961 & 6.85 \\
\hline 1918 & 6.92 & -12.20 & 8.08 & 20.72 & 8.05 & 6.16 & 1962 & 6.51 \\
\hline 1919 & 6.43 & -5.75 & 6.34 & 21.33 & 6.42 & 7.08 & 1963 & 7.42 \\
\hline 1920. & 6.54 & -10.30 & 5.21 & 19.94 & 9.51 & 6.09 & 1964 & 7.21 \\
\hline 1921 & 8.41 & -5.07 & 8.40 & 22.23 & 7.94 & 8.37 & 1965 & 6.05 \\
\hline 1922 & 7.27 & -9.13 & 7.67 & 21.04 & 10.43 & 7.50 & 1966 & 6.08 \\
\hline 1923 & 7.05 & -8.85 & 5.09 & 20.93 & 8.99 & 6.54 & 1967 & 6.33 \\
\hline 1924 & 5.46 & -7.19 & 4.88 & 19.01 & 8.70 & 6.35 & 1968 & 6.88 \\
\hline 1925 & 6.83 & -9.83 & 8.34 & 20.49 & 6.69 & 6.42 & 1969 & 6.10 \\
\hline 1926 & 6.64 & -6.66 & 6.85 & 20.26 & 6.48 & 6.73 & 1970 & 6.31 \\
\hline 1927 & 6.24 & -7.76 & 6.72 & 18.88 & 8.51 & 6.59 & 1971 & 6.60 \\
\hline 19225 & 7.23 & -8.77 & 6.71 & 19.68 & 8.15 & 6.44 & 1972 & 5.60 \\
\hline 1929 & 5.55 & -11.10 & $6 .(x)$ & 20.66 & 6.85 & 5.85 & 1973 & 7.73 \\
\hline 1930 & 7.57 & -8.05 & 7.31 & 21.75 & 8.43 & 7.36 & 1074 & 7.08 \\
\hline 1931 & 9.45 & -3.14 & 6.75 & 22.49 & 11.07 & 9.29 & 1975 & 6.71 \\
\hline 1932 & 6.53 & -6.40 & 5.89 & 21.69 & 6.95 & 7.03 & 1976 & 7.19 \\
\hline 1933 & 7.70 & -7.75 & 6.62 & 22.64 & 8.81 & 7.58 & 1977 & 7.38 \\
\hline 1934 & 8.23 & -6.64 & 8.59 & 22.22 & 9.16 & 8.33 & 1978 & 5.77 \\
\hline 1935 & $6 .(88$ & -7.64 & 5.82 & 21.26 & 7.00 & 6.61 & 1979 & 5.41 \\
\hline 1936 & 0.06 & -14.60 & 6.94 & 23.37 & $7 . \%$ & 5.90 & 1980 & 7.31 \\
\hline 1937 & 6.01 & -11.00 & 6.10 & 22.10 & 7.69 & 6.21 & $1 \% 81$ & 8.01 \\
\hline 1938 & 7.92 & -8.57 & 7.88 & 211.80 & 9.67 & 7.70 & 1982 & 6.07 \\
\hline 1939 & 8.05 & -7.96 & 7.73 & 21.39 & 9.73 & 7.72 & 1983 & 7.05 \\
\hline 1940 & 6.66 & -7.93 & 5.34 & 21.17 & 9.15 & 6.93 & 1984 & 7.08 \\
\hline 1941 & 8.07 & -7.39 & 8.21 & 21.48 & 9.31 & 7.90 & 1985 & 5.95 \\
\hline 1942 & 7.07 & -5.74 & 7.97 & 20.29 & 7.75 & 7.57 & 1986 & 7.48 \\
\hline 1943 & 6.51 & -9.58 & 5.28 & 21.50 & 7.42 & 6.16 & 1987 & 9.17 \\
\hline 1944 & 7.31 & -5.19 & 5.65 & 20.52 & 9.09 & 7.52 & & \\
\hline
\end{tabular}

- Calendar year mean (Jan-Dec)

tSeason year mean $=($ Win $=$ Dec-Feb; Spr = Mar-May; Sum $=$ Jun-Aug; Fall $=$ Sep-Nov $)$.

TRENDS '90 


\section{Average Temperature $\left({ }^{\circ} \mathrm{C}\right), 1901-1987$}

\begin{tabular}{|c|c|c|c|c|}
\hline Win & Spr & Sum & Fall & Annt \\
\hline-7.72 & 6.98 & 19.33 & 7.84 & 6.61 \\
\hline-8.67 & 9.14 & 20.37 & 7.89 & 7.18 \\
\hline-7.29 & 4.82 & 21.18 & $\quad 9.15$ & 6.97 \\
\hline-9.42 & 6.79 & 20.85 & 9.41 & 6.91 \\
\hline-10.10 & 7.30 & 21.91 & 9.08 & 7.04 \\
\hline-10.00 & 3.70 & 19.29 & 8.20 . & 5.29 \\
\hline-9.45 & 4.65 & 19.03 & 6.16 & 5.10 \\
\hline-8.47 & 6.15 & 21.28 & 8.31 & 6.82 \\
\hline-6.66 & 6.03 & 21.41 & 10.50 & 7.82 \\
\hline-5.81 & 5.60 & 21.35 & 9.16 & 7.58 \\
\hline-8.05 & 8.36 & 22.30 & 7.39 & 7.50 \\
\hline-10.80 & 5.38 & 21.28 & 9.28 & 6.29 \\
\hline-7.90 & 6.32 & 21.15 & 7.55 & 6.78 \\
\hline-6.36 & 7.25 & 19.53 & 9.45 & 7.47 \\
\hline-10.50 & 7.44 & 22.01 & 5.93 & 6.21 \\
\hline-7.07 & 4.46 & 20.48 & 9.21 & 6.77 \\
\hline-7.28 & 6.00 & 21.07 & 8.24 & 7.01 \\
\hline-10.30 & 6.10 & 19.98 & 9.12 & 6.23 \\
\hline-9.76 & 8.16 & 21.54 & 11.49 & 7.85 \\
\hline$-7,43$ & 6.86 & 20.80 & 8.23 & 7.11 \\
\hline-10.80 & 4.86 & 20.24 & 7.42 & 5.43 \\
\hline-9.05 & 6.33 & 20.93 & 7.65 & 6.47 \\
\hline-8.75 & 6.42 & 19.53 & 7.79 & 6.24 \\
\hline-8.23 & 7.70 & 20.50 & 8.46 & 7.12 \\
\hline-10.10 & 5.82 & 20.02 & 7.89 & 5.91 \\
\hline-9.62 & 5.89 & 21.55 & 7.95 & 6.44 \\
\hline-10.10 & 6.35 & 20.76 & 9.10 & 6.53 \\
\hline-10.40 & 6.61 & 20.23 & 7.13 & 5.88 \\
\hline-8.32 & 7.90 & 21.50 & $8 . \% 9$ & 7.54 \\
\hline-8.78 & 6.91 & 20,79 & 8.19 & 0.78 \\
\hline-7.74 & 4.98 & 21.41 & 8.64 & 6.82 \\
\hline-6.15 & 7.78 & 21.87 & 6.41 & 7.48 \\
\hline-10.20 & 10.80 & 20.79 & 7.94 & 7.34 \\
\hline-12.80 & 0.6 .3 & 20.75 & 8.74 & 5.84 \\
\hline-14.60 & 4.9 .3 & 20.18 & 8.15 & 4.82 \\
\hline-7.19 & 7.35 & 21.47 & $8 .(x)$ & 7.58 \\
\hline-5.90 & 8.92 & 20.71 & 8.92 & 8.17 \\
\hline-11.30 & 6.45 & 19.98 & 7.67 & 5.72 \\
\hline-4.72 & 5.75 & 22.53 & 8.76 & 8.08 \\
\hline-9.52 & 5.51 & 21.35 & 8.07 & 6.35 \\
\hline-4.35 & 9.75 & 19.35 & 5.74 & 6.39 \\
\hline-9.59 & 8.59 & 20.75 & 7.39 & 6.79 \\
\hline-3.57 & 10.08 & 21.67 & 8.42 & 9.15 \\
\hline
\end{tabular}

\section{REFERENCES}

Karl, T.R., G. Kukla, and J. Gavin. 1984. Decreasing diurnal temperature range in the United States and Canada from 1941 through 1980. Journal of Climate and Applied Meteorology 23:1489-1504.

Karl, T.R., G. Kukla, and J. Gavin. 1986. Relationship between decreased temperature range and precipitation trends in the United States and Canada, 1941-1980. Joumal of Climate and Applied Meteorology 26:1878-86.

Karl, T.R., C.N. Williams, Jr., P.J. Young, and W.M. Wendland. 1986. A model to estimate the time of observation bias associated with monthly mean maximum, minimum, and mean temperatures for the United States. Joumal of Climate and Applied Meteorology 25:145-60.

Karl, T.R., R.G. Baldwin, M.G. Burgin. 1988a. Time series of regional seasunal averages of maximum, minimum, and average temperature, and diumal temperature range across the United States: 1901-1984. Historical Climatology Series 4-5. National Climatic Data Center. National Occanic \& Almospheric A Iministration. National Environmental Satellitc, Data, and Information Service. Asheville, North Carolina.

Karl, T.R., H.F. Diaz, and G. Kukla. 1988 b. Urbanization: its detection and effect in the United States climate record. Journal of Climate 1:10\%9-1123.

Karl, T.R., C.N. Williams, Jr., and F.T. Quinlan. 1990. United States Historical Climatology (HCN) serial temperature and precipitation data. NDP-019/R1. Carbon Dioxide Information Analysis (enter. ()ak Ridge National Laboratory. ()ak Ridge, Tennessee. 


\section{Southern Plains}

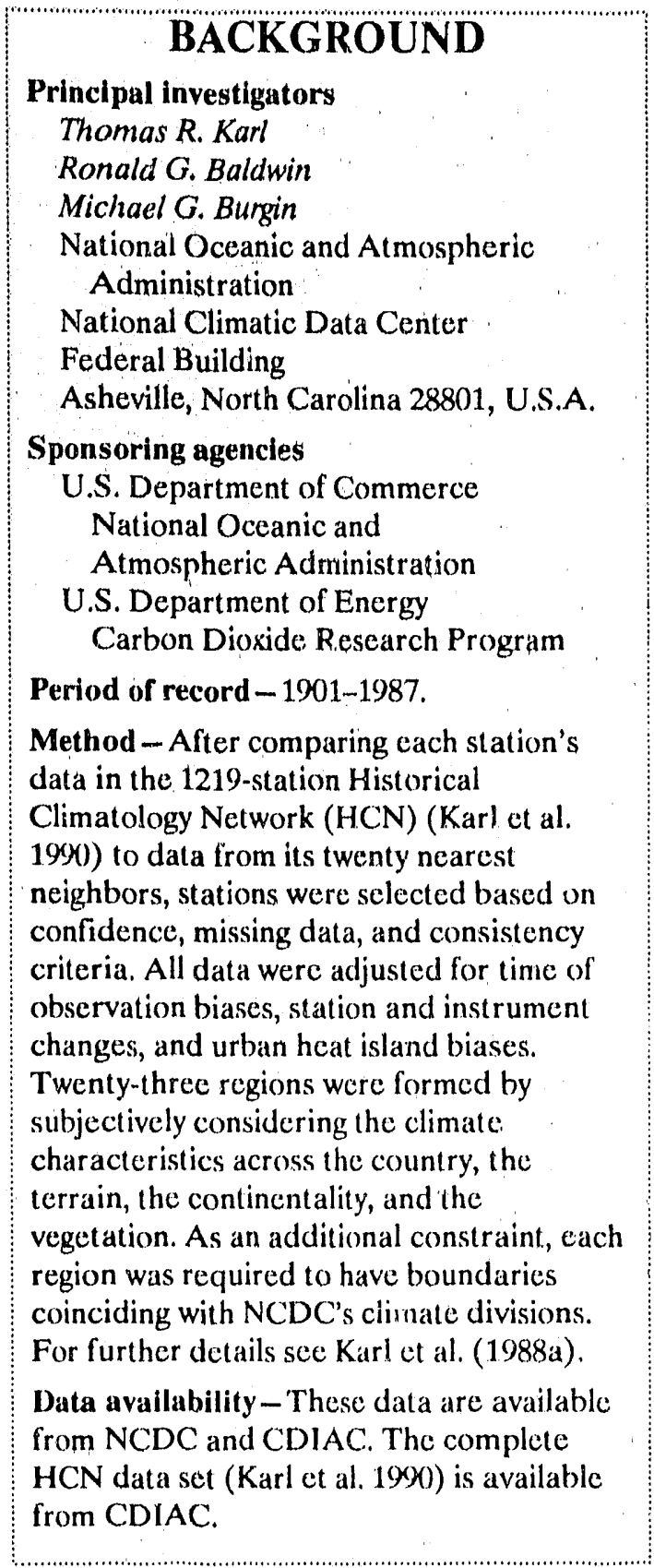
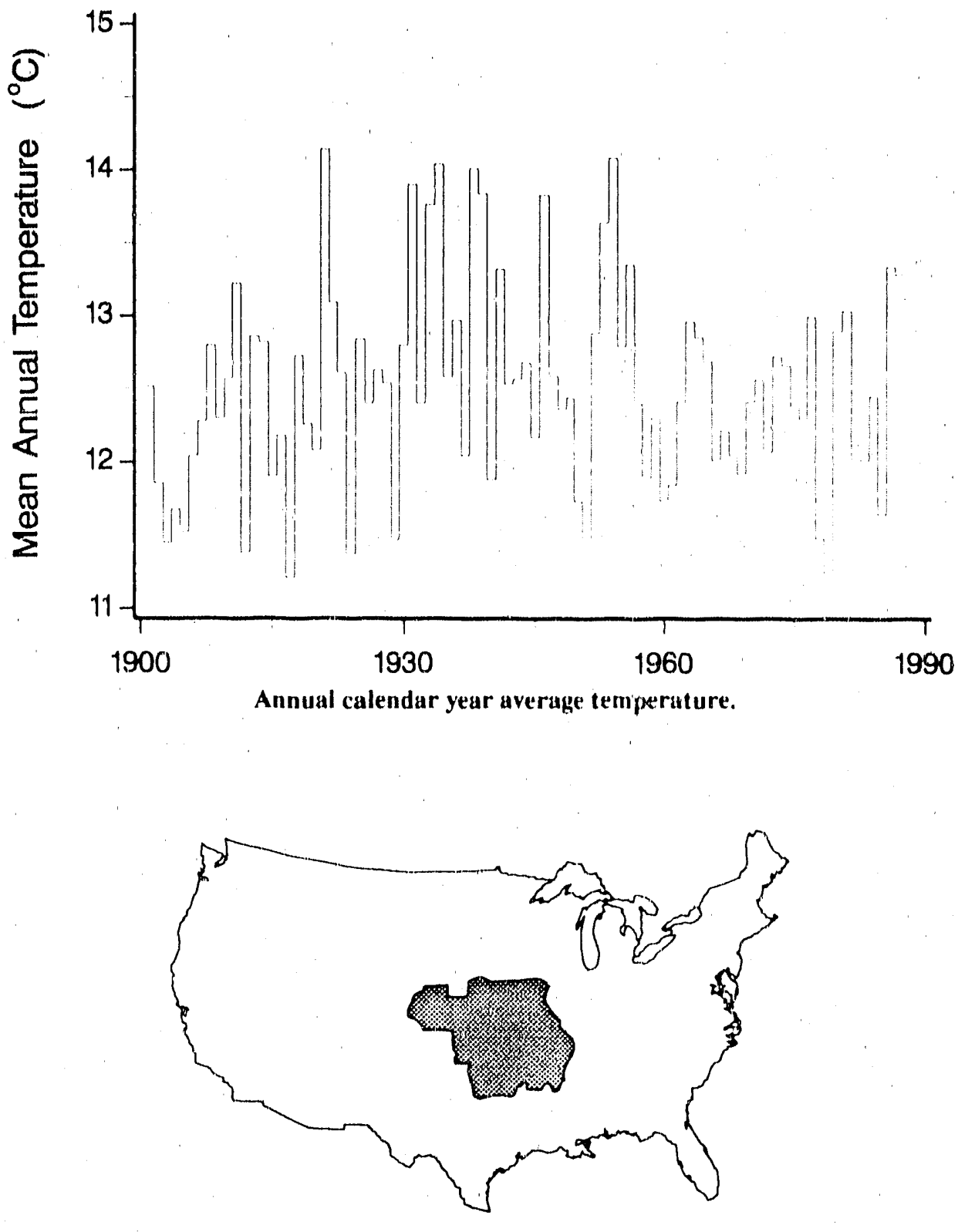

Southern Plains 


\section{U.S. Regional Temperatures}

\section{TRENDS}

On the basis of regional seasonal temperatures (i.e., maximum, minimam, average, and diurnal range! (s the United States, Karl et al. (1989a) combulted that the climate has changed over tore taritite century but that the changes have not been monotonic for the most part. Instead, the changes are somewhat unsteady and sometimes occur over a relatively short period of time. Karl el al. (1988a) also found a considerable amount of detailed information for each regional time series but reported that their salient features often could be summarized in time series plots for three aggregated regions: West, Central, and East. For the aggregated Central region, which includes this subregion, Karl et al. (1988a) reported that the annual average temperature time series can be divided inte three epochs: a cool heginning until the 1920k. followed by several decades of warm weather until atout $1(\mathcal{H}(x)$, and a somewhat coscles perioxt that was not as cool as earlier in the century. 


\section{Southern Plains}

\begin{tabular}{|c|c|c|c|c|c|c|c|c|}
\hline Year & Ann* & $\mathbf{W} / \mathbf{n}$ & Spr & Sum & Fall & Annt & Year & Ann: \\
\hline 1901 & 12.52 & $-0,02$ & 11.17 & 26.40 & 13.73 & 1.2 .82 & 1945 & 12.17 \\
\hline 1902 & 11.86 & -2.31 & 13.12 & 23.44 & 13.25 & 11.88 & 1946 & 13.83 \\
\hline 1903 & 11,45 & $-1,60$ & 12,09 & 22.57 & 12.26 & 11.33 & 1247 & 12.59 \\
\hline 1904 & 11.68 & -1.18 & 11.19 & 22.56 & 14.02 & $11: 64$ & 1948 & 12.36 \\
\hline 1905 & 11.52 & -4.14 & 12.98 & 23.80 & 13.38 & 11.50 & 1949 & $12: 44$ \\
\hline 1906 & 12.04 & 0.64 & 10.98 & 23.04 & 12.81 & 11.87 & 1950 & 11.73 \\
\hline 1907 & $\begin{array}{l}12.28 \\
\end{array}$ & 1.20 & 11.27 & 23.95 & 12.93 & 12.34 & 1951 & 11.45 \\
\hline 1908 & 12.80 & 1.29 & 13,04 & 23.25 & 13.45 & 12.76 & 1952 & 12.88 \\
\hline 1909 & 12.30 & 1.24 & 11.12 & 24.73 & 14.55 & 12.91 & 1953 & 13.64 \\
\hline 1910 & 12.57 & -2.62 & 13.81 & 23.67 & 13.81 & 12.16 & 1954 & 14.08 \\
\hline 1911 & 13.22 & 1.10 & 13.23 & 25.25 & 12.93 & 13.13 & 1955 & 12.79 \\
\hline 1912 & 11.38 & -2.71 & 10.76 & 23.78 & 13.45 & 11.32 & 1956 & 13.35 \\
\hline 1913 & 12,86 & -0.56 & 11.87 & 26.08 & 13.88 & 12.82 & 1957 & 12.40 \\
\hline 1914 & 12.82 & 0.89 & 12.06 & 25.78 & 14.64 & 13.34 & 1958 & 11.89 \\
\hline 1915 & 11.90 & -1.25 & 10.78 & 21.64 & 14.60 & 11.44 & 1959 & 12.30 \\
\hline 1916 & 12.18 & -0.58 & 12.24 & 24.68 & 13.39 & 12.43 & 1900 & 11.73 \\
\hline 1917 & 11.21 & -1.04 & 10.6 .5 & 23.53 & 12.46 & 11.40 & 1961 & 11.84 \\
\hline 1918 & 12.73 & -3.63 & 13.29 & 25.96 & $12,9.3$ & 12.13 & $1 \%, 2$ & 12.41 \\
\hline 1919 & 12.26 & 1.37 & 11.75 & 24.66 & 13.16 & 12.73 & 1963 & 12.96 \\
\hline 1920 & 12.08 & -0.86 & 11.28 & 23.07 & 13.52 & 11.75 & 1964 & 12.85 \\
\hline 1921 & 14,14 & 2.67 & 13.85 & 25.10 & 14.60 & 14.06 & 1965 & 12.69 \\
\hline 1922 & 13.09 & 0.51 & 12.61 & 24.67 & 14.80 & 13.15 & 1966 & 12.01 \\
\hline 1923 & 12.61 & 1.41 & 11.01 & 24.57 & 12.79 & 12.44 & $1 x, 7$ & 12.21 \\
\hline 1924 & 11.37 & 0.28 & 10.09 & 23.80 & 13.60 & 11.95 & 1968 & 12.04 \\
\hline 19,25 & 12.84 & -0.74 & 13.58 & 25.05 & 12.41 & 12.57 & 1969 & 11.92 \\
\hline 1926 & 12.40 & 1.36 & 11.17 & 24.26 & 12.77 & 12.39 & 1970 & 12.41 \\
\hline 1927 & 12.63 & 1.18 & 12.83 & 22.55 & 14.64 & 12.80 & 1971 & 12.56 \\
\hline 1928 & 12.54 & 0.32 & 12.15 & 23.15 & 13.24 & 12.22 & 1972 & 12.07 \\
\hline 1929 & 11.47 & -2.40 & 12.59 & 24.10 & 11.76 & 11.51 & 1973 & 12.72 \\
\hline 1930 & 12.80 & 0.19 & 12.50 & 24.98 & 13.63 & 12.83 & 1974 & 12.66 \\
\hline 1931 & 13.90 & 2.54 & 10.40 & 24.95 & 16.51 & 13.60 & 1975 & 12.38 \\
\hline 1932 & 12.40 & 2.60 & 11.69 & 25,05 & 12.02 & 12.91 & 1976 & 12.29 \\
\hline 1933 & 13.76 & 0.74 & 12.39 & 25.47 & 14.67 & 13.32 & 1977 & 12.90 \\
\hline 1934 & 14.04 & 2.15 & 13.05 & 28.07 & 14.20 & 14.37 & 1978 & 11.48 \\
\hline 1935 & 12.58 & 1.04 & 11.96 & 24.85 & 12.44 & 12.57 & 1979 & 11.22 \\
\hline 19.6 & 12.97 & -3.73 & 13.43 & 27.70 & 1.3 .50 & 12.73 & 1960 & 12.89 \\
\hline 1937 & 12.04 & -0.83 & 11.60 & 25.64 & 12.75 & 12.29 & 1981 & 13.03 \\
\hline 1.938 & 14.01 & 1.14 & 13.65 & 25.42 & 15.14 & 13.84 & 1982 & 12.02 \\
\hline 1939. & 13.84 & 1.35 & 13.07 & 25.11 & 15.22 & 13.69 & 1983 & 12.01 \\
\hline 1940 & 11.88 & -1.98 & 11.65 & 24.32 & 13.90 & 11.97 & 1984 & 12.45 \\
\hline 1941 & 13.32 & 1,04 & 12.78 & 24.75 & 14.43 & 13.25 & 198.5 & 11.64 \\
\hline 1942 & 12.53 & 0.69 & 12.82 & 24.24 & 13.50 & 12.81 & 1986 & 13.33 \\
\hline 1943 & 12.56 & 0.78 & 11.41 & 25.79 & 12.42 & 12.60 & 1987 & 13.28 \\
\hline 1944 & 12,88 & 1.16 & 11.22 & 24.54 & 14.12 & 12.76 & & \\
\hline
\end{tabular}

- Calendar year mean (Jan-Dec).

tSeason year mean $=($ Win $=$ Dec-Feb; Spr $=$ Mar-May; Sum $=$ Jun-Aug; lall $=$ Sep-Nov $)$.

TRENDS '90 


\section{Average Temperature $\left({ }^{\circ} \mathrm{C}\right)$, 1901-1987}

\begin{tabular}{|c|c|c|c|c|}
\hline W/n & Spr & Sum & Fall & Annt \\
\hline-0.23 & 12.71 & 23.05 & 13.61 & 12,28 \\
\hline 0.71 & 14.15 & 24.48 & 13.79 & 13.28 \\
\hline 0.84 & 10.36 & 24.86 & 14.91 & 12.74 \\
\hline-0.65 & 22.48 & 24.12 & 13.60 & 12.39 \\
\hline-0.62 & 12.35 & 24.42 & 13.51 & 12.42 \\
\hline 1.24 & $10 .(x)$ & 22,31 & 13.21 & 11.94 \\
\hline 0.10 & 10.78 & 23.31 & 11.60 & 11.45 \\
\hline 1.57 & 11.07 & 25.85 & 12.70 & 12.79 \\
\hline 1.77 & 11.95 & 25.67 & 14.82 & 13.55 \\
\hline 2.39 & 12.04 & 26.73 & 15.01 & 14.04 \\
\hline 0.36 & 13.67 & 24.78 & 13.28 & 13.02 \\
\hline-0.65 & $12.6 \$$ & 25.43 & 14.81 & 13.07 \\
\hline 0.92 & 11.56 & 24.79 & 11.88 & 12.29 \\
\hline 0.34 & 10.82 & 23.62 & 14.32 & 12.27 \\
\hline-1.13 & $12.7 \mathrm{j}$ & 24.43 & 11.82 & 11.97 \\
\hline-10.14 & 9.58 & 23.84 & 14.49 & 12.04 \\
\hline 0.49 & 11.25 & 23.39 & 12.75 & 11.97 \\
\hline-1.35 & 12.53 & 24.013 & 13.57 & 12.20 \\
\hline-1.69 & 13.88 & 25.28 & 16.00 & 13.37 \\
\hline$-(1.74$ & 12.85 & 24,34 & 13.63 & 12.52 \\
\hline-0.20 & 11.58 & 23.84 & 13.97 & 12.30 \\
\hline 0.23 & 1216 & 24.10 & 13.05 & 12.38 \\
\hline 0.26 & 13.17 & 22.6 .3 & 12.368 & 12.11 \\
\hline-0.28 & 12.23 & 24.21 & 12.82 & 12.24 \\
\hline-0.06 & 11.30 & 24.14 & 12.90 & 11.82 \\
\hline-0.75 & 12.19 & 24.67 & 12.73 & 12.21 \\
\hline-0.28 & 11.63 & 24.18 & 14.61 & 12.53 \\
\hline 0.68 & 12.95 & 23.194 & 12.36 & 12.48 \\
\hline-1$) .93$ & 12.24 & 24.49 & 1.4 .43 & 12.56 \\
\hline $0 .(1) 2$ & 13.866 & 23.89 & 12.49 & 12.57 \\
\hline-0.01 & 1113 & 24.44 & 13.3 .5 & 12.30 \\
\hline 2.42 & 12.48 & 23.92 & 11.05 & 12.47 \\
\hline-1.660 & 14.77 & $24,(x)$ & 13.76 & $12 . \%$ \\
\hline-4.42 & 11.69 & 24.62 & 14.10 & $11.5 !$ \\
\hline$-4.8 !$ & 11.76 & $23 .(x)$ & 13.22 & 10.96 \\
\hline-0.10 & 11.44 & 26.71 & 13.84 & 12.96 \\
\hline 1.37 & 13.48 & 24,40 & 13.55 & 13.19 \\
\hline-2.00 & 12.28 & 23.59 & 13.17 & 11.78 \\
\hline 1.58 & 10.34 & $25 .(0)$ & 14.24 & 12.24 \\
\hline-2.30 & 10.33 & 24.73 & 13.21 & 11.53 \\
\hline-1.48 & 14.11 & 23.40 & 12.50 & 12.14 \\
\hline 0.08 & 14.02 & 24.54 & 13.10 & 12.24 \\
\hline 1.73 & 13.84 & 24.71 & 12.88 & 13.25 \\
\hline
\end{tabular}

\section{REFERENCES}

Karl, T.R., G. Kukla, and J. Gavin, 1984. Decreasing diurnal temperature range in the United States and Canada from 1941 through 1980. Joumal of Climate and Applied Meteorology 23:1489-1504.

Karl, T.R., G. Kukla, and J. Gavin. 1986. Relationship between decreased temperature range and precipitation trends in the United States and Canada, 1941-1980. Joumal of Climate and Applied Meteorology 26:1878-86.

Karl, T.R., C.N. Williams, Jr., P.J. Young, and W.M. Wendland. 1986. A model to estimate the time of observation bias associated with monthly mean maximum, minimum, and mean temperatures for the United States. Joumal of Climate and Applied Mettorology 25:145-6().

Karl, T.R., R.G. Baldwin, M.(j. Burgin. 1988 a. Timie series of regional seasonal averages of maximum, minimum, and average temperature, and diumal temperature range across the United Stases: 1901-1984. Historical Climatology Series 4-5. National Climatic Data Center. National Oceanic \& Atmospheric Administration. National Environmental Satellite, Data, and Information Service. Asheville, North Carolina.

Karl, T.R., H.F. Diaz, and (i. Kukla. 1988b. Urbanization: its detection and effect in the United States climate record. Jourmal of Climate $1: 1(0(x)-1123$.

Karl, T.R., C.N. Williams, Jr., and F.T. Quinlan. 1990. United States Historical Climatology (HCN) serial temperature and precipitation data. NDP-019/R1. Carbon Dioxide Information Analysis Center. Oak Ridge National Laboratory. Oak Ridge, Tennessec. 


\section{South Coastal Plain}

\begin{tabular}{|c|}
\hline BACKGROUND \\
\hline $\begin{array}{l}\text { Principal investigators } \\
\text { Thomas } R . \text { Karl } \\
\text { Ronald G. Baldwin } \\
\text { Michael } G . \text { Bungin } \\
\text { National Oceanic and Atmospheric } \\
\text { Administration } \\
\text { National Climatic Data Center } \\
\text { Federal Building } \\
\text { Asheville, North Carolina } 28801 \text {, U.S.A. }\end{array}$ \\
\hline $\begin{array}{l}\text { Sponsoring agencies } \\
\text { U.S. Department of Commerce } \\
\text { National Oceanic and } \\
\text { Atmospheric Administration } \\
\text { U.S. Department of Encrgy } \\
\text { Carbon Dioxide Research Program }\end{array}$ \\
\hline $\begin{array}{l}\text { Period of record - } 1901-1987 . \\
\text { Method - After comparing each station's } \\
\text { data in the 1219-station Historical } \\
\text { Climatology Network (HCN) (Karl et al. } \\
199()) \text { to data from its twenty nearest } \\
\text { neighbors, stations were selected batsed on } \\
\text { confidence, missing data, and consistency } \\
\text { criteria. All data were adjusted for time of } \\
\text { observation biases, station and instrument } \\
\text { changes, and urban heat island biases. } \\
\text { Twenty-three regions were formed by } \\
\text { subjectively considering the climate } \\
\text { characteristics across the country, the } \\
\text { terrain, the continentality, and the } \\
\text { vegetation. As an additional constraint, each } \\
\text { region was recuired to have boundarics } \\
\text { coinciding with NCDC's climate divisions. } \\
\text { For further details sec Karl et al. (1988a). }\end{array}$ \\
\hline $\begin{array}{l}\text { Data availability - These data are available } \\
\text { from NCDC and CDIAC. The complete } \\
\text { HCN data set (Karl et al. } 19(0) \text { ) is available } \\
\text { from CDIAC. }\end{array}$ \\
\hline
\end{tabular}

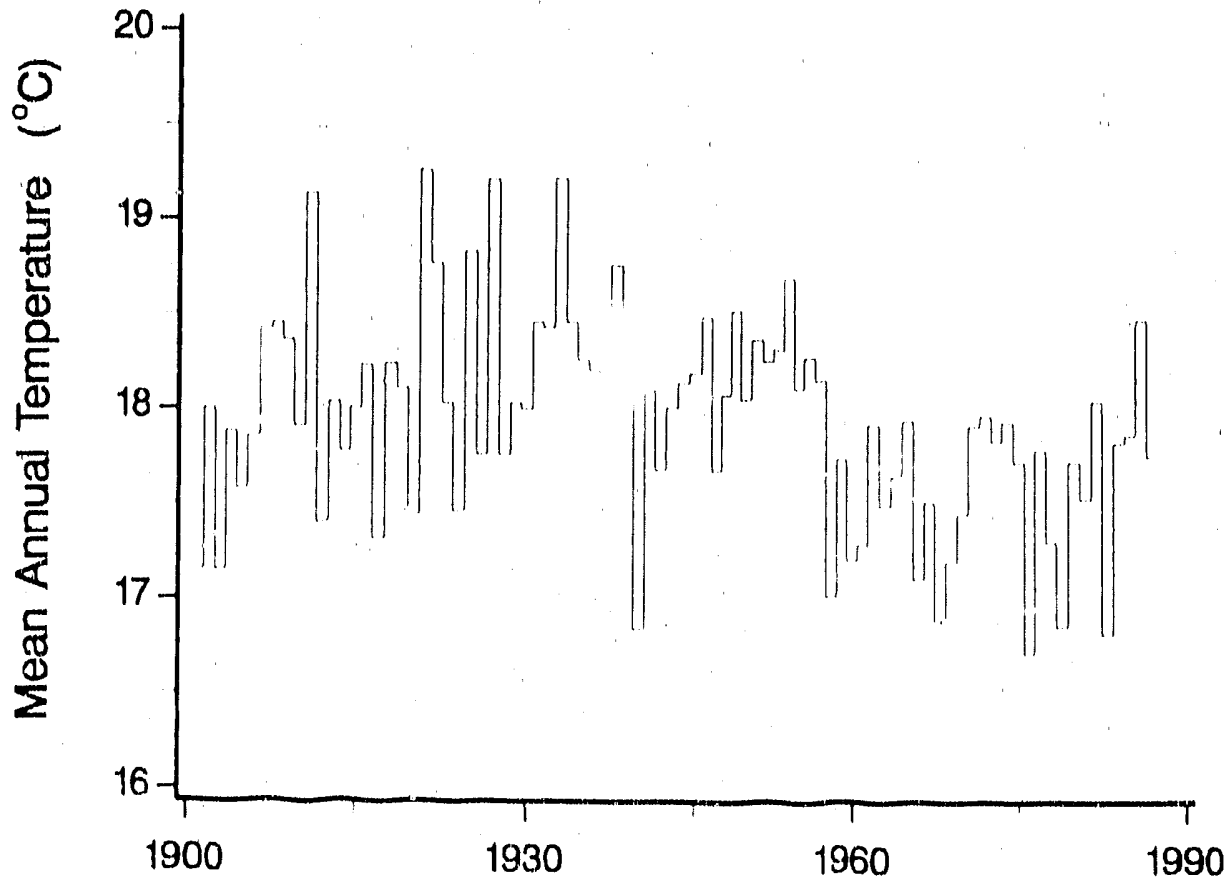

Annual calendar year average temperafure.

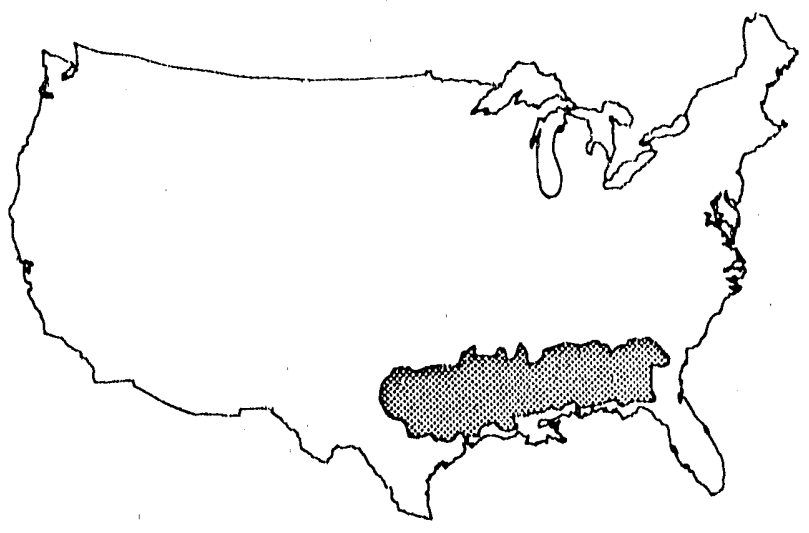

South Coastal Plain 


\section{TRENDS}

On the basis of regional seasonal temperatures (i.e., maximum, minimurn, average, and diurnal range) for the United States, Karl et al. (1988a) concluded that the climate has changed over tho recent century but that the changes have not been monotonic for the most part, Instead, the changes are somewhat unsteady and sometimes occur over a relatively short period of time. Karl et al. (1988a) also found a considerable amount of detailed information for each regional time series but reported that their salient features often could be summarized in time series plots for three aggregated regions: West, Central, and East. For the aggregated East region, which includes this subregion, Karl et al. (1988a) reported that the annual average temperature time series can be divided into three epochs: a warm epoch from the early 1920 s to the mid 1950s, preceded and followed by periods during which temperatures were generally at or below the mean for the century. 


\section{South Coastal Plain}

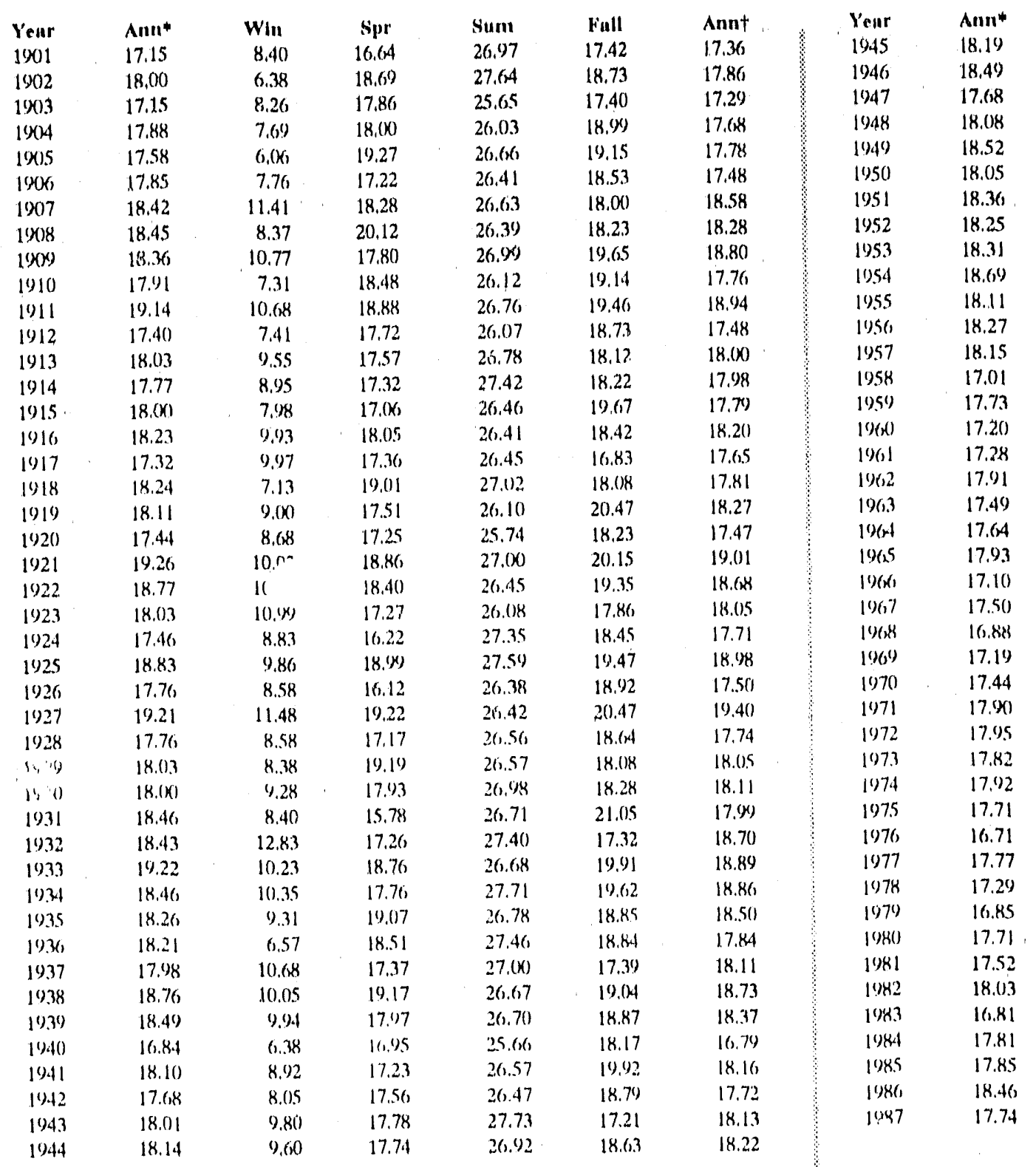

- Calendar year mean (Jan-Dec).

tSeason year mean $=\left(\right.$ Win $=$ Dec-lieb; Spr $=$ Mar-May; Sum $=J_{\text {un }}-A u g ;$ latl $=$ Sep-Now $)$. 


\section{Average 'Temperature}

\begin{tabular}{|c|c|c|c|c|}
\hline Win & Spr & SuIII & Full & Annt \\
\hline 8.76 & 18.96 & 26.27 & $19,(x)$ & 18.14 \\
\hline 8.48 & 18.89 & 25.8 .5 & 19.0 .5 & 18.07 \\
\hline 8.93 & 16.74 & 26,36 & 19.32 & 17.844 \\
\hline 7.84 & $|k .9|$ & 26,97 & 18.07 & 17.95 \\
\hline 11.21 & $1 \% .70$ & 20.47 & 18.79 & 18.94 \\
\hline 12.43 & 17.25 & 25.84 & 17.91 & 18.361 \\
\hline 8.58 & 17.5 .3 & 27.54 & 18.36 & 18.100 \\
\hline 11.77 & 17.16 & 27.93 & 17.08 & 18.49 \\
\hline 9.59 & 18.42 & 27.02 & 18.34 & 18.34 \\
\hline 9.82 & 17.59 & $28 .(4)$ & 19.04 & 18.6 .3 \\
\hline 8.78 & 19.37 & 25.80 & $18.3 \mathrm{k}$ & 18.10 \\
\hline 9,12 & $17 .(x)$ & $20,(k)$ & 18.08 & 17.94 \\
\hline 11.89 & 17.54 & 26.55 & 17.47 & 18.36 \\
\hline 6.93 & 10.8 .3 & 26.55 & 18.7 .5 & 17.27 \\
\hline 7.9 .5 & 17.58 & 26.31 & 18.30 & 17.53 \\
\hline 8.177 & 1.5 .12 & 26,67 & 19.05 & 17.4 .3 \\
\hline 7.71 & 17.26 & 25.17 & 18.22 & $17.16)$ \\
\hline 17.5 .5 & 17.261 & 20.82 & 18.16 & 18.0 .3 \\
\hline 0.31 & 19.18 & $20,0.5$ & 18.18 & 17.78 \\
\hline 5.80 & 1816 & 26,47 & 18.20 & 17.18 \\
\hline 9.01 & 17.82 & 26,013 & 18.45 & 17.95 \\
\hline $7 .(11)$ & 17.3 .3 & 25.83 & 17.97 & 17.18 \\
\hline 8.1 .5 & 19.24 & 25.32 & 16.67 & 17.3 .5 \\
\hline 7.46 & 17.2 .3 & $2(1.21)$ & 17.50 & 17.13 \\
\hline 7.kil & 10.47 & 26.61 & 17.6 .5 & 17.14 \\
\hline 0.81 & 17.78 & $20.10)$ & 18.07 & 17.19 \\
\hline 9.45 & $\mid(1,3)$ & 26.16 & $18 .(x)$ & 17.7 .3 \\
\hline $10.7 \mathrm{k}$ & 1812 & 25.45 & 18.26 & 18.25 \\
\hline 7.9 .4 & 17.54 & 20.017 & $19.1 \%$ & 17.87 \\
\hline 10.12 & 19.11 .3 & 25.511 & $17 .(11$ & 17.12 \\
\hline 9,81 & 17.4 .4 & 25.861 & 17.97 & 17.76 \\
\hline 9.15 & 17.48 & 25.34 & 15.41 & 10.83 .3 \\
\hline 5.7 .4 & $1 k .77$ & 27.27 & 18.80 & 17. $(r)$ \\
\hline 5.18 & 17.11 & 27.0 .5 & 19.47 & 17.25 \\
\hline 0.36 & 17.73 & $25 . x)$ & 17.72 & It.$K k$ \\
\hline $7 .(x)$ & $|0.91|$ & 27.77 & 18.28 & 17.72 \\
\hline 7.77 & 17.71 & 27.0 .3 & $1 x \cdot(x)$ & 17.50 \\
\hline 7.9 .4 & 18.22 & 26,41 & 18.31 & 17.70 \\
\hline 8.81 & $16.14 \mid$ & 26.38 & 18.15 & 17.34 \\
\hline$(0.74)$ & 17.25 & 26.111 & 18.49 & 17.13 \\
\hline K. 46 & 18.8 .4 & 26.45 & $(9)(x)$ & 18.4 .3 \\
\hline 8.41$)$ & 18.12 & 27.13 & $19+4$ & $\mid x, 30$ \\
\hline 8.19 & 17.6 .3 & 20,77 & 17.6 .5 & 17.56 \\
\hline
\end{tabular}

\section{REFERENCES}

Karl, T.R., G. Kukla, and J. Gavin. 1984. Decreasing diurnal temperature range in the United States and Canada from 1941. through 1980. Joumal of Climate and Applicad Moteorologn' 23:148:-15014.

Karl, T.R., C. Kukla, and J، Cavin. 1986. Relationship between decreased temperature range and precipitation trends in the United States and Canada, 1941-1980. Joumal of Climate and Applied Metcoroleng 26:1878-86.

Karl, T.R., C.,N. Williams, Jr., P.I. Young, and W.M. Wendland, 1986. A model to estimate the time of observation bias associated with monthly mean maximum, minimum, and mean temperatures for the United States. Joumal of Climate! and Applied Metcorology 25:145-(r).

Karl, T.R., R.G. Baldwin, M.(i. Burgin. 1988a. Time series of regionesl seasomal averages of maximum, minimum, and al'erage lemperature, and diurnal lemperature runge across the United Siates: 19(1) 1.-1984. Historical Climatology Series 4-5. National Climatic Dala Center. National ()ecanic \& Almospheric: Administration. National Environmental Salcllite, Data, and Information Service. Asheville, North Carolina.

Karl, T.R., H.F. Diaz, and (i. Kukla. 1986h. Urbanization: its detection and effect in the United States climate record. Journal of Climate 1:1090-1123.

Karl, T.R., C.N. Williams, Ir., and F.T. Quinlan. I9(x). United State"s ilistorical Climatology (HCN) serial temperature and precipitation data. NDP-()19/R1. Carbon Dioxide Information Analysis Center. ()ak Ridpre National Laboratory. ()ak Ridge, Tennessec. 


\section{Gulf Coast}

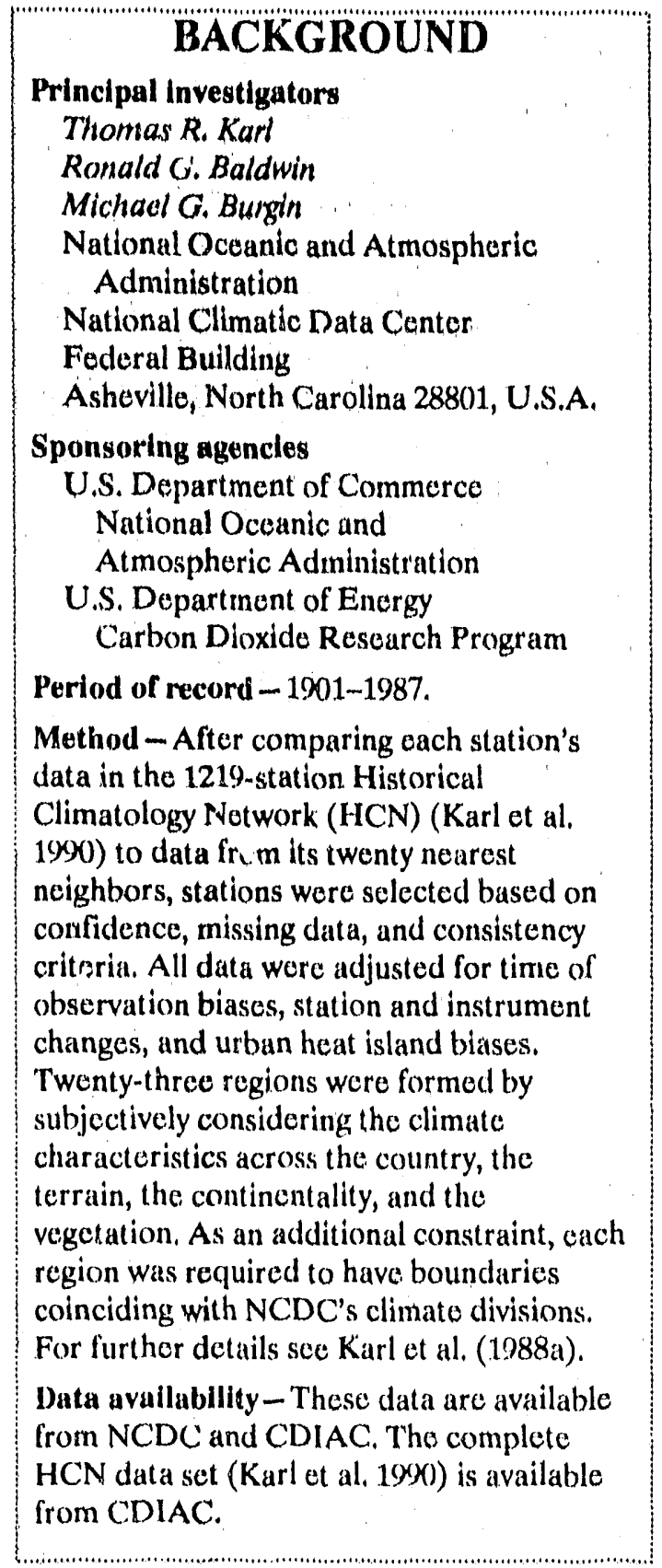
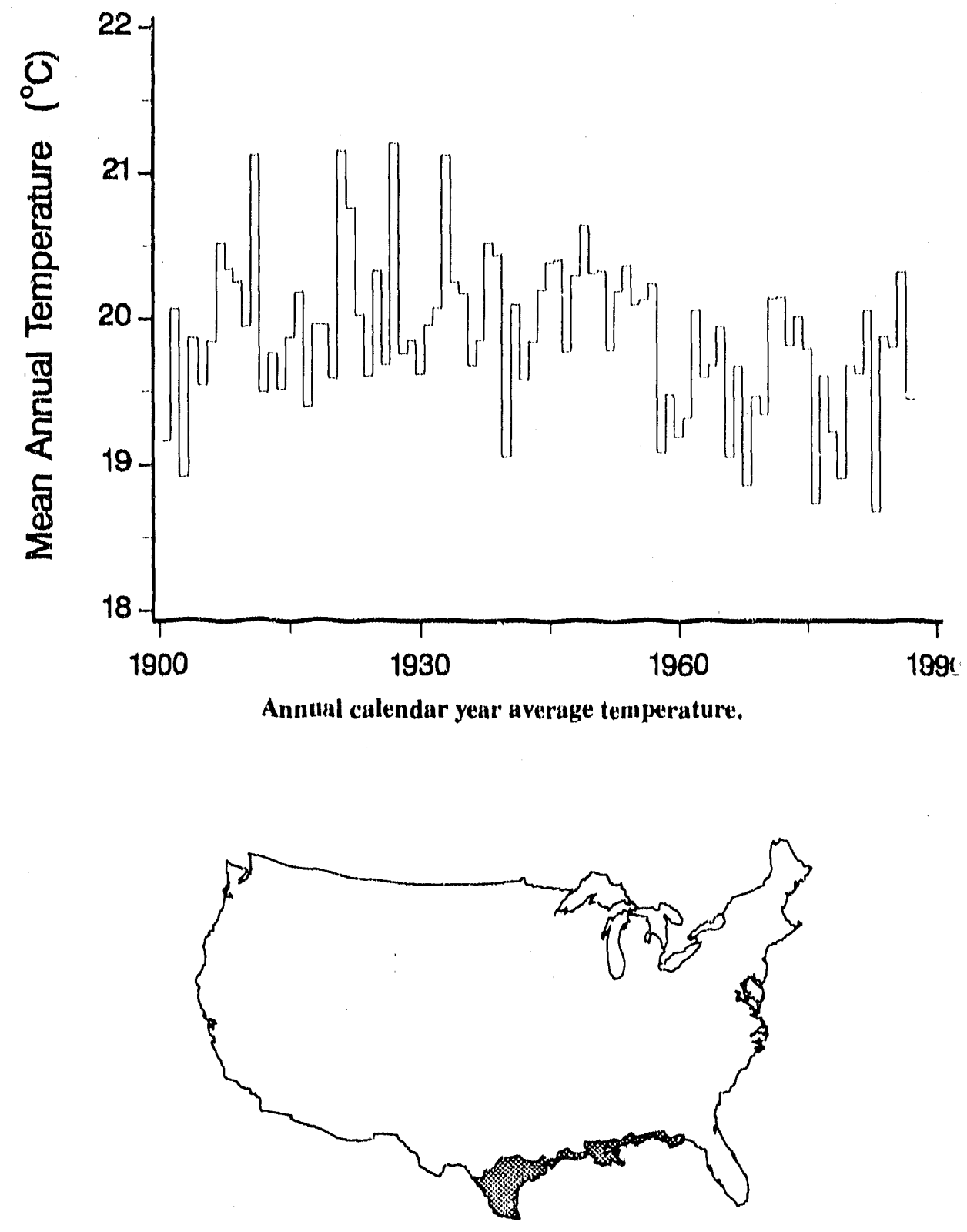

Gulf Constal 
U.S. HRegional Temperatures

kmo

\section{TRENDS}

On the basis of rogional seasonal temperatures (1.0., maximum, minimum, average, and diurnal range) for the United States, Karl ot al. (1988a) concluded that the climate has changed over the recent contury but that the changes have not been monotonic for the most part. Instead, the changes are somewhat unsteady and sometimes occur over a rolatively short poriod of time. Karl et al. (1988a) also found a considerable amount of detailed information for each regional time series but reported that their salient features often could be summarized in time series plots for three aggregated regions: West, Central, and East, For the aggregated East region, which includes his subregion, Karl et al. (1988a) reported chat the annual average temperature time series can be divided into throe epochs: a warm epoch from the carly 1920 s to the mid 1950s, preceded and followed by periods during which temperatures were generally al or below the mean for the century. 
Gulf Coast

\begin{tabular}{|c|c|c|c|c|c|c|c|c|}
\hline Year & Ann* & Win & Spr & Sum & Fall & Annt & Year & Ann* \\
\hline 1901 & 19.16 & 11.18 & 18.68 & 27.52 & 19.68 & 19.27 & 1945 & 20.39 \\
\hline 1902 & 20.06 & 9.98 & 20.62 & 28.09 & 21.08 & 19.94 & 1946 & 20.40 \\
\hline 1903 & 18.91 & 11.07 & 19.39 & 26.23 & 19.48 & 19.04 & 1947 & 19.77 \\
\hline 1904 & 19.86 & 11.43 & 20.14 & 26.54 & 20.84 & 19.74 & 1948 & 20.29 \\
\hline 1905 & 19.54 & 9.26 & 21.00 & 27.29 & 21.34 & 19.72 & 1949 & 20.64 \\
\hline 1906 & 19.84 & 10.26 & 19.23 & 27.59 & 20.60 & 19.42 & 1950 & 20.31 \\
\hline 1907 & 20.52 & 14.84 & 20.72 & 27.24 & 20.08 & 20.72 & 1951 & 20.33 \\
\hline 1908 & 20.34 & 11.75 & 21.96 & 27.12 & 19.77 & 20.15 & 1952 & 19.79 \\
\hline 1909 & 20.25 & 13.70 & 19.87 & 27.53 & 21.55 & 20.66 & 1953 & 20.19 \\
\hline 1910 & 19.94 & 10.62 & 20.26 & 27.05 & 2.0 .99 & 19.73 & 1954 & 20.36 \\
\hline 1911 & 21.11 & 14.44 & 20.99 & 27.47 & 21.12 & 21.00 & 1955 & 20.09 \\
\hline 1912 & 19.49 & 10.66 & 19.88 & 26.94 & 20.91 & 19.60 & 1956 & 20.12 \\
\hline 1913 & 19.76 & 12.41 & 19.24 & 26.92 & 20.32 & 19.72 & 1957 & 20.23 \\
\hline 1914 & 19.52 & 11.98 & 18.91 & 27.83 & 20.29 & 19.75 & 1958 & 19.08 \\
\hline 1915 & 19.57 & 10.61 & 18.39 & 27.75 & 21.65 & 19.60 & 1959 & 19.48 \\
\hline 1916 & 20.18 & 13.33 & 20.13 & 27.26 & 19.99 & 20.17 & 1960 & 19.19 \\
\hline 1917 & 19.39 & 13.10 & 19.36 & 27.33 & 18.75 & 19.63 & 1961 & 19.32 \\
\hline 1918 & 19.95 & 10.53 & 20.49 & 27.64 & 20.05 & 19.67 & 1962 & 20.05 \\
\hline 1919 & 19.95 & 11.42 & 19.28 & 26.91 & 22.41 & 20.00 & 1963 & 19.59 \\
\hline 1920 & 19.59 & 12.07 & 19.68 & 26.91 & 20.13 & 19.70 & $19 \times 4$ & 19.67 \\
\hline 1921 & 21.15 & 12.92 & 20.70 & 27.74 & 21.93 & 20.82 & 1965 & 19.94 \\
\hline 1922 & 20.76 & 13.73 & 20.51 & 27.34 & 21.16 & 20.68 & 1966 & 19.05 \\
\hline 1923 & 20.02 & 14.28 & 19.50 & 27.01 & 19.70 & 20.12 & 1967 & 19.67 \\
\hline 1924 & 19.60 & 11.60 & 18.47 & 28.11 & 21.06 & 19.81 & 1968 & 18.86 \\
\hline 1925 & 20.32 & 12.70 & 20.72 & 27.73 & 20.92 & 20.52 & 1969 & 19.46 \\
\hline 1926 & 19.68 & 11.00 & 18.11 & 27.30 & 20.86 & 19.32 & 1970 & 19.34 \\
\hline 1927 & 21.20 & 14.73 & 21.22 & 27.62 & 22.24 & 21.45 & 1971 & 20.13 \\
\hline 1928 & 19.76 & 11.18 & 19.42 & 27.81 & 20.63 & 19.76 & 1972 & 20.14 \\
\hline 1929 & 19.85 & 11.41 & 21.22 & 27.12 & 19.76 & 19.88 & 1973 & 19.81 \\
\hline 1930 & 19.62 & 11.77 & 19.51 & 27.36 & 20.23 & 19.71 & 1974 & 20.01 \\
\hline 1931 & 19.95 & 11.06 & 17.41 & 26.95 & 22.60 & 19.50 & 1975 & 19.79 \\
\hline 1932 & 20.07 & 15.48 & 18.80 & 27.96 & 18.96 & 20.30 & 1976 & 18.73 \\
\hline 1933 & 21.12 & 13.02 & 20.91 & 27.15 & 21.96 & 20.76 & 1977 & 19.60 \\
\hline 1934 & 20.25 & 13.67 & 19.51 & 27.75 & 21.57 & 20.62 & 1978 & 19.22 \\
\hline 1935 & 20.17 & 12.56 & 21.02 & 27.34 & 20.59 & 20.38 & 1979 & 18.90 \\
\hline 1936 & 19.68 & 10.16 & 19.87 & 27.50 & 20.20 & 19.43 & 1980 & 19.67 \\
\hline 1937 & 19.85 & 13.42 & 19.09 & 27.59 & 19.66 & 19.94 & 1981 & 19.62 \\
\hline 1938 & 20.52 & 12.78 & 21.08 & 27.69 & 20.37 & 20.48 & 1982 & 20.05 \\
\hline 1939 & 20.43 & 12.88 & 20.24 & 27.61 & 20.58 & 20.32 & 1983 & 18.68 \\
\hline 1940 & 19.05 & 9.68 & 19.27 & 26.93 & 20.06 & 18.98 & 1984 & 19.87 \\
\hline 1941 & 20.09 & 12.24 & 19.07 & 27.50 & 21.75 & 20.14 & 1985 & 19.80 \\
\hline 1942 & 19.58 & 11.08 & 19.30 & 27.33 & 20.70 & 19.60 & 1986 & 20.31 \\
\hline 1943 & 19.84 & 12.68 & 20.25 & 28.06 & 18.92 & 19.98 & 1987 & 19.44 \\
\hline 1944 & 20.20 & 12.71 & 19.82 & 27.85 & 20.51 & 20.22 & & \\
\hline
\end{tabular}

* Calendar year mean (Jan-Dec).

tSeason year mean $=($ Win $=$ Dec-Feb; Spr $=$ Mar-May; Sum $=$ Jun-Aug; Fall $=$ Sep-Nov $)$

TRENDS '90 
Average Temperature $\left({ }^{\circ} \mathrm{C}\right), 1901-1987$

$\begin{array}{rrrrr}\text { Win } & \text { Spr } & \text { Sum } & \text { Full } & \text { Ann† } \\ 12.27 & 21.08 & 27.43 & 21.06 & 20.46 \\ 11.31 & 20.67 & 27.01 & 21.35 & 20.08 \\ 11.60 & 19.16 & 27.48 & 21.38 & 19.91 \\ 11.04 & 21.13 & 28.08 & 20.13 & 20.09 \\ 14.42 & 19.93 & 27.33 & 20.99 & 20.67 \\ 15.82 & 19.17 & 27.09 & 20.26 & 20.59 \\ 11.88 & 19.68 & 28.24 & 20.46 & 20.07 \\ 14.81 & 18.91 & 27.96 & 18.43 & 20.03 \\ 12.29 & 21.00 & 27.79 & 19.97 & 20.27 \\ 12.50 & 19.68 & 28.10 & 20.64 & 20.23 \\ 11.90 & 21.24 & 26.75 & 20.40 & 20.07 \\ 12.35 & 19.92 & 27.21 & 20.16 & 19.91 \\ 14.99 & 19.80 & 27.59 & 19.38 & 20.44 \\ 9.64 & 19.05 & 27.54 & 20.75 & 19.24 \\ 10.74 & 19.26 & 27.18 & 20.22 & 19.35 \\ 10.43 & 18.46 & 27.57 & 20.89 & 19.34 \\ 10.51 & 19.64 & 26.24 & 20.11 & 19.13 \\ 12.68 & 19.29 & 27.95 & 20.87 & 20.19 \\ 9.48 & 21.57 & 27.54 & 20.92 & 19.88 \\ 8.74 & 20.21 & 27.47 & 20.52 & 19.23 \\ 12.01 & 19.77 & 26.88 & 21.10 & 19.94 \\ 10.40 & 19.48 & 26.58 & 20.18 & 19.16 \\ 10.97 & 21.32 & 26.66 & 19.09 & 19.51 \\ 10.43 & 19.26 & 26.95 & 19.61 & 19.06 \\ 11.27 & 18.41 & 27.65 & 20.07 & 19.35 \\ 10.19 & 19.60 & 26.98 & 19.77 & 19.14 \\ 12.95 & 19.04 & 26.98 & 20.96 & 19.98 \\ 14.09 & 20.48 & 26.98 & 20.43 & 20.50 \\ 10.49 & 19.69 & 27.08 & 22.03 & 19.84 \\ 12.98 & 21.01 & 26.54 & 19.36 & 19.97 \\ 12.89 & 19.75 & 26.77 & 20.04 & 19.86 \\ 11.89 & 19.76 & 26.37 & 17.34 & 18.84 \\ 8.97 & 20.10 & 27.68 & 20.97 & 19.43 \\ 8.50 & 19.51 & 27.56 & 21.35 & 19.23 \\ 9.58 & 19.67 & 26.93 & 19.61 & 18.95 \\ 11.23 & 19.19 & 28.27 & 19.95 & 19.66 \\ 10.45 & 19.77 & 27.78 & 20.55 & 19.64 \\ 11.08 & 20.07 & 27.69 & 20.47 & 19.83 \\ 11.36 & 18.04 & 27.08 & 20.03 & 19.13 \\ 9.47 & 19.68 & 26.87 & 20.79 & 19.20 \\ 11.31 & 20.79 & 27.33 & 22.04 & 20.37 \\ 11.39 & 19.96 & 27.78 & 21.61 & 20.18 \\ 10.99 & 18.99 & 27.36 & 19.61 & 19.24 \\ & & & & \end{array}$

\section{REFERENCES}

Karl, T.R., ( . Kukla, and J. Gavin. 1984.

Decreasing diurnal temperature range in the United States and Canada from 1941. through 1980. Ioumal of Climate and Applied Meteorology 23:1489-1504.

Karl, T.R., G. Kukla, and J. Gavin. 1986. Relationship between decreased temperature range and precipitation trends in the United States and Canada, 1941-1980. Journal of Climate and Applied Meteorology 26:1878-86.

Karl, T.R., C.N. Williams, Jr., P.J. Young, and W.M. Wendland. 1986. A model to estimate the time of observation bias associated with monthly mean maximum, minimum, and mean temperatures for the United States. Joumal of Climate and Applied Meteorology 25:145-60.

Karl, T.R., R.G. Baldwin, M.G. Burgin. $1988 \mathrm{a}$. Time series of regional seasonal averages of maximum, minimum, and average temperature, and diumal temperature range across the United States: 1901-1984. Historical Climatology Series 4-5. National Climatic Data Center. National Occanic \& Atmospheric Administration. National Environmental Satellite, Data, and Information Service. Asheville, North Carolina.

Karl, T.R., H.F. Diaz, and G. Kukia. 1988b. Urbanization: its detection and effect in the United States climate record. Journal of Climate 1:1099-1123.

Karl, T.R., C.N. Williams, Jr., and F.T. Quinlan. 1990. United States Historical Climatology (HCN) serial temperature and precipitation data. NDP-019/R1. Carbon Dioxide Information Analysis Center. Oak Ridge National Laboratory. Oak Ridge, Tennessee. 


\section{Great Lakes}

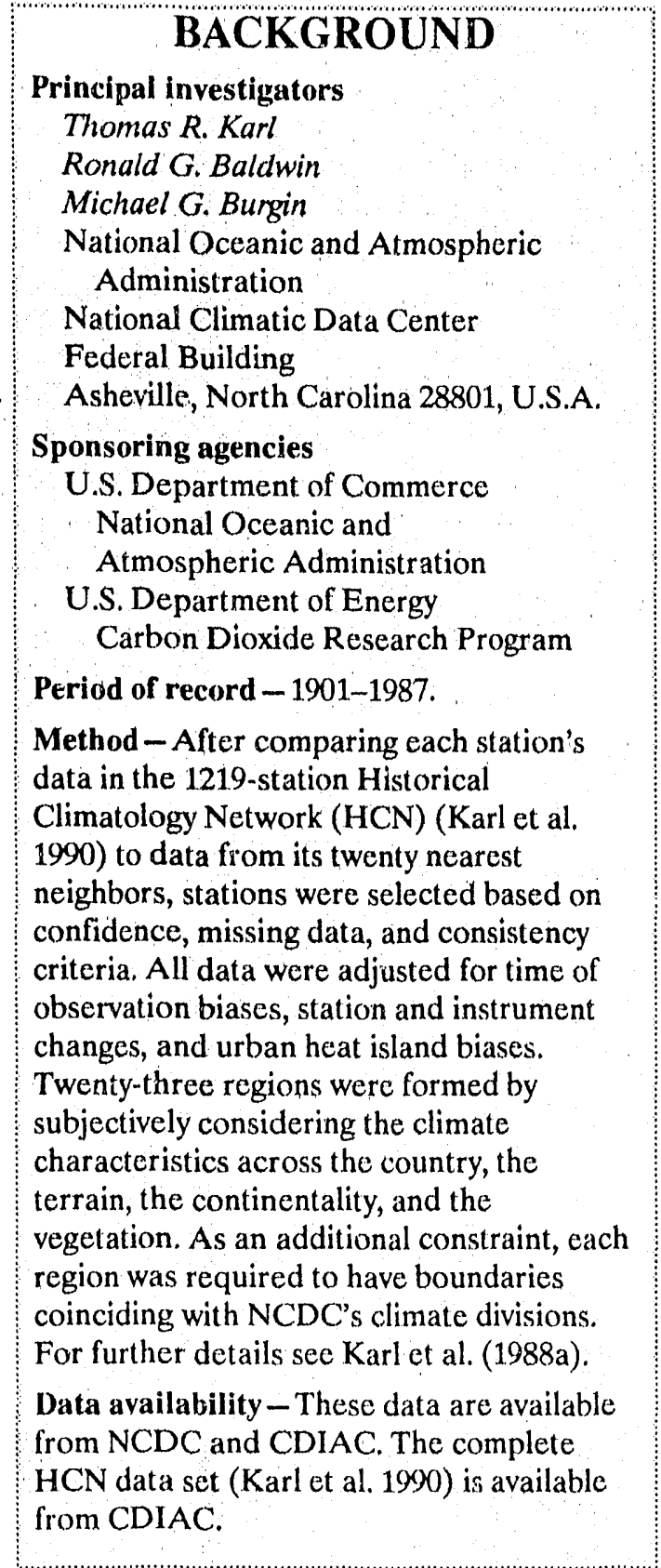

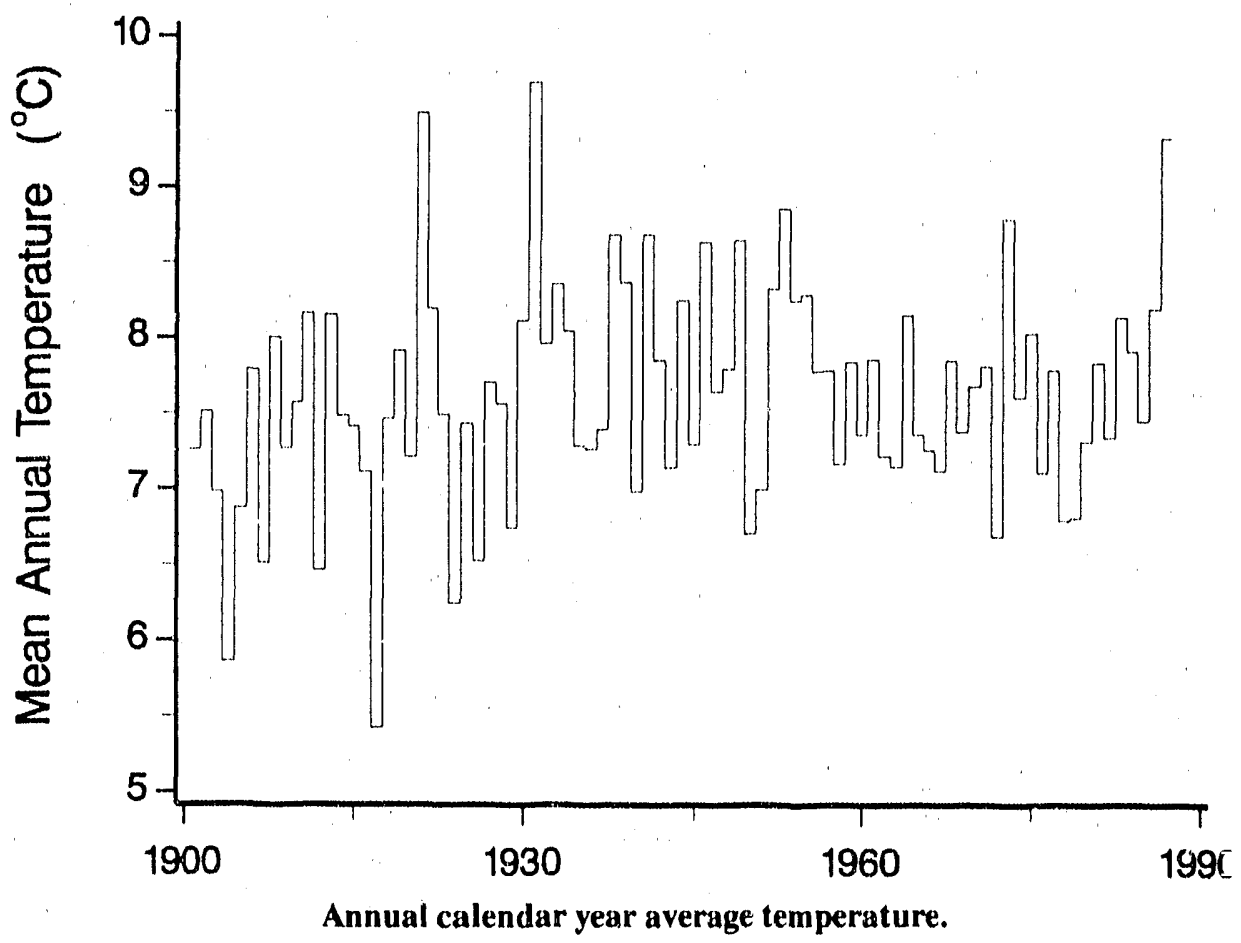




\section{TRENDS}

On the basis of regional seasonal temperatures (i.e., maximum, minimum, average, and diurnal range) for the United States, Karl et al. (1988a) concluded that the climate has changed over the recent century but that the changes have not been monotonic for the most part. Instead, the changes are somewhat unsteady and sometimes occur over a relatively short period of time. Karl et al. (1988a) also found a considerable amount of detailed information for each regional time series but reported that their salient features often could be summarized in time series plots for three aggregated regions: West, Central, and East. For the aggregated East region, which includes this subregion, Karl et al. (1988a) reported that the annual average temperature time series can be divided into three epochs: a warm epoch from the early 1920 s to the mid 1950 s, preceded and followed by periods during which temperatures were generally at or below the mean for the century. 


\section{Great Lakes}

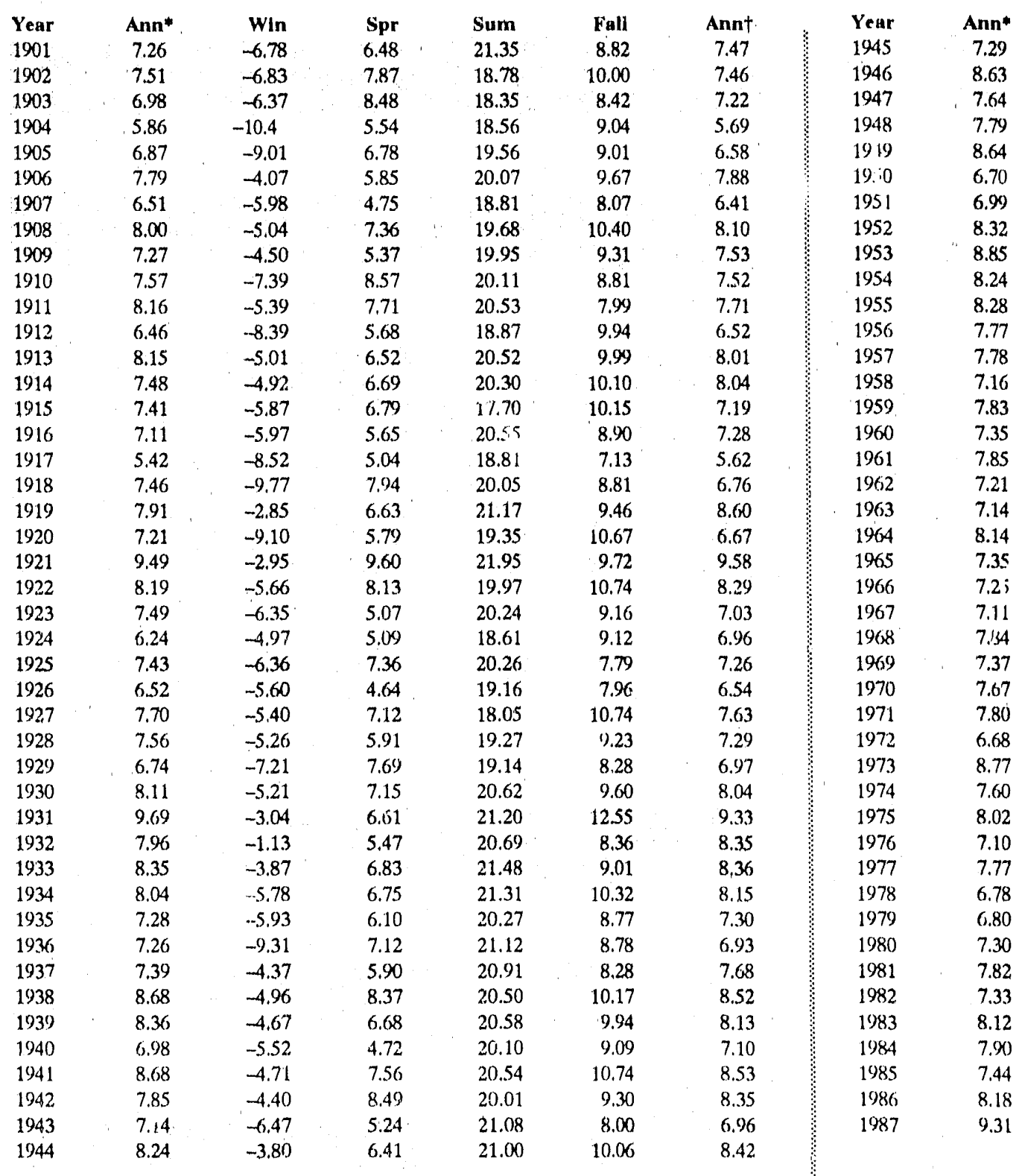

* Calendar year mean (Jan-Dec).

tSeason year mean $=($ Win $=$ Dec-Feb; Spr $=$ Mar-May; Sum $=$ Jun-Aug; Fall $=$ Scp-Nov $)$.

TRENDS '90 


\section{Average Temperature $\left({ }^{\circ} \mathrm{C}\right)$, 1901-1987}

\begin{tabular}{|c|c|c|c|c|}
\hline$W / n$ & Spr & Sunı & Fall & Annt \\
\hline-7.01 & 8.30 & 18.95 & 9.11 & 7.33 \\
\hline-5.81 & 8.85 & 19.31 & 10.69 & 8.26 \\
\hline-4.91 & 5.08 & 20.41 & 10.44 & 7.75 \\
\hline-6.67 & 7.07 & 20.12 & 10.34 & 7.71 \\
\hline-3.82 & 7.28 & 21.58 & 9.36 & 8.60 \\
\hline-4.13 & 4.76 & 18.75 & 9.04 & 7.10 \\
\hline$-6,42$ & 6.77 & 18.93 & 7.87 & 6.79 \\
\hline-4.37 & 6.79 & 20.88 & 8.91 & 8.05 \\
\hline-3.03 & 6.86 & 20.81 & 10.91 & 8.89 \\
\hline-3.05 & 6.30 & 20.21 & 9.92 & 8.34 \\
\hline-5.17 & 8.40 & 21.54 & 9.19 & 8.49 \\
\hline-5.69 & 5.67 & 19.87 & 9.87 & 7.43 \\
\hline-4.95 & 7.01 & 20.16 & 8.80 & 7.76 \\
\hline-5.21 & 7.14 & 18.84 & 10.09 & 7.71 \\
\hline-8.20 & 7.54 & 21.12 & 8.41 & 7.22 \\
\hline-3.80 & 5.25 & 19.40 & 10.33 & 7.79 \\
\hline-5.52 & 6.19 & 19.86 & 10.46 & 7.75 \\
\hline-7.09 & 7.48 & 19.44 & 9.26 & 7.28 \\
\hline-9.05 & 7.20 & 19.87 & 11.55 & 7.39 \\
\hline-5.89 & 7.85 & 19.92 & 9.44 & 7.83 \\
\hline-6.40 & 6.03 & 18.94 & 9.28 & 6.96 \\
\hline-5.10 & 6.12 & 20.37 & 8.88 & 7.57 \\
\hline-5.71 & 6.15 & 19.28 & 8.24 & 5.99 \\
\hline-5.83 & 7.82 & 20.01 & 10.02 & 8.00 \\
\hline-5.60 & 6.76 & 19.55 & 8.82 & 7.38 \\
\hline-7.21 & 6.99 & 20.61 & 10.06 & 7.61 \\
\hline-6.40 & 5.71 & 19.93 & 11.25 & 7.62 \\
\hline-5.80 & 6.13 & 19.18 & 8.26 & 6.94 \\
\hline-4.80 & 8.00 & 20.9 & 10.68 & 8.72 \\
\hline-5.65 & 7.01 & 19.78 & 8.67 & 7.45 \\
\hline-4.09 & 6.09 & 20.49 & 9.95 & 8.11 \\
\hline-4.62 & 7.75 & 20.19 & 6.80 & 7.53 \\
\hline-9.29 & 10.39 & 19.67 & 9.26 & 7.51 \\
\hline$-\{3.77$ & 6.04 & 19.80 & 9.80 & 6.72 \\
\hline-9.15 & 6.51 & 19.41 & 9.32 & 6.52 \\
\hline-5.28 & 6.82 & 20.30 & 8.56 & 7.59 \\
\hline-5.54 & 7.64 & 20.08 & 8.80 & 7.74 \\
\hline-7.71 & 7.02 & 18.89 & 9.62 & 6.95 \\
\hline-2.10 & 6.22 & 21.56 & 10.05 & 8.93 \\
\hline-6.41 & 5.33 & 20.60 & 9.63 & 7.27 \\
\hline-5.93 & 9.40 & 18.95 & 9.56 & $8 .(10)$ \\
\hline-6.87 & 8.82 & 19.68 & 9.08 & 7.68 \\
\hline-3.17 & 9.48 & 21.29 & 9.25 & 9.21 \\
\hline
\end{tabular}

\section{REFERENCES}

Karl, T.R., G. Kukla, and J. Gavin. 1984. Decreasing diurnal temperature range in the United States and Canada from 1941 through 1980. Joumal of Climate and Applied Meteorology 23:1489-1504.

Karl, T.R., G. Kukla; and J. Gavin. 1986. Relationship between decreased temperature range and precipitation trends in the United States and Canada, 1941-1980. Joumal of Climate and Applied Meteorology 26:1878-86.

Karl, T.R., C.N. Williams, Jr., P.J. Young, and W.M. Wendland. 1986. A model to estimate the time of observation bias associated with monthly mean maximum, minimum, and mean temperatures for the United States. Joumal of Climate and Applied Meteorology 25:145-60.

Karl, T.R., R.G. Baldwin, M.G. Burgin. 1988a. Time series of regional seasonal averages of maximum, minimum, and average temperature, and diumal temperature range across the United States: 1901-1984. Historical Climatology Series 4-5. National Climatic Data Center. National Occanic \& Atmospheric Administration. National Environmental Satellite, Data, and Information Service. Asheville, North Carolina.

Karl, T.R., H.F. Diaz, and G. Kukla. 1988b. Urbanization: its detection and effect in the United States climate record. Journal of Climate 1:1099-1123.

Karl, T.R., C.N. Williams, Jr., and

F.T. Quinlan, 1990. United States Historical Climatology (HCN) serial temperature and precipitation data. NDP-019/R1. Carbon Dioxide Information Analysis Center. Oak Ridge National Laboratory, Oak Ridge, Tennessec. 


\section{Eastern Prairies}

\begin{tabular}{l} 
BACKGROUND \\
Principal investigators \\
Thomas R. Karl \\
Ronald G. Baldwin \\
Michael G. Burgin \\
National Oceanic and Atmospheric \\
Administration \\
National Climatic Data Center \\
Federal Building \\
Asheville, North Carolina 28801, U.S.A. \\
Sponsoring agencies \\
U.S. Department of Commerce \\
National Oceanic and \\
Atmospheric Administration \\
U.S. Department of Encrgy \\
Carbon Dioxide Research Program \\
Period of record - 1901-1987. \\
Method - After comparing each station's \\
data in the L219-station Historical \\
Climatology Network (HCN) (Karl et al. \\
1990) to data from its twenty nearest \\
neighbors, stations were selected based on \\
confidence, missing data, and consistency \\
criteria. All data were adjusted for time of \\
observation biases, station and instrument \\
changes, and urban heat island biases. \\
Twentynthree regions were formed by \\
subjectively considering the climate \\
characteristics across the country, the \\
terrain, the continentality, and the \\
vegetation. As an additional constraint, each \\
region was required to have boundaries \\
coinciding with NCDC's climate divisions. \\
For further details see Karl et al. (1988a). \\
Data availability - These data are available \\
from NCDC and CDIAC. The complete \\
HCN data set (Karl et al. 1990) is available \\
from CDIAC. \\
\hline
\end{tabular}
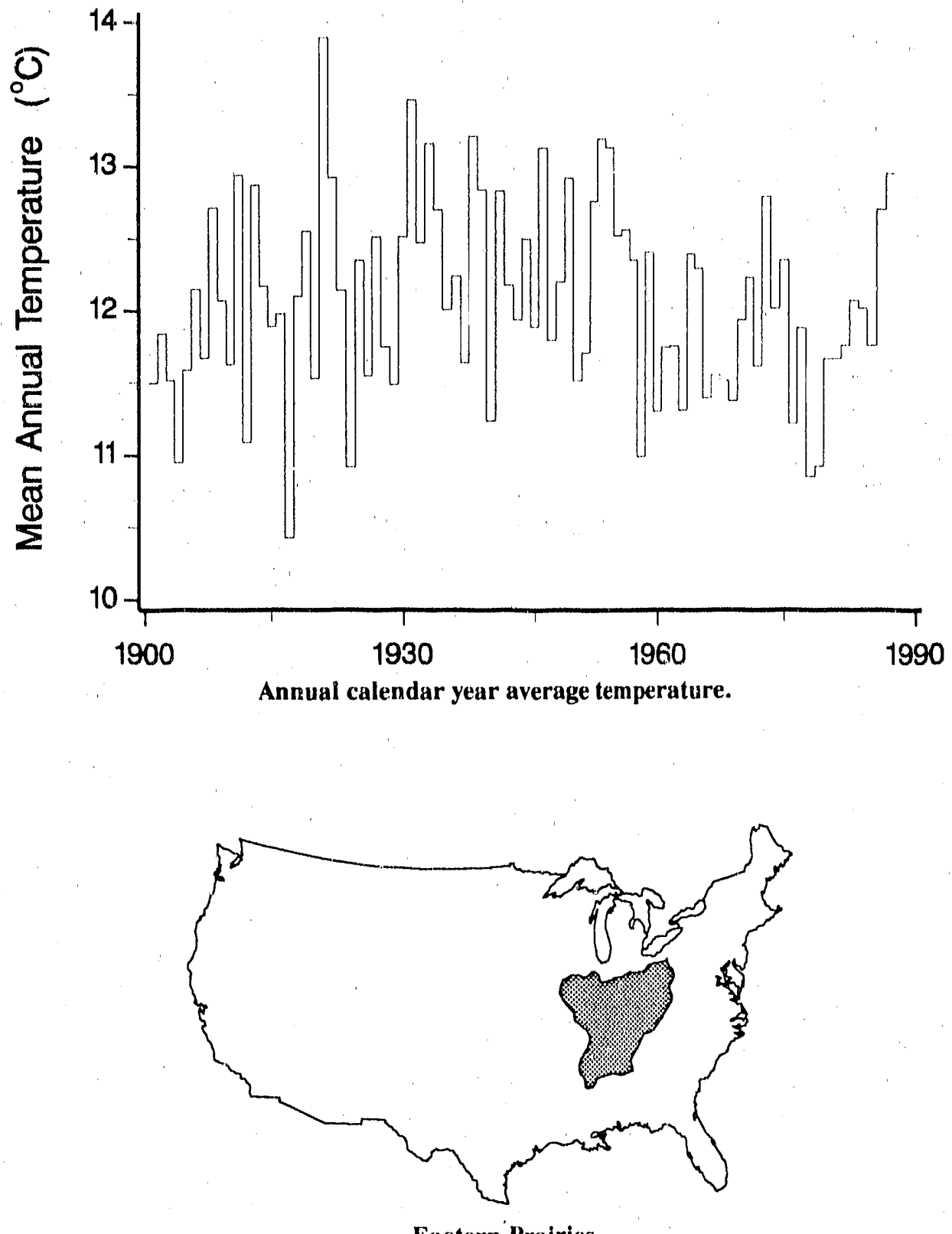

Eastern Prairies 


\section{TRENDS}

On the basis of regional seasonal temperatures (i.e., maximum, minimum, average, and diurnal range) for the United States, Karl et al. (1988a) concluded that the climate has changed over the recent century but that the changes have not been monotonic for the most part. Instead, the changes are somewhat unsteady and sometimes occur over a relatively short period of time. Karl et al. (1988a) also found a considerable amount of detailed information for each regional time series but reported that their salient features often could be summarized in time series plots for three aggregated regions: West, Central, and East. For the aggregated East region, which includes this subregion, Karl et al. (1988a) reported that the annual average temperature time series can be divided into three epochs: a warm epoch from the early 1920 s to the mid 1950 s, preceded and followed by periods during which temperatures were generally at or below the mean for the century. 


\section{Eastern Prairies}

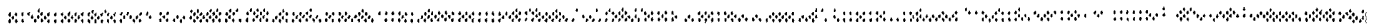

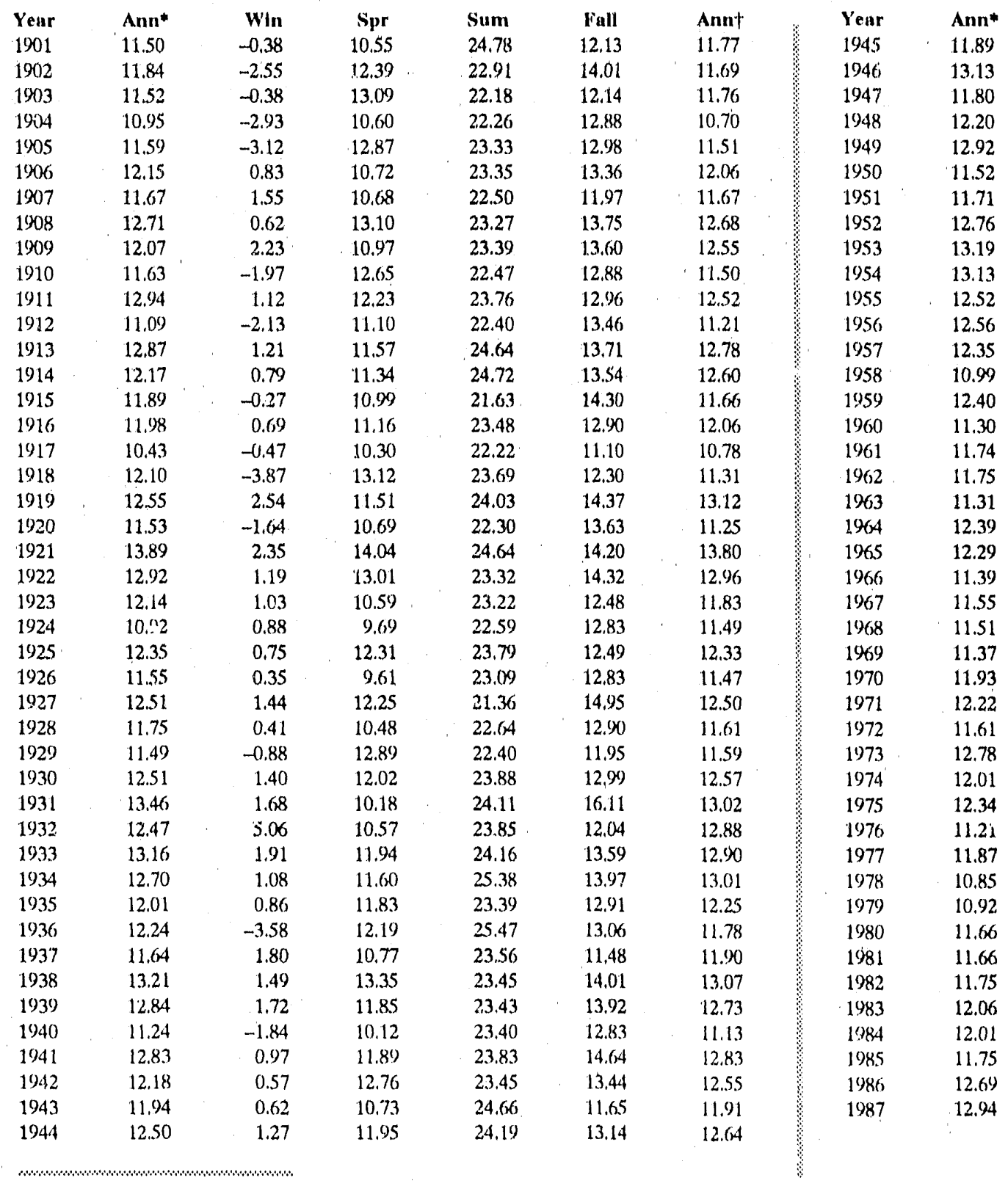

* Calendar year mean (Jan-Dec).

tSeason year mean (Win $=$ Dec-Feb; Spr $=$ Mar-May; Sum $=$ Jun-Aug; Fall $=S e p-N o v)$.

TRENDS' 90 
Average Temperature $\left({ }^{\circ} \mathrm{C}\right), 1901-1987$

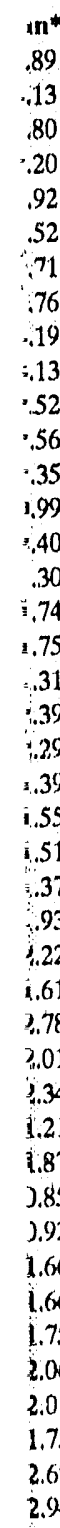

in

\begin{tabular}{|c|c|}
\hline Win & Spr \\
\hline-1.10 & 13.10 \\
\hline 0.25 & 13.63 \\
\hline 0.88 & 9.87 \\
\hline-0.70 & 12.53 \\
\hline 2.86 & 11.68 \\
\hline $3.2 \%$ & 10.56 \\
\hline-0.42 & 11.08 \\
\hline 2.37 & 11.44 \\
\hline 2.70 & 12.03 \\
\hline 2.49 & 11.59 \\
\hline 0.59 & 13.33 \\
\hline 0.39 & 11.57 \\
\hline 2.06 & 12.14 \\
\hline-0.48 & 10.80 \\
\hline-1.14 & 12.43 \\
\hline 1.06 & 9.24 \\
\hline-0.58 & 10.58 \\
\hline-0.20 & 12.00 \\
\hline-3.30 & 12.60 \\
\hline-1.67 & 12.78 \\
\hline 0.40 & 11.80 \\
\hline 0.24 & 11.02 \\
\hline 0.31 & 12.17 \\
\hline-0.99 & 11.58 \\
\hline-0.34 & 11.00 \\
\hline-2.16 & 12.05 \\
\hline 0.10 & 10.26 \\
\hline 1.40 & 11.78 \\
\hline 0.61 & 12.32 \\
\hline 1.12 & 12.73 \\
\hline 1.43 & 11.07 \\
\hline 1.51 & 12.49 \\
\hline-4.11 & 14.46 \\
\hline-4.67 & 10.58 \\
\hline-3.41 & 11.54 \\
\hline-0.41 & 10.65 \\
\hline-0.15 & 11.83 \\
\hline-2.19 & 12,03 \\
\hline 2.53 & 10.58 \\
\hline-1.45 & 9.79 \\
\hline-0.67 & 13,60 \\
\hline-0.69 & 13.10 \\
\hline 0.92 & 13.34 \\
\hline
\end{tabular}

\section{Sum}

22.41

22,35

23.20

23.28

24.15

21.76

23.01

24.78

24.40

24.59

23.60

2.3 .21

23.37

22.33

23.72

22.85

22.39

22.97

22.60

23.27

22.59

23.17

21.84

23.33

23.07

22.83

22.87

22.22

23.52

22.20

23.33

22.19

23.34

23.22

22.58

24.14

23.18

22.11

24.50

23.30

22.28

23.37

24.13

\section{Full}

13.33

14.24

13.95

13.27

12.85

12.50

11.86

12.06

13.90

13.93

13.04

13.40

12.22

13.38

12.64

13.87

13.76

12.86

14,50

13.07

13.48

12.13

11.4 .5

12.87

12.11

13.76

14.87

12.39

14.80

11.86

13.26

9.92

13.22

13.65

12.69

12.61

12.47

13.14

13.78

13.29

14.49

13.55

12.80
Annt

11.93

12.62

11.98

12.10

12.89

12.02

11.38

12.66

13.26

13.15

12.64

12.14

12.45

11.51

11.91

11.75

11.54

11.91

11.60

11.86

12.06

11.64

11.44

11.70

11.46

11.62

12,02

11.95

12.81

11.94

12,30

11.55

11.75

10.67

10.84

11.76

11.82

11.24

12.87

11.23

12.42

12.33

12.82

\section{REFERENCES}

Karl, T.R., G. Kukla, and J. Gavin. 1984. Decreasing diurnal temperature range in the United States and Canada from 1941 through 1980. Journal of Climate and Applied Meteorology 23:1489-1504.

Karl, T.R., G. Kukla, and J. Gavin. 1986.

Relationship between decreased

temperature range and precipitation trends in the United States and Canada, 1941-1980. Joumal of Climate and Applied Meteorology 26:1878-86.

Karl, T.R., C.N. Williams, Jr., P.J. Young, and W.M. Wendland. 1986. A model to estimate the time of observation bias associated with monthly mean maximum, minimum, and mean temperatures for the United States. Joumal of Climate and Applied Meteorology 25:145-60.

Karl, T.R., R.G. Baldwin, M.G. Burgin. 1988a. Time series of regional seasonal averages of maximum, minimum, and average temperature, and diumal temperature range across the United States: 1901-1984. Historical Climatology

Series 4-5. National Climatic Data Center. National Occanic \& Atmospheric Administration. National Environmental Satellite, Data, and Information Service. Ashevilile, North Carolina.

Karl, T.R., H.F. Diaz, and G. Kukla. 1988 b. Urbanization: its detection and effect in the United States climate record. Journal of Climate 1:10)(1123.

Karl, T.R., C.N. Williams, Jr., and

F.T. Ouinlan. 1990. United States Historical Climatology (HCN) serial temperature and precipitation data. NDP-(019/R 1. Carbon Dioxide Information Analysis Center, Oak Ridge National Laboratory. Oak Ridge, Tennessee. 


\section{Northern Appalachians}

BACKGROUND
Principal investigators
Thomas R. Karl
Ronald G, Baldwin
Michael G. Burgin
National Oceanic and Atmospheric
Administration
National Climatic Data Center
Federal Building
Asheville, North Carolina 28801, U.S.A.
Sponsoring agencies
U.S. Department of Commerce
National Oceanic and
Atmospheric Administration.
U.S. Department of Energy
Carbon Dioxide Research Program
Period of record - 1901-1987.
Method - After comparing each station's
data in the 1219-station Historical
Climatology Network (HCN) (Karl et al.
1990) to data from its twenty nearest
neighbors, stations were selected based on
confidence, missing data, and consistency
criteria. All data were adjusted for time of
observation biases, station and instrument
changes, and urban heat island biases.
Twenty-three regions were formed by
subjectively considering the climate
characteristics across the country, the
terrain, the continentality, and the
vegetation. As an additional constraint, each
region was required to have boundaries
coinciding with NCDC's climate divisions.
For further details see Karl et al. (1988a).
Data availability - These data are available
from NCDC and CDIAC: The complete
HCN data set (Karl et al. 1999) is available
from CDIAC.

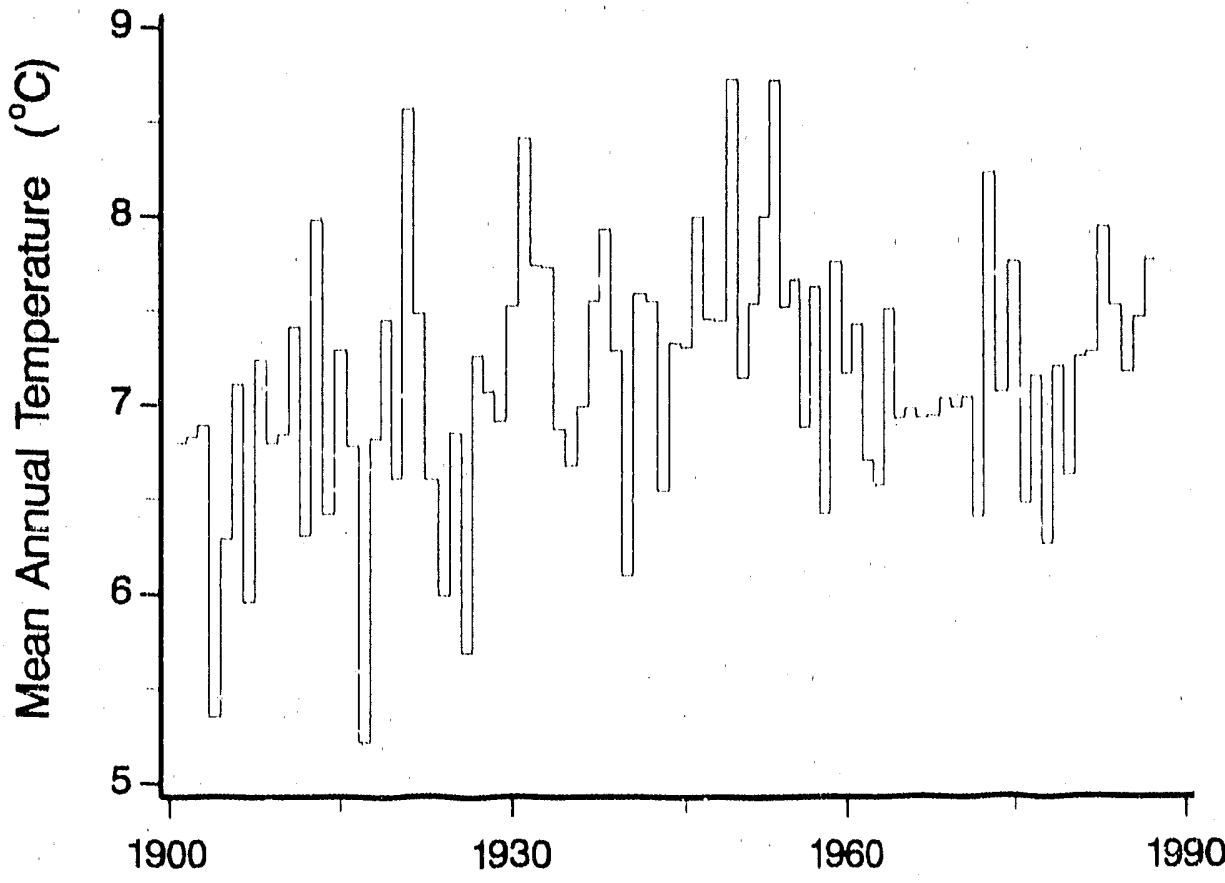

Annual calendar year average temperature.

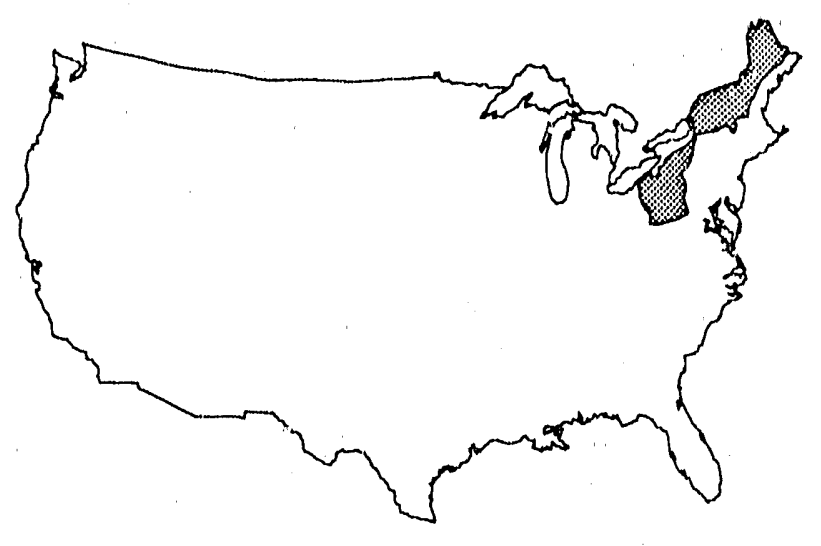

Northern Appalachians 


\section{TRENDS}

On the basis of regional seasonal temperatures (i.e., maximum, minimum, average, and diurnal range) for the United States, Karl et al. (1988a) concluded that the climate has changed over the recent century but that the changes have not been monotonic for the most part. Instead, the changes are somewhat unsteady and sometimes occur over a relatively short period of time. Karl et al. (1988a) also found a considerable amount of detailed information for each regional time series but reported that their salient features often could be summarized in time series plots for three aggregated regions: West, Central, and East. For the aggregated East region, which includes this subregion, Karl et al. (1988a) reported that the annual average temperature time series can be divided into three epochs: a warm cpoch from the early 1920s to the mid 1950s, preceded and followed by periods during which temperatures were generally at or below the mean for the century. 


\section{Northern Appalachians}

\begin{tabular}{|c|c|c|c|c|c|c|c|c|}
\hline Year & Ann* & W/in & Spr & Sum & Fall & Annt & Year & Ann* \\
\hline 1901. & 6.80 & -6.66 & 5.95 & 20.15 & 7.77 & 6.80 & 1945 & 7.31 \\
\hline 1902 & 6.83 & -6.24 & 6.93 & 17.60 & 9.56 & 6.96 & 1946 & 8.00 \\
\hline 1903 & 6.89 & -5.48 & 8.23 & 17.15 & 8.10 & 7.00 & 1947 & 7.46 \\
\hline 1904 & 5.35 & -9.23 & 5.48 & 18.24 & 7.10 & 5.40 & 1948 & 7.45 \\
\hline 1905 & 6.29 & -8.78 & 5.64 & 18.59 & 8.06 & 5.88 & 1949 & 8.73 \\
\hline 1906 & 7.11 & -3.68 & 4.71 & 19.55 & 8.80 & 7.34 & 1950 & 7.15 \\
\hline 1907 & 5.96 & -7.18 & 4.41 & 17.81 & 7.68 & 5.68 & 1951 & 7.54 \\
\hline 1908 & 7.24 & -5.61 & 6.32 & 19.22 & 9.67 & 7.40 & 1952 & 8.00 \\
\hline 1909 & 6.80 & -4.22 & 4.96 & 18.32 & 8.59 & 6.91 & 1953 & 8.72 \\
\hline 1910 & 6.84 & -6.15 & 7.64 & 18.38 & 8.27 & 7.04 & 1954 & 7.52 \\
\hline 1911 & 7.41 & -6.29 & 6.07 & 19.47 & 7.83 & 6.77 & 1955 & 7.66 \\
\hline 1912 & 6.31 & -6.74 & 5.11 & 17.61 & 9.56 & 6.38 & 1956 & 6.88 \\
\hline 1913 & 7.98 & -3.10 & 6.80 & 18.72 & 9.70 & 8.03 & 1957 & 7.62 \\
\hline 1914 & 6.42 & -6.09 & 5.48 & 18.61 & 8.84 & 6.71 & 1958 & 6.42 \\
\hline 1915 & 7.29 & -4.57 & 5.54 & 17.92 & 9.83 & 7.18 & 1959 & 7.75 \\
\hline 1916 & 6.78 & -4.96 & 4.54 & 19.20 & 8.56 & 6.83 & 1960 & 7.16 \\
\hline 1917 & 5.22 & -6.67 & 4.20 & 18.85 & 6.24 & 5.6 .5 & 1961 & 7.42 \\
\hline 1918 & 6.82 & -9.53 & 7.20 & 18.54 & 8.36 & 6.14 & 1962 & 6.70 \\
\hline 1919 & 7.45 & -3.12 & 6.08 & 19.50 & 9.13 & 7.90 & 1963 & 6.57 \\
\hline 1920 & 6.61 & -8.63 & 5.45 & 18.45 & 9.66 & 6.23 & 1964 & 7.50 \\
\hline 1921 & 8.57 & -3.49 & 9.23 & 19.92 & 9.34 & 8.75 & 1965 & 6.92 \\
\hline 1922 & 7.48 & -5.63 & 7.02 & 18.87 & 9.44 & 7.43 & 1966 & 6.97 \\
\hline 1923 & 6.60 & -6.75 & 4.42 & 18.38 & 8.73 & 6.19 & 1967 & 6.92 \\
\hline 1924 & 5.99 & -4.46 & 4.49 & $17 . \%$ & 8.09 & 6.52 & 1968 & 6.93 \\
\hline 1925 & 6.85 & -5.26 & 6.15 & 18.79 & 7.30 & 6.74 & 1769 & 7.02 \\
\hline 1926 & 5.69 & -5.73 & 3.23 & 17.86 & 8.14 & 5.87 & 1970 & 6.98 \\
\hline 1927 & 7.26 & -5.41 & 6.15 & 17.08 & 10.10 & 6.98 & 1971 & 7.03 \\
\hline 1928 & 7.07 & -4.63 & 4.79 & 18.94 & 8.59 & 6.92 & 1972 & 6.40 \\
\hline 1929 & 6.91 & -4.82 & 6.90 & 17.99 & 8.59 & 7.17 & 1973 & 8.21 \\
\hline 1930 & 7.52 & -4.41 & 5.89 & 19.03 & 9.34 & 7.46 & 1974 & 7.05 \\
\hline 1931 & 8.41 & -4.85 & 6.57 & 19.58 & 11.48 & 8.20 & 1975 & 7.74 \\
\hline 1932 & 7.74 & -1.35 & 4.72 & 18.73 & 8.93 & 7.76 & 1976 & 6.47 \\
\hline 1933 & 7.73 & -1.77 & 6.47 & 19.77 & 7.74 & 8.05 & 1977 & 7.14 \\
\hline 1934 & 6.87 & -7.64 & 6.04 & 19.53 & 9.68 & 6.90 & 1978 & 6.26 \\
\hline 1935 & 6.68 & -6.49 & 5.41 & 19.50 & 8.69 & 6.78 & 1979 & 7.19 \\
\hline 1936 & 6.99 & -7.99 & 7.05 & 19.13 & 8.29 & 6.62 & 1980 & 6.62 \\
\hline 1937 & 7.55 & -2.32 & 5.08 & 20.11 & 8.22 & 7.77 & 1981 & 7.24 \\
\hline 1938 & 7.93 & -4.93 & 7.16 & 19.90 & 8.90 & 7.76 & 1982 & 7.26 \\
\hline 1939 & 7.29 & -4.32 & 5.26 & 19.74 & 8.52 & 7.30 & 1983 & 7.92 \\
\hline 1940 & 6.10 & -6.69 & 4.39 & 18.72 & 7.78 & 6.05 & 1984 & 7.51 \\
\hline 1941 & 7.59 & -5.19 & 6.17 & 19.22 & 10.00 & 7.55 & 1985 & 7.16 \\
\hline 1942 & 7.55 & -5.15 & 8.33 & 19.13 & 9.31 & 7.90 & 1986 & 7.45 \\
\hline 1943 & 6.55 & -6.25 & 4.66 & 19.82 & 7.98 & 6.55 & 1987 & 7.75 \\
\hline 1944 & 7,33 & -.5 .35 & 5.87 & 19.95 & 8.94 & 7.35 & & \\
\hline
\end{tabular}

* Calendar year mean (Jan -Dec).

† Season year mean $\left(W_{1 n}=\right.$ Dec-Feb; Spr $=$ Mar-May; Sum =Jun-Aug; Fall $=$ Sep-Nov $)$.

TRENDS '90 
Average Temperature $\left({ }^{\circ} \mathrm{C}\right), 1901-1987$

\begin{tabular}{|c|c|c|c|c|}
\hline W/n & Spr & Sum & Fall & Annt \\
\hline-7.29 & 8.34 & 18.84 & 9.37 & 7.31 \\
\hline-5.98 & 7.93 & $18: 03$ & 10.73 & 7.68 \\
\hline-4.47 & 5.28 & 19.82 & 10.08 & 7.68 \\
\hline-7.01 & 6.54 & 19.12 & 10.05 & 7.18 \\
\hline-1.93 & 6.78 & $21.0 \mathrm{n}$ & 9.04 & 8.73 \\
\hline-2.73 & 4.61 & 18.56 & 9.07 & 7.38 \\
\hline-4.08 & 6.80 & 18.67 & 8.35 & 7.43 \\
\hline$-3,51$ & 6.14 & 19.95 & 8.93 & 7.88 \\
\hline-2.21 & 7.22 & 19.38 & 10.01 & 8.60 \\
\hline-3.06 & 6.25 & 18.54 & 9.56 & 7.82 \\
\hline-5.43 & 7.66 & 20.53 & 8.77 & 7.88 \\
\hline-5.43 & 4.09 & 18.27 & 8.77 & 6.43 \\
\hline-4.32 & 6.75 & 18.83 & 9.11 & 7.59 \\
\hline$-5,08$ & 6.32 & 17.99 & 9.13 & 7.09 \\
\hline-7.71 & 6.73 & 20.16 & 9.54 & 7.18 \\
\hline-3.57 & 5.60 & 18.48 & 9.64 & 7.54 \\
\hline-6.70 & 5.43 & 18.93 & 10.90 & 14 \\
\hline-5.57 & 6.84 & 18.46 & 7.92 & .91 \\
\hline-7.57 & 6.11 & 18.54 & 9.99 & 6.77 \\
\hline-6.17 & 7.24 & 18.44 & 8.79 & 7.07 \\
\hline-5.32 & 5.79 & 17.92 & 8.71 & 6.78 \\
\hline-4.73 & 5.50 & 19.18 & 8.65 & 7.15 \\
\hline-4.70 & 4.62 & 19.41 & 7.97 & 6.83 \\
\hline-6.70 & 7.04 & 18.81 & 9.61 & 7.19 \\
\hline-5.51 & 5.89 & 19.00 & 8.87 & 7.06 \\
\hline-7.75 & 6.19 & 19.06 & 10.22 & 6.93 \\
\hline-6.50 & 4.48 & 18.63 & 10.34 & 6.74 \\
\hline-4.81 & 5.00 & 18.19 & 7.51 & 6.47 \\
\hline-4.53 & 7.66 & 20.19 & 9.48 & 8.20 \\
\hline .4 .50 & 6.04 & 18.75 & 7.74 & 7.00 \\
\hline-3.38 & 5.70 & 19.67 & 9.73 & 7.93 \\
\hline-5.37 & 6.96 & 18.71 & 6.63 & 6.73 \\
\hline-8.16 & 8.35 & 18.50 & 9.02 & 6.93 \\
\hline-7.96 & 5.24 & 19.06 & 8.19 & 6.13 \\
\hline-7.33 & 7.22 & 18.73 & 9.54 & 7.04 \\
\hline-4.85 & 6.23 & 18.98 & 7.80 & 7.06 \\
\hline-6.18 & 7.13 & 19.00 & 7.87 & 6.95 \\
\hline-6.45 & 6.38 & 17.95 & 9.85 & 6.93 \\
\hline-2.38 & 6.46 & 19.90 & 9.66 & 8.44 \\
\hline-4.90 & 4.67 & 19.41 & 9.01 & 7.05 \\
\hline-4.74 & 7.41 & 17.99 & 9.81 & 7.62 \\
\hline-5.94 & 7.95 & 18.24 & 8.35 & 7.15 \\
\hline-5.04 & 7.96 & 19.49 & 8.35 & 7.69 \\
\hline
\end{tabular}

\section{REFERENCES}

Karl, T.R., G. Kukla, and J. Gavin. 1984.

Decreasing diurnal temperature range in the United States and Canada from 1941 through 1980. Journal of Climate and Applied Meteorology 23:1489-1504.

Karl, T.R., G. Kukla, and J. Gavin. 1986. Relationship between decreased tempurature range and precipitation trends in the United States and Canada, 1941-1980. Joumal of Climate and Applied Meteorology 26:1878-86.

Karl, T.R., C.N. Williams, Jr., P.J. Young, and W.M. Wendland. 1986. A model to estimate the time of observation bias associated with monthly mean maximum, minimum, and mean temperatures for the United States. Joumal of Climate and Applied Meteorology 25:145-60.

Karl, T.R., R.G. Baldwin, M.G. Burgin. 1988a. Time series of regional seasonal averages of maximum, minimum, and average temperature, and diumal temperature range across the United States: 1901-1984. Historical Climatology Series 4-5. National Climatic Data Center. National Oceanic \& Atmospheric Administration. National Environmental Satellite, Data, and Information Service. Asheville, North Carolina.

Karl, T.R., H.F. Diaz, and G. Kukla. 1988 b. Urbanization: its detection and effect in the United States climate record. Joumal of Climate 1:1099-1123.

Karl, T.R., C.N. Williams, Jr., and F.T. Quinlan. 1990. United States Historical Climatology $(H C N)$ serial temperature and precipitation data. NDP-019/R1. Carbon Dioxide Information Analysis Center. Oak Ridge National Laboratory. Oak Ridge, Tennessee. 


\section{Southern Appalachians}

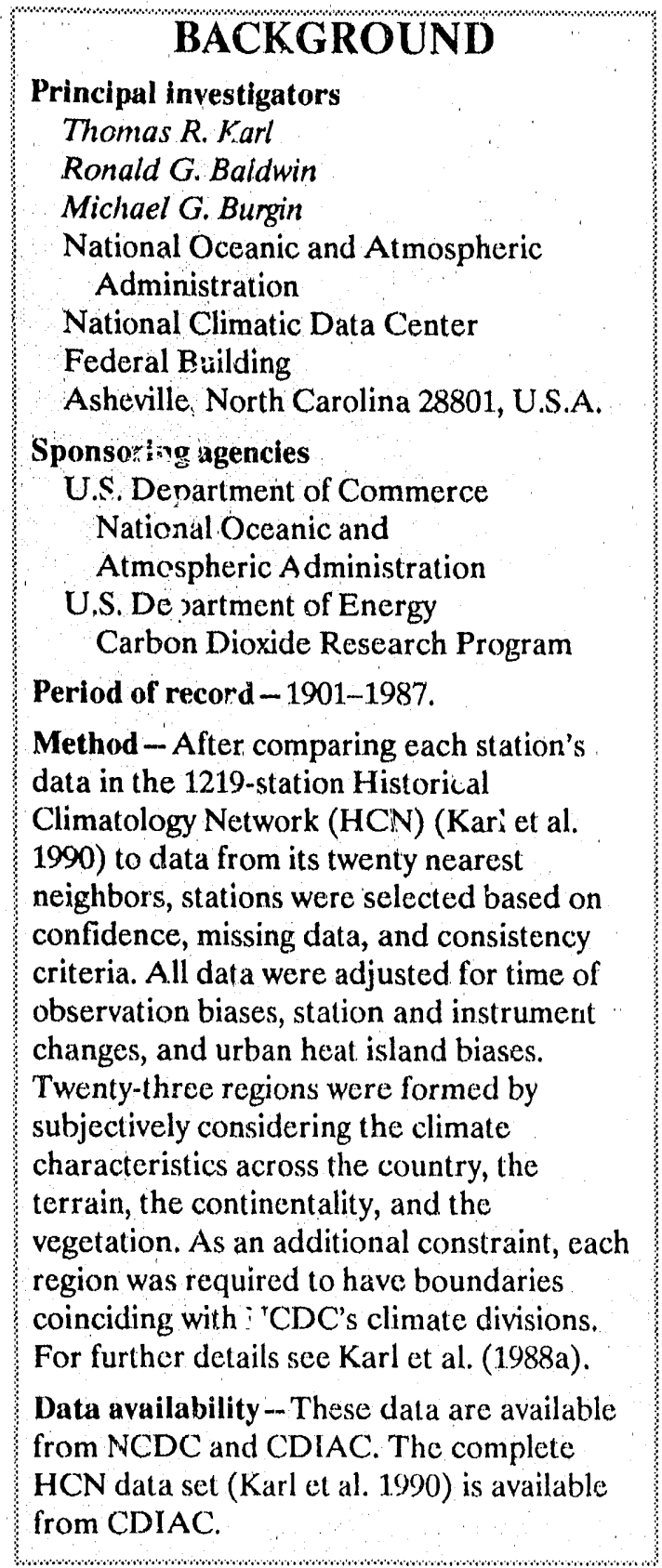
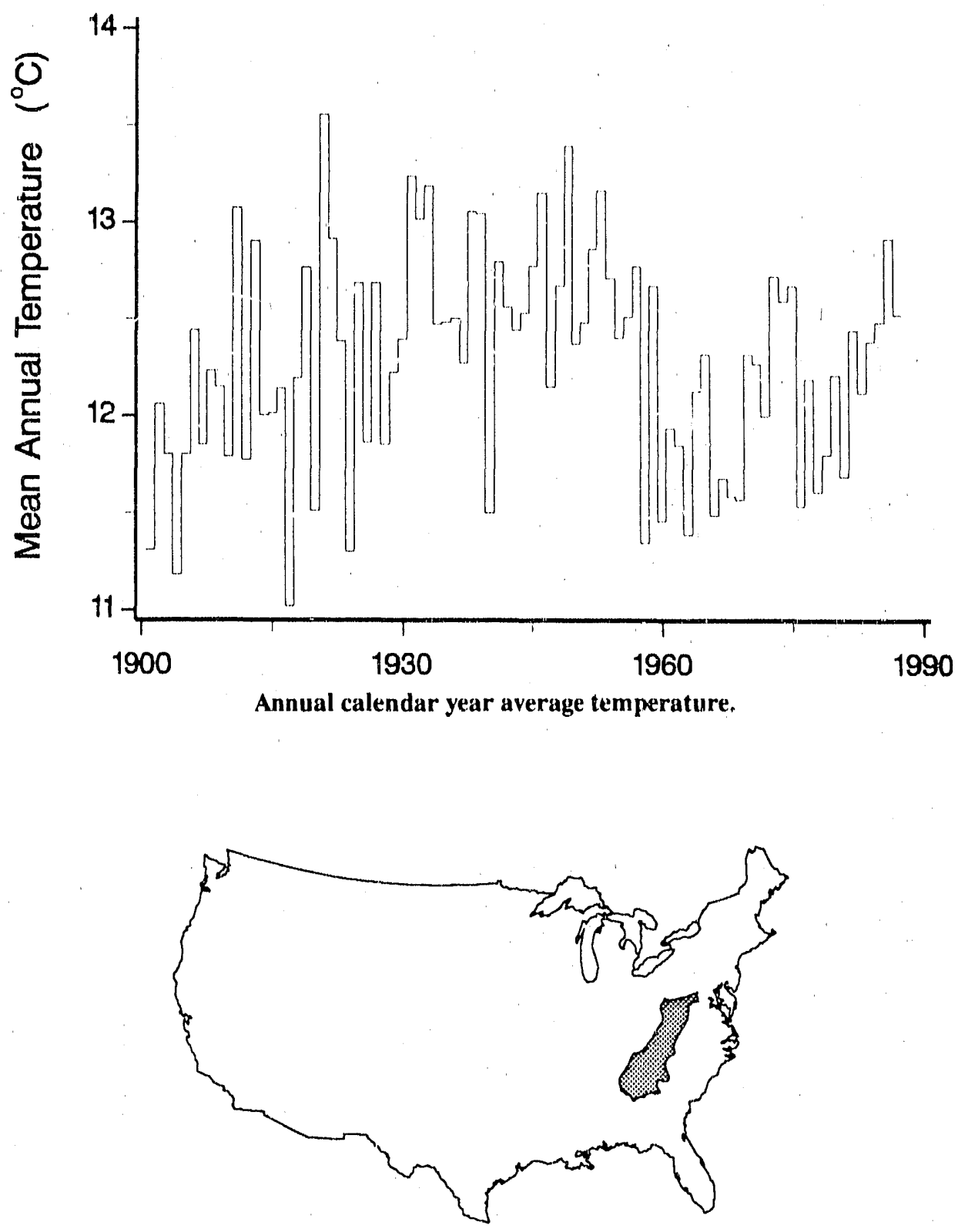

Southern Appalachians 


\section{TRENDS}

On the basis of regional seasonal temperatures (i.e., maximum, minimum, average, and diurnal range) for the United States, Karl et al. (1988a) concluded that the climate has changed over the recent century but that the changes have not been monotonic for the most part. Instead, the changes are somewhat unsteady and sometimes occur over a relatively short period of time. Karl et al. (1988a) also found a considerable amount of detailed information for each regional time series but reported that their salient features often could be summarized in time series plots for three aggregated regions: West, Central, and East. For the aggregated East region, which includes this subregion, Karl et al. (1988a) reported that the annual average temperat.re time series can be divided into three epochs: a warm epoch from the early 1920 s to the mid 1950s, preceded and followed by periods during which temperatures were generally at or below the mean for the century. 


\section{Southern Appalachians}

\begin{tabular}{|c|c|c|c|c|c|c|c|c|}
\hline Year & Ann* & Win & Spr & Sum & Fall & Annt & Year & Ann* \\
\hline 1901 & 11.31 & 1.21 & 10.64 & 22.76 & 11.29 & 11.48 & 1945 & 12.77 \\
\hline 1902 & 12.06 & -0.21 & 12.05 & 22.17 & 13.75 & 11.94 & 1946 & 13.15 \\
\hline 1903 & 11,80 & 2.03 & 13.08 & 21.41 & 11.69 & 12.05 & 1947 & 12.15 \\
\hline 1904 & 11.18 & -0.79 & 11.01 & 21.43 & 12.30 & 10.99 & 1948 & 12.67 \\
\hline 1905 & 11.80 & -0.82 & 12.95 & 22.00 & 12.81 & 11.73 & 1949 & 13.39 \\
\hline 1906 & 12.44 & 2.56 & 11.14 & 22.38 & 13.32 & 12.35 & 1950 & 12.37 \\
\hline 1907 & 11.85 & 3.24 & 11.37 & 21.15 & 11.93 & 11.92 & 1951 & 12.48 \\
\hline 1908 & 12.23 & 0.70 & 13,55 & 21.81 & 12.55 & 12.15 & 1952 & 12.86 \\
\hline 1909 & 12.15 & 4.13 & 11.38 & 21.68 & 12.74 & 12.48 & 1953 & 13.16 \\
\hline 1910 & 11.79 & 0.48 & 12.60 & 21.33 & 12.95 & 11.84 & 1954 & 12.71 \\
\hline 1911 & 13.07 & 2.60 & 11.58 & 22.80 & 13.47 & 12.61 & 1955 & 12.40 \\
\hline 1912 & 11.77 & 0.38 & 12.03 & 21.45 & 13.60 & 11.86 & 1956 & 12.51 \\
\hline 1913 & 12.90 & 3.84 & 12.44 & 22.49 & 12.68 & 12.86 & 1957 & 12.77 \\
\hline 1914 & 12.00 & 2.28 & 11.30 & 22.98 & 12.64 & 12.30 & 1958 & 11.35 \\
\hline 1915 & 12.01 & 1.67 & 10.89 & 21.35 & 13.80 & 11.92 & 1959 & 12.67 \\
\hline 1916 & 12.14 & 2.71 & 11.64 & 21.79 & 12.28 & 12.10 & 1960 & 11.46 \\
\hline 1917 & 11.02 & 2.15 & 11.08 & 21.70 & 10.82 & 11.44 & 1961 & 11,94 \\
\hline 1918 & 12.19 & -1.17 & 12.99 & 21.72 & 12.40 & 1.1 .48 & 1962 & 11.85 \\
\hline 1919 & 12.76 & 3.24 & 12.08 & 22.23 & 14.77 & 13.08 & 1963 & 11.39 \\
\hline 1920 & 11.51 & 0.84 & 10.59 & 21.19 & 13.00 & 11.41 & 1964 & 12.13 \\
\hline 1921 & 13.55 & 3.05 & 13.81 & 22.45 & 14.38 & 13.42 & 1965 & 12.32 \\
\hline 1922 & 12.91 & 3.31 & 12.88 & 22.00 & 13.36 & 12.89 & 1966 & 11.49 \\
\hline 1923 & 12.38 & 2.90 & 11.35 & 22.10 & 12.46 & 12.20 & 1967 & 11.68 \\
\hline 1924 & 11.30 & 2.51 & 10.13 & 21,97 & 12.00 & 11.65 & 1968 & 11.59 \\
\hline 1925 & 12.68 & 3.05 & 12.06 & 22.75 & 13.10 & 12.74 & 1969 & 11.57 \\
\hline 1926 & 11.86 & 1.84 & 10.17 & 22.16 & 12.94 & 11.77 & 1970 & 12.32 \\
\hline 1927 & 12.68 & 3.63 & 12.17 & 20.68 & 14.27 & 12.69 & 1971 & 12.27 \\
\hline 1928 & 11.85 & 2.19 & 10.69 & 21.90 & 12.57 & 11.84 & 1972 & 12.00 \\
\hline 1929 & 12.22 & 1.79 & 12.95 & 21.34 & 12.62 & 12.18 & 1973 & 12.72 \\
\hline 1930 & 12.39 & 3.74 & 11.90 & 22.25 & 12.74 & 12.66 & 1974 & 12.59 \\
\hline 1931 & 13.23 & 1.90 & 10.43 & 22.80 & 15.50 & 12.66 & 1975 & 12.67 \\
\hline 1932 & 13.01 & 6.85 & 10.93 & 22.71 & 12.60 & 13.27 & 1976 & 11.54 \\
\hline 1933 & 13.18 & 3.99 & 12.35 & 22.39 & 13.47 & 13.05 & 1977 & 12.19 \\
\hline 1934 & 12.47 & 2.30 & 11.51 & 23.51 & 13.69 & 12.75 & 1978 & 11.61 \\
\hline 1935 & 12.48 & 2.34 & 12.47 & 22.57 & 13.64 & 12.76 & 1979 & 11.80 \\
\hline 1936 & 12.50 & -0.85 & 12.44 & 23.26 & 13.54 & 12.10 & 1980 & 12.21 \\
\hline 1937 & 12.27 & 4.32 & 11,13 & 22.80 & 11.35 & 12.40 & 1981 & 11.69 \\
\hline 1938 & 13.05 & 3.27 & 13.24 & 22.20 & 13.36 & 13.02 & 1982 & 12.44 \\
\hline 1939 & 13.04 & 3.60 & 12.24 & 22.69 & 13.27 & 12.95 & i983 & 12.12 \\
\hline 1940 & 11.50 & 0.18 & 10.65 & 22.05 & 12.49 & 11.35 & 1984 & 12.38 \\
\hline 1941 & 12.79 & 2.31 & 11.59 & 22.61 & 14.79 & 12.82 & 1985 & 12.48 \\
\hline 1942 & 12.56 & 2.04 & 12.92 & 22.75 & 13.64 & 12.84 & 1986 & 12.91 \\
\hline 1943 & 12.44 & 2.72 & 11.41 & 23.48 & 11.88 & 12.37 & 1987 & 12.52 \\
\hline 1944 & 12.53 & 3.03 & 12.26 & 22.54 & 12.95 & 12.70 & & \\
\hline
\end{tabular}

- Calendar year mean (Jan-Dec).

†Season year mean $($ Win $=$ Dec-Feb; Spr $=$ Mar-May; Sum $=$ Jun-Aug; Fall $=$ Sep-Nov $)$.

TRENDS' 90 
Average Temperature $\left({ }^{\circ} \mathrm{C}\right), 1901-1987$

\begin{tabular}{rrrrr} 
Win & Spr & Sum & Full & Ann† \\
1.58 & 13.85 & 22.11 & 13.81 & 12.84 \\
1.93 & 13.30 & 21.51 & 14.12 & 12.72 \\
2.72 & 11.01 & 21.96 & 13.74 & 12.36 \\
1.29 & 13.32 & 22.31 & 13.17 & 12.52 \\
5.72 & 11.91 & 22.85 & 13.14 & 13.40 \\
5.58 & 11.20 & 21.43 & 12.55 & 12.69 \\
2.01 & 11.68 & 22.48 & 12.68 & 12.21 \\
4.24 & 11.82 & 23.52 & 12.11 & 12.92 \\
3.78 & 12.90 & 22.80 & 13.11 & 13.14 \\
3.45 & 11.82 & 22.74 & 13.30 & 12.82 \\
1.64 & 13.41 & 22.15 & 12.77 & 12.49 \\
1.74 & 11.45 & 21.98 & 12.55 & 11.93 \\
4.86 & 12.58 & 22.13 & 12.70 & 13.07 \\
0.36 & 11.03 & 22.10 & 13.14 & 11.66 \\
1.49 & 12.37 & 22.53 & 13.11 & 12.37 \\
2.46 & 9.62 & 21.99 & 13.27 & 11.84 \\
0.70 & 10.71 & 21.36 & 13.93 & 11.68 \\
2.53 & 11.74 & 21.54 & 12.40 & 12.06 \\
-0.75 & 12.62 & 21.32 & 13.05 & 11.56 \\
-0.19 & 12.22 & 21.91 & 12.59 & 11.63 \\
2.53 & 12.20 & 21.50 & 13.06 & 12.32 \\
1.35 & 11.31 & 21.83 & 12.01 & 11.64 \\
1.85 & 12.28 & 20.87 & 10.99 & 11.50 \\
0.63 & 11.83 & 22.33 & 12.79 & 11.89 \\
0.73 & 11.16 & 22.37 & 12.13 & 11.60 \\
-0.06 & 12.15 & 22.11 & 13.96 & 12.04 \\
1.88 & 10.27 & 21.73 & 14.12 & 12.00 \\
3.71 & 11.39 & 20.94 & 12.45 & 12.12 \\
2.88 & 12.09 & 22.43 & 14.34 & 12.94 \\
4.32 & 12.86 & 21.11 & 12.09 & 12.59 \\
3.45 & 11.54 & 22.18 & 13.56 & 12.68 \\
2.90 & 12.44 & 21.10 & 10.48 & 11.73 \\
-1.27 & 13.79 & 22.53 & 13.34 & 12.10 \\
-1.47 & 11.24 & 22.38 & 13.71 & 11.47 \\
0.35 & 12.35 & 21.23 & 13.06 & 11.78 \\
1.78 & 11.48 & 22.90 & 12.89 & 12.30 \\
1.18 & 11.65 & 22.41 & 12.11 & 11.86 \\
0.85 & 12.35 & 21.73 & 13.12 & 12.01 \\
3.10 & 11.07 & 22.55 & 12.86 & 12.54 \\
1.57 & 10.62 & 21.96 & 13.19 & 11.88 \\
\hline .47 & 13.07 & 21.43 & 14.92 & 12.97 \\
1.62 & 12.57 & 22.78 & 13.79 & 12.72 \\
\hline & 12.17 & 23.28 & 12.33 & 12.43
\end{tabular}

\section{REFERENCES}

Karl, T.R., G. Kukla, and J. Gavin. 1984. Decreasing diurnal temperature range in the United States and Canada from 1941 through 1980. Joumal of Climate and Applied Meteorology 23:1489-15()4. 'Karl, T.R., G. Kukla, and J. Gavin. 1986. Relationship between decreased temperature range and precipitation trends in the United States and Canada, 1941-1980. Joumal of Climate and Applied Meteorology 26:1878-86.

Karl, T.R., C.N. Williams, Jr., P.J. Young, and W.M. Wendland. 1986. A model to estimate the time of observation bias associated with monthly mean maximum, minimum, and mean temperatures for the United States. Joumal of Climate and Applied Meteorology 25:145-60.

Karl, T.R., R.G. Baldwin, M.G. Burgin. 1988a. Time series of regional seasonal averages of maximum, minimum, and average temperature, and diumal temperature range across the United States: 1901-1984. Historical Climatology Series 4-5. National Climatic Data Center. National Oceanic \& Atmospheric Administration. National Environmental Satellite, Data, and Information Service. Asheville, North Carolina.

Karl, T.R., H.F. Diaz, and G. Kukla. 1988b. Urbanization: its detection and effect in the United States climate record. Joumal of Climate 1:1099-1123.

Karl, T.R., C.N. Williams, Jr., and

F.T. Quinlan. 1990. United States Historical Climatology (HCN) serial temperature and precipitation data. NDP-019/R1. Carbon Dioxide Information Analysis Center. Oak Ridge National Laboratory. Oak Riäge, Tennessee. 


\section{Northern Piedmont}

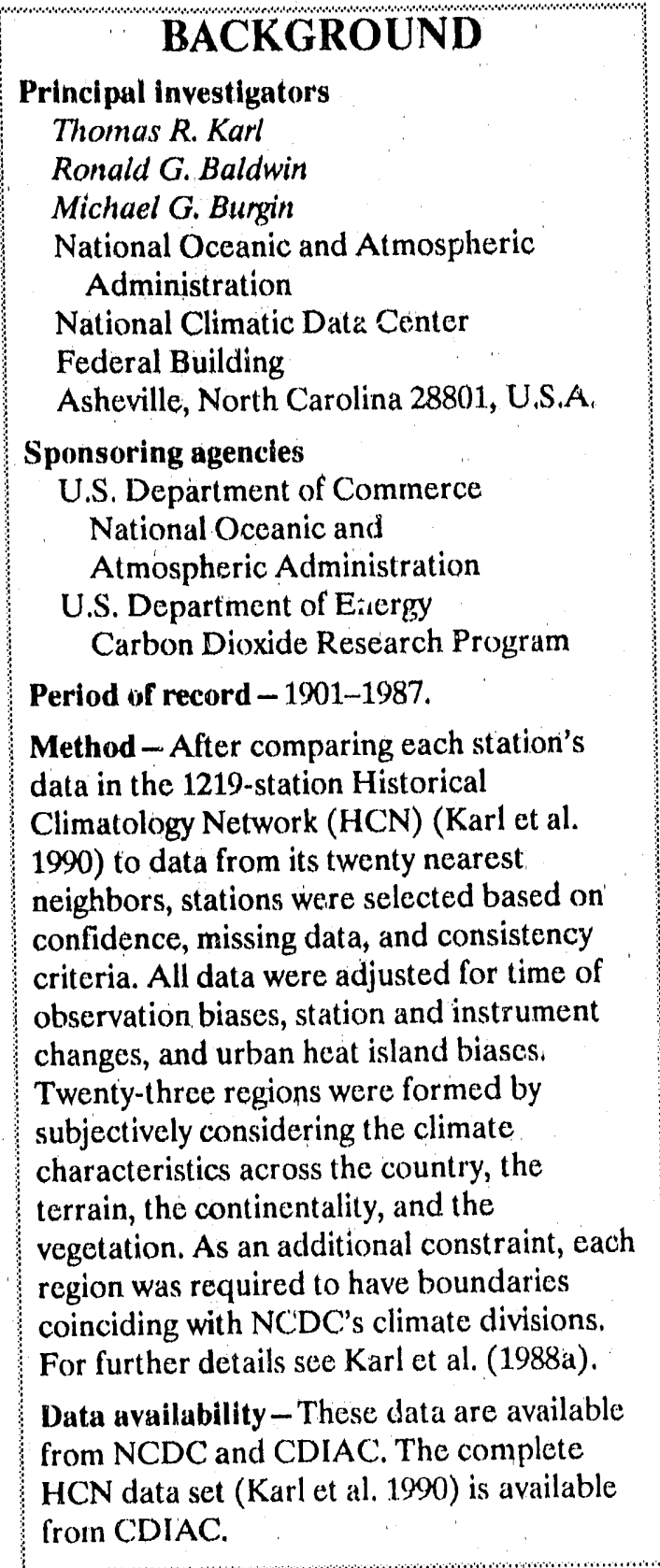

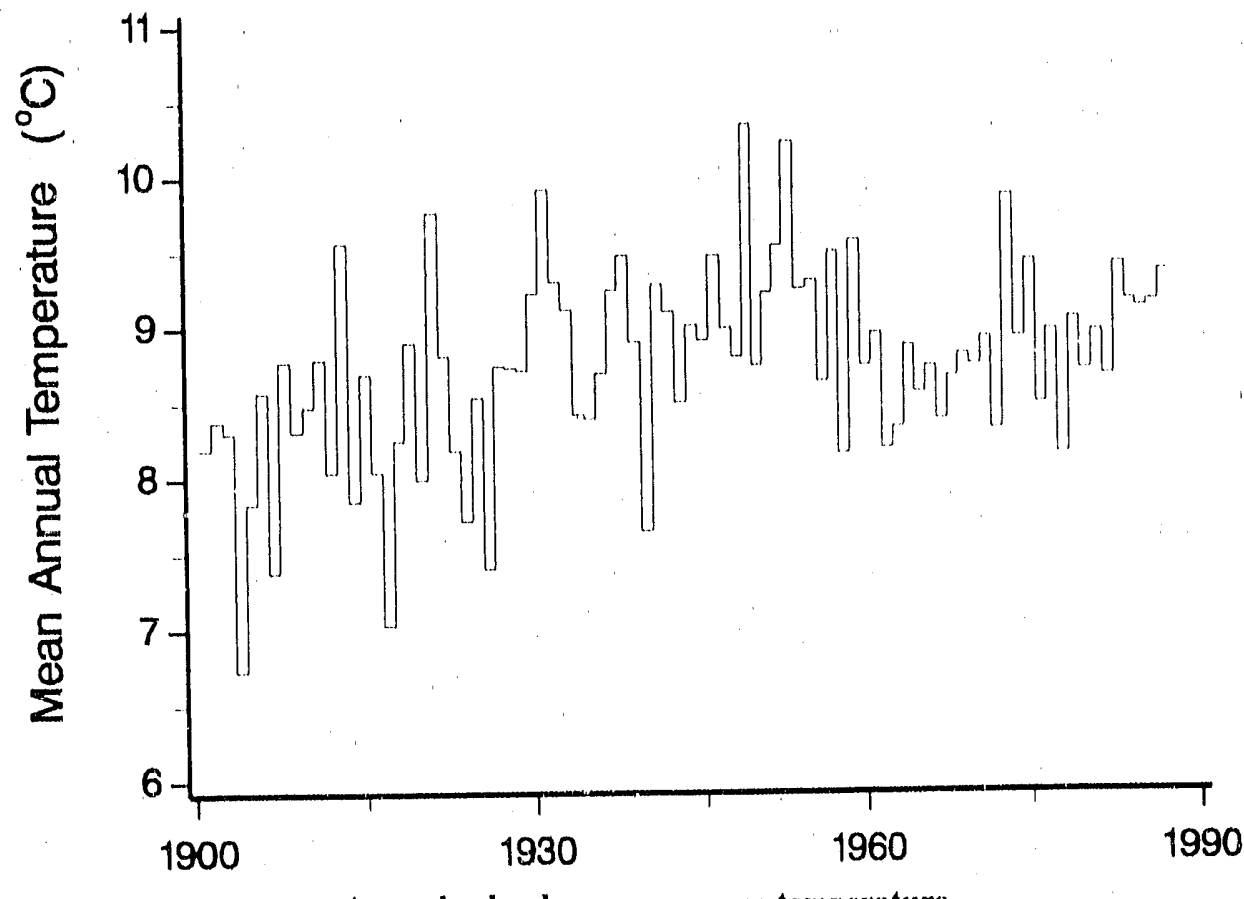

Annual calendar year average temperature.

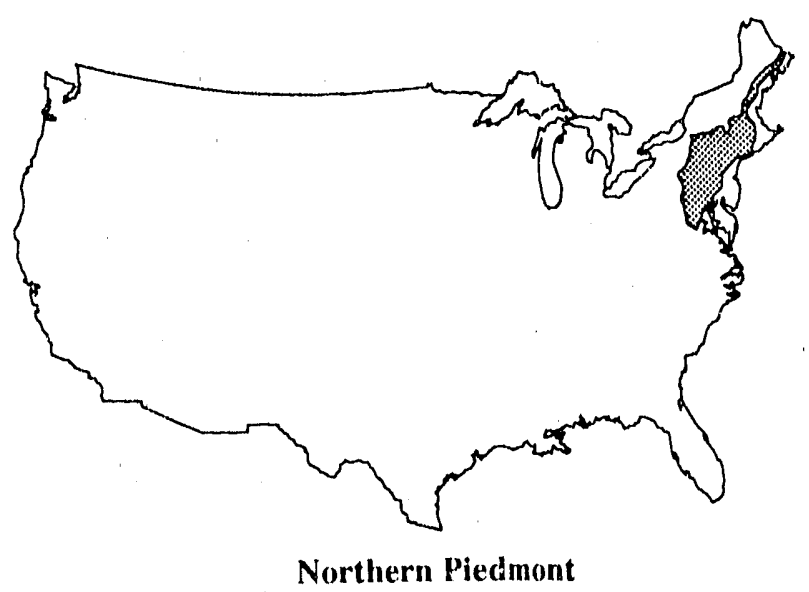




\section{U.S. Regional Temperatures}

\section{TRENDS}

On the basis of regional seasonal temperatures (i.e., maximum, minimum, average, and (liurnal range) for the United States, Karl et al. (1988a) concluded that the climate has changed over the recent century but that the changes have not been monotonic for the most part. Instead, the changes are somewhat unsteady and sometimes occur over a relatively short period of time. Karl et al. (1988a) also found a considerable amount of detailed information for each regional time series but reported that their salient features often could be summarized in time series plots for three aggregated regions: West, Central, and East. For the aggregated East region, which includes this subregion, Karl et al. (1988a) reported that the annual average temperature time series can be divided into three epochs: a warm epoch from the early 1920 s to the mid 1950s, preceded and followed by periods during which temperatures were generally at or below the mean for the century. 


\section{Northern Piedmont}

1 6 का

$\begin{array}{lcrrrrr}\text { Yenr } & \text { Ann* } & \text { Win } & \text { Spr } & \text { Sum } & \text { Full } & \text { Ann† } \\ 1901 & 8.19 & -4.50 & 7.13 & 21.21 & 9.03 & 8.22 \\ 1902 & 8.38 & -4.23 & 8.67 & 18.81 & 10.72 & 8.50 \\ 1903 & 8.30 & -3.52 & 9.68 & 17.98 & 9.36 & 8.37 \\ 1904 & 6.73 & -7.10 & 7.01 & 19.21 & 8.24 & 6.84 \\ 1905 & 7.83 & -6.88 & 7.39 & 19.64 & 9.35 & 7.37 \\ 1906 & 8.57 & -1.79 & 6.45 & 20.50 & 10.14 & 8.82 \\ 1907 & 7.38 & -5.48 & 5.86 & 19.02 & 9.00 & 7.10 \\ 1908 & 8.77 & -3.29 & 8.06 & 20.40 & 10.49 & 8.91 \\ 1909 & 8.31 & -2.23 & 6.81 & 19.38 & 9.75 & 8.43 \\ 1910 & 8.47 & -4.07 & 9.24 & 19.53 & 9.86 & 8.64 \\ 1911 & 8.79 & -4.20 & 7.63 & 20.35 & 9.19 & 8.24 \\ 1912 & 8.04 & -4.58 & 7.16 & 19.16 & 10.64 & 8.10 \\ 1913 & 9.56 & -1.05 & 8.61 & 20.00 & 10.84 & 9.59 \\ 1914 & 7.85 & -3.99 & 7.08 & 19.46 & 10.13 & 8.17 \\ 1915 & 8.69 & -2.60 & 7.24 & 18.95 & 10.79 & 8.60 \\ 1916 & 8.04 & -3.35 & 5.95 & 19.76 & 9.78 & 8.03 \\ 1917 & 7.03 & -4.07 & 5.76 & 20.28 & 7.84 & 7.45 \\ 1918 & 8.25 & -7.50 & 8.77 & 19.57 & 9.76 & 7.65 \\ 1919 & 8.90 & -1.43 & 8.10 & 20.11 & 10.37 & 9.29 \\ 1920 & 7.99 & -6.39 & 6.54 & 19.58 & 10.76 & 7.62 \\ 1921 & 9.76 & -1.82 & 19.49 & 20.48 & 10.61 & 9.94 \\ 1922 & 8.81 & -3.79 & 8.49 & 20.01 & 10.59 & 8.83 \\ 1923 & 8.18 & -5.18 & 6.49 & 19.68 & 10.04 & 7.75 \\ 1924 & 7.72 & -2.32 & 6.29 & 19.27 & 9.33 & 8.15 \\ 1925 & 8.53 & -3.25 & 7.99 & 20.24 & 8.75 & 8.43 \\ 1926 & 7.40 & -3.52 & \mathbf{5} 5.55 & 19.21 & 9.40 & 9.66 \\ 1927 & 8.74 & -3.59 & 7.37 & 18.43 & 11.37 & 8.39 \\ 1928 & 8.73 & -2.22 & 6.52 & 20.22 & 10.03 & 8.63 \\ 192.9 & 8.71 & -2.49 & 8.55 & 19.64 & 10.02 & 8.93 \\ 1930 & 9.22 & -2.39 & 7.78 & 20.63 & 10.76 & 9.19 \\ 1931 & 9.91 & -2.74 & 8.10 & 20.77 & 12.61 & 9.68 \\ 1932 & 9.30 & 0.34 & 6.82 & 20.12 & 10.27 & 9.39 \\ 1933 & 9.11 & -0.45 & 7.96 & 20.66 & 9.39 & 9.39 \\ 1934 & 8.42 & -5.55 & 7.71 & 20.53 & 10.74 & 8.36 \\ 1935 & 8.39 & -4.30 & 7.34 & 20.69 & 10.33 & 8.52 \\ 1936 & 8.69 & -5.77 & 8.92 & 20.49 & 9.69 & 8.33 \\ 1937 & 9.24 & -0.30 & 7.09 & 21.30 & 9.60 & 9.42 \\ 1938 & 9.47 & -2.69 & 8.65 & 21.08 & 10.41 & 9.36 \\ 1939 & 8.90 & -2.19 & 7.14 & 21.03 & 9.70 & 8.92 \\ 1940 & 7.65 & -4.13 & 5.96 & 19.58 & 8.99 & 7.60 \\ 1941 & 9.28 & -3.18 & 8.14 & 20.32 & 11.64 & 9.23 \\ 1942 & 9.10 & -2.96 & 9.81 & 20.28 & 10.63 & 9.44 \\ 1943 & 8.50 & -3.91 & 6.80 & 21.39 & 9.61 & 8.47 \\ 1944 & 9.01 & -3.19 & 7.71 & 21.18 & 10.31 & 9.00 \\ & & & & & & \end{array}$

Year

1945

1946

1947

1948

1949

1950

1951

1952

1953

1954

1955

1956

1957

1958

1959

1960

1961

1962

1963

1964

1965

1966

1967

1968

1969

1970

1971

1972

1973

1974

1975

1976

1977

1978

1979

1980

1981

1982

1983

1984

1985

1986

1987
Ann*

8.91

9.47

8,99

8.80

10.34

8.74

9.22

9.53

10.22

9.24

9.30

8.63

9.49

8.15

9.56

8.73

8.94

8.18

8.32

8.86

8.55

8.72

8.37

8.65

8.80

8.73

8.91

8.30

9.84

8.91

9.41

8.47

8.95

8.14

9.03

8.69

8.94

8.65

9.39

9.15

9.10

9.14

9.34

* Calendar year mean (Jan-Dec).

†Season year mean (Win $=$ Dec-Feb; Spr = Mar-May; Sum = Jun-Aug; Fall $=$ Sep-Nov).

TRENDS '90 
Average Temperature $\left({ }^{\circ} \mathrm{C}\right), 1901-1987$

\begin{tabular}{|c|c|c|c|c|}
\hline Win & Spr & Sum & Full & Annt \\
\hline-4.73 & 9.98 & 19.95 & 10.74 & 8.99 \\
\hline$-4,00$ & 9.27 & 19.28 & 12.04 & 9.14 \\
\hline-2.17 & 7.18 & 20.57 & 11.16 & 9.19 \\
\hline-5.23 & 7,93 & 20.32 & 11.37 & 8.59 \\
\hline-0.32 & 8.80 & 22.12 & 10.63 & 10.31 \\
\hline-1.05 & 6.36 & 19.75 & 10.58 & 8.91 \\
\hline-1.80 & 8.50 & 19,92 & 9.91 & 9.13 \\
\hline -1.46 & 7.85 & 21.28 & 10.14 & 9.45 \\
\hline-0.39 & 8.83 & 20.57 & 11.33 & 10.08 \\
\hline-0.98 & 8.07 & 19.88 & 10.92 & 9.47 \\
\hline-2.75 & 9.17 & 21.73 & 10.26 & 9.60 \\
\hline-3.16 & 5.94 & 19.81 & 10.05 & 8.16 \\
\hline-2.18 & 8.65 & 20.43 & 10.93 & 9.46 \\
\hline-2.72 & 7.83 & 19.53 & 10.28 & 8.73 \\
\hline-4.75 & 8.72 & 21.10 & 11.31 & 9.09 \\
\hline-1.33 & 7.22 & 19.99 & 10.68 & 9.14 \\
\hline$-4,92$ & 6.92 & 20.39 & 12.32 & 8.68 \\
\hline-3.73 & 8.27 & 19.70 & 9.19 & 8.36 \\
\hline-5.28 & 7.93 & 19.97 & 11.20 & 8.46 \\
\hline-4.25 & 8.35 & 19.09 & 10.28 & 8.52 \\
\hline-3.59 & 7.61 & 19.71 & 10.02 & 8.44 \\
\hline$-2,65$ & 7.06 & 20.86 & 10,04 & 8.83 \\
\hline-2.77 & 5.92 & 20.59 & 9.46 & 8.30 \\
\hline-4.36 & 8.49 & 20.29 & 11.01 & 8.86 \\
\hline-3.55 & 7.94 & 20.42 & 10.35 & 8.79 \\
\hline-4.95 & 7.85 & 20.52 & 11.50 & 8.73 \\
\hline-4.29 & 6.83 & 20.30 & 11.70 & 8.63 \\
\hline-2.35 & 7,00 & 19.71 & 9.13 & 8.37 \\
\hline-2.09 & 8.8 .3 & 21.40 & 10.97 & 9.78 \\
\hline-2.03 & 8.16 & 20.07 & 9.50 & 8.93 \\
\hline-1.32 & 7.54 & 20.64 & 11.37 & 9.56 \\
\hline-2.77 & 8.90 & 20.26 & 8.53 & 8.73 \\
\hline-5.72 & 9,99 & 20.04 & 10.70 & 8.75 \\
\hline-5.10 & 7.09 & 20.21 & 9.86 & 8.02 \\
\hline-4.36 & 8.98 & 20.02 & 10.97 & 8.90 \\
\hline-2.58 & 8.36 & 20.66 & 9.79 & 9.06 \\
\hline-3.80 & 8.82 & 20.47 & 9.58 & 8.77 \\
\hline-4.44 & 7.74 & 19.14 & 10.89 & 8.33 \\
\hline-1.01 & 8.14 & 21.02 & 10,95 & 9.77 \\
\hline-2.68 & 6.57 & 20.69 & 10.59 & 8.79 \\
\hline-2.30 & 9.25 & 19.64 & 11.38 & 9.49 \\
\hline-3.51 & 9.41 & 19.77 & 9.89 & 8.89 \\
\hline-2.70 & 9.20 & 20.76 & 9.94 & 9.30 \\
\hline
\end{tabular}

\section{REFERENCES}

Karl, T,R., G. Kukla, and J. Gavin, 1984. Decreasing diurnal temperature range in the United States and Canada from 1941 through 1980. Joumal of Climate and Applled Meteorology 23:1489-1504.

Karl, T.R., G. Kukla, and J. Gavin. 1986. Relationship between decreased temperature range and precipitation trends in the United States and Canada, 1941 1980. Joumial of Climate and Applied Meteorology 26:1878-86.

Karl, T.R., C.N. Williams, Jr., P.J. Young, and W.M. Wendland. 1986. A model to estimate the time of observation bias associated with monthly mean maximum, minimum, and mean temperatures for the United States. Joumal of Climate and Applied Meteorology 25:145-60.

Karl, T.R., R.G. Baldwin, M.G. Burgin. 1988a. Time series of regional seasonal averages of maximum, minimum, and average temperature, and diumal tempe "at"re range across the Uniled States: 191-1484. Historical Climatology Series 4-5. National Climatic Data Center. National Oceanic \& Atmospheric Administration. National Environmental Satellite, Data, and Information Service. Asheville, North Carolina.

Karl, T.R., H.F. Diaz, and G. Kukla. 1988b. Urbanization: its detection and effect in the United States climate record. Journal of Climate 1:1099-1123.

Karl, T.R., C.N. Williams, Jr., and F.T. Quinlan. 1990. United States Histo, ical Climatology (HCN) serial temperature and precipitation data. NDP-019/R1. Carbon Dioxide Information Analysis Center, Oak Ridge National Laboratory, Oak Ridge, Tennessee. 


\section{Southern Piedmont}

\begin{tabular}{l} 
BACKGROUND \\
Princlpal Investlgators \\
Thomas R. Karl \\
Ronald G, Baldwin \\
Michael G. Burgin \\
National Oceanic and Atmospheric \\
Administration \\
National Climatio Data Center \\
Federal Building \\
Asherille, North Carolina 28801, U.S.A. \\
Sponsorlng agencies \\
U.S. Department of Commerce \\
National Oceanic and \\
Atmospheric Administration \\
U.S. Department of Energy \\
Carbon Dioxide Research Program \\
Period of record - 1901-1987. \\
Method - After comparing each station's \\
data in the 1,419-station Historical \\
Climatology Network (HCN) (Karl et al. \\
1990) to data from its twenty nearest \\
neighbors, stations were selected based on \\
confidence, missing data, and consistency \\
criteria. All data were adjusted for time of \\
observation biases, station and instrument \\
changes, and urban heat island biaies, \\
Twenty-three regions were formed ty \\
subjectively considering the climate \\
characteristics across the country, the \\
terrain, the continentality, and the \\
vegetation. As an additional constraint, each \\
region was required to have boundaries \\
coinciding with NCDC's climate divisions, \\
For further details see Karl et al. (1988a) \\
Data avallability - These data are available \\
from NCDC and CDIAC. The complete \\
HCN data set (Karl et al. 1990) is available \\
from CDIAC. \\
\hline
\end{tabular}
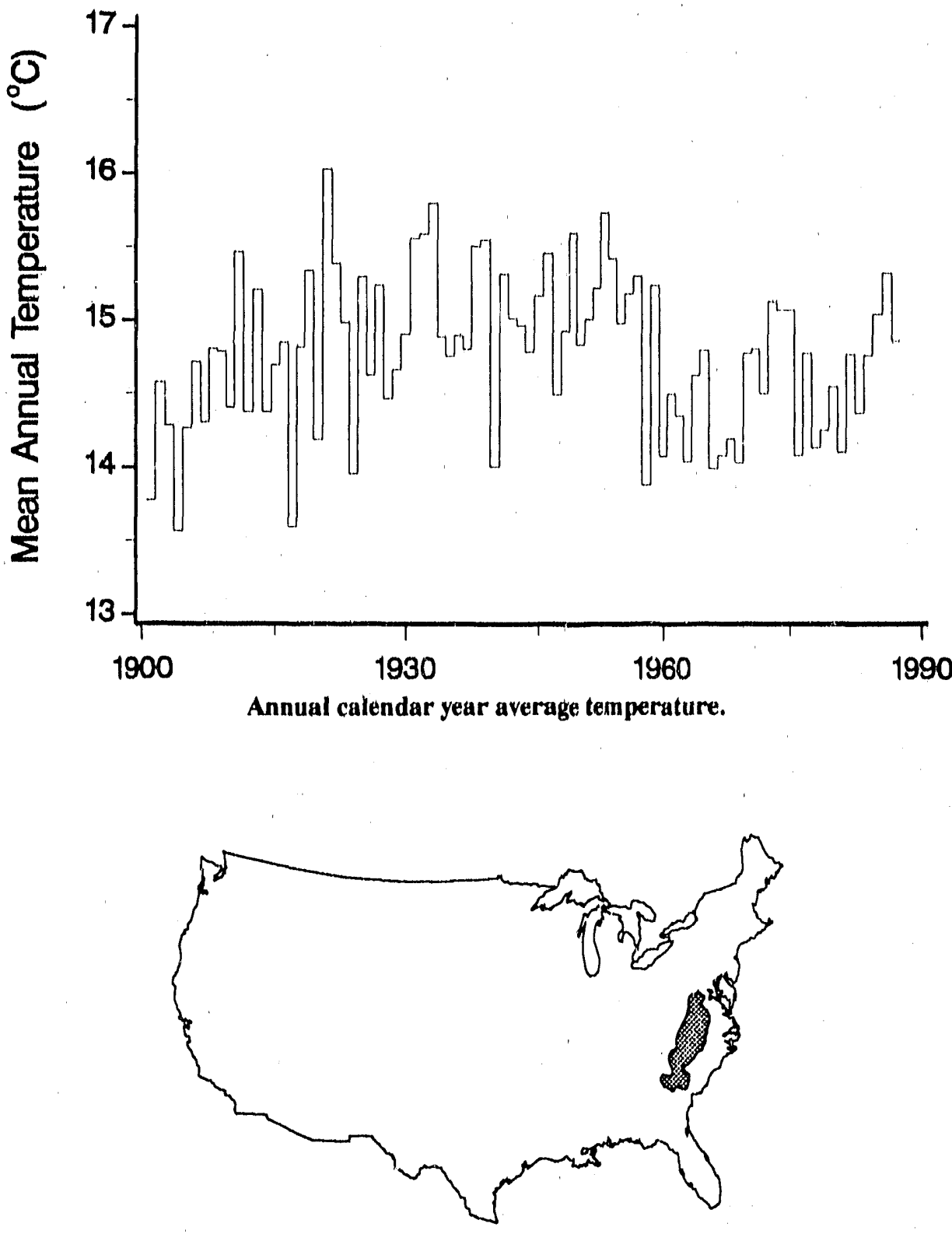

Southern Piedmont 


\section{U.S. Regional Temperatures}

\$Nक

\section{TRENDS}

On the basis of regional scasonal temperatures (l.e., maximum, minimum, average, and diurnal range) for the United States, Karl et al. (1988a) concluded that the climate has changed over the recent century but that the changes have not been monotonic for the most part. Instead, the changes are somewhat unsteady and sometimes occur over a relatively short period of time. Karl et al. (1988a) also found a considerable amount of detalled information for each regional time series but reported that their salient features often could be summarized in time series plots for three aggregated regions: West, Central, and East. For the aggregated East region, which includes this subregion, Karl et al. (1988a) reported that the annual average temperature time series can be divided into three epochs: a warm epoch from the early 1920 s to the mid 1950 s, preceded and followed by periods during which temperatures were generally at or below the mean for the century. 


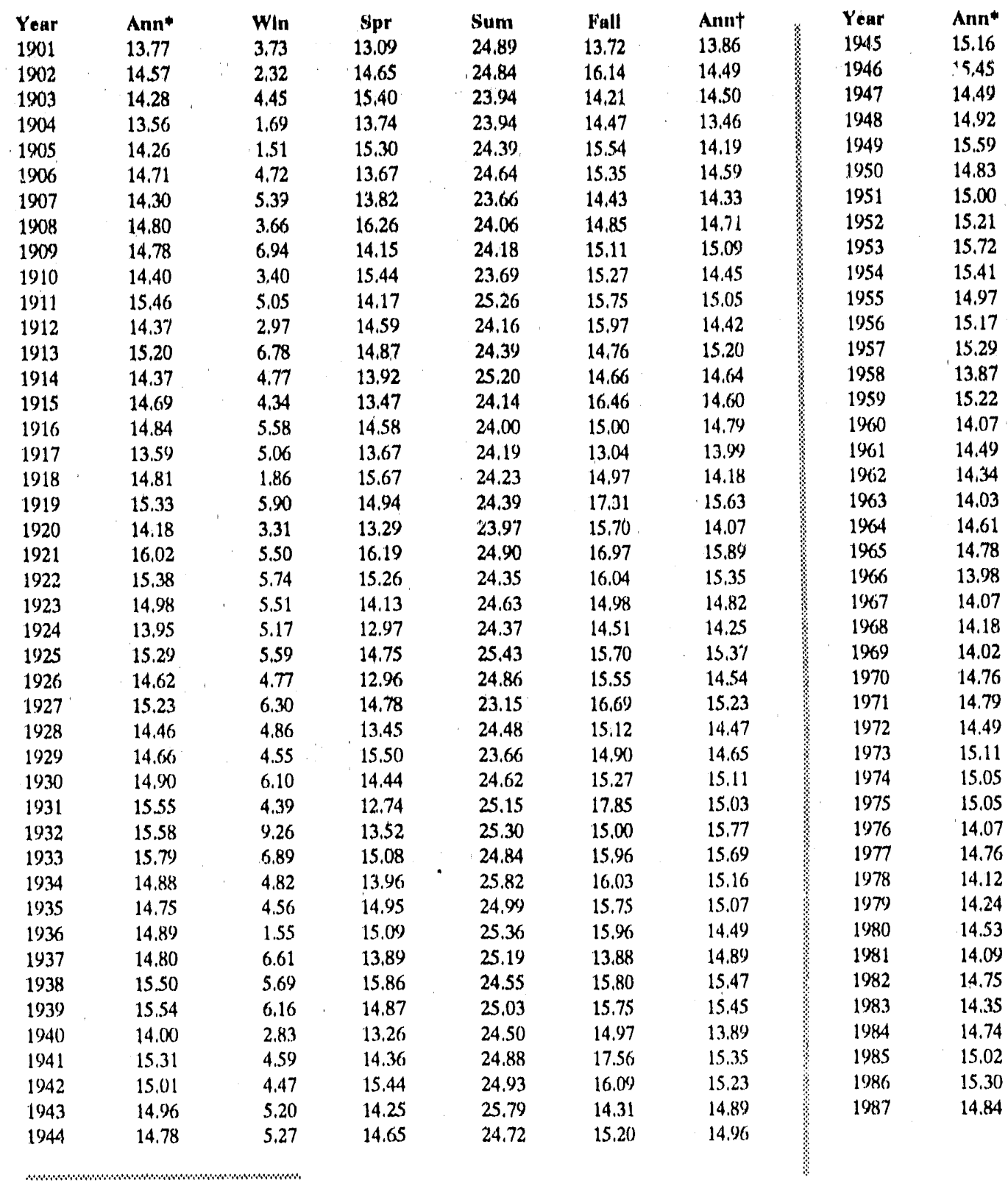

- Calendas year mean (Jan-Dec).

tSeason year mean (Win $=$ Dec-Feb; $S p r=$ Mar-May; Sum $=$ Jun-Aug; lall $=$ Sep-Nov).

TRENDS '90 
Average Temperature $\left({ }^{\circ} \mathrm{C}\right), 1901-1987$

\begin{tabular}{|c|c|c|c|c|}
\hline W/n & Spr & Sum & Fall & Alint \\
\hline 3.98 & 16,44 & 24,45 & 16.03 & 15.22 \\
\hline 4.34 & 15.69 & 23,63 & 16.33 & 15.00 \\
\hline 5.36 . & 13.59 & 24,07 & 15.89 & 14.73 \\
\hline 3.54 & 15,66 & 24.59 & 15,16 & 14.74 \\
\hline 8.09 & 14.31 & 24,83 & 15.34 & 15.64 \\
\hline 7.71 & 13.76 & 23.98 & 15.01 & 15.11 \\
\hline 4.58 & 14.08 & 24.90 & 15.28 & 14.71 \\
\hline 6.77 & 14.45 & 25,60 & 14.55 & 15,34 \\
\hline 6.23 & 15.52 & 25.22 & 15.65 & 15.65 \\
\hline 6.14 & 14.55 & 25.33 & 16.09 & 15.53 \\
\hline 4.52 & 16.12 & 24.46 & 15.07 & 15.05 \\
\hline 4.62 & 14.11 & 24.70 & 14.95 & 14.60 \\
\hline 7.76 & 15.12 & 24.39 & 15.11 & 15.59 \\
\hline 3.21 & 13.59 & 24.39 & 15.58 & 14.19 \\
\hline 4.21 & 15.11 & 24,81 & 15.64 & 14.94 \\
\hline 4.95 & 12.52 & 24.31 & 15.77 & 14.39 \\
\hline 3.44 & 13,48 & 23.79 & 16.32 & 14.26 \\
\hline 4.78 & 14.32 & 23.85 & 14.96 & 14.48 \\
\hline 2.33 & 15.23 & 23.94 & 15.27 & 14.19 \\
\hline 2.85 & 14.71 & 24.11 & 14.97 & 14.16 \\
\hline 5.36 & 14.76 & 23.71 & 15.44 & 14.82 \\
\hline 4.00 & 13.70 & 24.17 & 14.54 & 14.10 \\
\hline 4.45 & 14.50 & 23.15 & 13.29 & 13.85 \\
\hline 3.61 & 14.39 & 24.57 & 15.42 & 14.50 \\
\hline 3.25 & 13.85 & 24.52 & 14,44 & 14.01 \\
\hline 2.87 & 14.63 & 24.38 & 16.23 & 14.53 \\
\hline 4.71 & 12.88 & 24.04 & 16.38 & 14.50 \\
\hline 6.82 & 13.82 & 23.25 & 14.80 & 14,67 \\
\hline 5.28 & 14.57 & 24.59 & 16.72 & 15.29 \\
\hline 6.91 & 15.38 & 23.41 & 14.42 & 15.03 \\
\hline 6.15 & 13.96 & 24.09 & 16.23 & 15.11 \\
\hline 5.54 & 15.12 & 23.38 & 12.88 & 14.23 \\
\hline 1.77 & 16.18 & 25.05 & 15.62 & 14.66 \\
\hline 1.67 & 13.67 & 24.56 & 15,98 & 13.97 \\
\hline 3.28 & 14.85 & 23.44 & 15.54 & 14.28 \\
\hline 4.12 & 14.05 & 25.04 & 15.21 & 14.60 \\
\hline 3.80 & 14.11 & 24.56 & 14.44 & 14.23 \\
\hline 3.37 & 14.68 & 23,82 & 15.45 & 14.33 \\
\hline 5.24 & 13.47 & 24.90 & 15,35 & 14.74 \\
\hline 4.20 & 13.28 & 24.09 & 15.45 & 14.26 \\
\hline 5.17 & 15.64 & 23.90 & 17.30 & 15.50 \\
\hline 4.28 & 15.05 & 25.26 & 16.03 & 15.16 \\
\hline 4.21 & 14.34 & 25.65 & 14.82 & 14.76 \\
\hline
\end{tabular}

\section{REFERENCES}

Karl, T.R., G. Kukla, and J. Gavin. 1984. Decreasing diurnal temperature range in the United States and Canada from 1941 through 1980. Joumal of Climate and Applied Meteorology 23:1489-1504.

Karl, T.R., G, Kukla, and J. Gavin, 1986. Relationship between decreased temperature range and precipitation trends in the United States and Canada, 1941-1.980. Joumal of Climate and Applied Meteorology 26:1878-86.

Karl, T,R, C.N, Williams, Jr., P.J. Young, and W'M. Wendland. 1986. A model to estimate the time of observation bias associated with monthly mean maximum, minimum, and mean temperatures for the United States. Joumal of Climate and Applied Meteorology 25:145-60.

Karl, T'.R., R.G. Baldwin, M.G. Burgin. 1988a. Time series of regional seasonal averages of maximum, minimum, and average temperature, and diumal temperature range across the United States: 1901-1984. Historical Climatology Series 4-5. National Climatic Data Center. National Oceanic \& Atmospheric Administration. National Environmental Satellite, Data, and Information Service. Asheville, North Carolina.

Karl, T.R., H.F. Diaz, and G. Kukla. 1988 b. Urbanization: its detection and effect in the United States climate record. Joumal of Climate 1:1099-1123.

Karl, T.R., C.N. Williams, Jr., and F.T. Quinlan. 1990 . United States Historical Climatology (HCN) serial temperature and precipitation data. NDP-019/R1. Carbon Dioxide Information Analysis Center. Oak Ridge National Laboratory. Oak Ridge, 'Tennessee. 


\section{Coastal Northeast}

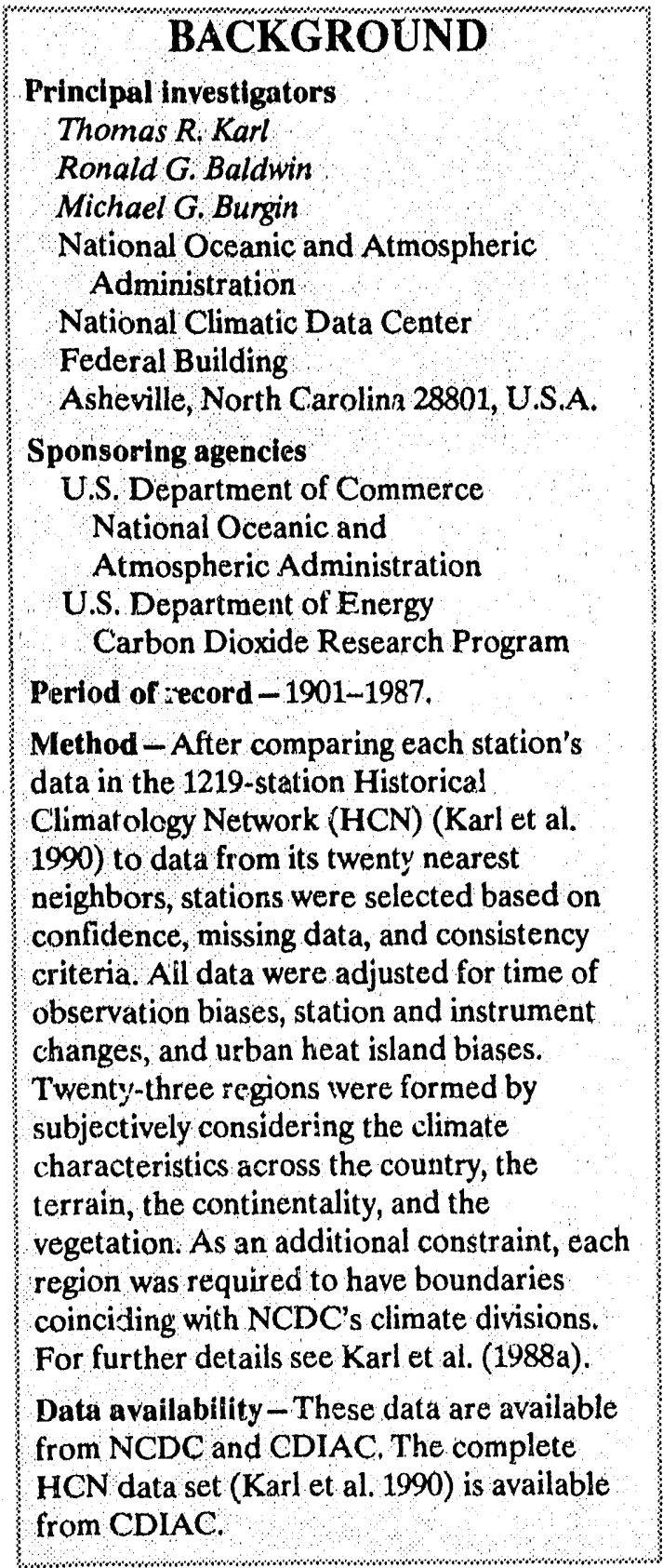
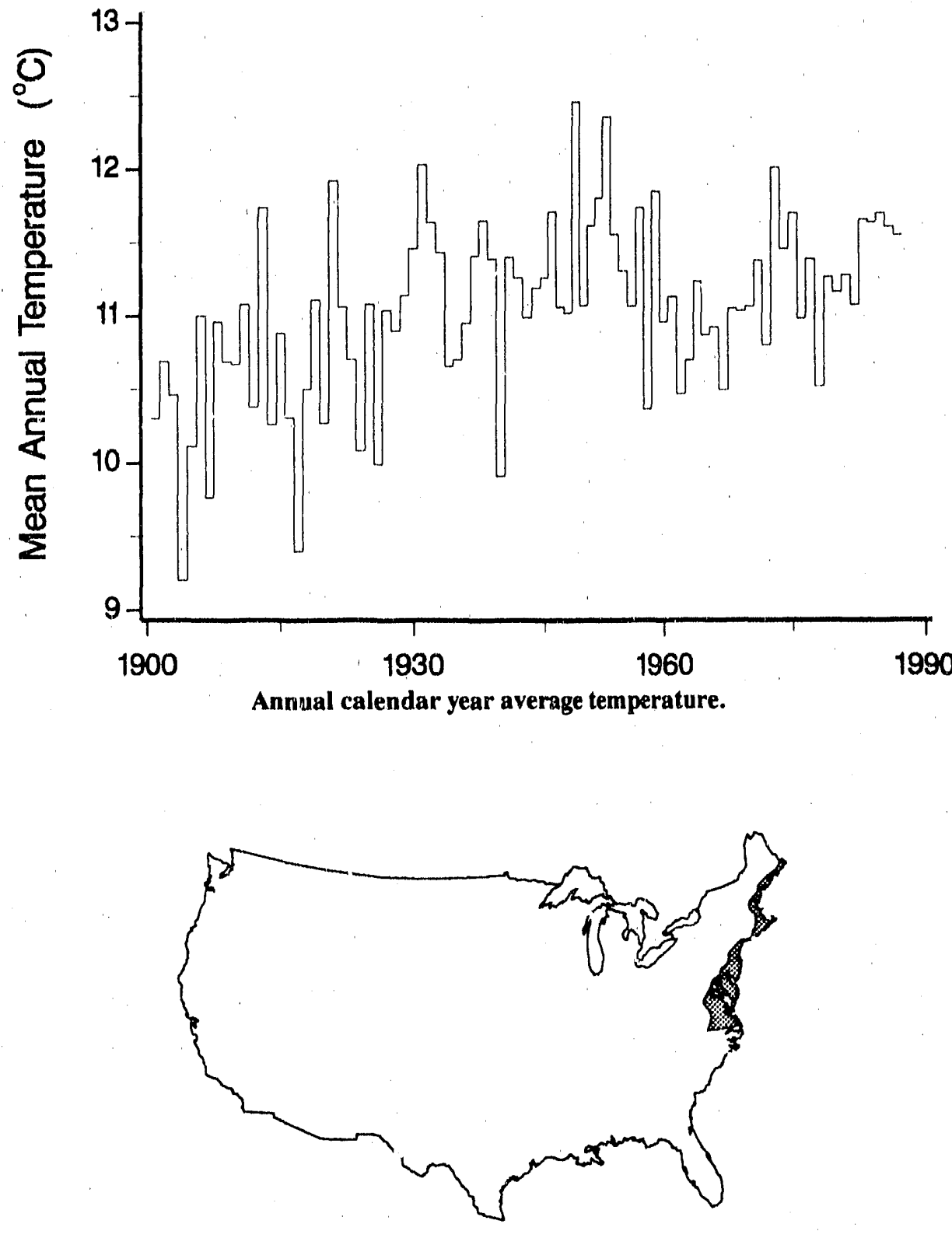

Coastal Northeast 
U.S. Regional Temperatures

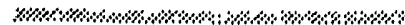

\section{TRENDS}

On the basis of regional seasonal temperatures (i.e., maximum, miniraum, average, and diurnal range) for the United States, Karl et al. (1988a) concluded that the climate has changed over the recsnt century but that the changes have not teen monotonic for the most part. Instead, the changes are somewhat unsteady and sometimes occur over a relatively short period of time: Karl et al. (1988a) also found a considerable amount of detailed information for each regional time series but reported that their salient features often could be surnmarized in time series plots for three aggregated regions: West, Central, and East. For the aggregated East region, which includes this subregion, Karl et al. (1988a) reported that the annual average temperaiure time series can be divided into three epochs: a warm epoch from the early 1920 s to the mid 1950s, preceded and followed by periods during which temperatures were generally at or below the mean for the century. 


\begin{tabular}{lrrrrrr} 
Year & Ann* & Wln & \multicolumn{1}{c}{ Spr } & Sum & Fall & Annt \\
1901 & 10.30 & -1.32 & 8.97 & 22.35 & 11.31 & 10.33 \\
1902 & 10.69 & -1.44 & 10.39 & 20.76 & 13.27 & 10.74 \\
1903 & 10.46 & -0.15 & 11.22 & 19.77 & 11.49 & 10.58 \\
1904 & 9.20 & -3.44 & 8.99 & 20.74 & 10.83 & 9.28 \\
1905 & 10.11 & -3.55 & 9.75 & 20.91 & 11.84 & 9.74 \\
1906 & 11.00 & 1.19 & 8.92 & 21.70 & 12.63 & 11.11 \\
1907 & 9.76 & -1.29 & 8.17 & 20.01 & 11.51 & 9.60 \\
1908 & 10.96 & -0.13 & 10.47 & 21.44 & 12.44 & 11.05 \\
190 & 10.69 & 1.63 & 9.23 & 20.75 & 11.96 & 10.90 \\
191 & 10.67 & -0.77 & 10.94 & 20.83 & 12.14 & 10.78 \\
1911 & 11.08 & -0.69 & 9.27 & 21.82 & 11.89 & 10.57 \\
1912 & 10.38 & -1.43 & 9.56 & 20.75 & 12.87 & 10.44 \\
1913 & 11.74 & 2.08 & 10.74 & 21.33 & 12.81 & 11.74 \\
1914 & 10.26 & -0.14 & 8.86 & 21.10 & 12.37 & 10.55 \\
1915 & 10.88 & 0.54 & 9.23 & 20.55 & 12.95 & 10.81 \\
1916 & 10.31 & 0.02 & 8.26 & 20.81 & 12.10 & 10.30 \\
1917 & 9.40 & -0.75 & 8.21 & 21.50 & 9.97 & 9.73 \\
1918 & 10.50 & -3.79 & 10.63 & 20.89 & 12.05 & 9.94 \\
1919 & 11.11 & 1.44 & 10.27 & 21.04 & 13.19 & 11.49 \\
1920 & 10.27 & -2.62 & 8.68 & 20.79 & 12.93 & 9.95 \\
1921 & 11.92 & 1.33 & 12.15 & 21.51 & 13.27 & 12.57 \\
1922 & 11.06 & -0.29 & 10.49 & 21.25 & 12.76 & 11.05 \\
1923 & 10.70 & -1.05 & 9.02 & 21.21 & 12.20 & 10.35 \\
1924 & 10.08 & 1.10 & 8.47 & 20.74 & 11.51 & 10.46 \\
1925 & 11.08 & 0.71 & 10.09 & 21.85 & 11.54 & 11.05 \\
1926 & 9.99 & -0.23 & 8.18 & 20.86 & 11.94 & 10.19 \\
1927 & 11.04 & -0.01 & 9.49 & 19.85 & 13.65 & 10.74 \\
1928 & 10.90 & 0.80 & 8.81 & 21.67 & 12.33 & 10.90 \\
1929 & 11.14 & 0.38 & 10.96 & 21.11 & 12.36 & 11.20 \\
1930 & 11.46 & 1.20 & 9.80 & 22.07 & 13.04 & 11.53 \\
1931 & 12.03 & 0.42 & 9.45 & 22.09 & 14.87 & 11.71 \\
1932 & 11.64 & 3.96 & 8.88 & 21.72 & 12.62 & 11.80 \\
1933 & 11.43 & 2.54 & 9.97 & 21.72 & 12.23 & 11.61 \\
1934 & 10.66 & -1.84 & 9.37 & 22.17 & 12.89 & 10.64 \\
1935 & 10.70 & -0.80 & 9.58 & 21.90 & 12.86 & 10.89 \\
1936 & 10.95 & -2.72 & 10.70 & 21.81 & 12.45 & 10.56 \\
1937 & 11.41 & 2.85 & 9.45 & 22.41 & 11.66 & 11.59 \\
1938 & 11.65 & 0.74 & 10.59 & 22.07 & 12.82 & 11.55 \\
1939 & 11.39 & 1.40 & 9.77 & 22.24 & 12.15 & 11.39 \\
1940 & 9.91 & -1.31 & 8.08 & 21.12 & 11.36 & 9.81 \\
1941 & 11.40 & 0.12 & 9.90 & 21.47 & 14.13 & 11.41 \\
1942 & 11.26 & 0.13 & 11.31 & 21.79 & 13.11 & 11.58 \\
1943 & 10.99 & -0.30 & 9.38 & 22.81 & 11.89 & 10.94 \\
1944 & 11.19 & 0.09 & 9.98 & 22.31 & 12.49 & 11.21 \\
& & & & & &
\end{tabular}

$\begin{array}{ll}\text { Year } & \text { Ann } \\ 1945 & 11.26 \\ 1946 & 11.71 \\ 1947 & 11.06 \\ 1948 & 11.02 \\ 1949 & 12.46 \\ 1950 & 11.07 \\ 1951 & 11.61 \\ 1952 & 11.86 \\ 1953 & 12.35 \\ 1954 & 11.55 \\ 1955 & 11.30 \\ 1956 & 11.06 \\ 1957 & 11.7 \\ 1958 & 10.36 \\ 1959 & 11.84 \\ 1960 & 10.95 \\ 1961 & 11.12 \\ 1962 & 10.46 \\ 1963 & 10.65 \\ 1964 & 11.2 \\ 1965 & 10.86 \\ 1966 & 10.91 \\ 1967 & 10.49 \\ 1968 & 11.04 \\ 1969 & 11.02 \\ 1970 & 11.05 \\ 1971 & 11.36 \\ 1972 & 10.79 \\ 1973 & 11.99 \\ 1974 & 11.44 \\ 1975 & 11.68 \\ 1976 & 10.97 \\ 1977 & 11.37 \\ 1978 & 10.51 \\ 1979 & 11.25 \\ 1980 & 11.15 \\ 1981 & 11.26 \\ 1982 & 11.06 \\ 1983 & 11.64 \\ 1984 & 11.62 \\ 1985 & 11.68 \\ 1986 & 11.59 \\ 1987 & 11.53 \\ & \end{array}$

" Calendar year mean (Jan-Dec).

†Season year mean $($ Win $=$ Dec-Feb; Spr $=$ Mar-May; Sum $=$ Jun-Aug; Fall $=$ Sep-Nov).

TRENDS '90 
Average Temperature $\left({ }^{\circ} \mathrm{C}\right), 1901-1987$

\begin{tabular}{|c|c|c|c|c|}
\hline Win & Spr & Sum & Fall & Annt \\
\hline-1.07 & 11.87 & 21.37 & 13.28 & 11.36 \\
\hline-0.34 & 11.12 & 20.57 & 14.01 & 11.34 \\
\hline 1.17 & 9.17 & 21.52 & 13.29 & 11.28 \\
\hline-1.57 & 10.06 & 21.60 & 13.21 & 10.82 \\
\hline 3.12 & 10.52 & 22.99 & 13.03 & 12.42 \\
\hline 2.74 & 8.50 & 21.14 & 12.67 & 11.26 \\
\hline 1,32 & 10.24 & 21.63 & 12.59 & 11.44 \\
\hline 2.14 & 10.03 & 22.82 & 12.33 & 11.83 \\
\hline 2.63 & 10.95 & 21.99 & 13.34 & 12.23 \\
\hline 2.30 & 10.13 & 21.48 & 13.12 & 11.76 \\
\hline 0.27 & 10.99 & 22.50 & 12.49 & 11.56 \\
\hline-0.15 & 8.43 & 21.34 & 12.45 & 10.51 \\
\hline 1.56 & 10.74 & 22,02 & 12.93 & 11.81 \\
\hline 0.12 & 9.50 & 21.29 & 12.59 & 10.87 \\
\hline-1.20 & 10,90 & 22.27 & 13.64 & 11.40 \\
\hline 1.72 & 8.98 & 21.70 & 12.94 & 11.34 \\
\hline-1.52 & 9.14 & 21.77 & 14.20 & 10.90 \\
\hline-0.37 & 10.18 & 20.98 & 11.66 & 10.61 \\
\hline-1.81 & 10.38 & 21.52 & 13.07 & 10.79 \\
\hline-0.75 & 10.31 & 21.36 & 12.45 & 10.84 \\
\hline 0.12 & 9.65 & 21,30 & 12.33 & 10.85 \\
\hline 0.22 & 9.18 & 22.24 & 12.33 & 10.99 \\
\hline 0.63 & 8.29 & 21.43 & 11.38 & 10.43 \\
\hline-0.94 & 10.27 & 22.14 & 13.35 & 11.20 \\
\hline-0.45 & 9.98 & 22.13 & 12.39 & 11.01 \\
\hline-1.31 & 9.53 & 21.98 & 13.83 & 11.01 \\
\hline-0.45 & 9.03 & 21.81 & 13.89 & 11.07 \\
\hline 1.59 & 9.15 & 21.04 & 11.66 & 10.86 \\
\hline 1.29 & 10.68 & 22.70 & 13.44 & 12.01 \\
\hline 1.62 & 10.58 & 21.55 & 12.07 & 11.45 \\
\hline 2.06 & 9.48 & 22.04 & 13.59 & 11.79 \\
\hline 1.21 & 11.06 & 21.84 & 10.78 & 11.22 \\
\hline-2.30 & 11.85 & 22.05 & 13.16 & 11.19 \\
\hline-1.84 & 9.12 & 21.83 & 12.42 & 10.38 \\
\hline-0.94 & 10.96 & 21.32 & 13.40 & 11.19 \\
\hline 0.43 & 10.44 & 22.51 & 12.42 & 11.43 \\
\hline-0.29 & 10.58 & 22.35 & 11.94 & 11.17 \\
\hline-0.79 & 9.82 & 21.03 & 13.04 & 10.76 \\
\hline 1.96 & 10.07 & 22.65 & 13.33 & 11.99 \\
\hline 0.49 & 8.96 & 22.31 & 13.09 & 11.21 \\
\hline 1.16 & 11.57 & 21.51 & 14.22 & 12.11 \\
\hline-0.07 & 11.02 & 21.96 & 12.68 & 11.40 \\
\hline 0.33 & 10.64 & 22.61 & 12.43 & 11.50 \\
\hline
\end{tabular}

\section{REFERENCES}

Karl, T.R., G. Kukla, and J. Gavin. 1984. Decreasing diurnal temperature range in the United States and Canada from 1941 through 1980. Joumal of Climate and Applied Meteorology 23:1489-1504.

Karl, T.R., G. Kukla, and J. Gavin. 1986. Relationship between decreased temperature range and precipitation trends in the United States and Canada, 1941-1980. Joumal of Climate and Applied Meteorology 26:1878-86.

Karl, T.R., C.N. Williams, Jr., P.J. Young, and W.M. Wendland. 1986. A model to estimate the time of observation bias associated with monthly mean maximum, minimum, and mean temperatures for the United States. Joumal of Climate and Applied Meteorology 25:145-60.

Karl, T.R., R.G. Baldwin, M.G. Burgin. 1988a. Time series of regional seasonal averages of maximum, minimum, and average temperature, and diumal temperature range across the United States: 1901-1984. Historical Climatology Series 4-5. National Climatic Data Center. National Oceanic \& Atmospheric Administration. National Environmental Satellite, Data, and Information Service. Asheville, North Carolina.

Karl, T.R., H.F. Diaz, and G. Kukla. 1988b. Urbanization: its detection and effect in the United States climate record. Journal of Climate 1:1099-1123.

Karl, T.R., C.N. Williams, Jr., and F.T. Quinlan. 1990. United States Historical Climatology (HCN) serial temperature and precipitation data. NDP-019/R1. Carbon Dioxide Information Analysis Center, Oak Ridge National Laboratory. Oak Ridge, Tennessee. 


\section{Coastal Southeast}

\begin{tabular}{|l|} 
BACKGROUND \\
Principal investigators \\
Thomas R. Karl \\
Ronald G. Baldwin \\
Michael G. Burgin \\
National Oceanic and Atmospheric \\
Administration \\
National Climatic Data Center \\
Federal Building \\
Asheville, North Carolina 28801, U.S.A. \\
Sponsoring agencies \\
U.S. Department of Commerce \\
National Oceanic and \\
Atmospheric Administration \\
U.S. Department of Energy \\
Carbon Dioxide Research Program \\
Period of record - 1901-1987. \\
Method - After comparing each station's \\
data in the 1219-station Historical \\
Climatology Network (HCN) (Karl et al. \\
1990) to data from its twenty nearest \\
neighbors, stations were selected based on \\
confidence, missing data, and consistency \\
criteria. All data were adjusted for time of \\
observation biases, station and instrument \\
changes, and urban heat island biases. \\
Twenty-three regions were formed by \\
subjectively considering the climate \\
characteristics across the country, the \\
terrain, the continentality, and the \\
vegetation. As an additional constraint, each \\
region was required to have boundaries \\
coinciding with NCDC's climate divisions. \\
For further details see Karl et al. (1988a). \\
Data avallability - These data are available \\
from NCDC and CDIAC. The complete \\
HCN data set (Karl et al. 1990) is available \\
from CDIAC. \\
a
\end{tabular}
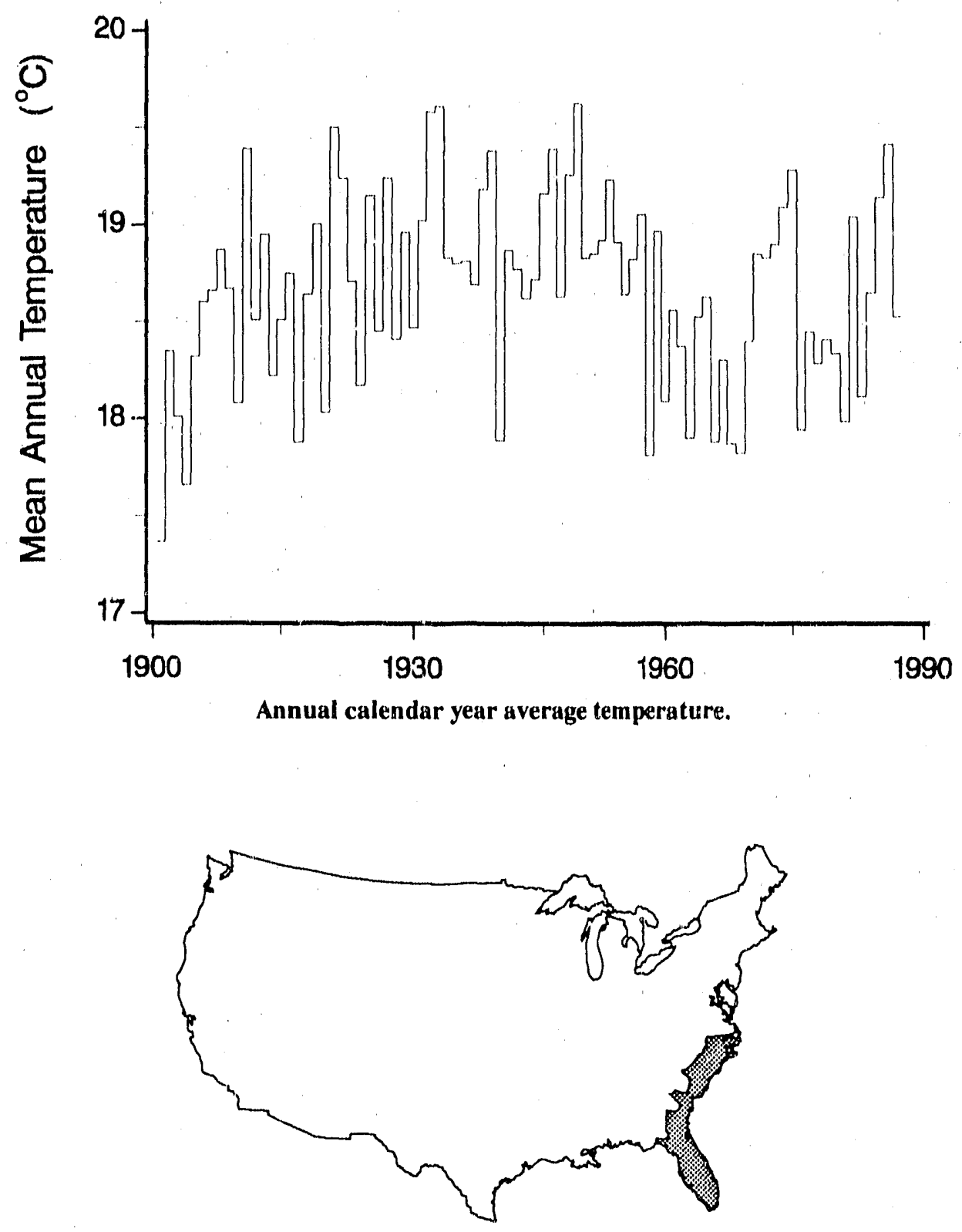

Coastal Southeast 


\section{TRENDS}

On the basis of regional seasonal temperatures (i.e., maximum, minimum, average, and diurnal range) for the United States, Karl et al. (1988a) concluded that the climate has changed over the recent century but that the changes have not been monotonic for the most part. Instead, the changes are somewhat unsteady and sometimes occur over a relatively short period of time. Karl et al. (1988a) also found a considerable amount of detailed information for each regional time series but reported that their salient features often could be summarized in time series plots for three aggregated regions: West, Central, and East. For the aggregated East region, which includes this subregion, Karl et al. (1988a) reported that the annual average temperature time series can be divided iato three epochs: a warm epoch fro.n the early 1920s to the mid 1950s, preceded and followed by periods during which. temperatures were generally at or below the mean for the century. 


\section{Coastal Southeast}

\begin{tabular}{|c|c|c|c|c|c|c|}
\hline Year & $\mathbf{A n n} \mathbf{n}^{*}$ & W/n & Spr & Sum & Fall & Ann' \\
\hline 1901 & 17.37 & 9.39 & $16 .(39)$ & 25.81 & 17.88 & 17.44 \\
\hline 1902 & 18.35 & 8.36 & 18,06 & 26.33 & 20.12 & 18.22 \\
\hline 1903 & 18.01 & $10 .(\%)$ & 18,49 & 25.80 & 17,97 & 18.31 \\
\hline 1904 & $17 .(x)$ & 8.12 & 17.73 & 25.44 & 18.52 & 17.45 \\
\hline 1905 & 18.32 & 8.46 & 19,02 & 25.97 & 19.72 & 18.29 \\
\hline 1006 & 18.60 & 10.55 & 17.79 & 26.21 & 19.64 & 18.55 \\
\hline 1907 & $18.66)$ & 11.44 & 18.26 & 25.85 & 19.06 & 18.65 \\
\hline 1908 & 18.87 & 9,96 & 20,04 & 25.89 & 18.97 & 18.71 \\
\hline $19(x)$ & 18.67 & 12.67 & 18.30 & 25.97 & 19.14 & 19.02 \\
\hline 1910 & 18.08 & 9.49 & 18.58 & 25.45 & 19.06 & 18.14 \\
\hline 1911 & 19,39 & 10.94 & $18 .\left(0^{4}\right)$ & 26.35 & 20.49 & 18.97 \\
\hline 1912 & 18.51 & 9.71 & 189.91 & 25.82 & 19.70 & 18.53 \\
\hline 1913 & 18.95 & 13.19 & 18.60 & 25.74 & $18.6 n)$ & 19.03 \\
\hline 1914 & 18.22 & 10.62 & 17.40 & 26.54 & 18.83 & 18.35 \\
\hline 1915 & 18.51 & 10.49 & 16.87 & 26.20 & 20.72 & 18.57 \\
\hline 1916 & 18.75 & 11.47 & 17.83 & 25.71 & 19.32 & 18.58 \\
\hline 1917 & 17.88 & 11.58 & 18.05 & 25.85 & 17.56 & 18.26 \\
\hline 1918 & 18.64 & 8.80 & 18.84 & 25.77 & 19,25 & 18.16 \\
\hline 1919 & 19.00 & 11.26 & 18.40 & 25.61 & 21.31 & 19.15 \\
\hline 1920 & 18.03 & 10.02 & 17.10 & 25.65 & 19.34 & 18.03 \\
\hline 1921 & 19.50 & 11.28 & 19.22 & 26.09 & 20.77 & 19.34 \\
\hline 1922 & 19.24 & 11.89 & 19.13 & 25.76 & 19.89 & 19.17 \\
\hline 1923 & 18.71 & 12.03 & 18.16 & 25.83 & 18.69 & 18.67 \\
\hline 1924 & 18.17 & 11.14 & 17.10 & 26.38 & 18.63 & 18.31 \\
\hline 1925 & 19,15 & 12.31 & 18.41 & 26.45 & 20.21 & 19.34 \\
\hline 1926 & 18.45 & 10.38 & 16.71 & 26.21 & 19.64 & 18.23 \\
\hline 1927 & 19.24 & 12.75 & 18.75 & 25.60 & 20,37 & 19.37 \\
\hline 1928 & 18.41 & 10.58 & 17,42 & 26.14 & 19.50 & 18.41 \\
\hline 1929 & 18.96 & 11.41 & 19.52 & 25.46 & 19.52 & 18.98 \\
\hline 1930 & 18.47 & 11.86 & 18.00 & 25.73 & 19.02 & 18.65 \\
\hline 1931 & 19.02 & 9.57 & 16.58 & 26.47 & 20.99 & 18.40 \\
\hline 1932 & 19.58 & 15.49 & 17.51 & 26.77 & 19.27 & 19.76 \\
\hline 1933 & 19.61 & 15.29 & 19.03 & 26.10 & 20.00 & 19.60 \\
\hline 1934 & 18.83 & 11.41 & 17.95 & 26.78 & 20.23 & 19.09 \\
\hline 1935 & 18.80 & 10.97 & 19.41 & 26.25 & 19.81 & 19.11 \\
\hline 1936 & 18.81 & 8.50 & 18.58 & 26.47 & 20.00 & 18.39 \\
\hline 1937 & 18.69 & 13.21 & 17.67 & 26,37 & 18.27 & 18.88 \\
\hline 1938 & 19.18 & 11.13 & 19.68 & 25.96 & 19.60 & $19 .\left(0^{\circ}\right)$ \\
\hline 1939 & 19.38 & 12.48 & 18.84 & 26.53 & 19.6 .3 & 19.37 \\
\hline 1940 & 17,89 & 8.58 & 16,99 & 26.41 & 18.84 & 17.71 \\
\hline 1941 & 18.87 & 10.40 & 17.4.2 & 26.64 & 21.18 & 18.91 \\
\hline 1942 & 18.77 & 10.19 & 18.43 & 26.70 & 20.25 & 18.89 \\
\hline 194.3 & 18.62 & 11.27 & 18.10 & 26.99 & 18.41 & 18.69 \\
\hline 1944 & 18.72 & 11.16 & 18.70 & 26.40 & 19.26 & 18.88 \\
\hline
\end{tabular}

$\begin{array}{ll}\text { Year } & \text { Ann* } \\ 1945 & 19.16 \\ 1946 & 19.39 \\ 1947 & 18.63 \\ 1948 & 19.26 \\ 1949 & 19.63 \\ 1950 & 18.83 \\ 1951 & 18.85 \\ 1952 & 18.92 \\ 1953 & 19.23 \\ 1954 & 18.91 \\ 1955 & 18.64 \\ 1956 & 18.82 \\ 1957 & 19.05 \\ 1958 & 17.81 \\ 1959 & 18.96 \\ 1960 & 18.09 \\ 1961 & 18.56 \\ 1962 & 18.37 \\ 1963 & 17.90 \\ 1964 & 18.52 \\ 1965 & 18.62 \\ 1966 & 17.88 \\ 1967 & 18.30 \\ 1968 & 17.87 \\ 1969 & 17.82 \\ 1970 & 18.39 \\ 1971 & 18.84 \\ 1972 & 18.82 \\ 1973 & 18.39 \\ 1974 & 19.08 \\ 1975 & 19.27 \\ 1976 & 17.94 \\ 1977 & 18.44 \\ 1978 & 18.28 \\ 1979 & 18.40 \\ 1980 & 18.33 \\ 1981 & 17.98 \\ 1982 & 19.03 \\ 1983 & 18.11 \\ 1984 & 18.64 \\ 1985 & 19.13 \\ 1986 & 19.40 \\ 1987 & 18.52 \\ & \end{array}$

- Calendar year mean (Jan-Dec).

tSeason year mean (Win = Dec-Feb; Spr = Mar-May, Sum = Jun-Aug; Fall = Sep-Nov). 


\section{U.S. Reglonal Temperatures}

\section{Average Temperature $\left({ }^{\circ} \mathrm{C}\right), 1901-1987$}

$\begin{array}{rrrrr}\text { Win } & \text { Spr } & \text { Sum } & \text { Full } & \text { Annt } \\ 10.19 & 20.02 & 26.21 & 20.09 & 19.13 \\ 10.71 & 19.18 & 25.63 & 20.61 & 19.03 \\ 11.66 & 17.78 & 25.63 & 20.09 & 18.79 \\ 10.30 & 19.69 & 26.44 & 19.85 & 19.07 \\ 14.37 & 18.39 & 26.38 & 19.66 & 19.70 \\ 14.05 & 17.63 & 26.06 & 19.04 & 19.20 \\ 9.93 & 17.81 & 26.60 & 19.52 & 18.46 \\ 12.56 & 18.27 & 27.11 & 18.77 & 19.17 \\ 11.45 & 19.45 & 26.23 & 19.23 & 19.09 \\ 11.86 & 18.18 & 27.00 & 19.38 & 19.10 \\ 9.91 & 19.43 & 25.85 & 19.28 & 18.612 \\ 10.37 & 17.94 & 26.30 & 18.97 & 18.40 \\ 13.52 & 18.53 & 26.04 & 19.34 & 19.36 \\ 8.16 & 17.43 & 26.43 & 19.83 & 17.96 \\ 10.43 & 18.46 & 26.28 & 20.14 & 18.83 \\ 10.29 & 16.72 & 26.13 & 20.14 & 18.32 \\ 9.40 & 17.87 & 25.89 & 19.89 & 18.26 \\ 11.38 & 17.93 & 26.06 & 18.94 & 18.58 \\ 8.49 & 18.82 & 25.96 & 18.89 & 18.04 \\ 8.55 & 18.57 & 25.84 & 19.35 & 18.07 \\ 11.30 & 18.53 & 25.62 & 19.60 & 18.76 \\ 9.76 & 17.47 & 25.46 & 19.13 & 17.96 \\ 10.27 & 18.81 & 25.22 & 17.83 & 18.03 \\ 9.48 & 17.98 & 26.31 & 19.08 & 18.21 \\ 8.96 & 17.17 & 26.35 & 18.80 & 17.82 \\ 8.29 & 18.52 & 26.10 & 19.69 & 18.15 \\ 10.89 & 16.93 & 26.05 & 20.32 & 18.55 \\ 13.15 & 17.87 & 25.45 & 19.55 & 19.00 \\ 10.85 & 18.62 & 26.20 & 20.70 & 19.09 \\ 12.88 & 19.19 & 25.40 & 18.76 & 19.06 \\ 12.43 & 18.52 & 26.11 & 20.20 & 19.32 \\ 10.81 & 18.79 & 25.38 & 17.19 & 18.04 \\ 7.78 & 19.35 & 26.67 & 19.69 & 18.37 \\ 7.76 & 17.95 & 26.34 & 20.42 & 18.12 \\ 9.79 & 18.55 & 25.84 & 19.90 & 18.52 \\ 9.71 & 18.18 & 26.61 & 19.29 & 18.44 \\ 8.65 & 17.94 & 26.82 & 18.54 & 17.99 \\ 10.35 & 18.65 & 26.13 & 19.47 & 18.65 \\ 10.74 & 17.14 & 26.39 & 19.38 & 18.41 \\ 10.11 & 17.74 & 25.93 & 19.39 & 18.29 \\ 10.90 & 19.21 & 26.25 & 21.80 & 19.54 \\ 10.40 & 18.36 & 26.94 & 21.08 & 19.20 \\ 10.35 & 17.61 & 27.03 & 19.069 & 18.51 \\ & & & & \end{array}$

\section{REFERENCES}

Karl, T.R., G, Kukla, and J. Gavin. 1984. Decreasing diurnal temperature renge in the United States and Canada from 1941 through 1980. Joumal of Climate and Applied Meteorology 23:1489-1504.

Karl, T.R., G, Kukla, and J. Gavin. 1986. Relationship between decreased temperature range and precipitation trends in the United States and Canada, 1941-1980. Joumal of Climate and Applied Meteorology 26:1878-86.

Karl, T.R., C.N, Williams, Jr., P.J, Young, and W.M. Wendland. 1986. A model to estimate the time of observation bias associated with monthly mean maximum, minimum, and mean temperatures for the United States. Joumal of Climate and Applied Meteorology 25:145-60.

Karl, T.R., R.G. Baldwin, M.G. Burgin. 1988a. Time series of regional seasonal averages of maximum, minimum, and average temperature, and diumal temperature range across the United States: 1901-1984. Historical Climatology Series 4-5. National Climatic Data Center. National Occanic \& Atmospheric Administration. National Environmental Satellite, Data, and Information Service. Asheville, North Carolina.

Karl, T.R., H.F. Diaz, and G. Kukla, 1988b. Urbanization: its detection and effect in the United States climate record. Joumal of Climate 1:1099-1123.

Karl, T,R, C.N. Williams, Ir $r$, and F.T. Quinlan. 1990. United States Historical Climatology $(H C N)$ serial temperature and precipitation data. NDP-019/R1. Carbon Dioxide Information Analysis Center, Oak Ridge National Laboratory. Oak Ridge, Tennessee. 
Appendixes -

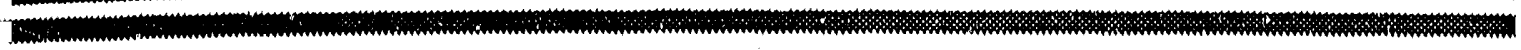




\section{Carbon Dloxide Information Anals}

The Carbon Dioxide Information Analysis Center (CDIAC), located within the Environmental Sciences Division of Oak Ridge National Laboratory, has been in operation since 1982. CDIAC provides information support to the international research, policy, and education comınunitics for evaluation of complex environmental issues associated with elevated lovels of atmospheric $\mathrm{CO}_{2}$, including potential climate change. CDIAC activities include obtaining and cvaluating data, articles, and reports; producing digital numeric data and computer model packages (NDPs and CMF's); distributing $\mathrm{CO}_{2}$-related reports; and producing the newsletter, CDIAC Communications, which has a worldwide distribution of over 5500 subscribers in 151 countries. To date, 38 NDPs and CMPs have been compiled, 12 issues of CDLAC Communications have been distributed, and CDIAC has responded to more than 16,000 information requests.

CDIAC is funded by the U.S. Department of Energy (DOE) to support its Carbon Dioxide Rescarch Program (CDRP). The goal of CDRP is to develop sound scientific information for policy formation and governmental action in response to changes of atmospheric $\mathrm{CO}_{2}$. CDRP's thrust during the past decade has been to (1) clucidate the processes that control the global carbon cycle 


\section{sls Center}

and provide predictions of future atmospheric $\mathrm{CO}_{2}$ change; (2) dovelop data and models of the processes by which changes in the Earth's radir,ive balance may change climate at global and regional scales and predict rates of potential climate change; and (3) develop the data and models required to defline and predict the combined effect of climate and $\mathrm{CO}_{2}$ on plants, crops, and ecosystems.

In 1989, CDRP moved from DOE's Office of Basic Energy Sciences into the Office of Health and Environmental Research. At the same time, it was combined with other atmospheric research activities under the Atmospheric and Climate Research Division, which is directed by Ari Patrinos. The CDRP managers (and their areas of responsibility) are Roger C. Dahiman (global carbon research, vegetation research, and educalion), Michael R. Riches (climate reseurch, quantitative links, oceans research, and resource analysis), and Thomas J. Gross (information and integration, including responsibility for CDIAC).

The malling address for the program is:

Carbon Dloxide Research Program Atmospheric and Climate Research Division (LR.76)

U.S. Department of Energy Washington, DC 20545, U.S.A. 


\section{Appendix B}

\section{Numeric Data Packages}

Detalled descriptions of data sets [CDIAC Numeric Data Packages (NDPs)] used to produco TRENDS' 90 aro presented in the next several pages. To order these NDPs or inquire about other CDIAC information products, an order form is provided at the end of this appendix. Simply copy tho order form, fill in the appropriato information, and return the completed form to CDIAC. If you have any questions about the avallability of these NDPs, you may contact CDIAC by phone, FAX, or any of the telecommunication networks listed below:

\author{
Carbon Dioxide Information Analysis Center$$
\text { Bullding I(XX), MS-6335 }
$$$$
\text { Oak Ridge Natlonal Labsoratory }
$$$$
\text { P.O. Box } 2 \text { (K)8 }
$$$$
\text { Oak Ridge, Tennessee 37831-6335, U.S.A. }
$$$$
\text { (615) } 574-(13901
$$$$
\text { 624-(1390) lNTS }
$$$$
574.2232 \mathrm{FAX}
$$ \\ BITNET: CDP@OKNISTC \\ OMNET: CDIAC \\ INTERNET: CDP@STCIO.CTD.ORNL.GOV
}

Atmospheric ( $\mathrm{CO}_{2}$ Concentratlons - Mauna Loa (Observatory, Hawall, 1958-1986, C. D. Kecling, Scripps Institution of Oceanography, CDIAC NDP (K)I/RL (Rov, 1986)

Since 1958, air samples have heen continuously collected at Mauna Loa Observatory and analyzed by infrared sipectroseopy for $\mathrm{CO}_{2}$ concentrations, Data are averaged to give monthly and annual utmospheric $\left(\mathrm{C}_{2}\right.$ concentrations.

These data represent the longest continuous record of atmospherie $\mathrm{CO})_{2}$ concentrations in the world. This precise data record covers a single silte, Mauna Loa Observatory, Hawail, which is a reliable indleator of the regional trend in the concentration of atmospheric $C_{2}()_{2}$ in the middle layers of the troposphere and thus is critical to $C\left(\mathrm{O}_{2}\right.$-related research. The data are in one file $(2.5 \mathrm{kB})$.

Globul Surfuce-Alr Temperature Variations: $1851-1984$. P. D. Jones, S. C., B. Ruper, P. M. Kelly, and T. M. L. Wigley, University of East Anglia, CDIAC NDP-()1)3/R1 (Rev. 1986)

Anomalles in monthly and annual surface-air temperatures in relation lo the 1951-1970 mean surface-air temperature were calculated for several periods: 1851-1984 for the Northern Hemisphere, 1858-1984 for the Southern Hemisphere excluding Antarctica, and 1958-1984 for the Southern Hemisphere including Antarctica. These estimates are derived from landhased meteorological station data and fixed-position weathership data interpolated onto a $5^{\circ}$ latitude by $10^{\circ}$ longitude grid. The data are in three liles, one for the anomalies in Northern Hemisphere temperatures (10 kB) and two for the anomalies in Southern Hemisphere lemperatures (9 kB and $2 \mathrm{kB}$ ).

Atmospheric $\mathrm{CO}_{2}$ Concentrutions - The NOAA/(iMCC Flask Sampling Network. T. J. Conway and P. Tans, National Oceanic and Atmospheric Administration. CDIAC NDP-(0)5/RI (Rov, 1)(1))

Flask air samples are collected approximately onec per week at 29 stations scattered around the globe. The carliest samples were taken in 1068, but the period of record valries from station to station. The samples are analyzed for atmospheric $\mathrm{CO}_{2}$ 


\section{Numeric Data Packages}

ifoncentration on a nondispersivo infrared gas analyzar apparatus at the NOAA/CMCC laborutery in Boulder, Colorado, The measurements are directly traceable to the primary $\mathrm{CO}_{2}$ standards of the World Moteorological Organization. Euch sample is charactorized by station, year, sampling date and time, flask identification number, $\mathrm{CC}_{2}$ concentration, date and time of unalysis, and quality indicators. The data are in 30) files: one file that contains data through 1981 $(946 \mathrm{kB})$ and one lile for each of 29 sites with data from 1981 through 1986 (ranging from 3,6 to $55,8 \mathrm{kB}$ ).

Production of $\mathrm{CO}_{2}$ from Fossill-Fuel Burning. R, M, Rotty and (i. Marland, Oak Ridge Associated Universities. CI)IAC NIDP-AKF (1984)

Global (C)2 emissions for 1950 through 1982 wore estinated by Marlind and Rotly from fucl production data from the U.N. Eneryy Sististics Yeartook (1983, 1984). Data before 1950 came from C. D. Reeling. Fucl-production data were used in these calculations because they appeared to be more reliable on a global basis thun fucl-consumption data. The data given are the yeur and annual global $\mathrm{CO}_{2}$ cmissions (annual global total; cumulative global total since 18(6); and annual global omissions from solid fucls, liquid fucls, matural gas, gas flaring, and cement manulacturing). These datu provide the only pre-1950) estimates of the amount of carbon emilted to the atmosphere from fossil-fuel burning. 'The $\mathrm{CO}_{2}$ emission record since 1950 has been updated and revised several times, with the most recent estimates published by Marland et al. The clata are in one file $(7.5 \mathrm{kB})$.

\section{Atmospherie $\mathrm{CO}_{2}$ Concentrutlons - The CSIRO (Australla)}

ik Monitoring Progrum from Aircruft for 1972-1981.

D. J. Beardsrnore and G. I. Pearman, Commonwealth Sicientific and Industrial Research Organization, CDIAC NDP-0(1)7 (1984)

From 1972 through 1981, air samples were collected in glass flasks from aircralt at a variety of latitudes and allitudes over Australia, New Zealand, and Antarctica. The samples were analyzed for $\mathrm{CO} 2$ concentrations by using a nondispersive infrated gas analysis. The resulting data contain the sampling 


\section{Appendix B}

dates, type of aircraft, flight number, flask identification number, sampling time, geographic sector, distance in kilometers from the listed distance measuring equipment station, station number of the radio navigation distance measuring equipment, altitude of the aircraft above mean sea level, sample analysis date, flask pressure, tertiary standards used for the analysis, type of analyzer used, and $\mathrm{CO}_{2}$ concentration. These data represent the first published record of $\mathrm{CO}_{2}$ concentrations in the Southern Hemisphere expressed in the $1981 \mathrm{CO}_{2}$ Calibration Scale of the World Meteorological Organization and provide a precise record of atmospheric $\mathrm{CO}_{2}$ concentrations in the troposphere and lower stratosphere over Australia and New Zealand. The data are in one file $(263 \mathrm{kB})$.

\section{Annual and Seasonal Global Temperature Anomalies in the} Troposphere and Low Stratosphere, 1958-Summer 1986. J. K. Angell and J. Korshover, National Oceanic and Atmospheric Administration. CDIAC NDP-(008/R1 (Rev. 1987)

For 1958 through 1986, anomalies in annual and seasonal temperatures in relation to a 1958-1977 mean (expressed in degrees Celsius) were calculated for the surface, troposphere ( $850-300 \mathrm{mb})$, tropopause $(300-100 \mathrm{mb})$, and low stratosphere $(100-50 \mathrm{mb}$ and $100-30 \mathrm{mb}$ ) layers on the basis of t'egion, hemispheres, and the globe. Most of the values are column-mean temperatures obtained from the differences in the heights of constant-pressure surfaces at individual radiosonde stations. The pressure-height data before 1980 were obtained from published values in Monthly Climatic Data for the World. These temperature anomalies may be used to analyze long-term temperature trends for a layer of the atmosphere (i.e., surface, troposphere, tropopause, and low stratosphere), a region (i.e., polar, temperate, subtropical, and equatorial regions), a hemisphere, or the globe. The data are in one file $(64.5 \mathrm{kB})$.
Atmospheric $\mathrm{CO}_{2}$ Concentrutions - The CSIRO Monitoring Program: Surface Data for Cape Grim, T'asmania. D. J. Beardsmore, G. I. Pearman, and R. C. O'Brien, Commonwealth Scientific and Industrial Research Organization. CDIAC NDP-010 (1985)

From 1976 through 1983, air samples collected from a high-volume general intake $10 \mathrm{~m}$ above the roof of the laboratory at Cape Grim, Tasmania, were dried and analyzed for $\mathrm{CO}_{2}$ concentrations with a nondispersive infrared gas analyzer. This baseline $\mathrm{CO}_{2}$ record from Cape Grim indicates the $\mathrm{CO}_{2}$ concentrations in large maritime air masses devoid of vegetative influences in this region of the Southern Hemisphere. The data available on each sample are sampling date; daily, monthly, and annual $\mathrm{CO}_{2}$ concentrations; standard deviation associated with each concentration; number of hours of data used to calculate the $\mathrm{CO}_{2}$ values; and the analyzer used. The data are in three files: daily $(17 \mathrm{kB})$, monthly $(3 \mathrm{kB})$, and annual (310 B).

United States Historical Climatology Network (HCN) Serial Temperature and Precipitation Data. T. R. Karl, C. N. Williams, Jr, and F. 'T. Quinlan, National Oceanic and Atmospheric Administration. CDIAC NDP-019/R1 (Rev. 1990)

Extending through 1987, this data base contains information on monthly total precipitation and temperatures from 1219 stations in the contiguous United States. To be included in the Historical Climatology Network ( $\mathrm{HCN})$, a station had to be currently active (1987), have at least 80 years of monthly temperature and precipitation data, and have experienced few station changes. These data were derived from a variety of sources, including the National Climatic Data Center archives, state climatologists, and published literature. The data base contains several hundred variables, including statc number, station number, monthly temperatures (minimum, maximum, and mean), total monthly precipitation, and time of observation. This is probably the best monthly temperature and precipitation data set available for the contiguous United States because station moves, instrument changes, urbanization effects, and time-of-observation differences have been considered and, 
where necessary, the data have been corrected. The data are in 13 files (one station inventory file, one station history file, six temperature files, one precipitation file, one time-of-observation correction file, and two quality assessment files). The file sizes range from $5 \mathrm{kB}$ to $\sim 50 \mathrm{MB}$ and are available on nine-track magnetic tape only.

\section{A Global Grid Point Surface-Air Temperature Data Set: 1851-1984. P. D. Jones, S. C. B. Raper, B. S. G. Cherry, C. M. Goodess, T. M. L. Wigley, B. Santer, and P. M. Kelly, University of East Anglia; R. S. Bradley, University of Massachusetts; H. F. Diaz, National Oceanic and Atmospheric Administration. CDIAC NDP-020 (1986)}

For 1851 through 1984, this data baiv presents anomolies in monthly surface-air temperatures for both hemispleres, in relation to a 1951-1970 reference period, on a $5^{\circ}$ latitude by $10^{\circ}$ longitude global grid. The basis of the data set is derived from the World Weather Records published by the Smithsonian Institution and the U.S. Weather Bureau. Additional data were added from meteorological archives. The records include the year, month, latitude, longitude, surface air temperature anomaly, number of stations used to calculate each gridded anomaly, and the mean value of the inverse of the great circle distance between the station and the grid point. The data are in two files (Northern and Southern hemispheres), each 19.63 MB in size and on nine-track magnetic tape only.

Global and Hemispheric Annual Temperature Variations between 1861 and 1988. P. D. Jones, T. M. L. Wigley, and P. B. Wright, University of East Anglia. CDIAC NDP-022/R1 (Rev. 1990)

This data set contains estimates of variation in global and hemispheric annual temperatures in relation to a 1950-1979 reference period, for 1861 through 1988. The estimates are based on corrected land and ocean data. Land data were derived from meteorological data and fixed-position weather-ship data that were corrected for nonclimatic errors, such as station shifts and/or instrument changes. The marine data were from the compilation of the Comprehensive 


\section{Appendix B}

Ocean-Atmosphere Data Set (COADS), which with updates extends to 1986. Updates to 1988 were made with hemispheric sea-surface temperature estimates produced by the U.K. Meteorological Office. Each record includes year and six annual temperature variations: one estimate each for the globe, the Northern Hemisphere, and the Southern Hemisphere and another estimate each that reflects an adjustment to account for the influence of El Niño/Southern Oscillation events. The data are in one file $(\mathrm{kB})$.

Estimates of $\mathrm{CO}_{2}$ Emissions from Fossil-Fuel Burning and Cement Manufacturing, Based on the U.N, Energy Statistics and the U.' Bureau of Mines Cement Manufacturing Data. G. Marland, T. A. Boden, P. Kanciruk, S. F. Huang, and T. R. Nelson, Oak Ridge National Laboratory; R. C. Griffin, Kentucky Wesleyan College. CDIAC NDP-030 (1989)

For 1950 through 1986, global and national annual estimates of $\mathrm{CO}_{2}$ emissions from fossil-fuel burning and cement production were calculated from energy statistics compiled by the U.N. Statistical Office and from cement-manufacturing data compiled by the U.S. Bureau of Mines. The resulting data base contains the annual amounts of global $\mathrm{CO}_{2}$ emissions and estimates of national $\mathrm{CO}_{2}$ emissions for more than 200 countries. Among many variables, these data include total emissions; emissions from gas, liquid, and solid fuels; and 
enissions from cement production. The data are in six files c (three for the U.N. statistics, one for the Bureau of Mines data, one for global $\mathrm{CO}_{2}$ emission estimates, and one for the national

iual $\mathrm{CO}_{2}$ emission estimates) ranging in size from 427 bytes to 4.85 $\mathrm{MB}$ and are available on nine-track magnetic tape only.

for Atmospheric $\mathrm{CO}_{2}$ Concentrations - The Canadian Background ta Air Pollution Monitoring Network. N. B. A. Trivett, Environment Canada. CDIAC NDP-134 (1989)

Flask air samples collected at roughly weekly intervals at three Canadian sites (Alert, Northwest Territories (July 1975 through October 1987); Sable Island, Nova Scotia (June 1975 through October 1987); and Cape St. James, British Columbia (May 1979 through October 1987)] were analyzed for $\mathrm{CO}_{2}$ concentration with the measurements directly traceable to the primary $\mathrm{CO}_{2}$ standards of the World Meteorological

tes Organization (WMO). Each record includes the date, a: mospheric $\mathrm{CO}_{2}$ concentration, and flask classification code.

sy They provide an accurate record of $\mathrm{CO}_{2}$ concentrations in lata Canada during the past decade. Because these data are directly ase traceable to WMO standards, this record may be compared with records from other Background Air Pollution Monitoring Network stations. The data are in three files (one for each of the monitoring stations) ranging in size from 3.2 to $12.8 \mathrm{kB}$. 


\section{Appendix B}

\section{Ordering CDIAC NDPs}

To order these NDPs, complete and return a copy of this form to CDIAC.

Additional CDIAC NDPs are described in detail in the Catalog of Data Bases and Reports (ORNL/CDLAC-34), also available from CDIAC.

Return completed form to:

Carbon Dioxide Information Analysis Center

Building 1(K)O, MS-6335

Oak Ridge National Laboratory

F.O. Box 2008

Oak Ridge, Tennessee 37831 -6335, U.S.A.

(615) 574- -1390

624-0390 FTS

574-2232 FAX

BINET: CDP@ORNLSTC

OMNET: CDIAC

INTERNET: CDP@STC10.CTD.ORNL.GOV

B-4 
Numeric Data Packages

\section{Order Form for CDIAC Numeric Data Packages}

\begin{tabular}{|c|c|c|c|}
\hline $\begin{array}{l}\text { NDP } \\
\text { Number }\end{array}$ & $\begin{array}{l}\text { Documentation } \\
\text { Only }\end{array}$ & $\begin{array}{l}\text { Documentation \& } \\
\text { Foppy Diskette } \\
51 / 4^{n} \quad 31 / 2^{n} \\
\end{array}$ & $\begin{array}{l}\text { Dxxcumentation \& } \\
\text { Magnetic Tape* }\end{array}$ \\
\hline NDP-001 & 11 & $11 \quad 11$ & 11 \\
\hline NDP-003 & ij & {$[1]$} & 11 \\
\hline NDP-005 & ij & 11 & 11 \\
\hline NDP-006 & ij & 11 & [1] \\
\hline NDP_.007 & [1] & 11 & $1 !$ \\
\hline NDP-008 & [1 & i & 11 \\
\hline NDP-010 & 11 & 11 & [1] \\
\hline NDP-019 & 11 & 11 & 11 \\
\hline NDP-020 & 11 & 11 & 11 \\
\hline NDP-022 & ij & [1] & \\
\hline NDP-030 & {$[1$} & 11 & 11 \\
\hline NDP-034 & [1] & 11 & 11 \\
\hline
\end{tabular}

Magnetic tapes are nine-track only. The following information MUST be completed if a magnetic tape is requested:

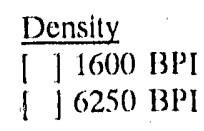

$\frac{\text { Label }}{\text { 1 / Nonlabeled }}$

Character Set
1 ] EBCDIC
1 ASCII

Please list special computer limitations or requirements:

Please send me additional information about CDIAC information products:
[. ] CDIAC Communications (newsletter),
1 ] Catalog of Data Bases and Reports (ORNL/CDIAC-34)
[ ] Please note change of name or address:

Name:

Organization:

Mailing Address:

Telephone:

FAX:

eMail Address: 


\section{Appendix C}

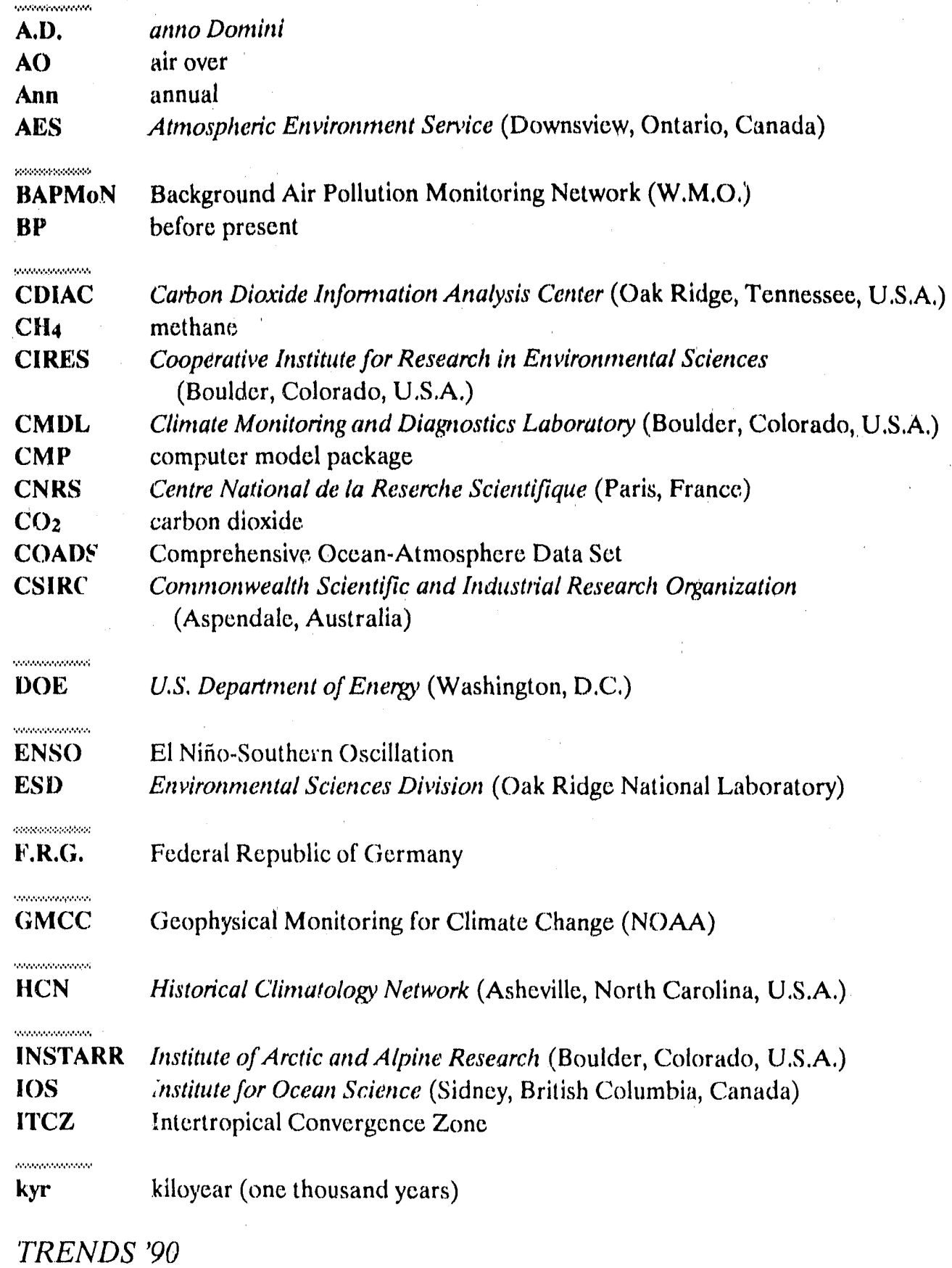




\section{Acronyms, Abbreviations, and Chemical Formulas}

\begin{tabular}{|c|c|}
\hline MÁT & marine air temperatures \\
\hline MLO & Mauna Loa Observatory (Hawail, U.S.A.) \\
\hline MSL & mean sea level \\
\hline NASA & National Aeronautic and Space Adininistration (U.S.A.) \\
\hline NCDC & National Climatic Data Center (Asheville, North Carolina, U.S.A.) \\
\hline NDIR & nondispersive infrared gas analyzer \\
\hline NDP & numeric data package \\
\hline NOAA & National Oceanic and Atmospheric Administration (U.S.A.) \\
\hline ORNL & Oak Ridge National Laboratory (Oak Ridge, Tennessee, U.S.A.) \\
\hline PIREN & Programme Interdisciplinaire de Reserche en l'Environnement (T'oulouse, France) \\
\hline PPB & parts per billion \\
\hline PPBV & parts per billion by volume \\
\hline PPM & parts per milition \\
\hline PPMY & parts per million by volume \\
\hline PRC & People's Republic of China \\
\hline SIO & Scripps Institution of Oceanography (La Jolla, California, U.S.A.) \\
\hline SPO & South Pole Observatory (Antarctica) \\
\hline SST & sea surface temperature \\
\hline TAFF & Terres Australes et Antarctiques Francaises \\
\hline U.K. & United Kingdom \\
\hline U.N. & United Nations \\
\hline UNEP & United Nations Environment Programme \\
\hline U.S.A. & United States of America \\
\hline U.S.S.R. & Union of Sovict Socialist Republics \\
\hline WMO & World Meteorological Organization \\
\hline yr & year \\
\hline
\end{tabular}



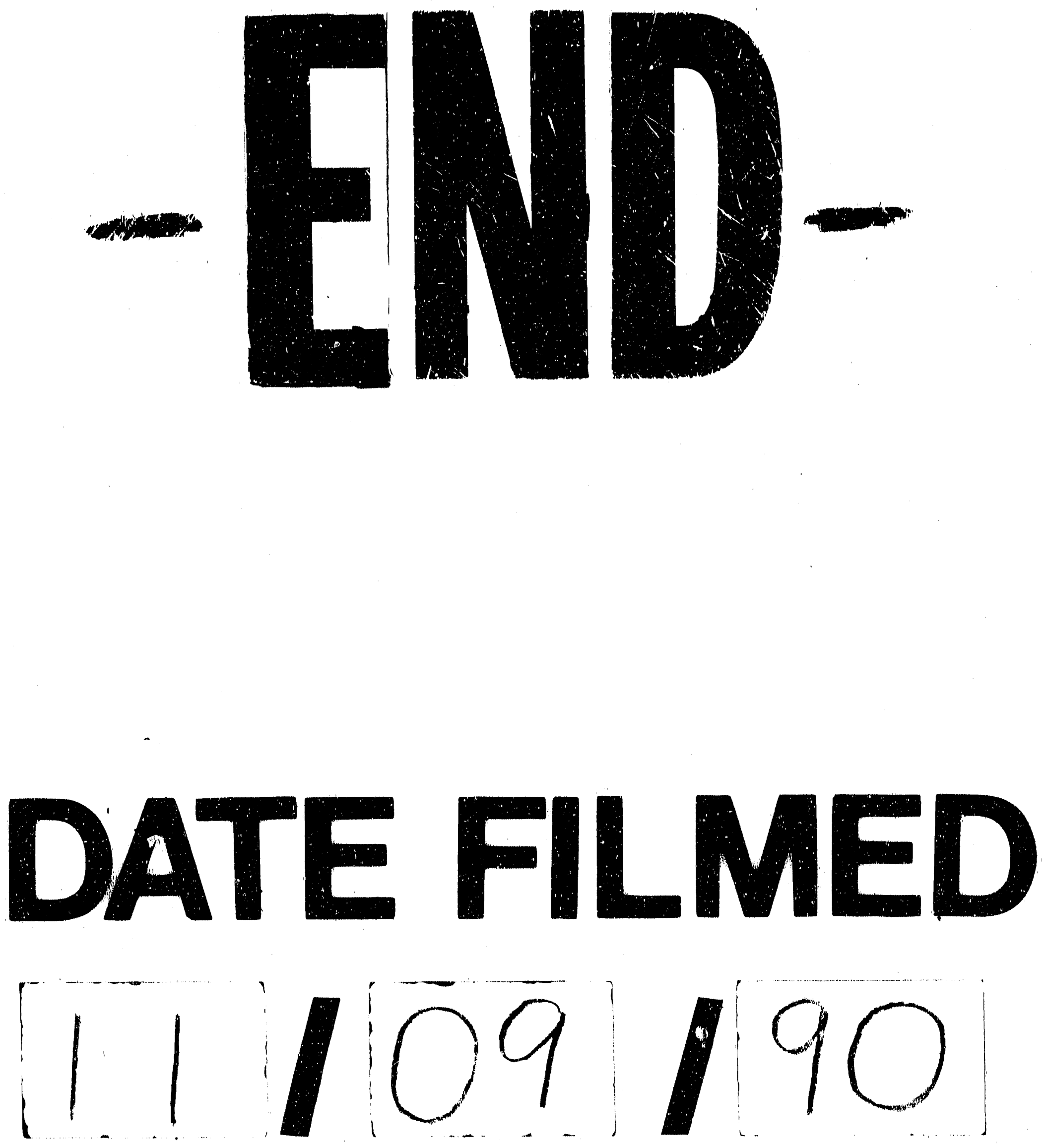
